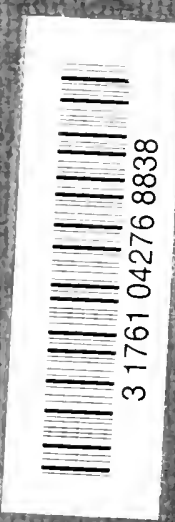

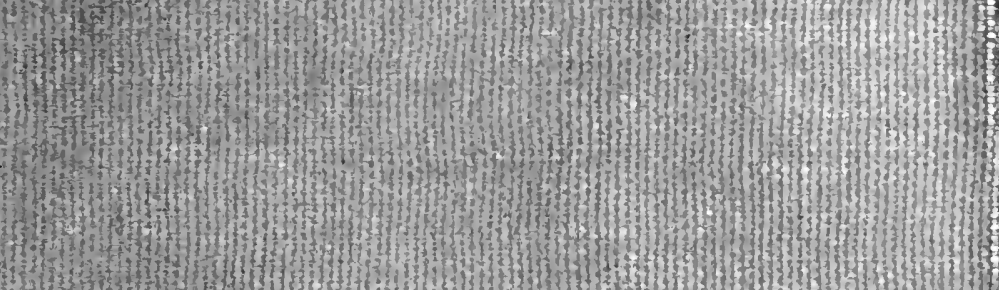
15.5. H.t.

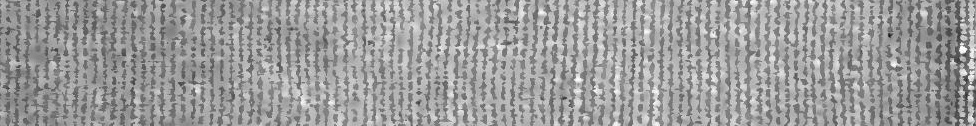
fithis Why

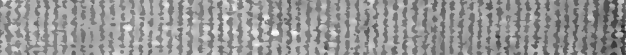

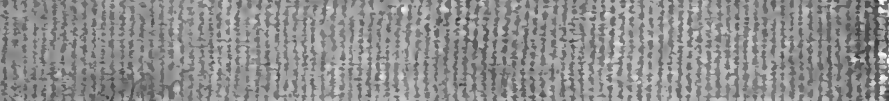

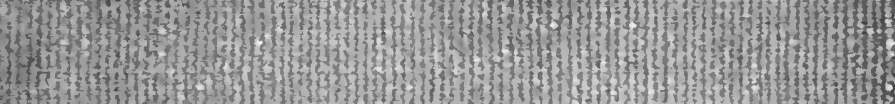
Hith

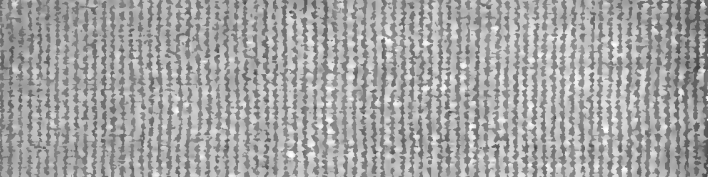
IIIII) Hifly Hown

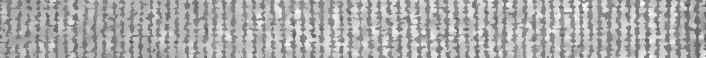
1. 


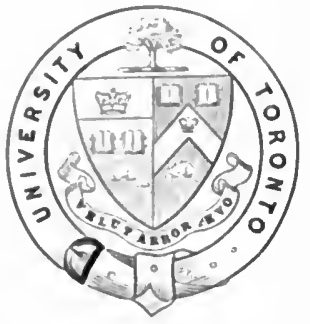

ricqueatbeo to

Tbe Tíbracy

of tbc

\section{Uniniversity of Toronto}

\section{by}

tbe late

Don. ADr. Zustice Farmour

tor many peats

a ADember of the Jisard of

Bovernore of tbe Dinfocratu 




COMMENTARIES

oN

THE COMMON LAW. 


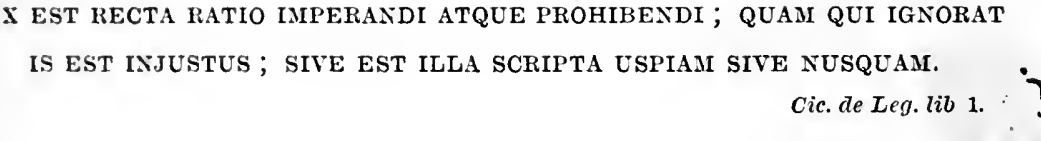




\section{HERBERT BROOM, LL.D., \\ AlTHOR OF "A SELECTION OF LEGAL MAXIMS," F.TC.}

NINTH EDITION.

$B Y$

W. F. A. ARCHIBALD, M.A.,

A MASTER OF THE SIPREME COLRT OF JCDICATLRE,

AND

H. A. COLEFAX, M.A.,

STUDEXT OF CHRIST CHLRCH, OXFORD, OF LIXCOLN'S IXN, BARRISTER-AT-LAW.

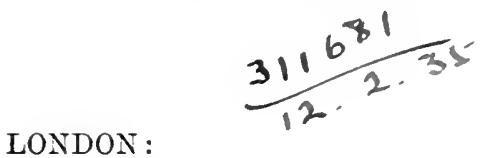

STEET \& MAXIELL, LIMITED, 3, CHANCERY LANE,

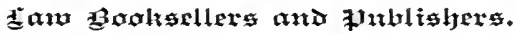

IIEREDITH, RAY, \& LITTLER, MANCHESTER;

HODGES, FIGGIS, \& CO., LTd., AND E. POXSONBY, DUBLIN;

THACKER, SPIXK, \& CO., CALCUTTA;

C. F. MAXWELL, MELBOURNE AND SYDNEY.

1896.

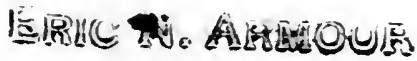


BRADBERY, AGNEW, \& CO. LD., PRINTERS, LONDON AND TONBRIDGE. 


\section{EDITORS' PREFACE TO THE NINTH EDITION.}

In preparing a further edition of this book, the Editors have endeavoured to insert the more important decisions which have been given since the publication of the last edition. The recent codification of the law relating to the Contract of Sale of Goods necessitated a new chapter. In other respects the Editors have not ventured to make any very material alterations in the book.

W. F. A. A.

H. A. C.

The Temple,

July, 1896. 



\section{PREFACE TO THE FIRST EDITION.}

THIs Work has been written with a view to filling what has long appeared to me a void in Legal Literature, its aim being to present explanatory comments on the Law, illustrated by Cases, selected in sufficient number and with sufficient care to enable the reader to pursue for himself in detail the matters debated or touched upon in the text. In the choice of topics for discussion, I have been guided in part by an examination of Standard Treatises, but yet more materially by an experience of three years, devoted almost exclusively to the delivery of Lectures upon the leading branches and departments of our Common Law. Whilst thus engaged in tracing out its principles and indicating its practice, my attention has been perpetually directed to points of difficulty or interest, imperatively needing elucidation, which had previously escaped my notice; on all such points, which, as they presented - themselves, were from time to time scrupulously noted down, I have in the ensuing pages attempted more or less fully to throw light. But besides this, I have, during the 
period referred to, necessarily applied myself to a diligent scrutiny of decided cases, and to the task, by no means light or easy, of choosing therefrom such as seemed specially adapted for educational purposes, for assisting towards the interpretation of important statutes, or for fixing in the mind a knowledge and correct apprehension of legal axioms and doctrines. Of such cases many have been abstracted in the text of this Work; others have been suggested for perusal in the notes, wherein also decisions of minor importance have throughout been so far arranged and classified, that they may readily be consulted in such manner as virtually to amplify the scope and proportionately to extend the usefulness of the Volume. To him who has not, before opening it, seriously concerned himself with the study of the Law, I would offer one suggestion, that, avoiding technicalities and details, he should, in the first instance, familiarise himself with its more inviting portions, particularly with the Introductory Chapter of each Book, and with the subdivisions of Book I., in which the nature of Legal Rights, enforceable by action, and of Extraordinary Remedies is treated of. *** With one word more, I may conclude. If it be true that Law is really worthy to be called a Science; if it be true that Lex est ratio MESSQUE SAPIENTIS ad jubendum et ad deterrendum idonea; if, further, we are justified in affirming that potius ignorantia juris litigiosa est quam scientia, is it indeed vain or inexpedient to hope that a sound lnowledge of Legal Principles may gradually be desiderated by and 
spread amongst the educated classes of this country? Is it futile or unwise to predicate that much and enduring good would thence result? As regards myself, whose main incentive to the preparation of these Commentaries has been a desire to facilitate the attainment of such end, the consciousness of having done so-in any, the slightest, degree-rould amply compensate for past labours.

\section{HERBERT BROON.}

Temple,

December $15 t h, 1855$. 



\section{CONTENTS.}

\section{BOOK I.}

\section{CHAPTER I.}

COMMON LAW-WHAT-OF WHAT ELEMENTS COMPOSED.

Municipal Law and Common Law-what they are . . $1-2$

Lex Scripta-what and how construed . . . . . 2-7-

Lex non Scripta-what it comprises . . . . . . 7-19

General Customs . . . . . . . . . . . 7

Lex Mercatoria-what it is . . . . . . . . 99

Particular or Local Customs . . . . . . . 10

Their requisites . . . . . . . . . . . . . . . . . . . .

Customs of the Country . . . . . . . . . 18

Usages of Trade . $\quad . \quad$. $\quad . \quad$. . . . 18

Lex non Scripta-how declared . . . . . . . 19

Principles to which our Common Law conforms $\quad$. . 20-21 -

\section{CHAPTER II. ᄂ}

COURTS OF LAW.

SEct. I.-The Superior Courts of Law.

1. Origin, History, and Jurisdiction of the Superior Courts of

Law . . . . . . . . . . . 22

Hundred and Shire Courts . . . . . . 23

The Aula Regis . . . . . . . . 23

Origin of Court of Exchequer . . . . . . 24

Common Pleas . . . . 26 -

King's Bench . . . . . 28

Jurisdiction of Superior Courts before Judicature Acts 32

High Court of Justice . . . 33 
Jurisdiction of Court of Appeal . . . . . 34

Supreme Court of Judicature • . 35

House of Lords . $\quad . \quad$. $\quad$. $\quad 36$

Concurrent Administration of Law and Equity . . . . $\quad 37-41$

General Principles as to Jurisdiction of Superior Courts . . . . . . . . $4 \mathbf{1}$

Agreement to oust Jurisdiction . . . . 41

Jurisdiction by Consent . . . . . . 43

Territorial limits of Jurisdiction . . . . 43

Service of process abroad . . . . . . . 44

0 2. Mode of Procedure in Banc, at Judge's Chambers, and in the District Registries . . . . . . . 45

Of what matters our Superior Courts take cognizance 45

Summary Jurisdiction of Superior Court . 46

Application by Motion . . . . . . 46

Motion-how made . . . . . . . . 47

Rules Nisi . . . . . . . . . . 48

'Sittings of Court of Appeal . . . . . . . 48

Power of a single Judge in Court of Appeal $\quad 49$

Divisional Courts of High Court of Justice . . . 49

Abolition of Terms . . . . . . . . . $\quad . \quad 50$

Vacration Judges . • . . . . . . 51

Powers of one Judge not constituting a Divisional

Court . . . . . . . . . 51

Jurisdiction of Judge at Chambers . . . . . 51

The Masters . . . . . . . . 52-54

The District Registrars . . . . . . $54-55$

Applications-how made . . . . . . 55-56

- Secr. II.-Ordinary Jurisdiction of the County Court.

Its general Jurisdiction $56-58$

in contract . . . . . 57

As to splitting demands . . . . . . . . . . 58

As to abandoning the excess of demand . . . . . 60

lemitting Aetion of Contract to County Court . . . . 61

Its Jurisdiction in tort . . . . . . . . 61

Cascs excluded from Jurisdiction of County Court . . 62-66

lemitting Action of Tort to County Court . . . . 65

Costs. . . . . . . . . 66 
Its Peculiar Jurisdiction . . . . 67

Counterclaim . . . . . . . . . . 68

\section{CHAPTER III.}

THE NATURE OF LEGAL RIGHTS ENFORCEABLE BY ACTION.

Definition of the term "right of action" . . . . 70

the words "damnum" and "injuria" . . . 71

Damnum sine injuriâ, whether actionable at law . . 71-82

Injuria sine damno, when actionable . . . . . 82-90

Dammum et injuria may fail to give a right of action . . 90

Where damage is too remote . . . . . . . 91-96

Where proper remedy is by indictment . . . . . 96

Penal action by party aggrieved . . . . . . . 99

Suspension of civil remedy when act is felonious . . . 99-102

Redress, when denied on grounds of public policy . . . 102

Non-liability of judicial officers . . . . . 103-107

Additional exceptions to rule that injuria sine damno is

actionable . . . . . . . . 107

\section{CHAPTER IV. D}

ORDINARY REMEDIES.

Secr. 1.-Action at Law.

Practice of the Superior Courts-how constituted . . 109

1. Considerations preliminary to issuing the Writ . . . $109-$

1. Whether the party proposing to sue has a com.

plete cause of action . . . . . 111

2. Right of Action, whether postponed or extin-

guished altogether . . . . . . 114

3. Where action is brought under provisions of an

Act of Parliament . . . . . 115

4. Whether notice of action is necessary . . . 115

5. As to the nature of the claim . . . 116

6. As to the choice of Parties to Actions . 117-124

effect of change of parties by death, \&c. . . 124

2. Proceedings from Writ to Appearance . . . . . 12:5

The writ of summons and how endorsed . 125-127

Writ for service out of the jurisdiction . . . . 127 
PAGE

Service of writ . $\cdot \quad$.

out of the jurisdiction . . . 129

Duration of the writ . . . . . . . 131

Renewal of writ . . . . . . . . . 131

Concurrent writs . . . . . . . . . . 131

Absconding debtor . . . . . . . . 132

Appearance . . . . . . . 133-136

Default of appearance . . . . . . . 136

3. Proceedings from Appearance to Trial-The Pleadings in the action . . . . . 137

Special case . . . . . . . . . 137

Trial without Pleadings . . . . . . 138

Rules of Pleading . . . . . . . 139-144

Pleading matters pendente lite . . . . . 144

Discontinuance. . . . . . . . 145

Demurrer . . . . . . . 145

The Claim . . . . . . . 145-146

Forms of action . . . . . . . . . . 146

Personal actions $\quad . \quad$. $\quad . \quad$. . . . 147

Peplevin . . . . . . . . 147

Statutory Forms of Pleadings . . . . . 148

The Defence . . . . . . . . 148

Default in Pleading . . . . . . 148-150

Counterclaim . . . . . . . . 150

Psyment into Court . . . . . . . 152

Statutes of Limitation . . . . . . 153-159

Proceedings against third party . . . . 160

The Reply and subsequent Pleadings . . . . . 163

Joinder in Issuc . $\quad . \quad$. $\quad . \quad$. 163

Interrogatories, kc. . . . . . . . . 164

Admission of documents . . . . . . . . 167

4. Proceedings in District Registries . . . . . . 168

What steps in an action are to be taken in a District

Registry . . . . . . . . . 168

liemoval of action to London . . . . . . . 169

5. The Trial . . . . . . . . . 170

Different modes of Trial . . . . . . $170 \rightarrow$

Trial by a Judge . . . . . . . 171

with assessors . . . . . . . 171

before referce . . . . . . . 172-174 
Preparing eridence for Trial .

Evidence by affidavit

174

on Commission . . . . . . 175

Attendance of Witnesses . . . . . . 176

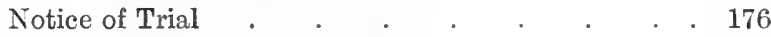

Time of giving Notice of Trial . . . . . . 176

Trial by a Jury . . . . . . 177-180

Nonsuit . . . . . . . . 180-181

New Trial . . . . . . . 182-184

Motion for Judgment . . . . . . . 184

Entry of Judgment . . . . . . . 186

Appeal . . . . . . . . 186-188

Powers of Court of Appeal . . . . . . . 188

6. Writs of Execution . . . . . . . . . . 189

Enforcing Conditional Judgment . . . . . 189

Staying Execution . . . . . . . 190

Writ-how issued . . . . . . . 190

Abolition of Outlawry $\quad . \quad$. . . . . . 191

Attachment . . . . . . . . . . . 191

Sequestration . . . . . . . 191-192

Recovery of Land . . . . . . . . 192

Delivery of Chattels . . . . . . 192-193

Recovery of Money . . . . . . . 193

Writ of fieri facias . . . . . . . . 194

elegit . . . . . . . . . 195

How long a Writ of Execution remains in force 195-196

\section{SECT. II.-Suit in the County Court. O}

Practice of the County Court-how constituted 196

Proceedings in the Suit

$196-202$

by certiorari and on appeal.

CHAPTER V.

EXTRAORDINARY REMEDIES.

1. By the act of the party injured . . . . . 205

Self-defence . . . . . . . . 205

Recaption . . . . . . . . . . 205

Eviction . . . . . . . 206-209 
xvi

CONTENTS.

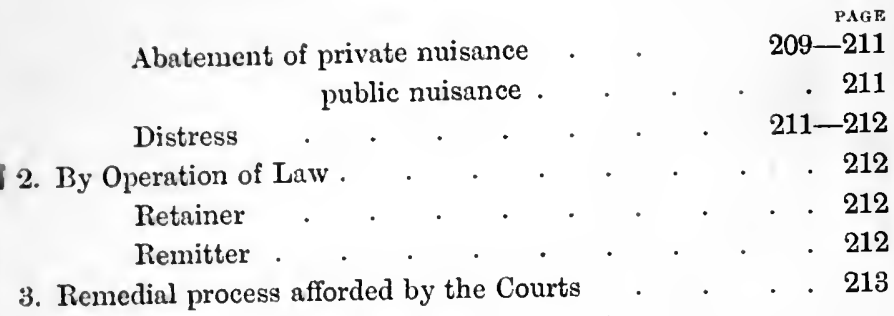

Nature of remedy afforded on motion or summons

$213-214$

Mandamus . . . . . . . 214-217

unInjunction. . . . . . . . . 217-220

Interim preservation of property . . . 220-221

Prohibition . . . . . . . 221-223

Quo warranto . . . . . . . . . 223

Certiorari . . . . . . . . 224

Procedendo . . . . . . . . . 224

Interpleader . . . . . . . 224-227

Attachment of debts or garnishment . . 227-228

Procedure to compel delivery of specific chattels 229-230

Summary procedure for recovery of small tenements

228-229

Criminal Information . . . . . 230-233

Habeas corpus . . . . . . 233-238

Petition of right, \&c. . . . . . 238-243

BOOK II. $\nabla$

CONTRACTS.

CHAPTER I.

CONTBACTS GENELALLY - THEIR CLASSIFICATION AND ATTRIBUTES.

Meaning of the term Contract . . . . . . 244

Contract executory, executed . . . . . . . 245

express, implied . . . . . . 245-248

$\Lambda$, contract is founded on consent . . . . . . 248

Incapacity to contract-how caused . . . . . . 249

Legislative Prohibitions . . . . . . 249-250 
Lex loci-how it operates

General remarks as to Contracts under Seal . . . . 263

Corenant-what . . . . . . . . 267

Different kinds of Covenants . . . . . . . 268-272

Bond-what . . . . . . . . 272

Doctrine of Merger as applicable to deeds generally . . 273

Estoppel by deed . . . . . . . 276-284

Relief in equity against fraudulent deed . . . . . . 284

Consideration, whether necessary to support Specialty 281-288

Contract under Seal may bind the heir . . . . . . 289

Specialty-how discharged . . . . . . 290-294

Obligatory force of Contract under Seal-how affected in

equity . . . . . . . . 294-296

Simple Contract-what . . . . . . . . 296

May be either executory or executed . . . . . . 296

Terms of Contract must be definitively arranged and settled . . . . . . . . . 297-299

Mutuality in a Contract-what it is . . . . 300-302

Analysis of a Simple Contract . . . . . 302-303

1. The Request . . . . . . . 303-311

Executed Consideration . . . . . 304

Principal and Surety . . . . . . . 306

2. The Consideration . . . . . . 311

Privity . . . . . . . . . . 312

3. The Promise . . . . . . . . . $321-326$

Moral Consideration . . . . . . . 325

Rules of general application relating to Contracts special or

simple . . . . . . . 327 et seq.

Effect of Fraud on Contracts . . . . . . . 327.

No distinction between legal and moral fraud . . . 330

Contracts uberrimæ fidei . . . . . . . . 331

Distinction between breach of warranty and fraud . . 340

warranty and representation . . . 342

Of Contracts void on various grounds . . . . . . . 346

in direct violation of law . . . . . 347

B.C.L. 

in restraint of trade . . . . . . 356

Of Immoral Contracts . . . . . . . . 365

\section{CHAPTER II.}

THE Statute of FRaCDS, \&c.

Parol Contract-what . . . . . . . . 368

Policy of the Statute of Frauds . . . . . . . . 373

Contracts within sect. 4 .

Meaning of word "agreement " used in abore section . $374-377$

Promise by executor to answer damages personally . . . 377

to answer for debt, sc., of another . . . . . 378

Of guarantees . . . . . . . . . 378-385

Lord Tenterden's Act . . . . . . . . . . . 384

Of agreements upon consideration of marriage . . . . . 385

Of contracts concerning land, sc. . . . . . . . 385-391

Of agreements not to be performed within a year 391-393

Contract within the Statute cannot be raried by parol . . 393

Other enactments which require writing to authenticate a

Contract . . . . . . . . . . 395

A specialty contrasted with a simple Contract _ . . . 395

Accord and satisfaction . . . . . . . . . . . . 396

Deed when requisite at common law . . . . . . . 398

required by the statute law . . . . . . 400

\section{CHAPTER III.}

CONTRACT OF SALE.

Formation of the Contract . . . . . . . 402

Definition of goods . . . . . . . . . 402

Capacity to contract . . . . . . . . 403

Formalitics of the Contract . . . . . . 404

Sect. 17 of the Statute of Frauds. . . . . . 404

Lord Tenterden's Act . . . . . . . 405

Sect. 4 of the Sale of Goods Act, 1893 . . . . . 406

Actual receipt . . . . . . . . . 408

"Acceptnuce" within sect. 4 of the Act . . . . 408

l'art payment . . . . . . . . . . 411

linurest . . . . . . . 4 411

Note or incmomalum of the Contract . . . . . 412 
Signature by agent .

The case of an auctioneer . . . . . . . 414

a broker . . . . . . . . . 416

a stock and share broker . . . . . . 417

Subject-matter of the Contract . . . . . . . 419

The price . . . . . . . . . . 420

Conditions and warranties . . . . . . . . 421

Implied conditions and warranties . . . . . 4 423-425

Sale by sample . . . . . . . . . . 424

Effects of the Contract . . . . . . . $425-431$

Transfer of property . . . . . . . . 425

risk . . . . . . . . . 428

title . . . . . . . . . . 429

Exceptions to general rule of law as to transfer of title . . . . . . . . . . . . 429

Effect of writs of execution in England and Ireland. 431

Performance of the Contract . . . . . . . . 432

Duties of buyer and seller . . . . . . . . . 432

Delivery . . . . . . . . . 4 $432-434$

Acceptance . . . . . . . . . . . 434

Liability of buyer for refusing or neglecting to take delivery . . . . . . . . . 435

Rights of unpaid seller against the goods . . . . 435-438

Unpaid seller's lien . . . . . . . . . . . . . . . . . . . . . . . . .

Stoppage in transitu . . . . . . . . . . . 436

Re-sale by buyer or seller . . . . . . . . . 438

Action for breach of Contract . . . . . . . 439

Seller's remedies . . . . . . . . . . 439

Buyer's remedies . . . . . . . . . 440

Measure of damages . . . . . . . . . . . 440

Remedy for breach of warranty . . . . . 440

Measure of damages . . . . . . . . . . . . 441

Auction Sales . . . . . . . . . . . 441

CHAPTER IT.

\section{NEGOTIABLE INSTRUMENTS.}

Negotiable instrument-what . . . . . . . 442

Chose in action-what . . . . . . . . 442 
Chose in action not assignable at common law $\quad . \quad$. $\quad 443$

Doctrine of equity as to assignment of a chose in action . . 445

Bill of Exchange, by whom introduced . . . . . 447

How defined . . . . . . . . . . 449

Its form . . . . . . . . . . . . 451

Its use in mercantile transactions . . . . . 453

The parties to a bill . . . . . . . . 453

Accommodation Bill-what . . . . . . . . 454

Negotiability . . . . . . . . . . 454

Indorsement-blank or special . . . . . . . 455

Delivery necessary after indorsement . . . . . 455

Restrictive indorsement . . . . . . . . . 455

Conditional delivery . . . . . . . . . . 456

Rights of holder . . . . . . . . . . . . 456

Transfer of overdue bill $\quad . \quad$. $\quad . \quad$. . . . . . 457

Parties to bill after indorsement . . . . . . 458

Steps to be taken by holder of bill when due . . . . 458

Presentment . . . . . . . . . . . 459

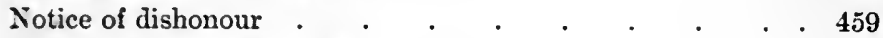

when dispensed with . . . . . . . 460

Effect of dishonour . . . . . . . . . . 462

What notice must be given . . . . . . . . 463

Within what time . . . . . . . . . . . 463

Contract of Acceptor . . . . . . . . . . 464

Drawer . . . . . . . . . 465

- Indorser . . . . . . . . 466

Nature of acceptance . . . . . . . . . . . 467

Application of doctrine of estoppel as against acceptor . $\quad 472$

Acceptance by procuration. . . . . . . . 472

for honour . . . . . . . . 474

Relation of banker and customer . . . . . . 474

Discharge of bill . . . . . . . . . . 476

Foreign bills . . . . . . . . . . 476

Protest . . . . . . . . . . . . 477

Cheque . . . . . . . . . . . 478

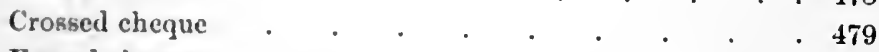

Forged cheque . . . . . . . . . . . . 481

Promissory note . . . . . . . . . . . 483

Form of . . . . . . . . . . . . 487

How distinguished from bill of exchange. . . . 488 
Contract of maker

Presentment

Bank-note

Rules as to presentment of

Ordinary matters of defence at law in actions upon bills and notes . . . . . . . . 497

Payment . . . . . . . . . . . . . . 497

No consideration . . . . . . . . . . . 498

Material alteration . . . . . . . . . 500

Loss of bill or note . . . . . . . . . . . 503

Illegality, fraud, duress, \&c. ․ . . . . . . 504

Assignment of life or marine policy . . . . . . 505

Bill of lading . $\quad$ • . . . . . . . . 505

Railway scrip, whether assignable . . . . . . 508

\section{CHAPTER V.}

\section{LANDLORD AND TENANT.}

Interests in land . . . . . . . . . 509

Demise for a term of years. . . . . . . . 510

Tenancy from year to year . . . . . . . 510

at will . . . . . . . . . . 512

sufferance . . . . . . . . . 513

Capacity of parties . . . . . . . . . . . 513

persons under disability. . . . . . . 513

infants . . . . . . . . . . 514

married women . . . . . . . 514

lunatics, convicts . . . . . . . . . 515

corporations . . . . . . . . 516

Crown . . . . . . . . . . 516

tenants for life . . . . . . . . . 516

mortgagors, mortgagees . . . . . . 517

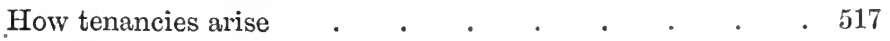

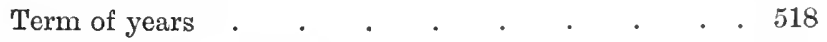

Tenancy from year to year . . . . . . . 519

at will . . . . . . . . . . 521

Rights and duties of parties . . . . . . . . 522 
Rights and duties as to quiet enjoyment . . . . . . 522

Rights of tenant on determination of tenancy . . . . 527

Tenant right . . . . . . . . 527

$\cdot \cdot \cdot 528$

voluntary..$+ \quad \cdot \quad \cdot \quad \cdot \quad \cdot \quad \cdot 529$

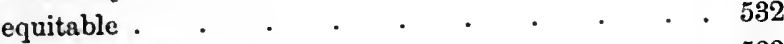

permissive . . . . . . . . 533

Liability of parties to repair $\quad . \quad$. $\quad . \quad$ : $\quad . \quad$. . 533

Covenants to repair . . . . . . . . . 534

Fixtures . . . . . . . . . . . 536

Time for tenant to remove fixtures. . . . . . 537

Trade fixtures . . . . . . . . . . . 538

Agricultural Holdings Acts . . . . . . . 539

Landlord's right of set-off . . . . . . . . 542

to make improvements. $\quad . \quad$. . . 543

Rent . . . . . 543

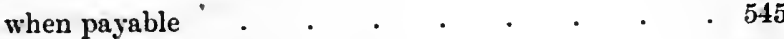

deductions $. \quad . \quad . \quad . \quad . \quad . \quad . \quad 546$

distress . . . . . . . . . 547

things privileged from distress $\quad . \quad$. $\quad . \quad$. $\quad 550$

lodger's goods . . $\quad . \quad . \quad . \quad . \quad . \quad .551$

property fraudulently removed . . . . . 554

distress how and when to be made . . . . 554

Assignments . . . . . . . . . . 556

Covenants running with the land . . . . . 557

Assignments by act of law . . . . . . . . . 559

on death of lessee $\quad . \quad . \quad . \quad . \quad . \quad . \quad 560$

bankruptcy of lessee $\quad . \quad . \quad . \quad . \quad .561$

Deternination of tenaneies . . . . . . . 562

Surrender by operation of law . . . . . . . . 563

Disclaimer . . . . . . . . . . 564

Forfeiture . . . . . . . . . . . 564

Yearly tenancy-notice . . . . . . . . . 565

Remedies . . . . . . . . . . 567

Replevin . . . . . . . . . . . 567

Use and occupation . . . . . . . . . . . 569

Action on covenant. $\quad . \quad$. $\quad . \quad . \quad$. $\quad . \quad$. $\quad .569$

for holding over . . . . . . . . . 570

recovery of land . . . . . . . . . . 571 
Rules for the construction of written contracts As to ambiguous contracts . . . . . . . . 574

Admissibility of evidence to identify subject-matter of contract 576 identify parties to contract . . 577 explain mercantile terms . $\quad 578$ annex term to written contract . 583

Inadmissibility of evidence of usage to vary terms of witten contract . . . . . . . . . 586

Questions as to admissibility and effect of evidence of usage, sc.-how determined . . . . . . . . . . 588

Enumeration of some leading rules of construction . . 593

\section{CHAPTER VII.}

THE CAPACITY TO CONTRACT-HOW IT MAY BE AFFECTED.

SEct. I.-Contracts with Mercantile Persons.

Contracts by principal and agent . . . . . . . 595

Agency-how constituted . . . . . . . . . 595

of three kinds . . . . . . . . . . 598

Fact of agency-how proved . . . . . . . . . . 599

Agency-how created . . . . . . . . . 600

Authority of agent-to what it extends . . . . . 603

Did the agent contract as such ?. . . . . . . 605

Respective liability of principal and agent . . . . . 606

Liability to seller of principal who has bona fide paid agent . 608

of agent who contracts without authority . . . 614

Contract in writing by agent . . . . . . . 618

How an agent should contract by specialty . . . . 622

Liability of innocent principal for fraud of agent . . . 623

Partnership-what it is at common law . . . . . . 626

rules in determining whether partnership exists 627

Agency of partner-its nature . . . . . . . . 632

Continuance of liability as partner. . . . . . . 638

Cessation of liability as partner . . . . . . . . . 638

Contracts by corporations . . . . . $642-650$

Trading companies . . . . . . . . . 650 
Leading provisions of the Bankruptcy Act, $46 \& 47$ Vict.

c. 52

$653-666$

Sect. II.-Contracts with Non-Mercantile Persons.

Contracts by an infant . . . . . . . . . 667

What are necessaries . $\quad . \quad$. $\quad . \quad . \quad . \quad . \quad . \quad 667$

Contracts by infant roid or voidable . . . . . 670-675

Effect of coverture at common law on the wife's capacity

to contract . . . . . . . . . . 675

Statutory provisions in favour of married women . . . 677

Married Women's Property Act, 1882 . $\quad$. $\quad$. $\quad$. $\quad 681$

Capacity of married women to contract . . . . 682-685

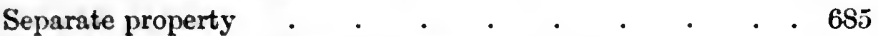

Husband and wife-their remedies against each other . . 686

Respective liability of for debts of wife before corerture . . 688

during coverture $689-700$

Contracts of lunatics and persons non compotes mentis . 700-704

Intoxication-its effect on contracts - . . . . . . 704

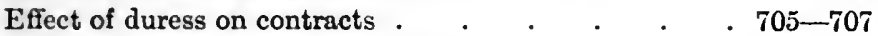

Incapacity of alien enemy or outlaw to contract . . . 707

Contracts of executors and administrators . . . . 708-714

Resumé of matters treated of in this Chapter . . . . . . $\mathbf{7 1 4}$

\section{CHAPTER VIII.}

THE MEASURE OF DAMAges IN ACtIONS OF CONTRACT.

Meaning of the term "damages" . . . . . 717-718

Intention of party, whether relerant to issue in action of

contract . . . . . . . . . . 718

Nominal damages, when recorerable . . . . $\quad .720$

Distinction between a penalty and liquidated damages . . 723

Measure of damages on contract to replace stock . . . 728

in action for breach of contract of hiring

and service, dic. 731

contract for sale

of land . . 732

Rule as to remoteness of damage considered . . . T34-741

Interest, when recoverable in action ex contractu . 741-744

Iuportance of a knowledge of the law of contracts $\quad . \quad$. 744 
BOOK III.

TORTS.

CHAPTER I.

TORTS GENERALLY-THEIR NATURE AND CLASSIFICATION.

Definition of a tort .

Right of action for a tort, whereon founded . . . . 746

Rights of action ex delicto.

Class I. Action for invasion of a right . . . 747

II. Action for breach of public duty, producing damage . . . . . . . 750

Action for breach of public duty at common

$$
\begin{aligned}
& \text { law . . . } 750 \\
& \text { statutory public duty . } 759
\end{aligned}
$$

III. Action for breach of private duty, producing damage . . . 767 statutory private duty . 768 private duty at common law . . . . 769

Tort flowing from breach of contract . . . . . . 769

Privity, whether necessary to support action ex delicto . . 770 Action for breach of duty undertaken . . . . . 779 founded on fraud, \&c., and consequential damage . . . . . . . 779 the malicious doing of an act causing damage . . 780 Classification of Torts . . . . . . . . 781

\section{CHAPTER II.}

TORTS TO THE PERSON AND REPUTATION.

Torts to the person-what . . . . . . . 782

Action for bodily injury-intention, whether material in . . 782 assault and battery $. \quad . \quad . \quad . \quad . \quad .784$

other bodily injuries . . . . . . . 786 where plaintiff has contributed to injury $\quad$. 787 
Liability of master for tortious act of servant $\quad . \quad 790-798$

attaching to owner of realty . . . . . . 798

Effect of ratification of tort . . . . . 8 800-806

Liability of master to servant for injury sustained by latter

in his service . . . . . . . . . 806-818

Employers' Liability Act, 1880 . . . . . . 811-815

Action for compensation where death has been caused by negligence . $. \quad . \quad . \quad . \quad . \quad . \quad . \quad 815$

Torts to the health and comfort of individuals . . . . 818

by sale of unwholesome food. . . . . . 819

nuisances affecting health or comfort . . . . 820

negligent treatment of patient . . . . . 823

affecting personal liberty . . . . . . . . 823

by false imprisonment . . . . . . . . 823

Liability of constable for false imprisonment . . . 828

justice of the peace for false imprisonment . . 831

Meaning of word "malice" in civil proceedings . . . 835

Action for malicious arrest . . . . . . . . 837

Torts to the reputation . . . . . . . . 839

Action for malicious prosecution. $\quad$. $\quad$. $\quad$. $\quad . \quad$. 839

maliciously suing out commission of bankruptcy . 844

libel . . . . . . . 844 et seq.

As to privileged communications . . . . . $850-858$

Publication of libel-what . . . . . . . . . . 858

Action for slander . . . . . . . . . . . . . 861

of title . . . . . . . . . $\quad .864$

\section{CHAPTER III.}

TORTS TO PROPERTY.

Sect. I.-Torts to Real Property.

Action for recovery of land . . . . . . . . $867-870$

Trespass to land. . . . . . . . . . $870-879$

ab initio . . . . . . . . . . 879

As to the ratification of a trespass . . . . . . 880

Nuisance to realty . . . . . . . . . . . 880

Easements . . . . . . . . . . . 882

Natural rights of property . . . . . . . . . . . 583

light to support for land . . . . . . . . . . 883

Land-how distinguished from water in legal contemplation . 855 
Right to flowing water . . . . . . . . . . 886

artificial watercoursc . . . . . . . . . . 888

Easements proper . . . . . . . . . . . 889

by express grant . . . . . . . . . . 889

implied grant . . . . . . . . . . 890

of necessity . . . . . . . . . . . $\quad$. 892

by prescription . . . . . . . . . 892

Prescription Act, sects. 1, 2 . . . . . . . . $893-896$

sect. 3.-Light . . . . $896-900$

4.--Interruption, what . . . 900

7.--Persons under disability . . . 901

Abandonment of easement . . . . . . . . 901

Extent of right to light and air . . . . . . . . . 902

running water . . . . . . . 902

artificial watercourse . . . . . . 903

subterranean water . . . . . . . 904

ways . . . . . . . . . 908

support for buildings . . . . . . 908

Sect. II.-Torts to Personal Property.

Chattels, personal-what . . . . . . . . 911

Torts to personalty-how classitied . . . . . . 911

in possession . . . . . . . 912

out of the owner's possession . . . 915

Bailments . . . . . . . . . . . 915

Class I. Trust for exclusive benefit of Bailor . . 917

II. Trust for exclusive benefit of Bailee . 920

III. Trust for benefit of both parties . . 921

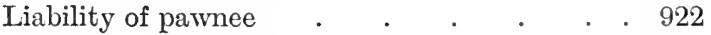

innkeeper . . . . . 926

boarding-house keeper. . . 929

lodging-house keeper . . . 930

land-carrier . . . 9 930-947

Torts by third persons to chattels under bailment . . 947

\section{CHAPTER IV.}

TORTS NOT DIRECTLY AFFECTING THE PERSON OR PROPERTY.

Distinction between torts to absolute and torts to relative rights 
Torts to absolute rights considered 950

Fraud in connection with companies . . . . . 952-960

Directors' Liability Act . . . . . . . . . 954

Estoppel in pais . . . . . . . . . . . . 960

Torts to relative rights considered. $\quad . \quad$. $\quad . \quad$. $\quad .966$

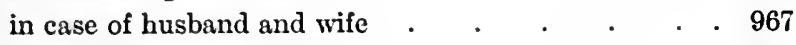

parent and child . $\quad . \quad . \quad . \quad . \quad .967$

master and servant . $\quad . \quad$. $\quad . \quad$. 969

\section{CHAPTER V.}

THE MEASURE OF DAMAGES IN ACTIONS OF TORT.

Damages in tort are to be regarded as compensatory . . $\quad 971$ Intention or motive of wrong-doer, whether material in estimat.

ing damages . . . . . . . . . . . 976

Damages-general and special damage . $\quad . \quad$. $\quad . \quad$. 979

Consequential damage is recoverable, provided it be not too

remote . . . . . . . . . . 980

The question, In what respects does a tort differ from a contract and from a crime ? considered . . . . 983

BOOK IV.

CRIMINAL LAW.

CHAPTER I.

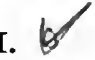

CHMINAL LAW GENERALLY-ITS ELEMENTARY PRINCIPLES.

Importance of a knowledge of Criminal Law . . . . . 986

Ignorance of law no excuse for infringing it . . . . . 986

The law speaks imperatively . . . . . . . . . . 986

Meaning of the word "crime" . . . . . . . 988

A crime is an offence of a public nature . . . . . 990

Intention-what-how far material to constitute crime . . 992

Malice-what-in connection with criminal law . . . 994

The unind may be actively or passively in fault . . . . 995

Intention-low provable . . . . . . . . . . . 996 
Mere intention not cognizable by law $\quad . \quad$. . . . . 997

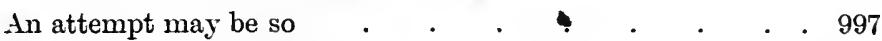

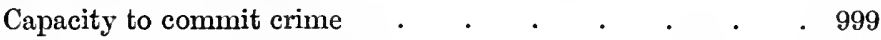

Remarks as to irresponsibility of one non compos mentis . 1001

Rules upon this subject laid down in M'Naghten's case 1002-1004

Responsibility of one who commits crime whilst intoxicated . 1007

As to the criminal responsibility of an infant . . . . 1009

a feme covert . . . . 1011

\section{CHAPTER II. 0}

OFFENCES AGAinst THE SOVEREIGN, THE STATE, AND THE COMIYUNITY.

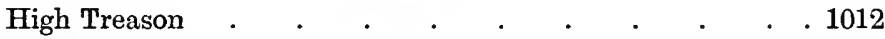

Allegiance, natural or local c . . . . . . . . 1012

to whom due . $\quad . \quad . \quad . \quad . \quad . \quad . \quad .1013$

Statute of Treasons . . . . . . . . 1013-1016

What is an overt act of treason . . . . . . . . 1016

Remarks as to the doctrine of constructive treason . . 1018

Offences against the State, endangering the public safety . . 1019

Conspiracy . . . . . . . . . . . 1020

Offences against the Executive Power . . . . . . 1023

Administration of Justice . . . 1024

by judicial officers . . 1024

private persons . $\quad .1024$

Public Peace . . . . . . 1025

Riot. . . . . . . . 1025

Riot Act . . . . . . . . 1027

Forcible entry . . . . . . 1028

Trade . . . . . . . . 1029

Morals and Police . . . . . . 1029

Nuisance . . . . . . . . . . . 1030

\section{CHAPTER III.}

OFFENCES AGAINST INDIVIDUALS.

Sect. I.-Offences against the Person, Reputation, and Property.

Degrees of homicide . . . . . . . . . . 1032

Murder, manslaughter-how defined . . . . . . 1032 
What is malice, express or implied

As to the presumption that homicide is malicious . . . 1035

Homicide on provocation . . . . . . . . . . 1036

during struggle in anger . $\quad . \quad . \quad . \quad . \quad . \quad .1039$

caused by undue correction . . . . . . 1040

through negligence . . . . . . . . . 1040

of medical practitioner . . . 1042

trustees of road, \&c. . . . 1042

in resisting officer of justice . $\quad . \quad . \quad . \quad . \quad .1043$

where justifiable $. \quad . \quad . \quad . \quad . \quad . \quad .1045$

excusable . . . . . . . . 1046

On indictment for murder, jury may convict of felonious

homicide . . . . . . . . . 1048

Indictment for assault and battery, where it lies . . . 1048

aggravated assault, where it lies . . 1048

The offence of libel-in what it consists . . . . . 1050

Provisions of Mr. Fox's Libel Act considered . . . . 1051

$6 \& 7$ Vict. c. 96 as to libel . . . . . . 1052

Criminal information may be granted for libel . . . 1055

Indictment will lie for threatening to publish libel, \&c. . . 1055

Newspaper Libel and Registration Act . . . . . 1055

Corrupt and Illegal Practices Prevention Act, 1895 . . . 1056

Simple larceny-how defined . . . . . . . . 1057

Of what things larceny cannot be committed at common law 1057

Property in chattel stolen-how laid . . . . . . 1059

Possession, actual or constructive . . . . . . . 1059

Where property alleged to have been stolen came rightfully

into possession of the accused . . . . . . 1060

Larceny includes a trespass . . . . . . . . 1061

Where goods are obtained in pursuance of a contract . . 1063

The taking must have been animo furandi . . . . . 1064

Under what circumstances the appropriation of lost goods

may amount to larceny . . . . . . . 1065

Doctrine of relation-how it may apply in larceny . . . 1068

The 'asportation'-what . . . . . . . . . 1069

Larceny effected by means of innocent agent. . . . . 1070

Receiving stolen goods . . . . . . . . 1070

Obtaining goods, money, kc., by false pretences . . . . 1071

Larceny by a clerk or scrvant . . . . . . . 1073

Embezzlement . . . . . . . 1073 
Larceny from the person . . . . . . . . . 1074

Robbery . . . . . . . . . . . 1074

\section{CHAPTER IV. O}

CRIMINAL PROCEDURE.

The Director of Public Prosecutions-his duties . . . 1076

General view of the jurisdiction of Justices of the Peace : 1079

Offences not cognizable at Quarter Sessions . . 1079-1080

Powers of Justices in regard to indictable offences. . . . 1080

Summary Jurisdiction of Justices-42 \& 43 Vict. c. 49 1081-1085

Procedure by indictment $. \quad . \quad \cdot \quad . \quad . \quad . \quad .1086$

Proceedings at the trial . . . . . . . . 1088

Rules of Evidence to be observed . . . . . . . 1090

Entry of judgment . . . . . . . . . . . 1095

Court for Crown Cases Reserved . . . . . . . . 1096

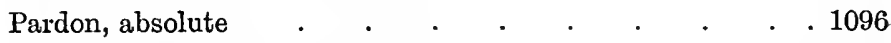
conditional . $\quad . \quad . \quad . \quad . \quad . \quad . \quad .1097$

Forfeiture for felony abolished . . . . . . . . 1097

Concluding Remarks . . . . . . . . . . . 1097

INDEX $\quad \cdot \quad \cdot \quad \cdot \quad \cdot \quad \cdot \quad \cdot \quad \cdot \quad \cdot \quad \cdot \quad \cdot \quad \cdot 1099$ 



\section{TABLE OF CASES.}

A.

Aввотт $v$. Machie, 789

- $v$. Parfitt, 123

- v. Wolsey, 411

Abel $v$. Lee, 4

Aberdare Local Board v. Hammett, 994

Abley $\because$. Dale, 4, 830

Abouloff $v$. Oppenheimer, 261

Abraham $v$. Reywolds, $757,807,809$

Abrahams 2 . Deakin, 793, 843

Abrath $v$. North-Eastern li. C., 839,842

Abrey $v$. Crux, 370

Absolon $v$. Mlarks, 487

Acey $v$. Fernie, 615

Ackerman $v$. Elurensperger, 743

Ackers $v$. Howard, 573

Acocks $v$. Phillips, 545

Acraman $v$. MLorrice, 405

Acton $x$. Blundell, $76,7 \pi, 79,88 \tau$, 905

Adams' Trusts, In re, $6 \mathrm{S6}$

- $v$. Andrews, 399, 785

- v. Clutterbuck, 44, 37

- $v$. Freemantle, 33,47

- $v$. Gibney, 52.2

- v. Grane, 551

- $\quad$. Hagger, 545, 569

- $v$. Lindsell, 299

- $v$. London and Yorkshire R. C., 91

- $v$. Wordley, 370

Adamson $v$. Newcastle Steamship

Freight Insur. Ass., 368

Addie $x$. Western Bank of Scotland, 623,957

Addison $v$. Gandasequi, 607

- $v$. Mayor of l'reston, 318

Agacio $v$. Forbes, 636

Agar $v$. Athenæum Life Ass. Soc. 651

Asricnltural Cattle Insur. Co. $v$.

Fitzgerald, 501

Aitkin, Re, 213

Alabaster $v$. Harness, 356

Albion Assurance Co., Re, 626

Alchorne $v$. Gomme, 549
Alcinous $v$. Nygrin, 707

Alcock $v$. Alcock, 702

- $v$. Snith, 478

Alcoy R. C. $\imath$. Greenhill, 162

Aldenburgh $v$. Peaple, 554

Alder $v$. Boyle, 112

- $v$. Keighley, $718,723,728$

Alderson $x$. Daddison, 376,385 , $386,392,396,961$

- $\quad r$. Waistell, 785

Aldis $x$. Chapman, 699

Aldons $r$. Cornwell, 503

Aldrell's case, 822, 902

Aldridge $r$. Great Western R. C., 940,941

v. Haines, 832

Alexander $v$. Barker, 637

- $\quad v$. Jenkins, 862

- $\quad v$. Jones, 196

- $\quad$. North-Eastern R. C., 853

- $\quad r$ Thomas, 450

$x$. Vanderzee, 579

Algernon Sidney's ease, 1018

Alhambra, The, 583

Alina, The, 4

Allan $v$. Gomme, 908

- $v$. Sundius, $5 \$ 3$

Allaway $v$. Wagstaff, 885

Allday $v$. Great Western R. C., 939

Allen, Ex prxte, Re Fussell, 561

- $v$. Allen, 671

- $v$. Bennet, 414

- $v$. Edmundson, 462

- $v$. Flicker, 556

- $v$. Hayward, 796

- $v$. Inpett, 37

- $v$. Jackson, 355

- $v$. London and South-Western R. C., 797

- v. New Gas Co., 808, 809

- $\quad$. Sea, Fire and Life Ass. Co., 488

- $v$. Sharp, 147

- $v$. Smith, S78, 928

- $v$. Tayior, 892

- $v$. Waldegrave, 616

- $v$. Walker, 466

B.C.L. 
Allen r. Wright, s:20

Alleyne $r$. Reg, , 261, 278

Allhusen r. Brooking, 520

Alliance Bank $r$. Kearsley, 633, 636

Alloway $r$. Steere, 562

of Simla $r$. Carey, 44

Allsop $r$. Allsnn, is4, $\$ 63$

Allum $r$. Boultbee, 192, 183

Alsager $r$. Close, 972

Alston $v$. Grant, $767, s 00, s \& 1$

- r. Herring. 94, 9\$1

- $r$. Scales, sio

Alton 2 . Midland R. C., 312, 946, 969

Ambergate. \&c., R. C. $v$. Midland R. C. 879

Ambrose $\tau$. Kerrison, 700

American Ilust Corporation $v$, Hendry. 554

Amott $r$. Holden, 155

Anderson $v$. Gorrie, 104, 1i1

$$
\begin{aligned}
& \text { - } \quad \text { Martindale, } 263 \\
& \text { - } \quad \text {. Morice. } 112 \\
& \text { - } \quad \text {. Oppenheimer, ss. } \\
& \text { - } v \text {. Radcliffe, } 356 \\
& \text { - v. Read, } 354
\end{aligned}
$$

Anlrewes $r$. Elliott, 43

Andrews, Ex partc, 237

$$
\begin{aligned}
& \text { - } \quad r \text {. Dally, } 616 \\
& \text { - } \quad \text { E.lliott, } 961 \\
& \text { - r. Lairrence, } 501 \\
& \text { - } \quad \text {. Marris, 829 } \\
& \text { - v. Mockford, 77, } 953
\end{aligned}
$$

Angell $r$. Duke, 387

Angus $x$. Clifford, 336

- . Dalton, $\$ 93$ (see Daltou ข. Angus)

- . MeLachlan, s78, 928

Anoll. r. Hanteock. $67 \mathrm{I}$

- (6 Mol. 27). 759

- (6 Mod. 30s), 221

- (11 Mon. 99), \$45

- (1 P. Wins.), 221

- (1 Salk. 246), 207

- Es parte, 233

Anonymons case, 593

Auseli $c$. Baker, 275

Anthony r. Haneys, 206

Applehee r. l'ercy, 786

Aprleby r. Franklin, 100, 102

- . Johnson, 298

- t. Myers, 113, 719

Aplileton r. Binks, 622

$$
\text { r. Campihell, } 365
$$

A pus r. Dav, ] 83,975

Aroher $t$. Buynes, $\$ 13$

$$
\text { - t. Jajues, } 250
$$$$
\text { - c. Markli, } 361
$$

Arden r. Pullen, 8.34

- r. Turker, 636
Arg. Mitcheson $r$. Nicol, 114

Arkwright $v$. Gell, 903

Arnistead $x$. Wilde, 9.27

Armory $v$. Delamirie, $74 \overline{7}, 912,9 \overline{7}$, 1068

Arinstrong, In re, cx partc Gilchrist, ist

$v$ Sancaslitive and Yorkshire R. C., $7 \$ 9$

- $\quad$ :. Milburn, 159

- $\quad v$. Stukes, 57\%, 609, 611. 613

r. Toler, 350, 351

Armsworth 2 . South-Eastern I. C., 815

Armytage $x$. Haley, 975

Aruison r. Smith, 953

Arinold $v$. Blaker, 14

$$
\begin{aligned}
& \text { - } v \text {. Cheque Bank, 452 } \\
& \text { - } \quad \text {. Holbrook, 14, 209, } 211 \\
& \text { - } v \text {. Jetferson, } 948 \\
& \text { - v. Mayor of Poole, 613, } \\
& 644
\end{aligned}
$$$$
\text { v. Ridge, } 3
$$

Arrow Shipping Co. 2 . Tyme Jn. provement Conmmissioners, 757

Arrowsmitls $v$. Le Mesmrier, 824

Arthur, Re. T21

- $\quad$. liaton. 605

- 2:. Bokenhan, 18

Ash $v$. Daunay, 877,879

Asbiury Railway Carriage and lron Co. $v$. Riche, $30 j, 65 i$

Asliby $v$. Ashby, 712

- v. White, 83, 85, 87, 89,99 , $7 \pm 3,766^{\circ}$

Aslicroft $x$. Bourne, 832

Ashendon $v$. Loudon, Brighton, sc., R. C., 938

Asher $r$. Whitlock, 868

Ashtield $v$. Ashtield, 514

Aslifortl $v$. Redford, 579

Ashley $v$. Harison, 92

Ashmole $v$. Wainwright, 70 T

Ashpitel r. Bryan, 960

Asliton $x$. Shermau, 615

Aslwworth $t$. Mounsey, 315, 575

$$
\imath \text {. Stanwix, } 808
$$

Asken's, Dr., case, 215

Aslatt $r$. Southampton, \&c.., 218

Aslin $v$. Parkin, $\$ 68$

Aspden 2 . Seddon, 80

Aspuliu 2 . Austin, 301

Aspinall $r$. Wake, 711

Assoj r. Yates, 94, is9

Atherley 2 . Harvey, 39

Atkins i. Arcedeckne, $30 \%$

- $\quad$. Banwell, 305

- ข. Culwood, 695

Atkinson $r$. leuby, 281,356 
Atkinson $v$. Newcastle and Gateshead Waterworks Co., $98,10 \overline{7}, 760$

- $\quad$ r. Pocock, 333

- $\quad$ s. Stephens, 323, 605, 722 2. Warne, 826

Atkyns $v$. Kimnier, ${ }^{\circ} 361,725,726$, 989

- $v$. Pearce, 698

Atlee $v$. Backhouse, 616

Attack $v$. Bramwell, 567, 972, 973

Attenborough $v$. St. Katharine's

Dork Co., 225

Att.-Genl. v. Barker, 25, 33

- $v$. Conduit Colliery Co. 82

- $\quad v$. Constable, 33

- v. Cox, 564

- $\quad v$. Ioughty, 902

- v. Fullerton, 526

- $\quad v$. Great Eastern R. C.,651

-. $v$. Hallett, 3,33

- v. Halling, 25

- $\quad$ i. Hertford (Marquis of), 6

- v. Hollingwortll, 281

- $\quad$. Hormer, 867

- $v$. Kingston, 33

- $\quad v$. Lamplongh, 6

- v. Manchester (Corporation of), 820

- $\quad v$. Metropolitan R. C., 96

- $\quad$. Pratt, 453

- v. Shetfield Gas Consumer's' Co., 820

- $v$. Sillem, 993

- $\quad$. Tomline, 79, 82

- v. Walthamstow, 219

- v. Windsor (Dean, \&c., of), 36

Att.-Gen. Lancaster $v$. Dnke of Devonshire, 231

- v. London and Nortl. Western R. C., 145

Attwood v. Emery, 579

- $\quad v$. Sellar, 10, 19

- $\quad v$. Small, 333, 338, 345

- v. Taylor, 742, 743

Aubrey $v$. Fisher, 5.31

Aulton $v$. Atkins, 245, 629

Auriol $v$. Mills, 558

Austin, app., Dowling, resp., 824, $82 \pi, 839$

- v. Dowling, 62

- v. Evans, 183

- $\quad$. Great Western R. C., 946

- $v$. Guardians of Bethmal Green, 643

- v. Manchester, Sireffield aud Lincolnshire R. C., 937, 941
Anstralasia (Bank of) v. Ineillat, 348,634

Antey $v$. Hutchinson, 606

Auworth $v$. Johnson, 533,536

Avards $v$. Rhodes, 43

Avery $v$. Bowden, 113

- v. Cheslyn, 537

- v. Langford, 363

Awle $v$. Dixon, 468

Axford $v$. Reicl, 688

Ayerst $v$. Jelıkins, 366

Aynsley $v$. Glover, 895

Ayrey $v$. Fearnsides, 487

Ayscough $v$. Bullar, 117

Azémar ₹. Casella, 339

b.

BABBAGE $v$. Coulbourn, 42

Balscock v. Lawson, 329.601

Babomneau $v$. Farrell, 860

Bachelour $v$. Gage, 558

Backhouse $v$. Bonomi, $71,82,89$, $158,159,884$

i. Hall, 379

Bacon Ex parte, I re $^{2}$ Bond, 260 - v. Dubarry, 623

Baddeley $v$. Denton, 62

badeley $v$. Consolidated Bank, 628 $v$. Vigurs. 974

Badische Anilin Fabrak v. Sehott, $354,361,363$

Baerlein $v$. Chartered Mercantile Bank, 52

Bagge $\tau$. Mawby, 549

Bagnall $v$. London and NortliWestern R. C., 82

Bagot $v$. Bagot, 529

Bagneley $v$. Hawley, 925

Bahia, \&e. R. C.. In re, 960

Bailey, In re, 236

- v. Appleyard, $890^{\circ}$

- v. Bidwell, 499

- $v$. De Crespigny, 271

- v. Harris, 349

- v. Macanley, 600

- v. Porter, 490

- $v$. Stephens, 15

- $v$. Swecting, 406, 413

Bain $v$. Fothergill, $733,730^{\circ}$

Baines $v$. Evining, 598, 600

- $v$. Geary, 363

Baird $v$. Fortune, 158

- $v$. Williamson, 83

Baker, Re, 63

- $v$. Bank of Australasial, 225

- v. Gray, 399

- v. Hedgecock, 363

- v. Holtzaptlel, $546^{\circ}$ 
Baker $\boldsymbol{r}$. Sampson, 697

- r. Sehright, 532

- 2 . White, 355

Baldry $v$. Bates, 601

Baldwin $v$. Casella, 786

- $r$. London, Chatham and Dover R. C., 738

Palfe 2 . West, 779,919

Balfour $r$. Sea Fire. sic., Co., 443

Ball, Ex purte, re Shepherd 101

- $v$. Dunsterville, 636

- $v$. Storie, 294

- ข. Warwick, 356

Ballacorkish Mining Co. $v$. Harrison, $7 \%, 905$

Ballard $r$. Dyson, 908

- $\quad v$. Tomlinson, 905

Bally $v$. Wells, 270,558

Balmain $x$. Lickfold, 67

Baniford $v$. Turnley, $8 \$ 1$

Bandon (Earl of) $v$. Becher, 261

Jandy $x$. Cartwright, 522.2

Bankart $\tau$. Bowers, 112

$v$. Tennant, $s \leqslant 9$

Banker $x$. Midland R. C., 812

Bankers' case, 242

Banks, app., Crossland, resp., 391

- r. Foodfellow, 704

- $\quad r$. Rebbeck, 229

Banner Ex parte, re Blythe, 311, 313

- $v$. Berrilge, 153

Bannennan $x$. White, $3 \$ 3$

Banyster $x$. Trussel, 707

Barber $v$. Brown, 305

$$
\begin{aligned}
& \text { - } \quad v \text {. Fox, } 299 \\
& \text { - } \quad \text {. Lamb, } 261 \\
& \text { - } x \text {. Lawrence, } 544 \\
& \text { - } \quad \text {. Lesiter, } 91,840,843,981 \\
& \text { - } r \text {. Meyerstein, 506 } \\
& \text { - } \quad r \text {. Pott, } 608 \\
& \text { - } r \text {. Riclards, 456, } 457
\end{aligned}
$$

liarber surgeons of London 2. Pelson, 647

liarclay $x$. l'earson, 27s

l'arden $r$. le Keverber 700

Parham $x$. Dennis, 969

liarker $x$. Allan, 369

- $\tau$. Highley, 606

- $\quad$. Midlanil R. C., 778

- $\quad$. St. Guinton, 279

- $\tau$. Sterue, 458,477

- 2 . Stone, 48.

Barley $\tau$. Walford, 35 ?

liarlow r. Koss, 5

Baruard $v$. Coulscall, 555

Barnarliston $r$. Soause, 19, 73,104

Barzurdo $r$. Ford, 237

$$
\text { - } \text { r. IlcHugh, } 23 \pi
$$

Harnes $r$. Jonch, 892

$$
\text { - } r \text {. Trye, } 689
$$

Barnes $x$. Ward, 754, 762, 817

Birnett $r$. Allen, 862

- $\quad r$. Guilliford (Earl of), 121, 709,874

- $\quad v$ Lambert, 652

- $\quad v$. South London Tramways Co., 623

Barney r. Adams, 207

Baron $v$. Husluand, 317

larongl $v$. White, 49:3

Barret $r$. Blagrave, 295

Barrett $v$. Parrett, 530

$v$. Long, $850, \mathrm{~s} 60$

Barrick $v$. Buba, 707,719

Barrowet, Ex parte, 9s6, 958

Barrow, Ex yarte, 663

- v. Arnand, 9s0

- v. Dyster, $586^{\circ}$

- $\quad$. Isilacs, 565

Barry $v$. Croskey, 774

- ¿. Peruvian Corporation, 52

Barthulomew $v$. Bushnell, 340, 769

Bartlett $2:$ Baker, 755 $\imath$. Markwick, 113, 729

- $v$. Holmes, 504, 730

- $\quad$. Purnell, 415

- $\quad$ : Vinor, 349

- 2 . Wells, 142, 395, 674

Barton 2 . Bricknell, 831

- ข. Gainer, 399

- $\quad$. Pigrott, 349

Bartonshill Coal Co. $v$. MeGuire, 809. $\$ 11$

$\imath$. Reit, 790 , 809

barwick $v$. English Joint Stock Bank, 330, 331, $333,623,624,793$

Basebé $r$. Matthews, $8 \neq 3$

Bass 2 . Gregory, 902

Basset $r$. Long, 61

Bassett $v$. Godsehall, 832

Basten $v$. Carew, 832

liatard $v$. Hawes, $30^{-}, 205,630,722$

Batchelor $x$. Fortescue, 754

Bateman r. Bluck, 211

- $\quad v$. Lyall, 863

- $\quad r$, Mid-Wales R. C., 645

-- $\quad$. Poplar Board of Works, 759

liateh is case, 881

Bates $r$. Hewitt, 331

lateson $x$. Gosling, 115

Bathurst (lBorougli of) $r$. Macpher. son, $9 \bar{i}, 95$

Batson r. liung, 381

- $\tau$. Хewman, 354

Hatteshill $v$. Leed, 973, 975

Batthyany $\therefore$. Walford, 145 
Battley $v$. Lewis, 638

Batut $v$. Hartley, 916

Bawden $v$. Howell, 636

- $v$. London, Edinburgh and Glassow Insurance Co., 625

Baxendale $v$. Bennett, 468, 476,482

$$
\begin{gathered}
-\quad v . \text { Great Eastern R. C., } \\
935 \\
-\quad v . \text { Great Western R. C., } \\
\quad 936 \\
-\quad v . \quad \text { London, Chatham } \\
\text { and Dover R. C., } 736
\end{gathered}
$$

Baxter $v$. Portsmonth (Earl of), 701

- v. Taylor, 876

Baỵley, Ex parte, 214

- $\quad v$. Bradley, 519

- $\quad v$. Fitzmanrice, 297

- $v$. Great Western R. C., 891, 908

- $v$. Manchester, Sheffield and Lincolnshire R. C., 793

- v. Wilkins, 603

Baylis $v$. Dinely, 670

- $v$. Le Gros, 269, 535

- $v$. Lintott, 67

- $v$. Strickland, 829, 832

Bayliss $v$. Fisher, 567

Baynes $v$ : Brewster, 141, 825

Baynton $v$. Collins, 686 v. Morgan, 563

Bazeley $v$. Forder, 697

Beal $v$. South Devon R.C., 939, 939

Beale $\imath$. Caddick, 630

- $v$. Monls, 638

- $v$. Sander's, 321, 536

Bealey $v$. Steuart, 300

Beard $v$. Webb, 700

Beardmore $r$. Carrington, 975,976

Beasley $r$. Clarke, 895

$$
\text { - } v \text {. Rooney, } 686
$$

Beatson $v$. Skene, 851,857

Beattie $v$. Ebury (Lord), 396

$$
v \text {. Nair, } 207
$$

Beatty $v$. Gillbanks, 1026

Beanrain $v$. Scott, 106

Beavan $v$. M'Donnell, 702, 703

Beanfort (Duke of) $v$. Bates, 535

$$
\text { - } \quad v \text {. Smith, } 12
$$

(Mayor of), 581

Beanmont $v$. Greathead, $397,49 \mathrm{~S}$

$v$. Reeve, $288,310,325$

Becher $v$. Great Eastern R. C., 946 - $v$. Jones, 743

Beck $v$. Pierce, 689

Beckett $v$. Adidynan, 379

$$
\begin{aligned}
& \text { - } \quad v \text {. Midland R. C., } 95 \\
& -\quad v . \text { Ramsdale, 25\% } \\
& -\quad v . \text { Tasker, } 683
\end{aligned}
$$

Beckford $v$. Crutwell, 580

Beckliaw v. Drake, 578, 636, 660, $724,725,731$

Beckwith $v$. Philby, 827

Beildall $v$. Maitland, 20 7 , 208, 209, 1028

Bedford $v$. Deakin, 639

Bedford (Duke of) $v$. The Trustees of the British Mnseum, 295

Becch $v$. Jones, 454

Beely $v$. Parry, 556

Beer $v$. Foakes, 397

Beeston $v$. Beeston, 354

v. Weate, 903

Begbie v. Phosphate Scwage Co., 311,328

Behn $r$. Burness, 339, 342, 722

- $v$. Lemble, $773,775,952$

Beirne $v$. Dord, 248

Belcher $v$. MeIntosh $\mathbf{1}, 534$

- $v$. Smith, 226

Beldon $v$. Campbell, 605

Belfast and Ballymena, \&c., R. C. $v$. Keys, 944

Belfour $v$. Weston, 546

Belknap's case, 700

Bell $v$. Antwerp Line, 130

- $v$. Buckley, 456, 498

- v. Carey, 720

- $v$. Ingestre (Viscount), 456

- $v$. Midland R. C., 876, 978

- v. Jíorrison, 153

- v. Quebec (Corporation of), 76

- $\imath$. Simpson, 978

Bellairs $v$. 'Tncker, 332

Bellamy $v$. Burch, 863

- $v$. Debenham, 299

Belshaw v. Bush, 115

Bellson, $R e, 236$

Belt $v$. Lawes, 182, 859

Benett $v$. Peninsular and Oriental Steamboat Co., 138

Benham $v$. United Guarantee, \&c., Co., 344

Benjamin v. Storr, 96, 97

Bennett $v$. Allcott. 968

- v. Bayes, 973

- v. Deacon, 849

- $v$. Mellor, 926

Bennison $v$. Cartwright, 900

Beuns v. Mosley, 237

Benson v. Chapman, 606

- v. Duncan, 605

- $\quad$ : Flower, 660,661

Bent $v$. Wakefield Bank, 320

Bentall $r$. Burn, 40S

Bentinck $v$. Dorrien, 472

$$
\begin{aligned}
& \imath \text { Lomlon Joint Stock } \\
& \text { liank, } 445
\end{aligned}
$$


lientley, Ro, 515

- r. Fleming, 182

- $v$. Grittiu, 695

- $v$. Vilmont, 430

Bergheim $v$. Great Eastern R. C., 931, 945

Berkeley $\tau$. Harly, 399, 622

Berkshire Woollen Co. $x$. Proctor, 592

Bernina, The, 789,815

Bernstein $v$. Baxenulale, 934

Berrey $r$. Lindley, 520

Herringer $\boldsymbol{r}$. Great Eastern K. C., ii1, 969

Rerry $r$ Da Costa, 720, 975

Berwick $\tau$. Horsfall, 306, 579

(Mayor, \&r., of) r. Oswall, $\therefore 90$

Besant $\tau$. Cross, 370

Bessant $r$. Great Western R. C.,647

Bessell $r$. Wilson, 833

Besset, Ex parte, 235

Bessey $v$. Wyudham, 283

Best $r$. Hayes, 2:24

Beswick $v$. Capluer, 58

Bettini $थ$. Gye, 321

Betts $r$. Burch, 724, 725

Bevan $r$. Carr, 392

Beverley $r$. Lincoln Gas Light and Coke Co., 644

Beverley's case, 702, 704

Bewley $r$. Atkinson, s9;

Bibly $r$. Carter, 81, 905

Biccird r. Shepherd, $\delta \subseteq 3$

Bickerlike $r$. Bollman, 461

Bickerton $x$. Burrell, 619

Bickett $r$. SIorris, $\$ \$ 6.888$

Bickforl $v$. Parson, 550

Bideler $x$. Bridges, 397

Biddle r. Bond, 924

Bidlyood $r$. Way, 67i

Biffin $\tau$. Bimell, 696

Bignell $r$. Buzzanl. 864

- r. Clark, 5is

- - Harpur, 712

Bill r. Bament, 114, 412

Bisugle, lic, 501

Binks r. Sourh Yorkshire R. C., 817

Binniugton 2 . Wallis, 288

Birch $r$. Dawson, $53 i$

- $\tau$. Liverpool (Earl of), 392

- r. Stephenson. 52t;

- r. Wijght, 569

Bird r. Boulter, 415,416

- $\tau$. Brown, 30t, s01, 803

- v. (ireville (Lorr), 245, 569

- r. Higgrinson, 390

- r. Hollirnok, 21, 751, 762, 7s9

- r. Jolver, 8ะt

- r. Peagrum, 67\%
Birkenhearl, sr., R. C. $x$ Palcher, - 672

Birkett $v$. Whiteharen Junction R. C., 817

Birkmyr $r$. Daruell, 3\$0, 381

Bishop, Ex parte, lic Fox, 306, 309

- r. Balkis Co., 960

- $r$. Bellord Charity (Trustees of), 799

- v. Elliott, 537

- $v$ Jersey (Countess of), 630 , म335

Bissell $r$. Fox, 481, 483

Blachford $r$. Dor, 843

Blaek 2 . Pallymena Comm., 905

- $x$. Baxendale, 73s

- $v$. Christchurch Finance Co.. 754

- r. Clay, 539

Blackiorongli $r$. Davis, 221

Blackburn $v$. Flarelle, 573

$$
\begin{array}{ll}
-\quad & \text { r. Haslam, } 331 \\
-\quad & \text { Mason, } 585 \\
-\quad \text { Vigors, } 331
\end{array}
$$

Blackbume $v$. Somer, 904

Blackett $x$. Pradley, 13, 884

- $\quad r$. Royal Exch. Ass. Co., 586

ข. Weir, 630

Blackliam $\imath$. Pugh, 851

Blacklock 2 . Dobie, 356

Blackmore $r$. Vestry of Mile End, Sc.. 754

Blades $r$. Free, 617

- . Higgs, 206, 207, 1058

- $v$ Lawrence, 61

Blagg $\tau$. Sturt, 852

Blagrare $x$. Bristol Waterworks Co., i4, 92, 981

Blaikie 2 . Stembrilge, 792

Blair $x$. Bromley, 154, 630

$-v$. Ormond, 155

Blake, In rc, 213

- . Alhion Life Ass. Co., 333, 337,959

- $v$. Barnaril, 784

- $r$ Bealumont, $4 i 1$

- r. Misllamel R. C.. 818

- $v$. Thisst, 753, 798

Blake's case, $290,292,293$

Blakemore $\because$ Bristol and Exeter R. C., 776, 779, 920

Blakesley $r$. Smallwool, 712

blamires, $v$. Lancaslire and Yorkshin li. C., 752

Blaml $\bullet$. Crowley, 268, 590

- r. Ross. Tis

Blandy $x$. De Burah, 312

Blasco $x$. Fletcher, 606

lilayomire $v$. Haley, 968 
Blenkinsop $v$. Clayton, 411

Blewett, app., Jenkins, resp)., 14

igh $v$. Brent, 387

Bliss $v$. Hall, 822, 902

Blofeld $v$. Payne, 85

Bloodworth $x$. Gray, 8 ô2

Bloomer v. Bernstein, 114

Blower $v$. Great Western R. C., 932

Bloxam $v$. Sanders, 426, 949

Bluck $v$. Gompertz, 379

Blyth $x$. Birminghan Waterworks Co., 751

- $v$. Dennett, 979

Boaler $v$. Mayor, 275

Boast $v$. Firth, 719

Boden $v$. French, 593

Bodeuham, Ex parte, 213

Bodger v. Arch, 157, 709

Bodley $v$. Reynolds, 980

Bosgett $v$. Frier, 700

Bolch $v$. Smitb, 754, 767

Bolckow $v$. Seymour, 369

Boldero $x$. London \& Westminster Dise. Co., 284

Bolingbroke (Lord) $v$. Swindon Local Board, 790

Bolton $v$. Lambert, 596

- v. Madden, 353

Bond $v$. Evans, 994

- $v$. Rosling, 518

Bone 2 . Ekless, 352

Bonfield $r$. Smith, 631

Bonham's (Dr.) case, 8

Bonnard $v$. Perryman, 861

Bonomi $v$. Backhonse, 908 (see Back. house $v$. Bonomi)

Bonsey $v$. Wordsworth, 58, 59

Boon v. Howard, 4

Boorman $v$. Brown, 67, 720

Booth $v$. Arnold, 862

- v. Briscoe, 118

- $\quad$. Clive, 116

- v. Taylor, 218

Boraston $v$. Green, 528

Borlick $r$. Head, 813

Borneman v. Wilson, 124

Boroughe's case, 546

Borradaile $v$. Hunter, 1001

Borries v. Imperial Ottoman Bank, 613,614

Borrowman v. Rossel, 371

Bosanquet $v$. Wray, 629

Bosley $v$. Davies, 987

Bostock $v$. North Staffordshire R. C., 820

Boswell $v$. Smith, 636

Bott $v$. Ackroyd, 831

Botterill $v$. Whytchead, 862

Botting $v$. Martin, 556
Bottomley $v$. Fisher, 635

- v. Nuttall, 114, 115, 631, 637

Bottomley's case, 650

Boughton $v$. Knight, 1002, 1004

Boulter $v$. Peplow, 722

Boulton $v$. Jones, 248, 312

Bourne $v$. Fosbrooke, 399

- $v$. Gatliff, 5\$1, 931

-- $v$. Mason, 315

Bovill $v$. Hammoud, 629

Bovins $v$. Hutchinson, 91

Bowdell $v$. Parsous, 113

Bowden $v$. Briscoe, 877

Bowditch $v$. Balchin, 828

Bowen $v$. Anderson, 566

- $\quad v$. Erans, 329

- $v$. Hall, -92, 93, 970

Bower $v$. Hartley, 160

- $v$. Peate, 769, 795

Bowerbank $v$. Monteiro, 467

Bowes $v$. Foster, 283, 9ó

- $v$. Howe, 490

- $v$. Shand, 579, 581

Bowker $v$. Burdekin, 266, 636

- v. Evans, 123

Bowles v. Drake, 65

Bowle's case, 532

Bowman v. Blyth, 994

$v$. Taylor, 276

Bowring $v$. Shepherủ, 586

Bowry $v$. Bennet, 365

Box $v$. Green, 58

- $v$. Jubb, 73

Boxsius $v$. Goblet, 852

Boyce $v$. Higgins, 99, 115 i. Warburton, 743

Boyd $v$. Bischoffsheim, 50

Boydell $v$. Drummond, 376, 391

Boynton $v$. Boyntou, 124

Bracegirdle $v$. Heald, 391 $v$ Orford, 975

Bracewell $v$. Williams, 311, 315

Bradburn $v$. Foley, 17, 525 $v$. Great Western R. C., 818

Bradbury, Ex parte, 237 v. Mlorgau, 713

Braddick $v$. Thom 1 son, 293

Brad ford (Corporation of) $v$. Pickles, 77,908

Bradford $\imath$. Williams, 112

Bradlaugh $v$. Clarke, 99, 318

— $\quad v$. Newdegate, 356

Bradley $v$. Copley, 914

- $\quad v$. Eyre, 261

- $\quad v$. Holdsworth, 387

- $\quad v$. Newcastle (Master, sc., of), 581 
Bradshaw r. Beard, 700

- r. Lancashire and York. shire R. C., 710,711

Brady r. Oastler, 574, 721

$$
\text { - } v \text { Todi, } 601
$$

Brain $x$. Thomas, 107,760

Brainard $r$. Connecticut River R. C., 753

Braithwaite $r$. Skinner, 759

Bramley $v$. Chesterton, 740

Branuigan $x$. Robiuson, 812

Brampion $x$. Beddoes, 362

Bramweli $v$. Attack, 880

Braudâo v. Barnett, 9

Braudon $v$. Curling, 707

$$
\text { - } \quad \text { v. Hubbard, } 636
$$

Brandt r. Lawrence, 114

Brantom $x$. Griffits, 385

Brase v. Maitland, 775, 941

Brassington $v$. Ault, 713

Brasyer $r$. Jlaclean, 90

Braunstein $x$. Accidental Death Insurance Co., 4:

Brayne $r$. Bather, 868

Bree $r$. Holbech, 159

Breedon $x$. Gill, 222

Brenan's case, 237

Brett r. Brett, 5

Brettel $v$. Willianı, 634, 635

Brewer $x$. Jones, 605

Brice $v$. Bannister, 446

Bridden $\tau$. Great Northern R. C.. 931

Bridge $x$. Grand Junction R. C., 211,787

Bridger $v$. Savage, 354

Briclges $x$. Garrett, 602

- v. Hawkesworth, 912, 1068

- r. Nortli Lunilon R. C., 751. 752

Brierly v. Kendall, 914, 974

Briggs $v$. Oliver, 752

Bright $x$. Walker $893,895,901$

Brine r. IMazalgette, 850

- r. Great Western R. C., $1+2$

Brimsinead $\imath$. Harrison, 257, 259

Brissac $r$. Rathloule, :61

Bristol, \&c., R. C., Re, 217

liristol Aerated Bread Co. v. Maggrs, 297,299

Bristol and Exeter R. C. r. Collins, 94'2

Bristol r. Wilsmore (Earl of), 206

Bristow r. Cormican, 867

- $v$. Sequeville, 14

- r. Towers, 707

- r. Whitmore, 606

Britnin $v$. Ronsiter, 391, 405

Britisls Columbia Saw Mill Co. 2 . Netsleshifp, 735, 738
British Empire Mutual Life Assurance Co. $v$. Browne, 301

- British Linen Co. r. Calledonian Insurance Co., 482

British Mutual lank Co. $v$. Charnwood Forest Railway, 623

British Wagon Co. $v$. Lea, 446

Brittain $v$. Fimmaird, $\$ 32$

$$
\text { - } v \text {. Lloyd, } 304
$$

Britton $x$. Cole, s01

- $\quad v$. Great Western Cotton

Broad $v$. Ham, 843

$$
\text { Co., } 764
$$

- $\quad v$. Jolliffe, $3: 8$

Broadbent $v$. Ramsbotham, 76,905 r. Wilkes, 15

Broadwood v. Granara, 578, 928

Brocklesby $x$. 'lemperance Bulluing Society, 602

Brodie $r$. Howard, 605

Brogilen $v$. Metropolitan R. C., 249, 298

Bromage $v$. Prosser, 836, 816

Brook $v$. Hook, 505

- $r$. Riwl, 864

Brooke $v$. Brooke, $67 \bar{\tau}$

- $v$. Montarne, 855

Brooker $v$. Scott, 669

Brookes $z$. Drystale, 267

Brooks $x$. Elkins, 487

- $\quad r$. Hassall, 601

- $\quad$. Mlitehell, 492

Broon $\tau$. Bachelor, 379

$$
\text { v. Hall, } 736,740
$$

Broome $r$ Wooton, 258, 259

Broughton $x$. Jackson, 826

broun $x$. Kemnedy, 322

Brown, Ex parte, 237

- $\quad$. Accrington Cotton Co., $81 \mathrm{~s}$

- $r$. Ackroyd, 697

- $r$. Alabaster, 891

- ¿ Boorman, 767,769

- $v$. Brine. 311

- $r$. Butterley Coal Co., 811

- $v$. Byrne, 578, 583, 587

- r. Cliajman, 830

- r. Cocking, 62

- v. Colley, 105

- $r$. De Winton, $486,4 S 7$

- v. Glem, 554

- v. Great Western R. C., Tss

- $v$ Harralan, 486

- r. Hawkes, 843

- c. Howard, 159

- $v$. Joirell, 702

- r. Jones, 829

- $v$. killger, 631

- $r$. Langley, 371

- r. Mallett, 755 
Brown $v$. Muller, 440

- v. Notley, 873

- v. Powell Coal Co., 505

- $v$. Robins, 81

- v. Shevill, 551

- v. Smith, 863

- $v$. Tapscot, 629, 630

- $v$. Wales, $520^{\circ}$

- $v$. Wooton, 258

Browne $v$. Burton, 265

- $v$. Dawson, 207

- $\quad$. Hare, 506

- $\quad v$. Joddrell, 515

- $v$. La Trinirlad, 650

- v. lee, 308

- v. Powell, 545

- $\quad v$ Price, 720

Browning $v$. Dunn, 554

- v. Provineial Ins. Co. of

Browmigg $v$. Rite, 636 Canada, 622

Brutf $v$. Conybeare, 575,576

Brunsden v. Humphrey, 260

Brunskill $v$. l'owell, 59

Brunswick(Duke of) $v$. Harmer, 158, 858

Brunt v. Midland R. C., 934 $v$. Slowman, 975

Bryant $v$. Bobbett, 838

$$
\begin{array}{ll} 
& v \text {. Clutton, } 831 \\
- & v . \text { Foot, } 19 \\
- & v \text { Herbert, } 67 \\
-\quad & v . \text { Lefever, } 72 \\
-\quad & v \text {. Wardell, } 949
\end{array}
$$

Buccleugh (Duke of) $v$. Metropolitan Poarlel of Works, 95 $v$. Wakefielı,

Buchanan $v$. Hardy, 1035 $14,80,908$

Buckby $v$. Cotes, 878

Buckhurst Peerage case, 8

Buckland $v$. Butterfield, 537, 539

Buckle v. Knoop, 583

Buckley, Ex parte, 634

- v. Barber, 641

- v. Collier, 677

- v. Gross, 912,1068

Buckmaster $x$. Russell, 325

Bueks $v$. Sonth Yorkshire and River

$$
\text { Dun Co., } 755
$$

Buckton $v$. Higgs, 152

Buenos Ayres, \&c., R. C. $v$. Northern

R. C. of Buenos Ayres, 43

Bull $v$. Chapman, 349,652

Bullen $v$. Sliarp, 626

Buller $v$. Crips, 485

Bullers $v$. Dickinson, 899

Bullock $v$. Caird, 44

- $\quad$. Dodds, 707
Bulwer $r$. Bulwer, 527

Bunbury Hewson, 121

Bunch 2 . Great Westem R. C., 913

Bunn v. Guy, 362

Bunting $v$. Hicks, 76, 905

Burchell $v$. Clark, 4 $v$. Huskisson, 754

Burchfield $v$. Noore, 502

Burden, Ex parte, re Neil, 724

Burder $v$. Veley, 222

Burlett, In re, Exparte Byrne, 348 $v$. Colman, 879

Burdick $x$. Sewell, 508

Burges $x$. Lamb, 532

- $v$. Wickliam, 340, 583

Burgess $v$. Clements, 927

- $v$. Eve, 331

$$
\text { v. Gray, } 795,799
$$

Burghart $v$. Hall, 669

Burke $v$. Rooney, 140

- $v$. Sonth-Eastern R. C., 9.22

Burley $v$. Bethune, 832

Burling $v$. Reed, 208, 210

Burlinson $v$. Hall, 446

Burmester $v$. Norris, 605

Buruarl, app., Haggis, resp., 669, 673

Burnby $v$. Bollett, 819

Burnes $v$. Penuell, 1022

$$
v \text {. Purnell, } 338
$$

Burnett v. Lynch, 558

Burnley Co-operative Society $v$. Casson, 667

Burns $v$. Poulsom, 790

Buron $v$. Denman, 103, 804, 880

Burridge $v$. Nicholetts, $205,206,877$

Burrows $v$. March Gas and Coke Co., 736

Burt $v$. Haslett, 537

Burton v. Gray, 295

- v. Great Northern R. C., 301

- $v$. Henson, 786

Bush v. Martin, 156

v. Steimmann, 799

Bushel $v$. Wheeler, 408

Bushell's case, 105

Bustros $v$. White, 166

Buszard $v$. Capel, 544

Buteher $v$. Butcher, 207, 873

- v. London and SouthWestern R. C., 947

- v. Stead, 666

- $v$. Stewart, 380

Butler, Ex parte, 690

- $\quad$. Butler, 682

- $v$. Hunter, 795, 799

- v. Knight, 84

- $\quad v$. Manchester, Sheffield, and Lincolushire R. C., 786 
Butt $v$. Great Western R. C., 932, 936, 937

Buttemere $v$. Hayes, 38T

Buxton $v$. North-Eastem R. C., 764, 787

- r. Rust, $37 \%, 414$

Brme $x$. Boadle, 790

- $\quad r$. Van Tienhoren, 299

c.

Canaval (Duke de) $v$. Collins, 706 Cahill $r$. Dawson, 720, 973

- $v$. Lonilon and North. Western R. C., 944

Caine $\tau$. Coulton, 152

- $r$. Horsfall, 582

Caines $v$. Smith, 112

Calcraft $r$. Gilbs, 183

Calcler $v$. Dobell, 607, 622

- $v$. Halket, 106

Caldicott $v$. Griffiths, 629

Caledonian Insurance Co. $v$. Gilmor, 42

Caledonian R. C. $v$. Carmichael, 744 r. Sprot, 884,909 $v$ W ilker's Trustees, 96

Callaghan $v$. Callaghan, 283

Calley थ. Charman, 697

Callisher $r$. Bischoffsheim, 311, 313

Callow $v$. Jenkinson, $1 \pm 2,261,618$

Calmady $\imath$. Rowe, 581

Calton $v$. Bragg, 743

Calvin's ease, 20, 1013

Calye's ease, 926,927

Caniac $t$. Warriuer, 500

Cambefort $r$. Chajman, 258, 273

Cambridge (Mayor, \&e., of) $r$. Dennis, 290

Cameron 2 . Charing Cross R. C., 96

Camilge $r$. Allenby, 493, 494

Camniell 2 . Sewell, 260, 261, 605

Camoys r. Suturr, 920

Campanari $\because$. Woodburn, 617,712

Campluall $v$. Fleming, 328

$$
\begin{aligned}
& \text { - } \quad \text {. Hicks, } 608 \\
& \text { - } \quad \text { r. Loader, } 229 \\
& \text { - } \quad \text {. lieg., } 1095 \\
& \text { - v. spottiswoode, 853 }
\end{aligned}
$$

Caundian prisoners' case (The), 236 , 237

Cauham r. Barry, 279

Cann v. Wilson, $336^{\circ}$

Cannam $v$. Farmer, 395, 961

Cannan $\tau$. Reyuolsk, 201

Canning $v$. Fàıนเคตr, 332

Caut $\tau$. l'arsons, 824
Canterbury (Viscomnt) $r$. Attorney-

General, 103, 241, 53:3

Cape $v$. Scott, 211

Capel $v$. Buszard, 554

- $v$. Jones, 845

Capital and Counties Bank $v$. Henby, 861

Capper $\imath$ : Wallace, 583

Card $r$. Case, 786

Cardross (Lord), Re, 213

Carlill $v$. Carbolic Smoke Ball Co., $298,300,311,318-320$

Carlon $v$. Ireland, 444, 493

Carlos $r$. Fancourt, 450

Carlyon 2 . Lorering, 15

Carmarthen (Javor of) $v$. Lewis, 646

Carne $v$. Brice, $67 \%$

Carnes $v$. Nisbett, 358, 726

Carpenter $v$. Buller, $\mathbf{S} 4$

Carpue $r$. Loudon and Brighton

R. C., 116,790

Carr $v$. Allatt, 400

- $v$. Duckett, 864

- v. Foster, 896, 901

- $v$. Hinchliff, b13

- v. Hood, 74, 853

- v. Jackson, 619

Carr $v$. Lancashire and Yorkshire R. C., 941

- $v$ London and Nortl-Western R. C., 961,964

- $v$. Montetiore, 582

- $v$. Smith. 630

Carratt $x$. Morley, 829, 830

Carrington $v$. Roots, 389

Carrol $v$. Blencow, 700

Carstairs $v$. Taylor, 882

Carter $v$. Carter, 524

- $v$. Crick, 343,579

- v. Drysuale, \$14

- $v$. Flower, 461

- $r$ Scargill, 112

- v. Stubbs, 140

- $v$. Whalley, 641

- $v$. White, 468,471

Cary $v$. Matthews, 554

Casey $v$. Aruott, 129

Cashill $x$. Wright, 927

Casseres $r$. Bell, $70 \boldsymbol{\tau}$

Castellain $v$. Preston, 332

Castle $v$. Sworder, 408

Castrique $r$. Beh:ens, $\pi 6, s+3$

$$
\begin{array}{ll}
\text { - } & v \text {. Beruabo, 111, } 464 \\
-\quad & v \text {. Pmrie, 261 } \\
-\quad & \text { Page, 2, } 3
\end{array}
$$

Castro r. Murray, 46

Caswell 2 . Worth, 705.789

Catelipole $x$. Ambergate, sc., R.C. 768

Caton $r$. Caton, 376 
Cator $v$. Great Western Insurance Co. of New York, 723

Cattell $v$. Ireson, 988

Caterall $x$. Hiudle, 602

Cattle $r$. Stockton Waterwks. Co.,92

Cattley $v$. Arnold, 511

Catton $v$. Bennett, 726

Caunt $v$. Thompson, 462

Cave $r$. Hastings, 376

- $v$. Mills, 960

Cavcy $v$. Leadbitter, 881

Caygill $v$. Bowcr, 623, 624

Cayzer $v$. Carron Co., 788

Cliadborn $v$. Green, 521

Chadburn $v$. Moore, 603

Chadwick $v$. Herapath, 846

$$
\text { - } \quad v \text {. Magor, } 911
$$

Chalmers $v$. Shackell, 845

Chamber Coll. Co. $v$. Hopwood, 903

Chamberlain $v$. Boyd, 863

$$
\begin{aligned}
& \text { - } \quad v \text {. Hazlewoor, } 968 \\
& \text { - } \quad v \text {. King, 116 } \\
& \text { - } v \text { Williamson, } 710 \\
& v \text {. Young, 451 }
\end{aligned}
$$

Chamberlaine $v$. Chester and Birkenheal R. C., 749

Chambers $v$. Caulfield, 183, 975

$$
\begin{array}{ll}
- & v \text { Jennings, 221 } \\
- & v . \text { Kingham, 562 } \\
- & v \text { Mason, } 604 \\
- & v . \text { Miller, 206 }
\end{array}
$$

Chambres $v$. Jones, 606

Chandelor $v$. Lopus, 342

Chandler $v$. Broughton, 786

$$
\text { - } \quad v \text {. Doulton, } 568
$$

Chandos v. Talbot, 531

Chanter $v$. Hopkins, 339, 342

Chapleo $v$. Brunswick Building Society, 602, 624

Chaplin $v$. Clarke, 298

$$
\text { - v. Rogers, } 408
$$

Chapman Ex parte, 232, 1055

$$
\begin{aligned}
& \text { - } \quad v \text {. Great Western R. C., } \\
& 943 \\
& \text { - } \quad v \text {. Partridge, } 417 \\
& \text { - } \quad \text {. Pickersgill, 766, } 814 \\
& \text { - } \quad v \text {. Rothwell, 754, } 767 \\
& \text { - } \quad v \text {. Speller, } 925 \\
& \text { - } \quad v \text {. Van Toll, } 966
\end{aligned}
$$

Chappell $v$. Gregory, 534

Chapple $r$. Cooper, 668, 669, 692

Charles $v$. Altin, 730

- v. Blackwell, 483

- $v$. Taylor, 807

Charlesworth $v$. Holt, 268

Charman $v$. South-Eastern R. C., 762

Charnley $v$. Grundy, 504
Chascmore 2 . Richards, $76,77,79$, - 905

- $\quad v$. Turner, 157, 324

Chater $v$. Beckett, 378

Chauntler $v$. Pohinson, 881

Cheesman $r$. Exall, 924

Cheetham $r$. Hampson, 526, 536

- $\quad v$. Janchester (Jayor, \&c., of), $\mathrm{S01}$

Cherry $v$. Endean, 224

- $\quad v$. Heming, 261, 392

- $v$. Thompson, 113

Chesman $v$. Naiuby, 358

Chester $v$. Powell, 248

Chesterficld (Earl of) $v$. Janssen, 355

Chereley $v$. Fuller, 297

Chew $r$ : Holroyd, 64

Chichester $v$. Lethbridge, 891

Chidell $v$. Galswortlyy, 400

Child, Ex parte, 236

- $v$. Aftleck, 849

- $v$. Stenning, 119, 569

Childers $v$. Wooler, $773,780,803$, 952

Childs $r$. Jonins, 712

Chilton $v$. Carrington, 230

- v. London and Croydon R. C., 793,976

Chinery $v$. Viall, 426, 913, 949, 972

Chippendale $v$. Lancashire and Yorkshire R. C., 941

$v$. Tomlinson, 664

Chivers $v$. Savage, 62

Cholmeley $v$. Paxton, 532

Chorley $v$. Bolcot, 322

Chown $v$. Parrott, 604, 966

Christie $v$. Borelly, $32 \mathrm{~L}$

- $\quad v$. Davey, 822

- $v$. Winnington, 266

Cliristoffersen $v$. Hansen, 619

Christopherson $v$. Bare, 785

Chudleigh's case, 5

Church $v$. Inperial Gas Light and Coke Co., 644

Churchill $x$. Bertrand, 712

$$
v \text {. Siggers, 838, } 839
$$

Churchward $r$ : Reg., 113, 241

Cincinnati (Bank of) $v$. Buckingham's Executors, 253

Citizens' Bank of Louisiana $v$. First National Bank of New Orleans, 385

City Bank $v$. Barrow, 602

City of Glasgow Union R. C. $v$. Hunter, 96

Clapham $r$. Shillito, 344, 345

Clare $v$. Lamb, $31 \%$

- v. Maynard, 740 
Clare and Darnell's case, 668

Clark $v$. Alexander, 156

- v. Chambers, 94, 751, 759

- $v$. Gilbert, 9]4

- r. Gray, 932

- r. Lazarus, 500

- v. Molyneux, 848, 850

- $r$. Newsam, 83j

Clarke, In re, 238

- $v$. Cogge, 891

- $r$. Cncktielul Union, 644, 645

- $x$. Dickson, 328, 329, 952 .

- $v$. Hart, 961

- $\imath$ Holmes, s0s

- r. Martin, 485

- r. Mlill rall Doek Co., 551

- $v$. Roystone, 586

- $v$. Sniarilge, 511

Clarke's case, 237

Clarkson $v$. Il nsgrave, 81 t

Claxton $v$. Swift, 449

Clay $v$. Sonthern, 622

Clayards 2 . Dethick, 789

Clayton r. Blakey, 510

$$
\text { - } \quad \text { - Corby, 15, } 901
$$

Clayton's case, 265

Cleary $v$. Booth, 1050

Cleather $r$ : Twisden, 635

Clegg $v$. Wearden, 82 - $v$. Rowlind, 529

Clements $x$. Lonilon and Nortls-

- $\quad$. Olarly. 839 Western K. C., 670

Clementson r. Nason, 4

Clemontsour $r$. Blessig, $70 \bar{T}$

Clerk $v$. Berwick (Mlayor, \&e., of), 236

Cleveland r. Spier, 807

Cliff $v$. Midland li. C., 752

Clifford $\bullet$. Brandon, 8:5

- $\quad v$. Laton, 696

- (Lord) $v$. Watts, 268

Clift $r$. Scluwabe, 581, 1001

Clifton, E.c purte, 213

Climier. Wool, 536, 538

Clothier $r$. Webster, 753,881

Clrugh $r$. London anil Nortl-

Westeru R. C., 328, 934

Clowes $x$. Hughes, 549

Clubb x. Hutson, 278

Clugas $r$. Penaluna, 350

Clutton $x$. Atteuborough, 45.

Clyde Xas. Co. $x$. Barelay, 792

Coates $r$. Collin, 271

Coatsworth r. Johison, 520

Colbe $x$. liecke. 315

- r. Great Viestern R. C., 952

- $r$. Stokes, 512,562

Coblett $r$. Grey, 784, 824
Coblett $r$. Hudson, 829

- $v$. Slowman, 235

- v. Warner, 116

Cobledick, Ex perte, 213

Cochran $x$. Retberg, $5 \$ 8$

Cochrane $x$. Mloore, 399, 400

Cockayue $r$. Hodgkisson, 845 , 850

Cockbunn $x$. Alexander, 582, 722

Cockerell, Ex parte, 262

$$
\text { _. } \quad \text {. Aucompte, } 633
$$

- $\quad r$. Cholmeley, 532

Cocking $r$. Wind, $386^{\circ}$

Cockle $\imath$. South-Eastern R. C., 751

Cockilll $v$. Sparks, 325

Cocks $v$. Ilasterman, 476,495

- 2 . Purday, $70 \bar{T}$

Coth $x$. Cabe, s.29, 1044

Coe $v$. Clay, 523

- $v$ Platt, 764,765

- $v$. Wise, 755, 767

Collee $r$. Brian, 630

Coxgrs $v$. Bemand, 779, 917, 920, $921,923,924,931$

Cohen ". Hale, 545

- $v$. Huskisson, 825

- v. Mitchell, 664

- v. Sonth-Eistern R. C., 938, 945

Cohn r. Davidson, 246

Colehester (Ilayor of) $v$. Brooke, 211,1030

Cole $r$. Bishop, 328

- v. Greene, 531

- $v$. Nor!lı-Westem Bank, 431, 602,614

- $x$. Snry, 545

Colebeck $r$. (iirllers' Co., 767

Coleman $v$. Riche's, 797,966

Coles $x$. Paek, 379

- $v$. Strick, 356

Collard $r$. South. Easterm R. C., 7.11

Collen $v$. Wright, 246, 342, 615, 620,741

Collett थ. Curling: 545

- v. Foster, 797,804

- v. J.mion and SorthWestern K. C., 764

Collingwond $r$. Berkeley, 600

Collins r. Blantern, $276,280,282$, 283. 348,351

- $\quad$. Cave, 76, 41, 776, 7\$1, 981

- $v$. Evaus, 334

-- $\quad \therefore$ Johuson, 213

- r. Lncke, 42.357

- r. Martin, 457

- $v$. Midlle Level Commissions:rs, 755,980

Collis $x$. Selelen, 757,776

Collis $x$. Selden, $75 \pi, 776$ 
Colonial Bank v. Cady, 396, 445

Colpoys $v$. Colpoys, 576 $v$. Whinney, 443

Colyer $v$. Finch, 751

Combes's case, 597,622

Commercial Bank of South Australia, In $r e, 466,742$

Commings $v$. Heard, 262

Commissioner of Stamps $v$. Hope, 275

Companhia de Mloçambique $v$. British South Africa Co., 870

Concha $v$. Concha, 115, 261

Congleton (Mayor of) $v$. Pattison, 270,557

Congreve $v$. Evetts, 399

Connor $v$. Kent, 1022

Conolly $v$. Baxter, $\$ 69$

Constable $x$. Nicholson, 15

Constantine $r$. Wellock, 100, 102

Cook $r$. Bath (Hayor of), 901

- $v$. Corbett, 556

- $r$. Field, 356

- $v$. Gordon, 204

- $r$. Hartle, 972

- v. Hopewell, 85, 397

- $v$. Lister, 309,396

- $v$. Moffatt, $2 \Sigma_{3}$

- $v$. Nortl Metropolitan Tram. ways $\mathrm{C}$... 250, 811

- $v$. Ward, 845,858

- $v$. Wildes, 847,850

- $v$. Wright, 313

Cooke $v$. Clayworth, 705

- v. Eshelby, 614

- $\quad v$. Gill, 223

- $v$. Seeley, 606, 636

- $v$. Waring, $72,330,786$

- 2 . Wilson, 622,767

Cooksey $r$. Haynes, 182

Cooling $v$. Great Northern R. C., $18 \%$

Coombes r. Dibble, 354

Coombs $v$. Bristol and Exeter R. C., 597

Coondoo r: Mookerjee, 76, 356, 843

Cooper $x$. Asprer, 226
- $\quad$. Bill, 507
- $\quad$. Crabtree, 87,872
- $\quad v$. Hubbuck, 18, 897, 900
- $v$ Lloyd, 697, 698
- $\quad v$ London and R. C., 112
- $v$ Parker, 326, 398
- $\quad$. Pritchard, 662
- $\quad$ : Simmons, 670,936
- $\quad v$. Slade, 615
- $\quad v$. Stephenson, 213, 966
- $\quad$. Straker, 896,899
- $\quad$. Willomatt, 949

Cooper's case, 548

Cope $v$. Albienson, 297

- $\imath$. Rowlands, 348,349

- $v$. Thames Haven Dock and R. C. 644,651

Copeman $v$. Hart, 58

Copin $v$. Adanison, 261

Copper Miners' Co. (The) $v$. Fox, 645,647

Coppin $r$. Walker, 416

Coppinger $v$. Cubbins, 531

Coppock $x$. Burer, 353

Corbett $v$. Brown, 334, 980

- v. Packington, 769

- $\quad x$. Plowden, 549

Corby $v$. Hill, 754, 755, 757, 767

Core, app., James, resp., 994

Cork $r$. Baker, 385

Cork and Bandon R. C. $v$. Cazenove, 672

- $v$. Goode, 156, 263

Corkling $v$. Massey, 34:2, 370

Corn $v$. Mathers, 670

Cornell $\imath$. Hay, 759

Corner $v$ : Shew, 711, 712

Cornfoot $v$. Fowke, 333, 337

Cornforth $v$. Smithard, 157

Coruhill $v$. Hudson, 156

Cornish $v$. Abington, 600, 961

- v. Cleife, 535

- $\quad \imath$ Stubbs, 889

Cornman v. Eastem Counties R. C., 751,788

Cornwell r. Metropolitan Commissioners of Sewers, 754

Corpe $v$. Overton, 673

Corpus Christi College v. Rogers, 563

Cort $v$. Ambergate, Nottingham, and Boston R. C., 113, 728, 766

Cory $v$. Thames Ironworks, \&c., Co., 738

Costa licia $v$. Erlanger, 6

Coster $v$. Merest. 18:

Cothay $r$. Femuell, 613

Cotterell $r$. Jones, 76,843

Cotterill $v$. Hobby, 979

Cotton $v$. James, 811

- $v$. Wood, 817

Conch $r$. Steel, 760

Couldery $v$ : Bartrum, 398

Couling $v$. Coxe, 757

Conlthart $v$. Clementson, 379

Coupé Co. $\imath$. Maddick, 922

Courtenay $v$. Earle, 771

Couturier $v$. Hastie, 35:2, 420, 579

Covas $r$. Bingham, 590

Coventry $v$. Apsley, 158

- v. Great Eastern R. C., 
Coverdale $\imath$. Charlton, $140^{\circ}$

Cowan $x$. Milbcmu, 365 r. U'Counor, 300

Cowanl $\imath$. Baddeler, 784,1049

Cowell $r$. Amman Co., $60^{\circ}$

- v. Eilwards, $30 \tau$

- r. Watts, 710

Cowgill, lie, 237

Cowley r. sumlerland (Mayor, ite. of), 761,808

- $\quad v$. Sewmarket Local board, 755

Cux, Ere parte, 237

- r. Hurbidge, 756

- $x$. Glue, si5

- $\therefore$ Great Western R. C., 813

- r. Hakes, 237

- $r$. Hickman, 626, 629

- . Hubbard, 619, 630

- $x$. Lee, 845,860

- v. Ieech, 213, 900

- r. Mattliers, 891

- r. Milland Counties li. C., 603

- r. Mitchell, 262

- $v$ Muncey, 970

- r. Rabbits, 7

- $x$. Troy, $\$ 76$

Coxhead $v$. Mullis, $6 \pi t$ $x$. Richards, 849 , \$5 1

Coxou $x$. Great Western R. C., 942

Crabtree $x$. Robinson, 555

Cracknell $x$. "lhetford, 757

Craig $x$. Hassel, 844

Cramer $v$. Mott, 555

Crabfurd $x$. Cocks, 641

Crawforl's case. 237

Crawshay $r$. Thompson, 85

Crears $\tau$. Hunter, 313

Cree $r$. Sonervail, 329

Creed $r$. Fisher, 15:

Crepp's $x$. Durlen, $\$ 33$

Crespigny $\bullet$. Wittenom, 5

Cripus r. Hartisoll, 35:-

- r. Hills, 669

- $r$. Julge, 812

Critchley, Ex parte, 355

Croft 1: Alisun, 797

- $x$. Lumlon and Xorth-Western li. C., 214

- v. Lumley, ift

- $x$. Stevells, sji

Crofton $r$. Crufton, tis i. P'orle, 601

Cronshaw $x$. Chapunan, 952

Croockewit $r$. Fleteher, 113, 501

Croome $v$. Lediard, 370

Cropler $\tau$. Cook, 18, 621, 622

Crosby $r$. Leng, 99

- . Warlsworth, $3 \& 9$, 8it
Cross $v$. Audrews. 783

- $v$. Cheshire, 630

- $r$. Cross, 925

- $v$. Williams, $600,633,652$

Crosse $r$. Duckers, 570

Crosstield $v$. Such, 641. 70S

Crossley $v$. Lightowler, 891, 901

Crosthwaite $x$. Gardner, 711

Cronch $ฯ$. Crédit Foncier of Eugland, $444,484,586,645$

- $v$. Great Northern R. C., 975

- $r$. London and Nortli-Western R. C., 933, 9t1, 944

r. Tregonning, 558

Crow $\imath$. Kogers, 315

Crowler $v$. Stewart, 212

r. Tiukler, $\$ 20$

Crowe $x$. Clay, 504

$$
\text { i. Price, } 228
$$

Clowhurst $v$. Amersham Burial Board, 71 : 882 . 915

-- $\quad v$. Laverack, 326,391

Crowther $v$. Farrer, 311

C'rump r. Day, 226

Cubitt $x$. Misise, 209

Cullen $v$. Thomson's Trustees, $i \Sigma 0$, s01, 952

Cumber $\tau$. Wane, 397

Cumberlege $v$. Lawson, 206

Cumming $r$. Belborough. 546

- $\quad$ ince, 504, 706

$\tau$. Shand, 84

Cummins $v$. Cummins, 708

Cundell $v$. Dawson, 350

Cundy, app., Le Coull, resp., 993, r. Lindsay, 430

Cunliffe $r$. Whiteliead, 455

Cunningham $r$. Dunn, 296, 719

Curlewis $v$. Clarke, 398

- v. Mornington (Earl of), 158

Currie $x$. Misa, 311, 499

Cursour $r$. Belworthy, $3: 8$

Curt is 1: Courtis, 862

- $v$. Stoom, 6, 61

- $v$. Wliteler, 548

- v. Williamson. $60 \pi$

Curwen $r$. Milburn, $15 \pi$

Cinsaek $r$. London and North-Western R. C., 203

Cuthlest $x$. Cumming, 18, 5\$3

Cuthbertsou $r$. Irving, 395

$$
\text { - r. lassous, } 792,796
$$

Cutler $r$. Lomlon and North-W"estern R. C., 938

Czech r. General Steam Nar. Co., 752 
D.

DA Costa $r$. Jones, 354

Daintes $x$. Hartley, 860

Dakin $v$. Brown, 817

Dalby $r$. Dorthall, 967

- $v$. Hirst, 13, 18, 525

- v. India and London Life Insurance Co., 332

Dale $v$. Humfrey, 621,622

D.lrymple $v$. Leslie, 39

Dalton $v$. Augrus, $72,884,912,909$, 910

- $\quad v$. Denton, 757

- $\quad$ : Midland R. C., 220

- $\quad v$. South-Eastern R. C., 818

Daly $\imath$. Dublin, Wicklow, aud $\mathrm{V}^{\top}$ exford hailway, 710

Dalyell $v$. Tyrer, $79 \cdot 2$

Danimaree's case, 1018

Dand $v$. Kingscote, 892

Dando $v$. Builen, 742

Dane $v$. Kirkwall, 515, 702

Daniel $v$. Gracie, 544

- $v$. Metropolitan R. C., 751

- v. Stepney, 553

- $v$. Woodroffe, 213

Daniels $r$. Fielding, 838

Dalln $v$. Spurrier, 889

Dansey $v$. Richardson, 878,920 , 929,930

Damube, \&c., R. C. $v$. Xenos, 729

Darby $r$. Harris, 550

- $v$. Ouseley, 847, 850

D'Arc $v$. London and Nortli-Western R. C., 935

Darey r. Askwith, 530, 892

D'Arey $v$. Tamar, sc., 276

Dargan $v$. Davies, 556

Darley v. Reg., 223, 224

Darlington (Lord) $v$. Cock, 129

Darneil $v$. Williams, 500

Darnell's Case, 234

Darrell $v$. Tibbitts, 331

Dartnail $r$. Howard, 918

Dashwood $v$. Magniac, 531

Dauglish $v$. Temment, 281

Davey $v$. Lontlon and South-Western R. C., 788

- $v$. Shannoll, 392

Davidson $r$. Cooper, 266, 501

Davies, app., Harvey, resp., 994

- v. Davies, 352, 356, 363, 533

- $\quad v$. Evton, 527

- $\quad v$. Fletcher, 829

- $v$. Jenkins. 75

-. Mann, 211, 787

- v. Marshall, 960

- $\quad v$. Penton, 724

- $\quad v$. Sear, 890
Davies, $x$. Snead, $84 \overline{7}, 851$

- v. Sdomon, 91, 863

- $\quad v$. Thomas, 513, 662

- $\quad v$. Wilkinson, 487

-.. $\quad v$. Williams, 211, 896, 968

Davis, Ex parte, $r$ Sneezum, 653

- $v$. Artingstall, 416

- v. Bonford, 396

-- v. Burrell, 207

-- v. Danks, 416, 870, 948

- v. Davis, 628

- $\quad v$. Duncan, 852

- $v$. Flagstalf Silver Min. Co., 69

- $v$. Howard, 586

- $v$. Jones, 266,574

- $v$. Masoll, 362

-- $v$. Russell, 827

- $v$. Shepstone, 853, 854

- $\quad$. Smyth, 743

- $v$. Treliarne, 885

- v. Walton, 62

Davison $v$. Donaldson, 470, 612

$$
\begin{array}{ll}
\text { - } & v . \text { Duncan, 856 } \\
\text { - } & v . \text { Gent, 563, 564 } \\
\text { v. Wilson, 208-210 }
\end{array}
$$

Dawes $x$. Dowling, 569

- v. Hainess, 504

- v. P'eck, 117

Dawkes $v$. Deioraine (Lord), 450

Dawkins $v$. Paulet (Lord), 102, $83 \pi, 855,85 i$

- $\quad v$. Rokeby (Lord), 102, 857

- v. Saxe Weimar, 46

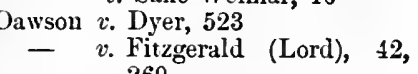
269

- $\quad$. Lawley, 604

Day $v$. Bather, 926

$v$. Midlaud R. C., 764

- $v$. Browurigg, 72

- $v$. Longhurst, 454

Deacon $v$. Gridley, 311

Deakin $v$. Lakin, 682

Dean $v$. Peal, 968

Deane $v$. Clayton, 751, 9S5

Dearden $v$. 'Townsend, 946

Death, Ex parte, 223

De Bergnis $v$. Armistead, 347

Dehenhain $v$. Mellon, 692, 693, 695, 696,698

De Cadaval (Duke) $v$. Collins, 706

De Cordova $v$. De Cordova, 329

Deering 2 . Winchilsca (Lord), 207

De Franceseo $v$. Barnum, 670

Degg $v$. Midland R. C., 750,807

De Goze $v$. Rowe, 266

De Grave 2 : Nonmouth (Mayor, \&c., of ), 645

De Greuchy $x$. Wills, 681

De Hatt $v$. Stevenson, 118 
De Havilland $v$. Bowerbank, 743

Delaney $r$. Fox, 395

De la liosa $x$. Prieto, 44, 322

De la Vega $\tau$. Vianna, 44

Delawarr (Earl of) 2 . Mliles, 581

Delegal $r$. Highley, 843, 853,855

Deller $r$. Prickett, 226

De Mattos 2 . Benjamin, 354

Je Mautort $r$. Sannders, 631

De Medina $r$. Grove, 261, 838,814

Dendy 2 . Henderson, $35 \%, 360$

$$
\text { -- t. Nicholl, } 564
$$

Dengate $r$. Gardiner, 677

Denison, Ex perte, 222

Denuis 2 . Tovell, 760

Dent $r$. Auction Nart Co., 897 $-r$. Dent, 228

Denton 2 . Great Northern R. C., $780,944,981$

- $\quad$. Peters, 456

- $\quad r$ Rodie, 744

Deposit and General Life Insurance $C .0 . r$. A scough, 323

Depperman $v$. Hubbersty, 615

Derecourt $r$. Corbishley, 825,828 , 1045

Derisley $\imath$. Custance, 289

De Roo $r$. Foster, 674

De Rotliscliild $v$. Royal Mail Steam Packet Co., 1074

Derry $r$. Peek, 330, 336, 952, 953

Deslandes $x$. Gregory; 619

Despard's case, 1091

De Tastet $v$. Shaw, 212

Deuters $v$. Townsend, 492

Devanx $r$. Steinkeller, 384

Deverill $r$. Burnell, 723

Devonshire (I)uke of) $v$. Eglin, $\$ \$ 9$

De Wahl 2 . Bramne, 690, 707

Dews 2: Riley, 829

Diblule $r$. Bowater, 545, 548, 554

Dicas 2:. Broughan (Lord), 106

Dick $x$. Tolhansen, 260, 690

Dickenson $v$. Fletcher, 994

$$
\text { v. Watson, } 1050
$$

Dickeson $v$. Hillyard, 856, 857

Dickinson $x$. Grand Junction Canal Co., 905, 907

थ. Nortl-Eastern R. C., 816

Dickson $\imath$. Combermere (Visc.), 1021

- $r$. Great Western R. C., 938

- r. lieuter's Telegraph Co., $312,330,342,620,741,770$

Digby $r$. Atkinson, 520

- 2 . Thom!son, 86,844

Diggle r. Higges, 354

- $\imath$. London and Blackwall

$$
\text { R. C., } 643
$$

Dincel $r$. Corlett, 722
Dime's case, 237

Dimes $x$. Grand Junction Canal Co., 182,222

-- $v$. Petley, 209, 211

Dimmack $v$. Bowley, 839

Dimmock $r$. Hallett, 332

Di Sora $x$. Phillips, 581

Ditcham $r$. Bond, 968 $v$. Worrall, 674

Dixon $x$. Bell, $751,786,969$

- $r$ Birch, 926

- $\because$ Bovill, 444

- r. Fawcus, 306, 981

- $v$. Hurrell, 695

- $\quad v$. London Small Arms Co., 241,242

- $r$. Metropolitau Boarl of Works, 71, 931

- $\quad$. Smith, 863

- $r$. White, 80,884

- 2 . Yates, 425,426

Dobbin $\tau$. Foster, 639

Dobell $r$. Hutchinson, 376

Dobie v. Larkan, 252

Dobsou $r$. Blackmore, 99, 876

- $\quad r$. Collis, 392

Dod $x$. Monger, 555

Dodd $r$. Acklom, 563

- $v$. Burehell, 878

Dodgson 2 : Bell, 676 - $\quad$. Scott, 261

Doe $d$. Barber $v$. Lawrence, 544

- $d$. Brayne $\tau$. Bather, 868

- $d$. Burrell $r$. Davis, 535

- $d$. Chadborn $v$. Green, 521

- d. Clarke $r$. Smaridge, 511

- d. Daniel $r$. Woodroffe, 213

- d. Darlington (Lord) 2 . Cock, 129

- d. Daries $r$. Thomas, 513, 662

- d. Edney $r$. Benlam, 544, 547

- d. Garnon $v$. Kinight, 265

- d. Harrop $x$. (ireen, 566

- d. Hudson $v$. Leeds and Bralford R. C., 878

- $d$. Jones $r$. Jones, 5i2?

- d. Martin r. Watts, 510

- d. Dattlewson 2 . Wrightman, $50^{\circ}$

- d. Jluston r. Glalwin, 293

- d. Nicholl $r$. Ilckeas, 522

- d. Parsley $v$. Day. 874

- d. Pennington $v$. Taniere, 648

- d. Plumer 2 . Mainby, 520

- d. Preedy 2 Holton, 576

- d. Rawlings 2 . Walker, 510

- $d$. Rigse r. Bell. 512, 522

- i. Rolierts 2 . Rol,erts, 283

- d. Hochestel (Jishol of) $r$. Bridges, $760^{\circ}$ 
Doe $d$. Shallcross $v$. Palmer, 501

- $d$. Strode $v$. Seaton, 868

- d. Tatum $v$. Catomore, 501

- d. Vickery $v$. Jackson, 535

- d. Wetherell $थ$. Bird, 533

- $d$. Williams $v$. Evans, 356

- $v$. Bonlter, 549

- $v$. Cooper, 564

- v. Courteuay, 553

-. v. Filliter, 975

-.. v. Grafton, 566

- v. Huddart, 868

- $v$. Kightley, 566

- v. Masters, 545

- v. Mizem, 566

- v. Paul, 545

- v. Phillips, 564

- v. Poole, 563

- v. Price, 566

- $v$. Pullen, 520

- $\imath$. Roberts, 514

- $v$. Robinson, 566

- $v$. Rollings, 564

- v. Stapelton, 566

- $v$. Thomas, 563, 567

- v. Watt, 564

- $v$. Wells, 564

- $v$. Wellsman, 868

- $v$. Wilkinson, 566

- v. Wood, 519

Doel $v$. Sheppard, 765,789

Doherty $v$. Allman, 218

Dolling $v$. White, 676

Doman $v$. Dibden, 743

Donald $v$. Snckling, 922, 924

Done $v$. Walley, 307

Donellan $v$. Read, 392

Donovan $v$. Laing Construction Syndicate, 790, 796, 806

Doolan $v$. Midland R. C., 793, 938

Doorman $v$. Jenkins, 918, 966

Dormay $v$. Borradaile, 1001

Doughty $v$. Bowman, 558 v. Firbank. 813

Douglas, Re, 237, 1024

- app., Dysart(Earl), resp.,15

- v. Corbett, 843

- v. Reg., 1024

- v. Watson, 370, 670

Dowman's case, 532

Downes $v$. Back, 728

Downing $v$. Capel, 116

Downman $v$. Tilliams, 618

Downton(Overseersof), Ex parte,215

Doyle $v$. Kaufman, 131

- v. O'Doherty, 855

Dracachi $v$. Anglo-Egyptian Nav. Co., 507

Drake $v$. Beckham, 631, 661

- v. Mitchell, 258, 273
Draycott $v$. Harrison, 682

Drayton $\imath:$ Dale, 664

Dresser $v$. Norwood, 614

Drew $v$. Nunn, 696, 702, 704

Dreyfus $v$. Peruvian Guano Co., 972

Driver $v$. Broad, 388

- $v$. Burton, 308, 317, 454, 636

Drummond $v$. Sant, 526 $v$. Van Ingen, 425

Drury v. Macaulay, 487

- . Macnamara, 518

- v. Molins, 570

Dublin and Wicklow R. C. v. Black, 672

Dublin, Wicklow and Wexford R.C. $v$. Slattery, 180, 752, 815

Du Bost v. Beresford, 844

Dubowski $v$. Goldstein, 361, 363

Duck $v$. Bates, 748

Duckworth $v$. Ewart, 736

$$
\text { - } v \text {. Johnson, } 751,818
$$

Dudden $v$. Clutton Union, 888,905

Dudley, In re, 213

- v. Ward, 538

Dudley, \&c., Banking Co. v. Spittle, 101

Dugdale $v$. Lovering, 247

- v. Reg., 998

- $v$. Robertson, 885

Duke v. Andrews, 298

- v. Ashby, 395

Dnmergue $v$. Rumsey, 194, 537

Duncan $v$. Cashin, 677

- v. Findlater, 796

- v. Hill, 586

- $v$. New South Wales Bank, 306

- v. Richmond, 213

- v. Scott, 504

- $\quad v$. Thwaites, 853

- $\quad r$. Topham, 299, 593

Duncombe $v$. Brighton Club Co., 741

Dundee Harbour (Trustees of) $v$. Dougall, 153

Dunford $v$. Trattles, 792

Dunk $v$. Hunter, 547

Dunlop $v$. Higgins, 297, 299

Dunn, $R e, 237$

- v. Birmingham Canal Co., 71, 82,751, ss2

- v. Reg., 246

- $v$. Sayles, 301

Duppa v. JIayo, 545

Durant $v$. Doe, $566^{\circ}$

Durrell $v$. Evans, 414

Dutton $\imath$. Marsh, 484

- v. Powles, 769

- v. Taylor, 891

Durergier $v$. Fellowes, 279 
Dwyer 2 . Meehan, 863

Dyke, Ex parte, Monish, 528 .

- $\quad$. Sweeting, 2\$9

Dynen $v$. Leach, so6, 808

Dynevor (Lord) $v$. Tennant, 901

Dyson r. Collick, 873

\section{E.}

EAIOx $\tau$. Jeffeck, 80

Fager $v$. Grimwoorl, 75, 968

Fagle ข. Charing Cross R. C., 95

Earle 2 . Hopwood, 356

- v. Oliver, 309, 324

East and West India Dock Co., $E x$ parte, re Clarke, 561, 562

East India Co. $v$. Paul, 159

East London Union $v$. Sletropolitau R. C., 734

East London Waterworks Co. $v$. Bailey, 647

East Union R. C. v. Cochrane, 445

Eastern Counties R. C. $v$. Broom, 793,801

- $\quad$ r. Marriage, 2

Eastland $v$. Burchell, 696

Easton $v$. Carter, 705

- v. London Joint Stock Bank, 445

Eastwond 2. Bain, 90, 332, 774, 780

Eaton $v$. Basher, 649

$$
\text { r. Kenyon, } 309,325
$$

- $v$. Bell, 616

- $v$. Swansea Waterworks, 896

Eubetts $r$. Conquest, 731

Ecclesiastical Commissioners $\tau$. Kino, 899

Eldowes 1. Hopkins, 743 ข. Merrall, 536, $646^{\circ}$

Eden 2 . Blake, 371,415

Edge $\tau$. Strafford, $38 \pi, 569$

Edger $\tau$. Kna I, 1\$3, 630

Edgeware Highway Poard $\imath$. Hartow Gas Co., 311, 350

Edgington $x$. Fitzmaurice, 335,328 , 952

Edgson 2 . Cardwell, $1 s 3$

Eilis $x$. Bury, 488

Edinonds, Ex parte, re Tipping. ข. Challis, 973

Elmondson $r$. Nuttall, 972

Filmonson $v$. Stevenson, 849

Edmunds $r$. liushell, 602

- $\quad \tau$. Wallingforl, 306, 315

bidney 2 . benlaan, 544,547
Edsall $v$. Russell, 862

Edwards, Ev parte, re Johnson, 213,317

- v. Aberayron Co., 42, 353

- ?. Barnard, 473

- $\quad$. Bangh, 315

- $\quad$. Grace, 711

- $\iota$. Great Western R. C., 742

- v. Havill, 605

- $v$. London and NorthWestern R. C., 797

- $\quad v$. Lowndes, 37

- $\quad v$. Midland R. C., 839

- $\quad v$. Reg., 195

- $\quad v$. Towels, 695

- v. Williams, 724

Edwick $x$. Hawkes, 207, 706, 1028

Efford $v$. Burgess, $56 \mathrm{~S}$

Egerton 2 . Brownlow (Earl), 5, 8, 352,353

v. Mathews, 414

Eggington, $R e, 23 \pi, 238$

$v$. Lichfield (Nayor of), 801,830

Eichlolz $v$. Bannister, 925

Elbinger $v$. Claye, 613

Elbinger Actien Gesellschaft $v$. Armstrong, 736

Eluridge $\because$ Stacey, 555

Eley $r$. Positive Life Ass. Co., 312, $348,391,392,650$

Elias $v$. Snowdon Slate Quarries Co., 529

Eliot $v$. Allen, 835

Ellen $r$. Tapn, 269

Ellershaw, $R e, 50$

Elliot 2 . Davis, 635

- $\quad v$. North-Eastern R. C., 909

- $v$. Von Glehn, 142

Elliott, Ex parte, 99

- v. Clayton, 664

- v. Hall, 751

- $\quad$ Kemp, 714

- . Richardson, 349,356

- $v$. Royal Exchange Ass. Co., 42

Ellis $v$. Great Western R. C., 751

- v. Hopper, 261

- $v$. Lofitus Iron Co., 86, 786, $871,87 \pi$

- $v$. Manchester Carriage Co., $\varepsilon 99$

- v. Reg., 255

- . Sheffield Gas Consumers' Co., 753, 754, 786, 798

- r. Strand District Board of Works, 107

Ellison $v$. Collingridge, 488 
Ellwell $v$. Proprietors of the Birmingham Canal Nav., 748

Elmore $v$. Kingscote, 413

Elphinstone r: Monkland, \&c., Co., 726

Elsam v. Denny, 456

Elsee 2 . Gatward, 919

Elston $v$. Rose, 62

Eltham $v$. Kingsman, 354

Elves $x$. Croft,, 361

Elwes $v$. Nawe, 539

Elwood v. Bullock, 14

Emblen v. Myers. 975

Eniblin v. Dartnell, 490

Embrey $v$. Owell, 88, 89, 886, 888

Emden $v$. Carte, 601, 664

Emery $r$. Barmett, 64

Emma Silver Mining Co. v. Lewis, 955

Ermmens r. Elderton, 113, 300, 324, 731

Emmerson $v$. Heelis, 415

Emmerton $v$. Mathews, 342, 819, 924

Emmet $v$. Dewhurst, 385

Emmett $v$. Norton, 693, 695, 697, 698

Emmons $v$. Pottle, 858

Empson v. Soden, 532, 537, 539

Fngiand (Bank of) $v$. Anderson, 635

$$
\begin{array}{ll}
- & v \text {. Cowley, } 914 \\
- & v . \text { Marsden, } 306 \\
- & v . \text { Shearburn, 528 } \\
- & v . \text { Vagliano, 6, 448, } \\
& 452,476,482
\end{array}
$$

Englisl Bank of the River Plate, In re, Ex parte Bank of Brazil, 465

English and Foreign Credit Co. $v$. Arduin, 298

Enraght $v$. Lord Penzance, 222

Entick $v$. Carrington, 830,870

Erlanger $v$. New Sombrero Phosphate Co., 329, 953, 956

Ernest $v$. Nicholls, 631, 651

Erskine $v$. Adeane, 369

Esdaile v. Sowerby, 490

Esposito 2 . Bowden, 113

Essex v. Daniell, 733

- v. Local Board for Acton, 96

Etherington $v$. Parrot, 692

Evans $v$. Brown, 664

- $v$. Drummond, 641

- v. Edmonds, 279, 283, 335

- v. Elliot, 549, 556

- v. Harlow, 863

- $v$. Harries, 863

- $\imath$. Hoare, 376

- v. Manchester, \&c., R. C., 750
Evans v. Mlarlett, 506

- $v$. Koberts, 386,389

- v. Roe, 369,393

- v. Walton, $75,969,970$

- $\quad x$. Wills, 202

Everett $v$. Collins, 545

- $v$. London Ass., 91

Ewart v. Belfast, 905

- $v$. Cochrane, 878

- v. Graliam, 874

Ewbank $v$. Nutting, 980

Ex parte Allen, $R c$ Fussell, 561

- Andrews, 237

- Anon. (4 Ad. \& E.). 233

- Bacon, In $r$ Bond, 260

- Ball, re Shepherd, 101

- Banner, re Blythe, 311, $3 i 3$

- Barronet, 986, 988

-- Barrow, 663

- Bayley, 214

- Besset, 235

- Bishop, re Fox, 306, 309

- Bodenham, 213

- Bradbury, 237

- Brown, 237

- Buckley, 634

- Burden, re Neil, 724

- Butler, 690

- Chapman, 232, 1055

- Child, 236

- Clifton, 213

- Cobledick, 213

- Cockerell, 262

- Cox, 237

- Critchley, 355

- Davis, re Sneezum, 658

- Deatl, 223

- Denison, 222

- Downton (Overseers of), 215

- Dyke, re Morrish, 528

- East \& West India Dock Co., re Clarke, 561, 562

Elmonds, $r e$ Tipping, 561

- Edwards, $r e$ Johnson, 213, 317

Elliott, 99

- Fentiman, 232

- Fernandez, 26

- Fisher, 214

- Franks, 700

- Fuller, re Long, 928

- Grant, In ve Plumb!y, 19

- Hamper, 631

Harris, $r$ Richardson, 562

Home, 684

- Jones, re Grissell, 684

- Jones, re Jones, 671

- Kibble, re Onslow, 674 
Ex partc Lennox, 675

- Lovering, re Jones, 562 . - Marlborough, Duke of, $232,233,1055$

- Martin, 201

- Medwin, 222

- Miles, re Isaacs, 506

- Miluer, 2s1

- Morgan, re Simpson, 284

- Nash, 215

- National Bank, re Phillips, 388

Phillips, 224

- Prankerd, 214

- Pulbrook, 1056

- Quincy, 537

- Ramshay, 224, 1024

- Reed, 456

- Richdale, 479

- Roberts, 495

- Rogers, 585

- Sandilands, 235

- Sinyth, 222

- Snowdon, 306

- Stephens, re Lavies, 538

- Story, 222

- Swan, 601, 961

- Tindal, 122

- Tucker, 221

- Voisey, Iir re hinight, 521

- Walton, re Lery, 3, 562 :

- Wason, 856.1022

- Watson, re Roberts, $664^{5}$

- Whittington, 528

- Woodhall, 23i

Exall $r$. Partridge, 525

Exchange Bank of Yarmouth $x:-$

Blethen. 266
Exchange Telegraph Co. v. Gregory 93,748

Exeter (Bishop of) $r$. Marshall, 146

Eyston $v$. Studd, 594

\section{F.}

Fabias $x$. Nunn, $3 \& 6$

Fairburn $\tau$. Eastrood, 301

Fairclongh $r$. Marshall, 219

Fairlie 2 . Fenton, $414,417,620$

Fairmanl $x$. Ires, 855

Fallowes थ. Taylor, 285, $28 \mathrm{~s}$

Falmouth (Lord) $l$. George, 10, 13 $v$. Thomas, $38 \tau$

Falvey 2 . Stanford, 182, 976

Fannin $\tau$. Anderson, 15f

Farebrother $v$. Simmons, 416

Farina 2 . Home, 4115

Farley $v$. Briant, 259

Farlic v. Danks, 839, 844
Farmeloe 2 . Baine, 964

Farquhar 2 . Morris, $7 \notin 3$

Farr $\vartheta$ Ward, 743

Farrant 2 : Barnes, 775,941

^. Thompson, 949

Farrar 2 . Deflinne, $6 \pm 1$

Farrow $v$. Wilson, $296, \pi 13$

Faulkner $v$. Lowe, 628

Faviell $\imath$. Eastern Connties R. C., 604

v. Gaskoin, 5S4

Fawcett $v$. Fowlis. 832

$v$. The York and North Midland R. C., 761

Fay 2 . Prentice, 89,881

Fayle 2 . Bird, 471

Fazakerly $\imath$. M'Knight, 501

Fearon 2 . Norvall, 229

Feather $v$. Reg., 241, 242, 243

Featherston $\because$. Wilkinson, $\tau 23$, 736

Featherstone $r$. Hutchinson, 345

Fell 2 . Knight, 878

- $\imath$. Whittaker, 91, 913

Feltham 2: England, 807

Felthouse $v$. Bindley, 297

Fenn $2:$ Bittleston, 949, 1082

i. Harrison, 495,615

Fentiman, Exc parte, 232

Fenton $v$. City of Dublin Steam Packet Co., 792

- $\quad$. Livingstone, 21

- v. Pearson, $70 \tau$

Ferens $r$. O'Brien, 1070

Feret $v$. Hill, 279, 365

Ferguson $v$. Cristall, 949

- .. Kinnoull (Earl of),

- $\quad$. Mahon, 128

ข. Nightingale, 536

Fergusson $\imath$. Fyffe, $7 \notin 2$

Fermor's case, 261

Fernandez, Ex parte, 26

Ferns r. Cart, 214, 296

Ferrand $v$. Bischoffsheim, 614

Feversham (Lord) $\imath$. Emerson, 260

Field $v$. Alames, 210, 551

- 2 . Lelean, 585

- $v$. Megaw, 440

Fielder $\imath$. Jarshall, 488

Filliter 2 . Phippard, 533

Filmer $r$. Delber, 604

Finch $x$. Blount, 972

Findon $v$. Parker, $3: 6$

Fine Art Soc. $\tau$. Union Bank, \&c., 445

Finlay r. Bristol and Fxeter R.C., 516

- v. Chirner, 710

- $\because$ Scott, 160 
Finley, In re, 659

Finucaue $r$. Small, 932

Firbank v. Humphreys, 620

Firth $v$. Bowling Iron Co., 71

Fish v. Hutchinson, 378

- $v$. Kelly, 322

- $v$. Kempton, 614

Fisher, Fic parte, 214

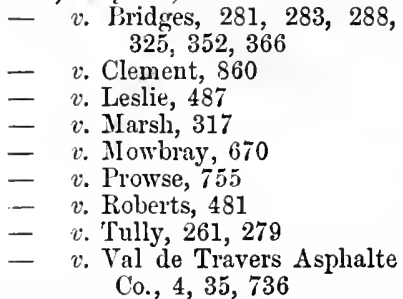

Fishmongers' Co. $v$. Robertson, 647

Fitch $v$. Snedaker, 319

Fitzgerald $v$. Boelim, 713

$$
\text { v. Dressler, } 380
$$

$v$. Fitzgerald, 676

Fitzjohn $v$. Mackinder, 75, 91, 844, 981

Fitzmaurice $v$. Bayley, 375

Fitzpatrick, app., Kelly, resp., 994

Fitzroy Bessemer, \&c., In re, 153

Fivaz $v$. Nicholls, 351, 355

Fleet v. Murton, 417, 577, 585, 620,622

- v. Perrins, 676

Fleetwood $v$. Hull, 558

Fleming $r$. Hislop, 822

- $v$. Manchester, Sheffield, \& Lincolnshire R. C., 67

Flemyng $v$. Hector, 633

Fletcher $v$. London and North. Fetherby $v$. Netropolitan District Western R. C., 181 : idi. R. C., 214

- v. Marillier, 554

- v. Peck, 245

- v. Smith, 79, 82, 782, 882

Flight $v$. Bentley, 548

- $v$. Bolland. 673

- v. Booth, 332

- v. Thomas, 822,896

Flindt $v$. Waters, 707

Flint $v$. Pike, 854

Flitters $v$. Allfrey, 67,260

Flood $v$. Jackson, 93, 835

Florence $v$. Drayson, 743 v. Jenings, 275,743

Flory $v$. Denny, 399, 924

Flower $v$. Adam, 817,981

- v. London and NorthWestern R. C., 670

- v. Sadler, 278,355

Floyd $v$. Barker, 104, 260

Flureau v. Thornhill, 733
Foquet $v$. Moor, 387

Forbes $v$. Cochrane, 8,20

- $v$. Lee Conservancy Board, 755

- v. Marshall, 488

- $v$. Smith, 156

Ford $v$. Beech, 114

- $v$. Catesworth, 296, 719

- v. Metropolitan District R. C., 96

- v. Tiley, 112

Fordham $v$. Akers, $R e, 64$

- v. London, Brighton, and South Coast R. C., 788

Foreman $v$. Free Fishers of Whitstable, 19

Fores $v$. Jolmes, 365

Forget $v$. Ostigny, 354

Forman $v$. Wright, 500

Forsdike $v$. Stone, 183

Forshaw $v$. De Wette, 67

Forster $v$. Macreth, 635

- $v$. Taylor, 350

Forth $v$. Simpson, 928

v. Stanton, 378,380

ster $v$. Allanson, 630

$v$. Bates, 709, 880, 915

$v$. Charles, 334

v. Dawber, 396,498

v. Green, 482

v. Mackinmon, 468,505

v. Mentor Ass. Co., 284,580 , 622,961

v. Oxford, \&c., R. C., 349

$v$. Reeves, 68,520

v. Usherwood, 61

$v$. Weston, 743

Foulger $v$. Newcomb, 862

$v$. Steadman, 993

Foulkes $v$. Metropolitan District R. C., 771, 942

Fountain $v$. Boodle, 849

Fowler $v$. Fowler, 928

- v. Hollins, 913

- v. Lock, 342, 916

-. $\quad$ Padget, 999

- v. Rickerby, 261

Fowlers $v$. Walker, 899

Fowles $v$. Great Western R. C., 942

Fox, Re, ex parte Bishop, 728

- $v$. Clifton, 183

- v. Frith, 629

- $v$. Gaunt, 826

- v. Harding, 740

- v. Nott, 508

Foxhall $r$. Barnett, 834, 980

France $v$. Gandet, 972 
Francis $x$. Cockrell, 341 $v$. Wilson, 743

Franconia, The, 815

Franklin $v$. Neate, $92 t$ $v$. Soutl-Eastern R. C., 818

Franks, Ex parte, 709

Fray $v$. Blackburn, 104

- $v$. Fray, $\$ 60$

- $v$. Voules, 84, 966, 973

Frayes $r$. Worms, 201

Frazer $v$. Cuthbertson, 605

- $\quad$. Hill, 842

- v. Jordan, 395

Free $v$. Burgoyne, 222

Free Fishers of Whitstable $v$. Gann, 19

Freeman $v$. Cooke, $601,638,961,962$ $x$. Rosher, 797,803

Freestone $v$. Butcher, 693, 694

Freeth $v$. Burr, 114

Fremantle $v$. London and North-

Western R. C., 751, 790

Frenlin $v$. Hamilton, 315

French $v$. French, 375

- $v$. Styring, 629

French Hoek (Coinm. of) v. Hugo, 887,895

Frend $v$. Dennett, 650

Freston, $I n v, 213$

Frewen $\tau$. Philipps, 896, 897

Friar 2 . Grey, 269

Friond $v$. Harrison, 288

Frith $r$. Reg., 242

Fritz $r$. Hobson, 76, 96

Fromont $r$. Coupland, 630

Frost $v$. Beavan, 702

- $v$. Chester (Mayor of), 215, 223

- $v$. Knight, 113

- $v$. Oliver, 596, 605

Fryer $v$. Gathercole, 858

- v. Kinnersley, 851

Fuller, Ex parte, re Long, 928

- $v$. Blackpool Winter Gardens Co., 748

- . Jackay, 62

Fnrnival $v$. Grove, 200, 563

Fyson 2 . Chambers, 664, 709

G.

Ganriel 2 . Dresser, 292

Gadd $r$. Houghton, 620

Gadslen $v$. Bartor, 226

Gaetano, The, 44

Gahan $v$. Lafitte, 100

Gale r. Ablott, 900
Gale v. Bates, 526

- $v$. Williamson, 286

Galizard $v$. Riganlt, 222

Gallatti $x$. Wakefield, 67

Galliard, app.,Laxton, $,{ }^{\prime} s p ., 829,1044$

Gallin $r$. London and Torth-Western R. C., ist

Galloway $r$. Bird, 147

Gallwey $v$. Jarshall, 863

Galsworthy $v$. Strutt, 725

Gambart $v$. Sumner, 749

Gandy $v$. Gandy, 312

$$
\text { - } \text { ?. Jubber, } 510
$$

Gange 2 . Lockwood, 535

Garden $v$. Bruce, 156,158

Gardiner, In ve, Ex parte Conlson, 684

Gardner $\imath$. Ingram, 521

- 2 . Lucas, 6

- $\quad$ r. Slate, 849

- $\quad v$. Welsh, 501, 502

Garnett 2. Bradley, 6, 38

- $\quad v$. Ferrand, 105, 831

- $\quad$. J'Kewan, 475

Garnons $v$. Knight, 265

Garrard 2 . Lewis, 468

Garrett v. Handley, 636

Garton $v$. Bristol and Exeter R. C., 933, 939

2. Great Western R. C., 116

Garwood $v$. Ede, 652

Gas Light and Coke Co. $v$. Hardy,

2: Turner,

$279,282,346$

Gaskill $v$. Skene, 397

Gaters $r$. Macleley, 677

Gathercole 2 . Miall, 853

Gautret 2. Egerton, 754

Gaved $v$. Jartyn, 896,903

Gay $v$. Lander, 487

- $v$. Mathews, 147

Gayford $v$. Nicholls, 753, soo

Gaylard 2 . Morris, 785

Geary v. P'hysic, 449

Geldis $v$. Bam Reserroir (Proprietors of), $95,95,757$

Gee, app., Lancashire and Yorkshire

$$
\text { R. C., rcsp. }, 735
$$

- v. Metropolitan R. C., 752

Geere $r$. Mare, $281,2 \& 3$

Geipel $v$. Smith, 113, 252

Gelen $v$. Hall, 106, \$34

Gell $v$. Burgess, 722

General Anction Co. $v$. Smith, 651

General South American Co., In re, 743

General Steam Nav. Co. $v$. British, sc. Nar. Co. 79.2 
General Steain Nav.Co. $v$. Guillou, 44

$$
\begin{aligned}
& \text { - } \quad \text { - v. Mann, } 759 \\
& v \text {. Morrison, }
\end{aligned}
$$

George, In $r$, Francis $v$. Bruce, 489,498

- $v$. Chamber's, 147

- v. Clagett, 613

- $v$ Skivington, 774,775

Geralopulo $v$. W ieler, 498

Gerard v. Lewis, 271

Gerhard $v$. Bates, 311, 318, 319, $338,508,772,776$

Gether $v$. Capper, 2, 590

Gibb $v$. Mather, 470, 471

Gibbon $v$. Budd, 322

- $v$. Gibbon, 43, 62

- $\quad v$. Pepper, 782, 789

Gibbons $v$. Alison, 838

- $v$. Vouillon, 114

Gibbs $v$. Cruikshank, 259, 974

- v. Flight, 14

- v. Fremont, $466,477,743$

- $\quad$ : Great Western R. C., 813

- v. Grey, 606

- v. Guild, 159

- $v$. Ralph: 181

- $v$. Société Industrielle, 478

Giblin $v$. McMullen, 918

Gibson, app., Barton, resp., 994

- v. Carruthers, 301

- $\quad v$. Crick, 18, 583

- $\quad v$. Holland, 414

- $\quad v$. Kirk, 569

- v. Muskett, 183

- v. Preston (Mayor of), 755

- $\quad v$. Small, 583, 584

- v. Winter, 623

Gidley $v$. Palmerston (Lord), 616

Gifford $v$. Young, 559

Gilbart $\imath$ : Dale, 947

Gilbert $v$. Schwenck, 969

- $v$. Sykes, 356

- $\quad v$. Trinity House, 755

Gilbertson $v$. Richards, 544

- $\quad$ r. Richardson, 94, 751, 786

Gilding $v$. Eyre, 839

Giles $v$. Hooper, 557

- v. Taff Vale R. C., 603, 943

$-v$. Walker, 767

Gill v. Dickinson, 14, 884

- v. Manchester, Sheffield, and

Gillard $v$. Brittan, 974 Lincolnshire R. C., 941

Gillespie, In re, ex parte Robarts, 466,742

Gillett $v$. Hill, 425

- $\quad$. Offor, 613

- $\quad$. Rippon, 306
Gillingham $v$. Gwyer, 554

Gilpin v. Fowler, 850, 851

Ginesi $v$. Cooper, 358

Gipps v. Gipps, 366

Girardy $v$. Richardson, 365

Giraud $\imath$. Richmond, 393

Girdlestone $v$. Brighton Aquarium Co., 117, 261

Gisbourn $v$. Hurst, 551

Gladwell $v$. Steggall, 772

Glaiser $v$. Rolls, 336

Glasgow (City of) Union R. C. $v$. Hunter, 96

Glover $v$. Coleman, 896, 900

Glyn, Jills \& Co. v. East and West India Dock Co., 505

Glynn v. Thomas, 91, 706

Godard $v$. Gray, 44, 261

Goddard $v$. Hodges, 629

- v. O'Brien, 398

Goddard's case, 265

Godefroy $v$. Jay, 966

Godfroy $v$. Dalton, 966

Godsall $v$. Boldero, 332

Godts $v$. Rose, 586

Godwin v. Francis, 377, 733

Goff $v$. Great Northern R. C., 603, 793

Goffin $v$. Donelly, 74, 856

Goldshede $v$. Swan, 327, 580

Goldthorpe $v$. Hardman, 786

Gompertz $v$. Bartlett, 495, 925

Good $v$. Isaacs, 582

Goodall $v$. Lowndes, 1024

$v$. Polhill, 498

Goode $v$. Harrison, 673,674

- $v$. Job, 155

Goodhart $v$. Hyett, 892

Goodland $v$. Blewith, 545

Goodnian v. Griffitlıs, 413

- v. Kennell, 798

v. Pocock, 731

Goodright $v$. Richardson, 562

$v$. Straphan, 514

Goodwin v. Cremer, 85, 397

v. Robarts, 445

Gordon $v$. Harper, 949

- v. Silber, 928

Gore $v$. Gibson, 504, 705

Gorgier $v$. DLieville, 445

Gorham $v$. Exeter' (Bishop of), $I m$ $r e, 8,222$

Gorris $v$. Scott, 107, 767

Gorrissen $v$. Perrin, 582

Gort $v$. Rowney, 118

Gorton v. Falkner, 550

v. Gregory, 271

Gosbell v. Archer, 415

Gosden $v$. Elphick, 8:27

Goslin v. Agricultural Hall Co., 796 
Gosman, $R e, 743$

Goss $x$. Nugent (Lord), 369, 370, $338,393,419$

Gott $\tau$. Gandy, $534,76 \bar{i}, 800$

Gough $v$. Gough, 539

- v. Heatley, 186

Gould $v$. Gapper, 222

Gourley $v$. Plimsoll, 165

Govier v. Hancock, 698

Grafton $v$. Eastern Counties R. C., 112

Graham $v$. Allsopp, 524

$$
\begin{aligned}
& \text { - v. Fretwell, } 416 \\
& \text { - v. Furber, } 703 \\
& \text { - } \quad v \text {. Hope, } 639 \\
& \text { - } \quad \text {. Musson, } 416 \\
& \text { - v. Peat, } 870 \\
& \text { - } v \text {. Tate, } 546
\end{aligned}
$$

Granger $v$. George, 159

Grant, Ex parte, in re Plumbly, 19

- v. Anderson, 120

- v. Brown, 115

- $r$. Cain pbell, 378

- v. Maddox, 531, 588

- v. Moser, 825

- $v$. Secretary of State for India, 246, 616, 804

Gratitudine, The, 605

Graves $v$. hey, 395

- v. Legg, 321, 583

- v. Weld, 527

Gray $v$. Fowler, 733

- $x$. Jefferies, 969

- v. Johuson, 84

- v. Pearson, 117

- v. Pullen, 753, 798

- v. Reg., 1059

- v. Smith, 642

- $r$. West, 67

Great Berlin Steamboat Co., Re, 355 Great Laxey Jining Co. v. Clague, 754

Great Northern Fishing Co. $r$. Edgehill, 107

Great Northern R. C., al'n., Behrens, resp., 934, 936

- v. Harrison, 764, $78 \overline{7}, 789$

$\begin{array}{lll}- & - & v \text {. Hawcroft, } 787 \\ - & - & v . \text { Morville, } 940\end{array}$

- $\quad$ - $\quad$. Mossop, 183

- $\quad$ - $v$. Shepherd, 944

- $\quad$ - $\quad$. Swaffield, 946

Great Western R. C., app., Rimell, resp. $.932,937$

$$
\begin{aligned}
& \text { - } \quad-v \text { Bennett, } 885 \\
& \text { - } \quad \text { - } v \text {. Crouch. } 946 \\
& \text { - } \quad \text { - v. Goodman, 945, }
\end{aligned}
$$

Great Western R. C. $v$. Redmayne, 741

v. Rous, 268

Great Western R. C. of Canada $v$. Braid, 751, 755, 790, 931

Greathead $v$. Bromley, 260

- v. Morley, 874

Greatre v. Hayward, 903

Greaves $v$. Fleming, 152

- $\quad v$. Tofield, 6

Grébert-Borgnis $v$. Nugrent, 736

Green v. Bartram, 825

- $v$. Beach, 197

- $v$. Button, 92

- $v$. Chapman, 853

- v. Cresswell, 381, 382

- $\quad v$. Duckett, 70?

- v. Eales, 534

- v. Elgie, $\$ 30$

- v. Greenbank, 674

- v. Humphreys, 154, 157

- v. Kopke, 618

- $v$. London General Omnibus Co., 793

- $v$. Wood, 4

Greene $v$. Bateman, 350

Greenland $v$. Chaplin, 788

Greenough $v$. McClelland, 370

Greenwood $v$. Hornsey, 896

Gregg $v$. Wells, 960

Gregory $v$. Brunswick (Duke of), 1021

- $\quad v$. Cotterell, 835

-- v. Hill, 786

- $v$. Mighell, 536

- v. Piper, 794, 797

- v. Reg., 1051, 1095

- v. Slowman, 975

- v. West Midland R. C., 939

Grell $v$. Levy, 356

Grey $v$. Gibbs, 606

Griffin $v$. Coleman, 828

Griffinhoofe $v$. Daubuz, 315

Griffith $v$. Middleton, 708

i. Young, 377

Griffiths $v$. Dudley (Earl of), 814,815

- v. Dunnett, 785

- $\quad v$. Gidlow, $789,806,808$

- $v$. Lewis, 116, 859, 860, 803

- v. Loudon \& St. Katharine Docks Co., 817

- v. Owen, 114,972

- v. Rigbs, 579

- v. Teetgen, 968

Grimbly $v$. Aykroyd, 58

Grimman $v$. Legge, 564

Grimsley $v$. Parker, 397

Grindell $v$. Godmond, 692 
Grinham $v$. Willey, 827

Grinnell $v$. Wells, 75,968

Grissell $v$. Bristowe, 18, 586

- $v$. Robinson, 306, 710

Gronvelt's case, 819

Grote $v$. Chester \& Holyhead R. C., 787

Groves $v$. Buck, 405

Grymes $v$. Boweren, 537

Guardians of Dartford Union $v$. Trickett, 298

Guardians of Lichfield Union $v$. Greene, 492

Guest $v$. Warren, 839

Guidon $v$. Robson, 632

Guild $v$. Conrad, 382

Guilford $v$. Lambeth, 61,69 $v$. Sims, 213

Guille $v$. Swan, 94

Gull $v$. Lindsay, 382

Gully $v$. Smith, 1030

Gunn $v$. Roberts, 605

Gunnestad v. Price, 6

Gunter $v$. Astor, 970

- v. Halsey, 385

Guppy v. Brittlebank, 826

Gurney v. Behrend, 506

- v. Evans, 632

- $v$. Womersley, 183, 495

Gwilliam $v$. Twist, 793

Gwinnell v. Eamer, 119, 799

- $\quad v$. Herbert, 488

Gwyn v. Godby, 744

H.

HACkwood $v$. Lyall, 605

Haddan v. Lott, 781, 981

Haddrick v. Heslop, 843

Hadfield's case, 1001

Hadley $v$. Baxendale, $440,735,736$, $737,738,740$

- v. Perks, 824, 827

v. Taylor, 754

Haigh $v$. Brooks, 312, 315

- v. Jones, 355

- v. Royal Mail Steam Packet Co., 815

- v. Sheffield (Town Council of), 996

Hailes $v$. Marks, 826, 842

Haines $v$. Roberts, 908

Haire $v$. Wilson, 845

Hakewill, In re, 236, 237, 238

Haldane $v$. Johnson, 292, 546

Hales $v$. London and North-Western

R. C., 738, 933

- v. Petit, 997

Halhead $v$. Young, 371
Halifax Union $v$. Wheelwright, 482, 483

Hall $v$. Ashhurst, 622

- v. Bainbridge, 266, 636

- v. Booth, 82 $\tau$

- v. Bristol (Mayor, \&e., of), 73

- v. Conder, 315, 729, 924

- v. Dyson, 313

- v. Fearnley, 789

- $v$ Fuller, 482

- v. Hollander, 969

- v. Janson, 583, 586

- v. Johuson, 807

- v. Levy, 115

- v. Lichfield Brewery Co., 72

- v. London (City of) Brewery Co., 523

- v. Lund, 878

- $v$. Nottingham, 17

- v. Piekard, 949

- v. Potter, 355

- v. Poyser, 182

- v. Swansea (Mayor, \&c., of), 645

- v. Warren, 703

- $v$. Wright, $711,719,729$

Hallack $v$. CambridgeUniversity, 221

Hallen $v$. Runder, 391

Hallett $v$. Dowdall, 651

- v. Wigram, 722

Halliday $v$. Holgate, 922, 924, 948

Halsey $v$. Brotherhood, 864

Halstead $v$. Skelton, 470, 471

Hambly $v$. Trott, 122

Hambro' $v$. Hull and London Fire Insurance Co., 651

Hamer $v$. Knowles, 910

Hamilton $x$. Anderson, 106

- v. Grainger, 365

- v. Spottiswoode, 449,487

- v. Telry, 298, 378

- v. Vaughan-Sherrin Electrical Co., 514, 673

- v. Young. 19

Hamlin v. Great Northern R. C., 971

-v. London and NorthWestern R. C., 981

Hamlyn $v$. Wood, 247

Hammack $v$. White, 817

Hammersley $v$. Biel (Baron de), 376, 385

Hammersmith, \&c., R. C. v. Brand, 95

Hammon's case, 1057

Hammond v. Bussey, 440, 736
- $\quad v$. Howell, 105
- $\quad$ v. St. Pancras, 759
v. Schofield, 258

Hammond's case, 237

Hamon $v$. Falle, 850,851 
Hampden $v$. Walsh, 354

Hamper, Ex parte, 631

Hance $2:$ Harding, 665

Hancke $v$. Hooper, 8:3

Hancock r. Austin, 547,555

$$
\begin{array}{ll}
- & \text { v. Caffyn, 660, 661 } \\
\text { - } & v \text {. Hancock, } 689 \\
- & v \text { Hodgson, 623 } \\
& v \text {. Noyes, 141 }
\end{array}
$$

Handcock $v$. Bäker, $8: 6,827$

Hanfstaengl $v$. Kaines, 748

Hankiuson $v$. Bilby, 860

Hanmer 2 . Chance, 901

Hannam $v$. Mockett, 1058

Hannay $r$. Smurthwaite, 117

Hansard $r$. Robinson, 503

Hanslip $v$. Padwick, 252, $7 \neq 0$

Harbidge 2 . Warwick, 897 , 898

Hardaker $x$. Illle District Council, 754

Hardcastle $r$. South Yorkshire Railway and liver Dun Co., 754

Harden $v$. Clifton, 501

Hardie $v$. Grant, 697, 698

Harding $x$. Harding, 446

$$
\text { - } v \text {. Preece, } 562
$$

Hardman $v$. Booth, 248, 312

Hardwick, Re, 213

Hardy $r$. Fothergill, 655

- $v$. Veaser, 475

Hare $v$. Groves, 546

- $v$. Henty, 10

Hargreave $\tau$. Spink, 429

Hargreares $v$. Parsons, 382, 419

Harley $v$. King, $55 \mathrm{~S}$

Harman $v$. Jolinson, 635

$$
\text { - } v \text {. Reeve, } 407
$$

Harmer $v$. Cornelius, 342

Harnett $v$. Maitland, 532, 534

Harnor $v$. Groves, $372,404,427$, 584

Harold $v$. Smith, 717

Harper $x$. Charlesworth, 873

$$
\text { - } v \text {. Williams, } 742
$$

Harries $v$. Thomas, $18 \mathrm{I}$

Harrington (Earl of), Re, 229

$$
\begin{array}{ll}
- & \text { ¿. Ramsay, } 64 \\
\text { v. Victoria Graving } \\
\text { Dock Co., 353, 955 }
\end{array}
$$

Harris, Ex parte, re Richardson, 562

- Inve, 224

- $v$. Brisco, 356

- r. Butler, 968

- $v$. Carter, 396

- $v$. De l'inna, 72, 896, 902

- r. Goodwyn, 291

- $v$. Great Western R. C., 36, 922

- $\quad$. Janes, 799
Harris $\imath$. Kemble, 344

- 2. Mobbs, 94, $78 \overline{7}, 817,820$

- $v$. Morris, 697

- $v$ Nickerson, 415

- $\because$ Osbourn, 604

- 2. Owners of "Franconia," 1078

$\div \quad v$ Quine, 44

- $v$. Rickett, 369

- $\quad$. Runnels, $3 \pm i$

- $v$. Ryding, 884

- $\quad v$. Thompson, $848,850,852$

- v. Venables, 311

- $v$. Warre, 844

Harris's case, 299

Harrison $r$. Abergavenny, 144

- $\quad$. Barnby, 545

- v. Blackburn, 510, \$73

- $\quad v$. Bush, $850,851,856,85 i$

- $v$. Cage, 385

- $\quad$. Fane, 183, 669

- v. Great Northern R. C., 881

- $v$. Harrison, $3 \& 9,72 s$

- v. Hyde, 576

- $\quad$. Jackson, 399, 622, 635

- $\quad v$. London, Brighton, \&c., R. C., 938,939

- $\quad$ r. Parker, 949

- v. Rutland (Duke of), 786, $8 i 1$

Harrop, app., Bayley, resp., 961

- $v$. Fisher, 457

- $\quad$ v. Green, 566

- $\quad v$. Hirst, $87,8 s$

Hart $v$. Alexander, 639

- $v$. Baxendale, $936^{\circ}$

- v. Crowley, 797

- $v$. Frontino Gold Mining Co., 395

- $v$. Prater, 668

- $v$. Stephens, 676

- $r$. Wall, 864

Hartas $v$. Ribbons, 586

Hartland $v$. Jukes, 156

Hartley v. Cummings, 300,360

- $\quad v$. Ponsonby, 313

- $v$. Rice, 355

Hartwell $v$. Ryde Commissioners, 98

Harvey $v$. Bridges, 206-208

- v. Facey, 298

- v. Grabham, 394

- $v$. Harrey, 537

- v. Johnston, 299, 301, 320

- $\quad$. Kay, 629

- v. Pocock, 974

- v. Walters, 89,881

Haseler 2 . Lemoyne, 803

Hasleham v. Young. 635

Haslock 2: Ferginsson, 384 
Hastelow $x$. Jackson, 278

Hastie $v$. Couturier, 382

Hastings v. Pear'son, 614 - v. Whitley, 361

Hatch $v$. Searles, 468

Hatchard $v$. MIège, 123, 865

Hawe $v$. Planner, 786

Hawes $v$. Harness, 328

- v. South-Eastern R. C., 739

Hawkins $v$. Alder, 183

$$
\text { - v. Harwood, 213, } 966
$$

Hawkshaw $v$. Parkins, 636

Hawtayne $v$. Bolurne, 605,634

Hawthorn $v$. Hammond, 878

Haycraft $v$. Creasy, $97 \tau$

Hayes $v$. Warren, 322

Hayling $v$. Okey, 785,872

Haylock $v$. Sparke, 834

Hayn $v$. Culliford, 750

Hayton $v$. Irwin, 583

$$
\text { - } v \text {. Wolfe, } 713
$$

Head $v$. Tattersall, 427

Heald $v$. Carey, 837, 913

- v. Kenwortly, 608, 613

Healey $v$. Story, 635

Heane $v$. Rogers, 961

Heap $v$. Barton, 537

Hearn $v$. London and South-Western

$$
\text { R. C., } 936
$$

Hearne $r$. Stowell, 845

Heath $v$. Chilton, 710, 713

- $v$. Sansom, 641

- $\quad$. Weaverham Overseers, 260

Heather $v$. Webb, 663

Heaven $v$. Pender, 751, 776

Hebditch $v$. JacIlwaine, 851

Hedges v. Tagg, 75, 968

Hedley $v$. Bainbridge, 635

- v. Pinkney S.S. Co., 811

Heffield $v$. Neadows, 381

Hegan $v$. Johnsoll, 547

Heilbutt $v$. Hickson, 425

Heineman $v$. Hale, 120

Helby $v$. Mathews, 430, 431

Hellawell $v$. Eastwood, 390,550

Hellier $v$. Casbard, $55 \overline{7}$

Helps v. Clayton, $31 \bar{\tau}, 668$

Helsham v. Blackwood, 845, 862, 1033

Hemans $v$. Picciotto, 269

Heming $v$. Power, 862

Hemmings $v$. Gasson, 847

Henderson $v$. Barnewall, 417

- v. Broomhead, 74, 856

- v. Comptoir d'Escompte de Paris, 506

- v. London and North. Western R. C., 934

- $\quad v$. Squire, 741
Henderson $v$. Stevenson, 922

Henkel $v$. Pape, 246

Henley v. Lyme Regis (Mayor of), 97

Henning $v$. Burnet, 908

Hensloe's case, 708

Henthorn $v$. Fraser, 299, 300

Henwood $v$. Harrison, 857

Herand $v$. Leaf, 633,637

Herbert $v$. MIarkwell, 928

- v. Sayer, 664

Herman $v$. Jeuchner, 355

Hermann Loog $v$. Bean, 863

Hermann $v$. Seneschal, 116

Herne 2 . Bembow, 533, 534

Herring $v$. Hudson, 829

- v. Metropolitan Board of Works, 95

Heseltine $v$. Siggers, 590

Heske $v$. Samuelson, 812

Heslop $v$. Chapman, 843

Hetherington $v$. Nortll-Eastern R. C., 816

Heugh $v$. London and NorthWestern R. C., 946

Hewett, In re, Ex parte Levene, 683

- $\quad$ : Barr, 131

- $\quad$ isham, 878

- v. Macquire, 877

Hewlett $v$. Allen, 250

Hewlins $v$. Shippam, 889

Hewston $v$. Phillips, 62

Hey $v$. Moorhonse, 207, 873

- v. Wyche, 720

Heyden's case, 5

Heylyn $v$. Adamson, 460, 488

Heywood $v$. Watson, 492

Heyworth $v$. Knight, 418

Hibbs $v$. Ross, 605

Hickman $v$. Haynes, 112, 373

Hicks $v$. Fanlkner, 840-842

- v. Gregory, 321

Higgens's case, 257, 273

Higgins $v$. Hopkins, 600, 615

- $\quad 2$. Livingstone, 616

- v. Pitt, 280, 283

- v. Senior, 577, 607, 621, 622

Higginson $v$. Simpson, 354

Hilbery v. Hatton, 913, 914

Hilcoat $v$. Canterbury (Archbishop) of), 759

Hill $v$. Balls, 72, 330, 757, 992

- v. Campbell, 166

- $v$. East and West India Dock

Co., 562

- $v$. Foley, 475

- v. Fox, 281

- $v$. Gomme, 295 
Hill $v$. Gray, 366

- v. Hart Davies, 219, 858

- v. Metropolitan Asylum District (Managers of), 95, $103,755,796,820,821$

- v. Saunders, 519

- $v$. Smith, 728

- $v$. The Proprietors of the Manchester Waterworks, 276

Hillary $x$. Gay, 207

Hilliard, Re, 213

Hills $v$. Laming, 276

- v. Mesnard, 58, 498

- $v$. Mitson, 356

Hilton $v$. Eekersley, 364

- v. Granville (Earl), 884

- $v$. Whitehead, 80

Hinde $v$. Gray, 361

- $v$. Whitehouse, 415,417

Hindley $v$. Haslam, 260

- v. Westmeath (Marquis of), 355,698

Hindustan (Bank of) $v$. Alison, 396

Hint on $v$. Dibbin, $93 \pi$

- $v$. Heather, 842, 843

- $\quad v$. Sparkes, 725

Hiort $v$. Bott, 914

- $v$. Loudon and North-Western

$$
\text { R. C., } 979
$$

Hipkins $r$. Birmingham \& Staffordshire Gas Light Co., 76, 751

Hipwell $v$. Knight, 252

Hirschfeld $v$. London, Brighton, and South Coast R. C., 281, 505

Hitcheock $v$. Coker, 359, 360362

- v. Humfrey, 470, 471

Hitchman $v$. Walton, 981

Hix $v$. Gardiner, 12

Hoad $v$. Grace, $32 \bar{\tau}, 380$

Hoadly $v$. M'Laine, 414

Hoare $v$. Niblett, 257

- $v$ Rennie, 114

- $r$. Silverlock, 183, 845, 854

Hobbit $v$. London \& North. Western R. C., 818

Holsbs $v$. Branscomb, 8:27

- v. Henning, 260

- $v$. London and Soutli. Western R. C., 736, 737, 981

Hobhouse's case, 236

Hobson $v$. Thelluson, 89, 980

Hoby $v$. Roebuck, 544

Hochster $v$. De la Tour, 112, 113, 729

Hodder $v$. Williams, 554, 748

Hodges $v$. Hodges, 697

- v. Lichfichl (Earl of), 732
Hodgkinson $v$. Eunor, 76, 80, 88\&, 905 v. Fletcher, 695

Hodgman $v$. West Midland R. C., 939

Hodgson v. Bell, 61

- v. Moulson, 80

- v. Scarlett, 855

- v. Sidney, 661

- v. Wood, 721

Hodkinson $v$. London and NorthWestern R. C., 947

Hodsman $r$. Grissel, 673

Hodsoll $v$. Stalebrass, 969

Hodson $v$. Walker, 229, 870

Hoey $v$. Felton, 92, 788, 981

Hogan $v$. Hand, 567

- v. Page, 743

Hogarth $v$. Jennings, 555

- v. Latham, 468

- $v$. Wherley, 599

Hogg $v$. Wart, 828

Holborn Union v. St. Leonard, Shoreditch, 107, 215, 759

Holborow $v$. Jones, $6 \pi$

Holerolt $v$. Hoggins, 606, 641

Holden $v$. Liverpool Gas Co., 788, 817

Holder $v$. Cope, 695

- v. Soulby, 917, 926, 929, 930

Holding $v$. Elliott, 369,622

Hole i. Harrison, 308

- $v$. Sittingbourne and Sheerness R. C., 753,798

Holford $x$. Bailey, 874

- $v$. George, 19

- v. Hankinson, 896

Holker $v$. Porritt, 888, 903

Holland $x$. Hodgson, 550

Hollins $v$. Fowler, 249, 801, 914

- v. Verney, 896

Hollis $v$. Marshall, 99

- v. Palmer, 157

Hollman $v$. Pullin, 621

Holloway $v$. Abel, 968

$$
\text { v. Res., 997, 1024, } 1095
$$

Holman $v$. Johnson, 350,353

Holme $v$. Brunskill, $56^{\circ} 3$

- $v$. Hammond, 626, 638

Holmes $v$. Bagge, 785,874

- $\quad$. Bell, 275

- $\quad x$. Blogg, 514

- $v$ Clarke, 764,811

- $v$. Higgins, 629

- $v$. Mather, $72,750,782,789$

- v. Mitchell, 380

- $\quad$ : Newlands, 870

-- v. Fortlı-Eastem R. C., 755.768

$x$. Onion, 792 
Holmes $v$. Wilson, 118

- $v$. Wood, 677

Holt $v$. Brien, 692

- v. Collyer, 579

- v. Ely, 613

- v. Frost, 225

- v. Ward, 301, 673

Holtby $v$. Hodgson, 683

Home, Ex parte, 684

Homer $v$. Ashford. 361

- $\quad v$. Taunton, 862

Homersham $v$. Wolverhampton

Waterworks Co., 650

Honck $v$. MIuller, 114

Honduras Inter-Oceanic R. C. $v$. Leferre, 119

Honess v. Stubbs, 843

Honywood $v$. Honywood, 531

Hood Barrs $v$. Catheart, 682, 683

Hooper $v$. Clark, 270

$$
v \text {. Heriot, } 682
$$

- v. Lane, 742

- $v$. London and North-Western R. C., 771, 942

- $\quad$ i. Marshall, 142

- $\quad v$. Stephens, 58

- $\quad v$. Williams, 487

Hope $v$. Evered, 828

- v. Hayley, 400

- v. Hope, 676

Hopkins, Re, 261

- $v$. Crowe, 827

- $\quad$. Grazebrook, 733

- $v$. Great Northern R. C., $86,95,980$

- v. Logan, 323

- v. Prescott, 348

- $v$. Swansea (Mayor of), 318

- $v$. Tanqueray, 343,344

- $v$. Ware, 545

Hopkinson $v$. Lovering, 658

Hopwood $v$. Thorn, 850, 863 $v$. Whaley, 560

Horler $v$. Carpenter, 112,379

Horn $v$. Thornborongh, 116

Horne $v$. Sidland R. C., 736

- v. Redfearn, 487

- v. Rouquette, 44, 467, 477

- $v$. Wingfield, 419

Horner $v$. Flintoff, 724

- $\quad v$. Graves, 359, 362

Hornsey Local Board $v$. Monarch Investment Building Society, 2

Horsefall v. Mfather, 534, 536

Horsey $v$. Graham, 387

Horsfall v. Hey, 390

- v. Testar, 535

- v. Thomas, 329

Horsley $v$. Bell, 616

- $\quad v$. Price, 583
Horsley $v$. Rush, 635

Horton $v$. Davon (Earl of), 226

- $v$. Sayer, 41

- $v$. Westminster Improvement Commissioners, 276

Hosking $v$. Phillips, 876, 973

Hotson 2 : Browne, 369

Hough $v$. Manzanos, 620, 621

- $v$. Windus, 6

Houlden $v$. Smith, 106

Houldsworth $v$. City of Glasgow Bank, 624, 957, 958

Houliston $v$. Smyth, 69-

Hounsell $v$. Smythe, 754,767

Hounsfield $v$. Drury, $\$ 38$

Household Fire Insurance Co. $v$. Grant, 300

How v. Greek, 301

Howard $v$. Barnard, 975

- v. Brownhill, 37

- $\quad v$. Crowther, 650, 661, 968

- $\quad$. Digby, 692, 695

- v. Gosset, 829

- v. Harris, 919

- $\quad v$. Hudson, 961

- $v$. Lovegrove, 719

- $v$. Oakes, 676

-- v. Shepherd, 506, 770, 776

- $v$. Sheward, 601

Howarth $v$. Sutcliffe, 64

Howden $v$. Haigh, 348

Howe $v$. Mark Finch, $8: 2$

- $v$. Smith, 411

Howell $v$. Coupland, 113

- v. Metropolitan R. C., 228

- v. Young, 159

Howells $v$. Landore Steel Co., 808

Howorth $v$. Tollemache, 948

Hoye $v$. Bush, 824

Hoyle, In re, Hoyle $v$. Hoyle, 379

Hubbard $v$. Goodley, 57, 58, 61

Huber $v$. Steiner, 44

Huckle $v$. Reynolds, 862

Hudson, app., II'Rae, resp., 993

- v. Baxendale, 946

- v. Clementson, 582

- $\quad v$. Leeds and Bradford

R. C., 878

- $\quad$ v. Revett, 266

- v. Roberts, 786

-- $\quad v$. Tabor, 79

- v. Williams, 535

Hudspeth $\imath$. Yarnold, 298

Hudston $v$. Midland R. C., 944

Huffell $v$. Armistead, 566

Huffer $v$. Allen, 260, 839

Hughes $v$. Buckland, 116

- v. Great Western R. C., 941 
Hughes $v$. Macfie, 789

- $v$. Reeves, 860

Hunill $v$. Twisden, 329

Huguenin $r$. Baseley, 285

HuIl $v$. Great Northern R. C., 818

Hulse $v$. Hulse, 310

Huinble $r$. Hunter, 612, 619

Hume $v$. Drnyff, 133, 191

Hunfrey $r$. Dile, 41 $7,585,620$

Humphreys, Re, 987

$$
\begin{array}{ll}
\text { - } & \text { ?. Green, } 385 \\
- & \text { Welling, } 353
\end{array}
$$

Humpluries $v$. Brogden, $73,80,883$,

$$
884,909
$$

Hunt $v$. Allgood, 519

$$
v \text {. Cousins, } 80,882
$$

- v. Bate, 304

- v. Bishop, 112

- v. De Blaquiere, 692, 697

- v. Great Northern li. C., 62, 250

-. v. Hunt, 687

- $v$. North Staffordshire R. C., 62

- v. Peake, 884, 910

- $v$. Wimbledon Local Board, $649,650,964$

Hunter $v$. Caldwell, 966

- $v$ Gibbons, 159

- $\quad v$. Parker, 399, 605, 622, 636

Hunting $r$. Sheldrake, 289

Huntley $v$. Simpson, 838

- $v$. Ward, 850

Hurdman $v$. Nolth-Eastern R. C, 882

Hurrell $\imath$. Ellis, 781

Hurst $\imath$. Great Western R. C., 912

- $v$. Hurst, 725

- $v$. Taylor, 766

Hussey v. Horne-Payne, 299, 373

Hutcheson $v$. Eaton, 620

Hutchins $v$. Chambers, 549

- $v$. Scott. 555

Hutchinsou $v$. Colorado Co., 160

- $\quad v$. Gillespie, 261

- v. Guion, 941, 981

- $\quad v$. liead, 315 - $v$ Tatlomı, 417, 585,

- v.York, Newcastle, and lerwick R. C., 787, 806,818

Hutchison $v$. Bowker, 579

Hutley 2 . Hutley, 356

Hutton v. Bulloch. 613

- r. Cruttwell, 978

- $\quad v$. Ward, 743

- v. Warren, 526, 527, 533, 583,584
Huzzey $r$. Ficld, 797

Hyams $v$. Webster, 759

Hyat v. Hare, 641

Hybart $v$. Parker, 444

Hyde $v$. Dean and Canons of Windsor, 122,289

- $\because$ Johnson, 156

- $r$. Seyssor, 967

Hydranlic Engineering Co. $v$.

IIcHattie, 739, 982

Hynde's case, 260

Hyne $x$. Dewiney, 487

1.

Івоттsом $v$. Peat. 757

Igculden $u$. May, 522, 543

Ilott $v$. Wilks, 21, 751

Imperial Gas Light Co. $v$. London Gas Light Co., 159, 952

Imperial Gas Light and Coke Co. $v$. Broadbent, 820

Imperial Loan Co. $v$. Stone, 703

Imperial Mar. Ins. Co. $v$. Fire Ins. Corp., 579

In re Adams' Trusts, 686

- Armstrong, Ex parte Gilchrist, 684

- Bahia, \&c., R. C., 960

- Bailey, 236

- Blake, 213

- Burdett, Ex parte Byrne, 348

- Clarke, 238

- Commercial Bank of South Anstralia, 466, 742

- Dulley, 213

- English Bank of the River Plate, E.c parte Bank of Brazil, 466

- Finley, 659

- Fitzroy Bessemer, \&c., 153

- Freston, 213

- Gardiner, Ex parte Coulson, 684

- Gen. South American Co., 743

- George, Francis $v$. Bruce, $\mathbf{4 8 9}$, 498

- Gillespie, Ex parte Robarts, 466,742

- Gorham v. Exeter (Bishop of), 8,222

- Hakewill, 236, 237, 238

- Harris, 224

- Hewett, Ex parte Levene, 683

- Hoyle, Hoyle 2 . Hoyle, 379

- Keller, 237

- Kingrston Cotton Mill Co., 957

- Laycock $v$. Pickles, 35;

- Letchford, 514 
In re London \& General Bank, 957

- Lynes, Ex parte Lester, 683

- Moser, $\mathbf{5 3 8}$

- National Coffee Palace Co., Ec parte Panmure, 620

- Ottos Kopje Co., 960, 973

- Paul, Ex parte Portarlington (Earl of), 539

- Power, 238

- Queade's Trusts, 680

- Railway and Electric Appliances Co., 271

- Rhodes, 701

- Robson, 265

- Sandilands, 264

- Solomon, Ex parte Dressler, 658

- Soltykoff, Ex parte Margrett, 167

- Somerset, Somerset $v$. Poulett, 153

- South American and Mexican Co., Ex parte Bank of England, 256, 260

- Spenser's Estates, 514

- Stonor's Trusts, 689

- Swain, Swain v. Bringeman, 153

- Thomas, 657

- Thompson, 214

- Tucker, 638, 686

- Tuff and Nottingham, 684

- Weare, 213

- Whitley, Ex parte Callan, 156,626

- Whittaker, 689

- Wilkes, 231

- Wilkins, 191

- Wylie, Wylie $v$. Moffatt, 685

Indermaur $\tau$. Dames, 754, 755

India (Secretary of State for) $v$.

Sahaba, 103, 804

Ingham $v$. Primrose, 476

Inglis $v$. Haigh, 156

Ingram $v$. Barnes, 250 v. Lawson, 845, 863

Ings $v$. London and South-Western R. C., 67

Inman $v$. Stamp, 387

Inman S S. Co. $r$. Bischoff, 91

Innes $v$. Wylie, 784

Insley $v$. Junes, 61

Ionides $v$. Pender, 331

Ireland $v$. Livingston, 298

v. Thompsou, 636

Ireland (Bank of) $v$. Trustees of Evans' Charities, 482, 601

Irons $v$. Smallpiece, 235, 399

Irvine $v$. Australia (Union Bank of), 305
Irvine $v$. Watson, 610

Irwin $v$. Braedwood, 862

- v. Dearman, 968

v. Grey, 240

Isaacs, $R e, 506$

Isaaeson $v$. Dirrant, 1013

Isberg $v$. Bowden, 613

Ivay $v$. Hedges, 754

Ivens $v$. Butler, 690

Iveson $v$. Moore, 821, 908

Izett $v$. Mountain. 933

Izon $v$. Gorton, 546

J.

JACKsos $v$. Burnham, 664

- $\quad v$. Cocker, $50 \mathrm{~S}$

- $\quad v$. Hill, 811

- $\quad v$. Hopperton, 848,849

- $\quad v$. Jackson, 252

- $\quad v$. Pesked, 871

- $\quad v$. Smithson, 786

- $\quad v$. Stopherd, 630

- v. Turquand, 3:8

- $v$. Union Jarine Insurance Co., 91, 113

- $v$. Woolley, 6, 157

Jacob $v$. King, 567

Jacobs $v$. Crédit Lyonnais, 44

Jacoby $v$. Whitmore, 361

Jakeman $v$. Cook, 663

James $v$, Brook, 863

- v. Campbell, 978

- v. Dearmer, 679

- v. Holditch, 494

- v. Isaacs, 306

- v. Phelps, 843

- v. Williams, 114

Jameson $v$. Brick and Stone Co., 664

- v. Midland R. C., 738

Jarmain $v$. Hooper, 604, 803

Jarvis $v$. Jarvis, 391

- $v$. Wilkins, 487

Jay $v$. Johnstone, 155

- v. Robinson, 688

Jeakes $v$. White, 387

Jebsen $v$. East and Trest India

Dock Co., 93, 629

Jeffereys $v$. Boosey, 748

Jeffreys $v$. Gurr, 306

Jeffries $v$. Alexander, 265

- $v$. Great Western R. C., 912, 915

Jeffs $r$. Day, 4400

Jelliet $v$. Broad, 358

Jelly $v$. Bradley, 785

Jenings $v$. Florence, 839

Jenkins $v$. Betham, 342.966

- v. Harvey, 11, 893 
Jenkins $v$. Hutchinson, 618

- v. Morris, 635, 704

- v. Power, 612

- $\quad v$. Tucker, 700

Junner $v$. A'Beckett, 845, 863

- $v$. Turner, 355

Jennings $v$ : Brown, 320

- $v$. Great Northern R. C.,

- v. Johnson, 351

- $\quad v$. Rundall, 674

Jervis $v$. Berridge, 373

Jessopp $v$. Lutwyche, 352

Jewel's case, 544

Jewson $v$. Gatti, 754

Jinks $v$. Edwards, 523

Joel $r$. MIorrison, $79 \overline{7}, 798$

John $v$. Bacon, 767

Johns $v$. Simons, 605

Johnson $v$. Baker, 266

- $\quad$. Crédit Lyounaise Co., $328,431,961$

-- $v$. Dodgson, 413, 414

- $\quad v$. Emerson, 839, 844

- $\quad$ i. Gallagher, 691

- $v$. Hudson, 349

-- $v$. Jones, 525

- $v$. Lancashire and Yorkshire R. C., 972

- $\quad x$. Lindsay, 806, 807

- $\quad$ v. Midland R. C., 933

- $\quad$. Pie, 673, 674

- v. Raylton, $\mathbf{5 8 3}$

-. $\quad v$. Royal Mail Steam Packet Co., 306, 312

- $\quad v$ Stear, 972

- $\quad r$. Windle, 476, 482

Johnston $v$. Orr-Ewing, 86

- $\quad v$. Sumner, 691, 692, 696, 697

Johnstone $v$. Hudleston, 570

$$
\begin{array}{ll} 
& \quad \text {. Mappin, 385 } \\
=\quad & \quad \text {. Marks, 669 } \\
-\quad & \text {. Milling, 112 } \\
-\quad & \quad \text { Sutton, 102, 804, 839, }
\end{array}
$$

Joliffe $r$. Baker, 330, 332

Jolliffe $r$. Wallasey Local Board, 116,755

Jolly $v$. Rees, 693,695

- $v$. Young, 581

Jones, Ex parte, $r c$ Grissell, 684

- Ex parte, re Jones, 671

- $v$. Adamson, 722

- $v$. Barkley, 269

- $v$. Boyce, 91

- v. Broadhurst, 460

- $\imath$. Cannock, 112

- r. Carter, 443
Jones $r$. Chapman, 207, 872

- v. Chappell, 531

- v. Clarke, 583

- $v$. Currey, 62

- v. Cuthbertson, $6 \pi j$

- $v$. Edney, 332

- $v$. Festiniog R. C., 751

- v. Flint, 389

- v. Gooday, $9 \pi 2$

- $\imath$. Gretton, 498

- $v$. Harrison, 652

- $v$. Hart, 801

- $v$. Hughes, 606

- $v$. Johnson, 147

- v. Jones, 209, 522

- . Just, 424

- $v$. Lees, 357

- v. Liverpool Corporation, 790,806

- $v$. Mackie, 847

- v. Marsh, 566

- $v$. Merionethshire Building Society, 355

- $v$. Mills, 564, 566

- v. Montevideo Gas Co., 38

- $v$. Morris, 524

- $v$. Orchard, 306

- v. Oren, 229

- $v$. Padgett, 424

- v. Powell, 822

- v. Pritchard, 58

- $v$. Randall, 353, 354

- $v$. Robinson, 443 .

- $v$. Ryde, 495

- v. St. Jolnn's Coll., 719

- v. Sawkins, 395

- $\because$ Simes, 121

- $v$. Tyler, 927

- $v$. Victoria Graving Dock Co., 44, 373, 37 7,393 , 414

- . Waite, 279,355

- $v$. Williams, 209

- $v$. Yates, 328

Jorden $v$. MLoney, 355, 960, 961

Jordin $v$. Crump, 751

Josling $v$. Irvine, $736^{\circ}$

- $v$. Kingsford, 574

Josselyn $v$. Parson, 358

Jourdain $v$. Wilson, 557

Joyner $v$. Weeks, 730

Jung $v$. Phosphate of Lime Co., 619

Junghluth $v$. Way, 504

Justice $v$. Gosling, 828

K.

Kaltexbach $\tau$. Lewis, 613

Kavanagh $\tau$. Gudge, 785 
Kaye $v$. Brett, 602

- v. Dutton, 315, 323

- v. Waghorn, 290

Keane $v$. Reynolds, 877

kearley $v$. Thomson, 278, 355

Kearney $v$. Lloyd, 1020, 1023

- v. London and South Coast R. C., 751, 772

TKearns $v$. Durell, 504

Kearsey $v$. Carstairs, 301

Kearslake $v$. Morgan, 114

Keate $v$. Phillips, 396

Keates $v$. Cadogan (Lord), 248, 366,767

Keen $v$. Henry, 930

- v. Millwall Dock Co., 814

- v. Priest, 211, 553, 567, 972, 973

Keene $v$. Dilke, 980

Keir $v$. Leeman, 278, 288, 1024

Kellard $v$. Rooke, 812

Keller, In re, 237

Kellock $v$. Enthoven, 586

Kelly $v$. Lawrence, 830

- v. Met. R. C., 67, 771

- v. Partington, 848

- v. Patterson, 519, 520

- $v$. Rogers, 523

- $v$. Sherlock, 975

- v. Tinling, 852

- v. Webster, 386, 387, 390

Kelner $v$. Baxter, 620

Kemble $v$. Farren, 724, 725

Kemp v. Clark, 506

- v. Falk, 439, 507

- $v$. Finden, 630

- $v$. Neville, 106

Kempe $v$. Gibbon, 155

Kempson $v$. Boyle, 369, 418

Kendal $v$. Narshall, 506

- $v$. Wood, 633, 636

Kendall $v$. Hamilton, 257, 258, 612

- $v$. London and SouthWestern R. C., 932

- $v$. Wilkinson, 832

Kendillon $v$. Maltby, 831

Kennaway $v$. Treleavan, 301

Kennedy $v$. Broun, 37, 304, 322

- (Lord) v. Panama, \&c., Mail Co., 341

v. Thomas, 459

Kennet and Avon Nav. Co. $v$. Witherington, 107

Kensit $v$. Great Eastern R. C., 886, 887,888

Kent $v$. Great Western R. C., 116

- $v$. Midland R. C., 947

- $v$. Shuckard, 926

- v. Thomas, 606
Kenworthy $v$. Schofield, 415

Kenyon, (m)., Hart, resp., 881

Kepp $v$. Wiggett, 284

Kerby $v$. Harding, 555

Kerkin $v$ Kerkin, 64, 229

kershaw $v$. Bailey, 850

Ketsey's case, 514

Key $v$. Catesworth, 506

Keyse $v$. Powell, 870

Kibble, Ex parte, re Onslow, 674

- $v$. Gough, 409

Kidderminster (Nayor of) $v$. Hardwick, $301,643,644,646,647$

Kiddle $v$. Lovett, $341,808,812$

Kidgill $v$. Moor, 86,876

Kidner $v$. Keith, 264

Kidston $v$. Empire Insurance Co. ,588

Killham $v$. Collier, 312, 353

Kimber $v$. The Press Association, 854

Kimbray $v$. Draper, 6

Kinıpton $v$. Willey, 58, 59

King $v$. Accumnlative Ass. Co., 111

- $v$. Basingham, 67t

- v. Davenport, 140

- $v$. Gillett, 396

- v. Hoare, 257, 258, 259

- $v$. Jones, 559, 720

- $v$. London Cab Co., 798, 930

- $v$. Norman, 260, 720

- v. Reg., 1025, 1095

- v. Sears, 304

- v. Shepherd, 223

- v. Spurr, 930

- v. Voss, 679

- v. Zimmerman, 503

Kingdon $v$. Nottle, 559

Kingsbridge Flour Mill Co. $v$. Same, 651

Kingsford $v$. Merry, 328

Kingston $v$. Preston, 269

Kingston Cotton Mill Co., In re. 957.

Kingston's (Dnchess of) case, 260, 261

Kingston-upon-Hull (Poor of) $v$. Petch, 297

Kinloch $v$. Nevile, 895

Kimning $v$. Buchanan, 830

Kirhy $v$. Simpson, 832, 834

Kirk $v$. Bell, 650

- v. Gibbs, 397

- $v$. Gregory, 915

Kirkham $v$ Marter, 383

Kirkstall Brewery Co. v. Furness R. C., 603

Kirton $v$. Eliott, 514

Kirwan $v$. Kirwan, 639

Kitchen $v$. Bartsch, 664 
Kitchenman $v$. Skeel, 712

Kitson $v$. Hardwick, 142, 664

Knapp $v$. London. Chatham, and Dover R. C., 210, 870, 878

Knight $v$. Abbott, 61

$$
\begin{aligned}
& -\quad v \text {. Benett, 547 } \\
& -\quad v \text { Egerton, 973 } \\
& -\quad v \text {. Fox, 795 }
\end{aligned}
$$$$
\text { - } v \text {. Hughes, } 306
$$

Knights $v$. Wiffen, 395

Knowlman $v$. Bluett, 391, 392

Finox $v$. Bushell, 694

- $v$. Hayman, 336

Kopitoff $v$. Wilson, 341, 583

\section{L.}

LABOUChere $\tau$. Dawson, 358

Lade $v$. Shepherd, 949

Ladyman $v$. Grave, $895,898,900$

Lafond $v$. Ruddock, 158

Lafone 2 . Sinith, S47

Laidler $v$. Burlinson, 427

Laing $v$. Whaley, 747,888

Laird $r$. Briggs, 4, 901

- v. Pim, 734

Lamb $v$. Brewster, 546

- $v$. Bunce, 308

- v. Great Northem R. C., 250

- $v$. Palk, 797, 798

- $v$. Pegg, 114

-- $v$. Walker, $71,72,89,971$

Lambert $v$. Bessey, $782,783,977$ $v$. Norris, 544,569

Lamert $v$. Heath, 496

Lampet's case, 443

Lampleigh $v$. Brathwait, 304

Lamprell $r$. Billerieay Union, 647

Lancaster $v$. Eve, 388

$$
v \text {. Walsh. } 320
$$

Landens $x$. Sheil, 224

Lane $r$. Benuett, 156

- $v$. Capsey, 211

- r. Dixon, 550

- $v$. Ironmonger, 694

- $v$. Nixon, 583

Lang $v$. Gale, 580

Iangmead $\boldsymbol{v}$. Naple, 260

Langridge $x$. Levy, 774,776

Langton $v$. Higgins, 369

$$
\text { v. Hughes, } 347
$$

Ianphier $\tau$. Phipos, 823

Lanyon $v$. Martin, 386

Lascelles $v$. Lord Onslow, 21

Lassence $v$. Tierney, 385

I atham $v$. Reg., 1095

$$
x \text {. Spedding, } 63
$$

Latimer $x$. Official Co.operative Soc., 910
La Touche, $v$. La Touche, 311

Latt $x$. Booth, 670

Latter $v$. Braddell, 785

Laugher $x$. Pointer, 790, 794: 796

Laurie $v$. Scholefield, 381

Lavery $v$. Pursell, 390, 391

- $v$. Turley, 3St

Lavey $v$. Reg., 1025

Law $v$. Local Board of Redditch, 727

Iawless $r$. Anglo-Egyptian Cotton, sc., Co., 848,850

Lawrance $v$. Norleys (Lord), 159

Lawrence $\imath$. Great Northern R. C., $8 s 1$

- $\quad$. Hiteh, 19

- $\quad$. Jenkins, 94, 981

- $\quad$ W. Walmsley, 371

- $\quad$ : Wileock, 43

- $\quad v$. Wilcocks, 742

Lawson $\tau$. Burness, 582

- v. London (Bank of), 85, 749,793

Lawton $v$. Lawton, 538

- $\quad$ : Salmon, 538

Lax $v$. Corporation of Darlington, 789

Lay $v$. Mottram, 267

Laycock $r$. Pickles, In re, 387

Layer $\imath$. Nelson, 308

Laythoarp $x$. Bryant, 301, 375, 376, 405,414

Lea $r$ : Alsergavenny Comm., 115

- $v$. Parker, 65

$-v$. Whitaker, 723,725

Leach $v$. Money, 830

- $v$. Thomas, 533, 534

Leader $v$. Rhys, 57

Leak $v$. Driffield, $6 s 2$

Leame $r$. Bray, $783,786,797$

Learoyl $v$. Brook, 214, 667

Leary $x$. Patrick, 6, 833

Leask $v$. Scott, 507

Leather Cloth Co. $v$. American Leather Cloth Co., \$5

- $\quad$ - v. Hieronimus, 414,419

- $\quad$ - $\quad$. Lorsont, 363

Leathley $v$. Sprers, 381

Lebenu $v$. General Steam Nav. Co., 933

Le Blanche $x$. London and NorthWestern R. C., 981

Le Contenr $v$. London and SouthWesteru R. C., 934

Iedwith $v$. Catelipole, 826

Lee, app)., Riley, resp., 91

- $r$. Bayes, 100, 913, 961

- Bude and Torrington Junetion R. C., 8, 261 
Lee $v$. Butler, 431

- $v$. Cooke, 549

- $v$. Everest, 597

- v. Gaskell, 391

- $v$. Griffin, 414

- v. Hart, 978

- $v$. Jones, 331

- $v$. Muggeridge, 309

- $v$. Nixey, 91

- $v$. Risdon, 390,539

- $v$. Simpson, 987

- v. Smith, 547

- v. Stevensoll, 870,874

- $v$. Walker, 769,966

Leeds and County Bank $v$. Walker, 502

Leeds and Thirsk R. C. $v$. Fearnley, 672

Leeds (Dnke of) $v$. Lord Amherst, 532

Leeming $v$. Snaith, 582

Leete $v$. Hart, 116

Le Fanu $v$. Ilalcolmson, 860

Legge $v$. Tucker, 67, 769

Leggott $v$. Barrett, 574

- $v$. Great Northern R. C., 710,818

Legh $v$. Hewitt, 18, 525

Lehain $v$. Philpott, 212

Leidemann $v$. Schult $z, 582$

Leigh $v$. Lillie, 725

Leighton $v$. Wales, 359, 725

Lekeux $v$. Nash, 558

Lemaitre $v$. Davis, 910

Leman $v$. Fletcher, 322

$$
\text { - v. Goulty, } 222
$$

- v. Honseley, 322

Le Lievre $v$. Gould, 336

Le MLason $v$. Dixon, 121, 123

Leinmon $v$. Webb, 209

Lemon $v$. Simmons, 687, 862

Lennard $v$. Robinson, 618

Lennox, Ex parte, 675

Leonard Watson's case, 235

Leonard's National Exchange Co., \&c. $v$. Drew, 333

Lepla $v$. Rogers, 731

Leroux $v$. Brown, 44, 377

Leslie $v$. Pounds, 799

Letchford, In re, 514

Lethbridge $v$. Mytton, 721

Levien $v$. Reg., 1097

Levy $v$. Baker, 705

- v. Edwards, 828

- v. Hale, 961, 980

- v. Langridge, 742

- v. Moylan, 106, 829

- $v$. Pyne, 635

Lewis $v$. Brass, 249, 299

- $v$. Bright, 349
Lewis $v$. Clifden, 730

- v. Clifton, 113, 961

- v. Collard, 966

- $v$. Davison, 347

- v. Great Western R. C., 938, 939,940

- $v$. Hillman, 328

- $v$. Levey, 853

- $v$. London, Chatham, and Dover R. C., 752

- v. Marshall, 589

- $\quad$. McKee, 508

- v. Nicholson, 618

- v. Peachey, 732

- $v$. Reade, 803

- $v$. Reilly, 631

- v. Walter, 855

Leyland $v$. Tancred, 838

Leyman $v$. Latimer, 845

Libels (the case of), 845

Lickbarrow v. Mlason, 330, 437, 505,506

Liddlow $v$. Wilmot, 695

Liddy $v$. Kennedy, 566

Liebenrood $v$. Viues, 526

Liford's case, 870,892

Lilley $v$. Doubleday, 736, 923

Lilly $v$. Hays, 317

Limpus $v$. General Onnibus Co., 797

Lincoln College case, 594

Lindall $v$. Penfold, 259

Lindley $v$. Lacy, 369

Lindsay $v$. Cundy, 248, 317

$v$. Leigh, 832

Lindsay Petroleum Co. v. Hurd, 328

Lindus $v$. Bradwell, 578

- v. Melrose, 635

Line $v$. Stephenson, 523

Linford $v$. Fitzroy, 831

Lingham $v$. Warren, 568

Linnegar $v$. Hodd, 326

Lion ins, Assoc. $v$. Tncker, 6

Lister $v$. Lane, 534

- $v$. Perryman, 826, 838

- v. Stubbs, 353

Litchfield $v$. Ready, 868, 874

Litt $v$. Martindale, 317

Littlefield $v$. Shee, 309, 325

Liver Alkali Co. v. Johnson, 931

Liverpool Adelphi Loan Association $v$. Fairhmrst, 674, 961

Liverpool Borongh Bank v. Eccles, $376,377,414$

$v$. Logan, 380

Liverpool Stores $v$. Smith, 219

Liversidge $v$. Broadbent, 317 , 442

Lloyd $v$. Guibert, 44 
Lloyd $v$. Joluuson, 365

- $v$. Jones, 64

- $v$. Oliver, 488

- v. Peell, 662

Lloyd's Banking Co. $v$. Ogle, 135

Lloyds $v$. Harper, 306, 379, 720

Lock $v$. Ashton, 830, 981

- v. Furze, 122

- v. Pearce, 295, 296

Lockett $v$. Nicklin, 584

Lockliart $v$. Baruard, 320

Lockley $v$. Pye, 974

Lockyer $v$. Ferryman, 260

Loftus $v$. Heriot, 682

Lohre $v$. Aitchison, 588

Lomas $v$. Bradshaw, 630

London and Brightiton Truman, 820

- and Continental Ass. Soc. $v$. Redgrave, $2 \pi 6$

- and County Banking Co. $v$. Ratcliffe, 9

- and County Banking Co. $r$. London and River Plate Bauk, 444

- and General Bank, In re, 957

- and North-Western R. C.

r. Dunham, 939

- - v. Evershed, 110

- $\quad$ - $v$. Glyun, 37

- $\quad$ - $\quad v$. Lindsay, 261 $v$. Price, 651

- and River Plate Bank $v$ Bank of Liverpool, 495

- Chartered Bank of Australia $v$. Leinpriere, 691

- Chatham, and Dover R. C. $v$. South-Eastern R. C., 741

- (Corporation of) $v$. Att.Gen., 25

- Dock Co. $v$. Sinnott, 643

- \&c.. Banking Co. $v$. Belton, 553

- Financial Assoc. $v$. Kelk, 651

- Gas Light Co. $v$. Chelsea (Vestry of), 269

- Guarantee, \&c. v. Fearnley, 306

- Joint Stock Bank $v$. London (Mayor, \&c., of), 223

- (Mayor of) $v$. Cox, 223

- $\quad$ - $v$. Huut, 646

$-v$ Pewterers
Co., 896

- and South-Western Bank r. Wentworth, 601
London and Universal Bank $v$. Clancarty, 742

Long $v$. Clarke, 555

- $v$. Orsi, 213, 966

Longbottom $v$. Longbottom, 62, 203

Lougman $r$. East, 172

Longmeid $v$. Holliday, 691, 775 , 967

Lonsdale (Lord) $v$. Rigg, 1058

Loosemore $v$. Radford, 721

Lord $v$. Hall, 456, 597

- $v$. Midland R. C., 938

- v. Price, 913

- $v$. Stephens, 252

- $v$. Sydney (Commissioners of),

Loring $v$. Warburton, 91

Lotan v. Cross, 949

Longher $v$. Williams, 5.59

Loukes $x$. Holbeach, 707

Lound $v$. Grimwade, 279

Love $\tau$. Bell, 14, 80, 885

Lovegrove $x$. White, 84

Lovejoy $v$. Cole, 57, 58, 61

Lovell $r$. Beauchamp, 671

- $v$. Howell, 807

- $v$. Nerrton, 679

Lovelock $v$. Franklyu, 112

Lovering, Ex parte, re Jones, 562

Low $v$. Bouverie, 336,965

Lowe $v$. Carpenter, 896, 901

- v. Fox, 155, 683

- $v$. Griffith, 514

- $v$. Loudon aud Nortll-Western

R. C., 648

- v. Peers, 355

- $v$. Steeie, 712

Lowley $v$. Rossi, 57

Lowrey $v$. Barker, 552

Lows $v$. Telford, 207, 208, 872, 102S, 1029

Lowther $v$. Heaver, 520

Lucas $r$. Beach, 629

- $v$. Beale, 622

- $v$. Bristow, 583, 587

- v. De la Conr, 636

- $v$. Dixon, 114, 406, 412

- $x$. Harris, 228

- v. Mason, 794, 797

- $v$. Tarleton, 90, 766

Jucy $v$. Mouflet, 427

Lndgater $v$. Lowe, 337

Ludlow (Mayor of) $v$. Charlton, 643

Lumley $x$. Gyc, 92, 93, 317, 969, 970,981

Lunn $v$. Thornton, 400

Lutterell $v$. Reynell, 100

Luttrel's case, 899

Lyde $v$. Barnard, 384

- $v$. Russell, 537 
Lyell $v$. Kennedy, 157, 165

Lygo $v$. Newbold, 764, 789

Lyle $v$. Richards, 576

Lynch $v$. Knight, 92, 863

v. Nurdin, 789

Lynde $v$. Anglo-Italian Hemp Spinning Co., 953

Lynes, In re, Ex parte Lester, 683 Lynn Regis (JIayor of) $v$. Taylor, 11 Lyon $v$. Fishmongers' Co., 76, 888, 905

- v. Knowles, 118

- $v$. Reed, $396,563,564$

Lyons $v$. Elliott, 551

- v. Martin, 797

Lystrom $v$. Cameron, 807

Lyth $v$. Ault, 314, 398, 639

Lythgoe $v$. Vernon, 914

\section{M.}

MLaber $v$. Maber, 157

MacAndrew $v$, Electric Telegraph Co., 933

MacArthur $v$. Seaforth (Lord), 728

Macbeath $v$. Haldimand, 606, 616, 804

MacCarthy $v$. British Shipowners' Co., 815

$v$. Young, 779, 921

Macdonald $v$ : Carington, 151

$v$. Longbottom, 575, 576

$v$. Whitfield, 307, 464

Macdonnell $v$. Marsden, 732

Macdougall $v$. Knight, 257, 854 $v$. Paterson, 2

Macfarlane $v$. Giannacopulo, 608

Machu $v$. London and South-

Western R. C., 793, 937

Macintosh $v$. Haydon, 489

Mackalley's case, 1033, 1043

Iackay $v$. Commercial Bank of New Brunswick, $623,624,793$

\section{$v$. Ford, 855}

Mackenzie $v$. I)unlop, 588 v. Pooley, 605

Maclae $v$. Sutherland, 634

Maclagan's case, 299

Maclatchie $v$. Haslain, 278

Maconchy $v$. Trower, 299

Macpherson $v$. Scottish Rights of Way Society, 908

Macrory $v$. Scott, 380

Macrow $v$. Great Western R. C., 944

I'Call $\%$. Taylor, 487

II 'Cance $v$. London and NorthWesteru R. C., 939
McCarthy $v$. Metropolitan Board of Works, 95,96

M[cCaull $v$. Strauss, 418

MIcCawley $v$. Furness, 787

McClure $v$. Little, 535

McCollin $v$. Gilpin, 576

McCord $v$. Cammell, 813

McEntire $v$. Crossley, 432

McGiffen v. Palmer's, \&c., Co., 812

McGowan $v$. Dyer, 793

McGregor $v$. MeGregor, 391, 392, 676

M'Gregor $v$. Thwaites, 844, 853, 862

I'Kay $v$. Rutherford, 391

I'Kenzie $v$. British Linen Co., 396,601

M'Kinnon $v$. Panson, 98

McKune $v$. Joynson, 320

I'Langhlin $v$. Pryor; 796

MeLean $v$. Clydesdale Banking Co., 311,478

McLeod $x$. Wakley, 74

IIcMahon $v$. Field, 736, 737, 789

M'Manus $v$. Crickett, 797

- v. Lancashire and Yorkshire R. C., 939

McManus $v$. Bark, 311

$$
\text { v. Cooke, 392, } 890
$$

II 'Naghten's case, 986, 1002, 1003, 1005

M'Pherson $v$. Daniels, 845, 995

$$
\text { v. Watt, } 328
$$

M'Queen $v$. Great Western R. C., 937

Maddick $v$. Marshıll, 600

Maddison $v$. Alderson, 406

Maddon $x$. White, 671

Maddox $v$. Wynne, 676

Magee $v$. Atkinson, 622

- v. Lavell, 723,725

Magnay $v$. Burt, $\mathrm{S} 38$

Magnus $v$. Scotland (National Bank of), 260

Magor $v$. Chadwick; 903

Magratlı $v$. Reichel, 257

Mahoney $v$. Ashlin, 477

Mahony $v$. Kekulé, 613, 618

Maile $v$. Mann, 604

Mainprice $v$. Westley, 317

Mainwaring $v$. Brandon, 740

$\begin{array}{ll}\text { - } & v . \text { Giles, } 874 \\ \text { - } & v \text {. Leslie, } 696 \\ & v . \text { Newman, } 629\end{array}$

Malden $v$. Fyson, 740

Mallalieu $v$. Hodgson, 281, 283

Mallan $v$. May, $361,362,580$

Mallet $v$. Batenian, 378 
Malpas $v$. London \& South. Western R. C., 574

Maltby $v$. Murrell, 460

Manby $v$. Scott, 668, 674, 690, $691,698,699$

Manchester Bonded, \&c., Co. $v$. Carr, 342

$$
\begin{aligned}
& \text { (Mayor) v. Williams, } \\
& \text { 793 } \\
& \text { \&c., Bank v. Cook, } 735 \\
& \text { - \&c., R. C., app., } \\
& \text { Fullarton, resp., 751 } \\
& \text { - \&c., R. C. v. Brown, } \\
& \text { 935, 940, 941 } \\
& \text { \&c., liy. v. Denaby } \\
& \text { Main Coll. Co., } 766 \\
& \text { \&c., R. C. } v \text { London } \\
& \text { and North. Western } \\
& \text { R. C., 151 } \\
& \quad \text { \&c., R. C. } v \text {. Wallis, } \\
& \quad 762
\end{aligned}
$$

Manders $v$. Williams, 948

Mangan $v$. Atterton, 789

Manley $v$. Boycot, 370

- v. Field, 968

- v. St. Helen's Canal and

Mann $v$. Brodie, 908 R. C.. $755,817,968$

Janning $v$. Fitzgeralı, 576

$v$. Phelps, 569

Mansell $v$. Reg., 1089

Mansfield $v$. Blackburn, 538

Manwaling $v$. Sands, 698

Manzoni $v$. Douglas, $81 \tau$

Marchant $v$. Lea Couservancy Board, 643

Mlardall $v$. Thellusson, 712

Mare $v$. Charles, 473

Marfell v. SouthWales R. C., 764

Mar. Ins. C'o. $x$. China, \&c., Co., 332

Marker $v$. Kenrick, 875

Markham $v$. Cobb, 102

Markwick $v$. Hardingham, 596

Marlborough (Duke of), Ex parte, $232,233,1055$

Marriot $v$. Hamptol1, 260

Marsack $v$. W' cbber, $306^{\circ}$

Marsden v. City, \&e., Ass. Co., 91

- v. Momre, 269

Marsh $v$. Billings 749

- $v$. Davies, 606

- $v$. Kieating, 99,630

- $v$. Loader, 1009

- v. Woorl, 301

Marshall $v$. Bown. 283

- $\quad v$. Broadluurst, 710,711

- $v$. Green, 390, 408

- $\quad$. Lynn, 252, 419
Marshall $v$. Nicholls, 107

- $\quad v$. Poole, 743

- $v$. Rutton, 675

- $\quad$. Ulleswater Steam Nav. Co., 874

- v. York, Newcastle and Berwick R. C., 771, 946

Marshalsea, The case of $106,829,830$ Martin, Ex parte, 201

- $v$. Bannister, 201

- v. Boure, 447

- v. Connah's Quay, 813

- v. Great Ind. Pen. R. C., 312,946

- $v$. Great Northern R. C., 788,980

- v. Mackonochie, 222

- $v$. Porter, 981

- v. Pycroft, 369

- v. Reid, 923

- v. Strachan, 868

- $\quad v$. Temperley, 792

- v. Watts, 510

Martindale $v$. Smith, 426

Martinez $v$. Gerber, 969

Martini $v$. Coles, 948

Mary's case, 75,99

Marzetti $v$. Willianıs, $84,85,475$, $482,720,973$

Masol $v$. Aird, 65

- v. Barker, 834

- v. Harvey, 112

- v. Hill, 887, 888

- v. Ruinsey, 635

- $v$. Shrewsbury and Hereford R. C., 118

Mason's case 1035

Maspons, \&c. $v$. Mildred, 613

Massey $v$. Guodall, 310, 321

- $v$. Johnisun, 386

Master $v$. Miller, 443, 445, 501

- Pilots, \&c., of Newcastleupon-Tyue $v$. Bradley, $5 \$ 1$

Masters $v$. Baretto, 487

- $\quad$ r. Barnwell, 182

- $\quad v$. Farris, 567

- $\quad v$. Green, 539,553

- v. Ibbersou, 278, 504

Mathew $v$. Blackmore, 272

Mathieson $v$. London and County Bank, 481

Matsolı $v$ laaird, 761

$v$. Wharam, 381

Mattlew $v$. Ollerton, 1050

Matthews $v$. Baxter, 505, 705

- $\quad v$. Biddulph 827

- $\quad v$. Discount Corp., 720

- $\quad v$. Munster, 604

Matthewgon $v$. Wrightman, 566

Mattley $v$. Wiseman, 19 
Matthias $v$. Mesuard, 551

IIattison $x$. Hart, 2

Manghan $v$. Sharpe, 399

Maund $v$. Monmouthshire Can. Co., 793.

Maw $v$. Jones, 732

Maxim Nordenfelt $v$. Nordenfelt, 363,364

Maxted $v$. Paine, 585

May $v$. Breed, 254

- $v$. Burdett, 786

- $v$. Seyler, 448

Mayhew $v$. Suttle, 872

Mayho v. Buckhurst, $55 \gamma^{\circ}$

Meakin, app., Morris, resp., 670

Mears $v$. London and South-Western R. C., 949

Mechelen $v$. Wallace, 387

SLedawar $v$. Grand Hotel Co., 928, 929

Medway Nav. Co. $v$. Romney (Earl of), $87,8 \leq 8$

Medwin, Ex parte,

Meek $v$. Wendt, 741

Meeus $x$. Thellusson, 12s

Meggs $v$. Binns, 213

Melanotte $v$. Teasdale, 487

Melhado $v$. l'orto Alegre R. C., 305, $31 \cdot 2,652$

Mellin $v$. Monico, 172

- v. White, s(j.)

Melliss $v$. Shirley Local Board, 349

Mellor $v$. Leather, 147

- $v$. Watkins, 56t, 889

Mellors $v$. Shaw, sus

Melville $r$. Doidge, 918

Melville's case, 1090

Membery $v$. Great Western R. C., 81:5

Senuie $\imath$. Blake, 147

Mercantile Steamship Co. $v$. Tyser, 331

Mercer and Moore, $R e, 658$

- $\quad v$. Irving, 726

- $v$. Woodgate, 14

Merchants of Staple of Eugland $v$. Bank of England, 482

Merchant Shipping Co. $v$. Armitage, 741

Mercier $v$. Williams, 680

Merest $x$. Harvey, 978

IEeriton $v$. Coomber, 208

Merivale $v$. Carson, 853, 857

Merrill $v$. Frame, 523

Merry $r$. Green, 1068

Mersey Docks Trustees $v$. Gibbs, 755,796

- $\quad x$. Penhallow, 755, 796

- \&c., Steel Co. v. Naylor, $6,114,433$ \[erywether $v$. Turner, 860

Messenger Armstrong, 512

$v$. Clarke, $67 \%$

Metcalf $v$. Rycroft, 622

Metcalfe $v$. Londou, Brightou, se., R. C., 932,937

$v$. Richardson, 463

Metropolitan Ass. $v$. Petel, 876

$\begin{array}{cc}- & \text { Bank } v \text {. Heiron, 153 } \\ - & -v . \text { Pooley, 46, } \\ - & \text { Board of Works } r . \\ \text { Jietropolitan R C., } \\ \text { 81 } \\ \text { R. C. v. Jackson, } 752 \\ \text { - Saloon Omnibus Co. }\end{array}$
$v$. Hawkins, 793

Metzner $v$. Bolton, 584

Meux v. Cobley, 52 7

- v. Great Eastern R. C., 312, 7 7 1,946

Jews $v$. Carr, 416

- v. Mews, 676

Meyer $v$. Decroix, 455

- $v$. Ralli, 44

Meyerhoff $v$. Frohlich, 157

Michell $v$. Willians, 840,842

IIickleth waite $v$. Mickleth waite, 532

- $v$. Newlay Bridge Co., $880^{\circ}$

Middleditch $v$. Ellis, 274,630

Middleton $v$. Fowler. 797

v. Gill, 743

Midland Insurance Co. $v$. Smith, $100,101,331$

- R. C., app., Pye, resp. 3,6.

- $\quad$ - v. Bromley, 947

- $\quad-v$. Daykin, 762

- $\quad$ - $v$. Miles, 891

- $\quad-v$. Robinson, 885

Migotti $v$. Colvill, 580, 838

Milburn $r$. Codd, 629

Miles, Ex parte, re Isaacs, 506

- v. Furber, 551

- v. Mcllwraith, 601, 961

- v. New Zealand Alford Est. Co., 311, 313, 392.

Jilgate $v$. Kebble, 949

Mill v. Hawker, 801

Sillar $v$. Taylor, 10, 21

Millen $v$. Brasch, 738,937

- v. Hawery, 206

Miller $v$. David, 91, 92, 750, 863

-- $\quad$. Dell, 158

- $v$. Hancock, 754

- $v$. Race, 492

- $\quad v$. Salomons, 3,5

- $v$. Tetherington, 586

Millership $x$. Brookes, 265

Milligan $v$. Wedge, 794

Millington $v$. Harwood, 67 
Millington $v$, Loring, 720

Mills $v$. Barber, 499

- v. Blackall, 301

- v. Colchester (Jayor, \&c., of), 19,759

- $v$. Dunham, 35\%, 361, 363

- v. Holton, 798, 919

Millward $v$. Littlewood, 353

Milne $v$. Marwool, 335, 338, 7 so, 952

Milner, Ex parte, 281

- $v$. Maclean, $102 \mathrm{~S}$

Milnes $v$. Dawson, 979

Milward $r$. Midland R. C., 812

Miner $v$. Gilmour, 887

Mineral Water, \&c., Soc. $v$. Booth, 364

Minshall v. Lloyd, 53

Slirabita $r$. Inperial Ottornan Bank, 505,506

Mitchel $r$. Reynolds, 356, 357, 361

Mitchell $v$. Cantrill, 896, 897

- $\quad v$. Crassweller, 798

- v. Darley Main Colliery, $71,72,82,89,158$, 782,971

- $\quad v$ Jenkins, 835, 840, 841

- $\quad$ : Knott, 759

- $\quad v$. Lancashire \& YorkshireR. C., 946

v. Micheson, 236

Mitcheson $v$. Nicol, 114, 306

Mittlelholzer $v$. Fullarton, 353

Moens $v$. Hejworth, 333, 335, 338

Moffatt $\imath$. Dickson, 215, 606 $v$. Van Millengen, 713

Mogul SS. Co. $\imath$. McGregor, Gow \&Co., 365, $835,989,1020,1022$

Mollett $r$. Wackerbartil, 418

Molton $v$. Camronx, 701, 705

Monk $v$. Noyes, 534

Monmouth Canal Co. $v$. Harford, 895

Monson r. Tussaud, s6, s61

Montacute 2 . Maxwell, 385

Montagu 2 . Forwood, 614

Montague $r$. Benedict, $693,694,697$

Moon r. Durden, 6 v. l'erkins, $46 \mathrm{~s}$

- $v$. Raphael, $9 \& 0$

- $v$. Towers, 802

Moorcock, 'l'he, 247

Moore $v$. Campbell, 413, 417, 419, 582

- r. Garwood, 298, 550, 652

- $v$. Guardner, 838

- v. Hall, 971

- $v$. kinipht, 159, 630

- $\quad$. Lambetl Waterworks Co., 754
Moore $v$, Metropolitan R. C., 793 .

- $v$. Rawson, 902

- v. Rose, 824

- $v$. Woolsey, 365

Morant $v$. Chamberlain, 755

Ioreton $r$. Hardern, 786

Morewood $x$. Pollok, 931

IIorgan, Ex parte, re Simpson, 284

$$
\begin{aligned}
& \text { - } \quad v \text {. Bain, } 114 \\
& \text { - v. Davies, } 566 \\
& \text { - v. Griffith, } 369 \\
& \text { - } v \text { Hardy, } 570 \\
& \text { - } \quad v \text {. Jones, } 743 \\
& \text { - r. Kinight, 66t } \\
& \text { - } \quad r \text { London General Omnibus } \\
& \text { Co., 250, } 811
\end{aligned}
$$

Moriarty $\imath$. Brooks, 785

Morison $r$. Thompson, 38

Morley $r$. Attenborough, 924, 925

- v. Boothby, 285

- $\quad$. Lougliman, 285

i. Renmoldson, 355

Morrell $v$. Martin, 106, 829

Morris $v$. Bethell, 395, 505

- $\quad$. Edgington, 523

- $r$ London \& Westminster Bank, 84

- v. Martin, 698

- $v$. Morris, 532

- $v$. Salberg, 803

- $v$ Vivian, 182

- $v$. Walker, 142

Morrison $v$. Cladwich, 524, 569

- v. General Steam Nav. Co., 759

- $\quad v$ Universal Marine In. surance Co., 934,960

Morritt $v$. North.Fastern R. C., 937

Mortimore 1: Wright, 326

Norton 2 . Copreland, 372

- $v$ Tilbett, 412

r. Woods, 547,549

Moseley $v$. Bland, 902

Moser, In re, $53 \mathrm{~s}$

Moss 2 . Gallimore, $549,555,556$.

- $v$. IIall, 312

- $v$. James, 563

- 2 . Sweet, 427

Mostyn 2 : Coles, 183 
Mostyn $v$. Fabrigas, 43, 104, 824, 839

$v$. West Mostyn Coal and Iron Co., 40, 151, 296, 522

Mouflet $v$. Cole, 361

Moule $v$. Garrett, 313, 559

Momusey $v$. Ismay, 13 $v$. Rankin, 387

Mounteashell (Earl of) $\imath$. Barber, $307,630,633$

Mountjoy $v$. Wood, 33

Mountnoy $v$. Collier, 63,64

Momntstephen $v$. Lakeman, 3s0, 381

Mousley $v$. Lndlam, 13

Ilowatt $r$. Londesborough (Lord), $273,593,7 \pm 2$

Mowbray $v$. Merryweather, 736

Moxham, The, 44

Iloxon $v$. London Tramways Co, 183

Moyce $v$. Newington, $107 \mathrm{~S}$

Moyle $v$. Jenkins, 814

Muggleton $v$. Barnett, 10

Iniv $v$. Crawford, 497

Mulcahy $v$. Reg., 1019, 1021, 1089

Mulkeril $v$. Lord, 117

Iuller $v$. Baldwin, 2

Inllett $r$. Hunt, 758

- $v$. Xason, 91, 757, 980, 992

Mulligan $v$. Cole, 845

Mulliner $v$. Florence, 878

Mullins, app., Collins, resp., 994

Mumford $v$. Gething, 357, 359, 369, 576

- $\quad r$. Oxford, Worcester, and Wolverhampton R. C., 876

Muncey $v$. Deunis, 528, 584

Munday $v$. Asprey, 375

v. Thames, \&e., Co., 814

Mundy $v$. Rutland (Duke of), 891

Inunicipal Building Society v. Kent, 2

Munster $r$. Lamb, 831, 855

v. South-Eastern I.C., 945

Murchie $v$. Black, 81

Murgatroyd $r$. Robinson, 858

Inrphy $v$. Boese, 414

- $\quad$ : Coralli, 799

- $\quad v$. Smith, $\$ 11$

- $\quad$. Wilson, 813

Murray $v$. Currie, 792,795

- . Mamn, 32S

- v. Stair (Earl of), 266

Murrell $v$, Fysh, 740

Murtagh $v$ B Barly, 202

Muschamp r. Manchester and Preston R. C., 942
Musgrave $v$. Horner, 570

Musgrove No. Nell, 840

Muston $v$. Gladwin, 243

Myers $v$. Sarl, 579, $581,556,588$

- v. Willis, 605

Myrtle $v$. Beaver, 616

Mytton $v$. Coek, 918

- $v$. Midland R. C., 77l, 942

X.

NAGLE $v$. Baylor, 50t, 705

Nargett $v$. Nias, 553

Nash, Ex parte, 215

- v. Lucas, 554

National Assurance Assoeiation 2 . Rest, 720

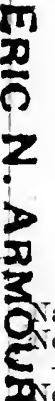

Bank, Ex parte, $*$ Phillips, 388

Bank $v$. Silke, 455,450

Coffee Palace Co. In $r$, Ex parte l'amuure, 620

Exchange Co. v. Drew, 333

Provineial Pank of England $v$. Jarkson, 264

Telephone Co. $v$ : Baker, 882

Taylor $v$. Collinge, 537

eale $v$. Ratelitte, 535

- $v$. Turton, 629

Needham $v$. Bremmer, 260, 697

- $\quad v$. Dowling, 855

- $\quad v$. Fraser, 758

Neilson $r$. James, 14, 585

Nelson $x$. Conch, $: 60$

- $\quad v$. Duteombe, 701

- $\quad v$. Liverpool Brewery Co., $119,767,799$

- $\quad v$. Serle, 378

Ness $v$. Angas, 963

Neville $x$. Kelly, 320

New Brunswick and Canada R. C'. $v$. Muggerilge, 332

New River Co., apm., Johnson, resp. 76

- 2 . Mather, 115 (Bank of) $r$. O'Connor; 230

Owston, 603, 843

New York Bowery, sc., Co. $r$. New York Fire, \&e., Co., 331

New Zealand Land Co. $v$. Watson, 613

Newail $r$. Tomlinson, 608

Newbiggin-by the-Sea Gas Co. $v$. Armistrong, 39

Newbigging $r$. Alam, 329

Newbould $v$. Colturan, 834 
Newcastle - upon - Tyue (Master Pilots, sc., of ) $r$. Bradley, 11

Newfoundland Government $v$. Newfoundland R. C., 151

Newhall $r$, lreson, 749

Newington $v$. Levy, 115

Newlands $v$. National Employers' Accident Association, 623

Newman $r$. Anderton, 544

Newry and Emniskillen R. C. $x$. Coombe, 514, 672

Newsome 2 : Coles, 639

Newson $x$. Pender, s98, 599

Newton, Re, 1095

- (Catherine), Re, 237

- (Frallcis), Re, 237

- $\quad$. Allin, 524

- $\quad v$. Boodle, 8.24

- $\quad$ : Chantler, 997

- $\quad$. Harland, 206, 20, 208

- $\quad v$. Holford, 969

Niblet $r$. Snith, 567

Nichol $v$ : Bestwick, 720,975

- $v$. Godts, 574,586

- $\quad v$. Martyn, 970

- $v$. Thompison, 744

Nicholas $\tau$. Chamberlain, 891

Nicholl $v$. Allew, 97

- $v$. Mclieag, 522

Nicholls $v$. Diamond, 473

- r. Stretton, 363

Nichols $\tau$. Hall, 994

- $v$. Marsland, $73,760,882,931$

Nicholson $v$ : Jradtield Union, 644, 647

- $\quad$ : Harper, 430

- $\quad$ : Gooch, 348

- $\quad$. Ricketts, 496, 634

Nickalls $x$. Mlerry, 585

Xickells $v$. Atherstone, $396,563,960$

Xicklin $x$. Williams, 89

$\mathrm{Nicol} v$. Beaumont, $\mathbf{S} 20$

- $r$. Nicol, 355

Nicoll $r$. Beere, 363

Nicolls $v$. liastarl, 921, 948

Nield $v$. London and North-Western

R. C., 904

Niell $r$. Morley, 702

Nielsen $r$. Wait, 583

Nind $v$. Nineteenth Century Buildiug Society, 295, 296

$-\tau$. Rhodes, 57

Nitro-Phosphate Cu. $x$. St. Kathar-

ine's Docks C'o., 931

Nixon $x$. Freeman, 554

Noble r. National Discount Co., 317, 442

-- $x$. Ward, 413,417

Noden r. Johnson, 785,786

Nokes' case, '523
Nordenfelt v. Maxim-Nordenfelt Co.. 361, 362, 363, ะ64

Nordenstrom $v$. Pitt, 322

Norfolk R. C. v. II'Namara, 275

Norris $v$. Beazley, 118

- $v$. Seed, 967

North $v$. Holroyd, 203

North-Eastern R. C. $x$. Elliot, 884 r. Wanless, 751

North Shore R. C. v. Pion, 76, S5s

- Stalfordshire R. C. 2 . Peek, 377

North-Western R. C. $r$. II'Michael, 514,672

Sortham $v$. Bowlen, 212,948

Northam $x$. Hurley, $8 \bar{i}, s 88$

Northcote $v$. Doughty, 674

Norton $v$. Ellam, 470,489 $v$. Fuzan, 698

Norwich (Mayor, \&c., of) $v$. Nortolk R. C., 348

Sosotti $i$. Page, 722

Notara $r$. Henderson, 723

Notting Hill, The, 735,739

Nottingham Hide Co. $v$. Bottrill, 379

Sowell $x$. Worcester (Mayor, sc., of), 651

Nugent $r$. Smith, 932

Nurse $v$. Durnlord, 39

Nittall $v$. Bracewell, 887,903

Nye $v$. Aloseley, 288

O.

O.1kEs $v$. Turquand, 329,957

- $v$. Wood, 786

Oakey $v$. Dalton, 123

Oakley $v$. Mlonck, 539

- $v$. Portsmouth and Ryde Steam Packet Co., 931

Oaste $v$. Tilylor, 447

Oates $v$. Frith, 544

- $v$. Hudson, 707

O'Brien $x$. Bryant, 845

- $\quad v$. Clement, 845,846

- $v$. Reg., 1018, 1089, 1095

Ochsenbein $\tau$. Papelier, 261

Ockenden $v$. Henly, 734

Ockford v. Barelli, 313

O'Connell $v$. Reg., 1020, 1089, 1095

0'Connell's case, 10:21

O'Connor $r$. Bradshaw, 281

Ogden $v$. Benas, 483

- $v$. Saunders, 253

Ogle $r$. Vane (Larl), 419

Ohrby $x$. Ryde Comm., 755

O'Kelly $x$. Harvey, 1026 
Oldershaw $v$. King, 327,380

Uliver $v$. Hunting, $3 \pi 6$

- $v$. Woodroffe, 670

Onoa Coal and Iron Co. v. Huntley, 792

O'Neil $r$. Everest, 751, 754

Onley $v$. Garduer, 895, 901

Onslow's case, 525

Onward Building Society $v$. Smithson, 276, 284

Onward, The, 605

Oppenheim $v$. White Lion Hotel Co., 928

Orby $v$. Moliun, 544

Orcliard $v$. Simpson, 579

Orchis, The, 306

Organ $v$. Brodie, 605

Orme $v$. Galloway, 315,743

Ormerod $v$. Todmorden, 886, 903

Ormond $r$. Holland, 808

Ormrod $v$. Huth, 334

Orr Ewing $v$. Colquhoun, 755, 886, 887

Osbaldiston $v$. Simpson, 355

Osborn $v$. Gillett, 100, 102, 969

- v. Veiteh, 1048

Osborne $v$. Harper, 630

- v. Homburg, 61

- v. Jacksoll, 812

- v. London \& Western R. C., 815

Osterman $v$. Bateman, 839

O'Sullivan $v$. Thomas, 354

Ottaway $v$. Hamilton, 692

Ottos Kopje Co., In re, 960, 973

Onlds $v$. Harrison, 400

Outhwaite $v$. Hudson, 181

Overend \& Gurney Co. v. Gibb, 328

Overton $v$. Banister, 674

- $\quad v$. Freeman, 753, 786,795

- $v$. Harvey, 261

Owen $v$. Burnett, 935

- v. Legh, 766

- v. Routh, 729

- v. Van Uster, 473

Owens $v$. Wynue, 549

Oxford (Mayor of) v. Crow, 643

Oxlade and North-Eastern R. C., Re $, 933,944$

P.

P. \& O. Stean Navigatiox Co. $v$. Sliand, 581, 935

Packington's case, 532

Padgett $v$. Bimus, 186

Page $v$. Morgan, 409

- v. Newman, 743
Page v. Norfolk, 297

Paget $x$. Folly, 569

Paice $v$. Walker, 620

Pain $v$. Whittaker, 949

Paine $v$. Strand Union, 647

Painter $v$. Abel, 601

Paley $v$. Garnett, 812

Palgrave $v$. Windham, 121

Palk $v$. Skinmer, 901

Palliser $v$. Gurney, 682

Palmer v. Fletcher, 891

- v. Forsytll, 236

- $v$. Grand Junction R. C., 936

- v. Johnson, 332

Panton $v$. Williams, 842,843

Pape $v$. Westacott, 602

Pappa v. Rose, 104

Paradine $v$. Jane, 760

Parana, The, 739

Pardington $v$. South Wales R. C., 941

Pardoe v. Price, 37

Paris v. Levy, 74, 853, 859

Parker $v$. Bristol and Exeter R. C., $203,616,707$

- v. Harris, 544

- v. Ibbetson, 584

- v. Mitehell, 896

- v. Rolls, 966

- v. South-Eastern R. C., 922

- v. Staniland, 389

- $v$. Taswell, 518

- v. Winlow, 618, 622

Parkes $v$. Prescott, 858

- v. Smith, 276

Parkins $v$. Carnuthers, 639

$$
\text { v. Scott, } 863
$$

Parkinson $v$. Lee, 424

Parmenter v. Webber, 545, 548, 569

Parmiter v. Coupland, 844, 853, 860,1052

Parrey v. Dunean, 554

Parrott $v$. Anderson, 606

- v. Eyre, 616

Parry $v$. Smith, 94, 795

Parsley $v$. Day, 874

Parsons $v$. Puiton, 145

- v. Gingell, 928

- v. St. Natthew, Bethnal Green, 98

Parton, app., Crofts, resp., 417, 418

Partridge $v$. Scott, 894

Pasley $v$. Freeman, 338, 384, 952

Pater $v$. Baker, 864

Paterson $v$. Gandasequi, 607, 608, 613

Patorni v. Campbell, 225 
Patrick $v$. Colerick, 206

$$
\text { — } \quad r \text {. Milner, } 252
$$

Patscheider $v$ : Great Western R. C., 947

Patten $v$. Rea, 798

Pattersoln $v$. Gas Light and Coke Co., 85

Pattinson $r$. Luckley, 112, 388, 501

Pattison $v$. Jones, 849

Paul, In ve, Ex parte Portarlington (Earl of), 539

- v. Summerhayes, 872

Pauling $v$. London and NorthWestern R. C., 648

Paulton $v$. Lonilon and Western R. C., 793

Paxton $x$. Courtuay, 18

- v. Popham, 280, 282

Payue $v$. Leconfield (Lord), 605

- $v$. New South Wales Coal, sc., Co., 651

$v$. Wilson, $321,327,430$

Paynter $v$. Williams, 308

Peachey $v$. liowland, 795, 798

Peacock $x$. Purcell, 465

Pearce $x$. Brookes, 365

- $v$. Davis, 545

Pearson $v$. Cox, $750,751,796$
- $\quad$. Glazebrook, 229
- $\quad$. Lemaitre, 846
- $v$. P'earson, 358
- $v$. Spencer, S78

Pease $x$. Chaytor, $8: 3,106,833$

- $v$. Gloahec, 506

Peate $v$. Dicken, 313

Pedley $v$. Davis, 829, 834

- $v$. Morris, 855

l'eck $v$. Gurney, 318, 330, 332, 624, $711,772,776$

- $x$. North Staffordshire R. C., $376,380,938-941$

- v. Ray, 164

Pegge $v$. Lanipeter Union, 647

Peyram $r$. Dixon, 812

Peirce $v$. Corf, 415

Pell $v$. Daubeily, 246

- $v$. Shearman, 974

Pellas $x$. Breslauer, $6 \pi$

Pelton $v$. Harrison, 683

Pemberton $r$. Chipman, os

- v. Colls, 863

r. Vaughan, 361,362

Pendlebury 2 . Greenlalgh, 98

l'enfold $v$. Abbot t, 122, 289

Penn $v$. Ward, 785

Pennell $v$. Alexander, 506, 606, 613, 619

Penney $r$. Slade: 831
Pennington $v$. Tanière, $64 \mathrm{~S}$

Penny $v$. Brice, 156,158

Penrose $v$. Martyr, 473

Penruddock's case, 881

Penton $v$. Browne, 749

- $v$. Robart, 539

Percival $x$. Hughes, 795

- $\quad v$. Olduere, 343

- v. Pelley, 61

- v. Stamp, 87T, 879

Perkins $v$. Yaughan, $\$ 26$

Perks $x$. Mylrea, 683

Perren $v$. Monmontlishire R. and C. C., 787,790

Perry $v$. Barnett, 19, 585

- $v$. Eames, $894,896^{\circ}$

- $v$. Fitzhowe, 209, 210

-- v. Skinner, 3

Petch $v$. Lyon, 274

Peter $v$. Comipton, 391, 392

- $v$. Kendal, 563

- $v$. Rich, 308

Peters $\boldsymbol{v}$. Fleming, 669

Peterson $v$. Ayre, 613

Peto $v$. Reynolds, 306,488

Petre $v$. Duncombe, 728,744

Petrie $v$. Dawson, 391

- $\quad r$. Nuttall, 260

Pettamberlass $v$. Thackoorseydass, 6

Peytoe's case, 293

Peyton $x$. Harting, 165

Phelps $v$. Lonton and North-Western R. C., 944

Philips $v$. Philip's, 325

Philipson $v$. Egremont (Earl of), 261

Phillipps $v$. Briard, 584

- $v$. Smith, 529

Phillips, Ex purte, 224

- $v$. Barnet, 675, 676

- $v$. Clark, 931, 933

- $\quad v$. Clift, 269

- v. Elwards, 933

- $\quad v$. Eyre, 6, 43, 44, 103, 801, 804,824

- $\quad v$ Foxall, 331

- $v$. Homfray, 711

- v. Naylor, 79, 838

- $\quad r$ Rees, 5,539

- r. South.Western R. C., 183, 976

- $\quad$. Warl, 258

Plillipson $x$. Hayter, 694

Pliilpot r. Hoare, 558

Phillpotts $x$. Phillpotts, 293

Pliospliate of Lime Co. $v$. Green, 305

Pianciani $r$. Loudon and Soutl.-

Westeru R. ('., 936)

Pickard $v$. Sears, 960, 961

- $v$. Smith, 754, 755 
Picker $v$. London and County Bank, 445

Pickering $v$. Busk, 602

- v. Gumning, 668

- v. Ilfracombe R. C., 348

- v. James, $83,90,748,766$

- v. Ruld, 881

Pickforl $v$. Grand Junction R. C., 936

Pirlgeon $v$. Burslem, 352

Pierce $v$. Williams, 740

Piggot $v$. Eastern Counties R. C., 790

Pigot's case, 501

Pike $v$. Eyre, 513

- v. Ongley, 417

Pilgrim v. Soutliampton and Dorchester R. C., 766

Pilkington $v$. Scott, 300,360

Pilmore $v$. Hood, 366

Pinard $v$. Klockmann, 477

Pindar $v$. Wadsworth, 86

Pinhorn $v$. Souster, 513, 567

Pinnell's case, 291, 397

Pinuington $v$. Galland, 878, 891, 892

Pinto $v$. Santos, 59

Pippin $v$. Shepherd, 772, 823

Pitman v. Woodbury, 301

Pitt $v$. Shew, 550

Pittard $v$. Oliver, 854

Pitts $v$. Beckett, 417

Place, Re, 261

- v. Potts, 260

Plasterers' Co. v. Parish Clerks' Co., 896

Plating Co. v. Farquharson, 356

Playford $v$. United Kingdom Tclegraph Co., 312, 770

Plevins $v$. Downing, 419

Plimmer $v$. Wellington (Mayor of), 889

Plumer v. Mainby, 520

Plumstead, \&c. v. Spackman, 3

Poirier v. Morris, 47 7,613

Polak $v$. Everett, 961

Polhill v. Walter, 332, 334, 473, 615,618

Polkinhorn $v$. Wright, 785

Pollard v. Ogden, 498

Pollen $v$. Brewer, 207

Pollitt v. Forrest, 544

Pollock $v$. Stacy, 548

Pontifex $v$. Midland R. C., 67

$v$. Severn, 172

- $\quad v$. Wilkinson, 419

Ponting $v$. Noakes, 882

Poole $v$. Canning, 690

- $v$. Tunbridge, 292

Poole's case, 390,538

Pooley v. Brown, 495
Pooley $v$. Harradine, 370

Popham v. Fickburn, 856

Popplewell $v$. Hodkinson, 905

Pordage $v$. Cole, 112, 269

Port Canning Land Co. $v$. Smitl, 298

Porter $v$. Palsgrave, 713

Portman $v$. Middleton, 736

Pott $v$. Clegg, 156, 475

Potter $v$. Faulkner, 807

Poulton $v$. London and Sontl-

Westeru R. C., 603

Pounder v. North-Eastern R. C., 982

Pounsett $v$. Fuller, 732

Poussard $v$. Spiers, 114

Pow $v$. Davis, 620, 741

Powell v. Fall, 751

- v. Graham, 122

- $v$. Hoyland, 1071

- $v$. Jessopp, 387

- v. Rees, 123

- v. Salisbury, 981

Power, In re, 238

- $v$. Butcher, 612

Powers $v$. Fowler, 375

Powis $v$. Snitl, 545

Powles $v$. Hider, 930

Powley v. Walker, 321, 525

Powuall $v$. Ferrand, 306

Powys $v$. Blagrave, 533, 570

Poyser $v$. Minors, 260

Pozzi v. Shipton, 769

Praed v. Graham, 976

Prankerd, Ex parte, 214

Preece $v$. Corrie, 509, 548

Preedy $v$. Holton, 576

Prehn $v$. Liverpool (Royal Bank of), $84,718,735,736$

Prentice $v$. Harrison, 829

Presland $v$. Bingham, 900

Preston v. Dania, 252, 273

- v. Lamont, 130

- $v$. Liverpool, Manchester, and Newcastle R. C., 353,652

- v. Merceau, 586

- v. Norfolk R. C., 799

- v. Peeke, 260

- v. Tamplin, 605

Preston's (Lord) case, 1017

Prestwich $v$. Poley, 604

Pretty $v$. Bickmore: 119, 799

Previdi v. Gatti, 814

Price $v$. Berrington, 701

- v. Easton, 315

- v. Great Western R. C., 743

- v. Green, 357, 363, 725

- v. Hewett, 674, 780

- v. Moulton, 275 
Price $v$. Price, 676

- v. Seeley, 824

- $v$. Severn, 182, 978

- v. Woodhonse, S79

- $v$. Worwood, 564

Prideaux $v$. Burnett, 342

Priestley $v$. Fernie, 612

$v$. Fowler, $7 \tau 5,806,80 \tau$

Priestman $v$. Thomas, 260

Prince $v$. Oriental Bank Corporation, 475,476

Prince of Wales Assurance Co. $v$. Harding, 650, 961

Printing, \&c., Co. v. Sampson, 354

Prior $v$. Hembrow, 122, 712

- $v$. Wilson, 845

Prison Commissioners $v$. Clerk of the Peace for Mliddlesex, 574

Pritchard $v$. Long, 974

Proctor $v$. Gibbons, 319

- $v$. Hodgson, 878

- v. Webster, 848

Prosser 2 . Wagner, 709

Protector Loan Co. v. Grice, 724

Prond $v$. Bates, 885

Proudfoot $\imath$. Hart, 534

$v$. Montefiore, 331

Prugnell $v$. Gosse, 358

Pryce $v$. Belcher, 83, 99

- v. Monmouthshire Canal and R. C., 7

Prynn's case, 231

Pugh v. Arton, 537

Pugsley $v$. Ropkins, 4

Pulbrook, Ex parte, 1050

v. Lawes, 386, 388

Pulling $v$. Great Eastern R. C., 711

Pullman $v$. Hill, 852, $85 \mathrm{~S}$

Purcell $r$. Towler, 854

Purcell's case, 260

Pursell $v$. Horn, 784

Purves $v$. Landell, 966

Pust $v$. Dowie, 321

Pye v. Muniford, 901

Pyer $v$. Carter, 878,891

Pym $v$. Campibell, 266, 369

- $v$. Great Northern R. C., 816,

Pyne 817,818 817,81
Dar, 533

Q.

Quarmax 2 . Burnett, $790,794,796$

Qnarrier v. Colston, 356

Quartz Hill, \&c., Co. v. Beall, 219

v. Eyrre, 839,

Queade's Trusts, In re, 689

844

Quick $\boldsymbol{r}$. Ludborrow, 711
Quilter $r$. Mapleson, 6, 564

Quincey $v$. Sharp, 15i

Quincy, Ex parte, 537

R.

RABose $v$. Williams, 613

Race $x$. Ward, 13

Rackstraw $v$. Imber, 630

Radley $v$. London and North-Westem R. C., 788, 815

Railton $v$. Hodgson, 608

Railway and Electric Appliances Co., In re, 271

Raiubow $v$. Juggrins, 961

Rainey, Re, 671

Ralli $v$. Dennistoun, 498

Ramadge $v$. Rran, 182

Ramazotti $x$. Bowring, 613

Ramsay $v$. M'Donald, 707

Ramsden $v$. Brearley, 678

- $\quad v$. Dyson, 889

- $\quad v$. Lupton, 349

Ramshay, Ex parte, 224, 1024

Ramuz $v$. Crowe, 503

Rand $v$. Vaughian, 554

Randall $v$. Newson, 424, 738, 787 , 982

- $\quad v$. Raper, 736,738

- $v$. Rhodes, 343

- $\quad$. Stevens, 207, 870

- $v$. Trimen, 342,741

Randle $v$. Deane, 554

- $v$. Gould, 355

Randleson $v$. Murray, 799

Randon $v$. Toby, 593

Rangeley $v$. Midland R. C., 883

Ranger $v$. Great Westerı R. C., 724

Rankin $v$. Potter, 91

Rann $v$. Hnghes, 369, 377

liannie $v$. Irvine, 361

Raphael $v$. Bank of England, 182, 492

Rapson $\imath$. Cubitt, 795

Rashleigh $v$. South-Fastern R. C., 267

Rawley $थ$. Rawley, 44, 37

Rawlings $v$. Till, 984

$$
v \text {. Walker, } 510
$$

Rawhinson $v$. Clarke, 293, 725

$$
\text { - } \quad v \text {. Shaw, } 713
$$

Rawlyns $v$. Vandyke, 697

Rawson $v$. Haigh, 978

Rawstron $v$. Taylor, 76, 905

Ray 2 . Barker, 135

Raymond $v$. Fitch, 121, 122, 560 $v$. Winton, 269

Rayner $v$. Grote, 619

- $v$. Mitchell, 798 
lic Aitkin, 213

- Albion Assurance Co., 626

- Arthur, 721

- Baker, 63

- Belson, 236

-- Bentlcy, 515

- Bingle, 501

- Bristol, \&c., R. C., 217

- Cardross (Lord), 213

- Cowgill, 237

- Douglas, 23i, 1024

- Dunn, 237

- Eqgington, 237, 238

- Ellershaw, 50

- Fordham $v$. Akers, 64

- Fox, Ex parte Bishop, 729

- Gosman, 743

- Great Berlin Steamboat Co., 355

- Hardwick, 213

- Harrington (Earl of), 229

- Hilliard, 213

- Hopkins, 261

- Humphreys, 987

- Isaacs, 506

- Mercer and Moore, 658

- Newton, 1095

- - (Catherine), 237

- - (Francis), 237

- Oxlade and North-Eastern R. C., 933,944

- Place, 261

- Rainey, 671

-- Stamford (Earl), 152

-- Stroud, 586, 592

- Taylor's Estate, 289

- Threfall, Exparte Queen's Benefit Building Society, 521

- Toleman. 928

- Weaver, 701

- Westzinthus, 507

- Willis, 382

- York (Dean of), 222

Read $v$. Coker, 784

- $v$. Edwards, 756

- $v$. Great Eastern R. C., 815

- v. Legard, 699, 701

Reade $v$. Conquest, 987

Reader $v$. Kingham, 380, 382

Readhead $v$. Miidland R. C., 341,787

Reddaway $v$. Banham, 86, 749

Reddish $v$. Pinnock, 630

Redgate $v$. Haymes, 987

Rellgrave $v$. Hurd, 329, 338, 345

Redmond $v$. Smith, 615

Reece $v$. Taylor, 825

Rced, Ex parte, 456

- v. Moore, 697

Reed's case, 1059

Reedie $v$. Iondon and North-Western R. C., $772,794,795,799,818$
Rees v. Willizms, 202

Reese River Silver Mining Co. $v$. Smith, 329, 330, 335

Reeve $v$. Conyngham (Marquis of), 695 - $v$. Whitmore, 400

Reeves $v$. Capper, 924

- $v$. Hearne, 324, 325

- $\quad$. Templar, 860

Reg. $v$. Adams, 1028, 1061

- $v$. Alison, 1034

- $v$. Allen, 1010

- $v$. Alleyue, 1024

- v. All Saints', Wigan, 215,217

- $v$. Ambergate N.\& B. R. C., 261

- $v$. Anderson, 1045

- $v$. Archer, 1072

- $v$. Ashwell, 916, 1061, 1062, $1063,1065,106 s^{\prime}$

- $v$. Aspinall, 1021, 1073, 1057

- $v$. Badger, 232

- $v$. Bailey, 994

- $\imath$. Baldry, 1092

- $v$. Barnes, 1071

- $v$. Barratt, 1049

- $v$. Barronet, 1033

- $v$. Barrow, 1049

$-v$. Bayley. 65

- $v$. Bennett, 1042

- $v$. Bernard, 1022

- $v$. Berry, 989

- $v$. Betts, 1031

- $v$. Bidwell, 1023

- $v$. Bird, 1011, 1089

- $v$. Biron, 216

- v. Bishop, 993

- $v$. Blake, 1021

- $v$. Blakemore, 278

- $v$. Bleasdale, 1070

- v. Bradford Nav. Co., 1030

- $v$. Bradlangh, 1050

- $v$. Bramley, 1064

- $v$. Bridby, 1023

- $v$. Brimilow, 1010

- $v$. Bristol and Exeter R. C., 215

- $v$. Brittleton, 688

- v. Broadley, 1010

- $v$. Brooks, 1011

- $v$. Brown, 216, 784, 997, 998, 1064,1096

- $v$. Buchanan, 990

- $v$. Buckmaster, 1057

- $v$. Burgess, 998

- $v$. Burton, 1001, 1073

- $v$. Buicher, 995

- v. Button, 1020

‥ $\because$. Cambrilge(Rernrder of ), 261

- $v$. Camplin, 1049

- $v$. Canuiff, 1039 
Reg. v. Canterbury (Archbishop of), 20,216

- v. Carlisle, 1020, 1021

- v. Carter, 1071

- $v$. Case, 1049

- v. Castro, 5. 1025

- v. Central Criminal Court (Judges, \&e.), 216

- v. Chandler, 991, 1034

- v. Chapman, 1025

- v. Charlesworth, 1031, 1089

- v. Charretie, 1024

- v. Chawton, 580

- $v$. Cheafor, 1058

- v. Cheeseman, 998

- v. Child, 995

- v. Chorley, 896

- v. Christopher, 1065

- v. City of London Court (Judge of), 4,814

- v. Clark, 992, 1088, 1096

- v. Clarke, 236, 1049

- v. Cleworth, 6

- v. Cluderay, 1035

- v. Cockburn, 1093

- v. Cohen, 1061

- v. Collins, 998

- v. Coney, 1039

- v. Cooke, 1025, 1073

- $v$. Cooper, 1072

- v. Cornish, 1062

- v. Cory, 1058

- v. Crawshaw, 986

- v. Crick, 1042

- v. Crook, 1042

- $v$. Cruse, 1008, 1011

- v. Cuddy, 1033

- v. Cumpton, 829

- $v$. Dadson, 1044, 1046

- v. Dalby, 14

- $v$. Dale, 1023

- v. Dant, 1042

- $v$. Davies, 1068

- v. Davis, 1009, 1039, 1043

- v. Day, 1049

- $v$. Deasy, 1019

- r. De Banks, 1062

- v. Dee, 1049

- $v$. Jerbỵshire, \&c., Co., 217

- $v$. Dixon. 1065

- v. Doherty, 1008

- $v$. Douglas, 231

- v. Doutre, 322

- $r$. Dowues, 1042

- $v$. Drage, 1071

- v. Duckworth, 784, 997

- v. Dulley, 1035, 1036

$-v$. Dulwich College (Master of), 581

- v. Dykes, 1011

- v. Eagle, 1039
Reg. v. Eagleton, 998

- v. Eilmonds, 46

- v. Elliot, 992, 1029

- v. Essex, 96, 751

- v. Evans, 395, 1061

- $v$. Everett, 62

- $v$. Faderman, 1089, 1096

- v. Falkingham, 1034

- v. Farrell, 1093

- $v$. Feist, 989

- v. Fennell, 1092

- v. Fenton, 1042

- $\boldsymbol{x}$. Ferguson, 998

- v. Ferrall, 1023

- $v$. Firth, 1070

- $v$. Fisher, 1036, 1046

- v. Flatman, 1060

- v. Flattery, 1049

- $v$. Fletcher, 989, 1049, 1096

- v. Flowers, 1061

-- $v$. Foley, 1058

- $v$. Foster, 1072

- v. Fox, 224

- v. Frampton, 1059

- $v$. Francis, 1072, 1090

- v. Franklin, 1042

- v. Fretwell, 999

- v. Friel, 1089

- v. Frost, 1018

- v. Gallagher, 1019

- $v$. Gamble, 215

- v. Gardner, 1061, 1072

- v. Garland, 214

- v. Garrett, 995

- $v$. Gibson, 1093

- v. Gill, 1074

- $v$. Gilmore, 1059

- v. Gloster, 1092

- v. Glyde, 1065

- $x$. Goddard, 1092

- v. Gompertz, 1021

- v. Goodbody, 1061

- $v$. Goode, 1007

- v. Gray, 1034

- $v$. Great Western R. C., 215, 216

- v. Green, 1089

- v. Greenacre, 1036

- v. Gregory, 232, 998, 1055

- v. Gruncell, 1064, 1069

- v. Gumey, 1021

- . Halliday, 997

- v. Hampton, 223

- $v$. Handley, 1064

- $v$. Hanson, 1049

- $v$. Harden, 64, 217

- $v$. Hardey, 278

- v. Harris, 992, 1027, 1029 1096

- v. Harrison, 217

- v. Harvey, 994 
Reg. v. Hassall, 1062

- v. Hatts, 1092

- $v$. Haughton, 261

- $v$. Hazelton, 1073

- $v$. Henson, 992

- $v$. Herford, 221

- $v$. Hertfordshire (Justices of), 222

- $v$. Hicklin, 996, 1029

- $v$. Higginson, 1001

- $v$. Hill, 996, 1002

- $v$. Hilton, 1070

- $v$. Hind, 1092

- $v$. Hollgkiss, 1025

- $v$. Holbrook, 5, 858, 1055

- $v$. Hollis, 1057

- v. Holloway, 1064

- $v$. Holmes, 992

- $v$. Hopkins, 215

- $v$. Hopley, 1040

- $v$. Hornsea (Inlabitants of), 1030

- $v$. Howell, 1027, 1028, 1058

- $\imath$. Hubbard, 1092

- $v$. Hudson, 1021

- v. Hughes, 1042

- $v$. Hull and Selby R. C., 215

- $v$. Huntley, 1046

- $v$. Hutchings, 260

- $v$. Ingall, 759

- $v$. Ingham, 994

- $v$. Ingram, 1011

- v. Inland Revenue (Commis. sioners of), 616

- $v$. Instan, 1034

- v. Jackson, 237

- $v$. James, 784

$-v$. Jarvis, 1092

- $v$. Jenkins, 1062, 1092

- $r$. Jessop, 1034

- $v$. Johnson, 1025, 1059

- $v$. Jones, 1057, 1073, 1092

- $v$. Jordan, 1010

- $v$. Judge of City of Lonilon Court, 4

- $v$. Judge of County Court of Halifix, 64

- v. Judge of County Court of Surrey, 202

- $v$. Justices of Huntingdon, 182

- $v$. Kain, 1093

- $v$. Kay, 1059

- $v$. Kelly, 1036, 1046

- $v$. Kenny, 1060

- v. Kenrick, 1020, 1021

- v. Kerrigan, 1072

- $v$. Kettle, 203

- $v$. Key, 1088

- $v$. Keyn, 1078

$-v$. King, 998, 1021, 1025

B.C.L.
Reg. $v$. Kirkham. 1038

- $v$. Kuight, 1089

- $v$. Labouchere, 232, 1050, 1053

- v. Laugford, 1027

- $v$. Langley, 1055

- v. Langmead, 1071

- $v$. Larner, 1072

- $v$. Latimer, 231, 995

- $v$. Laugher, 1092

- $v$. Lee, 1072

- $v$. Leeds and Bradford R. C., 6

- $v$. Lefroy, 202

- $x$. Lewis, 997

- $v$. Lichfield (Town Council of), 604

- $v$. Light, 828

- $v$. Lister, 992, 1030

- r. Local Gorernment Board, 223

- v. Lock, 1049

- $\imath$ London (Lord Mayor of), 687

- $v$. London and North- Western R. C., 216

- v. Longton Gas Co., 753

- $v$ Lord, 670

- $v$. Lords Commissioners of the Treasury, 215

- $\imath$. Lovell, 1057, 1074

- r. Lovett, 996

- v. Lowe, 1041

- v. Luckhurst, 1092

- $v$. Mainwaring, 216

$-v$. Mallory, 688

- $v$. Manning, 1011, 1020

- $v$. Jarsh, 998

- $v$. Marshall, 233, 1024

- $v$ Martin, 996, 997, 1049, 1072

- v. Masters, 1074

- $v$. Matthew's, 1011

- $v$. Mawgridge, 1032, 1038

- r. McDonald, 915, 1010

- v. McGrath, 1057, 1074

- $v$. MIcNaughton, 1026, 1044

- $v$. Mears, 1020

- $x$. Mellor, 1089

-- $v$. Metropolitan Boart of Works, 76, 95, 905

- $v$. Meyer, 261

- $v$. Michael, 995

- 2 . Middleton, 105i, 1063, 1072

- $v$. Millard, 1025

- $v$. Milledge, 182

- $i$. Millhouse, 1094

- $v$. Mitchell, 1092

- $v$. Mckale, 1059

- $v$. Mcah, 1089 
Reg. v. Moore, 100s, 1065, 1092

- $v$. Morgan, 1064

- $v$. Morris, 1089

- $v$. Morrish, 509

- $v$. Morrison, 1058

- v. Mortlock, 1023

- $v$. Morton, 261,265

- v. Most, 5; 1022

- $v$. Mutters, 1030

- v. Newboult, 1087

- verman, 233, 10.53-105.

- $v$. Nottingham Journal (Proprietors of), 233

- r. O'Brien, 1015

- $v$. O'Connor, 1020

- $v$. Oldham, 994

- $v$. Orton. 1095

- $v$. Osman, 1092

- $v$. Oxford, 1004

- r. Oxford (Bishop of), 215

- v. Oxford (Mayor, \&c., of), 215

- $v$. Palmer, $10 \mathrm{~S} s$

- $v$. Parker, 1087

- $v$. Parnell, 1020

- $x$. Pascoe, 1024

- $v$. Payne, 1091

- i. Peck, 1021

- $x$. Pembliton, 995

- $v$. Percr, 216

- $v$. Perkins, 1070

- $v$ Peters, 664

- c. Petrie, 1031

- $v$. Phelps, 1045

- $x$. Phillimore, 216

- v. Phillips, 1010

- v. Phill potts, 1025

- $v$. Pitts, 1033

- r. Plummer, 695

- $v$. Pocock, 1043

- r. Poole, 1064

- $v$. Porrell, 5\$1, 105\$, 1073

- v. Poynton, 1061

- $v$. Poyser, 1062

- $v$. Pratt, 1061

- 2 . Preston, 1066, 1068

- $r$. Price, 989, 1045

- $v$. Prince, 994, 996, 1063, 1072

- $v$. Privett, 1064

- $v$. Purchase, 1018

- $v$. Raines, 64

- $r$. Pamsay, 1050

- $v$ Read. 206, 1010, 1049, 105\$, 1073

- $v$. Reaney, 1092

- $r$. lieeve, 1092

- $v$. Rice, 1057

- $v$. Richards, 1048, 1064

- $v$. Riclimond, 3024

- $v$. Riley, 1068, 1093

- $v$. Roadley, 104y
Reg. 2 . Roberts, 998

- $v$. Robius, 1064

- $v$ Robinson, $115 \mathrm{~s}$

- $v$. Rogers, 1059

- $v$. Rose, 1047

- $r$. Rovre, 1059

- $v$. Rowlavds, 1020

- 2 . Powton, 1093

- $v$. Russell, 1031

-- $v$. Russett, 1057

-- 2 . Ryland, 991, 1034

- $v$. Rymer, sis, 927

- $\because$. Sadulers' Co., 270,328

- v. Salmon, 1041

- $\because$ Samways, 1070

- $\because$. Sattler, 1045

- . Saumders, 992, 1049

- 2. Saville, 233

- $v$ Seaife, 224

- $\imath$. Serné, 996, 997

- $r$. Serva, 1045

- r. Sharpe, 989

- $v$. Sheplierd, 991

- v. Sherwood, 1039

- $\imath$. Shickle, 1058

- $v$. Shimmin, 1094

- 2 . Shurner, 1092

- $v$. Shuttleworth, 10ss

- $v$. Silverlock, 1072

-- $v$. Sinmons, 1025

-.. Simpson, 1027, 10\%t

- $\imath$. Sleeman, 1092

- $v$. Sleep, 994

- $v$. Smith, $7,999,1011,1034$, $1035,1059,1061,1071$

- $v$. Southampton (Commissioners of), 215,217

- $v$. South-Eastern R. C., 217

- $v$. Sowerly, 1072

- $v$. Speed, 1072

- $v$. Stainer, 989

- $v$. Stamper, 1023

- $v$. Stanger, 233

- r. Stanton, 1049

-. 2. Stear, 1061, 1062

- v. Steel, 1086, 1096

- $v$. St. Albans (Bishop of), 222

- $v$. St. George, 784,997

- $v$. St. Martin's (Guardians of), 224

- v. St. Peler's, Exeter (Chapter of), 215

-. v. Stephens, 1030

- $v$ Stephensolı, 989

- $v$. Stokes, 1004

-r. Stone, 1025

- v. Stonor, 65

- $\imath$. Stowell, 1025

- $x$. Strilp, 1080, 1081

-. $v$. Surrey (Justices of), 21 $;, 224$ 
Reg. v. Swindall, 1041

- $v$. Thallman, 992

- v. Thetford (Mayor of), 647

-.. v. Thomas, 994, 1061

- $v$. Thomjison, 1021, 1064, 1072, 1091, 1092

- $r$. Thristle, 1061

- $i$. Thurborn, 1057, 1065, 1068

- $x$. Tivey, 1035

- $v$. Tolson, 1029

- $v$. Tonbridge (Overseers of), 6

- $v$. Towuley, 206, 1002, 1058

-- $v$. Train, 820,1030

- $v$. Trebilock, 1064

- $v$. Twiss, 221

-. $\quad$. Tyler, 1011, 1035

- $v$. Vann, 1031

- $v$. Vaughan, 95

-. $v$. Verm, 10, 12

- $v$. Villensky, 1070

-r $v$. Vincent, 948

-. $v$. Vine, 6

- $v$. Vodden, 1095

- $v$. Vreones. 1025

- $v$. Vyse, 1001

- $v$. Walls, 1074

- $v$. Walters, 1034

- v. Walton, 1074

- $v$. Warburton, 1021

- $v$. Ward, 995, 1025

- $v$. Waters, 1034

- v. Watson, 992

- v. Watts, 1058, 1073, 1074, 1093

- v. Webb, 992, 1096

- $v$. Weleh, 216, 300, 360

- v. Wellings, 1093

-- v. Welman, 1072

- $v$. West, 1067

- $v$. Westbrook, 544

- $v$. Westley, 1025

- v. White, 1034, 10\%0

- v. Whitehead, 1042

- v. Widdop, 1025

- v. Wigan, 214

- v. Wilks, 1088

- $v$. Williams, $755,796,1049$

- $v$. Wilson, 671. 995, 1064

- $v$. Woodrow, 987

- $v$. Woolley, 1072

- $v$. Worcestershire (Justices of), 216

- $v$. Woitley, 629

- v. Wright, 1073, 1074

- v. Wynn, 1061

-n $v$. Yates, 232

- $v$. York, 1064

Regnart $v$. Porter, 547

Reid $v$. Fairbanks, 590, 972, 981

- v. Reid, 6, 686
Rein $v$. Stein, 130

Reindel $v$. Schell, 724

lieneaux $v$. Teakle, 695

Remnie $v$. Clarke, 633

Reuss $v$. Picksley, 377

leuter $v$. Sala, 114, 252

Revett $v$. Brown, 8it

Revis $v$. Smith, 74, 856

Rex $v$. Abingdon (Lord), $\$ 56$

- $v$. Adams, 1071

- v. Arehdall, 224

- v. Bailey, 986

- v. Banks, 1061

- v. Barker, 232

- v. Barnard, 1072

- v. Barton (Inlabitants of), 233

- v. Beale, 1024

- v. Bear, 1055

- v. Bembridge, 1024

- $v$. Benfield, 232

- $v$. Berchet, 231

- v. Blake, 1029

- v. Borron, 232

- v. Brooke, 232

-- $v$. Brooks, 1058

- v. Burdett. 231, 233, 858, 1090

- $v$. Byron (Lord). 1032, 1038

- v. Cabbage, 1061

- v. Cambridge, 516

-- $v$. Canupbell, 1061

- $v$. Carlile, 854, 1050

- $v$. Carmarthen (Corporation of), 224

- $v$. Carroll, 1008

- $v$. Cheadle (Inlabitants of), 288

- $v$. Chester (Bishop of), 215

- v. Child, 1027

- $v$. Chillesford (Inlab. of), 671

- $v$. Cochrane (Lord), 1021

- $v$. Collett, 522

- $v$. Connor, 999

- v. Cook, 1045

- $v$. Cooke, 995

- v. Cowle, 214, 237

- $v$. Creevey, 854, 856

- $v$. Crossfield, 1008

- $v$. Curll, 1029

- $v$. Curran, 1045

- v. Curvan, 1045

- v. Dean, 1009

- $v$. De Berenger, 1021

- $v$. Denmison, 232

- v. Dixon, 996

- $v$. Drummond, 1092

- $v$. Dunnage, 990

- v. Dyson, 1034

- $v$. Eldershaw, 1010

- v. Esop, 986, 988

- v. Evans, 1033

- $v$. Eve, 233 
Rex v. Farrell, 1074

$-v$. Farrington, 995.997

- v. Ferrers (Earl), 1032

- $v$. Fillongley, 521

- $v$. Ford, 1045

- $v$. Friend, 991

- $v$. Fuller, 998

- v. Gill, 1050

- $v$. Gnosil. 1074

- $v$. Gordon (Lord George), 1018

- v. Grindley, 1008

- $v$. Groombridge, 1010

- v. Gwilt, 232, 233

- $v$. Hanson, 1022

- $v$. Hardy, 1016

- v. Hargrave, 1039

- v. Harland, 1028, 1029

- $v$. Hartley, 231

- $v$. Harvey, 231, 995, 997

- $v$. Haswell, 232, 233

- $v$. Hayward, 1033

- v. Heath, 998

- $v$. Heathcote, 214

- $v$. Hedges, 537

- $v$. Higgins, 998

- v. Holloway, 1064

- v. Hood, 1045

- $v$. Howartl, 824, 1045

- $v$. Howell, 1062

- v. Huggins, 1033, 1042

- $v$. Hughes, 1011

- $v$. Hunt, 995, 1046

- v. Isherwood, 232

- $v$. Ivens, 878

- v. Jaekson, 232, 1061

- $v$. James, 1027

- $v$. Jenour, 232

- v. Jobling, 522

- v. Johnson, 1089

- v. Jolitfe, 11

- $v$. Jollie, 231

- $v$. Jollifte, 232

- $v$. Jolles, 987

- $v$. Keite, 1040

- $v$. Kennett, 1027

- $v$. Kidd, 1010

- $v$. Kiug, 1070

- $v$. Lapler, 1074

- v. Iarrieu, 232

- $v$. Levett, 1046

- v. Lery, 1061

- $v$. Littleclale, 217

- $v$. Long, 1042

- $v$. Lords Commissioners of the Treasury, 616

- v. Lynch, 1038

- $v$. Manning, 1046

- $v$. Marshall, 232

- v. Martiu, 1058

- $v$. Mason, 1074
Rex $v$. Mazagora, 996

- $v$. Mead, 1058, 109.

- $v$. Meade, 1045

- $v$. Meakin, 1008

- v. M'Kay, 224

- $v$. Moore, 996, 106i, 1074

- $v$. Morfitt, 1064

- v. Morris, 1011

- $v$. Mucklow, 1068

- v. Murphy, 1039

- $r$. Niehol, 1049

- $v$ Oakley, 1028

- $r$. Ogden, 224

- $v$. O'Meara, 231

- $c$ Oneby, 1033

- $v$. Osborue, 232

- r. Owen, 1009, 1070

-- $v$. Pagham, 904

- r. Pateh, 1064

- $v$. Peach, 233

- v. Pear, 1061

- r. Pearson, 1070

- $v$. Peltier, 1020

- $v$. Perkins, 1039

- $v$. Philip, 996

- $v$. Picton, 1033

- $v$. Pimney, 1027

- $x$. Price, 1011,1028

- v. Pritchard, 1007

- $v$. Real, 785

- $v$. Richards, 1031

- v. Robinson, 231

- $v$. Rosinski, 1049

- $v$. Russell, 1034

- $v$. Sainsbury, 232

- $v$. Seotield, 998, 1015

- $v$. Seully, 1046

- $v$. Searing, 1058

- $v$. Sedley, 992, 1029

- $r$. Severn and Wye R. C., 215

- $v$. Seward, 1020

- $v$. Sharpness, 233

- $v$. Sheppard, 996

- $v$. Shirley, 1051, 1052

- $v$. Simson, 1070

- $v$. Smith, 1061

- $v$. Sinyth, $102 \mathrm{~S}$

- $v$. Spilling, 1042

- $v$. St. Asaph (Dean of), \$86, 1052

- v. St. Dumstan, 537

- $v$. St. Katharine's Dock Co., 215

- $\imath$. Stafford (Maruquis of), 215

- $v$. Stewarl, 233

- $v$. Story, 107:

- $v$. Sutton, 1010

- $v$. Thomas, 1007, 1008, 1028, 1037,1038

- $v$. Thompison, 1045 
Rex $v$. Tindall, 1031

- $v$ : Tooke, 2

- $v$. Trafford, 904

- v. Yan Butchell, 1042

-- v. Vaughan, 998, 1024

- $i$. Wall, 1033, 1040

- $i$. Walsh, 1070

- $r$. Ward, 1031

- r. Watson, 232, 1050, 1051, 1090

- $v$. Webb, 1042

- $v$. Wheatley, 990

- $v$. White, 224

- $r$. Whiteley, 1039

- $v$. Wiggs, 1040

- $v$. Wilde, 1009

- $r$. Wilkes, 21, 830, 1029

- $v$. Williams, 231,1029

- v. Wilson, 205, 206, 1028, 1029

- $v$. Withers, 233, 1052

- $v$. Woodburne, 994

- $v$. Woodcock, 1092, 1093

- $v$. Woodfall, 994, 1052

- $v$. Woolmer, 1045

- $v$. Young, 832

Reynell $x$. Lewis, 600, 652 $v$. Sprye, $328,346,356$

Reynolds $v$. Bridge, 724,726
- $\quad v$. Coleman, 130
- $v$. Doyle, 454
- $\quad$ v. Edwards, 908$$
v \text {. Wheeler, } 307
$$

Rhodles, In re, 701

- $v$. Airedale Drainage Com. missioners, 888

- $\quad v$. Forwood, 2శ1, 301

- In ro, 701

- $\quad v$. MLoules, 635

-- $v$. Sinethurst, 158

- $v$. Swithenbank, 670

Rhymmey R. C. $v$. Rhymney Iron

Rice $v$. Baxendale, 741 Co., 766

- $v$. Chute, 616

- $v$. Everitt, 616

- $v$. Shepherd, 697

Rich $v$. Basterfield, 118, 799, 800

Richarls $v$. Fry, 896

$$
\begin{aligned}
& \text { - } \quad v \text {. Harper, } 80 \\
& \text { - } \quad v \text {. Jenkins, } 677 \\
& \text {-- } \quad r \text {. Johnston, 396, } 961 \\
& \text { - } \quad v \text {. London, Brighton and }
\end{aligned}
$$

Richardson $v$. Chasen, 740,980 v. Du Bois, 696
Richarison Dunn, 740, 741

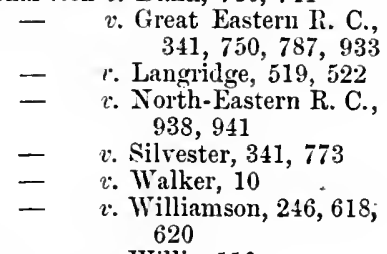

$v$. Willis, 110

Richbell $v$. Alexander, 676

Richdale, Ex parte, 479

Richmond $v$. Nicholson, 123

v. Smith, 926

Ricket $v$. Metropolitan R. C., 95

Ricketts $v$. Bennett, 605

- $v$. The East and West Iudia

Docks, \&c., R. C., 762

$r$. Weaver, $122,559,560$

Ridgway $v$. Allen, 226

Ridgway $\tau$. Wharton, 306, 376, 414

Riding $v$. Smith, 862

Ridley v. Plymonth, \&c., Baking Co., 651

Rigby $r$. Bennett, 892

- $v$. Great Westem R. C., 267

- $v$. Hewitt, 788

Rigg $v$. Lonsdale (Earl of), 874

Rigge $v$. Bell, 512, 522

Right d. Flower, v. Darby, 511 512

Piley $v$. Baxendale, 808

- ¿. Horne, 931, 932, 933

- v. Packington, 599, 600

Rimini $v$. Van Praagh, 6

Rippinghall $v$. Lloyd, 397

Risbourg $v$. Bruckner, 608, 613

Riseley $v$. Ryle, 544,547

Rist $v$. Faux, 968

Ritchie $v$. Smith, 349

Rivaz v. Gernssi, 331

River Wear Commissioners $v$. Adamson, $3,5,73,760$

Rixon $v$. Emary: 142

Roach $v$. Thompson, 306

- $v$. Wright, 226

Roatl $v$. Driscoll, 76

Robarts 2 . Tucker, 84, 475, 476

Robbins $v$. Fennell, 316

$$
\text { - } v \text {. Jones, } 754,799,817
$$

Robert Mary's case, 969

Roberts, Ex parte, 495

- v. Barker, 526, 586

- $\quad v$. Bethell, $46 \bar{\tau}$

- $\quad$. Brett, 112, 209

- v. Great Western $\mathrm{R} \mathrm{C.,}$ 751,762

- $\quad v$. Haines, 885 
Roberts $r$. Hughes, 182

- v. Orchard, 116

- $v$. Richards, 903

- $\quad$. Roberts. 283, $\varepsilon 63$

- $\quad$. Rose, 211

- v. Smith, 246, 808

- $\quad v$. Tayler, 785

- $v$. Tucker, 375, 392

Robertsou $v$. Fleming, $312,778,966$

- $\quad v$. French, 582

- $\quad$ v. Jackson, 581

- v. Macdonogh, 322

Robins 2: Cubitt, s12

$v$. Norris, 676

- $v$. Gray, 929

- v. May, 487

Pobinson $v$ Alexander, 156
- $\quad$ r. Bland, 720
- $\quad$ r. Davidson, 296
- $\quad$ r. Gell, 759
- 2 . Gleadow, 608
- $\quad$. Harman, 727,732
- $\quad 2$ Hoffman, 545
- $\quad$. London and Soutl. Western R. C., 939
- $\quad v$. Lynes, 683
- v. Mlarchant, 863
- $\quad v$. Mollett, 19, 585, 592
- $\quad$. Rutter, $94 \mathrm{~S}$
Robson, In re, 265

$$
\text { v. Walker, } 551
$$
- $\quad$. Bennett, 476
- $\quad v$. Drummond, 446
- v. Nortl-Eastern R. C., 752
v. Oliver, 494

Rochdale Canal Co. $v$. King, 87, 888

- $\quad$ - $\quad$. Radeliffe, 895

Rochester (Bislop of) $\imath$. Bridges, 766

- (Dean, sc., of) v. Pierce, 646

- (Mayor of) r: Reg., 215, 216,217

Rochfort $v$. Atherly, 115

Roden $v$. Erton, 556

Rodgers $v$. Maw, 914

$$
\begin{aligned}
& \text { - } v \text {. Nowill, } 85 \\
& \text { - } \quad r \text {. Parker, 90, } 766
\end{aligned}
$$

Rodrigues $x$. Melhuish, 792

Rodwell $v$. Phillips, 389

Roe 2 . Birkenhead, Laucashire, aud Cheshire Junction R. C., 801,943

- d. Durant 2 . Doe, 566

- $v$. Pierce, 566

Roffey r. Greenwell, 488

Rogers, Ex parte, $5 \$ 5$
Rogers $v$. Bolton, 676

- $v$. Brenton, 14, 18

- $\quad v$. Clifton, $\$ 49$

-- $v$. Dutt, 72, 103, 747, 577

- $\quad$ : Haller, 328,369

- $v$ Humphreys, 549

- v. Lambert, $92 t$

- $v$. Langford, 493

- $r$. Maenamara, $7 \$ 1,864$

- $v$. Maddocks, 363

- $\quad v$. Rice, 295

- $v$. Spence, 661, 979

- $\imath$. Taylor, 15, 81, 90s

Rolin $r$. Steward, 84, 152, 4\$2, $718,720,863,973,976,979$

Rollason $v$. Leon, 518

Rolph 2: Crouch, 741

Romney Jarsh (Bailiffs of) $r$. Trinity House, 91

Rona, The, 606

Roope $r$. D'A vigdor, 101, 102

Rooth 2 . North-Eastern R. C., 938

- $v$. Wilson, 918, 948, 949

Roots $r$. Dormer (Lorl), 415

Roper $v$. Bumford, 545

- $v$. Holland, $3 \bar{\imath}$

- $v$. Johnson, 11: 440, 729

- $v$. Lendon, 42

Roret $v$. Lewis, 838

Roscorla $v$. Thomas, 323

Rose $v$. North-Eastern R. C., 752

- $v$. Wilson, $\$ 25$

Rosewarne $v$. Billing, 352

Rosewell $r$. Prior, 118, 891

Ross $r$. Fedden, 882

- $v$. Hill, 930

- $v$. Norman, 838

- $v$. Rugge-Price, 107,760

Rossiter $v$. Miller, 299, 372, 376

Rothes $v$. Kirkealdy, 4

Rotton $v$. Inglis, 498

Rouch $v$. Great Western R. C., $97 \mathrm{~S}$

Rouquette 2 . Orermann, 466, $4 i \pi$, 478

Rourke r. White Moss Colliery Co., $806^{\circ}$

Rousillon $v$. Rousillon, 353

Routledge $r$. Grant, 297

- $\quad$ Hislop, 259

Row $v$. Dawson, 446

Rowhotham $v$. Wilson, $80, s s 4$

Rowlands r. Samuel, 980

liowley $r$. Horne, 932

- $v$. Loniton and NorthWestern R. C., 81s

Royle $x$. Busbr, 605

Ruabon Briek Co. $x$. Great Western R. C., 855

Ruck $\imath$. Williams, 750,755 
Rucker r. Cammeyer, 417

Ruddock $v$. Marsh, 693

Rugg $v$. Minett, 427

- $v$. Weir, 114

Rumball $v$. Ball, 489

- $v$. Metropolitan Bank, 445

Rumsey $v$. Webb, 845

Rundle $v$. Little, 974

Runnacles $v$. Mesquita, 135

Russel $v$. Langstaffe, 490

Rnssell $v$. Briant, 118

$$
\begin{aligned}
& \text { - v. Cambefort, } 120 \\
& \text { - } v \text {. Corne, } 969 \\
& \text { - } \quad v \text {. Deron (Men of), } 98 \\
& \text { - } \quad v \text {. Nicolopulo, } 343 \\
& \text { - } \quad v \text {. Russell, } 90 \\
& \text { - } v \text {. Shenton, } 536 \\
& \text { - } v \text {. Thornton, } 331 \\
& \text { - } \quad v \text {. Watts, 891, } 892
\end{aligned}
$$

Russian Steam Nav. Co. v. Silva, 588

Rust $v$. Nottidge, 300

Rustomjee $v$. Reg., 242

Rutland (Duke of ) $x$. Bagshawe, 222

Ruttinger $v$. Temple, 326

Ryall $v$. Rowles, 446

Ryalls $v$. Leader, 853

- v. Reg., 105, 1095

Ryan $v$. Clark, 747,873

- $v$. Sams, 690

Ryder $v$. Wombwell, 669, 670

Rylands $x$. Fletcher, 782,882

\section{S.}

SaCheverell $v$. Froggatt, 559

Sack $v$. Ford, 792

Sadler $x$. Henlock, 754, 798

- $v$. Nixon, 630

- v. Smith, 262

Sainsbury $v$. Matthews, 389

Saint $v$. Pilley, 563

Sainter $v$. Ferguson, 357, 359

St. Helen's Smelting Company $v$. Tipping, 822,881

Salford (NIayor of) $v$. Lever, 353

Salisbury (IIIarquis of) $v$. Gladstone, 10,14

Salkeld $v$. Johnson, 5

Salmon $v$. Matthews, 544

$$
\text { - v. Watson, } 391
$$

- v. Webb, 370

Salomons $v$. Knight, 861

Salters' Co. $v$. Jay, 896

Sampson $v$. Easterby, 558

- $\quad v$. Hoddinott, $88,886,887$

$$
v \text {. Mackay, } 66
$$

Samuel $v$. Parne, 827

Sandeman $v$. Scurr, 792
Sanders $v$. Iaclean, 505

- v. Sanders, 154

- v. St. Neots Union, 647

- $\quad v$. Stuart, 735, 738, 973, 979

- $\quad v$. Teape, 786

- $v$. Vanzeller, 516

Sanderson $v$. Graves, 3S8, 392

Sandes $v$. Wildsmith, 118

Sandilands, Ex parte, 235

- In re, 264

- $\quad v$. Marsh, 630

Sandill $v$. Franklin, 566

Sands $v$. Child, 801

- $v$. Clarke, 112, 490

Sanitary Commissioners of Gibraltar v. Orfila, 755

Sanquer $v$. London and SouthWestern R. C., 9\$1

Sansom $v$. St. Leonard, Shoreditch, 37

Santos $v$. Illidge, 353

Sapsford $v$. Fletcher, 521

Sarl $v$. Bourdillon, 414, 581

Sarson $v$. Roberts, 24S, 569

Saul $v$. Jones, 471

Saunders $v$. Mills, 853

$$
\text { v. Topp, } 408
$$

Saunderson $v$. Griffiths, 690

- $\quad v$. Jackson, 376, 414

Sarille $r$. Sweeney, 677

$$
\text { v. Piper, 452, } 574
$$

Saxby $v$. Easterbrook, 219

- v. Hennett, 85

- $v$. Manchester, Sheffield, \&c., R. C., 800

Sayers $v$. Collyer, 295

Sayles $v$. Blane, 306

Sayre $v$. Rochford (Earl of), 830

Scaife $r$. Farrant, 922, 931

Scales $v$. Cheese, 860

Scaltock $v$. Harston, 556

Scarf $v$. Jardine, $640,96 \mathrm{I}$

Scarpellini $r$. Atcheson, 676

Scattergood $v$. Sylvester, 913

Schack $v$. Anthony, 622

Schakell $v$. Rosier, 348

Schibsby $v$. Westenholz, 44, 261

Schmaltz $v$. Avery, 619

Scholfield $v$. Londesborough (EarI of), 468,482

Schreiber $r$. Dinkel, 733

Schroder $v$. Central Bank, 475

Schultze $v$. Great Easteru Ry., 738

Schuster $v$. Mc Kellar, 792

Scofield $v$. Hincks, 539

Scorell $v$. Poxall, 359

Scothorn $r$. South Staffordshire R. C., 942 
Scotland (Royal Bank of) $r$. Totten. ham, 479

Scotson 2 . Pegg, 311, 324

Scott $v$. Avery, $41,42,353$

- v. Brown, 207, 1021, 1022

- 2 . Clifton School Boarl, $64 \mathrm{~s}$

- v. Dickson, 952

- $\quad$. Ebury (Lord), 620

- v. Legg, 6

- $x$. Liverpool (Corporation of), 41

- $\quad$. London, \&c., Docks Co., 752

- $v$. Morley, 683

- $v$. Pape, 896,899

- $r$. Royal Wax Candle Co., 130

- $v$ Scott, 797

- $x$. Seymour (Lord), 43

- $x$. Shepherd, 94, 751, 783, $780^{\circ}$

- $v$. Stansfelel, 104, 855

Scottish Nortli-Eastern R. C. $v$. Sterrart, 651

Scrivener $v$. Pask, 599, 796

Seagram 2: Tnek, 153

Seaman $r$. Netherelift, $\$ 56$

Seare $v$. Prentice, 823

Searle $v$. Laverick, 341, 921

- v. Lindsay, 808

Sears $v$. Lyons, 975

Seath $v$. Mloore, 425,427

Seaton $v$. Benedict, 692

Sebag $x$. Abitbol, $4 \pi 1,4 \pi 2$

Sedidon $v$. Bolton (Bank of), 900

Sedgwick $r$. Danieil, 629, 630

Sedman $v$. Walker, 93

Seeger 2 . Dnthie, 269

Selby $v$. East Anglican R. C., 445

- $x$. Eden, 41

- $v$. Greaves, $5 \ddagger 7$

Sellin $v$. Price, 501

Semayne's case, 554,748

Semenza $v$. Brinsley, 614

Semple's case, 1064

Senao is. Noel, 200

Senior $r$. Ward, 787

Sentance $x$. Poole, 705

Serff $r$. Aeton Local Boarl, 908

Seroka $r$. Kattenburg, 682

Seton $v$. Iafone, 962,964

Seward $r$. Vera Cruz, 815

Sewell 2 . Jones, 63, 64

Seymour $v$. liridge, 19, 555

- $\quad v$ Greenwool, 797

- 2. Matulox, 767

Shackell $v$. Rosier, 351

Shadwell $r$. Shadrell, 304,312

Shatfers $v$. General Steam Naviga. tion Co., 812

Slalleross $x$. I'almer, 501
Shannon $x$. Shannon, 147

Shardlow $x$. Cotterell, 370

Sharman $x$. Brandt, 414,417

-- $\quad r$ Sharman, 386

Sharp $x$. Powell, 94

Sharpe $r$. Brice, $7: 22$ v. Gibbs, 275

Sharrod $v$. London and North-

Western R. C., 702, 793

Shat tock $v$. Carden, 261

Shaw $\because$. Chairitie, 825

- $\imath$. Jersey (Earl of), 218

- $v$. Port Phillip Gold Mining Co., 476,623

- $v$. Stenton, 523

- 2. Thackray, 705

- 2 . York and North Midland R. C., 941

Sheba Gold Mlining Co. $\imath$. Trubshawe, $7 \notin 2$

Shedden $v$. Patrick, 261, 262

Sheehy $v$. Professional Life Assurance Co., 128

Sheffield $x$. London Joint Stock Bank, 445

- Nickel Co. $v$. Unwin, 323

- Pernanent Building Soriety $2:$ Aizlewood, 651

Shelfer 2 . City of London Electric

Lighting Co., 881

Shelton $r$, Livins, 371,415

- $\quad$. Springett, 326

Shepheard $x$. Whitaker, 845

Shepherd $v$. Bristol and Exeter R. C., 946

- $\quad v$ Harrison, 506

- $\quad$. Hills, 263

- $\quad$ Johnson, 728

Sherrington $v$. Fates, 676

sherwin $x$, Swinlall, $\$ 36$

Shillibeer 2: Glyn, 919

Shillito 2 . Thompson, 819, 991

Ship's case, 341

Ship Money (case of), 28

Shippey r. Grey, 39

Slinretf $x$. Wilks, 638

Shore $x$. Wilson, 581, 58s

Short $x$. Kalloway, 306. $7 \pm 0$

- r. II'Carthy, 159

- 2 . Simpsoli, 507

- $r$. Stone, 112

Shortridge $x$. Young, 226

Shower $x$. Pilck, 399, 979

Shrewsbury and Birmingham R. C. $r$. London and North-Western li. C., 353

Shrewsbury's (Earl of) ease, 594

Shrewsbury Peerage case, 5

Shubrick $x$. Sahmond, 285

shubrook $r$. Tuffnell, 892 
Slunttleworth $v$. Le Fleming, 894 Siboni $v$. Kirkman, 122, 289, 711 Sibree $v$. Tripp, $397,398,487$

Sibthorpe $v$. Brumel, 269

Sickens $v$. I'ving, 601

Siddon $v$. East, 33

Siddons $v$. Short, 218

Sidney's (Algernon) case, 1018

Sievewright $v$. Archibald, 414, 418

Siggers $v$. Evans, 263, 400

Sikes $v$. Wild, 732

Silcock $v$. Farmer, 528

Silk $v$. Osborn, 664

Simn $v$ Anglo-American Telegraph Co., 961

Simmons $v$. Edwards, 676

$$
\begin{array}{ll}
\text { - } & v . \text { Lillystone, 977 } \\
- & v \text { London Joint } \\
\text { Bank, 445 } & \text { Stock } \\
- & v . \text { Millingen, 828 } \\
-\quad & v . \text { Mitchell, 862 } \\
-\quad & v . \text { Norton, 531 }
\end{array}
$$

Simun $v$. Motivos, 414

Simons $v$. Great Western R. C., 939, 941

- $v$ Patcliett, 620, 733, 741

Simper $v$. Foley, 896

Simpson $v$. Accidental Death Insurance Co., 961

- v. Bloss, 352

- $\quad v$. Crippin, 114

-- $\quad v$. Eggington, 805

- v. Hartopp, 550, 551

- $\quad v$. Howden (Lord) $, 279,353$

- $\quad v$ Lamı, 356, 779

- v. London and NorthWestern K. C., 738, 741

- v. Margitson, 580

- $\quad v$. Robinsoll, 850

- $v$. Sarage, 876

- $\quad v$. Thomson, 117, 981

- $v$. Wells, 11, 14

Sims $v$. Bond, 613,636

- v. Brittain, 636

-. v. Brutton, 635

- v. Marryat, 925

Simson $v$. London General Omnibus Co., 752

Siner $v$. Great Western R. C., 751

Singer Machine Manufacturers $v$. Wilson, 85

- Manufacturing Co. $v$. London and SouthWestern R. C., 928

Singh $v$. Pattuk, 87, 889, 903

Singleton $v$. Eastern Counties R. C., 789

Sirdar Gurlyal Singh $v$. Faridkote (Rajah of), 44
Six Carpenters' case, 565, 879, 830 Skeate $v$. Beale, 707

Skeet $v$. Lindsay, $15 \pi$

Skinner $v$. Lonclon (City of), \&e., 736,768

- v. London, Brighton, and Sonth Coast R. C., 790 v. Stocks, 636

Skinners' Co. $v$. Knight, 295

Skipp v. Eastern Counties R. C., 806,807

Slark $v$. Highgate Archway Co., 645 Slater $v$. Baker, 823

- $v$. Jones, 114

Sleath $v$. Wilson, 797, 798

Sleddon $v$. Cruikshank, 391

Sleigh $v$. Sleigh, 454, 500

Slim $v$. Great Northern R. C., 941, 943

Slocombe $v$. Lyall, 872

Sloper $v$. Cottrell, 677

Slowman $v$. Dutton, 862

Small $v$. Smith, 651

Smart $v$. Harding, 386

- $v$. Jones, 399

- v. Morton, 885

- $v$. Sandars, 315

Smee $v$. Smee, 704

Smeed $v$. Foord, 741

Smeeton $v$. Collier, 52

Smethurst $v$. Mitchell, 608

Smith $v$. Anderson, 626

- v. Bailey, 797

- v. Baker, 203, 812, 815, 914

- $\imath$. Barnhanı, 995

- v. Barrett, 516

- $v$. Braine, 499

- $\quad$. Bromley, 350,356

- v. Chadwick, 952

- v. Compton, 306

- r. Cook, 916

- v. Cuff, 356

- v. Darby, 80

- $\quad$. Dearlove, 928

- v. Fletcher, 82, 882

- v. Fox, 159

- v. Gleat Eastern R. C., 786

- $v$. Green, 72, 330, 736, 738, $7 \pm 1,757$

- $v$. Hixon, 967

- v. Howell, 740

- $v$. Hurhes, 331

- v. Huil Glass Co., 650, 651

- v. Jeffryes, 575,586

- v. Kay, 338

- $\quad v$. Keal, 604, 803

- $v$. Kenrick, 73, 82, 904

- v. King, 675

- $v$. Land and House Property Co. , 332, 338, 345 
Smith $v$. Lindo, $348,349,417$

- $v$. London and North-Wes. tern R. C., 94

- v. London and Soutb-Western R. C., 751

- v. London Dock Co., 754

- $v$. London, Brighton, and South Coast R. C., 936, 937

- $v$. Marrable, 248, 569

- 2 . Marsack, 142

- $v$. Mawhood, 349

- $v$. M'Guire, 602

— v. Milles, 873, 914

- $v$. Monteith, 504

- $v$. Neale, $315,377,392,924$

-. $v$. Pent, 558

- . Plomer, 690

- $v$. Roche, 326

- $v$. Salzmann, 281, 356

- $v$. Scott, 285

— $v$. Shirley, 526

- $v$. Sorby, 353, 955

- $v$. Steele, 808, 811, S18

- v. Surnian, 3\$6, 390, 405

- $v$. Thackerah, 82,158

- $v$. Thompson, 268, 591, 732

- $v$. Thorne, 157,325

-- v. Troup, 604

- $v$. Trowsdale, 291, 293

- $v$. Vertue, 469

- $v$. Whitlock, 689

- $v$. Wilsou, 579, 580, 588

- $\quad v$. Woodfine, 720

- v. Wright, 206

Smith O'Brien's case, $109 i$

Smout $v$. Ilbery, $616,617,691$

Smurthwaite $r$. Hannay, 118

Smyth, Ex parte, 222 $v$. Wilkius, 508

Snead $v$. Watkins, 878

Sneesby $v$. Lancashire and Yorkshire R. C., 94, 981

Sncll $v$. Finch, 251

Suelling 2 . Huntingfield (Lord), 391

Snow $\imath$. Franklin, 290

- $v$. Whiteliear, S0, 882, 905

Snowdon, Ex parte, 306

- $v$. Daris, 616

Soar $v$. Ashwell, 153

Solly $v$. Forbes, 275

Solomon, In re, Ex partc Dressler, 655

v. Vintners' Co. (The), 910

Soltan 2 . De Held, $820-\$ 22$

Soltykoff, In re Mlargrett, Ex parte, 167

Somerset, Inre, Somerset $x$. Punlett, 153
Somerset $v$. Hart, 994

$v$. Wade, 994

Sonerville $v$. Hawkins, $848-850$

Sommerville $x$. Mirehouse, $72, \$ 31$

Soper $v$. Aruold, 312

Souch $v$. Strawbridge, 391, 392

South American and Jerican Co. . In re, Ex paste Bank of Eugland, 256,260

Sonthampton Steam Colliery Co. $v$. Clarke, 588

Southampton (Lord) 2. Brown, 263

Southeote $r$. Stanley, $75 \overline{7}, 767$

South-Eastern R. 'C. $\imath$. Railway Commissioners, 5

South-Eastern K. C. $\tau$. Warton, 284

Southee $v$. Denny, 862

Soutl Hetton Coal Co. $v$. Sortl. Eastern News Association, 794

Sonth of Ireland Colliery Co. $v$. Waddle, 644,645

South Staffordshire Waterworks $v$. Sharman, 912,:068

Southwell $v$. Bowditch, 5\&5, 619, 620

Sorrarl $r$. Leggatt, 534

Sowerby $r$. Butcher, 622

- $\quad v$. Coleman, 12

- $v$. Wadsworth, i0

Spaight $v$. Tedcastle, 775

Spalding $r$. Ruding, 507

Sparrow 2 . Carruthers, 700

$$
\text { v. Paris, } 726
$$

Spartali $r$. Benecke, 585

Spedding $r$. Nevell, 246, 342, 741

Speight $v$. Oliviera, 968

Spence 2 . Healcy, 291, 293

Spencer's case, 270, 522, 544, 556, 557,558

Spencer $\boldsymbol{\imath}$. Harding, 246, 320

$$
\text { r. Slater, } 254
$$

Spenser's Estates, In rc, 514

Spice $v$. Bacon, 928

Slicer 2 . Cooper, 581

Spill $x$. Maule, 848

Spindler $r$. Grellett, 490

Spittle $v$. Lavender, 62:2

Spoor 1 . Green, 71,90s

Spreadbury 2 . Chapman, 692

Sproat $\tau$. Inthew, 472

Sprott $v$. Powell, 616

Sprye $\tau$. P'orter, 356

Spurrier $v$. Allen, 615

Squires v. Campbell, 902

Stables $r$. Eley, 797

Stafford $r$. Coney, 908

Stafford (Mayor of) 2 . Till, 646

Stainbank $r$. Fenniug, 605

r. Sheprari. 60 :

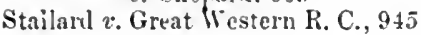


Stamford (Earl), Re, 152

Stamford Banking Co. $v$. Smith, 15

Stammers $r$. Yearsley, 827

Standewick $r$. Hopkins, 182

Stanley $v$. Dowdeswell, 298

- $\quad$. Haycs, 523

- $\quad v$. Powell, 786

- $v$. Western Insurance Co. 91

Stanton $v$. Richardson, 341,723

Staple $v$. Héydon, 891

Stapleton $x$. Haymen, 912

Starely $r$. Allcock, 548

Stavers $v$. Curliug, 269

Stead $\imath$. Anderson, 977

- $\imath$. Dawber, 419

Stearine, \&c., Co. $v$. Heintzmann, 581

Steeds $v$. Steeds, 291, 294

Steel, app., State Line Steamship Co. resp., 506, 933

- $v$. Dixon, 306

- $v$. Lester, 792

- $\quad v$. Sonth-Eastern R. C., 796

Steele $x$. Brannan, 996, 1029

- v. Hoe, 327

- v. Mart, 265

- $\imath$. Williams, 616

Steer $v$. Crowley, 720

Steiglitz v. Egginton, 636

Stephens, Ex parte, Re Laries, 538 $v$. Australasian Insurance Society, 579, 592

- $\quad v$ Elwall, 801, 914

- $\quad v$. London and South. Westem R. C., 936

- $\quad v$. Myers, 784

- $\quad v$. Reynolds, 634

Stephenson $v$. Raine, 62,63

Sterry $r$. Clifton, 348,356

Stenart $v$. Jones, 62

Stevens $v$. Copp, $2 \overline{7} 0$

- $v$. Gourley, 346

- v. Jeacoeke, 107,766

- v. Midland Counties R. C., 839

- $\quad v$. Trevor-Garrick, 689

- $v$. Underwood, 504

- v. Woodward, 797

Stevenson $v$. Hardie, 691

- $\quad x$. Maclean, 299

- $\quad v$ Newnham, 328, 837

- v. Watson, 104

Steward $v$. Gromett, $75,843,844$

- $v$. Young, 864

Stewart $v$. Casey, 305

- $v$. Eildowes, 419

- v. London and North. Western R. C., 945

- $\quad v$. Merchants, \&c., Co., 586
Stewart $\%$ Rogerson, 723

- v. West India, sc., Co., 592

Stikeman $v$. Dawson, 673

Stiles $v$. Noakes, 853

Stimson v. Farnham, 90, 960

Stirling $v$. Maitland, $271,301,729$

Stockdale $v$. Onwhyn, 365

Stockport Waterworks Co. $v$. Potter, 903

Stocks $v$. Booth, 874

- v. Dobson, 446

Stoekton R. C. $v$. Barrett, 7

Stoessiger $v$. South-Eastern R. C., 934

Stoglon $v$. Lee, 682

Stone $v$. City and County Bank, 954

- $v$. Corporation of Yeovil, 4

- v. Hyde, 814

-- v. Jaekson, 754

- v. London and County Bank, 329

- $v$. MIarsh, 99

Stoneliouse $v$. Elliott, 828 $v$. Gent, 605

Stonor's Trusts, $I m, r e, 689$

Storer $v$. Gordon, 263

Story, Ex parte, 222

- $v$. Ashton, 797

- $\imath$ Richardson, 636

Stourbridge Canal Co. $v$. Dudley (Earl of), 909

Stowel $v$. Zouch (Lord), 5

Stowell $v$, Robinson, 394

Strachan $v$. Thomas, 569

- $v$. Universal Stock Exchange, 354

Strachey $v$. Osborne (Lord), 67

Stradling $v$. MIorgan, 6

Straker $i$. Graham, 182

Stranks 2 . St. John, 321

Strauss $v$. County Hotel Co., 927

- $v$. Francis, 604

Street $v$. Blay, 341

- v. Gover, 162

- v. Union Bank of Spain, 72

Streeter $v$. Horlock, 322

Strelley $v$. Pearson, 219

Stribley $v$ Imperial Marine Ins. Co., 331

Strickland $v$. Turner, 315

v. Ward, 832

Strode 2 . Seaton, 868

Strong $v$. Foster, 370

Strother $v$. Barr, 876

Strond, Re, 586, 592

Stroughill $r$. Buck, 284

Stroyan $v$. Knowles, 81, 910

Strutt $v$. Farlar, 728

Stuart $v$. Bell, 850 
Stuart $v$. Erans, 815

$$
r \text {. Wilkins, } 340
$$

Stubs $v$ Stubs, 121

Stucley $v$. Bailey, 343

Studds $v$. Watson, 376

Sturgeon $v$. Wingtield, 519

Sturgis $v$. Narell, 155

$$
v \text {. Joy, } 216
$$

Sturt $v$. Blagg, 860

Styles $x$. Wardle, 265

Submarine Telegralph Co. $x$.Dickson, 43,755

Suffield $v$. Brown, 878,891

$$
\text { - v. England (Bank of), } 502
$$

Summers $v$. City Bank, 680 r. Solomon, 598,603

Sumbolf $v$. Alford, 786

Surtees $x$. Ellison, 6

Suse $r$. Pompe, 5\$4, 743

Sussex Peerage case, 5, 1092

Sutcliffe $v$. Booth, 903

Sutherland $v$. Murray, 844

Sutton $x$. Barnett, 219

- v. Grey, 382

- $v$. Johnstone, 855

- $\quad v$. South-Eastem R. C., 213

Svensden $v$. Wallace, 10, 19

Swain, In re, Swain $v$. Pringeman,1 153 - v. Ayres, 295

Swainson $\because$. North-Eastern R. C., 807,817

Swan, Ex parte, 601, 961

- $v$. North British Australian Co., 4S2, 601, 961

Swann $v$. Falmouth (Earl of), 555

- $v$. Phillips, 334

Swansborough $\tau$. Coventry, 891, 892

Srratman $x$. Ambler, 301

Sweet $t$. Lee, 375, 377

Sweeting $\boldsymbol{v}$. Darthez, 590

- $\quad$ r. Pearce, 601

- $\quad v$. Turnel, 426

Swift $v$. Jewsbury, 331, 333, 354, 793,952

Swinburn $r$. Ainslie, $3 \$ 9$

Swindell $x$. Bulkeley, 156

Swindon Waterworks Co. $r$. Wilts aud Berks Canal Nar. Co., 887

Swinfen $\varepsilon$. Chelmsford (Lord), 104, 604

- ¿. Swinfen, 604

Swimnerton $t$. Stafford (Maryuis of), 183

Swire $v$. Francis, $624,793,959$

- $\quad r$ Leach, 551, 972

Sydserff $\because$. Reg., 1021

Syers $t$. Jonas, 5S4

Sykes $\varepsilon$. Dixon, 300

- . Giles, 416
Sykes $x$. Sykes, 714

Symonds $i$. Dimstale, 224

- $\quad r$ Lloyd, 584

Symons $\boldsymbol{v}$. Leaker, 901

- $v$. Rees, 62

Syms $v$. Chaplin, 935

Synge $t$. Synge, 113, 729

Syred $v$. C'arruthers, 923

$\mathrm{T}$.

TAafFe $v$. Downes, 105

Tabart $v$. Tipper, 853

Taff Vale R. C. $\imath$. Davis, 6

Talley $v$. Great Western R. C., 945

Tallis 2 . Tallis, $357,359, \ddot{6} 61,363$

Tamvaco $v$. Simpson, 972

'Tancred $v$. Allgood, 915

v. Delagoa Bay R. C., 446

Tanham $v$. Nicholson, 566

Tammer $v$. Smart, 15i

Taplin $x$. Florence, 399, 416

Tapling $v$. Jones, 896,897 , 899

Tapp $r$. Jones, 228

Tapscott $r$. Balfour, 582

Tarbuck $v$. Bispham, 702

Tarleton $v$. Shingler, 500

Tarn $v$. Sydney (Commercial Banking Co. of), 708

Tarner 2 . Walker, 91, 319

'larrant $r$. Webb, sos

Tarry $x$. Ashton, 750

Tasker $v$. Shepherd, 122

Tasker $v$. Tasker, 686

'l'assell $r$. Cooper, 475, 613

Tatam $v$. Haslar, 499

- $r$. Reeve, 354

Tate $v$. Ayslop, $33 \mathrm{i}$

Tatem $r$. Chaplin, $55 \pi$

Tattan $r$. Great Western R. C., 67 , 769,946

Tattersall 2 . National Steamship' Co., 933

v. Parkinson, 397

Tatton $v$. Darke, 554

- $v$. Wade, $91,384,780$

Tatum $v$. Catomore, 501

Tamuton 2 . Costar, 206, 207

Taverner $r$. Little, 797

'Taylor d. Atkyns z. Horde, $\$ 65$

- $v$ Adlyman, 57

- $r$ Aslitun, 334

- v. Buwers, 275, 352

- $\quad v$ Burgess, 370

- $v$. Calciwell, 113, 12:2, 289, $420,711,719,729,921$

- $\quad$. Chester, 365

- 1. Chichester, \&i., R. C., 353,721 
Taylor $x$. Cole, 206

$$
\begin{aligned}
& \text { - } v \text {. Crowlanil Gas, \&c., Co., } \\
& 349,652 \\
& \text { - } v \text {. Great Northern R. C., } \\
& 933 \\
& \text { - } \quad v \text {. Greenhalgh, 98, } 107 \\
& \text { - } v \text {. Hawkins, 848, } 849 \\
& \text { - } v \text {. Hilary, } 396 \\
& \text { - } \quad \imath \text {. Jones, } 299 \\
& \text { - } \quad 2 \text {. Manchester, Sheffield, ant }
\end{aligned}
$$

Taylor's Estate, Re, 239

Teague $v$. Hubbard, 629

Teall $v$. Anty, 387, 389

Tebbutt $v$. Bristol and Exeter R. C., 791

Teggin $v$. Langford, 226

Temperton $\imath$. Russell, 93, 118, 835, 970

Tempest $v$. Kilner, 443, 508

Temple $v$. Pullen, 468

Templeman $v$. Haydon, 790

Tennant $v$. Goldwin, 80

Tennent $x$. City of Glasgow Bank, $650,957,958$

Teriy $\imath$. Hutchinson, 968, 975

Thacker $v$. Hardy, 354, 959

Thackeray $v$. Wood, 897

Thackoorseydass $\imath$. Dhondmull, 354

Thame $v$. Boast, 397

Tharpe $\tau$. Stallwood, 709,880 , 915

Tharratt $v$. Trevor, 213

Tharsis Sulphur Co. $v$. Loftus, 104

Thateher $v$. England, 320 v. Morel, 582

Theobald $\imath$. Railway Passengers' Assurance Co., 740

Thistlewood's case, 1091

Thol $v$. Henderson, 739

Thom $v$. Bigland, 332, 333

Thomas, In $r e, 657$

- $\quad v$. Birmingham Canal Co., s9

- $\quad v$. Bishop, 449

- $\quad$. Brown, 706

- $v$. Churton, 104, 855

- $\quad$. Cook, 307

- $\quad$ i. Cross, 58

- $\quad$. Edwards, 615

- $\quad v$. Exeter, 181
Thomas $v$. Fredericks, 399

- $\quad v$. Hudson, 829

- $\quad$. Owen, 891

- $\quad v$ Quartermaine, 750,812 , 814.815

- $\quad$ : Queen (The), 241

- $\quad v$. Shillibeer, 639

- $\quad v$. Thomas, 312, 315

- $\quad$. Williams, 862

Thomlinson's case, 235

Thompson, Iin re, 214
- $\quad v$ Bell, 445, 475, 606
- $\quad x$ Dominy, 506
- $\quad \imath$. Gardiner, 414, 417
- $\quad$ i. Gordon, 213
- $\quad v$. Hopper, 981
- $\quad v$. Hudson, 724
- $\quad v$. Ingham, 63
- $\quad$. Lacy, 878,926
- $\quad$. Maberley, 521
- $\quad r$. Mashitz, 551
- $\quad$. Montgomery, 749
- $\quad v$. North-Eastern R. C., 789
- $\quad$ v. Percival, 639
- $\quad r$ Pettitt, 972, !81
- $\quad r$ Ross, 968
- $\quad r$ Wood, 980
- $\quad v$. Wright, 226

Thomson $v$. Daven port, 607, 608, 611,613

- $\quad r$. Eastwood, 159

$i$. Mitchell, 796

Thorn $v$. London (JIayor, \&c., of ), 248

Thorne $\imath$. Deas, 779

- $\quad$. Hearl, 159

- $\quad$. Smith, 498

- $\quad$. Taw Vale R. C., 820

- $\quad$. Tilbury, 924

Thornton $r$. Adams, 554

- $\quad$. Jeuns, 304,320

Thorogood $x$. Bryan, 789

Thoronghgood's case, 266

Thorpe $r$. Eyre, 528

- $v$. Thorpe, 321

Thoyts $v$. Hobbs, 978

Three Towns Banking Co. $\imath$. Maddever, 471

Threfall, Re, Ev parte Queen's Benefit Building Society, 521

v. Borwick, 878,928

Throckmerton $v$. Tracy, 594

Thrussell $v$. Handyside, 751, 815

Thunder $r$. Belcher, 517

Thurborn's case, 1066

Thursby $\imath$. Plant, 558

Thurtell $\imath$. Beaumolit, 183

Thwaites $v$. Wilding, 549 
Thynue $v$. Shove, 358

Tickle $v$. Brown, 895, 896

Tidey $v$. Mollett, 518

Tidnian $v$. Ainslie, 859

Tighe $v$. Cooper, 845

Timnins $v$. Giblins, 495

$v$. Rowlinson, 571

Timotlyy $v$. Simpson, 825

Tinclal, Ex parte, 122

- $v$. Brown, 462

Tindall $v$. Bell, 9S0

$$
\text { - v. Taylor, } 506
$$

Tinkler's case, 1092

Tiuniswood $v$. Pattison, 829

Tipper $v$. Bicknell, 310, 320

Tipping $v$. St. Helen's Smelting W'orks, 902

Titterton $v$. Cooper, 562

Tobacco-Pi ire Makers' Co. v. Loder, 156

Tobin $v$. Reg., 241, 2ł3

Todel $v$. Emly, 633

$-v$. Flight, 118, 799

Toft $v$. Rayner, 221

Toke $v$. Andrews, 151

Toleman, Re, 9:2s

Tomkins $v$. Saffer ey, 19

Tomkinsou $v$. Balkis Consolidated Co., 336, 396, 960, 961

Tomliue $v$. Reg., 241

Tomlinson $v$. Gell, 380

Tommey $v$. White, $30^{\circ}$

Toms $v$. Wilson, 974

Tone $v$. Preston, 895

Toogood $x$. Spyring, 847, 849, 851

Toomer $v$. London, Brighton, and South Coast R. C., 751, 788

Topham $r$. Morecraft, 677

Toppin $v$. Lomas, 387

Torrence $v$. Gibbins, 968

Torriano $x$. Young, 533, 536

Torrington (Lord) $v$. Lowe, 586

Totterlell v. Fareham Brick Co., 648

Toussaint $v$. Martinnant, 30\&, 630

Touteng $v$. Hubbard, 113

Towns $v$. Mead. 156

Tormsend $v$. 'Thorpe, 222

Tozer $v$. Child, 83

$$
\text { v. Wathen, } 8: 6
$$

- $v$. Mashford, 862

Trade Auxiliary Co. $v$. Middles. borongh Tradesmen's Protection Association, 748

Treadwiı $x$. Great Eastern R. C., 934

Tredwen $v$. Bourne, 605

v. Holman, 42

Trego v. Hunt, 358,642

Trent $v$. Hunt, 251, 555
Trevillian $v$. Pine, 554

Trevivan $v$. Lawrence, 519

Trimble $v$. Hill, 354

Trneman $v$. I.oler, $418,57 \mathrm{~s}$

Truman $v$. London and Brighton R. C., 95

Truscott $v$. Merchant Taylors Co., $18,896,897$

Tryon $v$. Nitional Provinciai Institution, 117

Tuck $v$. Priester, 748

Tucker, Ex parte, 221

$$
\begin{aligned}
& \text { - In re, 635, } 686 \\
& \text { - v. Chaplin, } 817 \\
& \text { - v. Linger, 14, 525, 526 } \\
& \text { - } \quad r \text {. Newman, } 876 \\
& \text { - } \quad \text {. Tueker, til3 }
\end{aligned}
$$

Tutf and Nottingliam, In $v e, 6 S 4$

Tuff 2 . Warman, 787

Tugman $v$. Hopkins, 6it

Tullay $v$. Reed, 785

Tullidge $v$. Wade, 975

Tullis $v$. Jackson, 55.4

Tumey $v$. Midlawd R. C., Sot

Tunnieliffe $v$. Moss, 86:

Tupper $v$. Foulkes, 264

Turgot, The, 605

Turnbull $v$. Forman, 683

Turner 2 . Allay, 545

- $\quad$. Ambler, 843

- v. Beny, is

- $\quad v$. Cameron's Coalbrook Steam Coal Co., 874

- $\quad$. Davies, 190, 307

- v. Doe, $\vdots 13,566$

- v. Evans, 362

- v. Ford, 915

- $\quad v$. Goldsmith, 271

- $\quad$ : Goulden, 104, 342

- $v$. Great Western R. C., 204

- v. Harileastle, $97 \pm$

- ヶ. Hardey, 713

- v. Harvey, 331

- v. Hayden, 471

- v. Heduesforl Gas Co., 16.2

- . liendal (Mayor of), 226, 615

- $\quad x$. Liverpool Docks!'Trustees of), $506^{\circ}$

- v. Masou, 326

- $\quad$. Neymott, 207

- v. Stones, 493

- v. Thomas, 613

Turney $v$. Dodwell, 157, 498

'luryuand $v$. Fearon, 117

Tuson $r$. Evaus, 847

Tweddle $v$. Atkinson, 312, 315

'Tweed $v$. Nills, 925

Twopenny $v$. Young, 275 
Twycross $v$. Grant, 6, 124, 711,722 , $759,953,956,978$

Twyman $v$. Knowles, 86, 974

Twynam $v$. Pickard, 559

Twyne's Case, 286

Tyerm:an $v$. Smith, 961

Tyers $v$. Rosedale, \&c., Iron Co., 419,729

Tyue, dc., Commissioners $v$. General Steam Nav. Co., 792

Tyrrell $v$. Woolley, 633

Tyson $v$. Smith, I0, 12, 13, 525

\section{U.}

UnELL $v$. Atherton, $333,337,618$, 623

Underhill $v$. Deverenx, 195

- v. Ellicombe, 766

Underwood $v$. Hewson, 783,1050

Ungley $v$. Ungley, 386,650

Union S:e:mship Co. of New Zealand $x$. Melbourne Harbour, 2

United Service (The), 933

Unwin $v$. Clarke, 729

- v. Hanson, 6

Upton $v$. Townend, 206

Urquhart $v$. Macpherson, 329, 952

U. S. v. II GGlue, 1008

Usill v. Hales, 832,853

\section{V.}

Val de Travers Co. $v$. London Tramways Co., 117

Valentini $v$. Canali, 667

Vallance $v$. Blagden, 366

$$
\text { - } v \text {. Falle, } 98
$$

Valpy $v$. Gibson, 420

Van Baggen $v$. Baines, 579

Van Casteel v. Booker, 506

Vandenburgh $v$. Truax, 94

Van der Donckt $v$. Thellnson, 490

Vane $v$. Barnard (Lord), 532

Vanquelin $v$. Bonard, 261

Vansittart $v$. Taylor, 43

Van 'Toll $v$. Chapman, 966

$$
v \text {. South-Eastern R. C., }
$$

Vase $v$. Delaval, 182

Vaughan $v$. Hancock, 387

$$
\begin{aligned}
& \text { - } \quad \text {. Mattluews, } 709 \\
& -\quad v . \text { Taff Vale R. C., } 751 \text {, } \\
& 790
\end{aligned}
$$

Vaughton $v$. London and North. Western R. C.., 937

Veitch $v$. Russell, 322

Veley $v$. Burḋer, 215
Venables 6 . East India Co., 121, 714 v. Smith, $797,798,930$

Venezuela R. C. $v$. Kisch, 332

Vera Crinz, The, 815

Vere $v$. Ashby, 631, 638

Vernon $v$. Hallam, 363

- $v$. Sinith, 270

Vertue $v$. East Anglian R. C., 445

Vicars $v$. Wilcocks, 91, 92

Vickery $r$. Jackson, 5:35

Victorian Railway Commissioners $v$. Coultas, 735

Victors $v$. Davies, 305

Vilmont $v$. Pentley, 1078

Viner $v$. Vanghan, 529

Viney $v$. Bignold, 42

Violett $v$. Sympson, 844

Vivian v. Mersey Docks Board, 755 - v. Moat, 564

Vlierboom $v$. Cliapman, 605

Voinet $v$. Barrett, 44

Voisey, Ex parte, In re linight, 521

Vollans $v$. Fletcher, 298

Vose $v$. Lancashire and Yorkshire R. C., 806

Vyvyan $v$. Arthur, 557

\section{W.}

WADDELl $v$. Blockey, 974, 978

Wade $v$. Simeon, 313,758

- v. Wilson, Fie Bentley, 515

Wadham v. North-Eastern R. C., 96

Warlling $v$. Oliphant, $66 \dot{4}$

Wadsworth $v$. Bentley, 862

Wain $v$. Bailey, 504

r. Sprain (Queen of), 64

- $v$. Warlters, 375,380

Wait $v$. Baker, 428, 506

- $v$. Jones, 348

Waite $v$. Gale, 712

- v. North-Eastern R. C., 789

Waithman $v$. Wakefield, 695

Wake $v$. Hall, 388

- $v$. Harrop, 371

- $v$. Tinkler, 613

Wakefield $v$. Buccleugh (Duke of), 884

v. Newbon, 707

Wakelin $v$. London and Sonth-

Western R. C., 788

Wakeman $v$. Lindsey, 555
- $v$. Robinson, 789

Wakley $v$. Cooke, 845

- $v$. Healey, 845

Walesby $x$. Goulston, 58 
Walker $v$. Bartlett, 357

- v. Bralford Old Bank, 446

- $v$. British Guarantee As. sociation, 927

- $\quad v$. Broadhurst, 721

- $\quad v$. Brogden, 845

- r. Goe, 91,981

- $\quad v$. Great Western R. C., 603

- $\quad v$. Hamilton, 743

- $v$. Hatton, 306, 740

-- $\quad r$. Hill, 381

- v. Hirsch, 626

- $\quad$ Honner, 996,1030

- $\quad v$. Hunter, 550, 802

- $\quad v$. Matthews. 913

- $\quad v$. Midland R. C., 767

- $\quad$. Nussey, 411

- $\quad x$. Perkins, 288, 365

- $\quad v$. South-Eastern R. C., $79 i$

- $\quad v$. York and North-Midland R. C., 940, 941

Wall $r$. City of London Real Property Co., 733

. Taylor. 748

Waller $v$. Drakeford, 676, 961

- $r$ Loch, 858

- $\quad$. Sontl-Eastern P. C., 811

Walley $r$. McConnell, $8 ? 0$

Wallis $v$. Day, 288, 361

- $\quad r$. Hands, 564

- $v$. Hepburn, 140

- $\quad r$. Littell, 369

- $\quad$. Smith, $726^{\circ}$

Walls $r$. Atcheson, 563

Walmesley $r$. Cooper, 730

Walmsley $\boldsymbol{r}$. Milne, 390,550

Walsh $x$. India (Secretary of State for), 719

- $v$. Lincoln (Bishop of), 146, 348

- $\quad r$. Lonsdale, 68, 520, 547, 563

t. Whiteley, 812

Walshe $v$. Provan, 60.636

Walstab $r$. Spottiswoode. 652

Walter $r$. Everard, 667, 67v

- $\quad$. Rumball, 556

- $\quad$. Selfe, 822, 902

- $\quad$. Smith, 924

Walton, Ex parle, Re Lery, 3, 562 - $v$. Mascall, 470

Wankford 2 . Wankforl, 708,713

Wanstall $v$. Pooley, 91

Want $x$. Stallihrass, 312

Warburton $v$, Great Western R. C., 811

- $\quad r$ Loveland, 2

Ward (Lord) $v$. Parke, $895,896,501$, 563
Ward (Lord) $r$. Andland, 123

\begin{tabular}{|c|c|}
\hline & \\
\hline & $r$ Erans, 485,545 \\
\hline & $\because$ Freeman, 105 \\
\hline & 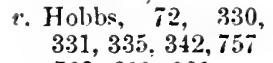 \\
\hline & $\begin{array}{l}760,819,991 \\
\text { v. Llovd, } 355\end{array}$ \\
\hline & i. Londes borough \\
\hline & v. Robius, 896 \\
\hline & $\because$ Ward. 896 \\
\hline
\end{tabular}

Wardall $v$. Usher, 539

Warlow $r$. Harrison, 404, 415

Warne $r$. Seebohm, 748

Warner, app., Ridiliford, resp., $8 \Omega 4$

Warrington $t$. Early. 502

Warwick $r$. Bruce, 389,673

- $\quad r$. Foulkes, 827, 974

- $r$ Q Queen's College, Oxford, 895,900

r. Rogers, 476

Wason, Ex marte, 856, 1022

- $\quad r$ Walter, 852

Waterfall $\imath$. Penistone. 390,550

Waterford, \&c., R. C. 2 . Pidcock, 508

Waterpark (Lord) $x$. Fennell, 576

Waters $t$. Handley, 57

v. Towers. 629,738

Watherell $v$. Howells, 532

Watkin $r$. Hall, 859, 863

Watkins $r$. Great Northern R. C., 766

$v$. Rymill, 922,938

Watson, Ex parte, Ro Roherts, 664

- $\quad$ r. Charlemont (Earl of), 283

- $\quad$ r. Lane, 395

- $\quad$. Macquire, 914

- $v$. MeLean. 972

-- $\quad v$. Russell, 31i, 499

- $v$. Spratley, 387

- $\quad r$. Whitmore, 842

Watson's case, 1091

Watteau $r$. Fenwick, 602

Watts 2 . Friend, 390

- $v$. Kelson, 891

- $\quad$. Porter, 966, 973

- $v$. Ress, 712

Wangh $v$. Middleton, 3,6

- $\quad$. Morris, 283, 350, 365

Way $x$. Great Eastern R. C., 93i

Weare, In re, 213

Weatherston $v$. Hawkins, 848

Weaver, $R e, 701$

- v. Bush, 785

- $v$. Lloyd, 845

- $\quad x$. Warl, 783,786

Webb $r$. Adkins, 708 
Webb v. Austin, 519

- v. Beavan, 206, 862

- v. Bird, 72, 895

- $v$. Cowitell, 711

- v. Dixon, 562

- v. Fox, 913

- $v$. Herne Bay Commissioners, 601

- v. Plummer, 526, 586

- $v$. Portland Manufacturing Co., 88, 89, 903

- v. Spicer, 115

Webber $v$. Lee, 387

- v. Tivill, 156

Weblin $v$. Ballard, 812, 813, 815

Webster $v$. Kirk, 156

- $\quad$. Rickards, 686

- $\quad$. Speneer, 121, 710

- v. Watts, 825

- v. Whewall, 219

Weeks v. Propert, 246, 721

Weems $v$. Mathieson, 808, 809

Weeton $v$. Wondeock, 538, 875

Wegg-Prosser $v$. Evans, 258, 273

Weidner $v$. Hogrgett, 606

Weir $v$. Barnett, $337,793,953,959$

- $v$. Bell, 330, 336, 337, 623, $624,777,793,959,960$

- v. Preedy, 534

Welch $v$. London and NorthWestern R. C., 945

Welehman v. Sturgis, 121, 709, 880

Welden $v$. Bridgwater, 874

Weldon $v$. De Bathe, 683, 863

- v. Neal, 237

- $v$. Winslow, 683

Welfare $v$. London and Brighton R. C., 752

Weller $v$. Baker, 93

- v. London, Brighton, and South Coast R. C., 788

- v. Spiers, 562

Wellock $v$. Constantine, 785

Wells $v$. Abrahams, 100, 101, 102

- v. Hortons, 391

- $v$. Kingston-npon-Hull, 644

-. v. Watling, 86

Welsh $v$. Hall, 874

Wemyss, app., Hopkins, resp., 1089

Wenlock (Baroness) v. River Dee Co., 651

Weiman v. Ash, 675, 850, 851, 859

Wennall $\%$. Adney, 308, 309, 324

Wennliak $v$. Morgan, 859, 980

Wentworth $v$. Cock, 289, 711

Werner $v$. Humphreys, 710

West $v$. Baxendale, 826

- $v$. Blakeway, 291, 537

- v. Houghton, 720

- v. Jackson, 320

B.C.L.
West $v$ Nibbs, 879

- $v$. West, 304

- $v$. Wheeler, 692

Westaway $v$. Frost, 844

Western Counties' Manure Co. $v$. Lawe's Chemical Manure Co., 864

Western National Bank of New York $v$. Perez Triana and Co., 120

Westhead $v$. Sproson, 301, 327

West London Commercial Bank $v$. Kitson, 473

West London R. C. v. London and Nortli-Western R. C., 268

West Nolfolk, \&c. $v$. Achdale, 79

Westohy $v$. Day, 19

Westropp $v$. Solomon, 496, 603, 925

Westwiek $v$. Theodor, 269

Westzinthus, Re, 507

Wetherell $v$. Bird, 535 v. Jones, 348,352

Whaite $v$. Lancashire and Yorkshire R. C., 934

Whaley Bridge, \&c., Co. $v$. Green, 956

Whalley $r$. Lancashire and Yorkshire R. C., 904

- $\quad v$. Pepper, 838

Wharton $v$. Mackenzie, 669

Whatman $v$. Pearson, 797

Whentley $r$. Boyd, 301 v. Patrick, 797

Wheaton $v$. Maple, $11,894,896$

Wheeldon $v$. limrrows, 878, 891, 892

Whecler $v$. Bavidge, 584

- $\quad x$ Branseombe, 525

- $\quad v$. Montefiore, 874

- $v$. Whiting, 825

Wheelton $v$. Hardisty, 332

Wheepdale's case, 501

Whincup $v$. Hughes, 214, 296

Whinney $v$. Schmidt, 223

Whistler $v$. Forster, 429,457

v. Haneock, 140

White, app., Greenish, resp., 960

- $v$. Bass, 878, 891

White $v$. Binstead, 226

- $v$. Bluett, 315

- $\quad v$. Cohen, 822

- $v$. Crisp, 755

- $\quad$. Cuyler, 275, 622

- v. France, 754, 755

- $\quad$. Garden, 328, 1071

- v. Great Western R. C., 941

- v. Hindley Local Board, 754

- $\quad v$. Humphery, 779,918

- v. Hunt, 559

-- v. Merritt, 780 
White $v$. Morris, 914

- $\quad$. Mullett, 912

- v. North, 487

- v. Phillips, 755, 767

- $v$. Proctor, 415

-- $v$. Spettigue, 100

Whitchead $r$. Bennett, 539

$$
\begin{array}{ll}
- & v \text {. Lord, 604 } \\
-\quad & v \text {. Parks, } 888 \\
-\quad & v \text { Walker, 472 }
\end{array}
$$

Whitehouse $r$. Fellowes, 158

Whiteley $r$. Adams, 845,851 $v$. Pepper, 753,755

Whiteman $\imath$. Hawkins, 769,966

Whitfield $v$. South-Eastern R. C., 793

थ. Weedon, 526

Whitlan $v$. Kiersliaw, 571, 975

Whitley, In $r e$, Callan, Ex parte, 156,626

Whitmore $v$. Hnmpluries, 158, 526

Whittaker, In re, 689

$$
\text { v. Jackson, } 260
$$

Whittick $v$. Mozley, 386

Whittingham $v$. Hill, 668

Whittington, Ex parte, 528

Whittle, app., Franklin, resp., 300

Whitty $v$. Dillon, 531

Whitwell $v$. Perrin, 605

Whitworth $v$. Hall, 844

Wickham $v$. Gattrill, 101

$$
\text { - } v \text {. Lee, } 59,571
$$

Widders, app., Gorton, vesp., 504

Wiggett $r$. Fox, 806

Wigglesworth $v$. Dallison, 14, 52 , 584

Wigmore $v$. Jay, 806, 818

Wilbraham $r$. Snow, 915

Wilby $v$. Elgee, 157

- v. Elston, 863

Willcock $v$. Terrell, 228

Wild $v$. Holt, 981

- v. Waygood, 812

Wildbor $v$. Rainforth, 206

Wilde $v$. Gibson, 334

- $v$. Ninsterley, 884

- $v$. Sheridan, 44

Wilder 2 . Speer, 556

Wiles $v$. Woodward, 284

Wilkes, In re, 231'

- $v$. The Hungerford Market Co., 95

Wilkes $r$. Wool, 830,975

Wilkin $v$. Manning, 356

$$
\text { - } v \text {. lieed, } 780
$$

Wilkins, In re, 191

$$
\text { - v. Day, } 820
$$

$$
\text { - } v \text {. Wood, } 525
$$

Wilkinson $x$. Auglo - Californian Gold Alining Co., 266, 508
Wilkinson v. Caudlish, 606

$$
\begin{aligned}
& \text { - } \quad x \text {. Coverdale, } 779,919 \\
& \text { - v. Evans, } 413 \\
& \text { - v. Fairrie, } 767 \\
& \text { - } v \text {. Grant, } 317 \\
& \text { - } \quad v \text { Hall, } 549 \\
& \text { - } \quad v \text { Jagger, } 203 \\
& \text { - } \quad v \text {.Jolinson, 495 } \\
& \text { - } \quad \text {. Kirby, 868, 572 } \\
& \text { - } \quad v \text {. Verity, } 158
\end{aligned}
$$

Wilks $r$. Back, 399, 622

- $v$. Wood, T42

Willans $v$. Taylor, 840

Willetts $r$. Watts, 812

Willey $v$. Parratt, 298

Williams, app., Wheeler, resp., 44,37

$$
\begin{aligned}
& \text { - } \quad x \text {. Bayley, } 278 \\
& \text { - } \quad v \text {. Burrell, 122, 2i2, 557, }
\end{aligned}
$$

Williams $r$. Wilcox, 141

- $\quad r$ Williams, 111, 570, 740, 989,1058

Williams' case, 99

Williamson $v$. Barbour, 592

Willis, lic, 382
ข. Barton, 608

$v$. Freer, 849 
Willis $v$, Howe (Earl), 159

- $r$. Palmer, 605

Willison $v$. Pattison, 707

Willongh by $v$. Horridge, 930

Wills $v$. Murray, 289

Wilmer $v$. White, 662

Wilmhurst r. Bowker, 506

Wilsford $v$. Wood, 638

Wilson, app., Cookson, resp., 250

- v. Abbott, 566

- $\quad v$. Barkēr, 801

- $\quad$. Barthrop, 615

- v. Bevan, 590

- $\quad$ v. Braddyll, 397

- $\quad v$. Brett, 919, 920

- $\quad$. Curzon (Viscount), 629, 652

- $\quad$. Cutting, 630

- $\quad$. Fincl Hatton, 248,569

- $\quad v$. Ford, 697

- $\quad$ r. Glossop, 599, 691, 698

- v. Hart, 608

- $v$. Hodson, 714

- $\quad r$. Knubley, 289

- $\quad v$ Lancashire and Yorkshire R. C., 738

- v. Lewis, 638

- v. Mackreth, 874

- $\quad v$. Merry, 808,811

- v. Newberry, 71, 768, 782, 882

- v. Newport Dock Co., 738

- $v$. Nightingale, 555

- v. Smyth, 695

- $\quad v$. Strugnell, 355

- $\quad v$. Tumman, 802

- v. Waddell, 79

- v. Wallani, 658

- v. Willes, 15

- $\quad v$. Wilson, 36,355

- $\quad$. Zulueta, 613, 619

Wilson's (Carus) case, 237, 238

Wiltshear $v$. Cottrell, 390, 876

Wincl $v$. Thames Conservators, 755 - $v$. Winch, 62

Windhill Local Board v. Vint, 278

Windsor and Aunapolis R. C. $v$. Reg., 241, 243

Wing $v$. Mill, 308

Winn $v$. White, 534

Winship $v$. Hudspeth, 896

Winsor $v$. Reg., 1095

Winter $v$. Bartholomew, 226

Winterbottom $v$. Derby (Lord), 97 $v$. Wright, 775,776 , 807

Winterburn $r$. Brooks, 785

Wintle $v$. Crowther, 631

Wise $t$. Great Westem R. C., 941
Wiseman $v$. Booker, $86,760,763$, 871

Witherley v. Regent's Canal Co., 754,817

Withers $v$. Parker, 802

Wollaston $v$. Hakewill, 560

- $\quad v$. Stafford, 549

Wolmershansen $v$. Gullick, 307

Womersley $v$. Dalby, 525

Wontner $v$. Shairp, 2\$3, 298, 652

Wood $v$. Boosey, 748

- v. Copper Miners' Co., 267

- v. Curling, 767

- $v$. Fenwick, 670

- $v$. Hewett, 550

- $v$. Lane, 824

-- $v$. Leadbitter, 399, 785, 889

- v. MeCarthy, 118

- $v$. Morewood, 981

-. v. Mytton, 486, 48

- $v$. Nunn, 555

- $v$ Perry, 58

- v. Priestner, 379

- $\quad$. Silcock, 249

-- v. Slack, 501

- $v$. Wand, 87, 888, 889, 903

- $\quad r$. Woad, 90, 629, 768

Woodbridge $r$. Spooner, 369

Woodcock $v$. Houldsworth, 464

Woodger $v$. Great Western R. C., 738

Woodliall, Ex parte, 237

Woodhams $r$. Newnan, 58, 60

Woodin $x$. Burford, 615

Wooding $v$. Oxley, 825

Woodland $v$. Fear, 482, 495

Woodley $r$. Metropolitan R. C., 807,815

Woods $v$. Finnis, 770

- v. Thiedemanu, 475

Woodward $v$. London and NortllWestern R. C., 934

$$
\text { - } \quad v \text {. Walton, } 968
$$$$
\text { v. Watts, } 4
$$

Wooler $v$. Knott, 268

Woolfe $v$. Horne, 414, 606, 948

Woollen $v$. Wright, 803

Wootton $v$. Dawkins, 751

Workman $v$. Great Northern R. C., 973

Worth $v$. Gilling, 786

- $v$. Terrington, 786, 824

Worthington $r$. Jeffries, 223

$$
\text { - v. Warrington, } 7 \overline{3} 3
$$

Wotherspoon $v$. Currie, 749

Wray $v$. Milestone, 630

Wren $r$. Wield, 864

Wright $v$. Burroughes, 207

- $v$. Colls; 315

- v. Crookes, 802 
Wright $\imath$. Dannah, $4 ! 6$

- $\quad \tau$. Dewes, 551

- $v$. Hickling, 370

- $v$. Howard, 887

- $\quad v$. Leonard, 674,961

-- $\quad v$ Loudon General Omuibus Co., 115

- $v$. London and North. Western R. C., 755 , 768,807

- v. Midland R. C., 787, 788

- $v$. Mills, 195

- $\quad$. Pearson, 786

- $\quad$. Stavert, 387

- $\quad$. Williams, 896

- v. Wilson, 324

- . Woodgate, 848

Wrightup $\varepsilon$. Chamberlain, $7 \pm 0$

Wyatt $r$. Harrison, 81,910

- $v$. White, 842

Wyld 2 . Hopkins, 600, 652

- $\imath$. Pickford. 937

Wylie, In re, Wylie $r$. Moffatt, 685

$\mathrm{x}$.

Xexus $\bullet$. Wicklam, 264, 265

l.

Yal:Mouth $v$. France, 811, 812, $\$ 15$

Yates $\imath$. Freckleton, 316
Yates $v$. Jack, $\$ 97$

Yeatman $v$. Dempsey, 758

Yeoman 2 . Ellison, 547

York (Dean of), Re, 222

Jork, Newcastle and Berwick R. C., t. Crisp, 940, 941

York's case, 1009

Yorkshire Banking Co. $v$. l Beaston, 577

Yorston $\imath$. Fether, 709, 880

Young $v$. Austen, 370

- $r$. Billiter, 328

- $r$. Cole, 495

- $*$ Davis, 98, 107

- r. Forler, 66s

- $v$. Grote, 482

- $\quad$. Hughes, 444, 445

- $v$. Kitchin, 151

- $v$. Leamington (Corporation of'), 649,650

- $\quad v$. Maerae, 864

- $r$. Pridd, 967

- $\quad$. Raincock, 284

- $\quad v$. Spencer, 876

- $v$. Taylor, 308

- $v$. Timmins, 359

-- ข. Waud, 978

\section{$\%$}

Zovcn 4. Parson, 514, 671

Zonche (Lord) v. Dalbiac, 10

Zunz r. Soutl-Eastern R. C., 939

Zwilchenbart $\iota$. Henderson, 506 


\section{COMMENTARIES}

\section{ON \\ THE COMMON LAW.}

\section{BOOK I.}

\section{CHAPTER I.}

\section{COMMON LAW-WHAT-OF WHAT ELEMENTS COMPOSED.}

Municipal Law in its highest and widest sense comprises all those rules, written or traditionary, which have been laid down for the guidance of the community, and to which its members must, if they would avoid penal consequences or civil liabilities, more or less stringently devised, necessarily conform.

The word "law," indeed, ex vi termini, implies a sanction (a). Laws must be imposed by some adequate power $(b)$, and in civilised communities, at all events, they are in theory certain and determinate, for misera est servitus ubi jus est vagum aut incognitum (c). According to a well-known definition, municipal law is, in such communities, "a rule of civil conduct prescribed by the supreme power in a state commanding what is right and prohibiting what is wrong" $(d)$.

(a) "Law" is defined as " anything laid down, sc. as a rule of action; a rule imposed, fixed, or established, decreed, or determined :" Richardson Dict. ad voc.

(b) Quod quisque populus ipse sibi B.C.L. jus constituit, id ipsius proprium civitatis est, vocaturque jus civile, quasi jus proprium ipsius civitatis. I. 1. 2. 1.; Dig. 1. 1. 9.

(c) 4 Inst. 246.

(d) 1 Bla. Com. 44. 
Common law.

Lex scripta -how con. strued.

The term "common law" will be used throughout this volume in its strict and proper sense as signifying that particular portion of municipal law which was in former times administered exclusively by the common law tribunals and is now administered by them concurrently with and modified by equitable doctrines. Our Common Law is composed of two elements or materials, the lex scripta and the lex non scripta.

The lex scripta comprises the statute law of the land, the duty of interpreting which devolves upon the Judges (e), who are guided in such interpretation by various recognised rules or canons of construction, of which the primary, or, as it has been called, the "golden" rule, has been thus expressed-" to give to all the words of an Act of Parliament their plain and ordinary meaning, unless such a construction leads to absurdity or injustice" $(f)$, - " to give to the words used by the legislature their plain and natural meaning, unless it is manifest, from the general scope and intention of the statute, injustice and absurdity would result from so construing them " $(g)$. Judges cannot "speculate upon the intentions of the legislature, which are neither expressed in terms nor conveyed by implication;" their "duty is to interpret the words of a statute according to their plain and grammatical meaning," when "they are not controlled by anything to be found in the context" (h).

(e) See per Eyrc, C. J., R. v. Tooke, 25 How. St. Tr. 726. See the Interpretation Act, 1889 (52 \& 53 Vict. c. 63).

(f) Per Jervis, C. J., Castrique v. Page, 13 C. B. 463-4 ; Judgm., MIacdougall v. Paterson, 11 C. B. 769 ; Collins v. Welch, 5 C. P. D. 29.

(g) Per Jervis, C. J., Mattison v. IIart, 14 C. B. 385 ; per Burton, J., Warburton r. Loveland d. Ivie, i Huds. \& Br. 648; per Maule, J., Gether v. Capper, 15 C. B. 706 . See Eastern Counties R. C. v. MIarriage, 9 H. L. Ca. $32 ; S . C ., 2$ H. \& N.
625. See Union Steamship Co. of New Zealand v. Mclbourne Harb. Trust Comin., 9 App. Cas. 369 ; Hornsey Loeal Board v. Monareh Investment Building Society, 24 Q. B. D. 1, atp. 5, per Lord Esher, M. R.

(h) Judgm., Muller v. Baldwin, L. R. 9 Q. B. 461 ; Richards v. ALCBride, 8 Q. B. D. at p. 122. "It is never very safe ground, in the construction of a statute, to gire weight to views of its policy, which are themselves open to doubt and controversy," per Lord Selborne, C., Munic. Building Soc. v. Kent, 9 App. Cas. 273. 
The rule, said Parke, B., in Perry v. Skinner (i), by which the Court is to be guided in construing Acts of Parliament, is to look at the precise words used, and to construe them in their ordinary sense, unless this construction would lead to any absurdity or manifest injustice; and, if it should, so to vary and modify the words as to avoid that which it certainly could not have been the intention of the legislature to effect $(k)$.

So, in Miller v. Salomons (l), we find the same learned Judge observing, that "words which are plain enough in their ordinary sense may, when they would involve any absurdity or inconsistency, or repugnance to the clear intention of the legislature, to be collected from the whole of the Act or Acts in pari materia to be construed with it, or other legitimate grounds of interpretation, be modified or altered so as to avoid that absurdity, inconsistency, or repugnance, but no further;" for then the Court may predicate that the words never could have been used by the framers of the law in their ordinary sense, and the strict grammatical construction will bend to the obvious intention of the legislature $(m)$.

It would seem, however, according to some authorities, that the application of this rule must be confined to cases where the "incongruity" or " absurdity" in question arises manifestly within the particular enactment $(n), e x . g r$., so as to render it nugatory or self-contradictory,-or within some enactment on the like subject; and that the Court cannot construe plain and unambiguous words in other than their literal and ordinary sense, merely because, in their opinion,

(i) 2 M. \& W. 476.

(k) Adopted per Williams, J., Midland R. C., app., Pye, resp., 10 C. B., N. S. 194 ; River Wear Commissioners v. Adamson, 2 App. Cas. 764-5; Ex p. Walton, re Levy, $17 \mathrm{Ch}$. D. at p. 751 ; Plumstead, \&c. v. Spackman, 13 Q. B. D. 878.

(l) 7 Exch. 546 . (m) See also per Pollock, C. B., Waugh v. Middleton, 8 Exch. 357; per Maule, J., Arnold v. Ridge, 13 C. B. 763 ; per MLartin, B., Att.-Gen. v. Hallett, 2 H. \& N. 374; per Lord Campbell, C. J., 8 E. \& B. 875-6.

(n) Sed vide per Jervis, C. J., Castrique v. Page, supra, n. $(f)$. 
such a construction may lead to " an absurdity," or even to "manifest injustice" $(o)$, though it is admitted that "words may be modified or varied where their import is doubtful or obscure" $(p)$.

"It is," however, "a true canon of construction that where a word is found in a statute $(q)$, or in any other instrument or document, which cannot possibly have a sensible meaning," a Court of law " not only may but must eliminate it in order that the intention may be carried out" $(r)$.

The embarrassment often experienced in applying the "golden " rule for the interpretation of Acts of Parliament results, of course, from the difficulty of keeping within the line, which, under our administrative system, separates the office of declaring the law from that of making it.

In theory, the distinction just adverted to is clear and well marked; in practice, it is difficult to observe,-judicis est jus dicere, non jus dare. It is the province of the statesman, not of the lawyer, to discuss, and of the legislature to determine, what is best for the public good, and to provide for it by proper enactments. It is the province of the Judge to expound the law only: the written, from the statutes; the unwritten law, from the decisions of his predecessors and of the existing Courts, or from text-writers of acknowledged authority, and upon the principles to be clearly deduced from them by sound reason and just inference;

(o) See Judgm., Abley r. Dale, 11 C. B. 390 , with which acc. per $C \%$ ompton, J., Woodicard v. Watts, 2 E. \& B. 458 . See also per Lord Imman, C. J., Green v. Wood, 7 Q. B. 185; per Jessel, M. R., The Alina, 5 Ex. D. 230 (see the remarks of Lord Eshes, M. R., upon this case in Reg. v. Judge of City of London Court, 1892, I Q. B. 273, and in Pugsley v. Ropkins, 1892, 2 R. B. 184), and per Lord Blackburn, Rothes v. Kirkealdy, 7 App. Cas. 702.

(p) Judgm., Abley v. Dale, supra. Abel v. Lee. L. R. 6 C. P. 371, adopted per Brett, J., Boon v. Hourard, L. R.
9 C. P. 299-300; Clementson r. Mason, L. R. 10 C. P. 209, 217 ; per Grove, J., Williams v. Evans, 1 Ex. D. 281-2.

(q) See per Mollish, L. J., Fisher v. Val de Travers Asphalte Co., I C. P. D. 259 .

(r) Per Archibald, J., Stone r. Corporation of Yeuvil, 1 C. P. D. 705 ; Burchell v. Clark, 2 C. P. D. 88 ; but semble: though the Court may eliminate a word, it cannot insert another in its place. See Laird r. Briggs, 19 Cb. D. 22,33 . 
it is not, however, the duty of a Judge to speculate upon what may be most in his opinion for the advantage of the community $(s)$.

With a view to ascertaining the intention of the legislature in framing the provisions of a statute, our Judges are guided, as before said, by recognised rules, some of the more important of which are specified in Heydon's case $(t)$, to the following purport and effect:- that in all statutes, be they penal or beneficial, restricting or enlarging of the common law, four things are to be considered, viz. 1. What was the common law before the making of the $\operatorname{Act}(u) ; 2$. What was the mischief and defect against which the common law did not provide; 3 . What remedy the Parliament hath resolved and applied to cure the disease of the commonwealth; and, 4. The true reason of the remedy $(x)$. And, having satisfied themselves with reference to these various points, it is the duty of the Judges to make such construction as shall "suppress the mischief and advance the remedy ( $y)$, putting down all subtle inventions and evasions for continuance of the mischief, et pro privato commodo; and adding force and life

(s) Per Parkie, B., Egerton v. Earl Brownlow, 4 H. L. Ca. 123.

( $t$ ) 3 Rep. 7 ; cited Judgm., Reg. v. Castro, L. R. 9 Q. B. 360 ; and in River Wear Commissioners v. Adamson, 2 App. Cas. 764, also in Reg. v. Holbrook, 4 Q. B. D. 46 ; Chudleigh's case, 1 Rep. $122 b, 123 a$. See also Miller v. Salomons, 7 Exch. 522; Judgm., Salkeld v. Johnson, 2 Exch. 273 ; per Coleridge, J., 11 Q. B. 579.

(u) 2 Rep. Pref. ix. x.; per Pollock, C. B., 2 Exch. 332. See Philipps v. Rees, 24 Q. B. D. 17.

(x) The Court will therefore, when necessary, look at the preamble of the Act. Per Tindal, C. J., Sussex Peerage case, 11 Cl. \& F. 143 ; per Sir $J$. Nicholl, Brett v. Brett, 3 Addams, 210 ; Stourel v. Lord Zouch, Plowd. 369; per Buller, J., Crespigny v. Wittenoom, 4 T. R. 790 . See also Barlow v. Ross, 24 Q. B. D. $381,389$. The title of an Act has occasionally been referred to as aiding in its construction; but " it is certainly no part of the law, and, in strictness, ought not to be taken into consideration at all." Judgm., 2 Exch. 283. See also The Shrewsbury Peerage case, $7 \mathrm{H}$. L. Ca. 1 ; 16 How. St. Tr. $743 n$. Therefore, if the words of an Act "are really and fairly doubtful, then, according to well-known legal principles, and principles of common sense, historical investigation may be used for the purpose of clearing away the doubt which the phraseology of the statute creates." Per Lord Coleridge, C. J., Reg. r. Most, 7 Q. B. D. 251 . But on the other hand, an Act cannot be construed by reference to a debate in Parliament, per Lord Selborne, South-Eastern $R$. C. v. Railway Commissioners, 50 L. J. Q. B. 203. 273. 
to the cure and remedy, according to the true intent of the makers of the Act, pro bono publico" $(z)$.

To the rules just stated, some others, by reason of their great practical importance, may here be added. First, A statute must in general, on principles of obvious convenience and justice, be construed as prospective, and not as retrospective in its operation, unless it relates to procedure only $(a)$. But this elementary rule is one of construction, and will yield to the intention of the legislature if sufficiently expressed $(b)$. Secondly, "When an Act of Parliament is repealed it must be considered, except as to transactions past and closed, as if it had never existed" $(c)$. Thirdly, General words occurring in a statute "shall be restrained unto the fitness of the matter or person" $(d)$; "general terms following particular ones apply only to such persons or things as are ejusdem generis" $(e)$. Fourthly, A penal statute, or a statute which imposes a duty, tax or toll, cannot be extended by infer-

(z) As to construing Acts of Parliament, see further per Lord Hatherley, Garnett r. Bradley, 3 App. Cas. 952, citing Stradling r. Morgan, Plowd. 204. See also per Cockburn, C. J., in Twycross v. Grant, 2 C. P. D. at p. 530, and per Cleasby, B., in Scott v. Legg, 2 Ex. D. at p. 42, and per Jessel, M. R., in Mersey, \&c. Co. v. Naylor, 9 Q. B. D. at p. 660 ; per James, L. J., Greaves v. Tofield, 14 Ch. D. $5 \% 1$; per Lord Esher, M. R., Lion Ins. Assoc. v. Tueker, 12 Q. B. D. 186, 190 ; and Reg. v. Overscers of Tonbridge, 13 Q. B. D. 342 ; per Boucn, L. J., Reid v. Reid, 31 Ch. D. 402,408; and Curtis v. Stovin, 22 Q. B. D.513, 517; Unein v. Hanson, 1891, 2 Q. B. 115 ; Taff Tale R.C.v. Davis, 1894, 1 Q. B. 43, at pp.51, 53,54 , and 1895, A. C. 542 (reversing C.A.), at p. 547. As to the construction of a codifying Act, ef. Bank of England r. Vagliano, 1891, A. C., at p. 144.

(a) See Gardner r. Lucas, 3 App. Cas. 597, 601, 603. See per Mcllish, L. J., in Costa Rica r. Erlanger, 3 Ch. D. 69.

(b) Per Parke, B., Moon r. Durden, 2 Exch. 22, 43; Judgm., Phillips r.
Eyre, L. R. 6 Q. B. 23 ; Reg.v. Vine, L. R. 10 Q. B. 195 ; Kimbray v. Draper, L. R. 3 Q. B. 160 ; Williams v. Smith, 4 H. \& N. 559, 563, 564; per Erle, C. J., Midland R. C., app., Pye, resp., 10 C. B., N. S. 191 ; Jackson v. Woolley, 8 E. \& B. 778, 784; per Rolfe, B., Att..Gen. r. Marquis of Hertford, 3 Exch. 685; Pettamberdass $\mathrm{v}$. Thackoorseydass, 7 Moo. P. C. Cas. 239; Waugh v. IFiddleton, 8 Exch. 352 ; Reg. v. Leeds and Bradford R. C., 18 Q. B. 343 ; per Lord Campbell, C. J., Leary v. Patrick, 15 Q. B. 271; Quilter v. MIapleson, 9 Q.B. D. $672 ; H o u g h$ r. Windus, 12 Q. B. D. 224 .

(c) Per Lord Tenterden, C. J., Surtees v. Ellison, 9 B. \& C. 752, cited per Quain, J., Rimini v. Van Praagh, L. R. 8 Q. B. 5 ; Att.-Gen. v. Lamplough, 3 Ex. D. 214, 217, 218. As to the revival of repealed Acts, see 52 \& 53 Vict. c. 63 , s. 11 , subs. 1 .

(d) Bacon, Max. Reg. 10.

(e) Per Cockburn, C. J., Reg. r. Clevorth, 4 B. \& S. 932, adopted per Cleasby, B., Gunnestad v. Price, L. R. $10 \mathrm{Ex} .70$. 
ence $(f)$, but is said to be construed strictly in the sense that "in dubio" the Court will always lean against the construction which imposes a burden on the subject $(g)$.

The lex non scripta is an unwritten law, comprising those principles, usages, and rules of conduct applicable to the Lex non scripta. government and security of person and property which do not depend for their authority upon any existing express and positive declaration of the will of the legislature. It comprises, and mainly consists of, "customs," whether general or particular, and is often called the "customary law." These customs mostly date from a remote antiquity, and are in some instances believed to have originated from Acts of the legislature of which no trace or record now remains. It has, therefore, been justly said, that the lex non scripta consists of those rules and maxims concerning the persons and property of men which have obtained by the tacit assent and usage of the inhabitants of this country, and have the same force and authority as Acts of Parliament; the only difference between the two being, that the consent and approbation of the people with respect to the one is signified by their immemorial use and practice, whereas their approbation of, and consent to, the other, is declared by Parliament, to whose enactments every member of the community is considered as a party $(h)$.

Customs, as already intimated, may be either general or particular. As referable to general customs, properly so General customs. called, may be specified unwritten rules of law relating to the course in which lands descend by inheritance; or to the solemnities and obligation of contracts $(i)$; or to the principles applicable to the expounding of wills, deeds, and Acts of Parliament; or those which indicate the remedies for

(f) Reg. v.'Smith, L. R. 1 C. C. 266, 271. See Leg. Max., 6th ed., 527.

(g) Per Lord Brougham in Stockton R. C. v. Barrett, 11 Cl. \& F. at p. 607 ; Cox v. Rabbits, 3 App. Cas. 473 ;
Pryce v. Monmouthshire Canal and Railway Cics., 4 Id. 197.

(h) 1 Reeves, Hist. Eng. Law, 2nd ed. 2 .

(i) As to the obligatory force of contracts, post, Book II., Chap. 1. 
civil injuries. Doctrines such as these depend mainly upon immemorial usage for their support.

It was formerly held by Lord Coke and others, that the lex non scripta might, in some imaginable cases, control the statute law, if that law were against common right and reason, or repugnant or impossible to be performed $(k)$, but in modern times these dicta have been treated rather as a warning than an authority, and are understood to mean that the Courts will give the statutes a reasonable construction where possible $(l)$. It is noticeable, however, that our customary law will, in many cases, nullify the acts and contracts of individuals, and will even interfere with the dispositions which they may make of their private property. A man, for instance, could not alter the usual common law line of descent by a creation of his own $(m)$. He could not give an estate in fee simple to a person and his heirs on the maternal side, because the law had already said how a fee simple estate should descend. In this case, the law would not allow of a capricious disposition of property, and still less would it sanction the attaching of any condition to property which is against the public good. Thus, a case occurs in the old books of a man making a condition that his devisee should not cultivate his arable land; which is void, because it is against the prosperity of the country, and for no other reason $(n)$. But although the law of England will not allow a man to indulge in every fanciful disposition of his property, it will allow him to put his estates in settlement for the purpose of providing for those who are to come after him, and, in doing so, it gives him all the rational power of dis-

(k) Dr. Bonham's case, 8 Rep. 118, a; per Best, J., Forbes v. Cochrane, 2 B. \& C. 471 ; Arg., Gorham v. Bp. of Exeter, 5 Exch. 671.

(l) Lee v. Bude and Torrington Junction R. C., L. R. 6 C. P. 576, 582; Maxwell on Statutes, 2nd ed., p. 316 . (m) Per Lord St. Leonards, Egerton v. Earl Brounlow, 4 H. L. Ca. 241. Even "the crown cannot give to a grant of a dignity or honour a quality of descent unknown to the law." The Buckhurst Peerage, 2 App. Cas. 1, 21. (n) Per Lord St. Leonards, 4 H. L. Ca. 241. 
position which he can reasonably desire. Even upon the power of disposition by settlement, it will, however, impose such limits and restraints as are required by considerations having reference to the public good: the principles which govern its decisions upon this subject being embodied in the maxim, Sic utere tuo ut alienum non ladas (which applies to the public in at least as full force as to individuals), and in the equally expressive maxims, Nihil quod est inconveniens est licitum, and Salus reipublica suprema lex (o).

Conspicuous amongst general customs stands the lex mercatoria, or law merchant, a branch of law deduced from the practice and customs of merchants, aided and regulated by a long series of judicial decisions, as also by the express enactments of the legislature, which has, especially of late years, exercised much vigilance in aiding fair commercial enterprise on the one hand, and in checking undue speculation on the other.

To evidence of mercantile custom, which, when established and shown to prevail generally, becomes part of our unwritten law, much weight is attached in courts of justice. In Brandâo v. Barnett ( $p$ ), Lord Campbell remarked that " the general lien of bankers is part of the law merchant, and is to be judicially noticed, like the negotiability of bills of exchange, or the days of grace allowed for their payment. When a general usage has been judicially ascertained and established, it becomes part of the law merchant, which courts of justice are bound to know and recognise. Such has been the invariable understanding and practice in Westminster Hall for a great many years; there is no decision or dictum to the contrary; and justice could not be administered if evidence were to be given toties quoties to support 195 .

(o) See per Lord Truro, 4 H. L. Ca.

(p) 3 C. B. 519,530 ; S. C., 12 Cl. \& F. 787 ; approved in London Chartered Bank of Australia v. White,
4 App. Cas. 413, 422 ; per Best, C. J., 5 Bing. 164. See as to banker's lien, London \& County Banking Co. v. Ratcliffe, 5 App. Cas. 722.
Lex mercatoria. 
such usages, an issue being joined upon them in each particular case" $(q)$.

Particular or local customs.

A particular or local custom may be defined to be a usage which " has obtained the force of law, and is, in truth, the binding law within a particular district, or at a particular place, of the persons and things which it concerns" $(r)$. A custom, therefore, in so far as it extends, supersedes the general law $(s)$.

Such is the custom of gavelkind in Kent and some other parts of the kingdom, which ordains, among other things, that not the eldest son only of the father shall succeed to his inheritance, but all the sons alike; and that, though the ancestor be attainted and hanged, yet the heir shall succeed to his estate without any escheat to the lord. Such is the custom which prevails in divers ancient boroughs, and therefore called borough-English, that the youngest son shall inherit the estate in preference to all his elder brothers $(t)$. Such is the custom in other boroughs, that a widow shall be entitled for her dower to all her husband's lands, whereas at the common law she shall be endowed of one-third part only. Such, also, are the special and particular customs of manors, of which every one has more or less, and which bind all the copyhold and customary tenants who hold of the said manors $(u)$. "Custom," indeed, " is the very life of a manor." It must, however, as we shall presently see, be "fair, convenient, and reasonable" $(x)$.

(q) Cited per Byles, J., Hare v. Henly, 10 C. B., N. S. 85. In Atwood v. Sellar, 4 Q. B. D. 342 ; 5 Q. B. D. 286 ; a long-established practice amongst average adjusters was much considered. See Svensden $\mathrm{r}$. Wallace, 13 Q. B. D. 69 ; 10 App. Cas. 404.

(r) Judgm., Tyson v. Smith, 9 Ad. \& E. 421; per Yates, J., Millar $v$. Taylor, 4 Burr. 2368.

(s) Judgment, Lord Falmouth r. George, 5 Bing. 293.

(t) See Aruggleton v. Barnett (in
Error), 2 H. \& N. 653; S. C., 1 Id. 282. Williams' Real Prop. 17th ed., 57 .

(ii) See per Cockburm, C. J., Muggleton r. Barnett, 2 H. \& Nं. 681. As to manorial customs, see Richardson v. Walker, 3 B. \& C. 827 ; per Lord Crancorth, Marquis of Salisbury $\mathbf{v}$. Gladstone, 9 H. L. Ca. 701, cited L. R. 2 C. P. 77 ; Lord Zouche v. Dalbiac, L. R. 10 Ex. $17 \%$.

$(x)$ See Reg. V. Venn, L. R. 10 Q. B. 310,319 . 
The above and similar particular customs, being deviations from the general law of the land, are good only by virtue of long-continued usage and of that consent, on the part of such portions of the community as are more immediately affected by them, which is to be implied therefrom.

1. Such a custom, therefore, says Sir W. Blackstone, in order that it may be legal and binding, must "have been used so long that the memory of man runneth not to the contrary " $(y)$; so that, if any one can show the beginning of it, it is no good custom. For which reason no custom can prevail against an express Act of Parliament, since the statute itself is a proof of a time when such a custom did not exist (z).

Now, legal memory dates from the first year of the reign of Richard I. ; but it must not, therefore, be supposed that it was, even prior to the stat. $2 \& 3$ Will. 4 , c. 71 , in all cases necessary to produce evidence extending over so long a period, of the existence of a particular custom in dispute. From proof of the enjoyment of a custom for a much less period, $e x . g r .$, for so short a time as twenty years, a jury has, in the absence of evidence to the contrary, been held justified in finding that the custom had existed immemorially $(a)$. And now, where a claim " may be lawfully made" at the common law, by custom, prescription (b), or grant, to any right of common, or other profit or benefit to be taken and enjoyed from or upon "the land of any person," or "to any way or other easement $(c)$, or to any watercourse, or the use of any

(y) See Simpson v. Wells, L. R. 7 Q. B. 214, 217.

(z) 1 Bla. Com. 76.

(a) Jenkins v. Harvey, 1 Cr. M. \& R. 877; cited Master Pilots, \&c., of Newcastle-upon-Tyne v. Bradley, 21 L. J., Q. B. 196 ; S. C., 2 E. \& B. 428 , n. ; R. v. Joliffe, 2 B. \& C. 54 . See also Duke of Beaufort v. Smith, 4 Exch. 450.

(b) A particular custom is a local usage not annexed to any person, whereas prescription is a strictly personal right,

Particular customwhence it dates, \&c.

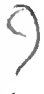


water to be enjoyed or derived " upon or from the land of any person, reference will have to be made to the 1st and 2nd sects. respectively of the statute just mentioned, which was passed with a view to shortening " the time of prescription in certain cases."

Particular custom must have been continued;

2. A particular custom must have been continued; because " any interruption would cause a temporary ceasing; the revival gives it a new beginning, which will be within time of memory, and, thereupon, the custom will be void. But this must be understood with regard to an interruption of the right; for an interruption of the possession only for ten or twenty years will not destroy the custom. As, if the inhabitants of a parish have a customary right of watering their cattle at a certain pool, the custom is not destroyed though they do not use it for ten years, it only becomes more difficult to prove; but if the right be anyhow discontinued for a day, the custom is quite at an end " $(d)$.

Where a custom has been thus "continued" in the sense above assigned to that term, it, in fact, comes at last to an agreement which has been evidenced by such repeated acts of assent on both sides from the earliest times, beginning before the time of memory, and continuing down to our own times, that it has become the law of the particular place wherein it has been shown to obtain (e).

$\rightarrow$ and

peaceably enjoyed.

-mist be reasonable.

3. A particular custom, to be valid, must have been peaceable, and acquiesced in, not subject to contention and dispute ; for, as such a custom derives its force and authority from common consent, the fact of its having been immemorially disputed, either at law or otherwise, would be a proof that such consent was wanting $(f)$.

4. It must also be reasonable, or, rather, must not be unreasonable $(g)$. " A custom," therefore, " may be good,

(d) 1 Bla. Com. 77.

(e) Judgm., Tyson v. Sinith, 9 Ad. s. E. 425 .

(f) 1 Bla. Com. 77. (g) Id. Hix v. Gardiner, 2 Bulstr. 195; Sowerby v. Coleman, L. R. 2 Ex. 96. See Reg. v. Venn, L. R. 10 Q. B. 310 . 
though the particular reason of it cannot be assigned, for it sufficeth, if no good legal reason can be assigned against it. Thus, a custom in a parish that no man shall put his beast into the common till the 3rd of October would be good; and yet it would be hard to show the reason why that day in particular is fixed upon, rather than the day before or after. But a custom that no cattle shall be put in till the lord of the manor has first put in his, is unreasonable, and, therefore, bad : for, peradventure, the lord will never put in his, and then the tenants will lose all their profits" $(h)$.

A custom, however, is not unreasonable, merely because it is contrary to a particular maxim or rule of the common law, for Consuetudo ex certâ causâ rationabili usitata privat communem legem, as the customs of gavelkind and boroughEnglish, which are directly contrary to the law of descent; or, again, the custom of Kent, which is contrary to the law of escheat (i). Nor is a custom unreasonable because it is prejudicial to the interests of a private man, if it be for the benefit of the commonwealth : as the custom to turn the plough upon the headland of another, in favour of husbandry, or to dry nets on the land of another, in favour of fishing, and for the benefit of navigation $(j)$; or to take water from his well $(k)$.

It is not an unreasonable custom that a tenant, who is bound to use a farm in a good and tenantable manner, and according to the rules of good husbandry, shall be at liberty, on quitting the farm, to charge his landlord with a portion of the expenses of draining land which requires draining according to good husbandry, though the drainage be done without his landlord's knowledge or consent $(l)$. And a

(h) 1 Bla. Com. 77 ; and cases supra.

(i) Ante, p. 10.

(j) Judgm., Tyson v. Smith, 9 Ad. \& E. 421 ; Lord Falmouth v. George, 5 Bing. 286.

(k) Race v. Ward, 4 E. \& B. 702.

(l) Mousley v. Ludlan, 21 L. J.,
Q. B. 64 ; Dalby v. Hirst, 1 B. \& B. 224. With reference to the reasonableness of particular alleged customs, see also Mounsey v. Ismay, 1 H. \& C. 729 ; Hilton v. Earl Granville, 5 Q. B. 701 ; commented on and followed in Blackctt v. Bradley, 1 B. \& S. 940, 
custom that a tenant shall have the waygoing crop after the expiration of his term, is reasonable and good. "It is just ; for he who sows ought to reap; and it is for the benefit and encouragement of agriculture. It is, indeed, against the general rule of law concerning emblements, which are not allowed to tenants who know when their term is to cease, because it is held to be their fault or folly to have sown when they knew their interest would expire before they could reap. But the custom of a particular place may rectify what otherwise would be imprudence or folly" $(\mathrm{m})$.

In The Marquis of Salisbury v. Gladstone (n), a custom was held not unreasonable for the copyholders of inheritance in a manor without licence from the lord to dig and get clay without limit in and from their copyhold tenements for the purpose of making bricks to be sold off the manor. So also a custom for an agricultural tenant, where the lessor had reserved the minerals, to sell such flints as were turned up by ploughing, was held good, the evidence showing that their removal was necessary for the cultivation of the farm $(o)$.

5. A custom ought to be certain. And, therefore, a custom that lands shall descend to the most worthy of the owner's blood, is void; for how shall this worth be determined? But a custom that lands shall descend to the next male of the blood exclusive of females, is certain, and therefore good. So a custom to pay twopence an acre in lieu of tithes is good; but to pay sometimes twopence, and some-

954-5; Rogers v. Brenton, 10 Q. B. 26 ; Elwood v. Bullock, 6 Q. B. 383 (distinguished in Simpson v. Trlls, L. R. 7 Q. B. 214, 216); Amold v. Blaker, L. R. 6 Q. B. 433 (citing Elucood v. Bullock, supra, and approving Mereer v. Woodgate, L. R. 5 Q. B. 26) ; Arnold v. Holbrook, L. R. 8 Q. B. 96; Duke of Buccleugh v. Wakcfield, I. R. 4 H. L. 377,406 ; dist. Love v. Bell, 9 App. Cas. 286 ; Gibbs v. Flight, 3 C. B. 581 ; Reg. v. Dalby, 3 Q. B.
602; Le Casc de Tanistry, Darss, 28 b, 34; Gill v. Dickinson, 5 Q. B. D. 159 .

(m) Wigglesworth v. Dallison, Dougl. 201 ; S. C., 1 Smith's Leading Cases, 9 th ed. 569 .

(n) 6 H. \& N. 123 ; S. C., 9 H. L. Ca. 692 ; followed in Blevett, app., Jenkins, resp., 12 C. B., N. S. 16,30 .

(o) Tucker v. Linger, 21 Ch. I. 18 ; 8 App. Cas. 508. 
times threepence, as the occupier of the land pleases, is bad, for its uncertainty $(p)$.

On the ground of uncertainty the following custom was held bad : viz., for all the customary tenants of a manor, having gardens, parcels of their tenements, to dig, take, and carry away from a waste within the manor "for the purpose of making and repairing grass plots in the gardens, parcels of the same respectively, for the improvement thereof, such turf covered with grass fit for the pasture of cattle; as hath been fit and proper to be so used and spent every year, at all times in the year, as often and in such quantity as occasion " may require (q). "A custom," said Lord Ellenborough, C. J., with reference to this case, "however ancient, must not be indefinite and uncertain; and here it is not defined what sort of improvement the custom extends to." And he added - "there is nothing to restrain the tenants from taking the whole of the turbary of the common, and destroying the pasture altogether. A custom of this description ought to have some limit; but here there is no limitation to the custom as laid but caprice and fancy" $(r)$. A custom however to pay a year's improved value by way of fine on a copyhold estate might be good, though the value is a thing uncertain; for it may at any time be ascertained, and the maxim of law is Id certum est quod certum reddi potest ( $(s)$.

In Broadbent v. Wilkes ( $t$ ), we have an instance of a custom being held void on the twofold ground that it was unBroadbent $\mathbf{v}$. Wilkes. reasonable and uncertain. There the custom claimed (so far as it need here be stated) was, that when and as often as the lord of the manor, or his tenants of the collieries or coalmines, sunk pits in certain freehold lands within and parcel

(p) 1 Bla. Com. 78; Le Case de Tanistry, Davys, 28 b, 35 ; Blewett v. Tregonning, 3 Ad. \& E. 554.

(q) Wilson v. Willes, 7 East, 121 ;

8 R. R. 604, Preface, vii.

$(r)$ See also Clayton v. Corby, 5 Q. B. 415; Bailey v. Stephens, 12 C. B., N. S. 91 ; Constable v. Nicholson, 14
C. B., N. S. 230 ; Douglas, app., Earl Dysart, resp., 10 C. B., N. S. 688.

(s) 1 Bla. Com. 78.

$(t)$ Willes, $360 ; S . C$. (in Error), 1 Wils. $63 ; 2$ Str. 1224 ; with which compare Rogers r. Taylor, 1 H. \& N. 706 ; Carlyon v. Lovering, Id. 784. 
of the said manor, for the working of the said pits, and to get coals thereout, the lord and his tenants might cast the earth, stones, \&c., coming therefrom in heaps " on the land near to such pits," "there to remain and continue " at " his and their will and pleasure:" in giving judgment with reference to the validity of this custom, Willes, C. J., remarked, "The objection that this custom is only beneficial to the lord, and greatly prejudicial to the tenants, is, we think, of no weight; for it might have a reasonable commencement, notwithstanding, for the lord might take less for the land on the account of this disadvantage to his tenant. But the true objections to this custom are, that it is uncertain, and, likewise, unreasonable, as it may deprive the tenant of the whole benefit of the land; and it cannot be presumed that the tenant at first would come into such an agreement." He also remarked, that every custom " must be certain, for two plain reasons: 1st, because if it be not certain, it cannot be proved to have been time out of mind, for how can anything be said to have been time out of mind when it is not certain what it is ? 2 ndly, it must be certain, because every custom presupposes a grant, and if a grant be not certain it is void." The Chief Justice then observed that, tested by the foregoing rule, the custom above set out was bad, as being neither certain nor intelligible; especially by reason of the expression "near" to" used in setting out the custom, to which expression no precise and definite meaning can be attached.

After thus pointing out the uncertainty of the alleged custom, Willes, C. J., proceeded to say, that all customs must be reasonable, otherwise they are void, "and certainly no custom can be more unreasonable than the present. It may deprive the tenant of the whole profits of the land; for the lord or his tenants may dig coal-pits when and as often as they please; and may, in such case, lay their coals, \&c., on any part of the tenant's land, if near to such coal-pits, at what time of the year they please, and may let them lie there as 
long as they please:" so that "they may be laid on the tenant's land and continue there for ever, though it may be more convenient for the lord to bring them on his own land ; which is absurd and unreasonable."

A custom however for the inhabitants of a parish to enter upon plaintiff's enclosed field within the parish and erect a maypole therein, and enjoy on the land any lawful and innocent recreation at any time in the year, has been held reasonable and sufficiently certain $(u)$.

Again prima facie the landlord is the person liable to the outgoing tenant for seed, tillage, and so forth, properly bestowed by him upon a farm, and an alleged custom or usage that the outgoing tenant shall look to the incoming tenant for payment to the exclusion of the landlord's liability, is unreasonable, uncertain, and prejudicial to the interests both of landlords and of tenants $(x)$.

6. A custom, though established by consent, must, when established, be compulsory, and not left to the option of every man, whether he will use it or no; therefore, a custom that all the inhabitants of a particular district shall be rated toward the maintenance of a bridge will be good; but a custom that every man is to contribute thereto at his own pleasure, is idle and absurd, and indeed no custom at all $(y)$.

7. Customs must be consistent with each other-one custom cannot be set up in opposition to another; for, if both are really customs, then they are of equal antiquity, and must have been established by mutual consent, which to say of contradictory customs is absurd $(z)$.

8. With reference to the interpretation of customs it will suffice to say that customs, especially where they derogate How from the general rights of property, must be construed

Particular customs must be compulsory -and consistent.
(u) Hall v. Nottingham, I Ex. D. 1.
(x) Bradburn v. Foley, 3 C. P. D. 129,135 .
(y) 1 Bla. Com. 78.
(z) 1 Bla. Com. 78.

B.C.L. 
Customs of the country.

Particnlar

strictly (a); they are not to be "enlarged beyond the usage" (b) ; they may be abrogated by statute $(c)$.

Besides local customs properly so called, there are, in different parts of the country, certain customs existing, which, unless excluded expressly or impliedly by agreement between parties, regulate, to some extent, the relation of landlord and tenant, or affect the reciprocal rights of incoming and outgoing tenants, and are usually known as " customs of the country." Now a custom $(d)$ belonging to this class need not be shown to have existed immemorially, but will be established on proof of a usage, recognised and acted upon in the particular neighbourhood, applicable to farms of a like description with that in regard to which its existence is specifically asserted $(e)$. A "custom of the country," in order that it may be good, must be reasonable (as will appear by reference to some of the cases already cited), and sufficiently definite and certain.

trade.

Very similar to the customs of the country last mentioned, as regards their operation upon the contracts of parties, are particular usages of trade which exist in certain places; and, in order to be effective, must be reasonable $(f)$, and must be proved by apt evidence in courts of justice. The legal effect of usages of trade will be hereafter noticed $(g)$.

(a) Judgm., Rogers r. Brenton, 10 Q. B. 57 ; per Baylcy, J., 2 B. \& C. 839.

(b) Judgm., Arthur r. Bokenham, 11 Mod. 160 ; see per Cockburn, C. J., 2 II. \& X. 680-1.

(c) Truscott v. Merchant Taylors Co., 11 Exch. 855 ; Cooper v. Hubbuck, 12 C. B., N. S. 456.

(d) The word "custom" thus used "cannot mean a custom in the strict Jegal signification of the word: for that must be taken with reference to some defined limit or space, which is essential to every custom properly so called:" per Jord Ellenbmongh, C. J., Legh r.IIcu'itt, 4 East, 154, 159, 7 R.R. 545 ; see Cooke Agric. Ten., 2nd ed. c. 4, p. 58 , et seq. (e) See Dalby v. Hirst, 1 B. \& B. 224 , where the question was raised at Nisi Prius.

(f) See Cropper v. Cook, L. R. 3 C. P. 194 ; Grisscll r. Bristolce, L. R. 4 C. P. 36 ; Cuthbert r. Cumming, 11 Exch. 405, 10 Id. 809; Paxton r. Courtnay, 2 Fost. \& Fin. N. P. Ca. 131 ; Gibson v. Crick, 1 H. \& C. 142.

(g) See particularly Book II., Chap. VI., Mercantile customs seem properly divisible into three classes: -1 . Customis "which all nations agree in and take notice of," and which are held to be part of the law of England. 2. Customs prevailing throughout the length and breadth of this country, which also have the force of law here, and are in general judicially noticed, without proof. 
Purely local usages are sometimes embodied in and may be evidenced by byelaws operative amongst a section of the community. Thus, the rules of the London Stock Exchange as to defaulting members are the rules of a domestic forum, which have no influence on the rights of persons who are not amenable as members to the jurisdiction of that body (h).

As our lex scripta must be interpreted, so must our lex non scripta be declared by the judges (i) whose office, as already stated $(k)$, it is jus dicere, and whose decisions, when collected in the reports, exhibit our common law, as it has actually been applied to facts differing from each other, as well in kind as in their combinations. Judicial decisions, indeed, afford the best-oftentimes the only-evidence of what law is ; and, in arriving at these decisions, the Judges allow themselves to be guided by established precedents, and by the admitted maxims of the law.

In conformity with our most approved commentators, I have mentioned maxims as an important element of our common law. Of these maxims, which embody principles of much value, when their application is rightly understood, many have been derived from the Roman or Civil Law;

3. Customs purely local, such as are alluded to in the text, which must be proved. See a learned note, 8 C. B. 967. The custom of London is certified by the Recorder: see Westoby $\mathbf{v}$. Day, 2 E. \& B. 605; Matthey v. Wiseman, 18 C. B., N. S., 657 .

Eridence of long-continued usage may have much weight in support of a pecuniary demand; for instance, it has been said that "every intendment ought to be made in favour of a payment which has been uninterruptedly receired time out of mind, supposing it presumably capable of a legal origin." Per Lord Chelmsford, Free Fishers of Whitstable v. Gann, 20 C. B., N. S., 27. See also Foreman v. Free Fishers of Whitstable, L. R. 4 H. L. 266 ; Holford v. George, L. R. 3 Q. B. 639 ; Lawrence v. Hitch, Id. 521; Bryant v. Foot, Id. 497 ; Mills v. Mayor, \&c., of Colchester, L. R., 3 C. P. 575; Attwood v. Sellar, 4 Q. B. D. 342 ; 5 Q. B. D. 268. Distinguished in Svensden v. Wallace, 13 Q. B. D. 69 ; 10 App. Cas. 404.

(h) Tomkins v. Safferey, 3 App. Cas. 213. See Ex $p$. Grant, In re Plumbly, 13 Ch. D. 667, 680. As to reasonableness of customs of the Stock Exchange, see Hamilton v. Young, 7 L. R. Ir. Ch. 289 ; Neilson v. James, 9 Q. B. D. 546 ; Robinson r. Mollett, L. R. 7 H. L. 802 ; Perry v. Barnett, 15 Q. B. D. 394 ; Seymour v. Bridge, Ib. 363 . See also post, p. 585 , n. $(f)$.

(i) See per North, C. J., Barnnardiston r. Soame, 6 How. St. Tr. 1095, 1116.

(k) Ante, p. 4.
Lex non scripta clared. 
and, although it be true, as judicially remarked, that this law forms no rule binding in itself upon the subjects of these realms; yet, in deciding a case upon principle, where no direct authority can be cited from the books, our Courts will listen to arguments drawn from the Institutes and Pandects of Justinian, and will rejoice if their conclusions are shown to be in conformity with that law, which is "the fruit of the researches of the most learned men, the collective wisdom of ages, and the groundwork of the municipal law of most of the countries in Europe" (l).

The law conforms to certain great
principles.

Law of Nature.

The law of England, whether statutory or customary, professes to act in accordance with, and to be regulated by, certain great fundamental principles. It professes to act and adjudicate conformably to the law of Nature, the law of God, to common sense, to legal reason, justice, and humanity $(m)$.

"The law of Nature," says Blackstone (n), "being coeval with mankind, is superior in obligation to any other ;" "no human laws are of any validity, if contrary to this." We read also in Calvin's case (o) that the "law of Nature is part of the Laws of England:" and in Forbes v. Cochrane $(p)$, that " the proceedings in our Courts are founded upon the law of England, and that law is again founded upon the law of Nature and the revealed law of God." So that if a "right sought to be enforced is inconsistent with either of these, the English municipal Courts cannot recognise it." Nay, in the case last cited, it is even laid down as a maxim, that international comity, or comitas

(l) Judgm., 12 M. \& W. 353; per Best, C. J., 5 Bing. 167 ; Hale, Hist. Com. Law, 24. In Reg. v. Archbishop of Canterbury, 11 Q. B. 649, Lord Denman observed, that the canon law forms no part of the Law of England, unless it has been brought into use and acted upon in this country; and that the burden of proof rests on those who affirm the adoption of any portion of it here.

(m) See Ram. Sci. Leg. Judgm. 10.

(n) 1 Com. 41.

(o) 7 Rep. 4, 6.

(p) 2 B. \& C. 471. 
inter communitates, "cannot prevail in any" case where it violates the law of our own country, the law of Nature, or the law of God" $(q)$.

In Ilott v. Wilks $(r)$ it is judicially affirmed that " the law of England will not sanction what is inconsistent with Considerations of humanity" (s).

Legal reason and common sense are frequently invoked by the administrators of our law as guides whom they may Reason and Common safely follow $(t)$. By "legal reason," however, is here to be understood that schooled and tutored reason which a well-trained legal intellect brings to bear upon the question submitted to it. "Discretion," observed Lord Mansfield, C. J., in $R$. v. Wilkes (u), "when applied to a court of justice, means sound discretion guided by law. It must be governed by rule, not by humour ; it must not be arbitrary, vague, and fanciful, but legal and regular."

We need then scarce hesitate to adopt the expressions of Willes, J., in Millar v. Taylor (x), that "principles of private justice, moral fitness, and public convenience," "when applied to a new subject, make common law without a precedent-much more, when received and approved by usage;" or those of Aston, J., delivering his opinion in the same case $(y)$, who appeals in support of it to "the law of Nature and truth," "the light of reason and the common sense of mankind;" and examines in detail what he designates as "certain great truths and sound propositions," by which man, as a rational creature, is laid under the obligation of being governed.

(q) See Fenton v. Livingstone, 3 Macq. H. L. Ca. 497.

(v) 3 B. \& Ald. 319 ; 22 R.R. 400, cited per Best, C. J., Bird v. Holbrook, 4 Bing. 640-1.

(8) See for instance the Stat. $39 \&$ 40 Vict. c. 77 , for prevention of eruelty to animals.

$(t)$ "However technical, rules are to be attended to, and in some cases cannot be dispensed with; yet in administering justice we must not lose sight of common sense." Per Lord Kenyon, C. J., 1 East, 208.
(u) 4 Burr. 2539.
(x) 4 Id. 2312.
(y) Id. $2337,2343$. 


\section{CHAPTER II.}

\section{COURTS OF LAW.}

Having, in the last Chapter, shown what our Common Law is, and set forth concisely the elements of which it is composed, I proceed to inquire into the nature and constitution of the tribunals by which it is administered :- first, glancing at the Origin, History, and Jurisdiction of the Three Superior Law Courts, now replaced by the Queen's Bench Division of the High Court of Justice, together with the mode in which business is conducted there; and, secondly, exhibiting, with brevity, the extent and limits of the ordinary jurisdiction of our County Courts.

SEct. I.-The Superior Courts of Law.

1. Their Origin, History, and Jurisdiction.

2. Mode of Procedure in Banc, at Judges' Chamber's, and in the District Registries.

1. Origin, History, and Jurisdiction of the Superior Courts of Law (a).

Immediately prior to, and at the date of, the Norman Conquest, the ordinary legal tribunals of most practical importance established in this country were the County and the Hundred Courts $(b)$, which institutions traced their descent from a distant age, and from tribes amongst whom the name and office of king were alike unknown; on which

(a) Reference should be made to History of English Law, Pollock and Maitland, vol. i., chaps. i.-vi. (b) 1 Reeves, Hist. Eng. Law, 2nd ed. 7 . 
account, a learned writer has observed, that our common law jurisdiction may be considered as emanating from the people $(c)$. The Hundred Court was composed of the Thanes and landlords whose demesnes were included within the hundred; and was held under the head officer or earldorman of the particular district, assisted by the bishop of the diocese $(d)$.

It was, however, in the Shire (e) Court, which seems to have been held twice yearly, that the principal causes were, at the time now spoken of, heard and determined. In this Court cognizance was had of offences which concerned the crown or public, as felonies, breaches of the peace, nuisances, and the like, as well as of questions involving the title to land. Whilst, in all civil suits, the Shire Court appears to have had an original jurisdiction similar to that of the Hundred Court, besides an appellate jurisdiction over the subordinate tribunal $(f)$.

When William the Conqueror was established on the throne of England, an important change in the machinery for administering justice was effected, which gradually led to the establishment of three Superior Courts of Common Law. I allude to the introduction into this country of the office of Chief Justiciar $(g)$, and the gradual centralisation of judicial power which was effected here by the establishment of the Aula, or Curia, Regis or Supreme Council of the sovereign, - a Court which was invested with some most important functions of a purely judicial nature $(h)$.

From the Supreme Council or Court, where the king, in

(c) Palgr. King's Counc. 10.

(d) 1 Yalgr. Eng. Comm. 98, 101.

(e) The shire seems sometimes to have been formed by placing one or more hundreds under the government of an earl or his deputy: 1 Palgr. Eng. Comm. 117.

$(f) 1$ Palgr: Eng. Comm. 119; Dugd. Orig. Chap. 14 (p. 29). See 2 Hall. Mird. Ages, 140. It must be remembered that, during the period here re- ferred to, when force was an element in most transactions giving rise to litigation, purely civil matters rarely called for adjudication.

(g) As to the nature of the functions delegated to the king's justiciars, see 1 Yalgr. Eng. Comm. 289; Madox, Hist. Exch., Chap. 2.

(h) See further as to the Aula Regis, Sillar, Eng. Gov., vol. ii., pp. 108, 121,264 et seq.
Hundred

Court.

County or Shire Court

Norman

Conquest.

Change then effected. 
theory, was always present, which attended on his person, and was therefore ambulatory as the Sovereign changed his place of abode, may be derived the Courts of Exchequer, Common Pleas, and King's Bench, extinguished, though reproduced under other designations, by the Judicature Act, $1873(i)$. These three Courts were originally in the nature of Committees, delegated by the Sovereign for the despatch of specific branches of the business of his Court; but which, by degrees, assumed a permanent and an altogether separate existence $(j)$.

Original jurisdiction of Exchequer as Court of Revenue.

Is juristic. tion in private suits.

To commence with the Court of Exchequer. It will be admitted that, on the introduction of the feudal system into this country, together with the burthens incident to it, of escheat, forfeiture, fines for alienation, for wardship, marriage, and the like, the claims of the Crown, as lord paramount, upon the subject must have become so complicated and multifarious as to require the sole and undivided attention of some peculiar department of the Royal Council; and to this necessity may be ascribed the origin of the Court of Exchequer, which, in its inception, was but a part of the Supreme Council, appointed to sit in the king's palace, for the purpose of auditing his accounts and compelling payment of such feudal dues as were in arrear to him.

Although, however, the jurisdiction of the Exchequer was, in the first instance, principally, or, as some think, wholly confined to matters connected with the revenue, or springing out of the feudal relation of lord and vassal, it is certain that at a very early period this Court had acquired jurisdiction in personal actions not at all affecting the rights or revenues of the Crown $(k)$. And although the Statute of

(i) $36 \& 37$ Vict. c. 66, ss. 16,34 .

(j) 1 Palgr. Eng. Comm. 291. The resolution of the authority of the Aula Regis into three independent jurisdictions appears to have taken place very gradually. That the severance was not complete at the beginning of the four. teeuth century, appears from entries cited from the Rolls of the King's Bench by Mr. Serjeant Manning, in his learned work entitled Serriens ad Legem. p. 253. See also Coop. Pub. Ree. rol. i., pp. 232, 411.

(k) 1 Reeves, Hist. Eng. Law, 2ud ed., 51. Madox, Hist. Exch. 2nd ed., rol. i., p. 209 ; vol. ii., p. 73. 
Rutland (10 Edw. 1, sec. 11) contained $\&$ clause $(l):-$ "That no plea shall be holden or pleaded in the Exchequer aforesaid unless it do specially concern us and our ministers aforesaid," yet the practice of the Exchequer did not alter, but the Court in question continued to entertain causes of a personal nature between the subjects of the Crown, by holding that this statute did not apply to suits between subjects who were debtors to the Crown, and then by conniving at the plaintiff's falsely suggesting that he was such a debtor; and that by reason of the defendant not paying what he owed to the plaintiff, the plaintiff would himself be less able to pay what he owed to the Crown $(m)$. The formula to which this fiction gave rise in the process of the Court (usually known as the clause of quo minus) having long obtained, was finally abolished by the Uniformity of Process Act (2 Will. 4, c. 39).

The Court of Exchequer also exercised equitable jurisdiction ; so that when Blackstone wrote $(n)$, and, indeed, until the statute 5 Vict. c. $5(o)$, the same jurisdiction was exercised and the same system of redress pursued on the Equity Side of the Exchequer as in the Court of Chancery, save only in respect of some few matters peculiar to each tribunal, and as to which the other could not interfere.

However, by the 1st section of the Act just mentioned (5 Vict. c. 5), the equity jurisdiction of the Court of Exchequer was for the most part $(p)$ abolished and transferred to the Court of Chancery.

So early as the reign of Henry I., perhaps even in that of William the Conqueror $(q)$, assizes seem to have been occa-

(l) So 28 Edw. 1, st. 3, c. 4, enacted, that " no Common Pleas shall be from henceforth holden in the Exchequer contrary to the form of the Great Charter."

(ii) 1 Sell. Prac. Introduc. 10, 32.

(n) 3 Bla. Com. 426.

(o) See also 5 \& 6 Vict. c. 86.

$(p)$ As to the jurisdiction of the $\mathrm{Ex}$ chequer-in revenue causes see Att.-
Gen. ז. Halling, 15 M. \& W. 687 ; Corporation of London v. Att.-Gen., $1 \mathrm{H}$. L. Cas. 440-where the Crown is entitled to be actor, see Att.-Gen. v. Barker, L. R. 7 Ex. 177.

As to remoring into the Exchequer an action affecting the rights of the Crown, see also post, p. 33 .

(q) 1 Reeves, Hist. Eng. Law, 2nd 
sionally held by Justices in Eyre (in itinere) ( $r$ ), who, by reason of the inconvenience which suitors suffered in being compelled to attend the King's Court from place to place, were commissioned to hold circuits for the administration of justice in counties and districts where the Supreme Court did not chance to be. From the judgment of these Itinerant Justices, in whose institution we see the germ of our system of Assize and Nisi Prius, a right of appeal lay to the Court of Aula Regis, the frequent exercise of which right seems to have brought back to that Court the final determination of most cases of importance throughout the kingdom. Indeed, the expense and delay occasioned to suitors in having to resort to the Supreme Court, coupled perhaps with the jealousy entertained by the Crown of so porrerful a subject

Court of

Common Pleas, when separated from the Aula Regis. as the Chief Justiciar ( $s$, are believed ultimately to have led to the erection of the Court of Common Pleas, which seems to have become first separated, or at all events distinguishable from the Aula Regis in the time of Richard I. $(t)$, or perhaps in that of King John. We know, indeed, that by an article of Magna Charta, it was, in the reign of King John, expressly stipulated that the Common Pleas should not thenceforward follow the King's Ccurt, but should be held in some fixed locality : Communia Placitanon sequantur Curiam nostram sed in aliquo loco certo teneantur. One of the great practical grievances of that time was the necessity of following the King's Court in order to obtain justice, and hence the above article of Magna Charta.

We know historically that from the reign of Henry III. the Court of the Common Pleas, or Common Bench (except

ed., 54; i Palgr. Eng. Comm. 293. The practice of issuing commissions of assize was reduced to a system by Henry II., who divided the counties into circuits, and appointed itinerant justices, who seem to have had a ciril as well as a criminal jurisdiction within each county: 1 Palgr. Eng. Comm. 295; 2 Hill. Middle Ages, 188:
Madox, Hist. Exch., 2nd ed., rol. i. pp. 121-2.

(v) As to whose authority and functions, see Ex parte Fernandez, $10 \mathrm{C}$. B., N. S. $29,42$.

(8) See Gilb. C. P. Introd. 30.

(t) Id. 1 Reeres, Hist. Eng. Law, 2nd ed., p. 57. See Dugd. Orig. Jurid. Chap. 18. 
during some unimportant intervals of time) remained stationary at Westminster.

Although the final establishment of the Court of Common Pleas at Westminster effectually removed one grievance of magnitude, which had been felt by the community at large, yet it created another. Suitors, indeed, were then no longer obliged to travel about after the King's Court in order to obtain justice ; they were, however, not the less compelled, when in want of it, to come, from even the most distant parts of England, up to Westminster. Now, to remedy this inconvenience, the Stat. of Westminster 2 (13 Ed. 1, c. 10) was passed, by which it was, amongst other things, enacted that any person impleaded "before the justices at Westminster, or in the King's Bench, or before justices assigned to take Assizes," \&c., might make a general attorney $(u)$ to sue for him, "which attorney shall have full power in all pleas moved during the circuit, until the pleas be determined." The better opinion seems, indeed, to be, that the Employ attorneys in superior above statute of Westminster 2nd applied in strictness only to appearance by attorney, and not to the conduct of the suit by him after an appearance had been once made; for we learn from Glanville (temp. Henry II.), that even then a party might (after an appearance had been once entered by himself in person) appoint some other individual, corresponding substantially with an attorney, to represent him during the subsequent stages of the suit. Much inconvenience must, however, have been spared to suitors by the above-mentioned statute of Edward I. $(v)$; and it is thought, that the habitual employment of attorneys, of right, in the Courts at Westminster may properly be ascribed to it.

To return, however, to the History of our Courts of Law, -the office of Chief Justiciar, having been deprived of

(a) An attorney is "one put in the place, stead, or turn of another to manage his matters of law." Com. by
Broom and Hadley, vol. iii., p. 22.

(v) See 1 Reeves, Hist. Eng. Law, 2nd ed., 169; 2 Id. 169. 
much of its importance by the establishment,- - first, of the Court of Exchequer, and, afterwards, of the Court of Common Pleas-and its dignity having been further affected by the secession of the Chancellor from the Aula Regis in the time of Henry III.,--seems, towards the close of that reign, to have fallen altogether into desuetude, until revived under a somewhat similar title, though with different functions by Edward I.

To that prince (as history informs us) we are indebted, as well for the assignment of more precise limits to the respective jurisdictions of the Common Pleas and Exchequer,

Definitive establishment of Court of King's Bench. as for the definitive establishment of the Court of King's Bench $(x)$, and as it would seem for the appointment of a chief magistrate, presiding over this latter Court, and endowed with a twofold jurisdiction: 1st, over all pleas of the Crown not relating to the revenue; and, 2ndly, over matters of a private nature involving injuries alleged to have been committed with force, or in which the defendant was charged with falsity or deceit.

Within the former of these two branches of jurisdiction, i.e., Pleas of the Crown, were comprised the cognizance of all felonies and misdemeanors, a general controlling power over other Courts of Criminal jurisdiction, and the right of inquiring into matters touching franchises and liberties, or the wrongful usurpation of official functions. Where justice was obstructed or improperly declined, this high functionary was empowered to compel its performance by inferior courts,

(x) "Ancicntly ealled Curia Domini Regis, because oftentimes the king hiniself sat here in person, and had his justices a latere suo residentes: " Dugd. Orig. Jurid. Chap. 17 (p. 38). See Arg. in the Case of Ship Mloney, 3 How. St. Tr. 861-2 ; Allen Prerog. Cr. 92-3; Palgr. King's Counc. p. 62.

When King James I., at the suggestion of Bancroft, Archbishop of Canterbury, wished to take upon himself the cognisance and exclusive decision of matters touching the jurisdiction of
Courts ecclesiastical, he was thus answered by Lord Coke, in the presence of all the Judges of the land:- "The king in his own person, cannot adjudge any case, either criminal-as treason or felony-or betwixt party and party, concerning their goods, chattels, and inheritance; but this ought to be determined and adjudged in some court of justice, according to the law and custom of England:" Prohibitions de? Roy, 12 Rep. 63. 
colporations and magistrates. And, where jurisdiction was exceeded or improperly assumed, he had the right of interfering to prevent or stop its undue exercise.

Under the latter head of jurisdiction, appertaining to the Chief Justiceship, was included the cognisance of trespasses committed $v i$ et armis, of ejectment, replevin, rescue, pound breach, and of actions founded on deceit. All which causes of action, indeed, savoured strongly of a criminal nature, as shown by this fact, that the defendant, if found guilty, was liable to pay a fine to the Crown, as well as damages to the party injured.

At first, then, the Court of King's Bench had, in strictly civil cases, a very circumscribed jurisdiction; but this it Extension of contrived to amplify and extend, in a manner which may here briefly be explained. In ancient times actions in the superior courts were commenced by original writ, issuing out of Chancery under the Great Seal.

Various specific forms of writs became established in the Court of Chancery, which at length it was thought necessary strictly to observe; so that it was not unusual in early times for a plaintiff, when no writ could be found in Chancery that suited his case, to apply to the Council for a new one $(y)$. To prevent the inconvenience and possibly the denial of justice thus occasioned, it became necessary (especially when contracts increased in number, and wrongs, unknown in the ruder ages, became prevalent) to provide by a statute passed in the 13th year of Edward I. (stat. Westm. 2, c. 24), as follows: viz., that whensoever, from thenceforth, in one case, a writ should be found in the Chancery, and in a like case (in consimili casu) falling under the same right, and requiring like remedy, no precedent of a writ could be produced, the clerks in Chancery should agree in forming a new one. Consequent upon the passing of this statute,

(y) 1 Spence, Chanc. Jur. 226. 
various new writs were prepared in and issued out of Chancery, so that a suitor who had received an injury to which no writ previously in use was applicable, could thenceforth have one framed according to the exigency of his own particular case ; and the action founded upon this writ was, from the words ' in consimili casu' used in the act, called an action of 'trespass on the case,' and was afterwards denominated an action 'on the case' merely. Of this form of action, the Court of King's Bench claimed cognisance, by having the original writ made returnable before them as well as in the Court of Common Pleas, on the ground that it was for a trespass, for which a fine was, in strictness, payable to the Crown, although the wrongful act was not alleged to have been committed $r i$ et armis; and thus a large class of cases, comprising injuries consequential upon tort, was brought within the jurisdiction of the Court of King's Bench.

Not only where the cause of action savoured of trespass strictly speaking, but in actions also founded upon contract, did the Court of King's Bench, by resorting to a fiction, likewise assume jurisdiction. The modus operandi here adopted consisted in allowing a plaintiff, in the first instance, to complain of a trespass against a defendant, and afterwards, when he had thus brought him into Court, to waive his charge of trespass altogether, and to declare against him for a debt, breach of contract, or other matter of a purely civil nature.

The jurisdiction of the Court of King's Bench was, moreover, still further extended, in a manner which is explained by Sir E. Coke (z), who says that this Court had power to hold plea in all personal actions and ejectment, against any one being in the custody of the marshal or officer of the Court, because a party so circumstanced might, if sued in 
any other Court, have pleaded the privilege of the Court of King's Bench ; and this latter Court would, consequently, in order to prevent a failure of justice, which might thus ensue, entertain the suit. Hence, where a person was once in custody of the marshal of the King's Bench at one man's suit, and was brought within the jurisdiction of that Court, he might be compelled before the same tribunal to answer to the complaint of any other man.

Thus did the Court of King's Bench obtain jurisdiction over all civil actions of a personal nature; and, although, by a subsequent statute (13 Car. 2, st. 2, c. 2 ), this acquired, or rather usurped, jurisdiction of the Court, had nearly met with a decisive check, yet it was retained by an exercise of ingenuity not inferior to that by which it had in the first instance been assumed.

The last-mentioned statute enacted, that, where the defendant was to be held to bail for more than $40 l$., by virtue of process issuing out of the Court of King's Bench or Common Pleas, the true cause of action should be specified in the writ or process; and, had no mode of evading this statute been devised, it is evident that many civil actions of considerable magnitude must (except where really founded on trespass) have been altogether withdrawn from the cognisance of the King's Bench. However, out of this dilemma, the justices of that Court extricated themselves in the following manner. A plaintiff, whose cause of action justified him in holding the defendant to bail for more than 40l., was permitted, in his process, to command the sheriff to arrest the defendant, in order that he might answer the plaintiff in a plea of trespass, and also for a debt (or as the case might be). So that, by the introduction into the process of this ac etiam clause (as it was called), jurisdiction having been first given to the Court by the fictitious allegation of a trespass as the ground of complaint, the words of the statute were then complied with, by setting forth the 
true cause of action in the writ. This peculiar form of procedure was finally abolished by the Uniformity of Process Act (2 Will. 4, c. 39), and a simpler form substituted for it called a writ of summons.

Jurisdiction of Superior before Judi. cature Acts.

To sum up, then, the extent and nature of the jurisdiction exercised by our principal Courts of Common Law, just prior to the operation of the Judicature Acts, 1873 and 1875-in all personal actions and in ejectment, they had co-equal and concurrent jurisdiction; an appeal from any County Court lay to any one of our three superior Courts indifferently. The Court of Queen's Bench had peculiarly delegated to it the surveillance over all inferior tribunals, which, as Sir W. Blackstone (a) tells us, it kept within the bounds of their authority, either removing their proceedings by certiorari for its own special determination, or by writ of prohibition, staying their progress in the Court below. It superintended by quo warranto and mandamus, all civil corporations in the kingdom. It commanded magistrates and others to do what their duty required in any case where there was no other specific remedy available. It protected the liberty of the subject by speedy and summary interposition, and took cognisance both of civil and criminal matters, of the one on the Plea, and of the other on the Crown side of the Court.

Prior to the Judicature Act becoming operative, the Court of Common Pleas had a special cognisance of real actions hereinafter mentioned. It was also the Court of Appeal from the decisions of the revising barristers, under the statute $6 \& 7$ Vict. c. 18 ; and the certificates of acknowledgments by married women, under the Act for the Abolition of Fines and Recoveries ( $3 \& 4$ Will. 4, c. 74$)$, with the affidavits verifying them, were filed of record in this Court, in pursuance of the 85th section of that statute.

The Court of Exchequer had, whilst in existence, peculiar

(a) 3 Com. 41, 42; 9 Rep. 118, a. 
and exclusive cognisance of matters of revenue (b), ex. gr., of complaints arising out of alleged infringements of the laws regulating the Customs and Excise,-of matters involving the payment of stamp or other duties to government-or where on any issue raised between private parties the title of the Crown was brought in question $(c)$, or the interests of the revenue were threatened. If, therefore, an action touching any of the matters just specified were brought in the Court of Queen's Bench or Common Pleas, or in a County Court $(d)$, it would, on motion, have been removed into the Exchequer $(e)$ : the basis of the jurisdiction exercised by that Court in so removing it, being, as remarked by a learned Judge in Att.-Gen. v. Kingston, $(f)$ (which was an action against a revenue officer for the value of goods seized by him in execution of his duty), that it was deemed a contempt of the Exchequer to proceed elsewhere in respect of any matter within its own peculiar jurisdiction.

The prerogative of the Crown to intervene in actions affecting the rights, privileges, or revenue of the Sovereign has not been affected by the Judicature Acts $(g)$.

Under the Judicature Act, 1873, the ancient Courts of Queen's Bench, Common Pleas and Exchequer became Divisions of the High Court of Justice-which is a Superior Court of Record $(h)$ composed of Judges specified in the Judicature Act, 1873, s. 5 (explained by the Judicature Act, 1875 , s. $3(i)$ ), and clothed with the jurisdiction which at the commencement of that Act was "vested in or capable

(b) The stats. $22 \& 23$ Vict. c. 21 , 28 \& 29 Vict. c. 104 , amended the practice and procedure of the Court of Exchequer on the Revenue side, and in Crown suits.

(c) See, for instance, Att.-Gen. v. Barker, L. R. 7 Ex. 177. 58.

(d) Ifountjoy . Wood, 1 H. \& N.

(e) Adams v. Fremantle, 2 Exch. 453 ; Att.-Gen. v. Hallett, $15 \mathrm{M}$. \& W. 97; Siddon v. East, 1 C. \& J. B.C.L.
12.

(f) 8 M. \& W. 163.

(g) Att.-Gen. v. Constable, 4 Ex. D. 172 .

(h) $36 \& 37$ Vict. c. 66 , s. 16.

(i) Of which Act, see also ss. 7, 8 . By stat. $40 \& 41$ Vict. c. 9 , s. 2 , Her Majesty was empowered to appoint a judge of the High Court of Justice in addition to the number of judges of that court authorised to be appointed by the Judicature Acts.
High Court of Justice. 
of being exercised by," all or any of the Courts mentioned in the Act $(k)$. By an order in Council dated 16th December, 1880, under the powers of s. 32 of the Judicature Act, 1873, the Common Pleas and Exchequer Divisions have now become merged in the Queen's Bench Division, and the offices of Lord Chief Justice of the Common Pleas Division and Lord Chief Baron of the Exchequer Division have been abolished.

Higher in degree than the High Court of Justice is the Court of Appeal, which is a Superior Court of Record (l), consisting of Judges denominated "ex officio," "ordinary," and "additional" $(m)$. To this tribunal have been transferred, besides equitable (n) and some other jurisdiction which need not be specified-" all jurisdiction and powers" of the previously existing Court of Exchequer Chamber (o).

By the Judicature Act, 1873, s. 19, the Court of Appeal has jurisdiction to hear and determine appeals from any judgment or order (with certain exceptions $(p)$ not here material) of the High Court of Justice, or any Judge there-

(k) Of which the most important are the Court of Chancery as a Common Law Court as well as a Court of Equity ; the Courts of Queen's Bench, Conmon Pleas and Exchequer, as a Conrt of Rerenue, as well as a Common Law Court; the High Court of Adniralty ; the Courts of Probate and for Dirorce and Matrimonial Causes; and Courts created by commissions of assize, oyer and terminer, and gaol delivery, s. 16.

By s. 17 certain branches of Equity jurisdiction are not to be transferred to the High Court of Justice. Nor by 38 \& 39 Vict. c. 77, s. 9 , is the jurisdiction of the London Court of Bankruptcy to be so transferred. This section was repealed, however, by s. 169 of the Bankruptey Act, 1883. By s. 93, subs. 1, of this last-mentioned Act the London Bankruptey Court was united and consolidated with the Supreme Court of Judicature.

(I) 36 \& 37 Vict. c. 66, s. 18. (m) 38 \& 39 Vict. c. 77 , s. 4 . See also $54 \& 55$ Vict. c. 53, s. 1 .

(n) Of which the most important parts are the appellate jurisdiction and porrers of the Lord Chancellor and the Court of Appeal in Chancery, $36 \& 3 \pi$ Vict. c. 66, s. 18.

(a) This Court derired its origin from the stat. $31 \mathrm{Edw}$. 3., st. 1, c. 12, and was first established to hear and determine causes brought before it by Writ of Error from the Common Law side of the Exchequer. The jurisdiction and constitution of this Court were, howerer, altered by the $11 \mathrm{Gen}$. $4 \& 1$ Will. 4 , c. $70,-$ s. 8 of which enacted that Writs of Error from any judgment given by the Court of King's Bench, Common Pleas, or Exchequer, should be returnable before the Judges of the other two Courts in the Exchequer Chamber.

(p) See also $39 \& 40$ Yict. c. 59 , s. 20 . 
of. No Judge, however, of the said Court of Appeal can sit as a Judge on the hearing of an appeal from any judgment or order made by himself, or made by any Divisional Court $(q)$ of which he was a member $(r)$; though he is not precluded from sitting in the Appellate Court at the hearing of an appeal in an action pending in the Division of which he is a member if he took no part in making the order appealed from $(s)$.

The Court of Appeal has some original jurisdiction, inasmuch as it is enacted that for all purposes incidental to the hearing and determination of any appeal within its jurisdiction, and the amendment, execution, and enforcement of any judgment or order made on any such appeal, and for the purpose of every other authority expressly given to the Court of Appeal, it shall have all the power, authority, and jurisdiction vested in the High Court of Justice $(t)$.

In the Supreme Court of Judicature have been " united and consolidated together" $(u)$ the jurisdiction and funcSupreme Court of tions formerly exercised by the Court of Chancery, the Courts of Queen's Bench, Common Pleas and Exchequer, the High Court of Admiralty, the Courts of Probate and for Divorce and Matrimonial Causes. And the Supreme Court consists of two permanent Divisions, viz., the High Court of Justice exercising original jurisdiction, with appellate jurisdiction from some inferior Courts $(x)$, and the Court of Appeal exercising appellate jurisdiction with such original jurisdiction as may be incident to the determination of an appeal (y).

The Supreme Court in its entirety has no judicial functions to perform; it is, however, charged with important

p. 49 .

(2) As to Dirisional Courts, post,

(r) 38 \& 39 Vict. c. $7 \pi$, s. 4.

(s) Fisherv. Val de Travers Asphalte Co., 1 C. P. D. 259. (t) $36 \& 37$ Vict. c. 66 , s. 19 .

(u) $36 \& 37$ Vict. c. 66, s. 3.

(x) Post, p. 50.

(y) S. 4. 
Honse of Lords.

High Court of Chancery.

duties in regard to the making of rules and regulating the procedure $(z)$.

A final appeal lies to the House of Lords $(a)$ as constituted by "The Appellate Jurisdiction Act, 1876 " (b), from any order or judgment of the Court of Appeal (c). The appeal must be brought by way of petition to the House praying that " the matter of the order or judgment appealed against may be reviewed before Her Majesty the Queen in her Court of Parliament in order that the said Court may determine what of right, and according to the law and custom of this realm $(d)$, ought to be done in the subjectmatter of such appeal" (e).

It is beyond the province of this book to dwell at length upon the origin and jurisdiction of the High Court of Chancery, but we may say in passing that that Court is generally supposed to have come into existence from the fact that persons who found the remedies granted by the Common Law Courts insufficient applied the only remedy they had by petitioning the King in Parliament or in his Council; and such petitions being referred by the King to the Chancellor, that officer acquired a permanent jurisdiction over them.

The Chancellor's Court was called the High Court of Chancery, and in it the principles of Equity, in contradistinction to those of Common Law, were administered,

(z) $36 \& 37$ Vict. c. $66,8.75 ; 38$ \& 39 Vict. c. 77 , s. 17 ; see also $44 \&$ 45 Vict. c. 68 , s. 19 ; and $57 \& 58$ Vict. c. 16, s. 4 .

(a) The Ilouse of Lords proceeds in "all matters of judgment" secundum legem terræ (Arg., 8 How. St. Tr. 315), and though conforming to its own prior decisions (Att.-Gen. v. Dean, \&c., of Windsor, 8 H. L. Ca. 369, 391-2 ; et vide per Lord Kingsdown, Id. 459 ; Tominey v. White, 3 H. L. Ca. 49 ; per Blackburn, J., Harris r. Great Westcrn R. C., I Q. B. D. 528 ; per Lord Campbell, C. J., 1 E. \& B. 804 ; per Alexander, C. B., 3 Bing. 562. See
Wilson v. Wilson, 5 H. L. Ca. 40, 63), may decline to recognise as binding judgments pronounced by inferior tri. bunals.

As to the importance of adhering to settled law, see per Coleridge, J., $6 \mathrm{H}$. L. Ca. 537 .

(b) $39 \& 40$ Vict. c. 59.

(c) Id. s. 3. As to appeals in forma pauperis, the House of Lords may ou the report of its appeal committee refuse permission to sue in such form, 56 $\& 57$ Vict. c. 22.

(d) See note (a), supra.

(e) $39 \& 40$ Vict. c. 59, s. 4. 
and relief was given to suitors which could not be obtained elsewhere.

By the Judicature Act, 1873, s. 16, the jurisdiction of this Court has been transferred to the High Court of Justice.

The jurisdiction of the Queen's Bench Division of the High Court of Justice, and the jurisdiction of the Court of Appeal in regard to matters originating at law, with which Larr and be concur. rently adonly we are here concerned, is in virtue of certain provisions of the Judicature Act, 1873, far more ample than that of old exercised respectively by the three Superior Courts of Common Law and by the Exchequer Chamber. By the Queen's Bench Division of the High Court of Justice, and by the Court of Appeal law and equity are concurrently administered in accordance with certain rules $(f)$ : it must, however, be borne in mind that matters exclusively within the cognisance of the High Court of Chancery have been assigned to the Chancery Division of the High Court of Justice, and if prosecuted elsewhere may be transferred thither $(g)$.

In connection with what has been just said, it may perhaps be needless to observe that a claim purely equitable in its nature would not support an action at law $(h) ; e x . g r$. , a cestui que trust cannot sue his trustee at law for money due in his capacity of trustee, unless indeed the latter has admitted that it is due, and that he holds it in his hands (i).

It may be remembered, however, that by an action at law

(f) $36 \& 37$ Vict. c. 66 , s. 24.

(g) See 38 \& 39 Vict. c. 77, s. 11; Order xlix. Post, Chap. 4.

(h) Per Erle, J., London and North Western R. C. v. Glynn, 28 L. J. Q. B., 192 (citing Allen v. Impett, 8 Taunt. 263). See Pardoe r. Price, 16 M. \& W. 451 ; distinguished in
Sansom v. St. Leonard, Shorditch, L. R. 4 C. P. 654,657 ; Edwards v. Loundes, 1 E. \& B. 81.

(i) Howard v. Brownhill, 23 L. J., Q. B. 23 ; Roper . Holland, 3 Ad. \& E. 99 ; cited Judgm., Kennedy v. Broun, 13 C. B., N. S., 741. 
the result of a suit in equity founded on the same facts might sometimes be attained. Thus " an agent is bound to account to his principal or employer for all profits made by him in the course of his employment or service," and is compellable to account in equity, whilst there is also "a legal duty" "clearly incumbent" on the agent "whenever any profits so made have reached his hands, and there is no account in regard to them remaining to be taken and adjusted between him and his employer, to pay over the amount as money absolutely belonging to his employer" $(k)$.

The purpose of the Judicature Acts, as judicially observed $(l)$, "was to establish one great tribunal with consistent and homogeneous action in all its parts." Further, the object of the legislature was to effect as far as possible "an assimilation of practice and procedure" in Courts of Law and Equity and to some extent also of doctrine. Accordingly as regards certain matters specified in the Judicature Act, 1873, s. 25 (amended by the Judicature Act, 1875, s. 10), the law to be administered by the Common Law Divisions of the High Court of Justice and by the Court of Appeal has been altered and declared, and the 11th and concluding clause of that (25th) section applying to matters not before particularly mentioned therein has enacted that where with reference to them "there is any conflict or variance between the Rules of Equity and the Rules of Common Law," "the Rules of Equity shall prevail."

The assimilation of the practice in Courts of Law to that in Equity has been exemplified in many cases, for instance by the disallowance of criminating interrogatories $(m)$, and also with regard to the practice in discovery $(n)$ of documents. But in matters of practice not provided for by the

(k) Morison r. Thompson, L. R. 9 Q. B. $480,486$.

(I) Per Lord O'Hagan, Garnett v. Bradley, 3 App. Cas. 958. (m) Atherley r. Harecy, 2 Q. B. D. $524,527-9$, post.

(v) Jomes r. Monterideo Gas Co., 5 Q. B. D. 556. 
new rules that practice which appears to be the best is to prevail $(p)$.

A careful study of the wording of the Judicature Act, 1873 , ss. 24 and 25, will show how important are the changes effected by the legislature with a view to assimilating the procedure and doctrines at Law to those of Equity.

By s. 25, to some portions only of which reference can from time to time be made in this volume, the law to be administered in England in regard to no fewer than eleven particulars $(q)$ has been amended and declared, whilst by the. preceding section (24) ample provision is made for determining and adjudicating on matters of equity which may arise during the progress of a suit at law.

Let us suppose that the plaintiff sues in respect of a strictly legal claim or, may be, claims to be entitled to "relief founded upon a legal right" which before the Act " could only have been given by a Court of Equity" $(r)$, and let us further suppose that the defendant by way of answer thereto "claims to be entitled to any equitable estate or right, or to relief upon any equitable ground against any deed, instrument, or contract, or against any right, title, or claim asserted" by the plaintiff, or alleges any ground of equitable defence thereto, the Court or Judge will under the circumstances supposed give to every such equitable estate, right, or ground of relief claimed, and to every such equitable defence alleged, the same effect, by way of defence against the plaintiff's claim, as the Court of Chancery would formerly have given "if the same or the like matters had been relied on by way of defence in any suit or proceeding instituted in that Court for the same or the like purpose" (s). Thus where an action was brought in the Common Pleas

(p) See Newbiggin-by-the-Sea Gas Co. v. Armstrong, 13 Ch. D. 310 ; Nurse v. Durnford, 13 Ch. D. 764; Dalrymple v. Leslie, 8 Q. B. D. 5 ; Shippey v. Grey, 49 L. J. C. P. 524. (q) See particularly subsections 6-8. Subs. 1 is replaced by $38 \& 39$ Vict. c. 77, s. 10 .

(r) 36 \& 37 Vict. c. 66 , s. 24 (1).

(s) $36 \& 37$ Vict. c. 66 , s. 24 (2). 
Division of the High Court of Justice and the defendant relied on an equity to have a deed set aside as part of his defence, it was held that the Division in which the action was pending might give effect to the equity so far as it was incidental to the purposes of the defence $(t)$.

So relief will be granted to a defendant who properly claims it by his pleading " in respect of any equitable estate or right, or other matter of equity," as well as in respect of any legal estate, right, or title claimed or asserted by him, and which might have been obtained in an action instituted by the defendant for that purpose $(u)$. And relief relating to or connected with the original subject of the action may also be claimed and will be granted against any other person whether a party $(x)$ to the action or not, "who shall have been duly served with notice in writing of such claim," the relief being such "as might properly have been granted against such person if he had been made a defendant to a cause duly instituted by the same defendant for the like purpose; and every person served with any such notice shall thenceforth be deemed a party to such cause or matter, with the same rights in respect of his defence against such claim, as if he had been duly sued in the ordinary way" by the defendant $(y)$.

Again, a Court of Law will recognise and take notice of equitable estates, titles, and rights, duties and liabilities appearing incidentally in the course of an action in like manner as the Court of Chancery would formerly have done $(z)$.

Besides the above mentioned statutory provisions it is generally enacted that a Court of Law or Judge thereof "shall recogmise and give effect to all legal claims and

(t) Mostyn v. West Mostyn Coal and Iron Co., 1 C. P. D. 145.

(u) 36 \& 37 Vict. c. 66, s. 24 (3).

(x) "Party" includes every person served with notice of, or attending any proceeding, although not named on the record, $36 \& 37$ Vict. c. 66 , s. 100 .

(y) $36 \& 37$ Vict. c. 66, s. 24 (3). As to how this is practically carried out. and to what extent it is limited by the rules, see post, p. 160 .

(z) Id. s. $24(4)$. 
demands, and all estates, titles, rights, duties, obligations and liabilities existing by the Common Law or by any custom, or created by any Statute, in the same manner as the same would have been recognised and given effect to" before the passing of the Judicature Act, 1873, by any of the Courts whose jurisdiction was thereby transferred to the High Court of Justice (a).

Lastly, in connection with this part of our subject, it is provided that the High Court of Justice and the Court of Appeal in every cause or matter pending before them respectively, "shall have power to grant, and shall grant, either absolutely or on such reasonable terms and conditions as to them shall seem just, all such remedies whatsoever as any of the parties thereto may appear to be entitled to in respect of any and every legal or equitable claim properly brought forward by them respectively in such cause or matter ; so that, as far as possible, all matters so in controversy between the said parties respectively may be completely and finally determined, and all multiplicity of legal proceedings concerning any of such matters avoided;" and to prevent the conflicts which used to take place between the Equity and Common Law Courts, it is now provided that no proceeding in the High Court of Justice or Court of Appeal can be restrained by prohibition or injunction (b).

As regards the jurisdiction of the Superior Courts of Law, certain general principles have been held applicable.

In the first place, on grounds of public policy, any agreement, the object of which is to prevent the suffering party from coming for redress into a Court of Law, or, in othel words, "which ousts the Courts of their jurisdiction altogether," is void (c). It is not, however, unlawful for

General principles as to jurisdiction.

Agreement to oust ju. risdiction of the Courts. (a) $36 \& 37$ Vict. c. 66 , s. 24 (6).

(b) Id. s. $24(5,7)$.

(c) Scott v. Avery, 8 Exch. 487,
500 ; S. C., 5 H. L. Ca., 811, explained in Horton v. Sayer, 4 H. \& N. 649, 651 ; Scott $\mathrm{v}$. Corporation of Liver- 
parties to enter into an agreement with respect to the mode of settling the amount of damage, in case any should be sustained, or the time for paying it, or any matter of a similar kind which does not go to the root of the action $(d)$. The question which then arises is whether an arbitration or award is necessary before a complete cause of action arises, that is to say is made a condition precedent to an action, or whether the agreement to refer disputes is a collateral and independent one. That question must be determined in each case by the construction of the particular contract, and the intention of the parties to be collected from its language $(e)$.

In determining such construction it has been said that in cases where there is first a covenant to pay, and secondly a covenant to refer, the covenants are distinct and collateral, and the plaintiff may sue on the first, leaving the defendant to pursue one of two courses, i.e., either to bring an action for not referring, or to apply under s. 11 of the Common Law Procedure Act, $1854(f)$, to stay the action until there has been an arbitration, in which case a Judge has power to prevent the case going to a jury if the arbitration can be fairly enforced $(g)$; or, as it was put by Lord Cranworth in Scott v. Avery (h), "If I covenant with A. to do particular" acts, and it is also covenanted between us that any question which may arise as to the breach of the covenants shall be referred to arbitration, that latter covenant does not prevent the covenantee from bringing an action. A right of action

pool, 3 De G. \& J. 334, 360 ; Braunstein r. Aceidental Death Insurance Co., 1 B. \& S. 782.

(d) Per Brett, L. J., in Edwards v. Aberayron Co., 1 Q. B. D. 563 at p. 596 ; Roper r. Lendon, 1 E. \& E. 825; but see Tredwen r. Holman, 1 H. \& C. 72 at p. 80. See also Caledonian Insurance Co. v. Gilmor, 1893, A. C. s.๊.

(e) Per Sir M. Smith in Collins v. Loeke, 4 App. Cas. 674, 689; distin- guished in riney r. Bignold, 20 Q. B. D. 172; Elliott v. Royal Exehange, I. R. 2 Ex. 237; Dauson v. Fitzgerald, 1 Ex. D. 257; Babbage v. Coulboum, 9 Q. B. D. 235.

(f) Repealed by the Arbitration Act, 1889 (52 \& 53 Vict. c. 49 ), which has amended and consolidated the enactments relating to arbitration.

(g) Per Jessel, M.R., in Daucson r. Fitzgerald, 1 Ex. D. 257 at p. 260.

(i) 5 H. L. C. at p. 848 . 
has accrued, and it would be against the policy of the law to give effect to an agreement that such a right should not be enforced through the medium of the ordinary tribunals. But if $I$ covenant with A. B. that if $I$ do or omit to do a certain act, then I will pay to him such a sum as J.S. shall award as the amount of damage sustained by him, then, until J. S. has made his award, and I have omitted to pay the sum awarded, my covenant has not been broken and no right of action has arisen."

2ndly. As on the one hand parties cannot oust the jurisdiction of the Courts by their own agreement or convention, so, on the other hand, they cannot, by consent, give the Courts jurisdiction over matters which do not properly fall within it $(i)$; for all Judges must derive their authority from the Crown by some commission warranted by law $(j)$, and they cannot act officially dehors the scope of the powers thus confided to them.

3rdly. The jurisdiction of our superior Courts of law in civil cases is usually said to extend over the counties of Territorial limits of England and Wales, and the town of Berwick-uponTweed $(k)$. This definition cannot however be accepted as quite satisfactory, even in reference to civil cases, for in one sense our superior Courts have a more extensive jurisdiction; $e x . g r$. , they may take cognisance of actions in personam in respect either of contracts or torts, though the cause of action may have arisen abroad, and though the parties to it may be aliens, provided service can be effected in accordance with the rules of the Courts themselves $(l)$; but, in adjudicating upon such cases, our Courts will have

(i) See per Maule, J., Gibbon r. Gibbon, 22 L. J., C. P. 133-4; Avards v. Rhodes, 8 Exch. 312 ; Lawrence v. Wilcock, 11 Ad. \& E. 941 : Vansittart r. Taylor, 4 E. \& B. 910,912 . See Andreves r. Elliott, 6 E. \& B. 338.

(j) Bac. Abr. Courts (B).

(k) 1 Chitt. Arch. Pr.

(l) See Mostyn r. Fabrigas, Cowp.
$161 ; 1$ Sm. L. C., 9th ed., 628, and p. 689 ; Buenos Ayres, \&e., R. C. r. Worthern R. C. of Buenos Ayres, 2 Q. B. D. 210 ; Phillips v. Eyre, L. R. 6 Q. B. $1 ; 4$ Q. B. 225 ; Seott v. Loid Seymour, 1 H. \& C. 219, 231 ; Submarine Telegraph Co. r. Diekson, 15 C. B., N. S. 759 .
Jurisdiction by consent. 
Service of process abroad.

regard to the laws of the country in which the cause of action arose, albeit their mode of procedure will be in conformity with our own law and practice. In other words, all that relates ad litis decisionem is, in such cases, adopted from the foreign country; and so much of the law as affects the remedy only, or that relates ad litis ordinationem, is taken from the lex for $i$ of that country in which the action is brought $(m)$. For instance, a document which by the law of the foreign country in which it was made, would there be inadmissible in evidence for want of a stamp, may, nevertheless, be received in our Courts. But, if for want of a stamp the contract would be altogether void in the foreign country, it could not here be enforced $(n)$.

4thly. Not only may causes of action which have originated abroad be sometimes brought within the cognisance of our Courts, but persons resident abroad, whether foreigners or subjects of the Crown, may, under certain statutory provisions, and subject to certain conditions, hereafter mentioned, be effectually served with process issuing out of them : and thus actions may be commenced in this country and prosecuted against absentees with a view ultimately to issuing execution against their property and effects here situate $(o)$ : though civil process, by way of attachment against the person of a defendant, cannot be enforced

(m) Judgm., Huber r. Stciner, 2 Bing. N. C. 202 ; Bullock r. Caird, I. R. 10 Q. B. 276 ; Harris v. Quine, I. R. 4 Q. B. 653 ; Phillips r. Eyre, supra; De la Rosa r. Prieto, 16 C. B., N.S.578; De la Vega v. Tianna, I B. \& Ad. 284; Gen. Steam Nav. Co. v. Guillou, 11 M. \& W. 877,895 ; cited Judgm., Schibsby v. Westenholz, L. R. 6 Q. B. 157: and in The Moxham, 1 P. D. 113 ; Voinet v. Barrett, $54 \mathrm{I}$.J. Q. B. 521 ; Meyer v. Ralli, I C. P. D. 358; Horne v. Rouquette, 3 Q. B. D. 514 ; Godard r. Gray, L. R. 6 Q. B. 139 ; Wilde r. Sheridan, 21 L. J. Q. B. 260 ; Lloyd v. Guibert, L. R. 1 Q. B. 115, distinguished in The Gactanc,
7 P. D. 4 ; Leroux r. Broun, 12 C. B. 801 (as to which vide per Willes, J.. Williams, app., Whecler, resp., \& C. B., N. S. 316 ; and per Ficld, J.. Racley r. Rauley, 1 Q. B. D. 460 . 461), cited in Jones r. Victoria Gravin! Jock Co., 2 Q. B. D. 323; Alliance Bk. of Simla r. Carey, 5 C. P. D. 429 ; Adams v. Clutterbuck, 10 Q. B. D. 403 ; Jacobs v. Crédit Lyonnais, 12 Q. B. D. 589. See the Judgment of the Earl of Selborne in Sirdar Gurdyal Singh v. Rajuh of Faridkate, 1894, A. C. 670 . 275 .

(n) Dristow r. Sequecille, 5 Exch. (o) Post, Chap. 4. 
beyond the limits of this kingdom; because, in such case, the maxim holds-Extra territorium jus dicenti impune non paretur $(p)$.

2. Mode of Procedure in Banc, at Judges' Chambers, and in the District Registries.

The matters which are brought within the cognisance of our superior Courts of law may be divided or parcelled out into three branches, viz., 1st, purely Civil ; 2ndly, quasi of what matters our superior Courts take cognisance. Criminal; and 3rdly, Criminal-Proceedings.

To the first head, of purely civil matters or proceedings, might be referred the entire theory of, and practice connected with, private rights, wrongs, and remedies; the pleadings in actions; the practice to be observed therein; everything, in short, connected with, or ancillary or incidental to, the conduct of an action.

Within the second of the two heads just specified might be included matters or proceedings connected with indictments for nuisances, the non-repair of roads, \&c., criminal informations, applications for writs of quo warranto, mandamus, or prohibition, questions raised for judicial decision in connection with the administration of the Poor Law, and many other kindred or analogous matters which it would be useless to enumerate.

As falling under the third head of purely criminal proceedings might be specified an application for a habeas corpus to bring up the body of a prisoner, a motion to quash an inquisition, to remove an indictment for a misdemeanor into the Queen's Bench Division from Sessions or from the

(p) We may remind the reader that a criminal offender, who has gone abroad, may in some cases be brought within the jurisdiction of our Courts by virtue of international treaties; and further that in statutory language " the rightful jurisdiction of Her Majesty, her heirs and successors, extends and has always extended over the open seas adjacent to the coasts of the United Kingdom and of all other parts of Her Majesty's dominions to such a distance as is necessary for the defence and security of such dominions:" $41 \& 42$ Vict. c. 73, Preamble. See Foreign Jurisdiction Act, 1890, 53 \& 54 Vict. c. 37 . 
Central Criminal Court; everything, in short, connected with or originating out of the general criminal law of the land $(q)$.

Summary jurisdiction.

Summary jurisdiction is exercised by a superior Court in virtue either of the common or of the statute law. So far as it exists at common law, it is calculated:-1. To prevent the regulations of the Court from being infringed; 2 . To prevent their authority from being abused $(r) ; 3$. To prevent it from producing hardship; 4. To enforce good conduct on the part of those, ex. gr. solicitors (s), who are peculiarly within its jurisdiction.

A superior Court of law is often called on to exercise jurisdiction on motion made to it, by rule or order of the Court founded thereupon : a motion being an application to the Court, praying it to grant a rule, either a rule nisi to show cause, or a rule absolute, in respect of some particular matter within its cognisance.

It is expressly ordered $(t)$, that where by the Rules appended to the Judicature Act, 1875, an application is authorised to be made to the Court or a Judge in an action, such application, if made to a Divisional Court or to a Judge in Court, shall be made by motion $(u)$; also, that no rule or order to show cause shall be granted in any action, or to set aside, remit, or enforce an award, or for attachment, or to answer the matters in an affidavit, or to strike

(q) As to what are criminal proceedings, see cases decided under s. 47 Jud. Act, 1873 ; Wils., 7th ed., 41.

(r) The Court, in the exercise of its discretion, will stay the proceedings in an action as being frivolous and rexatious and an abuse of its process : Castro r. Murray, L. R. 10 Ex. 213; Dawkins r. Saxe Weimar, 1 Q. B. D. 499; Metrop. Bank v. Pooley, 10 App. Cas. 211.

The Court, moreorer, will sometimes " exercise the jurisdiction, which it unde $u_{\text {' }}$ dly possesses, of risiting a vexatiots abuse of any process of the Court with the payment of costs." P'er Cock- burn, C. J., Reg. r. Edmonds, L. R. 9 Q. B. $598,602$.

(s) All persons admitted as solicitors or attorneys or empowered to practise in any Court the jurisdiction of which has been transferred to the High Court of Justice or the Court of Appeal, are designated "Solicitors of the Supreme Court" - and are deemed officers thereof and subject to its jurisdiction, 36 \& 37 Vict. c. 66, s. 87 , amended by 38 \& 39 Vict. c. 77, s. 14 . As to striking off the Roll, cf. Solicitors Act, 1888, 51 \& 52 Vict. c. 65, s.s. 12-15.

(t) Order lii. R. 1.

(u) Id. 
off the rolls, or against a sheriff to pay money levied under an execution $(x)$.

It is further ordered, that (with certain exceptions) no motion shall be made without previous notice to the parties affected thereby. Though the Court or Judge, if satisfied that the delay caused by proceeding in the ordinary way might entail "irreparable or serious mischief," may make an order ex parte, upon terms, and any party affected by such order may move to set it aside $(y)$.

If on the hearing of a motion or other application the Court or Judge shall be of opinion that any person to whom notice has not been given ought to have notice, the motion or application will be dismissed, or the hearing thereof will be adjourned in order that notice may be given $(z)$.

A motion is made orally in open Court, being in general founded on an affidavit (a). It is indeed expressly ordered Motion, how made that upon any motion or summons evidence may be given by affidavit; though the Court or a Judge may, on the application of either party, order the attendance for crossexamination of the person making such affidavit (b). An affidavit must be confined to such facts as the witness is able of his own knowledge to prove, except on interlocutory motions, on which statements as to his belief, with the grounds thereof, may be admitted; and the costs of every affidavit which shall unnecessarily set forth matters of hearsay, or argumentative matter, or copies of or extracts from documents, must be paid by the party filing the same $(c)$. R. 3 .

(x) Order lii. R. 2. See Order xxxix. (y) Id. R. 3.

Unless the Court or Judge gire special leave to the contrary, there must be at least two clear days between the serrice of a notice of motion and the day named in the notice for hearing the motion. In applications to answer the matters in an affidavit, or to strike off the Rolls, the time is ten days. R. 5.

(z) Id. R. 6. See also Rules 7-9.

(a) An order may, howerer, be made on the mere suggestion of the AttorneyGeneral; see, for instance, Adams $\mathrm{r}$. Freemantle, 2 Exch. 453.

(b) Order xxxviii. R. I. s.s. 20 . 
Rules nisi

When the application is for a rule nisi or to show cause, the motion is made ex parte in the first instance, and if the rule be granted it must be drawn up and served upon the other party, and will call upon him to appear and show cause within a time specified.

If, on the day appointed for that purpose and specified in the rule or notice, as the case may be, no cause is shown on behalf of the party upon whom it has been served and whom it seeks to affect, the rule will be made absolute, that is to say, the application will be granted. If, howerer, cause is shown against it, that is, if counsel appear and argue in opposition to the rule or application, the Court will, in the exercise of their discretion, either discharge the rule, or in part or altogether make it absolute, or refuse or grant the application. In some cases they will refer the matter thus brought before them to one of the Masters of the Court, that he may inquire into and report upon it. If the rule be made absolute, and be not re-opened by permission of the Court (which, however, has been seldom granted), or if the application stated in the notice be granted, non-compliance with its requirements will in general be a contempt of Court, and punishable by attachment; which is a judicial writ directed to the sheriff, and commanding him to arrest the individual who has been guilty of the contempt $(d)$.

Sittings of Court of Alpeal.

The Court of Appeal is empowered to sit at the same time in two divisions. Subject, however, to this provision, that every appeal to the Court shall, where the subjectmatter thereof is a final order, decree, or judgment, be heard before not less than three Judges of the said Court, sitting together, and shall, when the subject-matter of the

(d) See Form of Writ of Attachment, Jud. Acts, App. H. No. 12.

A rule nisi will sometimes be envarged, i.e., further time for showing canse will be granted, either by consent of the parties, or on special grounds, submitted to the Court Cause, moreover, is sometimes, with a riew to preventing delay and expense, shown in the first instance, i.e., on the rule nisi being moved. 
appeal is an interlocutory order, decree, or judgment, be heard before not less than two such Judges; any doubt which may arise as to what decrees, orders, or judgments are final, and what are interlocutory, being determinable by the Court of Appeal (e).

Further, any direction incidental to a pending cause or matter not involving the decision of an appeal, may be given by a single Judge of the Court, who may also during vacaPower of a single Judge in Court of Appeal. tion make any interim order to prevent prejudice to the claims of parties pending the appeal ; but every such order may be discharged or varied by the Court of Appeal or a Divisional Court thereof $(f)$.

Much legal work is transacted by Divisional Courts of the High Court of Justice:-the stat. $39 \& 40$ Vict. c. 59 , s. 17 , enacting that henceforth "every action and proceeding in the High Court of Justice, and all business arising out of the same," except as afterwards provided, "shall, so far as is practicable and convenient, be heard, determined, and disposed of before a single Judge," and all proceedings in an action subsequent to the trial and down to and including the final judgment, must be had and taken before the Judge who presided at the trial of the cause.

Divisional Courts of the High Court of Justice may be held, nevertheless, for the transaction of business ordered to be heard there-any such Divisional Court when held being constituted of two Judges only, unless it be deemed expedient that a greater number of Judges should attend. For carrying into effect the foregoing enactments, rules have been duly framed $(g)$.

Any appeal from Petty or Quarter Sessions, from a County Court, or other inferior Court, which might formerly have been brought to any Court or Judge whose jurisdiction

(c) $38 \& 39$ Vict. c. 77, s. 12. $(f) 36 \& 37$ Vict. c. 66 , s. 52.

Every application to a Judge of the Court of Appeal must be by motion:

B.C.L.
Order Iviii., R. 18, and Order lii.

(g) $39 \& 40$ Vict. c. 59, s. $17 ; 47 \&$ 48 Vict. c. 61, s. 4 ; Order lix.

High Court of JusticeDivisional Courts of. 
has been transferred to the High Court, may be heard and determined by a Divisional Court thereof; the determination of any such appeal being final unless special leare to appeal from the same be given $(h)$.

Leave of the Court or Judge making an order by consent, or as to costs which by law are left to the discretion of the Court, will be requisite before an appeal from it will lie (i).

Abolition of terms.
Sittings and racations of Court of Appeal and High Court of Justice.

It may be convenient here to state that the division of the legal year into terms has so far as relates to the administration of justice been abolished; there will not, therefore, henceforth be terms applicable to any sitting or business of the High Court of Justice, or of the Court of Appeal, such Courts and the Judges thereof respectively being empowered to sit and act, at any time, and at any place, for the transaction of business, or for the discharge of any duty which by Act of Parliament, or otherwise, is required to be discharged during or after term $(k)$.

The sittings of the Court of Appeal, and the sittings in London and Middlesex, of the High Court of Justice, are four in every year; viz., the Michaelmas $(l)$, Hilary $(m)$, Easter $(n)$, and Trinity $(o)$ sittings. The vacations to be observed in the several courts and offices of the Supreme Court are the Long vacation $(p)$, the Christmas vacation $(q)$,

(h) 36 \& 37 Vict. c. 66, s. 45 . See Re Ellershaw, 1 Q. B. D. 481 . S. 1 , subs. 5, of the Judicature (Procedure) Act, 1894 (57 \& 58 Vict. c. 16), would appear to modify this section in that leave to appeal may be given either by that Court or the Court of Appeal. See also s. 2.

(i) Id. s. 49. See also as to where leare necessary, 57 \& 53 Vict. c. 16 , 8. 1. A motion to discharge or vary an order of a single Judge of the C.A. under s. 52, Jud. Act, 1872 , is not within the section. Boyd v. Bischoffsheim, (1895) 1 Ch. 1, C. A.

(k) Id. s. 26.

(l) Commencing on the 24th of
October and terminating on the 21 st of December.

(m) Commencing on the 11th of January and terminating on the Wednesdar before Easter.

(n) Commencing on the Tuesday after Easter week and terminating on the Friday before Whitsunday.

(o) Conmencing on the Tuesdar after Whitsun week and terminating on the 12th of August.

(p) Commencing on the 13th of August and terminating on the 23rd of October.

(q) Commencing on the 24th of December and terminating on the 6th of January. 
the Easter vacation $(r)$, and the Whitsun vacation $(s)$, the days of the commencement and termination of each sitting and vacation being included in such sitting and vacation respectively $(t)$.

Two of the Judges of the High Court of Justice, selected at the commencement of each long vacation, and acting as Vacation Vacation Judges for one year from their appointment, attend at Chambers for the hearing in London or Middlesex during vacation of all such applications as may need to be immediately or promptly heard $(u)$.

The Vacation Judges are empowered to sit either separately or together as a Divisional Court as occasion may require, and may hear and dispose of all causes, matters, and other business to whichever division the same may be assigned $(x)$.

Any Judge of the High Court of Justice may, subject to the rules of Court, exercise in Court or at Chambers the jurisdiction vested in the High Court, in such matters as might formerly have been heard in Court or Chambers, by a single Judge of any Court whose jurisdiction has been transferred to the High Court. In such case the Judge sitting in Court is deemed to constitute a Court (y).

Very many matters of importance and urgency connected with the three heads of procedure mentioned at the comJnrisdiction of Judge at mencement of this sub-section are disposed of at Judges' chambers. This branch of a Judge's jurisdiction $(z)$ depends on long established practice and usage, recognised, sanctioned, and extended by the legislature. Regarding it, I will merely say that if a particular Act of Parliament requires that an application founded upon it should be made

Powers of one Judge not consti. tuting a Court.

Chambers.

(r) Commencing on Good Friday and terminating on Easter Tuesday.

(s) Commencing on the Saturday before Whitsunday and terminating on the Tuesday after Whitsunday.

( $t$ ) Order lxiii., Rules $1,4,5$.

(u) Id. R. 11 (see $36 \& 37$ Vict. c.
66, s. 28).

(x) See Rules 12, 15.

(y) $36 \& 37$ Vict. c. 66 , s. 39 ; Id. s. 16 .

(z) As to the origin of which see Wilmot's Opinions, p. 264. 
to the Court in banc, the jurisdiction of a Judge at Chambers is wholly excluded. If a distinction is specially made between the authority and powers to be exercised in banc, and those confided to a Judge at Chambers, provided the intention of the legislature be clearly expressed, no difficulty can occur. If some special power or authority is given to " the Courts" by statute, the presumption will be, that it was intended to be exercised as the Courts usually exercise their jurisdiction; so that it may fall within the province of a Judge at Chambers to put in force the provisions of the Act in question (a).

An order made by a Judge at Chambers may, except in certain cases $(b)$, be set aside or discharged by a Divisional Court; or by a Judge sitting in Court, in the Chancery Division $(c)$; with an appeal to the Court of Appeal.

The appeal from the Judge's decision must be made. by motion within eight days after the decisions appealed against $(d)$.

Special provisions have recently been made for the dispatch of commercial business. Commercial causes which include causes arising out of the ordinary transactions of merchants and traders, are within such provisions $(e)$.

The Masters.

Besides the Judges, there were, before the passing of the Judicature Acts, attached to each of the three Courts at Westminster five Masters, who performed many of the less onerous duties which once devolved upon the Judges $(f)$. The Masters formerly attached to the Courts of Queen's Bench, Common Pleas, or Exchequer respectively, are now attached to the Queen's Bench Division of the High Court of Justice $(g)$. And by a more recent statute $(h)$ there has

(a) See per Parke, B., Smeeton v. Collier, 5 D. \& L. 189, 190.

(b) See $36 \& 37$ Vict. c. 66 , s. 49. See also the Judicature (Procedure) Act, 1894 (57 \& 58 Vict. c. 16), s. 1.

(c) Id. s. 50 ; Order liv., R. 23.

(d) Order liv., R. 23.

(e) See W. N. 1895 (Appx, of O. \&
R.), p. 2 ; cf Baerlein v. Chartered Mercantile Bank, (1895) 2 Ch. 488, C.A. ; Barry v. Pcruvian Corporation, (1896) 1 Q. B. 208, C. A.

(f) See $30 \& 31$ Vict. c. 68 (repealed $44 \& 45$ Vict. c. 59, 8. 3 ).

(g) Order lx., R. 1.

(h) 42 \& 43 Vict. c. 78 , ss. $4-7$. 
been established " a central office of the Supreme Court of Judicature," in and with which have been "concentrated and amalgamated" various offices, including those of the Masters of the Queen's Bench, Common Pleas, and Exchequer Division. This central office is placed under the control and superintendence of the Masters henceforth to be designated "Masters of the Supreme Court of Judicature," and the business performed there is distributed among the various officials in such manner as directed by rules of Court $(i)$.

Further, it is enacted $(j)$ that " the several officers of the central office shall be interchangeable one with another, and shall be capable of performing and liable to perform the duties of each other in any department of the office, and generally shall perform such duties and have such powers in relation to the business of the Supreme Court as may be directed by rules of Court."

A Master transacts all such business, and exercises such authority and jurisdiction in respect of the same as may be transacted or exercised by a Judge at Chambers, except in respect of certain matters $(k)$.

Besides the above duties the Masters tax solicitors' bills of costs generally in common law matters, examine affidavits, and investigate matters specially referred to them. The Masters have, moreover, the custody of the records, and are often appealed to as being, in some sort, the depositaries of the rules of practice of the Courts. They have likewise duties to discharge, formerly connected with the branches of exclusive jurisdiction of each Court.

An application at Chambers, whether to a Judge or to a Master, is made in a summary way ex parte or by summons;

(i) S. 12 (1); see Order lxi.

(j) S. $12(2)$.

(k) Order liv., R. 12 . See also Order liv., R. $12 \mathrm{~A}$, by which a
Master may exercise all the jurisdiction and powers conferred upon the Court or a Judge by the Arbitration Act, 1889. 
should any matter, however, appear to the Master proper for the decision of a Judge, such matter may be referred to the Judge accordingly, and the Judge may either dispose of the same or refer it back to the Master with such directions as he may think fit. Any person affected by an order or decision of a Master may appeal therefrom to a Judge at Chambers; such appeal being by indorsement upon the summons by the Master, or by notice in writing, within four days after the decision complained of, or such further time as may be allowed by a Judge or Master. An appeal from a Master's decision will be no stay of proceedings unless so ordered by a Judge or Master (l).

With a view to facilitating "the prosecution in country districts of such proceedings as may be more speedily, cheaply, and conveniently carried on therein," District Registrars have been appointed by Order in Council for districts thereby defined, from which writs of summons for the commencement of actions in the High Court of Justice may be issued, and in which various proceedings incident to an action may be taken and recorded. One registrar, or two joint registrars, may thus be appointed, and every registrar for a district is deemed to be an officer of the Supreme Court, and is subject accordingly to its jurisdiction $(m)$. A district registrar may now, subject to certain regulations, from time to time appoint a deputy $(n)$.

In each district registry is used a seal impressed on every writ and other document issued out of or filed in it, and every such writ and document, or copy thereof, purporting to be sealed with the seal of such registry, is receivable in evidence without further proof thereof $(o)$.

District registrars are empowered to administer oaths

(l) Order liv., R. 21, 22.

(m) 36 \& 37 Tict. c. 66 , s. 60 , as amended by 38 \& 39 Vict. c. 77 , s. 13. In the abore sections the persons qualified to be district registrars are specified.

(n) $39 \& 40$ Vict. c. 59 , s. 22.

(o) 36 \& 37 Vict. c. 66 , s. 61 . 
and perform such other duties in respect of proceedings pending in the High Court of Justice or in the Court of Appeal as may be assigned to them $(p)$.

The duties devolving on the district registrars are similar to those of a Master, but only extend to actions proceeding in the district registry $(q)$. An application to a district registrar must be made in the same manner as an application at Chambers. Should any matter appear to the district registrar proper for the decision of a Judge, the registrar may refer the same to a Judge accordingly, who will either dispose of it or refer it back to the registrar with fitting directions. And any person affected by an order or decision of the registrar may appeal therefrom to a Judge; such appeal being by indorsement upon the summons, or by notice in writing, within six days after the party complaining has notice of the order, finding, or decision complained of, or such further time as may be allowed $(r)$.

District registrars are subject to the orders and directions of the Court or a Judge as fully as any other officer of the Court.

Excepting in the case of appeals, applications at Applications Chambers, or before the district registrars, are made either -how made. ex parte or by summons supported, if necessary, by affidavit $(s)$. The summons must be served two clear days before the return thereof, unless in any case it be otherwise ordered, or unless it be a summons for time, in which last case it may be served on the day previous to its return $(t)$. An originating summons, to which an appearance is required, directs the person on whom it is served to appear thereto within eight days after service (u). After such appearance the time for attendance is fixed by notice under
(p) $36 \& 37$ Vict. c. 66, s. 62.
(a) Order xxxr., R. 5, 5A, 6.
(s) Order lir., R. I.
(r) Id. R. 9.
(t) Order lir., R. 4E.
(e) Id., R. 4 B. 
seal, which notice must be served four clear days before the return day $(x)$.

Sect. II. Ordinary Jurisdiction of the County Court.

As falling within the ordinary jurisdiction of the County Court $(y)$ will here principally be noticed breach of contract, ejectment, and tort. I may, however, by way of preface, observe, that although, as regards these, the jurisdiction of the Court is limited, yet with respect to all actions assigned to the Queen's Bench Division of the High Court, if both parties "agree by a memorandum signed by them, or their respective solicitors," that any County Court named therein shall have power to try such action, such County Court will thus have jurisdiction to try the same $(z)$.

Where an action is brought in any other than the High Court which could have been brought in a County Court, and the verdict recovered is for a less sum than 10l., the plaintiff will not be entitled to recover from the defendant a greater amount of costs than he would have been allowed if the action had been brought in the County Court (a). Also, where an action is commenced in the High Court which might have been brought in the County Court, the consequence may be its compulsory removal into such latter Court, or loss of costs by the plaintiff (b).

And further, if an action or matter is commenced in a County Court over which that Court has no jurisdiction, the Judge must, unless the parties consent to the Court having jurisdiction, "order it to be struck out," and has power to "award costs in the same manner, to the same extent, and recoverable in the same manner, as if the Court

(x) Order liv., R. $4 \mathrm{D}$.

(y) The County Court here spoken of, which is entirely a creature of the statute law, must not, of course, be confounded with the sheriff's court, which represeuts the old County Court of the Anglo-Saxon and Normau times, ante, p. 23.

(z) The County Courts Act, 1858

(51. \& 52 Vict. c. 43), s. 64.

(a) 51 \& 52 Vict. c. 43 , s. $11 \%$.

(b) Id. ss. 65, 66, 116 : Order $\mathrm{l} x$ r., R. 12 . 
had jurisdiction therein, and the plaintiff had not appeared, or had appeared and failed to prove his demand or complaint" $(c)$. Thus careful has the legislature been to throw obstacles in the way of unnecessarily costly litigation, and to induce or compel a suitor to seek redress in the local tribunal whensoever it can properly be afforded there.

The County Court has jurisdiction to entertain all personal actions where the "debt, demand, or damage," Jurisdiction in contract. does not exceed the sum of $50 l$., whether "on balance of account or otherwise," or "after an admitted set-off" (d). This Court may accordingly take cognizance of an action upon a bill of exchange or promissory note (e), or for the recovery of goods in specie $(f)$ within the value of $50 l .(g)$; though not of an action upon a judgment recovered in a superior Court $(h)$; nor where the claim is for beer consumed on the premises where sold or supplied, or money lent for obtaining the same $(i)$.

But what, it may be asked, is the precise meaning of the expression "balance of account?" The answer is, that these words are intended to apply to accounts which have been adjusted, settled, ascertained, or balanced by the parties, or to any debt which has been reduced within the prescribed limit of 50l. by payment, or something equivalent thereto. Suppose, for instance, a claim to be preferred in the County Court for a sum below 50l., and suppose it appears that the debt originally due from the defendant exceeded that amount, but has been reduced below it by payment before action brought, the defendant will not, under such circumstances, be entitled to say that the case

(c) $51 \& 52$ Vict. c. 43, s. 114.

(d) Id. ss. 56, 57. See Hubbard v. Goodley, 25 Q. B. D. 156. Cf. however, Lorejoy v. Cole, (1894) Q. B. 861.

(e) Waters r. Handley, 6 D. \& L. 88 ; Nind v. Rhodes, 5 D. \& L. 621. See also Lowley r. Rossi, 12 Q. B. 952 ; $18 \& 19$ Vict. c. 67 . The operation of this statute in County Courts is preserved by $46 \& 47$ Vict. c. 49 , s. 7 . 309

(g) Leader v. Rhys, 10 C. B. N. S., 369 .

(h) 51 \& 52 Vict. c. 43 , s. 63.

(i) Id. s. 182. 
is without the jurisdiction of the County Court $(k)$. So, if anything other than money be received in reduction of a debt by agreement of the parties, that will be equivalent to payment, so as to bring the case within the jurisdiction of the County Court $(l)$, the question whether it was so received or not, being determinable from the evidence pro and con. which may be adduced.

A set-off admitted by the defendant before action will bring a claim within the jurisdiction of the County Court $(m)$. But clearly a case will not be cognisable by the County Court in which a claim exceeding 50l. is reduced by a plea of set-off within that amount; for if it were so, the Court might be called upon to investigate tro several claims, each of them far exceeding the limits of its statutory jurisdiction $(n)$.

Another point to be here noticed is, that "it shall not be lawful for any plaintiff to divide any cause of action, for the purpose of bringing two or more actions" in the County Court. But a plaintiff having a cause of action for more than 50l., may, if so minded, abandon the excess, and recover to an amount not exceeding the 50l. $(0)$.

As explanatory of the above section (which, in common parlance, is said to forbid the "splitting of a demand,") Grimbly v. Aykroyd ( $p$ ) should be consulted. There, in delivering judgment the Court of Exchequer drew a distinc-

(k) See per Maule, J., Woodhams r. Necman, 7 C. B. 654 ; per Parke, B., Turner v. Berry, 5 Exch. 858.

(l) See Hooper r. Stephens, 4 Ad. \& E. Il; Hills v. Mesnard, 10 Q. B. 266.

(m) 51 \& 52 Vict. c. 43, s. $5 \pi$; II alcsby v. Goulston, I. R. 1 C. P'. 567 ; Hubbard r. Goodley, 25 Q. B. D. 156 ; ef. also Locejoy v. Cole, (1894) 2 Q. B. 861. As to the distinction between "payment" and "set-off," see Thomas r. Cross, 7 Exch. 728 .

(n) Woodlums r. Texman, 7 C. B. 654; Besuick r. Capper; Id. 669 ;
Kimpton r. Willey, 1 L. M. \& P. 280.

(o) This abandonment of the excess must be made upon the particulars of demand. The County Court Rules, 1889 , Order vi., R. $1 \mathrm{a}, 51$ \& 52 Vict. c. 43 , s. 81 .

(p) 1 Exch. 479; Judgm., Hood r. Ierry, 3 Exch. 445; Judgm., Bonscy v. Wordsuorth, 18 C. B. 334-5; Copeman v. Hart, 14 C. B., X. S., 731, 735; per Erle, J., Jones v. Pritchard, 6 D. \& L. 530. See also Box r. Green, 9 Exch. 503. 
tion between a claim or demand comprising several distinct and independent matters, which may be recovered by separate suits in the County Court ( $q$ ), and a running account consisting, indeed, of various items, but which is meant to constitute one entire debt. Where in the case of a tradesman's bill, they remarked, one item is connected with another in this sense, that the dealing is not intended to terminate with one contract, but to be continuous, so that one item, if not paid, shall be united with another and form one entire demand, the plaintiff cannot split these items into separate causes of action, but must sue for the aggregate amount $(r)$.

Let us suppose a case somewhat analogous to that just considered, but in reality to be decided on other grounds :that a banker receives a sum of money, belonging to different persons severally, from their agent, who is charged to divide it amongst them in distinct proportions; let us further suppose that the aggregate sum paid into the bank exceeds $50 l$., but that the several undivided portions of which it is composed fall respectively within that limit; it is, of course, under the circumstances stated, clear, that an action would not lie in the County Court at suit of the agent for the entire deposit paid into the bank, inasmuch as that would be without the jurisdiction of the inferior tribunal; but it is also clear, that an action could not be maintained there for his several share by any one of the individuals beneficially interested in the fund, upon this ground, that the original contract was not with him, but was between the banker and the agent $(s)$.

Again, it is a common practice for farmers and graziers to send their cattle to a particular salesman, who perhaps sells to one individual a lot of beasts belonging to different

(q) See Brunstill v. Powell, 1 L. M. \& P. 550; Kimpton v. Willey, Id. 280 ; Wiekham v. Lee, 12 Q. B. 521.

(r) See per Jervis, C. J., Bonsey v.
Wordsworth, 18 C. B. 328-9. 447.

(s) See Pinto v. Santos, 5 Taunt. 
owners. Now, here the contract of sale is between the salesman and the purchaser, so that each separate owner could not sue the latter for the price of his cattle $(t)$.

In the event of his abandoning the excess, howerer, " the judgment of the Court" upon the plaint "shall be in full discharge of all demands in respect of " the "cause of action," and "entry of the judgment shall be made accordingly;" the consequence of abandoning the excess of his demand over the 50l. will therefore be to preclude the plaintiff from afterwards recovering it by action, and, should the defendant have any ground of set-off available, such abandonment may be attended with additional inconvenience and prejudice. This results from the fact that a plaintiff cannot compel his adversary to plead a set-off; and should he abandon the excess of his demand, so as to bring his claim within the jurisdiction of the County Court, and then be met by a set-off, he might of course be altogether defeated in his action; and, at all events, the claimant would find himself exposed to the risk of having his demand reduced, not merely by the amount abandoned, but also by the amount of the set-off. If, on the other hand, the defendant does not plead his set-off to the plaintiff's reduced demand, but sues for it in a cross action, then the plaintiff will be debarred in that action from setting off any of the abandoned portion of his original claim by the express words of the 81st section of the Act $(u)$.

In practice, therefore, a plaintiff will do well to avail himself of the power of abandonment above alluded to, only where the excess abandoned is unimportant in amount, or in cases where no set-off can be established, and where the recovery of any part of his demand might be jeopardised by delay.

At p. 66 will be found stated the consequence, as regards

(t) Per Martin, B., Walshe v. Provan, 8 Exch. 852.

(ii) See per Maule, J., Woudhams r. Sewman, 7 C. B. 666-i. 
costs, of suing for breach of contract in a superior Court, where a County Court might have entertained the action. Other consequences may also follow from so doing. For where in an action of contract there brought, "the claim indorsed on the writ does not exceed 100l., or where such claim, though it originally exceeded 100l., is reduced by payment $(x)$, an admitted set-off, or otherwise, to a sum not exceeding 100l.," it is competent for either party, if the whole or part of the plaintiff's demand be contested, to apply to a Judge of the High Court at Chambers to order Remitting contract to County such action to be tried in any Court in which it might have been commenced $(y)$, or in any Court convenient thereto, and the Judge shall, unless there be good cause to the contrary, order that the action be there tried accordingly $(z)$.

Although the County Court, as originally constituted, had a jurisdiction limited in amount over "all pleas of personal Jurisdiction in tort. actions," and consequently in tort as well as in contract, the following cases were, nevertheless, prior to the enactment $30 \& 31$ Vict. c. 142 (a) wholly, or save by consent of parties excluded from the jurisdiction of that Court $(b)$ :-any action of ejectment; or in which the title to a corporeal or incor-

(x) "The payment, which is to have the effect of reducing the original claim below 50l." (the limit previous to the County Court Act, 1888), "must hare been made before action:" per Cur. Osborne ₹. Homburg, 1 Ex. D. 48 ; approved in Foster r. Usheruood, 3 Ex. D. 1. See Percival v. Pedley, 18 Q. B. D. 635 (see this case, $H u b$ bard v. Goodley, 25 Q. B. D. 856 , and Lovejoy v. Cole, (1894) 2 Q. B. 861); cf. also Hodgson v. Bell, 24 Q. B. D. 525. 513.

(y) Cf. Curtis v. Stovin, 22 Q. B. D.

(z) 51 \& 52 Vict. c. 43 , s. 65 . See Blades v. Lawrence, L. R. 9 Q. B. 374.

Where the claim indorsed on the writ of summons was for " $50 l$. and interest at the rate of $5 l$. per cent. per annum from the date hereof until payment or judgment." the claim was held to exceed $50 \mathrm{l}$. (the limit previously to C. C. A. 1888): Insley v. Junes, 4 Ex. D. 16. If the claim be for unliquidated damages the order cannot be made, Knight v. Abbott, 10 Q. B. D. 11. See also Basset v. Long, (1894) 2 Q. B. 332. As to unliquidated counterclaim, see Guilford v. Lambeth, (1895) 1 Q. B. 92, C. A., aftirming, (1894) 2 Q. B. 832. An action for a sum not exceeding 100l., brought in the High Court on a contract, to which a counterclaim for unliquidated damages is pleaded, can be ordered to be tried in a County Court (vide s. c.).

(a) The County Courts Act, 1867 .

(b) $9 \& 10$ Vict. c. 95 , s. $58 ; 19 \&$ 20 Vict. 108, s. 23. 
poreal (c) hereditament, or to any toll $(d)$, fair, market, or franchise (e) might be in question; any action in which the validity $(f)$ of a devise, bequest, or limitation under a will or settlement might be disputed; any action for a malicious prosecution $(g)$, or for libel, slander, seduction, or breach of promise of marriage. A great extension of jurisdiction was, however, by the statute above specified, given to the County Courts in respect of some of the matters above enumerated, and a further extension by the County Courts Act, 1888.

Ejectment and questions of title.

In the first place an action of ejectment now lies in the County Court, where neither the value of the lands, tenements or hereditaments claimed, nor the rent payable in respect thereof, exceeds the sum of $50 l$. yearly $(h)$.

Secondly, the County Court has now jurisdiction to try any action in which the title to any corporeal or incorporeal hereditaments may come in question where neither the value of the lands, tenements, or hereditaments in dispute, nor the rent payable in respect thereof, shall exceed the sum of $50 l$. by the year, or in case of an easement or licence where neither the value nor reserved rent of the lands, tenements, or hereditaments in respect of which the easement or licence is claimed, or on, through, over, or under which such easement or licence is claimed, shall exceed such sum yearly (i).

(c) See Stephenson r. Raine, 2 E. \& B. 744; Davis v. Watton, 8 Exch. 153; Baddeley v. Denton, 4 Exch. 508 ; Steuart v. Jones, 1 E. \& B. 22.

(d) Reg. v. Everett, 1 E. \& B. 273 ; Hunt v. Great Northern R. C., 2 L. M. \& P. $268 ; S . C ., 10$ C. B. 900. 153.

(e) See Daris v. Walton, 8 Exch.

(f) The County Court Judge has jurisdiction, however, in regard to a claim for a legacy, when its "validity" is not disputed, post, p. 67. See also Gibbon r. Gibbon, 13 C. B. 205; Hewston v. Phillips, 11 Exch. 699; Winch v. Winch, 13 C. B. 128; Longbottom v. Longbottom, 8 Exch. 203; Fuller v. Maekay, 2 E. \& B. 573. (g) Jones r. Currey, 2 L. M. \& P. 474; Hunt $\vee$. North Staffordshire R. C., 2 H. \& N. 451 ; Austin v. Douling, L. R. 5 C. P. 534. See Chicers v. Savage, 5 E. \& B. 697.

(h) 51 \& 52 Vict. c. 43 , s. 59 ; Brown r. Cocking, L. R. 3 Q. B. 672: Elston v. Rose, L. R. 4 Q. B. 4. See Symons v. Rees, I Ex. D. 416.

(i) 51 \& 52 Vict. c. 43 , s. 60 . "Easement" does not apply to the easement of a public right of way. "I think it applies only where there is a dominant aud a servient tenement, the value of the reserved rent of either of which does not exceed the sum of $50 l$. br the rear"; per Smith, J., Hawkins v. Rutter, (1891) 2 Q. B. 
In connection with cases in which the "title" to land is in question before the County Court, two questions of considerable interest to the practitioner demand consideration :1. How is the Judge of that Court to act when the title to land is alleged to be or is in question? 2. When may it properly be said to be so ?

1. The plaintiff may possibly, in his particulars, so far exhibit the true substance and nature of his claim, as altogether to exclude it from the cognisance of the Court to which he would refer it, and here of course no practical difficulty as to the mode of dealing with the claim can be felt $(k)$. Again, the objection to the jurisdiction, founded on the subject-matter in dispute, though not appearing on the particulars or summons, may be raised by the defendant at the hearing; and, if so, the duty of the Judge will be, in the first instance, to inquire into the case, with a view to satisfying himself whether the title does really come in question or does not. Should he think that it does come in question, he will dismiss the summons; should he think that it does not come in question, he will hear and adjudicate upon the claim : the remedy open to the party dissatisfied with the decision of the Judge being by application to the superior Court, in the former case, for a mandamus, and, in the latter, for a prohibition, to issue to the County Court $(l)$. It is not, however, absolutely incumbent on a defendant sued in a County Court, who knows that the title to land must come in question, to wait until the hearing, in order then to put forward the objection. It is quite open to him, if so minded, upon being served with process out of the inferior Court, to apply at once for a prohibition to

668, at p. 673. If a County Court takes upon itself the cognizance of any action orer which it has not jurisdiction, the proper remedy is a writ of prohibition. As to a writ of prohibition, see post, p. 221.

(k) See Sewell v. Jones, 1 L. M. \&

\section{P. 525 .}

(l) Latham v. Spedding, 2 I. M. \& P. 378; Judgm., Thompson v. Ingham, 1 L. M. \& P. 219 ; cited per Watson, B., Re Baker, 2 H. \& N. 234 ; Stephenson v. Raine, 2 E. \& B. 744 ; Mountnoy v. Collier, 1 E. \& B. 630. 
restrain the County Court Judge from proceeding further with the case $(m)$, the application being supported by proper affidavits.

2. When or under what circumstances may the title to a corporeal hereditament properly be said to be in question $(n)$ ? It is clear that a mere colourable pretence of title, or a claim to what can have no valid existence in law, will not suffice to oust the jurisdiction of the County Court ; the title must be brought bona fide in question $(o)$. Thus, if a tenant be sued for use and occupation, and rely on the fact, that his landlord's title has expired during the tenancy, evidence of such fact will oust the jurisdiction of the County Court $(p)$. So, if a party were charged in a County Court with a liability arising by reason of his ownership of land, and he disclaimed the ownership, a question of title would be raised, and the jurisdiction of the Court would, in the absence of any enactment overriding the County Court Act, be ousted $(q)$.

Where in any action in the County Court " the title to any corporeal or incorporeal hereditament, or to any toll, fair, market, or franchise $(r)$, shall incidentally come in question, the Judge shall have power to decide the claim which it is the immediate object of the action to enforce, if both parties at the hearing shall consent, in any writing signed by them, or their solicitors, to the Judge having such power : but the judgment of the Court shall not be evidence of title between the parties or their privies in any

(in) Per Wightman, J., Sewell v. Jones, 1 L. M. \& P. 525. See Wadsuorth v. Queen of Spain, 17 Q. B. 171.

(n) See Mourarth v. Sutcliffe, (1895) 2 Q. B. 358 , C. A.

(o) Lloyd v. Jones, 6 C. B. 81.

(p) Mountnoy v. Collier, 1 E. \& B. 630. See Kerkin v. Kerkin, 3 E. \& B. 399 ; Chew v. Holroyd, 1 Exch. 249 ; Emery v. Barnett, 27 L. J., C. P. 216 ; S. C., 4 C. B., N. S. 423. (a) Reg. v. Harden, 2 E. \& B. 188.
But the County Court has cognisance of replevin, even where the title to land does come in question: Reg. v. Raines, 1 E. \& B. 855; Re Fordham $\mathrm{x}$. Akers, 4 B. \& S. 578. See also Earl of Harrington v. Ransay, 8 Exch. 879 , and 2 E. \& B. 669. (See, howerer, s. 138 of the C. C. A. 1888.)

(r) A patent is a franchise, ef. Reg. v. Inalifax C. C., (1891) 2 Q. B. 263, affirming $S . C .,(1891) 1$ Q. B. 793. 
other action or matter in that Court, or in any other Court; and such consent shall not prejudice or affect any right of appeal of either of the parties to such first-mentioned action" (s).

Thirdly, any person against whom an action of tort is brought in the High Court may make an affidavit $(t)$ that the plaintiff has no visible means $(u)$ of paying the costs of Remitting
action of tort to County the defendant should a verdict be not found for the plaintiff, and thereupon a Judge of the High Court may make an order that-unless the plaintiff shall, within a time to be therein mentioned, give full security for the defendant's costs to the satisfaction of one of the Masters of the said Court, or satisfy a Judge of the High Court that he has a cause of action fit to be prosecuted in the superior Court,all proceedings in the action shall be stayed; or in the event of the plaintiff being unable or unwilling to give such security, or failing to satisfy a Judge as aforesaid, that the cause be remitted for trial before a County Court to be therein named; and thereupon the plaintiff shall lodge the original writ and the order with the Registrar of such County Court, who will appoint a day for the trial of the action, notice whereof shall be sent by post or otherwise by the Registrar to both parties or their solicitors, and the action and all proceedings therein shall be tried and taken in such Court as if the action had originally been commenced therein; and the costs of the parties in respect of the proceedings subsequent to the order of the Judge of the High Court shall be allowed according to the scale of costs for the time being in use in the County Courts, and the costs of the order and all proceedings previously thereto shall be allowed according to the scale of costs for the time being in use in the Supreme Court $(x)$.

(s) 51 \& 52 Vict. c. 43 , s. 61.

(t) Reg. v. Stonor, 50 L. T. 97. 835 .

(u) Lea v. Parker, 13 Q. B. D.

B.C.L. (x) $51 \& 52$ Vict. c. 43 , s. 66 . See Bowles v. Drake, 8 Q. B. D. 325 ; R. v. Bayley, Mrason r. Aird, 8 Q. B. D. 411 . 
We have shown in the preceding pages that the restrictions formerly imposed upon the jurisdiction of the County Court in actions of tort have been considerably relaxed, and need only further observe, as to this part of our subject, that the jurisdiction of the County Court has been extended to all cases of replevin (which lies in general where goods have been wrongfully distrained), and is no longer confined, as it formerly was, by certain provisions of the stat. $19 \& 20$ Vict. c. $108(y)$, to the case of goods distrained for rent or damage feasant.

Costs. The consequence of suing in a superior Court for a debt, damage, or demand recoverable in the County Court may be serious, so far as regards the right to costs of the plaintiff if successful, for should the plaintiff recover $(z)$ a sum less than 20l. if the action is founded on contract, or 10l. if founded on tort $(a)$, whether by verdict, judgment by default, or otherwise, he will not be entitled to any costs of suit unless the Judge certify on the record that there was sufficient reason for bringing such action in such superior Court, or unless the High Court or a Judge thereof at Chambers allow such costs. If he recovers $20 l$. or upwards, but less than 50l, in an action founded on contract, or $10 l$. or upwards, but less than $20 l$, in an action of tort, subject to the Judge certifying as above or the costs being allowed as above mentioned, he will be allowed only such costs as he would have been entitled to had he commenced lis action in the County Court. However, in an action founded on contract, if the plaintiff, within 21 days after service of the writ or such time as may be ordered by the Court or a Judge, obtains an order under Order XIV. of the Rules of the Supreme Court to enter judgment for 20l. or more, he will be entitled to costs according to the High Court

(y) Sects. 63 et seq. and cf. $23 \& 24$ Vict. c. $126,8.22 ; 51 \& 52$ Vict. c. 43 , s. 134 .

(z) See Corcell r. The Ammam Co.,
6 B. \& S. 333.

(a) See Sampson r. Mackay, L. R. 4 Q. B. 643. 
scale $(b)$. The mode of distinguishing between an action of contract and an action of tort, in reference to the above clause of the enactment cited, may be learned from the cases infra (c). The rules of the Supreme Court, 1883, provide that " in actions founded on contract in which the plaintiff recovers by judgment or otherwise, a sum (exclusive of costs) not exceeding $50 l$., he shall be entitled to no more costs than he would have been entitled to, had he brought his action in a County Court, unless the Court or a Judge otherwise orders $(d)$.

Besides the matters already noticed as falling within the cognisance of the County Court, that Court has some peculiar branches of jurisdiction, to which the briefest reference must suffice. Thus, the County Court may inquire into any demand not exceeding in amount 50l., in respect of "the whole or part of the unliquidated balance of a partnership account," or "of a distributive share" of personal estate "under an intestacy," or " of any legacy under a will" (e). These Courts have also

(b) 51 \& 52 Vict. c. 43 , s. 116. Balmain v. Lickfold, L. R. 10 C. P. 203, 208; Flitters v. Allfiey, Id. 29 ; Holborow v. Jones, 1 L. R. 4 C. P. 14 ; Ings v. London and South Western R. C., Id. 17 ; Gray v. West, L. R., 4 Q. B. 175 ; Forshaw v. De Wette, L. R. 6 Ex. 200 ; Pellas v. Breslauer, L. R. 6 Q. B. 438 . See per Cotton, L. J., Galatti v. Wakefield, 4 Ex. D. 251.

Under the above section the Judge is justified in declining to certify for costs, if he is reasonably satisfied that the action should not have been brought at all-though his discretion in this respect is open to review: Strachey $\mathrm{v}$. Lord Osborne, L. R. 10 C. P. 92.

(c) Pontifex v. Midland R. C., 3 Q. B. D. 23; distinguished in Fleming v. Manchester, Sheffeld and Lincolnshire R. C., 4 Q. B. D. 81, 84; Bryant v. Herbert, 3 C. P. D. 389 ; Baylis v. Lintott, L. R. 8 C. P. 345 (distinguishiug Tattan v. Gt. Western R. C., 2 E. \& E. 844); Legge $\mathbf{\text { v. }}$
Tucker, 1 H. \& N. 500 ; Morgan v. Ravey, 6 Id. 265; per Tindal, C. J., Boorman v. Brown, 3 Q. B. 516.

An action in respect of personal injuries caused by the negligence or misfeasance of a servant of a Railway Co., is an action for tort even though the plaintiff had taken a ticket. If the action is brought in the High Court and the plaintiff recovers to the amount of $20 l$., he is entitled to his full costs of action, Taylor r. MLanchester, Sheffield and Lincolnshire R. C., (1895) 1 Q. B. 134, C. A. See also Kelly v. Met. R. C., (1895) \& Q. B. 944, C. A.

(d) Ord. Ixv., R. 12. Where exactly $50 l$. was recovered and no special order or certificate obtained only County Court costs were allowed, Millington v. Harwood, (1892) 2 Q. B. 166, cf. the words "not exceeding" with the words "less than" in s. 116 of the C. C. A., 1888.

(e) $51 \& 52$ Vict. c. 43 , s. 58.
Peculiar

jurisdiction. 
acquired special jurisdiction by statute in the cases referred to below $(f)$.

The County Court, besides its jurisdiction by action at law, has had conferred upon it an important Equitable, Admiralty, and Bankruptcy jurisdiction, and may be called on to perform duties under numerous Acts of Parliament, which cannot here be noticed $(g)$. It is also, in some cases, invested with power to afford redress of an extraordinary kind, as on interpleader $(h)$, or where the possession of any house, land, or other corporeal hereditament is unlawfully withheld by the tenant from his landlord (i) ; cases requiring the exercise of these peculiar powers do not, however, fall properly within the scope or design of the present chapter, although more specific allusion to some of them will be made in the Fifth Chapter of this Book, which treats generally of Extraordinary Remedies.

Counterclaim.

Lastly, the County Court is empowered to grant in a proceeding before it such relief as might in the like case be given by the High Court of Justice, and to give the same effect to every ground of defence or counter-claim, equitable or legal, as might there be given $(k)$, and where in a proceeding before it any defence or counter-claim of the defendant involves matter beyond the jurisdiction of the Court, the competence of the Court to dispose of the whole

(f) Rivers Pollution Act, 1876, 39 $\& 40$ Vict. c. 75 , ss. 10,11 ; The Telegraph Act, 1878,41 \& 42 Vict. c. 76, s. 4 ; Employers' Liability Act, $1880,43 \& 44$ Vict. c. 42 , s. 6 ; Alkali, \&c., Works Regulation Act, 1881, $44 \& 45$ Vict. c. 37 , s. 22 (as to which see also the Act of $1892,55 \& 56$ Vict. c. 30$)$; Tithe Act, 1891,54 Vict. c. 8 ; Industrial and Provident Societies Act, $1893,56 \& 57$ Vict. c. 39, s. 23.

(g) As to these branches of jurisdiction the reader is referred to works specially dealing with this subject.

(h) See, for instance, 51 \& 52 Vict. c. 43, s. 157 .

(i) Ib. s. 138.

(k) $36 \& 37$ Vict. c. 66, s. 89 .
The rules of law enacted and declared by the Judicature Acts are applied in the County Court. Id. s. 91.

In a recent case, Foster v. Reeves, 1892,2 Q. B. 255 , the C. $A$. held that an action which, by reason of the Judicature Acts, the plaintiff would have been able to maintain in the High Court could not succeed in the County Court, because the Judge had no juris. diction to decree specific performance of an agreement affecting property whose value exceeded $500 l$., and consequently could not apply the equitable doctrine of Walsh v. Lonsdale (cf. p. 498). Neither 8. 89 nor s. 91 was cited. 
matter in controversy between the parties, so far as relates to the demand of the plaintiff and the defence thereto, will not be affected, but no relief exceeding that which the Court has jurisdiction to administer shall be given to the defendant upon any such counter-claim. In such case the High Court, or any Division or Judge thereof, may order that the whole proceeding be transferred from the County Court to the High Court, to be there continued and prosecuted $(l)$. The full effect of the section last referred to and the one preceding it was carefully considered in the case of Davis v. Flagstaff Silver Mining Co. $(m)$, the Court of Appeal holding that, under those sections, inferior Courts may give effect to counter-claims relating to matters beyond the jurisdiction of the Court by way of defence to and to the extent of the plaintiff's claim, but that they have no power to award to a defendant in respect of such counterclaim damages in excess of the claim. But it would appear, from the decision of the Court of Appeal in Guilford v. Lambeth $(n)$, that where an action is sent down to the County Court under s. 65 of the County Courts Act, 1888, that the County Court Judge has jurisdiction to deal with a counter-claim for unliquidated damages.

(l) $36 \& 37$ Vict. c. 66 , s. 90 .

(m) 3 C. P. D. 228.

(n) (1895) 1 Q. B. 92, affirming S. C. (1894) 2 Q. B. 832 . 


\section{CHAPTER III.}

THE NATURE OF LEGAL RIGHTS ENFORCEABLE BY ACTION.

IN this Chapter I shall inquire generally $(a)$ as to the nature of that right which gives a remedy at law. To prevent misconception, however, during the progress of this inquiry, I would at the outset observe, that the remedy obtainable in a Court of law is in kind either ordinary or extraordinary - it may be by action, or it may be by mandamus, by summary application to the Court, or in various other ways, which will be specified in the concluding Chapter of this Book. At present, however, I shall restrict myself to considering under what circumstances the remedy by action is available at law to an injured party, and what may be the true definition and meaning of the term "right of action" in connection with legal science.

Right of actionwhat.

A "right of action" was, in the Roman law, defined to be jus persequendi in judicio quod sibi debetur (b),-it exists, according to our common law, wherever a legal claim to damages, or to the recovery of some specific thing, has accrued; the action itself being the formal and prescribed mode of procedure, whereby the right is vindicated or

(a) The inquiry as to the nature of legal rights and remedies is here pursued generally. It will be resumed hereafter as to Contracts, in Bk. II. and as to Torts in Bk. III.

(b) I. 4, 6, pr., adopted in Co. Litt. 285 a. In the Roman or Civil Law,
" the word actio was used originalls to denote the particular form in which certain legal proceedings were carried on; from this it was transferred to signify the legal remedy by which every person might enforce his right." Phillimore, Introd. to Rom. L., p. 61. 
enforced. It follows, from the definition just given, that, before commencing an action in any. given case, the practitioner must consider whether any right of action in truth exists.

Now, it is not every substantial wrong, still less every imaginary grievance, which affords a right of action for redress. Nor is it true, that for every kind of damage for loss occasioned by the act of another, a remedy is given by the law. It not unfrequently happens, that damage, palpable and undeniable though it be, is, in technical phraseology, damnum sine injuriâ, that is, damage unaccompanied by any tortious or wrongful act whereof cognizance can be taken in a Court of Justice.

Here, accordingly, it becomes necessary to define respectively the words damnum and injuria, or, at all events, to state in what precise sense, and with what signification, it is in this Volume proposed to use them.

The word injuria will be employed as signifying a "legal Injuria. wrong," that is a wrong cognisable or recognised as such by the law $(c)$. The word damnum will be used as signifying "damage," not necessarily pecuniary or perceptible, but appreciable, and capable in legal contemplation of being estimated $(d)$.

Such being the sense assignable to the word damnum and to injuria, I proceed to establish, by apposite examples, this

Damnum.

(c) Omne quod non jure fit injuria fieri dicitur: Brisson, ad verb. Injuria; 1 Inst. $158 \mathrm{~b}$.

"Injurious results frequently arise to individuals from the execution of works of public utility which are authorised by Acts of Parliament, such as a railway, which may be lawfully worked in an ordinary and reasonable manner, although it occasion a damnum to individuals. The reason is, that being authorised by the legislature the reasonable working can be no injuria." Per Mellor, J., Dunn v. Birmingham Canal Co., L. R. 7 Q. B. 273 ; $S$. $C$., affirmed I. R. 8 Q. B.
42; Dixon v. Metrop. Bd. of Works, 7 Q. B. D. 418.

(d) As showing the distinction between damnum and injuria, see $B a c k$ house จ. Bonomi, 9 H. L. Ca. 503 ; S. C., E. B. \& E. 646, 622 (distinguished in Spoor v. Grcen, I. R. 9 Ex. $99,111)$; Lamb v. Walker, 3 Q. B. D. 389 ; overruled in Mitchell v. Darley Main Colliery, 14 Q.B.D. 125; 11 App. Cas. 127 ; Wilson v. Newberry, L. R. 7 Q. B. 31 ; distinguished in Firth v. Bowling Iron Co., 3 C. P. D. 254; Crowhurst v. Amershan Burial Board, 4 Ex. D. 5; and cases cited post, pp. 87 , et seq.
Damnum sine injuria 
proposition, that dammum sine injuria-damage unaccompanied by legal wrong, is not actionable at law (e).

Of this particular kind of damnum just spoken of, the law of contracts does not readily afford us instances; because, there, the mere breach of a covenant or agreement between parties is in itself an injuria of which our law, acting in accordance with the most elementary principles of jurisprudence, will take notice $(f)$. But when we turn to the consideration of torts or wrongs, sufficient examples in affirmance of the proposition above laid down will be found, without much research, to present themselves.

In illustration of such damage might be mentioned the loss inflicted on a schoolmaster by the establishment of a rival school adjacent to his own, or on a millowner by the erection of a mill contiguous to his own, and the consequent loss of custom $(g)$, or by an interruption of the current of air to his mill $(h)$ or to a person's chimneys $(i)$. In these cases it has been held that there is no injuria or legal wrong upon which an action could be founded $(j)$.

The Mogul S. S. Co. v. McGregor Gow (k), affords an interesting example of acts which, although they inflict damage, do not give rise to a cause of action. A combination of shipowners agreed to regulate the division of cargoes and freight from a particular port, and that a rebate should be allowed to all shippers who shipped only with the members of the combination. The plaintiffs, being by

(e) As to this proposition, see the judgments delivered in $L a m b$ v. Walker, 3 Q. B. D. 389 : overruled in Mitehell v. Darley Main Colliery, 14 Q. B. D. 125; 11 App. Cas. 127; Holmes v. Mather, L. R. 10 Ex. 261 ; Rogers v. Dutt, 13 Moo. P. C. 209.

(f) Post, Book II.

(g) Arg. 10 St. Tr. 403.

(h) Webb v. Bird, 13 C. B., N. S. 841 ; S. C., 10 Id. 268; Harris v. De Pinna, 33 Ch. D. 238; see, however, per Lord Selborne in Dalton v. Angus, 6 App. Cas. at p. 798 ; and Ilall v. Lichfield Brewery Co., 49 L. J.
Ch. 655.

(i) Bryant v. Lefever, 4 C. P. D. 172 , where various instances of dam. num absque injuriâ are given. See also Street v. Union Bank of Spain, 30 Ch. D. 156 ; Day v. Brownrigg, 10 Ch. D. 294.

(j) See, also, Hill v. Balls, 2 H. \& N. 299 ; with which compare Smith v. Green, I C. P. D. 92 ; Ward r. Hobbs, 4 App. Cas. 13 ; Cooke v. Waring, 2 II. \& C. 332 ; Sommerville v. Mirehonse, 1 B. \& S. 652,657 .

(k) (1892) A. C. 25, affirming C. A. 23 Q. B. D. 598. 
reason of the acts of the members of the combination compelled to carry at unremunerative rates, brought an action, alleging a conspiracy to injure. The House of Lords held that the acts being done with the lawful purpose of extending the trade and increasing the profits of members of the combination, and not being unlawful, gave the plaintiffs no cause of action.

It would also be easy to show that a man may, without incurring liability, so use his own property as to cause damage to his neighbour, provided the damnum be not injuriosum $(l)$. For instance, the principle has often been recognised, that "one landowner cannot, by altering the condition of his land, deprive the owner of the adjoining land of the privilege of using his own as he might have done before. Thus he cannot, by building a house near the margin of his land, prevent his neighbour from excavating his own land, although it may endanger the house $(m)$; nor from building on his own land, although it may obstruct windows, unless, indeed, by lapse of time, the adjoining land has become subject to a right analogous to what, in the Roman law, was called a servitude $(n)$.

Apposite to this subject are the remarks of North, C.J., in Barnardiston v. Soame (o). " "There is sometimes," says he, "damnum absque injuria though the thing be done on purpose to bring a loss upon another without any design of benefit to himself; as, if a new house be erected contiguous to my ground, I may build anything on purpose to blind the lights of that new house, and no action will accrue, though the malice were never so great $(p)$; much less will

(l) As to damage caused by vis major, see Nichols v. Irarsland, 2 Ex. D. 1; $B o x$ จ. Jubb, 4 Ex. D. 76, 79; River Wear Commissioners v. Adamson, 2 App. Cas. 743. Post.

(m) See Hall v. Mrayor, \&c., of Bristol, L. R. 2 C. P. 322.

(n) Judgm., Sinith v. Kenrick, 7 C. B. 565-6; Humphries v. Brogden,
12 Q. B. 739, and cases cited post, pp. 80, et seq.

(o) 6 How. St. Tr. 1099 ; which was an action against the sheriff for a double return of members to serve in parliament.

( $p$ ) See, also, per Lord Wensleydale, 7 H. L. Ca. 388. 
it lie when a man acts for his own safety. If a jury will find a special verdict; if a Judge will advise and take time to consider; if a bishop will delay a patron and impannel a jury to inquire of the right of patronage; you cannot bring an action for these delays though you suppose it to be done maliciously and on purpose to put you to charges; though you suppose it to be done scienter, knowing the law to be clear; for they take but the liberty the law has provided for their safety, and there can be no demonstration that they have no real doubts, for these are within their own breasts: it would be very mischievous that a man might not have leave to doubt without so great a peril."

To take an instance of a different kind : a comment upon a literary production, exposing its follies and errors, and holding up the author to ridicule, will not be deemed a libel $(q)$, provided such comment does not exceed the limits of fair and candid criticism, by attacking the character of the witer unconnected with his publication; and a comment of this description everyone has a right to publish, although the author may suffer a loss from it $(r)$. In such a case, although there be damnum there is no injuria; and even the loss is that which the party criticised ought to sustain, inasmuch as it is presumably the loss of fame and profits to which he was not fairly entitled (s). So, however harsh or hasty, or even untrue may be the conduct of a person speaking on a privileged occasion, if he honestly and bon $\hat{\imath}$ fide believes what he utters to be true, no action will lie: it is damnum absque injuric $(t)$. A fortiori, where words are uttered neither

(q) See the definition of a libel, post, Book III. Chap. 2.

(r) See per Iord Elenborough, C.J., Car. v. Hood, 1 Camp. 355, n.; 10 R. R. T01, n.; McLeod v. Wakley, 3 Car. \& P. 311. See Paris v. Levy, 9 C. B., N. S. 342.

(s) Per Lord Ellenborough, C. J., Carr v. Hood, supra. (t) Per Willes, J., Revis v. Smith, 18 C. B. 143; Henderson v. Broomhead, 4 H. \& N. 569. See Blagrate v. Bristol Waterworks Co., 1 H. \& N. 369, 383; Goftin v. Donelly, 6 Q. B. D. 307 .

"If a man were to make false oath of threats used against him, and maliciously and without reasonable and 
actionable per se, nor spoken with reference to a person in his trade or profession, nor productive of special damage, there is in law no injuria, and, consequently, no right of action $(u)$.

Again, an action for seduction is in our law founded upon a fiction; the basis of this action, when brought even by a father to recover damages for the seduction of his daughter, having " been uniformly placed from the earliest times not upon the seduction itself, which is the wrongful act of the defendant, but upon the loss of service of the daughter, in which service," the parent "is supposed to have a legal right or interest." It has, accordingly, always been held, that, in an action for seduction, loss of service must be alleged and must be proved at the trial, or the plaintiff will fail, notwithstanding the production of evidence conclusive as regards the guilt of the defendant; for the wrong done by his act our law does not esteem per se as an injuria, using that word in its strict sense, but merely as damnum sine injuriâ, for which, consequently, an action will not lie $(x)$.

In further illustration of the nature of damnum sine injuriâ may be mentioned the case of Daries v. Jenkins $(y)$, which decides that an action will not lie against a solicitor, who, being retained to sue for a debt a person of the same name as the plaintiff, by mistake and without malice takes all the proceedings to judgment and execution inclusive against the plaintiff; in this case it is, of course, obvious, that the individual thus sued by mistake would have a good defence to the action, and would, if successful, recover in it

probable cause to exhibit articles of the peace against another, such a proceeding would be actionable;" per Erle, C. J., Steward v. Gromett, 29 L. J., C. P. $175 ; S . C ., 7$ C. B., N. S. 191 ; Fitzjohn v. Machinder, 9 C. B., N. S. 505 ; S. C., 8 Id. 78.

(u) Post, Book III. Chap. 2.
Action for seduction.
Action for suing plaintiff by nistake. 
Action for draining off water from plaintiff's

พrell.

such costs as on taxation the law allows. If, however, it be asked, what further remedy he might have for the inconvenience and trouble occasioned him, the answer is, that, in point of law, if the proceedings were adopted purely through mistake, though damage may have resulted to him, it is damnum absque injuriâ, for which no action would lie. Every defendant, against whom an action is unnecessarily brought, experiences some injury or inconvenience beyond what the costs will compensate him for $(z)$.

So, again, Acton v. Blundell (a), and Chasemore v. Richards $(b)$, specially illustrate the nature of damnum sine injuriâ. In the former of these cases it is laid down as a proposition generally true, that our law gives to the owner of land all that lies beneath its surface; whence it follows that the owner may dig beneath such surface at his free will and pleasure : and if, in so digging, he casually does an injury to his neighbour-as by draining off the water from his well - such injury cannot, in the absence of any prescriptive right, become the foundation of an action.

In Chasemore v. Richards (c), the facts were as under :The plaintiff, a landowner and millowner, had, for above sixty years, enjoyed the use of a stream, which was chiefly supplied by subterranean water percolating through the substrata. Water which would otherwise have thus supplied the stream was diverted from it by the defendant, an adjoin-

(z) Per Rolfe, B., 11 M. \& W. 756. See Cotterell r. Joncs, 11 C. B. 713 ; approved in Coondoo v. Mookerjee, 2 App. Cas. 186 ; Collins r. Cave, $4 \mathrm{H}$. \& N. 225, 235 (where the Court remark that "it is difficult to see that it is actionable to induce a third person to bring a wrongful action"); $S . C ., 6$ Id. 131; Castrique r. Behrens, 3 E. \& E. 709,721 .

(a) 12 M. \& W. 324. See Roath v. Driscoll, 20 Day (U. S.), R. 533; Ravestron v. Taylor, 11 Exch. 369 ; Broadbent v. Ramsbotham, Id. 602, 617 ; distinguished Bunting v. Hicks, 70 L. T., N. S. 455 ; Hipkins v.
Birmingham and Staffordshire Gas Light Co., 5 H. \& N. 74; S. C., 6 Id. 250.

(b) 7 II. L. Ca. 349 ; Hodgkinson r. Ennor, 4 B. \& S. $229,241,242$. See Lyon r. Fishmongers' Co., 1 App. Cas. 662; followed in Fritz r. Hob. son, 14 Ch. D. 544 ; considered in Bell v. Corporation of Quebec, 5 App. Cas. 99; North Shore R. C. v. Pton, 14 App. Cas. 612.

(c) 7 H. L. Ca. 349; New River Co., app., Johnson, resp., 2 E. \& E. 435 ; Keg. F. Metropolitan Board of Horks, 3 B. \& S. 710. 
ing landowner, who dug on his own ground a well for the purpose of supplying water to the inhabitants of the district. Plaintiff having lost the use of the stream, was held to have no right of action against defendant for thus abstracting the water, which "was of sensible value in and towards the working" of the mill.

"The cases of Acton v. Blundell (d) and Chasemore v. Richards" (e), it has been said $(f)$, " have affirmed conclusively this proposition, that the disturbance or removal of the soil in a man's own land, though it is the means (by process of natural percolation) of drying up his neighbour's spring or well, does not constitute the invasion of a legal right, and will not sustain an action. And, further, that it makes no difference whether the damage arise by the water percolating away, so that it ceases to flow along channels through which it previously found its way to the spring or well; or whether, having found its way to the spring or well, it ceases to be retained there."

In the recent case of Corporation of Bradford v. Pickles $(g)$, the House of Lords decided that the right of the owner of land to divert or appropriate percolating water within his own land so as to deprive his neighbour of it, is the same whatever his motive may be, whether malicious or otherwise.

We thus see that large and distinct classes of cases occur, in which damage and loss are occasioned to an individual by the act of another, and yet no redress is given him by the law $(h)$, but if the above cases, and others which might be mentioned to a like effect, were examined with due care, it would be found, that, in thus declining to recognise the validity of the claims for pecuniary compensation there put

(d) 12 M. \& W. 324.

(e) 7 H. L. C. 349.

(f) Per Lord Penzance, delivering judgm. in Ballacorkish Silver Mining Co. v. Harrison, L. R. 5 P. C. C.
60,61 .

(g) (1895) A. C. 587, affirming C. A., (1895) 1 Ch. 145.

(h) Et vide per Willes, J., 4 C. B.,

N. S. 345 . 
forth, our law acts in deference to principles wider in their operation, and of greater moment to the community at large, than those are, the authority of which it may, at first sight, appear to have impugned. To take for instance, successively, the cases which have been just put as illustrative of the nature of legal injuries and wrongs; as to the first, I would observe, that the existence of the fiction upon which an action for seduction with us is founded seems referable to this elementary principle, that our law does not regard the quality of actions from the point of view which a moralist would select, it does not weigh them in his scales, nor does it allow the mere turpitude of an act, per se, to give it jurisdiction. It usually inquires, rather, whether any and what damage directly estimable by reference to a pecuniary standard has been sustained. Such is the rule which holds generally true in civil cases, although there are exceptions to it; as, where malice is recognised as an essential ingredient in an actionable wrong. The truth of what has been just said does not seem to be at all affected by the fact that a jury may and will, in many cases, be influenced in assessing damages for a wrong by a consideration of the motives which may have prompted to its commission (i).

In the second of the three instances above put-that, viz., of an action brought unsuccessfully, but which, nevertheless, causes inconvenience and anxiety of mind-nay, even positive loss to a defendant,- - the reasons why redress and pecuniary compensation for the inconvenience so caused cannot be enforced, would seem to be that our Courts of Justice are open to all suitors who there seek to prosecute their claims in the manner prescribed by law, and that anything having a tendency to stifle or prevent such inquiry, ex. gr., the fear of being mulcted in heavy costs beyond that comparatively reasonable amount ascertained by

(i) Post, Book III. Chap. 5. 
taxation according to the scale allowed by law, would be highly inexpedient $(j)$.

In explanation of the last of the instances of damnum sine injuria above specified, a reference to Acton v. Blundell, and Chasemore v. Richards (k), will show, that, although under the circumstances there appearing, two great legal principles were prima facie in conflict, the greater of these was, and justly, allowed to prevail: the principles in apparent antagonism were the doctrine lying at the root of what is called the social compact, that the absolute owner of property may deal with it as he likes, and the rule which so restricts the use and enjoyment of property as to prevent injury, i.e., legal injury, to a neighbour.

The general rule is "that the owner of one piece of land has a right to use it in the natural course of user, unless in so doing he interferes with some right created either by law or contract," therefore the owner of minerals has a right to take away the whole of them in his land, and a servitude to prevent such an user must be founded on something more than mere neighbourhood $(l)$.

In the absence of evidence of prescription there is, at common law, no liability imposed on the owner of land to maintain a wall in front of such land protecting it from the water in a creek communicating with the sea. He will not, therefore, be liable to the occupier of adjoining land for damage done to it through non-repair of the seawall $(m)$.

The prima facie right of every occupier of a piece of land is, to enjoy that land free from all invasion of filth or other

(j) In Phillips v. Naylor, 3 H. \& N. 20, Martin, B., asks: "Suppose a man, knowing that a debt has been paid, brings an action in a superior Court, gets judgment, and arrests the defendant, could it be contended that an action would lie against him?"

(k) Ante, p. 76. (l) Wilson v. Waddell, 2 App. Cas. 95 , 99 ; with which compare Fletcher v. Smith, Id. 781 .

(m) Hudson v. Tabor, 1 Q. B. D. 225 ; S. C. ; affirmed 2 Id. 290 . See Att.-Gen. v. Tomline, 14 Ch. D. 58 ; dist. in West Norfolk, \&c. v. Archdale, 16 Q. B. D. 754 . 
matter coming from any artificial structure on land adjoining. He may be bound by prescription or otherwise to receive such matter; but the burthen of showing that he is so bound rests on those who seek to impose an easement upon $\operatorname{him}(n)$.

Great care is, doubtless, often needed in determining whether or not a particular mode of enjoying property is innocent and lawful: and "the books of Reports," it has been said, " abound with decisions restraining a man's acts upon and with his own property, where the necessary or probable consequence of such acts is to do damage to others." The judgment in Humphries v. Brogden (o), whence the above extract is taken, will be found instructive with reference to this subject. There it appeared that the surface of land (by which is meant the superficies and soil lying over the minerals) belonged to one man, whilst the minerals belonged to another; no evidence of title, nor any covenant $(p)$ appeared to regulate or qualify the rights of enjoyment of the respective occupants, and the question was, whether the owner of the minerals might remove them without leaving support sufficient to maintain the surface in its natural state. Now, the jury in this case negatived the existence of negligence on the part of the defendant who had worked the mines, and found that he had worked carefully and according to the custom of the country, but without leaving sufficient pillars or supports for the superincumbent soil.

Upon the facts and finding of the jury above set out, the

(n) Judgm., IIumphries v. Cousins, 2 C. P. D. 243-4. See Hodgkinson v. Emor, 4 B. \& S. at p. 241, per Blackburn, J., citing Tennant $\checkmark$. Goldwin. Salk. 361 ; Snow r. Whitehead, 27 Ch. D. 588 .

(o) 12 Q. B. 739 (where the previous authorities are noticed); Roubotham v. Wilson, 8 H. L. Ca. 348; Duke of Buccleugh v. Wakeficld, L. R. 4 H. L. 377 ; dist. in Love r. Bell, 9 App. Cus.
286 ; Smith v. Darby, I. R. 7 Q. B. 716 ; Eadon v. Jeffcock, L. R. 7 Ex. 379 ; Richards r. Harper, L. R. 1 Ex. 199. See, also, Hilton r. Whitehead, 12 Q. B. 734, and cases cited post.

(p) See Hodgson r. Moulson, is C. B., N. S. 332 ; Aspden r. Seddon, 1 Ex. D. 496, $50 \pi$, which is a curious case bearing generally on the subject, supra: Dixon r. White, 8 App. Cas 833. 
Court of Queen's Bench gave judgment in favour of the plaintiff, and in doing so made some remarks which are apposite for my present purpose. If, they said ( $q$ ), A., seised in fee of land next adjoining land of B., erect a new house on his land, " and part of the house is erected on the confines of his land next adjoining the land of B., if B. afterwards digs his land near to the foundation of the house of A., but not touching the land of A., whereby the foundation of the house and the house itself fall into the pit, still no action lies at the suit of A. against B., because this was the fault of $\mathrm{A}$. himself that he built his house so near to the land of B., for he could not by his act hinder B. from making the most profitable use of B.'s own land" $(r)$; the case here put offering, consequently, an example of damnum absque injuriâ or damage unaccompanied by any actionable wrong. But, on the other hand, the Court proceeded to remark, a man who has land next adjoining to mine cannot dig his own land so near to mine, that thereby my land shall fall into his pit; and for so doing, if an action were brought, it seems clear, on principles of natural justice, that it would lie. Now, although the existence of such a right to lateral support for land from the adjoining soil manifestly places a restraint on the enjoyment of the adjacent property, the existence and validity of the right in question may nevertheless be sustained by this simple reasoning, that " if the neighbouring owners might excavate their soil on every side up to the boundary line to an indefinite depth, land thus deprived of support on all sides could not stand by its own coherence alone," and infinite mischief might thus be caused to an innocent party.

Further, in connection with this subject the student may

(q) Citing 2 Rolle's Abr. Trespass (1), pl. 1 .

(v) See per Watson, B., Rogers v. Taylor, 2 H. \& N. 834; Wurchie v. Black, 19 C. B., N. S. 190 ; Metropolitan Board of Works v. Metro-

33.C.L. politan R. C., L. R., 4 C. P. 192 ; 3 Id. 612 ; Brown v. Robins, 4 H. \& N. 186 ; cited judgm., Stroyan v. Knowles, 6 H. \& N. 465; Bibby v. Carter, 4 H. \& N. 153; Wyatt v. Harrison, 3 B. \& Ad. 871 . 
consult the case of Smith v. Kenrick (s)-which decided that it is "the natural right of each of the owners of two adjoining coal mines-neither being subject to any servitude to the other-to work his own in the manner most convenient and beneficial to himself, although the natural consequence may be, that some prejudice may accrue to the owner of the adjoining mine, so long as that does not arise from the negligent or malicious conduct of the party" $(t),-$ and Backhouse v. Bonomi ( $u)$.

Cases such as the foregoing are of much practical importance, and show how embarrassing and difficult may be the questions presenting themselves where distinct rights which in their enjoyment encroach upon each other, are claimed by different individuals; the points to be decided in such cases usually being - which of the two rights is subservient to the other? Is the alleged wrongful act damnum absque injuria and irremediable?

Injuria sine damuo.

In deference to the authorities already cited, we may assume that damnum sine injurici is not actionable. And on this assumption, I proceed to illustrate and explain the correlative proposition-that injuria sine damno (to adopt technical phraseology) does very frequently suffice as the foundation of an action: the above phrase being used to indicate a wrong-remediable at law-though not productive of actual damage to the complainant. The phrase applies only where a legal injury has been done, or where a legal right has been violated.

(8) 7 C. B. 515,564 , distinguished in Atc.-Gen. v. Tumline, $1 \pm$ Ch. D. 63 ; Baird v. Williamson, 15 C. B., N. S., 376; Fletcher r. Smith, 2 App. Cas. 781; atfirming Smith r. Fletcher, L. R. 9 Ex. 64; Inmn v. Birminghan Can. Co., L. R. I Q. B. 244 ; S. C. affirmed, L. R. 8 Q. B. 42 ; Clegg r. Dearden, 12 Q. B. 5 Tं.

$(t)$ The defendant occupying a mine situated higher than plaintiff's mine, would have no right to be au active agent in sending water into the lower mine ; Baird r. Williamson, supra. See Bagnall v. London and Worth Western R. Co., 1 H. \& C. $544 ;$ s. C., TH. \& N. 423 .

(u) 9 H. L. Ca. 503; Smith r. Thacterah, I. R. 1 C. 1'. 564, considered; Att.-Gen. r. Conduit Colliery Co., (1895) 1 Q. B, 301; Witchell r. Darley Main Colliery, 14 Q. B. D. 125, 11 App. Cas. 127. 
As explanatory of what is meant by injuria sine damno, Ashby v. reference may, in the first instance, be made to the great case of $A s h b y$ v. White (x), which has much interest in a constitutional as well as in a strictly legal point of view. It is here precisely in point, as showing clearly that it is actionable to deprive a man_of a right given him by law, although no damage, loss, or injury has been thereby occasioned. Ashby v. White was an action against a returning officer for maliciously $(y)$ refusing to receive the plaintiff's vote at the election of burgesses to serve in Parliament; and it was held by Lord Holt, C. J., and the House of Lords, that the action well lay, although the candidates in whose favour the vote had been tendered were in fact elected; the decision proceeding upon this ground, that the plaintiff had a legal right and privilege to give his vote; and that having been disturbed in the enjoyment of such right, an action was maintainable at his suit against the party causing the disturbance.

In the course of his celebrated judgment in this case, Lord Holt, after first showing that the right of voting at the election of burgesses is a privilege of much moment, and that the deprivation of it is an injury, thus proceeds: "If the plaintiff has a right he must of necessity have a means to vindicate and maintain it, and a remedy if he is injured in the exercise or enjoyment of it. And, indeed, it is a vain thing to imagine a right without a remedy, for want of right and want of remedy are reciprocal." Lord Holt then applies himself to one particular argument, which had been urged, viz., that an action was not maintainable because no actual hurt or damage had been done to the plaintiff (inasmuch as, although his vote was rejected, the

(x) 2 Lord Raym. 938, 953, and 14 How. St. Tr. 6950 ; 1 Smith L. C., 9th ed. 268.

(y) Malice is essential as an ingredient in this injuria when actionable: Tozer v. Child, 6 E. \& B. 289 ; S. C., 
candidates for whom it had been tendered were in fact elected as representatives) ; and observes that, " surely every injury imports a damage, though it does not cost the party one farthing;" and it is impossible to prove the contrary, he adds, "for a damage is not merely pecuniary, but an injury imports a damage where a man is thereby injured of his right." Now, it is quite clear, that, in thus speaking, Lord Holt uses the term "injury," as synonymous with " injuria" in its strict sense, i.e., as signifying a wrong recognised as such by the law; and when so understood, the propositicn which he lays down, viewed by the light of subsequent decisions, does not seem to be at all too broadly stated.

Marzetti v. Williams.

Another important case exemplifying the phrase injuria sine damno is Marzetti v. Williams (z), which decided that an action will lie against a banker, having sufficient funds in his hands belonging to a customer, for refusing to honor his cheque, although the customer did not thereby sustain any actual loss or damage $(a)$. Here the action was in tort for the breach of duty cast by the custom of trade upon a banker; but the action might have been founded upon the contract implied by law as existing between a customer and his banker, that the latter will pay cheques drawn by the former, provided he has in his hands sufficient funds for that purpose. For a breach of the duty here indicated substantial damages may be awarded $(b)$.

Strictly in accordance with Marzetti v. Williams was the decision in Fray v. Voules (c). That was an action brought by a client against her attorney for consenting to an order for a stet processus, in two actions at suit of the client,

(z) 1 B. \& Ad. 415; Cumming v. Shand, 5 H. \& N. 95: Gray v. Johnston, L. R. 3 H. L. 1.

(a) But the banker might take a reasonable time to satisfy himself as to the genuineness of the cheque, if presented under suspicious circumstances. See per Maule, J., Robarts v. Tuclier, 16 Q. B. 577 . But see post, p. 476 . (b) Rolin r. Stcucard, 14 C. B. 595 ; Prehn v. Royal Bank of Licerpool, I. R. 5 Ex. 92, 99; but see Morris $\mathrm{r}$. London and Westm. Bank, 1 C. \& E. 498.

(c) 1 F. \& E. 839 ; Butler r. Knight, L. R. 2 Ex. 109 ; Lovegrove . White, L. R. 6 C. P. 440. 
"without the authority and consent, and against the will, and contrary to the direction of the plaintiff." Plea-that " in entering the stet processus, and in staying all further proceedings, and in committing the several grievances complained of, he (defendant) acted in a reasonable, careful, skilful, and proper manner, and in pursuance of, and in obedience to, and in accordance with the advice, opinion, and discretion of certain counsel learned in the law, then retained and employed by the plaintiff, \&c." On demurrer, this plea was held bad; for " a retainer to sue, with positive directions not to compromise, makes it the duty of the attorney not to compromise; and if he does so, it is a breach of his duty," for which, whether the action be shaped in contract or tort, nominal damages at all events will be recoverable.

Cases of various kinds and complexions, differing from those just cited, might readily be adduced in support of the proposition that injuria sine damno is actionable. Such, in actions founded purely upon contract, is, as we shall hereafter see, the general rule. "Where there is a breach of an express contract," says Parke, J., in Marzetti v. Williams, supra, " nominal damages may be recovered" $(d)$; though no damage has really been sustained $(e)$.

So a bare trespass to land $(f)$-the infringement of a patent $(g)$ or of a copyright-will be actionable. And it has been held, that the tortious invasion, unaccompanied by special damage, of the right to a trade-mark $(h)$ is so $(i)$.

(d) 1 B. \& Ad. 425.

(e) Per Erle, J., Goodwin v. Cremer, 18 Q. B. 761. See per Bramuell, B., Cook v. Hopewell, 11 Exch. 559.

( $f$ ) See Lord Holt's judgment in Ashby r. White, as published sepa. rately, 1837. See also this judgment as reported, Ld. Raym. $938 ; 3$ Bla. Com. 120, 209.

(g) See, for instance, Saxby r. Hemett, L. R. 8 Ex. 210. See, also, Patterson v. Gas Light and Coke Co., 3 App. Cas. 239; Irarsden $v$. Saville
Street Co., 3 Ex. D. 203.

(h) "The right to a trade-mark is a right closely resembling, though not exactly the same as, coprright." Per Lord Cranworth, 11 H. L. Ca. 533.

(i) Blofeld v. Payne, 4 B. \& Ad. 410 ; Crawshay v. Thompson, 4 M. \& G. 357 ; Rodgers v. Nouvill, 5 C. B. 109 ; “Singer" Machine Manufacturers v. Wilson, $3 \mathrm{App}$. Cas. 376 . See Lawson v. Bank of London, 18 C. B. 84; Leather Cloth Co. v. American Leather Cloth Co., 11 H. L. Ca. 523; 
An action moreover lies for interference with or diverting traffic from an ancient ferry-proof being given that the plaintiff's right has been violated (k).

The following examples, taken indifferently from various branches of the law, will be found to throw additional light upon this subject:-

A libel has been defined to be "a malicious defamation, expressed in printing or writing, or by signs, pictures, \&c., tending to injure the reputation of another, and thereby exposing such person to public hatred, contempt, or ridicule" $(l)$. This malicious defamatory statement, when published on an occasion which does not privilege the publication, constitutes an injuria whence the law will imply damage.

There is another important class of cases which can title. hardly be passed over in silence, whilst taking notice of the strict legal meaning of the word injuria. I allude to those where it is material to the preservation of a right that its invasion, although productive of no positive or appreciable damage, should not be tolerated or suffered with impunity. Thus, an action will lie for an entry on the land of another, though no real damage be occasioned thereby $(m)$, one main reason being, that repeated acts of going over the land might eventually be relied upon as evidence of title to do so, and thereby the right of the plaintiff to the absolute enjoyment of the land might be injuriously affected. So, in an action by a commoner for a trespass to his common, evidence need not be given of the actual exercise of rights of common by the plaintiff $(n)$. The proposition may

Johnston จ. Orr Eving \& Co., 7 App. Cas. 219. As to trade name, see Reddaway v. Banham, (1896) A. C. 199. No one has any right to represent his goods as the goods of somehody else (per Lord Halsbury, L.C., at p. 204).

(k) Hopkins v. Great Northern R. Co., 2 Q. B. D. 224, 229, et seq. (l) 2 Selw. X. P., 13th ed., 981, citing Digby v. Thompson, 4 B. \& Ad. 821. As to exhibition of effigy, see Monson ₹. Tussaud, (1894) I Q. B. 671. (m) See Tuyman v. Knoules, $13 \mathrm{C}$. B. 222 ; Ellis v. Loftus Iron Co., L. R. 10 C. P. 10 ; Wiseman v. Booker, 3 C. P. D. 184 .

(n) Per Taunton, J., 1 B. \& Ad. 
indeed be generally stated that "wherever one man does an act which, if repeated, would operate in derogation of the rights of another, he is liable to an action, without particular damage, at the suit of the person whose right may be affected" $(o)$.

In The Rochdale Canal Company v. King ( $p)$, the declaration stated that a certain canal had been made by the plaintiffs in pursuance of the stat. 34 Geo. 3 , c. 78 , by the 113 th section of which the owners of land, within the distance of twenty yards from the canal, were empowered to draw water from it, by means of pipes, for the supply of their steamengines, and for "the sole purpose" of condensing the steam used for working such engines; the declaration charged that the defendants had "deceived and defrauded the plaintiffs" in this, to wit, that they had used the water drawn from the canal for purposes other than that allowed by the Act, and that the navigation of the canal had been thereby impeded and obstructed. No proof of damage at all, however, was given at the trial, and the question, under these circumstances, was, whether or not the action at suit of the company was maintainable. It was held to be so, on the ground-1st, that the company being invested by the Legislature with certain rights, might, in accordance with the rule laid down in Ashby v. White $(q)$, sue for an invasion of them, without giving evidence of express damage ; 2ndly, that the general principle here applied,-that, although no appreciable damage might possibly be sustained in the particular instance by the wrongful act complained of, yet, inasmuch as the repetition of such act might be made, in time, the foundation of a claim to do it, damage, in law,

426; Wells v. Watling, 2 W. Bl. 1233; Pindar v. Wadsworth, 2 East, 154; 6 R.R.412; 1 Wms. Saund. 346a. See Kidgill v. Moor, 9 C. B. 364.

(o) Per Kelly, C. B., Harrop v. Hirst, L. R. 4 Ex. 47.

(p) 14 Q. B. 122, 136, distinguished in Cooper v. Crabtree, 20 Ch. D. 589; Medway Navigation Co. v. Earl of Romney, 9 C. B., N. S., 575 ; Wood v. Waud, 3 Exch. 748, 780 ; approved in Singh v. Pattuk, 4 App. Cas. 121; Northam v. Hurley, 1 E. \& B. 665.

(q) Ante, p. 83. 
had already been suffered by the plaintiffs, in respect of which an action was maintainable.

In Harrop v. Hirst $(r)$ the facts were as under :-The plaintiffs in common with other inhabitants of a particular district enjoyed a customary right at all times to have water from a spout situate in a highway within the district for domestic purposes. The defendant, a riparian owner on the stream which supplied the spout with water, on various occasions prevented such large quantities of water from reaching the spout, as to render what remained insufficient for the inhabitants entitled to use it; an action was held maintainable against the defendant for diverting the water, although the plaintiffs had not themselves suffered thereby any actual personal damage or inconvenience.

This part of my subject, having reference to injuria sine damno, may conclude with a reference to two additional authorities which are directly in support of what has been said: 1st, Embrey v. Ouen (s), which was an action for diverting water from a stream, and where the Court in giving judgment observe that "actual perceptible damage is not indispensable as the foundation of an action; it is sufficient to show the violation of a right, in which case the law will presume damage." 2ndly, the judgment of $\mathrm{Mr}$. Justice Story in Webl v. The Portland Manufacturing Company $(t)$ (which was also an action for diverting water), where that able jurist thus expressed himself with regard to the first question which arose in the case, viz., whether, to maintain the pending suit, it was essential for the plaintiff to establish that any actual damage had been sustained by him? "I can very well understand that no action lies in a case where there is damnum absque injuria (u), that is, where there is a damage done without

(r) L. R. 4 Ex. 43.

(8) 6 Exch. 353 ; Sampson r. Hoddinott, 1 C. B., N. S., 590 affirmed 3
C. B., X. S., 596.

(t) 3 Sumner (U. S.) R. 189.

(u) Ante, p. 71 , et seq. 
any wrong or violation of any right of the plaintiff. But I am not able to understand how it can correctly be said, in a legal sense, that an action will not lie, even in case of a wrong or violation of a right, unless it is followed by some perceptible damage which can be established as a matter of fact; in other words, that injuria sine damno is not actionable. On the contrary, from my earliest reading, I have considered it laid up among the very elements of the common law, that, wherever there is a wrong, there is a remedy to redress it ; that every injury imports damage in the nature of it: and if no other damage is established, the party injured is entitled to a verdict for nominal damages. $A$ fortiori, this doctrine applies where there is not only a violation of a right of the plaintiff, but the act of the defendant, if continued, may become the foundation, by lapse of time, of an adverse right in the defendant; for then it assumes the character, not merely of a violation of a right, tending to diminish its value, but it goes to the absolute destruction and extinguishment of it." Actual perceptible damage, continues Mr. Justice Story, is not indispensable as the foundation of an action. The law tolerates no further inquiry than whether there has been the violation of a right. If so, the party injured is entitled to maintain his action for nominal damages in vindication of his right $(x)$.

(x) Judgm., 3 Sumner (U. S.) R. 189 ; Fay v. Prentice, 1 C. B. 828. See Harvey v. Walters, L. R. 8 C. P. 162. In Nieklin v. Williams, 10 Exch. 267, Parke, B., observes that " every injury to a right imports a damage, as laid down in the case of Ashby v. White, by Lord Holt, and adopted and recognised in several other cases referred to in $W e b b$ v. The Portland Manufacturing Co., and Embrey v. Owen." See, however, Thomas . Birmingham Canal Co., 49 L. J. Q. B. 851 , in which the above authorities do not appear to have been referred to. Nicklin r. Williams, supra, was rightly decided, although some of the dicta contained in it may be ques. tionable; per Lord Westbury, C., Backihouse ४. Bonomi, 9 H. L. Ca. 512. But see Mitchell v. Darley Mrain Colliery, 14 Q. B. D. 125; 11 App. Cas. 127, overruling Nicklin v. Williams, ubi supra, and Lamb v. Walker, 3 Q. B. D. 389.

An action is not maintainable against the sheriff for negligence in not levying under a $f$. $f a$. without proof of actual pecuniary damage: Hobson v. Thelluson, L. R. 2 Q. B. 642 ; nor will an action lie against the sheriff for a false return unless actual damage has been 
The examples above cited will probably be thought to have established this proposition, that injuria sine damno is, in a very large class of cases, actionable at law ; there are indeed, as will hereafter appear $(y)$, many wrongful acts, i.e. acts not merely morally wrong and indefensible, but even contra legem, which give no right of action by our law, unless productive of special and substantial damage to the complainant; for instance, the breach of a public duty or the nonfeasance of something required to be performed by the statute law, would not be actionable at suit of one who had sustained no damage by reason of the breach of duty or of the nonfeasance $(z)$. So, again, mere negligence, mala fides (a), fraud, or misrepresentation $(b)$, could not give a right of action unless damage were caused thereby or resulted therefrom; and where words are spoken not actionable in themselves, special damage must in general be not only averred in the plaintiff's claim but proved at the trial, in order that an action may be maintainable; in these and similar cases it is sometimes said, that injuria and damnum must combine in order to constitute a right enforceable by action, or, regard being had to the meaning assigned to each of those words, at p. 71, we may perhaps say, that in none of the cases just alluded to does the alleged wrong, unless when accompanied by substantial damage, fill out the true measure and conception of a legal injury $(c)$.

Damnum et injuria may fail to give a right of action.

But, besides cases such as have been noticed, others present themselves, the distinctive peculiarity of which might be exhibited by saying, that the combination of the two

caused thereby to the plaintiff : Stimson v. Farnham, L. R. 7 Q. B. 175. See Brasyer v. Maclean, L. R. 6 P. C. 398.

(y) Post, Book III.

(z) Id.

(a) See Wood r. Wood, L. R. 9 Ex. 190, distinguished in Russcll v. Russell, 14 Ch. D. 478. (b) Eastucood v. Bain, 3 H. \& $\mathrm{X}$. 738.

(c) Sometimes a particular statute gives a right of action only where damage has been sustained: see Rodger's v. Parlier, 18 C. B. 112 , recognised in Laccas v. Tarlcton, $3 \mathrm{H}$. $\mathbb{A}$. 116,120 ; I'ickering v. James, L. R. 8 C. U. 489. 
ingredients of damnum and injuria will there fail, for peculiar reasons, to constitute a ground of action $(d)$.

To this class may be referred every case in which an injury done productive of damage to another is, in legal conDamage too remote. templation, too remote to entitle the injured party to redress $(e)$, or in which the injuria did not with sufficient directness produce the damnum $(f)$. For instance, "it is a well-established and settled rule that the underwriter is liable for no loss which is not proximately caused by the perils insured against. The maxim, causa proxima non remota spectatur, is a fundamental principle of insurance law" $(g)$. So the rule of law is that negligence, to render a defendant liable, " must be the causa causans, or the proximate cause of the injury, and not merely a causa sine quâ non" $(h)$. So, to revert for a moment to the case of an action for slander when the words used are not actionable per se, it has been held that the special damage relied upon to support the action should be a 'legal' and 'natural' or 'reasonable' consequence of the words spoken $(i) ; e x . g r$. , it would not suffice to show, that, by reason of them, some third person had been led to commit an assault and battery on the plaintiff $(j)$.

(d) See, for instance, Glynn v. Thomas, 11 Exch. 870, commented on in Loring v. Warburton, E. B. \& E. 508, and distinguished in Fell v. Whittaker, L. R. 7 Q. B. $120,124$.

(e) Everett v. London Ass., 19 C. B., N. S., 126 ; Stanley v. Western Insur. Co., L. R. 3 Ex. 71 ; Marsden r. City, \&c., Ass. Co., I. IR. 1 C. P. 232 ; Tarner v. Wulker, L. R. 2 Q. B. 301 ; Bovins v. Hutchinson, $18 \mathrm{C}$. B., N. S., 445 ; Lee, app., Riley, resp. Id. 722 ; Mullett v. MLason, L. R. 1 C. P. 559; Wanstall v. Pooley, 6 Cl. \& F. 910, n.

(f) Per Coleridge, J., Tatton v. Wade, 18 C. B. 386 . See also Walker v. Goe, 4 H. \& N. 350: S. C., 3 Id. 395 ; Collins v. Cave, 4 H. \& N. 229 ; S. C., 6 Id. 131; Barber r. Lesiter, 7 C. B., N. S., 175 ; Fitzjohn v. Mackinder, 9 C. B., N. S., 505. (g) Per Martin, B., Rankin v. Potter, L. R. 6 H. L. 143 ; Jackson v. Union Marine Ins. Co., L. R. 10 C. $P$. 125. The above maxim applies specially to marine insurances, per Lord Fitzgerald in Inman SS. Co. v. Bischoff, 7 App. Cas. 692.

(h) Judgm., Bailiffs of Romney Marsh v. Trinity House, L. R. 5 Ex. 204, 208 ; S. C., affirmed, L. R. $7 \mathrm{Ex}$. 247 ; Adams v. London \& Yorkshive R. C., L. R. 4 C. P. 739, approving Jones v. Boyce, 1 Stark. N. P. C. 493, $495 ; 18$ R. R. 812 ; see dictum of Brett, J., in Adains v. London \& Yorkshive R. C., at p. 744, approved Lee v. Nixey, 63 I. T., N. S., 285.

(i) Miller v. David, L. R.9 C.P.118; Davies v. Solomon, L. R. 7 Q. B. 112.

(j) Per Lord Ellenborough, C. J., Vicars v. Wilcocks, 8 East, 1 ; 9 R. R. 361, Preface, vi; but see Bowen v. Hall, 
It was at one time thought that an action would not be maintainable for inducing another to break a contract-the act of inducing being done maliciously and with intent to injure the plaintiff; the breach of contract being a wrongful act of the contracting party, which, upon the authority of the decisions below cited $(k)$, was regarded as neither a 'legal' nor a 'natural ' consequence of the defendant's act. The point here adverted to was much considered in Lumley v. Gye $(l)$, where the majority of the Court seemed to be of opinion, that an action founded in tort would lie under the circumstances just supposed, and that no conclusion to the contrary can fairly and accurately be drawn from previous decisions.

"Suppose," said Crompton, J., in that case, that "a trader, with a malicious intent to ruin a rival trader, goes to a banker or other party who owes money to his rival, and begs him not to pay the money which he owes him, and by that means ruins or greatly prejudices the party, I am by no means prepared to say, that an action could not be maintained, and that damages beyond the amount of the debt, if the injury were great, or much less than such amount if the injury were less serious, might not be recovered."

So, again, Erle, J., in the same case, remarked, "It is clear that the procurement of the violation of a right is a cause of action in all instances where the violation is an actionable wrong, - as in violations of a right to property, whether real or personal, or to personal security; he who procures the wrong, is a joint wrongdoer, and may be sued either alone or jointly with the agent, in the appropriate action, for the wrong eomplained of." Now, the principle

6 Q. B. D. 333 ; Ashley r. IIarrison,

1 Esp. 48; 3 R. R. 686; Taylor $\mathrm{s}$. Neri, Id. 386: Green r. Button, 2 Cr. M. \& R. 707; Blagrave $r$. Bristol Waterworks Co., 1 HI. \& N. 369.

(k) Vicars 5 . Wileocks, 8 East, 1 ; 9 R. R. 361, Preface, vi; Miller $\mathrm{r}$. David, L. R. 9 C. P. 118, 126 ; Hoey r. Felton, 11 C. B., N. S., 142,146 ; Ashley v. Harrison, 1 Esp. 48 ; 3 R.R. 686 ; Ticars v. Wilcocks, supra, is cummented on in Lynch v. Kright, $9 \mathrm{H}$. L. Ca. $577,590,600$.

(l) 2 E. \& B. 216 , cited in Cattle r. Stockton Watericorks Co., L. R. 10 Q. B. $453,457,458$. 
which governs such cases clearly is, that "he who maliciously procures a damage to another, by violation of his right, ought to. be made to indemnify;" and this principle, by parity of reasoning, seems to hold, "whether he procures an actionable wrong or breach of contract;" for "he who procures the non-delivery of goods according to contract may inflict an injury the same as he who procures the abstraction of goods after delivery, and both ought on the same ground to be made responsible " $(m)$. It has since been decided in the Court of Appeal, affirming the decision of the majority of the Judges in Lumley v. Gye, that an action lies against a third person who maliciously induces another to break his contract of exclusive personal service with an employer which would naturally cause, and did in fact cause, an injury to the employer, although the relation of master and servant may not exist between the employer and employed $(n)$.

In Temperton v. Russell (o), not only was an action for maliciously producing breaches of contracts other than those of personal service held maintainable, $X_{\text {but also an }}$ action for maliciously conspiring together to injure the plaintiffs by preventing persons from entering into contracts with them. Further, in Flood v. Jackson (p), an action for maliciously inducing a master to discharge a servant from his employment, even though the discharge did not amount to a breach of the contract of employment, was held to be maintainable. In each case damages had resulted to the plaintiff. + It is, however, sufficient to prove facts from which it may properly be inferred that some damage must result to the plaintiff from the defendant's wrongful acts, without proving specific damage $(q)$.

(m) 2 E. \& B. 232, 233. In connection with Lumley v. Gye, cited in the text, see Sedman v. Walker, 1 Exch. 589; per cur. Weller v. Balier, 2 Wils. 422 ; cited Judgm., Jebsen v. East and West India Dock Co., L. R. 10 C. P. 306 ; Bowen v. Hall, 6 Q. B. D. 333 . (n) Boucen r. Hall, supra; Temperton v. Russell, (1893) 1 Q. B. 715 (C. A.).

(o) (1893) 1 Q. B. 715 (C. A.).

(p) (1895) 2 Q. B. 21 (C. A.).

(q) Exchange Telegraph Co. T. Gregory, (1896) 1 Q. B. 147 (C. A.).

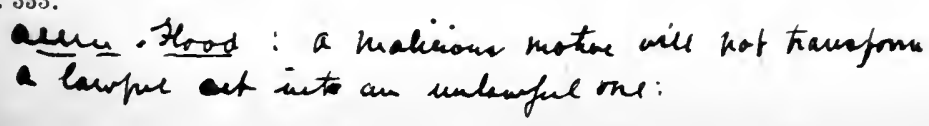


To return to the consideration of actions, solely and exclusively founded upon tort, the case of Scott v. Shepherd $(r)$ shows what, in actions of that class, is meant by saying that damage is or is not the "natural" or "probable" consequence of an act done $(s)$. There, it was held, that trespass would lie against an individual who first set a squib in motion, which, after being thrown about in selfdefence (and, therefore, lawfully) by various persons, at last put out the plaintiff's eye. The decision thus come to proceeding mainly upon this ground, that the parties intervening between the plaintiff and the defendant, having acted for their own safety and for self-preservation, could not be regarded as free agents; and that consequently there was, to use the expression of Chief Justice De Grey, a "chain of effects," which connected together the wrongdoer and the injured party, rendering the former responsible for the damage resulting from this tortious act to the latter.

To a like effect with the preceding case is that of Vandenburgh v. Truax $(t)$ : there the defendant had pursued another with a view to assaulting him, and had thus driven him for protection into the plaintiff's shop, where, in consequence of the pursued party running against a cask of wine, injury was done. It was contended, upon these facts, that the defendant was not liable, inasmuch as the damage was occasioned, not directly by him, but by a third party, who might properly be regarded as altogether a free agent; the Court, however, took a different view of the matter

(r) 2 W. Bla. 892 ; 1 Smith, I. C., 9th ed., 480; Lawrence v. Jenkins, I. R. 8 Q. B. 274 ; Sneesby v. Lancashire and Yorkshive R. C., 1 Q. B. D. 42 ; Swith r. London and North Westcrn R. C., I. R. 6 C. P. 14: see Gilbertson r. Richardson, 5 C. B. 502 ; Pary v. Smith, 4 C. P. D. 325.

(s) See per Grove, J., Sharp r. Poucll, L. K. 7 C. I'. 253, 259, where the damage was held to be too remote.

(t) 4 Denio (U. S.) R. 464: see also Grille v. Suan, 19 Johns. (U. S.) R. 381, cited Sedgw. Dam., 2nd ed., 79; Assop v. Iates, 2 II. \& N. 768; Alston v. Herring, 11 Exch. 822.

In Clark r. Chambers, 3 Q. B. D. $32 \tau$, many cases concerning remoteness of damage are collected. See also Harris V. Kobbs, 3 Ex. D. 268. 
before them, remarking that it had been laid down as a general rule that when " one does an illegal or mischievous act, which is likely to prove injurious to others, and when he does a legal act in such a careless and improper manner that injury to third persons may probably ensue, he is answerable in some form of action for all the consequences which may directly and naturally result from his conduct." Such being the general rule applicable in determining as to the liability of an individual under circumstances at all similar to those above detailed, it is observable, that the existence or non-existence of a urongful intent on his part is not at all adverted to in it; the reason being, that in the case put, the presence or absence of such intention would be wholly immaterial in regard to the abstract question, whether or not legal liability would be entailed by the particular act done $(u)$.

The doctrine as to remoteness of damage will hereafter be considered more at length in connection respectively with actions founded upon contracts $(v)$ and those originating out of tort $(w)$. This doctrine has on various occasions been applied to claims for pecuniary compensation, under two important enactments $(x)$, which empower certain public companies to carry out their works, and make them responsible in damages for injury caused to an individual by their acts. From these decisions $(y)$ we deduce that,

(u) Post, Book III.

(v) Post, Book II.

(w) Post, Book III., Chap. 5.

(x) $8 \& 9$ Vict. ce. $18,20$.

(y) Ricket r. Metropolitan R. Co., L. R. 2 H. L. 175 (which shows that Wilkes $\mathrm{r}$. The Hungerford Market Co., 2 Bing. N. C. 281 , is no longer to be relied upon, is indeed overruled, per Willes, J., Beckett v. Midland R. C., L. R. 3 C. P. 100), where the prior cases are reviewed; MCCarthy v. Metropolitan Board of Works, L. R. 8 C. P. 191 ; S. C. affirmed, L. R. 7 II. L. 243 ; Reg. v. Metropolitan Board of Works, L. R. 4 Q. B. 361 ;
Hammersmith, \&c., R. C. v. Brand, L. R. 4 H. L. 171; Hill v. Managers of Metrop. Asylum District,4 Q. B. D. 441 ; 6 App. Cas. 193 ; dist. in Truman v. London and Brighton R. C., 25 Ch. D. 423; 11 App. Cas. 45; Geddis v. Proprietors of Bann Reservoir, 3 App. Cas. 430 ; Hopkins r. Great Northern R. C., 2 Q. B. D. 224: Duke of Buccleugh v. Metropolitan Board of Works, L. R. 5 H. L. 418 ; Reg. v. Taughan, L. R. 4 Q. B. 190. See also Eagle r. Charing Cross R. C., L. R. 2 C. P. 638 ; Herring v. Metropolitan Board of Works, 19 C. B., N. S. 510 ; Cameron r. Char- 
unless an injury so caused would have been the subject of a claim for damage at common law, it could not, unless expressly so provided, lay a foundation for such claim when occasioned by something done in the exercise of statutory powers, as in the case of a temporary obstruction to a highway-causing loss of trade to an individual-occasioned by the performance of some lawful and necessary work; which would not, according to the weight of authority, be actionable at common law $(z)$.

It has been held that statutory compensation cannot be claimed by reason of the noise or smoke of trains, whether part of the claimant's lands be taken or not $(a)$.

Where proper remedy ment.

Cases next to be noticed as illustrating the proposition that damnum et injuria will sometimes fail to give a right of action, depend upon a rule concisely laid down by Sir W. Blackstone $(b)$, that " the law gives no private remedy for anything but a private wrong;" and, "therefore," as he proceeds to remark, " no action lies for a public or common nuisance, but an indictment only; because, the damage being common to all the king's subjects, no one can assign his particular proportion of it, or, if he could, it would be extremely hard if every subject in the kingdom were allowed to harass the offender with separate actions." Where, however, an individual suffers from an indictable offence, as a nuisance, extraordinary damage - that is, damage over and above that which in common with the rest of the com.

ing Cross R. C., Id. 764. See propositions laid down by Lord Selborne in Caledonian R. C. v. Walker's Tinstees, 7 App. Cas. 259; Wadham v. NorthEastern R. C., 14 Q. B. D. 747; Essex v. Local Board for Acton, 14 App. Cas. 153, affirming Reg. v. Essex, $14 Q$. B. D. 753 , but reversing $17 Q$. B. D. 447 ; Ford v. Metrop. Dist. R., 17 Q. B. D. 12; Attomey-Generalv. Metropolitan R. C., (1894) 1 Q. B. 384 (C. A.).

(z) "Loss of custom by itsclf being a purely personal right of action (ever if it exist), has no refercnce to land. and is not the subject of compensa. tion : "Piggott, Law of Torts, p. 175. citing McCarthy v. Metrop. Board of Works, ubi sup.; Caledonian R. C. $\mathbf{v}$. Talker's Trustees, ubi sup. ; Benjamin v. Storr, L. R. 9 C. P. 400 ; Fritz V. Hobson, 14 Ch. D. 542.

(a) City of Glasgow Union R. C. r. Hunter, L. R. 2 Sc. App. Cas..78.

(b) 3 Com. 219. 
munity he sustains-he will be entitled, in respect of such special and peculiar damage, to maintain an action $(c)$.

Accordingly, Sir E. Coke observes (d), that there is a "diversitie" between the mode of procedure for disturbance of a private and a public way: in the former case, " the law," he says, "doth give unto the landowner, whose right or easement is disturbed, an action for recovery of damages; but if the way be a common way, and if any man be disturbed in going that way, or if a ditch be made across it so that he cannot go, yet he shall not have an action (e); and this the law has provided for avoiding of multiplicity of suits; for such common nuisance the apt remedy being by presentment before a grand jury in the proper Court."

In Henley v. The Mayor of Lyme Regis $(f)$, which may further elucidate the present subject, the declaration set forth a charter casting an obligation upon the corporation (the defendants in the action) to do repairs, which were of general and public concern, to certain banks and seashore; the declaration also averred, that they had neglected to do such repairs; and that the plaintiff had, in consequence, sustained special damage. The Judges, in delivering their opinion to the House of Lords with reference to the sufficiency of the declaration in this case, laid it down as clear and undoubted law, that, wherever an indictment lies for non-repair, an action founded on tort will lie at the suit of a party sustaining any peculiar damage; and generally, that where the Crown, for the benefit of the public, has made a grant imposing certain public duties, and that grant has been accepted, the public may enforce

(c) 3 Bla. Com. 220. See ex. gr. Bemjamin v. Storr, L. R. 9 C. P. 400.

(d) 1 Inst. 56 a.

(e) See Winterbottom v. Lord Derby,

L. R. 2 Ex. 316. (f) 5 Bing. 91 ; S. C., 3 B. \& Ad. 77,$93 ; 2$ Cl. \& F. 331 ; per Erle, C. J., Nicholl v. Allen, 1 B. \& S. 936 ; S. C., Id. 916; Borough of Bathurst v. Macpherson, 4 App. Cas. 256, 267. 
the performance of those duties by indictment, and individuals peculiarly injured by action $(g)$.

The principle upon which the preceding case was decided has been referred to and explained by the Court of Exchequer $(h)$ in these words: "There is no doubt of the truth, of the general rule, that where an indictment can be maintained against an individual or a corporation for something done to the general damage of the public, an action *** can be maintained for a special damage thereby done to an individual, as in the ordinary case of a nuisance in the highway, by a stranger digging a trench across it, on by the default of the person bound to repair rations tenure" (i).

It may moreover be laid down that where a duty is created, for the benefit of the public, by Act of Parliament, and a specific remedy is thereby provided for a breach of the duty, it must be a question of construction whether the specific remedy was intended to be substituted for or to be provided in addition to the common law remedy by an indictment for the public, or by action for an individua who sustains a special or particular injury $(k)$.

The rule of law, which, in certain cases of a quasi criminal nature, merges the right of action in the more ap and efficient mode of procedure by indictment, is referre by high authorities $(l)$ to this reason, that multiplicity $o$ suits should, wherever practicable, be avoided. The reasor assigned must not, however, be pushed further than estab lished precedents or express decisions will justify ; for, a

(g) Geddis v. Proprietors of Bann Reservoir, 3 App. Cas. 430.

(h) M'Kinnon r. Panson, 8 Exch. 319 ; $S$. $C$. (in error), 9 Id. 600 (recognizing Russell $\mathrm{v}$. Men of Deron, $2 \mathrm{~T}$. R. 667; 1 R. R. 585); Yonng r. Daris, 7 H.S. $760 ; S . C ., 2$ HI. \& C. 197 , eited in Taylor v. Greenhalgh, I. R. 9 Q. B. 487, 489; Peudlebury r. Greenhalgh, 1 Q. B. D. 36 ; Parsons s. St. Nattlicu,
Bethnal Green, L. R. 3 C. P. 56.

(i) See Hartuell v. Ryde Commis sioners, 4 B. \& S. 361.

(k) Judgm., Borongh of Bathurst v Macpherson, 4 App. Cas. 268; citin Athinson v. Deveastle Waterworks Co 2 Ex. D. 441 ; Tallance r. Falle, 1 Q. B. D. 109.

(I) 4 Bla. Com. 167. 
Lord Holt remarked in Ashby v. White (m), "If men will multiply injuries, actions must be multiplied too ; for every man that is injured ought to have his recompense. Suppose the defendant had beat forty or fifty men, the damage done to each one is peculiar to himself ; and he shall have his action. So, if many persons receive a private injury by a public nuisance, every man shall have his action $(n)$. Indeed, where many men are offended by one particular act, there they must proceed by way of indictment and not of action, for in that case the law will not multiply actions. But it is otherwise when one man only is offended by that act, he shall have his action; as if a man dig a pit in a common, every commoner shall have his action on the case, per quod communiam suam in tam amplo modo habere non potuit, for every commoner has a separate right" $(o)$.

Where an Act of Parliament imposes a penalty on any Penalaction one violating its provisions, but enacts that no proceeding by "party." for recovery of such penalty shall be taken by any person other than "a party grieved," without the consent in writing of the Attorney-General, a plaintiff suing without such consent will be required to show that his private interests have been affected by the act complained of, and that he has been "aggrieved" thereby specially, and not merely as one of the public $(p)$.

As connected with the distinction between public and private wrongs, another point may properly be noticed, viz., the suspension of the civil remedy where the act done is felonious. "The policy of the law," said Lord Ellenborough, C. J. (q), " requires, that, before the party injured

(m) L. Raym. 938 ; ante, p. 83.

(n) Citing IVilliams's case, 5 Rep. 72 ; Co. Litt. 56 a.

(o) See also Mary's case, 5 Rep. 113 a ; Dobson v. Blackmore, 9 Q. B. 991, 1002 ; Judgm., Pryce v. Belcher, 3 C. B. 92.

(p) Boyce v. Higgins, 14 C. B. 1;
Hollis r. Marshall, 2 H. \& N. 755 ; Bradlaugh v. Clarke, 8 App. Cas. 354.

(q) Crosby v. Leng, 12 East, 413 ; 11 R.R. 437 ; Stone v. Marsh, 6 B. \& C. 551, 564; Marsh v. Keating, 1 Bing. N. C. 198, 217 ; Ex p. Elliott, 2 Deac. 179. 
by any felonious act can seek civil redress for it, the matter should be heard and disposed of before the proper criminal tribunal, in order that the justice of the country may be first satisfied in respect of the public offence;" for, as remarked by another learned Judge in the case here referred to, it might very likely happen that criminal justice would be defeated if the injured party were first permitted to obtain a civil satisfaction for the injury.

This rule does not apply as between the party injured and a third person innocent of the felony $(r)$, nor does it affect a party who has sustained consequential damage, and is not under any obligation to prosecute $(s)$.

This rule has been severely criticised, and doubts have from time to time been expressed as to whether or not it has any real existence; but an examination of the cases will show that it has never formerly been overridden, though various difficulties have been placed in the way of its application. Thus, in Wells v. Abrahams $(t)$, it was laid down that a Judge cannot nonsuit a plaintiff on its appearing in evidence at the trial that the mrongful act complained of was a felony, and it was further added that the failure to prosecute could not be pleaded as a defence, apparently on the principle that nemo allegans suam turpitudinem est audiendus (u).

And, again, in The Midland Insurance Co. v. Smith (x), it was decided that a statement of claim was not demurrable simply because it showed that the plaintiff was suing for damages for a felonious act. "There is nothing," said the learned Judge, " to show whether the plaintiffs have or have

(r) White v. Spettigue, 13 M. \& W. 603: Lee v. Bayes, 18 C. 3. 599 ; Osborn v. Gillett, L. R. 8 Ex. 58.

(8) Appleby v.Franklin, 17 Q. B. D. 93 ; Osborn r. Gillett, ubi sup.

(t) L. R. 7 Q. B. 554 . Constantine จ. Welloek, 2 H. \& C. 146.

(u) Luttercll จ. Reynell, 1 Mod.
282. This reasoning, however, seem open to the objection taken by a recen writer, that the plea is not a confessior of guilt, but a claim to a verdict on th criminal charge brought by the plainti and denied by the defendant, riz. Piggott, Law of Torts, p. 5 .

$(x) 6$ Q. B. D. 561 . 
not neglected to prosecute the felon; and it is consistent with the demurrer that the felon may in fact have been convicted, and as it seems clear to me that the prosecution of the felon is not an absolute condition precedent to the accruing of the cause of action, the statement of claim is prima facie sufficient." Further, in a subsequent case the Court held generally that the question could not be raised on demurrer to a statement of claim $(y)$.

This point was much considered in Ex parte Ball, re Shepherd (z), where it was decided that the trustee of a bankrupt was not prevented by this rule from proving against the estate of the felon, even though the bankrupt himself might have been, and Baggallay, L. J., took occasion to lay down the following propositions, which were subsequently adopted in The Midland Insurance Co. v. Smith (a) :-

1. That a felonious act may give rise to a maintainable action.

2. That the cause of action arises upon the commission of the offence.

3. That, notwithstanding the existence of the cause of action, the policy of the law will not allow the person injured to seek civil redress, if he has failed in his duty of bringing or endeavouring to bring the felon to justice.

4. That the rule has no application to cases in which the offender has been brought to justice at the instance of some other person, or in which prosecution is impossible by reason of the death or escape of the felon $(b)$.

It has been suggested that the only way in which the objection could be rendered available would be by an applieation to the summary jurisdiction of the Court $(c)$, and to

(y) Roope v. D'Avigdor, 10 Q. B. D.

(z) $10 \mathrm{Ch}$. D. 667 .

(a) 6 Q. B. D. 561.

(b) Wickham r. Gattrill, 2 Sm. \& G.

353 ; Dudley, \&e., Banking Co. v.
Spittle, 1 Johns. \& H. 14, and cases cited supra.

(c) Wells v. Abrahams, L. R. 7 Q. B. 554 ; Roope v. D'Avigdor, 10 Q. B. D. 412 . 
this effect was the decision in the recent case of Appleby v. Franklin $(d)$, where the existence of the rule was fully recognised, and it was said that, though the objection cannot be taken by plea or demurrer (Roope v. D'Avigdor $(e)$ ), and though it is at least doubtful whether it is a ground for nonsuit (Wells v. Abrahams $(f)$ ), "yet it seems clear from what is said in Markham v. Cobb (g), that it is in the power of the Court to strike out that part of the claim upon a summary application." "The authorities which have been referred to," it was said by Wills, J., in the same case, "leave no doubt that no action can be maintained for a civil injury resulting to the plaintiff from a felonious act on the part of the defendant, until public justice has been vindicated by a prosecution of the criminal. It is equally clear that the objection to the maintenance of the action cannot be raised by plea or by demurrer, or, as it would seem, by way of nonsuit, inasmuch as the cause of action still subsists."

The operation of this doctrine is excluded by the first section of Lord Campbell's Act ( $9 \& 10$ Vict. c. 93) in any case remediable under the provisions of that statute; though a master cannot sue for an injury causing the immediate death of his servant $(h)$.

Redress denied on grounds of public policy.

Besides cases like the preceding, where the private merges in the public wrong, others again present themselves in which considerations of general expediency or public policy forbid our Courts to interfere, or to compel compensation to a claimant for damage caused by the act of another. As illustrative of what is here meant, reference may be made to Jolinstone v. Sutton (i), which shows that an action will not lie"against a commanding officer for anything done by

(d) 17 Q. B. D. 93.

(c) 10 Q. B. D. 412.

(f) L. R. 7 Q. B.554. Constantine

v. Wellock, 2 H. C. 146.

(g) Sir W. Jones, 147.

(h) Osborn v Gillett, ubi sup. (i) 1 T. R. 493, 510, 754; 1 R.R. 25\%, 269. In Datkins v. Lord Rokeby, L. R. 8 Q. B. $2.55 ; S . C$., affirmed L. R. 7 IH. I. 744: and Dackins r. Lord Paulet, I. R. 5 Q. B. 94, many cases illustrating the text are collected. 
aim in the course of discharging his duty or incidental thereto ; to Buron v. Denman ( $k$ ), which seems to show that the ratification by the Crown of a trespass ipso facto alters its character, and renders it no longer actionable; to Plillips v. Eyre $(l)$, which shows that a colonial measure of indemnity may neutralize the tortious quality of an act; and to the fundamental doctrine of our constitution which declares , that " the King can do no wrong" $(m)$. It may be laid down generally that the exemption from liability of officers carrying out government orders rests upon this ground, that their conduct under such circumstances is an act of state, for which public policy forbids that they should be held responsible $(n)$.

Now, in cases falling within the scope of the principles above adverted to, grievous wrong may possibly be done, and damage may be caused to an individual, and yet no kind of remedy, or, at all events, no remedy by action, may be open to him in a Court of law. Such cases consequently offer exceptions to the rule which ordinarily prevails, that damnum et injuria constitute a ground of action.

Another important class of decisions, resting strictly on grounds of " public policy," demands attention in connection with what has been just said. I allude to those which affirm the doctrine of the non-liability of judicial officers for damage resulting from acts done by them in that capacity.

A little reflection might lead one to suppose that a discretionary power, so extensive as that provided by our con-of the ourts. stitution to the Judges of the Superior Courts, must be accompanied with a corresponding degree of irresponsibility. If, therefore, the Judge in the exercise of his discretion

(k) 2 Exch. 167, and cases there cited. Acc. judgm., Secretary of State of India r. Sahaba, 13 Moo. P. C. C. S6.

(l) L. R. 6 Q. B. 1,4 Q. B. 225.

(m) Leg. Mac., 6th ed., pp. 46 et seq.; per Lord Lyndhurst, C., Viscount
Canterbury v. Att.-Gen., 1 Phill. 306. See judgm., Rogers v. Dutt, 13 Moo. P. C. C. 236 .

(n) Per Pollock, B., Hill v. Manager's of Letropolitan Asylum District, 4 Q. B. D. 441 ; 6 App. Cas. 193.
Non liajudicial officers, 
commits an error, he will, as a general rule, be protected from penal or even from civil liability $(o)$. The law, says Lord Bacon ( $p$ ), has so much respect for the certainty of judgments and authority of Judges, that it will not permit any error to be assigned which impeaches them in their trust and office, and in wilful abuse of the same, but only in ignorance and mistaking either of the law or of the case and matter in fact. "No action," says North, C. J. (q), "will lie against a Judge for what he does judicially, though it should be laid falsò malitiosè et scienter $(r)$. They who are entrusted to judge ought to be free from rexation, that they may determine without fear; the law requires courage in a Judge, and therefore provides security for the support of that courage." Therefore, says Lord Mansfield, C. J. (s), " by the law of England, if an action be brought against a Judge of Record for an act done by him in his judicial capacity he may plead that he did it as a Judge of Record, and that will be a complete justification" :-ex. gr. in an action for slander $(t)$.

The general principle of exemption from liability thus laid down is of great importance. It is necessary to the free and impartial administration of justice, that those who have been $\checkmark$ appointed to dispense it " should be uninfluenced by fear and unbiassed by hope. Judges have not been invested with this privilege for their own protection merely; it is calculated for the benefit of the people by insuring to them a calm,

(o) $A$ person in the position of an arbitrator is not liable for negligence; Tharsis Sulphur Co. v. Loftus, L. R. 8 C. P. 1 ; Pappa v. Rose, L. R. 7 C. P. 32,$525 ;$ Stevenson v. Iratson, 4 C. P. D. 148, 162; Turner r. Goulden, L. R. 9 C. P. $57,59$.

(p) Max. 17 ; Floyd v. Barker, 12 Rep. 23.

(q) Bamardiston r. Soame, 6 How. St. Tr. 1096. Et vide per North, C. J., in S.C., 6 St. Tr. 1107 , who adduces instances where actions "have been rejected for norelty and reasons of inconrenience:" Sucinfen $\nabla$. Lord Chelmsford, 5 H. \& N. 890 .

(r) Citing 12 Rep. 24; Fray r. Blackbun, 3 B. \& S. 576; Thomas v. Churton, 2 Id. 475. See Anderson $\mathbf{v}$. Gorrie, (1895) 1 Q. B. 668 (C. A.).

(s) Mostyn r. Futrigas, Cowp. 161, at p. 172;1 Smith, L. C., 9th ed., 628,644 . 220.

(t) Scott r. Stansfeld, L. R. 3 Ex. 
steady, and impartial administration of justice" $(u)$. The same principle is thus stated by Baron Greene : "It is a principle of law, established from the earliest times, that the acts of a Judge of a Court of Record, if within the limits of his jurisdiction, are not to be reviewed or questioned in an action brought against him. This principle is most important as regards not only the Judge but the general interests of justice, and ought not to be impaired or frittered away on light or subtle grounds or distinctions " $(x)$.

So in Garnett v. Ferrand (y), it is laid down by Lord Tenterden, as a general rule of very great antiquity $(z)$, " that no action uill lie against a Judge of Record for any matter done by him in the exercise of his judicial functions." "In the imperfection of human nature," says the same learned Judge, it is better that an individual should occasionally suffer a wrong, than that the course of justice should be impeded and fettered by constant and perpetual restraints and apprehensions on the part of those who are to administer it. Corruption is quite another matter; so also are neglect of duty and misconduct : for these I trust there is, and always will be, some due course of punishment by public prosecution."

But although the general principle thus laid down appears, at first sight, sufficiently clear and definite, difficulty may sometimes be felt in determining what acts can and what cannot properly be considered as judicial, so as to fall within its operation. 'T'aaffe v. Downes (a), however, shows, that if it be once established that the particular act in question "emanated from and was appropriate to the legal duties" of the office of Judge of a Court of Record, such act may be

(u) Taaffe v. Downes, 3 Moo. P. C. C. 36, n., cited per Parke, B., Ryalls v. Reg., 11 Q. B. 796.

(x) Ward r. Freeman, 2 Ir. C. L. Rep. at p. 467.

(y) 6 B. \& C. 611.

(z) See Hainmond v. Howell, 1
Mod. 184 ; S. C., 2 Mod. 218; Bushell's case, 1 Mod. 119.

(a) 3 Moo. P. C. C. 60 , n.; Broun v. Copley, 1 Sc. N. R. 350 ; per Lord Brougham, Ferguson v. Earl of Kinnoull, 9 Cl. \& F. 289, 290. 
viewed as purely judicial, and therefore, within the rule. Nor will the test here suggested be applicable merely to acts done in open Court, it will apply also to such as are done at Chambers; equal privilege in either case attaching to the judicial office $(b)$.

If, moreover, the Judge of a Court, not of Record, has a criminal or quasi-criminal jurisdiction in respect of the matter sub judice, the person charged, and the place where the offence is alleged to have been committed, he will, it seems, be irresponsible for an act done in the exercise of his judicial functions $(c)$.

Where, however, the particular act complained of was done by the Judge when not acting judicially, or in respect of a matter not mithin his jurisdiction, the principle just stated does not apply. Thus, in Calder v. Halket (d), we find it broadly laid down, that " English Judges, when they act wholly without jurisdiction, whether they may suppose they had it or not, have no privilege." And Dicas v. Lord Brongham (e), which was an action of trespass against the then Lord Chancellor for a committal for contempt under an order alleged to be illegal, will not be found to impugn the proposition just stated, because there the matter in question certainly fell within the general jurisdiction of the Judge.

Again, where an individual acts in a judicial capacity under an invalid appointment or commission, we have express authority for saying that the party so acting would not be privileged or exempted from civil liability.

In Gahan v. Lafitte $(f)$, an action for trespass and false

(b) Per Lord Norbury, 3 Moo. P. C. C. $60, \mathrm{n}$.

(c) Kemp r. Nerille, 10 C. B., N. S., $523,547,551$, and cases there cited.

(d) 3 Moo. P. C. C. 28 ; Case of the Marshalsea, 10 Rep. 68 b., cited judgm., Morrell v. Martin, 3 M. \& Gr. 595 ; Houlden v. Simith, 14 (Q. B.
841, cited Gelen v. Hall, 2 H. \& $\mathbf{X}$. 379. See Lery r. Moylan, 10 C. B. 189 ; Beaurain v. Scott, 3 Camp. 3s8; Pease v. Chaytor, 3 B. \& S. 623, 641, $644,6.54$.

(c) 6 Car. \& P. 249; Hamilton r. Anderson, 3 Уacq. H. L. Ca. 363.

(f) 3 Moore, P. C. C. 382. 
nprisonment was held to lie against individuals exercising re office of Judges, in one of our West India Islands, of a 'Jlonial court, under commissions from the governor of the Hand which were informal and void. And this case is, uerefore, directly in point, as sustaining the proposition ist stated.

The above remarks amply suffice to show that the honesty nd integrity of a Judge of one of our superior Courts, when cting in his judicial capacity, cannot be brought in question h action. Of course, if a mistake he committed by him in oint of law, his decision may ordinarily be revised, by a uperior tribunal.

By passing under review the defences available in actions ounded either upon contract or in tort, further instances rill present themselves, where for one reason or another ur law interferes to protect parties from civil liability by uction for wrong done, ex. gr., for breach of contract, on he ground of infancy or coverture,-or for personal injury saused by negligence, on the ground that the suffering arty has, by the want of ordinary care, himself conributed to cause the damage complained of,-or, again, rhere the express words or general scope and purview of a statute bar the remedy by action, or fail to give it $(g)$. I shall not, indeed, just now attempt to examine the addijional cases here adverted to as being in their nature zxceptional to the above rule, for such an inquiry, if oroperly pursued, would, in truth, be identical with a lisquisition upon legal principles generally, whence alone the existence of legal rights can be deduced.

(g) Compare Atkinson v. Sewcastle and Gateshead Waterworks Co., $2 \mathrm{Ex}$. D. 411 ; Holborn Union ז. Sít. Leonard, Shoreditch, 2 Q. B. D. 145 ; distinguished, Ellis v. Strand District Board of Torks, 67 L. T., N. S. 307 ; Ross จ. Rugge-Price, 1 Ex. D. 269 ; followed in Brain v. Thomas, 50 L. J' Q. B. 66t; Gorris r. Seott, L. R. 9
Ex. 125 ; Foung v. Davis, 2 H. \& C. 197 ; S. C., 7 H. \& N. 760 , cited in Taylor v. Greenhalgh, L. R. 9 Q. B. 487, 489; Stevcns v. Jeacoche, 11 Q. B. 731 ; Narshall r. Nicholls, 18 Q. B. 882 ; Femet and Avon Wav. Co. v. Witherington, Id. 531, 544; Great Northern Fishing Co. v. Edgehill, 11 Q. B. D. 225. 
It may, however, in concluding this division of $\mathrm{m}$ : subject, be well to call to mind, that, in the vast majorit. of cases which are brought into Courts of justice, botl damnum and injuria combine (though sometimes, for specif reasons, ineffectually) in support of the claims put forth the object of a plaintiff usually $(h)$ being to recover by hi action,-if not liquidated or ascertained, at all eventssubstantial damages. The usual test, however, applied t. determine whether or not a legal right has in any given cas been invaded, would seem to be this, -are or are no nominal damages recoverable at suit of the claimant? I they be, then, clearly, a right has been invaded, and a action will lie.

(h) That is, where the action is not brought for recovery of land or of some

chattel in specie, or to rindicate right, or in some other cases. 


\section{CHAPTER IV.}

ORDINARY REMEDIES.

SeCr. 1.-Action at Law.

2.-Suit in the County Court.

Sect. 1.-Action at Law.

The practice observed in our Superior Courts of Law is or the most part regulated by the Judicature Acts of 1873 ind 1875, and the Rules of Court framed under these Practice of the Superior Courts of Law-how nactments,-should points, however, occur apparently constituted. innoticed therein by the Legislature, recourse must be had ;o the pre-existing practice $(a)$ as expounded by well-known nriters. And Acts of Parliament relating to the former Courts will be construed as if made with reference to the Courts constituted in lieu of them (b).

\section{Considerations preliminary to issuing the Writ.}

The word "action" has since the Judicature Acts acquired a much more extended meaning than formerly, including as it now does suits in the Chancery and Admiralty and Probate Divisions (c). We are, however, at present only concerned with actions within the cogni-

(a) Order i., R. $2 ; 36 \& 37$ Vict. c. 66 , s. 23 ; Order lxxii., R. 2.

(b) 36 \& 37 Vict. c. 66 , s. $76 ; 38$ $\& 39$ Vict. c. 77, s. 24 .

(c) "Action" means " a civil proceeding commenced by writ, or in such other manner as may be prescribed by Rules of Court." It does not include a criminal proceeding by the Crown : $36 \& 37$ Vict. c. 66 , s. 100 ; and see Order i., R. 1. 
sance of the Queen's Bench Division which were former called " actions at law."

Sir E. Coke tells us (d) that "an action is the leg demand of a man's right;" ex. gr., if a statute gives a rig. to a sum of money, and provides no means of recovering the remedy is by action $(e)$.

The philosophical mode of presenting the above subje to the mind would seem to be by referring to the distinctio between perfect and imperfect rights $(f)$ and obligations, $\mathrm{f}$ the idea of a perfect right implies that he on whom it conferred must have some sufficient and adequate means enforcing it. But a resort to violence and force canno with due regard to the interests of society, be entrusted any one of its individual members who may think himse aggrieved; and this for a threefold reason-1st, becau the complainant himself cannot properly be allowed decide as to the fact of a wrong having been done; 2 ndl because he might lack the power of compelling compens tion for it; and 3rdly, because, if he possessed the powe he might exercise it in a manner detrimental to the interes and well-being of the community.

The State, therefore, undertakes the task of deciding to the fact whether or not a wrong has been done, and judging as to the nature of the right alleged to have bee invaded; and further, when necessary, it likewise assum the privilege of vindicating the party aggrieved against th aggressor. Now, all this is effected in very many cas through the medium of an action at law, whereby an ind vidual member of the community puts in motion th machinery provided by the State for the purpose of obtair

(d) Co. Litt. 285, a.

(e) Per Cur., Richurdson v. Willis, I. R. 8 Ex. il. In London and North Western R. C. V. Evershed, 3 App. Cas. 1029, an action for money had and received was held maintainable to recorer a sum which had been ore charged.

(f) Private rights, i.e., rights e jored exclusively and enforceable individuals, are here spoken of. 
ng a formal recognition - of the justice of his claim, and hen of compelling its enforcement against his adversary. in the conception, therefore, of an action at law, the actor Ir plaintiff, the reus or defendant, and the judex or judge, ure essential elements.

Before, however, an individual conceiving that he is aggrieved can safely resort to this remedy by action, he hould satisfy himself in regard to several preliminary matters: he should inquire whether a complete cause of retion is rested in him; whether or not the right of action has been postponed or extinguished, or has become barred by any Statute of Limitations; or has become merged; or whether he is estopped from suing; he should consider also whether or not any notice of action is requisite, and, if so, to whom and when it must be given. Further, it will be necessary, before issuing the writ, to determine as to the nature of the claim to be put forward, and where and how it should be presented; and lastly, it will be proper to select the parties by and against whom respectively the action should be brought.

1. In the first place, then, the party proposing to sue should satisfy himself that he has a complete cause of action Is the cause of action against the defendant; for, at the trial, he will have to show that a right of action existed and was vested in him before he commenced his suit (g), i.e., before he issued his writ, the date of the writ being, as will hereafter appear, that of the commencement of the action. Sometimes, on instituting the inquiry here suggested, it will be found that the supposed contract, relied upon as the ground of action, was, in fact, never fully assented to by the opposite party, or that its terms were not defined with sufficient precision to render it binding $(h)$, or that a right of action was in-

(g) Castrique v. Bernabo, 6 Q. B. 498; Williams r. Whlliams, L. R. 9 C. P. 6.59 ; King v. Accumulative Ass.
Co., 3 C. B., X. S. 151.

(h) Post, Book II., Chap. 1. 
tended to accrue solely upon the happening of some event which has not yet occurred (i). Thus a person who contracts to do work and supply materials, may expressly agree to complete the whole and be paid when the work is done, and not till then. In any such case the period of completion is fixed by the agreement of the parties as the period of payment and nothing can be got sooner ( $k$ ).

Again, a right of action may have been meant to accrue upon the performance, by the contractee, of some condition precedent which he has failed to perform $(l)$. Though if a man binds himself to do certain acts which he afterwards renders himself unable to perform, he thereby dispenses with the performance of conditions precedent to the acts which he has so rendered himself unable to perform $(m)$.

It cannot, however, be laid down as a universal rule, that where, by agreement, an act is to be done on a future day, no action can be brought for a breach of the agreement till the day for doing the act in question has arrived. "If," said Lord Camplell, C. J. (n), " a man promises to marry a woman on a future day, and before that day marries another woman, he is instantly liable to an action for breach of promise of marriage $(o)$. If a man contracts to execute a lease on and from a certain day for a certain term, and before that day executes a lease to another for the same term, he may be immediately sued for breaking the contract $(p)$. So, if a man contracts to sell and deliver

(i) Alder v. Boyle, 4 C. B. 635; Pattinson v. Luckley, L. R. 10 Ex. 330.

(k) Vide per Lord O'Hagan, Anderson v. Morice, 1 App. Cas. 738 et seq.

(I) Cooper v. London and Brighton R. C., 4 Ex. D. 88; Carter v. Scargill, I. R. 10 Q. B. 564; Mason v. Harvey, S Exch. 819; Grafton r. Eastern Counties R. C., Id. 699; Hunt r. Bishop, Id. 675; Bradford v. Williams, L. R. 7 Ex. 259; Bankart v. Boucers, I. R. 1 C. 1'. 484 ; Pordage v. Colc, 1 Wms. Saunds. 320, a (4): Junces v. Camuock, 3 H. L. Ca. 700 ;
Roberts r. Brett, 11 Id. 337.

(m) Judgm., Sands v. Clarke, 8 C. 13.762 .

(n) Hochster v. De la Tour, 2 E. \& B. 678 ; Roper r. Johnson, L. R. 8 C. P. 167. See Hickman r. Hayncs, L. R. 10 C. P. 598 ; Johnstone v. Milling, 16 Q. B. D. 460.

(b) Short r. Stone, 8 Q. B. 358. See Caines v. Smith, 15 M. \& W. 189.

(p) Ford r. Tiley, 6 B. \& C. 325 ; Locelock r. Franklyn, 8 Q. B. 371. See Horler v. Curpenter, 2 C. B., N. S., 56 . 
pecific goods on a future day, and before the day he sells nd deliver's them to another, he is immediately liable to n action at the suit of the person with whom he first conracted to sell and deliver them" $(q)$. "All the cases "dmit," said Lord Alvanley, in Touteng v. Hubbard ( $r$ ), "that where a party has been disabled from performing his ontract by his own default, it is not competent for him to llege the circumstances by which he was prevented as an xcuse for his omission." In cases of this kind, it may be hat, by the contract to do an act on a future day, a elation, $e x . g r$. , that of betrothed persons $(s)$, is constituted etween the parties, which raises an implied promise, that, n the meantime, neither will do anything to the prejudice if the other inconsistent with that relation; and upon a reach of this implied promise an action will lie without raiting for the expiration of the time specified in the riginal contract $(t)$.

Cases such as cited seem to support the proposition " that vhere a contract is made with reference to certain anticirated circumstances, and where, without any default of ither party, it becomes wholly inapplicable to or impossible if application to any such circumstances, it ceases to have my application; it cannot be applied to other circumstances shich could not have been in the contemplation of the arties when the contract was made" $(u)$.

(q) Bowdell v. Parsons, 10 East, 59.

(r) 3 B. \& P. 302, adopted in Espoito v. Bowden, 4 E. \& B. $978 ;$ S. C. reversed in error), 7 Id. 763 ; Geipel - Smith, L. R. 7 Q. B. 404.

(s) Frost v. Knight, L. R. 7 Ex. 11, 5 Ex. 332, eited judgm., Cherry . Thompson, I. R. 7 Q. B. 579.

(t) Judgm., Hochster v. De La Tour, E. \& B. 689, 694, recognised Avery Bouden, 5 E. \& B. 728 ; S. C., 6 d. 962; and cited Chwehward v. Reg., 6 B. \& S. 854,855 ; Crooekewit - Fletcher, 1 H. \& N. 915 ; per Erle, . J., Bartholonew v. Markwick, 15 B.C.L.
C. B., N. S., 716 ; per Maule, J., Lewis v. Cliftan, 14 C. B. 253; and per Jervis, C. J., 6 E. \& B. 961 ; Cort v. Ambergate, Nottingham, and Boston R. C., 17 Q. B. 127 ; Emmens v. Elderton, 4 H. L. Ca. 624; Synge v. Synge, (1894) I Q. B. 466 (C. A.).

(ut) Per Brett, J., Jaekson v. Union Marine Insuranee Co., L. R. 8 C. P. 581 ; S. C., 10 Id. 125, 145 ; Howell v. Coupland, L. R. 9 Q.B. $462 ; S . C$. , aff. 1 Q. B. D. 258 ; Appleby v. Nyers, L. R. 2 C. P. 651 ; Taylor v. Caldwell, 3 B. \& S. 826; Chapman v. Withers, 20 Q. B. D. 824. 
So the inability of the contractee to perform his part o the contract may justify the contractor in rescinding it $(x)$ And a nice question often arises as to whether or not th conduct of one party to a contract justifies the other is supposing that performance of it has been abandoned $(y)$.

The 17th section of the Statute of Frauds $(z)$ offered strong illustration of the rule, that no action should b commenced until the cause of action is complete; fo although that section only required some memorandum i writing of a contract, not that the entire contract itse should be in writing, nevertheless a memorandum signe after action brought would not satisfy the statute $(a)$.

IIas the right of retion been lostponed, or extinsuished sc.?

2. The party proposing to sue will do well to conside whether or not the right of action has been postponed $b$ the act of the parties or has been altogether extinguished This right may be postponed, as by credit being given for specified period $(b)$, or by the receipt of a bill of exchans or promissory note payable at some future day, "for and o account of "the cause of action (c); which is a sort qualified or conditional payment $(d)$. The right in questic may be altogether extinguished $(e)$, as by merger $(f), \mathrm{k}$ payment, or by a release; and if once extinguished, $f$ ever so short a time, it cannot again revive $(g)$.

(x) Poussard r. Spiers, 1 Q. B. D. $410,414$.

(y) Morgan v. Bain, L. R. 10 C. P. 15 ; Bloomer v. Bernstein, L. R. 9 C. P. 5Ss ; Frecth v. Burr, L. R. 9 C. P. 208; Simpson r. Crippin, L. R. 8 Q. B. 14 ; Brandt r. Lawrence, 1 Q. B. D. 344 : Reuter r. Sala, 4 C. P. D. 239 ; Hoare ז. Remie, 5 H. \& N. 19; Honck r. Mfuller, 7 Q. B. D. 92 ; Mersey, fe., Steel Co. r. Naylor, 9 Q. B. D. 666 .

(z) Now repealed and replaced by s. 4 , subs. i., of $56 \& 5 i$ Vict. c. $7 i$ (the Sale of Goods Act, 1893). Sce post, p. 406.

(a) Arg. Mitelicson r. Nicol, 7 Exch. 935; Bill r. Bament, 9 M. \& W. 36 ; Lucas v. Dixon, 22 Q. B. D. 357. (b) See per Patteson, J., Lamb Pegg, 1 Dowl. 447.

(c) Kearslahe r. Morgan, $5 \mathrm{~T}$. 513 ; per Pollock, C. B., Grifiths Oxen, 13 M. \& W. 64 ; Jumes Williams, Id. 828; and cases cif Gibbons r. Touillon, 8 C. B. 48 See Rugg r. Weir, 16 C. B., N. $4 i 1$.

(d) Bottomley v. Nuttall, is C. N. S. 137, and cases there cited.

(e) See, in connection with the te Croft $r$ London and Worth Wist. R. C., 3 B. \& S. 436.

(f) Post, Book II., Chap. 1.

(g) Ford r. Bcch, 11 Q. B. 8 867: distinguished in Slater r. Jor L. R. 8 Ex. 190, 192; Gibbons Vouillon, 8 C. B. 483; Delshaw 
Sometimes a plaintiff, in order to avoid incurring useless spense and disappointment, will be well advised to examine he Statute of Limitations (h) applicable to his case, with a iew to ascertaining whether his remedy is barred by its rovisions, or with a view to preventing its operation.

It may also be advisable for the claimant also to consider hether the proposed action can be barred by applying the octrine of res judicata (i), or, is so, by some express nactment.

3. Where the proposed action is to be brought under the rovisions of an Act of Parliament, care must be taken that Statutory
requirements. se requirements (if any) of the particular Act having ference to matters preliminary to the issuing of the writ e complied with $(k)$. In some cases, for instance, the onsent of a Judge $(l)$, or of the Attorney-General $(m)$, may $e$ indispensable before commencing the action.

4. Another point for consideration may be, whether or ot any kind of notice is necessary before suing.

It is indeed true, that, wherever the enforcement of a ight of action is contemplated, some reasonable notice of 1e intended proceeding (even when not in strictness equisite), or some demand for pecuniary compensation, or sme request for the performance of that which has been rongfully left undone, should be made upon the opposite arty, in order that a fair opportunity for an amicable sttlement may thus be afforded him. And hence it is, lat a respectable solicitor will always make a demand of Jme sort on behalf of his client before complying with his istructions as to issuing the writ. Cases do, moreover,

:sh, 11 C. B. 191 ; Webb v. Spicer, ; Q. B. 885 ; Bottomley v. Nuttall, pra. See Bateson v. Gosling, L. R. C. P. 9 ; Newington v. Levy, L. R. C. P. 607 , followed in Hall v. Levy, R. 10 C. B. 154.

(h) Post, pp. 153 et seq.

(i) See, for instance, Wright $\mathrm{v}$. ondon General Omnibus Co., 2 Q. B.
D. 271 ; Concha v. Concha, 11 App. Cas. 541 .

(k) See, for instance, New River Co. จ. Nather, L. R. 10 C. P. 442 ; Lea v. Abergavenny Comm., I6 Q. B. D. 18.

(l) Grant v. Brown, 1 D. \& L. 799.

(m) Boyce v. Higgins, 14 C. B. I ;

Rochfort v. Atherlcy, 1 Ex. D. 511.
Sotice of action. 
present themselves, in which proof of a demand and refusal may, on other grounds, be highly expedient, or may even be indispensable to a successful issue, $e x . g r$., where the action is brought for "wrongfully depriving plaintiff of goods," it may, in the absence of other proof, be needed as evidence of the tort; or in an action for slander, which it may be unsafe to bring without previously inquiring whether the adverse party means to abide by the slanderous imputation complained of or will retract it $(n)$.

But, besides cases like those just alluded to, there are many statutes, under which formal notice is essential before commencing an action $(o)$; something having been done which ought not to have been done, or something omitted which ought to have been done $(p)$.

Where protection of this kind is conferred by the statute law, difficulty may occur in determining whether the defendant has so acted as to have brought himself within the words and meaning of the particular clause, which requires that notice of action should be given $(q)$.

Demaud of warraut.

Nature of claiu.

In some cases it is also necessary, before commencing an action against constables and other officers, to make a demand for the warrant under which they committed the act complained of $(r)$.

5. Assuming that proper notice, when it is requisite, has been given, the plaintiff must carefully consider " the nature of the claim " to be made, or of " the relief or remedy" to

(n) Per Lord Denman, C. J., Griffiths v. Lexis, 7 Q. 13. 66 .

As to giving defendant sufficient opportunity of tendering amends before commencing proceedings, see $56 \& 57$ Vict. c. 61 , s. 1 (d).

(o) See Joliffe v. Wallasey Loeal Board, L. R.9 C. P. 62, and cases there cited; Chamberlain v. King, I. R. 6 C. I. 474; Fent r. Great Western R. C., 3 C. B. T14; Carpue v. London and Brighton R. C., 5 Q. B. 747. 81,82 . (q) Hughes v. Buekland, 15 MS. \& W. 346 , with which compare Douning v. Capel, L. R. 2 C. P. 461. See Horn v. Thornborough, 3 Exch. 846; Cobbett r. Narner, 1 H. \& N. 388; Garton .v. Great Western R. C., E. B. \& E. 837 ; Booth v. Clive, 10 C. B. 827; Acc. Hermann r. Seneschal 13 C. B., N. S. 392, 404; Roberts v. Orchard, 2 H. \& C. 769 (with which compare Leete r. Hart, L. R. 3 C. P. 322); Chamberlain v. King, L. R. 6 C. P. 474.

(r) 24 Geo. 2, c. 44 , s. 6 ; 51 \& 52 Vict. c. 43, s. 54 . 
be required in the action, a statement whereof must be indorsed upon the writ of summons $(s)$. And if the claim be foundea on a legal right, the plaintiff will assign it to the Queen's Bench Division of the High Court of Justice. Should a mistake be made in thus assigning the action, delay and expense may be incurred.

6. Before commencing his action, the plaintiff must of course determine by and against whom it should be brought; bearing in mind these elementary rules (1) that a man cannot sue himself $(t)$, and (2) that the onus of showing that a complainant has lost the ordinary right to maintain an action lies on him who denies such right ( $u$.).

In general, "The proper person to bring an action is the person whose right has been violated" $(x)$. He, for instance, should sue whose legal right or property has been affected by the tortious act of another $(y)$. A non-compliance with this rule will not, however, necessarily defeat the action; for should it be commenced in the name of the wrong person as plaintiff, the Court or Judge will, if satisfied that it has been so commenced through a bon $\hat{\imath}$ fide mistake (and if it be necessary for the determination of the real matter in dispute so to do), order any other person or persons to be substituted or added as plaintiff or plaintiffs upon such terms as may be just (z), provided he or they consent (a). Moreover, all persons may be joined as plaintiffs in whom the right to any relief claimed is alleged to exist, whether jointly, severally, or in the alternative $(b)$. Thus an action for libel has been held maintainable at suit

(s) Post, p. 125.

(t) Simpson v. Thomson, 3 App. Cas. 288. See Girdlestone v. Brighton Aquarium Co., 4 Ex. D. 107.

(u) Mulkern v. Lord, 4 App. Cas. $182,193$.

(x) Per Willes, J., Gray v. Pearson, L. R. 5 C. P. 574.

(y) See per Lord Kenyon, C. J., Dawes v. Peck, 8 T. R. $332 ; 4$ R. R. 675. (z) Order xvi., R. 2. Turquand v. Fearon, 4 Q. B. D. 280; Val de Travers Co. v. London Tramways Co., 48 L. J. C. P. 312 . See Ayscough v. Bullar, 41 Ch. D. 341.

(a) Tryon v. Nat. Prov. Inst., 16 Q. B. D. 678 .

(b) Order xvi., R. 1. See as to this rule, Hannay $\nabla$. Smurthwaite, (1893) 2 Q. B. 412 , per Bowen, L. J., and (1894) A. C. 494.
Parties to action. 
of eight persons neither in partnership nor otherwise interested than as haring been jointly libelled $(c)$.

Judgment, moreover, may be given for one or more of several plaintiffs for such relief as he or they may be entitled to $(d)$. And where there are numerous parties having the same interest in one action, one or more of such parties may sue or be sued, or may be authorized by the Court to defend in such action, on behalf or for the benefit of all interested ( $(c)$.

The most general rule at common law as to choosing the defendant in an action is-that the person committing the alleged breach of contract or tortious act, or asserting a right or title adverse to the plaintiff's, should be sued. And it has been judicially observed that " all parties against whom remedy or relief is sought should if possible be joined in the same action " $(f)$.

It may, moreover, be advisable to join two persons as codefendants if doubt exists as to which of them is liable, $e x . g r$. , if the owner of land erect on it a nuisance and then demise the land for a term, he will be liable for the erection of the nuisance in the first instance, though circumstances must determine whether the lessor or lessee be liable for its continuance, whether the demise could be held to operate as an affirmance of the nuisance $(g)$, or whether the tenant has

(c) Booth r. Briscoe, 2 Q. B. D. 496 ; Gort v. Rotcney, 17 Q. B. D. 625. See the observations upon these cases, Smurthuaite r. Hamnay, (1894) A. C. 494, reversing C. A., (1893) 2 Q. B. 412 ; cf. also Sandes v. Wildsmith, (1893) 1 Q. B. 771.

(d) Order xvi., R. 1.

The defendant, though unsuccessful, will, howerer, be entitled to his costs occasioned by the misjoinder.

(e) Order xri., R. 9. De Hart v. Stecenson, 1 Q. B. D. 313 . This rule applies only to persons who have or claim some proprietary right, which they are asserting or defending in the cause or matter, ef. Temperton v. Russell,
(1893) 1 Q. B. 435 (C. A.). See also Wood r. McCarthy, (1893) \& Q. B. 775 , where it was held that the order can be made even although some of those, on whose behalf authority to defend is giren, object.

(f) Norris r. Beazley, 2 C. P. D. 87. (g) Rosewell v. Prior, 2 Salk. 460; Mason r. Shrewsbury and Hereford R. C., I. R. 6 Q. B. 578 ; Todd v. Flight, 9 C. B., N. S. 377 ; Rich v. Basterfield, 4 C. B. 801; Russell v. Briant, 8 C. B. 836 ; recognised in Lyon v. Knowles, 3 B. \& S. 563, 565 ; 5 Id., 751 ; Holmes v. Wilson, $10 \mathrm{Ad}$. \& E. 503. 
undertaken to keep the premises in repair and thereby has relieved the landlord from responsibility $(h)$. " There are," it has been said, "only two ways in which landlords or" owners can be made liable in the case of an injury to a stranger by the defective repair of premises let to a tenant, the occupier and the occupier alone being prima facie liable: 1st, in the case of a contract by the landlord to do repairs, where the tenant can sue him for not repairing; 2ndly, in the case of a misfeasance by the landlord, as, for instance, where he lets premises in a ruinous condition " (i).

Now, in a state of things such as referred to, and generally, where in an action, founded upon contract or otherwise, the plaintiff is in doubt as to the person from whom he is entitled to redress, he may join two or more defendants, to the intent that the question as to which, if any, of them be liable, and to what extent, may be determined $(k)$. The plaintiff may also join as defendants in an action all persons against whom the right to any relief is alleged to exist, whether jointly, severally, or in the alternative. And judgment may be given against one or more of the defendants according to their respective liabilities $(l)$. Moreover, it is not necessary that each defendant should be interested as to every cause of action included in any proceeding against him, but such order as may appear just will be made to prevent a defendant from being embarrassed or put to expense by being required to attend proceedings in the action in which he may have no interest $(m)$. Further, the plaintiff may, at his option, join as parties to the action all or any of the persons severally, or jointly and severally, liable on any one contract, including parties to bills of exchange and promissory notes $(n)$. And no action will be defeated by reason

(h) Pretty v. Bickmore, L. R. 8 C. P. 401 ; approved in Gwinnell v. Eamer, L. R. 10 C. P. 658.

(i) Nelson v. Liverpool Brewery Co., 2 C. P. D. 311.

(k) Order xvi., R. 7. Honduras
Inter-oceanic R. C. v. Lefevre, 2 Ex. D. 301 ; Child v. Stenning, 5 Ch. D. 695.

(l) Order xvi., R. 4.

(m) Id., R. 5 .

(n) Id., R. 6. 
of the misjoinder or non-joinder of parties, the Court dealing with the matter in controversy so far as regards the rights and interests of the persons actually before it $(o)$.

Besides the above general statutory provisions as to the choice and joinder of parties to an action, some specific rules applieable in particular cases have been promulgated.

Partners. Any two or more persons claiming or being liable as copartners, and carrying on business within the jurisdiction, may sue or be sued in the name of the firm of which they were co-partners at the time when the cause of action accrued: and in such case application may be made by summons to a Judge for a statement of the names of the persons who are co-partners in such firm, to be furnished in such manner, and verified on oath or otherwise, as the Judge may direct; if the plaintiff knows the firm to have been dissolved before action, he must serve the partners separately $(p)$.

Any person carrying on business within the jurisdiction in a name or style other than his own name may be sued in such name or style as if it were a firm name; and, so far as the nature of the case will permit, all rules relating to proceedings against firms shall apply $(q)$.

Trustee in Lankruptcy.

Infants.

Married wonter.

Claims by a trustee in bankruptcy as such cannot, unless by leave, be joined with a claim by him in any other capacity $(r)$.

Infants may respectively sue as plaintiffs by their next friends, and may defend by their guardians appointed for that purpose. A married woman may sue and be sued as provided by the Married Women's Property Act, 1882 (s).

(o) Order xri., R. 11.

(p) Order xlviii., A., Rules 1 and 3. If the firm does not carry on business within the jurisdiction it cannot be sued in the firm name, Russell $\mathrm{r}$. Cambefort, 23 Q. B. D. 526; Western National Bank of New York v. Perez Triana \& Co., (1891) I Q. B. 304;
Heineman v. Hale, (1891) 2 Q. B. 83. An agency even though the name of the firm be painted on the door will not. suffice, Grant r. Anderson, (1892) I Q. B. 108 .

(q) Order xlviii., A., R. 11.

(r) Order xriii., R. 3.

(s) Order xri., R. 16. As to mar- 
And claims by or against husband and wife may, unless otherwise ordered, be joined with claims by or against either of them separately $(t)$.

Where a lunatic or person of unsound mind, not so found by inquisition, might formerly have sued as plaintiff or Non would have been liable to be sued as defendant in an action $(u)$, he may sue by his committee or next friend, and may defend an action by his committee or guardian $(v)$.

In respect of a breach of contract committed in the lifetime of a contractor, his executors or administrators may Executors and armiin general sue at common law $(x)$. The right of personal representatives to sue in tort is however given and regulated by statute $(y)$. By the $4 \mathrm{Edw} .3$, c. 7, reciting, that, "in times past executors have not had actions for a trespass done to their testators, as of the goods and chattels of the same testators carried away in their lifetime," it is enacted, "that the executors in such cases shall have an action against the trespassers," in like manner as they whose executors they are should have had if they were living. An administrator is within the equity of this statute, and by $25 \mathrm{Edw} .3$, st. 5, c. 5, the like remedy is extended to the executor of executors.

Again, the $3 \& 4$ Will. 4, c. 42, provides, upon certain conditions, a remedy by the executors or administrators for injuries done to the real estate of any deceased person committed in his lifetime $(z)$. The most important modification, however, of the maxim Actio personalis moritur cum per-

ried women, cf. Married Women's Property Act, 1893, (56 \& 57 Vict. c. 63), s. 1 .

(t) Order xviii., Rules 4 \& 7 .

(u) Post, Book II.

(v) Order xvi., R. 17.

(x) Book II.

Executors have a joint and entire interest in the testator's goods, even when one only of them has proved the will; Webster v. Spencer, 3 B. \& Ald. 363. See Venables v. East India Co., 2 Exch. 633 ; Stubs v. Stubs, 1 H. \&
C. 257, 265.

(y) 1 Wms. Saund. 216a. ; Le Mason v. Dixon, Sir W. Jones, 174 ; Raymond v. Fitch, 2 Cr. M. \& R. 588 ; Palgrave v. Windham, 1 Str. 212 ; Bunbury v. Hewson, 3 Exch. 558; Morgan v. Thomas, 8 Exch. 302; Welchman v. Sturgis, 13 Q. B. 552; Barnett v. Earl of Guildford, 11 Exch. 19, and cases cited post, Book II., Chap. VII., s. 2 .

(z) Sect. 2. Cf. Jones v. Simes, 43 Ch. D. 607 . 
son $\hat{a}(a)$ has been effected by the stat. $9 \& 10$ Vict. c. 93 (amended by $27 \& 28$ Vict. c. 95 ), which was enacted with a view of compensating the families of persons killed by accident, and which the reader will find commented on hereafter.

Another general rule with regard to executors and administrators is that being personal representatives of the deceased, though not expressly named $(b)$, they are liable, to the extent of assets, on all his covenants and contracts broken in his lifetime, and on such as are broken after his death, provided that his skill or taste were not required for their performance $(c)$, and that they were not to be performed by him in person or limited expressly to his lifetime (d). In Hambley v. Trott (e), Lord Mansfield laid it down, that, "when the cause of action is money due, or a contract to be performed, gain or acquisition of the testator by the work and labour or property of another, or a promise of the testator, express or implied,-where these are the causes of action, the action survives against the executor."

The $3 \& 4$ Will. 4, c. 42, s. 2, regulates in some important particulars $(f)$ actions against executors and administrators. It recites that there had been no remedy provided by law for certain wrongs done by a person deceased in his lifetime to another in respect of his property real or personal-and it then proceeds to enact that action of "trespass or on the

(a) Raymond r. Fitch, 2 Cr. M. \& R. 597 ; Richetts v. Wenver, 12 M. \& W. 723; Leg. Max., 6th ed., p. 855.

(b) Williams v. Burrell, I C. B. 402; Lock v. Furze, 19 C. B., N. S. 96.

(c) Siboni v. Kirkman, 1 M. \& W. 423; Tasker v. Shepherd, 6 H. S N. 575 .

(d) Hyde v. Dean and Canons of II-indsor, Cro. Eliz. 552 ; cited per Wightman, J., Penfold v. Abbott, 32 L. J., Q. B. 6i, 68; JKorgan v. Ravey, 6 H. \& N. 265: Judgm., Taylor v.
Calduell, 3 B. \& S. 835 .

(e) 1 Cowp. 375. See Ex parte Tindal, 8 Bing. 40t; Poucell v. Grahan, 7 Taunt. 580; 18 R.R. 593; $3 \& 4$ Will. 4 , c. 42, s. $14 ; 4 \& 5$ W. \& MY. c. 24 , s. 12 ; Prior v. Hembrow, 8 M. \& W. $889,890$.

(f) As to the liability ex delicto of personal representatives generally, see Hambly v. Trott, 1 Cowp. 373, 375, recognised 7 Ad. \& E. 429 : per Lord Kenyon, C. J., 3 T. R., 549 ; Com. Dig. "Administration" (B. 15). 
case," i.e., for a direct or indirect tort, " may be maintained against the executors or administrators of any person deceased," the wrong having been done by him in his lifetime to another in respect of property real or personal $(a)$, so as such injury shall have been committed within six calendar months before such person's death (h), and so as such action shall be brought within six calendar months after such executors or administrators shall have taken upon themselves the administration of the estate and effects of such person $(i)$. Thus, for a tort to the property of another, whether real or personal, a remedy adapted to the circumstances may be enforced against the personal representatives of the party originally liable $(j)$.

But neither the above Act nor the $9 \& 10$ Vict. c. $93(k)$ (amended by $27 \& 28$ Vict. c. 95) supply any remedy against the representatives of one deceased who has committed a tort to the person of another, whether death has or has not thence resulted.

Claims by $(l)$ or against an executor or administrator, as such, may, unless otherwise ordered, be joined with claims by or against him personally, if alleged to arise with reference to the estate in respect of which the plaintiff or defendant sues or is sued as representative $(m)$. It is further provided that trustees, executors and administrators may sue and be sued on behalf of or as representing the property or estate of which they are representatives, without joining any of the parties beneficially interested therein, though

(g) See Mrorgan v. Ravey, 6 H. \& N. 265 . 134 . 426.

(i) See Powell v. Rees, 7 Ad. \& E.

(j) Ward v. Audland, 16 M. \& W. S62; Le Mason v. Dixon, Sir W. Jones, 173,174 ; and authorities cited supra, n. $(f)$.

(k) Lord Campbell's Act. Comparable with the right of action under this statute is the right of the legal personal representative under the Employer's Liability Act, 1880 ( 43 \& 44 Vict. c. 42).

(l) The rule at common law is that executors may sue as such where the damages recovered would be assets: Abbott v. Parfitt, L. R. 6 Q. B. 346 . See also Hatchard v. Mègc, 18 Q. B. D. 771 ; Oakey v. Dalton, 35 Ch. D. 700 ; Bowker v. Evans, 15 Q. B. D. 565.

(m) Order xviii., Rules 5 and 7 . 
Change of parties by leath, ic.

the Court or a Judge may, at any stage of the proceedings, order any of such persons to be made parties to the action, either in addition to or in lieu of those previously existing $(n)$.

By Order XVII. the proceedings in an action are not abated by reason of the marriage, death, or bankruptcy of any of the parties to it, if the cause of action survive or continue, and do not become defective by the assignment, creation, or derolution of any estate or title pendente lite $(o)$.

In case of such marriage, death or bankruptcy, or the devolution of estate by operation of law, of any party to an action, the Court or a Judge may, if it be necessary for the complete settlement of all the questions involved in the action, order that the husband, personal representative, trustee, or other successor in interest, if any, of such party be made a party to the action $(p)$. And in case of any assignment, creation, or devolution of any estate or title pendente lite, the action may be continued by or against the person to or upon whom such estate or title has come or devolved $(q)$.

Where by reason of marriage, death $(r)$, or bankruptcy, or any other event occurring after the commencement of an action, and causing a change or transmission of interest or liability, or by reason of any person interested coming into existence after the commencement of the action, it becomes necessary or desirable that any person not already a party should be made a party to the action, or that any person already a party should be made a party thereto in some other capacity, an order to that effect may be obtained $(s)$.

(u) Id. ; Order xvi., R. 8. This rule applies to trustees, executors and administrators, sned in proceedings to enforce a security by foreclosure or otherwise (R. S. C., Nor. 1893, R. 4).

(o) Order xvii., R. I.

(p) Order xrii., R. 2. Such person becomes personally liable to the costs; see Boynton v. Boynton, 4 App.Ca. 733 ; Borneman v. Wilson, 28 Ch. D. 53 .

(q) Id., R. 3.

(r) See Tuycross r. Grant, 4 C. P. D. 40 .

(s) Order xvii., R. 4. 
Where a defendant in the action claims to be entitled to contribution or indemnity, over against any person not a party to the action, such person may, after notice in form provided, be made a party to the action, and his liability to the defendant may be decided at the trial $(t)$.

\section{Proceedings from Writ inclusive to Appearance.}

Assuming that the various points suggested for consideration before commencing an "action" have been disposed of, the first step to be taken is that of summoning the party against whom the action is to be brought into the Court in which it is meant to be carried on. It is accordingly ordered that "every action in the High Court of Justice shall be commenced by a writ of summons, dated of the day when issued, indorsed with a statement of the nature of the claim made, or of the relief or remedy required in the action, and specifying the Division of the High Court to which it is intended that the action should be assigned " $(u)$.

The writ of summons, if meant for service within the jurisdiction, is addressed to the defendant, and is thus worded: "We command you, That within eight days after the service of this writ on you, inclusive of the day of such service, you do cause an appearance to be entered for you in an action at the suit of $A . B$. ; and take notice, that in default of your so doing the plaintiff may proceed therein, and judgment may be given in your absence" $(x)$.

Should a mistake be made in selecting a Division of the High Court to which the action is assigned, a transfer of the action to some other Division would be ordered, otherwise all interlocutory proceedings in the action will be taken in the Division specified in the writ $(y)$.

(t) Order xri., Rules 48 to 55 .

(ii) Order ii., Rules 1, 8.

(x) R. S. C., App. (A), Part I.,

Form No. 1.

(y) $39 \& 39$ Vict, c. 77, s. 11 ;

Order xlix. 
The indorsement of claim must be made on the writ of summons before it is issued (z). It is not, however, essential that this indorsement should set forth the precise ground of complaint, or the precise remedy or relief to which the plaintiff considers himself entitled. The indorsement may by leave of the Court or Judge be amended if necessary $(a)$. If the plaintiff sues or the defendant is sued in a representative capacity, this should be shown by the indorsement $(b)$.

Special in. dorsement.

Where the plaintiff seeks merely to recover "a debt or liquidated demand in money payable by the defendant, with or without interest, arising (A) upon a contract, express or implied," ex. gr., " on a bill of exchange, promissory note, cheque, or other simple contract debt, or (в) on a bond or contract under seal for payment of a liquidated amount of money, or (c) on a statute where the sum sought to be recovered is a fixed sum of money or in the nature of a debt other than a penalty, or (D) on a guaranty, whether under seal or not, where the claim against the principal is in respect of a debt or liquidated demand only, or (E) on a trust, or $(F)$ in actions for the recovery of land, with or without a claim for rent or mesne profits, by a landlord against a tenant whose term has expired, or has been duly determined by a notice to quit, or against persons claiming under such tenant, the writ of summons may, at the option of the plaintiff, be specially indorsed with a statement of his claim or of the remedy or relief to which he claims to be entitled" $(c)$. And wherever the plaintiff's claim is for a debt or liquidated demand only, the indorsement, besides stating the nature of the claim, should state the amount claimed for debt, or in respect of such demand, and for costs respectively, and should further state, that upon pay.

(z) Order iii., R. 1.

(a) Order xxviii., R. 1. And see

(b) Order iii., R. 4. Order sx., R. 4.

(c) Order iii., R. 6. 
ment thereof within four days after service, or in case of a writ not for service within the jurisdiction within the time allowed for appearance, further proceedings will be stayed $(d)$.

A special indorsement on the writ of summons will enable the plaintiff, in case of appearance or of default of appearance by defendant, to obtain speedy judgment against $\operatorname{him}(e)$.

I may add that the address of plaintiff, and of his solicitor, if one be employed, must be indorsed upon the writ of summons $(f)$, and if on demand made by defendant, such solicitor state that the writ was not issued by him, or with his authority or privity, proceedings in the action will be stayed $(g)$.

A writ specially indorsed under Order III., R. 6, is now a statement of claim, and is regarded as a pleading $(h)$.

The form of a writ of summons for service or notice out of the jurisdiction (i) differs somewhat from that given at Writ for service out of the jurisp. 125, inasmuch as the time allowed in it for appearance diction.

is determined by reference to the locality where the defendant is or is supposed to be. This form has to be used not only where a single defendant but where one or more of several defendants is or are out of the jurisdiction.

A writ is issued by being sealed by the proper officer with whom a copy is filed $(k)$.

The plaintiff in an action, wherever resident, may either issue a writ of summons out of the central office in London, or out of the registry of any district. Should the defendant reside or carry on business within such district, the writ of summons, issued out of the district registry, must state on the face of it that the defendant do cause an appearance

Writ, how issued.

Writ, where issued. (d) Id., R. 7.

R. 3 .

(f) Order iv.

(g) Order vii., R. 1. (h) Order xx., R. 1 (A).

(i) R. S. C., App. (A), Part I., Form No. 5 .

(k) Order v., Rules 11, 12. 
to be entered at that registry. But should the defendant neither reside nor carry on business within such district there must be a statement on the face of the writ that he may cause an appearance to be entered at his option either at the district registry or at the central office $(l)$.

Service of

When the writ has been issued and sealed it must-unless writ. the defendant by his solicitor agrees to accept service and enters an appearance-be served on $\operatorname{him}(m)$. Service of the writ is required on grounds of natural justice-which demands that every man shall have notice of legal proceedings instituted against him, in order that he may defend himself accordingly - this proposition, which scarcely needs authority to support it, may be illustrated by cases where it has been held to be a sufficient answer to an action upon a foreign judgment in our Courts, that notice of the proceedings abroad was not duly given to the defendant. Thus, in Ferguson v. Mahon (n), to an action on a judgment obtained in the Court of Common Pleas in Ireland, the defendant pleaded that he had never been arrested upon, or served with, or at any time had notice of any process of the Court at the plaintiff's suit for the cause of action on which the judgment was obtained, and that he (the defendant) had never appeared to the action; and this plea was held good, because, said Lord Denman, C. J., "when it appears, as here, that the defendant has never had notice of the proceeding or been before the Court, it is impossible for us to allow the judgment to be made the foundation of an action in this country."

Service of the writ of summons is made by delivering a copy of the writ to the defendant personally, and at the same time showing him the original, if demanded-should, however, the plaintiff be unable to effect prompt personal

(l) Order v., Rules 1 to 4 .

(m) Order ix., Rules 1, 2.

(n) 11 Ad. \& E. 179 ; see Meens v. Thellusson, 8 Exch. 638; Sheehy v. Professional Life Ass. Co., 13 C. B. 787 ; Leg. Max., 6th ed., p. 106. 
service, the Court or Judge may make such order for substituted or other service, or for the substitution of notice for service, as may seem just $(o)$.

The mode of serving the writ on particular defendants and in particular actions is specified in Order IX.; and in an action to recover land in case of vacant possession $(p)$, service of the writ when it cannot otherwise be effected may be made by posting a copy of it upon the door of the dwelling-house or other conspicuous part of the property in question $(q)$.

The person serving a writ of summons is required, within three days at most after such service, to indorse on the writ the day of the month and week of the service thereof, otherwise the plaintiff will not be at liberty, in case of nonappearance, to proceed as he otherwise might do by default; and every affidavit of service of the writ must mention the day on which such indorsement was made, which rule applies to substituted as well as other service $(r)$.

Service out of the jurisdiction of a writ of summons or notice (s) of a writ of summons may be allowed by the Court Service out of the jurisor a Judge in certain cases, viz., whenever (A) the whole subject-matter of the action is land, situate within the jurisdiction, with or without rents or profits $(t)$; or (B) any act, deed, will, contract, obligation or liability affecting land or hereditaments situate within the jurisdiction, is sought to be construed, rectified, set aside, or enforced in the action;

(o) Order ix., R. 2.

(p) I.e., where the premises sought to be recovered are wholly deserted and roid. However, even where there is no tenant actually upon the premises, a distinction must be taken between a case where the tenant has actually abandoned the possession, and a case where, although he has discontinued to occupy the premises, he still retains the virtual possession of them or other. wise. In the former only of the two cases just specified must the claimant proceed as upon a racant possession; Doe d. Lord Darlington v. Cock, $4 \mathrm{~B}$. \& C. 259.

(q) Order ix., R. 9.

(r) Id., R. 15 .

(s) Where the defendant is neither a British subject nor in British dominions notice of the writ, not the writ itself, must be served in accordance with the comity of nations : Order xi., R. 6 .

(t) See Casey v. Arnott,2 C.P.D. 24. 
or (c) any relief is sought against any person domiciled or ordinarily resident within the jurisdiction; or (D) in certain administration cases; or (E) when the action is founded on any breach or alleged breach within the jurisdiction of any contract wherever made, which according to the terms thereof ought to be performed within the jurisdiction, unless the defendant is domiciled or ordinarily resident in Scotland or Ireland $(u)$; or ( $F$ ) any injunction is sought as to anything to be done within the jurisdiction, or any nuisance within the jurisdiction is sought to be prevented or removed, whether damages are or are not also sought in respect thereof; or (G) any person out of the jurisdiction is a necessary or proper party to an action properly brought against some other person duly served within the jurisdiction $(x)$.

The question whether the subject-matter of an action is such that service of a writ out of the jurisdiction ought to be allowed, is for the decision of a Judge at Chambers, subject to appeal, and the defendant cannot raise the question by statement of defence $(y)$.

Every application for an order for leave to serve the writ or notice on a defendant out of the jurisdiction must be supported by affidavit, or other evidence stating that in the belief of the deponent the plaintiff has a good cause of action, and showing in what place or country such defendant is or probably may be found, and whether such defendant is a British subject or not, and the grounds upon which the application is made $(z)$, and by the order giving leave to effect such service or give such notice a time is limited after such service or notice within which the defendant is to enter an appearance, such time to depend on the place or

(u) See Reynolds r. Coleman, 35 W. R. 813. See also this case explained Bell v. Antwerp Line, (1891) 1 Q. B. 103, C.A.: and followed Rein v. Stein, (1892) I Q. B. 753 .

$(x)$ Order xi., R. 1. See Scott v.
Royal Wax Candle Co., 1 Q. B. D. 404. 361 .

(y) Preston v. Lamont, 1 Ex. D.

(z) Order xi., R. 4. 
country where or within which the writ is to be served or the notice given $(a)$.

Notice in lieu of service must be given in the manner in which writs of summons are served $(b)$.

The writ of summons remains in force for twelve calendar months and must be served within that period from the Duration of writ. date thereof. Should the defendant, however, not have been served with the writ, the plaintiff, in order to prevent the operation of the Statute of Limitations $(c)$, or for other purposes, may before the expiration of the twelve months renew the writ on leave obtained from a master or the district registrar to do so, and the master or registrar, if satisfied that reasonable efforts have been made to serve the defendant, or for other good reason, may order that the original or concurrent writ of summons be renewed for six months from the date of such renewal, and so from time to time during the currency of the renewed writ. The mrit cannot be renewed if the Statute of Limitations has run so as to bar the debt or claim (d).

The writ is renewed by being marked with a seal bearing the date of its renewal, and a writ of summons so renewed will remain in force from the date of the issuing of the original writ of summons $(e)$.

With a view to facilitating service of the writ of summons where there are several defendants resident in different parts of the country, or where there is a single defendant whose precise residence is not known, it is competent to a plaintiff on issuing the original writ, or at any time during twelve months afterwards, to issue one or more concurrent writ or writs, each such writ to bear teste of the same day

(a) Order xi., R. 5.

(b) Id., R. 7 .

(c) Post, p. 153, et seq.

(d) Doyle v. Kaufman, 3 Q. B. D. T, 340; followed Hewett v. Barr, (1891) 1 Q. B. 98 .

(e) Order viii., R. 1.
The production of a writ of summons purporting to be marked with the seal of the Court, showing the same to have been renewed, will be suficient evidence thereof, and of the commencement of the action as of the first date of such renewed writ: Id., R. 2.
Renewal of writ.

Concurrent writs. 
as the original writ, and to be marked with a seal bearing the word "concurrent," and the date of issuing the concurrent writ; a concurrent writ will only be in force for the period during which the original writ is so $(f)$.

A writ for service within the jurisdiction may be issued and marked as a concurrent writ with one for service, or whereof notice in lieu of service is to be given, out of the jurisdiction; and rice versâ $(g)$.

It may be well here to mention the stat. $32 \& 33$ Vict. c. $62(h)$, which enacts (s. 6) that a person shall not be arrested upon mesne process; but where the plaintiff suing in an action in a superior court, in which the defendant would formerly have been liable to arrest, proves at any time before final judgment by evidence on oath, to the satisfaction of a Judge, that the plaintiff has good cause of action against the defendant to the amount of $50 l$. or upwards, and that there is probable cause for believing that the defendant is about to quit England unless he be apprehended, and that the absence of the defendant from England will materially prejudice the plaintiff in the prosecution of his action; that is to say, that his evidence is absolutely necessary, not that judgment cannot be realised if he goes; disclosing the facts he is to prove, so that if he admits them no order will be made (i), such Judge may order the defendant to be arrested and imprisoned for a period not exceeding six months, unless and until he has sooner given the prescribed security, not exceeding the amount claimed in the action, that he will not go out of England without the leave of the Court. Where, however, the action is for a penalty or sum in the nature of a penalty, other than a penalty in respect of any contract, it will not be necessary to prove that the absence of the defendant from England will materially prejudice the plaintiff in the 
prosecution of his action, and the security given (instead of being that the defendant will not go out of England) will be to the effect that any sum recovered against the defendant in the action shall be paid, or that the defendant shall be rendered to prison. The defendant cannot be kept in prison after final judgment has been signed $(k)$.

A defendant enters his appearance to a writ of summons Appearance. by delivering to the proper officer a memorandum in writing dated on the day of delivering the same, and containing the name of the defendant's solicitor, or stating that the defendant defends in person; he must on the same day give notice to the plaintiff of his appearance either by notice in writing or by letter $(l)$.

The appearance ought regularly in accordance with the exigence of the writ to be entered within eight days after it has been served $(m)$. A defendant may, however, appear at any time before judgment. Though, if he do so after the time limited for appearance, he will not, unless otherwise ordered, be entitled to any further time for delivering his defence, or for any other purpose, than if he had appeared according to the writ $(n)$. The appearance may be entered in London (o), unless when the defendant to a writ issued in a district registry resides or carries on business within the district, in which case he must appear in the district registry $(p)$, though, should he neither reside nor carry on business in the district, he may appear either in the district registry or in London $(q)$.

If the defendant appears, or any of the defendants appear, 214.

(k) Hume v. Druyff, L. R., 8 Ex.

(l) Order xii., Rules 8, 9. As to the memorandum of appearance, see also Id., R. 13. A solicitor not entering an appearance in pursuance of his written undertaking so to do on behalf of any defendant will be liable to an attachment : R. 18.

(m) Ante, p. 125. (n) Order xii., R. 22.

Partners sued in the name of their firm, must appear individually in their own names. But all subsequent proceedings will continue in the name of the firm: Order xlviii. A, R. 5 .

(o) Order xii., R. 1.

(p) Id., R. 4.

(q) Id., R. 5. 
in London the action will proceed there unless the Court or a Judge be satisfied that the defendant so appearing is a merely formal defendant, or has no substantial cause to interfere in the conduct of the action $(r)$. And if a sole defendant appears, or all the defendants appear, in the district registry, or if all the defendants who appear, appear in the district registry and the others make default in appearance, then, subject to the power of removal $(s)$, the action will proceed in the district registry $(t)$.

A person appearing to defend an action for the recovery of land as landlord in respect of property whereof he is in possession only by his tenant, must state in his appearance that he appears as landlord $(u)$, and a defendant appearing to a writ of summons for the recovery of land will be at liberty to limit his defence to a part only of the property mentioned in the writ $(x)$. A person not named as a defendant in a writ of summons for the recovery of land may, by leave, appear and defend, on filing an affidavit showing that he is in possession of the land either by himself or by his tenant $(y)$.

Appearance to writ specially indorsed. Order XIV.

The benefit derivable to a plaintiff from specially indorsing the writ of summons when that can be done $(z)$ is in part (a) indicated by Order XIV., for where the defendant appears to a writ so indorsed the plaintiff may, on affidavit verifying the cause of action, and swearing that in the deponent's belief there is no defence to it, call on the defendant to show cause why the plaintiff should not be at liberty to sign final judgment for the claim indorsed on the writ, together with interest and costs; and thereupon, unless the defendant, by affidavit, by his own viva roce evidence, or otherwise, satisfy the Court or Judge that he has a good defence to the action

(r) Order xii., R. 7 .

(s) Order xxxr., R. 13 et seq.

(t) Order xii., R. 6.

(iv) R. 26.

(x) R. 28. (y) R. 25 .

(z) Ante, p. 126.

(a) See, as to default of appearance to a writ specially indorsed, post, p. 136. 
on the merits, or disclose such facts as the Court or Judge may think sufficient to entitle him to be permitted to defend the action, an order will be made empowering the plaintiff to enter judgment accordingly $(b)$.

If at the hearing of the application it appears that any claim which could not have been specially indorsed under Order III., Rule 6, has been included in the indorsement on the writ, the Judge may, if he think fit, amend the indorsement by striking out such claim, or may deal with the claim as if no other claim had been included in the indorsement, and allow the action to proceed as respects the residue of the claim $(c)$.

The power thus given to the Court or Judge where the defendant has appeared to a specially indorsed writ of summons to allow the plaintiff to sign final judgment, is intended to be exercised where it is shown, either from the acknowledgment of the debt by the defendant or from other circumstances, that the defence would be for the mere - purpose of delay $(d)$.

The application above mentioned must be made by summons returnable not less than four clear days after service $(e)$; the defendant may show cause against it by affidavit or (except in actions for the recovery of land) by offering to bring into Court the sum indorsed on the writ, or the Judge may allow the defendant to be examined upon oath. The affidavit must state whether the alleged defence goes to the whole or to part only, and if so, to what part, of the plaintiff's claim $(f)$. Should it appear that the defence set up by the defendant applies only to a part of the plaintiff's claim; or that any part of his claim is admitted; the plaintiff will, subject to terms, have judgment forthwith for such part of his claim as the defence does not apply to or

(b) Order xiv., R. 1 (a). See Runnacles v. IIesquita, 1 Q. B. D. 416 ; Ray v. Barker, 4 Ex. D. 279.

(c) Id., R. I (b). (d) Lloyd's Banking Co. v. Ogle, 1

Ex. D. 262.

(e) Order xiv., R. 2.

(f) Id., R. 3 . 
as is admitted to be due, and the defendant may be allowed to defend as to the residue of the plaintiff's claim $(g)$. Where the defence is a doubtful one, leave to defend is usually made conditional upon the giving of security or the payment of money into Court $(h)$.

Defanlt of appearance.

Should a defendant fail to appear to the writ of summons, the plaintiff before proceeding upon default as undermentioned, must file an affidavit of service of the writ or of notice in lieu of service, as the case may be $(i)$.

Where the writ is indorsed for a liquidated demand, whether specially or otherwise, and the defendant fails, or all the defendants if more than one fail to appear thereto, the plaintiff may enter final judgment for any sum not exceeding the sum indorsed on the writ, together with interest at the rate specified (if any), or (if no rate be specified) at the rate of five per cent. per annum to the date of judgment, and costs $(k)$.

Further, where the defendant fails, or all the defendants fail, to appear to the writ of summons and the plaintiff's claim is for detention of goods and pecuniary damages, or either of them, in that case interlocutory judgment may be entered and a writ of inquiry will issue to assess the value of the goods and the damages, or the damages only, as the case may be, in respect of the causes of action disclosed by the indorsement on the writ of summons; or by order of the Court or a Judge such value and amount of damages, or either of them, may be ascertained in any way in which a question arising in an action may be tried $(l)$.

Where the writ is indorsed with a claim for detention of

(g) Order xir., R. 4. See also R. 5, applicable where there are sereral defendants.

(h) See Order xiv., R. 6.

(i) Order xiii., R. 2.

Where no appearance has been entered to a writ of summons for a defendant who is an infant or of uusound mind not so found by inquisition, the plaintiff may apply to the Court or a Judge for an order that some proper person be assigned guardian of such defendant, by whom he may appear and defend the action: Id., R. I.

(k) Id., R. 3.

(l) Id., R. 5; where some of the defeudants only appear, see Rules 4,6 . 
goods and pecuniary damages, or either of them, and also for a liquidated demand, and the defendant fails, or all the defendants if more than one fail to appear, the plaintiff may enter final judgment for the debt or liquidated demand, interest, and costs against the defendant or defendants failing to appear, and inferlocutory judgment for the value of the goods and damages, or damages only, as the case may be; and he may then proceed with regard to these respective parts of his claim in the manner already pointed out, treating them as though they were independent claims in separate actions $(m)$.

If no appearance within the time limited for it be entered in an action for the recovery of land, or if an appearance be entered but the defence be limited to part only, the plaintiff may enter a judgment that the person whose title is asserted in the writ shall recover possession of the land, or of the part thereof to which the defence does not apply (n). And if a claim for mesne profits, arrears of rent, or damages for breach of contract, be indorsed upon the writ, the plaintiff may enter judgment for the land, and proceed as to such other claim so indorsed (o). Any judgment by default may be set aside or varied upon terms $(p)$.

\section{Proceedings from Appearance to Trial.}

The Pleadings in the Action.

The parties to an action may, after the writ of summons has been issued, concur in stating questions of law arising therein for the opinion of the Court, in the form of a special case concisely stating such facts and documents as may be necessary to enable the Court to decide the questions raised by it. Upon the argument of the case the Court will draw from the facts and documents stated therein any inference,

(m) Order xiii,, R. 7 .

(n) Id., R. 8. (o) Id, R. 9.

( $p)$ Id., R. 10. 
Trial without pleadings.

of fact or law, which might have been drawn therefrom if proved at a trial $(q)$. But no special case in an action to which a married woman (not being a party thereto in respect of her separate property or of any separate right of action by or against her), or any infant, or person of unsound mind, is a party, can be set down for argument without leave $(r)$. Also, if during the progress of the pleadings, a question of law is found to be involved, which it would be convenient to have decided before any evidence is given or any question or issue of fact is tried or referred, the Court or Judge may order that the question of law be raised, for the opinion of the Court, by special case or otherwise, and that such further proceedings as the decision of such question may render unnecessary be stayed $(s)$.

The ordinary method, however, of raising questions in dispute for decision in a superior Court, is by written pleadings made by the plaintiff and defendant of their respective grounds of action and defence. A plaintiff may, however, proceed to trial without pleadings subject to the following rules $(t)$ : (1) the indorsement of the writ of summons shall contain a statement sufficient to give notice of the nature of the claim made, or of the relief or remedy sought, and shall state that if the defendant appears the plaintiff intends to proceed to trial without pleadings ; (2) within ten days after appearance the plaintiff shall serve a twenty-one days' notice of trial $(u)$; (3) the defendant may, within ten days after appearance, apply by summons for the delivery of a stateunent of claim, and on such summons the Judge may order either that a statement of claim be delivered or that the action proceed to trial without pleadings, in which latter case the Judge may order either party to deliver particulars ;

(q) Order xxxiv., R. 1.

(r) R. 4.

(s) R. 2.

(t) Order xriii., $A$. (u) Form 16 (A), App. B., with such variations as circumstances may require. 
(4) if the Judge orders the action to proceed to trial without pleadings and makes no order for particulars all defences shall be open at the trial to the defendant. Where particulars are ordered the parties shall be bound by them so far as regards matters in respect of which particulars were ordered; (5) where the defendant has not taken out a summons for the delivery of a statement of claim he shall not rely on a set-off or counter-claim, or on a special defence $(v)$, unless (within ten days of appearance) he give notice, stating the grounds and particulars upon which he relies; (6) if the writ of summons be indorsed with a statement that if the defendant appears the plaintiff will proceed to trial without pleadings, no pleadings shall be required or delivered, except by order of the Judge made under Rule 3 .

The pleadings in an action, assuming that issues of fact Pleadings only are raised therein, are in general limited to the claim, generally. i.e., the statement of complaint, and of the relief or remedy to which the plaintiff claims to be entitled-the statement of defence, set-off, or counter-claim (if any) -and the reply thereto; such statements are to be as brief as the nature of the case will admit, the costs of unnecessary prolixity being borne by the party chargeable with it (u). And no pleading subsequent to reply other than a joinder of issue can be pleaded without leave, and then only upon terms $(x)$.

Unless otherwise ordered, the limit of time within which a statement of claim, if necessary at all, may be delivered is six weeks from the time of the defendant's entering his appearance (y), and should it not be delivered within the time allowed for that purpose, the defendant may apply to the Court or a Judge to dismiss the action, with costs, for want of prosecution; whereupon the action may be dismissed, or

(v) Infancy, coverture, fraud, Statute of Limitations, discharge under the Bankruptcy Acts. (w) Order xix., Rules 1, 2.

(x) Order xxiii,, R. 2.

(y) Order xx., R. $1(d)$. 
such other order, upon terms, may be made as shall seem just $(z)$.

If an order be made dismissing the action for want of prosecution, unless a statement of claim be delivered within a week, and the week expires without the claim having been delivered, the action is dead, and the Court has no jurisdiction further to extend the time for delivery of the statement of claim (a).

The defence must be delivered within ten days from the delivery of the statement of claim, or from the time limited for appearance whichever shall be last $(b)$ - the reply within three weeks after the defence or the last of the defences has been delivered $(c)$-and every subsequent pleading within four days after the delivery of that preceding it $(d)$. The consequences of default of pleading will appear in the ensuing pages.

The rules of pleading now in force aim at effecting brevity and precision, and at avoiding and discountenancing technicalities. By these rules, moreover, ample opportunities are allowed, during the progress of an action, of amending the pleadings so as to relieve from needless delay and expense the litigating parties. Thus, by Order XXVIII. it is provided (R. 1), that "the Court or" a Judge may, at any stage of the proceedings, allow either party to alter or amend his indorsement or pleadings, in such manner and on such terms as may seem just, and all such amendments shall be made as may be necessary for the purpose of determining the real questions in controversy between the parties."

The following rules apply to both the parties to an action.

(z) Order xxvii., R. 1.

(a) Whistler $\mathrm{r}$. Hancock, 3 Q. B. D. 83 ; followed in Wallis v. Hepburn, Id. $8+\mathrm{n}$. (1); and King r. Darenport, 4 Q. B. D. 402. See Burke r. Rooney,
4 C. P. D. 226 ; Carter ₹. Stubbs, 6 Q. B. D. 116.
(b) Order xxi., R. 6.
(c) Order xxiii., R. 1.
(d) Id., R. 3. 
Every pleading must contain only a statement in a summary form of the material facts on which the party pleading relies, but not the evidence by which they are to be proved $(e)$. The statement of claim must state specifically the relief which the plaintiff claims, either simply or in the alternative. And the same rule applies to any counterclaim made, or relief claimed by the defendant, in his statement of defence $(f)$. Where the plaintiff seeks relief in respect of several distinct claims or causes of complaint founded upon separate and distinct grounds, they are to be stated, as far as may be, separately and distinctly. And the like rule applies to the defendant $(g)$. Further, every allegation of fact in a pleading, if not denied specifically or by necessary implication, or stated to be not admitted in the pleading of the opposite party, is taken to be admitted (h), excepting where no reply or subsequent pleading is delivered, in which case all the material statements in the preceding pleading are deemed to have been denied and put in issue (i). And any party to a cause or matter may give notice, by his pleading or otherwise in writing, that he admits the truth of the whole or any part of the case of any other party $(j)$.

Each party pleading must raise by his pleading all matters which show the action or counter-claim not to be maintainable, or that the transaction is either void or voidable in point of law, and all such grounds of defence or reply, as the case may be, as, if not raised, would be likely to take the opposite party by surprise, or would raise issues of fact not arising out of the preceding pleadings, as, for instance,

(e) Order xix., R. 4 .

It has long been held a fault in pleading to set out facts by way of eridence or argument: Baynes v. Brevster, 1 Gale and Dav. 674: per Lord Denman, C:J., Williams v. Wilcox, 8 Ad. \& E. 331 ; Hancock v. Noyes, 9 Exch. 388. (f) Order xx., R. 6.

(g) Id., R. 7 .

(h) Order xix., R. 13; except as against an infant, lunatic, or person of unsound mind not so found by inquisition: Id.

(i) Order xxrii., R. 13.

(j) Order xxxii., R. 1. 
fraud, Statute of Limitations, release, payment, performance, facts showing illegality either by statute or common law, or Statute of Frauds $(k)$.

A pleading must be self-consistent and must not, except by way of amendment, raise any new ground of claim or contain any allegation of fact inconsistent with the previous pleadings of the party pleading the same $(l)$.

A denial in pleading must be specific, so that it will not suffice for a defendant in his defence to deny generally the grounds alleged by the statement of claim, or for a plaintiff in his reply to deny generally the grounds alleged in a defence by way of counter-claim, but each party must deal specifically with each allegation of fact of which he does not admit the truth, except damages $(m)$. A joinder of issue by either party operates, however, as a denial of every material allegation of fact in the pleading upon which issue is joined, and if it except facts which the party may be willing to admit, it then operates as a denial of the facts not so admitted $(n)$.

Further, a pleading, which denies an allegation of fact in the previous pleading, must not do so evasively, but must answer the point of substance: $c x . g r .$, if it be alleged that the other party received a sum of money, it is not sufficient to deny that he received that particular amount, but he must deny that he received that sum or any part thereof, or else set out how much he received.-So when a matter of fact is alleged with divers circumstances, it is not sufficient to deny it as alleged along with those circumstances, but a

(k) Order xix., R. 15.

(I) Id., R. 16.

The defect in plcadiur above indicated is techuically called a "depar. ture" as illustrating its nature:- - see Smith v. Marsack, 6 C. B. 486; Elliot v, Fon Glehn, 13 Q. B. 632; Morvis r. Walker, 15 Q. B. 589 ; Callow v. Jenkinson, 6 Exch. 666; Brine v. Grat Western R. C., 2 B. \& S. 402 ; Bartlett v. Wells i B. \& S.
836; Rixon r. Emary, I. R. 3 C. P. 546 ; hitson v. Havduick, L. R. 7 C. P. $473 ;$ Hooper v. Marshall, L. R. 5 C. I'. 4 .

(m) Id., R. 17.

By R. 12 the right of a defendant to plead "not guilty" by statute remains unaffected. But if the defendant so plead he cannot plead any other defence without leave.

(in) Id., R. 18. 
fair and substantial answer must be given $(o)$. When a contract is alleged in pleading, a bare denial of the contract by the opposite party will be construed only as a denial of the making of the contract in fact; not of its legality or its sufficiency in law, whether with reference to the Statute of Frauds or otherwise $(p)$. And if either party wishes to deny the right of any other party to claim as executor, or as trustee, whether in bankruptcy or otherwise, or in any representative or other alleged capacity, or the alleged constitution of any partnership firm, he must deny the same specifically $(q)$.

With a view to ensuring conciseness in pleading it is ordered:-That where the contents of a document are material, it shall suffice in pleading to state the effect thereof as briefly as possible, without setting out the whole or any part of such document, unless the precise words contained in it are material $(r)$. That where malice, fraudulent intention, knowledge, or other condition of the mind of a person needs to be alleged, the same may be alleged as a fact without setting out the circumstances from which it is to be inferred $(s)$. That notice to a person of any fact, matter, or thing, may be alleged as a fact, unless the form or the precise terms of such notice be material $(t)$. That where a contract or relation between persons not arising from an express agreement, is to be implied from letters or conversations or from circumstances, it shall suffice to allege such contract or relation as a fact, and to refer generally to such letters, conversations, or circumstances without setting them out in detail. And if in such case the person so pleading desires to rely in the alternative upon more contracts or relations than one as to be implied from such circumstances, he may state the same in the alternative $(u)$.
(o) Order xix., R. 19.
(p) Id., R. 20.
(s) Order xix., R. 22.
(q) Order xxi., R. 5.
(r) Order xix., R. 21.
(t) Id., R. 23.
(u) Id., R. 24. 
That neither party need allege any matter of fact which the law presumes in his favour or as to which the burden of proof lies upon the other side, unless the same has first been specifically denied $(x)$. -Ex. gr., consideration for a bill of exchange where the plaintiff sues only on the bill, and not for the consideration as a substantive ground of claim, need not be alleged.

Pleading matters pendente lite.

Matters which arise pending an action may be pleaded; thus a ground of defence which has arisen after action brought, but before the defendant has delivered his statement of defence, and before the time limited for his doing so has expired, may be pleaded by the defendant in his statement of defence, either alone or together with other grounds of defence $(y)$. So, if, after a statement of defence has been delivered, a ground of defence arises to a set-off or counter-claim alleged therein by defendant, the plaintiff may raise it in his reply, either alone or together with any other ground of reply $(z)$. Further, when a ground of defence arises after the defendant has delivered a statement of defence, or after the time limited for his doing so has expired, the defendant may, and where any ground of defence to any set-off or counterclaim arises after reply, or after the time limited for delivering a reply has expired, the plaintiff may, within eight days after such ground of defence has arisen, or at any subsequent time, by leave, deliver a further defence or further reply, as the case may be, setting forth the same (a). And when a defendant, in his statement of defence, or in any further statement of defence, alleges any ground of defence which has arisen after the commencement of the action, the plaintiff may deliver a confession of such defence, and thereupon may sign judgment for his costs up to the time of the pleading of such defence unless otherwise ordered (b).

(x) Order xix., R. 25.

(y) Order xxiv., R. 1.

(z) Id.

(a) Id., R. 2. (b) Id., R. 3.

See Harrison $\mathrm{r}$. Abergavenny, W. .. $1887,156$. 
Under the provisions of Order XXVI., and subject Discontinuthereto, it is competent to the plaintiff, wholly or in part, to discontinue his action, and to the defendant wholly or in part, to withdraw his defence thereto, or counterclaim.

Objections to the sufficiency of a pleading in point of law were formerly raised by demurrer, which was an allegation Demurrers abolished. that the pleading or part demurred to was "bad in law." But now by Order XXV. demurrer's are abolished, and any party is entitled to raise by his pleadings any point of law; and any point so raised will be disposed of by the judge who tries the cause at or after the trial, provided that, by consent of the parties, or by order of the Court or a Judge on the application of either party, the same may be set down for hearing and disposed of at any time before the trial $(c)$. If, in the opinion of the Court or a Judge, the decision of such point of law substantially disposes of the whole action, or of any distinct cause of action, ground of defence, set-off, counter-claim, or reply therein, the Court or Judge may thereupon dismiss the action or make such other order therein as may be just (d).

The Court or a Judge may order any pleading to be struck out, on the ground that it discloses no reasonable cause of action or answer, and in any such case, or in case of the action or defence being shown by the pleadings to be frivolous or vexatious, the Court or a Judge may order the action to be stayed or dismissed, or judgment to be entered accordingly, as may be just (e). This latter rule, however, is not intended to revive demurrers in another form, but only to get rid of frivolous actions and defences $(f)$.

No statement of claim is to be delivered when the writ is specially indorsed, beyond the indorsement which is deemed

(e) Order xxy., R. 2.

(d) Id., R. 3.

(e) Id., R. 4.

(f) Parsons v. Burton, W. N. 1883,

B.C.L.
215 ; Batthyany v. Walford, W. N. 1884, 37; Attorney-General Lancaster v. L. N. W. Ry. Co., (1892) 3 Ch. 274 , C. A. 
to be a statement of claim, or where the plaintiff indorses the writ with a statement of his intention, if the defendant appears, to proceed to trial without pleadings, and the defendant does not apply by summons to have a statement of claim delivered or the Judge refuses such application $(g)$. Nor is it necessary in other cases unless demanded by the defendant by notice in writing within eight days after appearance. If the defendant gives such notice, the plaintiff has five reeks after receiving it within which to deliver the statement of claim, and though not demanded, he may, within six weeks after the appearance has been entered, deliver one, though the costs of an unnecessary statement of claim may be imposed upon the party by whose fault it was delivered $(h)$.

A plaintiff may in general unite in the same action several causes of action, but should it appear that any of such causes of action cannot be conveniently tried or disposed of together, separate trials of any of them may be ordered (i). No cause of action, however, may, unless by leave, be joined with an action for the recovery of land, except claims in respect of mesne profits or arrears of rent or double value in respect of the premises claimed, or any part thereof, and damages for breach of any contract under which the same or any part thereof are held, or for any wrong or injury to the premises claimed $(j)$.

Since the passing of the Judicature Acts, "forms of action," it has been judicially observed $(k)$, " no longer exist." I may conveniently observe, however, that actions have from remote times been divided into three classes, real actions, $e x . g r$., actions of dower or quare impedit $(l)$; mixed

(g) Order xriii., A. Rr. 3,6 ; ef. p. 138, ante.

(h) Order xx., R. 1.

(i) Order xriii., Rules 1, 2, 8, 9.

(j) Order xriii., R. 2. As to joinder of claims by parties in different capacities, see Rules $3,4,5$. (k) Per Brett, I. J., Coverdale v. Charlton, 4 Q. B. D. 119.

(l) As to which, see Bishop of Exeter v. Marshall, L. R. 3 H. L. 17; Walsh v. Bishop of Lincoln, L. R. 10 C. P. 518 . 
actions, whereof that which alone survives is ejectment for the recovery of land; and personal actions.

Personal actions include those which are brought for the Personal recovery of goods and chattels, or for damages for breach of aetions. contract, or for wrôngs done to the person or property. This class of actions is divisible into actions founded upon contract (ex contractu) and actions founded upon tort or wrong (ex delicto). Actions ex contractu may be brought for liquidated i.e., ascertained, or for unliquidated damages. Personal actions ex delicto may be brought for unliquidated damages, or for the conversion of personalty, or for a specific chattel or its value.

Replevin is a peculiar action, usually brought for goods Replertn. taken under a distress, though said to be maintainable in some other cases where there has been a wrongful taking of goods out of the possession of the party who replevies $(m)$. When a person alleges that his goods have been unjustly distrained, whether for rent in arrear or for damage feasant, he may have them replevied, that is, redelivered to him upon giving security to prosecute an action with effect $(n)$ and without delay, against the distrainer, for the purpose of trying the legality of the distress, and (if the right be determined in favour of the latter) to return the goods. The action of replevin was formerly commenced in the Sheriff's Court and continued in one of the new County Courts $(o)$, but now it may be commenced in a superior Court $(p)$; the Sheriff's powers and responsibilities with respect to replevins having ceased, and the Registrars of County Courts being empowered to grant replevins $(q)$.

(m) Shannon v. Shannon, 1 Sch. \& Lef. 324 ; 9 R. R. 36, Preface, v. ; Allen v. Sharp, 2 Exch. 352; Jones v. Johnson, 5 Exch. 862 ; Mellor v. Leather, 1 E. \& B. 619; Galloway จ. Bird, 4 Bing. 299; per Parke, B., George v. Chambers, 11 M. \& W. 159; per Wightman, J., Gay v. Mathews, 32 L. J. M. C. 60. See, howerer, Mennie v. Blake, 6 E. \& B. 842. (n) 51 \& 52 Vict. c. 43 , s. 134.

(o) Ib., s. 136.

(p) Ib., s. 135.

(q) Ib., s. 134. Any action of replevin brought in a County Court may be removed by certiorari into a superior Court by the Defendant upon his complying with the conditions expressed in Ib., s. 137. 
Statutory forms of claims.
The statement of claim by a plaintiff suing in the Queen's Bench Division of the High Court of Justice is in the form of a narrative free from technical words and phraseology. The statement of claim, which must be intituled of the Division, specify the date when the writ issued, and name the parties, is arranged in numbered paragraphs.

Appendices C, D, and E, to the Rules of the Supreme Court, 1883, give forms of pleadings which are to be used where applicable. Where these forms are not applicable, forms of the like character as near as may be are to be used. And where these forms are applicable and sufficient, any longer forms will be deemed prolix, and the costs occasioned by such prolixity will be disallowed or borne by the party so using the same, as the case may be $(r)$.

The defence. Within ten days after the statement of claim has been delivered to the defendant, or within ten days from the time limited for appearance-whichever may be last, the defendant must, unless the time for doing so be extended, deliver his defence (s). Where the defendant has appeared in the action and neither received nor required the delivery of a statement of claim, he must, unless further time be allowed, deliver his defence within ten days after his appearance $(t)$. And where the defendant has appeared to a writ specially indorsed, and has (under Order XIV., Rule 1, noticed at p. 134) been permitted to defend the action, he must deliver his defence, if any, within the time limited by the order giving him leave to defend, or if no time be thereby limited, then within eight days after the order $(u)$.

The consequences of making default in pleading vary according to the nature of the plaintiff's claim-if it be only for a debt or liquidated demand, and the defendant does not, within the time allowed for that purpose, deliver a defence, the plaintiff may, at the expiration of such time, enter final

(r) Order six., R. 5.

(8) Order xxi., R. 6.

( $t$ ) Id., R. 7 .

(u) Id., R. 8 . 
judgment for the amount claimed, with costs $(x)$; and should there in this case be several defendants, of whom one makes default, the plaintiff may enter final judgment against the defendant so in default, and issue execution thereupon without prejudicing his right to proceed against the other defendants $(y)$. If the plaintiff's claim be for detention of goods and pecuniary damages, or either of them, and the defendant, or all the defendants if more than one, make default, the plaintiff may enter an interlocutory judgment against him or them, upon which a writ of inquiry will issue to assess the value of the goods and damages, or the damages only, as the case may be; or the value and amount of damages, or either of them, may by order be ascertained in any way which the Court or Judge may direct $(z)$. If in such action there be several defendants, of whom one or more make default, the plaintiff may enter an interlocutory judgment against the defendant or defendants so in default, and proceed with his action against the others $(a)$. Should the plaintiff's claim be for a debt or liquidated demand, and also for detention of goods and pecuniary damages, or pecuniary damages only, and any defendant makes default, the plaintiff may enter final judgment for the debt or liquidated demand, and also enter interlocutory judgment for the value of the goods and the damages, or the damages only, as the case may be, and proceed in respect of the latter judgment as above mentioned (b).

In any action not already specified, $e x . g r$., for a mandamus or injunction, if the defendant makes default in delivering a defence, the plaintiff may set down the action on motion for judgment, and such judgment will be given as upon the statement of claim the Court or a Judge may consider the plaintiff entitled to $(c)$. And where, in such
(x) Order xxvii., R. 2.
(a) Id., R. 5.
(y) Id., R. 3.
(b) Id., R. 6.
(z) Order xxvii., R. 4.
(c) Id., R. 11. 
action, there are several defendants, then if one of such defendants make default, the plaintiff may either (if the cause of action is severable) set down the action at once on motion for judgment against the defendant so making default, or may set it down against him at the time when it is entered for trial or set down on motion for judgment against the other defendants $(d)$.

Lastly, in an action for the recovery of land, if the defendant makes default, the plaintiff may enter a judgment that the person whose title is asserted in the writ of summons shall recover possession of the land, with costs $(e)$. And where the plaintiff has endorsed a claim for mesne profits, arrears of rent or double value in respect of the premises claimed or any part of them, or damages for breach of contract upon his writ for the recovery of land, if the defendant makes default, or some or one of the defendants make default, the plaintiff may enter judgment, and proceed against the defaulting defendant or defendants $(f)$.

The defence in an action at law may put forward some matter in justification of the defendant, or neutralising the plaintiff's alleged right, or in denial of his claim, though extra costs may be incurred by the defendant, if he should deny or not admit by his defence allegations of facts which in the opinion of the Court or Judge ought to have been admitted $(g)$. The grounds of defence ordinarily available in an action, whether for recovery of land-for breach of contract-or for tort, may be collected from Books II. and III. of these commentaries. Being here concerned with practice rather than principles, I can only say that the defendant besides or instead of relying on any such

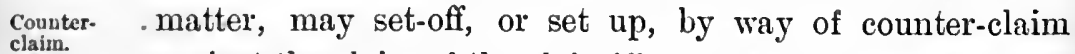
against the claim of the plaintiff, any right or claim, whether such set-off or counter-claim sound in damages or not, and

(d) Order xrrii., R. 12.

(e) Id., R. 7 .

(f) Id., R. 8 .

(g) Order xxi., R. 9. 
such set-off or counter-claim will have the same effect as a statement of claim in a cross action, so as to enable the Court to pronounce a final judgment in the same action, both on the original and on the cross claim. But if on the application of the plaintiff before trial it appear that such set-off or counter-claim cannot be conveniently disposed of in the pending action, or ought not to be allowed, permission to the defendant to avail himself thereof may be refused $(h)$.

And where a defendant seeks to rely upon facts as supporting a right of counter-claim, his statement of defence must state specifically that he does so by way of counterclaim $(i)$.

We may add that the counter-claim need not show a claim to an amount equalling the plaintiff's claim $(k)$. And that a defendant cannot set up by way of counter-claim against the claim of a plaintiff suing in a distinct personal character-ex. gr., as an executor-claims against him personally and as executor $(l)$.

Further, when two or more plaintiffs sue for a joint claim, the defendant may set up against each individual plaintiff a separate counter-claim sounding in damages; ex. gr., two railway companies having, as joint lessees of a railway, sued for statutory tolls, it was held that the defendant might set up against each company separate counterclaims for damages in respect of delay in the delivery of goods $(m)$.

From the statutory forms in the Appendix to the Rules of the Supreme Court, 1883, it will be seen that the defence states in concise terms, without technical expressions, the substance and nature of the transaction relied on by way of

(h) Order xix., R. 3. See Young v. Kitchin, 3 Ex. D. 127 (approved, Newfoundland Gov. v. Newfoundland R. C., 13 App. Cas. 199). As to counterclaiming to a counterclaim, see Toke v. Andrews, 8 Q. B. D. 428 .

(i) Order xxi., R. 10. (k) Mostyn v. West Mostyn Coal and Iron Co., 1 C. P. D. 145.

(l) Mracdonald v, Carington, 4 C. P. D. 28 .

(m) Manchester, Sheffield and Lincolnshive R. C. v. London and North Western R. C., 2 Ex. D. 243. 
answer to the plaintiff's claim; ex. gr., that money was paid in satisfaction of it, or that a bill or promissory note was so taken by the plaintiff $(n)$. The legal effect, however, of the transaction must of course be thoroughly scrutinised, regard being also had to the parties to it.

Payment into Court.

The defence of payment of money into Court in satisfaction of the plaintiff's claim is now allowed and regulated by Order XXII., which provides that where an action or counter-claim is brought to recover a debt or damages the defendant or plaintiff may before or at the time of delivering his defence or reply, or by leave at any later time, pay into Court a sum of money by way of satisfaction, excepting on a bond with a special condition, in which case payment can only be made to particular breaches. Payment into Court must be pleaded, and the claim or cause of action in satisfaction of which it is made must be specified (o). Such payment admits the liability unless made with a denial of liability, which may be done in all cases other than libel and slander.

If the defendant pays money into Court before delivering his defence he must serve upon the plaintiff a notice specifying the fact of payment, and also the claim or cause of action in respect of which such payment has been made, in a form provided $(p)$, and in that case the plaintiff may within four days after receipt of such notice-or if such payment is first signified in a defence delivered, then before reply-accept it in satisfaction of the claim or cause of the action in respect of which it is paid in, and may tax his costs and sign judgment for them if necessary $(q)$. When the liability is denied, the plaintiff may either accept the money and stop the action except as to costs $(r)$, or, if he considers the sum insufficient, the action will proceed, the money remaining 764.

(n) See Caine v. Coulton, 1 H. \& C.

(o) Order xxii., R. 2.

(p) Id. R. 4.

(q) Id., R. 7. See Greaves v.
Fleming, 4 Q. B. D. 226 ; Buckton . Higgs, 4 Ex. D. 174. 909.

(r) Re Earl Stamford, 33 W. R. 
in Court, and in case the defendant should ultimately win, the money will be repaid to him (s). A counter-claim is dealt with similarly $(t)$. With a defence setting up tender before action the sum of money alleged to have been tendered must be brought into Court $(u)$.

The object of the Statutes of Limitation is, we are told $(x)$, $\begin{gathered}\text { Statates of } \\ \text { Limitation }\end{gathered}$ " to preserve the peace of the kingdom, and to prevent those innumerable perjuries which might ensue if a man were allowed to bring an action for any injury committed at any distance of time." Of such statutes the leading provisions only can here be briefly noticed. This ground of defence must be pleaded $(y)$. It is inapplicable where the claim is by a cestui que trust against his trustee for any property held on an express trust or in respect of any breach of such trust $(z)$.

First, then, as regards realty, special reference must be made to the "Real Property Limitation Act, 1874" (a), which became operative January 1, 1879. By this statute various sections of the $3 \& 4$ Will. 4 , c. 27 , have been repealed. The term of six years has been substituted for ten years in the 18th section of the last mentioned Act, and in the same section the term of twelve years has been substituted for twenty years. Of the Act thus dealt with, the unrepealed residue is to be construed with the more recent

(s) Order xxii., R. 6.

(t) Id., R. 9.

(u) Id., R. 3.

(x) 3 Bla. Com., p. 307 ; see also per Story, J., Bell v. Morrison, 1 Peters (U. S.) R. 360 . Per Lord St. Leonards, Trustees of Dundee Harbour v. Dougall, 1 Macq. H. L. Ca. 321.

(y) Order xix., R. 15.

(z) 36 \& 37 Vict. c. 66 , s. 25 (2). See Banner v. Berridge, $18 \mathrm{Ch}$. D. 254 ; Seagram v. Tuck, $18 \mathrm{Ch}$. D. 296. This does not apply to implied trusts, Metrop. Bank v. Heiron, 5 Ex. D. 319, distinguished in Fitzroy Bessemer, \&c., In re, 50 L. T. 144. See Soar r. Ashwell (1893), 2 Q. B. 390 (C.A.), where the cases distin- guishing implied and express trusts are considered. Upon limitation of actions against trustees, see the Trustee Act, 1888 (51 \& 52 Vict. c. 59), s. 8. In actions commenced after January, 1890 , trustees enjoy the privilege of the Statutes of Limitation except in cases of fraud, fraudulent breach of trust to which the trustee was party or privy, or where the action is to recover trust property, or the proceeds thereof, still retained by the trustee, or previously received by the trustee and converted to his use. Cf. In re Somerset, Somerset v. Poulett, (1894) $1 \mathrm{Ch} .231$; In re Suain, Swain v. Bringeman, (1891) 3 Ch. 233.

(a) $37 \& 38$ Vict. c. 57.
Recovery of land, \&c. 
enactment-and so is the 7 Will. 4 and 1 Vict. c. 28 , the period of limitation, twenty years therein mentioned, being now reduced to twelve years.

The law upon this subject, : therefore, is briefly as follows :-

(1.) No land or rent can be recovered but within twelve years after the right of action accrued, either to the person through whom the plaintiff claims or within twelve years after the right accrued to the person bringing the action. But when an acknowledgment in writing of the title of the person claiming the land or rent has been made to him by the person in possession of it, the right of the former party will be deemed to have first accrued at the time when such acknowledgment was given $(b)$.

(2.) The right to sue for land or rent is deemed to have accrued in respect of an estate or interest in reversion or remainder, or other future estate or interest, when the same shall become an estate or interest in possession.

But when the person entitled to a particular estate on determination of which any future estate or interest was expectant shall not have been in possession or receipt of profits of such land or in receipt of such rent, at the time when his interest determined, no action can be brought but within twelve years after the time when the right to sue accrued to the person whose interest shall have determined, or within six years next after the time when the estate of the person becoming entitled in possession shall have become vested in possession-whicherer of those two periods shall be the longer.

(3.) If at the time at which the right of any person to sue for the recovery of land shall have accrued such person shall have been under these disabilities-infancy-coverture -idiotcy-lunacy or unsoundness of mind, then such per-

(b) Green v. Humplireys, 23 Ch. D. 207; rev. 26 Id. 474; Sanders r. Sanders, W. N. 1881, 149. 
son or the person claiming through him may-notwithstanding the twelve or six years mentioned-sue for the land at any time within six years next after the time when the person to whom such right shall first have accrued shall have ceased to be under such disability or died, whichever of those events shall have first happened. No time, however, is to be allowed on account of the absence beyond seas of the person entitled to sue, or of any one through whom he claims. And the utmost time allowed for disabilities is limited to thirty years.

(4.) A mortgagor will be barred at the end of twelve years from the time when the mortgagee took possession or from the last written acknowledgment by the mortgagee of the mortgagor's title.

(5.) Money charged upon land will be deemed to be satisfied at the end of twelve years if no interest has been paid nor acknowledgment in writing has been made in the meantime.

By $3 \& 4$ Will. 4, c. 42 , s. 3 , an action for breach of specialty. covenant or upon bond $(c)$ or other specialty, must be commenced within twenty years after accrual of the cause of such action $(d)$. The 4th section contains a proviso with regard to persons labouring under certain disabilities $(e)$; and the 5 th section provides, that in cases of due acknowledgment in writing or payment on account of principal or interest, then the statute shall not preclude an action for the cause acknowledged till twenty years after such acknowledgment $(f)$.

(c) 3 \& 4 Will. 4 , c. 42 , s. 3 ; Sturgis v. Davell, 4 H. \& N. 622; S. C., 6 Id. $120 ;$ Amott v. Holden, 18 Q. B. 593 ; Kempe v. Gibbon, 12 Q. B. 662 ; but see $37 \& 38$ Vict. c. 57 , s. 8 .

(d) See Lowe v. Fox, 15 Q. B. D. 667. The remedy upon a judgment recovered in an action of curenant is barred after the lapse of twelve years, see Jay v. Johnstone, (1893) 1 Q. B.
189 (affirming S.C. loc. cit. at p. 25). "Judgment" in s. 8 of the Real Property Limitation Act, 1874, refers to judgments generally, and is not restricted to judgments which operate as charges upon laud, cf. S.C.

(e) See $19 \& 20$ Vict. c. 97 , s. 10 .

(f) Blair v. Ormond, 17 Q. B. 439 ; 1 De G. \& S. 428; Kempe v. Gibbon, 12 Q. B. 662 ; Goode v. $J o b, 1$ E. \& E. 6 . 
The effect of the 21 Jac. 1 , c. 16, s. 3 , is that actions on simple contract generally (other than for such accounts as concern the trade of merchandise between merchant and merchant ( $g$ ), their factors or servants), and actions for debt grounded upon any lending or contract without specialty $(h)$, must be commenced and sued within six years next after the cause of such action, and not after $(i)$. The 7 th section of this Act $(j$ ) relates to persons labouring under particular disabilities (which have been revised by the Mercantile Law Amendment Act, $1856(k))$, and enacts, that persons so situated must sue within six years after the particular disability shall have ceased.

An executor cannot maintain an action for a debt which accrued to his testator, and for which he might have sued more than six years before the issuing of the writ $(l)$. But, under what is called the equity of the statute, where an action has been commenced within the period of limitation and the defendant dies, the plaintiff has a right to bring a new action against the executor or administrator if he do so within a reasonable time, notwithstanding that the time limited by the statute may have elapsed $(m)$.

The statute 9 Geo. 4 , c. $14(n)$ (commonly called Lord

(g) With respect to the limitation of action for Merchants' Acccunts, see 19 \& 20 Vict. c. 97, s. 9 ; Hebber v. Tivill, 2 Wms. Saund. 124; Robinson v. Alexander, 2 Cl. \& F. 717, 737; Inglis v. Haigh, 8 M. \& W. 769; Pott v. Clegg, 16 M. \& IV. 321.

(h) Cork and Bandon R. C. v. Goode, 13 C. R. 826; Hebster v. Kirk, 17 Q. B. 944, Tobacco Pipe Makers Co. v. Loder, 16 Q. B. 76.5.

(i) See Hartland v. Jukes, 1 H. \& C. 667,675 ; Bush v. Martin, 2 HI. \& C. 311 ; Garden v. Bruce, L. R. 3 C. P. 300 .

(j) See also as to defendants, $4 \&$ 5 Ann. c. 16,8 . 19 ; Fannin v. $A n-$ derson, 7 Q. B. 811; Touns v. Mead, 16 C. 13. 123 ; Lane v. Bennett, 1 II. \& IV. 70 ; Forbes v. Smith, 11 Exch. 161. (k) $19 \& 20$ Vict. c. 97 , ss: 10,12 ; Cornill v. Hudson, 8 E. \& B. 429.

(l) Penny v. Brice, 18 C. B., N. S., 393.

(m) Swindell v. Bulkeley, 18 Q. B. D. 250 .

(n) By s. 1 of which statute " no acknowledgment or promise by words only shall be deemed sufficient eridence of a new or continuing contract, whereby to take any case out of the operation of " the 21 Jac. 1, s. 16, "or to deprive any party of the benefit thereof, unless such acknowledgment or promise shall be made or contained by or in some writing to be signed by the party chargeable thereby:" Hyde r. Johnson, 2 Bing. N. C. 776 ; Clark v. Alexander, 8 Scott, N. R. 147; see Whitley, in re, Callan, exp., $32 \mathrm{Ch}$. D. 337. The section above cited also 
Tenterden's Act), was enacted to meet numerous questions which had " arisen in actions founded on simple contract as to the proof and effect of acknowledgments and promises offered in evidence for the purpose of taking cases out of the operation " of the above-mentioned Statute of James, and with the express view that a defendant should not lose the benefit of that statute by an informal or casual acknowledgment of a debt or contract which might previously (o) have been interpreted to bar the operation of the latter Act. The 9 Geo. 4, c. 14, does not alter the law as to the effect of an acknowledgment of a debt; it alters only the manner in which the acknowledgment must be proved $(p)$. Very numerous cases have been decided as to these questions. What is an "acknowledgment" of a debt, from which a promise to pay it may be implied? is the promise relied on absolute or conditional? if conditional, has apt evidence been adduced to show that the condition has been performed $(q)$ ? what is a sufficient promise founded on good consideration to take a case out of the operation of the statute $(r)$ ? and generally what is the true legal effect of the enactment here adverted to $(s)$ ?

With regard to personal actions for tort, the period of limitation assigned by the Statute of James above men-

makes provision respecting the chargeability of joint contractors, and proceeds :- "Provided always, that nothing herein contained shall alter or take away or lessen the effect of any payment of any principal or interest made by any person whatsoever:" Hollis v. Palmer, 2 Bing. N. C. 713 ; Turney v. Dodwell, 3 E. \& B. 136; Maber v. Maber, L. R. 2 Ex. 153; Bodger v. Arch, 10 Exch. 333.

(o) See, as to the effect of an acknowledgment or part payment of a debt, per Blackburn, J., Morgan v. Rowlands, L. R. 7 Q. B. 497 ; explained in Green v. Humphreys, $26 \mathrm{Ch}$. D. at p. 478.

(p) Per Williams, J., Sinith v. Thorn, 18 Q. B. 134; Jackson v.
Woolley, 8 E. \& B. 778.

(q) Chasemore v. Turner, L. R. 10 Q. B. 500; Meyerhoff v. Froehlich, 4 C. P. D. 63 ; Skeet v. Lindsay, 2 Ex. D. 314; Quincey v. Sharp, 1 Id. 72; Curwen v. Milburn, 42 Ch. D. 424 (following Skeet v. Lindsay, and Quincey v. Sharp; the C. A. affirmed North, J.'s order on other grounds); Cornforth v. Smithard, 5 H. \& N. 13; Tanner v. Smart, 6 B. \& C. 603 (followed in Stamford Banking Co. v. Smith, (1892) 1 Q. B. 765); Lyell v. Kennedy, 14 App. Cas. 437 (reversing C. A., 18 Q. B. D. 796). 497.

(r) Wilby . Elgee, L. R. 10 C. P.

(s) See preceding notes. 
tioned is:-in an action for assault, battery, or false imprisonment $(t)$, four years ; for slander, two years; for any other ordinary personal tort, six years $(u)$. Besides the enactments as to the limitation of actions just considered, special provisions occur in various other statutes respecting the time within which particular actions must respectively be brought, such provisions being in general framed for the protection of certain classes of defendants on grounds of public policy.

Whenever a Statute of Limitation is primâ facie pleadable, the precise point of time from which it runs should carefully be marked $(x)$, and likewise the legal status of the party entitled to sue at that epoch, the maxim of law being contra non valentem agere nulla currit prescriptio ; conformably to which rule the several provisions with respect to " disability," already ( $y$ ) mentioned, suspend the operation of the statute in question until such disability has ceased. So soon, however, as a complainant has a right to commence an action, the statute begins to run, ex. gr., if by an agreement money is to be paid on the happening of a certain contingency, the statute will begin to run when that event has occurred and a breach of the agreement has been committed. But whenever the time of limitation has once begun to run, it continues so to do $(z)$. Again, when in an action of simple contract on a plea of the Statute of Limitations the breach was shown to have occurred more than six years before the commencement of the proceed-

(t) Coventry v. Apsley, 2 Salk. 420.

(u) See Backhouse v. Bonomi, $8 \mathrm{H}$. I. Ca. 503; Swith v. Thackerah, L. R. 1 C. I. 564 ; Whitehouse v. Feilowes, 10 C. B., S. S., 765, 785, 786 ; Mitchell v. Darley Mtain Colliery Co., 11 App. Cas. 127. See Duke of Brunswick v. Harmer, 14 Q. B. 185 (which was an action for libel); and cases cited in Rose. N. P., 16th ed., Index, tit. "Limitations," subtit. " action on the ease."

$(x)$ See, for instance, Wilkinson $\mathrm{v}$.
Verity, L. R. 6 C. P. 206; Whitmore v. Humphries, L. R. 7 C. P. 1 ; Garden r. Bruce, L. R. 3 C. P. 300 . See Miller v. Dell, (1891) 1 Q. B. 468, (C. A.).

(y) Ante, p. 154.

(z) Curlevis v. Earl of Mornington, 7 E. \& B. 283 ; Rhodes v. Sinethurst, 4 M. \& W. 42 ; S. C., 6 M. \& W. 351 ; Penny r. Brice, 18 C. B., N. S., 393; Baird v. Fortune, 4 Macq. H. L. Ca. 127. See Lafond ₹. Ruddock, 13 C. B. 813,819 . 
ings, the plea was held to be a good bar to the action, although the plaintiff had delayed commencing proceedings sooner by reason of the defendant's conduct (a). Equity, however, in cases of fraud will interfere to prevent the party defrauded from being deprived of his rights by a strict application of the statute $(b)$.

Order XIX., R. 3, provides that a defendant in an action may set off, or set up, by way of counter-claim against the Set-off or counterclaims of the plaintiff, any right or claim, whether such set-off or counter-claim sound in damages or not, and such set-off or counter-claim shall have the same effect as a cross action, so as to enable the Court to pronounce a final judgment in the same action, both on the original and on the cross-claim. But the Court or a Judge may, on the application of the plaintiff before trial, if in the opinion of the Court or Judge such set-off or counter-claim cannot be conveniently disposed of in the pending action, or ought not to be allowed, refuse permission to the defendant to avail himself thereof.

The Court or a Judge has power to exclude a counterclaim which should be disposed of in an independent action $(c)$. A counter-claim may be proceeded with, although the action of the plaintiff may have been stayed,

(a) East India Co. v. Paui, 7 Moo. P. C. C. 111 ; Short v. M'Carthy, 3 B. \& Ald. $626 ; 22$ R. R. 503 ; Brown v. Howard, 2 B. \& B. 73 ; Howell v. Young, 5 B. \& C. 259; Granger v. George, Id. 149. See, howerer, remarks of the Exch. Chamber in Backhouse v. Bonomi, E. 1. \& E. 659 ; Smith v. Fox, 6 Hire, 286 ; Bree v. Holbech, 2 Dougl. 65̆4a.

It has been held to be no answer at law to a plea of the Statute of Limitations that the plaintiff was prevented by the frand of the defendant from knowing of the cause of action until after the period of limitation had expired; for, as remarked by Pollock, C. B., it would open a flood of litigation if Courts of law were to hold that the statute does not run in cases where fraud has been practised: Imperial Gas Light Co. v. London Gas Light Co., 10 Exch. 43; Hunter v. Gibbons, 1 H. \& N. 459. See, also, s. 26, $3 \& 4$ Will. 4, c. 27 , Laurance v. Norreys (Lord), 15 App. Cas., 210 ; Willis v. Howe (Earl), (1893) 2 Ch. 545.

(b) Gibbs พ. Guild, 9 Q. B. D. 59 ; distinguished in Armstrong v. Milburn, 54 L. T. 247; affirmed ib. 723 ; and see per Lord O'Hagan, Thomson v. Eastwood, 2 App. Cas. 252. See Blaiv. v. Bromley, 5 Hare, 542, and Moore v. Knight, (1891) 1 Ch. 547, with which cf. Thorne r. Heard, (1894) I Ch. 599, affirmed (1895) A. C. 495.

(c) Order xxi., R. 15. 
discontinued, or dismissed $(d)$. The judgment is given for the balance after the counter-claim is disposed of $(e)$.

Proceedings against thind party.

We have already seen $(f)$ that the Queen's Bench Division of the High Court of Justice is empowered to grant to a defendant in an action "relief relating to or connected with the original subject of the cause or matter" claimed against any other person not a party to the action "who shall have been duly served with notice in writing of such claim "-the relief granted being such "as might properly have been granted against such person if he had been made a defendant to a cause duly instituted by the same defendant for the like purpose;" and every such person so served with notice will thenceforth be deemed a party to the action, with the same rights in respect of his defence against the claim asserted as if he had been duly sued in the ordinary way by the defendant $(g)$. Such being in substance the enactment upon this subject, we will show how it is to be practically carried out.

Where a defendant claims to be entitled to contribution, or indemnity, against any person not a party to the action, he may, by leave of the Court or a Judge, issue a notice to that effect $(h)$, which may be in the form provided (i).

The plaintiff is entitled to be served with the summons for leave to serve a third party notice, and if the introduction of the third party into the action would materially prejudice the plaintiff, the order may be rescinded $(k)$.

A copy of this notice is to be filed and served on the person to whom it is addressed as a writ of summons is served, and must, unless otherwise ordered, be served by the defendant within the time limited for delivering his statement of defence; and with it must be served a copy of

(d) Order xxi., R. 16.
(c) Id., R. 17.
(f) Ante, p. 40.
(g) $36 \& 37$ Vict. c. 66, s. 24 (3).
(h) Order xri., R. 48. (i) App. (B), Form 1.

(i) Finlay r. Scott, W. N., 18s4, 8; Bouer v. Hartley, I Q. B. D.652 ; Hutchinson v. Colorado Co., W. N., 1884, 40 . 
the statement of claim, or if there be no statement of claim, then a copy of the writ of summons in the action $(l)$. Should the person so served with notice desire to dispute the plaintiff's claim in the action as against the defendant on whose behalf the notice has been given, or his own liability to the defendant, he must enter an appearance in the action within eight days from the service of the notice. In default of his so doing, he will be deemed to admit the validity of the judgment obtained against such defendant, whether obtained by consent or otherwise, and his own liability, to contribute or indemnify, as the case may be, to the extent claimed in the third party notice. Provided, however, that a person so served and failing to appear within the eight days may apply for leave to appear, which may be given upon terms $(m)$. In case the third party fails to appear pursuant to the notice the Rules enable the defendant to obtain judgment against him whether the defendant defends the action himself or $\operatorname{not}(n)$.

If a third party served under the above rules appears pursuant to the notice, the defendant giving it may apply to the Court or a Judge for directions as to the mode or time of having the question of the third party's liability determined; and upon the hearing of such application, the Court or Judge, if satisfied that there is a proper question to be tried, will give liberty to the person served to defend the action upon such terms as shall seem just, and will direct such documents to be delivered, or such amendments to be made, and generally such proceedings to be taken, as may appear proper for having the question raised most conveniently determined $(o)$. The Rules enable a defendant to enforce a similar claim against a co-defendant, and the costs in all cases are in the discretion of the Court or Judge $(p)$.
(l) Order xri., R. 48.
(m) Id., R. 49.
(o) Order xri., Rr. 52, 53.
(n) Id., Rr. 50, 51.
(p) Id., Rr. 54, 55.

B.C.L. 
Where a defendant by his defence sets up a counter-claim which raises questions between himself and the plaintiff along with any other persons, he must add to the title of his defence a further title similar to that in a statement of claim, setting forth the names of all the persons who, if such counter-claim were to be enforced by cross action, would be defendants thereto, and must deliver his defence to such of them as are parties to the action within the period within which he is required to deliver it to the plaintiff $(q)$.

The third party must be summoned to appear by being served with a copy of the defence in like manner as a writ of summons is served $(r)$; he must then appear to the action (s), and may deliver a reply to the counter-claim within the time within which he might deliver a defence if it were a statement of claim $(t)$. Where, however, a defendant by his statement of defence sets up a counter-claim, if the plaintiff or any other person named in manner aforesaid as party to such counter-claim contends that the claim thereby raised ought not to be disposed of by way of counter-claim, but in an independent action, application may, at any time before reply, be made for an order that such counter-claim may be excluded $(u)$. It has been held moreover that a person named in a defence, as a party to a counter-claim thereby made, cannot counter-claim against the defendant $(x)$.

In any case in which an issue arises in an action other than between plaintiff and defendant, if a party to such issue makes default in pleading, the opposite party may apply to the Court or a Judge for such judgment, if any, as upon the pleadings he may appear to be entitled to; and

(g) Order xxi., R. 11. Turner v. Hednesford Gas Co., 3 Ex. D. 145.

(r) Order xxi., R. 12.

(s) Id., R. 13 .

(t) Id., R. 14. (u) Order xxi., R. 15.

(x) Street v. Goeer, 2 Q. B. D. 498, followed Alcoy R. C. r. Greenhill, (1896) 1 Ch. 19. 
judgment will be entered accordingly, or such other order as may be necessary to do complete justice between the parties will be made $(y)$. Any judgment, by default, however, may upon terms be set aside $(z)$.

The reply, if any, is to be delivered, unless an extension of time be allowed, within twenty-one days after the defence or the last of the defences has been delivered (a). And no The reply and subsequent pleadings. pleading subsequent to reply other than a joinder of issue can be pleaded without leave, and then only upon such terms as may be thought fit (b). Any such pleading must, unless the time be extended, be delivered within four days after the delivery of the previous pleading $(c)$, and where a counter-claim is pleaded, a reply thereto shall be subject to the Rules applicable to the statement of defence. If the plaintiff does not deliver a reply or any party does not deliver any subsequent pleading within the period allowed for that purpose, the pleadings will then be deemed to be closed, and all the material statements of fact in the pleading last delivered will be deemed to have been denied and put in issue $(d)$.

As soon as either party has joined issue upon any pleading of the opposite party simply, without adding any further Joinder of issue. or other pleading thereto, or has made default as mentioned in Order XXVII. R. 13, the pleadings as between the parties will be closed $(e)$. Should it appear, however, to a Judge that the statement of claim or defence or reply do not sufficiently define the issues of fact in dispute between the parties, he may direct them to prepare issues, to be settled if the parties differ, by the Judge $(f)$. When the facts will admit of it the parties may concur in stating the questions of law in the form of a special case for the opinion of the Court $(g)$, or an order may be made when necessary for
(y) Order xxvii., R. 14.
(z) Id., R. 15.
(a) Order xxiii., R. 1.
(b) Id., R. 2.
(c) Id., R. 3.

(d) Order xxvii., R. 13.

(e) Order xxiii., R. 5.

(f) Order xxxiii., R. 1 .

(g) Order xxxiv., R. 1. 
raising a question of law and deciding it before questions of fact, which the decision may render unnecessary to be tried $(h)$.

Interroga.
tories. It may be as well now to advert to certain provisions con-

tained in the new procedure by which interrogatories and discovery, inspection, and admissions are regulated. The provisions referred to are contained in Orders XXXI. and XXXII. of the R. S. C. 1883, of which an epitome merely can here be given.

By Order XXXI. it is directed that in any cause or matter the plaintiff or defendant by leave of the Court or a Judge may deliver interrogatories in writing for the examination of the opposite parties, or any one or more of such parties, with a note at the foot thereof, stating which of such interrogatories each of such persons is required to answer: no party, however, can deliver more than one set of interrogatories to the same party without an order for that purpose, and interrogatories which do not relate to any matters in question in the cause or matter shall be deemed irrelevant, notwithstanding that they might be admissible on the oral cross-examination of a witness (i). On an application for leave to deliver interrogatories, the particular interrogatories proposed to be delivered must be submitted to the Court or Judge. In deciding upon such application, the Court or Judge must take into account any offer made by the party sought to be interrogated, to deliver particulars, make admissions, or to produce documents relating to the matters in question, and leave will be given as to such only of the interrogatories submitted as shall be deemed necessary either for disposing fairly of the cause or matter or for saving costs $(j)$. Where any party to an action is a body corporate or a joint stock company, or any other body of

(h) Order xxxiv., R. 2.

(i) Order xxxi., R. 1. Leave to deliver interrogatories is now necessary in all cases. (j) Order xxxi., R. 2. Allowing an interrogatory does not preclude any objection being taken under R. 6, infra, Pcek v. Ray, (1894) \& Ch. 282. 
persons, empowered to sue or be sued, an opposite party may apply at Chambers for an order allowing him to deliver interrogatories to any member or officer of such corporation, company or body, and the order may accordingly be made $(k)$. The costs of interrogatories " exhibited unreasonably, vexatiously, or at improper length," will have to be borne in any event by the party in fault $(l)$.

A party called upon to answer interrogatories may, within seven days after service of the interrogatories, apply at Chambers to set them aside on the ground that they have been exhibited unreasonably or vexatiously, or to strike them out, on the ground that they are prolix, oppressive, unnecessary or scandalous. Any objection, however, that any of them are scandalous or irrelevant or not put bona fide for the purposes of the action, or that the matter inquired after is not sufficiently material at that stage of the action, or on any other ground, may be taken in the affidavit in answer $(m)$. It has been stated ( $n$ ) as "a fundamental rule, that interrogatories are not to be allowed for the purpose of enabling a party to see if he has a case," but they may be allowed "to enable him to support his case, or to see if his case can be supported."

Interrogatories must be answered by affidavit to be filed within ten days, or within such other time as may be allowed (o). Should the person interrogated omit to answer, or answer insufficiently or improperly $(p)$, the party interrogating may apply for an order requiring him to answer, or to answer further, as the case may be. And an order may thereupon be made requiring him to answer or answer further by affidavit or by vivâ voce examination $(q)$.

(k) Order xxxi., R. 5.

(l) Id. R. 3. See Form of Interrogatories, App. (B) No. 6.

$(m)$ Order xxxi., Rr. 6, 7.

(n) Per Brett, J., Gourley v. Plimsoll, L. R. 8 C. P. 374. (o) Order xxxi., R. 8 .

(p) See Peyton r. Harting, L. R. 9 C. P. 9, approved, Lyell v. Kennedy, 27 Ch. D. 1.

(q) Order xxxi., R. 11. Any party may, at the trial of a cause, matter, 
During the pendency of an action the production by any party thereto upon oath of documents in his possession or power relating to any matter in question in such action may be ordered by the Court or a Judge, to be dealt with, when produced, in such manner as may seem just $(r)$. Any party, moreover, may, without filing an affidavit, apply to the Court or a Judge for an order directing any other party to the action to make discovery on oath of the documents which are or have been in his possession or power, relating to any matter in question in the action, and the Court or Judge may make such order as he may think fit, or refuse it, provided that discovery shall not be ordered when and so far as the Court or a Judge shall be of opinion that it is not necessary either for the disposing fairly of the cause or matter, or for saving costs $(s)$, and the party against whom such application is made may in his affidavit specify documents which he objects to produce $(t)$. The payment of a deposit into Court is now a condition precedent to an order for discovery either by interrogatories or otherwise $(u)$.

Further, every party to a cause or matter may at any time before or at the hearing thereof, give notice in writing to any other party, in whose pleadings or affidavits reference is made to a document to produce it for inspection; and a party not complying with such notice will not afterwards be at liberty to put such document in evidence on his behalf in the cause or matter, unless he shall satisfy the Court or Judge that it relates only to his own title, he being a defendant to the action, or that he had

or issue, use in eridence any one or more of the answers, or any part of an answer, of the opposite party to interrogatories without putting in the others, or the whole of such answer: in such case the Judge, howerer, may look at the whole of the answers, and if he shall be of opinion that any others of them are so connected with those put in that the last-mentioned answers ought not to be used without them, he may direct them to be put in. R. 24 .

(v) Order xxxi., R. 14. See Bustras v. White, 1 Q. B. D. 423.

(s) Id., R. 12.

(t) Id., R. 13. See Hill r. Campbell, L. R. 10 C. P. 222.

(u) Order xxxi., Rr. 25, 26. 
some other sufficient cause for not complying with the notice $(x)$.

The party to whom such notice to produce as just referred to is given must state a time and place for the inspection of the documents, or, if he objects to produce any of them, must specify on what ground he does so $(y)$. Should he omit to give notice of a time for inspection, or should he object to give inspection elsewhere than at the office of his solicitor, the party desiring it may apply to the Court or a Judge for an order for inspection $(z)$.

Should the party from whom discovery or inspection is sought object to the same, or part thereof, the Court or a Judge may-if satisfied that the right to discovery or inspection depends on the determination of any issue or question in dispute in the cause or matter, or that for any other reason it is desirable that any issue or question in dispute in the cause or matter should be determined before deciding upon the right to the discovery or inspection sought-order that such issue or question be determined first, and reserve the question as to the discovery or inspection $(a)$.

Disobedience to an order to answer interrogatories, or for discovery or inspection of documents, will expose the party disobeying such order to attachment. He will also, if a plaintiff, be liable to have his action dismissed for want of prosecution, and, if a defendant, to have his defence, if any, struck out, and to be placed in the same position as if he had not defended $(b)$.

Any party may give notice in writing admitting the truth of the whole or any part of his adversary's case, and either Admission of docu. party to an action may call upon the other party to admit any document, "saving all just exceptions;" and in case

(x) Id., R. 15. See Form of Notice under the above rule, App. (B), No. 9.

(y) Order xxxi., R. 17 . (z) Id., R. 18.

(a) Id., R. 20.

(b) Id., R. 21. 
Admission of facts.

of refusal or neglect to admit, after such notice, the costs of proving such document will have to be paid by the party so neglecting or refusing, whatever the result of the action may be, unless at the hearing or trial the Court or a Judge may certify that the refusal to admit was reasonable; and no costs of proving any document will be allowed unless such notice as above mentioned be given, except where the omission to give it is, in the opinion of the taxing officer, a saving of expense $(c)$. Similarly any party may require any other party to admit specific facts under peril of paying the costs occasioned by such refusal, unless such refusal be held reasonable, whatever the result of the action may be $(d)$. When admissions sufficient for the purpose have been made, judgment may be obtained $(e)$.

\section{Proceedings in District Registries.}

The office and functions of a district registrar having been already briefly noticed $(f)$ and reference having been incidentally made to some proceedings in the district registry $(g)$, I may add that where an action originates in such registry, all steps in it, unless otherwise expressly provided by Rules of Court or judicially ordered, must there be taken down to, and including, the entry of final judgment, as also certain subsequent proceedings for enforcing the judgment $(h)$. Where the writ of summons is issued out of a district registry and the plaintiff is entitled to enter interlocutory judgment (i); or where the action proceeds in the district registry and the plaintiff is entitled to enter a like judgment $(k)$; such interlocutory judgment, and, when damages have been assessed, final judgment

(c) Order xxxii., Rr. 1, 2.

(d) Id., R. 4.

(e) Id., R. 6.

(f) Ante, pp. 54, 55.

(g) As to issuing the writ of summons out of a district registry, ante, p. 127 ; as to entering an appearance there, ante, p. 133.

(h) Order xxxr., Rules 1 and 5.

(i) Under Order xiii.

(i) Under Order xxrii. 
must, unless otherwise ordered, be entered in the district registry $(l)$.

Where an action proceeds in the district registry all pleadings and other documents required to be filed must be filed in the district registry $(m)$, and all writs of execution for enforcing any judgment or order therein must, unless otherwise ordered, issue from it, and the costs are taxed there $(n)$.

An action which would otherwise proceed in a district registry may be removed thence to London by the defendant as of right in the following cases $(o)$, viz., where the action being brought for a debt or for recovery of land, the writ of summons is specially indorsed with the necessary particulars of the claim under Order III., Rule $6(p)$, and the plaintiff does not within four days after the appearance of defendant give notice of an application for an order against him for final judgment $(q)$; in this case the action may be removed at any time after the expiration of such four days, and before a defence has been delivered; and before the time for delivering it has expired:-where the writ is specially indorsed, and the plaintiff has made such application as just mentioned, and the defendant has obtained leave to defend the action $(q)$, then such defendant may remove the action at any time after the order giving him leave to defend, and before delivering a defence and before the expiration of the time for doing so:-also where the writ is not specially indorsed a defendant may remove the action at any time after appearance, and before delivering a defence, and before the expiration of the time for doing so $(r)$.

In any of the cases just specified the cause or matter may be removed by serving upon the other parties to it,

(l) Order xxxv., R. 2.

(m) Id., R. 19.

(n) Id., R. 4.

(p) Ante, p. 126.

(o) Id., R. 13.

(q) Under Order xiv.

(r) Order xxxv., R. 13. 
and delivering to the district registrar, a notice, that the defendant desires the action to be removed to London; the action will thereupon be removed, unless the Court or a Judge be satisfied that the defendant giving such notice is a merely formal defendant, or has no substantial cause to interfere in the conduct of the action, or if other good cause appear an order may be made that the action proceed in the district registry notwithstanding the notice given $(s)$.

In a case not provided for as above any party to an action proceeding in a district registry may apply to the Court or a Judge, or to the district registrar, for an order to remove the action from the district registry to London, and an order may be made accordingly, upon terms $(t)$. On the other hand, a party to an action proceeding in London may apply for an order to remove the action from London to a district registry, and such order may be made $(u)$.

Whenever proceedings are removed from a district registry to London, the registrar will transmit to the proper officer of the High Court of Justice all original documents (if any) filed in the district registry, and a copy of all entries in the books of the district registry of the proceedings in the action $(x)$.

\section{The Trial.}

An action at Law may be tried and heard either before a Judge,-or before a Judge sitting with assessors,-or before a Judge and Jury,-or subject to restrictions presently stated, before an official or special referee, with or without assessors $(y)$; as to each of which modes of trial some few observations must suffice.
(s) Order xxxy., R. 14.
(t) Id., R. 16.
(iv) Id., R. 17.
(x) Id., R. 20.
(y) Order xxxvi., R. 7 . 
In actions of slander, libel, false imprisonment, malicious prosecution, seduction, or breach of promise of marriage, either party may have the issues of fact tried by a Judge and jury $(z)$; in all other cases trial by jury can only be obtained by order $(a)$.

Every trial of any question or issue of fact with a jury is by a single judge, unless specially ordered to be held by two or more judges (b). A trial without a jury may (c), however, be directed, if it appear desirable, of any issue of facts, or partly of fact and partly of law, arising in a cause or matter which could formerly, without consent of parties, have been tried without a jury $(d)$. And, further, in any cause or matter the Court or a Judge of the Division to which it is assigned may order the trial of such cause or matter or of any issue of fact, or partly of fact and partly of law, arising in it, to be by a commissioner appointed in pursuance of the Judicature Act, 1873, s. 29 , or at the sittings to be held in Middlesex or London, and such cause, matter, or issue shall be so tried accordingly $(e)$ : a cause or matter not involving any question of fact being triable and determinable in like manner by consent $(f)$.

It is competent to the High Court of Justice or the Court of Appeal in any cause or matter in which it may be expeTrial with assessors. dient so to do, to call in the aid of one or more assessors specially qualified, and try and hear such cause or matter wholly or partially with such assistance $(g)$. Trials with assessors take place in such manner and upon such terms as may be directed $(h)$.

(z) Order xxxri., R. 2.

(a) Id., R. 6.

(b) Order xxxri., R. 9. See $A n$ derson r. Gorrie, 10 Times L. R. 383.

(c) Id., R. 4. See Day, Com. I. Proc. Acts, 4th ed., pp. 4, 246, et seq. (d) E.g. under $17 \& 18$ Vict. c. 125 , ss. 3 et seq., repealed by the Arbitration Act, $1889,52 \& 53$ Vict. c. 49.

(e) Order xxxri., R. 44.

(f) $36 \& 37$ Vict. c. 66 , s. 29.

(g) Id., s. 56.

(h) Order xxxvi., R. 43. 
Trial before referee.

Nany remarks have been made judicially in the cases below cited (i) respecting the power possessed by the Court or a Judge to refer questions to an official referee $(k)$, and respecting the limits of his jurisdiction when a matter has been referred to him.

Touching this subject we may in the first place quote the words of a learned judge who observes that, "Before the Judicature Acts (1873 and 1875) there were several modes in which disputes were remitted to the decision of third persons. There was the common law reference to an arbitrator constituted by the consent of the parties. There was the compulsory reference to an arbitrator under the provisions of the C. L. Proc. Act, 1854. There was the reference to the master to report in the Common Law Courts as to matters of discipline and similar questions, and in the Court of Chancery there was the reference into chambers. It was not intended by the Judicature Acts to interfere with these references, and they at present exist with all their incidents" $(l)$.

Now under the Arbitration Act, 1889 (52 \& 53 Vict. c. 49), subject to the Rules of Court and to any right to have particular cases tried by a jury, the Court or a Judge may refer any question arising in any cause or matter (other than a criminal proceeding by the Crown) for inquiry or report to any official or special referee. The report of an official or special referee may be adopted wholly or partially by the Court or a Judge, and if so adopted may be enforced as a judgment or order $(m)$.

Further, under the same Act, in any cause or matter (other than a criminal proceeding by the Crown), (a) if all parties interested who are not under any disability consent: or, (b) if the cause or matter requires any prolonged exami-

(i) Longman v. East, Pontifex v. Sctern, Mellin v. Monico, 3 C. P. D. 142.

(k) As to this officer, see $36 \& 37$
Vict. c. 66 , s. 83 .

(i) Cf. the Arbitration Act, 1889, ss. 12,17 .

(m) $52 \& 53$ Vict. c. 49 , s. 13. 
nation of documents or any scientific or local investigation which cannot in the opinion of the Court or a Judge conveniently be made before a jury or conducted by the Court through its other ordinary officers: or, (c) if the question in dispute consists wholly or in part of matters of account; the Court or a Judge may at any time order the whole cause or matter, or any question or issue of fact arising therein, to be tried before a special referee or arbitrator respectively agreed on by the parties, or before an official referee or officer of the Court $(n)$.

When an issue or a question is thus referred, the referee may, subject to order, hold the trial at or adjourn it to any place which he may deem most convenient, and he may have any inspection or view, either by himself or with his assessors (if any), which he may deem expedient for the better disposal of the controversy before him. The referee must, unless otherwise directed, proceed with the trial de die in diem as in an action tried by a jury (o), evidence being taken before him, and the attendance of witnesses being enforced by subpœena, and the trial being conducted in the same manner, as nearly as circumstances will admit, as if before a judge $(p)$. The referee has no power to commit to prison or to enforce an order by attachment $(q)$.

The referee may, before the conclusion of the trial, or by his report under the reference, submit any question arising therein for the decision of the Court, or state any facts specially, with power to the Court to draw inferences therefrom, and in any such case the order to be made on such submission or statement will be entered as the Court may direct; and the Court may require any explanation or reasons from the referee, and may remit the cause or matter, or part thereof, for re-trial or further consideration
(n) 52 \& 53 Vict. c. 49 , s. 14.
(o) Order xxxvi., R. 48.
c. 49, ss. $7,8,15(1)$.
( $p$ ) Id., R. 49. See 52 \& 53 Vict.
(q) Id., R. 51. 
to the same or any other referee, or the Court may decide the question referred to any referee on the evidence taken before him, either with or without additional evidence, as the Court may direct $(r)$.

Subject to any order to be made by the Court or a Judge ordering the reference, the referee has the same authority with respect to discovery and production of documents, and in the conduct of any reference or trial, and the same power to direct that judgment be entered for any or either party, as a Judge of the High Court (s).

Preparing evidence

for trial ;

Before trial at Nisi Prius, the important duty devolves upon either litigant of preparing evidence in support of the case upon which he intends to rely. This will be either documentary or oral.

-documentary evidence.

If a document be not admitted $(t)$ it must be proved; however, a deed thirty sears old proves itself ; and it is unnecessary to call the attesting witness to prove "any instrument, to the validity of which attestation is not requisite," such instrument being provable by admission or otherwise, as if there had been no attesting witness thereto $(u)$. Should any document required for evidence by either party be in the possession of his adversary, notice should be given him to produce it $(x)$. If it be in the hands of a third party, its production may be enforced by a subpœna duces tecum. Evidence by Evidence may now, by consent of the plaintiff and de-
attdavit. fendant in an action, be taken beforehand by affidavit; such affidavits to be filed and delivered within fourteen days after consent given, or such other time as may be agreed upon or allowed $(y)$; and within a like period counter affidavits may be delivered by defendant (z), and affidavits in reply may be filed within seven days, or such

(r) Order xxxri., R. 52. See $52 \&$ 53 Vict. c. 49 , ss. $7,19$.

(s) Id., R. 50.

(t) Ante, p. 167 . (ii) C. L. Proc. Act, 1854, s. 26.

(x) Order xxxi., Rules 15-18.

(y) Order xxxviii., R. 25.

(z) Id., R. 26. 
other time as aforesaid, after the expiration of the preceding period. Such affidavits as last mentioned must be confined to matters "strictly in reply" $(a)$.

When evidence is thus taken by affidavit, any party desiring to cross-examine a deponent may serve upon the party filing the affidavit a notice in writing, requiring the production of the deponent for cross-examination before the Court at the trial, such notice to be served at any time before the expiration of fourteen days after the time allowed for filing affidavits in reply, or within such time as may be specially appointed; and unless such deponent is produced accordingly, his affidavit cannot, unless by special leave of the Court, be used as evidence (b). The attendance of a deponent for cross-examination may be compelled in the same way as the attendance of a witness to be examined (c). And where necessary for the purposes of justice, an order may be made for the examination upon oath before the Court or Judge, or before an officer of the Court, or some other person, of a witness, either at home or abroad; whose deposition is to be filed in. Court, and to be given in evidence therein on such terms, if any, as may be directed $(d)$. Where a witness cannot be produced at Evidence on the trial, or is going abroad, or resides in a foreign country, his evidence is frequently taken on commission, i.e., before a commissioner or examiner appointed by the Court or Judge, and the depositions can be used at the trial unless the witness could at that time be produced personally.

Generally, in the absence of any agreement in writing between the solicitors of all parties, the witnesses at the trial of an action or at an assessment of damages, must be examined vivâ voce in open court, but the Court or a Judge may at any time for sufficient reason order that any
(a) Order xxxviii., R. 27.
(b) Id., R. 28.
(c) Id., R. 29.
(d) Order xxxvii., R. 5. 
Oral evidence.

Attendance of witnesses.

Notice of trial.

Time of giving notice of trial, \&c. particular fact or facts may be proved by affidavit, or that the affidavit of a witness be read at the hearing or trial, on reasonable conditions, or that any witness whose attendance in Court ought for sufficient cause to be dispensed with, be examined by interrogatories or otherwise, unless it appears to the Court or Judge that the other party bonâ fide desires the production of a witness for cross-examination, and that such witness can be produced, in which case an order will not be made authorising the evidence of such witness to be given by the affidavit (e).

The attendance of a witness at Nisi Prius to give oral evidence is procured by serving him with a subpœena ad testificandum $(f)$. The mode of doing this and the liability of witnesses neglecting to attend when duly summoned, will be found stated in Books of Practice, to which the reader must here be referred.

Before trial, due notice of it must be given, i.e., a ten days' notice, unless the opposite party has consented or is under terms or has been ordered to take short notice, i.e., four days' notice of trial, or unless some other period be expressly ordered $(g)$. This notice must be given before entering the action for trial $(h)$, and cannot be countermanded except by consent or by leave, subject to such terms as to costs, or otherwise, as may be just (i). It must state whether it is for the trial of the cause or matter or of issues therein; the place and day for which the cause is entered for trial must be mentioned $(k)$.

Notice of trial may be given in any cause or matter by the plaintiff or other party in the position of plaintiff. Such notice may be given with the reply (if any) whether it closes the pleadings or not, or at any time after the issues of fact are ready for trial $(l)$.

(c) Order xxxrii., R. 1.

(f) See Order xxxvii., R. 26, et seq.

(g) Order xxxri., R. 14.

(h) Id., R. 15.

(i) Id., R. 19.

(k) Id., Rr. 13, 13a. See Form, App. (B), No. 16.

(l) Id., R. 11. 
If, however, the plaintiff does not within six weeks after the close of the pleadings, or within such extended time as may be allowed, give notice of trial, the defendant may give such notice, or may apply to have the action dismissed for want of prosecution $(m)$.

Subject to Rules 1 to 7 of Order XXXVI. the Court or a Judge may, at any time or from time to time, order that different questions of fact arising in an action be tried by different modes of trial, or that one or more questions of fact be tried before others, and may appoint the place for trial $(n)$.

Let us now suppose that notice of trial has been duly given, that the action has been entered for trial $(o)$, and that the party entering it has delivered to the proper officers two copies of the pleadings, one for the Judge's use $(p)$. The action will then be called on at Nisi Prius in its proper turn.

The jurors for trying the issues raised are summoned by the sheriff $(q)$, and in early times were merely witnesses who spoke from knowledge with reference to the facts in issue-so that what the country knew, the country testified. If, for instance, a deed was pleaded, the witnesses named in the attesting clause were summoned upon the jury, because they were the persons whose evidence, being already recorded, was deemed essential to a decision of the case. So, when an estate was created by parol, and the names of the persons who heard the declarations were ascertained, they were ordered to be on the panel; and, acting on the same principle in other cases, the sheriff

(m) Id., R. 12. When the evidence in an action is taken by affidavit, the notice of trial must be given at the same time after the close of the evidence as in other cases after the close of the pleadings. Order xxxviii., R. 30 .
(n) Order xxxvi., R. 8.
(o) See Order xxxvi., Rules 15, 20
B.C.L.

-29 .

(p) R. 30.

$(q)$ The law relating to the qualifications, summoning, attendance and remuneration of special and common juries was amended by stat. $33 \& 34$ Yict. c. 77.
Trial by jury 
followed the direction of the writ, and returned the names of the good and lawful men by whom the truth could best be known :-in other words, he selected the parties who happened to be best cognisant of the facts, those, for instance, who had seen the peaceable possession of the demandant of land, and the unlawful entry upon it of the intruder. Such methods of deciding civil controversies were, indeed, well adapted to a state of society, when the possession of land was the most usual and important point which could come before a jury, and when all transactions by which the right of property was acquired had every possible publicity. But the neighbouring freeholders or inhabitants of a district were ill competent to declare the truth, when they were called upon to give their verdict concerning questions arising out of transactions, which were generally withdrawn from their notice, as the social system grew more refined, and became more complicated $(r)$.

The jury summoned to try the cause are sworn to give their verdict according to the evidence, and either party may challenge the array, that is the whole panel collectively, or he may challenge the poll, that is the individual jurymen on the panel $(s)$.

The cause being called on, should it happen that the plaintiff appears and the defendant does not appear, the plaintiff may proceed to prove his claim so far as the burden of proof lies upon him $(t)$. If when the cause is called on the defendant appears, and the plaintiff does not appear, the defendant, if he has no counter-claim, will be entitled to judgment dismissing the action, but if he has a counterclaim then he may prove such counter-claim so far as the burden of proof lies upon him $(u)$. But any verdict or judgment obtained where one party does not appear at the

(r) Ialgr. Orig. Auth. of King's Com. p. 358. Counc. pp. 53-55.

(夕) See 1 Chitt. Arch. Pr.; 3 Bla.

(t) Order xxxvi., R. 31 .

(v) Id., R. 32. 
trial, may be set aside, upon terms, on application made within six days after the trial $(x)$.

The jury being sworn, the case is opened by the plaintiff or defendant (as may be) in person or by counsel making a Opening the case. statement as well of the purport of the pleadings as of the evidence which it is proposed to offer in support of them. The right to begin devolves most commonly upon the plaintiff, in virtue of the rule that he on whom the burden of making out the affirmative of the issue lies-in other words, the party against whom, if no evidence were offered on either side, the verdict would pass-is entitled to begin.

Assuming that the plaintiff begins, and that the case has been duly opened, his counsel calls evidence in its support, Order of proceedings. which is summed up by a second address to the jury, unless it be previously announced that evidence is to be offered on the other side. In this latter event, the second speech of plaintiff's counsel is deferred until the evidence thus announced has been laid before the Court, and summed up by the defendant's counsel. Thus it will be perceived that where evidence is offered for the defendant, the party beginning has the general reply-that is, the opportunity afforded him of commenting on the whole case, as well on his own evidence as on that of his opponent.

The evidence on behalf of the defendant is in like manner first stated by counsel, then adduced, and afterwards summed up by him in his turn, although, of course, if he do not offer evidence, his sole duty will be to comment on that of the other side $(y)$.

During the trial, it is within the province of the presiding Province of Judge to disallow vexatious and irrelevant questions put in the julge. cross-examination, to rule as to questions of law which present themselves, to decide as to the admissibility of evidence, to allow amendments, and, if he deem it expedient

(x) Id., R. 33.

(y) Order xxxri, R. 36. 
for the interests of justice, to postpone or adjourn the trial for such time and to such place, and upon such terms, as lie may think fit $(z)$. It is also for the Judge to "sum up" and explain to the jury the evidence adduced, with a view to their delivering their verdict on the issues presented for their determination. And where there is conflicting evidence on a question of fact, whatever may be the opinion of the Judge as to the value of that evidence it must be left for the decision of the jury $(a)$.

Province of jury.

Although in theory it is the office of the jury to deliver their verdict on the issues of fact raised by the pleadings, yet in practice, where the evidence before the Court is complicated and difficult in its legal application, the direction of the Judge may, by assisting the jury in the elucidation of the evidence and as regards its connection with any specific issue, virtually determine how the verdict ought to be found. That the jury may persist in finding on an issue contrary to the expressed opinion and direction of the Judge, is true; but if this should subsequently be made apparent to the Court, the verdict might be set aside as being against evidence or perverse $(b)$. The jury, however, are usually content to exercise the discretionary power confided to them, subject to and in accordance with the advice or suggestion proffered by the Judge, under whose direction the jury may return a special verdict, finding the facts of the case, and leaving the Court subsequently to pronounce as to the legal effect and signification of such verdict.

Jury dis. cluarged,

Further, it is within the discretion of a Judge at Nisi wheu. Prius, under particular circumstances, to discharge the jury from giving any verdict, as where they cannot agree therein, and the Judge sees fit to excuse their so doing.

cnstit. A "nonsuit" was said to occur when a plaintiff with-

(z) Order xxxri., R. 34.

(a) Dublin, Wicklow and Wexford

R. C. v. Slattery, 3 App. Cas. 1155.

(b) Post, p. 183. 
drew (c) from the contention at Nisi Prius, because he was satisfied that he could not then support his case, or upon the Judge expressing his opinion that the action was not maintainable; though it was, notwithstanding the opinion so judicially expressed, within the discretion of the plaintiff himself, to submit to be nonsuited. Under the repealed Rule 6 of Order XLI., a judgment of nonsuit, unless otherwise directed, had the same effect as a judgment upon the merits for the defendant; but this rule has been repealed, and no other rule substituted for it.

A juror is sometimes withdrawn by the consent of both parties to the action upon terms arranged between them with a view to the final settlement of the litigation $(d)$. If there is a breach of the terms on which the juror was withdrawn, the Court can retry the action (e).

The Judge must, at or after trial, direct judgment to be Judgment. entered as he shall think right, and no motion for judgment shall be necessary in order to obtain such judgment $(f)$.

Should a set-off or counterclaim be established as a defence against the plaintiff's claim, and the balance be in favour of the defendant, judgment for such balance may be given for the defendant, or such relief as he may be entitled to upon the merits of the case may be adjudged to him $(g)$.

The judgment will be entered at the trial with accompanying directions by the proper officer (h). And the costs, when the trial is by jury, as a general rule, follow the event; in most other cases they are in the discretion of the Court (i).

(c) "At common law, the subject has a right to be nonsuited at any stage of the proceedings he may please, and thereby to reserve to himself the power of bringing a fresh action for the same subject-matter ; " per Parke, B., Outhwaite v. Hudson, 7 Exch. 381. A judge has no right to order a non-suit on plaintiff's opening unless with consent of counsel, Fletcher r. L. \& N.W. R. C., (1892) 1 Q. B. 122. (d) See per Pollock, C. B., Gibbs v. Ralph, 14 M. \& W. 805 ; per Lord Abinger, C. B., Harries v. Thomas, 2 M. \& W. 37,38 .

(e) Thomas v. Exeter, \&c., Co., 18

Q. B. D. 822 .
(f) Order xxxvi., R. 39.
(g) Order xxi., R. 37.
(h) Order xxxvi., Rules 41, 42.
(i) See Order lxv.

Withdrawing a juror. 
New trial.

A new trial of the action may be granted on any one of various grounds. A usual ground of moving for it is misdirection or the improper admission or rejection of evidence; such a ground, however, will not suffice to support the motion unless in the opinion of the Court to which the application is made some substantial wrong or miscarriage has been thereby occasioned in the trial, or because the verdict of the jury was not taken upon some question in the action, even though the Judge at the trial was not asked to leave it to them; and should it appear that "such wrong or miscarriage affects part only of the matter in controversy, or some or one only of the parties, the Court may give final judgment as to part thereof, or some or one only of the parties, and direct a new trial as to the other part only, or as to the other party or parties" $(k)$. A new trial may, in accordance with precedents, be granted in any of the following cases :- If the Judge who tried the cause was disqualified by reason of pecuniary interest in the subject-matter before the Court $(l)$; if the successful party $(m)$, or officer of the Court $(n)$, or the jury $(o)$ were guilty of gross misconduct, or if the jury instead of deciding the issues submitted to them made a compromise, and so agreed to find for the plaintiff the nominal damages only $(p)$; if a mistake has been made in entering the verdict $(q)$; or if the damages awarded by the jury be glaringly excessive $\left(r^{\circ}\right)$, or palpably

(k) Order xxxix., R. 6.

(l) Dimes r. Grand Junetion Canal Co., 3 H. L. Ca. 759; and see Williams r. Great Wrstern R. C., 3 H. \& X. 869 ; Reg. v. Mrilledge, 4 Q. B. D. 332. See Jieg. r. JJ. of Huntingdon, 4 Q. B. D. 522. $2 \% 2$.

(m) Coster v. Merest, 3 B. \& I3. 23.

(ii) Bentley r. Fleming, 3 D. \& L.

(a) Straker v. Graham, 4 M. \& W. 721 ; per Lord Abinger, C. B., Marris v. Vitian, 10 M. S W. 140 . See Standeucick v. Hopkins, 2 D. S I. 502 ; Ramadge v. Ryan, 9 Bing. 333; Hall v. Poyser, 13 M. \& W. 600 ; Allum r. Boultbee, 9 Exch. 738 ; Jase r. Delaval, 1 T. R. 11. See Cooling r. Great Forthein R.C., 15 Q. B. 4S6; Cooksey v. Haynes, 27 L. J., Exch. $3 \% 1$.

(p) Fultey r. Stanford, L. R. 10 Q. B. 54 .

(q) Roberts r. Hughes, T M. \& W. 399: Raphael v. Bunk of England, 17 C. B. 161 .

(r) Creed r. Fisher, 9 Exch. 472. See Masters v. Barmeell, 7 Bing. 224; Price r. Serem, Id. 316: Rolin r. Stevard, 14 C. B. 595 ; Belt r. Laues, 12 Q. B. D. 356. 
insufficient $(s)$. It is also deemed good ground for requiring that the issues should be submitted to another jury, if it is made out that the verdict was obtained by 'surprise' $(t)$, or that new evidence, discovered subsequent to the trial, is now available to the applicant, or that the verdict was procured and obtained by perjury and conspiracy $(u)$, or was manifestly against the weight of evidence $(x)$, or was perverse $(y)$ : and generally upon satisfying the Court that there has been a miscarriage of justice remediable by a new trial ( $z$ ), it will be granted to the applicant who moves for it in time either absolutely or upon such conditions as may seem equitable. It must, however, be remembered, that whilst it is a principle with our Courts that failure of justice should be corrected and its perfect administration be secured (a), yet another important object, which legal tribunals must not lose sight of, "is that causes should be determined, and determined finally" $(b)$.

The party desirous of obtaining a new trial of a cause on which a verdict has been found by a jury, must apply for the same to the Court of Appeal (c). The application

(s) Richards v. Rose, 9 Exch. 218 ; Chainbers v. Caulfield, 6 East. 244; Phillips v. South Western R. C., 4 Q. B. D. 406. See Apps v. Day, 14 C. B. 112 ; Forsdike v. Stone, L. R. 3 C. P. 607 ; Mostyn v. Coles, 7 H. \& N. 872 ; post, Bk. II.

( $t)$ Per Maule, J., Hoare v. Silverlock, 9 C. B. 22 ; Austin v. Evans, 2 M. \& Gr. 430 ; Edger ₹. Knapp, 5 M. \& Gr. 753 . 339 .

(u) Thurtell v. Beaumont, 1 Bing.

(x) A new trial " on the ground that the verdict is contrary to the weight of eridence, will not be granted for either party when the sum given or recoverable is under $£ 20$, and the action is for damages only, and does not involve any other question of right:" Lush. I'r. 3rd ed., p. 636. Replevin is not within the above rule: Edgson v. Carduell, L. R. S C. P. 647,648.

(y) Hawkins v. Alder, 18 C. B.
640; Gurney v. Womersley, 4 E. \& B. 133; Harrison v. Fane, 1 M. \& Gr. 550 .

(z) Tilliams v. Evans, 2 M. \& W. 220; Allum v. Boulthee, 9 Exch. 738; Fox v. Clifton, 9 Bing. 115; Benett v. Peninsular and Oriental Steam Boat Co., 16 C.: B. 29.

(a) See per Lord Kenyon, C. J., Caleraft v. Gibbs, 5 T. R. 19: per Mansfield, C. J., Suinnerton r. Marquis of Stafford, 3 Taunt. 232; Gilson r. Muskett, 4 M. \& Gr. 160, 171.

(b) Per IFilles, J., Grat Northern R. C. v. ILossop, 17 C. B. 140 . See this case distinguished Moxon $\mathrm{v}$. London Tramways Co., 57 L. J. Q. B. 446 (affirmed 37 W. R. 132).

(e) Order xixix., R. 1 A. The application used to be to the Dirisional Court, but the rule was anended February, 1892, in accordance with the provisions of the Judic. Act, 1890, s. 1. 
must be by notice of motion stating the grounds of the application, and whether all or part only of the verdict or findings is complained of. Such notice must be a fourteen days' notice, and must be served within eight days after the trial if in London or Middlesex, or if elsewhere within seven days after the last day of sitting on the circuits for England and Wales during which the trial shall have taken place $(d)$. Where there has been a trial without a jury, the motion for the new trial must be made by appeal to the Court of Appeal (e).

A new trial may be ordered on any question in an action, without interfering with the finding or decision upon any other question in it $(f)$.

Motion for judgment.

The Judge shall, at or after trial, direct judgment to be entered as he shall think right, and no motion for judgment shall be necessary in order to obtain such judgment $(g)$.

When the case has been tried by jury, and the Judge has, at or after the trial, directed judgment, any party may apply to set it aside, and to enter any other judgment, on the ground that such judgment was wrong because the finding of the jury was not properly entered $(h)$.

When, at or after a trial by a Judge either with or without a jury, the Judge has directed judgment to be entered, any party may apply to set it aside and to enter any other, on the ground that upon the finding as entered, the judgment so directed was wrong (i).

In either of these latter cases the application must be made to the Court of Appeal.

The two following Rules are applicable where issues have been ordered to be tried, or issues or questions of fact to be determined in any manner:-

(d) Order xxxix., Rules 3, 4.

(e) Id., R. 1. The appeal to the C. A. must be under the rules of Order lviii.

(f) Id., R. 7.

(g) Order xxxri., R. 39. Jud. Act, 1890, s. 2.

(h) Id., R. 3.

(i) Id., R. 4. 
First, Where all such issues or questions have been determined, the plaintiff may at once set down a motion for judgment. If he does not so set it down, and give notice thereof to the other parties within ten days after his right so to do has arisen, then after the expiration of such ten days any defendant may set down a motion for judgment, and give notice thereof to the other parties $(k)$.

Secondly, Where some only of such issues or questions of fact have been tried or determined, any party who considers that the result of such trial or determination renders the trial or determination of the others of them unnecessary, or renders it desirable that the trial or determination thereof should be postponed, may apply for leave to set down a motion for judgment, without waiting for such trial or determination. And such leave may accordingly be given upon terms, and with any directions as to postponing the trial of the other questions of fact which may appear desirable $(l)$.

Upon motion, whether for judgment, or for a new trial, the Court may draw all inferences of fact, not inconsistent with the finding of the jury, and if satisfied that it has before it all the materials necessary for finally determining the questions in dispute, or any of them, or for awarding any relief sought, may give judgment accordingly, or may, if it shall be of opinion that it has not sufficient materials before it to enable it to give judgment, direct the motion to stand over for further consideration, and direct such issues or questions to be tried or determined, and such accounts and inquiries to be taken and made as it may think fit $(m)$. It is here noticeable that by Order XXXIII., Rule 2, the Court or a Judge may, at any stage of the proceedings in a cause or matter, direct necessary inquiries. or accounts to be made or taken, notwithstanding that it may appear that
(k) Order xl., R. 7.
(m) Id., R. 10.
(l) Id., R. 8. 
there is some special or further relief sought for or some special issue to be tried, as to which it may be proper that the cause or matter should proceed in the ordinary manner.

The rules above set forth in regard to a motion for judgment do not apply where a party to an action seeks at some stage thereof, upon admissions of fact in the pleadings, for such order as he may be entitled to, without waiting for the determination of any other question between the parties. In this latter case the application may be made by summons at Chambers, so soon as the right of the party applying to the relief claimed has appeared from the pleadings, and thereupon relief will be given upon fitting terms $(n)$.

Entry of judguent.

Judgment is entered in a Book to be kept by the proper officer, to whom must be delivered a copy of the pleadings in the action $(o)$. This entry, when judgment is pronounced in Court, must be dated as of the day on which it is pronounced, and the judgment will take effect from such date, subject to the power of the Court to ante-date or post-date it $(p)$. In any other case, the entry of judgment must be dated as of the day on which the requisite documents $(q)$ are left with the proper officel for the purpose of such entry, and the judgment will take effect from that date $(r)$.

Proceedings on appeal were simplified by the Judicature Act, 1875, 1st Sched., Order LVIII., by Rule 1 of which bills of exceptions and proceedings in error were abolished. No appeal from an interlocutory order, or from any order whether final or interlocutory in any matter not being an action, can, except by special leave of the Court of Appeal, be brought after the expiration of fourteen days; and no

(i) Order rxxii., R. 6; Padlyett r. Bimis, W. N. 1884, 10; Gough v. Heatley, 49 L. T. 772.

(o) Urder sli., R. 1. (p) Id., R. 3.

(q) Id., Rr. 1, 5.

(r) Id., R. 4. 
other appeal can, except by such leave, be brought after the expiration of three months; the said respective periods to be calculated, in the case of an appeal from an order in Chambers, from the time when such order was pronounced, or when the appellant first had notice thereof, and in all other cases from the time at "which the judgment or order is signed, entered, or otherwise perfected, or, in the case of the refusal of an application, from the date of such refusal (s). An appeal does not operate as a stay of execution or of proceedings under the decision appealed from, except so far as may be ordered, and no intermediate act or proceeding will be invalidated, except so far as the Court appealed from may direct $(t)$.

An appeal to the Court of Appeal is by way of re-hearing by notice of motion stating whether the whole or part only of the judgment or order appealed from is complained of, and in the latter case specifying what part $(u)$. Notice of appeal if from a judgment, final or interlocutory, or from a final order, is a fourteen days' notice, and if from an interlocutory order, is a four days' notice $(x)$. It must be served upon all parties directly affected by the appeal, and if so directed on all or any parties to the action, or upon any person not a party thereto, the Court in this latter case being empowered to postpone or adjourn the hearing of the appeal upon terms, and to give such judgment and to make such order as might have been given or made if the persons served with notice had been originally parties $(y)$.

A respondent meaning to contend upon the hearing of the appeal that the decision of the Court below should be varied, must give notice thereof to any parties who may be affected by such contention $(z)$. Notice, if the appeal be from a final judgment, being an eight days' notice, if from an interlocu-

(s) Order lviii., R. 15. Cnder which Rule, also, security for costs may be directed to be giren.

(t) Id., R. 16. (u) Id., R. 1.

(x) Id., R. 3.

(y) Id., R. 2.

(z) Id., R. 6. 
Powers of Court of Appeal tory order, a two days' notice $(a)$. And where an ex parte application has been refused by the Court below, an application for a similar purpose may be made to the Court of Appeal ex parte within four days from the date of such refusal, or within such enlarged time as may be allowed (b).

The Court of Appeal is clothed with all the powers and duties as to amendment and otherwise of the Court of First Instance, together with full discretionary power to receive further evidence upon questions of fact, such evidence to be either by oral examination in Court, by affidavit, or by deposition taken before an examiner or commissioner. Such further evidence may be given without special leave upon interlocutory applications, or in any case as to matters which have occurred after the date of the decision appealed from. Upon appeal from a judgment after trial upon the merits, such further evidence (save as to matters subsequent as aforesaid) will be admitted by leave, and on special grounds only. The Court of Appeal is empowered to draw inferences of fact and to give any judgment and make any order which ought to have been made, and to make such further or other order as the particular case may require, and the powers aforesaid may be exercised by the Court, notwithstanding that the notice of appeal may be that part only of the decision may be reversed or varied, and such powers may also be exercised in favour of respondents or parties who may not have appealed from or complained of the decision, and the Court has full discretion as to the $\operatorname{costs}(c)$.

No interlocutory order or rule from which there has been no appeal will operate so as to bar or prejudice the Court of Appeal from giving such decision upon the appeal as may be just $(d)$.

Every application to a Judge of the Court of Appeal must

(a) Id., R. 7 .

(b) Id., R. 10.

(c) Order lviii., R. 4. As to evi-

dence before the Court of Appeal, see Rules 11-13. (d) Id., R. 14. 
be by motion (e), and where such application may be made either to the Court below or to the Court of Appeal, or to a Judge of either Court, it must be made in the first instance to the Court or Judge below $(f)$.

By the Judicature (Procedure) Act, 1894, the right of appeal has been restricted in certain respects. No appeal is allowed from an order allowing an extension of time for appealing from a judgment or order $(g)$, or, except with the leave of the Judge, from any interlocutory order or judgment made or given by a Judge except in certain cases set forth in section 1, sub-section 1 , of that Act. There is no appeal from an order of a Judge giving unconditional leave to defend an action, although an appeal still lies from an order refusing such leave $(h)$. In matters of practice and procedure every appeal from a Judge shall be to the Court of Appeal (i).

\section{Writs of Execution.}

Judgment in an action having been obtained is enforceable by execution in regard to which certain rules generally applicable have been promulgated $(k)$. These rules do not, however, take away or curtail any right which previously existed to enforce or give effect to any judgment or order $(l)$.

Where a judgment is to the effect that a party is entitled to relief upon the fulfilment of some condition or contingency, such party may, upon the fulfilment of the condition or contingency, and demand made upon the party against whom he is entitled to relief, apply for leave to issue execution against him. And the Court or Judge may, if satisfied that the right to relief has arisen pursuant to the terms of the judgment or order, order execution to issue accordingly,

(e) Id., R. 18.

(f) Id., R. 17 .

(g) $57 \& 58$ Vict. c. 16 (Judicature

Procedure Act, 1894), s. 1, sub-s. 1. (h) Id., s. 1, sub-ss. 2, 3.

(i) Id., s. 1, sub-s. 4.

(k) Order xlii.

(l) Id., Rr. 28, 29. 
or may direct that any question necessary for the determination of the rights of the parties be tried $(m)$.

Staying execution.

A party against whom judgment has been given may apply for a stay of execution or other relief against such judgment; if he does so upon the ground of facts which have arisen too late to be pleaded, relief, upon such terms as may be just, may be given $(n)$.

Every order of the Court or a Judge may be enforced in like manner as a judgment to the same effect $(o)$. And a person not a party to a cause or matter may enforce obedience to an order made in his favour or may have an order enforced against him, by the like process, as if he were such party $(p)$.

Before a writ of execution can be issued, the judgment on which it is to issue, or an office copy thereof, showing the date of entry of the judgment, must be produced to the proper officer, who must be satisfied that the requisite time has elapsed to entitle the judgment creditor to execution $(q)$. And before issuing the writ, a præcipe for that purpose must be filed, containing the title of the action, the reference to the record, the date of the judgment, and of the order, if any, directing the execntion to be issued, and the names of the parties against whom it is to be issued; such prxcipe being signed by the solicitor of the party issuing it, or by the party issuing it, if he do so in person $(v)$. The writ of execution, moreover, is endorsed with the address of either the solicitor or the party, whether plaintiff or defendant, if suing or sued in person $(s)$, and must bear date of the day on which it is issued $(t)$.

(m) Id., R. 9.

(ii) 36 \& 37 Vict. c. 66, s. 24 , ss. 5, Order xlii., R. 27, which also abolishes the proceeding by auditâ querelì.

An auditâ querelâ was " a writ to be delivered from an unjust judgment or exfeution by setting them aside for some injustice of the party that obtained them, which could not be pleader in bar to the action:" Bac. Abr. tit.
Aud. Quer. See Com. Dig. Aud. Quer. Tumer v. Daries, 2 Wms. Saund. 137, n. and notes thereto, and $147, \mathrm{n} .1$.
(o) Order xlii., R. 24.
(p) Id., R. 26.
(q) Order xlii., R. 11.
(r) Id.. R. 12.
(s) Id., R. 13.
(t) Id., R. 14. 
Before noticing the ordinary writs of execution (u), we Outlawry. may observe that outlawry has been altogether abolished in civil proceedings by stat. $42 \& 43$ Vict. c. 59 , s. 3 , which enacts that after the passing of that Act, "no person shall be outlawed or waived in or in consequence of any civil proceeding, and no proceedings to outlawry or waiver in or in consequence of any civil proceeding shall be taken at the instance of the Crown or otherwise."

The writ of attachment is directed against the person $(x)$, and has the same effect as this writ issued out of the Court of Chancery heretofore had $(y)$. It cannot be issued without leave of the Court or a Judge, to be applied for on notice to the party against whom the attachment is to be issued (z). This writ commands the Sheriff " to attach C.D. to answer as well touching a contempt which he it is alleged hath committed, as also such other matters as shall be laid to his charge, and further to perform and abide such order as the Court shall make."

Where a person is by judgment or order directed to pay money into Court, or to do any other act in a limited time, and after due service of such judgment or order refuses or neglects to obey the same, the person prosecuting the judgment will, at the expiration of the time limited for the performance thereof, be entitled, without any order for that purpose, to issue a writ of sequestration against the estate and effects of the disobedient person, having the same effect as such writ heretofore had when issued out of Chancery. The proceeds of the sequestration are to be dealt with in

(u) The Forms of these Writs, of which respectively the substance is given in the text, are contained in App. (H) to the Rules of Court.

$(x)$ The Debtors Act, 1869 (32 \& 33 Vict. c. 62) abolished arrest for debt after judgment obtained, though it allows an order to be made under circumstances for the imprisonment of a debtor; that, however, " is a different procedure from charging a debtor in execution:" per Blackburn, J., In ve Wilkins, L. R. 8 Q. B. 110; Hume v. Druyff, L. R. 8 Ex. 214; and see Bankruptey Act, 1883, 46 \& 47 Vict. c. 52 , s. 25 (see Bankruptcy Act, 1890, $53 \& 54$ Vict. c. 71, s. 7 ).

(y) Order xliv., R. 1.

(z) Id., R. 2.

Attachment.

Sequestra. tion. 
the same manner as they would heretofore have been dealt with by that Court (a).

The writ of sequestration, directed to Commissioners (in number not less than four), after referring to the judgment or order for payment of money, or, as the case may be, empowers them to "enter upon all the messuages, lands, tenements, and real estate whatsoever of the said C. D., and to collect, receive, and sequester into their hands not only all the rents and profits thereof, but also all his goods, chattels, and personal estates whatsoever;" and commands the said Commissioners to enter upon all the messuages, \&c., of the said C. D., and to collect and get not only the rents and profits of his said real estate, but also all his goods, chattels, and personal estate, and detain and keep the same under sequestration in their hands until the said C. D. shall [pay into Court to the credit of the said action the sum of $£-$, or, as the case may be] and clear his contempt.

A judgment for the recovery of the possession of land may be enforced by writ of possession as heretofore in an action of ejectment. And where the defendant is by any judgment or order directed to deliver up possession of land, the person prosecuting such judgment may, without any order for that purpose, sue out a writ of possession on filing an affidavit showing due service of the judgment and that the same has not been obeyed $(b)$. The writ, after stating that by the said judgment A. B. recovered (or E.F. was ordered to deliver to A. B.) possession of land specified, commands the sheriff to "enter the same, and cause the said A. B. to have possession of the said land and premises with the appurtenances."

A writ for delivery of property other than land or

(a) Order xliii. R. 6.

$\Lambda$ judgment for the payment of money into Court may be enforeed by attachment: Order xlii., R. 4.

(b) Order xlii., R. 5 ; Order slvii., Rr. 1, 2. 
money $(c)$ commands the sheriff to cause the chattels recovered by the judgment to be returned to A. B., and if the said chattels cannot be found [to distrain C. D. by all his lands and chattels, so that neither the said C. D. nor any one for him do lay hands on the same until the said C. D. render to the said A. B. the said chattels], or [of the goods and chattels of C. D. to cause to be made $\&$ - (the assessed value of the chattel)].

Money or costs payable under a judgment may, immediately after the judgment has been entered, be recovered by writ of fieri facias or of elegit. If, however, the judgment is for payment within a period therein mentioned, no such writ can be issued until after the expiration of such period, though at the time of giving judgment, or afterwards, leave may be given to issue execution before, or execution may be stayed until any time after the expiration of the period prescribed $(d)$. Writs of fieri facias and of elegit have the same force and effect, and are executed in the same manner as before the Judicature Acts $(e)$.

Every writ of execution for the recovery of money must be endorsed with a direction to the sheriff to lery the amount really due under the judgment or order, and also to levy interest thereon, if sought to be recovered, at the rate of $4 l$. per cent. per annum from the time when the judgment or order was entered up, or where there is an agreement between the parties that more than $4 l$. per cent. interest shall be secured by the judgment, then to levy the amount of interest agreed on $(f)$. And in every case of execution the party entitled thereto may levy the poundage, fees, and expenses of execution, over and above the sum recovered $(g)$.

Where a judgment or order is against partners in the

(c) As to which see Order xlii., Proc. Acts, 2nd ed. Index, tits. Fi. R. 6 ; Order xlriii.

Fa., Elegit.
(d) Order xlii., Rr. 3 \& 17.
(f) Order xlii., R. 16.
(e) Order xliii., R. 1. See Day, C. L.
(g) Id., R. 15.

B.C.L. 
name of the firm, execution may issue in manner following:-(1) Against any property of the partnership: (2) Against any person who has appeared in his own name under Order XLVIII., Rule 5 or 6 , or who has admitted on the pleadings that $h \in$ is, or has been adjudged to be a partner: (3) Against any person who has been served, as a partner, with the writ of summons, and has failed to appear. Should the party who has obtained judgment, moreover, claim to be entitled to issue execution against any other person as being a member of the firm, he may apply for leave to do so, which will be given if the liability be not disputed, or if disputed, an order may be made that the liability of such third person be tried and determined. But except as against any property of the partnership, a judgment against a firm does not render liable, release, or otherwise affect any member thereof who was out of the jurisdiction when the writ was issued, and who has not appeared to the writ unless he has been made a party to the action under Order XI., or has been served within the jurisdiction after the writ in the action was issued $(h)$.

Under the writ of fieri facias the sheriff may seize all the goods and chattels (i), moneys, notes, cheques, bills, specialties, and securities for money $(k)$ belonging to the defendant at the time of the writ being delivered to the sheriff, with the exception of wearing apparel, bedding and trade implements to the value of $5 l$. $(l)$, and (in a qualified degree) certain agricultural produce $(m)$; the levy of goods and chattels, moreover, being made subject to the claim (if any) of the landlord of the judgment debtor for a year's rent $(n)$, and to some other claims which need not here be particularised.

The writ of fieri facias commands the sheriff that of the

(h) Order xlviiia., R. 8.

(i) See Dumergue v. Rumsey, 2 H. \& C. $7 \%$.

(k) As to charging stocks, shares, \&c., in which the judgment debtor is interested, see Order xlri. (l) See $8 \& 9$ Vict. c. 127, s. $8: 1$ \& 2 Vict. c. 110, s. 12 . As to attachment of debts, post, Chap. 5 .

(m) 56 Geo. 3 , c. 50 ; and see 14 \& 15 Vict. c. 25, s. 2.

(n) 8 Anu. c. 1\%, s. 1. 
goods and chattels of C. D. he cause to be made the sum of $£-$, and also interest thereon at the rate of $£-$ per centum per annum, from the - day of - $(o)$, which said sum of money and interest were in a certain action, wherein A.B. is plaintiff, and C. D. and others are defendants, by a judgment bearing date the _- day of -, adjudged to be paid by the said C. D. to A. B. together with certain costs in the said judgment mentioned, and which costs have been taxed and allowed at the sum of of $\&$ - And that of the goods and chattels of the said C. D., he further cause to be made the said sum of $£-$ [costs], together with interest thereon at the rate of $4 l$. per centum per annum, from the —- day of - $(o)$, and that he have that money and interest in Court immediately after execution, to be paid to the said A. B., in pursuance of the judgment.

The writ of elegit $(p)$ was formerly employed to obtain satisfaction from the land as well as the goods of the judgWrit of elegit. ment debtor, but the 146th section of the Bankruptcy Act, 1883 , provides that a sheriff shall not under a writ of elegit deliver the goods of a debtor, nor shall a writ of elegit extend to goods.

Writs (ex. gr., that of venditioni exponas) in aid of the writ of fi. fa. or of elegit, may be issued and executed in the same manner as heretofore $(q)$.

A writ of execution if unexecuted will remain in force for one year only from its issue, but may, at any time before

(o) Day of the judgment or order, or day on which money is directed to be paid, or day from which interest is directed by the order to run, as the case may be.

$(p)$.The writ of elegit was first given by $13 \mathrm{Edw}$. 1, c. 18 . The 29 Car. 2 , c. 3, enlarged the effect of the above statute. See generally, as to the writ of elegit, the notes to Underhill $\mathbf{v}$. Devereux, 2 Wms. Saund. 68, and Williams Real Property, 17th ed. As to registration, see $51 \& 52$ Vict. c. 51 .
As to vacating registration, see $53 \& 54$ Vict. c. 69 , s. 19 .

(q) Order xliii., R. 5.

'The writ of extent is issued for the purpose of enforcing execution on behalf of the Crown. The practice and learning in regard to it may be collected from Edwards v. Reg. (in error), 9 Exch. 628 ; S. C., Id. 32, cited per Cur. Wright v. Afills, $4 \mathrm{H}$. \& N. $491,493,494 ; 3$ Bla. Com. p. 420 ; West on Extents. 
its expiration, by leave, be renewed for one year from the date of such renewal, and so on from time to time during the continuance of the renered writ. A writ of execution so renewed has effect, and will be entitled to priority, according to the time of the original delivery thereof $(r)$.

As between the original parties to a judgment or order, execution may issue at any time within six years from the recovery of the judgment or order $(s)$. Where, however, this period has elapsed since the judgment or order, or any change has taken place by death or otherwise in the parties entitled or liable to execution, and in certain other specified cases, the party alleging himself to be entitled thereto may apply for leave to issue execution, and such order may be made accordingly, or an order may be made that any question necessary for determining the rights of the parties be tried $(t)$.

\section{Sect. 2.-Suit in the County Court.}

Practice of the County court-how constituted.

Plaint.
The practice of the County Courts is regulated by the statute law, ante, pp. 56, et seq., and by rules made in pursuance of statutory powers $(u)$.

The suit or action $(x)$ in a County Court is commenced by plaint, which generally must be entered in the County Court within the district of which the defendant or one of the defendants dwells $(y)$ or carries on his business at the time of bringing the action; or it may be entered, by leave of the Judge or Registrar, in the County Court within the district of which the defendant or one of the defendants dwelt or carried on business, at any time within six calendar months next before the time of action brought; or, with the like leave, in the County Court in the district

(r) Order xlii., Rr. 20, 21.

(s) Id., R. 22 .

(t) Id., R. 23.

(iv) The County Court Rules, 1859; (December) 1889 ; 1892; (July) 1892 .
These rules are cited as the County Court Rules, 1889.

(x) Order r., R. 1.

(y) See Alexander v. Jones, L. R. 1 Ex. 133. 
of which the cause of action wholly or in part arose (z), unless, indeed, the plaintiff dwells or carries on his business, and the defendant likewise does so, within a metropolitan district, or in the City of London, in which case the plaint may be entered either in the plaintiff's or in the defendant's district $(a)$.

Upon entry $(b)$ of the plaint a summons to appear is summons. issued, which will be in the form provided by the rules, either for an ordinary or for a default summons. The summons, when in the ordinary form, is issued to the bailiff of the Court $(c)$, to be by him served $(d)$ on the defendant ten clear days at least before the holding of the Court at which it is returnable. To the summons must be annexed a copy of the plaintiff's particulars of demand, in those cases where they are required $(e)$.

Where the action is for debt or liquidated money demand, the plaintiff may, on filing a proper affidavit $(f)$, issue a summons in a particular form requiring the defendant to give notice of his intention to defend. This summons must be personally served on the defendant, and if he do not, within eight days after service, inclusive of the day thereof, give notice in writing, signed by himself or his solicitor, to the Registrar of the Court from which the summons issued, of his intention to defend, the plaintiff may, after eight days and within two months from the day of service, upon proof of the service, or of an order for leave to proceed as if personal service had been effected, have judgment entered up against the defendant for the amount of his claim and costs $(g)$, which will be ordered to be paid forthwith, or at such time or times, and by such instalments, if any, as the plaintiff, or his solicitor, shall in writing have consented

(z) 51 \& 52 Vict. c. 43 , s. 74 ; see Green v. Beach, L. R. 8 Ex. 208.

(a) Ib., s. 84 .

(b) Order vii.

(c) Order vii., R. 8 .

(d) As to proof of serrice see $51 \&$
52 Vict. c. 43 , s. 78 .

(e) See Order vii., R. 4.

(f) $51 \& 52$ Vict. c. 43 , s. 86 , and form 14 (B). County Court Rules, 1889.

(g) 51 \& 52 Tict. c. 43 , s. 86.

Particulars of demand. summons.

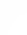


to take at the time of the entry of the plaint or of the judgment.

Where the defendant gives notice of defence, the Registrar must, immediately upon the receipt thereof, send a letter to the plaintiff or his solicitor by post, stating that the defendant has given such notice, and must send by post, to both plaintiff and defendant, notice of the day upon which the trial is to take place, at least six clear days before the day fixed.

If the defendant neglect to give notice of defence, he shall, nevertheless, be let in by the Judge or Registrar to defend, upon an affidavit disclosing a defence upon the merits, and explaining his neglect, such terms being imposed as may be just. And where personal service of the summons cannot be effected, and the Judge or Registrar is satisfied by affidavit that reasonable efforts have been made to effect such service, and either that the summons has come to the knowledge of the defendant, or that he wilfully evades service of the same, the plaintiff may have leave to proceed as if personal service had been effected, subject to such conditions as may seem fit $(h)$.

No other summons than in the ordinary form can, without leave of the Judge or Registrar, be issued where the amount claimed does not exceed $\mathfrak{\& 5}$, unless the action be for the price, value, or hire of goods which, or some part of which, were sold and delivered or let on hire to the defendant to be used or dealt with in the way of his trade, profession, or calling $(i)$.

There are no written pleadings in a suit in the County Court; but of any one or more of certain defences when meant to be set up, notice, unless the plaintiff consent to waive it, must be given to the Registrar. These defences $(k)$ are Set-off or Counter-claim, Infancy, Coverture, the Statute
(h) $51 \& 52$ Vict. c. 43, s. 86.
(i) Id.
(k) Order x., R. 10 et seq. 
of Limitations, statutory discharge by bankruptcy $(l)$, and in an action for libel and slander, that the alleged defamatory words are true in substance. Notice of a statutory defence in an action of tort must also be given $(m)$.

In the County Court counter-claims and equitable defences may be set up and relied upon by the defendant, though if the counter-claim be for an amount exceeding the limits of jurisdiction of the local Court, the action may be removed into the Queen's Bench Division of the High Court by order of a Master $(n)$.

Interrogatories may by leave be delivered by either party in the suit to his adversary, and an inspection and discovery of documents may be obtained (o).

A Judge of County Courts is empowered, whether within the district of any of his courts or not, to make any order, or exercise, on ex parte application, any jurisdiction in an action pending in any court of which he is Judge, which, if the same related to an action in a superior Court, might be made or exercised by a Judge at Chambers, and, with the consent of both parties, he may hear and decide a matter at any place either within or without such district $(p)$.

When no jury has been impannelled, the Judge himself trial. determines matters as well of fact as of law $(q)$; though in any action the Judge may, if he think fit, on the application of either party, summon to his assistance one or more persons of skill and experience in the matter to which it relates, who may be willing, for remuneration, to sit with the Judge and act as assessors; where, however, a person is proposed to be summoned as an assessor, objection to him may be taken by either party $(r)$.

A jury may be summoned on the requisition of either party to the suit, as matter of right, whenever the amount
(l) 51 \& 52 Tict. c. 43 , s. 82.
(m) Order x., R. 18.
(n) Ante, p. 69.
(p) $51 \& 52$ Vict. c. 43 , s. 9 .
(o) Order xvi.
(q) Ib. s. 100.
(r) $51 \& 52$ Vict. c. 43 , s. 103. 
claimed exceeds $\mathfrak{E} 5$, unless the action is of the nature assigned to the Chancery Division of the High Court; and in any case where such amount does not exceed $£ 5$, the Judge may, on the application of either party, order the action to be tried by a jury (s).

Assuming that both parties to the suit appear, the Judge, either with or without a jury, and with or without assessors, as the case may be, proceeds to hear the cause; but if the defendant appears and admits the claim, the Registrar may, by leave of the Judge, or in case of the Judge's death or unavoidable absence, settle the terms and conditions upon which it is to be paid, and may enter up judgment accordingly $(t)$.

If in an action brought in the County Court founded on contract, the defendant does not appear at the hearing, either in person or by some one duly authorized on his behalf, and no sufficient excuse for his absence is shown, the Registrar may, by leave of the Judge, or in case of the Judge's death or unavoidable absence, upon due proof of the service of the summons and of the debt being due and owing, enter up judgment for the plaintiff, and have the same power to make an order for payment by instalments, or to enter up judgment of nonsuit, or to strike out or adjourn the action, as the Judge of the Court has; but the judgment so entered up, and any execution thereon, may be set aside by the Judge of the Court and a new trial granted upon such terms, if any, as the Judge may think fit $(u)$.

Should neither counsel nor solicitors attend, at the hearing of an action in the County Court, the Judge must endeavour to elicit from the parties and their witnesses (whose attendance is procured by summons $(x)$ ), such facts

(s) 51 \& 52 Vict. c. 43, s. 101.

(t) Ib. s. 92.

(u) Ib. s. 90.

(x) Ib. 5. 111. Either party to the action may obtain of the Registrar of the Court summonses to witnesses, with or without a clause requiring the production of books, deeds, papers, and 
as will enable him to determine the question or questions in dispute. When the case is closed on both sides, the Judge, if unassisted by a jury, decides both on fact and law; but, if assisted by a jury, he will direct them in point of law, whilst they decide upon the facts. Judgment is Judgment. then given for the plaintiff or defendant-unless, indeed, the former be nonsuited-and entered on the minutes of the Court. The Judge also directs the mode of payment (which in certain cases may be by instalments) of any sum to which he may find the plaintiff entitled $(y)$. The costs of the action abide the event, unless the Judge shall otherwise order, and execution "may issue for the recovery of any such costs in like manner as for any debt adjudged in the said Court" $(z)$.

The Judge of a County Court, moreover, has in a case within his jurisdiction power to grant an injunction against a nuisance, and to commit to prison for disobedience thereto $(a)$.

When the judgment has been entered up, it may be Execution. enforced by execution against the goods, leviable by writ of fieri facias; and it may be worth notice, that the wearing apparel and bedding of the judgment debtor or his family, and the tools and implements of his trade, to the value of $£ 5$, are protected from seizure $(b)$.

Payment of money under a judgment or order of the County Court may sometimes be enforced by commitment to prison of the defaulting debtor. This jurisdiction can be exercised by the Judge or his deputy by an order made in open court, and showing on its face the ground on which

writings in the possession or control of the person summoned as a witness, 51 $\& 52$ Vict. c. 43 , s. 110 .

(y) 51 \& 52 Vict. c. 43 , s. 105 ; Form 34 .

(z) Id. s. 113.

When an order has been made for the debt to be paid by instalments, execution will not issue till after default in payment of an instalment; and it may then issue for the whole sum due: Id. s. 149 .

(a) Ex parte Martin, 4 Q. B. D. 212; Martin v. Bannister, Id. 491.

(b) 51 \& 52 Vict. c. 43 , s. 147.

As to interpleader where the goods taken in execution are claimed by a third person, see Id. s. 157. 
it is issued. The commitment may be for a term of not exceeding six weeks $(c)$.

Where a debtor has once been committed upon a judgment summons under the Debtors Act, 1869 (32 \& 33 Vict. c. 62), s. 5, for non-payment of a debt, though for a period short of six weeks (the limit imposed by that section), a second warrant of commitment cannot be issued against him in respect of the same debt. Where, however, the debt has been made payable by instalments, the debtor may be committed for the full period of six weeks for default in payment of each instalment $(d)$.

A County Court Judge has power also to commit for contempt of Court (e).

New trial. It is competent to either party, dissatisfied with the verdict, or decision of the case, to apply for a new trial, which the Judge may in his discretion order to take place before a jury, although the action was not originally so tried $(f)$.

The High Court or a Judge thereof (Master) may order the rari. removal into the High Court, by writ of certiorari or otherwise, of any action or matter commenced in the Court under the provisions of the County Courts Act, if the High Court or a Judge thereof deem it desirable that the action or matter shall be tried in the High Court, and upon such terms as to payment of costs, giving security, or otherwise as the High Court or the Judge thereof thinks fit to impose $(g)$. One of the usual grounds for granting the writ is, that difficult questions of law will arise in the suit $(h)$.

(c) $32 \& 33$ Vict. c. 62, s. j. 229.

(d) Evans r. Wills, 1 C. P. D.

(c) The porrer of a County Court Judge to commit for contempt under $51 \& 52$ Vict. c. 43 , s. 162 , which reproduces $9 \& 10$ Vict. c. 95, s. 113 , with the extension to the case of insult offered to a witness, is limited to a con. tempt in facia curia, and does not extend to a contempt committed out of Court: Reg. v. Lefroy, L. R. 8 Q. B. 134. See Reg. r. Judge of County Court of Surrey, 13 Q. B. D. 963.

(f) Order xxxi., R. 2. As to Judge's power to grant new trial, see s. 93 of the C. C. A. (1S88), and Murtagh r. Barry, 24 Q. B. D. 632.

(g) 51 \& 52 Vict. c. 43, s. 126. See also, Id. s. 124.

(i) See Rees v. Williams, 7 Exch. 
If any party in any action or matter is dissatisfied with the determination or direction of the Judge in point of law Appeal to superior or equity, or upon the admission or rejection of any evidence, the party aggrieved by the judgment, direction, decision or order of the Judge, may appeal from the same to the High Court, in such manner and subject to such conditions as may be for the time being provided by the Rules of the Supreme Court regulating the procedure on appeals from Inferior Courts to the High Court (i). However, unless the Judge grant leave to appeal, there is no appeal in any action of contract or tort, other than an action of ejectment or an action in which the title to any corporeal or incorporeal hereditament shall have come in question, where the debt or damage claimed does not exceed 20l., nor in any action of replevin, where the amount of rent or the damage or value of the goods seized does not exceed that sum, nor in any action for the recovery of tenements where the yearly rent or value of the premises does not exceed 20l., nor in interpleader proceedings where the money claimed or the value of the goods or chattels claimed, or of the proceeds thereof, does not exceed 20l. $(k)$. Further, no appeal lies from the decision of the Judge, if before such decision is pronounced the parties agree, in writing, signed by themselves or their solicitors or agents, that his decision shall be final, and no such agreement requires a stamp $(l)$. To facilitate appeals, at the trial or hearing of any action or matter, in which there is a right of appeal, the County Court Judge, at the request of either party, will make a

51 ; Parker v. Bristol and Exeter $R$. C., 6 Exch. 184; Longbottom v. Longbottom, 8 Exch. 203, 208.

(i) 51 \& 52 Vict. c. 43 , s. 120 . The right of appeal under s. 120 is only in respect of a question of law raised and submitted to the County Court Judge at the trial, Smith v. Baker, (1891) A. C. 325. See also R. S. C. Order ix.; Reg. v. Kettle, 17 Q. B. D. 761 ; Wilkinson v. Jaggar, 20 Q. B.
D. 423 ; Cusack r. L. \& N. W. R. Co., (1891) 1 Q. B. 347 ; Order xxxii. of the County Court Rules, 1889.

(k) $51 \quad \& \quad 52$ Vict. c. 43 , s. 120. The plaintiff cannot at the trial abandon the excess of his claim over $20 l$., so as to deprive the defendant of his right of appeal, North v. Holroyd, L. R. 3 Ex. 69.

(l) Id. s. 123. 
note of any question of law then raised, of the facts in evidence in relation thereto, and of his decision thereon, and of his decision of the action or matter. A copy of such note must be furnished to the party requiring the same for the purpose of appeal $(m)$. This note may be made by the Judge even after the hearing of the suit $(n)$, but in the absence of such notes the Court may act on any other evidence or statement they may deem sufficient $(o)$.

(m) $51 \& 52$ Vict. c. 43 , ss. 120 , 121.

(n) See Turner v. Great Western R. C., 2 Q. B. D. $125,126$. (o) R. S. C. Ord. lix., R. 8. This rule applies only if a copy has been applied for and refused, Cook r. Gordon, 61 L. J. Q. B. 445. 


\section{CHAPTER V.}

\section{EXTRAORDINARY REMEDIES.}

A wrong may, in certain cases, be redressed, or its con- Extraorditinuance may be prevented: I. By the act of the party

nary remedies-how injured; II. By the mere operation of law, independently of the ordinary mode of procedure; III. By the exercise of extraordinary judicial powers.

I. Under the first of the above three clauses falls the remedy by self-defence, which is founded on the right derived to us from the law of nature to repel force by force. by act of party. But although the law permits this to be done in certain cases, it behoves one who thus undertakes his own protection, or that of his dependents, not to overstep the bounds of moderation, nor use force exceeding in degree what may be necessary for effecting the end in view; for, by so doing, he may perchance constitute himself an aggressor. The licence thus conceded, is not, however, restricted to a defence of the person merely: for the rightful owner, in peaceable possession of property, may defend such possession by force, and will be therein justified (a).

Recaption is a remedy sometimes given to a man when he Recaption. has been wrongfully deprived of his goods by another. "If a man takes my goods and carries them into his own land, I may justify my entry into the said land to take my goods again; for they came there by his own act" (b). But if it cannot be shown that my goods so came there, the mere E. 825 .

(a) Judgm., R. v. Wilson, 3 Ad. \& $\quad$ ridge v. Nicholetts, 6 H. \& N. 383,

(b) Vin. Abr. Trespass, I. (a); Bur392 . 
fact of their being on another man's land will not justify my entering thereon and repossessing myself of my goods $(c)$. If, however, they are found on a common, in a fair, or at a public inn, it is laid down that they may be lawfully re-seized by the rightful owner $(d)$.

Besides the justification thus in certain cases afforded to one who enters upon the premises of another to repossess himself of goods tortiously placed there, parties may similarly right themselves, without resorting to law, under some other circumstances : for example, in the case of fruit dropping from one man's tree on to the land of another, or of trees themselves falling thereon. In such case the owner of the fruit or of the trees may justify entering his neighbour's land to recover his property on the ground of accident $(e)$. This natural right of recaption, as it has been called $(f)$, may justify an assault by the owner of goods to repossess himself of them when wrongfully in the possession of another, who, by tortiously taking, does not acquire any property in them $(g)$.

Eviction. An entry by the lawful owner upon lands and tenements of which another is in possession without right, is also in some cases permitted. There is no doubt that where one has taken and holds possession mrongfully of land, the lawful owner may make a peaceable entry thereon $(h)$; and

(c) Per Parke, B., Patrick r. Colerick, 3 M. \& W. 496; Anthony v. Ilancys, 8 Bing. 186.

(d) 3 Bla. Com., p. 4 ; per Pollock, C. B., Burridge v. Nicholetts, 6 H. \& N. 389. See Earl of Bristol v. Wilsmore, 1 B. \& C. 514 .

(e) Per Tindal, C. J., Anthony v. Hancys, 8 Bing. 192, commenting on Millen v. Hawery, Latch, 13; and Vin. Abr. Trespass, H., a, 2, and L., a ; Webb r. Beavan, 7 Scott, $\Gamma$. R., 937, n. 15. As to recovery of loppings, which necessarily fall on to the lands of another, see Ir. Bk. 6 Edw. 4, fo. 18, 19, and Millen r. Havery, ubi supra.

(f) 3 Bla. Com., p. 4.

(g) Blades r. Higgs, 11 H. L. Ca.
621 ; cited per Bovill, C. J., Reg. v. Tounley, L. R. 1 C. C. 317 ; Smith v. Wright, $6 \mathrm{H}:$ \& N. 821 . See Chambers r. Miller, 13 C. B., N. S., 125; Reg. r. Read, 3 Q. B. D. 131.

(h) Per Lord Fenyon, C. J., Taylor r. Cole, 3 T. R. 295, 1 R. R. 706, cited per Lord Dcuman, C.J., Harcey v. Bridges, 1 Exch. 263; Judgm. R. . Wilson, 3 A. \& E. 824; Taunton r. Costai, 7 T. R. 431; 4 R. R. 481 ; Wildbor r. Rainforth, 8 B. \& C. 4; Neuton v. Harland, 1 M. \& Gr. 644, per Bosanquet, J., at p. 659 . As to what constitutes eviction, see Judgm. Epton r. Tornend, 17 C. B. 30 ; Furnital r. Grose, 8 C. B., N. S. 496 . 
it has also been held that the breaking open of the door in the absence of the wrongful possessor will not prevent the entry being peaceable (i). It is also clear that after such entry, and when possession has been obtained, the lawful owner may by virtue of his possession justify the removal of the wrongful possessor, using no unnecessary force; "Formerly a doubt was entertained whether a landlord was justified in entering and expelling the tenant on the expiration of his term. But that doubt has been set at rest for ever since the case of Taunton v. Costar $(k)$, subject, of course, to any question of excess" $(l)$. Actual entry, with sufficient title, for the purpose of taking possession, is sufficient to vest the possession in the lawful owner, and to make any previous tenants in possession, and all other persons who afterwards remain on the property without his leave and licence, trespassers $(m)$, and as such liable in an action $(n)$.

There is, however, considerable conflict of judicial decision as to whether the lawful owner can justify a forcible entry, and the subsequent expulsion of the wrongful holder. On this point the cases cited below should be consulted $(o)$. It is certain that the wrongful holder can-l

(i) Turner v. Meymott, 1 Bing. 158.

(k) 7 T. R. 431 ; 4 R. R. 481.

(h) Per Wilde, C. J., Wright v. Burroughes, 3 C. B. 685,699 ; Harvey v. Bridges, 14 M. \& W. 437.

$(m)$ "A trespasser may in any case be turned off land before he has gained possession, and he does not gain possession until there has been something like acquiescence in the physical fact of his occupation on the part of the rightful owner." Pollock, Law of Torts, 4th ed., 345; Browne v. Dawson, 12 A. \& E. 624 ; followed in Scott v. Brown, 51 L. T. 746.

(n) Anon., 1 Salk. 246; Butcher จ. Bistcher, 7 B. \& C. 399 ; Barney v. Adams, 2 Cro. \& Jer. 235; Hey v. Moorhouse, 6 Bing. N. C. 52 ; Jones r. Chapman, 2 Exch. 803; Davis v. Burrell, 10 C. B. 821; Randall v. Sterens, 2 E. \& B. 611 . (o) Newton v. Harland, 1 M. \& Gr. 644 ; 1 Scott, N. R. 490; Hillary v. Gay, 6 C. \& P. 284. [These cases are cited as erroneous, Cole on Ejectment, p. 71 , and there stated to have been in effect overruled by later decisions. Cf. 1 Sm. L. C., 9th ed. p. 151]; Harvey v. Bridges, 14 M. \& W. 437,442 ; affirmed 1 Exch. 261; Jones v. Chapman, 2 Exch. 803, 821; Davis v. Burrell, 10 C. B. 825; Pollen v. Brewer, 7 C. B., N. S. 371 ; Blades v. Higgs, 10 C. B., N. S. 713; Lows v. Telford, 1 App. Cas. 414, 426; Beddall v. Maitland, 17 Ch. D. 174; Edwick v. Hawkes, 18 Ch. D. 199 [where Newton v. Harland, ubi supra, was upheld]; Beattie v. IVair, 10 L. R. Ir. 208 [where the Court declined to decide whether Newton $\mathbf{v}$. Harland was still law]. 
not treat the lawful possessor as a trespasser, or claim damages for the entry $(p)$. Mr. Justice Fry says, "Damages cannot be recovered against the rightful owner for a forcible entry on land . . . The result of the cases appears to me to be this, that, inasmuch as the possession of the defendant was unlawful, he can recover no damages for the forcible entry of the plaintiff. He can recover no damages for the entry, because the possession was not legally his, and he can recover none for the force used in the entry, because though the Statute 5 Ric. II. 1, 8, creates a crime, it gives no civil remedy" $(q)$.

But it is by no means clear whether a forcible entry will give such lawful possession as to enable the person entering to justify in a civil action an assault committed in the course of removing the wrongful holder. On the one hand may be cited the dicta of Parke, B., in Harrey v. Bridges $(r)$, apparently approved by Lord Selborne in Lou's v. Telford (s), and on the other the judgment of Fry, J., in Beddall v. Maitland $(t)$, supporting the opinion of the majority of the Court of Common Pleas in Neuton v. Harland (u), that such an entry being unlawful under the statute, could not give such lawful possession as would enable the owner to justify the forcible expulsion of the wrongful holder. In either case the party so entering will run the risk of an indictment under 5 Ric. II. 1, 8; and it further seems that in such cases the wrongful holder may obtain damages, not for the forcible entry, but in respect of any wrongful independent acts (such as an assault, or an injury to furniture) which are done in the course of, or after, the forcible entry; "because the person doing them cannot allege that the acts

( $p$ ) Cf. cases above cited; Davison v. Wilson, 11 Q. B. 890 ; Burling v. Reed, Ib. 904; Meriton ₹. Coombes, 1 L. II. \& P. 510. 188 .

(q) Beddall r. Maitland, 17 Ch. D. (r) 14 M. \& W. 442.

(s) 1 App. Cas. 426.

(t) 17 Ch. D. 174 . 490 . 
were lawful unless justified by a lawful entry, and he cannot plead that he has a lawful possession " $(x)$.

Again, subject to the condition that no riot be committed by the act, a nuisance (y) may be abated, i.e., removed, by Abatement of private the party injured thereby, whether it be a private nuisance - such as the obstruction of an individual's ancient lights. 1 . - or a public nuisance, - as where a gate is placed unlawfully across the king's highway $(z)$. It has, however, been held that under certain circumstances notice must be given, before abating a private nuisance, to the person on whose land it exists (a). In Lemmon v. Webb (b), the House of Lords decided that where branches of trees overhang the soil of another person, the person whose soil they overhang is entitled to remove those branches without notice to his neighbour on whose side of the boundary the trees grow. The act of removing the branches did not involve a trespass. In Perry v. Fitzhowe (c), some material points in reference to the subject under consideration were determined. The action there was for trespass; and the main question presented for discussion was, whether the defendant could lawfully pull down the plaintiff's dwelling-house, he and his family being in it at the time, and the dwelling-house in question having been wrongfully erected upon a place over which the defendant had a right of common, which was thus infringed? In determining the question the Court observed, that a person who is injured by a private nuisance may, as a general rule, abate it; and within this rule the case of a commoner is included, so that he may abate a nuisance

(x) Per Fry, J., Beddall v. Maitland, 17 Ch. D. 188 . "The correct view seems to be that the possession of a rightful owner gained by forcible entry is lawful as between the parties, but he shall be punished for the breach of the peace by losing it, besides making a fine to the king." Pollock, Law of Torts, 4th ed., 345.
(y) Post, Bk. III., Chap. 3.
(z) Judgm., 7 Q. B. 377; see Cubitt
B.C.L.

v. Maxse, L. R. 8 C. P. 704. 176.

(a) Jones v. Williams, 11 M. \& W.

(b) (1895), A. C. 1, affirming C. A., (1894) 3 Ch. 1.

(c) 8 Q. B. 757 (with which acc. Jones v. Jones, 1 H. \& C. 1, 6; Dimes v. Petley, 15 Q. B. 276, 283; Arnold v. Holbrook, L. R. 8 Q. B. 96; 101 ; Davison v. Wilson, 11 Q. B. 890 . 
which interferes with his right, so far as may be necessary for its exercise. Nor does the nature of the building which may obstruct the exercise of the right seem material. A house may be pulled down just as much as a barn or any other building. Does, then, the fact that individuals are in the house at the time in question, render the fact of pulling it down unlawful? Reasoning by analogy from the law of distress, it seems to do so. $A$ horse on which a man is riding, or tools which he is using, cannot be distrained, on account of the imminent risk which there would be of a breach of the peace taking place if such a distress were permitted $(d)$; and surely, it ras argued, the risk of a breach of the peace is much more imminent in the case of pulling down a house in which persons actually are (e). An act done under such circumstances would be specially calculated to excite violence; and the law will not permit any man to pursue his remedy at such risk $(f)$.

From the decision adverted to, we must not infer that the rightful owner of land could not justify the forcible expulsion from it of a mere trespasser who had taken possession, or the pulling down of a house wrongfully built upon it by such a trespasser. It cannot be that a mere stranger acquires a title by intrusion, except where his possession has continued during the period prescribed by the Statutes of Limitation. In such a case the owner of the soil may enter, and, with a view to ejecting the tenant, pull down any house which he may have erected there, although he be inhabiting it at the time $(g)$.

In Perry v. Fitzhoue, moreover, it will be found that the plea of justification did not contain any averment of notice

(d) Field v. Adames, 12 Ad. \& E. 649.

(e) See Knapp v. London, Chatham \& Hover R. C., 2 II. \& C. 212.

(f) "Perry v. Fitzhoue seems to show that any unlawful inclosure of a waste land may be abated by the com. moners as a nuisance, provided that the removal of the encroachment can be effected without the risk of a breach of the peace:" per Lush, J., Lascelles r. Lord Onslow, 2 (2. B. D. 447.

(g) Burling v. Read, 11 Q. B. 904: Davison r. Wilson, Id. 890. 
to the plaintiff previous to the alleged trespass. And in Daries v. Williams (h), it was expressly held that where a house has been wrongfully built upon a common, and obstructs the enjoyment of the right of common, a commoner may, after notice and request to the plaintiff to remove the house, pull it down, although the plaintiff is actually inhabiting it and present therein.

In regard to the abating of a public nuisance, it is laid down (i), that " if a new gate be erected across the public Abatement
of public of public highway, which is a common nuisance, any of the king's subjects passing that way may cut it down and destroy it." The cases below referred to $(j)$, however, show that to justify a private individual in abating on his own authority such a nuisance, it must appear that it does him a special injury; and he can only interfere with it as far as may be necessary to exercise his right of passing along the highway with reasonable convenience, and not because the obstruction happens to be there. "A private individual can abate a nuisance " only "when necessary to exercise a right" $(k)$.

Another "case in which," says Blackstone, "the law Distress. allows a man to be his own avenger, or to minister redress to himself, is that of distraining cattle $(l)$, or goods for nonpayment of rent or other duties; or, distraining another's cattle damage feasant, that is, doing damage or trespassing upon his land $(m)$. " The analogy," it has been observed, "between the case of distress taken damage feasant, and distress for rent is obvious. At common law each was only a pledge; the distress for rent is more a voluntary act than

(h) 16 Q. B. 546; approved Lane v. Capsey, (1891) $3 \mathrm{Ch} .411$.

(i) 3 Bla. Com., p. 5 .

(1) Dimes v. Petley, 15 Q. B. 276; cited and followed in Arnold v. Holbrook, L. R. 8 Q. B. 101 ; Bridge v. Grand Junction R. C., 3 M. \& W. 244 ; Davies v. MIann, 10 M. \& W. 546; Mayor of Colchester v. Brooke,
7 Q. B. 339 ; Bateman v. Bluck, 19 Q. B. 870 ; Roberts v. Rose, 3 H. \& C. $162 ; S . C .$, L. R. 1 Ex. 82.

(k) Per Cockburn, C. J., Arnold r. Holbrook, L. R. 8 Q. B. 100.

(l) Keen v. Priest, 4 H. \& N. 236.

(m) 3 Bla. Com., p. 6. See Cape ₹. Scott, L. R. 9 Q. B. 269. 
the distress damage feasant, because in the latter case the man [who distrains] may be said to be acting on the compulsion of the trespass" $(n)$. The right of distress is also given to enforce the recovery of other duties besides those in the nature of debt;-for example, assessments and rates under special Acts of Parliament. Into the mode of enforcing a remedy by distress in any of these cases it is not the object of this Work minutely to enter.

Remedies by operation of law.

II. Remedies by the mere operation of law-independent of the ordinary mode of procedure-are afforded when parties are so peculiarly circumstanced, that for some reason they cannot appeal through the usual channels of justice for redress; and " the benignity of the law is such as, when to preserve the principles and grounds of law it depriveth a man of his remedy without his own fault, it will rather put him in a better degree and condition than in a worse" $(o)$.

These remedies are :-

Retainer.

1. By retainer-when a creditor is made executor or administrator to his debtor, and is entitled to retain out of the assets of the deceased the debt due to himself, in preference to paying other creditors $(p)$.

Rennitter. 2. By remitter-" where he who hath the true property or jus proprietatis in lands, but is out of possession thereof, and hath no right to enter without recovering possession in an action, hath afterwards the freehold cast upon him by some subsequent, and of course defective, title. In this case he is remitted, or sent back by the operation of law to his ancient and more certain title" $(q)$.

(ii) Judgm., Lehain r. Philpott, I. R. 10 Ex. 246, where it was held that when a landlord distrains for rent and does not sell the goods he cannot bring an action for the rent so long as he bolds the distress, though it be insuffi. cient to satisfy the rent due.

(o) Bac. Max., reg. 9.

(p) 1 Wms. Saund. 333 , n. s. ; De
Tastet v. Shaw, 1 B. \& Ald. 664; Com. on Laws of England, by Broom and Hadley, III., 11. This right is not affected by the Act abolishing the distinction between specialty and simple contract debts, 32 \& 33 Vict. c. 46 ; see Crouder v. Stevart, 16 Ch. D. 368.

(q) 3 Bla. Com., p. 19 . See Doe d. Daniel r. Woodroffe, 2 H. L. Ca. 811 ; 
III. In general our Common Law Courts do not on summary application adjudicate between parties upon rights, which may by action be duly investigated. To this rule there are, however, exceptions. Thus, a solicitor, being an Motion or officer of the Court, and in that character amenable to its surveillance, may sometimes be compelled in a summary way to do that for the not doing of which an action would have lain, and he may also sometimes on motion be punished for gross negligence $(r)$.

The jurisdiction exercised by the Courts in such cases depends upon the character assumed by the party against whom a complaint is put forth, so that it has been repeatedly held that the Court will not interfere summarily to compel payment of money or the restitution of deeds detained by a solicitor, unless the deeds or monies were received by him in the character of solicitor, or whilst acting as such for the applicant $(s)$.

To punish, "by attachment, misconduct or disobedience in its officers" would seem to be the main object for which the Court interferes summarily $(t)$ in the class of cases referred to. Indeed, the jurisdiction of a Court of law on

S. C., 15 M. \& W. $769 ; 10$ M. \& W. 608.

(r) Long v. Orsi, 18 C. B. 610 ; Cox v. Leech, 1 C. B., N. S. 617 ; Meggs v. Binns, 2 Bing. N. C. 625 ; Hawkins . Harwood, 4 Exch. 503; Cooper v. Stephenson, 21 L. J. Q. B. 292 ; Tharratt v. Trevor, 7 Exch. 161 ; Ex parte Eduards, re Johnson, 8 Q. B. D. 62. When the High Court makes an order ordering a solicitor to be struck off the rolls for misconduct, it does so in exercise of a disciplinary jurisdiction over its own officers, and not of a jurisdiction in any criminal cause or matter within the meaning of section 47 of the Judicature Act, 1873, and therefore an appeal lies from such order to the Court of Appeal : per the whole Court of Appeal, Re Hardwick, 12 Q. B. D. 148. See the Solicitors Act, 1888 (51 \& 52 Vict. c. 65 ), ss.
12-15. A solicitor may be struck off for an offence haring no relation to his character as solicitor, cf. In re Weare, (1893) 2 Q. B. 439.

(s) Re Aitkin, 4 B. \& Ald. $49 ; 22$ R. R. 616 ; Ex parte Bodenham, 8 Ad. \& E. 959; Re Lord Cardross, 5 M. \& W. 545; Ex parte Cobledick, 12 Q. 'B. D. 149 .

In Re Blake, 3 E. \& E. 38, the rule supra is stated more broadly by Cockbus?n, C. J.

(t) Per Coleridge, J., Re Hilliard, 2 D. \& L. 919. See Thompson v. Gordon, 15 M. \& W. 610 ; Ex parte Clifton, 5 D. P. C. 218 ; Duncan r. Richmond, 7 Taunt. 391; Collins $\mathbf{}$. Johnson, 16 C. B. 588; Guilford v. Sims, 13 C. B. 371 . See also 32 \& 33 Vict. c. 62 , s. 4 (4); In ve Freston, 11 Q. B. D. 545 ; In re.Dudley, 12 Q. B. D. 44 . 
motion or summons, not merely orer its officers, but generally, is essentially regulated by its discretion $(u)$ in the exercise whereof an extraordinary remedy will sometimes be extended to an applicant, in pursuance of the great principle, that "where there is a right there is a remedy ; sometimes it will be refused, $v i z$., where private convenience is made to bend to general considerations of expediency or motives of policy.

The extraordinary jurisdiction exercised by our legal tribunals in cases other than those above alluded to, is for the most part: 1 , by prerogative writ of mandamus ; 2 , by injunction; 3 , by order for the interim preservation of property ; 4 , by writ of prohibition; 5 , by proceedings in the nature of a writ of quo warranto; 6 , by writ of certiorari ; 7 , on interpleader ; 8, by attachment of debts or garnishment; 9, by summary proceedings for the recovery of possession of small tenements; 10 , by proceedings for the specific delivery of chattels; 11 , by criminal information; 12 , by writ of habeas corpus ; 13 , by petition of right and monstrans de droit.

Mandamus. 1. The writ of mandamus is a high prerogative writ $(x)$, which is not, however, ex debito justitice $(y)$-issuing in the Queen's name out of the Queen's Bench Division of the High Court of Justice, on application made to it by

(iv) Common Law Courts have in some cases, on equitable principles, interfered between a solicitor and his articled clerk, to order that the premium paid by the latter be refunded, wholly or in part; Ex parte Bayley, 9 B. \& C. 691 ; Ex parte Fisher, 1 Chit. R. 694 ; Ex parte Prankerd, 3 13. A Ald. 257; In re Thompson, 1 Exch. 864. But see Whincup v. Hughes, L. R. 6 C. P. 78; followed in Ferns v. Carr, 28 Ch. D. 409, and also in Learoyd v. Brook, (1891) 1 Q. B. 431.

(x) As to the meaning of the term "prerogative" as applied to the writ of Mandamus, see Tapping on Man- damus, p. 4; per Lord Mansfield, C. R., $l_{\text {. }}$ v. Coucle, 2 Burr. $855 ; R$. r. Heathcote, 10 Mod. 54. As to an action of mandamus, which is a proceeding to enforce the performance of a duty in the performance of which the plaintiff is personally interested, and for non-performance of which he has no other equally effectual remedy, see Order liii., Rr. 1-4. Such an action may lie though no actual damage has been sustained. See Fotherby v? Metrop. R. C., L. R. 2 C. P. 188.

(y) Reg. r. Garland, L. R. 5 Q. B. 269 ; Reg. v. Wigan, L. R. 9 Q. B. 325. 
motion $(z)$. The writ commands those to whom it is directed to perform some specified duty. It is granted on affidavit where the party injured " hath a right to have anything done and hath no other specific means of compelling its performance" (a). "As a rule," indeed, "mandamus does not lie where any other remedy exists" (b).

Sometimes, however, this method of redress is available where the process provided by the law is tedious or incomplete $(c)$; though the Court will refuse thus to exert its extraordinary powers where the ordinary remedy by action is adequate to enforce the legal right in question $(d)$. And although a mandamus will be granted "when that has not been done which a statute orders to be done," it will not be allowed to go "for the purpose of undoing what has been done" (e). Nor will the exercise of a discretionary power be thus enforced $(f)$.

The proceeding by mandamus appears to have been "originally confined in its operation to a very limited class of cases affecting the administration of public affairs; such as the election of corporate officers, the restoration of officers improperly removed, the compelling inferior Courts

(z) Crown Office Rules, 1886, Rr. 60 to 79. "A writ of mandamus is a prerogative writ, and not a writ of right, and it is in this sense in the discretion of the Court whether it shall be granted or not:" Reg. v. All Saints, Wigan, 1 App. Cas. 611, 620.

The Crown is not amenable to this jurisdiction, nor are servants of the Crown: Reg. v. Lords Comm. of the Treasury, L. R. 7 Q. B. 387, 394.

(a) See Mayor of Rochester v. Reg., E. B. \& E. 1031, 1033.

(b) Per Mellor, J., Guardians of Holbon Lnion v. Vestry of St. Leonard, Shoreditch, 2 Q. B. D. 149.

(c) See per Sir $W$. Follett, arguendo, Feley v. Burder, 12 Ad. \& E. 266, citing $R$. v. Bishop of Chester, 1 T. R. 404; 1 R. R. 237; Frost v. Mayor, \&c., of Chester, 5 E. \& B. 531; and R. v. Mavquis of Stafford, 3 T. R. 652 ; 8 R. R. 668. See Dr. Ashew's Case,
4 Burr. 2188-9; R. v. St. Katharine's Dock Co., 4 B. \& Ad. 360 ; R. v. Severn and Wye R. C., 2 B. \& Ald. 646, 21 R. R. 433, commented on per Lord Denman, C. J. Reg. . . Gamble, 11 Ad. \& E. 72, and explained Reg. v. G. W.R. Co., 62 L.J.Q. B. 572 , at p. 580 (per Bowen, L. J.).

(d) Keg. v. Hull and Selby R. C., 6 Q. B. 70 ; Reg. v. Hopkins, 1 Q. B. 161 ; Reg. v. Chapter of St. Peter's, Exeter, 12 Ad. \& E. 512 ; Reg. $\vee$. Mayor, gic., of Oxford, 6 Ad. \& E. 349 ; Reg. v. Bristol and Exeter R. C., 3 Railw. Cas. 777. See Moffatt v. Dickson, 13 C. B. 543; Ex parte Overseers of Downton, 8 E. \& B. 856 ; Reg. v. Comm. of Southampton, 1 B. \& S. 5 .

(e) Per Lord Campbell, C. J., Ex parte Nash, 15 Q. B. 95.

(f) See Reg. v. Bishop of Oxford, 4 Q. B. D. $52 \%$. 
to proceed in matters within their jurisdiction, or public officers to perform duties $(g)$ imposed upon them by common law or by statute, as to make a rate and the like $(h)$. In more recent times, however, the applicability of the remedy in question has been extended, not merely to the cases first above mentioned, but to some others. In the course of modern legislation, no session of Parliament occurs in which Acts of Parliament do not pass for making railways, forming docks, building bridges, improving towns, and for carrying out an infinite variety of public works, for the most part to be done by joint-stock corporations or companies for the benefit of shareholders. Now in almost every Act of this kind, provisions are to be found, which direct that the company shall do certain works for the benefit of individuals, ex. gr., making communications between lands intersected by works authorised by the Act, substituting new buildings for others which have been removed, making roads and communications in lieu of old ones blocked up or injured, and other works of a similar character. In the event of non-compliance with any such enactment, the individual who suffers detriment therefrom may resort to the remedy of mandamus (i).

Further, control will in general be exercised over inferior ( $j$ ) Courts by mandamus, when the latter, having jurisdiction, refuse to act $(k)$; but the writ is not granted on the ground that in any particular case the Court below has come to an unjust or improper conclusion $(l)$. It is,

(g) See Mayor of Rochester v. Reg., supra, n. (a); Keg. v. Maimuaring, E. B. \& E. $474 ;$ Reg. r. Percy, L. R. 9 Q. B. 64 . As to which case, see Reg. v. Biron, 14 Q. B. D. 474; Reg. v. Phillimore, ib.; 51 L. T. 205.

(h) C. L. Com., 2nd Rep., p. 40.

(i) But cf. Reg. v. G. W. R. Co., 62 L. J. Q. B. 572, and cases there cited. A writ of mandamus is the proper remedy for enforcing the taking up of awards under the Lands Clauses Act (8\& 9 Vict. c. 20$), R e g$. v. $L . N$.
W. R. Co., (1894) 2 Q. B. 512.

(j) The Central Crininal Court is a superior Court, to the judges and justices of which mandamus will not lie. Reg. v. Judges, \&c., Central Criminal Court, 11 Q. B. D. 479.

(k) Reg. v. Brown, 7 E. \& B. 757.

(l) Reg. v. Justices of Worcestershive, 3 E. \& B. 477 ; Sturgis v. Joy, 2 E. \& B. 740 ; Reg. v. Welch, 2 E. \& B. 357 ; Reg. v. Archbishop of Canterbury, 11 Q. B. 483. 
however, sometimes issued in aid of legal proceedings, as by ordering that a creditor of a company should be at liberty to inspect the register of the shareholders with a view to his issuing execution against them $(m)$, or it may issue to the mayor and assessors of a borough commanding them to revise the burgess list $(n)$. The writ will be refused where, if granted, it would be nugatory or useless or unnecessary, or where it must ultimately fail (o), à fortiori it will be refused when it is sought for the purpose of enforcing a claim founded on an illegality, for it is a writ emphatically in subsidium justitice $(p)$.

The writ, in the first instance, commands the party to whom it is addressed to do the act required, or to make a return thereto, by showing cause why he does not do it $(q)$; and unless he does the act or succeeds in quashing the writ as insufficient on the face of it, he must proceed to answer the writ or demur to it,-if judgment is given against him, the Court awards a peremptory mandamus, and in cases of private injury, damages and costs $(r)$.

"Where the Judges grant a peremptory mandamus, which is a determination of the right and not a mere dealing with the writ, they decide according to the merits of the case, and not upon their own discretion " (s).

Disobedience to a peremptory mandamus is punishable by writ of attachment or by committal, and the Court may further direct the act to be done and charge the defendant with the costs $(t)$.

2. The proceeding by injunction is appropriate for pre- Injunction.

(m) Reg. v. Derbyshire, \&c., Co., 3 E. \& B. 784 ; Reg. v. Harrison, 9 Q. B. 794 .

(n) See for instance Mayor of Rocliester v. Reg., E. B. \& E. 1024.

(o) Tapping on Mandamus, p. 15; Re The Bristol, \&c., Railw. Co., 3 Q. B. D. 10 .

(p) Per curiam, R. v. Littledale, 10 L. R. Ir. 78 .
(1) See Reg. r. Commissioner's of Southampton, 1 B. \& S. 5.

(r) See Reg. V. Justices of Surrey, 9 Q. B. 37 ; Reg. v. Harden, 1 B. C. C. 214 ; Reg. v. South Eastem R. C., 4 H. L. Ca. 471 ; R. S. C., Ord. liii., Rules ó et seq.

(s) Reg. v. All Saints, Wigan, 1

App. Cas. 611, 620.

( $t$ ) Order xlii., Rr. T, 30.
Return to writ. 
venting the committal, repetition or continuance of any breach of contract or tort $(u)$, and is frequently exercised for the protection of legal rights to property pending litigation $(x)$. The writ of injunction is now abolished, and this remedy is granted by judgment or order having the same effect which a writ of injunction previously had $(y)$. If the injunction is asked before, at or after the hearing of the cause, to prevent any threatened or apprehended waste or trespass to land, it may be granted, if the Court think fit, whether the person against whom such injunction is sought is or is not in possession under any claim or title or otherwise, or (if out of possession) does or does not claim a right to do the act sought to be restrained under any colour of title: and whether the estates claimed by both or by either of the parties are legal or equitable $(z)$. There must in general be an action, either proceeding or immediately in contemplation, to determine the right in respect of which an injunction is asked for, but the Court has power to grant an injunction even when there is no ground of action.

It has been held that the vendor of land adjoining other land of his own under which are mines and minerals, and who knows at the time of sale that the vendee is about to erect upon the land purchased substantial buildings, impliedly covenants that he will not use the adjoining land or permit it to be used in such a manner as to derogate from his grant, and may, eren though no actual damage has been sustained by the vendee, be restrained from doing so (a). Again, a mortgagor in receipt of the rents and profits of the mortgaged premises has a sufficient interest

(ii) As to claims for damages and other redress, see Shaw $\nabla$. Earl of Jersey, 4 C. 1'. D. 120, 359; Morgan v. Metropolitan R. C., L. R. \& C. 1.97; Booth v. Taylor, L. R. 1 Ex. 51; Sutton v. South-East. R. C., Id. 32 ; Aslatt v. Southampton, gc., 16 Ch. D. 148.

$(x)$ The doctrines in Equity in regard to injunction for breach of covenant, are stated by Lord Cairns, C., in Joherty r. Allman, 3 App. Cas. 709, 720.

(y) Ord. 1., R. 11.

(z) $36 \& 37$ Vict. c. 66 , s. 25 (8). $57^{2}$. 
to enable him to maintain an action for an injunction, to restrain an injury done to the mortgaged property without joining the mortgagee (b). And an injunction may be granted to restrain a defendant from publishing of the plaintiff to the injury of his trade, matter which a jury have found to be libellous (c), or to restrain the publication of libellous matter reflecting upon a society or company $(d)$. Where the remedy at law is inadequate, a mandatory injunction will be granted to compel the party complained of to do the necessary acts to establish the plaintiff's legal right, as for instance by pulling down a building he had no right to erect, provided the damage is substantial (e).

Disobedience to a judgment requiring any person to do any act other than the payment of money, or to abstain from doing anything, may be enforced by writ of attachment or by committal, and injunctions are usually enforced against corporations by sequestration $(f)$.

"No cause or proceeding at any time pending in the High Court of Justice, or before the Court of Appeal, shall be restrained by prohibition or injunction; but every matter of equity on which an injunction against the prosecution of any such cause or proceeding might have been obtained, if this Act had not passed, either unconditionally or on any terms or conditions, may be relied on by way of defence thereto." $(g)$. Either of the said Courts, however, may direct a stay of proceedings in any cause or matter pending before it if it shall think fit; and any person, whether a party or not to such cause or matter, who would formerly have been entitled "to apply to any Court to restrain the prosecution thereof, or who may be entitled to

(b) Fairelough v. Marshall, $4 \mathrm{Ex}$. D. 37 .

(c) Saxby v. Easterbrook, 3 C. P. D. 339.

(d) Hill v. Havt Davies, 21 Ch. D. 798 ; Quas'z Hill, ge., Co. v. Beall, 20 Ch. D. 501. Cf. also Liverpool Stores v. Smith, 37 Ch. D. 170. (e) Webster v. Wheuall, 42 L. T. 868. See Strelley v. Pear'son, $15 \mathrm{Ch}$. D. 113.

$(f)$ Ord. xlii., R. 7 ; Sutton v. Barnett, W. N., 1877,167; Att.-Gen. v. Walthamstow, W. N., $1878,90$.

(g) 36 \& 37 Vict. c. $\hat{e} 6$, s. $24(\overline{0})$. 
enforce, by attachment or otherwise, any judgment, decree, rule, or order, contrary to which all or any part of the proceedings in such cause or matter may have been taken, shall be at liberty to apply to the said Courts respectively, by motion in a summary way, for a stay of proceedings in such cause or matter, either generally, or so far as may be necessary for the purpose of justice; and the Court shall thereupon make such order as shall be just."

Interim preservation of property.
3. Under Order L. (h), when by any contract a primâ facie case of liability is established, and there is alleged as matter of defence a right to be relieved wholly or partially therefrom, an order may be made for the preservation or interim custody of the subject-matter of the litigation, or that the amount in dispute be brought into Court or otherwise secured. The application for such order may be made by the plaintiff at any time after his right thereto appears from the pleadings; or, if there be no pleadings, is made to appear by affidavit or otherwise (i).

An order may also be made, on the application of any party to an action, for the sale, by any person named therein, in such manner, and on such terms as may seem desirable, of any goods, wares, or merchandise which may be of a perishable nature, or likely to be injured from keeping, or which for any other sufficient reason it may be desirable to have sold at once $(k)$. Further, upon application as last aforesaid, and upon such terms as may be just, an order may be obtained for the detention, preservation, or inspection of any property or thing, being the subject of the causo or matter as to which any question may arise therein, and to authorise the entry of any person upon any land or building in the possession of a party to the cause or matter, and to authorise samples to be taken, or any observation to be made or experiment tried, which may seem (k) R. 2 . (h) R. 1.
(i) R. 7 . 
expedient for the purpose of obtaining full information or evidence $(l)$ bearing on the subject in litigation. The judge also has power to inspect $(m)$. And where the property in dispute is only detained for a lien the owner may obtain an order to recover possession of his property upon payment of a sufficient sum into Court to abide the event (n).

A mandamus or an injunction may be granted, or a receiver appointed, by an interlocutory Order of the Court, either unconditionally or upon terms, in any case in which it may appear just or convenient that such order should be made $(o)$.

4. The writ of prohibition issues out of a superior Court Prohibition. of Law $(p)$, and is directed to the Judge of an inferior $(q)$ Court, or the parties to a suit therein, or both conjointly, requiring that the proceedings which have been commenced there be either conditionally stayed or peremptorily stopped $(r)$. The object of the writ is the keeping of the Court to which it is directed within its proper jurisdiction $(s)$, or to repress the assumption of authority by any pretended Court $(t)$.

The writ of prohibition may issue to an ecclesiastical Court (u), where something is being done by it "contrary to

Prohibition to Ecclesias. tical Court. (l) R. 3.

(m) R. 4.

(n) R. 8.

(o) $36 \& 37$ Vict. c. 66 , s. 25 (8), Ord. 1., R. 6.

(p) Com. Dig. Prohibition (B.); Anon., 1 P. Wms. 476 ; Blackborough จ. Davis, Id. 43 . See $51 \& 52$ Vict. c. 43, s. 127 .

As to whether the granting of a prohibition is ex debito justitix or discretionary, see Bac. Abr. Prohibition (B.).

(q) We have already seen that a cause pending in the High Court of Justice or before the Court of Appeal cannot be restrained by prohibition or injunction, ante, p. 219.

(r) Anon., 6 Mod. 308; Bac. Abr. Prohibition (F.).

(8) Com. Dig. Prohibition (C.) ; 2
Salk. 552 ; Reg. v. Herford, 3 E. \& E. 115, which shows that prohibition may issue to a Court having crimiual jurisdiction.

( $t)$ Chambers v. Jennings, Salk. 553.

(u) In earlier times, one of the main uses of the writ of prohibition was to restrain the jurisdiction of the Ecclesiastical Courts ; see Coke, 2nd Inst. tit. "Articuli Cleri" for the history of the disputes between the common law and ecclesiastical courts, in respect of the prohibitions issued to the latter by the former. See per Coltman, J., Toft v. Rayner, 5 C. B. 162. Many authorities as to granting this writ are collected in the notes to Ex parte Tucker, 1 M. \& G. 519. See also Hallack v. Cambridge Univ., 1 Q. B. 593, followed in Reg. v. Twiss, L. R. 4 Q. B. 
the general law of the land, or manifestly out of the jurisdiction of the Court" $(x)$.

Thus, if an ecclesiastical Court "meddle with a matter purely temporal" (y), civil, or criminal $(z)$, or with a wrong for which at common law there is a remedy (a), it oversteps its jurisdiction-and so where, either in the construction of a statute the spiritual court errs, or where a suit therein is " determined contrary to the right by the common law" $(b)$, the remedy is by prohibition. This principle indeed of the pre-eminence of the common law is broadly laid down by Lord Ellenborough, C. J., when he says, "The Courts of common law have in all cases in which matter of temporal nature has incidentally arisen, granted prohibition to Courts acting by the rules of the civil law, where such Courts have decided on such temporal matters in a manner different from that in which the Courts of common law would decide upon the same" $(c)$.

Prohibition to the tern. poral courts.

Prohibition to the temporal Courts is limited to those cases where they act either without, or in excess of jurisdiction. Thus the writ will not lie in respect of mere irregularities which may have occurred in the proceedings

410; Re Dean of Iork, 2 Q. B. 1 ; Burder v. Veley, 12 Ad. \& E. 233; Ex parte Denison, 4 E. \& B. 292 ; In re Gorham v. Bishop of Exeter, 5 Exch. 630 ; S. C., 10 C. B. 102 ; 15 Q. B. 52; Martin v. Mackonochie, 3 Q. B. D. $730 ; 4$ Q. B. D. 697 ; 6 App. Cas. 424 ; Reg. r. Bishop of St. Albans, 9 Q. B. D. 454.

(x) Per Littledale, J., Ex parte Smyth, 3 Ad. \& E. 724 : per Talfourd, J., Ex parte Story, 12 C. B. $77 \%$; Vin. Abr. Prohibition (Q.).

Where the judge of any inferior court, spiritual or temporal, is interested in a cause, a prohibition will issue to restrain him from hearing it. See $E x$ parte Medwin, 1 E. \& B. 609 . See also Reg. T. Justices of Hertfordshire, 6 Q. B. 753 ; Dimes v. Grand Junction Canal Co., 3 H. L. Ca. 759.

(y) As opposed to mere " spiritualia : - sic dicta quia non habent mixturam temporalium: " 2 Inst. 488.

(z) Bac. Abr. Prohibition (L.).

(a) Galizard v. Rigault, Salk. 552; Free r. Burgoyne, 5 B. \& C. 400; Tounsend v. Thorpe, 2 Ld. Raym. 1507 .

(b) Com. Dig. Prohibition (G. 23); per Lord Ellenborough, C. J., Gould v. Gapper, 5 East, 366 ; 7 R. R. 766; Ex parte ILeduin, 1 E. \& B. 609 ; Ex parte Story, 12 C. B. 767 ; per Lord Kenyon, C. J., Leman v. Goulty, 3 T. R. 4; 1 R. R. 624 ; Duke of Rutland v. Bagshave, 14 Q. B. 869: Enraght v. Lord Penzance, 7 App. Cas. 240.

(c) Gould r. Gapper, 5 East, 371 ; 7 R. R. 766 ; Breedon v. Gill, 5 Mod. 272 ; Bac. Abr. Prohibition (L. 5). But where the spiritual court has sole jurisdiction, its proceedings need not be goverued by the rules of common law: Com. Dig. Prohibition (G. 22). 
of the inferior Court, nor because the Judge, in deciding any particular question properly before him, has erred in his judgment upon the law $(d)$. Should the question as to granting the writ appear doubtful, pleadings as in an ordinary action may be directed by the Court upon which judgment will ensue (e). But when it is clear both in law and fact that the inferior Court is acting in excess of or without jurisdiction the writ of prohibition will issue $(f)$, and all proceedings must be suspended, by those to whom it is directed, upon pain of attachment $(g)$.

5. The writ of Quo Warranto-now obsolete-was a writ of right of the Crown, issuing out of the Queen's Bench, and lay only in respect of an usurpation of the rights or prerogative thereof $(h)$. Proceedings by information (i) in the nature of a writ of quo warranto $(j)$ are now substituted in the place of the ancient writ, and considerable light has been thrown upon their applicability and scope by the judgment in Darley v. Reg. (k), where it is laid down that "this proceeding by information in the nature of quo warranto, will lie for usurping any office, whether created What information will by charter alone or by the Crown with the consent of parliament, provided that the office be of a public nature and a substantive office-not merely the function or employment of a deputy or servant held at the will and pleasure of others; for with respect to such an employment, the Court certainly will not interfere, and the information will not properly lie" $(l)$.

(d) See Mayor, \&c., of London $\mathrm{r}$. Cox, L. R. 2 H. L. 239 ; cited in Cooke v. Gill, L. R. 8 C. P. 107; as to which see Whinney r. Schmidt, L. R. 8 C. P. 118; London Joint Stock Bank v. Mayor, \&c., of London, 1 C. P. D. 1; Ex parte Death, 18 Q. B. 647 ; Reg. v. Local Goverment Board, 10 Q. B. D. 309.

(e) See 1 Will. 4, c. 21, s. 1 (now repealed), and Order lxviii., R. 3.

(f) Worthington v. Jeffires, L. R.
10 C. P. $379,387-8$, where the cases are collected.

(g) Ante, p. 191.

(h) Per Lord Kenyon, C. J., King v. Shephesd, 4 T. R. 381; Frost v. Mayor of Chester, 5 E. \& B. 531.

(i) As to the meaning of the term "information," see post.

(j) $47 \& 48$ Vict. c. 61 , s. 15.

(k) 12 Cl. \& F. 520, cited Keg. v. Hampton, 6 B. \& S. 931.

(l) Per Tindal, C. J., 12 Cl. \& F.
Quo warranto. 
Thus three tests of the applicability of the proceeding by information in the nature of a quo warranto are presented - the source of the office, its tenure, and its duties $(m)$; and within the limits indicated in Darley v. Reg., it is the appropriate civil remedy for trying disputes between private parties as to the authority by which an office or franchise should be held $(i)$, and for ousting those who have im. properly assumed to exercise either $(o)$.

Certiorari.

6. The writ of certiorari $(p)$ is issued for the purpose of removing a suit from an inferior into one of the superior Courts of common law ; and is not a writ of course though an applicant having a peculiar grievance of his own may be entitled to it ex debito justitice $(p)$. A certiorari is directed to the Judge or officers of an inferior Court, commanding him or them to return the record of a cause there depending, to the end that more sure and speedy justice may be done between the parties $(q)$. The right of thus removing a cause exists at common law $(r)$, but has from time to time been limited to some extent in its applicability by statute.

Procedeudo. If the superior Court should consider that a cause has been thus improperly removed, it may issue a writ of procedendo $(s)$, commanding the inferior Court to proceed, or the writ of certiorari may be quashed on motion.

7. With respect to interpleader the procedure and practice are now contained in Order LVII. The Inter-

541, 542; see per Iord Brougham, Id. 545 ; R. v. Arehdall, 8 Ad. \& E. 284 , n. (a); Reg. v. Fox, \& E. \& 13. 939.

(m) Per Erle, J., Reg-v. Guardians of St. Nurtin 17 Q. B. 163 ; where see also the remarks of the other learned Judges upon Inarley r. Reg. 173.

(ii) Ex parte Kamshay, 18 Q. B.

(o) In re Harris, 6 Ad. \& E. 475.

As to what may be brought under the notice of the Court by the AttorneyGeneral, and what may be tried at the relation of a private individual, by leave of the Court, see per Lord Tenterden, C. J., R. v. Oyden, 10 B. \& C. 233 ; R. v. Corporation of Carmarthen, 2 Burr. $\$ 69$; R. r. $\boldsymbol{M} \dot{h} a y, 5$ B. \& C. 640,$646 ; R$. v. White, 5 Ad. \& E. 613.

(p) Reg. r. Justiees of Surrey, L. R. 5 Q. B. 466.

(q) Bae. Abr. Certiorari (A.), (F.); Lawdens v. Sheil, 3 Dowl. 90; Ex parte Phillips, 2 Ad. \& E. 686.

(r) Symonds v. Dimsdale, 2 Exch. 533. Explained, Cherry v. Endean, 55 I. J. (Q. B. 292.

(s) Reg. v. Scaife, 18 Q. B. 773. 
pleader Acts $1 \& 2$ Will. 4, c. 58, and $23 \& 24$ Vict. c. 126, which applied to all actions, were intended by the legislature to remedy mischief of the following nature $(t)$ : " a person in possession of goods might be sued by some one setting up a title to them; if the claim was contested he might be defeated and be liable to pay the value of the goods; and afterwards he might be sued by some other claimant to the goods, and it would be no defence to say that the value of the goods had been already paid to a prior claimant; the new claimant, if he was the real owner, would be entitled to recover in respect of them, and to say that he was not bound by the proceedings in the former action. Therefore, a person who had committed no legal wrong, but was simply in possession of goods claimed by other persons, might be compelled to pay their value twice over. The only remedy for this hardship was the expensive procedure by a bill of interpleader" $(u)$. To do away with this inconvenient state of matters the Stat. $1 \&$ 2 Will. 4 , c. 58 was passed.

Proceedings by interpleader were then devised to enable Courts of Law to give relief against adverse claims made upon persons having no interest in the subject of such claims $(x)$. For this purpose, it was enacted that, if a defendant sued in any action formerly designated respectively " assumpsit," " debt," “detinue," or "trover " (y), in a superior Court at Westminster, should, after declaration and before plea, show that he did not "claim any interest $(z)$ in the subject-matter of the suit, but that the

(t) Per Bramwell, L. J., Attenborough v. St. Katharine's Dock Co., 3 C. P. D. $450,454$.

(u) As to which, see Rogers's Judic. Acts, p. 61 .

(x) See 1 \& 2 Will. 4, c. 58, s. 1 ; Baker v. Bank of Australasia, I C. B., N. S. 515 .

$(y)$ That is to say-any action for breach of simple contract,- for a liqui-

B.C.L. dated sum, for detention of goods,for wrongfully dealing with them and depriving plaintiff of them; post, Books II. and III.

(z) Patorni v. Campbell, 12 M. \& W. 277. See Holt v. Frost, $3 \mathrm{H}$. \& N. 821 ; Attenborough v. St. Katharine's Dock Co., 3 C. P. D. 450. 
right thereto is claimed by (a) or supposed to belong to some third party, who has sued or is expected to sue for the same; and that such defendant does not in any manner collude $(b)$ with such third party, but is ready to bring into Court, or to pay or dispose of the subject-matter of the action in such manner as the Court or any Judge thereof may order or direct" $(c)$; then the Court or Judge might order such third party to appear and state the nature of his claim, and maintain or relinquish it ; and the Judge might further "order such third party to make himself defendant in the same or some other action," and also "direct which of the parties shall be plaintiff or defendant on such trial, or, with the consent of the plaintiff and such third party," " dispose of the merits of their claims, and determine the same in a summary manner" (d). Sheriffs and other officers, in execution of process of the superior Courts, who are thereby exposed to the hazard and expense of actions, in respect of claims made to goods seized by the trustees of bankrupts and other persons, might also apply to the Court for relief and protection by interpleader $(e)$. The C. L. Proc. Act, 1860 (23 \& 24 Vict. c. 126), introduced further important provisions affecting the practice-in suits of interpleader. By this statute the proceedings of interpleader might be taken "though the title of the claimants to the money, goods, or chattels in question, or to the proceeds or value thereof, have not a common origin, but are adverse

\section{(a).}

(b) Belcher r. Smith, 9 Bing. 82 ; Thompson r. Wiight, 13 Q. B. D. 632.

(c) 1 \& 2 Will. 4, c. 58, s. 1.

(d) 1 \& 2 Will. 4, c. 53, s. 1 ; Deller r. Priclett, 15 Q. B. 1081; Ridgway r. Allen, 29 L. J., Q. B. 97; per Jollock, C. B., Horton r. Enrl of Deron, 4 Exch. 499 ; Jolton r. Alidland K. C., 12 C. B. 458; Turner s. Mayor, sc. of hendal, 13 M. \& W.
171.

(e) 1 \& 2 Will. 4 , c. 58 , s. 6 ; Cooper r. Asprey, 3 B. \& S. 932 ; Crump r. Day, \& C. B. 760 ; Whiter. Binstead, 13 C. B. 304; Gadsden v. Barrou, 9 Exch. 514; Winter r. Bartholomeri, 11 Exch. 704.

And see $1 \& 2$ Vict. c. 45 , which gare to a Judge the same powers as the Court for relief of sheriff: Teggin r. Langford, 10 M. \& W. 5 5.6; shortridge v. loung, 12 JI. \& W. 5 . 
to and independent of one another" $(f)$. The new rules of Order LVII. are framed upon these statutes and the decisions under them, and they contain a compendious statement of the present practice in interpleader $(g)$.

8. In our list of Extraordinary Remedies may be included the mode of redress by attachment of debts or garnishment, now regulated by Order $\mathrm{XLV}$. Under the Rules of the Supreme Court, the party entitled to enforce a judgment or order for the recovery of money may apply to the Court or a Judge for an order that the debtor be orally examined as to whether any and what debts are owing to him, and as to what means or property he has, and an order may thereupon be made for his examination, and for the production of books or documents $(h)$. The examination will be before a Judge or officer of the Court (i), and either before or after such examination, upon the ex parte application of the creditor, and upon the affidavit by him or his solicitor stating that judgment has been recovered or an order made, and that it is still unsatisfied, and to what amount, and that some other person is indebted to the debtor, and is within the jurisdiction, an order may be made that all debts owing or accruing from such third person,- the garnishee,-to the debtor be attached to answer the judgment or order; and that the garnishee show cause why he should not pay the creditor the debt due from him to the debtor, or so much thereof as may be sufficient to satisfy the judgment or order $(j)$.

Service of the order for an attachment of debts or notice thereof will bind them in the hands of the garnishee $(k)$. Should he not dispute the debt claimed to be due, nor pay into Court the amount due from him to the debtor, or an

(f) Sect. 12. See Best v. Hayes, 1 H. \& C. 718.

(g) These statutes are now repealed with the exception of s. 17 of $23 \& 24$ Vict. c. 126 ; as to which section see also Order lvii., R. 11 .

(h) Order xlii., R. 32.

(i) Id.

(j) Order xlv., R. 1 .

(k) R. 2.
Attachment of debts or garnishment. 
amount equal to the debt, execution for the same may without any previous writ or process issue against him $(l)$. Should the garnishee dispute his liability, an order may be made that an issue for determining it be tried ( $m$ ).

Should it be suggested by the garnishee that the debt sought to be attached belongs to some third person, or that some third person has a lien or charge upon it, an order may be made that such third person appear, and state the nature and particulars of his claim upon the debt $(n)$. And after hearing his allegations, as well as those of any other person ordered to appear, or in case of such third person not appearing, the Court or Judge may order execution to issue to levy the amount due from the garnishee, or any question to be tried, and may bar the claim of such third person, or make any other order upon such terms as may be just and reasonable $(o)$.

Payment made by or execution levied upon the garnishee under any such proceeding as aforesaid will be a valid discharge to him as against the judgment debtor, to the amount paid or levied $(p)$.

Debts to be attachable must be absolute, and not merely conditional $(q)$, although a debt certain payable at a future day is sufficient $(r)$.

It has been held that pensions for past services are attachable, unless made inalienable by statute $(s)$, but the half-pay of a military or naval officer is exempt on the ground of public policy $(t)$.

9. The summary proceedings which have been provided for enabling a landlord to recover possession of small tene-

(l) R. 3.

(m) R. 4.

(ง) R. 5.

(o) R. 6.

(p) R. 7.

(q) Houcll v. Metrop. R. C., 19 Ch. D. 508 .

(r) Tapp v. Jones, L. R. 10 Q. B.
591.

(s) Lucas v. Harris, 18 Q. B. D. 127; followed Crouce $\nabla$. Price, 22 Q. B. D. 429 .

( $t$ ) Dent v. Dent, L. R. 1 P. \& D. 366 ; Willcock r. Terrell, 3 Ex. D. 323 . 
ments from a tenant, who holds over after the determination of his term, may be taken before the justices of the peace, under 1 \& 2 Vict. c. 74, or before the Judge of a county court, under $51 \& 52$ Vict. c. $43(u)$. The former of these statutes applies where the premises are held at will, or for any term not exceeding seven years; and the tenant is liable either to pay no rent or a rent under 20l. a year $(x)$. Proceedings under the county court statute, which are commenced by plaint and summons, and refer only to the ordinary relation of landlord and tenant $(y)$, are restricted to those tenancies "where neither the value of the premises nor the rent payable in respect thereof" exceeds the sum of $50 l$. per annum. If the term of tenancy of such premises has expired or been duly determined by notice, but the tenant persists in holding over, then, upon the necessary proofs being adduced before the Judge, he may order possession to be given to the landlord; and if such order be not obeyed, the registrar of the Court may issue a warrant to the high bailiff, authorising him to give such possession, who may in obedience to the warrant take with him all necessary assistance $(z)$. If the title comes in question the County Court has nevertheless jurisdiction in these cases. Although prior to the County Courts Act, 1888, it had no such jurisdiction if the value or rent exceeded 20l. per annum (a). An appeal, however, lies from it to a superior Court, where the yearly rent or value of the premises exceeds 20l., or by leave of the County Court Judge, where it is less than that amount (b).

10. In the list of Extraordinary Remedies is, on account livery of specific chattels.

(u) Sects. 138-143. As to the effect of which see per Channell, B., Hodson v. Walker, L. R. 7 Ex. 61 et seq.

(x) Sect. 1.

(y) Jones V. Owen, 5 D. \& L. 669 ; Banks v. Rebbeck, 2 L. M. \& P. 452 ; Fearon v. Norvall, 5 D. \& L. 444 ; Re Earl of Harrington, 2 E. \& B. 669 ; Kerkin v. Kerkin, 3 E. \& B. 399. (z) 51 \& 52 Vict. c. 43 , ss. 138-143; Campbell v. Loader, 3 H. \& C. 520.

(a) 51 \& 52 Vict. c. 43, s. 60 (extending the jurisdiction to 50l.). See 30 \& 31 Vict. c. 142, s. 12, and Pearson v. Glazebrook, L. K. 3 Ex. 27 (decided before the passing of the lastmentioned Act).

(b) 51 \& 52 Vict. c. 43, s. 120. 
of its peculiar stringency, included the procedure available for compelling the delivery to plaintiff of specific goods or chattels. This procedure varies in its nature, as will at once appear.

Under Order XLVIII. $(c)$ when money is deemed by the plaintiff an inadequate compensation for the loss to him of the chattel in respect of which he sues, he may apply to the Court to order that execution shall issue for the delivery of the property detained, without giving the defendant the option of retaining such property upon paying the value assessed; and that if the property cannot be found, unless otherwise ordered, the sheriff shall distrain the defendant by his lands and chattels, till the defendant deliver the property, or, at the option of the plaintiff, that the sheriff cause to be made of the defendant's goods the assessed value of the property $(d)$.

Delivery of goods sold may sometimes be enforced under the Sale of Goods Act, 1893 (56 \& 57 Vict. c. 71), s. 52 (e).

11. A criminal information is a proceeding in the Court of Queen's Bench $(f)$, by which the Attorney-General or the Queen's attorney and coroner "gives the Court to understand and be informed of " a misdemeanor. It differs from an indictment principally in this respect, that the latter is found and presented by the grand jury $(g)$, "whereas an information is only the allegation of the officer who exhibits it" $(h)$.

(c) As to which, sec Chilton v. Carrington, 15 C. B. 730 ; followed Bank of New South Wales v. ('Connor, 14 App. Cas. 273.

(d) And see Order l., R. 8, where the property is only detained for a lieu.

(e) See post, p. 440. The section reproduces $19 \& 20$ Vict. c. 97, s. 2 (the Mercantile Jaw Amendment Aet), as altered by the Judieature Acts and Rules. For form of writ of execution for the delivery of goods, see R. S. C., App. (H), Form 10.

$(f)$ An information, formerly in the
Court of Exchequer, is brought in respect of property or revenue of the Crown, for intrusion, for breach of the excise laws, ic., see Manning's Exehequer Iract. See stat. $28 \& 29$ Viet. c. $10 t$ (partly repealed by 38 \& 39 Viet. c. 66,44 \& 45 Viet. e. 59 , and $50 \& 51$ Viet. e. 55 ), for regulating the procedure and practice in Crown suits in the Exchequer, and Reg. Gen. East. T. 1866, in pursuance therenf. See L. R. 1 Ex. 389.

(g) Yost, Book 1V., Chap. 4.

(h) Bate. Abr. Informations (A).

As to the legality of informations at 
The Attorney-General, and in his absence the SolicitorGeneral (i), has a right, ex officio, to file a criminal information in respect of any misdemeanor; but he rarely asserts this right, except when cases brought under his notice appear of so grave a character that they affect good government, as being eminently dangerous to the public welfare or directly derogatory to the dignity of the Crown $(k)$. An information on the other hand, filed at the relation of a private individual by the Queen's coroner, is always in respect of some misdemeanor, which, though serious in its nature, assumes a character less formidable and flagitious. Nor can proceedings be taken in this latter mode without leave of the Court being first obtained, and security thereupon given to prosecute with effect, and pay costs to the defendant if he should be acquitted $(l)$. The Court exercises its discretion in thus granting or refusing permission to file a criminal information, on reference to the nature of the offence alleged, and the surrounding circumstances. It will decline to allow an information to be filed in respect of any trivial offence $(m)$, or after unnecessary delay has occurred in applying to the Court $(n)$; or, generally, unless flagrant misconduct on the part of the alleged misdemeanant, and entire rectitude on the part of the applicant, be made apparent $(n)$. On the other hand the remedy in question is granted by the Court in cases of gross libel on public bodies $(o)$, or on the public conduct of individuals holding

common law, and their prosecution in the Star Chamber, see Prynn's ease, 5 Mod. 459. See also Shower's learned " intended argument," in R.v. Berchet, 1 Show. 107. For the constitutional character of the proceedings by information, see note to 13 State Tr. 1369-71.

(i) In re Wilkes, $19 \mathrm{St}$. Tr. 1102, 112\%. The Att.-Gen. for the Duchy of Lancaster cannot exhibit an information in the High Court of Justice. Att.-Gen. of the Duchy, etc. inf. Duke of Jevonshire, dett., 14 Q. B. D. 195. (k) Keg. r. Douglas, 13 Q. B. 42,
74; R. v. Burdett, 3 B. \& Ald. 717; 22 R. R. 539 ; and 4 B. \& Ald. 115 ; 23 R. R. 251 ; R. r. Harrey, 3 D. \& R. 464. See 2 Hawk. P. C. c. 26 ; Bac. Abr. Information (B).

(l) $4 \& 5 \mathrm{~W} . \& \mathrm{M}$. c. 18 ; see 6 \& 7 Vict. c. 96 ; Rig. v. Latimer, 15 Q. B. $107 \%$.

(m) Bac. Abr. Information (A).

(n) R. v. Robinson, 1 W. Bla. 541; $R$. v. Jollie, 4 B. \& Ad. $867 ; R$. . Hartley, $R$. .. O'Meara, Id. 869, n. (a).

(o) R. r. Williams, 5 B. \& Ald. 
eminent position (as peers and members of the House of Commons $(p)$ ), or dignified office (as Judges and magistrates of the land $(q))$; and in some cases the Court has lent its protection when private individuals and their families $(r)$ have been subjected to malicious and excessive insult and slander. In view of a recent decision it seems that this power will only be exercised in cases where the magnitude or pernicious effect of the offence seems to call for the most public animadversion $(s)$. It was also held that the fiat of the Public Prosecutor under the Newspaper Libel and Registration Act, 1881, was not necessary before proceeding by a criminal information $(t)$. Criminal informations may also be filed against Judges and magistrates for illegal, unjust, and wilfully oppressive conduct, arising from corrupt and malignant motives $(u)$, as distinguished from error of judgment.

A criminal information also lies for bribery or an attempt to bribe at a parliamentary or other public election $(x)$, or for using means to pervert or vilify public justice $(y)$, for challenging another to fight a duel $(z)$, or for grievous personal assault (a), as well as in other cases which need not be here particularised (b).

It is important to observe, however, that the Court will never, even under circumstances such as those just indicated,

$595 ; 24$ R. R. 480 ; R. v. Jennur, ? Mod. 400 ; I. v. Osborne, 2 Barnard. 138, $166 ; 2$ Swanst. 502, n. $(c)$.

(p) 1. v. Hasucll, I Dougl. 387; Reg. v. Fates, 11 Q. B. D. 750.

(2) is regards slander on magistrates, Ex parte Chapman, 1 Ad. \& E. 773 ; 3 Chitt. Crim. I. 898; Ex parte Duke of Marlborough, 5 Q. B.95.5.

(r) lieg. v. Gregory, 8 Ad. \& E. 907 ; R. r. Demvison, Lofft, 148 ; $l$. v. Benficld, 2 Burr. 980.

(s) Reg. v. Labouehcre, 12 Q. B. D. 320 , per Lord Coleridge, C. J., at p. 330 .

(t) Reg. v. Fates, 11 Q. B. D. 750. Sce 51 d 52 Vict. c. 64 , s. 8 .

(u) I'er Lord Campbell, C. J., R. v.
Marshall, 4 E. \& B. $480 ; R$. v. Barker, 1 East, 186 ; per Ashurst, J., IR. v. Jaekson, 1 T. R. 653 ; 1 R. R. 343 ; R. v. Sainsbury, 4 T. R. 457 ; 2 R. R. 433 : R. v. Borron, 3 B. E Ald. 432 ; 22 R. R. $44 \pi$; per Patteson, J., Ex parte Fintiman, 2 Ad. \& E. 129; per Ashurst, J., R. v. Brooke, 2 T. R. 190. Sce Reg. v. Badyer, 4 Q. B. 468 .

(x) R. v. Isheruood, 2 Kenyon, R. 202.

(y) R. v. Jolliffe, 4 T. R. 285; 2 R. R. 383 ; R. v. Watson, 2 T. R. 199 ; 1 R. R. 461 .

(z) IR. v. Larrieu, $i$ Ad. \& E. $27 \%$.

(a) k. v. Guilt, 11 Ad. \& E. 587. 42.

(b) See Cole, Crim. Inform., pp. 38, 
lend its sanction to the employment of the extraordinary remedy in question, when he who seeks it has participated in any way in the misconduct complained of $(c)$, nor where he does not come for the assistance of the Court "with clean hands" $(d)$; nor if he has retaliated with the same weapons of the use of which against himself he complains (e); nor if he has resorted to other means of obtaining redress or satisfaction $(f)$. Hence, where an information is applied for in respect of a libel, the applicant must, in general, swear to his innocence of the imputations made against $\operatorname{him}(g)$; and, in all cases he must adduce, in the first instance, sufficient ground in support of his motion $(h)$. Accordingly, a rule nisi for a criminal information is sometimes moved for by one who would clear himself from false and slanderous accusations, the main object of the applicant being simply to employ the opportunity thus afforded him of filing exculpatory affidavits (i).

The trial of a criminal information takes place on the civil side of the Court, evidence being gone into touching the facts which constitute the offence $(k)$. If the defendant be found guilty, matters of aggravation and extenuation may be entertained upon affidavit, when he is called up for judgment.

12. The reader of English history being necessarily Habeas familiar with the nature of the writ of habeas corpus, will

(e) R. .. Peach, I Burr. 548; R. v. Steward, 2 B. \& Ad. 12 ; R. v. Guilt, 11 Ad. \& E. 587. 315 .

(d) Per Lord Mansficld, C. J., Lofft,

As to proceedings on criminal information, see Reg. v. Newman, I E. \& B. 268, 558; S. C., Dearsl. C. C. 85.

(e) Per Lord Denman, C. J., Reg. v. Proprietors of the Nottingham Journal, 9 Dowl. 1043.

(f) Reg. V. Marshall, 4 E. \& B. 475 ; Ex parte Anon, 4 Ad. \& E. 576, n. $(a)$. (g) R. v. Haswell, I Dougl. 387; Cole, Crim. Inform., p. 53.

(h) R. v. Inhabs. of Barton, 9 Dowl. 1022 ; R. v. Eve, 5 Ad. \& E. 780 ; Reg. v. Stanger, L. R. 6 Q. B. 352.

(i) Per Lord Denman, C. J., Ex parte Duke of Marlborough, 5 Q. B. 956.

(k) R. r. Sharpness, I T. R. 229; R. v. Withers, 3 T. R. 428 ; R. v. Burdett, 4 B. \& Ald. 3I4, 319; 23 R. R. 284. As to costs, see Rey. v. Saville, 18 Q. B. 703. 
readily understand wherefore this, the festinum remedium, must be here considered amongst Extraordinary Remedies. The record of the struggles made to maintain this mode of relief in its full force and integrity proves the value attached to it in former times. At earlier epochs, during transitional stages of our constitution $(l)$-when legal rights were less perfectly defined or less capable of enforcement than they now are, and the various elements in the state were unsettled and ill-balanced - the virtue and applicability of the writ of habeas corpus were not unfrequently impugned, albeit as often vigorously reasserted. It exists in these days, the most important remedy of the class now under notice which a Court of common law can be called on to afford: a remark whereof the truth becomes obvious, when it is remembered, that the writ here spoken of is adapted $(m)$ to effect the great object enunciated in Magna Charta (n), that " no man shall be taken or imprisoned unless by lawful judgment of his peers or by the law of the land." How essential it was deemed to insist upon this great principle of common law may be seen, moreover, by reference to subsequent pages of the statute-book. Thus the $25 \mathrm{Edw} .3$, st. 5, c. 4, after reciting the above clause in Magna Charta, which is designated as "the great charter" of our liberties,"-proceeds to enact, that thenceforth none shall be taken by petition or suggestion made to our Lord the King or to his council, unless it be by indictment or presentment of the good and lawful people of the same neighbourhood, or by process made on writ original at common law; and in another statute of the same reign $(o)$ the like doctrine is again mequivocally declared.

On one memorable occasion $(p)$, when the principles

(l) See Hall, Const. IIist., Sth ed., p. jo.

rol. 3, p. 12; Rowlancl's Man. Eng. Const., pp. 549-.5̄3.

(im) 4 Inst. $182,290$.

(i) 9 IIcn. 3 , c. 29 , which is ouly declaratory of the common law, 2 Inst., (o) 42 Edw. 3, c. 3.

(p) Darnell's case, 3 How. St. Tr.1; and see the general Index to the same work (vol. 34), tit. Habeas Corpus, for further refurences. 
affirmed in Magna Charta and the practical method of asserting them $(q)$ by writ of habeas corpus were contested, the arguments both of the bench and of the bar not only set forth elaborately the learning connected with the writ in question, but also show in how many antecedent cases the liberty of the subject had been violated with impunity, and how important consequently it was, that the law which assumed to protect that liberty should be vindicated. It will be remembered, that one of the marked consequences of this case was the Petition of Right $(r)$, which was followed by the statute abolishing the Star Chamber (s), and by an "Act for the better securing the Liberty of the Subject," \&c., usually styled the Habeas Corpus Act $(t)$.

This latter enactment introduced no new principle into the law of England; there being abundant evidence to show that the right to the writ now spoken of existed at common law $(u)$. The provisions of the Habeas Corpus Act were, however, mainly levelled against this right being rendered inoperative, and against the keeping in illegal custody of those who had "been committed for criminal or supposed criminal matters," contrary "to the known laws of the land, whereby many of the king's subjects have been, and hereafter may be, long detained in prison in such cases where by law they are bailable, to their great charges and vexation" $(x)$. The 2 nd section, therefore, proceeds to enact how the writ shall be promptly returned and obeyed in all such cases of criminal or supposed criminal nature, unless the commitment be "for treason or felony, plainly and specially expressed in the warrant of commitment;"

(q) 2 Inst. 55.

(v) 3 Car. 1, c. 1. See Hall. Const. Hist., 8th ed., vol. 1, p. 414; Macaulay, Hist. Eng., vol. 1, chap. 2.

(s) 16 Car. 1, c. 10; Rowland's Man. Eng. Const., p. 334 .

(t) 31 Car. 2, c. 2.

(u) Thomlinson's cast, 12 Rep. 104; Ex parte. Sandilands, 21 L. J., Q. B.
342; Ex parte Besset, 6 Q. B. 481 ; Lconard Watson's case, 9 Ad. \& E. 731 .

And see the Petition of Right, 3 Car. 1, e. 1 .

(x) 31 Car. 2, c. 2, s. 1 . See Cubbctt v. Slowman, 9 Exch. $633 ;$ S. C., 4 Exch. 747 ; Hall. Const. Hist., 8th ed., vol. 2, pp. 352-3. 
and in this latter case provision is made by the 7 th section of the Act, for the speedy trial or discharge from imprison. ment, either on or without bail, of the prisoner.

Another important statute (56 Geo. 3, c. 100, intituled "An Act for more effectually securing the Liberty of the Subject"), relating also to the writ of habeas corpus, had for its object the extending of "the remedy of such writ and enforcing obedience thereunto, and preventing delays in the execution thereof," to those cases where persons are confined "otheruise than for some criminal or supposed criminal matter," except persons imprisoned for debt or by process in any civil suit (y).

It may be observed, that the writ of hab. corp. ad subjiciendum, to which the above statutes mainly refer, and to which we are now confining our attention, is one onlythough incomparably the most important-of a rather large class of writs of habeas corpus $(z)$. Its object being, as already indicated $(a)$, to effect deliverance from illegal confinement $(b)$, it commands the party detaining the prisoner to produce his body, with the true statement of the time of his caption and the cause of his detention $(c)$. The writ is granted by the Queen's Bench Division or a Judge thereof either by motion or upon application ex parte, or upon summons as the case may be, wherever probable and sufficient ground has been assigned for the interposition of its authority $(d)$, and lies to any part of the Queen's

(y) Sect. 1.

(z) The writ ad faciendum et recipiendum (or, as it is semetimes called, of habeas corpus cum causâ) issues to bring up the persou of a defendaut who is in custody under civil process of an inferior Court, and likewise to remove the suit, connected with which he has been taken in executiou, into the superior Court whence the writ has issued: Mitchell v. Micheson, 1 B. \& C. 513 ; as to the difference between which proceeding and that by certiorari, see Clerk v. Mayor, \&c., of Berucick,
4 B. \& C. 649 ; Palmer v. Forsyth, Id. 401.

(a) See further as to the object to which this writ may be applied, Mr. Fry's report of The Canadian Prisoners' case; S. C., 5 M. \& W. 32,9 Ad. \& E. 731 .

(b) Ex parte Child, 15 C. B. 238; In re Hakercill, 12 C. B. 223.

(c) See In re Bailey, 3 E. \& $\mathbf{B}$. $60{ }^{\circ}$; Re Belsan, 7 Moo. P. C. C. 1312 ; Reg. v. Clarke, 7 E. \& B. 186.

(d) See Crown Office Rules, 1886, R. 235 et seq. Hobhouse's case, 3 B. \& 
dominions, not having a Court of Justice with authority to issue such writ $(e)$ and to insure its due execution $(f)$, for the Sovereign, it has been said, ought to have an account why any of his subjects are imprisoned $(g)$. The Court of Appeal has no jurisdiction to hear an appeal from an order of the High Court discharging a person from custody under a habeas corpus $(h)$. An appeal, however, lies from an order directing a writ to issue (i), as well as from the refusal to make such order or to order a discharge $(j)$, provided that the subject-matter of the proceedings in respect of which the application is made be not criminal $(k)$.

The return to the writ is made by producing the prisoner, and setting forth the grounds and proceedings upon which he is in custody $(l)$. If this return is deemed to present sufficient matter in justification of the prisoner's detention, he is remanded to his former custody ; if insufficient, he is discharged therefrom $(m)$. The return cannot be traversed $(n)$, nor need it be verified by affidavit $(o)$; but its validity is determined upon argument $(p)$, on the day of the return, though sometimes new matter is allowed to

Ald. 420 ; 22 R.R. 443 ; Brenan's case, 10 Q. B. 492 ; Re Dunn, 5 C. B. 215 ; Re Cowgill, 16 Q. B. 336 ; Ex parte Bradbu'y, 14 C. B. 15 ; Re Catherine Newton, 13 Q. B. 716; Re Francis Newton, 16 C. B. 97 . The writ will not be granted to bring up persons for the purpose of moving for, or showing cause against, rules: Benns v. Losley, 2 C. B., N. S. 116 ; or of arguing a case in person, Weldon v. Neal, 15 Q. B. D. 471 . 280.

(e) See Ex paste Brown, 5 B. \& S. (f) $25 \& 26$ Vict. c. 20 , s. 1.

(g) Bac. Abr. Hab. Cor. (B.) 2 ; R. v. Cowle, 2 Burr. 834 ; Craufurd's case, 13 Q. B. 613 . 506.

(h) Bell Cox v. Hakes, 15 App. Cas.

(i) Barnardo v. Ford, (1892) A. C. 326, affirming C. A., 24 Q. B. D. 283 ; Barnado v. McHugh, (1891) A. C. 388, affirming C. A., (1891)
1 Q. B. 194.

(j) Ex parte Bcll-Cox, 20 Q. B. D. 1 ; cf. also Reg. v. Jackson, (1891) 1 Q. B. 671 , n.

(k) Ex parte Woodhall, 20 Q. B. D. 832 ; In re Keller, 22 L. R. Ir. 158.

(l) Disobedience to the writ is punishable by attachment: see Corner's Cr. Off. Pr., p. 116.

(m) Re Douglas, 3 Q. B. 825 ; Hammond's case, 9 Q. B. 92. 117.

(n) Corner's Cr. Off. Pr., pp. 116,

(o) Per Jervis, C. J., In re Hakewill, 12 C. B. 228.

(p) As to what is a sufficient return to the writ, see The Canadian Prisoner's case, ante, n. (a); Re Hakcwell, ubi supra; Re Eggington, 2 E. \& B. 707 ; Dimcs's case, 14 Q. B. 554; Clarke's casc, 2 Q. B. 619 ; Ex parte Andrews, 4 C. B. 226; Carus Wilson's case, 7 Q. B. 984: Crawford's case, 13 Q. B. 613.
Return to the writ. 
be introduced to guide the discretion of the Court $(q)$. A writ of habeas corpus will indeed sometimes be quashed on the ground of irregularity or fraud, but not for matter that could have been properly returned to it $(r)$.

Although the space-necessarily limited-which has been here devoted to a consideration of the writ of habeas corpus, might be well deemed inadequate thereto, if measured solely by the importance of the theme, yet its social value, as well as its constitutional significance, has been to some extent indicated, and may be more fully appreciated on reference to the various authorities which have been cited. Under proper regulation and restraint, the writ has proved a safeguard inferior to none afforded by our constitution, whether for the protection of the subject when threatened by the Crown, or generally for the preservation of the weaker members of society from the oppression of the strong. In all cases, remarks $\mathrm{Mr}$. Seldon $(s)$, where any right or liberty belongs to the subject by any positive law-written or unwitten-if there were not also a remedy by law for the enjoying or regaining of that right or liberty when violated or taken from him, the positive law were most vain and to no purpose; and as regards the right to liberty of the person, if there were not a remedy available in case of restraint, it were vain to speak of laws ordaining that it was not to be restrained. But there are in law divers remedies for the enlarging of a freeman imprisoned, amongst which the most common and best known, and (as above shown) the most practically beneficial, is that by habeas corpus.

13. The last extraordinary modes of redress at suit of the subject which need here be mentioned, are by petition

(q) Re Eggington, 2 E. \& B. 717 ; Re Halietcill, ubi supra; per I'atteson, J., 7 Q. B. 1010 .

(r) Carus IIilson's casc, 7 Q. B. 984, 1001; and see In re Power, 2
Russ. 583; In re Clarke, 2 Q. B. 619.

(s) See his argument in debate on the Petition of Riglat, 3 How. St. Tr. 95 . 
of right and by monstrans de droit, manifestation or plea of right. The former of these remedies is permitted where the Sovereign being in possession of any hereditament or chattel, the petitioner suggests such a right thereto as controverts the title of the Crown. The grounds of the petitioner's claim are set forth in the petition, and then, upon this answer being endorsed thereon by the Sovereign, soit droit fait al partie (let right be done to the party), a commission will issue to inquire as to the truth of the case suggested, after the return of which the Attorney-General may plead in bar, and the question raised will be determined upon issue or demurrer as in a suit between subject and subject. Where the right of the subject as well as that of the Crown appears upon record, there the party shall have his remedy by monstrans de droit, which is putting in a claim of right grounded upon facts already acknowledged and established, and praying the judgment of the Court whether upon these facts the Crown or the subject has the right. Upon the nature of the above remedies, which are, however, still available to the subject, it would be useless to enlarge, inasmuch as a better and more effectual process has been provided by the statute $23 \& 24$ Vict. c. 34 , the object of which was to amend and simplify the proceedings by petition of right, and to assimilate them to the ordinary procedure by action at law or suit in equity.

Under the statute cited, a petition of right may, if the suppliant think fit, be addressed to the Sovereign, entitled in any superior Court of common law in which the subjectmatter of such petition or any material part thereof would have been cognizable if the same had been a matter in dispute between subject and subject. The petition must set forth with convenient certainty the facts which are supposed to entitle the suppliant to relief, and must be signed by him, his counsel or solicitor $(t)$. The petition is to be left

(t) $23 \& 24$ Vict. c. 34 , s. 1. 
with the Home Secretary in order that it may be submitted to the Sovereign for consideration, and that her fiat that "right be done" may be granted thereupon $(u)$.

A copy of the petition and fiat when obtained must be left at the office of the Solicitor to the Treasury, indorsed as required, and praying for a plea or answer on behalf of the Crown within twenty-eight days. The petition will then be transmitted to the particular department to which the subject-matter thereof may relate, and will be duly prosecuted $(x)$.

If the petition be presented for the recovery of real or personal property or any right therein which has been granted away or disposed of by the Crown, a copy of such petition, allowance, and fiat must be served upon and left at the place of abode of the person in the possession, occupation, or enjoyment of such property or right, indorsed with a notice that he appear to the petition within eight days and plead thereto in the Court in which the same is prosecuted within fourteen days after service, and such an appearance must be entered, and a defence put in within the time specified if the party served means to contest the petition $(y)$.

Any point of law may be raised by pleading or demurring to the petition on behalf of the Crown or by or on behalf of any third person who has become a party to the proceedings $(z)$. And thereupon, after argument, judgment will be given either for the Crown, or such third party, or for the suppliant $(a)$. If for the suppliant, the tenor and purport of such judgment will, after the lapse of fourteen days from the making, giving, or affirming of it, be certified to the Commissioners of the Treasury or to the Treasurer of her Majesty's Household in the form given by the

(w) $23 \& 24$ Vict. c. 34 , s. 2 . See Irein v. Grey, L. R. 2 I1. L. 20 ; L. R. 1 C. P. $171 ; 3$ F. \& F. 635.

(x) Id. s. 3. (y) $23 \& 24$ Vict. c. 34 , s. $\overline{5}$.

(z) Id. s. 6 .

(a) Id. ss. 9, 10. 
Act (b), and pursuant thereto the Commissioners of the Treasury will pay the amount of monies and costs due under the judgment to the suppliant out of any funds in their hands for the time being legally applicable thereto, or which may afterwards be voted by Parliament for that purpose, provided the petition relate to any public matter. But in case the petition relate to any private property of or enjoyed by her Majesty, or any contract or engagement made by or on behalf of her Majesty, or any matter affecting the Queen in her private capacity, a certificate as aforesaid must be sent to the Treasurer of the Queen's Household, and the amount to which the suppliant is entitled will be paid him out of such funds or monies as her Majesty may direct to be applied for that purpose (c).

In early times, doubtless, a remedy against the Crown was sought almost exclusively in regard to real property, and in Thomas v. The Queen (d) it was contended that a petition of right does not lie for any other object than specific chattels or land-that it does not lie for breach of contract, nor to recover money claimed either by way of debt or damages ; and in this case remarks were made throwing light on the nature and applicability of the remedy before us. The Court there say substantially as follows:-A contract can be made on behalf of the Crown with a subject which can be enforced by the Attorney-General suing on behalf of the Crown against the subject, and if the subject has no means of enforcing the contract on his part, there is a want of reciprocity $(e)$. Now it is quite settled that on account of her dignity no action can be brought against the Queen;

(b) Id. s. 13.

(c) Id. s. 14.

(d) L. R. 10 Q. B. 31 ; approved in Windsor and Annapolis R. C. v. Reg., 11 App. Cas. 607 ; Visct. Canterbury v. Att.-Gen., 1 Phill. 306; Tobin v. Reg., I4 C. B., N. S., $505 ; 16$ Id. 310 ; Churchward v. Reg., L. R. 1 Q. B. 173 ; Feather v. Reg., 6 B. \& B.C.L.
S. 2.57 ; as to which see Dixon v. London Small Arms Co., 1 App. Cas. 632; and Windsor and Annapolis $R$. C. v. Reg.. ubi supra.

(e) On a petition of right the Crown is entitled as against the suppliant to discovery: Tomline v. Reg., 4 Ex. D. 252. 
the redress, therefore, if any, must be by petition of right regulated by $23 \& 24$ Vict. c. 34 , under s. 9 of which statute a judgment might be had where it appeared to the Court that the plaintiff was entitled to be paid damages for the non-fulfilment of a contract. The statute provides $(f)$, however, that nothing therein "shall be construed to give to the subject any remedy against the Crown in any case in which he would not have been entitled to such remedy" before the passing of the Act. The Court, therefore, in the case under notice, had to consider whether at common law a petition of right lies in respect of the non-fulfilment of a contract made by an authorized agent of the Sovereign, and founding their judgment mainly on The Bankers' case (g), they held that it does so.

Care must of course be taken, as in the case of an ordinary action, that the remedy above adverted to be not misconceived, ex. gr., as being directed against the Sovereign with a view to obtaining satisfaction out of the public funds of this country, when the proper remedy, if any, would be against the Secretary of State in Council for India, with a view to obtaining satisfaction out of the revenues of that empire $(h)$. So a petition of right has been held not to lie against the Crown for invading a patent granted to a subject, for "all grants made by the Crown must be taken in a favourable light to the grantor" (i), though that principle would only apply where the Crown, by its servants, invaded the patent, and would not protect a subject contracting for the sale to Government of patented articles manufactured by him without a licence from the patentee $(k)$.

Cases as to the applicability of the remedy by petition of right as against the Crown have necessarily involved a con-

(f) S. 7 .

(g) 14 IIow.St. Tr.1; Broom, Const. L. pp. 238 et seq.

(h) Frith r. Reg., I. R. 7 Ex. 365. See Rustomjce r. Reg., 1 Q. B. D.
487 ; S. C. affirmed 2 Id. 69.

(i) Feathes v. Reg., 6 B. \& S. 257.

(k) Dixon r. London Small Arms Co., I App. Ces. 632, considering Feather r. Reg., supra. 
sideration in our Law Courts of the well-establi shed maxim, that "the king can do no wrong." This maxim, it has been judicially remarked $(l)$, is true in the sense that the Sorereign " is not liable to be sued civilly or criminally for a supposed wrong." That which the sovereign does personally the law presumes will not be wrong: that which the sovereign does by command to his servants cannot be a wrong in the Sovereign, because if the command is unlawful it is in law no command, and the servant is responsible for the unlawful act the same as if there had been no command." Nor in such a case could compensation be obtained from the Sovereign by petition of right. "A petition of right," it has been further said $(m)$, "which complains of a tortious act done by the Crown, or by a public servant by the authority of the Crown, discloses no matter of eomplaint which can entitle the petitioner to redress. As in the eye of the law no such wrong can be done, so in law no right to redress can arise; and the petition, therefore, which rests on such a foundation falls at once to the ground." "No authority," horrever, " is needed to establish that a servant of the Crown is responsible in law for a tortious act done to a fellow-subject, though done by the authority of the Crown ;" a proposition supported by principles " which are too well settled to admit of question, and which are alike essential to uphold the dignity of the Crown on the one hand and the rights and liberties of the subject on the other" $(n)$.

(l) Tobin v. Reg., 16 C. B., N. S., $353,354$.

(m) Feather v. Reg., 6 B. \& S. 2956; Windsor and Annapouis R. C. $\mathrm{r}$.
Reg., 11 App. Cas. 607.

(n) Judgm., 6 B.\& S. 297, and cases there collected. 


\section{BOOK II. \\ CONTRACTS.}

\section{CHAPTER I. \\ CONTRACTS GENERALLY-THEIR CLASSIFICATION AND ATTRIBUTES.}

Meaning

of term

"contract."

In its widest and most general sense, the word Contract signifies an engagement, obligation (a), or compact $(b)$,which may be either unilateral or inter partes $(c)$.

A contract may be of record-special or simple: if simple, it requires a "consideration" to support it $(d)$. Before, however, treating of or even attempting to discriminate between the specific kinds of contracts just mentioned, some remarks may be offered touching contracts generally and the legal properties inherent in them.

A contract or compact between two or more parties $(e)$ may be executory or executed,-express or implied.

(a) Obligationum substantia in eo consistit, ut alium nobis obstringat ad dandum aliquid, vel faciendum, vel prestandum: D. 44. 7, 3, pr.

"A contract is a transaction in which each party comes under an obligation to the other, and each reciprocally acquires a right to what is promised by the otber:" 1 Powell, Contr.,pp. 6,7 .

(b) Roget, Thesaur. (768, 769.)

(c) Coutractus proprie ultro eitroque obligatio, quam Greci $\sigma \nu \nu a ́ \lambda \lambda a \gamma \mu \alpha$ rocant; Brisson, ad verb. Coutractus.
Omnem obligationem pro contractu habendam, existimandum est; ut, ubicunque aliquis obligetur, et contrahi videatur; quamvis non ex crediti causâ debeatur: D. 5. 1. 20.

Contractus dicitur quasi actus contra actum : 2 Rep. 15. a.

(d) The definition of "consideration" is given in connection with the subject of simple contract, post.

(e) Et est pactio, duorum pluriumre in idem placitum consensus : D. 2. 14 . 1. s. 2 . 
An executory contract is one in which a party binds him. self to do or not to do a particular thing $(f)$. A contract executed is one in which the "object of contract" is performed $(g)$. "If A. agrees to change horses with B., and they do it immediately, in which case the possession and the right are transferred together," we have before us an instance of an executed contract. If $A$. and B. agree to exchange horses next week, "here the right only vests, and their reciprocal property is not in possession but in action " $(h)$; the contract accordingly, in this latter case, is executory only. A contract may be executed as regards one of the parties to it, and executory as regards the other; as, for instance, if $\mathrm{A}$. on the actual delivery and receipt of B.'s horse, promises and undertakes to deliver over his own horse to B. in the course of the week ensuing.

Upon an executed, as well as upon an executory contract, a right of action may be founded; and the former as well as the latter may contain obligations binding in futuro on the parties to it; $e x . g r$. , a grant in its own nature amounts to an extinguishment of the right of the grantor, and implies a contract not to re-assert that right, so that a party is technically said to be estopped by his own grant (i), or to have impliedly covenanted that he will not do any act in derogation of his own deed $(k)$.

An express contract is one of which the terms are, at the time of making it, defined in writing or openly uttered and arowed $(l)$, as where an agreement is entered into by which either of the parties to it promises the other that something

(f) A contract is usually said to be executory either when one party performs and the other is trusted, or when neither party performs but each trusts the other: 1 Powell, Contr., p. 23 j.

(g) Fletcher v. Pech, 6 Cranch, (U.S.) R. 136. A contract executed is usually described by some particular term applicable to its nature, as a sale, a grant, a lease, an assignment, a mortgage, or the like; 1 Powell, Contr., p. 234.

(h) 2 Bla. Com. 443.

(i) Per Marshall, C. J., Fletcher v. Peck, 6 Cranch, (U. S.) R. 137.

(k) See Aulton v. Atkins, 18 C. B. 249.

(l) 2 Bla. Com. 443.
Contract express; 
is done already or shall be done at some future time, or where goods of a certain kind and quality are ordered,-to be paid for at a specified rate.

-inplied. An implied contract, on the other hand, is one "which reason and justice dictate, and which the law, therefore, presumes that every man undertakes to perform " $(m)$. In it, accordingly, the law implies, from the antecedent acts of persons, what their obligations are to be; whereas, if an express contract be made, the parties themselves thereby define or assume to define them.

In the case of an implied contract, however, the law does not vary or introduce new terms into an existing agreement or compact; it merely declares that particular acts, unaccompanied or unexplained by express stipulations, give rise to particular duties or liabilities; and it then proceeds as if the parties had precisely stipulated for their performance. Thus, to take the example of an implied contract, which Sir W. Blackstone gives $(n)$ : “If I employ a person to do any business for me or to perform any work, the law implies that I undertook or contracted to pay him as much as his labour deserves" $(o)$; and such amount may be recovered from me just as surely as if there had been a written agreement between the other party and myself to that effect. If, however, I am desirous beforehand that the work in question should be done for a fixed sum, I ought to have an express agreement specifying it, and so limiting and defining my liability. An undertaking

(ii) 2 Bla. Com. 443. See Pell $\mathrm{r}$. Daubeny, 5 Exch. 955; Spedding r. Nerell, L. R. 4 C. P. 212; Collen r. Wright, 8 E. \& B. 647; Wecks v. Propert, I. R. 3 C. P. 427 ; Richardson . Williamson, L. R. 6 Q. B. 276: Colun v. Javidson, 2 Q. B. 455.

(n) 2 Com. 443.

(o) In Roberts v. Smith, 4 H. \& X. 315 , there was wo contract under which the plaintifi could claim to be remunerated. Sce Spencer v. Harding, L. R. j C. P. 561 ; Henkel v. Pape, L. R. $6 \mathrm{Ex}, 7$.

"The majority of officers enter the military or naral service on the basis and faith of the existing rules of the serrice: but this cannot be held to constitute a contract not to dismiss or remove them at will: " judgm., Grant r. Secretary of State for India, 2 C. P. 1. 459. Cf. also Dum v. Regina, (1596) 1 Q. B. 116, C. A. 
to indemnify is under many dissimilar states of facts to be implied $(p)$.

To exhibit the purport of what has just been said in a somewhat different form, contracts, whether express or implied, are founded upon the actual agreement of the parties thereto, the only distinction between them being in regard to the mode of proof. In an implied contract the law only supplies that which, although not stated, must be presumed, so as to complete the agreement intended by the parties.

Bowen, L. J., in the case of The Moorcock ( $q$ ) says : "An implied warranty, or, as it is called, a covenant in law, as distinguished from an express contract or express warranty, really is in all cases founded on the presumed intention of the parties, and upon reason. The implication which the law draws from what must obviously have been the intention of the parties, the law draws with the object of giving efficacy to the transaction and preventing such a failure of consideration as cannot have been within the contemplation of either side; and I believe if one were to take all the cases, and they are many, of implied warranties or covenants in law, it will be found that in all of them the law is raising an implication from the presumed intention of the parties with the object of giving to the transaction such efficacy as both parties must have intended that at all events it should have." So where a person avails himself of the benefit of services done for him, although without his positive authority or request, the law supplies the formal words of contract, and presumes him to have promised an adequate compensation. So, where a person buys an article without stipulating for the price, he is presumed to have undertaken to pay its market value or

(p) See, for instance, Dugdale v. Lord Esher, M.P., in Hamlyn v. Lovering: L. R. 10 C. P. 196, 201.

(q) 14 P. D. at p. 68: quoted by

Wood, (1891) 2 Q. B. at p. 492. 
what it is fairly worth $(r)$; and where he holds the money of another as trustee or bailee, the law supposes a promise to restore it $(s)$.

What has been said may thus further be exemplified :-

In an agreement to let a furnished house there is an implied condition that the house shall be fit for occupation at the time at which the tenancy is to begin, and if such condition be not fulfilled, ex. gr., owing to defective drainage, the intended tenant is entitled to rescind the contract $(t)$.

On the other hand, where plans and a specification for the execution of a certain work are prepared for the use of those who are asked to tender for its execution, the person asking for the tenders does not enter into any implied warranty that the work can be successfully executed according to such plans and specification $(u)$.

Consent is of the essence of contract.

Bearing in mind, then, what a contract is, and what is meant by a contract "executory" or "executed""express" or " implied," we must in the next place observe that a contract is founded on consent $(x)$, on the aggregatio mentium or " union of minds in regard to some particular matter." It is of the essence of every contract or agreement, that the parties to be bound thereby should consent, expressly or impliedly, to whatever is stipulated therein: for otherwise no obligation or reciprocal right can be created between them $(y)$. To this effect the civil law lays down,

(r) Sale of Goods Act, 1893, s. 8, sub.s. 2.

(8) See Beirne v. Dord, 1 Selden (U.S.) R. 102.

(t) Wilson r. Finch Hatton, $2 \mathrm{Ex}$. D. 336, following Smith v. Marrable, 11 M. \& W. 5 ; Birdv. Lord Greville, 1 C. \& E. 317; Chester v. Poucll, 52 L. T. 722. Secus, if house not furnished, Keates r. Lord Cadogan, 10 C. B. 591. There is no implied condition that a furnished house shall continue fit for occupation through the term of the lease, Sarson r. Roberts, (1895) 2 R. B. 395 , C. A. Cf. also, $53 \& 54$ Vict. c. 70 , s. 75 , by which with respect to the letting of tenements of a value therein specified, it is enacted that " there shall be implied a condi. tion that the house is at the commence. ment of the holding in all respects reasonably fit for human habitation."

(iv) Thorn r. Mayor, \&c., of London, 1 App. Cas. 120, 128.

$(x)$ "Assent," remarks Erle, J., 5 E. \& B. 374 , " is an ambiguous word: it may mean an external act or a resolution of the mind."

(y) 1 Powell Contr., p. 9. See Boulton r. Jones, 2 H. \& N. 564; Hardman r. Booth, 1 H. \& C. 803, 807 ; Lindsay r. Cundy, 3 App. Cas. 
that in omnibus rebus qua dominium transferunt, concurvat, oportet, affectus ex utrîque parte contrahentium; nam sive ea renditio, sive donatio, sive conductio, sive qualibet alia causa contrahendi fuit, nisi animus utriusque consentit, perduci ad effectum id quod inchoatur non potest (z).

The law of contracts accordingly will be found to fall under the first of the three subdivisions of the jus privatum of the Romans. The jus privatum, it may be remembered, was that particular part of the Roman law which concerned the rights of individuals-jus privatum est quod ad singulorum utilitatem spectat (a); and, as we read in the Digest, omne jus aut consensus fecit, aut necessitas constituit, aut firmarit consuctudo (b). Now, a contract or agreement is jus quod consensus fecit,- $-\dot{a}$ law which the parties have framed and voluntarily prescribed to themselves for their own guidance $(c)$.

Consent obviously implies acquiescence of the mind in something proposed or affirmed. The term involves in contemplation of law the existence of a physical and moral power of assenting, as well as a deliberate and free exercise of such power. Hence, the absence of any of these capacities in either of the parties to a contract renders the person labouring under it incapable of binding himself thereby $(d)$.

But besides incapacity to contract arising from any one of the causes just indicated, the law sometimes interferes Legislative
prohibi. to prohibit the making of certain kinds of contracts, or to

4099 ; Hollins v. Fouler, L. R. 7 H. L. 757 ; Lewis v. Brass, 3 Q. B. D. 667 ; questioned in Food r. Silcock, 52 L. T. 251.

(z) D. 44.7. 55.

(a) I. 1. 1. 4 ; D. 1. 1. 1 .

(b) D. 1. 3. 40 .

(c) "There is no principle of law better established than this, that even although parties may intend to have their agreement expressed in the most solemn and complete form that con- veyancers and solicitors are able to prepare, still there may be a consensus between the parties far short of a complete mode of expressing it, and that consensus may be discovered from letters or from other documents of an inperfect and incomplete description " as regards form: per Lord crims, C., Brogden v. Metropolitan R. C., 2 App. Cas. 672.

(d) See 1 Powell Coutr., p. 10. 
annul them if made. The law, as remarked by Maule, J. (e), does not often interfere to prevent persons, who have attained their majority, from contracting in any way they think proper. Generally speaking, the rule is, that people may contract as they please. "That is the general law of the land. But occasionally there occur in the course of experience cases in which it is found desirable to depart from that general principle-cases of particular inconvenience in particular trades or employments, and with reference to particular classes: for instance in the case of seamen, whose contracts are the subject of special legislative provision-the law considering that particular class of men to be in a state of perpetual pupilage."

So, with reference to the Truck Act ( $1 \& 2$ Will. 4, c. 37) $(f)$, the same learned Judge observed that the intention of that statute was to "afford protection to a class of persons not very well able to protect themselves;" and that the restriction imposed by that enactment was found necessary, inasmuch as the leaving to parties the unfettered right to contract in respect of labour in such way as they may choose, is, in certain trades, replete with mischief and inconvenience $(g)$.

The foregoing remarks may, for the present, suffice to show, that the capacity to contract, which, as a general rule, is inherent in every man, is sometimes partially abrogated by the legislature with a view to protecting and benefiting particular classes of the community.

(e) 13 C. B. 176.

(f) Amended by 50 \& 51 Vict. c. 46. By s. 2, the provisions of the principal Act are extended to any workman as defined in the Employers and Workmen Act, 1875 , s. 10 . An onnibus conductor (Morgan r. London General Omnibus Co., 12 Q. B. D. 201), the driver of a tram-car (Cook $\mathrm{r}$. Noith Met. Tramuays Co., 18 Q. B. D. 683 ), and a railway guard (Hunt v. Great Northern R. C., (1891) 1 Q. B. 601), are not within the provisions of the principal Act. As to money deducted and paid by employer to sick tund, ef. Lamb v. G. i. R. Co., (1891) 2 Q. B. 281 ; Hewlett v. Allen, (1894) App. Cas. 383, affirming $S$. C., (1892) 2 Q. B. 662, C. A.

(g) Per Maule, J., 13 C. B. 176; per Keating, J., Archer v. Jamcs, 2 B. \& S. 73 ; per Byles, J., Id. \$3. See Ingram v. Barncs, 7 E. \& B. 115 , 132 ; IIilson, app., Cookson, resp., 13 C. B., X. S. 496 . 
Even where the legislature does not expressly interfere to prohibit contracts, acknowledged principles of law may operate in such a manner as materially to vary or qualify them.

Sometimes, no doubt, parties may be presumed to have contracted with reference to, and to have tacitly intended to Lex locihow it be bound by, the lex loci; for instance, if A. promises by a written instrument, worded in the form of a promissory note, to pay B. or order $100 l$. at sixty days after date, the sum specified will, by operation of law, become really due and payable sixty-three days after date; and, in the case here put, both the payee and the maker of the note may reasonably be supposed to have had the rule of the Law Merchant in their contemplation $(h)$.

Cases may, however, occur, when contracting parties, ignorant of the rules of law, find their expressed intentions thwarted and defeated thereby ; and when the lex loci may be considered as governing the contract, not by consent of the parties, but by its own superior force and efficacy (i).

Three instances will suffice in illustration of the above remark, and may serve to throw some further light upon the doctrine of consent in reference to contracts as well as upon the mode in which the lex loci operates upon them. Let us suppose that a mortgagor stipulates that the mortgagee shall have the land mortgaged absolutely, if the debt be not paid at the time stipulated ; here the lex loci, nevertheless, steps in and declares that the mortgagee's title shall not be absolute, but that the estate shall be redeemable, although the mortgage debt be, in fact, not repaid at the time appointed $(k)$.

So, if a man, in consideration of an immediate loan of

(h) These three days, called days of grace, are now included in the provisions of the Bills of Exchange Act, 1882 , vide post.

(i) See this question discussed:
Judgm., 7 Cushing (U.S.) R. 30-31.

(k) See Trent v. Hunt, 9 Exch. 2122 , followed in Snell v. Finch, 13 C. B. N. S., 651 . 
$50 l$., binds himself in a penalty of $100 l$. to repay the $50 l$. within a year, and makes default, the lex loci will require him to pay the 50l. with interest only.

So "stipulations in contracts as to time $(l)$, or otherwise" $(m)$, which may, in accordance with equitable doctrines, not "be deemed to be or to have become of the essence of such contracts" ( $n$ ), will be liberally construed.

Now, in each of the foregoing cases the law of the land assumes to regulate, and may overrule to some extent, the particular contract entered into ; and in the sense, therefore, indicated by the preceding remarks, it will be true to say, that every contract is founded on consent, and governed by the lex loci.

Obligatory force of contract.

Assuming that contracts are thus mainly founded on consent, what, it may be asked, is it which gives to a contract its binding force and legal efficacy? Contracts and agreements, it may be said, are, in their terms and language, infinitely diversified; they deal with matters of every conceivable kind, and impose upon parties liabilities correspondingly various, such, indeed, as no human law, statutory or customary, could possibly have anticipated or devised. There can be no doubt that the obligatory force of contracts is in every civilised country derived tacitly from the law, by reason of the manifest necessity which exists, with a view to the well-being of the community, that every man should fairly and honestly perform what

(I) As to the strict doctrine of the common law upon this subject, see per Parke, B., Dobie v. Larkan, 10 Exch. 776,777 ; Preston v. Dania, L. R. 8 Ex. 19; Geipel v. Smith, L. R. 7 Q. B. 404; Marshall v. Lymn, 6 M. \& W. 109. As to the equitable doctrine, see per Allerson, B., Hipuell $\mathrm{r}$. Kinight, 1 Yo. \& C. 401, 415; Story, Fq. Jurisp., 12th ed., vol. i., p. 769 ; IIanslip y. Padxick, 5 Exch. 615, 623. (m) See Lord v. Stephens, 1 Yo. st Coll. 222 ; Jackson v. Jaekson, $1 \mathrm{Sm}$. \& Giff. 184.

(n) See Patrick v. Mriher, 2 C. P. D. $342 ; 36$ \& 37 Vict. e. 66 , s. $25(\pi)$.

In Reuter v. Sala, 4 C. P. D. 239, 242 , time was deemed to be of the essence of the contract. As to time in contracts of sale, see Sale of Goods Act, 1893 , s. 10, post, 1, 422. 
he has undertaken to do $(o)$. No state, perhaps, ever declared, by statute or positive law, that contracts shall be obligatory; but all states, assuming the pre-existence of the obligation of contracts, have superadded merely, by municipal law, the means of carrying the pre-existing obligation into effect $(p)$.

So far back, it has been said $(q)$, as human research carries us, we find the judicial power, as a part of the executive, administering justice by the application of remedies to violated rights or broken contracts. We find that power applying these remedies, on the idea that there is a pre-existing obligation imposed on every man to do what he has promised to do; that the breach of this obligation is an injury for which the injured party has a just claim to compensation; and that society ought to afford him a remedy for that injury. We find allusions to the mode of acquiring property, but we find no allusion, from the earliest time to any supposed act of the governing power giving obligation to contracts; and hence we may infer, that the doctrine in question is coeval with the existence of society, and, although it may be controlled, was not expressly given by human legislation $(r)$. Obligatio, as we read in the Institutes of Justinian (s), est juris vinculum quo necessitate astringimur alicujus rei solvende secundum nostra civitatis jura. Natural law says, that contracts (if not impeachable on special grounds) shall be binding; and municipal law indicates the manner in, or means by, which they may be enforced.

But although it be true that natural law and moral duty, acknowledged by the dictates of conscience, bind men to keep faith and to perform their engagements, yet the duty

(a) Quid enim tam congruum fidei humanse, quam ea, qua inter eos placuerunt, servare: D. 2. 14. 1, pr.

(p) Ogden v. Saunders, 12 Wheaton (U. S.) R. 213. See also Cook v. Mofjatt, 5 Howard (U. S.) R. 295;
Bank of Cincinnati v. Buckingham's Executors, Id. 323.

(q) See per Marshall, C. J., Ogden.

v. Saunders, supra.

(r) Id. pp. $344,355$.

(s) Lib. 3, tit. 13. 
thus cast upon them is not defined with sufticient precision and exactness to form a practical rule for the government of society in the various exigencies daily occurring. For instance, the law of nature requires that a person competent in point of age to make a promise or contract shall be bound by it; but it does not approach to the determination of the question, what shall be the age of majority $(t)$-a question which has, consequently, to be determined by positive arbitrary enactment.

It seems, then, in regard to the obligatory force of a contract, correct to say, that both municipal law and moral obligation concur in constituting it. And this is true, in regard as well to contracts made and to be executed within the state or country where the remedy is sought, as to those which are to be executed, or upon which the remedy is sought, in a state or country where the contract was not made. Universal law and natural obligation on the one hand, and municipal law on the other, are not antagonistic to each other. On the contrary, municipal law assumes the existence of moral duty arising from natural law, and regulates it so that it may form a plain and practical rule, adapted to the requirements of a civilised community $(u)$.

The term "obligation" has been thus far used as equivalent to "binding force" or "vinculum juris," and as consisting in the efficacy of the law which attaches to the contract, and, if it cannot enforce its performance, at all events gives pecuniary compensation in lieu of performance; but it must be remembered, that the word 'obligation' is also used as correlative to 'right,' so that, 'whatever I, by my contract, give another a right to require of me, I thereby lay myself under an obligation to give or to do.' This secondary meaning of the term in question flows immediately from its primary signification already adverted to. There can, 32 .

(t) Judgm., 7 Cushing (U. S.) R.

(1i) May r. Breed, 7 Cushing (U. S.) R. 31 ; I Bla. Com. 54. 
indeed, be no legal duty or obligation unless there be a legal mode of compelling its performance, and a contract imposes no obligation upon parties, unless it be a contract recognised as ralid by the law.

The requisites of a valid contract will become more apparent as we advance through this part of the volume; and, without pausing just now to inquire concerning them, these remarks introductory to the subject of contracts may conclude with one observation,- - that a contract will not be considered as fulfilled, nor its obligation as discharged, save by compliance with the requirements of law in relation thereto; a contract must be performed secundum nostre civitatis jura,-in that manner which the law prescribes, and in that sense which the law puts upon its language.

Law, indeed, to some considerable extent, gives to a contract its character, makes it what it is, regulates its limits and obligations, fixes the time when it shall commence, how it shall be executed or satisfied, and how it shall be terminated and discharged $(v)$.

Contracts are usually classified under three heads: 1 st. Contracts of records, such as judgments, cognovits $(u)$, and Classification of recognisances $(x)$; 2ndly. Contracts by specialty or under seal, which admit of subdivision into contracts unilateral, as bonds; and contracts inter partes, as indentures of

(v) See 7 Cushing (U. S.) R. 37.

(w) A cognovit is a written confession of an action, supposed to be given by the defendant in Court, which authorises the plaintiff, under circumstances specified, to enter up judgment and issue execution thereon against the defendant. This proceeding, howerel, has become obsolete, an order for judgment by consent having taken the place of it.

(x) A recognisance is an obligation of record entered into before some court of record or magistrate duly authorised, with condition to do some particular act: 2 Bla. Com. 341 .

A recognisance may be entered into either to the Crown-as, where a person enters into recognisances to appear to answer a criminal charge; or to a subject-as where bail is given to the sheriff. A recognisance by statute is either founded on a statute merchant or statute staple, or is in nature of a statute staple under the 23 Hen. 8, c. 6 ; 3 Rep. 11, note $(a)$.

A judgment of a court of record is said to be of a higher nature than a statute staple, statute merchant, or any recognisance acknowedged br assent of the parties without judicial proceeding: 6 Rep. $45 \mathrm{~b}$. As to the effect of a statute staple, see, further, judgm., Ellis r. Reg., 6 Exch. 925. 
demise; 3rdly. Simple contracts, or contracts not under seal, which are either written or verbal, or constituted partly by writing and partly by word of mouth, or by the conduct of parties.

The three great classes of contracts just specified have been advisedly arranged as above, for this reason, that contracts of record must be considered as of a higher nature than contracts of any other kind; and special, as superior in efficacy to simple contracts. With this preliminary remark, I proceed to point out the peculiar characteristics of each of the three classes of contracts above mentioned.

Of contracts of record, the most practically important kind is that constituted by the judgment of a court of record of competent jurisdiction (y). Such a judgment has these peculiar properties or characteristics : It effects or works a merger of the original cause of action; it operates as an estoppel $(z)$, and is conclusive as between the parties to it; it does not need any consideration to support it : it binds the land of the judgment debtor when the same is taken in execution $(a)$.

Merger. The true nature and effect in regard to the doctrine of merger of a judgment at common law will be apparent from he following remarks: Let us suppose that there has been a breach of some specific contract entered into between $A$. and B., A. being the contractee, and B. the party who has failed to perform his contract; now, if $A$. recovers a verdict for damages against B., and signs judgment thereupon, A.'s cause of action in respect of the breach of contract ceases to exist-it becomes merged in the judgment. So, if judg-

(y) " $A$ debt of record is a sum of money which appears to be due by the evidence of a court of record;" and "this is a contract of the highest naturc, being established by the sentence of a Court of Judicature :" 2 Bla. Com. 465.
$\Leftrightarrow$ Eren if by consent or default, South American and Mexican Co., In $\because e$, Ex parte Bank of England, (1895) 1 Ch. 37 .

(a) $27 \& 28$ Vict. c. 112 . As to registration, see $51 \& 52$ Vict. c. 51 . 
ment be recovered for a debt due by bond, the debt thus due becomes " by judicial proceeding and act in law," "transformed and metamorphosed into a matter of record" $(b)$; upon which latter security, uhilst it remains in force and unreversed, the plaintiff's remedy, if any, must, in such manner as the law allows, he had.

The doctrine of merger now under consideration is explained in King v. Hoare (c) in these words :- "If there be a breach of contract or wrong done, or any other cause of action by one against another, and judgment be recovered in a court of record, the judgment is a bar to the original cause of action, because it is thereby reduced to a certainty, and the object of the suit attained, so far as it can be at that stage; and it would be useless and vexatious to subject the defendant to another suit for the purpose of obtaining the same result." Hence the legal phrase transit in rem judicatam derives its force and aptitude; "the cause of action is changed into matter of record, which is of a higher nature, and the inferior remedy is merged in the higher." The above remarks equally apply "where there is but one cause of action, whether it be against a single person or many. The judgment of a court of record changes the nature of that cause of action, and prevents its being the subject of another suit, and then the cause of action, being single, cannot afterwards be divided into two." It was held accordingly, in the case whence the above extracts are taken, that a judgment, even without satisfaction, recovered against one of two joint debtors, is a bar to an action against the other $(d)$. This bar is not

(b) Higgens's case, 6 Rep. 45.

(c) 13 M. \& W. 494, 504; followed in Brinsmead ₹. Harrison, L. R. 7 C. P. 547, and approved in Kendall v. Hamilton, 4 App. Cas. 504. See Beckett v. Ramsdale, 31 Ch. D. 177; Magrath v. Reichel, 14.App. Cas. 665; Macdougall v. Knight, 25 Q. B. D. 1. (d) King v. Hoare, 13 M. \& W. B.C.L.
494. The rule applies eveu where one of the joint contractors is a married woman contracting in respect of her separate property, Hoare v. Niblett, (1891) 1 Q. B. 781. In Morgan r. Price, 4 Exch. 619, Parke, B., remarks:- "Suppose two persons jointly and severally liable to a party who recovers the whole amount trom one of 
removed by the joint contractor, against whom judgment has been recorered, consenting to the judgment being set aside $(e)$. In an action, however, against one of several joint contractors, a defence by way of estoppel of judgment obtained by another co-contractor must show that the former action was successfully resisted on some ground available in common to all the joint contractors $(f)$. Further, for a defence by way of estoppel of judgment to succeed, the cause of action to which it is pleaded must be the same as that in respect of which the judgment was recovered: e.g. an unsatisfied judgment against one joint contractor, on a cheque given by him alone for the joint debt, is not a bar to an action against the other joint contractor on the original contract $(g)$.

This doctrine of merger, of much practical importance, remains, notwithstanding the abolition of pleas in abatement $(h)$, unafiected by the Judicature Acts, and has been thus judicially explained (i) :- " It is the right of persons jointly liable to pay a debt to insist on being sued together. If then there are three persons so liable and the creditor sues tro of them and those two make no objection, the creditor may recover judgment against those two. But should he afterwards bring a farther action against the third, that third may justly contend that the three should be sued together. It is no answer to him to say that the other two were first sued and made no objection, for the objection is the objection of the third and not of the other two. Nor is it any answer to him to say that whatever he pays on the judgment against himself he may have allowed

them, he cannot sue the other." Acc. per Popham, C. J., in Broun r. ITootton, or Broome v. Wooton, infra, as explained per Cur. in King r. Hoare.

(e) Hammond v. Schofield, (1891) 1 Q. B. 453. 717.

(f) Phillips v. Ward, 2 H. \& C.

(g) Wegg-Prosser r. Evans, (1895)
1 Q. B. 108 (C. A., affirming $S$. C., (1894) 2 Q. B. 101), orerruling Cambetfort r. Chapman, 19 Q. B. D. 229, but following Drake r. Mitchell, 3 East, 251 ; 7 R. R. 449.

(h) Order xxi., R. 20.

(i) Per Earl Cairns, C., Eendall $\mathrm{r}$. Hamilton, 4 App. Cas. 515-16. 
in account with the others, because he may fairly require, with a view to his right of account or contribution, to have the identity and the amount of the debt constituted and declared in one and the same judgment with his co-contractors. If, therefore, when the third is sued and requires that the other two should be joined as parties the creditor has to admit that he cannot join the other two because he has recovered a judgment against them in the same cause of action, this is equivalent to saying that he has disabled himself from suing the third in the way in which the third has a right to be sued."

The doctrine of merger, as above stated, holds not merely where the original action was founded upon contract, but also where it was founded upon a tort or " wrong independent of contract;" the judgment in this latter case, as well as in the former, when obtained, constituting a contract of record, in which the right of action ex delicto is wholly merged. "If," therefore, "one hath judgment to recover" in trespass against one, and damages are certain " (that is, converted into certainty by the judgment), "although he be not satisfied, yet he shall not have a new action for this common trespass" $(j)$.

It has been held that judgment obtained in an action against one of several joint wrongdoers is a bar to an action against the others for the same cause, although such judgment remains unsatisfied $(k)$.

In any such case, according to the phrase already used, the original cause of action transit in rem judicatam; and we may conclude that "where judgment has been obtained for a debt as well as for a tort, the right given by the record merges the inferior remedy by action for the same debt or tort against another party" $(l)$.

(j) Per Popham, C. J., Broome v. Wooton, Yelv. $67 ;$ S. C., Cro. Jac. 73 ; cited 13 M. \& W. 504, 505; Lindall v. Penfold, 1 Leo. 19. Judgm., Routledge $\mathrm{r}$. Hislop, 2 E. \& E. ô49; Gibbs v. Cruikshank, L. R. 8 C. P. 4 In4.

(i) Brinsmead v. Harrison, I. R. 7

C. P. 517

(l) Judgm., King v. Howre, 13 M.

\& W. 506 . 
Estoppe1 by matter of record.

The next peculiarity to notice in a contract of record is, that " a record imports in itself a truth" $(m)$, and concludes all men against whom it is producible from denying anything appearing within the record $(n)$; so that, if an action be brought, and the merits of the question at issue be discussed between the parties, and a final judgment be obtained by either, the parties are concluded and cannot canvass the same question again in another action, although, perhaps, some objection or argument might have been urged upon the first trial which would have led to a different result $(o)$. A judgment then obtained inter partes $(p)$ will estop either of those parties from again agitating the matter decided between them $(q)$. But, according to the well-known ruleres inter alios acta alteri nocere non debet-a judgment cannot be used to estop or fix with liability one who is neither a party nor privy to it, who has had no opportunity to crossexamine the witnesses called upon the trial, or to dispute the conclusions to be drawn from the evidence there offered $(r)$.

(m) Floyd v. Barker, 12 Rep. 23. A record thus importing "credit and verity," "shall be tried only by itself," i.e., by production and inspection, the reason being, that there may thus be an end of controversy: 1 Inst. 260 a. See Preston v. Peek, E. B. \& E. 336.

(n) Hynde's ease, 4 Rep. 71 b.; Huffer v. Allen, L. R. 2 Ex. 15.

(o) Per Lord Fenyon, C. J., Greathead v. Bromley. 7 T. R. 456 ; 4 R. R. 490 ; Marriot v. Hampton, 7 T. R. $269 ; 4$ R. R. 439; Pretace IX.; 2 Sm. L. C., 9th ed., 441. See Dick v. Tolhausen, 4 H. \& N. 697; Whittaker r. Jackson, 2 H. \& C. 926; Langmead v. Maple, 18 C. B., X. S. 255; Lockyer r. Ferryman, 2 App. Cas. 519. In determining whether a judgment is an estoppel the Court is entitled to look at the facts which were before the Court previously and to give effect to new facts: Heath v. Weaverham Orerseers, (1894) 2 Q. B. 108; cf. also Magnus r. National Bank of Scotland, 57 L. J., Ch. 902.

(p) A judgment in rem operates directly ou the status of the thing adjudicated upon: vide per Erle, C. J., Hobbs v. Henning, 17 C. B., N. S. 823; Cammell r. Sewell, $5 \mathrm{H}$. \& $\mathrm{N}$. 728; S. C., 3 H. \& N. 617 ; Place r. Potts, 5 H. L. Ca. 383.

(a) For detailed information upon the subject here alluded to the reader is referred to the Duehess of Fingston's ease, 2 Smith, L. C., 9th ed., 812, and note thereto; Needham r. Bremmer, I. R. 1 C. P. 583 ; Lord Feversham v. Emerson, 11 Exch. 390-91. See also Nelson v. Couch, 15 C. B., N. S. 99 ; Flitters v. Allfrey, L. R. 10 C. P. 29; Hindley v. Haslam, 3 Q. B. D. 481 ; Reg. v. Hutchings, 6 Q. B. D. at p. 304 ; Poyser v. Minors, 7 Q. B. D. 329 ; Ex parte Bacon, In re Bond, 17 Ch. D. 447 ; Pureell's ease, 27 W. R. 170. But see Brunsden v. Humphrey, 11 Q. B. D. 131 ; S. C., reversed, 14 Q. B. D. 141 ; Senao $\mathrm{r}$. Noel, 15 Q. B. D. 550 ; Priestman v. Thomas, 9 P. D. 70; Ib. 110 ; South American and Mexiean Company, In $r e$, Bank of England, Ex parte, (1895) $1 \mathrm{Ch} .37$ (a judgment by consent).

(r) Judgm., King v. Norman, 4 C. 
But although, as between the parties to it, a judgment is thus conclusive, it is clearly impeachable where the maxim Nemo debet esse judex in propriâ causì has been infringed (s), or on the ground of fraud or of deception practised on the Court; for, as remarked in the Duchess of Kingston's case $(t)$, " fraud is an intrinsic collateral act which vitiates the most solemn proceedings of courts of justice. Lord Coke says $(u)$ it avoids all judicial acts, ecclesiastical or temporal." To a like effect the Court of Queen's Bench, in Philipson v. Earl of Egremont (v), observed that "fraud, no doubt, vitiates everything $(w)$; and the Court, upon being satisfied of such fraud, has a power to vacate, and would vacate, its own judgment" $(x)$. A judgment even of the

B. 884; Petrie r. Nuttall, 11 Exch. 569 ; Overton v. Harvey, 9 C. B. 324. See Reg. v. Ambergate, $N . \& B . R$. C., 1 E. \& B. 372 ; Reg. v. Haughton, Id. 501 ; Callow v. Jenkinson, 6 Exch. 666 ; Concha . Concha, 29 Ch. D. 268, 304; 11 App. Cas. 541, 568.

(s) Leg. Max., 6th ed., 110. See Ellis v. Hopper, 3 H. \& N. 766 ; Reg. v. Recorder of Cambridge, 8 E. \& B. 637 ; Reg. v. Mayer, 1 Q. B. D. 173 ; ante, p. $182(l) ; R e$ Hopkins, E. B. \& E. 100; London and NorthWestern R. C. v. Lindsay, 3 Macq. H. L. Ca. 99.

( $t$ ) Supra, n. (q); Shedden v. Patrick, 1 Macq. H. L. Ca. 535.

(u) Fermor's case, 3 Rep. 78 a. See Girdlestone v. Brighton Aquariun Co., 4 Ex. D. 107 ; 3 Id. 137.

(v) 6 Q. B. 586, 605, eiting Bradley v. Eyre, 11 M. \& W. 450.

(w) See, for example, Fisher v. Tully, 3 App. Cas. 627.

(x) Philipson v. Earl of Egremont, 6 Q. B. 587, 604 ; Lee v. Bude and Torrington Junction Railway, L. R. 6 C. P. 576; per Tindal, C. J., Fowler v. Rickerby, 2 M. \& Gr. 777; per Parke, B., Re Place, 8 Exch. 704; Shattock v. Carden, 6 Exch. 725; De Medina r. Grove, 10 Q. B. 152, 168. "There is no doubt of the jurisdiction of courts of equity to grant relief against a former decree, where the same has been obtained by fraud and imposition; for these will infect judgments at law and decrees of all courts; but they annul the whole in consideration of courts of equity;" Story, Eq. Pl., 7th ed., s. 426; Earl of Bandon r. Becher, 3 Cl. \& F. 479, 510 . See also Alleyne v. Reg., 5 E. \& B. 399; Dodgson v. Scott, 2 Exch. 457. As to setting aside a judgment on the ground of mistake, see Cannan v. Reynolds, 5 E. \& B. 301. The judgment of a foreign court is impeachable: Godard v. Gray, L. R. 6 Q. B. 139 ; Schibsby v. Westenholz, Id. 155 ; Cammell v. Seuell, 3 H. \& N. 617, 646; 5 Id. 728 ; Ochsenbein v. Papelier, L. R. 8 Ch. 695 ; Abouloff v. Oppenheimer, 10 Q. B. D. 295 . In Hutchinson v. Gillespie, 11 Exch. 798, 810, Alderson, B., observed: "It is laid down that wherever there is the judgment of a court of competent jurisdiction for payment of a sum of money, an action will lie thereon; for the law gives so much credit to the judgment as to consider that the sum is due." See Vanquclin v. Bonard, 15 C. B., N. S. 341, 367368 ; Brissac v. Rathbone, 6 H. \& X. 301 ; Castrique v. Imvie, L. R. 4 H. L. 414. See also Copin v. Adamson, L. R. 2 Ex. $345 ; S . C$., affirmed 1 Ex. D. 17.

As to a defence of judgment recorered in the Consular Court of Constautinople reference may be made to Barber $\mathbf{v}$. Lamb, 8 C. B., N. S. 95 ; distin- 
highest tribunal may be treated as a nullity, if obtained by fraud $(y)$. "There is," as remarked by Pollock, C. B. $(z)$, "no more stringent maxim than that no one shall be permitted to aver against a record; but where fraud can be shown this maxim does not apply."

So if it be made apparent that a judge's order "was obtained by fraud or by the suppression of information which it was essential that the Court should have, the Court will undoubtedly set aside the order" $(a)$.

Judgment binds the land.

Judgment is a con. sensual contract.

A judgment may be enforced by execution. It binds the land of the judgment debtor when such land has been actually delivered in execution by virtue of a writ of elegit or other lawful authority in pursuance of such judgment (b). The writ of execution must, hotrever, be duly registered (c).

A judgment being ordinarily rendered in invitum, cannot, it may perhaps be thought, accurately be designated a consensual contract. The point suggested is not unworthy of consideration. Let us suppose that A. sues and recovers judgment against $B$. for breach of a special agreement. The judgment in this case, founded on the verdict of the jury, fixes the amount of damages, and not merely imposes on B. an obligation to pay such amount; but also raises an implied undertaking on his part that he will pay it, whence his consent to pay the amount recovered may strictly be inferred. Without, however, resorting to technical reasoning for the purpose of disclosing in this peculiar species of contract the element of consent, another view of the matter before us may be presented. Every member of the community who appears, whether as plaintiff or defendant in a court of justice, must be regarded as submitting him-

guished in Frayes r. Worms, 10 Id. 149. See Cox r. Mitchell, 7 C. B., $\mathbf{~}$ S. 55. Is to the finality of an award, see Sadler r. Smith, L. R. 5 Q. B. 40; Commings r. Heard, L. R. 4 Q. B. 669.

(y) Shedden r. Patrick, I Macq. II. L. Ca. 535 . (z) 2 H. \& C. 347 .

(a) Per Lord Coleridgc, C. J., Ex parte Cuckerell, 4 C. P. D. 39.

(b) 27 \& 28 Vict. c. 112, s. 1.

(c) Id., s. 3, amending the 23 \& 24 Vict. c. 38 . See also 51 \& c. 51 . 
self to the course of procedure which it recognises-to the directions which it may promulgate-to such compulsory process consequent upon judgment, as it may countenance or award. It seems proper, therefore, to speak of a judgment as a contract assented to by both parties-the law implying an assent by the party against whom the judgment passes, to conform to its requirements.

A contract under seal or specialty is a contract in writing, the execution whereof is accompanied with certain solemnities which not merely indicate the assent of the contracting parties $(d)$, but give to their contract peculiar force and efficacy $(e)$.

A contract may be constituted by statute, and if so, is a specialty of the highest kind $(f)$.

An instrument under seal, when used betreen private persons, is, as Blackstone tells us $(g$ ), called a deed (factum), "because it is the most solemn and authentic act that a man can possibly perform with relation to the disposal of his property," i.e., with a view to affecting in any manner his own interests. The instrument in question may be unilateral or made by one party only; or it may be inter partes, i.e., made between two or more parties. At common law the right of action upon a deed inter partes is restricted to those only who are parties to it $(h)$. This rule, however, has been broken in upon by the stat. 8 \& 9 Vict. c. 100, s. 5, which provides that, under an indenture executed after the first of October, 1845, an immediate estate and

(d) " The general rule of law is that the assent of a party to a deed convering property to him is to be presumed, and a grant of goods, like any other common law conreyance operating by grant, passes the property without assent:" Judgm., Siggers v. Evans, 5 E. \& B. 380 .

(e) A deed is defined as "Scriptum solemne quo firmatur donum, concessio pactum contractus et hujusmodi :" Spelm. Gloss., title " Factum."
Contracts uuder sealgeneral reninaks as to. 
interest in any tenements or hereditaments, and the benefit of a condition or covenant respecting them, may be taken, although the taker thereof be not named as a party to the said indenture; and the section of the Act just cited further provides, that a deed purporting to be an indenture shall have the effect of an indenture, although not actually indented.

A specialty, as already intimated, is distinguished from a simple contract in writing by certain solemnities attendant on its execution-viz., by sealing ( $i$ ) and delivery $(j)$. It may indeed be laid down that, prior to the Statute of Frauds, signing was in no case deemed essential to the validity and obligatory force of a deed which had been executed by 'sealing and delivery $(k)$. Even now, the absence of the signature of a party to a deed, the subject. matter of which comes within the operation of that statute, would seem to be immaterial $(l)$, for the object of that enactment was "to prevent matters of importance from resting on the frail testimony of memory alone." It was not intended to apply to instruments already authenticated by a ceremony of a higher nature than a signature or a $\operatorname{mark}(m)$.

Delivery is essential to the due execution of a deed $(n)$; so that if executed after the day on which it purports to bear date, it takes effect from the day of delivery and not

(i) "A corporation seal is without wax, or paper or ink, it is commonly a blank impression:"'per Bovill, C. J., In re Sandilands, L. R. 6 C. P. 412 . As to which case, see Nat. Proo. Bank of England v. Jackson, 33 Ch. D. 1, 11.

(j) "Any instrument delivered as a deed, and which either itself passes an interest or property, or is in affirmance or confirmation of something whereby an interest or property passes, is a deed:" per Bovill, C. J., Reg. r. IJorton, L. R. 2 C. C. R. 27 . 56.

(k) Co. Litt. $35 \mathrm{~b}$; Shepp. Touch. (l) The signature of a party may, howerer, be required by the express provisions of the power or authority under which a deed is executed.

(m) Per Rolfe, B., Cherry ₹. Heming, 4 Exch. 636-7.

(n) As to evidenee of delivery, see Xenas r. Wickham, L. R. 2 H. L. 296 ; Kidner v. Keith, 15 C. B., N. S. 35 ; Tupper v. Foulkes, 9 Id. 797.

Delivery is not necessary in the case of a body corporate, for the fixing their common seal to the deed is tantamount to a delivery. Com. Dig. "Fait" (A. 3). 
from the day of the date, according to the maxim Traditio loqui facit chartam (o). "A deed," says Bayley, J. (p), " has no operation until delivery."

Although the usual practice in delivering a deed is to place the finger upon the seal or wafer (which has, in general, been previously affixed to the instrument), and to repeat the formula "I deliver this as my act and deed," yet it is clear, on the one hand, that delivery without words is sufficient $(q)$, and, on the other, that a deed may be delivered by words without any act of delivery $(r)$.

If, moreover, when a deed has been formally sealed and delivered, with apt words of delivery, it is retained by the party executing it, such retention will not per se affect the operation of the deed $(s)$; for "the efficacy of a deed depends on its being sealed and delivered by the maker of it ; not on his ceasing to retain possession of it " $(t)$. It is also clear, that delivery to a third person for the use of the party in whose favour the deed is made, provided the grantor parts with all control over the instrument, will make the deed effectual from the instant of such delivery; for the law will presume, if nothing appear to the contrary, that a man will accept what is for his benefit $(u)$.

A deed may, however, be delivered as an escrow, i.e., it may be delivered to a stranger to be kept by him until certain specified conditions be performed, and then to be delivered over to the grantee $(v)$. If, in point of fact, the

(o) Steele v. Ifart, 4 B. \& C. 272 ; Goddard's case, 2 Rep. 4; Clayton's case, 5 Rep. 1; per Patteson, J., Browne v. Burton, 17 L. J. Q. B. 50 . 911 .

(p) Styles v. Wardle, 4 B. \& C. $137 \mathrm{a}$ 58 .

(r) Co. Litt. 36 a ; Shepp. Touch.

(s) Doe d. Garnons v. Knight, 5 B. \& C. 671 ; Xenos v. Wickham, L. R. 2 H. L. 296.
In Jeffries v. Alexander, 8 H. L. Ca. 594 , a question arose whether an instrument was a deed or a testamentary paper. This case was considered in the Court of Appeal. See In re Robson, 19 Ch. D. 156 . See also Reg. v. Morton, L. R. 2 C. C. R. 22.

(t) Per Lord Cramworth, L. R. 2 H. L. 323.

(u) Doed. Gamons v. Knight, supra; 3 Rep. 26 b.

(v) Co. Litt. 36 a; Millership $v$. Brookes, 5 H. \& N. 797. 
deed is so delivered to a stranger not to take effect as a deed until some condition is performed, it will operate as an escrow, notwithstanding the delivery is in form absolute $(x)$. But though in the case of writings not under seal, the delivery, whilst in form absolute, may be shown to have been meant to operate only conditionally $(y)$, yet it is doubtful whether a deed can be delivered as an escrow upon certain conditions, to the party to whom it was made, or whether the delivery will not nevertheless be absolute, on the principle that in traditionibus chartarum non quod dictum sed quod factum est inspicitur (z).

The legal consequences which flow from the execution $(a)$ of a written contract by sealing and delivery are most im. portant. Directly an instrument containing a contract is sealed by the parties thereto it becomes a deed $(b)$, and as such is clothed with the following properties, which do not attach to a simple contract in writing. It works a merger; it operates by way of estoppel ; it requires no consideration to support it; it will in some cases bind the heir of the covenantor or obligor; it can, at common law, only be discharged by an instrument under seal, by the judgment of a Court of competent authority, or by Act of Parliament.

The limits necessarily prescribed for this treatise will not of course allow of any attempt to consider the forms of deeds, or the various modes which have been devised for

(x) De Goze v. Rouce, Moore, 300 ; Murray r. Earl of Stair, 2 B. \& C. 82; Johnson v. Baker, 4 B. \& Ald. 440 ; 23 R. R. 338.

(y) Christie r. Wimington, 8 Exch. 290 ; Davis v. Jones, 17 C. B. 634; Pym r. Campbell, 6 E. \& B. 374; Bowker v. Burdekin, 11 M. \& W. 147.

(z) Shepp. Touch. 59 ; Co. Litt. 36 a ; Com. Dig. Faits, A. 3, A. 4 ; where a number of early authorities are cited; Thoroughgood's case, 9 Rep. 136 a ; per Cressucll. J., Cumberlcge r. Lauson, 1 C. B., X.S., 718; Pym r. Campbell, 6 E. \& B. 374 ; per
Crompton, J.; Johnson r. Baker, 4 B. 5 Ald. $440 ; 23$ R. R. 338 ; Hudson r. Retctt, 5 Bing. 38 .

"The maxim of law, as well as of reason and good sense, is non quod dictum, sed quod factum est inspicitur," per Martin, B., 6 H. L. Ca. 722 .

(a) There cannot be a partial executiou of a deed: see Wilkinson r. AngloCalifornian Gold Mining Co., is Q. B. 728; Exch. Bank of Farmowth $\mathrm{r}$. Blethen, 10 App. Cas. 293.

(b) Per Coleridge, J., Hall r. Bainbridge, 12 Q. B. 707. See Davidson ₹. Cooper, 13 M. \& W. $343,353$. 
effecting, through their intervention, objects which are in kind almost infinitely diversified. The reader will bear in mind, however, that in every valid deed there must be parties able to contract, and also a thing or subject-matter to be contracted for, all which must be specified and set forth with some sufficient degree of certainty and precision; for instance, in every grant there must be a grantor, a grantee, and a thing granted; in ever.y lease, a lessor, a lessee, and a thing demised $(c)$.

The agreements of parties under seal usually contain, however, in addition to the above simple elements, stipulaCovenantwhat. tions and conventions, called covenants $(d)$, more or less elaborately worded, whereby either party rouches for the truth of certain facts, or binds himself to do or to refrain from doing certain things. Thus the grantor of an estate may covenant that he hath a right to convey, or that the grantee shall quietly enjoy the land; a lessee may covenant to pay his rent or to keep the premises in repair, \&c. (e).

No particular form of words is necessary to create a corenant; any words are sufficient for that purpose "which show an intention to be bound by the deed to do or omit that which is the subject of the covenant; any such rords are sufficient, and some such mords are necessary to malie a covenant $(f)$. It will readily be supposed that, where a deed has been informally prepared, much difficulty mar be felt in determining the intention of the parties to it, and in

(c) 2 Bla. Com. 296.

(d) A corenant may be defined to be "an agreement between two or more persons by an instrument in writing sealed and delivered, whereby some of the parties engage, or one of them engages, with the other or others of them, that some act hath or hath not already been done; or for the performance or non-performance of some specified duty:" Platt on Cov. p. 3. Per Grove, J., Brookes r: Drysdale, $3 \mathrm{C}$. P. D. 57 .

(e) 2 Bla. Com. 304. A man may corenant that a thing is already done, or that it shall be done. In the oue case the covenant is executed; in the other executory : Shepp. Touch. 162.

(f) Judgm., Rashleigh r. SouthEastern R. C., 10 C. B. 632; Trod v. Copper Miners' Co., 7 C. B. 906 ; per Parke, B., Rigby r. Great Wiestern R. C., 14 M. \& W. S15.

The recital in a deed may amount to a covenant where the inteution of the parties appears to have been that it should do so: Lay r. Mottram, 19 C. B., N. S. 479 . 
interpreting their covenants $(g)$. Upon this subject it may suffice to say that, although where the words of a covenant are clear and free from doubt, effect must be given to them; yet, if "a covenant may have two meanings, each of which is equally probable, in each of which the words are capable of expressing the same thing, and the question is in which of the two senses it is to be understood, that meaning which it is most probable the parties contemplated is the one that is to be adopted $(h)$.

"Generally speaking," remarks the learned Judge, whose words are above cited, "the construction of a written contract is for the Court; but when it is shown by extrinsic evidence that the terms of the contract are ambiguous, evidence is admissible to explain the ambiguity, and to show what the parties really meant. That is one of Lord Bacon's maxims (i). Where there is an election between two meanings, it is properly a question for the jury. So, if a man devise land to his 'cousin John,' and it appears that he has two cousins named John, extrinsic evidence is admissible to show to which of them he meant the land to go" $(j)$.

Corenants -indepen-

Covenants, when viewed in relation to each other, are divisible into three classes: 1 . Independent covenants, - that is to say, where either party may recover damages from the other for the injury he may have sustained by a breach of the corenants in his favour, and where it is no excuse for the defendant to allege a breach of the covenants on the part of the plaintiff. 2. Covenants which are conditional and dependent, - that is, in which the performance of one covenant depends on the prior performance of another: so that till the prior condition be performed, the

(g) See Lord Clifford r. Watts, L. R. 5 C. P. 57t; Charlesworth v. Holt, L. R. 9 Ex. 38 ; Great Western R. C. v. Rous, L. R. 4 H. L. 650 .

(h) Per Maule, J., West London R. C. . London \& N. W. R. C., 11 C. B.
324; Bland r. Croucley, 6 Exch. 522, 529 ; per Huddleston, B., Wooler T. hinott, 1 Ex. D. 129.

(i) Bac. Max. Reg. 25.

(j) Smith r. Thompson, 8 C. B. 59. 
other party is not liable to an action on his corenant $(k)$. 3. Covenants sometimes called concurrent, which are mutual conditions to be performed at the same time; and in these, if - concurone party is ready and offers to perform his part, and the other neglects or refuses to perform his, he who is ready and offers thus legally fulfils his engagement, and may therefore maintain an action against the other party for his default, even though neither be obliged to do the first act $(l)$.

Covenants, besides admitting of the classification above given, are also designated, regard being had to their nature and to the subject-matter which they concern, as real, personal, or collateral. A covenant real being such as is annexed to an estate and to be performed on it; a covenant personal being one whereof some person in particular shall have the benefit, or whereby he shall be charged, or one which is to be performed personally by the covenantor alone. The term collateral, when applied to a covenant, is commonly used in contradistinction to the term real, as above defined. A covenant is said to be collateral when the thing to be done in pursuance of it is "merely collater"al to the land, and doth not touch or concern the thing

(k) See, for instance, Roberts $\mathrm{v}$. Brett, 11 H. L. Ca. 337.

(l) Per Lord Mansfield, Kingston v. Preston, cited Jones r. Barkley, 2 Dougl. 689. Respecting the above classes of covenants, the reader is referred to Pordage r. Cole, 1 Saunds. 319 ; 1 Wms. Saund. 320 a (4) ; Platt on Cov. p. 70 ; per Tindal, C. J., Stavers พ. Curling, 3 Bing. X. C. 368 ; cited per Keating, J., Seeger. v. Duthie, 8 C. B., N. S. 70 ; Friar v. Grey, 15 Q. B. 891 , and 5 Exch. 584; London Gas Light Co. v. Vestry of Chelsea, 8 C. B., N. S. 215 ; Ellen v. Topp, 6 Exch. 424; Raymond v. Winton, L. R. 1 Ex. 244 ; Sibthorp v. Brunel, 3 Exch. 826.

In Pordage v. Cole, supra, it was "agreed" between A. (the plaintiff) and $B$. (the defendant) by instrument under seal, that B. should pay to A., before a dar named, a sum of moner for his lands, \&c. (whereof ôs. was actually paid as earnest). It was, in the first place, held, that, by this agreement, a covenant on the part of A. was raised to convey the land, and, secondly, that the corenants to par the money and to convey were independent of each other, so that A. might sue for the residue of his purchase-money before any conreyance by him of the land. See also Dawson v. Fitzgerald, 1 Ex. D. 257; Marsden v. Moore, 4 H. \& N. 500; Hemans v. Pieciotto, 1 C. B., N. S. 646 ; Eastem Counties R. C. v. Philipson, 16 C. B. 2; Phillips v. Clift, $4 \mathrm{H}$. \& N. 168; Baylis v. Le Gros, 4 C. B., N. S. 537; Westwieh r. Theodor, L. R. 10 Q. B. 224.
Covenants real, personal, and collateral. 
demised in any sort" $(m)$, or not so immediately as to pass with it to an assignee. Such a covenant is also said to be in gross.

If, for instance, a lessee corenant to pay rent or to repair, or if a lessor grant to his lessee the liberty of taking mood from off the demised premises to burn within his house or to repair his fences during the term, the covenant is " real;" it passes with the land to its assignee, so that he who takes the one becomes immediately subject to the other $(n)$. On the other hand, a covenant to pay a sum of money, or a covenant by a lessee not to hire certain persons to work in a mill about to be erected on the land demised (o), would be "personal" to the covenantor", and rould not bind his assignee. In this latter case the corenant might be said to be altogether " collateral " to the land.

To Spencer's case ( $p)$, which is the leading authority to show what covenants do or do not "run with land," i.e., pass with it from assignee to assignee, reference must be made for information upon that subject. It may, however, be well to present shortly the principal rules there laid down, as stated by Wilmot, C. J., in Bally v. Wells (q). "Covenants in leases," says that learned Judge, "extending to a thing ' in esse,' parcel of the demise, run with the land and bind the assignee, though he be not named-as to repair, \&c. And if they relate to a thing not 'in esse,' but yet the thing to be done is upon the land demised, as to build a new house or wall, the assignees, if named, are bound by the corenants $(v)$; but if they, in no manner touch or concern the thing demised, as to build a house on

(m) Speneer's case. 5 Rep. 16, 2nd Resol.; I Smith, L. C. 9th ed., 65.

(n) Id. ibid.

(o) Mayor of Congleton v. Pattison, 10 East, 130.

(p) 5 Rep. 15: Hilliams r. Earle, L. R. 3 Q. B. 739: Hooper r. Clark, L. R. 2 Q. B. 200 ; Stevens r. Copp, L. R. 4 Ex. 20. (a) Wilmot's Notes, 344 , cited per Holroyd, J., Ternon $\mathrm{v}$. Smith, 5 B. \& Ald. $\tau$, and in $2 \mathrm{Wms}$. Saund. 304 , (12).

(r) Whether or not assigns though not named are bound by covenants relating to things not in esse, see $1 \mathrm{Sm}$. L. C. 9th ed., 81, and cases there cited. 
other land, or to pay a collateral sum to the lessor, the assignee, though named, is not bound by such covenants; or if the lease is of sheep or other personal goods, the assignee, though named, is not bound by any covenant concerning them. The reasons why the assignees, though named, are not bound in the two last cases are not the same. In the first case it is because the thing covenanted to be done has not the least reference to the thing demised, it is a substantive, independent agreement, not quodam modo, but nullo modo, annexed or appurtenant to the thing leased. In the case of the mere personalty, the covenant doth concern and touch the thing demised, for it is to restore it or the value at the end of the term; but it doth not bind the assignee, because there is no privity, as there is in the case of a realty between the lessor and lessee and his assigns in respect of the reversion " $(s)$.

Again, a covenant may be express or implied $(t)$. "There are," says $\operatorname{Sir} E$. Coke $(u)$, "two kinds of covenants, viz., a Covenantscovenant in deed, and a covenant in law." A "covenant in law," properly speaking, being " an agreement which the law infers or implies from the use of certain words having a known legal operation ;" formerly, for instance, if a man by deed demised land for years an action would lie at suit of the tenant after ouster upon the word "demise," which imported or made a covenant in law for quiet enjoyment. Here the word in question, after having had its primary operation in creating the estate, derived from the law a secondary force, by being held to imply an agreement on

(8) See Gorton v. Gregory, 3 B. \& S. 90. As to who are assignees within Stat. Hen. VIII. c. 34 , see 1 Sm. L. C. 9 th ed., 73,98 . A railway company taking lands from a lessor under compulsion of law is not an assign, for whose acts the lessor can be made responsible. Bailey $\mathrm{r}$ : De Crespigny, L. R. 4 Q. B. 180 .

(t) As exemplifying the nature of an implied covenant, see Stirling $\nabla$. Maitland, 5 B. \& S. 840; Gerard V. Lewis, L. R. 2 C. P. 305 ; Coates r. Collins, L. R. 7 Q. B. 144 ; Rhodes $\mathrm{r}$. Forwood, 1 App. Cas. 256; Turner v. Goldsmith (distinguishing Rhodes r. Forvood), (1891), 1 Q. B. 544, C. A., at p. 549; Railuay and Electric Applianees Co., In re, 38 Ch. D. 597.

(u) Co. Litt. 139 b. 
the part of the grantor to protect and preserve the estate so by that word already created $(v)$. Now, however, by virtue of $44 \& 45$ Vict. c. 41 , s. 7 , in conveyances other than mortgages for valuable consideration, by a person who conveys and is expressed to convey as beneficial owner, the following corenants are implied : -1 . Right to convey. 2. Quiet enjoyment. 3. Freedom from incumbrance. 4. Further assurance. Implied covenants will run with the land $(x)$. A general rule applicable in interpreting deeds is this-expressum facit cessare tacitum-an express covenant excludes or controls an implied covenant having reference to the same subject-matter $(y)$.

Having now explained sufficiently for my present purpose the office of a covenant, having also pointed out the leading classes into which covenants are divisible, and shown how these classes are distinguishable from each other, I will exhibit very briefly the nature and structure of a bond, and then notice the peculiar properties inherent in instruments under seal.

A bond is " an instrument under seal, whereby one person becomes bound to another for the payment of a sum of money, or for the performance of any other act or thing. The person thus bound is called the "obligor," and he to whom the bond is given the "obligee." And this obligation may be either by or to one or several persons" $(z)$.

If a bond be merely for the payment of money, or for the performance of some particular act, without any condition in or annexed to it, the bond is said to be single; but there is in general a condition added to the bond in the nature of a defeasance, stipulating that if the obligor duly performs the act specified, the obligation shall be void, otherwise that it shall remain in full force. In case this

(v) Judgm., Williams $\mathrm{v}$. Burrell, 1 C. B. 429,430 ; Platt on Cor. Pt. 1, Ch. 2, s. 3.

(x) 1 Sm. L. C. 9 th ed., 79. (y) Leg. Max. 6th ed., 606: per Pollock, C. B., Mathere r. Blackmore, 1 H. \& X. 768, 772.

(z) Hurlstone on Bonds, p. 1. 
condition is not performed the bond becomes forfeited $(a)$, so that the entire penalty named therein was formerly recoverable at law. Now, however, by virtue of the stat. $4 \& 5$ Ann. c. 3 , ss. 12 and 13, in the case of a bond conditioned for the payment of money, the payment of the principal sum due, with interest and costs, even though the bond be forfeited, and a suit has been commenced thereon, will be a full satisfaction and discharge. Also by stat. $8 \& 9$ Will. 3, c. 11, s. 8, damages and costs of suit only are recoverable in an action upon a bond executed by way of security for the performance of covenants contained in any deed or indenture (b). And we have seen that where time is not deemed to be of the essence of a contract it will henceforth be construed at law as it would be in a court of equity $(c)$.

Of specific properties inherent in a deed, the first to be mentioned is that of merger. A deed being of a higher nature than a simple contract, will, if given or entered into Doctrine of merger as applicable to deets in relation to the same subject-matter, altogether merge or swallow up the latter, and extinguish any right of action which might have been founded upon it $(d)$. For instance, by the acceptance of a bond for a simple contract debt, the debt (according to the accustomed phraseology) will merge in the higher security $(e)$; and if a covenant be entered into

(a) The condition of a bond being for the benefit of the obligor, must, in general, be strictly performed: Hurlstone on Bonds, Ch. 2, s. 3.

(b) As to the effect and operation of this enactment, see Burlstone on Bonds. pp. 129, 131.

(c) Ante, p. 252. See Preston v. Dania, L. R. 8 Ex. 19.

(d) A debt due for rent is not, however, merged by giving a bond; because rent is a specialty debt: per Cresszell; J., 10 C. B. 574; Bull, N. P., 7th ed., 182 a. . Nor can one bond merge another bond: 6 Rep. $45 \mathrm{~b}$.

B.C.L. (e) Bac. Abr. Oblig. (D.); Higgens's case, 6 Rep. 44 b; per Lord Ellenborough, C. J., Drake v. Mitchell, 3 East, 251; 7 R. R. 449 (followed in Wegg Prosser r. Evans, (1895) 1 Q. B. 108); distinguished in Cambefort r. Chapman, 19 Q. B. D. 229 (overruled in Wegg Prosser v. Evans, r. supra); see Mowatt v. Lord Londesboroung, 4 E. \& B. 1. A specialty does not, strictly speaking, "merge or extinguish the debt; but it merges the remedy by way of proceeding upon the simple contract:" per Maule, J., 10 C. B. 573. 
to pay a sum of money actually due, the remedy thenceforth must be upon the covenant, and not upon the original cause of action $(f)$.

In Middleditch v. Ellis $(g)$ it is observed,- "The general principle is clear, that, where a debt is secured by a bond, covenant, or other specialty, there the obligation by simple contract is gone: the lesser security is merged in the greater;" and the principle thus stated was forcibly applied by the Court to the facts before them in the case just mentioned.

In order to trace out the full operation of the doctrine of merger, let us suppose that A., being indebted to B., in the sum of 100l. for goods sold and delivered, accepts a bill of exchange drawn upon him by $B$. at a date certain for that amount, and that the bill is taken by B. in lieu of immediate payment, the effect of this transaction will be to suspend or postpone, until the bill falls due, B.'s right of action against $A$. in respect of the goods sold. Let us next suppose, that the bill thus given is dishonoured at maturity, and that B., in lieu of then proceeding against A., as he would be entitled to do, in respect either of his original demand or upon the bill, agrees to take A.'s bond in the penal sum of $200 l$., conditioned for the payment to B. of the 100l. above mentioned, and interest thereupon, at some future day. Now, if default be made in payment of the amount thus secured, the only remedy at law available to $B$. against $A$. will be by action upon the bond, his right of suit, whether in respect of his original claim or of the bill, having become merged in and extinguished by the instrument under seal. To pursue this inquiry a step further, let us suppose that B. recovers judgment in an action of debt upon the bond against $A$., the sole mode of obtaining satisfaction from his debtor thenceforth available to $B$. will

(f) Post, p. 275 (i).

(g) 2 Exch. 626. See Petch v. Lyon,

9 Q. B. 147. 
be upon the judgment in which the bond debt will in itself have become merged, in accordance with a principle already explained, and which is expressed by the legal phrase transit in rem judicatam $(h)$.

But although the doctrine of merger in connection with specialties is in theory thus simple, difficulty occurs not unfrequently in applying it, for the rule in question is subject to some qualifications, which must now be noticed.

"In general," says Bayley, J., in Twopenny v. Young (i), "where a simple contract security for a debt is given, it is extinguished by a specialty security, if the remedy given by the latter is eo-extensive with that which the ereditor had upon the former." Observing the qualification thus introduced into the rule, we may conclude that a bond given for a limited sum would not operate to merge a debt of indefinite amount $(k)$, and that the contract under seal of a surety will not by operation of law extinguish the simple contract debt of the principal $(l)$. So, if one of two makers of a joint and several promissory note executes to the holder a mortgage to secure the amount, and covenants therein to pay it, the other maker is not thus discharged; the remedy given by the specialty being confined to one of the debtors only, and therefore not co-extensive with that which the creditor had upon the note $(m)$.

Where indeed it clearly appears on the face of an instrument under seal that the intention of the parties to it was, that the original debt secured thereby should continue to exist, or that the security (if any) previously given should remain in force, effect will be given to their intention $(n)$.

(h) See Florence r. Jcnings, 2 C. B. X. S. 454.

(i) 3 B. \& C. 208.

(k) Norfolk R. C. v. Mr'Yamara, 3 Exch. 628, 631.

(l) Whitev. Cuyler, 6T.R.176:3 R. R. 147; Holmes r. Bell, 3 M. \& Gr. 213. (m) Ansell v. Baker, 15 Q. B. 20; Sharpe v. Gibbs, 16 C. B., N. S. 527 ;
Boaler r. Mfayoi, 19 Id. 76 ; Solly v. Forbes, 2 Brod. \& B. 38 ; 22 R.R. 641 ; Tuopenny v, Young, 3 B. \& C. 208.

(n) Boaler v. Mayor, 19 C. B., X.S. 76, 82, 83, explaining Price v. Moulton, 10 C. B. 561 ; Commissioner of Stamps v. Hope, (1891), App. Cas. 476 (in which case see the remarks on Price v. Moulton). 
Estoppel by deed.
Collins $\mathrm{v}$. Blantern.

Inasmuch as a deed is a "solemn and authentic act," "a man," says Sir William Blackstone (o), "shall aways be estopped by his own deed, or not permitted to aver or prove anything in contradiction to what he has once so solemnly and deliberately arorred." "The principle," says Taunton, J. (p), "is that, where a man has entered into a solemn engagement by deed under his hand and seal as to certain facts, he shall not be permitted to deny any matter which he has so asserted."

As illustrating the operation of the rule just stated, Horton v. The Westminster Improrement Commissioners ( $q$ ) may be consulted.

In Hill v. The Proprietors of the Manchester Waterworks $(r)$ the obligor of a bond reciting a certain consideration was held to be estopped from pleading that the consideration was in fact different from that recited $(s)$. .

Both the foregoing cases, besides exemplifying the doctrine of estoppel by deed, may usefully be consulted with reference to this important qualification of it - that a deed is not in all cases conclusive by way of estoppel, but is impeachable for fraud or illegality.

The leading authority, however, in support of the qualification just specified of the doctrine of estoppel by deed is Collins v. Blantern ( $t$, which established that illegality may be pleaded as a defence to an action on a contract under seal.

(o) 2 Com. 295.

(p) Borman r. Taylor, 2 Ad. \& E. 291. "The principle of estoppel is that, whether there be a cause of action or not, the party cannot allege it:" per Coleridge, J., Parkes v. Smith, 15 Q. B. 312 .

(q) 7 Exch. 750, and cases there cited; London and Continental Ass. Soc. v. Redgrace, 4 C. B., N. S. 524; Bouman v. Taylor, supra; Hills v. Laming, 9 Exch. 256.

In an action on a boud against a company, it is a good defence that the seal of the company was affixed withou lawful authority, regard being had to statutory requirements: D'Arcy $\mathrm{F}$ Tamar, \&c., R. C., L. R. 2 Ex. 15 s.

(r) 2 B. \& Ad. 544.

(s) However, "an estoppel can only be effected by what is express an clearly a statement by which the partie mean to bind themselres in makin their contract" (per Bowen, L. J. Omeard Building Socicty v. Smithson (1893) $1 \mathrm{Ch}$. at p.'14).

(t) 2 Wils. 341 ; 1 Sm. L. C., 9 t ed., 398 . 
There, to a declaration in debt on a joint and several bond for 700l. the defendant pleaded the following facts :That, before and at the time of making the bond in question and the promissory note presently mentioned, his (the defendant's) co-obligors, together with three other parties, stood indicted at the suit of one John Rudge for wilful and corrupt perjury, and had severally pleaded not guilty to the charge; that when the trial was about to come on, it was agreed between John Rudge (the prosecutor), the plaintiff, and the parties indicted, that the plaintiff should give to the prosecutor his note for $350 l$. as a consideration for his not appearing to give evidence at the trial; it being further agreed that the bond sued upon should be executed by the defendant Blantern and his co-obligors to the plaintiff, to indemnify him in respect of the note on which he had, as just mentioned, become liable to the prosecutor.

Upon demurrer to the above plea, it was mainly contended on behalf of the plaintiff, that, the bond appearing on the face of it to be good and lawful, no averment could be admitted to show that it had, in fact, been given upon an illegal consideration.

In the judgment delivered by Wilmot, C. J., in the above celebrated case, three points solemnly discussed demand our attention:-1. Whether, on the facts alleged, the consideration for giving the bond was illegal. 2. Whether a bond given for an illegal consideration is void at common law $a b$ initio. 3. Whether, supposing the bond to be void, the facts disclosed in the plea to show that it was so, conld be averred and pleaded.

With regard to the 1st point above specified, the Court remarked, "This is an agreement to stifle a prosecution for wilful and corrupt perjury, a crime most detrimental to the commonwealth; for it is the duty of every man to prosecute, appear against, and bring offenders of this sort 
to justice $(u)$. . . . The promissory note was certainly roid: what right, then, hath the plaintiff to recover upon this bond, which was given to indemnify him from a note that was void? They are both bad, the consideration for giving them being wicked and unlawful."

As to the 2nd point, the Court held the bond to be void $a b$ initio, according to the principle laid down in the Institutes of Justinian (r), Quod turpi ex causâ promissum est, reluti si quis homicidium rel sacrilegium se facturum promittat, non valet.

"This," the Court proceeded to observe, with reference to the case before them, "is a contract to tempt a man to transgress the law, to do that which is injurious to the community : it is void by the common law, and the reason why the common law says such contracts are void is for the public good. You shall not stipulate for iniquity. All writers upon our law agree in this, - no polluted hand shall touch the pure fountains of Justice. Whoever is a party to an unlawful contract, if he hath once paid the money stipulated to be paid in pursuance thereof, he shall not have the help of a Court to fetch it back again " $(w)$.

As to the 3rd point, $v i z$., whether the matter relied upon as a defence could be pleaded? the Court remarked-"It is now objected as a maxim, that the law will not endure a

(u) See Keir v. Lecman, 6 Q. B. 308 ; S. C., 9 Q. B. 371 , followed in Windhill Local Board r. Vint, $45 \mathrm{Ch}$. D. 351 ; Reg. v. Hardey, 14 Q. B. 529 ; Reg. v. Blakemore, Id. 544; Master's v. Ibberson, 8 C. B. 100 ; Alleyme v. Reg., 5 E. \& B. 399; \#illiams v. Bayley, L. R. 1 H. L. 200, explained Flower Y. Sadler, 10 Q. B. I. 572, Maclatchic v. II aslam, 65 L. T. N. S. 691 ; Clubb r. IIutson, 18 C. B. N. S. 414.

(v) I. $3,19,24$.

(w) Cf. on this point Kearley $\mathrm{r}$. Thomson, 24 Q. B. D. 742. Fry, L.J., suggests that the dictum of Mellish, l.J., " if money is paid, or goods delivered for an illegal purpose, the person who has so paid the money or delivered the goods may recover them back before the illegal purpose is carried out," (cf. Taylor" r. Bouer's, 1 Q. B. D. 291), requires further consideration. However, where money is paid in respect of an illegal contract, to a stakeholder, the same may be recorered back if notice be giren before it is paid over; Hastelow r. Jackson, 8 B. \& C. 221 ; Barclay v. Pearson, (1593) 2 Ch. 154 ; a case arising out of a missing word competition, where the illegality was that the competition constituted a lottery within the meaning of 42 Geo. III. c. 119. 
fact in pais dehors a specialty to be averred against it, and that a deed cannot be defeated by anything less than a deed, and a record by a record $(x)$; and that, if there be no consideration for a bond, it is a gift. I answer that the present condition is for the payment of a sum of moner, but that payment to be made was grounded upon a vicious consideration, which is not inconsistent with the condition of the bond, but strikes at the contract itself in such a manner as shows that in truth the bond never had any legal entity; and if it never had any being at all, then the rule or maxim, that a deed must be defeated by a deed of equal strength, does not apply to this case. The law will legitimate the showing it void $a b$ initio, and this can only be done by pleading."

It would be wholly unnecessary to cite many cases at length $(y)$, with a view to fortifying the conclusions arrived at on arguments so convincing as those above abstracted; but attention may properly be directed to some few additional authorities in regard to the particular qualification of the rule as to estoppel by deed now under notice.

In The Gas Light and Coke Company v. Turner (z), a plea to an action of covenant for rent due under a lease alleging that the premises in question were demised to the defendant for an unlawful purpose, was held to be good. "The objection that has been urged on the part of the

(x) An obligation by record may however, be released by deed: per Parke, B., Barker v. St. Quinton, 12 M. \& W. 453. See the authorities cited Leg. Max. 6th ed., 832 et seq.

(y) See Duvergier v. Fellowes, $1 \mathrm{Cl}$. \& F. 39; Simpson r. Lord Houden, 9 Cl. \& F. 61 ; Jones $v$. Waite, Id. $10 \mathrm{I}$; Evans r. Edmonds, 13 C. B. 77 ; Canham r. Barry, 15 C. B. 597 ; Lound v. Grimucade, 39 Ch. D. 60 ŏ.

(z) 5 Bing. N. C. $666 ; S . C$., Id. 324 , with which compare Feret v. Hill, I5 C. B. 207 ; there plaintiff had been forcibly expelled by defendant from premises held under a written agreement into which defendant had been induced by plaintiff's misrepresentations to enter. Ejectment was held maintainable, inasmuch as an interest in the demised premises had actually passed by the agreement. The ground of the decision in Feret $r$. Hill is stated per Maule, J., I5 C. B. 611 ; et vide per Blickbu', J., Reg. r. Saddlers' Co., 32 L. J., Q. B. 343 . See also Lord Ward r. Lumley, 5 H. \& X. 87 ; Judgm., Fisher v. Tully, 3 App. Cas. 639 . 
defendant," said Tindal, C. J., delivering the judgment of the Court in that case, "is, that this is an action founded upon a contract, and that a Court of law will not lend its aid to enforce the performance of a contract between parties which appears upon the face of the record to have been entered into by both the contracting parties for the express purpose of carrying into effect that which is prohibited by the law of the land. And we think, both from authority and reason, this objection must be allowed to prevail. That no legal distinction can be supported between the application of this objection to parol contracts and to contracts under seal appears the necessary inference from the cases of Collins v. Blantern (a) and Paxton v. Popham (b), in both which cases the principle above laid down was acted upon by the Court; and in each of which the action was upon a bond; and it would, indeed, be inconsistent with reason and principle to hold, that, by the mere ceremony of putting a seal to an instrument, that is, by the voluntary act of the parties themselves, a contract which was void in itself on the ground of its being in violation of the law of the land, should be deemed valid, and an action be maintainable thereon in a Court of justice."

In Higgins v. Pitt (c), the plaintiff sued for the breach of a covenant contained in a composition deed, whereby the defendant and others had covenanted to indemnify the plaintiff from all loss, \&c., in respect of certain acceptances of his outstanding at the execution of the said deed. To this declaration the defendant pleaded that before executing the said indenture an agreement was entered into between the defendant, J. H. (his partner), and the plaintiff, under which the defendant and J. $\mathrm{H}$. were to receive from the plaintiff more than his other creditors. The Court held this plea to be good, on the ground that every such secret
(a) Ante, p. 276.
(c) 4 Exch. 312 .
(b) 9 East, 408. 
bargain is a fraud on the creditors and void when it is made $(d)$; so that it cannot be enforced even against a particeps criminis $(e)$.

In Mallalieu v. Hodgson $(f)$, the effect of fraud in invalidating a deed was also much considered. And from Hirschfeld v. The London, Brighton and South Coast R. C. (g), we infer that a fraudulent representation inducing the plaintiff to execute a release under seal may be set up by way of reply to a defence founded upon the deed of release.

The decision of the Court of Error in Fisher v. Bridges (h), is important with reference to the subject above adverted to. There, to a declaration in covenant for the payment of a certain sum of money, the defendant pleaded that, before the making of the deed declared upon, it was unlawfully agreed between the plaintiff and defendant that the former should sell and the latter purchase of him a conveyance of land for a term of years, in consideration of a sum of money to be paid by the defendant to the plaintiff, "to the intent and in order and for the purpose, as the plaintiff at the time of the making the said agreement well knew," that the land should be sold by lottery, contrary to statute; that afterwards, "in pursuance of the said illegal agreement," the land was assigned for the term, and a part of the purchase money remaining unpaid, the defendant, to secure the payment thereof, made the deed and covenant in the declaration mentioned. Upon these pleadings the Court of Queen's Bench held, that the contract in question appeared to have been made after the illegal transaction between the plaintiff and defendant had terminated; that

(d) See per MEllor, J., Dauglish r. Tement, L. R. 2 Q. B. 54 ; approved in Ex p. Milner, 15 Q. B. D. 605 .

(e) See Atkinson v. Denby, 7 H. \& N. $931 ; S . C ., 6$ Id. 778.

(f) 16 Q. B. 689, and cases cited Id. 706, 707. See per Parke, B., Smith v. Salzmann, 9 Exch. 543. (g) 2 Q. B. D. 1.

(h) 3 E. \& B. 642 (followed in Geere v. Mare, 2 H. \& C. $339,345,346)$, with which compare Hill $\mathrm{r}$. Fox, $4 \mathrm{H}$. \& N. 359. See Att.-Gen. r. Hollingworth, 2 H. \& N. 416; O'Connor v. Bradshaw, 5 Exch. 582. See, however, 1 Sm. L. C., 9th ed., 422. 
it formed no part of such transaction, and was consequently unaffected by it. The judgment thus given was, however, reversed in error upon reasoning of the following kind ;the original agreement was clearly tainted with illegality, inasmuch as all lotteries are prohibited by the stat. $10 \& 11$ Will. 3 , c. 17 , s. 1 : and by the 12 Geo. 2 , c. 28 , s. 4 , all sales of houses, lands, \&c., by lottery are declared to be void to all intents and purposes. The agreement being illegal, then, no action could have been brought to recover the purchase-money of the land which was the subjectmatter thereof; and the covenant accordingly, being connected with an illegal agreement, could not be enforced $(i)$. And, further, even if the plea above abstracted were not to be understood as alleging that the corenant declared upon was given in pursuance of an illegal agreement, it would, remarked the Court of Exchequer Chamber, still show a good defence to the action, for " the covenant was given for the payment of the purchase-money. It springs from and is the creature of that illegal agreement; and if the law would not enforce the illegal contract, so neither will it allow parties to enforce a security for purchase-money, which, by the original bargain, was tainted with illegality."

Since the case of Collins v. Blantern it has been held as settled law, that a deed is impeachable on the ground of illegality or of fraud, which, as already stated $(j)$, " vitiates everything," and to which the reasoning of Lord Chief Justice Wilmot, already cited, applies quite as forcibly as to illegality.

But although the general rule is free from doubt, that fraud or illegality may afford a good defence to an action upon a contract under seal, it would be erroneous to affirm that a deed tainted with illegality or fraud in its inception 
is necessarily void, and without "any legal entity" (k), as between all parties and for all purposes $(l)$.

It could not, indeed, be contended after perusing the cases below cited $(m)$, that a party to a contract under seal is in general estopped from alleging his own fraud, or his own participation in an illegal transaction by way of answer to an action upon the deed. But nevertheless a conveyance made with the object of contravening some particular statute may be invalidated thereby quoad that object, and yet may remain good and effectual as a conveyance against the grantor. Thus a conveyance made for the mere purpose of conferring a vote has been held void only to the extent of preventing the right of voting from being acquired, but valid between the parties to pass an interest in the land $(n)$. And an assignment of goods in fraud of creditors may be binding and unimpeachable as betreen the assignor and assignee $(o)$. In these and other cases of a like kind, the legal maxim would seem forcibly to apply, -Quod fieri non debet factum valet. Every transaction is, moreover, according to an universal rule, presumed to be valid; so that the proof of fraud lies upon the party by whom it is impugned $(p)$.

"The doctrine of estoppel," says Lord Denman, C. J. (q), "has been guarded with great strictness; not because the party enforcing it necessarily wishes to exclude the truth,

(k) Ante, p. 279.

(l) See Waugh r. Morris, L. R. 8 Q. B. 202.

(m) Collins r. Blantern, ante, p. 276; Higgins v. Pitt, ante, p. 280; (with which, however, compare Mallalieu v. Hodgson, ante, p. 281, and the remarks per Cnr. in Doe d. Roberts, v. Roberts, 2 B. \& Ald. 369,$370 ; 20$ R. R. 477); Fisher r. Bridges, 3 E. \& B. 642 ; Geere r. DIare, 2 H. \& C. 339 , 345, 346; Evans v. Edmonds, 13 C. B. 777; Wontner v. Shairp, 4 C. B. 404 ; Watson v. Earl of Charlemont, 12 Q. B. 856, 864 .

(n) Phillpotts r. Phillpotts, 10 C. B.
85, and cases cited per Mraule, J., Id. 95. See Marshall v. Boun, 7 M. \& Gr. 188; Callaghan v. Callaghan, 8 Cl. \& F. 374 .

(o) Bessey r. $\Gamma_{y}$ maham, 6 Q. B. 166, recognising Doe d. Roberts $v$. Roberts, 2 B. \& Ald. $36 T$; 20 R. R. 477. Boues r. Foster, 2 H. \&. Y. 779 , is clearly distinguishable from the cases cited supra.

(p) Per Parke, B., 8 Exch. 400. As to the maxim supra, see Leg. Max., 6th ed., pp. 175, 289, and cases there cited. 1 Sm. L. C., 9th ed., 421.

(q) 2 Ad. \& E. 289. 
for it is rather to be supposed that that is true which the opposite party has already recited under his hand and seal, but because the estoppel may exclude the truth." It is, therefore, a recognised rule that estoppels must be certain $(r)$. And where the matter relied upon as an estoppel occurs in the recital of a deed, the Court will look narrowly at the words used; for, although when a recital is intended to be a statement which all the parties to the deed have mutually agreed to admit as true, it is an estoppel upon all; yet when it is intended to be the statement of one party only, the estoppel is confined to that party; the intention being ascertained from construing the instrument $(s)$.

Relief in equity against fraudulent deed.

Consideration not. necessary to support leed.

Fraud may then be set up as a good defence at law to an action, even upon so solemnly authenticated an instrument as a deed, and although the stat. 13 Eliz. c. $5(t)$ has rendered utterly void as against creditors fraudulent bonds, grants, or conveyances, \&c., it is nevertheless to Courts of equity that recourse is usually had where the execution of a deed has been obtained by collusion or through misrepresentation or fraud. Where execution of a deed, ex. gr., a bond, has been obtained by a party under circumstances savouring of frand, it may often be advisable to sue in equity with a view to having the deed declared void, and for its delivery up and cancellation, rather than to await proceedings upon it at law.

Closely related to the doctrine of estoppel is this proposition-that "a deed requires no consideration to support

(r) Kepp v. Wiggett, 10 C. B. 35; Onuard Building Co. v. Smithson, (1893) 1 Ch. 1.

(s) Judgm., Stronghill v. Buck, 14 Q. B. 787 ; Young r. Raincock, 7 C. B. 310 ; Wiles r. Wooduard, 5 Exch. 557; Carpenter v. Buller, 8 M. \& W. 112 ; per Martin, B., South Eastern R. C. v. Warton, 6 H. \& N. 527 ; Foster r. Mentor As. Co., 3 E. \& B. 48. An estoppel by deed extends to persons claiming under the party who is estopped. But the recitals to a deed will not estop a party in an action not founded on the deed but collateral to it; Ex parte Morgan, re Simpson, 2 Ch. D. 89.

(t) See for instance, Spencer v. Slater, 4 Q. B. D. 13, distinguished in Boldero v. London \& Westminster Disc. Co., 5 Ex. D. 51. 
it" $(u)$. Where a contract has been duly executed by sealing and delivery - not being a deed of feofiment, nor operating by the Statute of Uses-the solemnity of the instrument dispenses, as between the parties to it (if it be a deed inter. partes), or, as between the obligor and obligee (if it be a bond), with the necessity of a consideration. "A man may, therefore," as once observed by Lord Mansfield $(v)$, "without consideration, enter into an express covenant under hand and seal;" and as Blackstone ( $u$ ), tells us, if a man enters into a voluntary bond, "he shall not be allowed to aver the want of a consideration, in order to evade the payment : for every bond, from the solemnity of the instrument, carries with it an internal evidence of a good consideration;" so that Courts of justice mill support it, in the absence of fraud as against the obligor himself, though not, in general, "to the prejudice of creditors or" strangers to the contract" $(x)$.

A deed, however, as we have already seen $(y)$, is impeachable for fraud; and one main ingredient in fraud, or in the proof of it, is not unfrequently a want of consideration $(z)$. When, moreover, the inquiry is respecting the operation of a deed with reference to the rights of third parties, proof of the absence of consideration may be almost conclusive evidence of collusive dealing and of an intention to defraud; and this remark will apply, whether the transaction in question be considered according to the principles of our common law, or with reference to the specific provisions of

(u) As to a bond or covenant in restraint of trade, post, p. 356, et seq.

(v) Shubrick v. Salmond, 3 Burr. 1639 ; Judgm., DLorley v. Boothby, 3 Birg. 111, 112.

(w) 2 Com. 446 : per Lord Fenyon, C. J., Fallowes v. Taylor, 7 T. R. 475 , 475 ; per Abbott, C. J., Tronss v. Smallpiece, 2 B. \& Ald. 551 , 554 ; 21 R. R. 395 ; Smith v. Scott, 6 C. B., N.S.771.

(x) 2 Bla. Com. 446. (y) Ante, pp. 276, 282.

(z) Equity, however, will not relieve against a voluntary gift, if there were no undue influence: Judgm. Huguenin v. Baseley, 14 Ves. 290;9 R. R. 148, 276; Preface, ri. The cases in which equity interposes or refuses its aid in farour of volunteers, are collected in Watson's Comp. of Equity; ubi vide Index, title "Toluntary Gitts." See Morley r. Loughman, (1\$93) 1 Ch. 736. 
the statutes 13 Eliz. c. 5 (a) (upon which Tuyne's casc (b) was decided), and 27 Eliz. c. $4(c)$.

Assuming, however, that there is consideration for a deed, that consideration may be of one or other of two kinds-it may be a good or it may be a raluable consideration. The distinction here presenting itself is clearly explained by Blackstone (d), who says, that " a good consideration is such as that of blood, or of natural love and affection," and "is founded on motives of generosity, prudence, and natural duty;" whereas, a "valuable consideration is such as money, marriage, or the like, which the law esteems an equivalent given for the grant."

Now, the above distinction is in very many cases extremely material, inasmuch as a voluntary deed, i.e., a deed made without any consideration at all, or even for a good, though not for a valuable consideration is void (when executed by an insolvent party) as against creditors, by virtue of the 13 Eliz. c. $5(e)$. Further, a deed made without any consideration or even for a good consideration, was, until the Voluntary Conveyances Act, $1893(f)$, void as against subsequent bon $\hat{\imath}$ fide purchasers for value, and even with notice. By section 2 of the above-mentioned act

(a) Made perpetual by the stat. 29 Eliz. c. 5 .

(b) 3 Rep. $80 ; 1$ Sm. I. C., 9th ed., 1.

(c) As to this statute, of. the Voluntary Converances Act, 1893, infra.

(d) 2 Com.p. 297. See also Shepp. Touch. p. 64.

(e) In Gale r. Williamson, 8 M. \& W. 405,410 , Rolfe, B., speaking of the stat. 13 Eliz. c. 5, observes, "It is a mistake to suppose that the statute makes roid, as against creditors, all roluntary deeds. All that it sars is that a practice of making corinous and fraudulent deeds had prevailed, and therefore, that all feoffments, gifts, Sc., of any lands or goods and chattels, as against the persons whose actions, debts, dec, by such covinous and fraudulent derices and practices, shall be disturbed, hindered, delared, or defraved, shall be roid. The Courts, in construing the statute, hare held it to include deeds made without consideration, as being primâ facie fraudulent, because necessarily tending to delay creditors. But the question in each case is, whether the deed is fraudulent or not; and to rebut the presumption of fraud, the party is surely at liberty to give in evidence all the circumstances of the transaction, not to contradict the consideration stated in the deed, but to take it out of the operation of the statute." As to the avoidance of voluntary settlements by a bankrupt, see the Bankruptcy Act, 1883 ( 46 5 47 Vict. c. 52), s. 47.

(f) 56 \& 57 Vict. c. 21 . 
of 1893 , however, it is enacted that no voluntary conveyance of any lands, tenements, or hereditaments, whether made before or after the passing of the Act, if in fact made bon $\hat{a}$ fide and without any fraudulent intent, shall $(g)$ be deemed fraudulent or covinous within the meaning of 27 Eliz. c. 4 by reason of any subsequent purchase for value, or be defeated under any of the provisions of such Act by a conveyance made upon any such purchase, any rule of law notwithstanding.

But, besides cases of the above class, there are others, connected with the transfer of realty, in which the question as to the existence of a consideration for a deed, or even as to the nature of such consideration, may have an important bearing on the rights and liabilities of parties. In equity, for instance, a feoffment to a stranger without consideration or declaration of a trust, is (irrespectively of statute law) regarded as made for the use of the feoffor, although in this case the legal estate would, prior to the Statute of Uses, have become transferred to and vested in the feoffee. From the absence of consideration for the grant and of any indication of a contrary intention, equity presumed that the feoffment was intended to be for the use of the feoffor, though such presumption might be rebutted by showing that any the smallest consideration had passed from the feoffee.

The effect of the Statute of Uses being to transfer the use into possession, its operation in the case supposed, that, namely, of a feoffment without consideration, would be to give to the feoffor the seisin and possession of the land, notwithstanding livery of seisin had been duly made to the feoffee, the use (according to the technical phrase), under the circumstances supposed, resulting to the feoffor. If, however, the feoffment be made "to the use" of the feoffee, the case is different, inasmuch as those words would, before

(g) The Act does not affect transactions completed before the passing of the Act, cf. s. 3 . 
the statute, have raised a trust for the benefit of the feoffee, and now, by its operation, vest in him the seisin and possession of the land. Therefore, since the Statute of Uses, it has become requisite to a feoffment, either that there should be a consideration for the gift, or that it should be expressed to be made not simply "unto," but " unto and to the use of" the feoffee. An inspection of any ordinary conveyance will show, that the receipt of the nominal consideration expressed therein is acknowledged by the grantor, who would consequently thus be estopped at law, in the absence of fraud, from calling in question, at any future time, the fact of a consideration having passed $(h)$.

Passing on to a notice of deeds other than conveyances, and assuming that there is neither fraud nor illegality in the transaction out of which the particular instrument originates, nor anything appearing in contravention of any statute, the mere absence or failure of consideration for a bond or covenant will, in a Court of law, be wholly immaterial $(i)$. Hence arises a noticeable distinction between the case of a deed founded on a past and insufficient consideration, and a deed executed with a view to carrying out an illegal purpose: the former, inasmuch as no consideration at all is required to support the contract, being good $(k)$, whilst the latter will be wholly void $(l)$.

With respect to contracts under seal, founded upon illegal considerations, nothing further need here be said, inasmuch as I shall presently have to inquire generally, and at some length, into the nature of the consideration for a promise and of the subject-matter of an agreement.

(h) See R. r. Inhabs. of Cheadle, 3 B. A Ad. 833, 838.

(i) Per Parke, B., Wallis r. Day, 2 MI. \& W. $27 \pi$.

(k) Arg. Beaimont r. Reeve, $8 \mathrm{Q}$. B. 485, and cases there cited; Nye $r$. Mcoseley, 6 B. \& C. 133; Friend r. Harrison, 2 C. \& P. 584; Fallowes v.
Taylar, 7 T. R. 475,477 , as to which, see heir r. Leeman, 15 L.J. Q. B. 360. See Fisher v. Bridges, 2 E. \& B. 118, 126,127 ; S. C. (in error), 3 Id. $64 \%$, cited ante, p. 281 .

(I) Bimington r. Wallis, 4 B. \& Ald. 650, 652; Walker v. Perkins, 3 Burr. 1568 ; Fisher v. Bridges, supra. 
Another peculiar characteristic of a contract under seal is this, that, in certain cases, it will bind the heir and sometimes even the devisee of the contracting party. Where, for instance, a person by bond, covenant, or other specialty, binds himself and his heirs, the beir and devisee are each liable for the default of the ancestor or testator, to the extent of assets freehold and copyhold which they have taken by descent or devise $(m)$.

In order, however, to render the heir liable on the ancestor's specialty, it is necessary, 1st, that he be expressly named in the bond or covenant $(n)$; and, 2ndly, that he have assets by descent from the covenantor; for though the covenant descends to the heir, whether he inherits any estate or not, it cannot be effectually put in suit until he has assets by descent $(o)$.

The heir of an obligor will clearly not be liable unless named in the ancestor's bond $(p)$, though the personal representatives of one who contracts by specialty are, although not named, liable to the extent of assets, except on a covenant, which, from its nature, must be performed by the covenantor and determines by his death $(q)$.

A remarkable distinction thus presents itself between a specialty and a simple contract, for liability in respect of the latter must be enforced, if at all, against the personal representatives of the contractor.

The stat. $32 \& 33$ Vict. c. 46 , abolished the distinction as to priority of payment which formerly existed between the specialty and simple contract debts of deceased persons.

(m) 11 Geo. $4 \& 1$ Will. 4 , c. 47 , ss. 3, 4. See $R e$ Taylor's Estate, 8 Exch. 384.

(n) Platt on Cor. 449; Bac. Abr. "Heir" (D.) \& (I.); Derisley v. Custance, 4 T. R. 75.

(o) 2 Bla. Com. 244. See Farley v. Briant, 3 Ad. \& E. $847,850,859$; per Grose, J., Wilson v. Kmubley, 7 East, 135; Dyke v. Sweeting, Willes, 585, 587; Hunting v. Sheldrake, 9 B.C.L.
M. \& W. 256 .

(p) See Barber v. Fox, 2 Wms. Saund. 136, 137 b; Co. Litt. 209 a.

(q) Hyde v. Dean of Windsor, Cro. Eliz. 552, 553; cited per Wightman, J., Penfold v. Abbott, 32 L. J., Q. B. 67, 68; Judgm., Taylor v. Calduell, 3 B. \& S. 835 ; Wills v. Murray, 4 Exch. 843; per Parke, B , Sibuni v. Kirkman, 1 M. \& W. 423; Wentworth v. Cock, 10 Ad. \& E. 42. 
And by the Judicature Act, 1875, s. 10, in the administration of the assets of any person who may die after the commencement of that Act and "whose estate may prove to be insufficient for the payment in full of his debts and liabilities," "the same rules shall prevail and be observed as to the respective rights of secured and unsecured creditors, and as to debts and liabilities provable and as to the valuation of annuities and future and contingent liabilities respectively, as may be in force for the time being under the law of bankruptcy with respect to the estates of persons adjudged bankrupt."

Specialty, how dis-

Rule at common law.

The last characteristic of a specialty which here requires notice is, that at law ( $r)$, a contract thus solemnly authenticated can only be dissolved, released, or discharged by matter of as high a nature as itself.

It is obvious, that, where matter of discharge by parol from a liability under seal exists at all, it must have arisen either before or after a breach of the special contract. According to our common law, if it has arisen before breach, the rule just stated strictly holds; if after breach, the matter of discharge may sometimes afford ground of defence to an action for damages.

Of the former of these two propositions, The Mayor, dec., of Beruick v. Osucald (s) illustrates the truth. There the defendant was sued in covenant upon a bond which he had entered into as surety for the due performance of his duty by one M., who had been elected to fill the office of treasurer of the town of Berwick. The breaches assigned were, that the said M. had not paid over, nor truly accounted for, certain monies to the plaintiffs. In answer to this declaration the defendant pleaded, inter alia, that, after the making

(r) See per Pollock, C. B., 1 II. \& N. 458.

(s) 1 E. \& B. 295 ; S. C., 3 Id. 653,5 H. L. Ca. 856, with which compare Irayor, sfe., of Cambridge $\mathrm{r}$.
Lennis, E. B. \& E. 660 , and cases there cited; Blake's case, 6 Rep. 44; Snow v. Franklin. 1 Lutw. 358; Táae v. Waghorn, 1 Taunt. 428, 10 R. R. $5 j 8$. 
of the bond in question, and before any of the breaches of covenant alleged, the said M., and others as his sureties, executed and delivered to the plaintiffs, and the plaintiffs accepted and received from them, another bond "in full satisfaction and discharge of "that declared upon, and of all covenants, sc., contained therein. The bond thus alleged to have been given in lieu of that declared upon was similar to it, save that the defendant was not named therein as a surety. The Court held that the plea thus put on the record was bad, because an accord and satisfaction cannot be pleaded to an action upon a deed before breach, and there was nothing in the second deed which could operate as a release of that previously executed $(t)$.

In conformity with the decision of the Court of Queen's Bench above mentioned is that of the Court of Exchequer in Spence v. Healey $(u)$, where it was held, that a covenant to pay a sum certain, after notice given, could not, before breach, be discharged by matter in pais, such as the delivery to the covenantee of goods and chattels by the covenantor.

In the case of Steeds v. Steeds (v), to an action brought by two obligees on a bond, accord and satisfaction by delivery of stock and goods to one of the plaintiffs was pleaded. The defence was held to be insufficient because, although the rule in equity that accord and satisfaction is a good defence to an action on a bond now prevails, still, in equity joint creditors are primâ facie regarded as interested not as joint tenants but as tenants in common, and the defence disclosed nothing to rebut this presumption.

But although it is true, that if an action be brought at law

(t) But " though the bond is under seal, the condition is of a thing resting on evidence only. It may be compared to matter in pais:" 1 Selw. N. P. 13th ed., 497, citing per Tindal, C. J., West v. Blakeway, 2 M. \& Gr. 751; Pinnell's case, 5 Rep. 117 a. (u) 8 Exch. 668, and cases cited Id. 669 , n. (b). See also Smith v. Trou'sdale, cited post, p. $293(d)$; West v. Blakex:ay, 2 M. \& Gr. 729; II 2 \% is v. Goodxyn, Id. 405.

(v) 22 Q. B. D. 537 . 
upon a specialty, the defendant cannot allege by way of legal discharge a parol agreement made before breach, that the covenant or obligation shall not be performed; yet, after breach, a parol agreement may, where the damages sought to be recovered as unliquidated, operate at law by way of accord and satisfaction $(x)$. "Nothing, however," says Parke, B. $(y)$, " can discharge a covenant to pay on a certain day but actual payment or tender on that day." Blake's case $(z)$, may be regarded as the leading authority in support of the qualification of the general rule just specified. 'That was an action for breach of a covenant to repair, brought against the assignee of the lease, to which the defendant pleaded an accord between himself and the plaintiff, and execution thereof, in satisfaction and discharge of his default in not repairing. Upon demurrer to this plea it was objected, that the "action of covenant was founded on the deed, which could not be discharged but by matter of as high a nature, and not by any accord or matter in pais, for nihil tam conveniens est naturali equitati ut unumquodque dissolvi eo ligamine quo ligatum est; and it appears by all our books, that neither arbitrament nor accord with satisfaction is a plea when the action is grounded on a deed." But in answer to this objection, it was resolved by the whole Court, that " the defendant's plea was good in the case at bar, for there is a difference when a duty accrues by the deed in certainty, tempore confectionis scripti, as by covenant, bill, or bond, to pay a sum of money, there this certain duty takes its essence and operation originally and solely by the writing, and

$(x)$ "The meaning of an accord and satisfaction is, that there has been an agreement, and that that agreement has been completely performed, and so there has been a total extinguishment of the original cause of action:" per Mlawle, J., Gabriel v. Diesser, 15 C. B. 628.

(y) Poole v. Tunbridye, 2 M. \& W. 223, 226 (cited Judgm., Maldane v.
Johnson, 8 Exch. 695), where it is observalile that the learned Judge is represented to have added the following words, which, however, do not appear in the $S . C$. as reported $6 \mathrm{~L}$.J., X.S., Exch. 74:-"Although if the party afterwards chooses to reccive the moner, that may be pleaded by way of accord and satisfactiou."

(z) 6 Rep. $43 \mathrm{~b}$. 
therefore, it ought to be avoided by a matter of as high a nature" . . . "but when no certain duty accrues by the deed, but a wrong or default subsequent, together with the deed, gives an action to recover damages," . . "for such wrong or default accord with satisfaction is a good plea."

Applying the rules thus stated to the facts before them, the Court further observed, in Blake's case, that the covenant to repair did not, at the time of making it, give the plaintiff any cause of action; but the wrong or default after in not repairing, together with the deed, gave a right to recover damages $(a)$ : and then laid down generally, that in all actions, where damages only $(b)$ are to be recovered, accord with satisfaction may be pleaded (c); though (as we elsewhere read) "where the covenant is for the payment of a sum certain, the covenantee has a right to object that the discharge is not by deed" $(d)$.

In the particular case of a covenant or bond to pay a sum of money on a day named, payment ad diem would be performance, -in the one case of the covenant-in the other of the condition of the bond, and, therefore, might, at common law, be set up by way of defence in an action upon the specialty. And by statute 4 \& 5 Ann. c. 3, s. 12, where debt is brought upon any bond, with a condition or defeasance to make void the same upon payment of a lesser sum at a day or place certain, if the obligor, his heirs, executors, or administrators have before the action brought

(a) The distinction appears to be this: there can be no dispensation with a contract under seal except by a release under seal. Accord and satisfaction before breach is therefore a bad plea in corenant, because it amounts to a dispensation. But accord and satistaction after breach is a good plea, because the subject-matter of the payment and acceptance in satisfaction is, - not the corenant, which remains entire,but the damages sustained by the particular breach of it, for which the action is brought:" 6 M. \& Gr. $262(a)$. See also Doe d. Muston v. Gladvin, 6 Q. B. 953; Raulinson v. Clarke, 14 MI. \& V. 187 .

(b) By which expression apparently must be understood unliquidated damages.

(c) 6 Rep. 44 b; Peytoe's case, 9 Rep. $7 \%$.

(d) Spence v. Healey, 8 Exch. 670. See Simith v. Trow $\bullet$ ale, 3 E. \& B. 83, with which compare Braddick v. Thompson, 8 East, 344 ; 15 R. R. 751. 
paid to the obligee, his executors or administrators, the principal and interest due by the condition or defeasance though such payment was not made strictly according to the condition or defeasance, yet it may be pleaded in bar of such action.

Rules of Equity here noticeable.

The obligatory force of a contract under seal may in equity be affected by matter which could not at law be set up by way of answer to an action founded on it. This remark may be exemplified by reference seriatim to some propositions stated in the preceding pages.

Equity will sometimes give relief where a condition precedent $(e)$ which should have been performed by the applicant has not been performed by him, and where at law such nonperformance might have been successfully insisted on. Thus, should there be a covenant by lessor to renew the lease subject to performance of a condition precedent by lessee, performance of this covenant will be enforced in equity, even though there may not have been "a literal and exact performance" of the condition by the lessee, or where there has been some laches on his part if excused by fraud or surprise or by unavoidable accident or ignorance that is not wilful.

Again, "The rule at law that evidence is not admissible to contradict a written instrument $(f)$, stated simpliciter is received in equity. That Court, however, assumes a jurisdiction to reform an instrument which, either by the frand or by the mistake of the party who drew it, admits of a construction inconsistent with the true agreement of the parties. And of necessity in the exercise of this jurisdiction a Court of Equity receives evidence of the true agreement in contradiction of the written instrument" $(g)$. In any such case the strict rules of law must henceforth $(h)$ give

(') Ante, p. 268.

(f) As to this rule, post, Chap. 2.

(g) I'er Sir J. Leach, Ball v. Storie,
1 Sim. \& Stu. 210, 219; 24 IR. R. 170.

(h) 36 \& 37 Vict. c. 66, s. 25 (11). 
way to equitable rules, and so must they under circum. stances quite dissimilar from those as yet suggested.

A contract under seal (i) may sometimes in equity be put an end to by a parol agreement $(k)$. Conduct not in accordance with good faith, or calculated to mislead, may disentitle a suitor to relief, and if an injunction be granted to restrain a breach of covenant the injunction will be dissolved on the ground of long acquiescence in such breach by the covenantee, though such acquiescence could afford no defence to an action at law for the breach of a covenant $(l)$. The Duke of Bedford v. The Trustees of the British Museum (m) shows that acts also of the covenantee might in view of the Court of Chancery render it inequitable to enforce the performance of a covenant.

Again, equity prefers compensation to forfeiture, and, quite irrespective of statute, relieved against the penalty of a bond; it relieved also against a forfeiture of the term for breach of a covenant to pay rent. By stat. 23 \& 24 Vict. c. 126 , s. 1 , a court of law was enabled in this latter case to give relief ; and now by stat. $44 \& 45$ Vict. c. 41 , s. $14(n)$, it is provided that no right of re-entry or forfeiture for a breach of any covenant or condition in a lease to which that section extends shall be enforceable, unless the lessor has served upon the lessee a notice specifying the breach, and requiring him to remedy the same if possible, and in any case make a money compensation (o) therefor, and the

(i) Ante, p. 263.

(b) Hill v. Gomme, 1 Bear. 540; Fry on Specific Perform., 3rd ed., 469.

(l) Barret v. Blagrave, 6 Ves. 104.

(m) 2 My. \& K. 552; Sayers v. Collyer, 24 C. D. 180 ; 28 Id. 103.

(n) See 55 \& 56 Vict. c. 13 . Where there is no actual lease and no right to specific performance, the section does not apply, Swain v. Ayres, 21 Q. B. D. 289 (C. A.). The section does not enable the Court to grant relief to an underlessee for breach of a covenant to repair contained in the head lease,
Burt v. Gray, (1891) 2 Q. B. 98, approved in Nind $\mathrm{r}$. Nineteenth Century building Society, (1894) 2 Q. B. 226 . See s. 4, ว็ \& 56 lict. c. 13.

(o) Where compensatiou is not desired, the notice need not demand compensation: Lock v. Pearee. (1892) 2 Ch. 328 (affirmed C. A., (1893) 2 Ch. 271). The compensatiou is, it would seem, to be measured by the same rule as damages in an action for breach: Shinners Co. v. Knight, (1891) 2 Q. B. 542 (C. A.). As to "compensation" not including cost of employing a surveyor and solicitor, cf. Skinners' $\mathrm{Co}$. 
lessee has failed to do so within a reasonable time. Further, the lessee can apply $(p)$ to the Court for relief, which may be granted on such terms as to compensation, \&c., as the Court shall think fit.

And further by the Judicature Act, 1873, s. 24, sub-s. 2 et seq., the Courts of common law are empowered to give to all equitable defences the same effect as would have been given in the Court of Chancery $(q)$.

Simple contractwhat.

A simple contract is a contract either in uriting not under seal, or rerbal, or implied from the acts and conduct of the parties $(r)$. It may be either executory or executed.

An exccutory simple contract, is an agreement,-either in writing not under seal or verbal or implied,--of two or more persons on sufficient consideration, to do or not to do a particular thing $(s)$.

A simple contract may be either wholly executed, i.c., each party to it may have performed that which he originally undertook to do, or it may be executed as regards one of the contracting parties and executory as regards the other $(t)$.

The distinctions here adverted to as existing amongst simple contracts, as well as the nature of an implied contract, will become apparent, not merely from a perusal of the pages immediately following, but from many portions of this Book,- especially those which treat of the operation

v. Fuight. Howerer, the lessor can now recover such cost as a debt due, ci. Conveyancing Act, 1892 (55 \& 56 Vict. c. 13), s. 2, sub-s. 1. This section does not apply to enable a lessor to recover from an underlessee, nor is a lessee, who, by complying with the requirements of a notice under s. 14, sub-8. 1, of the Conveyancing Act, 1881 , prevents a right of forfeiture from becoming enforceable, "relieved" within the meaning of the section: Nind v. Ninetenth Century Building Suciety, (1894) 2 Q. B. 226 (C. A.), reversing s. C., (1894) i Q. B. 472.

(p) Not by originating summons: Lock r. Pearce, loc. cit., and not atter the lessor has re-entered: Rogers v. Rice, (1892) $2 \mathrm{Ch} .170$.

(q) Mostyn r. West Mostyn Coal Co., 1 C. P. D. 145.

(r) A simple contract is sometimes in part evidenced by writing, and in part by words or conduct.

As to implied contracts, see Robinson v. Davidson, I. R. 6 Ex. 269 ; Whincup v. Huykes, L. R. 6 C. P. 78 ; followed in Ferns v. Carr, $28 \mathrm{Ch}$. D. 409 ; Farrow v. Wilson, I. R. 4 C. P'. 744; Ford v. Cotesurorth, L. R. 5 Q. B. 544 ; followed in Cumingham r. Jum, 3 C. P. D. 443.
(s) See 2 Bla. Com., p. 442.
(t) Ante, p. 245. 
of the Statute of Frauds, and of contracts mercantile or between particular persons. For the present, I shall restrict myself to such remarks concerning simple contracts generally as may lay the foundation for more minute knowledge upon this subject, directing attention from time to time to selected cases in illustration of what is said.

By the term "contract" used in the preceding paragraphs, must be understood an agreement or convention between parties, the terms of which have been definitively Terms of contract must be definitively arranged and settled; for, upon an agreement inchoate merely, and incomplete, no remedy can be enforced. Efficacy being imparted to a contract by the mutual consent of the contractor and contractee, no such force attaches to it so long as the negotiation is still pending and open, for " till both parties are agreed either has a right to be off " $(u)$.

Cope v. Albinson (x) will illustrate the above remark. There the defendant through his agent made an offer to the plaintiffs in these words, riz., "to pay a composition of seven shillings in the pound on your (the plaintiff's account) against his (the defendant's) nephew, J. A., the younger, and on your giving proper indemnification to both. In the event of your accepting the offer I will thank you to forward me full particulars of your account, in order that the same may be properly examined." This offer was accepted by the plaintiffs, and the particulars of their account forwarded accordingly; and a reasonable time, as was alleged, having elapsed for the payment of the composition by the defendant, they brought their action against him to compel payment of the same. The Court held the action not

(u) Per Best, C. J., Routledge v. Grant, 4 Bing. 661; Felthouse v. Bindley, 11 C. B., N. S. 869 ; Governor, \&c., of the Poor of Kingstonupon-Hull v. P'etch, 10 Exch. 610 ; Dunlop v. Higgins, 1 H. L. Ca. 381 ; Bayley v. Fitzmaurice, 6 E. \& B. 868 ;
S. $C ., 8$ Id. $664 ; 9$ H. L. Ca. 78; Cheveley v. Fuller, 13 C. B. 122; Bristol Aërated Bread Co. v. Maggs, 44 Ch. D. 616; Page v. Norfolk, 70 L. T. 781 .

(x) 8 Exch. 185. 
maintainable, the agreement not having been completed between the parties. "This," observed Parke, B., " is an agreement for a composition upon terms thereafter to be settled, and is like a contract for the purchase of an estate for such a sum as the parties may think fair."

In a recent case $(y)$ in the Privy Council the facts were the following. A. telegraphed "will you sell us B. P. H. ? Telegraph lowest cash price." $R$. in reply telegraphed " lowest price for B. P. H. 900l.," and A. then telegraphed accepting the property at the price. It was held that the mere statement of the lowest price at which the vendor would sell contained no implied contract to sell at that price to the persons maling the enquiry, and that there was no completed contract.

Again, if application for an absolute and unqualified allotment of shares in a projected company be made, and the letter of allotment contain the qualifications that the shares are not transferable, the proposal and acceptance, not being ad idem, will together fail to evidence a binding contract between the applicant for shares and the company $(z)$. And generally "where a contract is to be made out by an offer on one side and an acceptance on the other $(a)$, if the answer is equivocal, or anything is left to be done, the two do not constitute a binding contract" $(b)$.

Where, moreover, the existence and nature of a contract are to be gathered from a correspondence between parties,

(y) Harecy v. Facey, (1893) App. Cas. 552.

(z) Duke r. Andrewx, 2 Exch. 290, cited per Alderson, B., Willey v. P'arratt, 3 Exch. 213; Chaplin v. Clarke, 4 Exch. 403; Vollans v. Fletcher, 1 Fixch. 20 ; Hoove r. Garrood, Id. 686: Wontner r. Shairp, 4 C. B. 404; Hamilton r. Tervy, 11 C. B. 954 ; Mudspeth r. Yarnoll, 9 C. B. 625.

(a) See English and Foreign Credit Co. v. Arduin, L. R. 5 II. I. 64; Port Canning Land Co. v. Smith, L. R.
5 I. C. C. 114. As to communication of acceptance. ef. Brogden $v$. J.et. R. C., 2 App. Cas. pp. 691, 692 (per Lord Blackburu); Carlill v. Carbolic Smote Ball Co., (1593) I Q. B. at pp. 269, 270 (per Boncen, L. J.) ; Gunrdians of Dartford Lnion r. Trickett, 5 'T. L. R. at p. 620 (per Boren, L. J.)

(b) Per Grore, J., Appleby r. Johnson, L. R. 9 C. P. 163 ; Stanley v. Dovedesicell, L. R. 10 C. P. 102. See Ireland v. Livingston, L. R. 5 H. L. 39. 
the whole of that which passed between them must be taken into consideration $(c)$, and from it must be apparent an unqualified acceptance of the offer made, into which no new term $(d)$, unless assented to, can be introduced; if there be such there is no complete contract. Peradventure it may happen that the language used is ambiguous, and doubts may thereupon arise whether the parties were ad idem (e).

As regards mercantile contracts in general, which are thus frequently concluded by written correspondence between parties, it has been held that, where A. makes an offer by letter to B., and B. accepts that offer unconditionally, the contract is complete when B.'s letter is posted, although it may chance not to reach its destination $(f)$. And there seems to be no difference in principle between the case of a letter accepting an offer and a letter containing an order for goods $(g)$. But an offer sent by letter cannot be withdrawn by simply posting a subsequent letter, which does not, in the ordinary course of the post, arrive until after the first letter has arrived and been answered $(h)$. "An uncommunicated revocation is, for all practical purposes, no revocation at all" (i).

In a case of this lind the facts were these; - the defendant applied for shares in the plaintiff's company. The company allotted the shares to the defendant and duly addressed to him and posted a letter notifying the allotment, but the letter never was received by the de-

(c) Hussey v. Horne-Payne, 4 App. Cas. 311; Rossiter v. Miller, 3 App. Cas. 1124 ; cf. also Kay, J., in Bristol Aérated Bread Co. v. MLags, 44 Ch. D. 616 ; also the remarks of North, $\mathrm{J}$, in Bellamy r. Debenham, $45 \mathrm{Ch} . \mathrm{D}$. pp. 492-495.

(d) As to effect of a covering letter introducing new term, cf. Maconchy $\mathrm{v}$. Trotter, (1894) 2 Ir. R. 663.

(e) Per Cotton, L. J., Lewis v. Brass, 3 Q. B. D. 672.

(f) Dunean v. Topham, 8 C. B. 225 , $228 ;$ Dunlop v. Higgins, $1 \mathrm{H}$. L. Cas. 381 , 398 ; per Wilde, C. J., Harvey v.
Jolunston, 6 C. B. 304; Adams v. Lindsell, I B. \& Ald. 681, 19 R. R. 415 ; Taylor v. Jones, 1 C. P. D. 87.

(g) Per Lord Coleridye, C. J., 1 C. P. D. 90, citing Harris's case, L. R. 7 Ch. 587 .

(h) Byrne v. Tan Tienhoren, $5 \mathrm{C}$. P. D. 344 ; approved in Henthorm r. Fraser, (1892) 2 Ch. 27.

(i) Per Lush, J., Stevenson v. Maclean, 5 Q. B. D. 352 ; followed in Maelagan's case, 51 L. J. Cl. 844 ; and approved in Henthorn v. Fraser, loc. cit. 
fendant: the defendant was nevertheless held to have become a shareholder in the company $(k)$. However, there may be a question whether the offeree is entitled to use the post as the means of communicating his acceptance. In Henthorn v. Fraser, Lord Herschell says $(l)$, "Where the circumstances are such that it must have been within the contemplation of the parties that according to the ordinary usages of mankind, the post might be used as a means of communicating the acceptance of an offer, the acceptance is complete as soon as it is posted." In the same case Kay, L. J. says $(m)$, "posting an acceptance of an offer may be sufficient where it can be fairly inferred from the circumstances of the case that the acceptance might be sent by post."

Where an order to make certain bets was sent by telegraph from an office without the city to a person within the city who telegraphed that the order had been obeyed, the Court held that the contract of agency was made within the city $(n)$.

Again, there must be reciprocity of assent between the parties to a contract in order that it may be complete and binding $(o)$; and if the term mutuality be used as synonymous with "reciprocity of assent," it will be true to say that there must be mutuality in a contract (p). The term in question is, however, often employed to signify "reciprocity of obligation," and in this sense the rule which has been just stated does not invariably hold true. Important

(k) Honsehold Fire Ins. Co. r. Grant, 4 Ex. D. 216.

(I) Henthorn v. Fraser, loc. cit. at p. 33 ; also see Carlill v. Carbolic Simoke Ball Co., (1893) 1 Q. B. 256, jer Boicen, I. J., at p. 269.

(in) Henthorn r. Fraser, loc. cit. at p. 36 . 640 .

(n) Couan v. O'Comnor, 20 Q. B. D.

(o) Sce cases cited infra.

(p) A simple instance showing what is meant by " mutuality," presents itselt in the ordinary contract of sale.

As to mutuality in contracts of hiring and service, see Keg. r. Welch, 2 E. \& 13. 357 ; Harlley 8 . Cummings, 5 C. B. 247 ; Pilkington $r$ Scott, 15 M. \& W. 65\%; Whittle, app., Franklin, resp., 2 B. \& S. 49 ; Eimmens $r$. Elderton, 13 C. B. 495 ; S. C., \& H. L. Cas. 624; Rust v. Noltidge, 1 E. \& B. 99 ; Bcaley v. Stuart, 7 H. \& N. 753 ; Sykics r. Dixon, 9 A. S E. 693. 
classes of contracts might indeed be specified, in which, on their inception, legal liability attaches and can be enforced as against one only of the contracting parties $(q)$. For instance, an agreement within the 4th section of the Statute of Frauds will bind the party who has signed it, although there may be no legal remedy at his suit against the other by reason of this latter party having omitted to sign it $(r)$. The contract of an infant is in most cases voidable at his election, though quoad an adult contracting with him it absolutely binds $(s)$. The individual who executes a guarantee assumes liability, without having any power to compel the party to whom such security is given to supply the goods, or to extend the credit in pursuance of the terms of the guarantee $(t)$. This is clearly explained in the case infra (u) by Parke, B., who remarks that where one person says to another " in case you choose to employ this man as your agent for a week, I will be responsible for all such sums as he shall receive during that time and neglect to pay over to you:" the party indemnified is not therefore bound to employ the person designated by the guarantee; but if he do employ him, then the guarantee attaches and becomes binding on the party who gave it $(x)$.

Burton v. The Great Northern R. C. (y) may be cited for

(q) See Harvey v. Johnston, 6 C. B. 295 ; Mills v. Blackull, 11 Q. B. 358, 366 ; Gibson v. Carruthers, $8 \mathrm{M}$. \& W. 321 ; Warsh v. Wood, 9 B. \& C. 6.59 ; Kearsey v. Carstairs, 2 B. \& Ad. 716 ; Fairburn v. Eastwood, 6 M. \& IV. 679 .

(r) Laythoarp v. Bryant, 2 Bing. I. C. 735 ; post, p. 376 .

(s) Holt v. WVard, 2 Stra. 937; post, Chap. 7, s. 2.

(t) Per Wightman, J., Mills v. Blackall, 11 Q. B. 366.

(u) Kennaway v. Treleavan, 5 M. \& IV. 501 .

(x) See Westhead v. Sproson, 6 H. \& T. 728 . (y) 9 Exch. 507. See Rhodes $v$. Forwood, 1 App. Cas. 256, 272, citing Stivling v. Maitland, 5 B. \& S. 840 , 852. As to want of mutuality-in contracts under seal, see Aspdin r. Austin, 5 Q. B. 671; Dunn v. Sayles, Id. $685 ;-$ in contracts under seal, executed by one party only, see British Empire Mutual Life Assurance Co. V. Browne, 12 C. B. 723 ; Morgan v. Pike, 14 C. B. 473 ; Suatman v. Ambler, 8 Exch. 72 ; Pitman r. Woodbury, 3 Exch. 4 ; Whentley v. Boyd, 7 Exch. 20; How v. Grech, 3 H. \& C. 391 ;--in contracts with corporatious, INayor of hidderminster $v$. Havdwiek, L. R. 9 Ex. 13 ; post, Chap. 7, s. 1. 
the purpose of showing what is meant by "want of mutuality " in a contract. There the plaintiff by a memorandum of agreement between himself and a railway company (the defendants) undertook to provide waggons, horses, \&c., for the cartage of merchandise between $H$. and W., and to convey all such as might be presented to him for conveyance between those places. And he further undertook to perform all business entrusted to him, promptly and carefully, at a certain specified rate. And it was mutually agreed that the arrangement aforesaid should continue in force for the period of twelve months from the date thereof. The defendants having, before the expiration of that period, by written notice, terminated the agreement, the plaintiff sued them for breach of contract. But the Court of Exchequer, besides holding that the declaration, as framed upon the above agreement, was not supported by it, intimated a strong opinion that no action at all could, even if an amendment were made in the declaration, be maintained upon the contract in question against the company, inasmuch as it contained no provision binding them to send goods to the plaintiff for conveyance, and was, in fact, unilateral merely, and without mutuality. So a person who tenders to supply goods in answer to an advertisement, and whose tender is accepted, is bound to supply the goods when ordered, although no order for them need be given $(z)$.

Want of mutuality or reciprocity of obligation may sometimes be insisted on in a Court of Equity as affording a good ground of defence to a suit for specific performance of a contract, and this equitable doctrine is now recognised in Courts of Law (a).

Analysis of a simple contract.
If we analyse a simple contract, the terms of which have been definitely arranged between the parties to it $(b)$ s or (z) Great Northern R.C.v. Witham, p. 86.

J. R. 9 C. 1'. 16.

(a) Watson, Comp. of Equity, vol. 1, (b) Ante, p. 297. 
trace the progressive steps in its creation, we shall find that there must have been a request to the contractee by the contractor-a consideration moving from the contractee to the contractor-a promise by the contractor to the contractee to do, or to refrain from doing, a particular thing. Of these three ingredients in the contract, viz., the request - the consideration-and the promise-I shall briefly treat in the order just indicated, although it will be desirable for the reader, before perusing that which immediately follows, to familiarise himself with the definition of a "consideration" given at p. 311 .

To constitute a contract valid in law there must have Request. been a request to the contractee by the contractor, either express or implied by law. It is clear that if one requests another to pay money for him to a stranger, there is to be implied in the absence of any express promise, an undertaking to repay it; so that the amount, when paid, is a debt due to the party paying from him at whose request it is paid; and it is here wholly immaterial whether the money is paid in discharge of a debt due to the stranger or as a loan or gift to him. The request to pay, and the payment according to it, create a legal liability which attaches to the party making the request; and we shall presently see that whether the request be direct-as where the party is expressly desired by the defendant to pay-or indirectas where he is placed by him under a liability to pay, and does pay-is immaterial. If one ask another, instead of paying money for him, to lend him his acceptance for his accommodation, and the acceptor is obliged to pay it, the amount is money paid for the borrower, although the borrower be no party to the bill, nor in any way liable to the person who ultimately receives the amount. The borrower by requesting the acceptor to assume that character, which ultimately obliges him to pay, impliedly requests him to pay and is as much liable to repay as he 
would be on a direct request to pay money for him with a promise to repay it $(c)$.

Let us first take the instance of an executory contract, as " in consideration that you will serve me a year, I will give you £10." This is equivalent to suying, " in consideration that you, at my request, will serve me," \&c." In this case, therefore, and in every case where the consideration of a promise is executory, there must have been a request, or something tantamount to it, on the part of the promisor $(d)$.

Executed consideration.

Where, however, the act relied upon as the consideration for a promise is wholly past and executed (e), it is obvious that such act may or may not have been done at the request of the promisor, ex. gr., it may have been a mere voluntary courtesy. In this case the rule is that from a previous express request, followed by the execution of the consideration, a promise will always be implied; but " a bygone consideration, unless supported by a request, will not sustain a subsequent promise" $(f)$. "If," says Mr. Chancellor Kent $(g)$, " the consideration be wholly past and executed before the promise be made, it is not sufficient, unless the consideration arose at the instance or request of the party promising." Thus if a man disburse money about the affairs of another without request, and then the latter promise that, in consideration of the former having laid out money for him, he will pay him $£ 10$, that is not a good consideration being completely executed $(h)$.

In many cases, however, coming under the latter part of

(c) Judgm., Brittain r. Lloyd, I4 M. \& W. 773 .

(d) King r. Sears, 2 Cr. M. \& R. 53; Shadicell v. Shaduell, 9 C. B., X. S. 159 ; 30 L. J. C. P. 145.

(e) I'ost, p. 320 , et seq.

(f) Per Tindal, C. J., Thomton v. Jenyns, 1 M. \& Gr. 188, citing Hunt v. Bate, Dyer, 272 , and West r. West,
I Rolle, Abr. 11; King r. Sears, 2 Cr. M. \& R. 48.

(h) Judgm., 1 M. \& Gr. 188-9; Lampleigh v. Brathwait, Hob. 105 ; $1 \mathrm{Sm}$. L. C., 9th ed., 153, explained in Judgm., Kemedy r. Broun, 13 C. B., X. S. 740 . 
this rule, a request will be implied, either as collected from the circumstances, or by direct intendment of law.

1. Where the act stated as the consideration for a promise cannot, from its nature, have been a gratuitous kindness, but necessarily imports a request, such request need neither be averred nor specifically proved,-as in the case of money lent; for the mere statement that money was lent implies that it was advanced at the request of the party to whom the loan was made (i).

2. Again, where the party whom it is sought to charge upon a contract has derived benefit from that which is alleged to be the consideration for his promise, the accept. ance and enjoyment of this benefit will, in legal contemplation, suffice to imply an antecedent request. If, for instance, a man buys goods for me without my knowledge or request, and afterwards $I$ agree to receive the goods, my conduct, as showing a ratification of the contract, will dispense with the necessity of proving an express request $(k)$, according to the maxim, Omnis ratihabitio retrotrahitur et mandato priori aequiparatur $(l)$. So if A., unauthorised by me, makes a contract on my behalf with B., which I afterwards recognise and adopt, there is no difficulty in dealing with this contract as having been originally made with my authority. If $\mathrm{B}$. entered into the contract on the understanding that he was dealing with me, when I afterwards agree to admit that such was the case, B. is precisely in the condition in which he meant to be. If, on the other hand, B. did not believe A. to be acting for me, his condition is not altered by my adoption of his agency; for he may sue A. as principal at his option, and has the same

(i) Victors v. Davies, 12 M. \& W. 758 ; ef. also, per Bowen, L. J., Stewart v. Casey, (1892) 1 Ch., at p. 115.

(i) 1 Wms. Saund. 264 (1); Barber v. Brown, 1 C. B., N. S. 121 .

(l) As to this maxim, see Ashbury B.C.I.
Railway Carriage and Iron Co. v. Riche, L. R. 7 H. L. 653; Melhado v. Porto Alegre R. C., L. R. 9 C. P. 503 ; Phosphate of Lime Co. v. Grcen, L. R. 7 C. P. 43 ; Irvine v. Union Bank of Australia, 2 App. Cas. 366, 374. 
equities against me if I sue which he would have had against $\mathrm{A}$. $(\mathrm{m})$.

3. Where one party has been compelled to do that to which the other party was legally compellable, a request will be implied in law from the latter to the former to do the act relied on as the consideration, as well as a promise from the latter to repay the party so compelled $(n)$.

Principal and surety.

If the debt or liability is incurred entirely for a principal, the surety having become liable for him at his request, and being obliged to pay, is held at law to pay on an implied request from the principal that he will do so (o). A surety, however, who seeks to recover money paid by him from his principal, must show that he was under a reasonable obligation and necessity to make the payment. For if he improperly defends an action, and incurs costs, there will be no implied duty on the part of his principal to reimburse him those, unless the action was defended at the principal's request $(p)$. If, however, he make a reasonable and prudent compromise, he will be justified in so doing $(q)$.

From the rule just laid down, which is applicable in its terms to the particular case of principal and surety, may

(min) Judgm., Bird v. Brown, 4 Exch. 798-9 ; cited per IVilles. J., Bervick v. Horsfall, 4 C. B., N. S. 454 ; Mitche. son v. Nicol, 7 Exch. 929 ; Peto r. Reynolds, 9 Exch. 410; James v. Isaats, 12 C. B. 791 ; per Lord Wensleydale, Ridgway .. Wharton, 6 H. L. Cas. 296-7.

(n) Jeffreys v. Gurr, 2 B. \& Ad. 833; Pownal v. Ferrand, 6 B. \& C. 439 ; Grissell v. Robinson, 3 Bing. N. C. 10; Jones v. Orehard, 16 C. B. 614. As to what amounts to compulsion, see Johnson v. Royal Mail Steam Packet Co., L. R. 3 C. P. 44 ; England v. Marsden, L. R. 1 C. P. 529; sed vide per Thesiger, L. J., Ex p. Bishop, re Fox, 15 Ch. D. 417 ; and Edmunds v. Walling ford, 14 Q. B. D. 811,816 ; The Orehis, 15 P. D. 38.

(o) Judgm., 2 E. \& B. 296 ; Judgm., Sayles v. Blane, 14 Q. B. 205 ; Mar- sack v. Webber, 6 H. \& N. 1. As to the nature of the coutract between principal and surety, see Duncan v. New South Wales Bank, 6 App. Cas. 11 ; London Guarantee, \&e. v. Feamley, 5 App. Cas. 911 ; Lloyds v. Harper, 16 Ch. D. 290 ; and as to the rights of sureties, Steel v. Dixon, 17 Ch. D. 825; Ex $p$. Snoudon, Ib. 44.

(p) Knight v. Hughes, 1 M. \& M. 247; Gillett r. Rippon, Ib. 406 ; Roach v. Thompson, Ib. 487 ; Short v. Kalloway, 11 A. \& E. 28, ubi per Lord Denman, C. J., "No person has a right to inflame his own account against another, by incurring additional ex. pense in the unrighteous resistance to an action he cannot defend;" Walker v. Hatton, 10 M. \& W. 249.

(q) Smith v. Compton, 3 B. \& Ad. 407 ; Dixon v. Fawcus, 30 L. J. Q. B. 
readily be derived the doctrine of contribution amongst joint contractors. In a joint contract entered into for the benefit of all, each contractor takes upon himself a liability to pay the whole debt and each in effect takes upon himself a liability for each to the extent of the amount of his share : each, therefore, may be considered as becoming liable for the share of each one of his co-contractors, at the request of such co-contractor, and on being obliged to pay such share, a request to pay it is implied as against the party who ought to have paid it, and who is relieved from paying what, as between himself and the party who pays, he ought himself to have paid according to the original arrangement $(r)$.

The principle just stated applies where one of several joint contractors has, by legal process, been compelled to pay the joint debt, whether the action was brought against him alone or whether, judgment having been obtained against all the parties jointly liable, execution was issued and satisfaction enforced against one only $(s)$. But this right to contribution will be affected by any original arrangement or convention inter partes, inconsistent with the understanding that each is to pay his own share only. If by express arrangement one of the joint contractors, though liable to the creditor, is not, as between himself and his co-contractors, to be liable to pay any portion of the debt, it is clear that no action to compel contribution could be maintained against him $(t)$. So, where one surety

(r) Batard v. Hawes, 2 E. \& B. 287, 296.

(8) Earl of Mountcashell v. Barber, 14 C. B. 53 ; Concell . Edwards, 2 B. \& P. 268; Deering y. Lord Winchilsea, Ib. $270 ;$ Atkins $\mathrm{v}$ Arcedeckne, $24 \mathrm{Ch}$. D. 709, 714; Reynolds v. Wheeler, 10 C. B., N. S. 561 ; 30 L. J. C. P. 350 ; approved in Mracdonald $\mathbf{v}$. Whitfield, 8 App. Cas. 733, 747. In a recent case, Wright, J., decided that a surety against whom judgment has been obtained by the principal creditor for the full amount of the guarantee, but who has paid nothing, is entitled to a declaration of his right to contribution and to a prospective order that on paying his own share his co-surety shall indemnify him against further liability (Wolmershausen r. Gullick; (1893) 2 Ch. 514).

(t) Turner r. Davics, 2 Esp. 478; Done r. Walley, 2 Exch. 198; Thomas r. Cook, 8 B. \& C. 728. 
enters into an engagement of suretyship at the request of his co-surety, it has been held, that the co-surety paying the whole debt, can maintain no action (u). In such cases, the rule applies-expressum facit cessare tacitum-the request to pay, which, as above explained, the law ordinarily implies from one joint contractor to his co-contractor, can have no existence where there is an express contract inconsistent with it. Nor, to anticipate a little what I shall presently have to say, could there, under such circumstances, be implied a promise for repayment, because "promises in law," as remarked by Buller, J. (x), "only exist where there is no express stipulation between the parties."

At law the proportion recoverable seems to have been determined by the number of the original sureties $(y)$; but in equity the solvent sureties are liable to contribute inter se to the whole amount $(z)$, and it is presumed that by virtue of s. 25, sub-s. 11 of the Judicature Act, 1873, this rule will be followed in the future.

4. Again, where a man has voluntarily done that which another is legally compellable to do, and the latter afterwards in consideration thereof expressly promises, there an action will lie (a). It should, however, be observed that whereas in the previous cases both the request and the promise will be implied in law, it seems that in this case the request alone is implied, and that only when there has been an express promise (b). This last point, however, can hardly be regarded as certain. There is at least some authority for doubting whether one who has voluntarily done that whereto another was legally compellable, may not

(u) See Judgm., 2 E. \& B. 297.

(x) Toussaint v. Martimant, 2 T. R. 105 ; as to which case, see Young v. Taylor, 8 Taunt, at p. 322 ; Driver v. Burton, 17 Q. B. 989 .

(y) Vide per Bayley, J., Broune v. Lee, 6 I3. \& C. 697 ; Batard v. Haxes, 2 E. \& B. 287.

(z) Peter v. Rich, 1 Cha. R. 19;
Hole v. IIarvison, 1 Cha. Cas. 246; Layer v. Nelson, 1 Vern. 456.

(a) Hemall v. Adney, 3 B. \& P. 249 , in notis; 6 R. R. 780 , Preface v. ; Wing v. Mill, 1 B. \& Ald. 104 ; Paynter v. Williams, 1 C. \& M. 818 ; cf. Lamb v. Bunce, 4 M. \& S. 275; 16 R. R. 470.

(b) Atkins v. Banwell, 2 East, 505. 
recover from the latter even in the absence of an express promise $(c)$.

5. When the plaintiff has voluntarily done that which the defendant was only morally and not legally bound to do, it is, except in the cases to be presently referred to, the better opinion that no action will lie, even although the defendant has subsequently made an express promise. There was at one time a tendency to believe that an express promise coupled with a voluntary consideration would support an action, where there was a moral obligation upon the party benefited to do the act, in respect of which the action was brought $(d)$. But the contrary seems now to have been established, and it may be safely laid down that a mere moral obligation, however sacred, is not a sufficient consideration to make a subsequent promise binding upon the promisor $(e)$. The one exception to this rule is that suggested in the learned note to Wennall v. Adney $(f)$, where it is stated that an express promise can only revive a precedent good consideration, which might have been enforced at law through the medium of an implied promise, had it not been suspended by some positive rule of law; but can give no original cause of action, if the obligation on which it is founded never could have been enforced at law, though not barred by any legal maxim or statutory provision. Thus, to give an instance, a debt barred by the Statute of Limitations will be revived by a subsequent express promise $(g)$, but where a man had seduced a woman, and after cohabitation had ceased, by way of compensation

(c) Cook r. Lister, 13 C. B., N. S. 594, per Willes, J.; Ex p. Bishop, ve Fox, 15 Ch. D. p. 417, per Thesiger, L. J.

(d) Lee $\mathbf{}$. Mruggeridge, 5 Taunt. 36. (e) Littlefield v. Shee, 2 B. \& Ad. 811; Wennall v. Adney, 3 B. \& P. 249 , note; 6 R. R. 780, Preface v.; Eastwood v. Kenyon, 11 A. \& E. 432 , ubi per Lord Denman, C. J., "The doctrine (sc., that all promises deliberately made ought to be held binding) would annihilate the necessity for any consideration at all, inasmuch as the mere fact of giring a promise creates a moral obligation to perform it."

$(f)$ Ubi supra.

(g) Per Parke, B., Earle r. Oliver, 2 Exch. 86. 
expressly promised to pay her a yearly sum for her support, that promise was held not binding in law $(h)$.

6. Where the act of the plaintiff and the promise of the defendant take place at one and the same time, the law does not require, as in the case of a bygone transaction, that in order to make the promise binding, the plaintiff should have acted at the request of the defendant. Where the consideration moving from the one party and the promise or undertaking of the other are simultaneous, the law dispenses with proof of any previous request from the promisor to the promisee (i); and further, where the consideration is "continuing" $(k)$, an express request by the party whom it is sought to charge will be unnecessary. A good illustration of the nature of such a consideration is afforded by the case of Massey v. Goodall (l).

To sum up what has been said in the preceding pages respecting the first of the three ingredients (viz., the request) already specified $(m)$, as forming a complete contract. In every executory contract there must, ex necessitate $r e i$, have been a request on the part of the person promising. In executed contracts a request either express or implied must be shown. Such a request will be implied in law-1. Where from the circumstances of the case there must have been one, $c x . g r$., in the case of a loan. 2. Where the defendant has enjoyed the benefit of, or adopted and recognised the contract. 3. Where the plaintiff has been compelled to do that which the defendant was legally compellable to do. 4. Where the plaintiff has voluntarily done that which the defendant was legally compellable to do, and the latter has afterwards expressly promised; but not, with the exception above mentioned, when the original obligation on the defendant was merely moral and not

(h) Beaumont v. Recve, 8 Q. B. 483 ; ef. Hulse r. IIulse, 17 C. B. ill. 710 . (k) As to which see post, p. 321.

(l) 17 Q. B. 310 .

(ii) Ante, p. 303. 
legal. 5. Where the consideration moving from the plaintiff and the promise of the defendant were simultaneous. 6. Where the consideration is continuing.

2. Any act of the plaintiff from which the defendant Consideraderives a benefit or advantage, or any labour", trouble, detriment, or inconvenience, performed, taken, or sustained by the plaintiff, however small the benefit or inconvenience may be $(n)$, may suffice, in law, as a "consideration" to support a promise, and to sustain an action ex contractu (o). "A valuable consideration in the sense of the law may consist either in some right, interest, profit, or benefit accruing to one party, or some forbearance, detriment, loss, or responsibility given, suffered, or undertaken by the other" $(p)$. "A prejudice to the promisee incurred at the request of the promisor may be a consideration as well as a benefit to the promisor proceeding from the promisee: but this must be a prejudice on entering into the contract, not a prejudice from the breach of it" $(q)$. A promise without consideration will not support an action $(r)$. And on the ground of a failure of consideration, money paid is often recoverable, ex. gr. " where personal property is sold, it is not usual to add any condition of sale respecting the title of the vendor; and in the absence of any express stipulation, if the vendor cannot perform his part of the contract, the same ground that entitles the vendee to resist payment of the whole price entitles him also to recover

(n) 1 Selw. N. P., 12th ed., 55; Scotson v. Pegg, 6 H. \& N. 295; La Touche v. La Tonche, 3 H. \& C. 576 ; Bracewell v. Williams, L. R. 2 C. P. 196 ; Edgware Highuay Board v. Harrow Gas Co., L. R. 10 Q. B. 92, 96. See Begbie . Phosphate Sewage Co., 1 Q. B. D. 679; affirming S. C., L. R. 10 Q. B. 491.

(0) See Harris r. Venables, L. R. 7 Ex. 235 ; Callisher v. Bischoffsheim, L. R. 5 Q. B. 449 ; Judgm., L. R. 9 Q. B. 56-7; sed vide per Brett, L. J., Ex p. Banner, re Blythe, 17 Ch. D. 490 ; Miles v. New Zealand Alford
Est. Co., 32 Ch. D. 266, 283 ; Carlill v. Carbolic Smoke Ball Co., (1893) 1 Q. B. 256 .

(p) Currie r. Misa, L. R. 10 Ex. 162. See $M I^{\prime}$ Lean r. Clydesdale Banking Co., 9 App. Cas. 95, 111.

(q) Judgm., Gerhard v. Bates, 2 E. \& B. 487-8; Crouther v. Farrer, 15 Q. B. 677,680 .

Brown v. Brine, 1 Ex. D. 5, 7, is a curious case as to the validity of a consideration.

(r) Deacon v. Gridley, 15 C. B. 295. See Meגlanus v. Bark, L. R.5 Ex. 65. 
back any deposit he may have made in part payment thereof, on the ground that there has been a total failure of consideration $(s)$.

"An engagement," says Parke, B. ( $(t)$, " by a person to remunerate the act of another, which benefits the former, or puts the latter to any inconvenience or loss, is a binding engagement." And, again, " consideration," says Patteson, J. $(u)$, "means something which is of some ralue $(x)$ in the eye of the law, moving from the plaintiff. It may be some benefit to the defendant, or some detriment to the plaintiff, but, at all events, it must be moving from the plaintiff" $(y)$, that is to say, there must, except as set forth in Chap. iv. of this Book, be some kind of privity between the plaintiff and defendant in order to sustain an action ex contractu at suit of the former against the latter.

The term " privity," when used by legal writers must be understood to mean "a connection or bond of union (z) (ligamen) existing between parties in relation to some particular transaction;" and when it is said that an action will not lie for "want of privity" this phrase signifies that the plaintiff and defendant are strangers to each other quoad the subject-matter in dispute (a), or, at all events, that the plaintiff, the contractee, did not with sufficient directness conduce to the consideration for the undertaking

(.) Per Pollock, B., Want v. Stallibrass, L. R. 8 Ex. 183. See this case distinguished, Soper r. Amold, 37 Ch. D. at p. 101. See Clare v. Lamb, L. R. 10 C. P. 334.

(t) Moss v. Hall, 5 Exch. 50.

(u) Thomas r. Thomas, 2 Q. B. 859.

(x) Haigh v. Brooks, 10 Ad. \& E. 309; Shadwell v. Shadwell, 9 C. B., N. S. 159.

(y) Tueddle v. Atkinson, 1 B. \& S. 393. See also per Erle, J., Kilham r. Collier, 21 L. J. Q. B. 65; Gandy v. Gandy, 30 Ch. D. 57, 69.

(z) Per Wilde, C. J., Blandy r. De Burgh, 6 C. B. 634.

(a) See Playford v. United King. dom Telegraph Co., I. R. 4 Q. B. 706, followed in Dickson v. Reuter's Telegraph Co., 2 C. P. D. $62 ; S$. C., affirmed, 3 Id. 1 ; Eley v. Positive Life Ass. Co., 1 Ex. D. 88, affirming S. C., Id. 20 ; Melhado v. Porto Alegre $R$. C., L. R. 9 C. P. 503 ; Boulton v. Jones, 2 H. \& N. 564 ; Alton r. Midland R. C., 19 C. B., N. S. 213 (distinguished Taylor v. Manchester, Sheffield \& Lineolnshire R. C., (1895) 1 Q. B. 134, and in Meux r. G.E.R.C., (1895) 2 Q. B. 387 , C. A.) ; Nartin v. Great Ind. Pen. R. C., L. R. 3 Ex. 9 ; Johnson r. Royal Mail Stcom Paeket Co., L. R. 3 C. P. 38 ; Robertson v. Fleming, 4 Macq. Sc. App. Cas. 167. 
or promise of the defendant, the contractor. If, however, A. is liable at law by immediate privity of contract, which contract also confers a benefit, and the obligation of the contract is common to him and B., but the whole benefit of the contract is taken by B., A. is entit!ed to be indemnified by $\mathrm{B}$. in respect of the performance of the obligation $(b)$.

It will readily be inferred from the definitions of a legal "consideration," above given, that its nature may infinitely vary (c), "wherever," indeed, "a man may do an act without a breach of any legal or moral obligation, that act may be a valid consideration for a promise to pay money to him $(d)$ or to do any other thing." A few cases must here suffice to show the nature of a good legal consideration, and of privity.

The compromise of a claim may be a good consideration for a promise, though litigation may not have actually commenced (e), but to make it so, the party forbearing must believe that he has a good case $(f)$. It has also been held that where such belief exists it is immaterial that there was in reality no cause of action $(g)$.

Where plaintiff stipulated to discharge A. from a portion of a debt due to himself, and to permit B. to stand in his place as to that portion, defendant stipulating in return that B. should give plaintiff a promissory note, the consideration moving from plaintiff, viz., his agreement to permit B. to stand in the place of A. as his debtor, being an undertaking in legal contemplation detrimental to him, was held sufficient to sustain the promise by defendant $(h)$.

(b) Per Willes, J., Moule v. Garrett, L. R. 7 Ex. 104.

B. 872 .

(c) See Hartley v. Ponsonby, 7 E. \&

(d) Per Lord Campbell, C. J., Hall

v. Dyson, 21 L. .T. Q. B. 224, 226 :

S. C., 17 Q. B. 785 :

(e) Cook v. Wright, 1 B. \& S. 559.

(f) Wade v. Simeon, 2 C. B. 548. (g) Callisher v. Bisehoffsheim, I. R. 5 Q. B. 449 ; Oehford v. Barelli, 20 W. R. 116; sed vide per Brett, L. J., Ex p. Bamer, re Blythe, $17 \mathrm{Ch}$. D. 490 : Miles v. New Zealand Alford Est. Co., 32 Ch. D. 266 ; Crears v. Hunter, 19 Q. B. D. 341. 422 . 
In connection with the preceding case, Lyth v. Ault (i) may be consulted, which offers a curious illustration of the nature and sufficiency of the consideration which will support a promise at law. There the acceptance by a creditor of the sole and separate liability of one of two joint debtors was held to be a good consideration for an agreement to discharge the other debtor from liability. It might, indeed, prima facie, seem that the contract here disclosed was a mere nudum pactum, on the ground that the creditor would get nothing in return for his relinquishment of his claim against such last-mentioned party; but a little reflection will show that the substituted liability was in its nature different from that which originally subsisted, so that, inasmuch as the Court will not inquire into the adequacy of the consideration for a promise $(k)$, the agreement in question would be unimpeachable in a strictly legal point of view. It is, moreover, demonstrable, as remarked by Alderson, B., in the case before us, that the sole security of A. may be a better thing than the joint security of A. and B.; for by accepting the sole security of $A$., instead of the joint security of both debtors, the creditor possesses a legal remedy against A. during his lifetime, and against his assets after his death, and no security whatever against $B$. Whereas in the case of a joint security, after the death of A., there exists a lega] liability of B. and no legal liability of A.'s assets, but an equitable remedy against the assets of $A$., subject to the necessity of making B. a party to a suit in equity. Now, these two securities are different things, and therefore a bargain to take the one for the other is good. Cases may be suggested of $\mathrm{A}$. being rich and $\mathrm{B}$. poor, in which the advantage of taking $A$. as the debtor in lieu of $A$. and $B$. is clear; or it may be that A. is as rich as B., in which case the creditor may fairly consider that one debtor alone is preferable to both together $(l)$.

(i) 7 Exch. 669.

(k) Per Parle, B., 7 Exch. 671.

(l) 7 Exch. 674-5. 
But, although a Court of law will not inquire into the adequacy of the consideration for a promise, it will inquire 'so far as to satisfy itself that the consideration is of some value $(m)$, and not illusory merely $(n)$. Where, therefore, the consideration for the defendant's promise was stated to be the release and conveyance by the plaintiff of his interest in certain premises at the defendant's request, but the declaration did not show that the plaintiff had any interest in said premises, except a lien upon them, which was expressly reserved by him, the declaration was held bad as disclosing no legal consideration for the alleged promise (o).

Where A. being indebted to the plaintiff in a certain amount, and B. being indebted to $\mathrm{A}$. in another amount, the defendant in consideration of being permitted by $\mathrm{A}$. to sue B. in his name, promised to pay A.'s delbt to the plaintiff, and A. gave such permission; whereupon the defendant recovered from B.: judgment was arrested on the ground that the plaintiff was a mere stranger to the consideration for defendant's promise, having done nothing of trouble to himself or of benefit to the defendant $(p)$.

The ease last cited shows not only the nature of a sufficient legal consideration for a promise, but also the necessity of privity $(q)$ between the parties to an action founded upon promises, in order that it may be sustainable $(r)$. In Colb v. Becke $(s)$ this latter point receives apt illustration ; there B., the country solicitor of A., sent a sum of money to the defendants, who were B.'s London agents,

(m) Per Patteson, J., Thomas v. Thomas, cited ante, p. 312 ; Judgm., Haigh v. Brooks, 10 Ad. \& E. 320 ; Hall v. Conder, 2 C. B., N. S. 22 ; cited Smith v. Neale, Id. 89.

(n) White v. Bluett, 23 L. J. Ex. 36 ; Braceucll v. Williams, L. R. 2 C. P. 196.

(o) Kaye v. Dutton, 7 M. \& Gr. 807, cited Smart v. Sandars, 5 C. B. 904 ; Eduards v. Baugh, 11 M. \& W. 641; Strickland v. Tumer, 7 Exch. 208 ; Wright v. Colls, 8 C. B. 150 ;
Ashuorth v. Morensey, 9 Exch. 175; Fremlin v. Hamilton, 8 Exch. 308. See Hutehinson v. Rcad, 4 Exch. 761; Orme v. Galloway, 9 Exch. 544.

(p) Boume v. Mason, 1 Ventr. 6; Tweddle v. Atkinson, 1 B. \& S. 393, 397 ; Crow v. Rogers, I Stra. 592 ; Price v. Easton, 4 B. \& Ad. 433.

(q) Ante, p. 312.

(i) See Griffinhoofe v. Daubuz, 5 E. \& B. 746, 755; explained in Edmunds v. Wallingford, 14 Q. B. D. 811.

(s) 6 Q. B. 930. 
to be paid to C. on account of A., and the defendants promised $B$. to pay the money transmitted according to his B.'s directions; but afterwards, being applied to by C., refused to pay it, claiming a balance due to themselves from B. on a general account between them. Upon this state of facts it was held, that an action for money had and received would not lie against the defendants at suit of A. "The general rule," said Lord Denman, C. J., "undoubtedly is, that there is no privity between the agent in town and the client in the country: the former cannot maintain an action against the latter for his fees, nor the latter against the former for negligence. Something, therefore, is necessary, beyond the mere relation of the parties to each other as above stated, to make the agent in town liable to the client." The subject here touched upon is more fully explained in Robbins v. Fennell $(t)$, where it is laid down that the client cannot maintain an action for money had and received against the town agent of his solicitor, " unless the law will imply a contract to pay on request, from the relation which the several parties bear towards each other." Now the client employs a country solicitor, is answerable to him for costs, and in case of negligence or misconduct must come upon him for redress. He is entitled to credit for all sums which the solicitor may happen to owe him, and though he probably knows that the business must be carried on by a town agent, his payment for it to such agent is no discharge to him against the solicitor $(u)$. In like manner the solicitor employs and is liable to the town agent, who knows nothing of the client but his name, and is not even to that extent known by him. The town agent could not maintain an action for work and labour against the client by whom he was not employed; and the rights and liabilities of the parties in such a case rould be reciprocal $(x)$.

(t) 11 Q. B. $248,256$.

(u) Fates r. Freckleton, 2 Doug.

623.

(x) Judgm., 11 Q. B. 256. See 
A simple instance of the necessity of privity between parties in order to sustain an action founded upon contract is given by Parke, J., in Baron v. Husband (y), who says, "If I give a sum of money to my servant to pay a tradesman, the latter cannot maintain an action for money had and received against the servant." So, where A. contracts with B., acting as agent for C., the legal privity is between A. the contractor and C. the contractee: so that B. can in general neither sue nor be sued upon the $\operatorname{contract}(z)$.

Again, "Where a person has sold goods to A. B., or has been led to believe he has sold them to A. B., and delivered them as he supposes to A. B., and the person who had led him into that belief receives and carries off the goods and disposes of them to another, there has not been a selling to the person who fraudulently represents himself to be a servant or agent of the supposed purchaser A. B., and he cannot confer a good title on any one else, the property never having vested in him " $(a)$.

But; although " the remedy for breach of contract is by the general rule of our law confined to the contracting parties $(b)$, there are some cases in which the law will imply not merely the request but also the promise of the contractor $(c)$; and there are other cases in which an obligation to pay money is imposed, either by the law of the land, or

Helps v. Clayton, 17 C. B., N. S. 553; Wilkinson v. Grant, 18 C. B. 319 , where the solicitor of a proposed mortgagee was held not entitled to recover the amount of his charges from the proposed mortgagor-the negotiation for the mortgage having gone off through the default of the latter party. Now the town agent would most probably be ordered to pay the money to the client under the summary jurisdiction of the Court; Exp. Edwards, re Johnson, 7 Q. B. D. 155; 8 Q. B. D. 262. Ante, p. 213 .

(y) 4 B. \& Ad. 611,612 ; Williams v. Everett, 14 East, 582;13 R. R. 315 ; Lilly v. Hays, 5 Ad. \& E. 548 ; cited and distinguished in Noble $\mathbf{v}$.
National Discount Co., 5 H. \& N. 228, and in Liversidge v. Broadbent, 4 Id. 611.

(z) See further, as to want of privity, Litt v. Martindale, 18 C. B. 314; Watson v. Russell, 3 B. \& S. 34; Fisher v. Marsh, 6 B. \& S. 411; Mainprice v. Westley, Id. 420 ; Driver v. Burton, 17 Q. B. 989 ; Helps . Clayton, 17 C. B., N. S. 553.

(a) The above proposition is adopted per Cur. Lindsay v. Cundy, 2 Q. B. D. 96,100 ; S. C., affirmed 3 App. Cas. 459 ; following Hardman v. Booth, 1 H. \& C. 803 .

(b) Per Coleridge, J., Lumley v. Gye, 2 E. \& B. 246.

(c) Ante, p. 310 ; post, pp. 321,322 . 
by virtue of the bye-law of some corporate body-which bye-law within its limits, and with respect to the persons upon whom it lawfully operates, has the same effect as an Act of Parliament has upon the community at large (c). Further, an action will lie not merely where there is a contract express or implied between the parties, but wherever there is a legal right on the one side to receive the money sued for, and a legal liability on the other to pay it $(d)$. An action will also lie for recovery of a penalty under a statute $(e)$. But where a penalty is created by statute, and nothing is said as to who may recover it, and it is not created for the benefit of a party grieved, and the offence is not against an individual, it belongs to the Crown, and the Crown alone can maintain a suit for it $(f)$.

In Gerhard v. Bates ( $g$ ), the first count of the declaration alleged, that before the defendant's promise after mentioned, the defendant and others had formed a company, the capital of which was divided into a certain number of 1l. shares, out of which 12,000 were to be appropriated to the public at 12s. $6 d$. per share, free from further callsthat the defendant was a promoter and managing director of the company, and in offering the said 12,000 shares to the public, had, in such character, "guaranteed and promised to the bearers" of those shares a minimum annual dividend of 33 per cent., payable half-yearly, and that the said guarantee and promise should remain in force until the said 12s. $6 d$. per share should be thus repaid to the bearers of the 12,000 shares before mentioned. The declaration then averred, that the plaintiff, confiding in the defendant's said promise, became the purchaser and bearer

(c) Per Lord Abinger, C. B., Hopkins r. Mayor of Sicansea, 4 M. \& W. 640 ; 3 Bla. Com. 160.

(d) Addison r. Mayor of Preston, 12 C. B. 108, 133.

(e) 3 Bla. Com. 16 r.

(f) Bradlaugh r. Clarke, 8 App. Cas. 354 . (a) 2 E. \& B. 476; Peek r. Gurney, L. R. 6 H. L. 377 ; cited post, Bk. iii., Chap. 1 ; cf. also remarks upon Lord Camplell's judgment in Gerhard $\mathbf{r}$. Bates, of Lindley, L. J. (at p. 265), and of Boucn, L. J. (at p. 272), in Carlill r. Carbolic Smoke Ball Co., (1893) 1 Q. B. 256. 
of 2,500 of the 12,000 shares at $12 s .6 d$. per share, and took the same on the faith of the defendant's guarantee and promise, and not otherwise, and had fulfilled the engagement on his part, yet that the defendant had not paid any dividend. This count of the declaration was held to be bad on demurrer: 1st, because it did not sufficiently allege any promise to the plaintiff $(h)$; 2 ndly, because there appeared to be an entire absence of consideration, inasmuch as it was not stated, that, "from the plaintiff's buying and becoming bearer of " the shares mentioned, any benefit accrued to the defendant; or that, at the time when the contract was supposed to have been entered into, any prejudice accrued to the plaintiff; 3rdly, because there was nothing to show any request by the defendant to the plaintiff, and no privity was established between them. I have mentioned this case at some length, in order that the count above abstracted may be compared with the second count of the declaration hereafter noticed in connection with actions founded upon tort, and with the rule as to privity applicable in the latter class of cases.

With the facts and decision in Gerhard v. Bates, so far as above mentioned, may usefully be contrasted that peculiar class of cases there alluded to by Lord Campbell, in which it has been held, that an action may be maintained for a reward offered in a public advertisement, at suit of one who has fulfilled the conditions indicated therein (i). In such

(h) As to which, post, p. 321.

(i) See Williams v. Carwardine, 4 B. \& Ad. 621, which shows that the action can be maintained even when the plaintiff supplied the information from a different motive. Hawkins, J., in a note appended to his judgment in Carlill v. Carbolic Smoke Ball Co., (1892) 1 Q. B. at p. 489, says, referring to the case of Williams v. Carwardine: "I presume, however, that the offer had been brought to her knomledge before the information was given. Otherwise it is difficult to understand how it could be said that she was a party to a contract, or gave the information in fulfilment of the condition." In an American decision-Fitch v. Snedaker, (38 N. Y. 248)-it is laid down that one who did not know it had been offered cannot claim a reward. However, in Proctor v. Gibbons (64 L. T. 594), the plaintiff was held entitled to a reward, although he gave the information before the reward was offered, and consequently before he could have known of the offer. See also Tarner v. Walker, L. R. 1 Q. B. 
cases there might at first sight seem to be a want of privity ; there is, however, a distinct promise to any one who shall bring himself within the terms of the advertisement $(k)$; and there is a good consideration $(l)$ for the promise in the benefit to accrue to the promisor,-as in showing that he is heir-at-law to a person who died seised of real property and intestate; or prejudice to the promisee,-as, that he shall entitle himself to the reward by voluntarily coming forward as a witness. Those cases, nevertheless, remarked Lord Campbell, although not now to be questioned, are somewhat anomalous $(m)$.

The meaning of the term "consideration" and of "privity" being now apparent, it will be convenient to notice, that the consideration may be altogether past and executed at the time when the promise is made; it may be contemporaneous or concurrent with the promise (n), as, where two persons meet together and reciprocally promise to do certain specified things, the promise of the one party

641, and 2 Q. B. 301; Lockhart v. Bamard, 14 M. \& W. 674; Lancaster v. IValsh, 4 M. \& W. 16; Thateher. v. England, 3 C. B. 254; Bent v. Wakefield Bank, 4 C. P. D. 1; Mchune v. Joynson, 5 C. B., N. S. 218 ; Neville r. Kelly, 12 C. B., N. S. 740 ; Judgm., Hilliams v. Bymes, 1 Moo. P. C. C., X. S. 198.

(k) Cf., per Lindley, L. J., in Carlill v. Carbolic Smoke Ball Co., (1893) 1 Q. B. 256: “ * . . it is said that it is not made with any body in particular. Now that point is common to the words of this adrertisement, and to the words of all other advertisements offering rewards. They are offers to anybody who performs the conditions named in the advertisement, and anybody who does perform the condition accepts the offer" (at p. 262). Also, S. C., per Boucen, L. J.: "It is an offer made to all the world which is to ripen into a contract with anybody who comes forward and performs the conditions (at p. 268)."

(l) See Carlill v. Carbolic Smoke
Ball Co. (loc. cit.). The defendants had by advertisement offered a reward to anyone who, after using their smoke ball for a prescribed time and in a prescribed manner, should contract influenza. "It is quite obvious," (says Lindley, L.J., at p. 264) "that in the view of the adrertisers a use by the public of their remedy, if they can only get the public to have confidence enough to use it, will react and produce a sale which is directly beneficial to them. . . But there is another view. Does not the person who acts upon this advertisement and accepts the offer put himself to some inconvenience at the request of the defendants?" On this latter view, cf. also Boucen, L. J., at p. 271 .

(ii) See Spencer v. Harding, I. R. 5 C. P. 561 .

(ii) See West r. Jackson, 16 Q. B. 280; Tipper v. Bicknell, 3 Bing. N. C. 710; Thornton v. Jenyns, 1 M. \& Gr. 166; Harvey v. Johnston, 6 C. B., 295 
being the consideration for the promise of the other $(o)$. It may sometimes be correctly designated as "continuing," as in Pouley v. Walker $(p)$, where the subsisting relation of landlord and tenant was held to be a sufficient consideration for the tenant's promise to manage a farm in a husbandlike manner. Lastly, the consideration may be executory - as where A., in consideration that B. will do something specified at a future day, promises that he will himself do some other thing $(q)$. Now, in this case, difficulty may be felt in determining whether the promise made by one of these parties is, in truth, the consideration for that made by the other of them, or whether the performance of the one promise be the consideration for the other, in which latter case such performance will constitute a condition precedent to the right to sue. This difficulty can only be surmounted by looking narrowly at the words of the agreement entered into, and the intention of the contracting parties $(r)$.

3. The third ingredient which enters into the conception of a simple contract, complete in all its parts, is the promise The promise to do or not to do a particular thing made by the contractor to the contractee $(s)$. In every executory contract it is clear that there must be a promise-express or implied $(t)$ - by the former of these parties to the latter; for, if A. request B. to do something for him, and B. does it, the law will (if necessary) imply a promise by $A$. to remunerate $B$. for the trouble taken or inconvenience suffered on his behalf; though this implication may be rebutted by circumstances. So "where a relation exists between two parties, which

(o) See Christie v. Borelly, 7 C. B., N. S. $561,567$.

(p) 5 T. R. 373, 2 R. R. 619 ; recognised in Beale v. Sanders, 3 Bing. N.C. 850 . See also Massey r. Goodall, 17 Q. B. 310.

(q) See Hicks r. Gregory, 8 C. B. 378,387 ; Payne r. Wilson, 7 B. \& C. 423.

B.C.L. (r) See Thorpe v. Thorpe, 1 Ld. Raym. 662; Graves r. Legg, 9 Exch. $709 ;$ S. C., 11 Id. $6+2 ; 2$ H. \& N. 210 ; cited Pust v. Dowie, 5 B. \& S. 24,33 ; and in Bettini v. Gye, 1 Q. B. D. $183,186$.

(s) Ante, p. 303.

(t) Stranks v. St. John, L. R. 2 C. P. 376 . 
involves the performance of certain duties by one of them, and the payment of reward to him by the other, the law will imply, or the jury may infer; a promise by each party to do what is to be done by him " $(u)$.

In the case also of an executed consideration moved by a previous request $(x)$, express or implied, the law will, in general, in the absence of any express promise, imply a promise by the contractor $(y)$. There are, however, exceptions to this rule, the more important of which are as follows :-1. Under the particular circumstances specified at p. 310 , viz., where the plaintiff has voluntarily done that whereunto the defendant was legally compellable; for there, as already shown, an express promise by the defendant is necessary, in order that an action against him maybe sustain. able for breach of contract. 2. In the case of a barrister who cannot make a contract of hiring and service concerning advocacy in litigation $(z)$; or of a physician; who, although he may have acted at the request of the patient, will not, at common law (a), without proof of an actual contract, be entitled to sue him for services professionally rendered $(b)$; the presumption of law being here against the existence of a contract for remuneration (c). 3. In the case of infants, a class specially privileged and protected by statute (d). 4. In the case of a feme covert, who, in spite of recent

(u) Judgm., Morgan v. Ravey, $6 \mathrm{H}$. \& $\mathrm{N}$. 276 .

(x) The general rule, it will be remembered, is, that a past consideration will not support a subsequent promise, nnless moved by a previous request, ante, p. 304; Hayes r. Warren, 2 Stra. 933.

(y) See Nordenstrom v. Pitt, 13 M. \& W. 723 ; Streeter v. Horlock, 1 Bing. 34; Fish จ. Kelly, 17 C. B., N. S. 194.

(z) Kennedy v. Broun, 13 C. B., N. S. 677 ; Broun v. Kennedy, 33 L. J. Chanc. 71 ; Reg. r. Doutre, 9 App. Cas. 745 ; and this incapacity is reciprocal, Robertson v. Macdonogh, 6

\section{R. Ir. 433.}

(a) See Gibbon v. Budd, 2 H. \& C. 92; De la Rosa v. Prieto, 16 C. B., N.S. 578 : Leman r. Fleteher, L. R. 8 Q. B. 319; Lemau r. Houseley, L. R. 10 Q. B. 66.

(b) Chorley v. Bolcot, 4 T. R. 31i, 2 R. R. 395 ; Veitch . Russell, 3 Q. B. 928 . Now, howerer, by 22 \& 23 Vict. c. 90 , every physician may sue upon a contract implied in law, subject to the right of the College of Phrsicians to regulate this privilege by by-law.

(c) Per Colevidge, J., 3 Q. B. 937.

(d) $37 \& 38$ Vict. c. 62 , post, Chap. 7 . See, however. $5 \in \mathbb{s} 57$ Vict. c. 71, s. 2, post, p. 403 . 
legislation, is still in some measure protected. 5. In certain eases where the legal remedy is barred, although the right remains $(e)$.

Where the consideration, although past and executed, will support an action by reason of there having been an antecedent request, express or implied, it is a general and important rule, that the consideration " will support no other promise than such as would be implied by law" $(f)$.

Thus, where an account has been stated between parties, and a balance ascertained to be due from one of them to the other, the law implies a promise by the debtor, to pay on request, so that any ex post facto promise by him differing in its nature therefrom, ex. gr., to pay on a particular day named, would be nudum pactum, unless made upon a new consideration. If this were not so, there would, in truth, be "two co-existing promises on one consideration" $(g)$ a state of things manifestly incongruous and nonsensical.

Roscorla v. Thomas $(h)$ is usually cited with reference to the extent and nature of the promise which may be supported by an executed consideration : there the declaration stated, that, in consideration that plaintiff, at the request of defendant, had bought of defendant a horse at a certain price, defendant promised that the horse was sound and free from vice, \&c., whereas he was not free from vice; after verdict for the plaintiff it was objected, in arrest of judgment, that the precedent executed consideration was insufficient to support the subsequent alleged promise; and this objection was held fatal by the Court of Queen's Bench, for the promise must, as a general rule, be co-extensive with the consideration; but, "in the present case the

(e) Post, pp. 314, 315.

(f) "According to the current of recent authorities, beginning with Hopkins v. Logan, infra, and ending with Roscorla v. Thomas, infra, where the consideration is past and executed, it will support only such a promise as the law will imply from that executed consideration:" Judgm., 6 C. B. 174, and cases cited post.

(g) Hopkins v. Logan, 5 M. \& W. $241,249$.

(h) 3 Q. B. 234 ; Kaye v. Dutton, 7 M. \& Gr. 807 ; Atkinson v. Stephens, 7 Exch. 572. 
only promise that would result from the consideration as stated, and be co-extensive with it, would be to deliver the horse upon request;" and " the consideration stated would not raise an implied promise by the defendant that the horse was sound or free from vice." Lord Denman, C. J., after making the remarks above cited, proceeds to consider whether the consideration specified would support an express promise, and concludes from the cases that it rould not; because, "a consideration past and executed will support no other promise than such as would be implied by law" (i).

But, although it is generally true, as above stated, that a consideration past and executed will support only such a promise as the law will imply therefrom, that strict rule has, in certain cases, been departed from, and the Courts have held, that, where the consideration for a promise ras originally beneficial to the party promising, yet, if he be protected from liability by some provision of the statute or common law meant for his advantage, he may renounce the benefit of that law; and, if he promises to pay the debt, which is only what an honest man ought to do, he is then bound by the law to pay it $(k)$.

As exemplifying the qualification just stated of the general rule, let us take the case of a debt barred by the Statute of Limitations. A debt so barred, says Parke, B. $(l)$, is unquestionably a sufficient consideration for every promise, absolute or unqualified, qualified or conditional to pay it. Promises to pay a debt simply or by instalments, or when the party is able, are all equally supported by the past consideration, and when the debt has become payable instanter, may be given in evidence to support an action for

(i) See also Emmens r. Elderton, 4 H. L. Ca. 624 ; per $W_{\text {ilde, B., Scotson }}$ v. Pegg, 6 H. \& X. 301.

(k) Judgm., Eavle v. Olicer, 2 Exch. 90. citing note to Wensall r. Adney, 3 B. \& P. 252, 6 R. R. 780, Preface r.
(I) See Recves v. Hearne, 1 M. \& W. 323 ; Chasenore r. Turner, L. R. 10 Q. B. 500. Such promise, howerer, must be in writing, and signed by the promisor or his agent, 9 Geo. IV. c. 14 , s. $1 ; 19 \& 20$ Vict. c. 9 i, s. 13 . 
its recovery $(m)$. So, when the debt is not already barred by the statute, a promise to pay the creditor will revive it, and make it a new debt, and a promise to an executor to pay a debt due to his testator creates a new debt to him. But although an express promise revives the debt in any of the cases just mentioned, it must not thence be inferred that the debt will be a sufficient consideration to support a promise to do a collateral thing-as to supply goods, or to perform work and labour $(n)$. In such case, the promise would be but an accord unexecuted, and no action would lie for not executing it $(o)$.

One class of cases, viz., where there has been a moral consideration, for a subsequent express promise, must here be specially noticed, because it was at one time thought that the obligation thus created might sustain and render binding a subsequent express promise ; but this doctrine was shaken by Littlefield v. Shee $(p)$; and has been definitely exploded in Eastrood v. Kenyon ( $q$ ) and Beaumont v. Reere ( $r)$, where Lord Denman states the result of the cases to be, that "an express promise cannot be supported by a consideration from which the law could not imply a promise," save only in certain cases which he specifies.

The doctrine now accordingly established upon the point in question may be supported by reasoning such as Dr. Story urges in his Treatise on Bailments $(s)$ : "There are," says that eminent jurist, " many rights and duties of moral obligation which the common law does not even attempt to

(mi) In Smith v. Thorne, 18 Q. B. 139, Parke, B., obserres, "The acknowledgment must be consistent with an intention to pay, either on request, or else (which practically comes to the same thing) at the end of a particular period which has elapsed, or on some condition which has been fulfilled." Et ride per Wigram, V.-C., Philips v. Philips, 3 Hare, 281, 299; per Willians, J., Buekmaster v. Russell, 10 C. B., X. S. 749,750 , per Martin,
B., Cockrill v. Sparkes, 1 H. \& C 700 . 323.

(n) See Reeves v. Hearne, I M. \& W.

(o) Judgm., 2 Exch. 90.

(p) 2 B. E Ad. 811 ; ante, p. 309.

(q) 11 Ad. \& E. 438.

(r) 8 Q. B. 483: recognised in Fisher v. Bridges, 3 E. \& B. 642, reversing judgm., in $S . C ., 2 \mathrm{E} . \& \mathrm{~B}$. 118.

(s) 8th ed., p. 153. 
enforce. It deems them of imperfect obligation, and therefore leaves them to the conscience of the individual. And, in a practical sense there is wisdom in this course; for judicial tribunals would otherwise be overwhelmed with litigation, or would become scenes of the sharpest conflict upon questions of casuistry and conscience" $(t)$.

From what has been just said, it follows that the mere moral obligation on a father to maintain his child affords no inference of a legal promise to pay his debts; so that "if a father turns his son upon the world, the son's only resource, in the absence of anything to show a contract on the father's part, is to apply to the parish, and then the proper steps will be taken to enforce the performance of the parent's legal duty" (u). If, indeed, a father does any specific act, from which it may reasonably be inferred that he has authorised his son to contract a debt, he may be liable in respect of the debt so contracted $(x)$. But the law does not authorise a son to bind his father by his contracts $(y)$. Nor is there any legal obligation on the personal representative of the mother of a bastard child to expend the assets of the deceased in the maintenance of the child $(z)$.

Although when strictly and technically examined, a simple contract may be analysed as in the preceding pages, and, if thus analysed, will be found to consist of a request, a consideration, and a promise; yet so minute and critical an inquiry into its elements is often not needed, prelimi-

(t) Courts of law therefore " decide according to the legal obligations of parties:" per Alderson, B., Turner r. IIason, 14 II. \& W. 117.

(u) Per Jerris, C. J., Shelton r. Springett, 11 C. B. 45.5. Per Lord Abinger, C. B., Mortimore r. Wright, 6 M. \& W. 482 . A promise to the plaintiff (an unmarried woman), that, if she will abstain from affliating a child, the defendant will pay for its maintenance, is founded on good legal consideration; Linncgar r. Hodd, 5 C. B. 437 ; Jennings $v$ Broutn, 9 II. \& W. 496. See Crorchurst r. Laverack, 8 Exch. 20s; with which compare Simith r. Roehe, 6 C. B., N. S. 223: Cooper r. Parker, 14 C. B. 118.

(x) Per Lord Alinger, C. B., Mortimore r. Wright, supra.

(y) Per Mante, J., 11 C. B. 456.

(z) Ruttinger r. Temple, 4 B. S. S. 491 . 
nary to adjudicating in an action founded upon it. The truth of this remark will sufficiently appear from what has been already said relative to implied contracts, promises or requests (a). And we should also remember that frequently no question at all is raised as to the fact of some contract having been entered into between the parties, the sole issue at the trial having reference to the precise terms and nature of such contract. It sometimes happens, also, that a consideration, which at first sight appears to have been past at the time of the alleged promise, and therefore insufficient to support it, is found on examination to have been in truth concurrent, and consequently unexceptionable (b).

Notwithstanding, however, the simplification which has now been introduced into the system of pleading, a lawyer must still be conversant with the ingredients in a simple contract and able to appreciate the significance of each of them.

Having in the previous pages characterised and classified according to their rank the various kinds of contractshaving successively adverted to contracts of record-to special and to simple contracts, I propose to consider Some rules
of general application relating to contractsspecial or briefly some few rules of general and extensive application, which influence our Courts in adjudicating upon them, and which may with truth be said to have a direct and important bearing upon even the most ordinary dealings between man and man.

Now, with reference to contracts, of whatsoever kind they be, a primary rule is, that good faith must be observed Effect of fraud on between the contracting parties-ex dolo malo non oritur

(a) Ante, pp. 246, 303, 322.

(b) Steele v. Hoe, 14 Q. B. 431, 445. See Payne v. Wilson, 7 B. \& C. 423 ; cited 2 H. \& N. 524 ; Goldshede v. Swan, 1 Exch. 154; Oldershaw v.
King, 2 H. \& Г. 517, 399 ; cited per Bramuell, B., Hoad v. Grace, $7 \mathrm{H}$. $\mathrm{d}$ N. 497, and in Westhead v. Sproson, 6 H. \& N. 732. 
actio (c).-_"No contract," says Patteson, J. (d), " can arise out of a fraud (i.e., unless the party upon whom such fraud was practised chooses to accept and ratify the contract $(e)$ ), and an action brought upon a supposed contract which is shown to have arisen from fraud may be resisted." It might, indeed, be impossible to give a definition of what constitutes fraud, so as to meet all the various combinations of circumstances to which that word would apply; but there can be no difficulty in saying, that "whenever any one has by wilful misrepresentation induced another to part with his rights on the belief that such representation was true," this is, in the plainest and most obvious sense, a fraud which a Court of law will not tolerate $(f)$.

And " the relations of principal and agent $(g)$, trustee and cestui que trust, parent and child, guardian and ward, priest and penitent, all furnish instances in which the Courts of Equity have given protection and relief against the pressure

(c) See the remarks upon this maxim in Leg. Mar., 6th ed., 684 et seq.

(d) Campbell r. Fleming, 1 Ad. \& E. 42 ; Jones r. Fates, 9 B. \& C. 532, 539.

(e) See White r. Garden, 10 C. B. 919, 927 (where Talfourd, J., says, "A contract for the sale of goods, though obtained by fraud, is perfectly good, if the party defrauded thinks fit to ratify it"). Kingsford $r$. Merry, 1 H. S N. 503. See Johnson r. Crédit Lyornats Co., 3 C. P. D. 40.

In Stevenson v. Neumham, 13 C. B. 285,303 , the Court observed, "It must be considered as established, that fraud only gives a right to aroid a contract or purchase." And see Young v. Billiter, 8 H. L. Ca. 682 ; per Parke, B., Murray r. Mann, 2 Exch. 541.

In The Deposit and General Life Ins. Co. v. Ayscough, 6 E. \& B. 761, Lord Campbell, C. J., says, "It is now well settled that a contract tainted by fraud is not void, but is only roidable at the election of the party defrauded." Et vide per Pollock, C. B., Rogers r. Hadley, 2 H. \& C. 247.

In Haues v. Harness, L. R. 10 C. P. 166, Brett, J., observes, "The true legal doctrine is that fraud merely renders the contract roidable, that is to say, gives an option to the party defrauded to disaffirm the contract, but until he disaffirms it remains good." See Clough r. London \&. N. IV. R. C., L. R. 7 Ex. 26, 33, 34.

As to rescinding a contract on the ground of fraud, see Clarke r. Dickson, E. B. \& E. 148 ; cited Reg. r. Sa.tdler's' Co., 10 H. L. Ca. 421; Edgington r. Fitzmanrice, 29 Ch. D. 459, 482; Sheffield Nickel Co. r. Unwin, 2 Q. B. D. 214, 223 ; Cole v. Bishop, E. B. E E. 150, n. (1). Lindsay Petroleum Co. v. Hurd, L. R. 5 P. C. C. 221.

(f) Per Lord Cranworth, Reynell $\mathbf{}$. Sprye, 1 De G., M. \& G. 691. See Curson r. Belucorthy, 3 H. L. Ca. i42 ; Jackson r. Turquaud, L. R. 4 II. L. 305,315 ; Overend \& Gurney Co. v. $G i b b$, L. R. 5 H. L. 480 ; Beglie r. Phosphate Sewage Co., L. R. 10 Q. B. 491 ; 1 Q. B. U. 679.

(g) See per Lord Cairns, C., MIc Pherson v. Watt, 3 App. Cas. 254, 263-4, citing Lewis v. Hillman, 3 H. L. Cas. $\cdot 607,630$. 
of unfair advantage resulting from the relation and mutual position of the parties, whether in matters of contract or gift $(h)$.

The terms thus used in reference to fraud, whether at law or in equity, being necessarily very general, may, it is conceived, be so understood as to include any case involving it which can readily be suggested-whether the contract in question be executed or executory-special or simple (i).

On the ground of fraud, artifice, or deceit, as we have already seen $(k)$, the judgment of a Court of law may be set aside $(l)$, and a deed although duly executed may be successfully impugned; $\grave{a}$ fortiori, then may fraud be alleged to nullify a contract not under seal, or with a view to compelling the restitution of property transferred or money paid in pursuance of it $(m)$.

"Contracts," however, "which may be impeached on the ground of fraud are not void, but voidable only at the option of the party who is or may be injured by the fraud; subject to the condition that the other party, if the contract be disaffirmed, can be remitted to his former state" $(n)$; and that no innocent third party has in the mean time acquired rights under it (o). The rule also seems recognised that "Where one of two innocent parties must suffer" from the fraud of a third, the loss should fall on the one who enabled the third pal $y$ to commit the fraud" $(p)$.

(h) Per Lord Penzance, Erlanger v. New Sombrero Phosphate Co., 3 App. Cas. 1230. See De Cordova v. Dc Cordova, 4 App. Cas. 692.

(i) As to evidence of fraud, see Horsfall v. Thomas, 1 H. \& C. 90 .

(k) Ante, pp. 261, 276, et seq.

(l) See Bowen v. Evans, 2 H. L. Ca. 257.

(m) See the cases cited in notes, supra; Oakes v. Turquand, L. R. 2 H. L. 325 ; followed in Stone $\mathrm{r}$. London and County Bank, 3 C. P. D.
282, and in Cree v. Somertail, 4 App. Cas. 648; Reese River Silver Mining Co. v. Smith, L. R. 4 H. L. 61 ; followed in Redgrave v. Hurd, $20 \mathrm{Ch}$. D. 13 ; Newbigging v. Adam, $34 \mathrm{Ch}$. D. 582, affirmed 13 App. Cas. 308 ; Hughes v. Tuisden, 55 L. J. Ch. 481.

(n) Judgm., Urquhart v. Macpherson, 3 App. Cas. 837-8; approring Clarke v. Dickson, E. B. \& E. 148.

(o) Babcock r. Lauson, 4 Q. B. D. 394 .

(p) Judgm., Babcock v. Latson, 4 
A few cases shall presently be cited in illustration of the statement that fraud will vitiate and aroid a simple contract. It should first, however, be remarked that it was formerly held that there was a distinction between moral and legal fraud, but this opinion has been conclusively condemned by Bramicll, L. J. $(q)$. 'The supposed distinction arose from two mistaken theories as to the nature of fra ud-1, that a false statement made in good faith might amount to a fraud in law; 2, that concealment, without more, was fraudulent in legal contemplation. The law, however, now seems clear that a representation, to be fraudulent, must have been made either with knowledge of its falsehood $(r)$, or with such reckless disregard as to its truth, that the speaker must be held as responsible as if he had asserted what he knew to be untrue $(s)$; and further, that "mere non-disclosure of material facts, however morally censurable, would form no ground for an action for deceit or misrepresentation. There must be some active mis-statement of fact, or at all events such a partial and fragmentary statement of fact, as that the withholding of that which is not stated makes that which is stated absolutely false" $(t)$.

Thus it has been held $(u)$ that the sale of a glandered horse by a person knowing it to be so, gives no right of action to a buyer ignorant of the defect, and in consequence of it, sustainirg damage. " Here," remarked Bramuell, B., "the buyer knows of the possible existence of the defect, or he does not. On the former assumption he has

Q. B. D. 400-401; cf. per Ashhurst, J., Lickbarrow צ. Mason, 2 T. R. 70; $1 \mathrm{Sm}$. I. C., 9th ed., $74 \bar{i}$.

(q) Weir r. Bell, 3 Ex. D. 243; commenting on Bartick v. English Joint Stock Bank, L. R. 2 Ex. 259; Joliffe v. Baker, il Q. B. D. 25j; As to "legal fraud," cf. Derry r. Peak, 14 App. Cas. 346 (per Lord Brameell).

(r) Dickson v. Reuter's Telegraph
Co., 3 C. P. D. 1 ; Derry r. Peali, 14 App. Cas. $33 \pi$.

(s) Reese River Mrining Co. r. Smith, I. R. 4 H. L. 79 .

(t) Per Lord Caims, Peek r. Gumey, L. R. 6 H. L. 403.

(ii) Hill v. Balls, 2 H. \& N. 299, 305, 306 ; with which compare Cooke v. Waring, 2 H. \& C. 332 ; Smith r. Green, 1 C. P. D. 92 ; Wardv. Hobbs, 4 App. Cas. 13. 
no right of complaint if he chose to purchase without a warranty : on the latter assumption, he ought not to be any better off for his ignorance." The rule caveat emptor is in truth applicable under the circumstances supposed. It has been held, too, that the vendor of a chattel, in which there is a patent defect which greatly diminishes its value, will not incur liability by silence with regard to it $(x)$; and if $A$. treats with B., for the purchase of an estate, knowing that there is a valuable mine under it, and B. makes no inquiry, there is authority to show that A. is not bound either at law or in equity to give information as to the existence of the mine $(y)$. The mere passive acquiescence of the seller of a chattel in the self-deception of the buyer will not entitle the latter to avoid the contract $(z)$. Now in any of the cases here suggested, although the moralist might possibly condemn, our law would decline to give redress. Non omne quod licet honestum est (a).

There are, however, certain kinds of contracts, sometimes called contracts uberrime fidei, which will be affected by Contracts uberrinæ misrepresentation or non-disclosure, which would not invalidate an ordinary contract. 1. Contracts of marine and fire insurance $(b)$, which are contracts of indemnity $(c)$;

(x) Leg. Max., 6th ed., 736. The maxim, "Silence gires consent," does in some cases apply; for instance, "where there is a duty to speak, and the party does not, an assent may be inferred from his silence:" per Bramicell, B., Russell v. Thornton, 4 H. \& N. 798. See as regards the effect of concealing a material fact from the sureties to a guarantee, Lee v. Jones, 17 C. B., N. S. 482 ; from the person to whom the guarantee is given, $B a r$ wick v. English Joint Stock Bank, L. R. 2 Ex. 259; cited in Suift r. Jeusbury, L. R. 9 Q. B. 301, 312; Phillips v. Foxall, L. R. 7 Q. B. 666 ; Burgess v. Eve, L. R. 13 Eq. Cas. 457 . (y) Per Lord Eldon, Tumer v. Harvey, Jac. 178, 23 R. R. 15; per Cockburn, C. J., L. R. 6 Q. B. 604 .

(z) See per Lord O'Hagan, Ward v. Hobbs, 4 App. Cas. 26; Smith v.
Hнghes, L. R. 6 Q. B. 597.

(a) D. 50, 17, 144 .

(b) Lonides r. Pender, L. R. 9 Q. B. 537; Rivaz v. Gerussi, 6 Q. B. D. 222; Mercantilc Steamship Co. v. Tyser, 7 Q. B. D. 73 ; New Iork Bowery, \&c., Co. v. New Tork Fire, \&c., Co., 17 Wend. 359; Bates v. Hewit, L. R. 2 Q. B. 595 ; Proudfoot $\mathrm{v}$. Montefiore, L. R. 2 Q. B. 511 ; Stribley r. Imperial Marine Ins. Co., 1 Q. B. D. 507; Tate r. Hyslop, 15 Q. B. D. 379 ; Blackbu'n r. T'igor's, 12 App. Cas. 531, reversing $S_{.} C_{.}, 17$ Q. B. D. 553. With this last case, cf. Blackbunn r. Haslam, 21 Q. B. D. 144 , in which the person possessing knowledge materially affecting the risk, and which was not disclosed to the defendant, did effect the insurance.

(c) Darrell r. Tibbitts, 5 Q. B. D. 560 ; Midland Insurance Co. r. Smith 
a contract of life assurance differs, however, in both these respects, being neither a contract of indemnity $(d)$, nor liable to be affected by mere misrepresentation or non-disclosure apart from fraud (e). 2. A misdescription as to the thing sold, or the terms to which it is subject, will in the case of a sale of lands avoid the contract even in the absence of fraud $(f)$. 3. In contracts for the sale of shares by companies, the vendors are bound to state everything with strict and scrupulous accuracy, and not only to abstain from stating as a fact that which is not so, but to omit no one fact within their knowledge, the existence of which might in any degree affect the nature, extent or quality of the privileges and advantages, which the prospectus holds out as inducements to talie shares $(g)$.

The question how far fraud may exist in legal contemplation, apart from any fraudulent intent, has led to some conflict of opinion. As, for instance, where a person purported to accept a bill of exchange by procuration, when he knew that he had no such authority, but honestly believed that his acceptance would be sanctioned. The element of fraud here lies, not in the motive or intention, which, though innocent, was immaterial, but in the statement of a fact, false to the linowledge of the person making it $(h)$.

There has been considerable conflict of judicial decision

6 Q. B. D. 561 ; Castellain v. Preston, 11 Q. B. D. 380 ; Mar. Ins. Co. r. China, ge., Co., 11 Apl. Cas. 573.

(d) Jalby r. India \& London Life Ins. Co., 15 C. B. 365 , overruling Godsall r. Boldern, 9 East, 72.

(c) Wheelton r. IIardisty, 8 E. \& B. 232. As to when a contract of life insurance is complete, see Canning $\mathrm{v}$. Farquha), 16 Q. B. D. 727.

(f) Flight v. Booth, 1 Bing. N. C. 370 ; Jones 5 . Edney, 3 Camp. 28; as to the rule where the quantity has been erroneously stated by the rendor without fraud, see Joliffe v. Bakcr, 11 Q. B. D. 255 ; Palmer v. Johnson, 12 Q. B. D. 32 ; Id. 351 . As to "mere commendatory expressions," see Dimmock r. Ilallett, L. R. 2 Ch. 27; Smith v. Land and House Prop. Co., 28 Ch. D. $\%$.

(g) Per Hindersley, V.-C., New Brunswick and Canada R. C. v. Muggeridge, 1 Dr. \& Sm. 381; Tenezuela. R. C. v. Kisch, L. R. 2 II. L. 113 ; I'cek v. Gurney, L. R. 6 H. I. 403; Bellairs r. Tuclier, 13 Q. B. D. 562, 577. As to an action for deceit founded on statemeuts in a prospectus, cf. infra.

(h) Polkill r. Halter, 3 B. \& Ad. 114. See Thom v. Bigland, 8 Exch. 725, 729; Eiastucood r. Bain, 3 H. \& ‥ 738 . 
as to how far an innocent principal can be rendered liable for the fraud of his agent. A principal, it has been urged, may be responsible for the fraud of his agent, although quite innocent in a moral point of view. "Whether," remarks Lord Lyndhurst, in Attuood v. Small (i), "a particular representation be made by the principal, or by the agent whom he employs for the purpose of the contract, is wholly immaterial. If the agent acts fraudulently, even without the knowledge of the principal, what is that to the party contracting? The contract is vitiated." And again, according to the opinion of Lord Abinger, C. B., diss., in Cornfoot v. Fowke ( $k$ ), (a remarkable case, which seems however to have been well decided $(l)$,) " it is not correct to suppose that the legal definition of fraud and covin necessarily includes any degree of moral turpitude."

The weight of authority, however, viewed independently of the cases of Cornfoot v. Fowke and Udell v. Atherton, presently noticed, is against the views propounded by the eminent individual last named. "It is settled law," says Parke, B., in Thom v. Bigland ( $m$ ), "that independently of duty, no action will lie for a misrepresentation, unless the party making it knows it to be untrue, and makes it with a fraudulent intention to induce another to act on the faith of it, and to alter his position to his damage. This

(i) 6 Cl. \& F. 413. And see, per Lord Campbell, 1 H. L. Cas. 615. His Lordship there says, "In an action upon contract, the representation of an agent is the representation of the principal; but in an action * * for deceit the misrepresentation or concealment must be proved against the principal." See also Swift v. Jewsbury, L. R. 9 Q. B. 301,560 ; per Pollock, C. B., Atkinson v. Pocock, 1 Exch. 796, cited arg. 6 C. B. 322. Per Rolfe, B., 6 M. \& W. 370 ; Blake 7. Albion Life Ass. Co., 4 C. P. D. 94 ; see post, p. 623 .

(k) 6 M. \& W. 358 ; cited 8 E. \& B. 252 ; and in Moens v. Heyworth, 10 M. \& W. 155. (l) This case turned on a point of pleading, per Willes, J., Barwick v. English Joint Stock Bank, I. R. 2 Ex. 262 ; and it seems that had the defence been based upon misrepresentation, and not upon fraud, the defendant would have succeeded: per Lord $S t$. Leonards, National Exchange Co., \&c. จ. Drew, 2 Macq. H. L. Sc. 103.

Mr. J. Fry (Specif. Perf., end ed., p. 306) observes that the question, how far the fraud of the agent operates at law upon the efficacy of a contract, is of considerable difficulty. But it seems to be clear on general principles that it furnishes a sufficient defence to a suit for specific performance in equity.

(m) 8 Exch. 731 . 
appears from the cases of Collins v. Erans $(n)$ and Ormrod v. Huth $(0)$, which have perfectly settled the law on that point:"

In Wilde v. Gibson ( $p$ ), it was contended, that an action of deceit might be maintained, without proof of actual fraud ; but Lord Campbell answered, "From that position I entirely dissent. If you mean by 'fraud' an intention to injure the party to whom the representation is made, or to benefit the party who makes the representation, there may be an action of deceit without fraud; but there must be falsehood; there must be an assertion of that which the party making it knows to be untrue; the scienter must either be expressly alleged, or there must be an allegation that is tantamount to the scienter of the fraudulent representation, and this allegation must be proved at the trial " $(q)$; and his Lordship adds, "If that falsehood is stated without any view of benefiting the person who states the falsehood, or of injuring the person to whom the falsehood is stated, in one sense of the word you may say it is not fraudulent, but it is a breach of moral obligation, it is telling a lie; and if a lie is told, whereby a third person is prejudiced, although there may be no profit to the person who tells it, and although no injury was intended to the party to whom it is told, but a benefit to a third person, it is clearly a breach of moral obligation, and is a fraud which will support an action of deceit." The proposition here printed in italics seems to be altogether unimpeachable, and indicates the nature of the fallacy into which those have fallen who contend that legal fraud may exist without any admixture whatever of " moral turpitude."

Additional authorities might readily be cited in support of the view here adrocated. In Taylor v. Ashton (r),

(n) 5 Q. B. 820 .

(o) 14 M. \& W. 651 .

(p) 1 H. L. Ca. 605, 633.

(q) Citing Foster r. Charles, 7 Bing.
106 ; Polhill r. Walter, 3 B. \& Ad.

123 ; Corbett r. Broucn, 8 Bing. 37.

(r) 11 M. \& W. 401 . 
Parke, B., distinctly states his adhesion to the doctrine, that "an action for deceit will not lie, without proof of moral fraud;" and he further observes, that "there may undoubtedly be a fraudulent representation, if made dishonestly, of that which the party does not know to be untrue, if he does not know it to be true." Further, in delivering their judgment in the case just cited, the Court of Exchequer lay down, that in an action for false representation, and damage resulting therefrom, it is not necessary to show that the defendant knew the fact affirmed by him to be untrue; if he stated a fact which was untrue for a fraudulent purpose, he at the same time not believing that fact to be true, there would, under such circumstances, be both a legal and a moral fraud (s).

In connection with the subject just discussed, it is worthy of notice that a very learned judge has thus expressed himself: "I conceive, that if a man, having no knowledge whatever on the subject, takes upon himself to represent a certain state of facts to exist, he does so at his peril; and if it be done, either with a view to secure some benefit to himself or to deceive a third person, he is in law guilty of a fraud, for he takes upon himself to warrant his own belief of the truth of that which he so asserts. Although the person making the representation may have no knowledge of its falsehood, the representation may still have been fraudulently made" $(t)$. Further, it has been observed, that, "if persons take upon themselves to make assertions as to which they are ignorant whether they are true or untrue, they must, in a civil point of view, be held as responsible as if they had asserted that which they knew to be untrue" $(u)$. And, again, we read as follows: "It is well

(s) Judgm., 11 M. \& W. 415.

( $t)$ Per Maule, J., Evans r. Edmonds, 13 C. B. 786 ; and in Milne v. Marwood, 15 Id. 781. See per Cressuell, J., and Wilde, C. J., 6 C. B. 322 ; per Alderson, B., Moens v. Hey- worth, 10 M. \& W. 158. See Ward v. Hobbs, 4 App. Cas. 13.

(u) Per Lord Caims, Reese River Silver Mining Co. v. S'mith, L. R. 4 H. L. 79-80. See Edgington v. Fitzmaurice, 29 Ch. D. 459 , 482 . 
established that in an action of deceit a defendant may be liable not only if he has made statements which he knows to be false, but if he has made statements which in fact are untrue, recklessly; that is, without any reasonable grounds for believing them to be true, or under circumstances which show that he was careless whether they were in fact true or false" $(x)$. In the case here supposed is discernible negligence alin to fraud.

In Derry v. Peak (y), which was an action for deceit, the House of Lords decided that such an action will not lie in respect of a statement in a prospectus, if the statement was made with an honest belief in its truth (z). Lord Herschell says: "I think the authorities establish the following propositions. First, in order to sustain an action of deceit, there must be proof of fraud, and nothing short of that will suffice. Secondly, fraud is proved when it is shown that a false representation has been made (1) knowingly,

(x) Per Cotton, L. J., Weiv v. Bell, 3 Ex. D. 242. This dictum is correct only if by "without any reasonable grounds for believing them to be true" is understood "under such circumstances as show that he was careless whether they were in fact true or false:" cf. per Lord Bramwell, Derry v. Peak, 14 App. Cas. at p. 350 . Unless a person knows he is making a statement without reasonable grounds, the mere fact that he has made a statement without reasonable grounds is not couclusive evidence of fraud (per Lord Bramwell, at p. 351). See also per Lord Herschell (at p. 361).

(y) 14 App. Cas. 337. In Lord Herschell's judgment the authorities are reviewed. Upon this case and what it decided, cf. Bowen, L. J., in Low r. Bouverie, (1891) I Ch. at p. 105. Derry v. Peak decided that the action for deceit will lie only in respect of a fraudulent misrepresentation, and, further, that there is no duty enforceable at law to be careful in the representation that is made in the case of statements in a prospectus. The case does not apply where a legal obligation exists to supply correct information (cf. Lindley, L. J., Low v. Bonverie, loc. cit. at p. 100). As to such obligation, cf. Low r. Bouverie, loc. cit. ; Le Lievre r. Gould, (1893) 1 Q. B. 491 (C. A.) (overruling Can v. Wilson, $39 \mathrm{Ch}$. D. 39). As to statements made in a prospectus, see Glaiser พ. Rolls, 42 Ch. D. 436; Angus r. Clifford, (1891) 2 Ch. D. 449 ; with which compare $\boldsymbol{K}_{n}$ nox $\mathrm{r}$. Hayman, 8 T. L. R. 654 ; also 53 \& 54 Vict. c. 64 ('The Directors' Liability Act, 1890).

(z) An action for deceit and the necessary elements which must be proved in order to maintain it success. fully must be carefully distinguished from an action where rescission of contract is claimed on the ground of misrepresentation. "Where rescission is claimed it is only necessary to prove that there was misrepresentation" (per Lord Herschell, Derry v. Peak, loc. cit. at p. 359), and cf. Tomkinson v. Balkis Consolidated Co., (1891) 2 Q. B., per Lord Esher, M. R., at pp. 620 and 621 . 
or (2) without belief in its truth; or (3) recklessly, careless whether it be true or false . . . To prevent a false statement being fraudulent, there must, I think, always be an honest belief in its truth." Unreasonableness of belief is not a ground of action but is evidence of dishonesty $(a)$.

As connected with the subject before us, the two following cases must be noticed :-

In Cornfoot v. Fouke (b) a principal was held irresponsible for a mis-statement innocently made by his agent without authority from himself. The principal there sued for breach of contract, and on fraud being pleaded, obtained judgment, it being, as observed by Alderson, B., “impossible to sustain a charge of fraud when neither principal nor agent has committed any; the principal, because, though he knew the fact, he was not cognisant of the misrepresentation being made, nor ever directed the arent to make it; and the agent, because though he made a misrepresentation, yet he did not know it to be one at the time he made it, but gave his answer bon $\hat{\imath}$ fide."

In Udell v. Atherton (c) the action was ex delicto, founded on dolus dans locum contractui, producing damage, to which the defence, under a plea of Not Guilty, was that the fraud was that of the agent who made the contract, not of the defendant, the principal, who neither authorised nor knew of it $(d)$, and without impugning the well-established rule that "the principal is answerable for the act of an agent in the course of his business," the Court were equally divided in opinion as to the mode of applying that principle to the facts before them $(e)$.

Without further reference to the distinctions-sometimes

(a) Cf. per Lord Bramwell, S. C., at p. 353 .

(b) 5 M. \& W. 358. A principal who purposely employs an ignorant agent will be liable: Ludgater v. Loue, 44 L. T. 694.

(c) 7 H. \& N. 172.

B.C.L. (d) Post, Book III., Chap. I.

(e) Judgm.. Baricick v. English Joint Stock Bank, L. R. 2 Ex. 265 ; Weir r. Barnett, 3 Ex. D. 32; Weir v. Bell, Id. 238 ; Blake v. Albion Life Ass. Co., 4 C. P. D. 94, and cases post, Book III., Chap. 4. 
rather fine and unsatisfactory-just noticed, I may observe that fraud is not actionable nor available by way of defence to an action, unless, in the one case, it has occasioned damage to the complainant, or, in the other, has induced the defendant to contract. A bare lie, for instance, albeit told with an intent to injure, would not, if unproductive of damage, lay the foundation of an action $(f)$, nor would a misrepresentation, however corruptly made, afford a good defence to an action founded upon contract, unless it were shown to have operated as an inducement to the defendant to enter into the alleged contract.

The test proposed by Lord Brougham in Attuood v. Small $(g)$, seems to be accurate and practically useful in regard to one large and important class of frauds-those, viz., which are evidenced by misrepresentations and misstatements. In order to constitute any such fraud, it is there said, three circumstances must combine: it must appear, 1st, that the representation was contrary to the fact; 2ndly, that the party making it knew it to be contrary to the fact; and, 3rdly, and chiefly, that the false representation gave rise to the contracting of the other partythere must be dolus clans locum contractui, i.e., not merely a fraudulent attempt at overreaching, but an attempt so far successful as to have operated as an inducement to the other party to contract. "We consider it clear law," remark the Court of Queen's Bench in Gerhard v. Bates ( $h$ ), "that if A. fraudulently makes a representation which is false, and which he knows to be false, to B., meaning that $B$. shall act upon it, and $B$. believing it to be true, does act upon it, and thereby suffers a damage, B. may maintain an

(f) Judgm., 2 M. \& W. 531 ; per Buller, J., 3 T. R. 56 ; 2 Sm. L. C., 9 th ed., 64 .

(g) 6 Cl. \& F. 444; per Lord Wensloydale, Simith r. Kay, 7 H. L. Ca. 775: Milme r. Maricood, 15 C. B. 78 ; Burnes r. Purnell, 2 H. L. Ca.
529 et seq.; Joens v. Heyncorth, 10 M. \& W. 147; Pasley v. Freeman, 3 T. R. 51; 1 R. R. 634 ; 2 Sm. L. C., 9 th ed., it; Redgrare v. Hurd, $20 \mathrm{Ch}$. D. 1 ; Simith v. Land and House Prop. Co., 28 Ch. D. 7.

(h) 2 E. \& B. 488. 
action ** against $A$. for the deceit, there being here the conjunction of wrong and loss entitling the injured and suffering party to a compensation for damages."

When the conditions thus indicated are fulfilled, there can be no doubt that, according as the party on whom fraud has been practised is plaintiff or defendant, he may rely upon it as ground of action or a matter of defence against the party who has practised it.

Where damage is caused by an act primâ facie savouring of false representation, an action of course will not lie, if no element of fraud enters into it.

"If," it was judicially observed in Barley v. Walford (i), " every untrue statement which produces damage to another would found an action at law, a man might sue his neighbour for any mode of communicating erroneous information-such (for example) as having a conspicuous clock too slow-since plaintiff might be thereby prevented from attending to some duty or acquiring some benefit." A doctrine calculated to create legal responsibility so wide in cases where blame cannot really attach to any one must be restrained within some limits.

Great care may be requisite in discriminating between three classes of cases:-1. Where fraud is involved. 2. Where a warranty $(k)$ has been given. 3. Where a representation $(l)$ or statement has been made, erroneous indeed, but neither fraudulent nor incorporated with the contract. As to the first of these three classes enough has been for the present said $(\mathrm{m})$; it remains, therefore, to distinguish-

(i) 9 Q. B. 197, 208.

(b) "A warranty is an express or implied statement of something which the party undertakes shall be part of a contract, and though part of the contract, yet collateral to the express object of it." Per Lord Abinger, C. B., Chanter v. Hopkins, 4 M. \& W. 404, adopted, per Mfartin, B., Azémar v.
Casella, L. R. 2 C. P. 679.

(l) "A representation is a statement or assertion made by one party to the other, before or at the time of the contract, of some matter or circumstance relating to it: "Judgm., Behn v. Burness, 3 B. \& S. 753.

(m) See further as to eases involving fraud, post, Book III., Chap. 1, 4. 
Distinction between breach of warranty, and fraud.

1st, breach of warranty from fraud: and $2 \mathrm{ndly}$, a mere representation from a warranty.

1st. By way of illustration, let us take the case of a sale of goods, and we shall at once see that the distinction between a warranty that a personal chattel is sound and a fraud in the sale of it is broad and manifest (n).

If a man sell a horse to another, and expressly warrant him to be sound, the contract is broken if the horse prove otherwise'(o). The purchaser in such case relies upon the contract; and it is immaterial to him whether the vendor did or did not know of the unsoundness of the horse. In either case he is entitled to recover all the damages which he has sustained by reason of the breach of that contract. "A warranty," says Lord Mansfield $(p)$, " extends to all faults known and unknown to the seller."

Again, if the vendor say to the purchaser, "I do not know whether the horse is or is not sound, and therefore will not warrant him: all I can say is, that I hare long owned him, and lnow of no unsoundness ;" here manifestly is no warranty, and if the vendor spoke the truth no fraud. If, however, the vendee can show that the horse was unsound, that the vendor knew it to be so at the time of the sale, and that in consequence of the false representations made by him, the purchaser was defrauded, the rendor would be liable, not for a breach of a contract of warranty, for he made no such contract, but for maling representations which he linew to be false. In such case the guilty knowledge of the rendor would constitute an essential ingredient in the fraud, and in an action against him should be both alleged and proved.

(n) See the Judgment of Waite, J., Bartholomew r. Bushnell, 20 Day (U. S.) R. 275, 276; Nilliams $\dot{ }$ Sucrnsea Harbou" Timstees, 14 C. B., N. S., 84.5 .

(o) But " in a contract of sale, even in the case of an express warranty de- fects patent and known to the burer nust be taken to be excluded from the warrauty:" per Cockburn, C. J., Dinges is Wiekham, 3 B. \& S. 684; Leg. Max., 6th ed., 736 .

(p) Struat v. Wilkins, 1 Dougl. 20. l'er Lord Brongham, 6 Cl. \& F. 44. 
To entitle the vendee to recover under such circumstances, his action must be founded-not upon a breach of a contract of warranty, but-upon the frand practised by the vendor $(q)$.

Here is to be noticed an important distinction between the case where a contract may be rescinded on account of fraud, and that in which it may be rescinded on the ground of a difference in substance between the thing bargained for and that obtained. In the former case - " it is enough to show that there was a fraudulent representation as to any part of that which induced the party to enter into the contract which he seeks to rescind; but where there has been an innocent misrepresentation or misapprehension, it does not authorise a rescission, unless it is such as to show that there is a complete difference in substance between what was supposed to be and what was taken, so as to constitute a failure of consideration. For example, where a horse is bought under a belief that it is sound, if the purchaser was induced to buy by a fraudulent representation as to the horse's soundness, the contract may be rescinded. If it was induced by an honest misrepresentation as to its soundness, though it may be clear that both vendor and purchaser thought that they were dealing about a sound horse, and were in error, yet the purchaser must pay the whole price unless there was a warranty; and even if there was a warranty, he cannot return the horse and claim back the whole price, unless there was a condition to that effect in the contract" $(r)$.

In the case just put by way of illustration, the warranty

(q) See Richardson v. Silvester, L. R. 9 Q. B. 34.

(r) Judgm., Lord Kennedy v. Panama, \&c., Mail Co., L. R. 2 Q. B. 587, citing Street r. Blay, 2 B. \& Ad. 456; Ship's Case, 2 De G. J. \& S. 544 .

Compare Readhead v. Midland $R$. C., L. R. 4 Q. B. 379 ; cited in Stan- ton v. Riehardson, L. R. 7 C. P. 421, 435, 9 Id. 390 ; Richardson r. Great Eastern R. C., I C. P. D. 342, 344; Franeis v. Cockrell, L. R. 5 (2. B. 184, 501; eited in Kiddle v. Lorett, 16 Q. B. D. 605,609 ; Searlev. Lareviek, L. R. 9 Q. B. 122 ; Kopitoff $\mathrm{r}$. ITilson, 1 Q. B. D. 377 ; -in regard to warranty. 
(if any) is supposed to be express. Equally obvious, however, is the distiction between fraud and the breach of an implied warranty $(s)$.

"When a skilled labourer, artizan, or artist is employed, there is on his part an implied warranty that he is of skill reasonably competent to the task he undertakes,-spondes peritiam artis. Thus if an apothecary, a watchmalier, or a solicitor be employed for reward, they each impliedly undertake to possess and exercise reasonable skill in their several arts. The public profession of an art is a representation and undertaking to all the world that the professor possesses the requisite ability and skill. An express promise or express representation in the particular case is not necessary" $(t)$.

Further-if a man makes a contract as agent for another, he must be taken in law to promise that he is what he represents himself to be, and must answer for any damage which directly results from confidence being giren to his representations $(n)$.

Distinction between warranty and representation.

The distinction between a warranty and a representation is sometimes rather fine $(x)$. There is no doubt that a representation intended by the vendor as a warranty, and acted on as such by the vendee, amounts in law to a

(s) As to implied warranties in contract of sale, see Sale of Goods Act, 1893 , ss. 12-14, and post, pp. 423 et seq. Generally, as to what is a warranty, see Chandelor v. Lopus, 2 Cro. Jac. 2; 1 Sns. L. C., 9th ed., 186. As to implied warranty, see Chanter $v$. Hopkins, 4 M. \& W. 399, followed in Prideaux $\mathrm{v}$. Bumett, 1 C. B., N. S., 613; Enmerton r. Mathers, 7 II. \& N. $586 ;$ Hard v. Hobbs, 3 Q. B. D. 150: S. C., affirmed 4 App. Cas. 13; Fouler v. Lock, L. R. 7 C. P. 272; 10 Id. 90 . There is no inplied warranty that a building is fit for a special purpose: Manchester Bonded, \&c., Co. v. Carr, 5 C. P. D. 507.

(t) Judgm., Harmer r. Cornelius,
5 C. B., X. S., 246 ; per Jerris, C. J., Jenkins r. Betham, 15 C. B. 185, 189; per heating, J., Twrner v. Goulden, L. R. 9 C. P. 58 .

(i) Collen r. Wright, 7 E. \& B. 301 ; $S . C ., S$ Id. 647 (the principle of the decision in which case is stated in Dickson r. Reuter's Telegram Co., 3 C. I'. D. 5, 7, 8) ; Randall $\mathrm{r}$. Trimen, 18 C. B. 786 ; Spedding r. Necille, L. R. 4 C. P. $212 ;$ v. 1. 620 et seq.

$(x)$ Whether a descriptive statement in a written instrument is a mere representation or a substantive part of the contract is a question of construction for the Court: Judgmı, Behn r. Burness, 3 B. \& S. 75t; Corkling 8 . Massey, L. R. 8 C. P. 395. 
warranty $(y)$; and it is also well settled that such representation so operates, although made during a treaty for a sale, and some days before the sale was finally agreed upon, if it appear that it was not withdrawn, and provided the contract of sale does not exclude it by its terms. When, however, negotiations have actually terminated in a written contract, the parties thereby tacitly affirm that such writing contains the whole contract between them, and no new terms are allowed to be added to it by extraneous evidence $(z)$.

So where the contract between parties has not been reduced into writing, the tısts for determining whether a statement made by one of them does or does not amount to a warranty will be: was it made pending the contract? was it intended, and reasonably and bon $\hat{\imath}$ ficle accepted as a warranty $(a)$ ?

In Hopkins v. Tanqueray (b), the declaration stated that the defendant, by falsely and fraudulently representing and warranting a horse to be sound, sold it to the plaintiff; yet the said horse was not then sound as the defendant knew, \&c. There was no evidence offered of fraud, but the facts proved were these-the defendant, having sent a hor:se to Tattersall's to be sold by auction, went into the stable where it was on the day before the sale, and there found the plaintiff, with whom he had been previously acquainted, examining the horse's legs ; upon which the defendant said, "You have nothing to look for ; I assure you he is perfectly sound in every respect;" to this the plaintiff replied, "If you say so, I am satisfied," and he desisted from his examination. On the next day the horse was put up for sale by public auction without a warranty, and the plaintiff

(y) See Bannerman v. White, 10 C. B., N. S., 844 .

(z) See Randall v. Rhodes, 1 Curtis (U. S.) R. 92 ; Stuclcy v. Bailey, 1 H. \& C. 40 5.

(a) Stucley v. Bailcy, supra; Russell v. Nicolopulo, \& C. B., N. S., 362.

(b) 15 C. B. 130 : with which compare Percival v. Oltacre, 18 C. B. N. S., 398. See Carter r. Crick, 4 H. \& N. 412. 
purchased him for 280 guineas, having, as he stated, "made up his mind to buy the horse, relying on the defendant's positive assurance that he was sound." The horse subsequently turned out to be unsound; and the plaintiff, having re-sold him for less than he had given for him, sued the defendant for the loss and damage thus sustained. After verdict for the plaintiff, the question raised for the decision of the Court in banc, on motion for a nonsuit, was whether there was any evidence from which the jury could infer a warranty. The Court held that there was not-that what was said before the sale amounted to a representation only, not to a warranty; and that the defendant could not be liable for a mere representation, although contrary to the fact, unless it were fraudulently made.

A mere expression of opinion then, or of intention (c), will not be deemed tantamount to a warranty ; and further, in order to be operative as such, the representation relied upon must be shown to have been made pending the contract $(d)$.

Where a mis-statement has been made anterior to the completion of the contract, the question for consideration will be : Is there evidence of dolus dans locum contractui $(e)$ ? Upon this point, the remarks of Lord Langdale, M. R., in Clapham v. Shillito $(f)$, claim attention. Their purport is to shcw, that cases freqnently occur, in which, upon entering into contracts, misrepresentations made by one party have not been in any degree relied on by the other party. If the party to whom the representations were made himself resorted to the proper means of verification before he entered into the contract, it may appear that he relied upon the result of his own investigation, and not upon the

(c) Benham v. United Guarantee gc., Co., 7 Exch. 744 .

(d) Per Maule, J., Hopkins v. Tanqueray, ante. See further as to the distinction between a representation and a warranty, 2 Wms. Saund. 201.

(e) Ante, p. 337.

(f) 7 Bear. 149. See Harris v. Femble, 2 Dow \& Cl. 463. 
statements made to him on the other side; or, if the means of investigation and verification were at hand, and the attention of the party receiving the representations was drawn to them, the circumstances of the case may lead a jury to impute to the party alleged to have been misled such a knowledge of the facts as upon due inquiry he ought to have obtained, the notion of any reliance having been placed on the representations made to him being necessarily excluded.

Again, in endeavouring to ascertain what reliance was placed on representations, they should be considered with reference to the subject-matter which they concern, and the relative knowledge of the parties. If the subject is capable of being accurately known, and one party is or is supposed to be possessed of accurate knowledge, and the other is entirely ignorant, and a contract is entered into after representations made by the party who lnows or is supposed to know, without any means of verification being resorted to by the other, it may well enough be presumed, that the ignorant man relied on the statements made by him who was supposed to be better informed; but, if the subject is in its nature uncertain,-if all that is known about it is matter of inference from something else, and if the parties ma'ing and receiving representations on the subject have equal knowledge and means of acquiring knowledge, and equal skill, it is not easy to presume that representations made by one would have much or any influence on the other $(g)$. The remarks here made will serve to show, not only the mode in which a Court of equity will distinguish between fraud and mere mis-statement, but likewise, how the evidence in the class of cases here alluded to should be analysed in a Court of law $(h)$.

(g) Per Lord Langdale, M. R., Clapham v. Shillito, 7 Beav. 149, 150.

(h) Attwood v. Simall, $6 \mathrm{Cl}$ \& F. 232 , is the leading case upon the sub- ject adverted to in the text: Redgrave r. Hurd, $20 \mathrm{Ch}$. D. 1, where it is explained and commented on by Jessel, M. R.; Smith r. Land and House Prop. Co., 28 Ch. D. 7. 
Of contracts

illegalopposed to public policy-

Passing on to a brief notice of contracts and considerations which are illegal-as being in violation of positive law, or opposed to public policy, or immoral, I must repeat (i), that the remarks which follow will be found generally applicable as well to Special as to Simple Contracts. As regards the former of these, it has been observed $(k)$, that, "Notwithstanding the solemnity and force which the law ascribes to deeds, and all the strictness with which, in general, it prohibits the introduction of extrinsic evidence to prove that an instrument goes beyond, or does not fully contain, or incorrectly exhibits, the terms of the contract, which it was written and signed for the purpose of expressing or recording, the rule is settled (and not merely in Courts of equity) that a deed, $c x$ facie just and righteous, may be vitiated and avoided by alleging and adducing extrinsic evidence to prove that it was founded on a consideration, or had a view or purpose, contravening law or public policy."

So, in The Gas Light and Coke Co. v. Turner (l), Lord Abinger says, that all the decisions show, that, at common law, a contract entered into to effect an illegal purpose is roid and cannot be enforced, and it malies no difference that the contract is under seal. "It is true," continues that learned Judge, "that you cannot add to a contract under seal anything to vary the contract, but you may show dehors the instrument that such contract was entered into for an illegal purpose; such proof does not vary the terms of the contract, but merely shows the illegal object."

The objection of illegality applies then alike to special as to simple contracts. "Promises," as Paley tells us in his Moral Philosophy (m), "are not binding where the

(i) See the remarks, aute, p. 329.

(k) Yer hivight Bruce, L. J., Reynell จ. Sprye, 1 Je G. M. \& G. 672.

(I) 6 Bing. N. C. $324,32 \%$; and see per Tivdal, C. J., in $S_{.} C_{.}$, 5
Bing. X. C. 666, 675, cited ante, p. 280: Stevens v. Gourley, T C. B., N. S., 99.

(m) Vol, 1, p. 130 ; Whewell, El. Moral. pp. 233, 245, 246. 
performance is unlawful;" thus-to anticipate a little what I shall presently have to say-if two parties mutually agree, that one of them shall do an act contrary to the express provisions of a public statute, the act to be done being illegal, the promise that it shall be done is void.

An action, then, cannot be maintained upon a contract which is in direct violation of law, whether statutory or unwritten-which is of an immoral tendency-or contrary to sound policy. "The common law maxims are (n), Ex turpi causî non oritur actio, ex dolo malo non oritu actio. They prohibit everything which is unjust or contra bonos mores. The object of all law is to repress vice and to promote the general welfare of society, and it does not give its assistance to a person to enforce a demand originating in his breach or violation of its principles and enactments. Contracts in violation of statutes are void, and they are so whether the consideration to be performed or the act to be done be a violation of the statute" $(o)$.

It would be useless to adduce a cloud of authorities in support of the foregoing propositions :- "What," says Lord Ellenborough, C. J., " is done in contravention of the provisions of an Act of Parliament cannot be made the subjectmatter of an action" $(p)$. "Where a contract," says Lord Tenterden, C. J., "which a plaintiff seeks to enforce is expressly, or by implication, forbidden by the statute or common law, no Court will lend its assistance to give it effect. And there are numerous cases in the books where an action on the contract has failed because either the consideration for the promise or the act to be done was illegal, as being against the express provisions of

(n) See Harris v. Rumels, 12 Howard (U. S.) R. 83.

(o) Ibid. Where, lowever, the act which is the subject of the contract may according to the circumstances be lawful or unlawful, it will not he presumed that the contract was to do the
Contracts
in direct violation of law. 
the law, or contrary to justice, morality, and sound policy" $(q)$.

Either the consideration or the promise may be illegal.

It is, indeed, sufficiently obvious that a contract may be illegal quoad the consideration or quoad the promise. A distinction, however, here requires notice: a consideration bad in part is bad altogether $(r)$; whereas the promise may be to do several distinct and independent acts, of which some are legal and some are illegal; if so, the promise will be valid in regard to the former, void as to the latter of such acts $(s)$. So, a written agreement may be single and entire, founded on one entire consideration-it may be severable in its nature, and deal with matters which are unconnected with and independent of each other $(t)$. And, as remarked by Mr. Smith in his note to Collins v. Blantern (u), " in cases where the consideration is tainted by no illegality, but some of the conditions (if the contract in question be a bond) or promises (if it be a contract of any other description) are illegal, the illegality of those which are bad does not communicate itself to or contaminate those which are good, except where, in consequence of some peculiarity in the contract, its parts are inseparable or dependent upon one another."

Again, it may safely be laid down that, if a contract be

(q) Wetherell r. Jones, 3 B. \& Ad. 226 ; Judgm.. Cope v. Rorclands, 2 M. \& W. 157. See Smith v. Lindo, 5 C. B., N. S., 58T; 4 C. B., N. S., 395 ; Mayor, ge., of Morecich r. Worfolk R. C., 4 E. \& 13. 397 . And see a curious illustration of the doctrine of our law as to illegal contracts put by Lord Camplell, C. J., and Irightman, J., in Nicholson v. Gooch, 5 E. \& I. 1015. See also per Lord Cairns, C., Eley v. Pusitive Life Ass. Co., 1 Ex. D. 88, 89.

As to the question-What is a simoniaeal contract? see Walsh v. Bishop of Lincoln, L. R. 10 C. I'. 518.

(r) Wait r. Jorres, I Bing. N. C. 6.)6, 662 (citing Featherstone v. IHutehinson, Cro. Eliz. 199); Hoveden r. Maigh, 11 Ad. \& E. 1036; per
Tindal, C. J., Schakell r. Rosier, 2 Bing, N. C. 646 , who remarks :" Cndoubtedly, when a promise rests on two considerations, one of which is impossible or unintelligible, you may reject the impossible or unintelligible, and resort to that which is possible and plain.',

(s) See Bank of Australasia v. Breillat, 6 Moo. P. C. C. 152, 201.

( $t$ ) Hopkins r. Prescott, 4 C. B. 578, 593. See Sterry r. Clifton, 9 C. 13. 110 .

(ii) I Lead. Cas., 9th ed., 398: and see per IIillcs, J., I'ickering v. Ilfiracombe R. C., L. R. 3 C. I'. 250 ; Burditt, lure, bysme, ex parte, 20 Q. B. D. 310 . 
rendered illegal by statute $(x)$, it can make no difference in point of law whether the statute which makes it so has in view the protection of the revenue or any other object. The sole question will be-Does the statute mean to prolibit the contract $(y)$ ? Such an intention on the part of the Legislature may be manifested as well by the infliction of a penalty, as by express prohibitory words, for a penalty implies a prohibition (z). "I think," said Lord Esher, M. R., in a recent case $(a)$, "that this rule of interpretation has been laid down, that, although a statute contains no express words making void a contract which it prohibits, yet when it inflicts a penalty for the breach of the prohibition, you must consider the whole Act as well as the particular enactment in question, and come to a decision, either from the context or the subject-matter, whether the penalty is imposed with intent merely to deter persons from entering into the contract, or for the purposes of revenue, or whether it is intended that the contract shall not be entered into so as to be valid at law."

It seems to follow à fortiori from what has just been said, that, "if two parties enter into an agreement, whereby it is stipulated that one of them shall be enabled to commit an act that is contrary to public policy, and contrary to the provisions of an Act of Parliament, though not expressly prohibited thereby, except by the imposition of a penalty, the agreement is illegal and void" $(b)$. Upon this part of the subject I will merely add, that statutes

(x) See Ramsden v. Lupton, L. R. 9 Q. B. 17,25 .

(y) Cope r. Rovtands, 2 M. \& W. 149, 157; ace. Smith v. Marchood, 14 M. \& W. 452,464 (which recognises Johnson r. Hudson, 11 East, 180), and Taylor v. Croucland Gas, \&e., Co., 10 Exch. 293, 296 ; Bailey v. Harris, 12 Q. B. 905 ; Bull v. Chapman, 8 Exch. 444; Foster r. Oxford, §c., R. C., 13 C. B. 200 . See Smith v. Lindo, eited supra, n. $(q)$; Lewis r.
Bright, 4 E. \& B. 917 ; Elliott ร. Richardson, L. R. 5 C. P. 74 .

(z) Per Lord Holt, Bartlett r. Finor, Carth. 252; Cope v. Rovelands, supra ; Fergusson r. Norman, 5 Bing. $\mathbf{x}$. C. 76, 84, 85; Barton v. Piggott, L. R. 10 Q. B. 86,90 .

(a) Melliss v. Shivley Local Board, 16 Q. B. D. 446 ; reversing S. C., 14 Id., 911 .

(b) Per Maule, J., Ritchie v. Smith, 6 C. B. $462,477$. 
giving rise to questions as to the right to recover the price of goods by vendors who have not complied with the terms of such statutes, are of two classes,-the one class of statutes having for their object the raising and protection of the revenue-the other class being directed either to the protection of buyers and consumers or to some object of public policy (c). In connection with the former of these two classes, the difficulty most likely to occur to the practitioner will be in determining whether the infliction of a penalty implies a prohibition of the contract. In connection with the latter, the inquiry will, in the absence of any special contract, most probably be, whether, by reason of the vendor's non-compliance with the provisions of some specific statute, the law will decline to imply a promise on the part of the purchaser to pay for the goods sold $(d)$.

Assuming that a transaction has occurred clearly in contravention of law, and that the various points already suggested as likely to present difficulty have been satisfactorily disposed of, it may still be necessary to inquire whether the connection subsisting between such illegal transaction and the contract under consideration is sufficiently close to invalidate the latter ; $e x . g r$., whether the doing of an illegal act was contemplated by the contracting parties (e).

We have seen, that, where a contract grows immediately out of an illegal act, a Court of justice will not lend its aid to enforce it; a man, for instance, who imports goods for another in violation of our law, cannot maintain an action for the value or freight of the goods, or for advances made on them $(f)$. So it has been held, that one of two parties

(c) Judgm., Cundell v. Darson, 4 C. B. 376,397. See Forster v. Taylor, 5 B. \& Ad. 857,896 ; Smith v. Bromley, 2 Dougl. 696, note.

(d) Judgm., 4 C. 13. 397.

(c) See Edgexare Ilighuay Board v. Harroto Gils Co., I. R. 10 Q. B. 92 ; Waugh v. Morris, L. R. 8 Q. B.
202,207 ; Gicene v. Bateman, L. R. 5 H. I. 591.

(f) Armstiong v. Toler, 11 Whenton (U.S.) R. 258, which will be found well worthy of perusal: Holman $r$. Johnson, Cowp. 341, with which compare Clugas v. Penaluna, 4 T. R. $466 ; 2$ R. R. 442 . 
to an agreement to suppress a prosecution for felony cannot maintain an action against the other for an injury arising out of the transaction in which they have both been illegally engaged $(g)$. And where, in consideration, that plaintiff had published a libel at the defendant's request, and had, at the like request, consented to defend an action brought against plaintiff for such publication, the defendant promised to indemnify plaintiff from the costs of the action; the promise so to do was held to be void $(h)$.

So, if the contract in question be in part only connected with the illegal transaction, it will nevertheless be tainted thereby, ex. $g r$., if the importation of goods contraband of war were the result of a scheme to consign the goods to a third person on behalf of the importer, in order that he might protect and defend them for the owner in case they should be brought into jeopardy by seizure or by legal process, a bond afterwards given or promise made by the owner to the consignee by way of indemnity to the latter would, it is conceived, be invalid as constituting a part of the original transaction, although purporting to be a new and independent contract (i).

Thus far, then, the doctrine under consideration may, with tolerable precision, be enunciated. But then the question arises, does the taint in the original transaction infect and vitiate every contract growing out of it, however remotely connected with it? This cannot with reason be contended for; inasmuch as the consequence of such a rule would be, that parties innocently contracting might suffer for a precedent illegality connected with or perhaps giving rise to the subject-matter of their contract $(k)$. If, under such circumstances as here adverted

(g) Firaz v. Nicholls, 2 C. B. 501. 634.

(h) Shackell v. Rosier, 2 Bing. N. C.

(i) Armstrong v. Toles, 11 Wheat. (U.S.) R. 258; Collins v. Blantern, cited ante, p. 276 .

(k) Aimstiong v. Toler, 11 Wheat. (U. S.) R. 258, where examples illustrating the text are given. 
to, doubt is entertained, the test most likely to prove serviceable to the practitioner would seem to be, does the plaintiff require aid from the illegal transaction in order to establish his claim $(l)$ ? if so, his claim will, according as the defect is or is not apparent therein, be exposed either to an objection under Order XXV. or to the special defence of illegality.

Lastly, where the consideration and the matter to be performed are both legal, a plaintiff would not, it seems, be precluded from recovering by an infringement of the law collateral to and not contemplated by the contract in the performance of something to be done on his part $(m)$.

The decision of the Court of error in Fisher v. Bridges (n), abstracted at p. 281, is important with reference to contracts illegal by reason of their being opposed to the statute law.

Contracts opposed to public policy.

When a contract is said to be roid as "opposed to public policy," reference is made to that principle of law, in accordance with which "no subject can lawfully do that which has a tendency to be injurious to the public or against the public good-which may be termed, as it sometimes has been, the policy of the law, or 'public policy,' in relation to the administration of the la $\pi^{\prime \prime}(o)$. The "doctrine of the public

(l) Tuylor r. Bouers, 1 Q. B. D. 291, and cases there cited; Simpson v. Bloss, i Taunt. 246: 22 R. R. 509. See Bone v. Ekless, 5 H. \& N. 925.

(m) Per Lord Tenterden, C. J., Wetherell r. Jones, 3 B. \& Ad. 226; Fergusson v. Norman, 5 Bing. X. C. 76, 84; P'idgeun v. Burslem, 3 Exch. 470,471 , followed in Jessopp r. Lutvyche, 10 Exch. 614. See Roscrarne r. Billing, 15 C. B., N. S., 316.

(n) 3 E. \& B. 642 .

(o) Per Lord Truro, Egerton r. Farl Broumlow, 4 H. 1. Ca. 196, where the meaning of the term in question was mnch discussed. In that ease Purke, B., observes, that, "' 'ublic policy' is a rague and unsatisfactory term, and calculated to lead to uncertainty and error when applied to the decision of legal rights; it is capable of being understood in different senses: it may and does in its ordinary sense mean 'political expedience,' or that which is best for the common good of the community, and in that sense there may be every variety of opinion according to the education, habits, talents, and disposition of each person who is to decide whether an act is against public policy or not. To allow this to be a ground of judicial decision rould lead to the greatest uncertainty and confusion." And see per Aiderson, B., Id. 106 , and 5 M. \& W. 467 . For a discussion of the changes in the doctrine of pnblic policr, see Davies r. Davies, 36 Ch. D. 359. 
good or the public safety, or what is sometimes called pullic policy," as remarked by a learned Judge, "being the foundation of law, is supported by decisions in every branch of the law; and an unlimited number of cases may be cited $(p)$, as directly and distinctly deciding upon contracts and covenants on the avowed broad ground of the public good, and on that alone" $(q)$. This doctrine is asserted by Sir E. Coke, under the maxim Nihil quod est inconveniens est licitum $(r)$.

For instance, "When a bribe is given, or a promise of a bribe is made, to a person in the employ of another by some one who has contracted or is about to contract with the employer, with a view to inducing the person employed to act otherwise than with loyalty and fidelity to his employer, the agreement is a corrupt one and is not enforceable at law, whatever the actual effect produced on the mind of the person bribed may be" $(s)$.

Prima facie, as we have already seen, all persons are free to make such contracts as they please $(t)$, and are morally and legally bound by them, provided they

(p) Generally, as to agreements against public policy, see Shreusbury $\&$ Birmingham $R$. C. . . Loudon \& N. W. R. C., 6 H. L. Ca. 113 ; Simpson v. Lord Howden, 9 Cl. \& F. 61 ; Taylor v. Chichester, \&c., R. C., L. R. 2 Ex. 3う̄6; Preston v. Liverpool, MLanchester, \& Neucastle R. C., 5 H. L. Ca. 605 ; Coppock v. Bower, 4 M. \& W. 361 ; Mittelholzer v. Fullarton, 6 Q. B. 989 (with which compare Santos v. Illidge, 8 C. B., N. S., 861 ; S. C., 6 C. B., N. S., 841); Millward v. Littlewood, 5 Exch. 775; per Lord Mansfield, C. J., Jones $v$. Randall, 1 Cowp. 39; and in Holman v. Johnson, Id. 343 ; Kilham v. Collier, 21 L. J., Q. B. 65 ; Scott v. Avery, 8 Exch. 487,497 ; $s$. C., 5 H. L. Ca. 811 ; cited in Edwards v. Aberayron Insur. Soc., 1 Q. B. D. 575, 579, 584, 592, 595,598 ; Humphreys v. Welling, 1 H. \& C. 7 ; Bolton v. MIadden, L. R. 9 Q. B. 55 . (q) Per Pollock, C. B., Egerton v. Earl Brownlow, 4 H. L. Ca. 144, 145.

(r) Co. Litt. 66 a.

(s) Per Cockburn, C. J., Harrington v. Victoria Graving Dock Co., 3 Q. B. D. 551; Smith v. Sorby, Id. 552. See Salford (Mayorof) v. Lever, (1891) 1 Q. B. 168 , affirming $S . C ., 25$ Q. B. D. 363 . If the contract is disadrautageons to the principal he has two remedies : (1) be may recover from the agent as money had and received to his use, the amount of the bribe; (2) he may recover from the agent and the person who has paid the bribe, jointly or severally, damages for any loss sus. tained, withont allowing for any deduction in respect of money recovered under (1). In Lister v. Stubbs, 45 Ch. D. 15, it was decided that the agent is the principal's debtor, and not his trustee, in respect of money recsired as a bribe.

( $t$ ) Ante, p. 250. 
adopt the formalities required by the common and statute law. Contracts have, however, been deemed to be illegal and void in many cases as opposed to public policy: Thus, at common law, wagers $(u)$ which are foolish, or tend to annoy others, or to waste the time of the Court $(x)$, or to outrage decency, $(y)$ have been discountenanced. And if a wager were laid by a judge upon the event of a cause which he would be called upon to decide, it would be against the established rule-nemo in propriâ causâ judex esse debet $(z)$-and, irrespective of express enactment ( $a$ ), would be void (b).

It has, however, been said by a very learned Judge $(c)$, that this doctrine should not be extended. "It must not be forgotten that you are not to extend arbitrarily those rules which say that a given contract is void as being against public

(4) By 8 \& 9 Vict. c. 109 , s. 18, all contracts or agreements by way of gaming or wagering are null and void, and no action can be brought or maintained to recorer auy sum of money or valuable thing alleged to be won upon a wager, or which shall have been deposited with a stakeholder. The Act does not apply to money or valuables deposited as security, Strachan v. Universal Stock Exchange, (1896) A. C. 166, affirming (1895) 2 Q. B. 329. By the Gaming Act, 1892 (55 Fict. c." 97 , "any promise to pay any person any sum of money paid by him under or in respect of any contract or agreement rendered null and roid by $8 \& 9$ Vict. c. 109 , or to pay any sum of money by way of commission, fee, reward, or otherwise in respect of any such contract, or of any services in relation thereto or in connexion therewith, shall be null and void, and no action shall be brought or maiutained to recorer any such sum of money." On this latter Act, cf. Tatam $\mathrm{v}$. Reevc, (1893) 1 Q. B. 44 (money paid by plaintiff at defendant's request to persons with whom the defendant had lost bets, is not recoverable); De Mattos צ. Bcnjamin, 63 I. J. Q. B. 248 (the Act does not enable a person who has received money on behalf of another to retain it). Money deposited to abide the result of a race is not paid under or in respect of a wagering contract within the meaning of the Act, O'Sullivan r. Thomas, (1895) 1 Q. B. 698. As to speculation on the Stock Exchange, see Thacker r. Hardy, 4 Q. B. D. 685 ; Forget r. Ostigny, (1895) A. C. 318.

(x) Eltham v. Kingsman, 1 B. \& Ald. 683,$688 ; 19$ R. R. 417.

(y) Da Costa v. Jones, Cowp. 729 ; Thackoorseydass v. Dhondmull, 6 Moo. P. C. C. 300,310 .

(z) Ante, p. 261.

(a) See 8 \& 9 Vict. c. 109 ; Coombes v. Dibble, L. R. 1 Ex. 248 ; Beeston v. Becston, 1 Ex. D. 13 ; distinguished in Higginson r. Simpson, 2 C. P. D. 76 ; Diggle v. Higgs, 2 Ex. D. 422; approved in Trimble v. Hill, 5 App. Cas. 344; Hampden r. Walsh, 1 Q. B. D. 189 ; Batson v. Newman, 1 C. P. D. 573 ; see further as to wagering contracts, Anderson r. Read, 10 Q. B. D. 100 : Bridger $r$. Savage, 15 Q. B. D. 363.

(b) Jones v. Randall, Cowp. 37 .

(c) Per Jesscl, M. R., Printing, \&c., Co. v. Sampson, L. R. 19 Eq. Ca. 462, 465 ; quoted approvingly by Chitty, J., in Badische Anilin Fabrik v. Schott, (1892) 3 Ch. at p. 452, and in Tullis v. Jackson, 61 L. J. Ch. 655. 
policy, because if there is one thing more than another public policy requires, it is that men of full age and competent understanding shall have the utmost liberty of contracting, and that their contracts, when entered into freely and voluntarily, shall be held sacred, and shall be enfoiced by Courts of Justice. Therefore, you have this paramount public policy to consider-that you are not lightly to interfere with this freedom of contract."

Many other contracts have also been held to be illegal on principles long recognised by the common law, $e x . g r$. , marriage brocage bonds-that is, bonds for the procuring of marriages $(d)$; contracts not to marry $(e), s c$., not to marry at all, but a condition in a will in restraint of second marriage is not void $(f)$, or of marriage with an individual mentioned by name, or with a member of a class $(g)$; deeds and agreements made in contemplation of a future separation between husband and wife $(h)$; contracts made with a view to compromising prosecutions for felonies or misdemeanors $(i)$; contracts in restraint of trade or against alienation of land, including those which violate the law of perpetuities. So,

(d) Hall v. Potter, 3 Lev. 411: where the House of Lords held, that " all such contracts concerning marriages are of dangerous consequence, and not to be allowed." See also the cases on this subject cited arg., 15 Q. B. 469 ; Earl of Chesterfield v. Janssen, 1 Atk. $352 ; 1$ Wh. \& T., L. C. 592 .

(e) Morley v. Rennoldson, 2 Hare, 570 ; Lowe v. Peers, 4 Burr. 2225; S. C., Wilmot, 364 ; Baker v. White, 2 Vern. 215; Hartley v. Rice, 10 East, 22 ; 10 R. R. 228.

(f) Allen v. Jackson, 1 Ch. D. 399.

(g) Jenner v. Turner, 16 Ch. D. 188, and cases there cited.

(h) Hindley v. Mrarquis of Westmeath, 6 B. \& C. 200 . But a deed providing for the wife's support on an immediate separation is good: Jones v. Waite, 9 Cl. \& F. 101, affirming judgment in $S . C ., 5$ Bing. N. C. 341 . In Wilson v. Wilson, 1 H. L. Ca. 538, the authorities upon this subject are collected. See Randle v. Gould, 8 E. \& B. 457 ; Nicol v. Nicol, 31 Ch. D. 524.

(i) Ante, p. 278, n. (u). Fivaz v. Nicholls, 2C. B. 501 ; Ex parte Critchley, 3 D. \& L. 527 ; IVard v. Lloyd, 6 M. \& Gr. 785, followed in Flouer v. Sadler, 9 Q. B. D. 86 ; 10 Ib. 572 ; Haigh v. Jones, 5 M. \& Gr. 634 ; Osbaldiston v. Simpson, 13 Sim. 513; Jones v. Merionethshire Building Society, (1891) 2 Ch. 580, affirmed 1892, 1 Ch. 173. A contract to indemnify bail is against public policy and void: Wilson $\mathrm{r}$. Strugnell, 7 Q. B. D. 548 . Money, however, paid in pursuance of such a contract cannot be recovered, when the illegal act has already been effected : Herman v. Jeuchner, 15 Q. B. D. 561, overruling on this point, Wilson $r$. Strugnell, ub. supr., and see Re Great Berlin Steamboat Co., 26 Ch. D. 616 ; Kearley v. Thomson, 24 Q. B. D. 742, and ante, p. 278, n. $(u)$. 
in bankruptcy, the object and policy of the bankrupt laws is to make a rateable distribution of the bankrupt's property amongst all his creditors; and preferences given to particular creditors by a trader in contemplation of bankruptcy, or to induce a creditor to sign the composition deed $(k)$, or in fraud of the creditors $(l)$, are in violation of the policy of the bankrupt laws, and are therefore held to be illegal and void $(\mathrm{m})$. And, without multiplying instances of contracts which are opposed to public policy, we may conclude, in the words of Lord Ellenborough (n), that "wherever the tolerating of any species of contract has a tendency to produce a public mischief or inconvenience, such a contract has been held to be void."

Contracts $V$ Of the various kinds of contracts above enumerated, those in restraint of trade.

in restraint of trade, by reason of their practical importance, require some especial notice. Upon this subject the leading case is Mitchel v. Reynolds (o); and the law relating to contracts in restraint of trade may be shortly stated thus: that

(k) Atkinson v. Denby, 7 H. \& N. 934 ; S. C., 6 Id. 778, following Smith r. Bromley, 2 Dougl. 695, n., and Smith v. Cutf, 6 M. \& S. $160 ; 18$ R. R. 340 . (l) Blacklock v. Dobie, 1 C. P. D. 265.

(m) See per Cressuell, J., 4 H. L. Ca. 87; Smith r. Salzmam, 9 Exch. 535; Wilkin v. Mamning, Id. 575; IIills r. Mitson, 8 Exch. 751 ; Coles $\mathrm{r}$. Strick, 15 Q. B. 2.

(n) Gilbert r. Sykes, 16 East, 156 (as to which see the remarks, 4 II. I. Ca. 125,148 , and in 6 Moo. 1'. C. C. 312); 14 R. R. 327 ; Preface v.; see Cook ×. Field, 15 Q. B. 460 ; Doe d. Williams v. Evans, 1 C. B. 717. As to contracts for the sale of offices, see 2 Bing. 229, 247 ; Sterry v. Clifton, 9 C. B. 110. As to contracts originating ont of gambling transactions, see Quarrier v. Colston, 1 Phill. $14 \bar{i}$, and ante, p. 354, n. (u). As to champerty and maintenance, see Coondoo $\mathrm{r}$. Mooterjee, 2 App. Cas. 186; Hutley v. Hutley, I. R. 8 Q. B. 112; Elliots r. Richurdson, L. R. 5 C.
P. 744; Giell r. Levy, 16 C. B., N. S. 73; Anderson r. Radcliffe, E. B. \& E. 806 ; Sprye r. Porter, 7 E. d B. 58; Simpson r. Lamb, Id. 84; Earle r. Hopwood, 9 C. B., N. S., 566; Findon r. Parker, 11 M. \& W. 675; Reynell v. Sprye, 1 De G. M. \& G. 660 . See, also, 33 \& 34 Vict. c. 28 , ss. 4 , s: Bradlungh r. Newdegate, 11 Q. B. D. 1 ; Metrop. Bank v. Pooley, 10 App. Cas. 210, 217; Ball v. Wameick, 50 L. J. Q. B. 382 ; Plating Co. r. Farquharson, 17 Ch. D. 49 ; Alabaster r. Hamess, (1895) I Q. B. 339, C. A., aftirming $S . C .,(1894) 2$ Q. B. 897 ; Haris r. Brisco, 17 Q. B. D. 504, where it was held that it is a good defence to an action for maintenance that the defendant acted from charitable motires.

A promise by a solicitor not to charge his client anything for costs is not champerty, per Borill, C. J., Jennings r. Johnson, L. R. 8 C. P. 426.

(o) 1 P. Wms. 1S1; 1 Sm. L. C., 9th ed. 430 ; Lavies v. Davies, $36 \mathrm{Ch}$. D. 359 . 
"agreements "-whether under seal or not- " in restraint of trade are against public policy and void, unless the restraint they impose is partial only, and they are made on good consideration and are reasonable," the Courts not being disposed "to measure the adequacy of the consideration, if a real and bonâ fide consideration exists" $(p)$.

The judgment of the Court of Exchequer in Mallan v. May $(q)$ exhibits very clearly the general principles which have actuated our tribunals, as well of equity as of law, in upholding (with certain important limitations) contracts of the kind alluded to. Contracts in total restraint of trade (it is there said) which the law so much favours, are absolutely bad. Contracts in partial restraint of trade, if nothing more appears, are presumed to be bad $(r)$; but if the circumstances are set forth, that presumption may be excluded; and the Court are to judge of those circumstances, and to determine whether the contract submitted for their consideration be valid or not $(s)$.

Therefore, if there be simply a stipulation, though in an instrument under seal, that a trade or profession shall not be carried on in a particular place, without any recital in the deed, and without any averments showing circumstances rendering such a contract reasonable, the instrument is void. But if there are circumstances recited in the instrument (or

(p) Judgm., Collins v. Loeke, 4 App. Cas. 685. See Jones v. Lees, 1 H. \& N. 189; Dendy v. Henderson, 11 Exch. 194.

(q) 11 M. \& W. 653, 665; Price v. Green, 16 M. \& V. 346, 352; S. C., 13 MI. \& W. $695 ;$ Mrumford v. Gething, 7 C. B., N. S., 305.

(r) Acc. per Williams, J., Sainter v. Ferguson, 7 C. B. 730 .

It is observable, that, in Tallis v. Tallis, 1 E. \& B. 391, the Court of Queen's Bench remark thus:-“"In Miteliel v. Reynolds it is said, "wherever such contract (in restraint of trade) stat indifferenter, and for aught appears may be either good or bad, the law presumes it primâ facie to be bad.' But, according to the tenor of the later decisions, the contract is valid, unless some restriction is imposed beyond what the interest of the plaintiff requires."

(s) In Mills v. Dunham, (1891) $1 \mathrm{Ch}$. at p. 586, Lindley, L. J., says: "... to treat a restraint of trade as primâ facie bad, and throw upon the person supporting it the onus of showing that it is reasonable, is introducing a wholly unsound principle into the construction of documents. . . . You are to construe the contract, and then see whether it is legal." 
probably if they appear by averment), it is for the Court to determine, whether the contract in question be a fair and reasonable one or not; and the test appears to be-whether it be prejudicial or not to the public interests; for it is on grounds of public policy alone that these contracts are supported or avoided. Contracts for the partial restraint of trade are upheld, not because they are advantageous to the individual with whom the contract is made, and a sacrifice pro tanto of the rights of the community, but because it is for the benefit of the public at large that they should be enforced. Many of these partial restraints on trade are perfectly consistent with public convenience and the general interest, and have been supported; such is the case of the disposing of a shop in a particular place, with a contract on the part of the vendor not to carry on a trade in the same place. This is, in effect, the sale of a goodwill $(t)$, and offers an encouragement to trade, by allowing a party to dispose of all the fruits of his industry $(u)$. And such is the class of cases of much more frequent occurrence, of a tradesman, manufacturer, or professional man taking a servant or clerk into his service, with a contract that he will not carry on the same trade or profession within certain limits $(x)$. In such a case the public derives an advantage in the unrestrained choice which such a stipulation gives to the employer of able assistants, and the security it affords, that the master will

( $t$ ) The rendor is not entitled to canvass the customers of the old firm, Trego v. Hunt, (1896) App. Ca. 7 .

As to the definition of goodwill, see Ginesi v. Cooper, 14 Ch. D. 596. As to granting an injunction for breach of agreement, see Trego v. Hunt,(1896) App. Ca. 7 (reversing S. C., (1S95) 1 Ch. 462), overruling Pearson v. Pear. son, 27 Ch. D. 145, and approring Labuichere v. Dauson, 13 L. R. Eq. 322. The authorities are considered in Lord Hersehel's judgment.

The purehaser of a business to whom is assigned all the beneficial iuterest and goodwill of the vendor in the business, is entitled to use the rendor's name to show that the business purchased was formerly the vendor's, but not 80 as to expose the rendor to liability, Thynne v. Shove, 45 Ch. D. 577.

(ii) See Prugwell v. Gosse, Alern, 67 : Broad v. Jolliffe, Cro. Jac. 596 ; Jclliet v. Broad, Noy, 98.

$(x)$ See Chesman r. Nainby, 2 Ld. Raym. 1456; Carnes v. Nisbett, 31 I. J., Ex. 273; Josselyn v. Parson, I. R. i Ex. 127 . 
not withhold from the servant instruction in the secrets of his trade, and the communication of his own skill and experience, from the fear of his afterwards having a rival in the same business $(y)$.

Such being the general reasoning now recognised with regard to contracts in partial restraint of trade (z), let us inquire what conditions are essential to their validity, that is, under what circumstances such contracts will be deemed "fair and reasonable" by the Courts.

Now, in the first place, a contract in restraint of trade must have some consideration to support it. If there be no conSome consideration necessary. sideration for it, or a consideration of no real value $(a)$, the contract must " either be a fraud upon the rights of the party restrained or a mere voluntary contract, a nudum pactum, and therefore void" $(b)$. The Court, however, will not inquire respecting the adequacy of the consideration. This point was finally determined in Hitchcock v. Coker (c), since which case the law there laid down with reference to it has been uniformly adhered to $(d)$.

The Court can have no judicial perception of the ratio of the consideration to the restriction; if there were a legal consideration of value, passing to the contractor, the contract will be enforced, without reference to the quantum of that value $(e)$.

If the restraint of trade contemplated by the agreement between the parties be unreasonable, such agreement is void altogether; if not, it is lawful, the only question being whether there is a consideration to support it; and the

(y) Judgm., 11 M. \& W. 665-6; per Erle, C. J., Mrumford v. Gething, 29 L. J., C. P. 109,$110 ;$ S. C., 7 C. B., N. S., 305 .

(z) Such contracts were, however, formerly held to be illegal. See per Lord st. Leonards, 4 H. L. Ca. 237-9. (a) See per Lord Abinger, C. B., Leighton v. Wales, 3 M. \& W. 550.

(b) 6 Ad. \& E. 438,457 . The former rule, as to the adequacy of the consideration, will be found stated in Young v. Timmins, 1 C. \& J. 331; Horner v. Graves, 7 Bing. 735.

(c) 6 Ad. \& E. 438 .

(d) Per Williams, J., Sainter v.

Ferguson, 7 C. B. 730.

(e) Judgm., Tallis v. Tallis, 1 E. \& B. 410 . 
adequacy of the consideration the Court will not inquire into, but will leave the parties to make the bargain for themselves $(f)$.

Assuming that there is some consideration to support an agreement in restraint of trade, the reasonableness and validity of the contract will have mainly to be determined by reference to the degree of restraint which it seeks to impose, and which may be considered in regard as well to its duration as to the superficial area over which it is intended to be operative.

Duration of

In regard to the duration of the restriction, it is now restraint. settled that it may continue during the life of the contractor, and that it is limited neither to the period during which the contractee may carry on his business, nor even to the term of his life $(g)$.

The reasoning in support of this doctrine is as follows:"The goodwill of a trade is a subject of value and price. It may be sold, bequeathed, or become assets in the hands of the personal representative of a trader. And if the restriction as to time is to be held to be illegal if extended beyond the period of the party by himself carrying on the trade, the value of such goodwill considered in those various points of view is altogether destroyed" $(h)$. If then (to take a case of ordinary occurrence) it be not unreasonable, as undoubtedly it is not, to prevent a servant from entering into the same trade in the same town in which his master lives so long as the master carries on the trade there, it does not seem unreasonable that the restraint should be carried further, and should be allowed to continue if the master sells the trade, or bequeaths it, or if it becomes the property of his personal representative; that is, if it be reasonable that the master should by an agreement

(f) Per Alderson, B., Pilkington r. Scoll, 15 M. \& W. 660 , cited in Reg. v. Weleh, 2 E. \& B. 363, and Hartley . Cummings, 5 C. B. 247. (g) Sce Dendy r. Ifenderson, 11 Exch. 194 .

(h) Judgm., Hitcheock r. Coker, 6 Ad. \& E. 454 . 
secure himself from a diminution of the annual profits of his trade, it does not appear unreasonable that the restriction should go so far as to secure to the master the enjoyment of the price or value for which the trade would sell, or secure the enjoyment of the same trade to his purchaser, or legatee, or executor. And this can only be effected by making the restriction of the servant's setting up or entering into the trade or business within the given limit co-extensive with the servant's life (i).

The principle established by Hitchcock v. Coker, and recognised in subsequent cases, accordingly is that a restriction reasonably limited as to space, but enduring, for the life of the party restrained, may be valid $(k)$.

In determining as to the reasonableness of a contract in restraint of trade, regard being had to the extent of in regard area (l) over which it is to be in force, our Courts will consider whether the restraint in question, to which formerly some limit was considered necessary $(m)$, is larger and wider than the protection of the party with whom the contract is made can possibly require; if it be so, such restraint must be deemed unreasonable in

(i) Judgm., Hitchcock v. Coker, 6 Ad. \& E. 454, 455 ; Archer v. Marsh, Id. $959 ;$ Wallis v. Day, 2 M. \& W'. 273 ; Jacoby v. Whitmore, 49 L. T. 335.

(k) Judgm., Elves v. Croft, 10 C. B. 259, citing Mallan v. May, 11 M. \& W. 653 ; Rannie v. Irvine, 7 M. \& Gr. $969 ;$ Pemberton v. Vanghan, 10 Q. B. 87 ; Hastings v. Whitley, 2 Exch. 611 ; Atkyns v. Kinnier, 4 Exch. 776; acc. Tallis v. Tallis, 1 E. $\&$ B. 391 .

(l) Where distance is specified in such a contract, it must be measured in a straight line from one point to the other: Mloufict v. Cole, L. R. 8 Ex. 32 ; $S$. C., 7 Id. 70.

(m) Per Parker, C. J., Mitchel v. Reynolds, 1 P. Wms. 181; 1 Sm. L.
C., 9th ed., 430 ; Tallis v. Tallis, 1 E. \& B. 411 ; Ward v. Byme, 5 M. \& W. 548; Hinde v. Gray, 1 M. \& Gr. 195; per Best, C. J., Homer v. Ashford, 3 Bing. 326 ; ef. also p. 363, n. $(x)$. The test of the validity of a covenant in restraint of trade, whether limited or unlimited in the area of its application, is whether it be reasonable (Nordenfelt v. Mfaxim Nordenfelt, (1894) A. C. 535); Dubowski v. Goldstein, (1896) 1 Q. B. 478, C. A. In the following receut cases corenants unrestricted in space have been held valid: Mills $\mathrm{r}$. Dunham, (1891) 1 Ch. 576; Badische Anilin Fabrik r. Schatt, (1892) 3 Ch. 447; Nordenfelt $\mathrm{v}$. Maxim Nordenfelt Co., (1894) A. C. 535, affirming C. A., (1893) 1 Ch.630. 
law, and the contract which would enforce it will be void $(n)$.

Sometimes difficulty may be felt in applying the general principle just stated to particular facts; and where the question turns upon the reasonableness or unreasonableness of the restriction of the party from carrying on trade or business (o) within a certain space or district, the answer may depend upon various circumstances that may be brought to bear upon it: such as the nature of the trade or profession, the populousness of the neighbourhood, the mode in which the trade or profession is usually carried on $(p)$, and other matters with which the Court cannot in reason be supposed to be conversant. From decided cases we collect, however, that the interest of the party claiming protection has been held to extend very widely. Thus, contracts between professional men have been supported where the area of exclusion was apparently greater than the area of the plaintiff's practice. In Horner v. Graves (q) where the area of exclusion from practice as a dentist was a circle round York of the diameter of 200 miles, although holding the restriction too large, the Court observe, that, unless the case was such that the restraint was plainly and obviously unnecessary, they would not feel themselves justified in interfering. In Mallan v. May (r), where exclusion from the practice of a dentist in London was held to be reasonable and valid, the Court say, "it would be better to lay down such a limit as under any circumstances

(n) Judgm., Hitchoock v. Coker, 6 Ad. St E. 454 ; Nordenfelt r. Maxim Nordenfelt Co., (1894) A. C. 535.

(o) is to the meaning of the phrase "carrying on business" at a place, see Tunner v. Erans, 2 E. \& B. 512 ; S. C., 2 De G., M. \& G. 740; Brampton v. Berleces, 13 C. B., N. S., 538.

(p) Judgin., Ititcheock v. Coker, 6
Ad. \& E. 454 ; acc. Pemberton v. Fanghan, 10 Q. B. 87; Horner v. Graies, 7 Bing. 735,743 .

(q) 7 Bing. 735,744 , citing Datis $\mathrm{v}$. Mason, 5 T. R. $118 ; 2$ R. R. 562: and Burn v. Guy, 4 Fast, 190 ; T R. R. 560. (r) $11 \mathrm{MI}$ \& W. 667 ; and as to the construction of the agreement in this case, sce S. C., 13 M. \& M. 511. 
would be sufficient protection to the interest of the contracting party, and, if the limit stipulated for does not exceed that, to pronounce the contract to be valid." In Price v. Green (s), a covenant not to carry on a certain trade "within the cities of London or Westminster, or within the distance of 600 miles from the same respectively," was held to be divisible -good, so far as it related to London and Westminster ; but void as to the other part. And, in Tallis v. Tallis $(t)$, a covenant was held good, by which the defendant restricted himself from carrying on the business of a canvassing publisher in London and within $\mathbf{1 5 0}$ miles of the General Post Office, or in Liverpool or Manchester, or within a like distance of either of those towns; such restriction, regard being had to the nature of the plaintiff's business, not appearing to the Court to be unreasonable.

This principle has, of late, been extended even further. Thus in Leather Cloth Co. v. Lorsont (u), the defendant was held bound by his covenant not to carry on directly or indirectly, or allow others to carry on, in any part of Europe, the manufacture or sale of productions manufactured by the process sold by him to the plaintiffs. And in Rousillon v. Rousillon $(x)$, it was decided by Fry, J., that there is no absolute rule that a covenant in restraint of trade is void, if

(s) 16 M. \& W. $346 ;$ S. C., 13 M. \& W. 695 ; acc. Nicholls v. Stretton, 10 Q. B. 346 ; S. C., 7 Beav. 42 ; Baines v. Geary, $35 \mathrm{Ch}$. D. 154 (as to which case, see Dubonoslit v. Goldstein, (1896) 1 Q. B., at p. 486, per Rigby, L. J.); Rogers v. Iraddocks, (1892) 3 Ch. 346. The Court cannot create or carve out a new covenant for the sake of validating an instrument which otherrise would be roid (cf. Chitty, J., Baker v. Hedgecock, 39 Ch. D. 520 ).

$(t) 1$ E. \& B. 391 ; Nicoll v. Beere, 53 L. T. 659 . An agreement by a party not to be "concerned in any trading establishment" within a considerable portiou of a county, was upheld in Avery v. Langford, 1 Kay, 663 ; in the note to which case (Id. $667-8$ ) a useful abstract is giren of the previous decisions of the Courts of law and equity with reference to contracts in restraint of trade.

(u) L. R. 9 Eq. Ca. 345; Ternon v. Hallam, 34 Ch. D. 752. Sed vide per Cotton, L. J., Davies v. Duvies, 36 Ch. D. 359,385 .

(x) 14 Ch. D. 351 . As to whether it was ever the common law that restraints unlimited in space were ipso facto void, ef. Boxen, L. J., Maxim Tordenfelt v. Mordenfelt, (1893) $1 \mathrm{Ch}$. pp. 660-662; Nordenfelt v. Mraxim Nordenfelt Co., (1894) A. C. per Lord Hersehell, L. C., at p. 546 , and per Lord Macnaghten, at p. 562. See also Mills v. Dunham, (1891) 1 Ch. 576 ; Badische Anilin Fabritiv. Schott,(1892) 3 Ch. 44 . 
unlimited in regard to space. The question in each case is whether the restraint extends further than is necessary for the reasonable protection of the covenantee. If it does not do that, the performance of the covenant will be enforced, eren though the restriction be unlimited as to space. In the case just cited, an agreement not to represent any other champagne house for two year's after leaving the plaintiffs, nor to establish himself, nor associate himself with other persons or houses in the champagne trade for ten years after such leaving, was held binding on the defendant.

The House of Lords in Nordenfelt, appellant, v. Maxim Nordenfelt $C o .(y)$, respondents, decided that a covenant by which a patentee and manufacturer of guns and ammunition covenanted with a company to which his patents and business had been transferred, not to engage in the business of a manufacturer of guns and ammunition except in the company's behalf for a period of twenty-five years, although umrestricted as to space, was not, having regard to the nature of the business and the limited number of the customers (which were English and Foreign Governments), wider than was necessary for the protection of the company, nor against the interests of this country, and was therefore binding.

In accordance with the policy of our law, which is opposed to any undue restraint of trade, a bond was in Hilton $v$. Eckersley (z) held void, by which the obligors, who were mill-owners in a manufacturing town, agreed to carry on their trade conformably to the will of the majority ; the bond being designed to counteract a combination amongst the operatives, though not supported by any good consideration. Prima facie, remarked the Court of Exchequer Chamber in this case, it is the privilege of a trader in a free country, in all matters not contrary to law, to regulate his own mode of

(y) (1894) A. C. 535, affirming C. A. (S. C., s. n., Maxim Nordenfill r. Nordenfelt, (1893) 1 Ch. 630). (z) 6 E. \& B. 47 ; Mineral Water, ge., Soc. v. Booth, 36 Ch. D. 465. 
carrying on trade, according to his own discretion and choice $(a)$. If the law has in any matter regulated or restrained his mode of doing this, the law must be obeyed; but no power short of the general law ought to restrain his free discretion.

A few instances will suffice to show, that a contract of immoral tendency cannot, as between the parties thereto, be made the foundation of an action (b):-an agreement with a view to future illicit cohabitation is void $(c)$; the hire of a carriage $(d)$, or the rent of lodgings let to an immodest woman, to enable her to attract or to consort therein with the other sex cannot be recovered (e); a printseller cannot recover the price of libellous or indecent prints delivered to the defendant $(f)$, and generally " if a person makes a contract with the knowledge that another intends to apply its subject-matter to an immoral purpose, he cannot recorer upon it " $(g)$. "A contract lawful in itself " being " illegal if it be entered into with the object that the law should be violated" $(h)$.

It is clear, that past cohabitation or previous seduction would not be a good consideration for a parol promise, neither would it be an illegal consideration,-it would be no consideration at all. Inasmuch, however, as an instrument under seal does not require a consideration to support

(a) Quoted approringly by Lord Halsbury, L. C., in Moguil S.S. Co. v. BeGregor, Gow \& Co., (1892) A. C. 25. See this case, 23 Q. B. D. 598 (per Bowen, L. J., and Fry, L. J.), and loc. cit., disapproring Crompton, $J$.'s opinion, expressed in Hilton v. Eckersley, that the parties to a contract in restraint of trade are indictable. Contracts in restraint of trade are illegal only in the sense that the law will not enforce them.

(b) See Hoore v. Woolsey, 4 E. \& B. 243 , and cases infra.

(c) Walker v. Perkins, 3 Burr. 1568.

(d) Pearee v. Brookes, L. R. 1 Ex. 213. (e) Girardy r. Richardson, 1 Esp. 13; Appleton r. Campbell, 2 Carr. \& P. 347. See Jennings v. Throgmorton, R. \& M. 251 ; Boury v. Bennet, 1 Camp. $348 ; 10$ R. R. 697, Lloyel r. Johnson, 1 B. \& P. $340 ; 4$ R. R. 822; Feret v. Hill, 15 C. B. 207 ; cited Taylor v. Chester, L. R. 4 Q. B. 311; Hamilton r. Grainger, $5 \mathrm{H} . \& \mathrm{~N} .40$.

(f) Fores r. Johnes, 4 Esp. $97 ; 6$ R. R. 840. See Stockdale v. Onuhyn, 5 B. S C. 173.

(g) Per Mellor, J., Taylor v. Chester, L. R. 4 Q. B. 311 ; Coxtan r. Milboum, L. R. 2 Ex. 230.

(h) Judgm., Wrangh Y. Morris, L. R. 8 Q. B. 202 .
Inmoral contracts. 
it, a bond given for the maintenance of a woman, founded on past cohabitation, would be good (i); but it by no means thence follows, that a covenant to pay a sum of money tainted with illegality can be enforced $(k)$, ex. gr., a covenant to pay damages to a petitioner for divorce on the ground of adultery would be void as contrary to the policy of the law $(l)$. And if an agreement had been made to pay a sum of money in consideration of future cohabitation, and after cohabitation the money had remained unpaid, a bond given to secure that money could not under the circumstances be enforced $(m)$.

To sum up briefly what has here been said as to the effect of fraud and illegality upon a contract, whatever be its nature or subject-matter, the strictest good faith ought, both in its inception and performance, to be observed by the contracting parties. A want of bonk fides may be evinced as well by the wilful suppression of facts as by their mis-statement: qui tacet consentire videtur is a rule well recognised in law, and of no infrequent applicability. There may be a fraudulent representation sufficient to avoid a contract or to be the ground of an action, without actual active declaration by the party contracting $(n)$.

But, although good faith in its broad and comprehensive sense is thus required, and although a man will not be permitted to benefit by his own fraud or to take advantage of his own wrong, our law nevertheless expects that due care and a reasonable degree of caution should be exercised by either party to a contract. Sometimes, therefore, it will say to the disappointed suitor-vigilantibus non

(i) Tallance v. Blagden, $26 \mathrm{Ch} . \mathrm{D}$. 353.

(k) Judgm., Fisher v. Bridges, 3 E. \& B. 650 ; ante, p. 281.

(l) Gipps r. Gipps, 11 H. L. Ca. 1.

(in) Judgm., Fisher r. Bridges, supra. And vide per Lord Selborne, Ayerst v. Jonkins, L. R. 16 Eq. Ca.
275.

(ii) Per Coltman, J., Pilmore r. Hood, 5 Bing. N. C. 109 . See Keates v. Earl of Cadogan, 10 C. B. 591 (which explains Hill v. Gray, I stark. N. P. C. $434 ; 18$ R. R. 802), and cases there cited; ante, p. 330 . 
dormientibus jura subveniunt; and at other times, where evidence presents itself of a gross amount of negligence and want of caution, it will remind a purchaser, however innocent, that qui vult decipi decipiatur. Lastly, where an individual, seeking repayment of money improperly obtained from him, is shown to be contaminated with fraud, or to have participated in a transaction objectionable on moral grounds, or opposed to the word, intent, or policy of the law, it will altogether refuse to interfere, answering his application in the words of C. J. Wilmot (o), that "no polluted hand shall touch the pure fountains of justice."

And yet, whether lending or withholding its aid when supplicated for breach of contract, our law, which has been not inaptly designated as norma recti $(p)$, jubens honesta et prohibens contraria $(q)$, in no case acts contrary to the spirit of the rule laid down by the Prætor, but says with himPacta conventa, qua neque dolo malo neque adversus leges facta erunt, servabo (r).

(o) Ante, p. 278 .

(p) 3 Bulstr. 313 .

(q) 2 Inst. 588.

(r) D. $2,14,7, \S 3$. 


\section{CHAPTER II.}

\section{THE STATUTE OF FRAUDS, ETC.}

In the preceding pages the nature of a simple contract has been to some extent examined, and certain general rules applicable thereto have been laid down. No attempt, however, has yet been made fully to compare a simple with a special contract in respect of those characteristics appertaining to the latter which have been specified at p. 266 . That a 'consideration' is requisite to support a contract not under seal has indeed been shown, and from the explanation offered touching the doctrine of 'merger,' it will probably have been surmised that that particular doctrine, at all events, does not and cannot in strictness apply where the solemnity of a seal is wanting. Before, however, proceeding further with the comparison suggested, it becomes essential to indicate in what respect a simple contract evidenced by writing (a) differs from an oral agreement, and to exhibit some of the more important statutory regulations bearing upon this subject. In the present chapter I purpose, then, to commence with a brief view of the wording and practical operation of section 4 of the Statute of Frauds, and to conclude with some few additional remarks as to simple contracts generally.

Parol colstractwhat.

"All contracts are by the laws of England distinguished into agreements by specialty and agreements by parol; nor is there any such third class as contracts in writing; if they

(a) Some contracts are by mercantile custom required to be in writing - for instance-the word "charter" "im. ports a writing. A verbal charter is a thing unknown in maritime com merce:" per Lush, J.", Adanson $\mathrm{r}$ Newcastle Steam-ship Freight Insur Ass., 4 Q. B. D. $467,468$. 
are merely written and not specialties they are parol:" such are the words of Skynner, C. B., as reported in Rann v. Hughes (b). But, although this is so, our common law, which requires, as a general rule, that the best evidence of every transaction which the nature of the case admits of shall be given, ascribes a certain degree of weight and importance to a written, which it denies to an oral or merely verbal contract; that is to say, our law considers that, where an agreement between two parties has been reduced into writing, that writing itself offers the best evidence which can be given for determining what the intentions of the parties really were $(c)$, and what their reciprocal obligations are.

Hence, if there be a written contract between A. and B., which is duly signed by them, and is meant to constitute per se a complete and entire agreement $(d)$, evidence is (unless fraud be in issue $(e)$ ) inadmissible at law to show what passed by word of mouth between the parties, either before the written instrument was made, or during the time that it was in a state of preparation and adjustment, so as to vary its effect $(f)$; and even in equity, if there were no fraud, mistake

(b) 7 T. R. $350(a)$

(c) "It is contrary to the rules of law to admit extrinsic evidence to show that the intention of a party executing a written instrument is different from that apparent on the face of the instrument itself:" per Abbott, C. J., Woodbridge v. Spooner, 3 B. \& Ald. 233; 22 R. R. 365 ; see also Martin v. Pycroft, 2 De G., M. \& G. 785.

(d) See Harris v. Rickett, 4 H. \& N. 1; Pym v. Campbell, 6 E. \& B. 370, 374 (where Erle, J., says, "The distinction in point of law is, that evidence to vary the terms of an agreement in writing is not admissible, but eridence to show that there is not an agreement at all is admissible"): Rogers v. : Hadley, 2 H. \& C. 227, 249 ; Kempson v. Boyle, 3 H. \& C. 763 ; Bolckow v. Seymour, 17 C. B., N. S., 107; Lindley v. Lacey, Id. 578; Wallis v. Littell, 11 C. B., X. S., 369,375 ; judgm., Barker v. Allan,

\section{H. \& N. 72.}

An invoice is only eridence of a contract-not a contract per se: Holding v. Elliott, 5 H. \& X. 117 .

(e) Hotson v. Browne, 9 C. B., N. S., 442.

(f) Goss v. Lord Nugent, 5 B. \& Ad. 64,65 ; Evans v. Roe, L. R. 7 C. P. 138 ; Morgan v. Griffith, L. R. 6 Ex. 70 ; per Martin, B., Langton v. Higgins, $4 \mathrm{H}$. \& N. 408. "There is an ambiguity in the term 'parol evidence,' or rather there are two sorts of parol evidence, as to the admissibility of which discussion has arisen in many of the cases: the first is oral evidence as to the state of facts existing at the time the written agreement is made: the second is parol eridence of what is said on the occasion:" per Byles, J., Ilumford v. Gething, 29 L. J., C. P. 107 ; Erskine v. Adeane, L. R. 9 Ch. App. 760 . 
or surprise, verbal evidence to contradict the written agreement could not be received $(g)$.

When, however, an agreement has actually been reduced into writing, it is by our customary law competent to the parties at any time before breach of it by a new contract not in writing, either altogether to waive, dissolve, or annul the former agreement, or to add to, or vary the terms of it, and thus to make a new contract, which is to be proved partly by the written agreement and partly by the subsequent verbal terms engrafted thereupon $(h)$.

Thus, it is not competent to the acceptor of a bill of exchange to set up an oral contract entered into before his acceptance of the bill, and which is inconsistent with the contract appearing ex facie upon it (i). Neither can a like contemporaneous agreement, incompatible with that evidenced by the bill, be set up to vary or restrain it: ex. gr., evidence cannot be received of an oral agreement, that a bill drawn payable at three months shall not be payable till the expiration of four months from its date $(k)$. "It would," says Lord Abinger, C. B., in Adams v. Wordley (l), "be very dangerous to allow a party to alter in such a manner the absolute contract on the face of a bill of exchange; the effect of the cases is, that you are estopped from saying that you made any other contract than the absolute one on the face of the bill $(m)$. A contract, which seeks by subsequent oral matter to discharge altogether the contract created by the bill and create a new one, is wholly

(g) Watson, Comp. Eqty., I. 75, citing Croome v. Lediard, 2 M. \& K. 251.

(h) Goss r. Lord Nugent, supra ; Douglas r. Watson, 17 C. B. 685.

In connection with the text a general reference must here be made post to Chap. 6., which treats of the admissibility of eridence of custom or usage to explain a contract.

(i) Besant r. Cross, 10 C. B. 895. See Young v. Austen, L. R. 4 C. P. 553, followed in Corkling v. Massey,
L. R. 8 C. P. 395 ; Abrey จ. Crux, L. R. 5 C. P. 37 .

(k) Judgm., Manley v. Boyeot, 2 E. $\&$ B. 56 . See Salmon r. $W e b b, 3$ H. L. Ca. 510.

(l)1 M. \& W. 374, 380.

(m) See also per Willes, J., Strong $\nabla$. Foster, 17 C. B. 222; Taylor v. Burgess, 5 H. \& N. 1 ; Pooley r. Har. radine, 7 E. \& B. 431 ; Wright $\checkmark$. Hickling, L. R. 2 C. P. 199 ; Green. ough v. McClelland, 2 E. \& E. 424, 429. 
different, and may no doubt be given in evidence; it is consistent with the bill, but this is inconsistent with it."

The following case also illustrates the doctrine of our law just mentioned: Money was advanced upon the security of a joint and several promissory note by a loan society, and at the time of effecting the loan and making the note, a printed book of the society's rules was given to the defendant, who was one of the makers of the note. Now, the rules contained in this book would, if admissible in evidence, have varied the engagement which the defendant entered into as maker of the note. Nothing, however, appeared in writing to connect the rules in question with the note, and the Court held, that the express contract and engagement on the face of the note could not be thus varied $(n)$.

The strictness of the above rule, which excludes parol evidence at variance with the written contract, may, however, be qualified on equitable grounds, ex. gr., on the ground of mistake in framing the contract $(o)$.

In Eden v. Blake ( $p$ ) the action was brought by an auctioneer to recover the price of a dressing-case sold by him to the defendant at a public auction. The dressing-case in question had, in the printed catalogue of articles intended for sale, been described as having silver fittings; whereas, in point of fact, the fittings were plated only. In support, however, of the action, it was proposed to prove, that prior to the dressing-case being put up for sale, the auctioneer stated publicly, in the hearing of the defendant, that the catalogue was incorrect in describing the fittings as silver, and that the dressing-case would be sold as having plated fittings. The reception of this evidence was objected to, on the ground that

(n) Brown r. Langley, 4 M. \& Gr. 466. See Halhead v. Young, 6 E. \& B. 312 .

(o) Wake v. Harrop, 1 H. \& C. 202 ; S. C., 6 H. \& N. 768 ; Lawrence v. Walmsley, 12 C. B., N. S., 799.
See Borrowman v. Rossel, 16 C. B.; N. S., 58 .

(p) 13 M. \& W. 614, with which compare Shelton v. Livius, 2 C. \& J. 411 . 
it tended to vary the printed particulars of sale; the evidence tendered was, nevertheless, admitted, and, as the Court in banc held, rightly so, there having been no written contract between the parties. In this case the Statute of Frauds had no application, inasmuch as the price of the article sold was less than $10 l .(q)$. It has been held that in an action for a breach of warranty on the sale of goods under a written contract oral evidence is not admissible to show that the vendor's agent at the time of the sale represented the goods to be of a particular quality $(r)$.

Thus much, then, as to the superior efficacy which our common law attributes to a written over a merely verbal contract. It is in the next place to be remarked, that under the provisions of various statutes, particular kinds of contracts are expressly required to be in writing; and, where any such statute applies, it is quite clear that the whole of the contract which falls within its operation must be in writing, so that a written agreement or engagement between parties made conformably to its terms could not subsequently be varied by word of mouth $(s)$. Foremost in point of practical importance amongst such enactments stands the Statute of Frauds (29 Car. 2, c. 3) (t).

The Statute of Frauds was passed, as the preamble states, "for prevention of many fraudulent practices which are commonly endeavoured to be upheld by perjury and subornation of perjury." It has an important bearing, by virtue of several

(g) Post, p. 404.

(r) Harnor v. Groces, 15 C. B. 667.

(s) Where any such statute is thought to apply, care must be taken to distinguish between the sufficiency of the contract as a "final and binding agreement" and its sufficiencr, regard being had to the operation of the Act. See Rossiter v. Miller, 3 App. Cas. 1124, 1147.

( $t$ ) With reference to statutes such as above alluded to, the following remarks of Maule, J., in Mrorton $\mathbf{r}$.
Copeland, 16 C. B. 535, deserre atten. tion :-The learned judge obserres that a special object may sometimes be aimed at in requiring an instrument to be in writing, "viz., to identify the act as the act of the party, as in the case of a will, and in other instances mentioned in the Statute of Frauds, where the instrument is expressly required to be signed by the party to be charged thereby. In those cases the signature of the party serves to identify the writing as the very writing by which the party is to be bound. In 
of its provisions, upon the law merchant; and with reference more particularly to that branch of law attention will now be directed to it. The statute requires that certain contracts and agreements therein specified shall be in writing, or, at all events, shall be evidenced by some note or memorandum thereof in writing. It further indicates disabilities, which, in default of compliance with its requirements in this respect, will or may be entailed upon parties. In order to determine the precise nature of the disabilities, which under given circumstances may thus be incurred, close attention must be paid to the wording of the particular section of the Act bearing upon the transaction in question. Moreover, it must be borne in mind that the Statute of Frauds "is a weapon of defence not offence," and does not make any signed instrument a valid contract by reason of the signature, "if it is not such according to the good faith and real intention of the parties" $(u)$.

Omitting any allusion to those portions of the Act which relate to parol conveyances of land, leases and assignments, to nuncupative wills, devises, declarations of trust and other matters not properly falling within the scope of the Commentaries, we shall proceed to analyse, illustrate, and explain, by decided cases, its 4th section, and defer until the chapter on the Contract of Sale of Goods ( $x$ ) the consideration of s. 4, subs. 1, of the Sale of Goods Act, 1893, which has

some of the cases provided for by that statute the signature may be either that of the party himself, or that of an 'agent thereunto lawfully authorised by writing,' as in the case of leases (8. 3) ; or of 'some other person thereunto by him lawfully authorised,' as in the case of agreements (s. 4); or by some other person in his presence and by his express directions,' as in the case of a devise of land (s. 5); or 'in his presence and by his direction and consent' (s. 6); or by 'their agents thereunto lawfully authorised,' as in the case of the sale of goods (s. 17)." (The words are now, "his agent in that behalf," cf. s. 4, subs. 1, Sale of Goods Act, 1893 , and post, p. 406.) "The necessity of signature arises in every case from the express requirement of the statute. Signature does not necessarily mean writing a person's ehristian and surname, but any mark which identifies it as the act of the party."

(u) Per Lord Selborne, Jervis v. Berridge, 8 Ch. App. 360 ; and in Hussey v. Horne-Payne, 4 App. Cas. 323 ; judgm., Hickman v. Haynes, L. R. 10 C. P. 598. See Jmes r. Victoria Graving Dock Co., 2 Q. B. D. $314,323$.

(x) See post, p. 402 . 
been substituted for the 17 th section of the Statute of Frauds, our object being to call attention, albeit briefly, to every point of real practical importance connected with or likely to arise upon it.

29 Car. 2, c. 3 , s. 4 .

The 4th section of the statute enacts "That no action shall be brought,

- whereby to charge any executor or administrator upon any special promise to answer damages out of his own estate;

- or, whereby to charge the defendant upon any special promise to answer for the debt, default, or miscarriages of another person;

- or, to charge any person-upon any agreement made upon consideration of marriage;

- or, upon any contract or sale of lands, tenements, or hereditaments, or any interest in or concerning them ;

- or, upon any agreement that is not to be performed within the space of one year from the making thereof; unless the agreement upon which such action shall be brought, or some memorandum or note thereof, shall be in writing and signed by the party to be charged thereuth, or some other person thereunto by him lawfully authorised."

Now, looking at the above section, it will be found to enumerate five distinct classes of contracts, in regard to each of which it is enacted, that no action shall be brought unless the agreement which is the foundation of such action, or some memorandum or note thereof, shall be in writing and signed by the party to be charged therewith, or his duly authorised agent. It becomes, then, material, in limine,

Meaning of word "agreement" there used. to consider what may be the meaning of the word "agreement," just used. It has been formally decided, that this word "agreement" must be understood in its strict legal sense as including not merely the main terms of the contract, but likewise the consideration upon which it is founded. As 
to this point Wain v. Warlters (y) must still be regarded as the leading authority, although it is no longer necessary, as we shall presently see, that the consideration for which a guarantie was given should be stated therein $(z)$. There Lord Ellenborough, C. J., observes, that “It seems necessary for effectuating the object of the statute, that the consideration should be set down in writing as well as the promise, for otherwise the consideration might be illegal, or the promise might have been made upon a condition precedent, which the party charged may not afterwards be able to prove, the omission of which would materially vary the promise by turning that into an absolute promise which was only a conditional one: and then it would rest altogether on the conscience of the witness to assign another consideration in the one case, or to drop the condition in the other, and thus to introduce the very frauds and perjuries which it was the object of the Act to exclude, by requiring that the agreement should be reduced into writing, by which the consideration as well as the promise would be rendered certain."

The word "agreement," then, occurring in the 4th section of the Statute of Frauds, means an agreement complete as regards its material terms $(a)$, and will be satisfied by a writing which states the names of the parties (b), the suljectmatter of the contract, and (except where the instrument is a guarantie), the consideration upon which it is founded $(c)$. Several documents, moreover, which on the face of them are connected together by internal references (which may be

(y) 5 East, 10, 7 R. R. 645, Preface vi ; 2 Sm. L. C., 9 th ed., 266, cited per Erle, J., E. B. \& E. 980, Powers v. Fowler, 4 E. \& B. 511, 516.

Numerous cases upon the point in question are collected in note $(b)$ to French v. French, 2 M. \& Gr. 649.

(z) $19 \& 20$ Vict. c. 97 , s. 3 , cited post, p. 379 .

(a) See Fitzmaurice r. Bayley, 9 H. L. Ca. 78. The memorandum or note must be a memorandum of an agreement complete at the time the memorandum is made; Wunday v. Asprey, $13 \mathrm{Ch}$. D. 855 .

(b) Williams v. Lake, 2 E. \& E. 349 , approved in Williams v. Byrnes, 1 Moo. P. C. C., N. S., 154, 199.

(c) Per Tindal, C. J., Laythoarp v. Bryant, 2 Bing. N. C. 744: Roberts v. Tucker, 3 Exich. 632; Sucet r. Lee, 3 II. \& Gr. 452. 
supplemented by parol identification), may be put in evidence as constituting an agreement or a memorandum or note thereof, sufficient within the statute. Upon the point now adverted to, Boydell v. Drummond $(d)$ is the leading case, and the principle there acted upon has often been recognised $(e)$.

The written agreement required under the 4 th section of the Statute of Frauds need be signed $(f)$ by " the party to be charged therewith" only $(g)$. In Laythoarp v. Bryant (h), the vendor of leasehold premises who had not signed the memorandum of sale was held entitled to sue the purchaser who had signed it, the words of the 4th section of the statute being deemed explicit, and being thought to afford a ready answer to the argument founded on "want of mutuality" (i). "It is said," observed Tindal, C. J., in this case, "that unless the plaintiff signs there is a want of mutuality. Whose fault is that? The defendant might have required the vendor's signature to the contract; but the object of the statute was to secure the defendant's." It is settled that a written proposal, containing the terms of a projected contract, signed by the defendant, and assented

(d) 11 East, 142.

(e) Per Williams, J., Peek v. North Staffordshire R. C., E. B. \& E. 958 , 1000 ; S. C., 10 H. L. Ca. 473; Ridgway v. Wharton, 6 H. L. Ca. 238; cited in Rossiter v. Miller, 3 App. Cas. 1151 ; Saunderson v. Jackson, 2 B. \& P. 238, 5 R. R. 580; and cases cited Id. (a); Dobellv. Hutehinson, 3 Ad. \&E. 355,371 ; Hammersley v. Baron de Biel, 12 Cl. \& F. 45, explained Alderson v. Maddison, 5 Ex.D.278;7Q.B.D.174; 8 App. Cas. 467 ; see Cave v. Hastings, 7 Q. B. D. 125 ; Shardlow v. Cotterell, $20 \mathrm{Ch}$. D. 90 , reversing $S . C ., 18 \mathrm{Ch}$. D. 280 ; Studds v. Watson, 28 Ch. D. 305 ; Oliver v. Hunting, $44 \mathrm{Ch}$. D. 209 , where parol evidence was admitted to explain the circumstances under which a letter was written, and the evidence so admitted having connected the letter with a memorandum, the two were read together and held to constitute a sufficient memorandum within the Statute of Frauds.

$(f)$ The Statute of Frauds does not require a document to be subscribed but signed; a signature will be suffcient if it authenticates and governs every part of the instrument; Caton v. Caton, L. R. 2 H. L. 127.

$(g)$ As to signing by an agent, see the remarks in connection with s. 4, subs. 1 of the Sale of Goods Act, 1893, post, p. 414. See Evans r. Hoare, (1892) $1 \mathrm{Q}$. B. 593, where the insertion in a letter of the defendants' name by their authorised agent was held to amount to a signature sufficient to satisfy 8.4 of the Statute of Frauds.

(h) 2 Bing. N. C. 735; Liverpool Borough Bank v. Eccles, 4 H. \& N. 139, recognising Laythoarp v. Bryant, supra.

(i) Ante, p. 300. 
to orally by the plaintiff, will satisfy the 4 th section of the statute $(k)$.

Let us now consider for a moment what consequences will result from a non-compliance with the requirements contained in the concluding portion of the 4 th section of the Act. To satisfy ourselves with regard to these consequences, we must look at the introductory part of the same section, which says, that "no action shall be brought" in any of the various cases subsequently specified, unless the directions of the Legislature have been complied with; but it does not say that, in the event of non-compliance therewith, the contract itself shall be roid; and the distinction here suggested may sometimes be material $(l)$.

Bearing in mind the preceding observations, let us make inquiry respecting each of the five specific clauses into which the 4th section of the Statute of Frauds is divisible; and, first, as to "any special promise" by an executor or administrator "to answer damages out of his own estate." In order that an action may be maintainable against the personal representative upon such a promise, a writing signed by him or his agent must be produced in evidence, containing the promise, and disclosing - not necessarily in express terms, but at all events by its tenor-the consideration upon which the promise is founded $(m)$. A proposal made and accepted in writing, which was not intended to operate as an unqualified promise, but to form a part only of a suggested

(k) Smith v. Neale, 2 C. B., X. S. 67, recognised in Reuss v. Picksley, L. R. 1 Ex. 342 ; in Liverpool Borough Bank r. Eccles, 4 H. \& N. 139 ; and in North Staffordshire R. C. v. Peek, E. B. \& E. $994 ;$ S. C., 10 H. L. Ca. 473; Buxton v. Rust, L. R. 7 Ex. 280; Goodwin r. Francis, L. R. 5 C. P. 295 .

(l) Leroux v. Brown, 12 C. B. 801 (as to which, however, see per Willes, J., Williams, app., Wheeler, resp., 8 C. B., N. S., 316; and per Field, J., Rauley v. Rawley, 1 Q. B. D. 460 ,
461), cited in Jones v. Tictoria Graving Dock Co., 2 Q. B. D. 323. See Adams v. Clutterbuck, 10 Q. B. D. 403 . As to the effect of that part of the 4th section of the Statute of Frauds considered in the text, see Griffith v. Foung, 12 East, 513; 11 R. R. 478, per Tindal, C. J., Sweet v. Lee, 4 Scott, N. R., 90 ; v. post, p. 405 .

(m) Rann r. Hughes, 7 T. R. 350, n. ; S. C., 4 Bro. P. C. 27.

"The common law requires that there should be a sufficient consideration to support the promise; and the
Promise by executor, \&c., to damages personally. 
arrangement which was not, in its entirety, acquiesced in by the other party will not satisfy the statute $(n)$. Where the plaintiff declared that the defendant's testator was indebted to a third party, who after the testator's death assigned the debt to the plaintiff, and appointed him to receive it to his own use; and that the defendant in consideration that the plaintiff rould accept the defendant as his debtor, promised to pay it to the plaintiff; the consideration alleged was held to be insufficient to support the promise, so as to charge the defendant personally $(o)$. If, however, in this case, the promise had been in consideration of forbearance by the assignee of the debt to sue the executor, that would have been a valid consideration in law $(p)$.

Promise to answer for debt, \&c., of another.

Of guaranties.

The second clause of the 4 th section of the Statute of Frauds concerns "any special promise to answer for the debt, default or miscarriages of another person." Upon which it is enacted, that "no action shall be brought" unless the agreement containing such promise be "in writing, signed by the party to be charged therewith, or some other person thereunto by him lawfully authorised."

A guarantie is, in fact, a promise to answer for the payment of some debt, or the performance of some duty, in the event of the failure of another person, who is, in the first instance, liable for such payment or performance $(q)$, and consequently must, in order that an action may lie upon it, be in writing $(r)$.

As to the form of this instrument, it will suftice to observe, 1st. That the intention of the guarantor with regard to the period during which the guarantie is to be

statute adds a still further requisite, namely, that the promise should be in writing;" 1 Wms. Saund. 211 (2).

(i) Hamilton v. Terry, 11 C. B. 954.

(o) Forth r. Stanton, 1 Wms. Saund. 210. See Nelson v. Serle, 4 M. \& W. 795.

(p) 1 Wms. Saund., 6th ed., 209, $a(1)$.

(a) See Fell on Guar., 2nd ed., p. 1 ; Mallet v. Bateman, L. R. 1 C. P. 163. As to withdrawing a guarantie, see Grant v. Campbell, 6 Dow, 239, 252.

(r) See Fish r. Mutchinson, 2 Wils. 94: Chater r. Beckett, T T. R. 201, 4 R. R. 418 . 
in force should be clearly expressed, otherwise embarrassing questions of construction may arise $(s)$, and the guarantor should say whether he means to be liable for future advances only, or for past as well as future advances $(t)$; 2ndly. Inasmuch as the 4 th section of the Statute of Frauds does not require the contract itself to be in writing $(u)$, but a memorandum of it, and as a memorandum, properly signed, of a by-gone contract is sufficient to satisfy the Act, if words be introduced into a paper signed by " the party to be charged;" or if an alteration be made in it; the addition or alteration thus made may be considered as authenticated by the signature already on the instrument, provided it be plain that it was meant to be so authenticated $(x)$.

The special promise above mentioned must, according to the rule stated at p. 311 , be founded on a good consideration, though, by the $19 \& 20$ Vict. c. 97 , s. 3, it shall not "be deemed invalid to support an action, suit, or other proceeding to charge the person by whom such promise shall have been made, by reason only that the consideration for such promise does not appear in writing, or, by necessary inference, from a written document."

The meaning of the word "agreement," ascertained by the various decisions noticed at pages 374,375 , has, so far as regards the particular clause of the 4 th section of the Statute of Frauds now under notice, been thus materially modified, and the Courts have consequently been relieved from discussing the question, often found most embarrass-

(s) See Nottingham Hide Co. v. Bottrill, L. R. 8 C. P. 694 ; Coles v. Pack, L. R. 5 C. P. 65. As to "continuing" guaranties, see Coulthart $\mathrm{v}$. Clementson, 5 Q. B. D. 42 ; Lloyd's v. Harper, 16 Ch. D. 290 ; Beckett v. Addyman, 9 Q. B. D. 783 .

( $t$ See Broom v. Bachelor, 1 H. \& N. 255; Wood v. Priestner, L. R. 2 Ex. 282, 66; Horler v. Carpenter, 3
C. B., N. S., 172. See also 19 \& 20 Vict. c. 97 , s. 4 ; Backhouse r. Hall, 6 B. \& S. 507.

(u) Hoyle, In re, Hoyle v. Hoyle, (1893) 1 Ch. 84. C. A. held recital in a will of a verbal guarantie sufficient memorandum to satisfy the statute. 862 . 
ing $(y)$,-Does the consideration sufficiently appear upon the face of the guarantie?

But, although the statute thus abrogates the rule laid down in Wain v. Warlters (z), and enables a plaintiff to give parol evidence of the consideration for a guarantie, we must remember that "a consideration expressed in writing formerly discharged two offices: it sustained the promise and might also explain it," and now, "parol evidence, though it may supply the consideration, cannot go further and explain the promise" $(a)$.

Let us in the next place briefly consider what cases are within, and what are excluded from, the operation of that particular clause of the Statute of Frauds, the effect whereof we have been discussing. The clause in question applies where the object of the party seeking to avail himself of the guarantie is to charge the defendant upon his promise "to answer for the debt, default, or miscarriages of another." It has, therefore, no application where the evidence adduced discloses a direct liability attaching to the guarantor $(b)$, or an absolute transfer of liability to him from the original debtor. Where the individual whose debt is said to have been guarantied ceases altogether, upon the so-called guarantie being given, to be liable, there the transaction in question is not one which requires to be evidenced by writing within the Statute of Frauds. In Birkmyr v. Darnell (e), the distinction between a direct and a collateral liability is thus illustrated by the Court: "If," they say, "two come to

(y) See, for instance, Oldershaw $\mathrm{v}$. King, 2 H. \& N. 517, 399 ; cited per Bramwell, B., Hoad v. Grace, 7 H. \& N. 497 .

(z) Ante, p. 375 .

(a) Judgm., Holmes v. Mitchell, 7 C. B., N. S., 370, adopted per Williams, J., Peek v. North Staffordshire R. C., 29 L. J., Q. B. $103 ; S . C$., E. B. \& E. 958,10 H. L. Ca. 473.

(b) Forth v. Stanton, 1 Wms. Saund.
$211 b$; Fitzgerald v. Dressler, 7 C. B., N. S., 374; Reader v. Kingham, 13 C. B., N. S., 344 ; Mtacrory v. Scott, 5 Exch. 907 ; Liverpool Borough Bank จ. Logan, 5 II. \& N. 464.

(e) Salk. $27 ; 1$ Sm. L. C., 9th ed., 334 (as to which see Mountstephen $\mathrm{r}$. Lakeman, L. R. 7 Q. B. 196, 202 ; S. C., affirmed L. R. 7 H. L. 17); Tomlinson v. Gell, 6 Ad. \& E. 564 ; Butcher v. Stewart, 11 M. \& W. 857. 
a shop, and one buys, and the other, to gain him credit, promises the seller, 'If he does not pay you I will,' this is a collateral undertaking, and void without writing by the Statute of Frauds. But if he says 'Let him have the goods, I will see you paid,' this is an undertaking as for himself, and he shall be intended to be the very buyer, and the other to act but as his servant." It should be observed, that the cases here put by the Court are meant as examples merely, and to show that the surrounding circumstances may be looked at $(d)$, with a view to determining whether a particular transaction does or does not amount to a guarantie within the Statute of Frauds. The question will in truth be one of fact, as may be seen by comparing Matson v. Wharam (e) with Birkmyr v. Darnell, just cited, and by consulting the remarks of Pigott, B., in Mountstephen v. Lakeman $(f)$.

The subject before us is explained in the notes to Wms. Saund. $(g)$, where it is said that the subject of inquiry at Nisi Prius very often is-to whom was credit given? and such nice distinctions have been taken on the wording of the promise as to make it impossible to lay down any precise rule of construction with reference to it; but the jury must determine to whom the credit was given. If it appears that the credit was given to the defendant-that is, if the goods, \&c., were really sold to him, the clause of the statute cannot apply. But if it appears that the person for whose use the goods were furnished is liable, and a sufficient promise in writing by the defendant to pay the debt is produced, the plaintiff will be entitled to recover, the promise being collateral $(h)$. "If," observed Pollock, C. B. (h), "a

(d) Leathley v. Spyers, L. R. 5 C. P. 595,605 ; Heffield v. Mfeadows, L. R. 4 C. P. 595 ; Laurie v. Scholefield, Id. 622.

(e) 2 T. R. 80, 1 R. R. 429.

(f) L. R. 7 Q. B. $205 ;$ S.C., affirmed L. R. 7 H. L. 17 . (g) 1 Wms. Saund., 6th ed., 211 $b, c$. See Walker v. Hill, 5 H. \& $\mathrm{S}$. 419.

(h) Batson v. King, 4 H. \& N. 739, 740 , commenting on Green $\mathrm{r}$. Cresswell, 10 Ad. \& E. 453,459 . 
man says to another, 'If you will at my request put your. name to a bill of exchange, I will save you harmless,' that is not within the statute. It is not a responsibility for the debt of another. It amounts to a contract by one that if the other will put himself in a certain situation, the first will indemnify him against the consequences."

Such being the general mode of determining whether a case is or is not within the statute, it may be well to specify the following states of facts, in which it has been held or intimated by the Court that the statute would not apply :-

1. If A. agree to accept C., a debtor of B., as his debtor in lieu of B., such an arrangement clearly involves a transfer of liability from B. to C., and is very different from a guarantie by $\mathrm{C}$. as surety of B.'s debt to A. (i) : here consequently the statute does not apply.

2. The statute applies only to promises made to the person to whom another is already or is to become answerable. It must be a promise to be answerable for a debt of or a default in some duty by that other person towards the promisee $(k)$.

3. If A. undertake to B. that C. shall do a-particular thing, no privity existing between $B$. and C., the liability assumed by $\mathrm{A}$. will be direct, and not collateral $(l)$.

4. Where, in consideration of a del credere commission, A. undertakes to be responsible to $B$. for due payment of the purchase-money of goods to be sold through the agency of A., this undertaking does not fall within the statute, and need not be in writing $(m)$ : for, though the engagement

(i) Judgm., Gull r. Lindsay, 4 Exch. 52.

(k) Hargreates r. Parsons, 13 M. \& W. 561, 570; Reader r. Kingham, 13 C. B., N. S., 344, 353, 356; Cripps v. Hartnoll, 4 B. \& S. 414; Guild \& Co. r. Conrad, (1894) 2 Q. B. 885 (cf. observations in this case on Cripps v. Hartwoll, loc. cit., and Green v. Cressicell, 10 A. \& E. 453). (l) Hargreaves r. Parsons, supra.

(iii) Couturier v. Hastie, 8 Exch. 40; the judgment in which case was reversed in error on a point other than that mentioned in the text; see Hastie r. Conturier, 9 Exch. 102; S. C., 5 H. L. Ca. 673. See Re Willis, 4 Exch. 530; Sutton v. Grey, (1894) I (2. B. 285 (C. A.) (following Couturier v. Hastie). 
thus entered into by A. may terminate in a liability to pay the debt of another, that is not the immediate object for which the consideration is given $(n)$. Such an agent does not guarantee the solvency of the third party, but only undertakes to indemnify his employer against his own inadvertence or misfortune, should he make contracts for him with persons unable or unwilling to perform them $(o)$.

The clause before us applies, however, to promises to answer for the tortious default or miscarriage of another as well as for his breach of contract; and, accordingly, where A. had, without leave, ridden the plaintiff's horse and caused his death, a promise by the defendant to pay the plaintiff the damage which he had sustained, in consideration of the plaintiff forbearing to sue A., was held to be void because not in writing $(p)$.

The policy of the particular clause of the Statute of Frauds under consideration, obviously was to prevent that fraud and perjury which had been found by experience or was thought likely to arise from trusting to evidence of less authority than that of a written document, for fixing upon a defendant the responsibility for the debt, default, or miscarriage for which another person was primarily liable $(q)$. The clause in question seems to have successfully accomplished its object until a mode was discovered of evading it by shaping the demand, not upon a special promise of the defendant which is within the letter of the statute, but, upon a tort or wrong done to the plaintiff by some false or fraudulent representation of the defendant, made in order to induce him (the plaintiff) to contract with some third party: evidence of such representation when oral only, and insufficient therefore by reason of the statute to support an

(n) Judgm., 8 Exch. 55, 56.

(o) Anson on Contracts, 37 th ed., 346.

p) $1 \mathrm{Wms}$. Saund.,'6th ed., 211, $c$.

(l), citing Kirkham v. Marter, 2 B. \&
Ald. 613.

(q) Per Lord Abinger, C. B., 1 M. \& w. 117 . 
action ex contractu, being relied upon to sustain an action ex delieto $(r)$.

It was to remedy the inconvenience resulting from the frequency of actions framed in the manner just described, of which Pasley v. Freeman (s) offers the first reported example,

Stat. 9

Geo. 4, c. 14, s. 6 . that Lord Tenterden introduced into the stat. 9 Geo. 4, c. 14, its 6 th section $(t)$, which enacts, that "no action shall be brought whereby to charge any person upon or by reason of any representation or assurance made or given concerning or relating to the character, conduct, credit, ability, trade, or dealings of any other person, to the intent or purpose that such other person may obtain credit, money, or goods upon $(u)$, unless such representation or assurance be made in writing, signed by the party to be charged thereuith" $(v)$.

The general scope of the foregoing section, and especially the precise meaning which should be assigned to the word "ability" therein used, were much discussed in Lyde v. Barnard $(w)$. The requirements of this section will be satisfied if a false representation in writing be made which substantially contributed to the damage complained of, although an oral representation by the defendant may in part have contributed to it $(x)$. Assuming that an agreement really falls within that part of the 4 th section of the Statute of Frauds latterly considered, or within the 6th section of Lord Tenterden's Act, and must therefore be in writing, one thing is quite clear, viz., that when so written it cannot afterwards be varied or altered orally, for otherwise the intentions of the Legislature might manifestly be thwarted. This is a principle referred to and recognised in equity as well as at

(r) See per Parke, B., 1 II. \& W. 114.

(s) 3 T. R. 51; 1 R. R. 634; 2 Sm. L. C., 9 th ed., 74 .

( $t$ ) As to which, see per Pollock, C. B., 18 C. B. 381 .

(w) As to the error here apparent in the wording of the Act, see 1 M. \& W.
$104,110,115,123$.

(v) See Suift v. Jeusbury, L. R. 9 Q. B. 301 .

(w) 1 M. \& W. 101. See Swann r. Phillips, 8 Ad. \& E. 457 ; Haslock v. Fergusson, 7 Ad. \& E. 86 ; Devaux r. Steinkeller, 6 Bing. N. C. 84 .

(x) Tatton v. Tiade, 18 C. B. 371. 
law, as will be seen by looking at the judgment in Emmet v. Dewhurst (y), where several authorities bearing upon the subject before us are collected.

The third clause of the 4 th section of the Statute of Frauds has reference to " any agreement made upon consideration Agreement made upon consideration of of marriage." It may be dismissed with the remark, that Inarriage. these words do not apply to a promise to marry (z), but merely to contracts for the performance of collateral acts in consideration of marriage $(a)$.

Passing on then to the next clause-whieh concerns actions brought to charge any person "upon any contract Contract concerning or (b) sale of lands, tenements, and hereditaments, or any interest in or concerning them"-the first point that demands attention is that under certain circumstances, where there has been part performance of such a contract, equity will disregard the statutory requirements, and let in parol evidence of the contract. Though the existence of such a principle has never been in dispute, the decisions have been very conflicting as to what will amount to part performance sufficient to take the case out of the statute. The general rule is that the acts relied on "must be such as could be done with no other view or design than to perform the contract" $(c)$. "They must be unequivocally referable to the agreement" $(d)$. It would seem that payment of part, or even of the whole of the purchase-money will not be sufficient to exclude the operation of the statute $(e)$; on the other hand, the admission into possession

(y) 3 Mac. \& G. 587, 596.

(z) Cork v. Baker, 1 Str. 34; Harrison v. Cage, 1 Ld. Raym. 386, ad fin. See Jorden v. Money, 5 H. L. Ca. 185 ; Citizen's Bank of Louisiana P. First National Bank of New Orleans, L. R. 6 H. L. 352.

(a) See Montacute r. Maxwell, 1 P. Wins. 618; S. C., Prec. Chanc. 526; Hammersley v. De Biel, 12 Cl. \& F. 45, ited Lassence v. Tierney, 1 Mac. \& G. i71, 572; Johnstone v. Mappin, 60
L. J.Ch. 241; Watson, Comp.Eq. 1,550. (b) The word "of" was here probably intended.

(c) Per Lord Hardwicke, Gunter . Halsey, Ambl. 586.

(d) Per Baggallay, L. J., Alderson จ. Maddison, 7 Q. B. D., at p. 178 ; 8 App. Cas. 467.

(e) Per Brett, L. J., Humphreys v. Green, 10 Q. B. D., p. 160 ; sed vide per Baggallay, L. J., Alderson v. Maddison, ub. supr.

B.C.L. 
of a stranger is, speaking in general terms, a sufficient partperformance, for it is not explicable upon any other supposition than that it has resulted from a contract in respect of the land of which possession has been given $(f)$. The continuance, however, in possession of a tenant is not in itself a sufficient part-performance of a parol agreement for the purchase of the land from the landlord, for it is equally consistent with a right depending upon his tenancy $(g)$. Generally as to hat will or will not be such part-performance as to take the case out of the statute, reference should be made to the judgment of Lord Selborne in Alderson v. Maddison (h), where the previous cases are cited and considered.

With reference to the above clause, it has been observed, that the words "lands, tenements, or hereditaments" here used, seem to have been intended by the Legislature as equivalent to "fee simple;" and the words "any interest in or concerning them" seemed to have been used to denote a chattel interest, or some interest less than the fee simple (i). What then is an interest in or concerning land? What is "a contract of an interest in lands?" $(j)$. To these questions conflicting answers have, under special circumstances, been given; but, nevertheless, the principles which are to guide us in replying to them have been definitely ascertained. Little hesitation need be felt in affirming that an agreement to convey an equity of redemption $(k)$; a contract under which the plaintiff, in considera. tion of a sum of money, agrees to surrender his tenancy and to procure the defendant to be accepted in his place $(l)$

(f) Ib.: Ungleyv. Ungley, 4 Ch. D. 73, and $5 \mathrm{Ch}$. D. 887; Sharman v. Sharman, 67 L. T. 834 .

(g) Ib.: Fabian v. Nunn, L. R. 1 Ch. App. 35.

(h) 8 App. Cas. 467; Whittick v. Mozley, 1 C. \& E. 86; Lanyon v. Martin, 13 L. R. Ir. 297.

(i) Per Littledale, J., Evans v. Roberts, 5 B. \& C. 839 , and in Smith v. Surman, 9 B. \& C. 573.

(j) See per Bayley, B., I C. \& J 397 .

(k) Massey r. Johnson, 1 Frct 241.

(l) Cocking v. Ward, 1 C. B. 85 (as to which, see Pulbrook r. Lauces, Q. B. D. 289, 290), followed in Fell v. IVebster, 12 C. B. 283, and Smart v. Harding, 15 C. B. 652 , ar 
a contract for the acquisition of a lease of realty $(m)$; a contract to advance money on the security of land $(n)$; a contract to let furnished lodgings $(o)$; provided that the executory contract if executed would have conferred such an interest or property in land as to give a right to maintain a possessory action $(p)$; or, a contract whereby the plaintiff agrees to let a house to the defendant, to sell him certain furniture and fixtures therewith, and to make certain alterations and improvements therein, the defendant on his part agreeing to take the house and to pay for the furniture, fixtures, and alterations-is within the statute $(q)$. So, where A., being possessed of a messuage and premises for the residue of a term of years, agreed with $B$. to relinquish possession to him, and to suffer him to become tenant of the premises for the residue of the term, in consideration of B.'s paying a sum of money towards the dilapidations, this was held to be within the Act $(r)$. So, too, a grant of a right to shoot over land, and take away a part of the game killed, is a grant of an interest in land within the statute (s). Where, indeed, anything is done which substantially amounts to a parting with an interest in land, or which relates to the sale of such an interest, the agreement is within the statute $(t)$.

distinguished in Angell v. Duke, L. R. 10 Q. B. 178. See Lavery v. Turley, 6 H. \& N. 239 . In re Layeock v. Pickles, 4 B. \& S. 497 ; Teall v. Auty, 4 Moore, 542.

(m) Horsey v. Graham, L. R. 5 C. P. 9; Foquet v. Moor, 7 Exch. 870 . 496 .

(i) Mounsey v. Rankin, 1 C. \& E.

(o) Edge v. Strafford, 1 C. \& J. 391; Inman v. Stamp, 1 Stark. N. P. C. 12 ; 18 R. R. 740.

(p) Per Blackburn, J., Wright $\mathbf{v}$. Stavert, 2 E. \& E. 729.

(q) Vaughan v. Hancock, 3 C. B. 766 ; Mechelen v. Wallace, 7 Ad. \& E. 49 (with which compare Angell v. Duke, supra); Earl of Falmouth v. Thomas, 1 C. \& M. 89. (v) Buttemere v. Hayes, 5 M. \& W. 456.

(s) Webber v. Lec, 9 Q. B. D. 315.

( $t$ ) Per Maule, J., Kelly v. Webster, 12 C. B. $289,290$.

A contract for investigating the title to land has been held not to be within the statute: Jeakes r. White, 6 Exch. 873. Nor is a contract for the sale of shares in a railway company, Bradley v. Holdsuorth, 3 II. \& W. 422 ; or in a waterworks company, Bligh r. Brent, 2 Y. \& C. 268 ; or in a mining company conducted on the cost-book principle, Watson v. Spratley, 10 Exch. 222 (as to which see, per Maulc, J., Toppin v. Lomas, 16 C. B. 161); Powell v. Jessopp, 18 C. B. 336. See Walker v. Bartlett, Id. 845 . 
We may add also that where a special agreement has been entered into between plaintiff and defendant not sufficiently evidenced by writing to satisfy the Statute of Frauds, the facts of the case may nevertheless be such as to originate a claim for compensation or to entitle the plaintiff to recover back money paid as on a failure of consideration $(u)$.

Let us now turn for a moment to notice a class of cases differing somewhat from the above, and presenting greater difficulty, viz., those which concern things annexed to land and falling within the operation of a well-established maxim, Quicquid plantatur solo solo cedit $(v)$, - whatever is affixed to the soil becomes presumably $(w)$ in contemplation of law a part of it and subjected to the same incidents as the soil itself. Under this subdivision of my subject, I shall speak, first, of the growing produce of land, such as crops, fruit, and the like; secondly, of fixtures.

Now, it is to be observed that Lord Coke carefully distinguishes between land and the growing produce of the land. Upon the death of tenant for life, he says $(x)$, although the land belongs to the reversioner, the growing crop goes to the executor of the tenant for life as part of his personal estate (y). So, if a man be seised of land in right of his wife, and sow the ground, and die, his

A contract to sell debentures which are expressed to be a charge on all the property of a companr, in which property, at the time of the issue of the debentures and at the time of the contract of sale, was included certain leaseholds, is a contract within s. 4, Drieter v. Broad, (1893) I Q. B. 744 (C.A.), affirming same case loc. cit. at p. 539.

Goss v. Lord Nugent, 5 B. \& Ad. 58 , which shows that a written contract for the sale of land cannot be varied orally, is cited post. See also Sanderson Y. Graves, L. R. 10 Ex. 234. 284 .

(u) Pulbrook v. Latces, I Q. B. D.

In Pattinson v. Luckley, L. R. 10
Ex. 330 , the plaintiff tried unsuccessfully to recover on a quantum meruit.

(v) As to which, see Leg. Max., 6th ed., 376. This maxim does not apply to mining fixtures: Wake r. Hall, 7 Q. B. D. $295 ; 8$ App. Cas. 195.

(w) See Lancaster v. Eve, 5 C. B., N. S., 717,727 .

(x) Co. Litt. 55 b.

(y) Growing crops are not " personal chattels" within the Bills of Sale Act, $1854(17 \& 18$ Vict. c. 36$)$, ss. 1,7 ; Brantom v. Griffits, 2 C. J'. D. 212 ; distinguished in Ex parte National Bank, Re Phillips, 16 Ch. D. 104. They are, howerer, within 41 \& 42 Vict. c. 31 , and $44 \& 45$ Vict. c. 43 . 
executors shall have the corn; and if his wife die before him, he shall have it; for, although upon the death of the husband or wife the interest of the former in the land ceases, yet the growing corn is considered as part of his personal estate, and belongs to him or his executors. In these cases, Lord Coke considers the growing produce of the land as a personal chattel independent of and distinct from the land itself. And, reasoning by analogy to what is here said, our Courts have held, that a sale of any growing produce of the earth (reared by labour and expense), in actual existence at the time of the contract, whether it be in a state of maturity or not, is to be considered not as a sale of an interest in or concerning land within the meaning of the 4th section of the Statute of Frauds, but rather as a contract for the sale of goods, wares, and merchandises within the 17 th $(z)$ section of the Act $(a)$.

A contract, accordingly, for the sale of growing potatoes, which come within the description of emblements, and are deemed chattels by reason of their being raised by labour and manurance, is not required to be in writing $(b)$, whereas growing grass does not come within the description of goods and chattels, it goes to the heir and not to the executor, and cannot be taken under a fi. fa. (c); and these latter remarks are also applicable to growing fruit $(d)$ and to growing trees (e), unless, indeed, it clearly appear from the terms or nature of the particular contract, that the parties to it were dealing exclusively with the produce of the trees,

(z) See post, p. 404.

(a) Evans r. Roberts, 5 B. \& C. 840, 841 ; Judgm., 10 A. D. \& E. 758 ; per Hullock, B., 1 Y. \& J. 398; 1 Wms. Saund., 6th ed., $277 c$.

(b) Evans v. Roberts, 5 B. \& C. 829 ; Waruick v. Bruce, 2 M. \& S. 205 ; 14 R. R. 634 ; Sainsbury v. Matthews, 4 M. \& W. 343 ; Jones v. Flint, 10 Ad. \& E. 753; Parker v. Staniland, 11 East, 362 ; 10 R. R. 521. (c) Crosby v. Wadsucorth, 6 East 602 ; Carrington v. Roots, 2 M. \& W. 248 ; Jones v. Flint, 10 Ad. \& E. 753.

(d) Rodwell r. Phillips, 9 M. \& W. 501 .

(e) Scorell r. Boxall, 1 Y. \& J. 396; Conl. Dig. Biens (H); Teall v. Auty, 4 Moore, 542; Swinburn v. Ainslie, $30 \mathrm{Ch}$. D. $48 \overline{5}$; Harrison v. Harrison, 28 Ch. D. 220. 
when they should be cut down and severed from the freehold $(f)$.

Tenants' fixtures ( $g$ ) attached to (but not parcel of) the freehold bear a very strong resemblance, it has been observed $(h)$, to those growing crops which are not the spontaneous produce of the earth, but are raised by the labour and expense of the occupier of the land: even whilst thus attached they may be treated for some purposes as chattels $(i)$; for instance, in some cases they may be seized and sold under a fi. fa. $(j)$, and will go in like manner as crops of corn or other fructus industriales to the executor $(k)$. On the other hand, an action will not lie for tenants' fixtures before severance $(l)$, nor can they be treated as goods sold and delivered in an action for their price $(m)$. It is clear that a contract concerning an interest in land and fixtures must be in writing (n); but, when things annexed to the freehold are sold in contemplation of an immediate severance, and the contract does not transfer any interest whatever in the soil or freehold, ex. gr., between an outgoing tenant at the expiration of his term and the incoming tenant under a new demise, or wherever the subject of the contract is in the view of the parties a mere chattel, as where fixtures have been appraised and valued under an oral agreement for their sale, it may

(f) Marshallv. Green, 1 C. P. D. 35, 40, 44 (as to this case see per Chitty, J., in Lavery v. Pursell, $39 \mathrm{Ch}$. D. 508, at pp. 515-517): Simith v. Surman, 9 B. \& C. 561. See Watts v. Friend, 10 B. \& C. 446 . Emblements are now included in "goods" within the Sale of Goods Act, 1893, and are so within s. 4 , subs. 1 of that Act, which is substituted for 8.17 of the Statute of Frauds. See post, p. 406.

(g) As to the various meaniugs of the word "fixtures," see Judgm., Wiltshear v. Cottrell, 1 E. \& B. 690 ; Leg. Max., 5th ed., 418.

The test by which to distinguish between tenaut's and landlord's fixtures is specified in the Judgm.,
Hellawell v. Eastivood, 6 Exch. 312 , followed in Waterfall v. Penistone, 6 E. \& B. 876,888 , and distinguished in Walmsley v. Nilne, 7 C. B., X. S., $115,130-132$. 841 .

(h) Per Littledale, J., 5 B. \& C.

(i) Judgm., 1 C. M. \& R. 275.

(j) Poole's Case, 1 Salk. 368 . Per Parke, B., Horsfall r. Hey, 2 Exch. 779 ; Hellawell v, Eastwood, 2 Exch. $295^{\circ}$.

(k) Amos \& F. on Fixt., 3rd ed., cf. Index " Executor."

(l) Leg. Max., 6th ed., 399, n. (l).

(m) Lee v. Risdon, 7 Taunt. 188; 17 R. R. 484.

(n) Kelly v. Webster, 12 C. B. 283. 
reasonably be contended that the Statute of Frauds does not apply $(o)$.

If, however, an entire agreement be made for the sale of real and personal estate, and the agreement as to the land be within the statute and void, it cannot be supported as to the personal property which was sold with it $(p)$.

The fifth clause of the 4 th section of the Statute of Frauds relates to "any agreement that is not to be performed within the space of one year from the making thereof," the meaning of which words is explained in Peter v. Compton $(q)$, where it was held, that if the agreement in question is to be performed upon acontingency, but is not expressly to be performed after the year, there, inasmuch as the contingency might happen within the year, a note in writing is not necessary; but contra where it appears by the whole tenor of the agreement that it is to be performed after the expiration of the year $(r)$.

Hence a contract for the maintenance of a child, to enure so long as the defendant shall think proper,' was held not to be within the statute $(s)$; whilst, on the other hand, a contract for a year's service, to commence at a future day, is within the statute as being an agreement not to be performed (i.e., completely performed) within the year $(t)$; and

(o) Hallen v. Runder, 1 C. M. \& R. 266 ; followed in Lee $\vee$. Gaskell, 1 Q. B. D. 700. See Petrie v. Dawson, 2 Car. \& K. 138 ; Sleddon v. Cruikshank, 16 M. \& W. 71; see, however, Lavery v. Pursell, 39 Ch. D. 508, where a contract to sell the building materials of a house, with a condition that all materials should be removed within two months, was held to be within the 4th section. ".... the standing house is a hereditament" (per Chitty, J., at p. 514); see also Jarvis จ. Jarvis, 63 L. J. Ch. 10.

( $p$ ) Sugd. Conc. View of the Law of V. \& P., 14th ed., p. 127, where the cases are cited; Salmon v. Watson, 4 Moore, 73.

(q) Skin. 30 3 ; 1 Sm. L. C., 9th ed., 359 ; Wells v. Horton, 4 Bing. $40 ;$ Eley v. Positive Ass. Co., 1 Ex. D. 20.

(r) Peter v. Compton, supra. Boydell v. Drummond, 11 East, 142; 10 R. R. 450, Preface vi. ; is a leading authority upon the above point. See also $\boldsymbol{I}^{\prime} K^{\prime} a y$ v. Rutherford, 6 Moo. P. C. C. 413.

(s) Souch v. Straubridge, 2 C. B. 808; Knowlman v. Bluett, 1. R. 9 Ex. 1, 307. See Crouchurst r. Laverack, 8 Ex. 208; JlcGregor r. JLGGregor, 21 Q. B. D. 424.

(t) Bracegirdle v. Heald, 1 B. \& Ald. 722; 19 R. R. 442; Snelling r. Lord Humtingfield, I C. M. \& R. 20; Banks, app., Crossland, resp., L. R. 10 Q. B. 97 ; Britain v. Rossiter, 11 Q. B. D. 123, in
Agreement not to be performed within a year. 
a contract for service for more than a year subject to determination within the year upon the happening of a given event must be in writing $(u)$. Should it, moreover, appear from the nature of the contract that its performance was not contemplated within the year, the mere circumstance that it is defeasible within the year will not take it out of the operation of the statute, as shown by Birch v. Earl of Liverpool $(v)$, Roberts v. Tucker $(w)$, and other cases $(x)$.

The clause of the Act now under notice applies to such contracts only as are not to be performed on either side within the year $(y)$.

An agreement, consequently, whereby all that is to be done by the plaintiff constituting one entire consideration for the defendant's promise is capable of being performed within a year, and no part of what the plaintiff is to do constituting such consideration is intended to be postponed until after the expiration of the year, is not within the 4th section of the Act, notwithstanding the performance on the part of the defendant is or may be extended beyond that period $(z)$. And where by the terms of a contract one party can perform his part of it within a year, a subsequent request by the other party that such performance should be postponed until after a year will not if acceded to bring the case within the section $(a)$.

It follows from what has been just said, that Peter v. Compton, already alluded to, might have been decided upon

which case it has beeu decided that the equity of part-performance does not extend, and ought not to be extended, to contracts concerning any other subject-matter than land. P'er Iord Selborne, Alderson r. Maddison, 8 App. Cas. at p. 474 . See McIranns r. Cooke, 35 Ch. D. 681 .

(v) Dobson v. Collis, 1 H. \& X. 81.

(v) 9 B. \& C. 392.

(w) 3 Exch. 632, 643.

(x) Darey v. Shannon, 4 Ex. D. 81, 84,85 ; not followed McGregor $\mathrm{T}$. McGregor, 21 Q. B. D. 424; Eley v.
Positive Ass. Co., 1 Ex. D. 20, 29.

(y) Cherry v. Heming, \& Exch. 631 , aftirming Donellan .. Read, 3 B. \& Ad. 899 ; per Tirudal, C. J., Souch r. Strawbridge, 2 C. B. 814; as to which see per Bramuell, B., Sanderson r. Grates, L. R. 10 Ex. 238; per Blackburn, J., hnoulman v. Bluett, L. R. 9 Ex. 308: Mriles $r$. New Zeal. Alford Est. Co., 32 Ch. D. 266, 276, 296.

(z) Simith v. Neale, 2 C. B., X. S.,

(a) Bevan r. Carr, 1 C. \& E. 499. 
a ground other thar that on which the judgment actually rests, inasmuch as on looking at that case it will be seen that the contract there sued upon had in fact been wholly executed by one of the parties to it.

As before stated, a proposal in writing signed by the person to be bound, and accepted orally by the person to whom it is made, is a sufficient agreement to satisfy the statute (b).

Where an agreement falls within the words which we have been considering, and has been reduced into writing under the Act, it clearly cannot be varied by any subsequent oral contract between the parties. This proposition may be illustrated by Giraud v. Richmond (c), where it was held, that an agreement by which the plaintiff entered into the defendant's service at a salary payable yearly (which agreement, from its general scope and nature, clearly fell within the Statute of Frauds) could not be varied by evidence of a subsequent verbal agreement that the salary should be paid quarterly $(d)$.

It may seem almost superfluous to cite authorities in addition to those previously specified (e), with a view to showing that a written contract falling within the operation of the 4 th section of the Statute of Frauds, cannot be varied by a subsequent oral agreement between the contracting parties. One further case, a well-considered one, may be cited as illustrating the rule of evidence in question, as being in principle generally applicable where the statute law requires that a contract shall be in writing. The case alluded to is Goss v. Lord Nugent $(f)$.

In Goss v. Lord Nugent the facts were these:-By an agreement in writing the plaintiff contracted to sell to the

(b) Ante, p. 376. See Jones v. Victoria Graving Dock Co., 2 Q. B. D. 314.

(c) 2 C. B. 835 ; Willians v. Jones, 5 B. \& C. 108. (d) See also Evans v. Roe, L. R. 7 C. P. 138.

(e) Ante, p. 369. See also post, p. 418.

(f) 5 B. \& Ad. 58. 
defendant several lots of land, and to make a good title thereto; and the deposit-money was paid in pursuance of this agreement by the defendant; it was, however, afterwards discovered that a good title could not be made to one small lot included in the sale; but the defendant said he would accept the title notwithstanding this defect; and possession of the whole was given up to him. On delivery of the abstract of title by the vendor, the defendant's solicitor nevertheless objected to the title so far as regarded the small lot above mentioned, and the defendant refused to complete the purchase. An action having been brought by the vendor to recover the unpaid residue of the purchase-money, it was objected that oral evidence of a waiver by the defendant of his right to have a good title as to the small lot was not admissible, inasmuch as the Statute of Frauds required the whole agreement between the contracting parties to be in writing. And of this opinion was the Court in banc, Lord Denman remarking that the object of the statute was to exclude all oral evidence as to contracts for the sale of land, and to require that any such contract when sought to be enforced should be proved by writing only. His Lordship further observed, that in the case before the Court the contract sought to be enforced was not in truth the written agreement, but a new contract entered into by the parties, which it was proposed to prove partly by the original written agreement, and partly by the subsequent verbal agreement; so that the contract put in evidence to support the action was not entirely in writing $(g)$. In this case an opinion was however intimated by the Court, that a written contract concerning the sale of land may be wholly waired and abandoned by a subsequent oral agreement, so as to prevent either party from recovering upon the contract which was in writing $(h)$.

(g) Acc. Stoxell $\mathbf{v}$. Robinson, 3 Bing. N. C. 928 ; Harvey v. Grabham, 5 Ad. \& E. 61,74 .

(h) Judgm., 5 B. \& Ad. 66 . See Harvey v. Grabham, 5 Ad. \& E. 74. 
Besides the Statute of Frauds, there are various enactments which require that writing shall be used to authenticate transactions; to some few of such enactments reference is made in the course of these Commentaries (i). I shall now, without further inquiry as to written contracts in particular, conclude this chapter with some remarks respecting simple contracts generally-oral or written-the object immediately in view being to contrast a simple with a special contract, regard being had to the leading characteristics of either. I shall also specify some few cases, in each of which our law requires that the contract entered into between parties shall be under seal.

Now, on reference to p. 266, it will be seen that, at common law, a specialty works a merger; operates by A specialty contrasted way of estoppel; requires (subject to what has been simple said respecting contracts in restraint of trade $(k)$ ) no consideration to support it; will in some cases bind the heir of the covenantor or obligor; and can only be discharged by an instrument under seal $(l)$, or by the judgment of a Court of competent authority or by statute. A simple contract on the other hand, which fills the lowest rank amongst obligations recognised in law, cannot, it is obvious, work a merger; although it may operate as an admission, it does not, except in some peculiar cases $(m)$ act strictly by way of estoppel $(n)$. A simple contract does

(i) See, for instance, tit. Stat. Limitations.

(k) Ante, p. 356.

(l) See Judgm., Frazer r. Jordan, 8 E. \& B. 309.

$(m)$ For instance, a tenant is said to be "estopped" from denying his landlord's title. (See Judgm., Cuthbertson v. Irving, 4 H. \& N. 754, 755; S. C., 6 Id. 135. Delaney v. Fox, 2 C. B., N.S., 768 ; Watson v. Lane, 11 Exch. 769 ; per Wilde, B., Duke v. Ashby, 7 H. \& N. 602.) An agent is not permitted to dispute the title of his principal in the subject-matter of the agency. And the doctrine of estoppel has also some application in regard to bills of excliange and promissory notes. (Post, Chap. IV.) See Reg. r. Evans, 3 E. \& B. 363; Morris r. Bethell, L. R. 5 C. P. 47. This doctrine is sometimes applicable in a case of tort, post, Book III.

(n) See Cannam r. Farmer, 3 Exch. 698; Bartlett r. I'ells, 1 B. \& S. 836', and cases there cited; Grates v. Key, 3 B. \& Ad. 313 (which shows that a receipt not under seal is an admission only). Knights r. Wiffen, L. R. 5 Q. B. 660; Hart v. Frontino Gold Arining Co., L. R. 5 Ex. 111.

" The acts in pais, which bind 
(usually $(o)$ ) require a consideration to support it $(p)$; it will, as already stated $(q)$, and as we shall hereafter see at greater length, bind the personal not the real-representative of the contractor. An executory contract not under seal may (even, as it seems, when required to be in writing by statute) be discharged by parol before breach $(r)$.

"It is competent," says Parke, B. (s), "for both parties to an executory contract, by mutual agreement, without any satisfaction, to discharge the obligation of that contract." But the learned Judge proceeds to remark, that " an executed contract cannot be discharged except by release under seal, or by performance of the obligation, as by payment, where the obligation is to be performed by payment" $(t)$.

To an action for breach of contract, "accord and satisfaction" may afford a good ground of defence (u). Though, " it is clear, if the claim be for a liquidated and ascertained sum, payment of part cannot be satisfaction of the whole, although it may, under certain circumstances, be evidence of a gift of the remainder. But the gift of a thing of uncertain value may be a satisfaction of any sum due on a

parties by icay of estoppel, are but ferr, and are printed out by Lord Coke (Co. Litt. 352 a). They are all acts which anciently reall were, and in contemplation of law have alwars continued to be, acts of notoriety not less formal and solemn than the execution of a deed, such as livery, entry, acceptance of an estate, and the like. Whether a party had or liad not concurred in an act of this sort was deemed a matter which there could be no difficulty in ascertaining, and then the legal consequences followed." (Judgm., Lyon v. Reed, 13 M. \& W. 309 , cited Nickells v. Atherstone, 19 Q. B. 949.) $\Lambda$ s to estoppels by conduct or representations, see II'Kensie r. British Linen Co., 6 App. Cas. 82 ; Keate v. Phillips, 18 Ch. D. 560 ; Alderson r. Maddison, $i$ Q. B. D. 144; Colonial Bank r. Cady, 15, App. Cas. 267 (aftirming S. C., s.n. Williams v. Colonial Bank, $38 \mathrm{Ch}$. D. 388); Tomkinson r. Balkis Consolidated
Co., (1893) A. C. 396.

Estoppels bind parties and privies only, not strangers: Richards v. Johnston, 4 H. \& N. 660. See Bank of Hindustan r. Alison, L. R. 6 C. P. 222. 227 ; Beattie r. Lord Ebu'y, L. R. 7 H. I. 102.
(o) See post, Chap. IV.
(p) Ante, p. 311 et seq.
(q) Ante, p. 289.
(r) See Taylor r. Hilary, 1 Cr. M. R. $7+1$.

(s) Foster ₹. Dancber, 6 Exch. 851. King v. Gillett, 7 M. \& W. 55 , is important with reference to the point here adverted to. See also Harris v. Carter, 3 E. \& B. 559 ; Daris v. Bonford, 6 H. \& X. 245.

(t) Foster v. Davber, supra.

(iv) A rested right of action can only be got rid of br a release or an accord and satisfaction: per Milliams, J., Cook r. Lister, 13 C. B., N.S., 587, 518. 
simple contract. If the contract be by bond or covenant, it can be determined only by something of an equal or higher nature $(x)$ : but upon a mere simple contract it is clear that the debtor may give anything of inferior value in satisfaction of the sum due, provided it be not part of the sum itself;" for " if the creditor had the money itself, he might buy with it a thing of however inferior value, and that contract would be good; so he may accept the same thing in satisfaction of the whole sum, and that contract is good "; so anything, which can be a consideration and a new independent benefit to the person entitled to the larger sum, may be accepted in satisfaction $(y)$.

The reason why, as just stated, part payment cannot be pleaded in satisfaction of a debt, is thus explained in the case of Sibree v. Tripp above cited: "It is undoubtedly true that payment of a portion of a liquidated demand, in the same manner as the whole liquidated demand ought to be paid, is payment only in part, because it is not one bargain but two, viz., payment of part, and an agreement without consideration to give up the residue." But if you substitute for a sum of money a piece of paper or a stick of sealing-wax it is different, and the bargain may be carried out in its full integrity. A man may give in satisfaction of a debt of $100 l$., a horse of the value of $5 l$., but not $5 l$. If, however, the time or place of payment of the money given in satisfaction be different from that of the debt due, the smaller

(x) Ante, p. 290. Wilson v. Braddyll, 9 Exch. 718; Rippinghall v. Lloyd, 5 B. \& Ad. 742; cited per Bramuell, B., Kivk v. Gibbs, 1 H. \& N. 814.

(y) Per Parke, B., Sibree v. Tripp, 15 M. \& W. 33, 34, where Cumber v. Wane, Stra. 426, 1 Sm. L. C., 9th ed., 366 , is observed upon; Grimsley v. Parker, 3 Exch. 610, following Tattersall v. Parkinson, 16 M. \& W. 752. See Gaskill v. Skene, 14 Q. B. 664 ; Thame v. Boast, 12 Q. B. 808 ; Beal- mont v. Greathead, 2 C. B. 494 ; Goodwin v. Cremer, 18 Q. B. 757 ; Cook v. Hopeuell, 11 Exch. 555; Beer v. Foakes, 11 Q. B. D. $221 ; 9$ App. Cas. 605.

Pinnel's ease, 5 Rep. 117, which was an action of debt upon a bond, is a leading authority on the above subject, and is discussed at great length in the judgments in Beer v. Foakes, ubi supra. See Bidder v. Bridges, 37 Ch. D. 406 . 
sum may be a satisfaction of the larger, $e x . g r$. , "if for money, you give a negotiable security, you pay it in a different way ; the security may be worth more or less, it is of uncertain value" $(z)$, and may, therefore, in law, be an equivalent for a larger amount actually due.

The withdrawal by defendant of a plea of infancy has been held to be a sufficient consideration for an agreement by the plaintiff to accept a smaller in satisfaction of a larger sum $(a)$.

The technical rule of our common law above adverted to has not been directly affected by the Judicature Acts (b).

Thus much then as to the mode of discharging a parol contract at common law; and now, assuming that the characteristics of a contract, special or simple, have been sufficiently exhibited, one question which may reasonably be supposed to have suggested itself yet remains to be answered: Is a deed, under any, and if so, under what circumstances, indispensable to the validity of a transaction by our law? Without attempting fully to answer this question, I may observe that there are certain transactions which at common law, and certain other transactions

Deed-when requisite at commou law.

which by statute, are required to be evidenced by deed. At Common law, no incorporeal right or hereditament can be created or transferred otherwise than by deed; such a right is said to lie in grant and not in livery (c), and to pass by the mere delivering of the deed of grant or of assignment;

(z) Per Alderson, B., Sibree v. Tripp, 15 M. \& W. 38 ; per Parke, B., Curlewis r. Clarke, 3 Exch. 378 . See also Lyth v. Ault, 7 Exch. 669 ; Jones r. Sruckins, 5 C. B. 142; and cases, supra, n. (y).

(a) Cooper v. Parker, 14 C. B. 118 ; S. C., 15 C. B. 822.

(b) Vide per Jessell, M. R., Couldery v. Bartrum, 19 Ch. D. 394, 399. In Goddard v. O'Brien, 9 Q. B. D. 37, a cheque for $£ 100$, parable on demand, and accepted in satisfaction, was held a good accord and satisfaction for a deb of $£ 125$ is. $9 d$.

(c) Incorporeal property is so termes because it has no corprs, and is no tangible or visible, but exists only is legal contemplation. It may indee produce something substantial an beneficial to the owner, as in th instance of the right to tithes; but being incapable of actual possession and passing by the mere deed of grant it is therefore said to lie in grant The possession of corporcal propert 
a right of common, for instance, which is a profit a prendre, or a right of way, which is an easement or right in nature of an easement, cannot be granted or conveyed in fee simple, for life, or for years, without a deed $(d)$. An auctioneer, accordingly, who is employed under a parol agreement to sell goods upon the premises of a third party, has no such interest in the goods as will make the licence given him to enter upon the premises for the purpose of selling them irrevocable (e). Again, at common law, an authority to an agent to execute a deed for his principal must itself be under seal $(f)$. A corporation must in general contract by deed $(q)$. A gift of a chattel inter viros, if not perfected by delivery, must be evidenced by deed $(h)$. And a mere verbal gift of a chattel to a person in whose possession it is does not pass any property in the chattel to the donee (i). "By the law of England," says Lord Tenterden ( $k$ ), " in order to transfer property by gift, there must either be a deed or instrument of gift $(l)$, or there must be an actual delivery of the thing to the donee."

on the other hand, ex. gr., houses and land, is capable of actual and visible delivery and transfer, and is therefore said to lie in livery (meaning delivery of seisin or possession): Chitt. Gen. Pr., vol. 1, p. 203.

By stat. 8 \& 9 Vict. c. 106 , s. 2 , a corporeal hereditament "shall, as regards the conveyance of the immediate freehold thereof, be deemed to lie in grant as well as in livery."

(d) Wood v. Leadbitter, 13 M. \& W. 838 (which is a leading case upon this subject); Adams v. Andretss, 15 Q. B. 284, 296; Bird v. Higginson, 6 Ad. \& E. 824; S. C., 2 Id. 696; Thomas v. Fredericks, 10 Q. B. 775 ; Williams v. Morris, 8 M. \& W. 488. See Sinart v. Jones, 15 C. B., N. S., 717.

(e) Taplin v. Florence, 10 C. B. 744. (f) Harrison v. Jackson, $7 \mathrm{~T} . \mathrm{R}$. 207, 210; Wilks v. Back, 2 East, 142; 6 R. R. 409 ; Berkeley v. Hardy, 5 B. \& C. 355 ; Judgm., Hunter v. Parker, 7 M. \& W. 343.

(g) Post, Chap. VII., s. 1. (h) Irons v. Smallpiece, 2 B.\& Ald. 551 ; 21 R. R. 295. See Cochrane r. Moore, 25 Q. B. D. 57 , where in the judgment of $F_{r y}$ L. J., and Boxen, L. J., this question is gone into most fully. A chattel may be mortgaged by parol. Flory v. Denny, 7 Exch. 581 (which shows that "there may be a mortgage of chattels, as distinguished from a pledge, without delivery:" per Williams, J., Manghan v. Sharpe, 17 C. B., N. S., 464). See Barton v. Gainer, 3 H. \& X. 387 .

(i) Shouter v. Pilck, 4 Exch. 478; Bourne v. Fosbrooke, 18 C. B., N. S., $515,524$.

(k) Irons v. Smallpiece, 2 B. \& Ald. 552; 21 R. R. 395. See Congreve v. Evetts, 10 Exch. 298; Baker v. Gray, 17 C. B. 462.

(l) The expression here attributed to the learned Judge seems to imply that the assignment of a chattel may be effected by an instrument not under seal-a proposition unsustainable by the authorities: see per Ifaule, J., Lunn 
Deed-when required by the statute

law.

Under the statute law, the transfer of certain kinds of property is expressly required to be by deed. For instance, the Real Property Amendment Act (8 \& 9 Vict. c. 106) provides (s. 3), that a feoffinent (unless made under a custom by an infant) shall be void at law if not evidenced by deedthat a partition, exchange (except of copyholds), or lease required by law to be in writing, an assignment of a chattel interest (not being copyhold), or a surrender in writing of an interest in any hereditament not being a copyhold and not being an interest which might by law have been created without writing, shall also be void at law unless made by deed. So under the Merchant Shipping Act, 1894 (57 \& 58 Vict. c. 60 ), s. 24 , the transfer of any registered ship, or any share therein, to a person qualified to be owner of a British ship, is to be effected by bill of sale or instrument under scal, in the form given in the Schedule to the Act. And the statute in question likewise contains provisions (ss. 31 (1), 37) regulating the mode of mortgaging a ship or any share therein, and of making a transfer of such mortgage, for either of which purposes a deed is expressly rendered necessary.

It would be of little use, even did space permit, to enumerate the various contracts, to the validity of which a deed or a writing not under a seal is rendered necessary by the statute law. When difficulty arises in regard to any contract or transaction regulated by statute, such difficulty must be solved by reference to the precise words of the

v. Thornton, 1 C. B. 381,382 , and note by Serjt. Manning, Id. $381(d)$. Cf. also Cochrane v. Moore, 25 Q. B. D., at pp. 61,62 . In Oulds r. Harrison, 10 Exch. 575, Parke, B., observes, "It has been held that a gift is not binding unless it be by deed, or the subject of the gift be actually delivered: but if the point were res nova it would perhaps be decided differently." The decision in Lunn r. Thornton, supra (recognised in Hope v. Hayley, 5 E. \& B. 846), is founded on the maxim, "Nemo dat qui non habet:" per Willes, J., Chidell v. Galsuorthy, 6 C. B., N. S., 478. See Carr v. Allatt, 27 L. J. Ex. 385. As to the effect of a grant of a chattel by deed, see further, Siggers v. Evans, 5 E. \& B. 367; Reeve v. Whitmore, 33 L. J. Chanc. $63 ; S . C ., 32$ Id. 497 . 
Legislature applicable to the particular case; and general principles cannot, it is obvious, be deduced from special and arbitrary enactments. Upon this part of the subject, therefore, nothing further will here be said; and, in a later Chapter, I shall proceed to speak of certain contracts required for the most part to be in writing by the Law Merchant $(m)$.

(m) In the preceding Chapter no reference has been made to the Stamp Acts. Where any doubt occurs in regard to the necessity for a stamp or its amount, technical treatises must be consulted. 


\section{CHAPTER III.}

THE CONTRACT OF SALE OF GOODS.

The law relating to the sale of goods has been codified by the Sale of Goods Act, 1893 ( 56 \& 57 Vict. c. 71). In the following pages the main provisions of the Act are set forth. It should be observed that although the Act has made much of the case law dealing with the subject of the contract of sale matter of statutory enactment, in its saving clauses it expressly saves (1) the rules of bankruptcy relating to contracts of sale; (2) the rules of the common law including the law merchant, except where they are inconsistent with the provisions of the Act, more particularly the rules relating to the law of principal and agent, and to the effect of fraud, misrepresentation, duress or coercion, mistake, or other invalidating cause; (3) the enactments relating to Bills of Sale, and certain enactments affecting the sale of goods (ex. gr., the Sale of Foods and Drugs Acts), and also expressly excludes from its operation any transaction in the form of a contract of sale which i: intended to operate by way of mortgage, pledge, charge, or other security $(a)$.

Formation of the contract.

Sale or agreement to sell.

Definition of "goods."

A contract of sale of goods is a contract whereby th seller transfers, or agrees to transfer, the property in good to the buyer for a money consideration called the price (b) "Goods" include all chattels personal other than things ir 61 .

(a) As to these saring clauses, cf. 8. $\quad$ (b) S. 1, subs. 1. 
action and money, and in Scotland all corporeal moveables except money $(c)$. The term includes also emblements (in Scotland "industrial growing crops") and things attached to or forming part of the land which are agreed to be severed before sale, or under the contract of sale $(d)$. The goods may be either "specific," i.e., identified and agreed upon at the time the contract is made $(e)$, or " unascertained," i.e., defined by description only $(f)$. This latter class includes "future goods" or such as are to be manufactured or acquired by the seller after the contract is made $(g)$. A contract of sale may be absolute or conditional $(h)$. If under the contract of sale the property in the goods is transferred from the seller to the buyer, the contract is called a "sale"; but if the transfer of the property in the goods is to take place at a future time, or subject to some condition thereafter to be fulfilled, the contract is called an "agreement to sell" (i). An agreement to sell becomes a sale when the time elapses, or the conditions are fulfilled subject to which the property in the goods is to be transferred $(k)$. It will be seen that the statute contem. plates what the common law recognised, that the property in the goods may pass from the seller to the buyer by the contract itself. The civil law regarded the objective test of delivery as determining when the property passed. Capacity to buy and sell is regulated by the general law concerning capacity to contract and to transfer and acquire property $(l)$. Where necessaries are sold and delivered to an infant, or to a person who by reason of mental incapacity or drunkenness is incompetent to contract, he must pay a reasonable

(c) S. 62, subs. 1 .

(d) S. 62, subs. 1 .

(e) Id.

(f) Chalmers on the Sale of Goods Act, 1893.

(g) S. 62 , subs. 1 , cf. also s. 5 , subs. 1 .

(h) S. 1, subs. 2 .

(i) S. 1, subs. 3.

(k) S. 1, subs. 4 .

(l) S. 2, cf. post, Chap. 7. 
Formalities of the con. tract.

Statute of Frauds.

price therefor; "necessaries" being goods suitable to the condition in life of the infant or person, and to his actual requirements at the time of the sale and delivery $(m)$.

Subject to what is said in a later paragraph, and to the provisions of certain Acts of Parliament (n), and to the law affecting the formalities of contracts to which corporations are parties (o), a contract of sale may be made in writing (either with or without seal), or by word of mouth, or partly in writing and partly by word of mouth, or may be implied from the conduct of the parties $(p)$. All contracts for the sale of goods when " not to be performed within the space of 'one year from the making thereof," are of course within the operation of s. 4 of the Statute of Frauds, which is still in force $(q)$. Contracts for the sale of goods for the price of $10 l$. or upwards fell within the now repealed 17 th section of that Act. This section enacted that " no contract for the sale of any goods, wares, or merchandises, for the price of 10l. sterling or upwards, shall be allowed to be good, except the buyer shall accept part of the goods sc sold, and actually receive the same : or give something-ir earnest to bind the bargain; or in part of payment-or tha some note or memorandum in writing of the said bargain be made and signed by the parties to be charged by sucl contract or their agents thereunto lawfully authorised " $(r)$ At one time, it was thought doubtful whether the abor section was applicable to any executory contract, the subject

(m) Id.

(n) Post, p. 406. See the Merchant Shipping Act, 1894 (57 \& 58 Vict. c. $60)$, ss. $24,31,(1), 37$, and ante, p. 400 . As to sale of sculpture with copyright, see 54 Geo. III. c. 56.

(o) S. 3.

(p) S. 3. See contract with mercantile persons, Bk. II., Chap. $\pi$, s. 1 , post, p. 595 et seq.

(q) See ante, Chap. 2.

(r) This section concerned only direct sales-not contracts relating to or connected with them: Judgm., Warlow v.
Harrison, 1 E. \& E. 317.

Harnor Y. Groves, 15 C. B. 674, Manle J., observes that the object of th Statute of Frauds, "as appears fror its title and preamble, was to prever frauds and perjuries; the Legislatu knew that parties who make bargair with each other ofteu take very differe: viers of them; and therefore the provided, in order to remove the tempt: tion as much as possible, that in cas of contracts for the sale of goods $e$. ceeding the value of $10 l$. the contrac or some note or memorandum thered 
matter of which did not exist at the time of contracting, or was to be delivered afterwards $(s)$; and, accordingly, by the 7 th section of Lord Tenterden's Act (9 Geo. IV. c. 14), the enactment in question was expressly extended " to all contracts for the sale of goods of the value of $10 l$. sterling and upwards, notwithstanding the goods may be intended to be delivered at some future time, or may not at the time of such contract be actually made, procured, or provided, or fit or ready for delivery, or some act may be requisite for the making or completing thereof, or rendering the same fit for delivery."

It will be noticed that the language of the 17 th section differed from that of the 4 th section $(t)$ of the Statute of Frauds in the words affecting the efficacy of the contract; for, whereas the last-mentioned section merely provides that "no action shall be brought" in any one of the cases therein specified, unless the agreement sued upon be in writing, the 17th section said that no contract therein referred to should be "allowed to be good" if it were neither part performed in the manner there specified, nor evidenced by writing.

It was in consequence formerly held, that while the 4th section of the Act did not avoid contracts not signed in the manner thereby prescribed, but only precluded any right of action upon them, the 17 th section was stronger, and avoided contracts not made as it directed $(u)$. More recently, however, opinions were expressed that, notwithstanding the difference of language, the effect of the sections was the same. "In my opinion," said Brett, L. J., in Britain v.

stall be in writing. The intention of the I.egislature was that the writing should be the evidence, and the only eridence, of the contract, and that there should be no occasion to look beyond it. The usages of trade (post, Chap. 6) form the exception, because parties are supposed to contract with reference to them."

(s) See the remarks of Littledale, J., in Smith v. Surman, 9 B. \& C. 574 ; Groves v. Buck, 3 M. \& S. 178.

(t) See ante, p. $37 t$.

(u) Per Bosanquet, J., Laythoarp v. Bryant, 2 Bing. X. C. 747. 
Rossiter (x), "no distinction exists between the 4th and 17 th sections of the statute;" and in Maddison v. Alderson (y), Lord Blackburn remarked:- "I think it is now finally settled that the true construction of the Statute of Frauds, both the 4 th and the 17 th sections, is not to render the contracts within them void, still less illegal, but it is to render the kind of evidence required indispensable when it is sought to enforce the contract."

Keeping the above remarks in mind, we see that it was impossible to maintain an action upon any contract under the 17 th section for the sale of goods of the value of 107 . or upwards, unless there was on the part of the buyer an acceptance and actual receipt of part of the goods, or something given by way of earnest or in part payment, or unless there was a note or memorandum in writing of the bargain signed by the parties to be charged thereby, or their agents.

Section 4 of the Sale of Goods Act, 1893.

The 17th section of the Statute of Frauds, and the section of Lord Tenterden's Act alluded to above, have been repealed by the Sale of Goods Act, 1893. The 4th section $(z)$ of this last-mentioned Act has in its first two sub-sections reproduced in somewhat altered language these repealed enactments. The words of the 1 st sub-section are: "a contract for the sale of any goods of the ralue of 10l. or upwards shall not be enforceable by action unless the buyer shall accept part of the goods so sold, and actually receive the same, or give something in earnest to bind the contract, or in part payment, or unless some note or memorandum in writing of the contract be made and signed by the party to be charged or his agent in that behalf."

As regards alterations in language, "value" is substi-

(x) 11 Q. B. D. $123,127$.

(y) 8 App. Cas. 467, 485 ; Bailey v. Suceting, 9 C. B., N. S., 843 ; and see Pollock, Principles of Contract, 5th ed., p. 628. See also Lucas v. Dixon, 22 Q. B. D. at p. 360.

$(z)$ The provisions of this section do not apply to Scotland. 
tuted for "price" to give effect to cases which held that such was the operation of the construction of Lord Tenterden's Act with the 17th section (a). Further, the words "enforceable by action" are used in place of "allowed to be good" in conformity with what has been said above as to the identity of the 4 th and 17 th sections in affecting the efficacy of the contract. Other slight alterations will be noticed, but they do not call for any remark. The 2 nd subsection runs thus: "the provisions of this section apply to every such contract, notwithstanding that the goods may be intended to be delivered at some future time, or may not at the time of such contract be actually made, procured, or provided, or fit or ready for delivery, or some act may be requisite for the making or completing thereof, or rendering the same fit for delivery." The effect of this subsection is to bring executory contracts within the provisions of the section, and so make the necessary formalities the same in their case as in the case of executed contracts, exactly as the repealed section of Lord Tenterden's Act had done.

Let us in the next place consider what are the requisites that must be complied with in the case of contracts for the sale of goods of the value of $10 l$. or upwards, whether such contract be executed or only executory, in order to satisfy the section of the Sale of Goods Act, 1893, set out above. The section enacts that such a contract shall not be enforceable, unless the buyer shall accept part of the goods so sold, and actually receive the same: or give something-in earnest to bind the contract; or in part of payment, or unless some note or memorandum in writing of the contract be made and signed by the party to be charged or his agent in that behalf.

(a) Cf. Harman v. Reeve, 25 L. J. C. P. 257, and Chalmers on the Sale of Goods Act, 1893, at p. 13 (2nd ed., from which source the above words are taken). Cf. also pp. 143, 144. 
What, then, is an actual receipt of goods sufficient to satisfy the section of the Act above set out? In considering this question, as also in considering the other alternative requisites of the section, reference will be made to decisions upon the corresponding portions of the repealed 17 th section of the Statute of Frauds. Now, a receipt implies delivery (b), which may be actual or constructive; the statutory words 'actual receipt' signifying " delivery of the possession of the goods on behalf of the vendor to the vendee, and the receipt of the possession by the vendee $(c)$. A ' constructive receipt' may of course be evidenced in very many different ways. "Where goods are ponderous and incapable of being handed over from one to another, there need not," says Lord Kenyon, C. J., " be an actual delivery; but it may be done by that which is tantamount, such as the delivery of the key of a warehouse in which the goods are lodged, or by delivery of other indicia of property" (d). The larger the bulk of the goods, indeed, the more impracticable does a manual receipt become; something there must consequently be in the nature of constructive receipt as there is constructive delivery $(e)$. If, however, there be no delivery, either actual or constructive, there can be no receipt. Suppose, for instance, that after negotiations have taken place for the sale of goods, some act remains to be done by the purchaser, which must necessarily precede delivery, as the selection and marking of growing timber; while such act remains to be done there can be no delivery to, and consequently no receipt by, the purchaser $(f)$.

scceptance. What, in the next place, is an acceptance of goods within the meaning of the section? There was considerable

(b) Per Parke, B., Saunders v. Topp, 4 Exch. 394.

(c) Farina v. Holme, 16 M. \& W. 119, 123; cited per Crompton, J., Castle v. Sworder, 6 H. \& N. 838.

(d) Chaplin v. Rogers, 1 East, 192, 194 ; 6 R. R. 249; Marshall v. Grecn,
1 C. P. D. 35,41 . See Bentall r. Burn, 3 B. \& C. 423 . Farina v. Holme, supra.

(e) Per Williams, J., Bushel r. Wheeler, 15 Q. B. 445.

$(f)$ Acraman $\vee$. Morrice, 8 C. B. 449 . 
conflict of opinion as to what was the meaning of "acceptance" within the Statute of Frauds, and not a little straining to exempt from the operation of that statute cases in which it was pleaded. In Taylor v. Smith $(g)$ Lord Herschell said, referring to the Statute of Frauds, "acceptance is not used in the statute according to its common acceptance, and in what precise sense it is used has never been determined." The Sale of Goods Act, 1893 , in the 3rd subsection of the section we are now considering (i.e., the 4th), declares that: "There is an acceptance within the meaning of this section when the buyer does any act in relation to the goods which recognises a pre-existing contract of sale whether there be an acceptance in performance of the contract or not." This subsection adopts the language of Boren, L. J., in Page v. Morgan (h). The facts in that case (i) were as follows: There had been a sale of wheat by samples to the defendant, who, having received a number of sacks, delivered under the contract into his premises, opened them and examined their contents to see if they were equal to sample. Immediately after so doing, he gave notice to the seller that he refused the wheat as not being equal to sample. The jury found a verdict for the plaintiff, and on appeal it was argued that there had been no sufficient acceptance within the statute. "It seems to me," said Brett, M. R., "that the case of Kibble v. Gough (k) lays down the governing principle with regard to the question whether there is evidence of an acceptance to satisfy the 17th section of the Statute of Frauds. It was there pointed out that there must be under the statute both an acceptance and an actual receipt, but such acceptance need not be an absolute acceptance; all that is necessary is an acceptance

(g) 1893,2 Q. B. 65 (C. A.), at (2nd ed.).

p. 70 .

(h) Cf. infra, and see Chalmers on the Sale of Goods Act, 1893, at p. 14

(i) 15 Q. B. D. 228.

(k) 38 L. T. N. S. 204. 
which could not have been made except upon admission that there was a contract, and that the goods were sent to fulfil that contract. Cotton, L. J., in giving judgment in that case, said, "All that is wanted is a receipt and such an acceptance of the goods as shows that it has regard to the contract, but the contract may yet be left open to objection: so that it would not preclude a man from exercising such a power of rejection. I think that in this case enough had been done to satisfy the statute." The Master of the Rolls then reviewed the evidence and continued, "How could the defendant have had these sacks taken into his mill, and there opened and examined, without a recognition of the existence of a contract entitling him so to deal with them? How could any reasonable man come to any other conclusion from his dealing with them than that he had made a contract of purchase with regard to them, and that the goods were delivered to, and received by him under such contract, and examined by him to see if they were according to the contract? It seems to me clear that under these circumstances there was evidence for the jury of an acceptance within the meaning of the statute. I can conceive of many cases in which what is done with regard to the delivery and receipt of the goods may not afford evidence of an acceptance. Suppose that goods being taken into the defendant's warehouse by the defendant's servants, directly he sees them, instead of examining them, he orders them to be turned out, or refuses to have anything to do with them. There would then be an actual delivery, but there would be no acceptance of the goods, for it would be quite consistent with what was done that he entirely repudiated any contract for the purchase of the same. I rely for the purposes of my judgment in the present case on the fact that the defendant examined the goods to see if they agreed with the sample. I do not see how it is possible to come to any other conclusion with 
regard to that fact, than that it was a dealing with the goods involving an admission that there was a contract." "The statute says," remarked Bowen, L. J., in the same case, "that the contract shall not be good unless, among other alternative requisites, there has been an acceptance and actual receipt of some part of the goods. Having regard to the mischiefs at which the statute was aimed, it would appear a natural conclusion that the acceptance contemplated by the statute was such a dealing with the goods as amounts to a recognition of the contract."

In a recent case $(l)$ the goods were delivered to the buyer, who took a sample from them, and after examining it, said that the goods delivered were not equal to his sample and that he would not have them. It was held by the Court of Appeal that the buyer's conduct was evidence of an act reengnising a pre-existing contract.

With regard to that portion of the section which has reference to part payment, and upon which no particular Part payment. difficulty presents itself, it will be sufficient to say, that, in order to satisfy the corresponding words of the Statute of Frauds, it was held that there must be an actual payment of money by the purchaser to the vendor, or if no money passes, there must be an actual discharge or extinguishment of some debt due from the latter to the former $(m)$. Earnest Earnest. consists of any coin or thing of value given in token of the bargain, but which is not, as a rule, part of the price (n).

Pausing for a moment at this point in our inquiry we may summarise the effect of the section by saying that, although where the value of the goods amounts to $10 l$. or upwards the law regards a written memorandum of the bargain as of primary importance, it nevertheless dispenses with such

(l) Abbott ₹. Wolsey, 1895, 2 Q. B. 97 (C. A.).

(m) Blenkinsop v. Clayton, 7 Taunt. $597 \because 18$ R. R. 602 ; Walker v. Nussey, 16 M. \& W. 302 . (n) Cf. Howe r. Smith, 27 Ch. D., at pp. 101, 102, and see Chalmers on the Sale of Goods Act, 1893, at p. 145 (2nd ed.), where the above definition of earnest will be found. 
evidence where by mutual consent there has been part performance of the contract. Where, therefore, there has been payment of any sum by way of part payment, this act, on the part of the buyer, if acceded to on the part of the vendor, is sufficient, and the same effect is given to the corresponding act by the vendor of delivering part of the goods sold to the buyer, if the buyer shall accept such part and actually receive the same. Further, by analogy with the decisions on the repealed 17th section of the Statute of Frauds, we may aver that, as, on the one hand, part payment, however minute the sum paid may be, is sufficient to satisfy the statute, so, on the other, part delivery and acceptance, however minute the portion delivered and accepted may be, will suffice: and if either of these conditions be fulfilled, then the necessity of giving written evidence of the contract is waived, and it may be established by oral evidence $(o)$. Where a party sued upon a contract falling within the 17th section of the Statute of Frauds, it was held that he must be prepared to show a good contract actually in existence at the time of action brought; and to make it a good contract under the statute, there must be one of the requisites therein mentioned; so that a written memorandum or part payment after action brought, was held not sufficient to satisfy the statute $(p)$.

To pursue our inquiry as to the operation of the section :

Note or memorandum of the contract. In the absence of acceptance and actual receipt of part of the goods sold, or of anything given in earnest or in part payment, the concluding words of the section before us render necessary some note or memorandum in writing of the contract, signed by the party to be charged or lis agent in that behalf. Now, with regard to these concluding words, it will again be well to notice the decisions upon the

(o) See the Judgm., Morton v. Tib. bett, 15 Q. B. 433,434 .

(p) Bill r. Bament, 9 M. \& W. 40,
41 ; per Erle, J., 17 Q. B. 107 ; Lucas v. Dixon, 22 Q. B. D. 357. 
corresponding words of the repealed 17th section of the Statute of Frauds. The following are some of the matters settled by such decisions. The note or memorandum in writing relied upon as satisfying the repealed 17 th section should, it was held, so far set forth the termis of the contract actually made, that they might not be left in dubio, and that fraud and mistake respecting them might be excluded $(q)$; for instance, although a letter from the plaintiff to the defendant, together with the answer to it, would, it was held, if sufficiently explicit in regard to the particular agreement concluded between them $(r)$, constitute a sufficient memorandum in writing within the 17 th section, yet it would be otherwise if all the material terms of the contract specifically agreed to were not thus expressed; for, in such case, there would be no written evidence by an appeal to which any question in dispute arising upon the contract between the parties might be decided $(s)$; and it must, of course, be made to appear that the contract evidenced by the memorandum was that really concluded between them $(t)$. Where a contract in writing sufficient within the Statute of Frauds was afterwards altered by a rerbal agreement, such new agreement was held to be invalid for any purpose, either as establishing a new contract or as rescinding by implication the old one $(u)$. Further, it was held in the case of the Statute of Frauds that the price of goods sold or contracted for, arranged between the parties, should appear in the memorandum of their bargain $(x)$; whereas, if no particular price had been stipulated for, it would suffice to put down in writing the

(q) Per Lord Abinger, C. B., 2 M. \& W. 659 .

(r) See Bailey v. Sweeting, 9 C. B., N. S., 843; Wilkinson v. Evans, L. R. 1 C. P. 407 .

(8) Archer v. Baynes, 5 Exch. 62.5, and cases there cited; Goodman v. Griffiths, 1 H. \& N. 5it; Johnson v.
Dodgson, 2 M. \& W. 653. 323 .

$(t)$ Afoore r. Campbell, 10 Exch.

(u) Noble r. Ward, L. R. 1 Ex. 117 ; L. K. 2 Ex. 135. 583. (x) Elinore r. Kingscote, 5 B. \& C. 
terms of the contract really concluded $(y)$. Also, that the names of both parties to the contract must appear in the note or memorandum required by the 17 th section, or in some writing sufficiently connected with it $(z)$; but the signature of the party "to be charged" by the contract was sufficient (a), though appended to a separate letter or document referring to and recognising the contract $(b)$. The original contract if in writing, signed by both parties, whilst unrescinded was held to be the binding instrument, so that no subsequent memorandum signed by one party only could have any effect.

Aqent's sig- The signature to the "note or memorandum in writing," under the section of the Act, may be that of the "agent in that behalf" of the party to be charged. These words would, by analogy with the corresponding words of the 17 th section of the Statute of Frauds, seem to include a traveller, employed by a mercantile firm, acting within the scope of his regular duties and of the powers conferred upon himit may be that of an auctioneer, of a factor $(c)$, or of a broker $(d)$.

suthority of On the sale of goods by auction, the auctioneer, who auctioneer. may so contract as to render himself personally liable $(e)$, usually acts as agent as well for the buyer as the seller $(f)$.

(y) Hoadly v. M'Claine, 10 Bing. 482.

(z) See Sarl r. Bourdillon, 1 C. B., N. S., 188, which case, also, may assist in determining-What is a suffi. cient memorandum within the 17 th section? Et vide Ridguay v. Wharton, 6 H. L. Ca. 238: followed in Jones $\mathrm{r}$. Iictoria Graving Dock Co., 2 Q. B. D. 314,324 ; Lee v. Griffin, 1 B. \& S. 272 ; Gibson v. Holland, L. R. 1 C. P. 1; Williams v. Byrnes, 1 Moo. P.C.C., N. S., 154.

(a) Laythoarp v. Bryant, 2 Bing. N. C. 735 ; Liverpool Borongh Bank v. Eccles, 4 H. \& N. 139 ; Allen v. Bennet, 3 Taunt. 169 ; 12 R. R. 633 ; Johrson v. Dodgson, 2 X. \& W. 653; Durrell r. Evans, 1 H. \& C. 174, 186; S. C., 6 H. \& N. 660; Saunderson v. Jack: son, 2 B. \& P. 238; 5 R.R. 580 ; Egevton r. Mathews, 6 East, 307; 8 R. R. 489; per Patteson, J., Sievewright $\nabla$. Archibald, 17 Q. B. 114.

(b) Buxton v. Rust, L. R. 7 Ex. 279 ; Leather Cloth Co. v. Hieronimus, L. R. 10 Q. B. 140 .

(c) See Durrell v. Evans, 1 H. \& C. 174 ; distinguished in Murphy $\mathbf{v}$. Boese, L. R. 10 Ex. 126.

(d) See Fairlie v. Fenton, L. R. 5 Ex. 169; Sharman v. Brandt, L. R. 6 Q. B. 720; Thompson v. Gardiner, 1 C. P. D. 777.

(e) See, for instance, Woolfe v. Hornc, 2 Q. B. D. 355.

(f) Simon v. Motivos, 3 Burr. 1921. The auctioneer is clearly agent for the vendor. The assent of both parties is, 
$\mathrm{He}$ is not, however, ex vi termini, agent for both parties: whether he is so or not will depend upon the facts of the particular case $(g)$. The auctioneer was held to properly comply with the requirements of the Statute of Frauds on a public sale of goods to the amount of $10 l$. or upwards, if he wrote down in his sale book (containing a copy of the conditions of sale), the Christian and surname of the highest bidder as purchaser, and also the amount of the purchasemoney opposite to the lot purchased (h). When the auctioneer, or his clerk (i) acting under his direction, thus signed for the purchaser, the Statute of Frauds was satisfied, because there was thus made "a note or memorandum in writing" of the "bargain," signed by the lawfully authorised agent of the vendee, the authority to sign being indeed expressly given or signified on behalf of the purchaser by bidding $(k)$.

It is clear that, in the case just put, the contract between the vendor and vendee of the goods, constituted by the conditions of sale and description of the lot, cannot at the time of sale be varied by any oral statement of the auctioneer $(l)$. If any alteration be required in the conditions or particulars, such alteration should be made in writing before the sale of the lot in question has commenced. In general, moreover, as soon as the sale by auction has taken place, and the deposit-money has been paid, the

howerer, necessary to make the contract binding; assent is signified on the part of the seller by knocking down the hammer; on the part of the purchaser by bidding. A bidder has a locus pcenitentiæ, and may retract his bidding before the hammer falls; s. 58 , subs. 2 of the Act; and, on the other hand, the owner of the chattel put up for sale may at any time before the contract is complete reroke the auctioneer's authority: Judgm., Warlow F. Harrison, 1 E. \& E. 317. See also Harris r. Nickerson, L. R. 8 Q. B. 286.

(g) Bartlett F. Purnell, 4 Ad. \& E.
792.

(h) See Kenworthy v. Schofield, 2 B. \& C. 945 ; Hinde v. Whitehouse, 7 East, 558, 568; 8 R. R. 676; Peirce v. Corf, L. R. 9 Q. B. 210, 215, 217 ; Roots v. Lord Dosmer, 4 B. \& Ad. $77 ; 4$ C. B. $645(a)$.

(i) Bird v. Boulter, 4 B. \& Ad. 443. See Gosbell v. Archer, 2 Ad. \& E. 500; Peirce v. Corf, supra.

(k) Emmerson v. Heelis, 2 Taunt. 38,48; 11 R. R. 520 ; White v. Proctor, 4 Taunt. 209; 13 R.R. 580; supra, n. $(f)$.

(l) Shelton v. Livius, 2 Cr. \& J. 411 ; explained and distinguished in Eden v. Blake, 13 M \& W. 614, 617. 
authority of the auctioneer is at an end; and if the goods sent for public sale are not sold, or if there be any alteration in the conditions after the property is knocked down, the sale ought to be treated as one by private contract, and a written agreement should be prepared accordingly, and signed by the principals themselves $(m)$. "No doubt," remarks Pollock, C. B., in Meus v. Carr ( $n)$, "an auctioneer at the sale is agent for both seller and buyer, so as to bind them by his signature; but the moment the sale is orer the same principle does not apply, and the auctioneer is no longer the agent of both parties, but of the seller only ; and the signature of the seller or his agent cannot bind the buyer."

An auctioneer, it should be observed, is entitled to sue for the price of goods sold by him in the course of his business, because not only is he privy to the contract of sale, but he has a special property in the subject-matter of it (o). Now, it was held, that one of the parties to a sale of goods of the price of $10 l$. or upwards, could not act as agent for the other party so as to bind him under the statute by signing for him a memorandum of the sale $(p)$ : the auctioneer, therefore, when plaintiff in an action for the price of goods sold by him at auction, was, it was held, precluded from availing himself of his signature in his sale book of the defendant's name as a compliance with the Statute of Frauds $(q)$; though, if the signature in question were entered in the sale book by the auctioneer's clerk that would be sufficient $(r)$.

Another agent commonly concerned in the sale of goods, 6.31

(m) Sykes r. Giles, 5 M. \& W. 645,

(v) 1 H. \& N. 484, 488.

(o) Williams v. Arillington, $1 \mathrm{H}$. Bla. $81 ; 2$ R. R. 724 ; followed in Davis r. Artingstall, 49 L. J. Ch. 609 ; per Parke, J., Coppin r. Walker, 7 Taunt. $241 ; 17$ R. R. 505 ; per Lord Abinger, C. B., 5 M. \& W. 650 ;
Daris v. Danks, 3 Exch. 435, 437; Taplin r. Florence, 10 C. B. 744,764 .

(p) Graham v. Mrusson, 5 Bing. N.C.

603 ; Graham r. Freticell, 3 II. \& Gr. 368; Wright v. Dannah, 2 Camp. 203; 11 R. R. 693.

(q) Farebrother T. Simmons, 5 B. \& Ald. 333 ; 24 R. R. 399.

(r) Bird v. Bonlter, 4 B. \& Ad. 443. 
and who was held to be "lawfully authorised" to bind his principal under the 17th section of the Statute of Frauds, is a broker $(s)$, who may be defined to be an agent employed to make bargains and contracts between third persons in matters of trade, commerce or navigation, for a pecuniary compensation, called 'brokerage' or 'commission.'

A broker, who acts as well for the vendor as for the purchaser of "goods, wares, or merchandises," might, it was decided, undoubtedly bind either of his principals by signing a " note or memorandum in writing " of the bargain concluded between them, as required by the statute $(t)$; though, if a party to the contract, the broker could not sign it as agent for defendant so as to bind him within s. $17(u)$. Difficulty may, however, be felt in determining what constitutes the contract between the parties $(x)$, and what is a note or memorandum of it sufficient within the statute.

To explain this matter, let us refer to the practice of share-brokers and stock-brokers in the city of London $(y)$. When a contract of sale is there made through the medium of a broker, the broker may perhaps enter in his book $(z)$, and sign the contract; in cases where he did so, the entry thus made by him was held to constitute the contract binding on the parties, for, being authorised by the one party to sell, and

(s) Rucker г. Cammeyer, 1 Esp. 105; Hinde v. Whitehouse, 7 East, 569; 8 R. R. 676; Thompson v. Gardiner, 1 C. P. D. 777. A broker cannot, however, without the consent of his principal, delegate his authority; for delegata potestas non potest delegari : Henderson v. Barnewall, 1 Y.\& J. 387 ; Leg. Max., 6th ed., 794.

( $t$ Rueker v. Cammeyer, 1 Esp. 105 ; Parton, app., Crofts, resp., 16 C. B., N. S., 11 ; Chapman v. Partridge, 5 Esp. $256 ; 8$ R. R. 852 . Seo Pitts v. Beekett, 13 M. \& W. 743. (u) Sharman v. Brandt, L. R. 6 Q. B. 720. A broker cannot sue in his own name upon a contract made by him as broker: Fairlie v. Fenton, L. R.
5 Ex. 169; Sharman v. Brandt, supra.

$(x)$ See Moore v. Campbell, 10 Exch. 323 ; Noble v. Ward, L. R. 2 Ex. 13\%; 1 Id. 117.

(y) See Smith v. Lindo, 4 C. B., N. S., $395 ;$; $. C ., 5$ Id. $58 \%$. A broker who signs the contract in that character may, by virtue of a local usage, incur liability upon it as principal: Humfrey v. Dale, 7 E. \& B. $266: S . C$. (in Error), E. B. \& E. 1004, cited post, Chap. VI. ; Fleetv. Murton, L. R. 7 Q. B. 126; Hutehinson v. Tatham, L. R. 8 C. P. 4 S2; Pike v. Ongley, 18 Q. B. D. $70 \mathrm{~s}$. 345 .

(z) See Russell on Factors, pp. 46,

B.C.L. 
by the other to buy, in the terms of the contract-when the broker had reduced it into writing and signed it as their common agent, it bound them both according to the Statute of Frauds, as if both had signed it with their own hands.

Such is the duty of the broker, and it is further the practice for him to send what are called the bought and sold notes to his principals - the bought note to the buser, and the sold note to the seller-by way of intimating that he has acted upon their instructions. Sometimes, however, or rather as it would seem frequently, the broker omits to enter or sign any contract in his book, but contents himself with sending to his clients the bought and sold notes in the manner just mentioned. If these notes agreed, they were held, and justly, to constitute a binding contract, sufficient within the Statute of Frauds; but if there was any material (a) variance between them, the case of Siercurright v. Archibald (b) decided that they were both nullities, and that in that case consequently, there was, in the absence of part payment and part acceptance, no binding contract at all between the parties upon which an action could be brought. For contracting parties must consent ad idem; and where the terms of the tro notes differ, there can be no reason why faith should be given to the one rather than to the other $(c)$. But where the broker was employed by the seller alone, a contract effected by a note sent to and accepted by the purchaser, was not avoided by a variation in the note sent to the seller $(d)$.

Exactly as the cases cited previously (e) show that a written contract falling within the operation of the 4 th

(a) See Heyucorth r. Fright, 17 C. B., N. S., 298.

(b) 17 Q. B. 103 (where the cases are reviewed); Kempson r. Boyle, 3 H. \& C. 763 ; Parton, app., Crofts, resp., 16 C. B., N. S., 22, 23 ; per Parke, B., 10 Exch. 330. See Trueman r. Loder, 11 Ad. \& E. ōS9, cited post, Chap. 6. (c) A material alteration in the sold note made by the buyer without the knowledge or consent of the seller will prevent the former from suing on the contract: Mollett $\mathbf{}$. Wackerbarth, 5 C. B. 181 .

(d) McCaull v. Strauss, 1 C. \& E. 106.

(e) Ante, pp. 369, 393. 
section of the Statute of Frauds, cannot be varied $(f)$ by a subsequent oral agreement between the contracting parties, so also it was held in the case of the 17 th section. In Marshall v. Lynn (g), it appeared that the defendant had entered into a written contract for the purchase of potatoes, the price whereof exceeded $10 l$., from the plaintiff, to be shipped on board a vessel named in the contract, when she should next arrive at the port of W. An alteration in regard to the time of shipping the potatoes was afterwards agreed to verbally by the parties; and, in an action against the purchaser for not accepting them according to his contract, the point to be decided was, whether such alteration by parol of the written contract was binding. The Court of Exchequer held that it was not so,- that the same rule must prevail as to the construction of the 17 th section as had, in Goss v. Lord Nugent (h), prevailed in regard to the construction of the 4 th section of the Statute of Frauds; that, if the original written contract required by either of those sections be varied, and a new contract as to any of its material terms be substituted in the place of it, that new contract cannot be enforced in law unless it also be in writing (i). It seems, however, that the rule in question, whereby contracts in writing are not allowed to be subsequently varied by parol, applies only where the particular contract is required by law to be in writing $(k)$.

The goods which form the subject of a contract of sale may, as already stated, be either existing goods owned or Subjectthe contract. possessed by the seller or goods to be manufactured or

(f) See Leather Cloth Co. v. Hieronimus, L. R. 10 Q. B. 140 ; Stewart v. Eddowes, L. R. 9 C. P. 311 ; Tyers v. Rosedale, \&c., Iron Co., L. R. 10 Ex. 195.

(g) 6 M. \& W. 109.

(h) 5 B. \& Ad. 58 ; ante, p. 393. See also Hargreaves $\checkmark$. Parsons, 13 M. \&W. 561, 568; Horne v. Wingfield, 3 Scott, N. R. 340; Plevins v. Downing,
1 C. P. D. 220.

(i) Judgm., 6 M. \& W. 117 ; Stead v. Dawber, 10 Ad. \& E. 57 ; Ogle v. Earl Vane, L. R. 2 Q. B. 275, 282, 284. See Tyers v. Rosedale, $\& c$., Co., L. R. 10 Ex. 195; Moore v. Campbell, 10 Exch. 323, 332.

(k) Per Maule, J., Pontifex v. Hii. kinson, 2 C. B. 361 . 
acquired by the seller after the making of the contract, which are called "future goods" $(l)$. It may be that the contract is for the sale of goods, the acquisition of which by the seller depends upon a contingency which may or may not happen $(m)$. As for example, where the subject-matter is a crop not sown at the date of the contract. If by the contract the seller purports to effect a present sale of future goods, the contract operates as an agreement to sell (n). If the goods the subject of a contract of sale of specific goods have without the seller's knowledge perished at the time when the contract is made, the contract is void $(o)$. If the goods the subject of an agreement to sell specific goods perish subsequently to the making of the contract without any fault on the part of either seller or buyer before the risk passes to the buyer, the agreement is thereby avoided $(p)$.

The price. The price may be fixed by the contract or may be left to be fixed in some manner thereby agreed upon, or may be determined by the course of dealing between the parties $(q)$. In the absence of such determination of the price the buyer must pay a reasonable price; as to what is such is a question of fact $(r)$. "The omission," says Wilde, C. J., in Valpy v. Gibson (s), "of the particular mode or time of payment, or even of the price itself, does not necessarily invalidate a contract of sale. Goods may be sold, and frequently are sold, when it is the intention of the parties to bind themselves by a contract which does not specify the price or the mode of payment, leaving them to be settled by some future agreement, or to be determined by what is reasonable

(l) S. 5 , subs. 1 ; cf. also s. 62 , subs. I, as to "future goods."

(m) Id., subs. 2.

(n) Id., subs. 3.

(o) S. 6. The law as laid down in Couturier v. Hastie, 5 H. L. Ca. 673, is adopted.

(p) S. 7. "Fault" is defined s. 62, subs. 1, as "wrongful act or default." The principle is the same as that of the decision in Taylor v. Caldicell, 3 B. \& S. 826.

(q) S. 8, subs. 1.

(v) Id., subs. 2.

(s) 4 C. B. 564 . 
under the circumstances." It may be that the agreement to sell goods stipulates that the price is to be fixed by the valuation of a third party, and such third party cannot or does not make such valuation, in which case the agreement is avoided, but the buyer must, if the goods or any part thereof have been delivered to and appropriated by him, pay a reasonable price therefor $(t)$. If such third party is prevented from making the valuation by the fault of the seller or buyer, the party not in fault may maintain an action for damages against the party in fault $(u)$.

Contracts of sale may embody several terms either express or implied, some of which may be of vital importance, others Conditions and warran. only of subsidiary importance. The remedy for the breach of any term of a contract of sale as of any other contract, differs according as the intention of the parties was that the term should be regarded as of vital or only subsidiary importance. A breach of a term of only subsidiary importance gives the aggrieved party only a right to sue for damages in respect of such breach, but a breach of a term of vital importance gives the aggrieved party the right to repudiate the contract, or to sue for damages for the breach of the contract, as distinct from damages for the breach of such term. Such former term is called a warranty; such latter term, a condition. A warranty in a contract of sale is defined by the Act, as meaning as regards England and Ireland, "an agreement with reference to goods which are the subject of a contract of sale, but collateral to the main purpose of such contract, the breach of which gives rise to a claim for damages, but not to a right to reject the goods and treat the contract as repudiated.". As regards Scotland, a breach of warranty shall be deemed to be a failure to perform a material part of the contract $(x)$.

( $t$ ) S. 9, subs. 1. "Delirery" is dealt with later; see post, p. 432 et seq. (u) Id., subs. 2.

(x) S. 62. As to this subject see 
As to conditions and warranties in relation to contracts of sale the Act contains the following enactments :-

Unless a different intention appears from the terms of the contract, stipulations as to time of payment are not deemed to be of the essence of a contract of sale. Whether any other stipulation as to time is of the essence of the contract or not depends on the terms of the contract $(y)$.

In certain cases the breach of a condition may be treated as a breach of warranty. The Act contains the following provisions in reference to England and Ireland :-

(a.) Where a contract of sale is subject to any condition to be fulfilled by the seller, the buyer may waive the condition, or may elect to treat the breach of such condition as a breach of warranty $(z)$, and not as a ground for treating the contract as repudiated.

(b.) Whether a stipulation in a contract of sale is a condition, the breach of which may give rise to a right to treat the contract as repudiated or a warranty, the breach of which may give rise to a claim for damages, but not to a right to reject the goods and treat the contract as repudiated, depends in each case on the construction of the contract. A stipulation may be a condition, though called a warranty in the contract.

(c.) Where a contract of sale is not severable, and the buyer has accepted the goods, or part thereof, or where the contract is for specific goods, the property in which has passed to the buyer, the breach of any condition to be fulfilled by the seller can only be treated as a breach of warranty, and not as a ground for rejecting the goods and treating the contract as repudiated, unless there be a term of the contract express or implied to that effect.

Chalmers, loc. cit., at pp. 164-179. Anson on Contracts, 7 th ed., pp. 304309 : ante, p. 340 et seq.

iy) S. 10. In a contract of sale " month" means primâ facie calendar month.

( $)$ S. 11, subs. 1. As to remedy fur breach of warranty, cf. s. 53, post, p. 440. 
In Scotland, failure by the seller to perform any material part of a contract of sale is a breach of contract, which entitles the buyer either within a reasonable time after delivery to reject the goods and treat the contract as repudiated, or to retain the goods and treat the failure to perform such material part as a breach which may give rise to a claim for compensation or damages.

The case of any condition or warranty, fulfilment of which is excused by law by reason of impossibility or otherwise, is not affected by the section.

In a contract of sale, unless the circumstances of the contract are such as to show a different intention, there is :-

(1.) An implied condition on the part of the seller that in the case of a sale he has a right to sell the goods, and that in the case of an agreement to sell he will have a right to sell the goods at the time when the property is to pass $(a)$;

(2.) An implied warranty that the buyer shall have and enjoy quiet possession of the goods;

(3.) An implied warranty that the goods shall be free from any charge or encumbrance in favour of any third party, not declared or known to the buyer before or at the time when the contract is made $(b)$.

Where there is a contract for the sale of goods by description, there is an implied condition that the goods shall correspond with the description; and if the sale be by sample, as well as by description, it is not sufficient that the bulk of the goods corresponds with the sample if the goods do not also correspond with the description $(c)$.

Subject to the provisions of the Act and of any statute in that behalf $(d)$, there is no implied warranty or condition

(a) See post, p. 425 et seq.

(b) S. 12.

(c) S. 13 . (d) E.g., the Merchandise Marks Act, $1887(50 \& 51$ Vict. c. 25$)$, s. 17. 
as to the quality or fitness for any particular purpose of goods supplied under a contract of sale, except as follows :-

(1.) Where the buyer, expressly or by implication, makes known to the seller the particular purpose for which the goods are required, so as to show that the buyer relies on the seller's skill or judgment, and the goods are of a description which it is in the course of the seller's business to supply (whether he be the manufacturer or not), there is an implied condition that the goods shall be reasonably fit for such purpose $(e)$, provided that in the case of a contract for the sale of a specified article under its patent or other trade name, there is no implied condition as to its fitness for any particular purpose ;

(2.) Where goods are bought by description from a seller who deals in goods of that description (whether he be the manufacturer or not), there is an implied condition that the goods shall be of merchantable quality; provided that if the buyer has examined the goods, there shall be no implied condition as regards defects which such examination ought to have revealed $(f)$;

(3.) An implied warranty or condition as to quality or fitness for a particular purpose may be annexed by the usage of trade;

(4.) An express warranty or condition does not negative a warranty or condition implied by this Act unless inconsistent therewith $(g)$.

In the case of a contract for sale by sample, i.e., a contract in which there is a term either expressed or implied to that effect $(h)$, the following are implied conditions (i) :

(1.) That the bulk shall correspond with the sample;

(c) S. 14, subs. 1. Randall r. Nouson, 2 Q. B. D. 102 (C. A.), disapproving, at p. 106, Parkinson r. Lee, 2 East, $314 ; 6$ R. R. 429.

(f) S. 14, subs. 2. Jones $r$. Just,
L. R. 3 Q. B. 19\%. See Jones r. Padgett, 24 Q. B. D. 650 .

(g) S. 14 , subs. 4 .

(h) S. 15, subs. 1.

(i) Id., subs. 2. 
(2.) That the buyer shall have a reasonable opportunity of comparing the bulk with the sample;

(3.) That the goods shall be free from any defect, rendering them unmerchantable, which would not be apparent on reasonable examination of the sample $(i)$.

As has been indicated earlier, the transfer of property in the goods, the subject of the contract, may or may not be simultaneous with the completion of the contract. The distinction between "specific" and "unascertained" goods alluded to earlier, as well as the meaning of "future goods," must be kept in mind in considering the following provisions of the Act, dealing with the transfer of property as one of the effects of the contract. Where the contract is for the sale of unascertained goods no property in the goods passes to the buyer until the goods are ascertained $(l)$. "If the thing sold is not ascertained, and something is to be done before it is ascertained, it does not pass till it is ascertained" $(\mathrm{m})$. "If I agree to deliver a certain quantity of oil, as ten out of eighteen tons, no one ean say which part of the whole quantity I have agreed to deliver until a selection is made" $(n)$. Where, on the other hand, the contract is for the sale of specific goods, the property in them passes to the buyer at such time as the parties to the contract intend it should pass $(o)$. The Act has provided rules for ascertaining the intention of the parties as to the time at which the property in the goods is to pass to the buyer. These rules, which do not hold if a contrary intention appear, are the following $(p)$ :-

Rule 1. Where there is an unconditional contract for the sale of specific goods, in a deliverable state, the property in

(k) Cf. Drummond r. Tan Ingen, 12 App. Cas. 284.

(l) S. 16. See Dixon v. Fates, 5 B. \& Ad., at p. 340 ; Heilbutt v. Hickson, L. R. 7 C. P., at p. 449.

(m) Per Erle, J., 7 E. \& B. 900 ,
901.

(n) Per Bayley, B., Gillett v. Hill, 2 C. \& M. 53 5.

(o) S. 17, subs. 1. See Seath v. Moore, 11 App. Cas., at p. 370.

(p) S. 18. the contract. Transfer of property. 
the goods passes to the buyer when the contract is made, and it is immaterial whether the time of payment or the time of delivery, or both, be postponed $(q)$.

"If I sell my horse for money, I may keep him until I am paid, but I cannot have an action of debt until he be delivered; yet the property of the horse is, by the bargain, in the bargainee or buyer. But if he presently tender me my money, and I refuse it, he may take the horse or have an action of detinue" $(v)$. Again, "if I offer money for a thing in a market or fair, and the seller agree to take my offer, and whilst I am telling the money as fast as I can, he doth sell the thing to another: or when I have bought it, we agree that he shall lieep it until I can go home to my house to fetch the money; in both these cases, especially in the first, the bargains are good, so as the seller may not sell them afterwards to another: and upon the payment or tender and refusal of the money agreed upon, I may take or recover the things" $(s)$.

When goods are sold upon credit, and nothing is agreed upon as to the time of delivering the goods, the vendee is immediately entitled to the possession, and the right of possession and the right of property vest at once in him $(t)$. "If," says Wilde, C. J., " a vendor agrees to sell for a deferred payment, the property passes, and the vendee is entitled to call for a present delivery, without payment" $(u)$. "The sale of a specific chattel on credit," says Lord Denman, C. J. $(x)$, "though that credit may be limited to a definite period, transfers the property in the goods to the vendee, giving the vendor a right of action for the price and a lien upon the goods, if they remain in his possession, till that price be paid."

(q) Cf. per Blackbum, J., Suceting v. Tumer, L. R. 7 Q. B. 313 , and per I'erke, J., Jixon v. Iates, 5 B. \& Ad. 340.

(r) Noy, Mac. 88.

(s) 1 Shepp. Touch. 225. (t) Judgm., Bloxam v. Sanuders, 4 I. \& C. 948.

(ic) 10 C. B. $212,216$.

(x) Martindale v. Smith, 1 Q. B. 395; Chinery v. Viall, 5 H. \& N. 288, 293. 
Rule 2. Where there is a contract for the sale of specific goods, and the seller is bound to do something to the goods, for the purpose of putting them into a deliverable state, the property does not pass until such thing be done, and the buyer has notice thereof $(y)$.

Rule 3. Where there is a contract for the sale of specific goods in a deliverable state, but the seller is bound to weigh, measure, test, or do some other act or thing with reference to the goods for the purpose of ascertaining the price, the property does not pass until such act or thing be done, and the buyer has notice thereof.

Rule 4. When goods are delivered to the buyer on approval or "on sale or return" or other similar terms, the property therein passes to the buyer:-

(a.) When he signifies his approval or acceptance to the seller or does any other act adopting the transaction:

(b.) If he does not signify his approval or acceptance to the seller but retains the goods without giving notice of rejection, then, if a time has been fixed for the return of the goods, on the expiration of such time, and, if no time has been fixed, on the expiration of a reasonable time. What is a reasonable time is a question of fact $(z)$.

Rule 5. (1.) Where there is a contract for the sale of unascertained or future goods by description, and goods of that description and in a deliverable state are uncon-

(y) Cf. Rugg v. Minett, 11 East, $210 ; 10$ R. R. 475 ; Laidler v. Burlinson, 2 M. \& W. 615 ; Seath v. Moore, 11 App. Cas. 350 .

(z) Cf. Moss v. Sweet, 16 Q. B. 493. A rendee of goods who has used or sold a portion of them after he has liscovered that they are not in accordance with the contract, cannot repudiate the contract and recover back the price of the goods. Harnor v. Groves, 15 C. B. 667 . The vendor may, how- erer, hare acquiesced in the rendee's thus dealing with the goods: Lucy $\mathrm{v}$. Mouflet, 5 H. \& N. 229. The general rule is that " a buyer cannot return a specific chattel except it be in the same state as when it was bought" (per Bramuell, B.): Head v. Tattersall, L. R. 7 Ex. 11, 12 (which shows that the rule stated in this note supra may be qualified); per Bovill, C. J., L. R. 7 C. P. 451. 
ditionally appropriated to the contract, either by the seller with the assent of the buyer, or by the buyer with the assent of the seller, the property in the goods thereupon passes to the buyer. Such assent may be express or implied, and may be given either before or after the appropriation is made.

(2.) Where, in pursuance of the contract, the seller delivers the goods to the buyer, or to a carrier, or other bailee or custodier (whether named by the buyer or not), for the purpose of transmission to the buyer, and does not reserve the right of disposal, he is deemed to have unconditionally appropriated the goods to the contract $(a)$.

Where there is a contract for the sale of specific goods, or where goods are subsequently appropriated to the contract, the seller may, by the terms of the contract or appropriation, reserve the right of disposal of the goods until certain conditions are fulfilled. In such case, notwithstanding the delivery of the goods to the buyer, or to a carrier or other bailee, or custodier for the purpose of transmission to the buyer, the property in the goods does not pass to the buyer until the conditions imposed by the seller are fulfilled $(b)$. If goods are shipped, and by the bill of lading the goods are deliverable to the order of the seller or his agent, the seller is, primâ facie, deemed to reserve the right of disposal $(c)$. Where the seller of goods draws on the buyer for the price, and transmits the bill of exchange and bill of lading to the buyer together to secure acceptance or payment of the bill of exchange, the buyer is bound to return the bill of lading if he does not honour the bill of exchange, and if he wrongfully retains the bill of lading the property in the goods does not pass to him (d).

Rules as to transfer of risk.
The risk, prima facic, passes with the property. Thus,
(a) Cf. Wait v. Baker, 2 Exch., at
(c) S. 19 , subs. 2 .
(b) S. 19 , subs. 1 . p. 7 . 
unless otherwise agreed, the goods remain at the seller's risk until the property therein is transferred to the buyer, but when the property therein is transferred to the buyer, the goods are at the buyer's risk whether delivery has been made or not $(e)$. If, however, delivery has been delayed through the fault of either party, the goods are at the risk of the party in fault as regards any loss which might not have occurred but for such fault $(f)$.

The general rule of law is that no one can transfer a better title than he himself has $(g)$. Where goods are sold Transfer title. by a person who is not the owner thereof, and who does not sell them under the authority or with the consent of the owner, the buyer acquires no better title to the goods than the seller had, unless the owner of the goods is by bis conduct precluded from denying the seller's authority to sell $(h)$.

To the rule as thus stated there are exceptions. Where the goods are sold in market overt, according to the usage of the market, the buyer acquires a good title to the goods, orovided he buys them in good faith and without notice of iny defect or want of title on the part of the seller (i). Where the seller of goods has a voidable title thereto, but uis title has not been avoided at the time of the sale, the puyer acquires a good title to the goods, provided he buys

(c) S. 20.

(f) Id. The section does not affect he duties or liabilities of either a seller $r$ buyer as a bailee or custodier of the ;oods of the party: cf. s. 20, and see . 36, post, p. 434 .

(g) Cf. per Willes, J., Whistler v. orster, 32 L. J. C. P. 161, at p. 164. (h) S. 21, subs. 1. The Act does ot, however, affect the provisions of 1e Factors Act $(52 \& 53$ Vict. c. 45 , pplying to. England, and 53 \& 54 ict. c. 40, applying to Scotland), or ay enactment enabling the apparent wner of goods to dispose of them as if e were the true owner thereof (cf. 18 19 Vict. c. 111 , the Bankruptcy Act,
1883, the Bills of Sale Act, 1878). Further, the Act does not affect the validity of any contract of sale under any special common law or statutory power of sale or under the order of a Conrt of competent jurisdiction: see s. 21 , subs. $2(a)$ and $(b)$.

(i) S. 22 , subs. 1 . The section does not apply to Scotland. Horses are not within the section (cf. subs. 2); see 2 \& 3 Phil. \& Mar. c. 7 , and 31 Eliz. c. 12. All shops in the city of London are market orert, but a show-room as distinct from the shop is not market overt: Hargreave v. Spink, (1892) 1 Q. B. 25. 
them in good faith and without notice of the seller's defect of title $(k)$. Where goods have been stolen and the offender is prosecuted to conviction, the property in the goods so stolen revests in the person who was the owner of the goods, or his personal representative, notwithstanding any intermediate dealing with them, whether by sale in market overt or otherwise $(l)$; but where goods have been obtained by fraud or other wrongful means not amounting to larceny, the property in such goods shall not revest in the person who was the owner of the goods, or his personal representative, by reason only of the conviction of the offender $(m)$. Where a person having sold goods continues or is in posses. sion of the goods, or of the documents of title to the goods. the delivery or transfer by that person, or by a mercantile agent acting for him, of the goods or documents of title under any sale, pledge, or other disposition thereof, to any person receiving the same in good faith and without notice of the previous sale, shall have the same effect as if the person making the delivery or transfer were expressly authorised by the owner of the goods to make the same (n)

(k) S. 23. The case of Cunday v. Lindsay, 3 App. Cas. 459, niust be distinguished. The rendor had no title, having acquired the goods by a fraud, leading his vendors to suppose they were contracting with some person other than himself.

(I) S. 24, subs. 1 . The section does not apply to Scotland. In Payne v. Wilson, (1895) 1 Q. B. 653, the Court (Pollock, B., and Grantham, J.) held that the section does not include the case where a person has been found guilty of larceny as a bailee. The ground of the decision was expressed to be that the Act was passed to consolidate what was assumed to be the existing law, and effect was to be given to the proviso to s. 100 of $24 \& 25$ Vict. c. 96 , which expressly excludes the case of larceny by a bailee from the operation of the section. The Court further held that the agreement under which the person so convicted had acquired possession of the goods was such as to bring the case within s. 9 of the Factor Act. This construction of the agree ment was opposed to the conclusion the House of Lords subsequently came to in Helby v. Matheu's (cf. n. (o), infra) On appeal, the respondent admitted the appellant's right to succeed. The C.A gave effect to the decision of the Hous of Lords in Helby v. Mathews (ef 1895,2 Q. B. 537), and consequentl. the question of the construction 0 s. 24, subs. 1, of the Sale of Goods Ac did not arise.

(m) S. 24, subs. 2. Over-ridins Bentley v. Vilmont, 12 App. Cas. 471 and limiting the application of 5.1000 the Larceny Act, 1861 (24 \& 25 Vict c. 96) to the case of goods obtained by larceny (cf. Chalmers on the Sale o Goods Act, 1893, at p. 53).

(n) S. 25, subs. 1 ; cf. Nicholson v. Harper, (1895) 2 Ch. 415 . Thi subsection of $s$. 25 re-enacts with trifling alterations s. 8 of the Factor Act, 1889 . S. 8 itself re-enacts witl 
Where a person having bought or agreed to buy goods obtains, with the consent of the seller, possession of the goods or the documents of title to the goods, the delivery or transfer by that person, or by a mercantile agent acting for him, of the goods or documents of title, under any sale, pledge, or other disposition thereof, to any person receiving the same in good faith and without notice of any lien or other right of the original seller in respect of the goods, shall have the same effect as if the person making the delivery or transfer were a mercantile agent in possession of the goods or documents of title with the consent of the owner $(o)$. The term "mercantile agent" has the same meaning as in the Factors Acts.

A writ of fieri facias or other writ of execution against goods binds the property in the goods of the execution debtor as from the time when the writ is delivered to the Effects of writs of expeution in England sheriff or other officer charged with the enforcement of a writ of execution to be executed; it is the duty of the sheriff, without fee, upon the receipt of any such writ to endorse upon the back thereof the hour, day, month, and year when he received the same. The title to such goods acquired by any person in good faith and for valuable consideration is not prejudiced by such writ unless such person had at

an extension to the goods themselves s. 3 of the Act of 1877 . This lastmentioned section (s. 3 of the Act of 1877) was passed to alter the law as decided in Johnson $\nabla$. Crédit Lyonnais, 3 C. P. D. 32. The Factors Act, 1889 , some of whose sections (viz., ss. 8,9 , $\& 10)$ have been re-enacted in the Sale Jf Goods Act, 1893, repealed the prerious Acts, 4 Geo. 4, c. 53, 6 Geo. 4, 3. 94,5 \& 6 Vict. c. 39 , and 40 \& 41 Vict. c. 39 . The effect of the irst three of the repealed enactments s stated in Blackburn, J.'s judgnent in Cole v. North-Western Bank, s. R. 10 C. P. 354. The Act of 889 ( $52 \& 53$ Vict. c. 45 ) has been xtended to Scotland by 53 \& 54 Vict. . 40 (the Factors (Scotland) Act, $890)$. (o) Ib., subs. 2. This subsection of s. 25 re-enacts with trifling alterations s. 9 of the Factors Act, 1889. Upon the corresponding section (s. 4) of the Act of 1877 it was decided that for the section to apply it was not necessary that s. 17 of the Statute of Frauds should be complied with; it was enough if there was a de facto sale: Hugill v. Masker, 22 Q. B. D. 364 (C. A.). Whether a person in possession of goods under a so-called hirepurchase agreement who disposes of the goods or any part of them the subject of such agreement is within the section depends upon the terms of the agreement. Upon this point, ef. Helby v. Mathews, (1895) A. C. 471 (reversing C. A., (1894) 2 Q. B. 262, and distinguishing Lee v. Butler, 
the time when he acquired his title notice that such writ or any other writ by virtue of which the goods of the execution debtor might be seized or attached had been delivered to and remained unexecuted in the hands of the sheriff $(p)$.

Performance of the con. tract.

Delivery.

Both the seller and the buyer have duties in respect of the performance of the contract. Such duties may be defined by the contract, or failing that, are defined by the Act (q). Unless otherwise agreed, delivery of the goods and payment of the price are concurrent conditions-that is to say, the seller must be ready and willing to give possession of the goods to the buyer in exchange for the price, and the buyer must be ready and willing to pay the price in exchange for the possession of the goods $(r)$.

As to delivery, the following rules apply. In the absence of any expressed or implied agreement to the contrary, the place of delivery is the seller's place of business, if he has one, if not, his residence, except where the goods are at the time of making the contract to the knowledge of the parties in some other place, which in such case is the place of delivery $(s)$. It may be that under the contract the seller is bound to send the goods to the buyer. In such case, if no time is fixed within which the seller shall send the goods to the buyer, he must do so within a reasonable time ( $t)$. If the goods at the time of the contract of sale are in a third party's possession, there is no delivery by seller to buyer unless and until such third party acknowledges to the buyer that he holds the goods on his behalf $(u)$. Demand or tender of delivery may be treated as ineffectual unless made at a reasonable hour; as to what is such is a question of

(1893) 2 Q. B. 318 (C. A.)). See also McEntire v. Crossley, (1895) A. C. 457.

(p) S. 26. The section does not apply to Scotland. This section is a re-enactment of 8.16 of the Statute of Frauds, with the addition of "hour," and s. 1 of $19 \& 20$ Vict. c. 97.

(q) S. 27 .

(r) S. 28. (s) S. 29 , subs. 1 .

(t) Id., subs. 2 .

(iv) S. 29, subs. 3. The operation of the issue or transfer of documents of title to goods is not affected by the section. As to these, see the Bills of Lading Act, 1855 (18 \& 19 Vict. c. 111), and the Factors Act, 1889 (52 \& 53 Vict. c. 45$)$. 
fact $(x)$. The seller must, unless otherwise agreed, bear the cost of and incidental to putting the goods into a deliverable state $(y)$.

If the seller deliver to the buyer a wrong quantity of goods, whether too small or too large, the buyer may reject the whole, or he may retain the whole (or in the case where the quantity delivered is larger than that contracted for, he may retain the exact quantity and reject the rest), paying for the quantity retained at the contract rate $(z)$. Further, should the goods delivered be mixed with goods of a different description to those the seller contracted to sell, the buyer may reject the whole or retain such as are in accordance with the contract $(a)$. These rights of the buyer are, however, subject to any usage of trade, special agreement, or course of dealing between the parties $(b)$. Nor is the buyer, unless otherwise agreed, bound to accept delivery by instalments $(c)$. If the contract provides for delivery by stated instalments to be separately paid for, and the seller make defective deliveries in respect of one or more instalments, or the buyer neglects or refuses to take delivery of or pay for one or more instalments, it is a question in each case depending on the terms of the contract, and the circumstances of the case, whether the breach of contract is a repudiation of the whole contract, or whether it is a severable breach giving rise to a claim for compensation, but not a right to treat the whole contract as repudiated $(d)$. Where, in pursuance of a contract of sale, the seller is authorised or required to send the goods to the buyer, delivery of the goods to a carrier, whether named by the buyer or not, for the purpose of transmission to the buyer, is prim $\hat{a}$ facie deemed to be a delivery of the goods to the
(x) S. 29 , subs. 4 .
(b) Id., subs. 4.
(y) Id., subs. 5 .
(c) S. 31 , subs. 1 .
(z) S. 30, subss. 1 and 2.
(d) Id., subs. 2 ; cf. Mersey Steel
(a) Id., subs. 3.
Co. v. Naylor, 9 App. Cas. 434.

B.C.L. 
buyer (e). If the seller deliver the goods to a carrier, he must, unless otherwise agreed, make such contract with the carrier as, having regard to the nature of the goods and the other circumstances of the case is reasonable $(f)$, and, further, if the goods are to be carried by sea under circumstances under which it is usual to insure, he must, unless otherwise agreed, give the buyer notice enabling him to insure the goods $(g)$. If the seller agrees to deliver the goods at his own risk at a place other than that where the goods are when sold, the buyer must nevertheless, unless otherwise agreed, take any risk of deterioration in the goods necessarily incidental to the course of transit $(h)$.

Acceptance. As to acceptance, the buyer is deemed to have accepted the goods if he does any of the following: (1) intimates to the seller that he has accepted them; (2) does any act in relation to them inconsistent with the ownership of the seller; (3) retains the same without intimating within a reasonable time that he rejects them (i). The buyer is not deemed to have accepted goods which he has not previously to delivery examined, unless and until he has had a reasonable opportunity of examining them for the purpose of ascertaining whether they are in conformity with the contract $(k)$. Unless otherwise agreed, the seller when he tenders delivery of goods to the buyer, is bound on request to afford the buyer a reasonable opportunity of examining the goods for the purpose of ascertaining whether they are in conformity with the contract $(l)$. The buyer having the right to refuse to accept goods delivered to him, is not bound to return them to the seller; it is sufficient if he intimate to the seller that he refuses to accept them $(m)$.
(e) S. 32 , subs. 1 .
(f) Id., subs. 2.
(g) Id., subs. 3.
(h) S. 33.

(i) S. 35.

(k) S. 34 , subs. 1.

(l) Id., subs. 2.

(in) S. 36. 
When the seller is ready and willing to deliver the goods, and requests the buyer to take delivery, and the buyer does not within a reasonable time after such request take delivery of the goods, he is liable to the seller for any loss Liability of buyer for sieglecting or refusing to take delivery of occasioned by his neglect or refusal to take delivery, and also for a reasonable charge for the care and custody of the goods $(n)$.

A seller $(o)$ is deemed to be an unpaid seller within the meaning of the Act :-

(a.) When the whole of the price has not been paid or goods. tendered.

(b.) When a bill of exchange or other negotiable instrument has been received as conditional payment, and the condition on which it was received has not been fulfilled by reason of the dishonour of the instrument or otherwise $(p)$.

An unpaid seller of goods has, subject to the provisions of the Act $(q)$, and of any statute in that behalf $\left(r^{\circ}\right)$, notwithstanding that the property in the goods may have passed to the buyer, by implication of law $(s)$ :-

(a.) A lien on the goods or right to retain them for the price while he is in possession of them;

(b.) In case of the insolvency of the buyer, a right of stopping the goods in transitu after he has parted with the possession of them;

(c.) A right of re-sale as limited by this Act.

Further, where the property in goods has not passed to the buyer, the unpaid seller has, in addition to his other

(n) S. 37. The section expressly reierves the rights of the seller where the eglect or refusal of the buyer amounts o a repudiation of the contract. As 0 repudiation, cf. s. 31 . The seller's ourse would appear to be to proceed inder s. 57.

(o) The term includes any person rho is in the position of a seller, as for astance an agent of the seller to whom the bill of lading has been indorsed, or a consignor or -agent who has himself paid or is directly responsible for the price; cf. s. 38 , subs. 2 .

(p) S. 38 , subs. 1.

(q) Cf. s. 43 , post, p. 436 ; and s. 55.

(r) Cf. the Factors Act, 1859, and the Bills of Lading Act, 1855.

(s) S. 39 , subs. 1.
Rights of unpaid seller goods. 
remedies, a right of withholding delivery similar to and co-extensive with his rights of lien and stoppage in transitu where the property has passed to the buyer $(t)$.

Unpaid seller's lien.

Subject to the provisions of the Act $(u)$, the unpaid seller of goods in possession of them, even if in possession as agent, bailee or custodier for the buyer, is entitled to retain possession of them until payment or tender of the price in the following cases $(x)$ :-

(a.) Where the goods have been sold without any stipulation as to credit;

(b.) Where the goods have been sold on credit, but the term of credit has expired;

(c.) Where the buyer becomes insolvent.

Where an unpaid seller has made part delivery of the goods, he may exercise his right of lien or retention on the remainder, unless such part delivery has been made under such circumstances as to show an agreement to waive the lien or right of retention $(y)$.

The unpaid seller of goods loses his lien or right of retention $(z)$ :-

(a.) When he delivers the goods to a carrier or other bailee or custodier for the purpose of transmission to the buyer without reserving the right of disposal of the goods;

(b.) When the buyer or his agent lawfully obtains possession of the goods;

(c.) By waiver thereof.

The unpaid seller of goods, having a lien or right of retention thereon, does not lose his lien or right of retention by reason only that he has obtained judgment or decree for the price of the goods $(a)$.

Stoppage in transitu is a remedy the unpaid seller who

( $t$ ) S. 39, subs. 2. As to attachment by seller in Scotland, see $\mathrm{s} .40$.

(u) Cf. ss. 39, subss. 1 (aute, p. $435), 42$ (supra), and 55. (x) S. 41 .

(y) S. 42.

(z) S. 43 , subs. 1 .

(a) S. 43 , subs. 2. 
has parted with the possession of the goods has, when the buyer becomes insolvent $(b)$. It is, in fact, a right so long as the goods are in course of transit to resume possession of them and to retain them until payment or tender of the price $(c)$. The duration of the transit lasts from the time when the goods are delivered to a carrier by land or water, or other bailee or custodier, for the purpose of transmission to the buyer, until the buyer, or his agent in that behalf, takes delivery of them from such carrier or other bailee or custodier $(d)$. Should the buyer or his agent in that behalf obtain delivery of the goods before their arrival at the appointed destination, the transit is at an end (e). If, after the arrival of the goods at the appointed destination, the carrier or other bailee or custodier acknowledges to the buyer, or his agent, that he holds the goods on his behalf and continues in possession of them as bailee or custodier for the buyer, or his agent, the transit is at an end, and it is immaterial that a further destination for the goods may have been indicated by the buyer $(f)$. If the goods are rejected by the buyer, and the carrier or other bailee or custodier continues in possession of them, the transit is not deemed to be at an end, even if the seller has refused to receive them back $(g)$. When goods are delivered to a ship chartered by the buyer, it is a question depending on the circumstances of the particular case, whether they are in the possession of the master as a carrier or as agent to the buyer $(h)$. Where the carrier or other bailee or custodier wrongfully refuses to deliver the goods to the buyer, or his agent in that behalf, the transit is deemed to be at an end $(i)$. Where part delivery of the goods has

(b) I.e., has ceased to pay or cannot pay his debts when they become due, whether he has committed an act of bankruptey or not; cf. s. 67 , subs. 3 .

(c) S. 44. The section adopts the law as laid down in Lickbarrow $\mathrm{v}$. Mason, 1 Smith, L. C., 9th ed., 737. (d) S. 45 , subs. 1.

(e) Id., subs. 2.

(f) Id., subs. 3.

(g) Id., subs. 4.

(h) Id., subs. oे.

(i) Id., subs. 6. 
been made to the buyer or his agent in that behalf, the remainder of the goods may be stopped in transitu, unless such part delivery has been made under such circumstances as to show an agreement to give up possession of the whole of the goods $(k)$.

As to the method of exercising the right, the Act provides that: the unpaid seller may exercise his right of stoppage in transitu either by taking actual possession of the goods, or by giving notice of his claim to the carrier or other bailee or custodier in whose possession the goods are. Such notice may be given either to the person in actual possession of the goods or to his principal. In the latter case the notice, to be effectual, must be given at such time and under such circumstances that the principal, by the exercise of reasonable diligence, may communicate it to his servant or agent in time to prevent a delivery to the buyer $(l)$. When notice of stoppage in transitu is given by the seller to the carrier, or other bailee or custodier in possession of the goods, he must re-deliver the goods to, or according to the directions of, the seller. The expenses of such re-delivery must be borne by the seller $(m)$.

Re-sale by buyer or seller.

Subject to the provisions of the Act, the unpaid seller's right of lien or retention or stoppage in transitu is not affected by any sale or other disposition of the goods which the buyer may have made, unless the seller has assented thereto $(n)$. Provided that where a document of title to goods has been lawfully transferred to any person as buyer or owner of the goods, and that person transfers the document to a person who takes the document in good faith and for valuable consideration, then, if such last-mentioned transfer was by way of sale the umpaid seller's right of lien

(b) S. 45 , subs. 7 .

(I) S. 46 , subs. 1.

(iii) Id., subs. 2.

(II) S. 4\%. As expressed, the section subject to the provisious of the Act.
These provisions are presumably the sections of the Factors Act, 1859, embodied in s. 25, and the section (10) of that Act embodied in the proviso to the present section (s. 47). 
or retention or stoppage in transitu is defeated, and if such last-mentioned transfer was by way of pledge or other disposition for value, the unpaid seller's right of lien or retention or stoppage in transitu can only be exercised subject to the rights of the transferee $(o)$.

Except in the following cases the contract of sale is not rescinded by the mere exercise by an unpaid seller of his right of lien or retention or stoppage in transitu $(p)$. If an unpaid seller who has exercised his right of lien or retention or stoppage in transitu re-sells the goods, the buyer acquires a good title thereto as against the original buyer $(q)$. Where the goods are of a perishable nature, or where the unpaid seller gives notice to the buyer of his intention to re-sell, and the buyer does not within a reasonable time pay or tender the price, the unpaid seller may re-sell the goods and recover from the original buyer damages for any loss occasioned by his breach of contract $(r)$. Where the seller expressly reserves a right of re-sale in case the buyer should make default, and on the buyer making default, re-sells the goods, the original contract of sale is thereby rescinded, but without prejudice to any claim the seller may have for damages $(s)$.

If the buyer, either in the case where the property in the goods has passed to him, or where the price is by the contract payable on a certain day irrespective of delivery, wrongfully neglects or refuses to pay the price, the seller may recover the same in an action against the buyer $(t)$. If the buyer wrongfully neglects or refuses to accept and Remerlies of the seller. pay for the goods, the seller may in an action, in which the

(o) S. 47. The proviso re-enacts s. 10 of the Factors Act, 1889 ; cf. Kemp v. Falk, 7 App. Cas. 573 .

(p) S. 48 , subs. 1 .

(q) Id., subs. 2.

(r) Id., subs. 3 .

(s) Id., subs. 4.

(t) S. 49. Formerly, before the
Judicature Aets, the price of goods sold and delivered, or bargained and sold, was recoverable under the common indebitatus counts. In either case it was necessary that the property in the goods should have passed to the buyer, though in tlie latter case its delivery had not been made.
Actions for breach of the contract. 
measure of damages is the same as in the case where the seller refuses to deliver $(u)$, recover damages against the buyer $(x)$.

Remedies of If the seller wrongfully neglects or refuses to deliver,
the buyer. the buyer may recover, in an action for non-delivery, the damages directly and naturally resulting, in the ordinary course of events, from the seller's breach of contract $(y)$. As to the measure of damages in such action, if there is an available market for the goods, the measure is prima facie to be ascertained by the difference between the contract price and the marliet price of the goods at the time or times when they ought to have been delivered, or, if no time was fixed, then at the time of refusal to deliver $(z)$. If the seller was by the contract bound to deliver specific or ascertained goods, the Court may, if it thinks fit, direct that the contract shall be specifically performed, without giving the defendant the option of retaining the goods on payment of damages $(a)$.

Reinedy for breach of warranty.

Where there is a breach of warranty by the seller, or where the buyer elects, or is compelled, to treat any breach of a condition on the part of the seller as a breach of warranty, the buyer is not by reason only of such breach of warranty entitled to reject the goods; but he may (a.) set up against the seller the breach of warranty in diminution or extinction of the price; or (b.) maintain an action against the seller for damages for the breach of

(a) Cf. s. 51, subss. 2 and 3, infra.

(x) S. 50. If the buyer neglects or refuses to take delivery within a reasonable time after the seller, being ready and willing to deliver, has requested the buyer so to do, the buyer is liable to the seller for any loss occasioued by his neglect or refusal, and also for a reasonable charge for the care and custody of the goods (cf. s. 3i).

(y) S. 5l, subs. 2. This is an application of the rule in Hadlcy $\mathrm{v}$.
Baxendale, 8 Ex. 341 (ef. post, p. 735); cf. also Hammond r. Bussey, 20 Q. B.D. 79 (C. A.), and post, p. 736 (n. i).

(z) S. 51, suls. 3 . As to contracts for delivery by instalments, see Roper v. Johnson, L. R. 8 C. P. 167 ; Broucn v. Muller, L. R. 7 Ex. 319.

(a) S. 52. The section reproduces s. 2 of the Mercantile Law Amendment Act, 1856 (19 \& 20 Vict. c. 97$)$, which is repealed by s. 60 of the Act. 
warranty $(b)$. The measure of damages for breach of warranty is the estimated loss directly and naturally resylting, in the ordinary course of events, from the breach of warranty $(c)$. In the case of breach of warranty of quality such loss is primi facie the difference between the value of the goods at the time of delivery to the buyer and the value they would have had if they had answered to the warranty $(d)$. The fact that the buyer has set up the breach of warranty in diminution or extinction of the price does not prevent him from maintaining an action for the same breach of warranty if he has suffered further damage $(e)$.

The Act provides with regard to sales by auction as Anction follows $(f)$. Where goods are put up for sale by auction in lots, each lot is prima facie deemed to be the subject of a separate contract of sale. A sale by auction is complete when the auctioneer announces its completion by the fall of the hammer, or in other customary manner. Until such announcement is made any bidder may retract his bid. Where a sale by auction is not notified to be subject to a right to bid on behalf of the seller, it shall not be lawful for the seller to bid himself or to employ any person to bid at such sale, or for the auctioneer knowingly to take any bid from the seller or any such person. Any sale contravening this rule may be treated as fraudulent by the buyer. A sale by auction may be notified to be subject to a reserved or upset price, and a right to bid may also be reserved expressly by or on behalf of the seller. Where a right to id is expressly reserved, but not otherwise, the seller, or iny one person on his behalf, may bid at the auction.

(b) S. 53, subs. 1. In Chapman v. Vithers, 20 Q. B. D. 824, a horse sold rith a warranty was killed through no ault of the buyer, and the buyer uccessfully sued for breach of warranty, hough he could not by returning the orse comply with a condition of the sale that the horse should be returned by an agreed time if the buyer contended it did not correspond with the warranty.

(c) Id., subs. 2.

(d) Id., subs. 3.

(e) Id., subs. 4 .

(f) S. 58. Cf. ante, p. 414. 


\section{CHAPTER IV.}

NEgotiable INstrumeNts $(a)$.

Negotiable instrument -what.

Chosa in artion what ;

Tue term 'negotiable instrument' will here be used to signify an instrument which may be transferred by assignment from one person to another, so as to vest a legal title to the property represented or secured by it and a right of action directly founded upon it in the transferee $(b)$.

Every 'negotiable' instrument, accordingly, presents an exception to that general rule of our common lau' (c), which says, that 'choses in action' shall not be assignable $(d)$. In order to understand the meaning and scope of this rule, some few remarks are necessary.

In the first place, then, what is a 'chose in action'? This question may be answered by reference to the Termes de la Ley $(e)$, where we read that a chose in action "is where a man hath cause or may bring an action for some duty due to him," as upon an obligation, for a breach of covenant for a trespass, or the like; and, indeed, wherever a thing is not in possession, but where, for recovery of it, a

(a) An elementary view merely has in this chapter been attempted of the subject above specified. 'The author has contented himself with exhibiting a brief outline of the law applicable to it, and with pointing out from a multitude of cases those to which attention should specially be direeted.

(b) See Webst. Dict. ad rerb. "Negotiable."

(c) The rule in equity and the operation of the Judicature Act, 1873 , are shortly stated post, pp. $445,446$.

(d) In Noble v. National Discount Co., 5 H. \& N. 228, Bramicell, B., sars, "There is no doubt as to the law that if one person is indebted to another he cannot become under an obligation to a third party without the agreement of all three." See also per Martin, B., Lirersidge v. Broadbent, 4 H. \& $\mathrm{N}$. 610.
(e) Ed. 1708, p. 121. 
man is driven to his action (and consequently enjoys a right merely), such thing is called a chose in action $(f)$.

Now, it is to be observed, that, by an ancient maxim of $\frac{\text { not ac- }}{\text { signable }}$ the common law, a chose in action cannot be granted or at law. transferred to a stranger, so as to enable the transferee to sue upon it $(g)$. The policy of our law being, that maintenance, suppression of right, and stirring up of suits may thus be avoided; nothing in action or entry, says Sir E. Coke $(h)$, "can be granted over, for so, under colour thereof, pretended titles might be granted to great men, whereby rights might be trodden down and the weak oppressed, which the common law forbiddeth."

The rule which at law forbids the assignment of a shose in action applies generally as well to specialties as to simple contracts. Our law, observes a modern writer (i), "will not permit a person not privy to a contract to found a legal claim or remedy thereon in his own name by issignment from the party with whom the obligation was sntered into. It will not permit a person to become the reditor of another, without his consent; and the reason is, rot only that there are wanting the mutuality and privity ssential to constitute a contract, but that oppression and injust litigation would be encouraged, if persons-strangers 0 the stipulating party-(and with whom, perhaps, he rould not have contracted) could purchase causes of suit, nd divest the original creditor of his legal right of ction" (k). "It is," accordingly, " a well-known rule that a ond is not assignable at common law so as to enable the

(f) All personal chattels, not in issession, are choses in action : Vlonial Bank v. Whinney, 11 App. 15. 426 , where shares in an incorrated company, transferable only by ed, were held to be choses in action thin the Bankruptcy Act, 1883 $3 \& 47$ Vict. c. 55 , s. 44 (iii.) ).

(g) Supra, n. $(d)$; Co. Litt. 266 a ; $r$ Maule, J., Tempest v. Kilner, 2 B. 308 ; Jones v. Carter, 8 Q. B.
134, with which compare Jones $r$. Robinson, 1 Exch. 454 . And see per Buller, J., Master v. Miller, 4 T. R. 340,$341 ; 2$ R. R. 399 : 1 Sm. I. C., 9th ed., 825; per Willes. J., Balfour $r$. Sea Fire, \&e., Co., 3 C. B., X. S., 308.

(h) Co. Litt. 214 a ; Lampet's ctrse, I0 Rep. 48 a.

(i) Chitt., jun., on Bills, vol. 1. p. 30 .

(k) It appears to be the duty of a 
assignee to sue upon it in his own name" $(l)$. And there is authority for saying that "a party cannot make an instrument negotiable and not negotiable at the same time" (m).

Such being the doctrine of our law, an important question suggests itself, riz., whether a chose in action, not assignable under the Law Merchant or by statute, could, at its original creation, be made so by the express contract and intent of the parties to it. We may conclude, that this could not be done $(n)$; for, although in general the express terms of a contract constitute the law by which the rights of the contracting parties must be regulated, it does not seem to be competent for them to attach to their engagements, qualities not recognised by law as inherent in them, any more than it is competent to a man capriciously to attach conditions to land, which are opposed to the doctrines or spirit of our law $(o)$. The following propositions, therefore, seem to be true and unimpeachable - that a parol contract, as for the payment of money, cannot be endowed with a negotiable quality at the mere will of the parties to it, without reference to the recognised forms and usage of the Law Merchant; that a deed could not be rendered transferable and negotiable like a bill of exchange or an Exchequer bill $(p)$; that it is not competent to a person to create by his own act a transferable right of action on a contract $(q)$.

To the rule above stated with reference to the assignment

debtor in many cases, as in debt on bond, to find out his creditor, if he be within the realm. This duty would be one very difticult of performance on the part of the debtor, if choses in action were assignable. Hence, perliajs, one reason why such assiguments are not allowed at common law; Note (a), 6 C. 13.290.

(l) ler Martin, B., loung $r$. Huglers, 4 H. \& N. S4.

(iii) Per Compton, J., Carlon v. Ireland, 25 L. J., Q. B., 114; S. C., 5 E. \& B. 765.
(11) See Dixon v. Borill, 3 Macq. H. L. Ca. 1; Hybart v. Parke, 4 C. B. X. S., 209; C'rouch v. Credit Fon cier of England, L. R. 8 Q. B. 3 it followed in Lond. \& County Banking C". v. Loul. \& River Plate Bank. 20 Q. B. D. 232 (attirmed C. A., 2) Q. B. D. 535).

(o) Ante, p. 8 .

(p) Yer Parke, B., 6 M. \& W. 216 Crouch v. C'redit Fincier of Eingland supra.

(q) Judgm., L. R. 8 Q. B. 386. 
of choses in action, certain exceptions have been allowed; for instance, Courts of law were not bold enough to tie up the property of the Crown, or to prevent it from being transferred, so that the transferee might sue for it in his own name $(r)$. In the event of death, bankruptcy, and formerly of marriage, an assignment of a right of action might occur. Where a covenant runs with land, the right to sue upon it passes from assignee to assignee of the term or reversion, though it is observable that in this case a peculiar lind of privity-riz., that of estate-is created between the parties. Further, under particular Acts of Parliament, certain instruments, $e x . g r$., railway bonds (in some cases), bail bonds, and replevin bonds, have been made assignable $(s)$. And scrip issued in this country by the agent of a foreign government, entitling the holder on payment of the instalments, to delivery by the agent of definitive bonds of the foreign government, has been held to be negotiable, and to pass by delivery to a bon î ficle holder for value $(t)$.

The doctrine of equity in regard to the assignment of a chose in action has been different from that of our common law (u). If A., having a debt due to him from B., should equity as to assigning a chose in order it to be paid to C., such order would amount in equity

(v) Termes de la Ley (ed. 1708), "Chose in Action:" per Buller, J., Master v. Miller, 4 T. R. $340 ; 2$ R. R. 399 ; 1 Sm. L. C., 9th ed., 825.

(s) Vertue v. East Anglian R. C., 5 Exch. 280 : East Umion R. C. v. Cochrane, 9 Exch. 197. See Thompson r. Bell, 3 E. \& B. 236 ; Selby v. East Anglian R. C., 7 Exch. อ̃3 ; Joung v. Hughes, 4 H. \& N. 76.

$(t)$ Goodwin v. Robarts, 1 App. Cas. 176; Rumball v. Netropolitan Bank, 2 Q. B. D. 194 ; Gorgier v. Mieville, 3 B. \& C. 45 ; Fine Art Soc. v. Union Bank, $\{c ., 17$ Q. B. D. 705 , where it vas held that post-office orders did not all within the rule laid down in Goodvin v. Robarts, ubi supra; Picker. . London \& County Bank, 18 Q. B. D.
515 , where it was held that the quality of negotiability is determined by the usage of the English money market, and not by the law of the place of issue; Easton v. Lond. Joint Stock Zk., 56 L. J. Ch. 569 ; cf. also Simmons r. London Joint Stock Bank, (1892) (A. C.), reversing C. A., (1891) 1 Ch. 271; and Bentinch Y. London Joint Stock Bank, (1893) 2 Ch. 120, as to bonâ fide holder for value without notice. Also on the same point, Sheffield v. London Joint Stock Bunk, 13 App. Cas. 333 (reversing C. A., 34 Ch. D. 95). As to negotiability by estoppel, see Colonial Bank r. Cady, 15 App. Cas. 267 (affirming C. A., 38 Cb. D. 388).

(u) "The general rule is not disputed 
to an assignment of the debt, and might be enforced, although the debtor had not assented to the assignment $(x)$; but even then it will be necessary for the assignee to show that he gave consideration to the assignor, and notice to the debtor, and he will take, subject to any defences which the debtor would have had against the assignor (y).

By the Judicature Act, 1873, s. 25, sub. (6), an "absolute assignment" "not purporting to be by way of charge only, of any debt or other legal chose in action," is, subject to certain specified conditions, recognised in a Court of law. The assignment must be in writing under the hand of the assignor; express notice of it in writing must have been given to the debtor; it will then be effectual in law to pass and transfer: the legal right to the debt or chose in action from the date of such notice, and the legal remedy for it, even without the consent of the party liable $(z)$. The assignment, however, will be subject to all equities entitled to priority over the rights of the assignee; as if there be an equitable mortgage or lien attaching to the debt or chose in action.

The subsection (6) of the Judicature Act, 1873, s. 25, above cited, is subject to a proviso having reference to the case where notice has been given to the debtor that the assignment is disputed by the assignor, or any one claiming under him, or that there are other opposing or conflicting claims to the debt or chose in action; when this is so, a remedy is made available to the debtor by the process of

that a chose in action cannot be trans. ferred at law at all, but that in equity it mar be assigned: "Judgm., L. R. $8 Q$. B. 380 . As to this rule, and its limitation as regards the assignment of contract, see Robson v. Iirmmond, 2 B. \& Ad. 303, considered in Lritish Wagon Co. v. Len, 5 (2. B. D. 149.

(x) Watson, Compendium Equity, I. 79; Row v. Iarcsan, Ryall v. Roicles, 2 Tud. Eql. L. C. 731,734 , and Note thereto. See Ficld r. Megav, I. R. 4 C. P. 660 ; Jeffs พ. Day, I. R. 1 Q. B. 372.

(y) Filliams r. Sarrell, 4 Ves. 359 Stocks v. Dobson, 4 D. M. \& G. 15 .

$\Leftrightarrow$ Brice v. Bannister, 3 Q. B. D. 569 : Burlinson r. Hall, 12 Q. B. D. 34 ; Walker v. Bradford old Bank ib. 511; Harding v. Harding, 17 Q. B. D. 442; Tancerd v. Delagon Bas R. C., 23 Q. B. D. 239. 
interpleader, or he may pay the debt into Court in conformity with the provisions of the Acts for the relief of trustees.

In regard to certain important classes of instruments, riz., bills of exchange and promissory notes, when drawn, made, and indorsed in a manner which will presently be pointed out, the technical rule of our common law forbidding the assignment of a chose in action does not hold. The instruments just named are, indeed, anomalous, and such as the common law, acting consistently with its ancient principles, would not have sanctioned. They are the creatures of, and owe their origin to, the Law Merchant, to mercantile custom gradually recognised and reduced to a certain uniform system by the decisions of our Courts of justice and, in part, by legislative interference $(a)$.

To the Italian merchants, the introduction of bills of exchange into use amongst the mercantile community of Europe is referable $(b)$, these instruments having been known in the 14th century, although the first reported case relating to them is Martin v. Boure (c), decided in the Exchequer Chamber in the first year of James I.

In the infancy of our commerce, when its true interests were but imperfectly understood, Courts of law seem to have been reluctant to give their full effect to bills of exchange, and allowed them only between merchants $(d)$; to he reluctance of our Courts to recognise these instruments seing doubtless manifested in order to discourage innovation, and to suppress novelties in derogation of the common law.

In order to appreciate the extent of the innovation caused y the introduction of the instruments in question, we must irst consider the negotiable quality attaching to a bill of xchange, and remember that, if originally made payable to rrder or to bearer, it may in the one case be indorsed, and $\mathrm{n}$ the other delivered over, so as to vest a right of action

(a) Chitt., jun., on Bills, vol. 1, p. 28 .

(b) Roccus, by Ingersoll, pref., p. 10.

(c) Cro. Jae. 6.

(d) Oaste v. Toiyloi, Cro. Jac. 306. 
upon the bill in any holder in due course $(e)$. This quality of negotiability differs from the mere assignability of other choses in action, in certain important particulars. Firstly, no notice is necessary to complete the holder's title, and secondly, it is not liable to be defeated by defences which might have prevailed against the assignor, when the bill is negotiated before it is due.

Here, then, we have an instance, complete in all respects, of the assignment of a chose in action; and if it be asked whence this assignable quality is derived, we answer, originally from the usage of merchants, which usage has been long sanctioned judicially and by Parliament, so as to form at this day a component portion of our common law.

It is not, however, solely in respect of the quality just adverted to, that a bill of exchange differs from an ordinary simple contract. It differs therefrom in another important particular, viz., that a consideration for the bill will be presumed until the contrary appear, or at least until suspicion has been thrown upon the holder's title. A defendant in an action upon a bill is not permitted to call upon the plaintiff to prove the consideration which he gave for it, unless the defendant can, in the first instance, make out a prima facie case against the holder, and impeach his title, as by showing that possession of the bill was obtained by undue means, or that the bill had been lost, or was originally infected with illegality $(f)$.

The law relating to bills of exchange and promissory notes has now been codified ( $q$ ) by the Bills of Exchange

(e) 45 \& 46 Vict. c. 61, s. 29. This expression has been used in the Act as being less cumbrous than the technical legal phrase "bonâ fide holder for value," and denotes a person who took the bill in good faith and for value before it was due, and without notice of any defect in title of the person from whom he took it. (f) Per Pollock, C. B., May r. Seyler 2 Exch. 566 ; post.

(g) As to the Act generally and its coustruction, see per loord Herschell, in Bank of England r. Vagliano, (1591) (A. C.). at pp. 144, 145. "The Bills of Exchange Act was certainly not intended to be merely a code of the existing law. It is not open to ques. 
Act, 1882 ( $45 \& 46$ Vict. c. 61 ), the main provisions of which are set out in the following pages.

A bill of exchange is an unconditional order in writing addressed by one person to another, signed by the person Bill of exchangegiving it, requiring the person to whom it is addressed to pay on demand or at a fixed or determinable future time a certain sum in money to or to the order of a specified person, or to bearer $(h)$.

Let us briefly examine the various parts of the definition above given :-

1. A bill of exchange must be in writing, for so the usage of merchants required $(i)$, and so the statute law now enjoins $(k)$.

2. The order must be unconditional. An order to pay out of a particular fund is not a bill : but an unqualified order to pay, coupled with (A) an indication of a particular fund out of which the drawee is to reimburse himself, or a articular account to be debited with the amount, or (в) a itatement of the transaction which gives rise to the bill, is inconditional within the meaning of the Act $(l)$. A written uthority to pay money on account of the person giving $t$ will not constitute a valid bill, although it may be vidence of an agreement $(m)$. Again, an instrument xpressed to be payable on a contingency is not a bill, or will the happening of the event cure the defect. An istrument, therefore, in this form, "Pay C. or order 00l. on the arrival of the ship Germanic," is not a

In that it was intended to alter it, and $i$ niter it in certain respects" (ib., 145).

(h) $45 \& 46$ Vict. c. 61 , s. 3 , subs. 1 . bill does not of itself operate as an ignment of funds in the hands of ; drawee available for the payment reof, nor will he be liable on the trument if he do not accept it: 53.

i) "A bill of exchange," says Lord B.C.L.
Hardwick, " is a contract of a very particular nature, depending on the custom of merchants, and must be in writing:" Thomas v. Bishop, Rep. temp. Hardw. 2; Claxton v. Swift, Lutw. 878. See Geary v. Physic, 5 B. \& C. 234 .

(k) S. 3, subss. $1,2$.

(l) S. 3 , subs. 3.

(m) Hamilton v. Spottisuoode, 4 Exch. 200. 
bill $(n)$. The reason of this is that certainty is a great object in mercantile instruments. It would perplex the commercial transactions of mankind if negotiable securities were issued out into the world incumbered with conditions and contingencies, and if the persons to whom they were offered in negotiation were obliged to inquire when those uncertain events would probably be reduced to a certainty; and accordingly, unless they carry their own validity on the face of them, and conform to what is recognised by mercantile custom, they will not be negotiable (o). In Alexander v. Thomas $(p)$ the bill upon which the plaintiff sued was made payable, "ninety days after sight, or when realized;" and the insertion in the bill of these latter words led after verdict to an arrest of judgment, on this short ground-that the bill was made payable on a contingency, and was not consequently "a good bill of exchange drawn according to the custom of merchants."

3. The order must be to pay on demand, or at a fixed or determinable future time. A bill is payable on demand which is expressed to be payable, on demand, at sight, on presentation, or in which no time for payment is expressed $(q)$. A bill is payable at a future determinable time within the meaning of the Act, when it is expressed to be payable, 1. At a fixed period after date or sight, as "three months after date (or sight)." 2. On or at a fixec period after the occurrence of a specified event which is certain to happen, though the time of happening may be uncertain, as "three months $(r)$ after the death of A." ( $s$ )

4. The order must be for the payment of a sum certair in money. Therefore an order to deliver goods, or to pas.

(n) S. 11.

(o) Carlos r. Fancourt, 5 T. R. 485 , 486 ; 2 R. R. 647.

(p) 16 Q. B. 333 ; per cur., Dawkes v. Lord Deloraine, 2 W. Bl. 782.

(q) An orerdue bill when accepted or indorsed is as against the acceptor o indorser payable on demand : $s: 10$.

(v) $\mathrm{By}$ which will be understoo calendar months: s. 14, subs. 4.

(s) S. 11. 
money and do some other act in addition is not a bill $(t)$. But the sum payable will be certain, although it is required to be paid with interest, or by stated instalments with or without a provision that upon default in payment of any instalment the whole shall become due, or according to a ate of exchange indicated by, or to be ascertained according ;o, the directions of the bill $(u)$.

5. It is essential to the validity of the bill that the lrawee or drawees should be named, or otherwise indicated herein, with reasonable certainty $(x)$, but a bill of exchange nay not be directed to alternative or successive drawees $(y)$.

6. Finally, where the bill is not payable to bearer, the rayee must be named or indicated therein with reasonable ertainty $(z)$.

Such being the definition of a bill of exchange, it will Form of e convenient to observe its ordinary form, which is as nder :-

" [Three] months after date [or, On demand, or, At sight, , At [ten] days after sight], pay C. D., or order [or, 3arer], [or, pay to my order] one hundred pounds $(a)$.

To Mr. E. F., Merchant, "A. B.

Park Street, Bristol." $\}$

In the corner of the above instrument is usually written,

(t) S. 3, subs. 2.

iu) S. 9 , subs. 1 .

x) S. 6 , subs. 1 .

y) S. 6 , subs. 2 .

z) S. 7, subs. 1. See Chamberlain Ionng, (1893) 2 Q. B. 206 (C. A.), ere it was held that an instrument ich was made payable to "er" must be construed as meaning t it was payable to " $\mathrm{my}$ order," to the drawer's order.

v) The words "For value received" Ig unnecessary, s. 3, subs. 4 (b), are tted. Across the bill is written the ptance thus:-" Accepted, E. F." acceptance will be invalid unless omplies with the following condi- tions:-1. It must be written on the bill and signed by the drawee. The mere signature of the drawee without additional words is sufficient. 2. It must not express that the drawee will perform his promise by any other means than the payment of money: $s .17$, subs. 2. If the bill is drawn in a set (as to which see s. 71), the acceptance may be written on any part, and it must be written on one part only. If the drawee accepts more than one part, and such accepted parts get into the hands of different holders in due course, he will be liable upon every such part, as if it were a separate bill: s. 71 , subs. 4. 
in figures, the amount [£100] for which the bill is payable $(b)$; and it must be stamped according to the statutory scale of duties which may be in force. The Stamp Acts are expressly saved by section 97 , subsection 3 , a, of the Act. Where in a bill drawer and drawee are the same person, or where the drawee is a fictitious person, or a person not having capacity to contract, the holder may treat the instrument at his option either as a bill of exchange or a promissory note $(c)$. Where the payee is a fictitious or nonexisting person the bill may be treated as payable to bearer $(d)$. What is a fictitious or non-existing person within the meaning of this section has recently been considered by the House of Lords in the case of the Bank of England v. Vagliano $(e)$. A clerk of the respondents forged advice letters and drafts, and obtained payment of the latter and appropriated the money to his own use. He prepared the drafts by filling in, as the name of the drawer, that of o foreign correspondent of the respondents, and as the name of the payee, that of a foreign firm, which was an existing firm and a correspondent of the respondents, and ther procured the acceptance of his employers, the respondents Their lordships $(f)$ held that the respondents, and not the appellant Bank, must bear the loss, on the ground that th named payee was a fictitious or non-existing person withir the meaning of the section, and that the documents migh be treated as payable to bearer $(g)$.

(b) Where the sum payable is expressed in words and also in figures, and there is a discrepancy between the two, the sum denoted by the words is the amount payable: s. 9 , subs. 2 . This was also the old rule: Saunderson v. Piper, 5 Bing. N. C. 425.

(c) S. 5, subs. 2.

(d) S. 7 , subs. 3.

(c) (1891) A. C. 107. Cf. also Clutton r. Attenborongh, (1895) 2 Q. B. 707, C. A., affirming Id., p. 306.

(f) Lord Halsbury, L. C., Lords Watson, Merschell, Macnaghten, and
Morris ; contra, Lords Bramcell an Field.

(g) The Court of Appeal (Esher, M. P dissenting) had decided (23 Q. B. I 243 ) that it was a condition of $t)$ application of this section that $t$. aceeptor should know that the par was a fictitious person, and on th point the House of Lords overrnied tf Court of I ppeal. Lord Halsbirry, L. C the Earl of Selborne. Lords Wuts. and Iaenaghten, also on reaso turning on the conduct of the partis decided in the appellants' farour. 
Without pausing in this place to examine minutely the requisites of a bill of exchange in regard to form, let us proceed to consider its practical use. The use of negotiable Inercantile transacpaper in commercial dealings is well illustrated by Sir W. Blackstone in his Commentaries ( $h$ ), and by Chancellor Kent (i). Let us suppose that B., residing in Liverpool, wishes to receive $1000 l$. which await his orders in the hands of F. at New York. He applies to D., going from Liverpool to New York, to pay him the above amount less the usual rate of discount, and to take his draft or bill on $\mathrm{F}$. for the 1000l. payable at sight. Now this arrangement may, in ruth, accommodate both $B$. and D., for $B$. receives the ımount of his debt on transferring it to D., and D. carries is money across the Atlantic in the shape of a bill of xchange, without danger or risk in the transportation, and, in arriving at New York, he presents his bill to F. and is aid. The bill of exchange operates then in this way, that, accepted, it effects a transfer of the right of action as gainst F. (the party originally indebted) from B. to D. The meaning of drawing a bill is that the person on whom is drawn has the money of the drawer either actually in is hands, or by arrangement in account, which is the same ling" $(k)$.

The illustration thus given by $\mathrm{Sir}$ W. Blackstone introlces to us the three immediate parties to a bill of exchange The parties to a bill. ; originally drawn, and before it has been put into circulaon, viz., B., the drauer of the bill ; F., the draicee $(l)$ and hould he accept the bill) the acceptor'; D., the payee. Of ese $\mathrm{F}$. is the party primarily liable at suit of the payee, id $B$. is (with reference to $F$.) to be regarded in the light

h) Vol. 2, p. 466 .

i) 3 Kent Com., 12 th ed., p. 75.

k) Per Pigott, B., Att.-Gen. v. itt, L. R. 9 Ex. 145.

l) A bill may be addressed to two more drawees, whether they are partners or not, but an order addressed to two drawers inthe alternative, or in succession, is bad: s. 6 , subs. 2. As to the insertion of a "referee in case of need," see s. 15. 
of a surety, and will be liable to $\mathrm{D}$. in case of the nonacceptance or non-payment of the bill by $\mathrm{F}$.

Accommodation billwhat.

Negotiability.

An accommodation bill-that is, a bill drawn, accepted or indorsed by a party who has received no value therefor, for the purpose of lending his name to some other person, and with a view to his raising money upon it, or otherwise using it-stands on a somewhat peculiar footing, inasmuch as in this case there is an implied undertaking on the part of the dratrer to indemnify the acceptor against claims which may be made upon him in respect of the bill; and upon this implied contract of indemnity an action will lie against the former of these parties at the suit of the latter if obliged to take up the bill $(m)$. Even in the case of an accommodation bill, however, the drawer is not prima facic the party to pay it; upon the face of such a bill the party who is bound to pay it is the accommodation acceptor $(n)$; and it is immaterial whether the holder for value, when he took the bill, knew that the person charged was an accommodation party or not $(o)$.

But the use of mercantile instruments, such as are now spoken of, would be attended with very limited advantages if restricted to the immediate parties to them, i.e., if they were devoid of the quality of negotiability, which, in fact, they usually possess. This negotiable quality is inherent in bills of exchange, unless the bill contains words prohibiting transfer, or indicating an intention that it should not be transferable. Thus a bill payable to C. D., or "'bearer,' will pass like a bank-note by delicery, and if payable to C. D., or order, or simply to C. D., it will become negotiable on receiving the indorsement of C. D., and the negotiation will be completed by delivery after such indorsement $(p)$

(ii) Beech r. Jones, 5 C. 13. 696 ; Sleigh v. Sleigh, 5 Exch. 514 : Reynolds v. Doyle, 1 M. \& Gr. 753 ; Judgm., 9 C. 13. 181 ; Lriver v. Burton, 17 Q. B. 989. (n) Per Jervis, C. J., 13 C. B 914

(o) S. 28.

(p) S. 31 , subs. 3. See Day Longhurst, 62 L. J. Ch. 334 . 
If it is desired to make the bill not transferable, it should be drawn in the form "Pay C. D. only" $(q)$.

An indorsement may be in blank or special $(r)$; if in Indorsement blank, no indorsee is specified; if special, the person to blank or whom, or to whose order, the bill is to be payable is named. Now the great difference between these two modes of indorsement is this-that if the payee merely write his name on the back of a bill payable to order, i.e., if he indorse it in blank, the bill so indorsed becomes payable to bearer $(s)$; whereas if the payee indorse the bill specially, i.e., make it payable to "C. D." or to "C. D. or order," it will require the indorsement of C. D., either in blank or special before it is again assignable, so as to convey a right of action in respect of it to the next holder $(t)$.

Every contract on a bill, whether it be the drawer's, Delivery the acceptor's, or an indorser's, is incomplete and revocable $\begin{gathered}\text { neceessary } \\ \text { aftersin } \\ \text { dorsement. }\end{gathered}$ until delivery of the instrument in order to give effect thereto; provided that where an acceptance is written on a bill, and the drawee gives notice to or according to the directions of the person entitled to the bill that he has accepted it, the acceptance then becomes complete and irrevocable $(u)$. Consequently in either of the above cases, in order to complete the title of the holder by indorsement, there must be a delivery $(x)$ to him with that purpose by his indorser $(y)$.

An indorsement may be so worded as to prohibit the urther negotiation of the bill, or to express that it is a nere authority to deal with the bill as thereby directed, ind not a transfer of the ownership thereof, as, ex. gr., "Pay D. only," or "Pay D. or order for collection." It is

(q) S. 8, subss. 1, 4, 5. See Meyer $\mathbf{r}$. Deeroix, (1891) A. C. 520; National Bank v. Silke, (1891) 1 Q. B. 435.

(r) S. 32 , subs. 6 .

(8) S. 8 , subs. 3.

(t) See Cunliffe v. Whitehead, 3 ling. N. C. 828 . (uj S. 21, subs. 1 .

(x) S. 2. "Delivery" means transfer of possession, actual or constructive, from one person to another.

(y) S. 21 , subs. 1 . As to the engagement of the indorser, vide post, p. 466 .
Restrictive indorsenient. 
then called a restrictive indorsement, and the indorsee is precluded from transferring his rights without express authority, when all subsequent indorsers will take the bill with the same rights, and subject to the same liabilities, as Conditional the first indorsee under the restrictive indorsement $(z)$. As
delivery. between immediate parties, and as regards a remote party, other than a holder in due course, the delivery may be shown to have been conditional only, and not for the purpose of transferring the property $(a)$. So, when the fact of indorsement is denied, evidence is admissible to show that the alleged indorser wrote his name on the bill and delivered it to the alleged indorsee for the express purpose of retiring $(b)$ other bills, and on the express condition that they should be retired forthwith; and that such condition has not been complied with $(c)$. Where, however, E. drew and wrote his name on the back of a bill, and delivered it to $B$. to get it discounted, and B. deposited it for value with T. upon the terms, that, if not redeemed by a certain day, it was to be sold, it was held that there had been a valid indorsement and transfer of the bill from E. to T. $(d)$. A conditional indorsement may be disregarded by the payer $(e)$.

Rights of Where a bill has come into the hands of a holder in due holder. course, a valid delivery of the bill by all parties prior to him, so as to make them liable to him, is conclusively presumed $(f)$.

For the purposes of currency and the advantages flowing from an unchecked circulation of bills of exchange, the law provides that a holder in due course shall hold the bill free from any defect in title of prior parties, as well as from mere personal defences (ex. $g r$, a set-off), available

(z) S. 35 .

(a) S. 21, subs. 2.

(b) As to the meaning of this term, see Elsam v. Desmy, is C. B. 87: Bell r. Buckley, 11 Exch. 631 ; sed vide per Bacon, V.-C., Ex parte Reed, L. R. 14 Eq. Ca. 593. (c) Bell v. Tiscannt Ingestre, 12 Q. B. 317 ; and see Denton r. Peters, I. R. 5 Q. B. 475 .

(d) Barber v. Richards, 6 Exch. 63; see Lord v. Hall, 8 C. B. $62 i$.

(e) S. 33 .

(f) S. 21 , subs. 2. 
to prior parties among themselves. Where the title of the holder is defective, as by reason of fraud, if he negotiates the bill to a holder in due course, that holder obtains a good and complete title to the bill, and further, if he obtains payment of the bill, the person who pays him in due course gets a valid discharge for the bill $(g)$.

If, then, the holder of a bill puts his name on the back of it, and delivers it to his agent, who delivers it to a third person for value, that is an indorsement from the holder to such third person. And, where a bill is payable to bearer, any person who is the holder for value may sue upon it, whether the party from whom he has taken it had a title or not $(h)$.

The preceding remarks are applicable to a bill payable to bearer, and transferable by delivery; where, however, indorsement is necessary to the transfer of a bill, the indorsement will convey no title except as against the person making it, unless it be made by one who has a right to make the transfer. In case, then, of loss, by theft or accident, of a bill assignable by mere delivery, the thief or finder may confer a title by transferring it; if it be assignable by indorsement only, he cannot confer such title except as against himself $(i)$.

Where the holder of such a bill transfers it for value without indorsing it, the transfer gives the transferee such title as the transferor had in the bill, and the transferee in addition acquires the right to have the indorsement of the transferor. Until the indorsement is obtained, the transfer operates as an equitable assignment $(k)$. With regard to the indorsement of a bill of exchange, a $\begin{gathered}\text { Transfer or } \\ \text { overutue bill, }\end{gathered}$ few additional observations must suffice. The transfer of a

(g) S. 38, subss. 2, 3.

(h) Per Parke, B., Barber v. Richards, 6 Exch. 63, citing Collins v. Martin, 1 B. \& P. $648 ; 4$ R. R. 752.

(i) Bayley on Bills, 6th ed., pp.
$138,139$.

(k) S. 31 , subs. 4 . See Whistler v. Forster, 14 C. B., X. S., at p. 258 ; Harop v. Fisher, 10 C. B., N. S., at p. 203. 
Parties to bill after indorse-

nent.

Steps to be taken by holder of blll when due.

bill by indorsement may be either before or after acceptance, either before or after it has arrived at maturity. Where a bill which is not overdue has been dishonoured, any person, who takes it with notice of the dishonour, takes it subject to any defect of title attaching thereto at the time of dishonour, but this does not apply to a holder in due course $(l)$. If an overdue bill is negotiated, it can only be negotiated subject to any defect of title affecting it at its maturity, and thenceforward no person who takes it can acquire or give a better title than that which the person from whom he took it had $(m)$. A bill payable on demand is deemed to be overdue when it appears on the face of it to have been in circulation for an unreasonable length of time; what is such unreasonable length of time being a question of fact $(n)$.

When a bill of exchange has been indorsed over we have two new characters, that of indorser and that of indorsee, brought to notice, and we must therefore inquire what are the respective rights and liabilities of those parties.

Now, on the one hand, a transfer by indorsement vests in the indorsee a right of action against all the parties whose names are on the bill in case of default of acceptance or payment; and, on the other hand, every indorser of a bill is in the nature of a neu draver, and is liable to every succeeding holder in default of acceptance or payment by the drawee, the acceptor being still primarily liable upon the bill, the drawer and each indorser thereof being collaterally liable to the holder provided certain steps rendered necessary by the lau be duly taken by him.

In order to show what these preliminary steps are and what course should be adopted by the holder of a bill at so

(l) S. 36 , subs. 5 .

(im) S. 36, subs. 2. "Defect of title" is used in the Act as equivalent to "equity attaching to the bill." Cf. 8.29.

(in) S. 36 , subs. 3 ; by virtue of $\mathrm{s}$.
73 this subsection applies to cheques. $A$ person, therefore, who takes a stale cheque does so at his peril. It does not, however, apply to promissory notes: s. 86 , subs. 3 . 
many months after date when it falls due, let us suppose that it is payable to order-that it has been accepted and indorsed in proper form - that it has come into the holder's hands neither in its inception nor during its transfer tainted with illegality or fraud. Immediately such a bill becomes due-that is, under ordinary circumstances, on the fourth day inclusive, or on the third day exclusive, of that on which the bill is expressed to be payable $(o)$-the holder should present it, or cause it to be presented, for payment to the acceptor. If on presentment the bill be refused payment, then notice of dishonour ( $p$ ) must be given to every party (other than the acceptor) whose name appears upon Presentment. the bill, and against whom the holder may wish to secure a remedy.

So essential, indeed, are presentment and notice of dishonour to the success of an action against any party to the bill intermediate between the holder and the acceptor, that such action will in general fail if either of the preliminary steps just specified has been omitted, i.e., if the bill has not been presented for payment on the day when it became due, or if proper notice of dishonour has not been given.

From what has just been said, it will be seen in how different a position relatively to the holder stands the acceptor of a bill drawn and accepted according to the form given at p. 451 from that in which any intermediate party to it is placed; for the engagement entered into by the acceptor is to pay the bill at maturity, or at any time after maturity, until his liability may have become barred by

(o) The allowance of "days of grace" is now regulated by ss. 14,72 , subs. 5 . They will not be allowed if the bill be payable on demand, or if the bill itself provide otherwise: s. 14 , subs. 1 . Until the expiration of the last day of grace, the holder of a bill, in respect of which payment has been refused, has no cause of action: Kennedy v. Thomas, (1894) 2 Q. B. 759.

$(p)$ A bill may be dishonoured in two ways: 1. By non-acceptance, when, after due presentment, acceptance is refused or cannot be obtained, or if presentment is, excused, and the bill is not accepted; 2. By non-puyment, when, after due presentment, payment is refused or cannot be obtained, or if presentment is excused, and the bill is overdue and unpaid: s. 43 , subs. 1 ; s. 47 , subs. 1 .

Notice of dishonour. 
the Statute of Limitations. The acceptor, therefore, will not be discharged by non-presentment of the bill when due $(q)$; nor, of course, can he require notice of dishonour $(r)$.

In Jones v. Broadhurst (s) the legal relation subsisting between the parties to a bill is judicially commented on and explained. The Court there remark that the drawer and acceptor are parties to the same instrument as contractors with each other, and not as joint contractors with a third person; and that by the indorsement of the bill independent and different contracts arise on the respective parts of the drawer and the acceptor with the indorsees. The acceptor is primarily and absolutely liable to pay the bill according to its tenour. The drawer is liable only upon the contingencies of the acceptor's or drawee's making default, and of the holder's performing certain conditions precedent - such as presenting the bill according to its tenour, and giving due notice of the failure of the acceptor or drawee to pay upon a proper presentment $(t)$.

Noticewhen dispensed with.

Notice of dishonour will, however, be dispensed with in cases where after the exercise of reasonable diligence due notice cannot be given to or does not reach the drawer or indorser sought to be charged, or by waiver express or implied either before or after the time when notice should be given. It will also be dispensed with as regards the drawer: (1) where drawer and drawee are the same person; (2) where the drawee is a fictitious person or without the

(q) S. 52, subs. 1 ; s. 87 , subs. 1 . " $A$ person who accepts a bill of exchange or makes a promissory note payable on a giren day is liable to pay it when that day arrives, although no demand is made. He must be aware of the contract which he has entered into; and he has no right to say that he is taken by surprise, for he is bound to provide for payment on the day when the bill becomes due:" per Channell, B., Maltby v. Murrell, o

\section{H. \& N. 823.}

(v) Cf. Heylyn v. Adamson, 2 Burr. 669. Lord Mansfield's judgment in this case, exhibiting some of the elementary priuciples applicable to bills of exchange and promissory notes, is well worthy of perusil.

(s) 9 C. B. 173.

(t) As to the rules for presentment, and the excuses for delay or nonpresentment, see ss. 45,46 . 
capacity to contract; (3) where the drawer is the person to whom the bill is presented for payment; (4) where the drawee or acceptor is as between himself and the drawer under no obligation to accept or pay the bill ; (5) where the drawer has countermanded payment $(u)$.

No. 4 of the above cases recognises the exception to the general rule laid down in the celebrated case of Bickerdike v. Bollman (x), viz., where the action is against a party who has drawn an accommodation bill, having at the time no effects in the hands of the acceptor, and who had moreover no reasonable grounds for thinking that the bill would be paid. "The law," said Buller, J., in that case, " requires notice to be given, for this reason, because it is presumed that the bill is drawn on account of the drawee's having effects of the drawer in his hands; and if the latter has notice that the bill is not accepted or not paid, he may withdraw them immediately. But if he has no effects in the other's hands, then he cannot be injured for want of notice." Further, in Carter v. Flouer (y), the Court of Exchequer observed, that every bill will be presumed to have been drawn for value received, that is, on a person who was to accept and pay by reason of having value, and if the drawer draws on one who is not his debtor, nor has received any value for the bill, he must be considered (at least prima facie) to request him to accept and pay on account of the drawer, or, in other words, for his accommodation; and if the drawer does not provide funds in time, he necessarily knows that the bill will not be paid at maturity, and will not, therefore, be entitled to notice. But the case of an indorser of a bill of exchange stands on a different footing from that of a drawer. $\mathrm{He}$ is in the nature of a surety or guarantor of its payment on due presentment, and is presumed to know nothing about the arrangement between
(u) S. 50 , subs. $2(\mathrm{a}, \mathrm{b}, \mathrm{c})$.
(x) 1 T. R. 405 ; 1 R. R. 242 ;
2 Sm. L. C., 9th ed., 55.
(y) 16 M. \& W. 750,751 . 
the drawee and drawer. As regards the indorser, therefore, notice (save as mentioned above) will only be dispensed with (1) where he knew at the time of indorsement that the drawee was a fictitious person or without the capacity to contract; (2) where he is himself the person to whom the bill is presented for payment; or (3) where the bill was accepted or made for his accommodation $(z)$.

Save in these excepted cases, knowledge of the probability, however strong, that the bill will be dishonoured, cannot operate as a notice of dishonour, or dispense with it $(a)$. Nor will mere knowledge of the fact, that the bill has been dishonoured, be equivalent to notice, for "notice means something more than knowledge" (b). Besides, it is quite competent to the holder of a bill to give credit to the acceptor, and the effect of this, in accordance with a wellknown rule of law, would be to discharge the parties collaterally liable on the bill.

Some intimation must accordingly be given by the holder to any intermediate party whom he means to charge, that he does not intend to give credit to the acceptor.

Effect of dishonour.

When a bill of exchange has been presented and dishonoured, either by non-acceptance or non-payment, an immediate right of recourse, subject to the provisions of the Act as to acceptance for honour $(c)$, accrues to the holder against the drawer and all other prior parties to the bill $(d)$; and, in the former case, no subsequent presentment for payment is necessary, nor any notice of subsequent dishonour by non-payment, unless in the meantime the bill had been accepted $(e)$. In any case, notice must be given to all the parties to the bill whom the holder intends to make liable upon it, and any holder or indorser to whom

(z) S. 50 , subs. 2 (d). 400.

(b) Per Ashurst, J., Tindal v. Broen, 1 T. R. 167 ; 1 R. R. 171; per Rolfe, B., Allen v. Edmumdson, 2 Exch. 719, 725.

(c) Ss. 65-68.

(d) S. 43 , subs. 2 , s. 47 ; subs. 2.

(e) S. 48 , subs. 2 . 
such notice is not given will be discharged, subject to this, that where the bill has been dishonoured by nonacceptance, and due notice of dishonour has not been given, the rights of the holder in due. course, subsequent to the omission, will not be prejudiced thereby $(f)$.

Notice of dishonour, in order to be valid and effectual, must be given in accordance with the rules contained in What notice of dishonour section 49 of the Act. Their effect may be briefly summarised as follows:-Notice must be given by or on behalf of the holder or any indorser then liable on the bill, and when given enures for the benefit, in the one case of subsequent holders and all prior indorsers to whom the party so giving notice is liable; in the other, for that of the holder and all indorsers subsequent to the party to whom it is given. Notice may be given orally or in writing, or by both combined; no special form is necessary if the bill is sufficiently identified, and the fact of dishonour clearly intimated $(g)$. The return of a dishonoured bill to the drawer, or an indorser, is sufficient notice. In case of death, notice may be given to the personal representative: if the party be bankrupt, either to him personally or to his trustee. Where there are two or more drawers or indorsers, not partners, notice must be given to each, unless one has authority to receive it on behalf of all.

Further, this notice must be given within reasonable time; what is reasonable time for this purpose is explained Time to give notice of in the Act $(h)$. If the parties reside in the same place, notice must be sent so as to arrive on the next day; if in different places, it should be sent off on the day following the dishonour, if there is a convenient post, if not, by the

(f) S. 48, n. 1 .

(g) Thus, where, on the day after a bill became due, the holder's clerk alled upon the drawer and told him that the bill had been duly presented, ind that the acceptor could not pay it, o which the drawer replied that " he would see about it," it was held that the jury might from this conversation infer that the drawer had due notice of dishonour: Metcalfe $\mathrm{r}$. Richardson, 11 C. B. 1011.

(h) S. 49 , subs. 12. 
next post thereafter. Each party receiving notice has the same time to send it on to his antecedent party, as has a principal receiving notice from his agent. The notice is deemed given when posted, in spite of any miscarriage of the post-cffice (i).

Delay in giving notice of dishonour will be excused where the delay is caused by circumstances beyond the control of the party giving notice, and not imputable to his default, misconduct, or negligence; when, however, the cause of delay ceases to operate, the notice must be given with reasonable diligence $(h)$. We have already considered the cases in which notice of dishonour will be dispensed with as regards the drawer or indorser of a bill respectively $(l)$. It remains to add that the onus will lie upon the plaintiff of showing that his right of action was complete in all respects before the commencement of the suit, i.e., before the issuing of the writ of summons $(\mathrm{m})$.

Contract of scceptor.

We must repeat, that in the particular contract created by a bill of exchange the acceptor is regarded as the principal contractor, his engagement being that he will pay the bill according to the tenour of his acceptance $(n)$, whilst the indorsers are looked upon as his sureties, for the indorser only engages that he will compensate the holder, or a subsequent indorser who is compelled to pay the bill, if on due presentment it is dishonoured by the acceptor, provided that the requisite proceedings on dishonour be duly taken $(o)$.

Such is the "nature of the liability assumed by the acceptor of a bill of exchange, such the correlative right of

(i) Cf. Woodcock r. Houldsworth, 16 M. \& W. 124.

(k) S. 50, subs. 1.

(I) Ante, p. 460. 498.

(m) Castrique จ. Bernabo, 6 Q. B.

(ri) S. 54, subs. 1. As to "general" and "qualified" acceptances, see ss. 19,44 , and post, p. 467. (o) S. 55, subs. 2. Any person signing a bill otherwise than as drawer or acceptor incurs thereby the liabilities of an indorser to a holder in due course: s. 56 . As to the liabilities of persons indorsing as co-sureties, see Macdonald v. Whitfield, 8 App. Cas. 733. 
the holder of the bill against him. Let us, in the next place, inquire what particular kind of contract or engagement is entered into by the drawer and by the indorser of a bill respectively.

The drawer of a bill, by drawing it, engages that on due Contract of clawer. presentment it shall be accepted and paid according to its tenour, and that, if it be dishonoured, he will compensate the holder, or any indorser who is compelled to pay it, provided that the requisite proceedings on dishonour be duly aken. He is further precluded from denying to a holder in due course the existence of the payee, and his then apacity to indorse $(p)$.

Should the drawee make default in accepting the bill, n immediate right of recourse, subject to the provisions f the Act as to acceptances for honour $(q)$, accrues to the older against the drawer and indorsers, and no presentlent for payment is necessary $(r)$. The right of action aus acquired is not in respect of any special damage zused by the non-acceptance, but is a right of action on ie bill, i.e., to recover the full amount of the bill. The feet of the refusal to accept is, that the drawee says to 1e holder, "I will not pay your bill, you must go back " the drawer, and he must pay you." The holder thus "quires by the non-acceptance the most complete right of tion against the drawer which the nature of the case Imits of. Subject, however, to the provisions of the Act, hen a bill has been dishonoured by non-acceptance, notice dishonour must be given to the drawer and each indorser, d any drawer or indorser, to whom such notice is not ven, is discharged not only from his liability on the bill, $t$ also from any liability as regards the debt or conleration in respect of which it was given $(s)$. Such
p) S. 55 , subs. 1.
2) S. 65 .
(s) Peacock v. Purcell, 14 C. B.,
N.S., 748 .

i) S. 43 , subs. 2 .

3.C.L. 
failure to give notice will not however prejudice the rights of any subsequent holder in due course $(t)$.

A bill drawn upon a third person in discharge of a present debt, may in truth be regarded as an offer by the drawer, that if the payee will give time for payment, he will give an order on his debtor (the acceptor) to pay a given sum at a given time and place. The payee agrees to take this order, and to give the time required, with a proviso that if the acceptor do not accept and pay the bill, and he the payee (or the holder of the bill) give notice to the drawer of that default, the drawer shall pay him the amount specified in the bill, with lawful interest $(u)$.

The indorsement of a bill implies an undertaking from the indorser to the person in whose favour it is made, and to every other person to whom the bill may afterwards be transferred, similar to that which is implied by drauing a bill, so that every indorser is said to be in the nature o a new drawer $(x)$. The undertaking by an indorser is thus defined in the Act:- $\mathrm{He}$ engages, by indorsing it, that or due presentment the bill shall be accepted and paid accord ing to its tenour, and that if it be dishonoured, he mil compensate the holder or any indorser who is compelle to pay it, provided that the requisite proceedings on dis honour are duly taken. $\mathrm{He}$ is further precluded fror denying to a holder in due course the genuineness an regularity in all respects of the drawer's signature an all previous indorsements, and to his immediate o subsequent indorsee that the bill was at the time of $\mathrm{h}$

( $t$ ) S. 48. Notice of further dishonour by subsequent non-payment need not be given, unless in the meantime the bill has been accepted. Ante, p. 462 .

(ii) Judgm., Gilbs r. Fremont, 9 Exch. 30 ; distinguished in Rouquette r. Orermann, L. R. 10 Q. B. 542. The recovery of interest, other than that provided for in the bill itself (as to which see s. 9), upon dishonour prorided for by s. 57. See Re Gillesp Ex parte Robavte, 16 Q. B. D. 702; Id. 286, 292; English Bank of the Rie Plate, In re, Ex parte Bank of Bras (1893) 2 Ch. 438; Commercial Bank Sonth Australia, In re, 36 Ch. D. 52

$(x)$ Ante, p. 458 : per Parke, 1 Allen r. Walker, 2 M. \& W. 318 ; Littledalc, J., 5 A. \& E. 439. 
indorsement a valid and subsisting bill, and that he had then a good title thereto $(y)$.

Having suggested to the reader some general idea of the nodes in which bills of exchange are used in the comnercial world, of the relative positions in which the parties vhose names appear on them stand towards each other, and if their mutual rights and obligations, attention must be lirected more minutely to the nature of the acceptance, ndorsement, and notice of dishonour. We shall advert also o the nature of a foreign bill, of a cheque, of a promissory ote, and of a bank note, and specify some of the ordinary rounds of defence in actions upon such securities.

In the first place, then, what is the precise nature of an sceptance? The acceptance of a bill is the signification by Nature of le drawee of his assent to the order of the drawer $(z)$. he acceptor engages that he will pay the bill according to ie tenour of his acceptance, and, if he accepts generally, at he will pay according to the tenour of the bill $(a)$. ais engagement is made by the drawee of the bill, or by me one per procuration of the drawee, or for the honour of e drawee or some other party to the bill.

An acceptance by the drawee of a bill will, as we have eady seen $(b)$, be sufficient if it consists of the mere nature of the drawee without additional words. An eptance is either general or qualified $(c)$. A general eptance assents without qualification to the order of the wer; a qualified acceptance in express terms varies the ict of the bill as drawn $(d)$.

The fact of this acceptance may, as against the drawer, restrained by a contemporaneous agreement in writing ween the acceptor and himself $(e)$; but evidence of an

S. 55, subs. 2; cf. Horne v. uette, 3 Q. B. D. 519.

S. 17 , subs. 1 .

S. 54 , subs. 1 .

S. 17 , subs. 2 (a); ante, p. 451 , : as to the presumption respecting the date of an acceptance, see Roberts v. Bethell, 12 C. B. 778; cf. s. 12.

(c) S. 19, subs. 1.

(d) S. 19 , subs. 2 .

(e) Bowerbank v. IIonteiro, 4 Taunt.

344 ; 14 R. R. 679. 
oral agreement qualifying its operation would be inadmissible $(f)$. Where a simple signature, on a blank stamped paper, is delivered by the signer in order that it may be converted into a bill $(g)$, it operates as a prima facic authority to fill it up as a complete bill for any amoun the stamp will cover, using the signature for that of the drawer, or the acceptor, or an indorser $(h)$; in order that any such instrument when completed may be enforceable against any person who became a party thereto prior to its completion, it must be filled up within a reasonabl time (i), and strictly in accordance with the authority given; provided that if any such instrument after com pletion is negotiated to a holder in due course, it shal be valid and effectual for all purposes in his hands, an he may enforce it as if it had been filled up within reasonable time and strictly in accordance with th authority given $(k)$.

In Scholficld v. The Earl of Londesborough, a bill o exchange was accepted by the defendant, and after accept ance fraudulently altered by the drawer. The bill of originally presented to the acceptor bore a stamp coverin a sum considerably larger than that for which it purporte to be drawn, and had spaces on the face of it in which th words and figures necessary for the fraudulent alteratio were subsequently inserted. The Court of Appeal (Lor Esher, M. R., and Rigby, L. J., Lopes, L. J., dissentin,

(f) Ante, p. 370 .

(g) Thus, where a blank acceptance was stolen and filled in for $50 \mathrm{l}$. by the thief, the acceptor was held not liable on the bill to a subsequent holder in due course: Baxendale v. Bemett, 3 Q. B. D. 531 .

(b) S. 20, subs. 1 ; Barker r. Sterne, 9 Exch., at p. 686 ; Aude v. Dixon, 6 Exch. 869 ; Hogarth v. Latham, 3 Q. B. D. 643 ; Gavard r. Leuis, 10 Q. B. D. 30 . A bill accepted for valuable consideration, with the drawer's name left blank, may be co pleted by the drawer's name being add after the death of the acceptor: Car v. White, 20 Ch. D. 225 ; 25 Id. 6

(i) Reasonable time for this purp is a question of fact, s. 20, subs. cf. Montagn v. Perkins, 22 L. C. P. 187; Temple r. Pullen, 8 E. 389.

(i) S. 20 , subs. 2 ; Hateh r. Sear 2 Sm. \& G. 152,$153 ;$ Foster r. $\mathrm{A}$ kimon, I. R. 4 C. P., at p. 712 . 
seld, that as against the plaintiff; who was a bon $\hat{\imath}$ fule older for value, the defendant, assuming he had been segligent in accepting the bill in the form it was preented, was not estopped from setting up the true facts, and ras liable upon the bill only to the extent of the smaller mount for which he had accepted it, and not for the face alue of the fraudulently altered bill. They further held Lopes, L. J., dissenting) that as the defendant had not een guilty of a breach of duty, he was not negligent, and at even if he had been negligent, the forgery and not ne negligence was the proximate cause of the plaintiff's iss $(l)$.

An acceptance is qualified :-

(1.) If it is conditional, that is to say, if it makes the ryment by the acceptor dependent on the fulfilment a condition stated in the acceptance, ex.,$\eta$., " accepted tyable on delivery of bills of lading" $(\mathrm{m})$.

(2.) If it is partial, that is to say, if it engages pay part only of the amount for which the bill is awn.

(3.) If it is local, that is to say, if it engages to pay only a specified place.

(4.) If it is qualified as to time, ex. gr., if a bill drawn yable one month after date is accepted payable three onths after date.

(5.) If it is accepted by one or more of the drawees, but $t$ by all $(n)$.

With regard to locally qualified acceptances, it is proled by s. 19 , subs. 2 (c), reproducing the provisions of \& 2 Geo. 4, c. 78 , that an acceptance to pay at a iticular place is a general acceptance, unless it expressly

(1895) I Q. B. 536 (C. A.). There 1. 3 duty on the part of the acceptor i. rccepting a bill, not to facilitate l.d (see S. C.). (m) Smith r. Virtue, 30 L. J. C. P. 56.

(ii) S. 19 , subs. 2 ; cf. s. 6 , subs. 2 , ante, p. 453, n. $(l)$. 
states that the bill is to be paid there only and not elseuthere. Thus an acceptance "payable at Child's Bank" is a general acceptance; while an acceptance "payable at Child's Bank only" is locally qualified.

The effect of the above statutory provision $(o)$ is, that a bill of exchange draun generally on a party may be accepted in three different forms : either (1) generally, or (2) payable at a particular banker's, or (3) payable at a particular banker's and not elsewhere.

(1.) If the drawee accepts gencrally, he undertakes to pay the bill at maturity.

(2.) If he accepts payable at a banker's, he undertakes to pay the bill at maturity when presented for payment either to limself or at the banker's.

(3.) If he accepts payable at a banker's and not elsevhere, he contracts to pay the bill at maturity prorided it is pres sented at the banker's, but not otherwise $(p)$.

Whether a bill be accepted in one or in another of the above forms may be most material. In the first place, where a bill drawn generally on a party is accepted generally it will be remembered $(q)$ that presentment is not (unless the bill be payable at or after sight) requisite as a preliminary to charging the acceptor. "No reques or presentment is necessary to charge the acceptor of a bil or the maker of a note; he is bound to pay it at maturity and to find out the holder for that purpose" $(r)$. Th general rule is, that "the debtor must seek out hi creditor" $(s)$; and a person who guarantees payment of bill by the acceptor, cannot defend himself on the groun of want of presentment, unless he has sustained som

(o) As to the state of the law upon this point prior to the passing of the stat. $1 \& 2$ Geo. 4 , c. 78 , see judgm., Gibb r. Mather, s Bing. 220.

(p) Judgm., Halstead r. Skelton, 5 Q. B. $93,94$.

(q) Ante, p. 460 ; s. 52 , subs. 1.

(r) Per Parke, B., Walion Maseall, 13 M. \& W. 458 ; Norton Ellam, 2 M. \& W. 461.

(s) Per Coltman, J., Hitehcock Humfrey, 5 M. \& Gr. 563 ; per Jesese M. R., Davisou r. Domulelson, 9 Q. B. I at p. 620 . 
damage by the laches $(t)$ of the holder $(u)$. Where a bill is made payable in the body at a particular place $(x)$, or is accepted payable at a particular place, but is not made or accepted payable there only, the holder is not bound to present it there $(y)$, in order to charge the acceptor, but may present it wherever he can find him.

Where, however, a bill is accepted payable at a particular place, and, "not otherwise or elsewhere," presentment at ihat place is by the statute necessary in order that the icceptor may be chargeable. When, however, by the terms ff a qualified acceptance presentment for payment is required, ihe acceptor, in the absence of an express stipulation to hat effect, is not discharged by the omission to present he bill for payment on the day that it matures $(z)$.

The above provision applies only as between the acceptor f a bill and other parties to it; an acceptance may still be ualified as regards other parties to a bill, although general $\mathrm{s}$ against the acceptor $(a)$. The provision in the statute pplies where an action is brought against the acceptor of bill, but it does not extend to an action against the rawer or indorser; at all events, if a bill be addressed to le drawee at his residence, and the drawee accept it payble at a banker's, presentment at the banker's must be roved in an action against the drawer or indorser $(a)$.

An acceptance, though varying from the tenour of the bill, ill bind the person making it, but the holder of a bill is ititled from the undertaking of the drawer and indorsers

(t) "Laches" has been defined to "a neglect to do something which, law, a man is obliged to do;" per and Ellenborough, C. J., Sebag v. bitbol, 4 M. \& S. 462 ; cited per rd Tenterden, C. J., 4 B. \& C. 2. to the effect of laches at common $v$ and equity respectively, see Three uns Banking Co. v. Maddever, 27 . D. 523 .

'u) Hitcheock v. Humfrey, 5 M. \& .559, 572; Carter v. White, 20
Ch. D. $225 ; 25$ Id. 666.

(x) Selby v. Eden, 3 Bing. 611; Fayle v. Bird, 6 B. \& C. 531.

(y) See the judgment, Halstead $r$. Skelton, 5 Q. B. 93 ; Blake v. Beaumont, 4 M. \& Gr. 7 ; Tumer v. Hayden, 4 B. \& C. 1 ; Sebag . Alitbol, 4 M. \& S. 462.

(z) S. 52, subs. 2 .

(a) Saul v. Jones, 28 L. J. Q. B. 37,40 ; S. C., 1 E. \& E. $59 ;$ Gibbv. Mather, \& Bing. 211, 221. 
Application of doctrine of estoppel as against acceptor.

Accejtance by procuration. (if any) to expect an absolute acceptance by the drawee. $\mathrm{H}_{\theta}$ may, therefore, refuse to take a qualified acceptance, and if he does not obtain an unqualified one may treat the bill as dishonoured by non-acceptance. Where a qualified acceptance is taken, and the drawer or an indorser has not expressly or impliedly authorised the holder to take a qualified acceptance, or does not subsequently assent thereto, such drawer or indorser is discharged from his liability on the bill. The provisions of this subsection do not, however, apply to a partial acceptance whereof due notice has been given (b). When the holder takes a partial acceptance he should give notice of qualification, not of dishonour $(c)$, and the drawer or indorser of a bill receiving notice of a qualified acceptance, and not within a reasonable time expressing his dissent to the holder, will be deemed to have assented thereto $(d)$.

The doctrine of estoppel has some application as against the acceptor of a bill $(c)$. He is precluded from denying to a holder in due course.

(1.) The existence of the drawer, the genuineness of his signature, and his capacity and authority to draw the bill.

(2.) In the case of a bill payable to the drawer's order, the then capacity of the drawer to indorse, but not the genuineness or validity of his indorsement.

(3.) In the case of a bill payable to the order of a third person, the existence of the payee, and his then capacity to indorse, but not the genuineness or validity of his indorsement $(f)$.

Where a bill of exchange is accepted or indorsed per procuration, such signature operates as notice that the agent has but a limited authority to sign, and the principal

(b) S. 44, subss. 1, 2.

(c) Sebag v. Abitbol, 4 MI. \& S. 466 ; Whitchead v. Walker, 9 M. \& W. .j09; Bentinck v. Dorricn, 6 East, 399 : Sproat v. Watherc, I T. R. 184. (d) S. 44, subs. 3.

(e) As to estoppel as against 3 drawer or indorser, see pp. $46.5,466$.

(f) S. 54, subs. 2. 
is only bound by such signature if the agent in so signing was acting within the actual limits of his authority $(g)$. Where a person signs a bill as a drawer, indorser, or acceptor, and adds words to his signature, indicating that he signs for or on behalf of a principal, or in a representative character, he is not personally liable thereon: but the mere addition to his signature of words describing him as an agent, or as filling a representative character, does not exempt him from personal liability $(h)$. Where a bill was addressed to a firm, and accepted "per proc.," though really without authority from the firm, by one of the partners in his individual name, the partner so signing was held personally liable upon it (i); now, however, a stranger, or agent without authority, who accepts a bill per procuration of the drawee without his sanction, is not liable as a party to the bill, but will be liable in an action of tort for the misrepresentation as to his authority of which he has been guilty towards the holder $(k)$.

The signature of the name of a firm is equivalent to the signature by the person so signing of the names of all persons liable as partners in that firm $(l)$. But there is a distinction between the position of the parties, according as the firm is or is not a trading firm. A partner in a trading firm is primî facie entitled to bind his co-partners by drawing, ndorsing, or accepting bills in the name of the firm, and he presumption is absolute in favour of a holder in due ourse; but in the case of a non-trading firm, it lies on the erson seeking to enforce the bill to show that the partner,

(g) S. 25.

(h) S. 26.

(i) Ouen . Van Uster, 10 C. B. 18, and cases there cited, distinguished Edwards v. Barnard, 32 Ch. D. 17,452. See Nicholls v. Diamond, Exch. 154 ; Mare v. Charles, ó E. B. 978 ; Penrose v. Martyr, E. B. E. 499,503 .

(k) Polkill v. Walter, 3 B. \& Ad.
114 ; Chalm. Bills of Exchange Act, 1882 , 4th ed., p. 76 . As to the liability of directors accepting without authority "for and on behalf of " a company with no power to accept bills, see West London Commerciul Bank r. Kitson, 12 Q. B. D. 157 ; 13 Id. 360.

(l) S. 23 , subs. 2. 
who drew, indorsed, or accepted it, had authority to bind his co-partners $(m)$.

Where a bill of exchange has been protested for dishonour by non-acceptance, or protested for better security, and is not overdue, any person not being a party already liable thereon, may, with the consent of the holder, intervene and accept the bill supra protest, for the honour of any party liable thereon, or for the honour of the person for whose account the bill is drawn $(n)$. The acceptor for honour thereupon becomes liable to the holder, and to all parties to the bill subsequent to the party for whose honour he has accepted (o), and, if called upon to pay the bill, succeeds to the rights of the holder so paid, as against the party for whose honour payment has been made, and all parties liable to him $(p)$. An acceptance for honour may be for part only of the sum for which the bill is drawn; in order to be valid, it must be written on the bill, and indicate that it is an acceptance for honour, and further it must be signed by the person so accepting $(q)$. Should the acceptance for honour not expressly state for whose honour it is made, it is deemed to be an acceptance for the honour of the drawer $(r)$.

Where a bill has been protested for non-payment, any person may similarly intervene and pay it supra protest for the honour of any party liable upon it; such payment must be attested by a notarial act of honour (s). "A notarial act" means " any instrument, indorsement, note, or entry made or signed by a notary public in the execution of the duties of his office" $(t)$.

Relation of banker and eustomer.
From the propositions already stated, consequences flow, of much importance to the commercial world in general, and (m) Chalm. Bills of Exchange Aet, 185'2, 4th ed., p. 69.

(ii) S. 65 , subs. 1 .

(o) S. 66 , subs. 2 .

(p) S. 68 , subs. 5 .

(q) S. 65 , subss. $2,3$. (v) S. 65, subs. 4. As to the nature of the enragement entered into by the aceeptor tor honour, and the rules for protest and presentment, see ss. 66,67 .

(s) S. 68.

(t) Indian Stamp Act, 1870, s. 3. 
especially to bankers, one of whose principal duties consists in cashing negotiable securities on behalf of their customers.

The relation which subsists between banker and eustomer, apart from special agreement, is that of debtor and creditor. The customer is the creditor, and has in addition to the ordinary rights of a creditor, the right to draw cheques on his banker to the extent of the balance at his credit and disposal. If the banker, having sufficient funds in hand, dishonour's his customer's cheque, he is liable to him in an action for damages, even though the customer may not have sustained any actual loss or damage thereby $(u)$. When, however, a bank has several branches, a customer who has an account at one branch is not, in the absence of any special agreement, entitled to draw on another branch $(x)$.

When a bill is accepted payable at a banker's, the making the acceptance payable there is tantamount to an order on the part of the acceptor to the banker to pay the bill to the person who is, according to law, capable of giving a good discharge for it. If the bill is payable to order, it is an authority to pay the bill to any person who becomes holder by a genuine indorsement. If the bill be originally payable to bearer, or if it afterwards receive a genuine indorsement in blank, the acceptance constitutes an authority to the banker to pay the bill to the person who seems to be the holder (y).

A banker, however, who pays a bill bearing a forged indorsement, cannot charge his customer with the amount $(z)$,

(n) Marzetti v. Willians, 1 B. \& Ad. 415 ; and generally as to the elation between banker and customer, iee Hardy v. Veasey, L. R. 3 Ex. 107 ; Garnett v. Mc Kcwan, L. R. 8. Ex. 10 ; cited in Judgm., Prince r. Oriental Bank Corp., 3 App. Cas. 333; Pott $\because$ Clegg, 16 M. \& W. 321 ; Hill v. Foley, 2 H. L. Ca. 28; Thompson v. Bell, 10 Exch. 10; Tassell v. Cooper,
9 C. B. 509; Schroder r. Central Bank, 34 L. T. 735 ; ante, p. 84.

(x) Chalm. Bills of Exchange Act, 1882, 4th ed., p. 252; cf. Robarts r. Tuckes, 16 Q. B. 575 ; Ga'nett v. IIcKerean, L. R. 8 Ex. 10.

(y) Robarts r. Tuelies, 16 Q. B. 560 ; recognised and distinguished in Woods r. Thiedemam, 1 H. \& C. 47 s.

(z) Roburts v. Tucker, ubi supra. 
for " the general rule is, that no title can be obtained through a forgery" (a). And should the banker wish to avoid the responsibility of deciding on the genuineness of indorsements, he may require his customers to domicile their bills, i.e., make them payable at their orn offices, and to honour them by drawing cheques upon the bank. There is some authority for saying, that where a bill bearing a suspicious indorsement is presented for payment to a banker, he will be justified in deferring payment of the bill for a reasonable time, in order that he may make inquiries as to its genuineness $(b)$, but having regard to the duties of the holder, this seems very questionable.

Discharge of bill.

If an acceptor pay a bill at maturity or is then or subsequently becomes the owner thereof in his own right, the bill is discharged $(c)$. When, however, the bill is paid by the drawer, or an indorser, it is not discharged, but a drawer who pays a bill payable to, or to the order of a third party, may enforce payment thereof against the acceptor, though he cannot reissue the bill. Where a bill is paid by an indorser (or if payable to his own order by the drawer), the party paying it is remitted to his former rights as regards the acceptor or antecedent parties, and may, if he think fit, strike out his own and subsequent indorsements, and again negotiate the bill $(d)$.

\section{The remarlis to be found in this chapter respecting inland}

As to the banker's remedy against the person presenting the bill, see Cocks $\mathrm{v}$. Masterman, 9 B. \& C. 902.

As to revoking or cancelling an acceptance, see Cox r. Troy, 5 B. \& Ald. 4it; 24 R. R. 460; Ingham v. Primrose, 7 C. B., N.S., 82 ; commented on Baxendale v. Bennett, 3 Q. B. D. 525.

$A s$ to the liability of a banker who, by mistake, cancels the acceptance on a bill, which he afterwards receives orders not to pay, see Warevick v. liogers, 5 M. \& Gr. 340 ; approred in Prince v. Oricntal Bank Corp., 3 App. Cas. 325 ; Robson v. Bennett, 2
Taunt. 3ss : 11 R. R. 614.

(a) Y'er Tindal, C. J., Johnson $\mathrm{r}$. Windle, 3 Bing. X. C. 229; s. 24. But see Shaw v. Port Phillip Gold Mining Co., 13 Q. B. D. 103, 107.

(b) Robarts v. Tucker, 15 Q. B. 57-579; Chalm. Bills of Exchange, 4th ed., 204. Lord Bramecell disagrees with the suggestion (Bank of England v. Tagliano, (1891) A. C., at p. 141). See also, per Lord Macnaghten, at p. 157 .

(c) S. 59 , subs. 1 ; s. 61.

(d) S. 59 , subs. 2 (b). 
may readily be applied to foreign bills, provided the peculiar qualities attaching to instruments of this latter class are kept in view.

They will here be very briefly specified.

An inland bill is a bill which is, or on the face of it purports to be, both drawn and payable within the British Islands, or drawn within the British Islands upon some person resident therein; any other bill is a foreign bill $(e)$.

The form of a foreign usually differs from that of an inland bill ; the first-mentioned being often drawn at one or more usances : the "usance" being the period for payment customary as between the countries or particular places where the bill is respectively drawn and made payable $(f)$. Unless the contrary appear on the face of the bill the holder may treat it as an inland bill $(q)$.

Foreign bills, moreover, are usually drawn in partsthree or even more-which circulate together, or of which one or more parts may be circulated whilst another is forwarded for acceptance $(h)$. Each part, however, should specify or refer to the other parts of the set, and express that payment of it is conditional on the other parts of like "tenour and date" as itself remaining unpaid at maturity (i).

Again, where a foreign bill, appearing on the face of it Protest. to be such, has been dishonoured by non-acceptance or non-payment, it must be duly protested, failing which the drawer and indorsers will be discharged. A protest is a solemn declaration written by a notary under a copy of the bill, stating that payment or acceptance of it

(e) S. 4, subs. 1 : see Horne $\mathrm{v}$. Rouquette, 3 Q. B. D. 514 ; Rouquette v. Overmann, L. R. 10 Q. B. 525; Mahoney v. Ashlin, 2 B. \& Ad. 478 ; Barker r. Sterne, 9 Exeh. 684.

$(f)$ The form of a foreign bill of exchange may be seen in Poirier v.
Morris, 2 E. \& B. 95; Gibbs v. Fremont, 2 Exch. 25, and cases, supra, note $(e)$.

(g) S. 4, subs. 2.

(h) See Pinard r. Klockmam, 3

B. \& S. 388 .

(i) As to bills drawn in a set, see s. 71 . 
has been demanded and refused, the reason (if any) assigned for such refusal, and that the bill is consequently protested. This formality is required in case of dishonour of a foreign bill in conformity with the laws of most other countries, and because satisfactory evidence of dishonour is thus afforded to the drawer or indorser; for foreign Courts give credit to the acts of public functionaries, in like manner as a protest under the seal of a foreign notary is good evidence of dishonour in our Courts $(k)$. It is permissible but not necessary to protest or note a dishonoured inland bill $(l)$. Besides the peculiarities above specified as incident to foreign bills, we must remember that, where a bill of exchange drawn in one country is payable in another, a question of much importance sometimes presents itself-Is the lex loci contractîs or the lex loci solutionis to be employed to determine the rights and liabilities of the parties? The question of conflict of laws is dealt with in section 72 of the Bills of Exchange Act, 1882, of which it may briefly be said that it gives full effect to the maxim "locus regit actum," in so far as it validates transactions which might otherwise be invalid, while in so far as its operation is disabling, it is limited by the provisoes therein contained $(\mathrm{m})$.

Cheque. A cheque is a bill of exchange drawn on a banker payable on demand, and, save as otherwise provided in the Act, the provisions thereof applicable to a bill of exchange payable on demand apply to a cheque (n).

The banker who credits the account of a customer with the amount of a cheque, paid in by the customer with the intention that the amount of it shall be at once placed to s. 94 .

(k) As to protest of foreign bills, see

(I) S. 51, subs. 1.

(in) Cf. Rouquette v. Otermann, L. R. 10 (2. B. 525; Hirschfold v. Smith, L. R. 1 C. P. 340 . See Gibbs r. Société Industrielle, 25 Q. B. D. 399 ;

Alcock r. Smith, (1892) 1 Ch. 238.

(n) S. 73 ; cf. ss. 10,36 , subs. 3 ; s. 45 , subs. 2 ; s. 60 . See per Lord Blackburn, IIcLean v. Clydesdale Banking Co., 9 App. Cas. 93, 105, 106 ; per Worth, J., Crofton r. Crofton, 33 Ch. D. 612, 620 . 
his credit, becomes immediately a holder for value of the cheque $(o)$.

The duty and authority of a banker to pay a cheque drawn on him by a customer are determined by the happening of any one of three events:-1. By countermand of payment. 2. By his receiving notice of the customer's death. 3. By his becoming aware of the fact that his customer has committed an act of bankruptcy $(p)$.

By the present Act the rigour of the common law rule has been mitigated, by which, where a cheque was not presented within reasonable time, and the bank failed before presentment, the drawer of the cheque was discharged, and the holder had no remedy against the bank. Now, however, it is provided that, subject to the provisions of the Act, the drawer in such cases shall be discharged from his liability to the extent of the funds to his credit in the bank available for the payment of the cheque, had the same been presented within reasonable time, regard being had to the nature of the instrument, the usage of the trade and of bankers, and the facts of the case, and the drawee succeeds to the rights of the drawer against the banker, and can prove against his estate for the amount of the cheque $(q)$.

The practice of crossing cheques has an important bearing upon the rights of the parties to an instrument so treated, and is dealt with by sections $76-82$ of the Act $(r)$, which

(o) Royal Bank of Scotland v. Tottenhasn, (1894) 2 Q. B. 715 (C. A) (following on this point Ex parte Richdale, 19 Ch. D. 409). A postdated cheque stamped as a cheque, is admissible in evidence in an action brought, after the date of the cheque, by the holder, since under the Stamp det, 1891, the test of admissibility is whether the instrument appears, when endered in evidence, to be sufficiently tamped (S. C.)

(p) S. 75 , and s. 97 , saring the
Bankruptcy Acts.

(q) S. 74.

(r) By 46 \& 47 Yict. c. 55, s. 17, these sections are extended to any document issued by a customer of any banker, and intended to enable any person or body corporate to obtain payment from such banker of the sum mentioned in such document, and shall so extend in like manner as if the said document were a cheque. Such documents, however, are not thereby rendered negotiable instru- 
further define what a crossing is-whether "general," or "special," and with or without the words "not negotiable" $(s)$.

A cheque may be crossed by the drawer, and after issue may be crossed generally or specially by the holder, who may also add the words "not negotiable." If a cheque is crossed specially, the banker to whom it is crossed may again cross it specially to another banker for collection; and if a cheque uncrossed, or crossed generally, is sent to a banker for collection, he may cross it specially to himself $(t)$.

A crossing authorised by the Act is a material part of the cheque, which may not be obliterated, nor, save as in the Act provided, added to or altered $(u)$.

The duty of a banker on whom a crossed cheque is drawn is as follows:-If it is crossed generally, he must not pay it otherwise than to a banker; if specially, otherwise than to the banker to whom it is crossed. If he does pay the cheque otherwise than as above, he will be liable to the true owner of the cheque for any loss he may sustain by reason of the cheque having been so paid $(x)$. If he pays it as above, in good faith and without negligence, he (and the drawer, if the cheque has come into the hands of the payee) will be entitled to the same rights, and placed in the same position, as if payment of the cheque had been made to the true owner thereof $(y)$.

The following provision is one of considerable practical importance, and is aimed at protecting bankers against a particular kind of fraud which has recently been invented :Where a cheque is presented for payment which does not

ments. A cheque drawn parable to C.'s order was crossed with the words "Account of C., National Bank, Dnblin," was held not to be thereby rendered non-transferable: National Bank v. Silke, (1891) 1 Q. B. 435 (C. A.).

(s) S. 76, subss. $1,2$.

(t) S. 77 . (ii) S. 78 .

(x) S. 79 , subs. 2. A cheque crossed specially to more than one banker, except when crossed to an agent for collection being a banker, is not to be paid by the banker on whom it is drawn; s. 79 , subs. 1 .

(y) S. 80 . 
at the time of presentment appear to be crossed, or to have had a crossing which has been obliterated, or to have been added to or altered otherwise than as authorised by the Act, the banker paying the cheque in good faith and without negligence, shall not be responsible or incur any liability, nor shall the payment be questioned by reason of the cheque having been crossed, or of the crossing having been obliterated or having been added to or altered otherwise than as authorised by the Act, and of payment having been made otherwise than to a banker, or to the banker to whom the cheque is or was crossed, or to his agent for sollection being a banker as the case may be $(z)$.

Lastly, a person taking a crossed cheque which bears on t the words " not negotiable," will not have, and will not re capable of giving, a better title to the cheque than that rhich the person from whom he took it had $(a)$.

But a banker who has in good faith and without neglience received payment for a customer of a cheque crossed enerally or specially to himself will not, in case the title to he cheque proves null or defective, incur any liability to he true owner of the cheque by reason only of having eceived such payment $(b)$.

As in the case of an ordinary bill of exchange, so in that f a cheque, a banker has no authority from his principal pay any such draft unless signed or authenticated by imself and presented by some party who can give a lawful ischarge for it: a banker, therefore, who pays a forged leque, will clearly have to bear the loss himself, and innot throw it on his customer. So, if a banker pays a reque which has been fraudulently altered as regards the nount, he will have to suffer, unless he can show that the urty out of whose funds and on whose behalf he assumed

(z) S. 79 , subs. 2 .

(a) S. 81 . See Fisher v. Roberts, 6 nes L. R. 354 . (b) S. 82. See Mathieson r. London 8. County Bank, 5 C. P. D. 7 ; Bissell v. Fox, 53 L. T. 193.

B.C.I. 
to pay, by his own gross negligence and laches facilitated the commission of the fraud $(c)$.

Undoubtedly, says Best, C. J. (d), a banker who pays a forged cheque is in general bound to pay the amount again to his customer, because in the first instance he pays without authority, and because it is the duty of the banker to be acquainted with his customer's handwriting. But though that rule be perfectly well established, yet if it be the fault of the customer that the banker pays what he ought not to pay, the latter cannot be called on to pay again (e).

To a like effect, in another case $(f)$, Bayley, J., observes, that "the banker, as the depositor of the customer's money, is bound to pay from time to time such sums as the latter may order $(g)$. If, unfortunately, he pays money belonging to the customer upon an order which is not genuine, he must suffer; and, to justify the payment, he must shom that the order is genuine, not in signature only, but in

(c) Ioung v. Grote, 4 Bing. 253, commented on and explained per Pollock, C. B., Barker r. Stone, 9 Exch. 686,68i; Swan v: North British Australasian Co., 2 H. \& C. 175 , cited post; Johnson r. Windle, 3 Bing. N. C. 225, 229; British Linen Co. r. Calcdonian Insur. Co., 4 Macq. H. I. Ca. 107; Sicholfield v. Londesborough (Earl of), (1895) \& Q. B. 536. See Foster r. Green, 7 H. \& N. 881, 886.

loung v. Grote, supra, has been observed on by Brett, L. J., in Baxendale v. Bennett, 3 Q. B. D. 533, 534. See upon this Scholfield $r$. Londesborangh (Earl of), (1894) 2 Q. B., per Chavles, J., at p. 663 .

In Amold v. Cheque Bank, 1 C. P. D. 586, Lord Coleridge, C. J., delivering judgment, savs that Young r. Grote " must be considered as well decided, but various opinions have been $e x-$ pressed as to the ground of the decision." See also the judgm. in Halifax Union v. Wheelucright, L. R. 10 Ex. 191, 192.

(d) Foung v. Grote, supra.

(c) This qualification of the rule as to the banker's liability holds only where the customer has been guiltr o negligence of which the fraud is "th necessary or ordinary or likely result.' In The Bank of Ireland $\mathbf{v}$. Trustees o Erans' Charitics, 5 H. L. Ca. 389,410 Parke, B.. on behalt of the Judges observes, "If a man should lose hi cheque-book, or neglect to lock th desk in which it is kept, and a serran or stranger should take it up, it i impossible, in our opinion, to corten that a banker paring his forged chequ would be entitled to charge his custome with that payment." Cf. also Mer chants of Staple of Eugland r. Bank o England, 21 Q. B. D. 160 ; Amold Cheque Bank, 1 C. P. D. 578 . Se also Bank of England v. I'aglian (1891) (A. C.), per Lord Bramice at p. 136; also $S . C$., per Lord Fiel at p. 171 ; Scholfield r. Londesborong (Earl of) ,(1895) 1 Q. B. 536 (C. A. $75 \%$.

(f) IIall v. Fuller, 5 B. \&

(g) See Marzetti v. Williams, B. E Ad. 415 ; Rolin v. Steurard, 1 C. B. $595 ;$ Woodland r. Fear, 7 E. \&I 519,521 . 
every respect." In the case which gave occasion to these remarks, the cheque out of which the action originated had been altered by the holder, so as to indicate a much larger sum as payable under it than it had in the first instance been drawn for; the cheque so altered was paid by the vanker, who then claimed to charge his customer with the lifference between the two amounts. It was held, by upplying the prineiple of law already stated, that he was 1ot justified in doing so, there having been no laches in he customer.

We can merely further notice in connection with cheques he stat. 16 \& 17 Vict. c. 59 , s. 19 , which enacts as ollows:-That "any draft or order dramn upon a banker or a sum of money payable to order on demand which shall, hen presented for payment, purport to be indorsed by the erson to whom the same shall be drawn payable, shall be sufficient authority to such banker to pay the amount of ach draft or order to the bearer thereof; and it shall not o incumbent on such banker to prove that such indorseient, or any subsequent indorsement, was made by or nder the direction or authority of the person to whom the id draft or order was or is made payable either by the arrer or any indorser thereof" $(h)$.

This enactment, which protects the banker upon whom a reque is drawn against the forgery of the indorsement of e person to whose order it is made payable, does not tend to protect any other person who takes the cheque ion the faith of such forged indorsement (i).

A promissory note is an unconditional promise in writing Promissory zde by one person to another, signed by the maker,

h) See Charles r. Blachuell, 2 C. D. 151 ; Halifax Union v. Wheelght, L. R. 10 Ex. 183; Bissell r. , 53 L. T. 193. This section is :oduced in substance by s. 60 of the , but has not been repealed as it might possibly apply to some "drafts or orders," which are not bills or cheques. 513 . 
engaging to pay on demand or at a fixed or determinable future time, a sum certain in money to, or to the order of, a specified person, or to bearer $(k)$.

Before inquiring as to the nature and requisites of the above instrument, a few remarks as to its origin and the reason of its introduction amongst us may be proper. In regard to the latter part of this subject, the explanation offered by Mr. Kyd, in his Treatise on Bills of Exchange (t), appears satisfactory. He suggests that, as commerce advanced, the multiplicity of its concerns sometimes rendered necessary amongst mercantile persons a less complicated mode of payment than by bills of exchange. A trader, for instance, whose situation and circumstances rendered credit from the merchant or manufacturer who supplied him with goods absolutely requisite, might have so limited a connection with the commercial world, that he could not easily furnish his creditors with a bill of exchange on another man. But his own credit and respectability might, nevertheless, be such, that his simple promise of payment (reduced to writing for the purpose of evidence) would be quite as good as a bill on another. Hence we may reasonably conjecture that promissory notes originated.

This species of security seems to have become prevalent here about the middle of the 17th century ; and, according to Lord Holt ( $m$ ), was an "invention of the goldsmiths in Lombard-street."

The precise mode of the introduction into commercial transactions of instruments worded as promissory notes may, perhaps, be explained as follows :-

Prior to the year 1640 , the Royal Mint seems to have

(k) S. 83 (1).

It would seem that at common law neither a bill of exchange nor a promissory note can be under seal : Crouch r. Crédit Foncier of England, L. R. 8
Q.B.374,384. See Dutton r. Marsh,

L. R. 6 Q. B. 361 .

(I) P. 18: Story on Prom. Notes. 2nd ed., p. 7 .

(m) 6 I Iod. 29. 
served, to some extent, as a bank or place of deposit for the cash of wealthy merchants, whose custom was to leave their money there when they had no immediate occasion for it, and to draw it thence when wanted. In the year just named, however, King Charles I., as history informs us, took forcible possession of a large amount of funds which bad thus been lodged in his Nint, and the merchants seasing, consequently, to trust the Royal Mint as a place of leposit, were, shortly after the date just named, obliged to ave recourse to the goldsmiths, then principally domiciled n Lombard-street, who took upon themselves to act as ankers, and, in return for the sums deposited with them, ssued their notes payable to "order" or to "bearer" by ray of security $(n)$.

It seems clear, from reported cases (o), that bills of xchange had, long before the time just spolien of, been in se here amongst merchants; but some difficulty exists with eference to the question whether or not promissory notes rere, prior to the stat. $3 \& 4$ Ann. c. 2 , negotiable in like aanner and to the same extent as bills of exchange. We now, indeed, that Lord Holt strenuously opposed himself i) the placing of promissory notes on the same footing as ills of exchange, and to granting similar remedies upon nem $(p)$, but notwithstanding his opposition, there can be io doubt that these instruments had, during the latter half : the 17th century, been recognised in the mercantile orld as negotiable, and had there been regarded in the ume light as bills of exchange.

From the very obscurity, indeed, observable in the ports of cases upon bills and notes at the time in queson, and from the difficulty which exists in determining in ry particular case whether the instrument sued upon was

(n) Anderson, Hist. Com., rol. 2, 386; Macpher. Ann. Com., rol. 2, 411, 427; Gilbart, Hist. Bank., 1 ed., pp. 21, 22. See $W a r d$ v.
Evans, 2 Ld. Raym. 928.

(o) Ante, p. 447 .

(p) See Clarke v. Martin, Ld. Raym. 75í; Buller พ. Crips, 6 Mod. 29. 
in reality a bill or a note $(q)$, it may fairly be argued that the two classes of securities just named were then, even by lawyers, considered as mainly governed by the same rules and as dependent upon the same law-that law, viz., which is recognised amongst merchants, and is fashioned according to their exigencies.

We must not then regard as conclusive, with respect to the question just mooted, the preamble of the statute of Anne, which declares the previously existing law as in accordance with the expressed opinions of Lord Holt.

When, indeed, we reflect, that, prior to the time of Lord Mansfield, the leading principles of mercantile law had been comparatively little investigated, and certainly had not been reduced to any system-when we reflect, that, up to that date, some of the simplest points in connection with negotiable instruments had never been judicially decided $(r)$, we shall hardly wonder that doubt exists as to the precise light in which promissory notes were regarded by our legal tribunals during the latter half of the 17th century. Horever, the general effect of the stat. $3 \mathbb{\&} 4$ Ann. c. 9 (made perpetual by 7 Ann. c. 25 , s. 3) clearly was " to put promissory notes on the same footing with bills of exchange" $(s)$ : that statute expressly enacting $(t)-1$ st, That every note payable to an individual, or "order," or " bearer," may be put in suit by the payee or holder; 2ndly, that every such note shall be transferable in like manner as a bill of exchange, and so as to vest a right of action upon the instrument as against prior parties to it in the indorsee or holder.

These statutes are now repealed by section 96 of the Bills

(a) See 3 Burr. 1525.

(r) See Erans's Decis, of Lord Mans. field, rol. 2, pp. 59-81.

It was, howerer, reserved for I.ord Kenyon to adjudicate, that the dars of grace are to be allowed on a promissory note as on a bill; see Broven r. Har:- radan, 4 T. R. $14 S$.

(s) Per Ashurst, J., \& T. R. 153; per Lord K'nyon, C. J., 5 T. R. 485.

$(t)$ The wording of this statute พas much considered in Brotcn $\checkmark$. Ile Winton, 6 C. B. 356,359 ; and in ITood $\therefore$. Mytton, 10 Q. B. $810,811$. 
of Exchange Act, 1882, the provisions of which relating to bills of exchange are now, by virtue of section 89 , subs. 1 , and subject to the provisions of Part $V$., and the special exceptions contained in section 89 , subs. 2 , applicable with the necessary modifications to promissory notes.

The ordinary form of a promissory note is as follows:" $£ 100$.

"London, 1st January, 1855.

" [Three] months after" date [or On demand], or" At sight $(u)$ [or At [ten] days after sight], I promise to pay J. D. or order [or bearer] One Hundred Pounds. A. B."

The person signing the above instrument is called the naker; the person to whom it is made payable the payee; when transferred by indorsement the immediate parties o such transfer are, as in the case of a bill, termed the ndorser and indorsee.

No particular form of words is necessary to constitute a romissory note; and embarrassing questions may arise under the Stamp Acts or otherwise in regard to an instrunent ambiguously worded $(x)$, and presenting some features n common with a promissory note, others in common with n I.O. U. $(y)$, with a mere acknowledgment of a debt $(z)$, or ith an unilateral contract, or an agreement inter partes $(a)$. $\mathrm{n}$ instrument in the form of a note payable to maker's rder, is not a note within the meaning of the Bills of ixchange Act, 1882, unless and until it is indorsed by the raker (b). And, where an instrument is so framed as to

(u) As to days of grace, $r$. ante, 459 n. (o).

(x) See M'Call v. Taylor, 19 C. B., - S., 301.

(y) Brooks v. Elkins, 2 M. \& W. ; Fisher v. Leslie, 1 Esp. 426; elanotte v. Teasdale, $13 \mathrm{M}$. \& $\mathrm{W}$. 6.

(z) Hyne v. Dewdney, 21 L. J. B. 278 .

(a) Ibid.; White v. North, 3 Exch. 9 (following Horne v. Redfearn, 4 ng. N. C. 433); Hamilton v. Spottis- woode, 4 Exch. 200; Sibree v. Tripp, 15 M. \& W. 23; Robins V. May, 11 Ad. \& E. 213; Davies v. Wilkinson, 10 Ad. \& E. 98; Ayrey v. Fearnsides, 4 M. \& W. 168; Drkry v. Jaeaulay, 16 M. \& W. 146; Janis r. Wilkins, 7 M. \& W. 410.

(b) S. 83 , subs. 2 ; and see Masters v. Baretto, 8 C. B. 433 ; Hooper T. Williams, 2 Exch. 13 ; Broun v. De Winton, 6 C. B. 336; Gay र. Lander, Ibid.; Absolon v, Warks, 11 Q. B. 19; Mood r. Mytton, 10 Q. B. 805. 
cause doubt whether it is a bill of exchange or a promissory note, the holder will at his election be entitled to treat it as either $(c)$, for the words of an instrument are in general to be taken most strongly against the party using them $(d)$.

The distinction in general structure and character, which exists between a bill of exchange and a promissory note, is thus pointed out by Dr. Story (e). In a bill of exchange there are usually three original parties, the drawer, the payee, and the drawee, who, after acceptance, becomes the acceptor. In a promissory note there are but two original parties, the maker and the payee. In a bill of exchange the acceptor is, in contemplation of law, the primary debtor to the payee, and the drawer is but collaterally liable. In a promissory note the maker is, in contemplation of law, the primary debtor. When a negotiable note has been indorsed by the payee, then there occurs a striking resemblance in the relations of the parties upon both instruments, although they are not in all respects identical. The indorser of a note stands in the same relation to the subsequent parties to it as the drawer of a bill; and the maker of the note is under the same liabilities as the acceptor of a bill $(f)$. Hence the remarks already made respecting the rights and liabilities of parties to inland bills, may readily be applied to determine the mutual obligations of the parties to promissory notes. This latter subject will, accordingly, be here dismissed with some brief observations.

(e) Cf. s. 5, subs. 2.

(d) Edis r. Bury, 6 B. \& C. 433 ; Lloyd r. Oliver, 18 Q. B. 4il; per Lord Denman, C. J., Roffey r. Greenwell, 10 Ad. \& E. 225. See Forbes r. Marshall, 11 Exch. 166; Allen v. Sea Fire and Life Ass. Co., 9 C. B. 5it; Ellison v. Collingridge, Id. 570: Yeto v. Reynolds, 9 Exch. 410 ; Fielder v. Marshall, 9 C. B., N. S., 606. p. 5.

(e) Story on Prom. Notes, 2ud ed.,

(f) S. 89, subs. 2. In Heylyn v.
Adamson, 2 Burr. 676, Lord Mansfield says, "While a promissory note con. tinues in its original shape of a promise from one man to pay to another, it bears no similitude to a bill of exchange. When it is indorsed the resemblance begins, for then it is an order by the iudorser upon the maker of the note to par to the indorsee. This is the very definition of a bill of exchange."

See also Givinnell r. Herbert, 5 dd. s. E. $436,439,440$. 
The maker of a promissory note, by making it, engages that he will pay it according to its tenour, and is precluded Contract of maker of from denying to a holder in due course the existence of the payee, and his then capacity to indorse $(g)$. If then the note is not in the body of it made payable at a particular place, in which case it must be presented for payment at that place in order to render the maker liable, the maker will be liable to an action immediately the note falls due, without any demand or presentment for payment, because in that case his engagement is unconditionally to pay $(h)$.

That demand or presentment is not, under ordinary circumstances, necessary as against the maker of a note, may be kept in mind by the decision of the Court of Exchequer in Norton v. Ellam (i), which shows that a promissory note, even when payable on demand, is a present debt, and is payable without any demand; and accordingly the Statute of Limitations will begin to run from the date of such a note; the above case being similar to that of money lent, payable on request-where no demand or request is necessary before bringing the action, because the debt which constitutes the cause of action mises instantly on the loan being made.

Hardship may, no doubt, by operation of the rule of Iaw ust stated, be caused to the maker of a note, who, though silling to pay the same at maturity, cannot discover the hen holder of the instrument. From the possibility of iuch hardship being cast upon him, he may, however, 'elieve himself, by inserting a condition, requiring presentnent at some particular place in the note: and if he do 0 , the payee will be under the necessity of averring and roving presentment of the note before charging him, or

(g) S. 88 .

(h) S. 87 , subs. 1 .

(i) 2 M. \& W. 461 (ĉ́. George, In , Francis r. Bruce, 44 Ch. D. 627);
Rumball r. Ball, 10 Mod. 38. See per Abbott, C. J., Mracintosh v. Haydon, Ry. \& M. 363. 
of offering a sufficient legal excuse for its omission $(k)$. Delay, however, in making presentment for payment will be excused when the delay is caused by circumstances beyond the control of the holder, and not imputable to his default, misconduct, or negligence. When, horrever, the cause of delay ceases to operate, presentment must be made with reasonable diligence, except in those cases where either it cannot be duly effected after the exercise of reasonable diligence, or the maker has expressly or impliedly waired presentment $(l)$.

The fact that the holder has reason to believe that the note on presentment will be dishonoured (as, ex. gr., because the maker is bankrupt, or has generally declared that he will not pay it), will not dispense with the necessity of presentment $(m)$.

Contract of indorser of note.

The indorser of a promissory note is to be regarded as a surety merely for the party primarily liable upon the note.

As in the case of a bill, so in that of a note, an indorser can only be charged when presentment to the maker has been made $(n)$, and due notice of dishonour has been given. As regards presentment and notice to an indorser of dishonour, reference may be made to what has already been said upon these subjects $(o)$. And we may add that while, if a note is in the body of it made payable at a particular place, presentment there will be necessary in order to render an indorser liable, yet if a place of payment is indicated by way of memorandum only, the indorser will be rendered liable either by presentment there or by presentment elsewhere to the maker if sufficient in other respects $(p)$.

(k) S. 87, subs. 1. Cf. Sands r. Clarke, 8 C. B. 751 ; Tan der Donckt v. Thelluson, 8 C. B. 812 ; Emblin v. Dartnell, 12 M. \& W. 830 ; Spindler r. Grellett, 1 Exch. 384.

(l) S. 46.

(im) Hb. Cf. Bowes v. Howe, 5 Taunt. $30 ; 14$ R. R. 700 ; judgm., 8 C. B.
759, 760; Arg. Russel v. Langstaffe, Dougl. 515; Estaile r. Sovcerby, 11 East, 114; 10 R. R. 440; see also Bailey v. Porter, 14 M. \& W. 44.

(n) S. $8 \pi$, subs. 2 .

(o) Ante, p. 459 et seq.

(p) S. $8 \pi$, subs. 3. 
A further point of much practical importance arises as to the necessity for speedy presentment of negotiable paper, whether bills or notes.

In the first place, where a bill is payable after sight, or expressly stipulates that it shall be so presented, or is drawn payable elsewhere than at the residence or place of business of the drawee, presentment for acceptance will be necessary before it can be presented for payment, or any person made liable upon it. In the latter case, howerer, if the holder has not time, with the exercise of reasonable diligence, to present the bill for acceptance before presenting it for payment on the day it falls due, the delay caused by so presenting it Ior acceptance will be excused, and will not discharge the drawer or indorsees. Thus, if a bill is drawn in New York on Liverpool, payable a month after date in London, which only reaches the holder on the day it matures, he must present it for acceptance at Liverpool, but neither the drawer nor the indorsees (if any) will be discharged by the zonsequent delay in presenting it for payment at London $(q)$.

Secondly, subject to the provisions of the Act, when a bill is not payable on demand, it must be presented for payment on the day it becomes due $(r)$; if not, the drawer ind indorser will be discharged.

Thirdly, where a bill is payable on demand, it must se presented, subject to the provisions of the Act, within a 'easonable time after its issue, in order to render the drawer iable, and within a reasonable time after its indorsement, n order to render the indorser liable $(s)$.

Fourthly, where a bill payable after sight is negotiated, he holder must either present it for acceptance, or negotiate

(q) S. 39. As to what amounts to ue presentment for acceptance, and hen it will be excused, see s. 41. hese provisions do not apply to proissory notes.
(v) S. 45 , subs. 1 .
(s) S. 45 , subs. 2 .

As to promissory notes, see ss. 86 , 87. Presentment is necessary to reuder the maker liable only where the note is in the body made payable at a particular place, and where a note payable on demand has been indorsed, to reuder the indorser liable. 
it within a reasonable time, otherwise the drawer, and all prior indorsers, will be discharged $(t)$. In determining what is "reasonable time" in any case, regard will be had to the nature of the instrument, the usage of the trade, and the facts of the case $(u)$. A promissory note, payable on demand, is often intended to be a continuing security, and prompt presentment for payment will not then be required $(x)$.

Bank note.

A bank note is a promissory note made by a banker, payable to bearer on demand. A bank note has, however, some peculiar qualities $(y)$, of which the most important is that it circulates as money, and in the ordinary course of business is treated as such $(z)$. In Miller v. Race (a), Lord Mansfield says that bank notes are constantly and universally, both at home and abroad, treated as cash, and paid and receired as cash; and it is necessary for the purposes of commerce that their currency should be established and secured. It was there accordingly held, that a bonâ fide holder of a bank note for value is entitled to retain it as against a former owner from whom it has been stolen; the Court applying to a bank note the rule of law applicable to money, and observing that, "in the case of money stolen, the true owner cannot recover it after it has been paid away fairly and honestly upon a valuable and bon î fide consideration." In short, one who takes a bank note bona fide-i.e., giving value for it, and without notice that the party from whom he talies it has no titlemay recover upon it, although he may at the time have had the means of knowledge of such fact, and have neglected to avail himself of them (b).

(t) S. 40 .

(ii) S. 45 , subs. 2 ; s. 86 , subs. 2.

(x) Brooks v. Witchell, 9 II. \& W. 18: Heyuood v. Watson, 4 Bing. 496 ; Barough v. White, 4 B. \& C. 325, 328. See also Deuters v. Tounsend, 5 B. \& S. 613.

(y) Judgm., Guardians of Lichfield
Union r. Greene, 1 H. \& N. 889.

(z) The notes of the Bank of Eng. land constitute a legal tender, except by the Bank itself or its branches: 3 $d+$ Will. 4, c. 98, s. 6 .

(a) 1 Burr. $452 ; 1$ Sm. L. C., 9th ed. 491 .

(b) Raphael v. Bank of England, 
A bank note is expressly intended for circulation, and not meant as a continuing security in the hands of any Rule as tw presenttinent of $\mathrm{a}$ particular holder. The rule in regard to its presentment must therefore be separately examined-it has manifestly a direct bearing on the question-Under what circumstances will the payment of a debt in bank notes be equivalent to a payment in cash? The case of Camidge v. Allenby $(c)$ is a leading authority upon this subject $(d)$. There the facts were as under:-Certain corn was sold and delivered by the plaintiff to the defendant at York on the Saturday morning, and paid for at three o'clock the same afternoon in notes of the bank of D. \& Co., at Huddersfield. The bank in question had, in fact, stopped payment at eleven o'clock in the morning of the day named, and did not resume their payments. The insolvency of D. \& Co. was, however, unknown to either of the parties to the transaction above mentioned. The plaintiff neither circulated the notes nor presented them for payment, but a week after their receipt required the defendant to take back the notes and to pay him the amount of them. The question raised xccordingly was, whether, under the circumstances, the lefendant was legally compellable so to do. The answer ;o this question was perspicuously given by Mr. Justice Bayley, in a judgment, from which the following passages ure extracted :- "The rule," he says, " as to all negotiable nstruments is, that, if they are taken in payment of a re-existing debt, they operate as a discharge of that debt, inless the party who holds the instruments does all that he law requires to be done in order to obtain payment $f$ them. Then the question is, what it was the duty f the plaintiff to do in order to obtain payment of these otes? They were intended for circulation. But I

i C. B. 161. See per Crompton, J., id Lord Campbell, C. J., Carlon v. ieland, 5 E. \& B. 770,771 .

(c) 6 B. \& C. 373 . See also Turner v. Stones, 1 D. \& L. 122; Rogers r.

Langford, 1 Cr. \& M. 637 .

(d) See judgm., 1 H. \& N. 890. 
think that he was not bound immediately to circulate them or to send them into the bank for payment; but he was bound within a reasonable time after he had received them, either to circulate them or to present them for payment. Now, here it is conceded, that if there had not been any insolvency of the bankers, the notes should have been circulated or presented for payment on the Monday. It is clear that the plaintiff on that day might have had knowledge that the bankers had stopped payment, and having that knowledge, if presentment was unnecessary, he had then another duty to perform. In consequence of the negotiable nature of the instruments, it became his duty to give notice to the party who paid him the notes, that the bankers had become insolvent; and that he, the plaintifi, would resort to the defendant for payment of the notes; and it would then have been for the defendant to consider whether he could transfer the loss to any other person; for unless he had been guilty of negligence, he might perhaps have resorted to the person who paid him the notes." Upon such grounds it was held, in Camidge v. Allenby, that the plaintiff, by reason of his laches, was not entitled to recover, but must bear the loss occasioned by the failure of the bank. The learned Judge, whose words have just been cited, remarking, that though it might be hard that the entire loss should fall upon one individual, yet, " it is a general rule applicable to negotiable instruments, and not to be relaxed in particular instances, that the holder of such an instrument is to present promptly, or to communicate without delay notice of non-payment or of the insolvency of the acceptor of a bill or the maker of a note" $(e)$; and such notice must be communicated within a reasonable time, though not necessarily before the expiration of the time allowed for presentment $(f)$. 
Another question which, as connected with the preceding subject, may here be conveniently discussed, is this:What right has the holder of a bank note, or of any negotiable instrument passing from hand to hand without indorsement, as against his immediate transferor, should the instrumert transferred prove, by reason of some defect inherent in it, to be worthless? The answer to this question is supplied by section 58, subs. 2, of the Bills of Exchange Act, 1882, which declares that a transferor by delivery is not liable on the instrument $(g)$; he will, however, be liable to his immediate transferee, being a holder for value, on an implied warranty connected with but collateral to the instrument, to the effect that the instrument is what it purports to be, that he has a right to transfer it, and that, at the time of transfer, he was not aware of any fact which rendered it worthless $(h)$.

A person who receives forged bank notes in payment for goods sold, or who discounts a forged bill, will not, in general, be precluded from suing for the price of the goods, $x x$ for the amount advanced by way of discount, because in the one case there has been a total failure of consideration, ind, in the other, the payment was made under a mistake is to facts, and likewise without consideration (i).

Gompertz v. Bartlett $(k)$ should be consulted with reference o this part of the subject, and as shoring the application

(g) Cf. Ex parte Roberts, 2 Cox, 71; Fenn v. Harrison, 3 T. R. 757 . (h) S. 58 , subs. 3 .

(i) Jones v. Ryde, 5 Taunt. 488; 5 R. R. 561. See Wilkinson v. Johnon, 3 B. \& C. 428 ; Cocks v. Masterเat, 9 B. \& C. 902. Where, howver, such time has elapsed that the osition of the holder may be altered, loney paid and received in good faith $n$ a bill presented for payment when ue, cannot be recovered back from the older, although indorsements on the ill subsequently proved to be forgeries : ondon and River Plate Bank v. Bank of Liverpool, (1896) 1 Q. B. 7 .

(k) 2 E. \& B. 849 , which affirms Jones v. Ryde, 5 Taunt. 488 ; 15 R. R. 561 ; Foung r. Cole, 3 Bing. X. C. 724 ; Gurney v. Womersley, 4 E. \& B. 133. See Pooley r. Brown, 11 C. B., N. S., 566 : per Lord Kenyon, C. J., Fenn r. Harrison, 3 T. R. 759 .

A person who pays into a banker's worthless notes will, if there be no laches in the banker, have to bear the loss: Timmins r. Gibbins, 18 Q. B. 722. See Woolland v. Fear, 7 E. \& B. 519 . 
of the maxim Careat emptor in connection mith bills of exchange and promissory notes. The question there arose upon the sale of a bill of exchange. which, on the face of it, purported to be a foreign bill, but had, in fact, been dramn in London, and was unarailable for want of a stamp. This bill mas discounted br the plaintifi for the defendant, who did not indorse it but bonct fide beliered the bill to hare been drawn abroad. The question was, whether the plaintiff, haring thus purchased a worthless commodity, was entitled to recorer his purchase-moner from the rendor. The Court of Queen's Bench held that he wasapon this short ground-that eren in the absence of fraud a rendee is "entitled to hare an article answering the description of that which he bought." The principle of this decision will be found applicable in a great rariety of cases, wherever indeed forged or spurious paper passes for ralue from hand to hand.

As bearing upon the point before us (though not decided with reference to the particular class of instruments to which attention has latterly been confined) may be cited Lamert v. Heath $(l)$. There the question was, whether the price of certain scrip certificates of shares in the "Kentish Coast P. C." could be recorered back by the purchaser from the broker whom he had employed to bur them, these certifcates, although knomn and commonly dealt with in the moner market under that designation, being in fact spurious; such being the question raised between the parties, the Court of Exchequer laid down the law applicable to it in these terms:That, if the scrip actually purchased was the only scrip known in the market by the particular designation, the purchaser, in directing his broker to buy this scrip, and haring received it, had in trath got all that he had contracted to buy, and could not therefore recover its price from his broker.

(I) $15 \mathrm{M} . \&$ W. 456. Ste Hestropp r. Solomon, \& C. B. 345 , and cases there cited: Nicholson T. Rieketts, ? E. \& E. $49 \%$. 
Haring particularised the rarious points, which in zonnection with bills of exchange and promissory notes specially demand attention, it remains to sar somerhat as so matters of defence ordinarily available at lav in actions Orditu:y metters of defesce $\mathrm{x}$. lew is actions tyos bitis and ipon such instruments. As to four such grounds of defence mly, shall I here offer some remarks, riz., Payment-the lefence of No Consideration - of an unauthorised Alteration if the instrument-of its Loss; observing br 世ar of preface 0 this part of mr subject that the holder of a bill mar gree with the acceptor not to enforce his remedies against in, and may at the same time reserre his rights against nose who are liable in the second degree, so that the latter ill not be discharged $(m)$.

Payment of a bill, in order that it mar operate as a dis- Parmesin large of the drawee or acceptor, must be made in due course. ther by him or on his behalf $(n)$. That is to say, it must made at or after the maturits of the bill to the holder ereof, in good faith, and without notice that his title to e bill is defective (0). "A thing is deened to be done good faith, within the meaning of the Act, where it in fact done honestly, whether it is done negligently or $t "(p)$.

$A$ bill is not discharged br parment br the drawer or indorser, subject to this, that if the drawer par a bill ivable to, or to the order of a third party, he can enforce I rment thereof against the acceptor: he cannot, hoterer. rissue the bill. Further, if the bill is paid br an indorser, where payable to the dramer's order. is paid br the d.wer, the party so paring it is remitted to his former 5 hts as against the acceptor or anr antecedent parties. E may, therefore, strike out his omn and any subsequent a orsements, and again negotiate the bill $(q)$.

) Mwir T. Crancford, L. R. 2 Sc.

1) Cas. 456.

S. 59.

(c) S. 59, subs. 1 .

(p) 5.90.

(q) S. 59, subs. 2 .

C.I 
Where an accommodation bill is paid in due course by the party accommodated the bill is discharged $(r)$.

The cases below cited $(s)$ will suffice to show what will or will not amount to payment of a bill or note, so as to sustain the defence of payment in an action upon such an instrument. The character in which a bill is paid by a party liable on it-ex. gr., whether as indorser or as agent for the acceptor-will be a question of fact $(t)$.

A bill will also be discharged in the following cases:-1 If the acceptor is or becomes the holder of it, at or after maturity, in his own right. 2. If the holder, at or after maturity, absolutely and unconditionally renounces hi rights against the acceptor. Such renunciation, however must, in order to enure as a discharge, be made in writing unless the bill is delivered up to the acceptor (u).

Similarly the holder may renounce his rights against an party to the bill, before, at, or after maturity; but it i provided that this shall not affect the rights of a holder i due course, without notice of the renunciation.

3. An intentional cancellation by the holder, or his agen if apparent on the bill, will discharge it. Such cancellatio may be so applied to the signature of any party to the bil and will then enure to the discharge of all parties, to whom th party whose signature is so cancelled would have been liabl An unintentional, mistaken, or unauthorised cancellation inoperative, but the onus of proof will lie upon the perso who alleges such want of intention or authority $(x)$.

A bill or note prima facie imports consideration: ar

(r) S. 59 , subs. 3.

(s) Hills . Mesnard, 10 Q. B. 266; Thorne v. Smith, 10 C. B. 659 ; Williams v. James, 2 Exch. 798 (in error); Ralli v. Dennistoun, 6 Exch. 483 ; Jones v. Gretton, 8 Exch. 773; Turney r. Dorluell, 3 E. \& B. 136, distinguishing Foster v. Dauber, 6 Exch. 839; Beaumont y. Greathead, 2 C. B. 494; Bell v. Buckley, 11 Exch. 631.
As to payment supra protest, Geralopulo v. Wieler, 19 C. H. 69 per cur. Rotton v. Inglis, 2 Q. B. 68 Goodall v. Polhill, 1 C. B. 233.

(t) Pollard v. Ogden, 3 E. \&. B. 4

(v) A memorandum of the reauno tion is insufficient : the document $m$ ' be a record of the renunciation Gearge, In re, Francis F. Bruce, 44 D. 627 ).

(x) Ss. 61, 62, 63. 
every party whose signature appears on a bill is, prima racie, deemed to have become a party thereto for value $(y)$.

In order, therefore, to rebut this presumption, proof , hould be given that either the bill or the acceptance thereof vas obtained without consideration or by fraud, duress, or ither unlawful means, as for an illegal consideration, or hat it has been negotiated in breach of faith or under such ircumstances as amount to frand. In all these cases the older's title is defective $(z)$.

If, however, value has at any time been given for a bill, he holder is deemed to be a holder for value as regards the sceptor, and all parties to the bill who became parties ior to that time (a). Thus if a bill is indorsed for value A., who indorses it to his agent for collection, the agent ill be able to sue the acceptor, and any indorser prior to , but will not be able to sue A. So too a holder (whether r value or not), who derives his title to a bill through a ider in due course, and who is not himself a party to any fud or illegality affecting it, has all the rights of that lder in due course as regards the acceptor, and all parties the bill prior to that holder $(b)$.

The rule as to the onus probandi on the issue of "no 1sideration" is that proof must in the first instance be en by the party who relies on that defence, every holder a bill being prima facie deemed to be a holder in due rse. If, however, in an action on a bill it is admitted or 1 ved that the acceptance, issue, or subsequent negotiation the bill is affected by fraud, duress, or illegality, the den of proof is shifted, unless and until the holder ves that subsequent to the alleged fraud or illegality, le has in good faith been given for the bill $(c)$. The

S. 30 , subs. I ; and see Watson $\mathrm{r}$. R ll, 3 B. \& S. 34 ; Currie v. Misa,

10 Ex. 153.

S. 29 , subs. 2 .

S. 27 , subs. 2 .

S. 29 , subs. 3 . (c) S. 30, subs. 2. Cf. Wills v. Barber, 1 M. \& W. 425,432 ; Bailey v. Bidvell, 13 M. \& W. 76 ; Sinith v. Braine, 16 Q. B. 244. See Tatam v. Haslar, 23 Q. B. D. 345 . 
defence of "no consideration" is a defence pro tanto as to part only of a bill or note, as against an immediate party, though not against a remote party who is a holder in due course. For instance, by way of answer to an action upon such instrument, a man might say that, in adding up an account he erroneously supposed himself to be indebted in 100l., whereas in truth 10l. only was due. That in the case of a bill or note would be a good defence except as to $10 l$. $(d)$. A partial failure of consideration would not, however, arail as a defence to the whole bill or note $(e)$.

We have already $(f)$ seen that if a person lends his name to another for his accommodation, the party accommodated undertakes to pay the bill at maturity, and further, to indemnify the person accommodating him, in case that person is compelled to pay the bill for him. Hence there is " an implied authority to such person to pay it, if he be in that situation that he may be compelled by law to pas. the bill, though the holder do not actually compel him ts do so, and, after payment, he may sue the party accommo dated for money paid on his account; for such payment $i$ in truth under the implied authority given by the contrac of accommodation between the parties; and whether thi be a payment of the whole bill, or of only a part of $i$ makes no difference" $(g)$.

Where a bill or acceptance is materially altered, withor the consent of all parties liable on the bill, the bill aroided except as against a party who has himself mad authorised, or assented to $(h)$ the alteration, and subsequer indorsers (i); and this will be so whether the alteration 492.

(d) Forman v. Wright, 11 C. B.

(e) Clark r. Lazarus, 2 M. \& Gr. 167; Camac v. Warriner, 1 C. B. 356: Darnell r. Williams, 2 Stark. N. P. C. $166 ; 19$ R. R. 694 .

(f) Ante, p. 454 . 517 .

g) Judgm., Sleigh r. Sleigh, j Ex

(h) See Tarleton $\mathrm{v}$. Shingler, ; C. 812.

(i) S. 64, subs. 1 . 
made by the holder himself or by a stranger $(k)$; for " no man shall be permitted to take the chance of committing a fraud without running any risk of losing by the event when it is detected." $(l)$. And again, "a party who has the custody of an instrument made for his bencfit is bound to preserve it in its original state" $(\mathrm{m})$. If he omits to do so, and thus loses his remedy, he has no right to complain, since an alteration cannot be made in the instrument zxcept through fraud or laches on his part $(n)$.

The principle just stated and explained was in Pigot's Fase (o) first propounded in regard to deeds $(p)$, and has ince been extended to all instruments comprehending vords of contract $(q)$. Thus, in Davidson v. Cooper $(r)$, which may be regarded as a leading authority upon the ubject before us, the question arose with reference to a parantee (not under seal) which had been given by the lefendants to a banking company, and which, whilst in the laintiffs' possession, but without their knowledge or conent, had been altered, by the affixing of seals near to the ignatures of the defendants; in consequence whereof the istrument purported to be a specialty instead of a simple ontract. In this case judgment was finally given for the efendants, on the express ground that the adding of the als constituted a material alteration, inasmuch as it gave

(k) Master v. Miller, 4 T. R. 320 ; R. R. 399 ; $S$. C. (in Error) 2 H. Bl. 0 ; 1 Sm. L. C., 9th ed., 825 .

(l) Per Lord Kenyon, C. J., Master IIIller, ubi supra.

(m) Judg., Davidson v. Cooper, 13 \& W. 352 , cited 15 C. B. 692 .

(n) Ib.

(o) 11 Rep. 26 b; Whelpdale's se, 5 Id. 119 a.

p) See also Agricultural Cattle wr. Co. v. Fitzgerald, 16 Q. B. ?; cited per Wilde, B., Lord Ward Lumley, 29 L. J. Ex. 326 ; j H. \& 87 ; Sellin v. Price, L. R. 2 Ex. ; Wood v. Slack, L. R. 3 Q. B. ; Doe d. Tatum v. Catomore, 16
Q. B. 745 (with which compare Doe d. Shalleross v. Palmer, Id. 747); per Lord Denman, C. J., Harden v. Clifton, 1 Q. B. 524; see per Maule, J., Re Bingle, 15 C. B. 450.

(q) Per Willians, J., 5 C. B. 194; per Ashurst, J., Master v. Miller, 4 T. R. 331; 2 R.R. 399 ; I Sm. L. C., 9th ed., p. 825 ; Croockevit r. Fletcher, I H. \& N. 893; Gardnor v. Walsh, 5 E. \& B. 83 ; Fazakerly v. If Knight, 6 Id. 795; see Pattinson v. Luckley, L. R. 10 Ex. 330 .

(v) II M. \& W. 778; 13 M. \& W. 343; Andrews v. Lawrence, 19 C. B., N. S., 768 . 
in fact a different legal character to the writing to which they were attached, and would, if made with the consent of all interested, have completely changed as well the nature. of the relation towards each other of the parties to it as the remedies upon it.

The principle now under notice is strictly applied to all negotiable instruments. In Warrington v. Early $(s)$, the action was brought upon a promissory note, which had been made payable five months after date with lawful interest. It appeared, horrever, that in the corner of this note had been written, at the plaintiff's request, and unknown to the defendant, the following words :- "Interest to be paid at 6l. per cent. per annum." The alteration thus made was held to be material, and to vitiate the note. So if, after a bill of exchange, accepted generally, has been put into circulation, it be altered without the consent or knowledge of the acceptor, by adding to the acceptance words making the bill payable at a particular place, this alteration will vitiate the bill and discharge the acceptor from liability upon it, save as against a holder in due course under the proviso subsequently referred to $(t)$; for, although "the negotiability of bills of exchange is to be favoured," yet "with this view, it is material that their purity should be preserved" $(u)$. The following alterations, in particular are declared material by the Act, namely, any alteration of the date, the sum payable, the time or place of pay ment, or, where a bill has been accepted generally, the addition of a place of payment without the acceptor assent $(x)$. And it has also been held that the alteration 0 the number of a bank note $(y)$, and the addition of a make to a joint and several note $(z)$, are material alterations.

(8) 2 E. \& B. 763.

(t) Infra. 683.

(u) Burchield v. Moore, 3 E. \& B.

(x) S. 64 , subs. 2. (y) Suffield r. Bank of England,

Q. B. D. 555 ; Leeds and County Ban

v. Walker, 11 Q. B. D. 84. 83 .

(z) Gardner v. Walsh, 5 E. \& I 
An immaterial alteration will not, however, affect the validity of an instrument $(a)$; and it is further provided by the Act, in mitigation of the previous rigour of the law that, where a bill has been materially altered, but the alteration is not apparent, and the bill is in the hands of a holder in due course, such holder may avail himself of the bill as if it had not been altered, and may enforce payment of it according to its original tenour $(b)$.

Where a bill of exchange has been lost before falling due and not afterwards recovered, the question arises, Can a Loss of bill or note. cemedy upon the instrument be enforced at common aw? (c) and the answer to this question must depend upon he nature of the bill, and the form in which the defence is resented. If the bill be originally negotiable, i.e., payable "to C. D.," or "C. D. or order," or "to bearer," the cases relow cited $(d)$ show that at common law the acceptor is lot bound to pay the bill to any one suing as holder, who hall refuse or be unable to deliver up the bill-the reason ssigned being, that "by the custom of merchants the older of a bill should present the instrument at maturity $\mathrm{s}$ the acceptor, demand payment of its amount, and upon eceipt of the money, deliver up the bill"-the acceptor pon paying the bill having a right to its possession, "for is own security, and as his voucher and discharge pro into" $(e)$ in the account between himself and the party ho drew upon him-a right which remains to him 1ually where the payment is made under the compulry process of law. The rule is the same under the atute, which provides that where the holder of a bill esents it for payment, he shall exhibit the bill to the

(a) Aldous v. Cornwell, L. R. 3 Q. B. 3.

(b) S. 64 , subs. 1.

c) King v. Zimmerman, L. R. 6
C. P. 466 .

(d) Hansard v. Robinson, 7 B. \& C. 90 ; Ramuz v. Crowe, 1 Exch. 167.

(e) Judgm., 7 B. \& C. 94. 
person from whom he demands payment, and when a bill is paid the holder shall forthwith deliver it up to the party paying it $(f)$.

The rule above stated does not seem to hold in case of the loss of a non-negotiable bill or note $(g)$; the reason of the rule being then inapplicable; and it is now provided by the Act that where a bill has been lost before it is overdue, the holder may apply to the drawer to give him another bill of the same tenour, giving security, if required, to indemnify the drawer against all claims on the bill so lost, and in case of refusal can compel the drawer to give such duplicate bill. Further, in any action or proceeding upon a bill, the Court or a Judge may order that the loss of the instrument shall not be set up, provided an indemnity be given to the satisfaction of the Court or Judge against the claims of any other person upon the instrument in question $(h)$.

Illegality,

Besides the special grounds of defence above commented on, illegality, fraud (i), or duress may be set up in answer to an action upon a bill or note. As regards the two former o: these matters, the reader is referred to the general remark: bearing upon them contained in the first chapter of this book $(k)$. In regard to the last-named ground of defence, the cases below cited may be consulted $(l)$. Another ground 0 defence might be that the defendant signed the instrumen

(f) Ss. 69,70 . The loss of a nego. tiable bill, giren on account of a debt, was held to be an answer to an action for the debt as well as to one on the bill: Crove v. Clay, 9 Exch. 604; 8 Id. 295. See Widders, app., Gorton, resp., 1 C. B., N. S., 576; Jungbluth v. Way, 1 H. \& N. 71 ; Bartlett v. Holmes, 13 C. B. 630,638 .

(g) Yer Jervis, C. J., Chamley v. Grundy, 14 C. B. 608, 614; Wain r. Bailey, 10 A. \& E. 616.

(h) Ss. 69, 70.

(i) See Daues v. Harness, L. R. 10 C. P. 166. (k) Ante, pp. 327,$346 ;$ s. 29 , subs. 2 As to illegality of consideration for bill or note, see further Byles on Bill 9 th ed., Chap. 10 ; Iraster's v. Ibberson 8 C. B. 100. As to the defence intoxication, see Gore v. Gibson, I M. \& W. 623 ; Nagle r. Baylor, Lr. \& W. 60.

(l) Kearns r. Durell, 6 C. B. 5 s - (duress of goods); Dunean r. Scott, Camp. N. P. C. 100; Cumming Inee, 11 Q. B. 112 ; Stevens $\mathrm{r}$. Unde wood, 4 Bing. N. C. 655 (duress

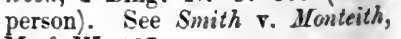
II. $\&$ W. $42 \pi$. 
when drunk $(m)$, or that his signature was forged $(n)$, as to which see section 24 of the Act.

Before dismissing the subject of negotiable instruments, we may add that:-

1. In virtue of stat. $30 \& 31$ Vict. c. 144 , the assignee Policy of of a life policy, and under stat. 31 \& 32 Vict. c. 86 , the assignee of a marine policy of insurance, may sue thereon in his own name. In the former case the assignee must give notice to the assurance company, and takes subject to all defences which would have been valid against his assignor $(o)$.

2. A bill of lading is a witten acknowledgment by the master of a vessel that he has received goods from the shipper $(p)$, to be conveyed on the terms therein expressed to their destination, and to be then delivered to the oarties therein designated. The ordinary practice is this: xhen goods are sent on board ship, the master or person rcting for him gives a receipt for them, and the master ifterwards signs three or four parts of a bill of lading (q), me of which is retained by the captain, another is ransmitted to the consignee, the other or others being reld by the consignor himself for his own security $(r)$. 'he bill of lading specifies that the goods sent are to be elivered to the consignee, or his assigns or order (s), or

(m) The contract of a drunken man is idable only, not void: Mattheu's v. axter, L. R. 8 Ex. 132.

(18) S. 24. See Brook v. Hook, .R. 6 Ex. 89 ; Foster v. Machinnon, R. 4 C. P. 704; Hirschfeld v. ondon, Brighton, and South Coast C., 2 Q. B. D. 1; Morris V. thell, L. R. 5 C. P. 47 .

(o) Ss. 2, 3.

(p) A shipowner is not estopped by e signature of the master to the bill lading from showing that the goods some of them were never actually $t$ on board: Broun v. Poucell Coal ., L. R. 10 C. P. 562.

(q) See Mirabita v. Imperial Ottoin Bank, 3 Ex. D. 164. (r) Per Buller, J., Lickbarrow v. Mason, 2 T. R. 72; 1 H. Bl. 357; 6 East, 21, n.: 1 R. R. 425, Preface xi.; 1 Sm. L. C., 9th ed., p. 737 . See, however, Glyn, Mills \& Co. v. East \&. West India Dock Co., 6 Q. B. D. 475 ; 7 App. Cas. 591 ; in which case two parts were forwarded to the consignees. In that case it was also decided that a shipowner or wharfinger delivering goods to an assignee of one part, bona fide and without notice or knowledge of any previous and better title thereto, is not guilty of a conversion of the goods as against the true owner. See as to this case Sanders v. Iuclean, 11 Q. B. D. 327 .

(s) A bill of lading omitting these
Bill of lading what. 
to the order or assigns of the consignor, or to order or assigns merely; and, according to the form of the instrument, it usually passes either by delivery or by indorsement and delivery.

At common law, however, a bill of lading transferred merely the property in the goods to which it related, but vested no right of action upon the instrument itself in the assignee $(t)$; who might, however, have sued for the goods, relying upon his documentary title to support the action $(u)$; the action being founded, not upon contract, but upon property and the right to possession of the goods claimed, and offering no similarity to an action ex contractu, directly founded upon a negotiable instrument $(x)$. The bill of lading only represents the goods; and the transfer of the symbol did not, prior to the stat. $18 \& 19$ Vict. c. 111 , operate more than a transfer of what it represented $(y)$.

The leading case on this subject is the celebrated case of Lickbarrou v. Mason (z), since which the law has been considered to be, that the bont fide transferee for value of a bill of lading, indorsed by the shipper or his consignee, and put into circulation by the authority of the shipper

words would not, it seems, be a nego. tiable instrument : Henderson r. Comp. toiv d'Escompte de Paris, L. R. j P. C. C. 253,260 .

(t) Thompson v. Dominy, 14 M. \& W. 403 ; Howard r. Shepherd, 9 C. B. 297 ; Sanders v. I'anzeller, 4 Q. B. 260 (recognised in Zuilchenbart $\mathrm{v}$. Henderson, 9 Exch. 728 ; and in temp v. Clark, 12 Q. B. 653); Evans v. Marlett, 1 Ld. Raym. 2 il ; judgm., Tindall v. Taylor, 24 L. J. Q. B. 12, $17 ; 4$ E. \& B. $219,22 i, 229$.

(u) Lickbarrow v. Mason, ubi supra. (x) Wilmhurst v. Bouker, 7 MI. \& Gr. 882 ; Turner v. Trustees of Liver. pool Docks, 6 Exch. 543; Shepherd $\mathrm{r}$. Harrison, I. R. 4 Q. B. 196 ; Key v. Cotesucorth, 7 Exch. 595 : Pennell v. Alexander, 3 E. \& B. 283; Wait v. Baker, 2 Exch. 1; Ian Casteel $v$.
Booker. Id. 691 ; Browne r. Hare, H. \& N. $822 ; s . C ., 3$ H. \& N. $4 \$ 4$ may be referred to as showing the effec of the indorsement of a bill of lading upon the title to and jus disponend over goods. See also per Cotton, L. J. Mirabita พ. Imperial Ottoman Bank 3.Ex. D. 172.

(y) Per Lord Campbell, C. J., Gur ney v. Bchrend, 3 E. \& B. 633, 634. Ct. per Lord Loughborough, in Lickbarrou v. Mason, ubi supra.

(z) Ubi supra ; Pease r. Gloahe L.R. 1 P.C. 227 ; Barber v. Meyerstein L. R. 4 H. L. $317,326,333$; Shes herd r. Harrison, 5 Id. 116; Stee app., State Line Stcamship Co., resp. 3 App. Cas. 72 ; Kendal r. Marshal 11 Q. B. D. 356; Ex parte, Miles I Isaucs, 15 Id. 39,47 . 
or consignee, has an absolute title to the goods, freed from the equitable right of the unpaid vendor to stop in transitu as against the purchaser (a). "Stoppage in transitu (b) can only take place where there is a rendor, a vendee, and a middleman, such as a carrier. If the goods come into the actual or constructive possession of the rendee, the vendor's right" to stop them in transitu is gone $(c)$. An unpaid vendor, therefore, may as against his vendee stop the goods at any time during the transit before they have come into the possession, actual or constructive, of the rendee: but if the vendee has assigned the goods by means of the bill of lading, for value to an innocent third party, such third party will have a claim to the goods, which the unpaid vendor cannot defeat, although as against the rendee he might have stopped the goods in transitu $(d)$.

The law, however, in regard to bills of lading, was naterially altered by the 18 \& 19 Vict. c. 111 , s. 1 whereof which alone can here be noticed) enacts that, "Every onsignee of goods named in a bill of lading, and every ndorsee of a bill of lading to whom the property in the ;oods therein mentioned shall pass, upon or by reason of uch consignment or indorsement, shall have transferred 0 and vested in him all rights of suit, and be subject to he same liabilities in respect of such goods as if the ontract contained in the bill of lading had been made with imself." Under this Act (e) the rights and liabilities of

(a) Judgm., 3 E. \& B. 637; Leask Scott, 2 Q. B. D. 376 ; cf. s. 10 of - Factors Act, 1889, 52 \& 53 Tict. 45 , which applies to "documents of le" as defined by s. 1, subs. 4 , the mmon law, as above stated, applicle to bills of lading. See also Sale Goods Act, 1893, 56 \& 57 Vict. $71,8.47$, reproducing and developing 10 of the Factors Act, 1889, and almers on the Sale of Goods Act, 93, 2nd ed., pp. 86, 87, and 1491-51. to bills of lading generally, ef.
Scrutton on Charterparties and Bills of Lading.

(b) See ante, p. 436.

(c) Per Martin, B., Cooper $\mathbf{}$. Bill, 3 H. \& C. 727.

(d) As to when the right to stop in transitu ceases, see Re Westzinthus, 5 B. \& Ad. 817 ; Spalding v. Ruding, 6 Bear. 376; Kemp v. Falk, 7 App. Cas. 573. See ante, p. 437 .

(e) See Short v. Simpson, L. R. 1 C. P. 248 ; Dracachi v. Anglo-Egyptian Sav. Co., L. R. 3 C. P. 190 ; 
Railway scrip.

the consignee or indorsee of the bill of lading pass from him by indorsement over to a third party $(f)$.

3. It might, perhaps, at first sight, be supposed that an ordinary scrip certificate $(g)$ of a projected railway company, which passes from hand to hand on the Stock Exchange, offers an instance, quite unexceptional, of the assignment of a chose in action; but on examination we shall find that this is not so, and that the purchase of scrip is, in truth, the purchase of a right to stand in the place of the original allottee, quoad his interest in the concern (h). So that an action for recovery of the deposit money originally paid must be brought in the name of the allottee-not in that of the purchaser of the scrip.

Lewis v. Mchce, L. R. 4 Ex. 58 ; 2 Ex. 37; Burdick v. Sercell, 10 Q. B. D. $363 ; 13$ Id. $159 ; 10$ App. Cas. 74 .

(f) Smurthwaite v. Wilkins, 11 C. B., N. S., 842. See Fox r. Nott, 6 H. \& N. 630.

(g) A share is a certain amount of interest in a particular company. A scrip certificate is evidence merely of the right to obtain shares. See Waterford, \&.c., R. C. v. Pidcock, 8 Exch. 279, 283, 284; Jackson v. Cocker, 4
Beav. 59.

As to scrip issued to subscribers for a loan to a foreign government, ante, p. 445 .

(h) See Gerhard r. Bates, 2 E. \& B. 476; Jackson v. Cocker, supra ; per Maule, J., Tempest $\mathbf{v}$. Kilner, 2 C. B. 308 ; Wilkinson v. Anglo-Californian Gold Mining Co., 18 Q. B. 728.

Various instruments, other than those mentioned in the text, are negotiable. 


\section{CHAPTER V.}

\section{LANDLORD AND TENANT.}

Interests in land are of various kinds. Estates for life, or in fee simple, are examples of those which are termed freehold, the consideration of which does not come within the scope of this work. Lesser interests in land than life estates are called chattel interests, and it is to the consideration of such interests that this chapter is confined.

The relation of landlord and tenant arises where one person called the lessor or landlord conveys his lands or tenements, usually in consideration of rent or other annual recompense, to another who is called the lessee or tenant, for years or at will, but always for a less time than the lessor has in the premises.

A conveyance of the landlord's whole interest is an rssignment and not a lease.

Thus in a case where one who held for a term which expired on 11th November, let the premises verbally from l1th September to that day, for a certain rent which ras payable immediately, it was held that this was a lemise of the whole term and not a mere letting $(a)$.

A lease is a contract for the exclusive possession of land wr tenements for some definite number of years or other leterminate period $(b)$.

Tenancies may be divided into four classes. Thus a

(a) Preece v. Corrie, 5 Bing. 24;

M. \& P. 57 .

(b) Reg. v. Morrish, 32 L. J. I. C. 245 . 
tenant may hold as (1) a tenant or lessee for a term of years ; (2) a tenant from year to year ; (3) a tenant at will; (4) or a tenant by sufferance.

Demise for a ternn of years.

Tenancy from year to year.

A tenancy or demise for a term of years has been thus defined by Littleton:- "Tenant for term of years is where a man letteth lands or tenements to another for term of certain years, after the number of years that is accorded betreen the lessor and lessee, and the lessee entereth by force of the lease, then is he tenant for years" (c). It is important to notice here that the term must be certain, otherwise there would only be a tenancy at will $(d)$; the lessee must have entered thereon by force of the lease, else the term of years is not created, but the lessee has only an interest in the term, and is not possessed of it. This interest is called an "interesse termini" $(e)$ and is alienable $(f)$.

Such an estate as one for years, is frequently called a "term" or terminus, because its duration is bounded or limited, it must have a certain beginning as well as a certain end $(g)$.

A tenancy from year to year exists where both landlord and tenant are entitled to notice before the tenancy can be determined by either of them. By the common law, such notice must be given at least a half-year before the expiration of the current year of the tenancy, so that the tenancy may expire at that period of the year at uhich it commenced $(h)$.

A tenancy from year to year is more than a mere letting for one year, and then, if not terminated by due notice, a further letting for the next year. In the case of Gandy r. Jubber (i), this tenancy is thus described by seven

(c) S. 58 of Littleton's Tenures.

(d) Co. Litt. 45 b, 54 b.

(e) Com. Dig., Estates by grant, G. 14; also 1 Wms. Saun. 250 f. (1); Harrison r. Blackbuss, 17 C.B., X. S., 678.

(f) Co. Litt. 46 b, 47 b a : Doed.
Raulings r. Walker, 5 B. \& C. 118.

(g) Co. Litt. 45 b.

(h) Doe d. Martin r. Watts, IT.R.

85: 4 R. R. 38 : Clayton r. Blakey, 8 T. R. $3 ; 4$ R. K. 575 .

(i) 9 B. \& S. $1 \mathrm{~s}$. 
Judges:- "We think it is a lease for two years (sic) certain, and that every year after it is a springing interest arising upon the first contract and parcel of it, so that if the lessee occupies for a number of years, these years by computation from the time past, make an entire lease for so many years, and that after the commencement of each new year, it becomes an entire lease sertain for the year past and also for the year so entered on, and that it is not a reletting at the commencement of the hird (sic) and subsequent years." The Judges here must have been thinking of a contract "for one year, and so on rom year to year," otherwise the tenancy could have been letermined at the end of the first year, the half-year's rotice having been previously given. This is laid down by jord Denman in the case of Doe d. Clarke v. Smaridge (k). 'Now a tenancy from year to year lasts only so long as both arties please; that is, it is determinable by either party at he end of any year, by giving notice to quit half a year efore the end of the year. There is no reason why it hould not be so determined by either party at the end of re first year; as well as at the end of any subsequent year, nless the parties have by express contract prevented such etermination. . . . It would be absurd in principle, nd even inconsistent with the contract, to hold that the nancy exists from year to year, determinable by half a zar's notice by either party, and yet to hold that neither in give such notice during the first year."

The same principle is laid down by Page-Wood, V.-C. in attley v. Arnold $(l)$. Speaking of tenancies from year to ar, he says:- "The moment any new year begins, the nant has a right to hold to the end of that year; and ere must be a half-year's notice to quit before the end of at term, per Buller, J., in Right v. Darly $(m)$. And in

k) 7 Q. B. 958 ; 14 L. J. Q. B. 327.

(m) 1 Term Rep. 163.

b) 1 J.\& H.p. 651 . 
Doe d. Rigge v. Bell (n) Lord Kenyon, C. J., applied the same principle to the end of a demise by parol. holding that the agreement being that the tenant shouid quit at Candlemas, if the lessee chose to determine the tenancy before the expiration of the seven years, he could only put an end to it at Candlemas."

These judgments illustrate the distinctive features of a tenancy from year to year, and are here noticed from their importance. The length of notice required by statute in certain cases will be dealt with further on, when the subject of determination of tenancies will be considered. A tenancy from year to year is not created by a demise for one year only; as the lease is to end on a precise day, there is no occasion for a notice to quit previously to bringing an action $(o)$.

Tenancy at will.

A tenancy at will is thus described by Littleton:- " Tenant at will is where lands or tenements are let by one man to another to have and to hold to him at the will of the lessor, by force of which lease the lessee is in possession. In this case the lessee is called tenant at will, because he hath no sure or certain estate, for the lessor may put him out a what time it pleaseth him " $(p)$. Where the tenancy is determinable at the will of one party, the law implies it is at that of the other also.

"It is regularly true that every lease at will must in lar be at the will of both parties, and therefore, when the lease is made to have and to hold at the will of the lessor, the lar implieth it to be at the will of the lessee also" $(q)$.

The distinctive feature of this tenancy is the fact of it being determinable at the will of either party. Thi determination may take place either by express intimation or on the commission of any act which is inconsistent witl

(n) 5 Term Rep. 471.

(o) Cobb v. Stokes, $\delta$ East, 358 ;

9 R. R. 464; also Messenger r. Arm-

strong, 1 T. R. 54; 1 R. R. 148:
Right d. Flover r. Darby, 1 T. F 162 ; I R. R. 169.

(p) S. 68.

(q) Co. Litt. 55 a. 
he existence of the tenancy $\left(r^{\circ}\right)$ as soon as the notice hereof reaches the other party $(s)$.

A tenant at sufferance is one who remains in possession Tenant at If the premises without the assent or dissent of the person mtitled thereto. This tenancy is a mere legal fiction, and annot be created by act of parties, for the consent of the andlord would convert it into a tenancy at will, or one rom year to year.

Before discussing the various ways in which the Capacity of elationship of landlord and tenant may be created, it ould be well to consider who may be lessors and issees. Generally, every person having any estate in unds or tenements, may grant leases of them for terms ad on conditions not in excess of or inconsistent with reir own estate therein. As a general rule, any leases anted for terms beyond the lessor's interest will deterine on the determination of that interest. Thus a demise $\checkmark$ a tenant from year to year to another, also to hold om year to year, is in legal operation a demise from ar to year during the continuance of the original demise the intermediate landlord, although at the time of aking the contract no such qualification is mentioned $(t)$. One class of persons must be here considered, namely, ose who are under disabilities arising from their status, ch as infants, married women, lumatics, and convicts. ley are not really exceptions to the above general rule, it inasmuch as the conditions under which they hold (3ir own estates are modified by the existence of certain gabilities, so their powers of leasing are similarly rected. The disabilities under which they labour will treated of in Chapter VII., and it only remains to

-) Co. Litt. 5̄5 b; Tumer v. Doe 1 iennett, 9 M. \& WT. 646.

Doe d. Davies v. Thomas, $6 \mathrm{Ex}$. 857 ; 20 L. J. Ex. 367 ; Pinhorn 3.C.L. v. Souster, 8 Exch. $763 ; 22$ L. J. Ex. 266.

( $t$ ) Pilie v. Eyre, 9 B. \& C. 909 : 4 M. \& R. 661. 
notice their position as regards leasing or taking leases of land or tenements.

Infants. The question about which there has been some doub is, as to whether a lease by an infant was roid or merely voidable, but the generally received view now is that the are only voidable $(u)$. Where such a custom exists, infant may make binding leases at the age of fifteen years $(x)$

Under the Supreme Court of Judicature Act, $1873(y)$ the Chancery Division of the High Court of Justic exercises the powers formerly exercised by the Court o Chancery, of granting power to infants in certain case to make leases where such were for the benefit of th estate $(z)$. All powers of leasing given by the Settle Estates Act, 1877 (a), may be exercised, under th supervision of the Court, by the guardian of the infant

The powers of leasing given to tenants for life an limited owners generally, under the Settled Land Ac 1882, extend to infants (b).

The general rule as to contracts applies to the liabilit for rent of an infant lessee. On attaining his majority the infant may be freed from liability for rent, by dis agreeing with the lease $(c)$, otherwise he will becon liable $(d)$. If the infant be lessee of lodgings, the rule respecting infants' contracts for necessaries will apply.

A married woman alone cannot make a lease (e), unle

(u) 1 Platton Leases; see particularly Zouch d. Abbot r. Parson, 3 Burr. 1806; Ketsey's case, Cro. Jac. 320: also Williams v. Moor, 11 M. \& W. 256; Ashfield v. Ashfield, Sir W. Jo. 157: The Newry \& Emniskillen Railicay Co. v. Cocmbe, 3 Exch. 565 : North-Western Railuay Co.v. Me.Michael, 5 Exch. 114 ; Doe v. Roberts, 16 M. \& W. 781.

(x) Co. Litt. $45 \mathrm{~b}$.

(y) 36 \& 37 Yict. c. 66, s. 34.

(z) 11 Geo. 4 \& 1 Wm. 4, c. 65, ss. 16, 17; Letehford, In $r, 2 \mathrm{Ch}$. Div. 719: 45 L. J. Ch. 530; Spenser's Estatcs, In re, 37 L. J. Ch. 18. (a) $40 \& 41$ Vict. c. 18 , ss. $46-t$ See also $44 \& 45$ Yict. c. 41 , s. 41.

(b) $45 \& 46$ Vict. c. 38, s. 59.

(c) Ketsey's case, Cro. Jac. 3? Louce v. Griffith, 1 Scott, 458.

(d) Holmes v. J3logg, 8 Taunt. 35 ;

R. R. 445 (see this case distinguish

IFamilton v. T'aughan-Sherrin Electri Co. (1894) 3 Ch.589); Kirton r. Flic 2 Bulst. 69: Neury \& Emiskillen ke uay Co. v. Coombe, 3 Exch. 565; Nor Westem Raileay Co. v. Me.Michael Exch. 14.

(e) Goodright v. Straphan, Coy 201 ; Sugden on Powers, Ch. 4, s. 
n pursuance of the Married Women's Property Acts $(f)$, rhere leasing powers are given to her under the proisions of a settlement, or she be living apart from her usband under a deed of separation $(g)$. With the conent of her husband, she may make leases in accordance ith the provisions of the Settled Estates Act, 1877. he leasing powers conferred by the Settled Land Act, s82 (h), on limited owners generally, extend to married omen tenants for life. They may exercise these powers ithout their husbands (i).

The general rules applying to married romen as to intracts they enter into apply also to them in relation to ases.

Besides the rules prevailing as to contracts made by Lunatics. natics, their powers of granting leases are regulated by atute. The Judge in Lunacy $(k)$ may, by order, authorise e committee of the lunatic to grant certain leases under e Lunacy Act, $1890(l)$. The Chancery Division of the igh Court may, under the Settled Estates Act, 1877 (m), thorise certain leases by the committee. The porrers ren by the Settled Land Act, 1882, to tenants for life, end to the committee of a lunatic tenant for life $(n)$. A latic may also be a lessee if the lease be for his benefit $(o)$. e committee of a lunatic may renew leases and surrender d. ones under the direction of the Judge in Lunacy ( $p)$. Jonvicts sentenced to death or penal servitude whose Convicts. sitence is unexpired cannot, without leave or unless -doned, grant leases $(q)$.

The power of owners of property to grant leases not ex-

$33 \& 34$ Vict. c. $93 ; 45 \& 46$ c. 75 .

20 s 21 Vict. c. 85, ss. 21 and 25. 45 \& 46 Vict. c. 38 .

Re Bentley, Wade v. Wilson, 54 - Ch. $782 ; 33$ W. R. 610.

Defined by s. 108, subs. 1 of the (l) 53 Vict. c. 5, ss. 120, 121, 122.

(in) 40 st 41 Vict. c. 18 .

(x) 45 s 46 Vict. c. $38,8.62$.

(o) Co. Litt. 2 b; Broune v. Joddrell, 3 C. \& I'. 30; M. \& M. 105 ; Dane v. Firkuall, S C. A 1'.679.

(p) See (l) supra.

(q) 33 .t 34 Vict. c. 23, ss. 7, 8, 30. 
Corporations.

The Crown.

Tenants for life.

ceeding their own interest therein, has been in some case curtailed and in others extended by statute. The former i the case with corporations, civil and ecclesiastical, thcromn and government departments. Extended powers o leasing have been given to tenants for life and other limite orrners, mortgagors and mortgagees.

The leasing powers of civil corporations, municipal an others, are regulated by their respective acts, public an private, and also by the Municipal Corporations Ac $1882(r)$. The rules prevailing as to contracts made b corporate bodies apply to leases $(s)$.

The universities of Oxford, Cambridge and Durham, an the colleges of Winchester and Eton, are empowered grant leases generally for 21 years, building leases for years, and mining leases for 60 years $(t)$.

From time to time a large number of statutes have bee passed limiting the common law powers of ecclesiastic corporations, sole and aggregate. Their leasing powe were expressly given and are now regulated by the Eccles astical Leasing Acts (u).

Corporations and trustees for charitable uses may lessees so long as the leases are in accordance with the $\mathrm{pr}$ visions of the Mortmain and Charitable Uses Act, $188 S(x$

The leasing powers of the Crown as to Crown lands a confined to the granting of leases for 31 years and thr lives, and building leases for 50 years or three lives $(y)$.

By the common law rule tenants for life could only gref leases limited by their own estates, which leases wor consequently determine on the death of the lessors.

(r) 45 \& 46 Vict. c. 50, s. 105 (as amended by 51 ( 52 Vict. c. 41, s. 72). See also 53 i 54 Vict. c. 70 , s. 74 , power to body corporate to lease for workmen's dwellings.

(8) Finleny r. Bristol and Exeter Railucay Co., 21 L. J. Ex. 117; see also 1 Kyd, Curp. 234-T; Simith r. Barrett, Sid. 161. (t) 21 \& 22 Vict. c. $44: 23 \mathrm{~d}$

Vict. c. $59 ; \operatorname{Rex}$ r. Cambridgd

Burr. 1656.

(u) 5 \& 6 Vict. c. $108 ; 21$ !

Vict. c. i\%.

(x) 51 it 52 Vict. c. 42.

(y) 1 Anne Stat. c. 1, s. $7 ; 10$ 4 , c. $50 ; 25$. 26 Vict. c. 37 . 
Now tenants for life, and, (under the Settled Land Act, L882 (z), limited owners generally,) may, under the Settled istates Act, 1877, and Settled Land Act, 1882 (a), grant, rith certain exceptions, leases generally for 21 years, buildng leases for 99 years, and mining leases for 60 years.

The Conveyancing Act, $1881(b)$, conferred on the mortagor or mortgagee in possession power to grant agricultural Mortigagors and mort$r$ occupation leases for 21 years and building leases for 9 years, on certain conditions therein enumerated. In ases where that Act does not talie effect by reason of the aortgage deed being prior to 1 Jan., 1882, or where the Act s excluded by express agreement, the mortgagor cannot, nless so empowered by the mortgage deed, grant a lease hich will be valid against the mortgagee $(c)$.

There is another exception to the common law rule that re tenant's interest determines with that of the landlord, Where the lease or tenancy of any farm or lands held by tenant at a rack-rent" (i.e., full rent obtainable in the larket) "shall determine by the death or cessor of the ;tate of any landlord entitled for his life, or for any other acertain interest, instead of claims to emblements, the nant shall continue to hold and occupy such farm or lands itil the expiration of the then current year of his tenancy, Id shall then quit upon the terms of his lease or holding, the same manner as if such lease or tenancy were then stermined by effluxion of time or other lawful means uring the continuance of the landlord's estate" $(d)$.

The next branch of the subject is the consideration of the rious modes in which the relationship of landlord and How tenancies arise. ant may be created.

z) 45 \& 46 Vict. c. 38 , ss. $58-62$.

a) 40 \& 41 Vict. c. $18 ; 45$ \& 46 t. e. 38 , ss. $6-14$. See also 52 \& Vict. c. $36 ; 53$ \& 54 Tict. c. 69 , $7-10$.

b) $44 \& 4.5$ Vict. c. 41.

) Thunder v. Belcher, 3 East, 449 .
See also as to agricultural holdinos the Tenants' Compensation Act, 1890, 53 \& 54 Vict. c. 57.

(d) It \& 15 Vict. c. 25. s. 1 ("The Landlord and 'Tenant Act, 18.5 1," so called by virtue of the Short Titles Act, 1892 ). 
Term of years, how created.

In considering the creation of a tenancy of a term of years it must be noted that most leases must be by deed. At common law writing was not necessary to the creation of a term of years, but by the Statute of Frauds "all leases, estates, interests of freehold, or terms of years, or any un. certain interest of, in, to, or out of any messuages, manors. lands, tenements, or hereditaments, made or created by livery and seisin only, or by parol, and not put in writing and signed by the parties so making or creating the same or their agents thereunto lawfully authorised by writing shall have the force and effect of leases or estates at wil only" (e).

To this there are exceptions,- " "all leases not exceedin the term of three years from the making thereof, whereupor the rent reserved to the landlord during such term shal amount unto two third parts, at the least, of the ful improved value of the thing demised" $(f)$.

The general necessity of a lease being in writing arise from the Statute of Frauds; but by the Real Propert (Amendment Act $(g)$, "a lease required by law to be it $\{$ writing, of any tenements or hereditaments made after 1 s of October, 1845, shall be void unless made by deed."

Now by the 7th section of the Settled Land Act, 1882, a leases made by limited owners under that $A$ ct must be $b$ deed $(h)$. This provision is more extensive than the Rea Property Amendment Act, and applies to leases for a periods however short, whether they come under th provisions of the Statute of Frauds or not.

Leases which do not fulfil the conditions imposed by t1 Statute of Frauds and the Real Property Amendment Ac will be construed as agreements (i).

(e) 29 Car. II. c. 3 , s. 1 .

(f) 29 Car. II. c. 3 , s. 2.

(a) 8 \& 9 Vict. c. 106, s. 3.

(h) $45 \& 46$ Vict. c. 38 , s. $i$.

(i) Drury v. Macnamara, ã E. \& B.
612; Bond r. Rosling, 1 B. S. S. 37 Rollason v. Leon, 7 II. $\mathcal{\&}$ s. is Parker s. Tasuell, 27 L. J. Ch. 8 l' 2 De G. \& J. 559 ; Tidey r. Moll 16 C. B., X. S., 298. 
A term of years may arise from the application of the doctrine of estoppel (ante, pp. 276-284) to contracts conserning land. Thus, if one having no interest therein, lemise premises for a term of years, and subsequently ıcquire an estate in them, then the lease takes effect, the essor being estopped from denying its validity $(k)$.

A tenancy for a fixed term less than one year, is classed rith tenancies for terms of years $(l)$.

It is not within the scope of this chapter to enter into he details of a lease, the usual covenants, when they re implied by law, \&c., which belong rather to Peal 'roperty Law $(m)$. They will, however, be noticed where ney bear on the rights and duties of landlord and tenant.

A tenancy from year to year was originally a dereloprent of a tenancy at will, by which the tenancy at will as determinable only at that period of the year at which it ommenced, and on reasonable notice. This was ultimately scided to be half a year. Thus a tenancy from year to anr may arise out of a simple letting. Thus simple perission to occupy land, creates but a tenancy at will, unless lere are circumstances to show an intention to create a nancy from year to year, as, for instance, an agreement pay rent by the quarter, or other aliquot part of a ar $(n)$ : but a tenancy from year to year will not be ferred from a simple payment made by the occupier. It may also arise by implication of law, as when a lessee lds over after the expiration of his lease, and pays rent his landlord, a tenancy from year to year is inferred cording to his former holding $(o)$; and it may shortly be

h) Co. Litt. 47 b; Bac. Abr. ises (0.); 2 Wnis. Saund. 830 ; rivan v. Lawrance, 1 Salk. 276; fl r. Saunders, 4 B. \& C. 529; fley v. Bradley, 5 C. B. 396 ; Webb 1ustin, 7 M. \& Gr. 701 ; Śtwrgeon VIringfield, 15 M. \& W. 224.

7) 2 Bl. Com. 140; Litt. s. 57 : 1. Abr. Lenses (I. 3). (m) The reader is referred to Williams' Treatise on Real Property,Goodere's and sinilar works.

(n) Doe v. Wood, 14 M. \& W. 682; Richardson r. Langridge, 4 Taunt. 128 ; 13 R. R. 570; Hunt v. Allgood, 10 C. B., X. S., 253.

(o) Kelly v. Patterson, L. R. 9 C. .'. $681 ; 43$ L. J. C. P. 320 ; 30 L. T. 342.
Tenancy

from year to year, how created. 
stated that where rent as from year to year is received from, or admitted to be due by, a person in possession of premises, without explanation or stipulation, the holding to be presumed is as of a tenancy from year to year, according to the holding of the tenant, and therefore commencing at a time corresponding to that from which he originally entered or held $(x)$.

Thus in Digly v. Atlinson ( $q$ ), the lease which had expired contained a covenant to repair, the tenant verbally agreed to hold over paying an additional rent, and nothing was expressed as to the terms of the new tenancy, the tenant was presumed to hold under the covenants of the former lease, and was held liable to rebuild the premises when destroyed by fire.

At common law, a tenant entering under an agreemen (c) for a lease, on paying rent or admitting it due, became a tenant from year to year. Since the Judicature Acts, this result does not follow in those cases in which the Court wil decree specific performance, but the tenant is in the sam position as if the lease had been granted to him $(r)$.

In all cases there must, unless rent be paid, be cir cumstances which prove the existence of a tenancy a distinguished from a mere licence to occupy $(s)$. A tenanc. from year to year may be created by agreement; as whes the parties agree that "the tenancy shall be from year t. (d) year," and such tenancy is determinable at the end 0 the first year $(t)$; but if the agreement is "for one year or for one year certain and so on from year to year," suc:

(p) Berrey r. Lindley, 3 M. \& G. 498 ; and see judgment in Felly $\mathrm{r}$. P'attersom, L. R. 9 C. I'. Gsi.

(q) 4 Camp. 275.

(v) Malsh $v$. Lonsdale, $21 \mathrm{Ch} . \mathrm{D}$. 9 ; 52 L. J. Ch. 2; 46 L. T. S58; Contsecorth $r$ Jolinson, 5i) L. J. Q. 13. 220 ; 54 J.'T. 520 ; Allhusen r. Brooking, 26 Ch. D. 559 ; 53 L. J.
Ch. 520; 51 I. T. 57; Losther Heaver, 41 Ch. D. 24 . Cf. al Foster' v. Reces, (1892) 2 Q. B. 25 cited at p. 68 , ante. $7+9$.

(s) Doe v. Pullen, 2 Bing. N.

(t) Doe d. Plumer r. Mainby, Q. B. 473. 
tenancy is not determinable until the end of the second year (u).

A lease from year to year may be made by parol, if the rent reserved be two-thirds at least of the full improved value $(x)$.

The relation of landlord and tenant may also be created by an "attornment" clause in a mortgage deed, whereby the mortgagor " "attorns" to or becomes tenant of the mortgagee. The tenancy thus created may be merely a tenancy at will, or one from year to year, determinable as the parties may agree. Lord Justice Cotton in a recent case said, "We are asked to say that the tenancy, stated in this attornment clause to be a yearly tenancy, was in fact a tenancy at will. The ground on which we are asked ;o say this, is, that power was given to the mortgagee to letermine the relation of landlord and tenant. But I know if no law or principle to prevent two persons agreeing that - yearly tenancy may be determined on whatever notice hey like. There is freedom of contract in this respect " $(y)$. "It was said that upon the terms of the deed it was mere tenancy at will. . . . You can only gather the ntention of the parties from the words they use, and here hey have not made it a tenancy at will. It is a tenancy :om month to month-a monthly tenancy. It may be put $n$ end to, no doubt, by the mortgagees if they think fit, but is not a tenancy at will " $(z)$.

A tenancy at will may be created by agreement express, s, "I give you a close to enjoy as long as I please, and Tenancy at will, how createrl. , take again when I please, and you shall pay nothing for " (a); or implied, as, where a person lives in a house,

(u) Doe d. Chadborn r. Green, 9 A. E. 65̆9: Thampson r. Maberley, 2 inip. 572 (questioned, Gardner v. gram, 61 L. J. N. S. 729 ).

(x) 29 Car. II., c. 3 , s. 2.

(y) Re Threlfall, Exx parte Queen's
Benefit Building Society, 16 Ch. D. 274 at p. $281 ; 50$ L. J. Ch. 318.

(z) Ex paite Ioisey, In re hinight, 21 Ch. D. 442 , per Jessel, M. R., on p. 457 ; 52 L. J. Ch. 121.

(a) Rex v. Fillongley, 1 T. R. 458 
rent free, by sufferance of the owner (b). It may also arise by implication of law, where there is no foundation for

(c) inferring a tenancy from year to year, as entry under a roid lease without any payment of or agreement as to rent $(c)$. An agreement to let premises as long as both parties like, the rent not being referable to an aliquot part of a year, creates only a tenancy at will $(d)$. A good example of a tenant at will, is the minister of a dissenting congregation placed in possession of a chapel and dwelling-house by trustees in whom the property is rested $(e)$. This tenancy

(8) may also be created by the operation of the Statute of Frauds (ante, p. 518) ( $f$ ).

Rights and duties of the parties.

Having examined the chief points connected with the creation of a tenancy, the next branch of the subject is the consideration of the rights and duties of landlord and tenant respectively.

Quiet enjoy- The first is the covenant for quiet enjoyment. That is,
ment. that the landlord not only agrees to let the tenant occupy the premises on certain conditions, but he also undertakes that the tenant shall quietly enjoy them, and shall not be disturbed by himself nor by anyone claiming under him, or paramount to him. This corenant is implied by law in every demise $(g)$.

In deeds the word "demise" had the effect of creating this covenant $(h)$, in a parol demise the law will imply an agreement for quiet enjoyment, but not for good title (i). In the case of a contract for a demise of land a promise of

(b) Rex r. Collett, R. \& R. C. C. $498 ; \operatorname{Rex}$ v. Jobling, R. \& R. C. C. 525 .

(c) Doe d. Rigge r. Bell, 5 T. R. 471 ; 2 R. R. 642.

(d) Richardson r. Langridge, 4 Taunt. 128 ; 13 R. R. 570.

(e) Doe d. Nichall v. IIcKeag, 10 B. \& C. 721 ; Doe d. Joncs v. Jones, 10 B. \& C. ils.

(f) 29 Car. II. c. 2, s. 2. (g) Spencer's case, 5 Rep. 17 a Bac. Abr. tit. Cotenant (B): Mostyn v. West Mostym Conl and Iron Co. 1 C. I. D. $145 ; 45$ L. J. C. P. 401 .

(h) Adams v. Gibney, 6 Bing. 666 Iggulden v. May, 9 Ves. $330 ;-7$ East. 237; 3 Smith, 269 ; 2 N. R. 449; R. R. 623 ; and see 9 R. R. $104 \mathrm{n}$.

(i) Bandy v. Cartucright, 8 Excl 913 ; 22 L. J. Exch. 285 . 
quiet enjoyment during the term is implied $(k)$. The effect of this implied covenant for quiet enjoyment may be nullified by an express covenant to limit it to the acts of the lessor and those claiming under him $(l)$.

A covenant that the lessee shall, while paying rent and performing his covenants quietly enjoy, \&c., is an absolute covenant for quiet enjoyment $(\mathrm{m})$. An action on this covenant may be maintained for the disturbance of a way of neces. sity $(n)$; or where the lessor uses his own quarry so as to cause water to percolate into the lessee's mine (o). A person who enters into an agreement to let premises which operates as a demise agrees impliedly to give possession of them $(p)$.

The common law rule only comes into operation in the ibsence of an express covenant. Thus where the lessor covesanted against eviction by himself and all persons claiming "by, from, or under him," it was held that there was no reach where the tenant was evicted by one whose title ras paramount to the lessor's $(q)$, or where an entry was nade upon the lessee and goods were seized by the colector of land tax for arrears due from the lessor before he demise. In this latter case Lord Demman, C. J., oints out that the claim was not by title from the essor, but against the lessor, and consequently the disurbance was not within the covenant $(r)$. When this ovenant has been broken the result is that the tenant ; relieved from the payment of rent during the continu-

(k) Hall r. City of London Brevery $0 ., 2$ B. \& S. 737 ; 31 L. J. Q. B. i7; 9 Jur. N. S. 18.

(l) Nokes' case, 4 Rep. 80 b; ine ז. Stephenson, 6 Scott, $447 ; 4$ ing. N. C. $678 ; S . C$. (in error), J ing. N. C. $183 ; 7$ Scott, 69 .

(m) Daueson V. Dyer, 2 ז. \& M. 9 ; j B. \& Ad. 584.

(18) Morris v. Edgington, 3 Taunt. ; 12 R. R. 579 .

(o) Shaw r. Stenton, 2 H. \& N.
8.58; 27 L. J. Ex. 253.

(p) Coe v. Chy ,5 Bing. 440; Jinhs v. Edwards, 11 Exch.775.

(q) Merrill v. Frame, 4 Taunt. 329; 13 R. R. 612.

(r) Stanley r. Hayes, 3 Q. B. 105. Seealso Kelly r. Rogers, (1892) 1 Q. B. 910 , C. A., where the owners of the reversion upon a lease having recoveret possession of the premises, it was hell that the covenant for quiet enjoyment in the under-lease was not thereby broken. 
ance of such breach, but is not released from the performance of any other covenant $(s)$.

Now under the Conveyancing Act, 1881, a covenant for quiet enjoyment will be implied with the person to whom a conveyance is made by the person conveying, if expressed to convey as beneficial ouner in a conreyance for value (other than a mortgage or in consideration of marriage), if freehold or leasehold $(t)$.

This covenant for quiet enjoyment gives rise to a right of the tenant to deduct certain moneys from his rent when due $(u)$. "A tenant who has been compelled by a superior landlord or other incumbrancer, having a title paramount to that of his immediate landlord, to pay sums due for ground rent or other like charges, may treat such payment as having been made in satisfaction or in part satisfaction of rent due to his immediate landlord, and may plead them as far as they extend, in bar to an avowry for rent in arrear. The principle is this:-The immediate landlord is bound to protect his tenant from all paramount claims; and when, therefore, the tenant is compelled, in order to protect himself in the enjoyment of the land in respect of which his rent is payable, to make payments which ought, as betreen himself and his landlord, to have been made by the latter, he is considered as having been authorised by the landlord so to apply his rent due or accruing due" $(x)$. The same view is clearly expressed by Chief Baron Pollock in Jones v. Morris: "The compulsory payment by the tenant of ground-rent, or other like charge, is in truth a partial eviction: and the landlord is presumed to authorise the payment by the tenant of his rent to those

(s) Morrison v. Chaduick, T C. B. 283: Jiveton v. Allin, 1 (2. B. 518 .

$(t) 4 t \leqslant 4$ Vict. c. 41 , s. 7 , subs. 1, (A.) and (B).

(ii) Sapsford v. Fletcher, 4 T. R. 5l1; Taylor r. Zamira, 6 Taunt $524: 16$ R. R. $66 \mathrm{~s}$; Carter v. Carter 5) Bing. 406.

$(x)$ Judgm. of Rolfe, B., in Grahar r. Illsopp, 3 Exch. on p. 198. 
who have a claim on the land paramount to his own, and against which (as being a partial eviction), he is bound to protect the party holding under him. If at the time of the demise, it had been expressly stipulated that the tenant might so apply his rent, no question could arise; and even though no such stipulation has been made in express terms, yet the law considers it as implied in every contract of demise" $(y)$. Similarly, a payment of rent by a lodger tenant whose goods are distrained by the superior landlord to the latter is, by the Lodger's' Goods Protection Act, 1871, deemed a ralid payment of any rent due from him to his immediate landlord $(z)$.

The mere existence of the relation of landlord and Cultiration. tenant is a sufficient consideration to raise an implied promise on the part of the latter to manage a farm in a husbandlike manner, and so to cultivate it as to prevent deterioration, if not to improve the land $(a)$.

The questions which arise as to what is a proper mode of cultivation under any given circumstances must be answered by a reference to the usages of husbandry in the district in which the land is $(b)$. The "custom of the country" to be recognised by law must fulfil sertain conditions:- thus, the custom in question must be reasonable and certain (c), though not immemorial (d).

The custom will prevail in all tenancies unless there be axpress corenants to the contrary effect $(e)$. The custom If the country need not be excluded by express terms if the

(3) 3 Exch. p. 747. See also Exall . Partridge, 8 T. R. 308; 4 R.R. 656 ; rohnson v. Jones, 9 A. \& E. 809 ; Theeler v. Branseombe, 5 Q. B. 373.

(z) 34 \& 35 Vict. c. 79 , s. 3 , see iost, p. 552.

(a) Pouley r. Walker, 5 T. R. 373;

R. R. 619 ;- Onslow's case, 16 Ves.

73. Ante. p. 321.

(b) Co. Litt. $270 \mathrm{~b}$; Legh v. Hercitt,
4 East, 154; 7 R. R. 545 ; Fomersley จ. Dally, 26 L. J. Ex, 219.

(e) Tucher r. Linger, 8 App. Cas. 508: 52 L. J. Ch. 941 ; Bradburn r. Foley, 3 C.P. D. $129 ; 47$ L. J. C. P. $331 ;$ Tysan v. Smith, 9 A. \& E. 421. Ante,p. 12.

(d) Dalby v. Hirst, 1 B. \& B. 224; 21 R. R. 577.

(e) Wilkins v. Wood, 17 L. J. Q. B. 319 . 
stipulations in the demise are of such a nature as to be inconsistent with it, and are therefore taken to exclude it by implication. There are numerous decisions as to what. constitute such implied exclusions $(f)$.

As the tenant must cultivate in a husbandlike manner, so he must keep all ditches, fences, and boundaries in repair $(g)$.

Express covenants are usually inserted in leases to define the course of cultivation to be adopted by the tenant. On the interpretation of such covenants many cases arise, as the words "all mines and minerals" were held not to include flints, when it was the usage in the district that such belonged to the tenant $(h)$. In this case the express covenant did not contradict the usage of the district. Again, the words "he should not remove or sell during the last year" from the farm in question any hay, fodder, or manure, was held to include not only that which was produced during the last year, but also what was produced at any time during the term (i); clover sown with corm is still "tillage" $(k)$; an agreement to cultivate and manage " as had been done" by the previous tenant applies only to his mode of cultivation on quitting, and not to the terms of his lease $(l)$. A covenant to cultivate "according to the best rules of husbandry practised in the neighbourhood" in an agricultural lease of a farm near London, was held not to be broken by the conversion of a part of the demised premises into a market garden, it beingr proved at the trial

(f) Hutton r. Warren, 1 M. \& W. 466 ; Tebb r. Plummer, 2 B. \& Ald. 746;21 R. R. 479; Holding v. Pigott, 7 Bing. 465; Tucher v. Linger, 8 App. Cas. 508 ; 52 L. J. Ch. 941 ; Roberts r. Barker, 1 Cr. \& M. 808.

(1) Whitfield $\mathbf{v}$ Weedon, 2 Chitt. 685; Whitmore v. Humphries, L. R. 7 C. I'. 1: 41 I. J. C. 1'. 43; Chectham v. Hampson, 4 T. R. 318; 2 R. R. 397 ; -Attorney-General v. Fullerton, 2 Ves. \& B. $263 ; 13$ R. R. $76 ;$ Brotn .
Tales, L. R. 15 Eq. $1+2$; Drummond v. Sant, L. R. 6 Q. B. $763 ; 41$ I. J. Q. B. 21. See also Co. Litt. 41 b. $50 \mathrm{~s}$.

(h) Tucker v. Linger, 8 App. Cas.

(i) Gale r. Bates, 3 II. \& C. S4: 33 I. J. Ex. 235; 10 Jur. N. S. 731 ; 10 L. T. $304 ; 12$ W. R. 715.

(k) Birch v. Steplienson, 3 Taunt. 469:12 R. R. 679. 719 .

(l) Liebemrood v. Tines, 1 Mer. 15, 
that other farms in the neighbourhood had been converted into market gardens $(m)$.

On the determination of the tenancy the rights of the tenant to the fruits of his labour depend on the nature of the tenancy, and in some cases on the mode of its termination.

In the case of all tenancies determinable at an uncertain time, that is, at a period which does not depend on the will of the tenant ( $n)$, and upon which he cannot calculate, the cenant had at common law a right to "emblements" (o), hat is, to enter, take, and carry away $(p)$ the profits of his jwn labour on the land. The crops which may be thus laimed are those which were raised by the tenant's labour, uch as corn, turnips, carrots, hemp, flax, potatoes, and the ike, also hops $(q)$, and which are, in the ordinary course if husbandry, produced within the year $(r)$.

In the case of tenancies at a rack rent for this right to mblements is substituted by statute (ante, p. 517) the right f the tenant to continue in occupation till the end of the urrent year' $(s)$. In the case of those tenancies, the end of which can be ${ }_{\text {right. }}^{\text {Tenant }}$ alculated on by the tenant, instead of the right to emblerents, there are certain rights to the away-going crops, llage, \&c.

In the absence of any express agreement, or any stipulaons in a lease, inconsistent with the usage of the district which the land is situated as to the tenant's rights on itting, such usage prevails. Like the case of customs meerning cultivation, the usage of the district is enforced ong with the provisions of the lease $(t)$.
(in) Meux r. Cobley, (1892) $2 \mathrm{Ch}$. 3.
(q) Co. Litt. 55 b (n. l).
n) Co. Titt. $55 \mathrm{~b}$; Davis r. Eyton, 3ing. 154.
o) Shep. Touch. 244; Buluer 8 . lwer, 2 B. \& Ald. $470 ; 21$ R. R. 358 . p) Co. Litt. 56 a.
(r) Graves vo Trold, ij B. \& Ad. 105.
-(s) $14 \& 15$ Tiet. c. $25, \mathrm{~s} .1$
(t) Wigglesccorth r. Dallison, 1 Smith, L. C., p. 569, 9th ed., and cases there cited; Hutton r. Marren, 1 M. S TV. 466.

Tenant's letermina tion of tenancy. 
A distinction must be observed between customs regulating the cultiration of the holding and customs prevailing on quitting. The latter are enforced whether the former are inconsistent with the lease or opposed to it $(u)$.

The right of the tenant to outgoing crops is not dependent upon his covenants respecting cultivation during the term $(x)$, unless it is expressly made so $(y)$.

These rights only exist to the tenant when his tenancy terminates in its natural course; not if it ends in any other manner, such as by forfeiture $(z)$, disclaimer under the Bankruptcy Act, 1869 (a), by an award (b), or by the tenant abandoning it $(c)$.

An express contract between the outgoing and incoming tenants may free the landlord from any liability.

These rights of the tenant on the termination of his tenancy are largely affected by the Agricultural Holdings Acts, 1875 and 1883, but it will be more convenient to consider their provisions after repairs and fixtures.

waste. Not only is it the duty of the tenant to cultivate the land he holds in a proper manner, but he must not do anything that would destroy any part of the premises demised. This is expressed by saying he must not com. mit waste. Waste is "a spoil or destruction in houses gardens, or trees, or other corporeal hereditaments to the disherison of him that hath the remainder or reversion in fee simple or in fee tail" $(d)$. Waste is of two kinds voluntary and permissire. Voluntary waste consists o acts done by the tenant, and permissive waste is neglec of his duty to keep the premises demised in a state 0 preservation.

(u) Molding v. Pigott, 7 Bing. 465 ; Muncey v. Dennis, 26 L. J. Fx. 66.

(x) Boraston $\vee$. Grecn, 16 East, 79 ; 14 R. R. 297.

(y) Holding v. Pigott, 7 Bing. 465.

$\Leftrightarrow$ Silcock r. Far'mer, 46 L. 'T. 404. (a) Ex parte Whittington, Buct 87; Ex parte Dyke, re Morrish, ? Ch. D. $410 ; 52$ I. J. Ch. 570.

(b) Thorpe v. Fiyre, 1 A. \& E. 92

(c) England r. Shearburn, 52 L. T. 2

(d) 2 Bl. Com., ch. 18. 
A tenant for a term of years was not restricted from Foluntary ommitting waste on the ground that the parties could riste. rrovide against it by the terms of their contract, but tenants f estates created by act of law were so restrained, such as mants by courtesy or in dower $(e)$. Two statutes, those of Iarlbridge $(f)$ and Gloncester $(g)$, were passed to alter this ate of the law $(h)$. There are very few decisions in the ises of tenants for a term of years as to waste, because of le existence usually of covenants on the subject. However, ; the rules respecting the committal of voluntary waste are re same in the case of a tenant for a term of years as one $r$ life, it is not out of place here to consider what these e. The general principle is that the substance of the tate is not to be diminished. This is clearly laid down in e case of Viner v. Vaughan (i). "On the general law ere is no controversy; a tenant for life has no right to tise the substance of the estate by opening mines or clay1 is, but he has a right to continue the working of mines d clay-pits where the author of the gift has previously che it; and for this reason, that the author of the gift has I. de them part of the profits of the land; but it does not How that the tenant for life has a right to open old a undoned pits and mines, or to commence opening any o les or pits which the author of the gift has merely made parations for opening" $(k)$.

n the case of Phillipps v. Smith (l), the question was nther a lessee for years committed waste by cutting down fows, leaving the stools or butts. It was held that he dic if so long as they were not a support to the bank of a t am against the water, or a shelter to a house. In deliver-

Viner's Ab. Waste (B); Com. Waste A 2 ; 2 Inst. 299.

, 52 Hen. 3 c. 23.

6 Edw. 1 c. 5.

2 Inst. 144, 299.

2 Bear. at p. 469 , per Lord f. Ifale, $\mathrm{X} . \mathrm{R}$. (k) See also Bagot v. Bagot, 32 Beav. 509 ; 33 L. J. Ch. 116; Cleg! F. Rowland, L. R. 2 Eq. 160 ; 3. L. J. Ch. 396; Elias v. Shoudon Slate Quarries Co., 48 L. J. Ch. 811 ; 4 App. Cas. 454 .

(l) 14 M. \& W. 589. 
ing the judgment of the Court, Baron Alderson said $(m)$, "The principle upon which waste depends is well stated in the case of Lord Darcy v. Askuth ( $n$ ), thus-' It is generally true tha ( the lessee hath no power to change the nature of the thin demised, he cannot turn meadow into arable, nor stub a woo to make it pasture, nor dry up an ancient pool or piscary nor suffer ground to be surrounded, nor destroy the pale 0 park, for then it ceaseth to be a park; nor he may no destroy the stock or breed of anything, because it dis herits and takes away the perpetuity of succession, a villains, fish, deer, young spring of roods, or the like Thus the destruction of germens, or young plants destine to become trees $(o)$, which destroys the future timber, waste; the cutting of apple trees in a garden or orchar or the cutting down a hedge of thorns $(p)$ which chang the nature of the thing demised; or the eradicating unseasonable cutting of white thorns $(q)$ which destroys th future growth, are all acts of waste. On the other han those acts are not waste which, as Richardson, C.J., Barrett v. Barrett $(r)$ says, are not prejudicial to th inheritance, as, in that case, the cutting of sallows, mapl, beeches, and thorns, then alleged to be of the age of thir three years, but which were not timber either by gene: law or particular local custom. So, likewise, cutting ev of oaks or ashes, where they are of seasonable rood, $i$. where they are cut usually as underwood, and in due cou are to grow up again from the stumps, is not waste. Th willows in this case are not timber trees, and when down they are not destroyed, but grow up again from th stumps and produce again their ordinary and usual prit by such growth; therefore neither is the thing demil destroyed, nor is the thing demised changed as to
(m) On p. 593
(ii) Hob. 234.
(p) Co. Litt. 53 a.
(o) Co. Litt. 43.
(q) Vin. Abr., Waste (E).
(r) Hetley, 35. 
nheritance, for profit remains as before, derivable from he reproduction of the wood from the stump of the willow ut down. Nor are the trees in such a situation as to make he eutting of them waste, by reason of what is called ollateral respect, as where trees not timber are situated so s to be useful for the protection of a house $(s)$, and so ecome as it were a part of the house; as willows growing ithin the site of a house $(t)$. Nor are they willows within iew of the manor house, which defend it from the wind, in a bank to sustain a bank (u), or like white thorns sed for the like purpose, or where they stand in a field spastured and are used for the shade of the beasts pasturing, and so are intended permanently to remain that particular form, for the advantage of those to whom e inheritance may thereafter come" $(x)$.

As to what trees may be cut without committing waste, re reader is referred to the judgment of Sir G. Jessel in mywood v. Honywood (y), where this part of the subject fully discussed. As a general rule, what trees are "imber" trees depends on the custom of the country $(z)$, sne, however, are always so reckoned, e.g., elm and ash more than 20 years' growth $(a)$. Other illustrations of Nite are:-The destroying of heir-looms, ploughing up a) ient meadow land (b), pulling down a house or other mlding demised, altering their nature by pulling down ttition walls $(c)$.

Co. Litt. 53.

Hob. 219.

12 H. $8,1$.

See also Co. Litt. 53 b, 54 b : finger v. Gubbins, 3 Jones \& Lat.

L. R. 18 Eq. on p. 309 . As to 1. cowers of a limited owner of a tim1 state, impeachable for waste, see yoood r. Magniac, (1893) $3 \mathrm{Ch}$. I) where the question of waste by cof g timber is discussed and particu- of timbered estates, in Sir G. Jessel's judgment in Honywood v. Honyurood.

(z) Chandos v. Talbot, 2 P. Wms. 606 .

(a) Whitty v. Dillon, 2 F. \& F. 67; Aubrey v. Fisher, 10 East, 446.

(b) Simmons v. Forton, 7 Bing. 648.

(c) Cole v. Greene, 1 Lev. 309 ; Jones v. Chappell, L. R. 20 Eq. 539 ; 44 L. J. Ch. 658. See also 2 Roll. Abr. 815 and $\mathrm{C}_{0}$. Litt. 53 a. 
Ploughing up strawberry-beds and removing a border of box, although planted by the tenant, have been held to amount to waste $(d)$.

If a demise be made "without impeachment of waste," the tenant can commit acts of waste with certain exceptions $(e)$. These exceptions are those acts which would amount to an unconscientious use of the property, and were so restrained by the Courts of Equity, such as cutting down timber which sheltered the house, or was planted to ornament it $(f)$, or destroying the mansion $(g)$.

Equitable waste.

This kind of waste is termed equitable waste.

By the Judicature Act, $1873(h)$, it is enacted that "Ar estate for life without impeachment of waste shall no confer or be deemed to have conferred upon the tenant for life any legal right to commit waste of the description known as equitable waste, unless an intention to confe such right shall expressly appear by the instrumen creating such estate." There is no corresponding claus to provide for the case of a tenant for a term of years probably because the case could very seldom arise, a express covenants as to repairs are usually inserted in a leases. But he would nevertheless be restrained fror committing equitable waste (i).

The rules respecting voluntary waste apply to a tenancies, but the committal of an act of voluntary was by a tenant at will at once determines the tenancy $(k)$, an renders the tenant liable to an action for trespass.

(d) Watherell v. Houcells, 1 Camp. 227 ; Empson v. Soden, 4 B. \& Ad. 655 .

(e) Dowman's case, 9 Rep. 10 b ; Bowles' case, 11 Rep. 82 b; 2 Bl. Com. 283 ; Burges r. Lamb, 16 Ves. 174; 10 R. R. 150 ; Cholmeley r. Pax* ton, 3 Bing. 211; Cockerell r. Cholmeley (S. C. In Error): 10 B. \& C. 564 ; Bac. Ab. Waste (N); Duke of Leeds r. Earl Amherst, 2 Phil. 117 ; Miclile- thraite r. Micklethecaite, 1 De G. \& 504; MLorris v. Morris, 15 Sim. 50 3 De G. \& J. 323 ; Baker v: Sebrig 13 Ch. D. 179.

(f) Packington's case, 3 Atk. 215

(g) Iane v. Lord Barnard, $2 \mathrm{Ve}$ 738 .

(h) $36 \& 37$ Vict. c. 66, s. 25 , subs

(i) See Bac. Ab., Whate (N).

(k) Harnett พ, Maitland, 16 M. \& $25 \%$ 
Permissive waste is committed when buildings are allowed Permissive o go to ruin by the timber therein rotting, or walls falling o pieces through not having been properly plastered $(l)$. Jerely omitting to roof an unroofed house, or leaving land uncultivated, does not amount to waste $(m)$, but leaving the ranks of a river unrepaired so that the water bursts through nd does damage amounts to waste $(n)$.

A tenant for a term of years is liable for permissive, aste only, if he be bound by a covenant to repair $(o)$.

An action for permissive waste does not lie against a nant from year to year $(p)$.

Nor is a tenant at will liable for permissive waste, the ncertain nature of his tenure freeing him from liability for pairs $(q)$.

The tenant for a term of year's is exempt, by statute, from ibility when the premises are destroyed by a fire caused cidentally. The 14 Geo. III. c. 78 repeals previous statutes Id enacts $(r)$, "No action, suit, or process whatever" shall had, maintained, or prosecuted against any person in rose house, chamber, stable, barn, or other building, or whose estate any fire shall accidentally begin. . . . Proled that no contract or agreement made between landlord od tenant shall be hereby defeated or made void."

"Accidentally" here does not include "caused by negli3ce" (s).

In the case of a tenant for a term of years the settlement questions likely to arise with regard to waste, is usually

Pyne v. Dor, 1 T. R. 55.

2) Co. Litt. $53 \mathrm{a} ;$ Hutton v. Warren, .\& TV. 466; Bacon's Abr., Waste

Co. Litt. 53 b; also Viner's Abr., te (I).

Herne v. Bembow, 4 Taunt. 764 ; 3) v. Blagrave, 4 De G. M. \& G. 1: see, howerer, the recent case, es v. Davies, 38 Ch. D. 499, where wich, J., decided that a tenant for years is liable for permissive waste.

(p) Torriano v. Foung, 6 C. \& P. 8; ef. also Auwonth r. Johnson, 5 C. \& P. 239 ; Leach v. Thomas, 7 C. it I. 327 .

(1) Litt., s. 71.

(i) S. 86 .

(s) 1 Bl. Com. 431; Viscount Canterbury r. Attorney-Goneral, 1 Phill. 315 ; Filliter v. Phippard, 11 Q. B. $34 \vec{i}$. 
Covenants to repair.

provided for by express covenants. In the absence of every express covenant, the tenant is bound to keep the premises in some repair, the extent of repairs required being. governed by the circumstances of the case, such as the length of his term and the nature of the premises $(t)$. The landlord is under no obligation whatever either to put or keep the premises in repair $(u)$.

The Courts give effect to the covenants entered into by the parties. Many questions arise as to what such covenants include, and there are many decisions on the meanings to be ascribed to the various terms used. Thus: An agreement to leave a farm "as he found it" is held to be one to leare it in tenantable repair if he found it so $(x)$. "Should and would substantially repair, uphold, and maintain a house," includes inside painting $(y)$; "habitable repair" means state of repair reasonably fit for the occupation of an in habitant (z); " external repairs" include boundary walls $(a)$ a covenant to repair a house does not include laying floor on an improved plan, nor putting on a new roof to a old house $(b)$. There a lessee corenanted to repair an maintain the premises demised, he ras held not liable $t$ rebuild a house, which was old, and had to be pulled dom owing to faults in the foundations $(c)$. There $\mathrm{A}$. agree with $\mathrm{B}$. to let a warehouse, "the building to be put by $n$ into good tenantable repair, it was held that $A$. was 11

(t) See Leach v. Thomas, 7 C. \& 1 . 327; Horsefall $\mathrm{r}$. Mather, Holt, $\mathbf{N}$. P. C. $7 ; 17$ R. R. 589 ; Herne . Bembox, 4 Taunt. 764 ; Hernett r. Matland, 16 M. \& W. at p. 262.

(ii) Chappell v. Gregory, 34 Beav. 250 ; Gott. Gandy, 23 L. J. Q. B. $1 ; 2$ E. \& B. S45; Arden v. Pullen, 10 M. \& W. 329.

(x) Winn v. White, 2 W. Bl. S40.

(y) Monk r. Noyes, I C. \& I'. 265.

(z) Belcher V. MeIntosh, S C. S P. 720 ; 2 M. \& Rob. 156 . "Good tenantable repair" is defined by Lopes, L. J., as " such repair as, haring regard to the age, character, and locality of t house, would make it reasonably fit the occupation of a reasonably-mind tenant of the class who would be lik to take it" (cf. Proudfoot r. HA 25 Q. B. D. at p. 55 ; the definit is adopted by Lord Esher, M. R., p. 52).

(a) Grecn v. Eales, 2 Q. B. 225 ;

L. J. Q. B. 63.

(b) Soucard $\mathbf{v}$. Leggatt, 7 C. 4

613; Wcir v. Preedy, 67 L. T. Ji 39.5 .

(c) Lister r. Lane, (1S93) 2 Q. 212 (C. A.). 
sound to put them into repair for any particular purpose, Ind that if $B$. required any extra support for his goods he hould have called A.'s attention to it while the repairs rere being executed $(d)$. Opening doors in a wall and lieepng them open (e), pulling down a wall between two yards $(f)$, re breaches of covenants to repair; not so the remoral of ixtures which can be replaced at the termination of the enancy $(g)$.

The covenant to repair generally extends to all buildings rected on the premises during the term, unless it is to ppair the "building demised," in which case it will not 1clude after-erected structures $(h)$.

A covenant by the lessee to yield up all "ways and ads" in a coal mine in good repair does not include ooden sleepers used for the purpose of a railway (i).

The covenant to repair may be a conditional one, as here the defendants agreed to lieep in repair, \&c., "the me being first put into repair by the plaintiff" ( $k$; or to pair "after notice" $(l)$, in which case the tenant's ibility only follows on the performance of those contions respectively.

The duties of repairing the premises in the case of a nant from year to year are not regulated by covenants. some cases, however, he is bound by some covenants in void lease. Thus, where a corporation by their agents reed to let to the defendant and the defendant to take rtain premises for three years, and the defendant agreed put and maintain the premises in repair and so give

d) McClure v. Little, 19 L. T. 287. e) Doe d. Vickery v. Jachson, 2 rk. 293; Gange v. Lockwood, 2 s. F. 110 .

f) Doe d. Wetherell v. Bird, 6 S: P. 195.

7) Doe d. Burrell r. Davis, 15 Jur.

h) Cornish v. Cleife, 3 H. \& C. 446 ; L. J. Ex. 19; 11 Jur., N. S., 181;
11 L.T. 606 ; 13 W. R. 359 ; Hudson v. Williams, 39 L. T. 632 .

(i) Duke of Beaufort r. Bates, 3 De G. F. \& J. 381 ; 31 L. J. Ch. 481 ; 6 L. T. $82 ; 10$ W. R. 200.

(k) Teale v. Ratcliffe, 15 Q. B. 916 ; 20 L. J. Q. B. $130 ; 15$ Jur. 166.

(l) Horsfall $\because$ Testar, I Moore, 89; 7 Taunt. 385 ; Baylis r. Lc Gros, 4 C. B., X. S., 537; 4 Jur., X. S., 513. 
them up at the end of the term, but the agreement, though executed, had not the seal of the corporation affixed, it was held that the tenancy was one from year to year, and that the tenant was liable on an implied promise to deliver up the premises in tenantable repair $(m)$. In another case where the defendants, having for several years paid the rent reserved under a void lease, were held liable to repair to the end of the term according to the covenant in the lease $(n)$. Generally a tenant from year to year is answerable for keeping the premises in fair repair (o) but not for ordinary wear and tear, nor if they be burn down $(p)$.

Connected with this branch of the subject are the rules relating to fixtures.

Fixtures. A "fixture" meant any chattel which on becoming affixed to the soil-quicquid plantatur solo solo cedit-becam part of the realty. The term "fixtures" now has come ts mean those things which form an exception to the abor rule, and which may be removed by the person wh. affixed them to the soil $(q)$. Fixtures may, as betwees landlord and tenant, be divided into three classes, orna mental and domestic fixtures, trade fixtures, and agricu tural fixtures. The rules are not the same with respect $t$ these three kinds of fixtures. With regard to ornamente and domestic fixtures these conditions must be fulfilled: th chattel must have been affixed by the tenant, and be of a ornamental character, or for domestic convenience; it mu: be capable of being removed entire, and must be slight! affixed. Such things as grates, ornamental chimne

(m) Ecclesiastical Commissioners $\mathrm{r}$. Iferrall, L. R. 4 Ex. $162 ; 38$ L. J. Ex. $93 ; 20$ L. T. $573 ; 17$ W. R. 676.

(i) Beale v. Sanders, 3 Bing. N. C. $850 ; 5$ Scott, $58 ; 3$ Hodges, $147 ; 1$ Jur. 1083.

(o) Awrorth r. Johnson, 5 C. \& P. 239 ; Cheetham v. Hampson, 4 T. R.
318: 2 R. R. 397 ; Gregory r. Mrighe

is Ves. $331 ; 11$ R. R. 207, Prefe

vii. ; Russell v. Shenton, 3 Q. B. 44

(p) Torriano v. Foung, $6 \mathrm{C}$. \&

s; Horsefall v. Mather, Holt, N. T.

17 R. R. 589 ; Ferguson v. Night gale, 2 Esp. $590 ; 5$ R. R. 757.

(q) Climie r. Wood, 37 L. J. E

159 ; L. R. 3 Ex. 257. 
pieces, wainscots fastened with screws, coppers, \&c. $(r)$. An outgoing tenant may remove an ornamental chimneypiece put up by himself during the tenancy, but not a plain chimney-piece because it is made of marble, nor has he any right to remove pillars of brick and mortar built on a dairy flocr to hold pans, although such pillar's are not let into the ground $(s)$.

Window-sashes which are merely fastened by laths nailed across the frames to prevent their falling out, are not fixed so the freehold, and therefore removable by the tenant $(t)$. But a tenant who is not a gardener by trade cannot remove in ornamental border of box, planted by himself on the lemised premises, unless by special agreement with his andlord $(u)$.

Similarly such articles as stoves and grates removable rithout injury to the chimney-place $(x)$, cornices $(y)$, bookases, and such like furniture fixed by screws to the wall $(z)$, ells $(a)$, and iron backs to chimneys $(b)$, are all tenant's $x$ tures.

The tenant may deprive himself of his right to remove xtures by covenant; as, if he undertake to "yield up" in ood repair all improvements and fixtures $(c)$.

The right to removal is lost as soon as the tenant ceases be such, and becomes a "trespasser" $(d)$. It exists so tenant to renove ng as his term lasts (e), or afterwards provided he holds

(r) Grymes v. Boweren, 6 Bing. 9. As to the limit of the rule, see cckland v. Butterfield, 2 Bro. \& ng. 54 ; 22 R. R. 649.

(8) Bishop r. Elliott, 11 Exch. 113 ;

L. J. Ex. 229 (Ex. Ch.).

(t) Rex v. Hedges, 1 Leach, C. C. 1 ; 2 East, P. C. 590 (n).

(u) Empson v. Soden, 4 B. \& Ad.

(x) Rex v. St. Dunstan, 4 B. \& C. y) Avery v. Cheslyn, 3 A. \& E.

z) Ex parte Quiney, 1 Atk. 47T;
Biveh v. Dauson, 2 A. \& E. 37.

(a) Lyde v. Russell, 1 B. \& Ad. 394.

(b) Harrey v. Harrey, 2- Str. $11+1$.

(c) Faylor v. Collinge, 1 Taunt. 19; 9 R. R. 691 ; Dumergue v. Rumsey, 2 H. \& C. 757 ; West r. Blateway, 2 I. d G. 729 ; Burt v. Haslett, 25 I. J. C. P. 201.

(d) Heap v. Barten, 21 I. J. C. I'. 153; Winshall v. Lloyd, 2 II. \& W. 450 ; Pugh v. ditan, L. R. S Eq. 626; 38 L. J. Ch. 619. 394 . 
under such circumstances that he is still considered a tenant $(f)$.

Where a lease is disclaimed by a trustee in bankruptcy. under the Bankruptcy Act, 1883, the Court, when granting leave to disclaim, makes "such orders with respect to fixtures, tenant's improvements, and other matters arising out of the tenancy, as the Court thinks just" $(g)$.

Trade fixtures.

The rights of the tenant to what are termed "trade" fixtures are more extensive than those to ordinary domestic or ornamental fixtures. This class of fixtures arose from the benefit the public at large derive from the growth and encouragement of manufacturing industries. No security could exist for capital employed in trade if such things as steam engines, cranes, \&c., were liable to become the property of the owner of the soil on the determination of the tenancy at an uncertain period, say the death of the landlord of a tenant for life. Certain conditions must be fulfilled in order that the articles in question be reckoned as fixtures.

These conditions are: (1) the articles must be or have the character of being chattels before they were put up; (2) there must exist a "custom" for the removal of such; (3) the removal must be possible without the chattel itself being destroyed, or injury ensuing to the estate. As examples of trade fixtures we have colliery machinery, including fire and steam engines $(h)$; soap-boilers' vats furnaces, brewing vessels, bakers' ovens (i), an engine and boiler, the former being screwed to planks, the latter fixed in brickwork $(k)$, saltpans fixed to a brick floor with mortar $(l)$. Also buildings if they are

(f) Ex parte Stephens, Re Lavies, 7 Ch. D. 127; Weeton r. Woorlcock, 7 M. \& W. 14 .

(g) $46 \& 47$ Vict. c. 52 , s. 55 , subs. 3 ; In re Moser, 13 Q. B. D. 738; 33 W.R. 16.

(h) Dudley r. Ward, Amb. 113;
Lauton v. Lauton, 3 Atk. 13.

(i) Poole's case, 1 Salk. 363.

(k) Climie r. Wood, L. R. $4 \mathrm{Er}$ 328 ; 38 L. J. Ex. 223.

(I) Lacton r. Salmon, I II. B! 259 , น.; 2 R. R. 764; Mansfield Blackbum, 6 bing. X. C. 438 . 
merely accessory to machinery $(m)$, greenhouses built by a nurseryman for his business (n), also trees planted by him for the purposes of his trade $(o)$; but he may not cut dorn those which have actually taken root $(p)$, nor remove vines if they are used for another purpose, viz., for fruit-bearing $(q)$. The common law rules respecting "agricultural" fixtures are not so favourable to the tenant as in the case of trade fixtures $(r)$. But now they are regulated by statutes. The first of these is the $14 \& 15$ Vict. c. 25 (1851), in which it is provided that buildings and machinery erected under certain conditions for the purpose of trade or agriculture shall be removable by the tenant if he leave the farm in the same condition as when he entered on it $(s)$. Provisions were also made to give the landlord the option of purchase, and to ascertain the value for this purpose.

The Agricultural Holdings Acts, 1875 and 1883, will $\underset{\text { Holdings }}{\text { Agricultura }}$ now be considered in so far as they relate to cultiration and fixtures. The former was repealed by the atter, but not retrospectively $(t)$, so will only be menioned incidentally.

The Agricultural Holdings Act, 1883 ( $u$ ), unlike that if 1875 , is compulsory, and extends to agricultural or astoral holdings of less than two acres in extent $\left(x^{\circ}\right)$.

(in) Whitehead r. Bernett, 27 L. J. subject is discussed. h. 474 .

(n) Penton r. Robart, 2 East, 88 ;

R. R. 376: compare Buckland v. butterfield, 2 Bro. \& Bing. 5ँ; 2 R. R. 649.

(o) Lee v. Risdon, 7 Taunt. 191; 7 R. R. 484; compare Empson v. oden, 4 B. \& Ad. 655 .

(p) Oakley v. Monck, 35 L. J. Ex. 7 ; L. R. 1 Ex. 159.

(q) Wardall v. $\dot{\text { ssher, } 10}$ L. J. P. $316 ; 3$ Scott, N. R. j08.

(r) Elues v. Maue, 3 East, 38 ; R. R. 523, Preface v., vi.; 2 Smith's . C. 182 (9th ed.), where the whole (s) S. 3 .

(t) $46 \& 47$ Vict. c. 61, s. 62 .

(iv) As to land under mortgage, ct. $53 \& 54$ Vict. c. 55 ; see the following cases decided on the Act of 1583: Masters v. Green, 20 Q. B. D. S0T; Scofield r. Hincks, 58 L. J. Q. B. 147: Phillips v. Rees, 24 Q. B. D. 17; Paul, In re, Ex parte Portarlington (Earl of ), 24 Q. B. D. 247; Gough r. Gough, (1891) 2 Q. B. 665; Black r. Clay, (1894) A. C. 368 (a case decided on the Scoteh Act).

(x) $46 \& 47$ Yict. c. 61 , ss. $54,5,5$; as to holdings of not more than tro 
It operates not only in the case of all tenancies commenced after the Act came into force, but in a modified manner to tenancies subsisting at that date, January 1st, 1884. A yearly tenancy falls under the former class from the first day after 1883, on which either landlord or tenant could determine such a tenancy $(y)$. Should the tenant not quit at the termination of his tenancy, but enter on a new one, he does not lose his right to compensation for improvements executed during that tenancy, but may claim for them on leaving at the determination of the subsequent tenancy $(z)$.

The Act does not extend to a tenancy at will, or to one for a less period than one year (a), nor can compensation be recovered for improvements executed during the last year of a tenancy, unless the landlord has assented or failed to object for a month after having received notice from the tenant to begin such improvement $(b)$.

A yearly tenant may recover for any improvements made by him during the last year of his tenancy before he receive notice to quit, and provided he give up his holding in due course in pursuance of such notice; and any tenant may recover for manuring, although it be during the last year of his tenancy $(c)$.

The improvements under this Act are divided into three classes. The first comprises buildings, making pasture, gardens, water meadows, roads and bridges, and improving them, watercourses and works for supplying water, planting osier beds, hops, orchards, and reclamation of waste land, and a few minor matters.

acres, cf. also the Allotments and Cottage Gardens Compensation for Crops Act, 1887 (50 \& 51 Vict. c. 26); as to market gardens, cf. $58 \quad \& 59$ Vict. c. 27 . (y) S. 61 .

(z) S. 58 .

(a) S. 61 .

(b) S. 59 .

(c) S. 59. 
The second class consists of drainage; the third of honing with undissolved bones, liming, chalking, claying, clay-burning, and marling land, consuming on the holding feeding-stuff not produced thereon and purchased manure $(d)$.

With respect to the three classes of improvements under this Act, the tenant is entitled, on quitting at the termiaation of his tenancy, to obtain from the landlord zompensation estimated at such an amount as fairly epresents the value of the improvements to an incoming jenant. That portion of this value which is due to the apabilities of the soil is not to be taken into account (e).

With respect to improvements of the first class, this right o compensation is conditional on the landlord's consent laving been previously obtained in writing, and since 25 th lug., $1883(f)$. This consent may be given on terms greed on between the parties, and if they agree to any ompensation at the termination of the tenancy for such mprovements, then such compensation shall be substituted or that under the Act $(f)$.

In the case of improvements of the first class made before 884 , and since 1873 , if the tenant be not entitled to comensation under the previous Act, or under any custom or ontract, he shall be entitled under this Act, provided the indlord consents thereto in writing before $1883(g)$.

With respect to the second class, the tenant must give the indlord from two to three months' written notice of the nprovements intended, and of the manner in which he prooses to carry them out. The parties may then agree as to hat the compensation shall be. Failing such an arrangeient, the landlord may execute the improrements himself ad charge the tenant 5 per cent. per annum on the outlay, he may recover the amount by a charge, recoverable as
(d) Schedule I:
(e) S. 1.
(f) S. 3.
(i) S. ?. 
rent, which would form a sinking fund and pay off the charge in twenty-five years, based on a rate of interest of 3l. per cent. per annum.

If the landlord do not execute the improvements within a reasonable time, then the tenant may do so and claim com. pensation for them. It is also open to the parties to come to an arrangement between themselves as to improvements of this class, and so dispense with the necessity of notice $(h)$.

With respect to improvements of this class executed between 1873 and 1884, the same rules prevail as with those of the first class, viz, that compensation be not otherwise provided for, and the landlord consent in writing before 1885 (i).

In the case of improvements of the third class, no notice to the landlord is required. It is provided, that if in any "future" tenancy fair and reasonable compensation be provided for by agreement, then such compensation shall be payable instead of that provided for by the Act, and similarly in the case of an "existing" tenancy where compensation is not otherwise provided for $(k)$.

Generally, where compensation in the case of an existing tenancy is provided for by custom, agreement, or the Act of 1875 , such compensation is payable instead of that under the subsequent Act $(l)$.

Landlord's right of set-off.

The tenant may claim, in addition to compensation, any sum due from the landlord as compensation for a breach of covenant; and the landlord may set off any benefit he allowed the tenant as a consideration for the execution of the improvements - the value of manure that would have been produced by consumption on the premises, of any hay, roots, \&c., removed during the last two years of the tenancy-any sums due for rent, waste, or breach of
(h) S. 4 .
(k) S. 5.
(i) S. 2.
(l) S. j. 
sovenant, and any rates or taxes payable by the tenant. The landlord's claim against the tenant for waste or bad ausbandry is limited to acts done during the last four years of the tenancy $(m)$.

When the landlord desires to make certain kinds of Landlord's mprovements specified in the Act, such as making roads, puilding cottages, opening mines, \&c., he may give notice to uit as to a part of the holding which, within twenty-eight lays, the tenant may accept by written notice, as a notice o quit for the entire holding. Should he not do this, he vecomes entitled to a reduction in his rent, which is to be ettled by agreement or by reference without appeal $(n)$.

Fixtures set up between 1874 and 1884 come under the rovisions of the Act of 1875 ; but those set up after 1883 re governed by the following provisions $(o)$ :-

Where a tenant affixes any engine, machinery, fencing, Affixing r other fixture, or erects, under certain conditions, any engine uilding, such becomes his property, and may be removed y him, on quitting his holding, provided that he give the andlord a month's written notice, pay all rent and disharge all obligations, shall not do any avoidable damage y such removal, and shall make good any damage so aused. The landlord may elect, before the expiration of ae notice, to purchase the fixture at a price which epresents its fair value to an incoming tenant.

Another duty the tenant owes to his landlord is that of Rent. aying "rent." This obligation follows from the creation f the tenancy. The words "yielding and paying" in a emise amount in law to a covenant to pay rent $(p)$.

Rent has been defined to be "an annual retur'n made $y$ the tenant either in labour, money, or provisions, in tribution for the land that passes", $(q)$. "It is defined
(m) S. 6.
(n) S. 41.
7 East, 23i; 3 Smith, 269; 8 R. R.
(c) S. 34 .
623; and see 9 R. R. 104 n.
(p) Iggulden v. May, 9 Ves, 330 ;
(q) Chief Baron Gilbert's Treatise on Rent, p. 9. 
to be a certain profit issuing yearly out of lands and tenements corporeal " $(r)$. It may consist of manual labour, as to plough a certain quantity of land yearly $(s)$. Rents may consist of the services of cleaning a parish church and ringing the bell $(t)$; or a royalty on bricks made in a certain brickfield $(u)$.

Rent must be reserved out of something to which the lessor can have recourse to distrain, consequently cannot be reserved out of incorporeal hereditaments $(x)$ (but such a reservation as a contract may bind the lessee $(y))$ : nor out of goods $(z)$.

Rent must be reserved to the lessor. As laid down by Littleton, "No rent (which is properly said a rent) may be reserved upon any feoffiment, gift or lease, but only to the feoffor, or to the donor, or to the lessor, or to their heirs, and in no manner it may be reserved to any strange person" (a).

It must also be certain ; if not fixed, must be ascertainable by the reservation (b). The rule is, "That no distress can be taken for any services that are not put into a certainty, nor can be reduced to a certainty ; for id certum est quod certum reddi potest," as "to shear all the sheep depasturing within the lord's manor" $(c)$.

Payments as "rent" which are not strictly so, such as a percentage on outlay on improvements to be made by the landlord $(d)$, payments reserved on an assignment of 8

(r) 2 Bl. Com. 41.

(s) 1 Inst. 142 a.

(t) Doe d. Edney r. Benham, 7

Q. B. $976: 14$ L. J. Q. B. 342 .

(u) Reg. r. Westbrook, 10 Q. B. 17 S : 16 L. J. M. C. S7.

(x) Buszard v. Capel, 8 B. \& C. $141 ; 2$ II. \& R. $197 ; 6$ Bing. 150.

(y) Jevel's case, 5 Co. 3 ; Co. Litt. 47 a: Bac. Ab., Rent (B); Viu. Abr. Reservation (B).

(z) 3rd resol. Spencer's case, 5 Rep. 17: Neuman r. Anderton, 2 X. R. 224; Salmon r. Matthews, S M. \& W. 827. (a) See also Oates r. Frith, Hob 130; Doe d. Barber r. Lawerence, Taunt. 23; Gilbertson v. Richards, II. $\mathbb{S}$ N. $27 \pi$.

(b) Co. Litt. 142 a.

(c) Co. Litt. 96 a. Also Parker $\mathrm{x}$ Harris, 1 Salk. 262; Orby r. Mohun 2 Vern. 531; Riseley r. Ryle, 11 M. W. 16 ; Daniel $r$. Gracie, 6 Q. B 145; Reg. v. Westbrook, 10 Q. B.17s Pollitt r. Forrest, 11 Q. B. 949.

(d) - Hoby v. Roebuel, 7 Taunt. 157 17 R. R. 477; Lambert r. Norri 2 M. E W. 333 . 
ase (e), are not recoverable by distress, but by actions on e. agreement $(f)$.

A rent reserved in general terms, without specifying any ne for payment, will be payable at the end of each When 145 able. ar $(g)$, even when a subsequent parol understanding is me to between the parties, that the rent is to be paid tarterly $(h)$.

The time at which the rent is payable is usually regulated a clause in the lease, which dispenses with a formal mand $(i)$. In the absence of any such clause, rent must demanded (in order to create forfeiture for nonpayment) fore and up to sunset $(k)$, on the day on the morning of rich it became due $(l)$. If the demand be made any oner on that day it will be bad $(m)$.

The ordinary rules, respecting the payment of money te, as to notes, cheques, \&c., hold good with the payment rent $(n)$.

The rent must be paid to the landlord in person, or to i) duly authorised agent $(o)$.

When the landlord is one of several joint tenants, he Hy (unless the lessee have notice from the other joint liants not to pay to him) receive rent from the lessee, and fe a good discharge for it $(p)$.

When rent is paid under a covenant, it is the duty of the crenantor to seek out the person to be paid, and pay or

3) Parmenter v. Webber, 8 Taunt. ; $; 20$ R. R. 575.

f) Adans v. Hagger, 4 Q. B. D. 4 ; 41 I. T. 224.

7) 2 Roll. Abr. 449 ; Cole v. Sury, I ch, 264; Collett v. Curling, 16 IJ. Q. B. 390 .

h) Turner v. Allday, Tyr. \& Gr.

Doe v. Masters, 2 B. \& C. 490.

b) Duppa v. Mayo, 1 Wms. Saund. 3. (m).

i) Dibule v. Bowater, 2 E. \& B. ); 22 L. J. Q. B. 396.

n) Doe v. Paul, 3 C. \& P. 613; scks v. Phillips, 5 H. \& N. 183. (n) Wasd v. Evans, 2 Ld. Raym. 928; Pearce v. Davis, I M. \& liob. 365 ; Cohen v. Hall, 3 Q. B. D. 371 ; 47 L. J. Q. B. 496 : Everett $r$. Collins, 2 Camp. 515; 11 R. R. 785: Hopkins v. Ware, L. R. 4 Ex. 268; 38 L. J. Ex. 147.

(o) Roper v. Bumford, 3 Taunt. 76; Broune v. Pouell, 4 Bing. 230: Goodland v. Blevith, 1 Camp. 477 ; 10 R. R. 731.

(p) Robinson v. Hoffman, 1 M. \& I'. 474; 4 Bing. 562; 3 C. \& l'. 234; Harrison v. Bamby, ó T. R. 246 ; 2 R. R. 584; Powis r. Smith, 5 B. \& Ald. $850 ; 24$ R. R. 587 . 
tender him the money $(q)$; when there is no covenant to the contrary effect, the rent is payable upon the land $(r)$.

In addition to the cases already mentioned (ante, p. 524 the tenant may make certain deductions from his rent These other cases are those in which this right has beer given by statute; the tenant being primarily responsibl for the payment of certain rates and taxes. The principa of these are the property tax and income tax (on amoun of rent), which are payable by the tenant on behalf of th landlord $(s)$, and for which the landlord must allow th deduction under a penalty of $50 l$. Others, such as certai rates under the Public Health Act $(t)$, and the Town Improvement Clauses Act $(u)$, are, in the absence of a: agreement to the contrary, if paid by the tenant, to $b$ allowed by the landlord. In tenancies for a short term $(x)$ or where the landlord undertakes and neglects to $\mathrm{pa}$ them $(y)$, the poor rates come under the same category.

If the tenant omit to deduct from his next rent th amount of taxes paid on behalf of the landlord, he cannc subsequently sue for it as money paid to his use $(z)$; if $\mathrm{b}$ deduct it from the next rent he can do so, unless he hax entered into any agreement to the contrary $(a)$. If th premises be burned down, the tenant is still liable to $\mathrm{pa}$ rent for them (b).

The relationship of landlord and tenant carries with the right of the landlord to "distrain " for rent due (se ante, p. 211). There are certain conditions which must 1

(q) Haldane v. Johnson, 8 Exch. 689 ; 22 L. J. Ex. 264 ; 17 Jur. 937.

(r) Boroughe's case, 4 Co. $72 \mathrm{n}$.

(s) $5 \& 6$ Vict. c. 35 , ss. 73,103 , and s. 60 , Sched. A., No. IV., r. 9. $25 \%$.

(t) 38 \& 39 Vict. c. 55, ss. 104, 214,

(u) Ibid. s. $160 ; 10 \& 11$ Vict. c. 34, s. 45 .

(x) 32 \& 33 Vict. c. 41, s. 1.

(y) Ibid. s. 8.

(z) Graham r. Tate, 1 M. \& S. 609 ;
Cumming v. Bedborough, 15 M. \& 438.

(a) Lamb v. Brewster, 4 Q. B. 220 ; 48 L. J. Q. B. 421.

(b) Baker พ. Holtzapfel, 4 Tau 45 ; 18 Ves. $115 ; 13$ R. R. 55 Izon r. Gorton, 5 Bing. N. C. 501 Arn. $39 ; 7$ Scott, 537 ; Belfour Weston, i T. R. 310 ; 1 R. R. 21 Hare v. Groees, 3 Anst. $687 ; 4 \mathrm{R}$. 835. 
ulfilled before this right becomes available for the landrrd. The rent must be certain, and there must be an ctual demise $(c)$, or the tenant must have entered into ossession under an agreement which can be specifically aforced, and which gives a power of distress to the undlord $(d)$.

The right exists by common law during the tenancy Distress. ly (e). Hence, in Lord Coke's time, the rent for the last zarter was reserved in advance $(f)$, for if it were payable Ladyday and Michaelmas, the term would have ended le moment the rent was due, and so the landlord would ive lost his remedy; even though the tenant continued in cupation after the determination of his tenancy $(g)$. Now is provided by statute $(h)$, that "any person having rent arrear, or due upon any lease for life or lives, or for ars, or at will, ended or determined, may distrain for ch arrears after the determination of the said respective lises, in the same manner as they might have done if s sh lease had not been ended or determined; provided \& $\mathrm{h}$ distress be made within six calendar months after the cermination of such lease, and during the continuance of s:h landlord's title or interest, and during the possession cthe tenant from whom such arrears become due."

This right also exists in the case of a tenancy at will, F. vided there be a yearly rent reserved (i), and also with veekly tenancy $(k)$. The rent must be certain, i.e., must ? calculable $(l)$. The rent must not only be due, but in

Hegan v. Johnson, 2 Taunt. Dunk v. Hunter, 5 B. \& Ald. ; 24 R. R. 390; Knight v. B. $t$ t, 3 Bing. 361 ; Riseley v. Ryle, 11. \& W. 16; Hancock v. Austin, 14. B., N. S., 634; Regnart v. Porter, 1g. 451 .

Walsh v. Lonsdale, $21 \mathrm{Ch} . \mathrm{D}$. ; 2 L. J. Ch. 2 ; 46 L. T. 858 ; 1 T. R. 109 ; Lee v. Smith, 23 L. J. H. 198.

Co. Litt. 47 b. (f) Co. Litt. 47 b.

(g) Williams v. Stiven, 9 Q. B. 14.

(h) 8 Anne, c. 14 , ss. 6,7 (c. 18 in Rer. Ed.).

(i) Morton v. Woods, L. R. 3 Q. B. 658 ; 4 Ib. 293 ; 37 L. J. Q. B. 242 ; 38 Ib. 81 .

(k) Yeoman r. Ellison, L. R. 2 C. P. 681 ; 36 L. J. C. P. 326.

(l) Ante, p. 544 ; Doe d. Edney v. Benham, 7 Q. B. 976; Selby v. Greaves, L. R. 3 C. P. 594, 603. 
arrear, so the landlord cannot distrain until the day after that on which the rent was payable $(m)$. If there be no express agreement, as the right to distrain arises by common law from the mere relationship of landlord and tenant, the former must have a reversion in himself to entitle him to distrain. It does not matter how short it be. For instance: A tenant from year to year, underletting from year to year, has a sufficient reversion to entitle him to distrain $(n)$, but not so a lessee, who has resigned the whole of his interest $(0)$. Again, where A., lessee of two farms, agrees with B. that he should have them during the leases, B. to remain tenant tc A. during that period, B. took possession and paid on year's rent to A., who afterwards distrained for rent ir arrear, it was held, that as the agreement amounted to as assignment of all A.'s interest, he had no reversion whicl entitled him to distrain $(p)$. Similarly, where the lessor' term expired on 11th Nov., and he let the premise from 11th Sept. to that day, by a verbal agreement, fo a certain rent payable immediately, it was held, that $b$ letting for the whole of his term, he had lost the right t distrain $(q)$. Since the right to distrain is incident to th reversion, the landlord loses, on assigning his interest, th right to distrain for rent due up to the date of assignmen He can only recover it as a debt $(r)$. On the death of $t$ lessor, his executor or administrator has by statute ( power to distrain during the continuance of possession the lessee, and within six months of the determination the lease, for all rent due to the lessor during his lifetime Distress may be made by a mortgagee, provided $t$

(m) Dibble v. Bowater, 22 L. J. Q. B. 396. 493.

(ii) Curtis v. Whecler, Moo. \& M.

(o) Cooper's case, 2 Wils. 375.

(p) Parmenter v. Weblier. 2 Moore, 656 ; 8 Taunt. 593 ; 20 R. R. 575.

(q) Precce r. Corrie, 5 Bing. 24; 2
M. \& P. 57. See also Pollock r. Std 9 Q. B. 1033; Williams v. Hayica 1 E. \& F. $1040 ; 28$ L. J. Q. 374.

(r) Flight $\mathbf{r}$. Bentley. 7 Sim. 1 Starely v. Alleock, 16 (2. B. 636: I. J. Q. B. 320 .

(s) 3 \& 4 Will. 4 c. 42, ss. 37,3 s 
relationship of landlord and tenant exist between him and the occupier $(t)$; and a mortgagor may distrain when privity of estate exists between him and the tenant, as where the latter is estopped from denying the mortgagor's title $(u)$.

The landlord cannot as a general rule distrain a second time for the same rent. "There is nothing more clear," said Baron Parke in Bagge v. Maulby (x), "than this, that a person cannot distrain twice for the same rent.

But if there is a fair opportunity, and there is no lawful or egal cause why he should not work out the payment of rent jy reason of the first distress, his duty is to work it out by he first distress, and he cannot distrain again.

The principle upon which, as a general rule, a landlord annot distrain twice is, that he must not vex his tenant by he exercise upon two occasions of this summary remedy." "Lawful or legal cause" would consist in such circumstances ss:- that the landlord mistook the value of the goods, such reing uncertain $(y)$, or the value of the cattle taken (where attle are distrained) was not sufficient $(z)$, or the tenant revented the landlord from realising the value of the goods istrained (a). Another class of exceptions are those cases vhere the landlord abandons the distress either through eing induced to do so by the false representations of the enant (b), or for his accommodation at his request (c).

Generally the landlord may distrain any goods he finds n the premises, because he is supposed to give credit to a

(t) Moss v. Gallimore, 1 Smith, .C., p. 604 (9th ed.). See also Roger's Humphreys, 4 A. \& E. $314 ; 44 \& 45$ ict. c. 41, s. 18 ; Doe r. Boulter, A. \& E. 675 ; Evans v. Elliot, 9 - \& E. 342 ; Corbett v. Plouden, 25 h. D. 678 ; 54 L.J.Ch. 109 ; Morton Bloods, 37 L. J. Q. B. 242; L. R. Q. B. 658 ; Cloues 5 . Hughes, L. R. Ex. $160 ; 39$ L. J. Ex. 62.

(u) Alchorne v. Gomme, 2 Bing. 54 ; ilkinson v. Hall, 3 Bing. N. C. 508. (x) 8 Exch. 641; 22 L. J. Ex. 236; Ouens v. Wymme, 4 E. \& B. 579. 589 .

(y) Hutchins v. Chambers, 1 Burr.

(z) 17 Car. 2 c. 7 , s. 4.

(a) Lee r. Caoke, 3 H. \& N. 203:

27 L. J. Ex. 337. 278 .

(b) Wollaston v. Stafford, 15 C. B.

(c) Thuates v. Wilding, 12 Q. B. D. 4 ; 53 L. J. Q. B. 1 ; 49 L. T. 396. See Bagge v. ILawby, supra. 
visible stock, he ought to have recourse to everything that he finds there $(d)$.

Things privileged from distress.

To this rule there are exceptions which may be divided into two classes-(1) things privileged absolutely, and (2) those protected only in a qualified manner. The former class include fixtures, since they are part of the thing demised, and other things which are in the eye of the law part of the estate, such are:-keys, windows and charters concerning the realty. By a common law rule things could not be distrained which could not be restored in the same condition (e).

Wightman, J., says, "Whether the tenant might or might not remove fixtures is one question, whether or not the goods could be restored in the same condition and are distrainable, is another" $(f)$. Formerly the landlord had to remove the goods distrained from the premises; as these chattels were only a pledge, hence the rule arose that things which could not be restored in the same condition were exempt from distress. Besides the nature of the attachment to the freehold, the object of such annexation must be considered; whether it was to improve the inheritance, or to ensure the more complete enjoyment of it as a chattel $(g)$, those aftixed for the former purpose are not liable to be distrained $(h)$.

Another class of things which cannot be distrained, are those which are delivered to a person exercising a public trade to be worked, carried, wrought up or managed in the way of his trade or employ. These things are privileged for the sake of trade and commerce (i). Such are:-a horse

(d) Gorton v. Falkner, 4 T. R. per Lord Kenyon, at p. 567 ; 2 R. R. 463.

(e) Judgment of Parke, B., in Mellawell v. Easticood, 6 Exch. on p. 311 ; quoting Gilbart on Distress and Co. Litt. 4 .

(f) Darby v. Harris, 1 Q. B. 899.

(g) Hellauell $r$. Easticood, 6 Exch. 295, 310; Holland v. Hodgson, L. R. 7 C. P. 333-340. (h) Darby v. Harris, supra; Iit r. Shere, 4 B. \& Ald. 206 ; Walmsle. v. Milne, 7 C. B., N. S., 115 ; Woo r. Heacett, 8Q. B. 913; Lane r. Diron 3 C. B. 776; Waterfall r. Penistone 6 E. \& B. $876 ; 28$ L. J. Q. B. 100.

(i) Simpson v. Hartopp, Willes, 51? See also $1 \mathrm{Sm}$. L. C. 463 , to which th reader is referred for the law as to ex. ceptions to distress. 
standing in a blacksmith's shop to be shod; corn delivered to b miller to be ground $(k)$; cattle sent to a butcher to be illed $(l)$; goods to a carrier to be carried $(m)$; or to an uctioneer to be sold upon his own premises $(n)$; goods ledged with a pawnbroker (o), or deposited for safe ustody, as furniture at a depository $(p)$; or goods with a rharfinger $(q)$, or granary-keeper $(r)$. "The exception has een acted on for so many years that it is impossible now to xtend it by judicial decision," said Lord Herschell, L. C., a Clarke v. Millwall Dock Co., in which case it was held hat a vessel in the process of being constructed, and aid for by the owner as the work progressed, was ot privileged from being subject to distress, not having een "delivered" to the builder $(s)$.

In the case of an innkeeper, the goods and horses of is guests at the inn are privileged so long as they re on the premises $(t)$. Again, things which are actually I some person's use are privileged, in order to prevent reaches of the peace occurring in the attempt to carry it such a distress $(u)$. Goods in the custody of the w are exempt $(x)$, except where growing crops have sen seized and sold under an execution, in which case so ng as they remain on the land, they are liable to be strained for rent which became due after the seizure ld sale $(y)$.

By statute, more exceptions have been established.

(k) Co. Litt. 47 a.

(l) Brown v. Shevill, 2 A. \& E.

(m) Gisbourn v. Hurst, 1 Salk. 250.

(n) Adams v. Grane, $1 \mathrm{Cr}$. \& M. ; Williams v. Holmes, 8 Exch. 861 . to limit of exception, Lyons v. lott, 1 Q. B. D. $210 ; 40$ L. J. B. 159 .

o) Swire v. Leach, 18 C. B., N. S., p) Miles r. Furber, I. R. 8 Q. B. ; 42 L. J. Q. B. 41 .

q) Thompson r. Mashitz, 1 Bing.
283.

(v) Mathias v. Mesnaid, 2 C. \& P. 353.

(s) 17 Q. B. D. $494,500$.

(t) Bac. Ab., Inns of Innkeeper's (B), Robinson v. Wralter, 3 Bulst. 269.

(ii) Co. Litt. 47 a; Simpson $v$. Hartopp, 1 Sm. I. C. 463 ; Firld v. Adams, 12 A. \& E. 649, ante, p. 210. (x) Co. Litt. 47 a; Wright v. Deves, 1 A. \& E. 641 .

(y) $14 \& 15$ Viet. c. 25, s. 2. 


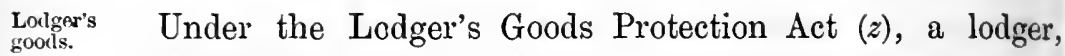
if distress be levied for rent due by the immediate to the superior landlord, may make a declaration (and inventory) that his immediate landlord has no property in the goods distrained, and that such goods are his lawful property; and then on serving such declaration on the bailiff, and on paying to the superior landlord whatever sum he may owe for rent to his immediate landlord, his goods are no longer liable to distress; and any further detention of them by the distrainer amounts to an illegal distress.

Under the law of Distress Amendment Act, 1888, the wearing apparel and bedding of a tenant and his family, and the tools and implements of his trade, to the value of $5 l$., are exempted from distress for rent, except after the expiration of seven days from a demand for possession of premises in respect of which the lease, term, or interest, of the tenant has determined $(a)$, and if such are taken contrary to the provisions of the Act a Court of Summary Jurisdiction may make a summary order that they, if not sold, be restored $(b)$.

Under the 6 \& 7 Vict. c. $40(c)$, frames, looms, material or tools in either woollen, worsted, linen, cotton, flax mohair, or silk manufactures, are exempt from distrain for rent under any execution or process whatever, unles: the rent for which distraint is made be owing by the owner of the loom or other machine.

Gas-meter, \&ic.

By the Gasworks Clauses Act, 1847 (d), "the under takers may let for hire any meter . . . and an. fittings for the gas . . . and such meters and fit tings shall not be subject to distress . . . for ren of the premises where the same may be used." Thi

(z) $34 \& 35$ Vict. c. 79.

(a) 51 \& 52 Vict. c. 21 , s. 4, and 51 \& 52 Vict. c. 43 (the County Courts Act, 1588 , s. 147 . (b) 58 \& 59 Vict. c. 24, s. 4 .

(c) S. 18.

(d) 10 \& 11 Vict, c 15, s, 14. 
provision includes such articles as gas - stoves let for bire $(e)$.

Rolling stock of a railway company employed in a Rotling solliery or other work, is not liable to be distrained or rent due by the parties using it, provided the conlitions requiring the owner to be indicated, be complied rith $(f)$.

By the Agricultural Holdings Act, 1883, " agricultural 11. other machinery which is the bon $\hat{\imath}$ fide property of person other than the tenant, and is on the premises f the tenant under a bon $\hat{\imath}$ fide agreement with him or the hire or use thereof in the conduct of his busiess, and live stock of all kinds which is the bon $\hat{a}$ fide roperty of a person other than the tenant, and is on he premises of the tenant solely for breeding purposes, hall not be distrained for rent in arrear" $(g)$.

The second class of exceptions privileged, but only conitionally, consists of such chattels as beasts of the lough, sheep, instruments of husbandry, tools not in stual use $(h)$. They cannot be distrained so long as lere are other chattels sufficient to satisfy the demand. Under the Agricultural Holdings Act, 1883, live stock at yistment on a holding, are conditionally exempt. If taken i to be fed, they are only distrainable for the amount due $r$ their feeding $(i)$.

Corn, hay, straw $(k)$, and growing crops when ripe (l), ough not distrainable at common law, have under certain nditions been made so by statute.

Unless the tenant make an agreement to the contrary (m),

'e) Gas Light \& Coke Co. v. Hardy, appeal, 17 Q. B. D. 619 .

f) 35 \& 36 Vict. c. 50, s. 3 .

q) $46 \& 47$ Vict. c. 61, s. 45 . h) 52 Hen. 3, stat. 4; Keen v. iest, 4 H. \& N. 236; 28 L. J. Ex. : Vargett v. Wias, 1 E. \& E. 439 , L. J. Q. B. 143 .
Agricultural Inachinery,

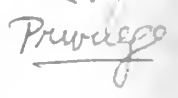

(i) $46 \& 47$ Tict. c. 61 , s. 45 ; London, \&c., Banking Co. v. Belton, 54 L. J. Q. B. 568 : 15 Q. B. D. 45\% : Masters พ. Green, 20 (Q. B. D. 807.

(k) 2 Wm. \& M., Sess. 1, c. 5, s. 2.

(l) 11 Geo. 2 c. 19 , ss. 8,9 .

(m) Deniel v. Stepney, L. R. 9 Ex. $185 ; 2.2$ W. R. 662. 
the landlord can only distrain on the lands out of which the rent issues (n). Thus, where the chattel distrained is a barge lying in the Thames, attached to the demised. property by ropes, it was held that the distress was illegal, the soil of the river bed not being demised $(o)$. By the common law, however, in cases where the tenant drore cattle off the premises in sight of the landlord coming to distrain, the latter could follow and distrain them, although they might go on to the highway $(p)$. By the Statute of Marlbridge, no one save the king can distrain " out of his fee, nor in the king's highway, nor in the common street" $(q)$.

Property fraudulently removed.

Distresshow and when made.

If the tenant, after the rent has become due $(r)$, fraudulently or clandestinely remove his orn (s) chattels off the premises, and there be not sufficient to distrain left $(t)$, then the landlord may within thirty days take and seize such goods, wherever found $(u)$. And the landlord may also distrain the cattle or stock of his tenant feeding upon any common appendant or appurtenant, or in any way belonging to the demised premises $(x)$. The rent must be in arrear at the time the goods are removed $(y)$.

The landlord may distrain by an agent or bailiff $(z)$, and, of course, also personally. The distress must be made between sunrise and sunset $(a)$, and the premises must be (except in the case of fraudulent removal $(b)$ ) entered without breaking open an outer $(c)$ door or a window $(d)$.

(n) Com. Dig., Distress (A. 3).

(o) Capelr. Buszard, 6 Bing. 150 ; also Gillinghamv. Guyer 16,L.T., X. S., 640.

(p) Co. Litt. 161 (a).

(q) 52 Hen. 3 c. 15.

(v) Rand v. Iaughan, 1 Bing. N. C. 767 ; Dibble v. Boncater, 2 E. \& 13. 564.

(s) Fletcher r. Marillitr, 9 A. \& E. 457; Thornton v. Adams, 5 M. \& S. $38 ; 17$ R. R. 257.

(t) Parrey r. Duncan, M. \& N. 533 ; 7 Bing. 243.

(u) 11 Geo. 2 c. 19 , ss. 127.

(x) Ibid. s. 8. $76 \%$. (z) Randle r. Deane, 2 Lutw. 1496: Cary r. Matthews, 1 Salk. 191: Trerillian v. Pine, 11 Mod. 112.

(a) Co. Litt. 142 a; 7 Rep. $i$ a: Aldenburgh v. Peaple, 6 C. \& P. 212 Tatton r. Darke, Nixon r. Freeman, 5 H. \& N. 647 ; 29 L. J. Ex. 271.

(b) Semayne's case, $1 \mathrm{Sm}$. L. C. 11 s.

(c) Brown v. Glenn, 16 Q. B. 2 it 20 L. J. Q. B. 205 ; Brosening r Dam, Bull. N. P. 81. See judgmen: of Boven, I. J., Americun Jfust Cor. poration r. Ifewdry, 62 L. J. Q. B 388 ; also Hodder v. Williams, (1895 2 Q. B. 663 (C. A.).

(d) Fash r. Lucas, L. R. 2 Q. B 
By the Law of Distress Amendment Act, 1888, the ailiff must be authorised to act as such by a certificate n writing $(e)$. A bailiff or other person distraining may limb over a fence $(f)$, or wall enclosing a garden $(g)$, and hus get to the building, and then proceed by any nfastened door or open window to effect a levy in the ouse.

A seizure must next be made (h). Any chattel may be iken hold of to symbolise the seizure of the whole (i), or ny words or acts which amount to an expression of an itention to distrain, will suffice $(k)$.

Before the landlord can sell $(l)$ to realise the amount of int due, he must serve a written $(m)$ notice of the distress $a$ the tenant, or at the chief mansion house (n), to specify stinctly the goods distrained, and the amount of rent ie $(o)$.

The appraisement (the necessity for which, except in the se where the tenant or owner of the goods requires it by iting, is now abolished $(p)$ ) and the sale cannot take place I five days after the distress, or until fifteen days after e distress if the tenant makes request in writing to the hdlord or other person levying distress, and gives security

" Handcock v. Austin, 32 I. J. (P. 252 ; Crabtree v. Robinson, 15 B. D. 312 ; 54 L. J. Q. B. 544 . -) $51 \& 52$ Vict. c. 21, s. 7 . By Distress for Rent Rules, 1888, le in pursuance of $s .8$ of the Act, l certificates are either special or eral; the former are granted by er a Judge or Registrar of a County $\mathrm{rt}$, the latter by a Judge. See Hogarth v. Jennings, (1892) $1 \mathrm{Q}$. 107 (C. A.). As to cancellation, see fF 59 Vict. c. 24 , s. 1. A penalty 10l. may be incurred by a bailiff ig without such certificate; cf. Id.,

Eldridge v. Staeey, 15 C. B., Y., 458 .

Long v. Clurke, (1894) 1 Q. B. (C. A.).

Eldrilge v. Stacey, 15 C. B.,
N. S., 458.

(i) Dod v. Monger, 6 Mod. 215.

(k) Hutchings v. Scott, 2 M. \& W. 809; Swann v. Earl of Fulmouth, 8 B.\& C. 456 ; Wood v. Num, ถै Bing. 10 ; Cramer v. Mott, I. R. j Q. B. 357 ; 39 L. J. Q. B. 172.

(l) Trent v. Hunt, 22 L. J. Ex. 318; 9 Exch. 14.

(m) Wilson v. Nightingale, 8 Q. B. 1034 .

(n) $2 \mathrm{Wm}$. \& ML., Sess. 1, c. 5, s. 1.

(o) Wakeman $\vee$. Lindsey, 14 Q. B. 625; Kerby v. Harding, 6 Exch. 234. See also Mross r. Gallimore, 1 Doug. $279,1 \mathrm{Sm}$. L. C., 9th ed., 60 t.

(p) 51 \& 52 Vict. c. 21 , s. 5 . In its stead the tenant may, on written request, and at his own cost, have the goods removed to a public auction room to be sold. 
for any additional cost occasioned by such extension $(q)$, during which period the goods are in the custody of the landlord, who is responsible for them $(r)$. For this purpose he may, except in the case of corn, straw (s), or growing crops $(t)$, remove them off the premises to impound them. Before 11 Geo. II. c. 19 was passed, the consent of the tenant was necessary to impound on the premises. This is now no longer so $(u)$.

After the expiration of the five days, if the owner desires appraisement, the person distraining may get the goods and chattels appraised by two $(x)$ competent $(y)$ persons, and then sell for the best price to be obtained $(z)$.

Under the rules of the common law, a contract could not be assigned (see ante, pp. 443,444 ); but though a lease is a contract, still it creates an estate, and an estate could by the common law be assigned, either by act of parties, or by act of law. If the landlord make an assignment of hi interest, it must be by deed, being an incorporeal heredita. ment (a). Formerly the tenant had to attorn to the net landlord, i.e., recognise him as such $(b)$. By statute thi is now no longer necessary. The assignment is complet without it, but the statute protects the tenant against bein made liable to the new landlord for rent due after th assignment, and paid to the old landlord in ignorance o it $(c)$. Before the Statute of Frauds, a tenant might assigy his term by parol, since that time every assignment mus be in writing $(d)$; and by the Real Property Amendmer

(I) $51 \& 52$ Vict. c. 21 , s. 6.

(r) Co. Litt. 47 b; Bac. Ab., Distress (D); Wilder r. Spcer, 8 A. \& E. 547 ; Bignell v. Clark, 29 L. J. Ex. $257 ; 12$ \& 13 Vict. c. 92 , s. 5 ; Daigan $\vee$ Davies, 2 Q. B. I. 118; $\$ 6$ l. J. M. C. 122.

(s) 2 W. \& M., Sess. 1, c. J.

(t) 11 Geo. 2 c. 19 , ss. 8, 9 .

(ii) S. 10.

(x) Allen v. Flicker, 10 A. \& E. 640.

(y) Roden r. Eyton, 6 C. B. 427 . (z) Walter v. Rumball, 1 Ld. Rarm 53 ; Cook r. Corbett, 24 W. R. 181.

(a) Beely v. Parry, 3 Ler. 1jt, ant p. 400 .

(b) Co. Litt. 309 b.

(c) Moss v. Gallimore, 1 Dougl. 27 $1 \mathrm{Sm} . \mathrm{L}$. C. 604 ; Spencer's ense, Smith's I. C.. p. 65 ; Scaltock v. Hit ston, 1 C. P. D. 106; 45 L. J. C.

125; Evans v, Elliott, 9 A. \& E. 3 \&

(d) 29 Car. 2 c. 3 , s. 3 . \&

Botting v. Martin, 1 Camp. 31 s. 
Lct, all assignments (after 1st Oct., 1845) of chattel interests a any tenements or hereditaments must be by deed ( $)$. ince an estate was assignable and a contract not, it followed nat the assignee was not bound by the covenants contained 1 the lease. To remedy this state of affairs, the statute f $32 \mathrm{Hen}$. VIII. c. 34 was passed, which gave the assignee f the reversion the same rights against the tenant and his ssigns as the landlord had $(f)$, and also gave to the tenant nd his assigns the same remedies against the reversioner nd his assigns, as they would have had against the original indlord $(g)$.

This statute was construed to refer only to covenants hich related to the subject-matter of the demise. These Covenant: running with the e said to "run with the land." The rules on the subject :e laid down in Spencer's case ( $h$ ), and have already been immarised, under the head of "Covenants," in Bk. II., hapter 1 (i). All covenants implied by law run with the nd, such as that implied from the words "yielding and rying " in a lease $(k)$, those covenants implied under" the onveyancing Act, $1881(l)$, a covenant that the lessee shall side on the premises $(m)$, or one implied that the lessee lall grind at the lessor's mill all corn grown on the lands mised, so long as the mill belonged to the same person $(n)$. ), where a landlord covenanted to supply the demised 'emises with water, it was held that the covenant ran with $\theta$ land, and with the reversion (o).

A covenant by a lessee of a beerhouse to conduct and anage the business of an inn, tavern, or beerhouse-keeper

(e) 8 \& 9 Vict. c. 106, s. 3.

'f) S. 1 ; Spencer's case and notes, 1 Smith's L. C., p. 65, is the hority on this subject.

g) S. 2 ; see also $44 \& 45$ Vict. 11, ss. 10,11 .

7) Supra. See also Mayho r. Buckrst, Cro. Jac. 438.

i) Ante, p. 269, et seq.

ii) Williams r. Burrell, 1 C. B.
402 ; Hellier v. Casbard, 1 Sid. 266; Giles v. Hooper, Carth. 135.

(l) $44 \& 45$ rict. c. 41, s. 7 .

(m) Tatem y. Chaplin, 2 H. Black. 133; 3 R. R. 360 . See also JIayor of Congleton v. Pattison, 10 East, 130.

(n) Tyryen 5 . Arthur, 1 B. \& C. 410,2 D. \& R. 670.

(a) Jourdain v. Witson, 4 B. \& All. $266 ; 23$ R. R. 268. 
in such proper and orderly manner as to afford no ground or pretext whereby the licence might be, or be in danger of being, suspended, discontinued, or forfeited runs with the lands $(p)$.

But if the covenant, though concerning the land demised, be one relating to something not in esse at the date of the covenant, it will not bind the assignee unless the words "and assigns" be in the covenant $(q)$. A covenant not to assign without leave of landlord, the "assigns" being mentioned, runs with the land $(r)$ : not so a covenant not to $\operatorname{assign}(s)$.

Since by an assignment by the tenant privity of estate between him and the landlord ceases, yet privity of contraci still exists between these parties $(t)$, consequently the tenan

3. still remains liable to the landlord on all express covenants Until the landlord recognise the assignee as tenant, he car sue the former tenant in debt for the rent $(u)$.

Where the lease is not by deed, the statute (32 Hen. VIII c. 34) does not apply; hence, although the lessor assign hi interest, yet his right of action against the lessee remains $(x)$ If the assignee of the term part with his interest, he i liable only for breaches of covenants, running with the land, committed while he held $(y)$, since his liability aros from his connection with the land. During this period th assignee is bound, as regards the lessee, to pay rent an perform the covenants $(z)$. This duty of indemnifying th 35 .

(p) Fleetwood v. Hull, 23 Q. B. D.

(q) Spencer's case and notes, $1 \mathrm{Sm}$. L. C., 9th ed., p. 65; Sampson $\mathbf{v}$. Easterby, 9 B. \& C. 505; 6 Bing. 644 (Ex. Ch.) ; Doughty v. Bowman, 11 Q. B. 444 .

(r) Willians v. Earle, L. R. 3 Q. B. 739 ; 37 L. J. Q. B. 231.

(8) Philpot v. Hoare, 2 Atk. 219. See Bally v. Wells, 3 Wils. 25, 33.

(t) Auriol v. Mills, 4 T. R. 94; 1 Sm. L. C., 8th ed., p. 839 ; Thursby v. Plant, and notes, 1 Wms. Saund. 240. Also Bachelour v. Gage, Car. 188 Barnard v. Godscall, Cro. Jac. 309.

(u) See judgment in Auriol v. Mill supra. 920 .

(x) Bickford v. Parson, 5 C. I

(y) Taylor v. Shum, 1 B. \& P. 21 4 R. R. 759 ; Harley v. King, Tyrwh. 692; 2 Cr. M. \& R. Is Lekeux v. Nash, 2 Str. 1221.

(z) Burnett v. Lynch, 5 B. \& 589; Smith v. Peat, 9 Exch. 16$]$ Crouch v. Tregonning, L. R. 7 E 88. 
riginal lessee falls on each successive assignee $(a)$. The tat. of Hen. VIII. also applies to cases of assignment $f$ a portion of the lands demised $(b)$. At common law, a ondition was not apportionable (c), but by statute $(d)$ the ssignee of each part of the reversion is entitled to all onditions and powers of re-entry as if these conditions, c., had been reserved to him.

Now by the Conveyancing Act, 1881 (e), the rent reserved I a lease, the benefit of all covenants and conditions lating to the thing demised go with the reversionary tate, and will on severance of reversion be apportioned id remain annexed to the several parts of the estate as cured. The covenants entered into by the lessor will, as $r$ as he can bind the reversionary estate, be annexed to it. An assignment by act of law takes place on the death of her lessor or lessee, and by the operation of the law of Assignment by act of inkruptcy.

On the death of the lessor if the land descend to the on death of ir he is liable on all covenants which run with the land, i the breaches occur after the landlord's death $(f)$; or if bstantial damage ensue after his death in consequence of 1)aches committed before that event $(g)$ to the extent of t. assets he has acquired by descent $(h)$. He may take avantage of all covenants running with the land, but not collateral ones (i). The heir's right to sue exists although covenant has been made with the ancestor and his cutors $(k)$. When the landlord's interest devolves on the cutor, the latter represents the deceased more closely

Moule v. Garrett, L. R. 5 Ex. 41 L. J. Ex. 62.

White r. Hunt, L. R. 6 Ex. 32 ; J. Ex. 23.

Troynam v. Pickard, 2 B \& Ald. 20 R. R. 368 ; Co. Litt. 215 a. $22 \& 23$ Vict. c. 35 , s. 3.

$44 \& 45$ Vict. c. 41 , ss. 10-12.

Lougher v. Williams, 2 Lev. 92.

Com. Dig. : Administration, B.

Corenant, B. 1 ; Kingdon .
Nottle, 1 M. \& S. 355 ; 14 R. R. 462 ;

King v. Jones, 5 Taunt. 418 ; 15 R. R. 533 ; Ricketts v. Weaver, 12 M. \& W. 718.

(h) Co. Litt. 209 a ; Gifford v. Young, 1 Lutw. 287.

(i) Fitzherbert, N. B., 145 D. and 146 D. ; Com. Dig. Covenant (B. 2).

(k) Lougher v. Williams, 2 Lev. 92; Sacheverell v. Froggatt, 2 Wms. Saund. 367 (a). 
than the heir does his ancestor $(l)$; he may sue the lessee for a breach of covenant not to fell, \&c., timber trees (which were excepted out of the demise) committed during the. testator's lifetime $(m)$; and the executor of a tenant for life need not aver damage to the personal estate when suing on a covenant to repair for breaches committed before testator's death $(n)$. Where the lessor's interest determined by his own death or that of another, the lessor's representative or the lessor himself might receive from the tenant a proportionate part of the rent due next pay-day, which accrued up to the determination of the lease $(o)$, but now by the Apportionment Act $(p), 1870$, all rent and similar periodic payments are (unless there be an express stipulation to the contrary effect) to be considered as accruing from day to day, and apportionable accordingly, the same being recoverable from the party who would otherwise be entitled.

On death of lessee.
On the death of the lessee his personal representative mas be sued in his capacity as such or as assignee. If he be sued as personal representative he is only liable to the extent of the assets $(q)$; if he be sued as assignee he can only fre himself from liability beyond the extent of the assets $b$. pleading that he was assignee as executor only, that th term is of no value, and that all the assets have bees administered $(q)$. Should he enter he will be liable for th profits he might by reasonable diligence have derived fror the premises $(r)$. Where any executor or administrator liabi as such has satisfied all liabilities under the lease up to th time when he assigns it, and has set apart a sufficient su. to meet future liabilities, he ceases to be personally liab

(l) Com. Dig., Covenant (C); Wil. liams v. Burrell, 1 C. B. 402.

(m) Raymond v. Fitch, 2 Cr. M. \& R. 588 . 718 .

(n) Ricketts r. Weacer, 12 M. \& W.

(o) 11 Geo. 2 c. 19, s. $15 ; 4 \& 5$
Will. 4 c. 22 , ss. 1 and 2.

(p) 33 \& 34 Vicț. c. 35, ss. 2, 3, and 7 .

(q) Wollaston v. Hakeroill, 3 Mf. Gr. 297 . 744 . 
$x$ any subsequent claim under the lease or agreement (i). The manner in which a term of years becomes vested in ne trustee in bankruptey is treated under "Bankruptey," on bank. p. 658,659 . The trustee cannot disclaim a part of the ringtcy of roperty $(k)$. The cases in which he may disclaim without ave of the Court (see p. 658) are:-Where the bankirupt is not assigned, sublet, or created any mortgage on the ase ; and (1) the rent reserved and real value of the proxty leased are under $20 l$. per annum; or (2) the estate is Iministered under provisions of sect. 121 of the Act gulating small bankruptcies, or (3) the trustee serves the ssor with notice to disclaim, and the lessor does not within ven days serve a notice on the trustee requiring the utter to be brought before the Court; or where the bankupt has sublet, or mortgaged the lease, and the trustee s.ves the lessor and the sub-lessee or the mortgagees with rtice of his intention to disclaim, and none of the parties - served within fourteen days after the receipt of such yice require the matter to be brought before the Court $(l)$. le disclaimer must be in writing signed by the trustee, al must be filed.

When the Court grants leave to disclaim it regards only interests of those immediately concerned in the adminisiion of the bankrupt's estate $(m)$.

The limit of time for disclaiming is twelve months from If trustee's appointment, or twelve months from the time in the property came to his knowledge, but such period (4) be extended by the Court $(n)$. This limit only applies 1. re there is no notice served by any person interested on it trustee calling on him to decide whether he will disclaim

$22 \& 23$ Vict. c. 35, s. 27.

Ex parte Allen, Re Fussell, 51 Ch. 725 ; 20 Ch. D. 341 .

46 \& 47 Vict. c. 52 , s. 55 , 87i) 3 , and Bankruptcy Rules, 1890, Ni. 9 .

Ex parte Edmonds, Re Tipping,
48 L. T. 77 ; Ex parte E. \& W. India Dock Co.. Re Clarke, 17 Ch. D. 759 ; 50 L. J. Ch. 789.

(n) $46 \& 47$ Vict. c. 52, s. 55 , subs. 1 , as amended by $53 \& 54$ Vict. c. 71 , s. 13 .

ว.L. 
or not, in which case the limit is twenty-eight days, or such extended time as the Court may allow (o). A trustee who does not disclaim is in the position of an assignee $(p)$; one who does is freed from all personal liability $(q)$. The effect of the disclaimer only extends so far as is necessary to release the bankrupt and trustee from liability $(v)$.

Thus, if the bankrupt be an assignee the original lessee is liable (s); if he be an original lessee who has sublet the pre mises the under-lessee is liable for the covenants in the original lease, and cannot be ejected while he observes them $(t)$

Determination of tenancies.

A lease for a fixed period or a term of years, or until certain event happens, terminates at the expiration of th period or term of years on the happening of the event, o on the expiration of the term $(u)$. So if the lease b determinable at the option of one of the parties, the part so determining it must give reasonable notice where non is provided for in the lease $(x)$.

As soon as the reversion and the term both vest in th

2 same person in the same right the term becomes merged $i$ the reversion and so ceases to exist $(y)$.

3. A tenancy may also terminate by surrender, that is by th tenant rendering up the estate to his immediate landlor Surrenders are divided into two classes-surrender by act parties, and surrender by operation of law.

(a) The Statute of Frauds enacts that an express surrend shall be by deed or note in writing $(z)$; and the Real $\mathrm{Pr}$

(o) S. 55, subs. 4 ; Ex parte Lovering, Re Jones, 43 L. J. Bkcy. 94, L. R. 9 Ch. 586 ; Ex parte Harris, Re Richard. son, 16 Ch. D. $613 ; 29$ W. R. 899.

(p) Titterton v. Cooper, 9 Q. B. D. 473; 51 I. J. Q. B. 472; Alloway v. Steere, 10 Q. B. D. 22 ; 52 L. J. Q. B. 38 .

(q) Lowrey v. Barker, 5.Ex. D. 170 ; 49 L. J. Ex. 433.

(v) S. 55, subs. 2 ; Ex parte $E . \$$ IV. India Dock Co., Re Clarke, 17 Ch. D. 759 ; 50 L. J. Ch. 789 ; Harding v. Precee, 51 L. J. Q. B.
515 ; 9 Q. B. D. 281.

(s) Hill v. E. \& W. India Dock 9 App. Cas. 448 ; 53 L. J. Ch. 842 (t) Ex parte Walton, Re Lery,

Ch. D. $746 ; 50$ L. J. Ch. 657.

(ui) Cobb v. Stokes, 8 East, 3 9 R. R. 464: Weller v. Spiers, W. R. 772 .

(x) Goodright $\mathrm{r}$. Richardson, $3 \mathrm{~T}$. 462 , as to which see Doe d. Webl. Dixon (1807) 9 R. R. 501. (y) Chambers r. Kingham, 10 D. $743 ; 48$ L. J. Ch. 169.

(z) 29 Car. 2 c. 3 , s. 3. 
rty Amendment Act requires that "a surrender in writing, hless of a copyhold interest or any interest which might law have been created without writing, shall be by ed" $(a)$.

If one of the parties by his acts puts himself into a sition which is inconsistent with the continuation of the Surrender by operation is, of law. Ise, and the other party assents thereto, then the law ilers a surrender of the lease. Where the tenant holding der one lease consents to the granting of a new lease he i)stopped from denying the landlord's title to grant it, and this implies the non-existence of any previous lease, the f. mer lease is surrendered by operation of law (b). The ne principle holds good where there is any new relati ship created between the parties inconsistent with that landlord and tenant; as, for instance, where the lessee f ferry became a servant and accounted for the profits (c), urrender by operation of law was held to have taken 3.e. Again, if the tenant quit the premises and the allord assent thereto or take possession (d), not merely Iola temporary purpose such as repairing, but under such Lumstances as to assent to the abandonment of the nises by the tenant $(e)$. There, however, there is a linge in the personality of the tenant change of possession necessary part of the consent, or, more correctly, there o surrender by operation of law unless the old tenant

8 \& 9 Vict. c. 106, s. 3 ; see (Joe v. Thomas, 9 B. \& C. 288 ; v. Lumley, 29 L. J. Ex.

Lyon v. Reed, 13 M. \& W. 285; (s Christi College r. Rogers, 49 Ex. 4; Davison v. Gent, $1 \mathrm{H}$. \&. 744; 26 L. J. Ex. 122; Walsh . trsdale, 21 Ch. D. 9 ; 52 L. J. As to aroidable leases, see Doe r. Ale, 11 Q. B. 713 ; 17 L. J. Q. B. 3 ; Doe r. Courtenay, 11 Q. B. (k) 17 L. J. Q. B. 151 ; as to surre of a part of premises: Holme $\mathrm{r}$. $B$ fill, 47 L. J. C. P. $610 ; 3$
Q. B. D. 495 ; Baynton r. Morgan, 22 Q. B. D. 74 (C. A.), 21 Q. B. D. 101.

(c) Peter v. Fendal, 6 B. \& C. 703.

(d) Dodd v. Acklom, 13 L. J. C. P. 11 ; Saint v. Pilley, L. R. 10 Ex. 13i; 44 L. J. Ex. 33 ; Nickells $r$. Ather. stone, 10 Q. B. 941 ; 16 L. J. Q. B. 37I; Walls v. Atcheson, 3 Bing. 462 .

(e) Furnivall r. Grove, 30 L. J. C. P. 3; Moss v. James, 47 L. J. Q. B. 160 . 
gives up possession to the new tenant at or about the tim of the grant of the new lease to which he assents $(f)$.

On the surrender of a lease the tenant remains liable fo breaches of covenant and for rent up to the day on whic the surrender takes effect $(g)$. If he have sublet th premises the under-tenant in this case, when the lease i merged, still remains liable under his lease or tenancy $(h)$.

Disclaimer. If the tenant either sublet a title to the property $\mathrm{i}$ another, or claim it himself $(i)$, or insist on any claim incor sistent with the relationship of landlord and tenant $(k), \mathrm{B}$ is said to disclaim. For example, a denial by a yeari tenant of his landlord's right to raise the rent will amous to a disclaimer $(l)$. But in the case of a tenant for a ter of years mere verbal disclaimer will not operate as forfeiture $(m)$.

Forfeiture. If a lease be granted on a condition which is broken, $t$ landlord may re-enter without having any provision f re-entry inserted in the lease. The landlord has a rig

1 to re-enter on breaches of covenants being committed, there be an express proviso for re-entry in the lease ( Such proviso for re-entry must be construed strictly ascertain if it was meant to include the breach of covene complained of $(o)$.

By the Conveyancing Act, 1881, the Court has por to relieve against forfeiture, except (1) for breaches covenant against assigning, underletting $(p)$, or part

(f) Wallis v. Hands, (1893) $2 \mathrm{Ch} .75$, following Lyon r. Reed, 13 M. \& W. 285 , and Davison v. Gent, 1 H. \& $\mathrm{N}$. 74 .

(g) Att.-Gen. v. Cox, 3 II. L. Ca. 240 ; Grimman v. Legge; 8 B. \& C. $324 ; 33$ \& 34 Vict. c. 35.

(i) Mellor r. Watkins, L. R. 9 Q. B. 400 ; Co. Litt. 3,386 ; 8 \& 9 Vict. c. 106, s. 9 .

(i) Jones v. Mills, 10 C. B., N. S. 788 ; 31 L. J. C. P. 66 ; Doe v. Cooper, 1 M. \& Gr. 139 ; 9 L. J. C. I'. 231 . (k) Doe v. Rollings, 4 C. B. 185

(l) Vivian . Moat, $16 \mathrm{Ch} . \mathrm{D}$. 50 L. J. Ch. 331.

(ii) Doe v. Wells, 10 A. \& E. 4

(n) Doe v. Philliys, 2 Bing Doe r. Watt, s B. \& C. $308,315$.

(o) Croft v. Lumley, 6 H. L. 612 ; 27 L. J. Q. B. 325 ; Quilt Mapleson, 9 Q. B. D. 672 ; Dene Nicholl, 4 C. B., N. S. 379, Croveder, J. ; Price v. Workood, ft. \& N. 512 .

(p) Where the lessee bad coren not to underlet without first obtal is 
ith possession of the land; (2) for forfeiture incurred by e lessee becoming bankrupt or his interest being taken in ecution; (3) or for breach of corenant in a mining lease, to inspection of workings, books, \&c.; or (4) for forture incurred by non-payment of rent. The right of -entry or forfeiture for breaches of covenant in a lease (ner than those excepted is not enforceable by action or nerwise, until the lessor serve notice thereof on the lessee, \&d the latter fail within a reasonable time to remedy the zach or make compensation for it. Where the lessor uceeds to enforce this right, the lessee may apply to the curt for relief, which may be granted on such terms as 9.y seem fit to the Court $(q)$.

in the case of a tenancy from year to year, a half-year's nice to quit is necessary from either party to the other tenancy: (cte, p. 510). But in the case of a tenancy in which the t:icultural Holdings Act, 1883, applies, a year's notice, iring with a year of tenancy, is required in the absence 3 written agreement to the contrary $(r)$. Under this , a landlord may give a tenant from year to year notice quit a part only of his holding, if the notice is given I a view to use the land for any of the improvement inoses mentioned in the Act $(s)$. In cases where a halfye's notice is enough, the half-year must consist of one ildred and eighty-two days, except where the tenancy menced on either of the usual days, viz., Michaelmas Jady Day. In case of a tenancy which commenced at Ly Day, notice on the 29th of September to quit at Lady

1f insent of the lessor, whose consent y ot to be arbitrarily withheld, and $t=3$ ssee had omitted to ask the lessor if isent to an under-lease, and had uiclet toarespectable and responsible If 1 , the Court of Appeal held that 82: omission, the result of forgetfif is on the part of the solicitor who pived the under-lease without rete: 1 ; to the head-lease, was a mis- take against which the Court would not grant relief: Barrono v. Isaacs, (1891) 1 Q. B. 417.

(q) 44 \& 45 rict. c. 41, s. 14. See p. 295, (n), (o), and p. 296, $(p)$, and see the Conveyancing Act, 189:2 (55 \& 56 Vict. c. 13).

(r) $46 \& 47$ Vict. c. 61, s. 33 .

(s) Id. s. 41. 
Day is $\operatorname{good}(t)$. Where the tenancy was entered upon at Michaelmas, notice served on the 26th of March is not a valid notice $(u)$.

The notice, which should be clear in all its terms $(x)$. should be given by the landlord or his agent $(y)$, either to the tenant personally or left at his house, its nature and contents being at the time explained to his servant or soms member of his family $(z)$. A yearly tenancy usually expire on the same day of the year as it commenced, but if th tenancy commence between the usual quarter days, an rent be paid for a portion of the quarter, and thenceforwar on the usual quarter days, the tenancy for the purpose 0 notice to quit is deemed to have commenced on the quarte day next succeeding the day of entry (a).

In cases of tenancies for shorter periods than one yea. such as lodger tenancies, the analogy to yearly tenancies the the length of notice to quit must be commensurate with th period of letting does not hold good; the length of noti necessary must be a matter of express contract or governe by usage $(b)$.

A tenancy at will is determined at the will or death either party $(c)$, which will may be either expressed implied from the doing of any act inconsistent with t: existence of the tenancy, such as the tenant committir voluntary waste $(d)$, or executing an assignment of 1

(t) Roe d. Durant r. Doe, 6 Bing. 574 ; Doe d. Mattheu'son r. Wrightman, 4 Esp. 6 ; 6 R. R. 834; Doe d. Harrop v. Green, Ibid. 198.

(u) Morgan v. Dacies, 3 C. P. D. 260.

(x) See Doe v. Willinson, 12 A. \& E. 743 ; Doev. Kightley, 7 T. R. 63.

(y) Doe v. Mizem, 2 M. \& Rob. 56; Doe v. Robinson, 3 Bing. N. C. 677. As to corporations, Roe v. Pierce, 2 Camp. 96.

(z) Jones v. Marsh, 4 T. R. 464; 2 R. R. 441; Tanham v. Nicholson, L. R. 5 H. L.561 ; Liddy r. Kennedy, L. R. 5 H. L. 134,20 W. R. 150 . (a) Doe r. Stapelton, 3 C. \& P. 2 Doe r. Grafton, 18 Q. B. 496; L. J. Q. B. 276 ; Sandill r. Frank L. R. 10 C. P. $377 ; 44$ L. J. C. 216.

(b) Huffell r. Arinistead, 7 C. \& 56 ; Wilsun v. Abbott, 3 B. \& C. Even in a reekly tenancy some no is requisite, Boven r. Anderson, (1) 1 Q. B. 164; cf. also Jones v. If 10 C. B., N. S. 788.

(c) Doe v. Price, 9 Bing. 356;

Litt. 55 b; Tumer v. Doe, 9 II. \& 646.

(d) Co. Litt. 57 a. 
nterest $(e)$, or the landlord granting a lease $(f)$, in the last wo cases as soon as knowledge thereof reaches the other arty $(g)$.

The principal remedy of the landlord for the recovery of nementes. ent has already been discussed under the head of Rights $(h)$. i the distress, however, be illegal or irregular, the tenant as certain remedies. If a distress be taken without good uuse, the owner may rescue, i.e., forcibly recover the goods istrained after they have been seized, and before they have zen impounded (i).

The common law remedy for unlawful distress is replerin, Replevin.

hich is a delivery of the goods to the tenant on his giving curity to bring an action of replevin against the disainer $(k)$.

Formerly replevin was made by the sheriff, but now all e processes necessary thereto are issued by the registral' the County Court, and executed by the high bailiff (l). the owner proceed in the Superior Court, he must comence his action within one week, if in the County Court thin one month; in each case he must give security to ver alleged rent and costs $(m)$. Besides the remedy of ) levin, the tenant may bring an action for illegal distress, i) which he can recover double value of the goods if they 1 ve been sold, and if the distress be made for rent and Ine be due (n), or the full value without deduction for rent i other cases $(o)$.

Formerly a landlord making an illegal distress (that is, ${ } \rightarrow$ where seizure is legal, but subsequent proceedings

Hogan r. Hand, 9 W. R. 673.

f) Pinhom v. Souster, 8 Exch. 763 ; I. J. Ex. 18.

Doe v. Thomas, 6 Exch. 857; 2) L. J. Ex. 367, and Pinhorn v. Siter, supra.

) Ante, p. 546 et seq.

Co. Litt., $160 \mathrm{~b} ; 47$ b.

As to when it is to be brought, Ior what goods, see Jacob v. King, aunt. 451 ; 15 R. R. 550 ; and
Niblet r. Smith, 4 T. R. 504.

(l) 51 \& 52 Vict. c. 43 , s. 134.

(m) 51 \& 52 Tict. c. 43, ss. 135, 136.

(n) 2 Wm. \& M., Sess. I., c. 5, s. 4 ; Masters v. Faris, 1 C. B. 715.

(o) Keen r. Priest, 28 L. J. Ex. 157; Attack v. Bramuell, 3 B. \& $\mathrm{S}$. $520 ; 32$ L. J. Q. B. 146 . As to man in possession, see Bayliss r. Fisher, $T$ Bing. 153. 
unlawful) was liable as a trespasser $a b$ initio $(p)$, but it was provided by statute, that where the rent was justly due, this should no longer be the rule, and that the tenant could recover in an action but for special damage only $(q)$.

The tenant may recover damages for excessive distress, and is not required to show special damages; he may sometimes recover only nominal damages $(r)$.

Disputes arising under the provisions of the Agricultural Holdings Act, 1883, with respect to distresses levied contrary to the provisions of that Act, may be determined by the County Court in which the holding is situated, or by a Court of summary jurisdiction (s), and the Court may make an order for the restoration of stock, or may declare the price to be allowed for feeding.

In cases of illegal or irregular distress, where the rent is under 15l., within the metropolitan police district, the tenant can recover his goods by a summary process before any of the police magistrates, who may, on the landlord making default in complying with any order made, order him to pay to the tenant the value of the distress, such sum not to exceed 15l. $(t)$.

Under the Lodgers' Goods Protection Act, the tenant may recover his goods, if taken in contravention of the provisions of the Act, by application to a magistrate, and also has a right of action against the superior landlord (u), In addition to having the power of distress, the landlord may bring an action to recover his rent, or the residue tha the distress did not satisfy $(x)$.

Where a lease is not by deed, the landlord can only

(p) Six Carpenters' case, 1 Sm. I. C., 9th ed. 144.

(q) 11 Geo. 2 c. 19, ss. 19, 20.

(r) 52 Hen. 3 c. 4 ; Chandlev r. Inoulton, 3 H. \& C. 553; 34 L. J. Ex. 89 . (s) 46 \& 47 Vict. c. 61, s. 46.

(t) 2 \& 3 Vict. c. 71, s. 39.

(u) 34 \& 35 Vict. c. 79, s. 2.

(x) Efford r. Burgess, 1 if. \& Rot 23 ; Lingham v. Warren, 2 B. \& I 36. 
-ecover arrears of rent for six years $(y)$; where the lease s by deed, he may sue on the tenant's covenant for twenty rear's' arrears (z). Under the Agricultural Holdings Act, 883 , distress can only be made for rent which became due ot more than one year previously $(a)$.

Besides these remedies, there is the common law right, onfirmed by statute, of the landlord to sue for use and cocuration. cupation $(b)$. This remedy exists in cases where there no actual contract of tenancy, but actual occupation, supled with an express or implied undertaking to pay for (c).

An action on the agreement is the proper remedy for ryments as "rent" which are not strictly rent $(d)$, such as percentage on an outlay for improvements (e), or payents reserved on an assignment of a lease $(f)$.

If, in the case of a letting of a furnished house, the uplied condition that the home is fit for habitation be not lfilled, the tenant may give up the house and furniture, d sue on the breach of contract $(g)$.

On breach of covenant for quiet enjoyment, the tenant is ieved from liability to pay rent $(h)$, and may, if there no eviction, sue for nominal damages for the actual cmage $(i)$. If the tenant be evicted, he may recover, in lition to the damage sustained, the value of the unexged residue of the term $(k)$.

1) 3 \& 4 Will. 4 c. 27 , s. 42 ; , than ₹. Thomas, 12 A. \& E. 536. ) $3 \& 4$ Will. 4 c. 42 , s. 3 ; lining v. Phelps, 10 Exch. 59; it v. Foley, 2 Bing. N. C. 679.

46 \& 47 Vict. c. 61, s. 44. Gibson v. Kirk, 1 Q. B. 850 ; reo. 2 c. 19 , s. 14.

Edge v. Strafford, 1 Cr. \& J. Conolly v. Baxter, 2 Stark. 527; T: h v. Wright, 1 T. R. $387 ; 1$ R.R. 2. Dauces v. Dowling, $22 \mathrm{~W}$. R. 779. Adams v. Hagger, 4 Q. B. D. 41 L. T. 224.

Lambert v. Torris, 2 M. \& W. (f) Parmenter v. Tebber, 8 Taunt. 593; 20 R. R. 575.

(g) Wilson v. Fineh Hatton, 2 Ex. D. $336 ; 46$ L. J. Ex. 489; Bird v. Lord Grerille, 1 Cab. \& El. 317; Smith v. Warable, 11 M. \& W. J. 'There is no implied promise that the furnished house shall continue tit for habitation throughout the term: Sorson v. Roberts, (1895) 2 Q. B. D. 39i), C. A. (h) Morrson v. Chadrich, 7 C. B. 283, 18 L. J. C. P. 189.

(i) Childr. Stenning, 11 Ch. D. S2; 48 L. J. Ch. 392 ; R. S. C.. Ord. XXXYI. r, 58.

(k) Williams r. Burvell, 1 C. B. 402.
Action on corenant. 
The landlord may sue for damages for injury to the reversion $(l)$ arising from the tenant's breach of the covenant to repair, or he may, if there be a clause in the lease to that effect, re-enter for forfeiture. In the latter case, the courts have discretionary power to grant relief to the tenant $(m)$.

Similarly, an action will lie against the tenant for injury to the reversion arising from acts of raste $(n)$. An injunction will not be granted against permissive waste $(o)$.

An injunction may be obtained against acts amounting to breaches of covenant to cultivate in a husbandlike manner $(p)$, but a mandatory injunction will not be granted to compel the lessee to cultivate in the manner prescribed by his lease $(q)$.

Under the Agricultural Holdings Act, 1883, the landlord may, on a claim for compensation, counterclaim for the amount of damage done by breach of covenant to repair, or acts of waste committed within four years previously $(r)$.

Holding over.

Where a tenant for "any term of life, lives, or years," wilfully holds over any lands or tenements after the determination of such terms, and "after a demand made and notice in writing given " for delivering possession thereof by the landlord or his duly authorised agent, he becomes liable to the landlord for double the annual value of the holding, which is to be recovered by action $(s)$. Where the tenant gives notice binding upon him to quit at the expiration of the notice, and upon which the landlord might bring an action of ejectment, and continues in possession, he is: similarly liable for double rent $(t)$.

(i) Morgan v. Hardy, 17 Q. B. D. $770 ;$ Williams r. Williams, L. R. 9 C. $1.659 ; 43$ L. J. C. I. 382 .

(m) $44 \& 45$ Vict. c. 41 , s. 14 .

(n) Whitham r. Kersharc, 16 Q. B. D. 613,54 L. T. 124 .

(o) Pourys r. Blagrace, 24 I. J. Ch. 143.

(p) Drury v. Molins, 6 Ves. $32 \mathrm{~s}$;
Crosse r. Duckers, 21 W. R. $28 \%$.

(q) Vusqrate r. Homer, 23 W. I 125, 31 L. T. 632.

(i) $46 \& 47$ Vict. c. 61, ss. 6 and 7

(s) 4 Geo. 2 c. 28 , s. 1.

(t) 11 Geo. 2 c. 19, s. 18

Johnstone v. Hudleston, 4 B. \&. C 935. 
In the former case, the double value cannot be recovered by distress $(u)$; in the latter, the double rent may be recovered either by distress or action; in both cases the action may be brought in the County Court if the amount claimed does not exceed $50 l$. $(x)$.

In former time there was a special action of ejectment, but now the action is one for the "recovery of land," and Action for is regulated by the rules of the Supreme Court. This form of action, and the effect of the Statute of Limitations thereon, are treated of in other parts of this work $(y)$.

(u) Timmins v. Rowlison, 3 Burr.

(x) Wickham v. Lee, 12 Q. B. 521 1605 .

(y) See p. 137. 


\section{CHAPTER VI.}

\section{EVIDENCE OF CUSTOI OR USAGE TO EXPLAIN WRITTEN CONTRACTS.}

Harisg in the previous chapters of this Book spoken of various kinds of written contracts, - of deeds, - of contracts required to be in writing by the Statute of Frauds and other enactments - of negotiable instruments-it is now proper to inquire respecting rules of interpretation and evidence applicable to such documents, so far, at all events, as those rules may be of practical importance in connection with ordinary mercantile transactions. An acquaintance with the forms and properties merely of particular instruments - with the principles which determine their validity,would avail little to the practitioner if unaccompanied by a knowledge of the elementary rules of evidence and of construction.

Of rules applicable for determining the meaning and intention of the parties to a written contract, a division intc two classes may be made; whereof the first will include those maxims to which the grammarian or logician would naturally have recourse, in order to explain an invertec sentence or a complicated phrase, and the second wil comprise such principles of construction as fall mor peculiarly within the lawyer's cognizance, whereby is regulated the admissibility of extrinsic evidence to explai language which either is in itself ambiguous, or, whel applied to extrinsic facts, becomes obscure and doubtful.

As falling under the former of the two classes of rules jus mentioned, the following well-known principles of constructios 
may be specified-that the true meaning of a word may often best be ascertained by looking at the accompanying words, or noscitur a sociis-that the express mention or specification of one thing must usually be understood as implying the exclusion of some other thing ejusdem generis not specified, expressio unius exclusio alterius $(a)$-that such words referred to should be read as if incorporated with the clause which makes reference to them, verba relata inesse videntur-that the relative must in general be taken as referring to the next antecedent, ad proximum antecedens fiat relatio, unless some other construction is, with a view to the meaning of the instrument, obviously needed. To the foregoing, some few analogous rules of construction-in their form of expression equally trite, and in their signification equally free from difficulty-might be added.

Now, it is obvious that the rules just enumerated are precisely those which an educated person would (without possessing legal knowledge) bring to bear upon the construction of any document submitted to his consideration. They are, indeed, rules of grammar rather than of law, and may accordingly be dismissed without further observation.

With regard to the second of the two classes of rules above mentioned, we must remember that, in certain cases, considerations of public policy and convenience require that unwritten contracts shall not be received in evidence;-that where the parties themselves have agreed to reduce into writing their contract, common sense has established the plain and intelligible rule, that the writing must bind, and that no spoken words can be allowed to relax or vary its obligation (b). "If A. and B. make a contract in writing, evidence is not admissible to show that A. meant something different from what is stated in the contract itself, and that

(a) Blackburn v. Flavelle, 6 App. Cas. 628 ; Ackers v. Howard, 16 Q. B. D. 739,753 .

(b) Per Lord Denman, C. J., 11 Ad. \& E. 598. 
B. at the time assented to it $(c)$. Similarly, where parties have made an executory contract, which is to be carried out by a deed afterwards executed, the real completed contract between the parties is to be found in the deed, and the written contract, even though recited in the deed, can only be referred to for the purpose of construing the deed itself. It cannot be looked at either for the purpose of enlarging or diminishing or modifying the contract which is to be found in the deed $(d)$. These well-known propositions are not, however, to be received without qualification or exception. Sometimes the language of a contract is ambiguous. Sometimes a rord or phrase occurring in it is of doubtful significance, or prima facie insensible. What mode of interpretation is then to be adopted with a view to carrying out, if possible, the intentions of the contracting parties? In attempting to answer this question, let us first advert to the rule of Lord Bacon, who tells us (e) that "there be two sorts of ambiguities of words: the one is ambiguitas patens, and the other latens. Patens is that which appears to be ambiguous upon the deed or instrument; latens is that which seemeth certain and without ambiguity for anything that appeareth upon the deed or instrument, but there is some collateral matter out of the deed that breedeth the ambiguity."

A simple instance of ambiguitas patens presents itsel where a blank occurs in some material part of a written con. tract $(f)$. "A latent ambiguity is where you show tha words apply equally to two different things or subject

(c) Per Pollock, C. B., Nichol v. Godts, 10 Exch. 124: Josling v. Kingsford, 13 C. B., N. S., 447, 457 ; Brady v. Oastler, 3 H. \& C. 112, 128 ; Malpas v. London and So. W. R. Co., L. R. 1 C. P. 336.

(d) Leggott v. Barrett, $15 \mathrm{Ch} . \mathrm{D}$. 306. See per Jessel, M. R., Prison Commissioncrs v. Clerk of the Peace for Middlesex, 9 Q. B. D. 511. (e) Max. reg. 25.

$(f)$ Wigr. Extr. Erid., 3rd ed., p 88. See also Saunderson v. Fiper, Bing. N. C. 425 ; Clayton $\checkmark$. Lor Nigent, 12 M. \& W. 200 . Parol evi dence may be admitted to show tha a written contract which has no dat was intended not to operate from if delivery, but from a future uncertai periud:'Davis v. Jones, 17 C. B. 625 
matters; and then evidence is admissible to show which of them was the thing or subject-matter intended " $(g)$. The word "ambiguous" is (we may remark) sometimes, not quite correctly, used in reference to that which is comprehensive or general. Properly speaking, however, an expression is "ambiguous" only when, from its very terms, it may mean either one thing or another; the use of a nomen gencrale, under which several different things may be included, does not necessarily create an ambiguity in the instrument containing it $(h)$.

Now, the short rule to be kept in mind with reference to the above two kinds of ambiguity is, that whereas extrinsic evidence is admissible to explain a latent, it cannot ordinarily be received to clear up a patent ambiguity. The application of this rule is, however, by no means free from difficulty, and can only be apprehended by a careful study and comparison of decided cases.

In general, no doubt, an ambiguity appearing within the four corners of an instrument must, as Lord Bacon observes (i), be removed, if at all, by construction (i.e., by a careful comparison of other portions of the instrument with that particular part in which the ambiguity arises), or by election (of which an example sometimes presents itself in the case of a grant or gift-the grantee or donee rendering, by his election of one specific thing out of several to which the words used might equally apply, that certain which was before uncertain); but never by averment or evidence of xtrinsic facts (k).

It would, nevertheless, be erroneous to suppose that exrinsic evidence is under no circumstances admissible to lear up a prima facie patent ambiguity in a written contract,

(g) Per Alderson, B., Smith v. effryes, 15 M. \& W. 561 ; Judgm., Bruff v. Conybeare, 13 C. B., X. S., 74, 275; Maedonald v. Longbottom, E. \& E. 977,987 . (h) See per Pollock, C. B., Ashworth

v. Dounsey, 9 Exch. 186, 187.

(i) Max. reg. 25.

(i) Id., ibid. 
Evidence to identify subjectmatter of contract-

for proof of facts may be given with a view to showing that the apparent uncertainty does not in truth exist; thus, if a thing be designated on the face of an instrument in terms imperfect and equivocal, admitting either of no meaning at all, when taken per se, or of a variety of different meanings, and referring tacitly or expressly for the ascertainment and completion of their meaning to extrinsic facts, it will be nc objection to the reception of evidence of those facts, that the ambiguity in question is manifested and arises directly on the face of the instrument $(l)$.

Speaking philosophically, indeed, we must always lool beyond the instrument itself, in order to ascertain it meaning $(m)$; thus, if the word Blackacre be used in lease, there must be evidence to show that the particula field is Blackacre $(n)$; "parcel or no parcel" being question of fact for the jury $(o)$, guided by the Judge as $t$ the construction of any documents which may be necessar. for its decision $(p)$. Now here the instrument appears o the face of it to be perfectly intelligible and free fror doubt, and yet extrinsic evidence must be received for th purpose of showing what the instrument refers to, or, $i$ other words, with a view to identifying the thing spoken or subject-matter of the contract $(q)$. In such cases, cour of law recognise that natural dependence which exis between language and the circumstances with reference which it is used, and which makes a knowledge of such ci cumstances or of facts within the knowledge of the parti necessary to a right interpretation of their language $(r)$.

(l) See per Sir Thomas Plumer, M. R., Colpoys v. Colpoys, Jac. 363, 364 .

(m) Per Rolfe, B., Clayton v. Lord Niegent, 13 M. \& W. 207.

(n) Per Coleridge, J., Doe d. Preedy v. Holton, 4 Ad. \& E. 82. See Bruff v. Conybearc, 13 C. B., N. S., 270 , 274; Lord Waterpark v. Fomell, 7 H. L. Ca. 650 .

(o) Mlanning v. Fitzgerald, 29 L. J.
Ex. 24 ; Harrison v. Hyde, Id. 11 S. $C ., 4$ H. \& N. 805.

(p) Lyle v. Richards, L. R. I L. 222 .

(q) See Mumford v. Gething, 7 13., N. S., 305; Mracdonald v. Loi bottom, 1 E. \& E. 977, 987; $\mathrm{AcCOl}$ v. Gilpin, 6 Q. B. D. 516.

(r) Per Coleridge, J., 4 Ad. \& 82; Wigr. Extr. Evid., 3rd ed., p. 
A few cases, illustrating what has been just said, in reference to ordinary trading contracts, may be useful :-

Where A. and B. trade under the firm of A., the name to partics A., when used in a contract relating to the particular trade, may in truth mean A. and B. ; and it has been held in the Court of Appeal that a bill of exchange, signed in the name of the one partner in whose name the business of a trading firm is being carried on is to be taken prim $\hat{a}$ facie to be the bill of the firm, though evidence is admissible to show that it was signed by the individual partner for private purposes $(u)$.

Let us next suppose that a vritten contract for the sale of goods is signed by C. Evidence will then be admissible io show that, in so signing it, he acted as agent for D., and not to discharge C. This point was decided in Higgins v. Fenior $(x)$, the Court observing, "There is no doubt that, where such an agreement is made, it is competent to show hat one or both of the contracting parties were agents for ther persons; and acted as such agents in making the ontract, so as to give the benefit of the contract on the ne hand to, and charge with liability on the other, the nnamed principals; and this, whether the agreement be $r$ be not required to be in writing by the Statute of rauds, and this evidence in no way contradicts the ritten agreement. It does not deny that it is binding n those whom, on the face of it, it purports to bind; ut shows that it also binds another, by reason that the ct of the agent, in signing the agreement, in pursuance t his authority, is in law the act of the principal. But, a the other hand, to allow evidence to be given that the arty who appears on the face of the instrument to be permally a contracting party is not such, would be to allow

(4) Yorkshire Banking Co. v. Beat, 5 C. P. D. 109 . See also $45 \& 46$ ct. c. 61, s. 23 .

B.C.L. (x) 8 M. \& W. 834 ; Armstrong $\nabla$. Stokes, L. R. 7 Q. B. 598, 607 ; Fleet v. Murton, L. R. 7 Q. B. 126, 131. 
parol evidence to contradict the written agreement; which cannot be done" $(y)$.

Again, parol evidence may be necessary in an action ex contractu, to show that the party sued is the person who made the contract declared upon, and who is bound by it. So whether a person contracts in his own name or in that of another, or in a feigned name, and whether the contract be signed by his own hand or that of an agent, are inquiries not different in their nature from the questionWho is the person who has just ordered goods in a shop? If he is sued for the price, and his identity is made out, the contract is not varied by appearing to have been made by him in a name not his own $(z)$.

The instances above given show that, in the most ordinary transactions, evidence dehors a written contract may be required, and will be admissible, to inform the Court or jury (as to whose respective functions in such cases some remarks will presently be offered) in regard to its true meaning and effect.

Mercantile terms-how explicable

Let us next suppose that terms are used in a written contract or mercantile instrument, which, although not familiar to the public, are known and understood by a particula class of persons in a certain special and peculiar sense evidence to that effect will be admissible, for the purpose of applying the instrument to its proper subject-matter and the case will be the same as if the parties in framin their contract had made use of a foreign language, whicl the Courts are not bound to understand. An instrumen so worded is not on that account void; it is certain an definite for all legal purposes, because it can be made $s$ through the medium of an expert. Conformably wit]

(y) Judgm., 8 M. \& W. $\$ 44$; Beckham v. Drake, 9 M. \& W. $79 ; S . C$. 11 Id. 315 ; 2 H. L. Ca. 579; per Williams, J., E. B. \& E. 1020-2.

(*) Judgm., Trueman V. Loder, 11
Ad. \& E. 594, 595 (as to which case, \& Judgm., 7 E. \& B. 278, 279 ; Broten: Byrne, 3 E. \& B. 703); per Moule, J Lindus v. Bradioell, 5 C. B. 591. 
these principles the Courts have long allowed mercantile instruments to be expounded according to the custom of nerchants, who have a style and language peculiar to hemselves, of which usage and custom are the legitimate nterpreters $(a)$.

Besides the case where an expression occurring in a ontract is wholly unintelligible, save to persons converant with the trade to which it relates, a term may re used therein which, besides its popular and ordinary neaning, bears also a technical signification. A doubt nay thereupon arise:-In which of its two senses, the rdinary or the technical is the word or phrase in uestion to be understood? This point will have to be etermined by the weight of evidence in favour of either iew which may be adduced $(b)$; subject, however, to the reliminary decision of the Court on inspection of the articular contract as to the admissibility of any extrinic evidence, such as tendered, to explain it $(c)$. Geneally speaking, the construction of a written contract is or the Court, unless it contains words of a technical or onventional use in a particular trade, in which case it is - may be for the jury $(d)$.

(a) Stark. Evid. 4th ed., p. 701, ed in Smith v. Wilson, 3 B. \& Ad. 8, 733 ; Myers v. Sarle, 3 E. \& E. 6 ; 30 L. J. Q. B. 9.

A mercantile usage once established recognised by the Courts without mal proof of it in each case. Steens v. Australasian Ins. So., I. R. C. P. 18,23 ; Imperial Mar. Ins. - v. Fire Ins. Corp., 4 C. P. D. 166, 1. Ante, p. 9.

(b) In Carter v. Crick, 4 H. \& N. 7, Pollock, C.B., observes, "that if rarty seeks to make out that certain rds used in a contract have a different septation from their ordinary sense, her for the purposes of trade or hin a certain market or a particular inty, he must prove it: not by ling witnesses, some of which say it one way and some the other, and then leaving it to the jury to say which they believe; but by clear, distinct, and irresistible evidence."

(c) Per Parke, B., Hutchison v. Bowker, 5 M. \& W. 542 .

In regard to the propositions abore laid down, see also Van Baggen v. Baines, 9 Exch. 523; Couturier $r$. Hastie, Id. 102; S. C., 8 Exch. 40 ; 5 H. L. Ca. 673 ; Griffiths v. Rigby, 1 H. \& N. 237 ; Attwood v. Emery, 1 C. B., N. S. 110 ; Orchard v. Simpson, 2 C. B., N. S., 299; Berwick v. Horsfall, 4 C. B., N. S., 460; Holt v. Collyer, 16 Ch. D. 718.

(d) Alexander v. Vanderzee, L. R. 7 C. P. 533, 534; considered in Boues v. Shand, 2 App. Cas. 455, 482 ; ace. Ashforth v. Redford, L. R. 9 C. P. 20 . 
In Simpson v. Margitson (e), the plaintiff, an auctioneer, claimed, under a written contract, certain commission upon the sale of an estate, "if sold by auction or within two months after." A sale of the estate was effected within two calendar months, though not within two lunar months, after the auction, and the Court held, that, although evidence would have been admissible to show that according to the usage of auctioneers, a ' month' signifies a calendar month, yet, in the absence of such evidence, the legal meaning of the word in question would be allowed to prevail. "It is clear," remarked Lord Denman, C. J., "that 'months' denote at law 'lunar' months, unless there is admissible evi dence of an intention in the parties using the word t denote 'calendar' months. If the context shows tha calendar months were intended, the Judge may adop that construction $(f)$. If the surrounding circumstance at the time the instrument was made show that th parties intended to use the word not in its primar. or strict sense, but in some secondary meaning, th Judge may construe it from such circumstances, accordin to the intention of the parties $(g)$. If there is evidenc that the word was used in a sense peculiar to a trade business, or place, the jury must say whether th parties used it in that peculiar sense $(h)$. If the meanin

(e) 11 Q. B. 23.

(f) Lang v. Gale, 1 M. \& S. 111 ; Reg. v. Chawton, I Q. B. 247.

A calendar month is a "legal and technical term." "In computing time by calendar months, the time must be reckoned by looking at the calendar, and not by counting days; " per Brett, L. J., Migotti $\nabla$. Colvill, 4 C. P. D. 238.

(g) Goldshede . Sucan, 1 Exch. 154; Walker v. Hunter, 2 C. B. 324 ; Bac. Max. reg. 10; Mallan v. May, 13 M. \& W. 511; Beckford v. Crutucell, 1 Moo. \& R. 187.

Where a contract is evidenced partly by writing, partly by proof of the haviour and conduct of parties, $t$ question as to what the contract w: will be for the jury: Moore r. Ge wood, 4 Exch. 681; per Lord Cam bell, C. J., Foster v. Mentor Life A. Co., 3 E. \& B. 79.

(h) Smith v. Wilson, 3 B. \& t 728 , where eridence was held adm sible, to show, that, by the custom the country in which a lease is ma the words "one thousand," when plied to rabbits, signified "twe hundred." This case shows that principle which regulates the admil bility of erilence to explain mercan 
of a word depends upon the usage of the place where anything under the instrument is to be done, evidence of such usage must be left to the jury" (i). The learned Judge further observed, that if technical words are used, the jury may have to assign their meaning $(k)$.

In accordance with the rules above laid down, Tindal, C. J., remarks, in Shore v. Wilson (l), that where any doubt arises as to the true sense and meaning of words used in a written instrument, or any difficulty presents itself as to their application under the surrounding circumstances, the sense and meaning of the language used may be investigated and ascertained by evidence dehors the instrument itself. Such investigation does of necessity take place in the interpretation of instruments written in a foreign anguage $(m)$-in the case of ancient instruments $(n)$; where, by lapse of time and change of manners, their words have acquired in the present age a different meaning rom that which they originally bore-in cases where terms of art or science occur-in mercantile contracts, which in nany instances use a peculiar language, intelligible to hose only who are conversant with trade and commerce-

ustruments is not confined to them, but pplies also to other kinds of contracts, hose, for instance, between landlord nd tenant.

See Grant v. Maddock, 15 M. \& W. 37 ; Myers v. Sarl, 3 E. \& E. 306 ; :0 L. J. Q. B. 9 ; Jolly v. Young. Esp. 186; Spicer v. Cooper, 1 Q. 3. 424 : cited Judgm., Sarl v. Bourillon, 1 C. B., N. S., 196.

(i) Citing Robertson v. Jackson, 2 B. 412 ; Bourne v. Gatliff, $11 \mathrm{Cl}$. F. 45 .

(k) See also per Lord Cairns, C., 3ouces v. Shand, 2 App. Cas. 462 et eq.

(l) 5 Scott, N. R. 1038. See also he observations of Parke, B., Clift v. chuabe, 3 C. B. 469.

(m) Di Sora v. Phillips, 10 H. L. 'a. 624 ; Stearine, \&c., Co. v. Heintzrann, 17 C. B., N. S., 56, 60. See - \& O. Steam Navigation Co. v.
Shand, 3 Moo. P. C. C., N. S., 272.

(n) Ancient grants and charters, when ambiguous, may be explained by evidence of modern usage : Calmady v. Rowe, 6 C. B. 861,893 , n. (a); Reg. v. Powell, 3 E. \& B. 377 ; Duke of Beaufort v. Mayor of Sicansea, 3 Exch. 413, 425; Reg. v. Master of Dulwich College, 17 Q. B. 600 ; Master Pilots, \&c., of Newcastle-upon-Tyne v. Bradley, 2 E. \& B. 428, n. (a); Bradley v. Master, \&c., of Newcastle, 2 E. \& B. 427. "It is not disputed that where the necessity of the case requires it, evidence of more recent usage and custom may be adduced for the purpose of explaining old or obsolete, or even imperfect expressions to be found in ancient documents. But the necessity must be apparent, the ambiguity niust be found to be existing." Per Bacon, V.-C., Delawarr (Earl of) v. Miles, 17 Ch. D. at p. 573 . 
and in other cases in which the words, besides their general common meaning, have acquired by custom or otherwise a well-known peculiar idiomatic meaning in the particular country in which the party using them was dwelling, or in the particular society of which he formed a member, and in which he passed his life. In all these cases evidence is admitted to expound the real meaning of the language used in an instrument, in order to enable the Court on Judge to construe it, and to carry such real meaning ints effect.

As illustrating the subject before us, tro cases may b mentioned. (1.) In Leidemann v. Schultz (o), it appeare that the defendant had chartered the plaintiff's vessel to proceed to Newcastle, and there to be ready forthwith, " $i$ regular turns of loading," to take on board a cargo of coa and coke. The Court of Common Pleas held, that, if ther were a usage at the port in question which could explain the expression above italicised, evidence of such usage wa admissible for that purpose. Evidence of this kind, how ever, will not be received if its admission would contradic another part of the contract. Thus, where a vessel under charter-party to go to Falmouth, and thence "to a saf port or as near thereto as she can safely get, and alway lay and discharge afloat," was ordered to Lowestoft, wher by reason of her draught she could not "always lay an discharge afloat," evidence that there was a custom of th port for vessels to be lightened in the roads before proceed ing into the harbour was held inadmissible, as going prove that Lowestoft did not mean Lowestoft, but som

(o) 14 C. B. 38 , with which compare Hudson v. Clementson, 18 C. B. 213.

See also, Tapscott $\mathrm{v}$. Balfour, L. R. 8 C. P. 46, followed Tharsis Sulphur Co. v. Morel, (1891) 2 Q. B. 647, and Good v. Isaaes, (1892) 2 Q. B. 555; Lawson v. Burness, 1 H. \& C. 396 ; Caine v. Horsfall, 1 Exch. 519 ; Cock- burn v. Alexander, 6 C. B. 79 Robertson v. French, 4 East, $130 ; 7$ R. 535 ; cited per Crompton, J., 4 B. S. 707 ; Carr v. Montefiore, 5 B. \& 408; Leeming v. Snaith, 162. B. 27 Moore v. Campbell, 10 Exch. 32 Gorrissen v. Perrin, 2 C. B., N. 681. 
thing else $(p)$. (2.) In Brown v. Byrne (q), the action was for freight by a shipowner against the indorsee of a bill of lading, which made certain goods deliverable to the order of the shipper or his assigns, he or they paying freight for the same at a certain rate per pound. The defendant having received the goods under the bill of lading, the question arose, whether he was entitled, by the custom of Liverpool, to claim a deduction of three months' discount from the freight? The Court held, on the authority of Hutton v. Warren $(r)$, that he was so entitled, for " the contract settles the rate of freight: whether or not discount is to be allowed on the payment, it leaves open; and to that the custom applies" $(s)$.

Not only may an expression which is susceptible of a technical meaning when occurring in a mercantile contract be thus, often, submitted for translation to the jury, but it is clearly established that an incident may be annexed to a written contract, either by the usage of trade or by the common law of the land $(t)$ in certain cases.

The custom of trade which is matter of evidence, may be used to annex incidents to all written contracts-commercial, agricultural, and others, - which do not by their terms exclude it; upon the presumption that the parties have contracted with reference to such usage if it is applicable $(u)$. "Customs of trade," it has been said, "consistent with

(p) The Alhambra, 6 P. D. 68; Hayton v. Irwin, 5 C. P. D. 130; post p. 586. See as to the meaning of the words "as near thereto as she may safely get," Capper v. Wallace, 5 Q. B. D. 163; cited in Nielson v. Wait, 14 Q. B. D. 522 ; Horsley v. Price, 11 Q. B. D. 244.

(q) 3 E. \& B. 703, cited and explained Judgm., Cuthbert v. Cumming, 10 Exch. $815 ; S . C ., 11$ Id. 405 ; and in Hall Y. Janson, 4 E. \& B. 500 ; followed in Graves v. Legg, 11 Exch. 645,646 ; S. C., 9 Id. 709; 2 H. \& N. 210 ; Lucas v. Bristow, E. B. \& E.
907,913 .

(v) 1 M. \& W. 466.

(s) See also Jones v. Clarkc, 2 II. \& N. $725 ;$ Allan v. Sundius, 1 H. \& C. 123; Gibson . Crick, Id. 142; Buckle v. Knoop, I. R. 2 Ex. 125.

$(t)$ Gibson v. Small, 4 H. L. Ca. 397 ; Kopitoff v. Wilson, 1 Q. B. D. 377, 381; Burges v. Wickham, 3 B. \& S. 669, 696 ; Biccard v. Shepherd, 14 Moo. P. C. C. 471 ; Lane v. Nixon, L. R. I C. P. 412; Johnsonv. Raylton, 7 Q. B. D. 438.

(u) Gibson v. Smalt, 4 H. L. Ca. 397.
Evidence to annex term to written contract. 
the terms of a written mercantile instrument, may be admissible, Tacite inesse videntur que sunt moris et consuetudinis" $(x)$.

Incidents may also be annexed to a contract by the custom of the country, or by the common law $(y)$.

As showing that evidence of custom is admissible to annex terms to a written contract provided they be not inconsistent with it, Wigglesworth v. Dallison (z) should be consulted. It was there held that a tenant, by lease under seal, might give in evidence a custom of the country that he should have the way-going crop after the expiration of his term, such custom not being repugnant to the express words and covenants of the lease. "The custom," said Lord Mansfield, " only superadds a right which is consequential to the taking -as a heriot may be due by custom, although not mentioned in the grant or lease."

In Syers v. Jonas (a), the contract under consideration of the Court was purely mercantile. It was for the sale of a specific parcel of tobacco, no reference being made to any sample, and yet evidence was received to show, that, by the usage of the tobacco trade, all sales were by sample, whether the contract did or did not so specify. The evidence proffered was here held to be receivable, upon the ground that the incident sought to be annexed to the written contract was not inconsistent with it, nor impliedly excluded by it; and the general rules laid down in former decisions were fully recognised and affirmed.

In Metzner v. Bolton $(b)$, the declaration stated that the

(x) Judgm., Suse v. Pompe, 8 C. B., N. S., 567 ; per Blackburn, J., L. R. 7 C. P. 103. 397.

(y) Gibson v. Sinall, 4 H. L. Ca.

(z) Dougl. $201 ; 1 \mathrm{Sm}$. L. C., 9th ed., p. 569.

See also Faviell v. Gaskoin, 7 Exch. 273 ; Hutton v. Warren, 1 M. \& W. 466 ; Muncey r. Dennis, 1 H. \& N.
216; Symonds v. Lloyd, 6 C. B. N. S., 691.

(a) 2 Exch. 111, with which compare Phillipps v. Briard, 1 H. \& N. 21; Harnor v. Groves, 15 C. B. 667.

See also Lockett v. Nicklin, 2 Exch. 93.

(b) 9 Exch. 518, cited per Martin, B., Wheeler v. Bavidge, Id. 671 ; Parker v. Ibbetson, 4 C. B., N. S., 352. 
plaintiff entered into the service of the defendant as a commercial traveller, at a yearly salary, and that the defendant agreed to continue him in his employ for a whole year, but discharged the plaintiff before the expiry of the time specified. The promise having been put in issue, at the trial the plaintiff himself was called as a witness, and in cross-examination admitted that there was a usage in the trade to dismiss with three months' notice; and the Court thought that evidence of this usage was properly admissible to annex a term to the written contract, for "general usages are tacitly annexed to all contracts relating to the business with reference to which they are made, unless the terms of such contracts expressly or impliedly exclude them."

In Humfrey v. Dale (c), evidence of usage in a paricular trade was held admissible to fix with liability as principals brokers, who in that character had signed a sontract for the purchase of oil, which was therein de;cribed as sold to their principals-such usage not contralicting the written instrument, but explaining its terms or adding to them a tacitly implied incident $(d)$. And ;enerally, any one of the public who enters into a contract in the Stock Exchange through his broker, a member of he Exchange, impliedly agrees that all reasonable (e) rules nd customs of the Stock Exchange affecting the rights nd liabilities of parties to such contract shall be imported ato and become part of it, and be binding upon himself, he principal, as well as upon his agent, the broker $(f)$.

(c) 7 E. \& B. 266 ; S. C., affirmed B. \& E. 1004 ; Fleet v. Murton, R. 7 Q. B. 126; Hutchirison v. atham, L. R. 8 C. P. 482. In Southell v. Bowditch, 1 C. P. D. 374 , there as no evidence of usage.

(d) See also Field v. Lelcan, 6 H. \& 617, commenting on Spartali v. enecke, 10 C. B. 212.

(e) See Robinson v. Mollett, L. R.
7 H. L. 802, cited post, p. 592, and distinguished in Ex parte Rogers, 15 Ch. D. 207 ; see also Neilson v. James, 9 Q. B. D. 546; Seymour $\vee$. Bridge, 14 Q. B. D. 460 ; Perry v. Barnett, Ib. 467 ; cf. Blackburn v. Mason, 68 L. T. 510 .

(f) See for instance, Maxted $\mathbf{v}$. Paine, L. R. 6 Ex. 132, and 4 Ex. 81 ; Nickalls Y. Lerry, L. R. 7 H. L. 530; 
Evidence of usage inadmissible to vary the terms of a written contract.

The limitation of the leading rule just intimated must, however, be carefully kept in view. Evidence of usage is inadmissible if it be inconsistent with, or if expressly or by implication it contradicts the terms of the written contract between the parties $(g)$. " Usage," says Lord Lyndhurst, C. B. (h), " may be admissible to explain what is doubtful ; it is never admissible to contradict what is plain" (i).

In $W e b b$ v. Plummer $(k)$, it appeared that the plaintiff had held a farm under a lease containing a covenant that the lessee should, on an assignment of the term, be paid by the incoming tenant for certain specified matters connected with the cultivation of the farm. The action was brought to recover a sum of money for foldage (l), being an allowance which, by the custom of the country, was pay. able to an outgoing by an incoming tenant, but which was not mentioned in the covenant. This evidence was held to be inadmissible, upon the ground that the express stipula tion for certain specified allowances excluded a claim fo: any other matter; Bayley, J., observing, that if the leas had been silent as to the terms upon which the tenant wa to quit, the custom of the country might have been relier upon as evidence in support of the right, but that th

Kellock v. Enthoven, I. R. 9 Q. B. 241 ; Duncan v. IIill, L. R. 8 Ex. 242 (distinguished Hartas v. Ribbons, 22 Q. B. D. 254); Bowring v. Shepherd, I. R.6 Q. B. 309; Grissell v. Bristoue, L. R. 4 C. P. 36, 45, 46; Lord Torrington v. Lowe, Id. 26; Daris v. Howard, 24 Q. B. D. 691.

(g) See Judgm., 3 E. \& B. 703 ; Preston v. Merceau, 2 W. Bl. 1249.

(h) Blackett v. Royal Exch. Ass. Co., 2 Cr. \& J. 219; as to which see per Cockburn, C. J., Mycrs v. Sarl, 3 E. \& E. 316,317 ; Miller v. Tetherington, 7 H. \& N. $954 ;$ S. C., 6 Id. 278,288 ; Hall v. Janson, 4 E. \& B. 500; Stewart v. Merchants, \&c., Co., 14 Q. B. D. 555 ; 16 Id. 619 .

(i) See Judgm., Croutch v. Crédit Foncier of England, L. R. 8 Q. B.
386 ; Godts v. Rose, 17 C. B. 224 234. Smith v. Jeffiryes, 15 M. \& II 561 , will, if carefully scrutinized, found useful as showing the differen which exists between evicience mere explanatory of the meaning of a $\mathrm{wo}$ used in trade, and evidence whis goes beyond this limit, and would ha the effect of setting up a new contra between the parties. See also Nich v. Godts, 10 Exch. 191, 194; Barro v. Dyster, 13 (2. B. D. 635 .

(k) 2 B. \& Ald. $746 ; 21$ R. R. 47

See also Re Stroud, 8 C. B. 502, a cases there cited; Clarke v. Roystor 13 M. \& W. 752.

(l) See Roberts v. Barker, $1 \mathrm{C}$ \& M. 808 ; Termes de la Ley, t "Faldage." 
distinct mention of some allowances excluded other's not named.

The following remarks of Mr. Justice Coleridge, delivering judgment in Broun v. Byrne (m), exhibit clearly the foundation and limits of that particular rule of our law of evidence, to an examination of which this chapter is principally devoted. "Mercantile contracts," observes the learned Judge, "are very commonly framed in a language peculiar to merchants : the intention of the parties, though perfectly well known to themselves, would often be defeated if this language were strictly construed according to its ordinary import in the world at large; evidence, therefore, of mercantile custom and usage is admitted, in order to expound it and arrive at its true meaning. Again, in all contracts, as to the subject-matter of which known usages prevail, parties are found to proceed with the tacit assumption of these usages; they commonly reduce into writing the special particulars of their agreement, but omit to specify hese known usages, which are included, however, as of course, by mutual understanding: evidence, therefore, of such incidents is receivable. The contract, in truth, is partly express and in writing, partly implied or understood ind unwritten. But, in these cases, a restriction is estabished on the soundest principle, that the evidence received nust not be of a particular which is repugnant to, or neonsistent with, the written contract. Merely that it raries the apparent contract is not enough to exclude the vidence; for it is impossible to add any material incident 0 the written terms of a contract without altering its iffect more or less. Neither in the construction of a conract among merchants, tradesmen, or others, will the sridence be excluded because the words are, in their rdinary meaning, unambiguous; for the principle of ad-

(m) 3 E. \& B. 703 (the facts in which ase are shortly stated, ante, p. 583), followed in Lucas y. Bristow, E. B. \& E. 907,913 . 
mission is, that words perfectly unambiguous in their ordinary meaning are used by the contractors in a different sense from that. What words more plain than ' a thousand,' ' a week,' 'a day'? 'Yet the cases are familiar in which 'a thousand' has been held to mean twelve hundred $(n)$; 'a week' a week only during the theatrical season $(0)$; 'a day' a working day $(p)$. In such cases the evidence neither adds to, nor qualifies, nor contradicts, the written contract; it only ascertains it by expounding the language" used by the contracting parties $(q)$.

Questions as to admissibility and effect of evidence of usage, \&c., how determined.

Here it may, perhaps, be asked-How are the various questions which arise respecting the construction of written contracts and the admissibility of evidence explanatory of them to be determined? Such questions, first, may be purely of law, for the opinion of the Court; or, secondly, may involve matter of fact as well as of law; or, thirdly, may be wholly for the jury. In regard to the two former classes of cases the following remarlis of Erskine, J., in Shore v. Wilson ( $(\cdot)$ are instructive :-

"The first general rule," said that learned Judge, "is that all instruments in writing are to be construed by the Court (s), and the meaning of the terms employed is to be ascertained and fixed by reference to the whole instrument but to nothing beyond it, unless specially referred to in the instrument itself. But this rule is subject to many excep tions. First, where the instrument is in a foreign language in which case the jury must ascertain the meaning of th

(n) Smith r. Wilson, 3 B. \& Ad. 728 (ante, p. $580(h)$, cited per Lord Cranuorth, C., Mackenzie v. Dunlop, 3 Macq. H. L. Ca. 26, who remarks that "General usage can only be proved by the multiplication of particular usages:" Id. 27.

(c) Grant v. Maddox, 15 M. \& W. 737. Et vide Mfyers v. Sarl, 3 E. \& E. 306 ; 30 L. J. Q. B. 9.

(p) Cochran v. Retberg, 3 Esp. 121.

(q) See also Russian Steam Nat.
Co. จ. Silva, 13 C. B., N. S., 610 cited Judgment, Southampton Stear Colliery Co. v. Clarke, L. R. 6 Ex. 56 Kidston v. Empire Ins. Co., L. R. C. P. $357 ; 1$ Id. 535 . See Lohre Aitchison, 3 Q. B. D. 558, 567.

(r) 5 Scott, N. R. 988.

(s) The reason of the rule being that the Court is supposed to be bette qualified than a jury for dischargin this duty : vide per Maule, J., 5 Scot N. R. 979 . 
terms upon the evidence of persons skilled in the particular language. Secondly, if the instrument be a mercantile contract, the meaning of the terms must be ascertained by the jury, according to their acceptation amongst merchants. Thirdly, if the terms are technical terms of art, their meaning must in like manner be ascertained by the evidence of persons skilled in the art to which they refer. In such ases the Court may at once determine, upon the inspection of the instrument, that it belongs to the province of the jury so ascertain the meaning of the words; and therefore that in the inquiry extrinsic evidence to some extent must be idmissible" $(t)$.

Besides the above, there are also some other cases in which he meaning of words employed in a written instrument is a it subject of inquiry upon evidence before a jury; but these urise not out of the language of the writing itself, but in :onsequence of facts that are brought to the knowledge of he Court by evidence dehors the instrument. "In such ases, the first duty of the Court is to ascertain the meaning If the words themselves, taken in connection with the whole ontext, and next to apply them to their proper object. In scertaining the meaning of any particular terms, the first ule is, that they are to be taken in their plain and ordinary neaning, unless from the context it should appear that the rarty has used them in a different sense. The first step in he inquiry, therefore, would be, whether it appears upon he face of the instrument itself that the writer has used the erms in any particular or extraordinary sense; for, if that hould be the case, then the instrument must be construed

( $t$ ) In Lewis v. Marshall, 7 M. \& r. 743, 744, the Court observe, "We ike the acknowledged distinction to be lis:-If the evidence offered at the ial by either party is evidence by law Imissible for the determination of the uestion before a jury, the Judge is ound to lay it before them, and to call upon them to decide upon the effect of such evidence; but whether such evidence, when offered, is of that character and description which makes it admissible by law, is a question which is for the determination of the Judge alone, and is left solely to his decision." 
according to that particular sense, whether more or lesi extensive than the primary meaning of the words themselves But if no such intention appears upon the face of the writing, it then becomes the duty of the Court to construe the words according to their plain, general, ordinary meaning (u), subject to certain qualifications. First, if the words used be technical terms of law, the Court must take them according to their strict legal acceptation, although ir general and ordinary use they may have acquired a mor extensive or a more limited sense; secondly, whether the are technical terms of law or words of ordinary use, the Cour may give them a more enlarged or more limited construc tion, whenever it is found that they cannot otherwise b applied at all" $(x)$.

In Gether v. Capper (y) two methods of construing mer cantile contracts are thus indicated by Maule, J.,--sucl instruments, he remarked, "are frequently so framed as t require considerable force of construction to apply them ; an in such cases the Courts have considered that they ought $t$ be dealt with so as to give effect to the general intent that i to be gathered from the whole of the instrument," this rul of construction is, however, "to be had recourse to onl in cases of necessity, where it is pretty clear that the partie

(u) “The general rule," says Tindal, C. J., 5 Scott, N. R. 1037, "I take to be, that, where the words of any written instrument are free from ambiguity in themselves, and where external circumstances do not create any doubt or difficulty as to the proper application of those words to claimants under the instrument or the subjectmatter to which the instrument relates, such instrument is always to be construed according to the strict, plain, common meaning of the words themselves; and that, in such case, evidence dehors the instrument, for the purpose of explaining it according to the surmised or alleged intention of the parties to the instrument, is utterly inadmis. sible."
"Where the intention of the partic to a contract is sufficiently apparen: effect must be given to it in that senst though some riolence be thereby dor to its words. Where the intention doubtful, the safest course is to tak the words in their ordinary sense. Per Cressicell, J., Witson r. Bevan, C. B. 684 .

See Coras v. Bingham, $23 \mathrm{~L}$. Q. B. 26 ; Seceeting v. Darthes, 14 C B. 538 ; Reid v. Fairbanks, 13 C. I 692; Heseltine v. Siggers, 1 Excl 856 ; per Parke, B., Bland v. Croucle! 6 Exch. 529.

(x) Per Erskine, J., 5 Scott, X. I 988, 989.

(y) $10^{\circ}$ C. B. 707 ; S. C., Id. 39. 
had some intention which cannot take effect at all, if a rigid mule of construction be applied to the instrument." But again-it is imperative on the Court "to adhere to the anguage of the contract where it has provided exactly for he event which has happened. A party has a right to Bay-'I have used language which aptly expresses my ntention, and therefore it is unnecessary to have recourse o the power of construction which is applied to obscure und doubtful contracts. I only ask of the Court to give the latural meaning to the words used in the instrument before t, without looking either to the right or to the left.'"

In regard to the third class of cases specified at p. 588, it rill be sufficient to say, that where there is an election to be aade between two meanings, either of which is assignable o a phrase or expression occurring in a written contract, or etween two or more persons or things to which such conract may relate, the question will properly be one for the ury, not for the Court to determine $(z)$.

Where, moreover, a question as to usage or custom arises pon a mercantile contract or upon a lease, and the jury are harged with its solution, the matter for their consideration ill be:-whether there was a recognised practice and usage ith reference to the transaction out of which the particular ritten contract, which is the subject matter of the action, cose, and to which it related, which gave a particular sense , the words employed in it, so that the parties might be apposed to have used the words in such sense $(a)$; or hether there was, in truth, any local custom such as it had zen proposed to annex to the written contract.

The character and description of evidence admissible for ie purpose of thus annexing a term to a mercantile contract, the fact of a general usage and practice prevailing in the urticular trade or business, not the judgment and opinion (z) See per Maule, J., Smith v.

(a) Judgm., 7 M. \& Gr. 744. sompson, 8 C. B. 59. 
of the witnesses who may be called to speak to it; for a contract may be safely and correctly interpreted by reference to the fact of usage, as it may be presumed that such fact. was known to the contracting parties, and that they contracted in conformity thereto $(b)$.

Assuming that evidence of usage in a particular branch of trade is admissible to explain mercantile expressions and to add incidents, or to annex usual terms and conditions which are not inconsistent with the written terms betreen the parties, we must add that the usage in question will be good only if it be reasonable, certain, and general, in the branch of trade or business in regard to which it is set up $(c)$. Such evidence, however, could not be admitted to convert a broker employed to buy for his employer, into a principal to sell to him, unless where the person employing the broker knew of and assented to the dealing on the footing of such custom $(d)$.

It may be collected from what has been thus far said that evidence of usage is admissible for various purposes in connection with the interpretation of written instruments.

Such evidence may, for instance, in some cases be adduced to annex incidents to them, to explain a particular word or phrase appearing therein, or to clear up and render definite and precise that which was indefinite and ambiguous. Confining my attention for a moment to the case of an ambiguous contract, we must remember that it rests with the plaintiff suing ex contractu, to set forth with precisior the agreement upon which he relies, and should he at the trial fail in establishing such an agreement, he may be

(b) Judgm., 7 M. \& Gr. 744.

(c) See Stephens v. Australasian Ins. Co., L. R. 8 C. P. 18 . In Stewart v. West India, \&c., Co., L. R. 8 Q. B. 88 , a particular custom, though disapproved of by the Court, had been expressly made part of the contract by the parties thereto. See also Berk- shire Woollen Co. v. Proctor, 7 Cush ing (U. S.), R. 422; Judgm., If Strond, 8 C. B. 531.

(d) Robinson v. Mollett, L. R. $7 \mathrm{H}$ L. 802,815 ; as to the full disclosur requisite before an agent can deal 8 principal with his employer, see $W i$ liamson v. Barbour, 9 Ch. D. 529. 
non-suited, or, at all events, may have to apply for leave to amend. Again, should the contract itself, which he then produces in evidence, be altogether ambiguous and meaningless, he will equally fail, because, as just observed, the onus is cast upon him of making out his right of action, and, further than this, of convincing the Court that the zonstruction which he has put upon the particular contract s the true one $(e)$.

In an Anonymous case $(f)$, illustrative of the foregoing emark, the jury found that the contract produced to them vas "quite unintelligible;" and the Judge was held justiied in ruling thereupon that the plaintiff had failed to ustain his declaration. Boden v. French $(g)$ may also be onsulted upon this subject.

Although in the present chapter I have not attempted to nter generally upon an examination of even the leading ules of construction applicable to written contracts, I canot at its conclusion forbear from giving a brief epitome f some of the rules alluded to-so worded as perchance, ithout much effort, to fix itself in the memory :-

"The sages of the law," it has been said $(h)$, "in the zposition of treaties, pacts, statutes, testaments, deeds, ad other instruments, have used and handed down to us les which are commended as the dictates of enlightened tason and common sense," whereof the following will Iffice for the present, viz.-

1. That the construction be made on the entire instruent and that one part of it do help to expound another, Id that every word (if it may be) may take effect, and ne be rejected, and that all parts do agree together, and

e) Where a promise is ambiguous, i to be construed "according to the se in which the promiser must be posed to wish and to believe that promise should be understood by promisee:" Judgm., Mowatt v. 'd Londesborough, 23 L. J. Q. B.

B.C.L.
177, 184 ; S. C., 3 E. \& B. $307,334$. (f) Cited per Jervis, C. J., 10 C. B. 889. See Duncan v. Topham, 8 C. B. 225.

(g) 10 C. B. 886.

(h) See arg., Randon v. Toby, 11 Howard (U. S.), R. ól1. 
there be no discordance therein-ex antecedentibus et consequentibus est optima interpretatio, for turpis est pars que cum suo toto non convenit, maledicta expositio que corrumpit textum.

2. That the construction be such as that the whole and every part of the instrument may take effect, and as much effect as may be for that purpose for which it was made (i).

3. To cavil about the words, in subversion of the plain intent of the parties, is a malice against justice and the nurse of injustice $(k)$.

4. A man ought not to rest on the letter only, nam qui haret in literi heret in cortice, but he ought to rely upon the sense, which is the kernel and the fruit, whereas the letter is but the shell $(l)$.

5. Falsa orthographia, falsa grammatica, non vitiat cartam vel concessionem; nor the singular instead of the plural number, nor the plural instead of the singular $(m)$.

6. The office of a good expositor is to make construction on all the parts together of an instrument, and not of one part only by itself-nemo enim aliquam partem recte intelliger possit antequam totum iterum atque iterum perlegerit $(n)$.

7. Construction must be made in suppression of the mischief and in advancement of the remedy $(o)$.

Should the construction proffered of an instrument be found to violate any of the rules above laid down, ex. gr. by dwelling upon a word only in disregard of the precedin and succeeding parts; should it corrupt the text or go bu skin-deep into its meaning, overlooking the general purpor and effect of the writing-we may at once reject it a fallacious, as based on wrong principles, and as likely $t$ frustrate rather than effectuate the intention of the con tracting parties.

(i) Shepp. Touch. 87 .

(k) See Throckmerton v. Tracy, Plowd. 161.

(l) Eyston v. Studd, Plowd. 467.

(m) Earl of Shrewsbury's case, 9
Rep. 48 a ; Co. Litt. 146 b.

(n) Lincoln College case, 3 Re $59 \mathrm{~b} ; 8$ Vin. Abr. 181.

(o) Co. Litt. 381 b. 


\section{CHAPTER VII.}

THE CAPACITY TO CONTRACT-HOW IT MAY BE AFFECTED.

I HAve now to speak of the capacity to contract-to show how in some cases this capacity may be affected by the haracter with which a contracting party is clothed-how 1 other cases, where the capacity to contract remains nimpaired, the mode of contracting is nevertheless ubjected to modification.

The matters intended for consideration in this Chapter zem naturally to subdivide themselves into two branches, f which the first will involve an examination of Contracts y Mercantile Persons, to wit, Principal and Agent artners - Incorporated Bodies - Bankrupts; and the cond will include such inquiries as may appear requisite regard to contracts by Non-mercantile Persons, to wit, emes Coverts, Infants, Non Compotes Mentis, Executors, id Administrators.

Sect. I.-Contracts with Mercantile Persons.

In treating of the mode of contracting by mercantile rsons, some brief remarks will first be made on the lation of Principal and Agent, which is one of paramount portance in regard to this inquiry.

"Agency," says Mr. Chancellor Kent in his Com- Agencyntaries $(a)$, "is founded upon a contract, either express tutecl. implied, by which one of the parties confides to the

(a) 12th ed., vol. 2, p. 614.

Q $Q 2$ 
other the management of some business to be transacted in his name or on his account, and by which the other assumes to do the business and to render an account of it." "The relation of principal and agent requires the consensus of both parties. There must be an express or implied assent to, or a subsequent ratification of, that relation" $(b)$. As the obligatory force of a contract rests on the consent of the contracting parties, so the authority of an agent tc contract for his principal rests on the consent of his principal ; and the question, whether there was consent tc the contract or to the authority, is to be tried according to the general principles for trying other questions $(c)$.

The maxim of the Roman law, Qui mandat ipse feciss videtur $(d)$, indicates briefly, but correctly, the ground 0 liability of a principal for the act of his agent; and, in the 6th Book of the Decretals (e) (which are a component par of the Corpus Juris Canonici $(f)$ ), we meet with the sam. rule, expressed almost in the form which is so familiar t our lawyers, Qui facit per alium est perinde ac si faciat pe seipsum.

The mere enunciation of the maxim stated shows ho wide must be its practical applicability; and a littl reflection will convince us, that comparatively few mercar tile transactions, or contracts made in the ordinary cours of life, are conducted exclusively by the principals, and witt out the intervention of any third party. A merchant, $f c$ example, employs his clerk to write his usual busines letters, to keep his books, and, not unfrequently, to condur his most confidential and important negotiations. So, if

(b) Per curiam, Markwick v. Hard. ingham, 15 Ch. D. 349. The acceptance by an agent, acting in excess of his authority, of an offer, may be ratified, and the contract so become binding, even although before ratification the offer has been withdrawn: Bolton $\vee$. Lambert, 41 Ch. D. 29 is.

(c) Per Erle, J., Frost r. Oliver, 2
E. $\mathbb{S}$ B. 318 .

Obligatio mandati consensu conta hentium consistit. D. 17. 1. pr.

(d) Mandare est gerendum aliqn alicui committere. Brisson ad res "Mandare."

(c) Ad finem. (Reg. Jur. 72.)

(f) As to which see Irring's Cir. I 4th ed., pp. 231-235. 
person enters a shop, in order to purchase the common necessaries of life, he will, in most cases, have to deal not mmediately with the principal, but with his servant or agent, ntrusted with the management of his business, whose duty $\mathrm{t}$ is to hand over to customers such things as may be reunired, and who is authorised to receive from them the price.

It is, moreover, a true proposition, subject only to some ew exceptions, that "whatever a man sui juris may do of rimself he may do by another" $(g)$; and hence we may eadily infer, that the matters transacted through the medium f agents are vastly multifarious. The question, indeed, in 11 cases in which a plaintiff seeks to fix a defendant with iability upon a contract, express or implied, must necessarily e "whether" such contract was made by the defendant by imself or his agent, with the plaintiff or his agent" (h), and ot merely whether the contract was entered into by the arties treating directly with each other. "It is a.clear ale that where a person is professedly acting as agent for nother the principal is bound, and not the agent" (i).

There are, indeed, some persons, ex. gr., infants, married omen, idiots, and lunatics, who, for reasons which will be secified in the subsequent section of this Chapter, are holly or partially incapable of contracting, and who are, lerefore, to a like extent, incapacitated from contracting $r$ agent. It by no means, however, follows that a person capable of contracting on his own behalf is incapacitated om acting as agent for another; thus, an infant may, in any cases, act as agent for an adult $(k)$, and, apart from

g) Story on Agency, 9th ed., p. 2. l'o the above rule there are, however intimated in the text), some excepas. Thus, in Combes's case, 9 Rep. a, it is said that "there are some ugs personal and so inseparably an:ed to the person of a man that he not do them by another." So the formance of a work of taste or art fided to A. could not by him be dele. gated to B. ; nor could a judicial officer, unless under some special statutory provision, depute his functions to another.

(h) Judgm., 15 M. \& W. 526. See Coombs v. Bristol and Exeter R. C., 3 H. \& N. 1. 291 .

(i) Judgm., Lee v. Ererest, 2 H. \& S. $_{\text {. }}$

(i) Co. Litt. 52 a. See Lord $\vee$. Hall, 8 C. B. 627 . 
special legislation on this subject, a married woman is held to contract as the agent of her husband.

The authority confided to an agent may be of one or other of three kinds: There may be, 1 . an express limited authority given to the agent to do some particular act, or to make scme particular contract; 2 . a larger authority, to make all con. tracts or to do all acts connected with a particular trade, business, or employment $(l)$; or, 3 . an authority to do all acts, without reference to their precise character, which the principal may personally do, and which he may, without violating the law, do by deputy. The first of these three kinds of authority will suffice to constitute a special, the second, to constitute a general $(m)$, the third, to constitute an universal, agency; but, as this last species of agency is (as may readily be supposed) of rare occurrence, we may here properly confine our attention to the two former kinds.

Of a special agency, an example would occur, if I com. missioned a friend to purchase a specific thing for me and on my account; of a general agency, where my servant orders goods of the neighbouring tradesmen for $\mathrm{m} 5$ use without any express instructions from me, but in the usual and admitted course of his duty $(n)$.

In relation to this latter lind of agency, Dr. Story (o) remarks, that "one man may be a general agent for his principal in one business, and another may be his genera agent in another business : and, in such case, each agen will be limited in his authority to the particular businest within the scope of his peculiar agency." Thus, "if \& man should be at once a banker and a merchant, carryin!

(7) Story on Agency, 9th ed., p. 17.

(m) In Baines r. Eving, L. R. 1 Ex. 324, Channell, B., says, that there may be "a general agent for a special purpose, for example, an agent to sigu all bills of exchange." (n) See, per Lord Abinger, C. B., M. \& W. 181. Summers v. Solomon 7 E. \& B. 879, exemplifies the natur of a general agency.

(o) Story on Agency, 9th ed., p. 20 
on each business distinctly, with separate clerks and agents for each branch, an agent in the one would not be deemed to possess any authority to act in the other; although each would or might, in a legal sense, be deemed a general agent."

The fact of agency may be proved by showing an express authority given to the alleged agent; by showing circumagencyhow Iroved stances from which the requisite authority must necessarily or may reasonably be inferred $(p)$; or by establishing the zxistence of a particular relation between parties whence an puthority to contract will be implied by law: for instance, he relation of partners, by which relation, when complete, no partner becomes at common law the agent of the firm or all purposes necessary for carrying on their particular partnership, whether general or special, or usually belonging fo it $(q)$, or the relation of husband and wife, by virtue If which the law, under certain circumstances, considers he husband to make his wife an agent $(r)$.

To explain and illustrate these remarks, let us suppose hat an action for goods sold and delivered, or for work nd labour, is brought by $\mathrm{A}$. against $\mathrm{B}$. The plaintiff, intion for goods sold and delivered, \&c in whom, in such a case, the burthen of proof lies, aust, in order to recover against the defendant, show that e (the defendant) contracted expressly or impliedly rith the plaintiff; expressly, by making a contract with the laintiff; impliedly, by giving an order to him under such ircumstances as show that it was not to be gratuitously recuted; and if the contract was not made by the efendant in person, it must be proved that it was made $y$ an agent of the defendant duly authorised, and that it as made as his contract. Assuming that the contract in

(p) See Hogarth v. Wherley, L. R. C. P. 630 .

(q) See S. 5, Partnership Act, 90 (53 \& 54 Vict. c. 39$)$.

(r) Judgm., 15 M. \& W. 527 . See
Riley v. Packington, L. R. 2 C. P. 536 ; Serivener v. Pask, L. R. 1 C. P. 715 ; Wilson v. Glossop, 20 Q. B. D. 354 : post. 
the given case was made by a third person, the point for decision will be-whether that third person was an agent for the defendant for the purpose of making it, and made the contract as such (s).

Now, in accordance with what has been already said, the agency may, under the circumstances supposed, be constituted by an express limited authority to make such a contract, or a larger authority to make all contracts falling within the class or description to which it belongs, or a general authority to make any; or it may be proved by showing that such a relation existed between the parties as by law would create the authority. If proof to such effect be given, and if further it be shown that the agent in making the contract acted on the authority given to him ( $t$ ), the principal will be bound by the contract, and the agent's contract will be his contract, but not otherwise (u). Agency, then, may be created by the immediate act of the principal, that is, by really giving authority to the agent, or representing to him that he is to have it; or by constituting that relation to which the law attaches agency. It may also be created by the representation of the defendant to the plaintiff that the party making the contract is the agent of the defendant, or that such relation exists as to constitute him agent; and if the plaintiff really makes the contract on the faith of such representation, the defendant is bound because he is estopped from disputing the truth of it with respect to that contract $(x)$; and the representation

(s) Judgm., Reynell $v$. Lewis, and Wyld r. Hopkins, 15 M. \& W. 527; Cross v. Williams, $i$ H. \& N. 675 . See Higgins v. Hopkins, 3 Exch. 163; Bailey v. Macauley, 13 Q. B. 815: Patrick v. Reynolds, I C. B., N. S., 727 ; Riley v. Packington, L. R. 2 C. P. 536 .

(t) See Baines v. Euing, L. R. 1 Ex. 320 .

(u) Judgm., 15 M. \& W. 527. (x) Collingrood v. Berkeley, 15 C. B. x. S., 145. The rule is that "if a man so conducts himself, whether intentionally or not. that a reasonabl person would infer that a certain state of things exists and acts on that in ference, he shall be afterwards estopper from denying it:" per Bramucell, B. Cornish $\mathrm{v}$. Abington, 4 H. \& N. 556 Maddick v. Mrarshall, 17 C. B., N. S. $829 ;$ S. C., 16 Id. 387. 
of an authority is quoad hoc (by virtue of the doctrine of estoppel) the same thing as a real authority given by the defendant to the supposed agent. This representation may be made directly to the plaintiff, or made publicly, so that it may be inferred to have reached him, and may be made by urords or conduct $(y)$.

Upon none of the foregoing propositions is there any loubt; and the true decision of questions involving the law of agency depends upon the proper application of the prinsiples set forth in them to the facts; such application being made by the jury, with due assistance from the Judge.

Assuming that an agency of some kind does in any given ase exist, an important difference is to be noted between a general' and a 'particular' agency ; for, if a particular' gent exceeds his authority, his principal is not bound by vhat he does $(z)$; whereas, if a general agent exceeds his uthority, his principal is bound, provided what he does is rithin the ordinary and usual scope of the business which ie is deputed to transact. "If a man by his conduct holds ut another as his agent-by permitting him to act in that haracter and deal with the world as a general agent, he must

(y) Judgm., 15 M. \& W. 527, 528, 30 , where the operation of the above le is explained. Judgm., Freeman Cooke, 2 Exch. 662, approved in CeKenzie v. British Linen Co., 6 App. as. 101, 109, and in Miles v. IIC. 'wraith, 8 Id. 120 ; Webb v. Herne ay Commissioners, L. R. 5 Q. B. !2; cited Bank of Ireland v. Trustees Erans' Charity, 5 H. L. Ca. 399 ; ran v. North British Australasian 3., 2 H. \& C. 175 ; S. C., 7 H. \& $603 ;$ Ex parte Swan, 7 C. B., S., 400 ; London S. W. Bank v. intworth, 5 Ex. D. 96 ; Babcock v. zwson, 5 Q. B. D. 284 ; Sweeting v. revce, 7 C. B., N. S., 449 ; S. C., 9 - 534 ; and cases cited as illustrating e doctrine of estoppel in pais, post, jok III., Chap. 4.

(z) See per Erle, C. J., Sickens v. ring, 29 L. J. C. P. 25,$29 ; S . C$., C. B., N. S., 165 ; Brady v. Todd,
9 C. B., N. S., 592 ; from which case the rule deducible is this:- "If the servant or agent of a private individual entrusted on one occasion to sell a horse, without authority from his master, takes upon himself to warraut the soundness of the animal, the master is not bound. But if the servant of a horse-dealer, or even one who only occasionally assists him in his business, being employed to sell, gires a warranty, the principal is bound, even though the agent or servant was expressly forbidden to warrant. In such a case there is an ostensible authority to do that which is usual in the conduct of the business of a horse-dealer:" per Byles, J., Howard v. Sheward, L. R. 2 C. P. 152 ; Painter v. Abcl, 2 H. \& C. 113. See Brooks v. Hassall, 49 L. T. $569 ;$ Baldry v. Bates, 52 Id. 620 . 
be taken to be the general agent of the person for whom he so acts, and the latter is bound, though in a particular instance the agent may have exceeded his authority" (a). So, if one person authorise another to assume the apparent right of disposing of property in the ordinary course of trade, it must be presumed that the apparent is the real authority, because strangers can only look to the acts of the parties, and to the external indicia of property, and cannot know the private communications which may pass between a principal and his agent $(b)$. If, however, a shopman, who is authorised to receive payment for goods sold over the counter only, receives money elsewhere than in the shop, that payment would not necessarily be good. The principal might be willing to trust the agent to receive money for him in the regular course of business in the shop when the latter was under his own eye, or under the eyes of those in whom he had confidence, but he might not wish to trust the agent with the receipt of money elsewhere $(c)$.

A. employed B. to manage his business, to which the drawing and accepting of bills of exchange was incidental; but it was stipulated between them that B. should not draw or accept bills. B. having accepted a bill in the name of " $\mathrm{B}$. \& Co.," A. was held liable on the bill to an indorsee, who took it without knowledge of A. and B. or the business $(d)$.

(a) Per Pollock, C. B., Smith r. I'Guire, 3 H. \& N. 562. See Chapleo v. Brunswick Builling Society, 6 Q. B. D. 696 .

(b) Per Lord Ellenborough, C. J., Pickering v. Busk, 15 East, $38 ; 13$ R. R. 364; Cole r. North-Western Bank, L. R. 9 C. P. 740. S. C., affirmed L. R. 10 C. P. 354, and approved in City Bank v. Barrouc, o. App. Cas. 677 ; Brocklesby r. Temperance Building Society, (1895) A. C. 173.

(c) Judgm., Kaye v. Brett, 5 Exch. 274. See further, as exemplifying the text, Willians r. Evans, L. R. 1 Q. B. 352 ; Catterall r. Hindle, L. R. 2 C. P. 368 ; Bridges v. Garrett, L. R. 5 C. P.
451: Pape r. Westacott, (1594) 1 Q. B 272 (C. A.). The defendant, an auc tioneer, was instructed not to part wit a written liceuse for a lessee to assig. until he had received payment of arrear of rent. The defendant, haring parte with the license in exchange for cheque for the arrears of rent and hi charges which was dishonoured, wa held liable for the full amount of th arrears of rent.

(d) Elmunds v. Bushell, L. R. Q. B. 97. With this case ct Wattcau v. Fonuick, (1893) 1 Q. I 346 , where, although the facts vel different, a similar principle was af plied. 
In Cox v. The Midland Countics R.C.(e), it was held, that the station master of a railway company could not bind the company by a contract for surgical attendance on an injured passenger without express authority for that purpose $(f)$, for the employer of an agent for a particular purpose gives only the authority necessary for that agency ander ordinary cireumstances, or the power's usually exercised by similar agents, if there be any evidence to show a particular usage. "Could it," asked the Court, " be maintained that a coachman, from whose carriage a passenger had fallen and broken his arm, or by which another person had been run over, . . . conld bind his master by a contract with a surgeon to cure the injured person, and oblige his master to pay the bill? We are of opinion that he could 1ot."

The authority of the case just cited as exemplifying our present subject has not beeen altogether unquestioned, and To what matters authorits of agent learly the power confided to an agent must, unless a conexteudx. rary intention manifestly appears, be understood as stending to everything which is necessary for or usually ncidental to exercising it with effect, or carrying out the bject for which it was intrusted $(g)$. For instance, a

(e) 3 Exch. 268. Another point ised in this case was, as to the power i the company to appoint the servant, ho assumed to act in their behalf, ithout an instrument under seal-as " which, see post, title "Corporation." ee also Giles v. Taff Vale R. C., 2 - \& B. 822; Goff v. Great Northern :C., 3 E. \& E. 672; Poulton v. Lonin and South-Western R. C., L. R. Q. B. 534 .

$(f)$ The general manager of a railas company has, howerer, such an iplied authority : Walker v. Great Testern R. C., L. R. 2 Ex. 228. See so Kirkstall Brewery Co. v. Furness C., L. R. 9 Q. B. 468.

As to the authority of a bank anager to direct the prosecution of an cender see Bank of New South Wales Ouston, 4 App. Cas, 270. Instruc- tions to a house agent to procure a purchaser and negotiate a sale do not amount to an anthority to the agent to bind his principal br a contract tor sale of real or leasehold property : Chadburn v. Moore, 61 L. J. Ch. $6 i^{4}$.

(g) Story on Agencr, 9th ed., p. il; Bayley r. Willins, 7 C. B. 886 ; Westropp r. Solomon, S Id. 34j. "A master who sends his servant to buy goods, and gires him no money to pay. donbtless anthorises him to pledge his credit; and a person who employs au agent to purchase goods on the usual terms of any particular trade gives the like authority, and so in other in. stances:" Juidgm., 9 I. \& W. T1s. (See Summers r. Solomon. 7 E. it B. 879.)

In the abore and similar cases, the rule of law and common sense applies: 
solicitor having been once retained in an action, has clearly cast upon him the duty of taking the necessary steps during its progress, but is not obliged to consult his client, or to seek specific instructions from him prior to each successive step in the action. Where, therefore, the torn council of a borough retained a solicitor to take proceedings in opposition to a rule nisi for a mandamus which had actually been obtained against them, and (the rule having been made absolute) they ordered their return to the writ of mandamus to be filed, this was held to be a sufficient authority for the solicitor to appear for the corporation at the trial of certain issues raised on the return (h).

Let us take, on the other hand, the case of a solicitor who (without having a general retainer) is authorised to do some particular act; his authority will then necessarily be confined to doing such act; and his right to recover for work done and matters incidental thereto, as against his client, will depend upon whether the business charged for fell within the scope of the authority with which he was invested or not (i). A solicitor is not justified in pledging his client's credit to a bailiff or other officers for fees, which, according to the usual course of practice, he ought in the first instance to pay out of his own pocket $(k)$. The

quando aliquid mandatur-mandatur et omne per quod pervenitur ad illud (5 Rep. 116), a rule of which the precise mode of application must of course depend upon the particular kind of agency which may chance to be in question, and the nature and extent of the authority usually conferred thereby.

(h) Reg. v. Toun Council of Lichfield, 10 Q. B. 534. 65.

(i) See Dawson r. Lauley, 4 Esp.

As to the duty of a solicitor who has been retained to conduct a suit, see Whitehead v. Lord, 7 Exch. 691; Harris צ. Osbourn, 2 Cr. \& M. E29. As to his power to refer it, see Chou'n r. Parrott, 14 C. B., N. S., 74, and cases there cited; Smith r. Troup,
7 C. B. 757, 764; Favicll r. Eastem Counties R. C., 2 Exch. 344, 351 . Filmer v. Delber, 3 Taunt. 4\$6; 12 R. R. 685. As to his power to bind his client, see Jarmain r. Hooper, 6 M. \& Gr. 82-; Smith r. Keal, 9 Q. B. D 340 .

The implied authority of a counse or solicitor to consent to a compromise was considered in Sicinfen r. Sicinfen. 1 C. B., N. S., 364; Suinfen v. Lord Chelmsford, 5 H. \& N. 890: Straus r. Francis, L. R. 1 Q. B. 379 Chambers v. Mason, 5 C. B., X. S. 59; Prestucich v. Poley, 18 C. B. N. S., \$06; Mattheres v. Mrunster, 2 Q. B. D. 141 .

(k) Maile v. Mann, 2 Esch. 608 and cases there cited. 
solicitor in the cause has been held liable for the costs of executing a $c a$. sa. to the bailiff, although not specially nominated by him $(l)$. But this case has since been overruled, on the ground that, apart from a contract express or implied to pay such fees, the law casts no such liability upon solicitors $(m)$.

Much difficulty often exists in determining the extent of the implied authority of an agent; and, in reference to this point when it arises, the nature of the agency in question, and the law applicable to it, will demand special consideration $(n)$. An inquiry as to the peculiar power possessed by the master of a ship, in cases of urgency or necessity, to pledge the credit of the owner for repairs done to her, \&c. (o) - to sell or hypothecate the ship and cargo (p) will illustrate the force of the remark above made.

Besides the difficulty just indicated, another, having reference to fact rather than to law, not unfrequently

(l) Brever v. Jones, 10 Exch. 655.

(m) Royle r. Busby, 6 Q. B. D. 171.

(n) Hawtayne Y. Boume, 7 M. \& W. 595 , should be consulted in regard to the implied authority of an agent. It was there held, that the resident agent appointed by the directors of a mining company to manage the mine is not impliedly authorised by the shareholders of the company to borrow money upon their credit in any case of necessity, however pressing. See par. ticularly the judgment of Parke, B., in the above case: Ricketts $r$. Bennett, 4 C. B. 686 ; Burmester v. Noris, 6 Exch. 796; Treduen v. Boume, 6 M. \& TV. 461. An anctioneer entrusted with goods for sale by public auction has no implied authority from the vendor to warrant them: Payne v. Lord Leconfield, 51 L. J. Q. B. 642.

(o) Arthur v. Barton, 6 M. \& W. 138 ; Gunn v. Roberts, L. R. 9 C. P. 331, 336, 338; Edwards v. Havill, 14 C. B. 107; Beldon v. Campbell, 6 Exch. 886; Organ v. Brodie, 10 Exch. 149 ; Johns v. Simons, 2 Q. B. 425; Stonehouse v. Gent, Id. 431 (a); Frost r. Otiver, 2 E.\& B. 301; The Turgot,
11 P. D. 21. See also 19 \& 20 Tict. c. 97, s. 8 .

As to evidence of ownership and liability of registered owner, see ${ }_{1}$ yer's v. Willis, 17 C. B. 77 ; S. C., 18 Id. 886 ; Brodie v. Howard, 17 C. B. 109 ; Hackwood v. Lyall, Id. 124; Mackenzie r. Pooley, 11 Exch. 638; Whituell r. Pervin, 4 C. B., N. S., 412,416 ; Hibbs v. Ross, L. R. 1 Q. B. 534; Frazer r. Cuthbertson, 6 Q. B. D. 92.

As to the power of one part owner to bind another for repairs, see Preston v. Tamplin, 2 H. \& N. $363,684$.

(p) The Gratitudine, 3 Rob. 240 ; The Onuard, L. R. 4 Ad. \& Eccl. 38, 58; Cammell v. Sevell, $3 \mathrm{H}$. \& $\mathrm{N}$. $617,635,644 ;$ S. C., 5 Id. 728; Stainbank v. Fenning, 11 C. B. 51, 88; Stainbank $\mathrm{r}$. Shepard, 13 C. B. 418; Willis v. Palmer, 7 C. B., N. S., 340 , 360; Ilierboom V. Chapman, 13 M. \& WV. 230, 239; Hunter v. Parker, 7 M. \& W. 322; Benson v. Dunean, 3 Exch. 644; S. C., 1 Exch. 537; Abbott, Shipp., 12th ed., p. 310. See Athinson v. Stephens, 7 Exch. 567. Generally as to the duty of the niaster 
What was the meaning and intention of the contracting parties?
Respective liability of principal and agent in certain cases.

presents itself, viz., in determining whether the particular act or transaction in virtue of which it is sought to charge a supposed principal was done by, or took place with, the agent in that character, or on his own individual account; this question will, in general, require solution by the jury. Its nature may be illustrated by the cases below cited $(q)$.

Again, inasmuch as "a person acting in the capacity of an agent may undoubtedly contract in such a manner as to make himself personally liable" $(r)$, the meaning and intention of the parties at the time of entering into an alleged contract must be considered with a view to determining the liability upon it, and, in any case such as alluded to, the true question will be, "whether, from anything that passed between the parties at the time, it was understood by them that the plaintiff was to rely upon the personal security of the defendant" (s), for it will not suffice that credit was given to the latter party unless he has pledged his credit either expressly or by implication $(t)$.

A few leading propositions will now be laid down, and a fer cases will be noticed, showing the respective liability of principal and agent on a contract by the agent, 1 . oral, wholly or in part; 2. written, but not under seal; 3 . by specialty. The inquiry here suggested, however briefly conducted, may serve to throw some further light upon the relative position of principal and agent; the capacity of a soi-disant agent to bind his principal; and the mode in

in case of damage to the ship see Blasco v. Fletcher, 14 C. B., N. S., 147 ; Benson. . Chapman, 8 C. B. $950 ; S . C ., 5$ C. B. 330,6 M. \& Gr. 792. See also Gibbs v. Grey, 2 H. N. 22 ; Grey r. Gibbs, ld. 26; Barkev v. Highlcy, 15 C. B., N. S., 27 ; Bristore r. Whitmore, 9 H. L. Ca. 391; The Rona, 51 L. T. 28.

(q) See Weidner v. Hoggett, 1 C. P. D. 533 ; Woolfe r. Horne, 2 Q. B. D. 355 ; Holevoft v. Hoggins, 2 C. B. 488 ; Parrott r. Anderson. 7 Exch. 93; Williams v. Deacon, 4 Exch.
397 ; Thompson v. Bell, 10 Exch. 10 Wilkinson r. Candlish, 5 Exch. 91

fent $x$. Thomas, 1 H. \& N. 473,478 Jones $v$. Hughes, 5 Exch. 104; Cooki r. Secley, 2 Exch. 746.

(v) Per Ashhu'st, J., Maebeath T Haldimand, 1 T. R. 181 ; 7 R. R. 177

(s) Per Ashhurst, J., ubi supra Fennell r. Alexander, 3 E. of B. 283.

(t) Autey r. Hutchinson, 6 C. B $266 ;$ Marsh r. Daries, 1 Exch. 665 See Chambres r. Jores, 5 Exch. 229 Loffatt r. Dickson, 13 C. B. 343. 
which, with a view to his own protection from liability, an agent should contract.

1. Of contracts by an agent, oral, wholly or in part, the Purchase of contract of sale specially claims attention; and, in the first $\underset{\text { goods }}{\operatorname{gont}}$. instance, it will be well to determine what are the rights of the seller of goods where the purchase has been made by an agent disclosed or undisclosed, and whether residing in this country or abroad, at the time of the contract. Now, the law upon this subject was discussed in three leading cases, viz., Paterson v. Gandasequi (u), Addison v. Gunlasequi $(x)$, and Thomson v. Davenport (y), upon which is ounded the legal doctrine recognised at this day applicable io it $(z)$.

The rules thus settled and established may be briefly stated as under :-

Where an agent contracts for the purchase of goods as rincipal, he, by so doing, incurs a personal liability; and f the real principal be known to the vendor at the time of contract for the sale of goods being entered into by the gent dealing in his own name, and credit be given to the yent, this latter party only can be sued on the contract $(a)$. $\mathrm{f}$, however, in this case, the seller of the goods make his leetion (b) to debit the principal, he cannot afterwards resort b the agent $(c)$, the question whether credit was given to re agent or to the principal being for the jury, for whose uidance in resolving it evidence of custom and usage will subject to the remarks made in the preceding chapter) be dmissible $(d)$.

(u) 15 East, 62; 13 R. R. 368, reface v.; $2 \mathrm{Sm}$. L. C., 9 th ed., 378.

(x) 4 Taunt. 574; 13 R. R. 689 ; Sm. L. C., 9 th ed., p. 387 .

(y) 9 B. \& C. 78 ; 2 Sm. L. C., h ed., p. 395.

(z) Per Maule, J., Smyth r. Anderi, 7 C. B. 34 .

(a) Paterson v. Gandasequi, 15 ist, $62 ; 13$ R. R. 368, Preface v.;
Addison v. Gandasequi, 4 Taunt. 574; 13 R. R. 689 ; Thomsan v. Darenport, 9 B. \& C. 78.

(b) As to evidence of election, see Calder v. Dobell, L. R. 6 C. P. 486 , citing Higgins v. Senior, 8 M. \& WV. 834 , and other cases.

(c) Per Lord Tenterden, C. J., and Littledale, J., Thomson v. Davenport, supra.

(d) See Curtis r. Williamson, L. R. 
Where the real principal in a contract for the purchase of goods (residing in this country) is unknown at the time of contracting, whether the agent represent himself as agent or not, the vendor may, on discovering the principal, debit either at his election (e), unless, indeed, something has been done to show an election on the part of the seller to take the agent as the actual buyer $(f)$, and to exonerate the principal $(g)$.

In cases where the principal has obtained goods through his agent, he will not be able to discharge himself from liability to the vendor by payment to his agent, even though such payment be made bon $\hat{\imath}$ fide and before his name has been disclosed. There is, however, a class of exceptions th this rule, as to which it was laid down by Parke, B., ir Heald v, Kenworthy (h), that, "if the conduct of the selle1 would make it unjust for him to call upon the buyer for the money, as, for example, where the principal is induced by the conduct of the seller to pay his agent the money, on thr faith that the agent and seller have come to a settlement or the matter, or if any representation to that effect is madi by the seller, either by words or conduct, the seller canno afterwards throw off the mask and sue the principal." Th discharge of the principal is here limited to cases where th seller is estopped by his own words or acts, but the exception has been stated with greater width by Lord Tenterden, C. J. and Bayley, J., who in Thomson v. Darenport (i) laid it dom

10 Q. B. $5 \pi, 59$. The liability of an agent who purchases goods at $a$ sale by auction was considered in IIlliamson v. Barton, 7 H. \& N. 899.

(e) Thomson r. Darenport, 9 B. S C. 78. Per Parke, J., Robinson v. Gleadou, 2 Bing. N. C. 161, 162; Patesson r. Gandasequi, 15 East, 62 ; 13 R. R. 368, Preface $\vee$.; Railton $\mathrm{r}$. Hodgson, 4 Taunt. 576, n.; 13 R. R. 691 , n.; Wilson v. Hart, 7 Taunt. 295. See Newall v. Tomlinson, L. R. C. I'. 405 .

(f) Per Maule, J., Smyth r. Ander. son, 7 C. B. 34 .

(g) Per Bayley, J., 2 B. \& C. $\$ 9$.

(h) 10 Exch. 739 . See per Mauh J., Smyth 8. Anderson, 7 C. B. 35 Sinethurst $\nabla$. Mitchell, 1 E. \& E. 622 Campbcll r. Hicks, 28 L. J. Ex. 70 Macfarlane v. Giamnacopmlo, 3 H. S I 860 ; Risbourg v. Bruckner, 3 C. B N. S., 812.

(i) 9 B. S C. 86 ; 2 Sm. L. C.. 91 ed., p. 395. See per Martin, B., Barb v. Pott, 4 H. \& N. $759,767:$ p Hill, J., Smethurst v. Mitchell, u supra. 
hat the right of the seller to recover against the subsequently liscovered principal might be defeated by an alteration of the state of the account between the principal and his agent, as, or instance, by payment of the agent by the principal, or f there was anything in the transaction which made it nequitable or unjust that the principal should pay. These lifferent opinions have more recently been considered in ome important cases, to which special reference will be nade.

In Armstrong v. Stokes ( $k$ ), the facts were as follows:The plaintiff had been in the habit of having dealings with Armstrong i. \& Co., who were commission merchants, acting someimes for themselves and sometimes as agents. The plainiff never inquired whether they were principals or not, and lways settled with them. The defendants gave R.\& Co. n order for some white shirtings; the course of business etween them had previously been that $R$. \& Co. bought rey shirtings in the market, bleached them white, and harged the defendants with the cost of the shirtings, leaching, packing, \&c., plus one per cent. commission. he defendants thereupon used to pay R. \& Co., and were ever brought into communication with any other parties. 1 the present case R. \& Co. obtained shirtings from the laintiff, and delivered them to the defendants, who paid - \& Co. as usual, and in good faith, on August 11th. - \& Co. should have paid the plaintiff on August 25th, It did not, and subsequently failed. Thereupon the aintiff sought to recover from the defendants as being the al principals. Upon this state of facts the Court of ueen's Bench, after an elaborate discussion of the reported ses, and especially of the above dicta, came to the conclusion at the wider view was the correct one, on the ground that persons were to be held liable "who were only discovered

(k) L. R. 7 Q. B. 598.

B.C.L. 
to be principals after they had fairly paid the price to those whom the vendor believed to be the principals, and to whom alone the vendor gave credit, it would produce intolerable hardship" $(l)$.

On the other hand, in Irvine v. Watson $(m)$ the facts were these :-The defendants employed C., a broker, to buy oil for them. C. bought oil of the plaintiff, telling him that he bought for principals, but not saying who they were. The terms of the sale were cash on or before delivery. The plaintiff delivered the oil to C., but did not insist on prepayment, and the defendants not knowing that the plaintif had not been paid, paid C., who shortly afterwards stopped payment, whereupon the plaintiff claimed to recover from the defendants as principals.

Mr. Justice Bowen, before whom the case was tried, held that, whereas in cases where the agent has not disclosed his principal no action can be brought against the latter, upor discovery of his existence, if he has in the meantime bond fide paid his agent, yet where the agent has disclosed the fact that he has a principal, without mentioning his name the seller may have recourse to the principal, even thougt the latter has bonî fide paid his agent, unless there ha been such conduct on the part of the seller, ex. gr., delay ir applying to the principal, as might justify the latter in concluding that the seller was not looking to his credit, bu to that of the agent. The effect of this decision was th confine the dicta of Lord Tenterden and Bayley, J. $(n)$, th cases where the principal was never disclosed, and to appl: the rule as laid down by Parke, B. (o), to cases where th existence of the principal was disclosed, though his nam was concealed.

On appeal, however, the Court $(p)$, while upholding th

(l) At p. 610 .

(m) 5 Q. B. D. 102 ; Ib. 414.

(n) Supra. (o) Supra.

(p) 5 Q. B. D. 414. 
lecision of Bowen, J., as far as it applied to the case of a lisclosed but unnamed principal, intimated considerable loubt as to whether the law would not be the same even $n$ the case of an undisclosed principal, and expressed an pinion unfavourable to Armstrong v. Stokes $(q)$. With eference to the distinction drawn by the Court in that case retween the case where the seller at the time of the sale upposes the agent to be himself a principal, and gives redit to him alone, and the case where he knows that the erson with whom he is dealing has a principal behind, hough he does not know who the principal is, Bramwell, s. J., remarked: "It is to my mind certainly difficult to nderstand that distinction, or to see how the mere fact of ae vendor knowing or not knowing that the agent has a rincipal behind can affect the liability of that principal. should certainly have thought that his liability would epend upon what he himself knew, that is to say, hether he knew that the vendor had a claim against im and would look to him for payment in the agent's efault" $(r)$.

The Court were unanimous in holding that the rule as id down by Parke, B., was a more correct statement of Le law than the dicta in Thomson v. Darenport (s), and rett, L. J., while suggesting that the rule intended to be id down in Armstrong v. Stokes ( $t$ ) was, that where the ller deals with the agent as sole principal, and the nature the agent's business is such that the buyer ought to lieve that the seller has so dealt with him, it would in ich cases be unjust to allow the seller to recover from the incipal after the latter had paid the agent, yet added that could such a case arise again the Court reserved the right reconsidering it.

To the same effect is the decision in the subsequent case
(q) L. R. 7 Q. B. 598, supra.
r) 6 Q. B. D. 417,418 .
(s) Supra.
( $t$ ) Supra. 
of Davison v. Donaldson (u), that, in order to discharge a principal from his liability for a debt contracted by his agent, the principal must show that the creditor has him. self misled him into supposing that he has elected to give exclusive credit to the agent, and that the principal has been prejudiced by that supposition.

The net result appears to be that unless the seller either by his own laches, in not demanding payment with due promptness $(x)$, or by so conducting himself as to lead the buyer to believe that he has been paid by the agent, has estopped himself from proceeding against the principal, the latter, whether unnamed or undisclosed, will not be discharged by payment to an agent, unless such payment as a matter of fact reaches the seller.

This alternative liability may, however, be defeated by the express terms of the contract, as where, an agent having in a charter-party described himself as ouner of a ship, it was held that he could not be regarded as an agent, and therefore his principal could neither sue nor be sued on the contract $(y)$, or may be determined by the election of the other party.

"Where an agent contracts in his own name for an undisclosed principal, the person with whom he contracts may sue the agent, or he may sue the principal, but if he sues the agent and recovers judgment, he cannot afterwards sue the principal, even although the judgment does nor result in satisfaction of the debt" $(z)$.

The rule stated respecting the liability of an undisclosed principal may be affected by the usage of trade and the mutual understanding between parties which results there from (a). Thus, where a British merchant effects a purchas

(11) 9 Q. B. D. 623 .

(x) As to the delay, see Davison r. Donallson, ubi supra. 310 .

(y) Humble v. Hunter, 12 Q. B.

(z) Per Earl Cairns, C., Kendull v.
Iramilton, 4 App. Cas. 514; citin

Pritstley v. Fermie, 3 H. \& C. 977.

(a) See, per Bayley, J., Pourer y

Butcher, 13 B. \& C. 339-341; PE

Lord Ellenborough, C. J., Jenkins

Pouer, 6 M. \& S. 287, 18 R. R. 375 
for a foreign principal, credit is prima facie considered as having been given exclusively to the former (b), although eridence will be admissible to show a different intention $(c)$.

Again, if an agent makes an oral contract in his ou $n$ name, the principal may sue as well as be sued upon it; for it is a general rule, that whenever an express contract is nade an action is maintainable upon it, either in the name of the person with whom it was actually made, or in the ame of the person with whom in point of law it rras nade $(d)$. . It is a well-known rule, that where an agent nakes a contract in his own name, but for a principal whose rame is not disclosed, the principal may come forward and inforce it $(e)$.

Where, however, a principal permits his agent to sell goods sale of $\mathrm{s}$ apparent principal, and afterwards intervenes, the buyer is gocds by ntitled to be placed in the same situation at the time of the isclosure of the true principal as if the agent had been the eal contracting party, and is entitled to the same defence, ihether it be by common law or by statute-by payment or $y$ set-off-as he was entitled to at that time against the gent, the apparent principal $(f)$. Further, by the Factors

(b) Thomson r. Datenport, 9 B. \& - 87, 88; Paterson v. Gandasequi, 5 East, 69; 13 R. R. 368 ; Hreuce v. ; Hutton v. Bulloch, L. R. Q. B. 572, affirming $S . C .$, L. R. Q. B. 331; Armstrong v. Stolies, . K. 7 Q. B. 598, 605; Now Zealand and Co. T. Watson, 7 Q. B. D. 374; splained in Kaltenbaeh r. Lexis, 10 pp. Cus. 6I7 ; Maspors, \&e. v. Milred, 9 Q. B. D. 530; 8 App. Cas. it; Elbinger v. Claye, L. R. 8 Q. B. 13, 316; Smyth r. Anderson, 7 C. . 21; Wilson v. Zulueta, 1t Q. B. 5, 414; Poirier v. Morris, 2 E. \& 89. See Peterson v. Ayre, 13 - B. 353 ; Pennell v. Alexander, 3 E. B. 283 .

(c) Mahony v. Keluulé, It C. B. 10; per Parke, B., Heald v. Kenorthy, 10 Exch. 739. See Gillett v. ffor, 18 C. B. 905,915 .

(d) Cothay v. Fennell, 10 B. \& C.
671 ; Sims v. Bond, 5 B. \& Ad. 389. The agent was beld entitled to sue in Tassell r. Cooper, 9 C. B. 509; Holt v. Ely, 1 E. \& B. 795 .

(e) See, for instance, Risborrg $\vee$. Bruekner, 3 C. B., S. S., 812.

(f) Judgm., Isberg v. Bouden, 8 Exch. 859; Ramazotti v. Bon'rixg, 7 C. B., S. S. 85I ; Tucker v. Tueler, 4 B. \& Ad. $750 ; C(\omega)$ v. Hinchliff, 4 B. \& C. 547; Gcorge v. Clugett, 7 T. R. $359 ; 4$ R. R. 462 (as to which see Borries r. Imperial Ottoman Bank, L. R. 9 C. P. 38; Tu"ne" v. Thomas, L. R. 6 C. P. 610); Rabone v. Williams, 7 T. R. 360 (n) ; 4 R. R. 463 (n); Wake v. Tinkler, 16 East, 36.

The rule stated in the text is most frequently acted upon in sales by factors, agents, or partners, in which cases either the noninal or real contractor may sue; but it may be applied to other cases: Judgm., Sims v. Bond, 
Liability of agent who contracts without authority.

Act, 1889, where a mercantile agent is, with the consent of the owner, in possession of goods or of the documents of title to goods, any sale, pledge, or other disposition of the goods made by him when acting in the ordinary course of business of a mercantile agent, is, subject to the provisions of the Act, as valid as if he were expressly authorised by the owner of the goods to make the same, provided the person taking under the disposition acts in good faith, and has no notice that the person maling the disposition is acting without authority. Any such disposition is valid notwithstanding the determination of the consent unless the person taking under the disposition has notice that the consent has determined. If a mercantile agent has obtained possession of any documents of title to goods by reason of his being, or having been, with the consent of the owner, in possession of the goods répresented thereby, or of any other documents of title to the goods, his possession of the firstmentioned documents is, for the purposes of the Act, deemed to be with the consent of the owner $(g)$.

Where an individual, assuming to act in the capacity of agent for another, acts, in truth, without authority from him, the pretended principal will not, subject to what has been already said upon this subject $(h)$, be bound by such acts

5 B. \& Ad. 393 ; cf. Montagu v. Fortrood, (1893) 2 Q. B. 350 (C. A.): unless, indeed, where the buyer of goods knows that the vendor sells as agent: Firh $\mathrm{v}$. Kempton, 7 C. B. 687, 694; Ferrand r. Hischoffsheim, 4 C. B., N. S., 710 ; Semenza v. Brinsley, 18 C. B., N. S., 467 : cited per Brett, J., Borries v. Imperial Ottoman Bank, L. R. 9 C. P. 47 ; Dresser v. Norecood, 17 C. B., N.S., 466 ; Cooke r. Eshelby, 12 App. Cas. 271.

(d) "Mercantile agent" is definerl (s. 1) as " a mercantile agent having in the customary course of his business as such agent authority either to sell goods, or to consign goods for the purpose of aale, or to buy goods, or to raise money on the security of goods." A jeweller's assistant emplored at a small salarr to sell goods retail on commission is no within the definition: Hastings r. Par son, (1893) 1 Q. B. 62. "There is nd such business as that of an agent $t$ pledge with pawnbrokers for the pur pose of raising money for the emplose of the agent", (per Mather, J., a p. 64). "Document of title" is de fined s. 1, subs. 4. The Factors $A c t$ 1889 (52 \& 53 Vict. c. 45 ), has IE pealed the previous Acts, 4 Geo. c. 83,6 Geo. 4 c. 94,5 \& 6 Vict c. 39 , and $40 \& 41$ Vict. c. 39 . Th effect of the first three of these repeale enactments is stated in Blachiburn, J.' judgment in Cole r. North-Wester Bank, L. R. 10 C. Y. 354.

(h) Ante, p. 601 et seq. 
and a remedy, in such form as under the circumstances may be appropriate, must be had against the party assuming to contract (i). For instance, if "A. employs B. to work for C. without warrant from C., A. is liable to pay for it" $(k)$; nor will it make any difference if B., in truth, believe A. to be the agent of C. $(l)$; for, in order to charge C., B. would have to prove a contract with him, express or implied, and with him in the character of principal, either directly or through the intervention of some third person $(m)$. A familiar instance, illustrative of this remark, occurs where an action is brought against a candidate for electioneering expenses, or for goods supplied on his credit, but ordered by a third party, assuming to act for him. Here the fact of agency must be clearly established-that is to say, it must be shown that the alleged agent was employed by the defendant alone, or jointly with others, or that he was employed by some third party, who was himself duly authorised by the defendant for such purpose; and an action would fail if it appeared that the defendant, instead of being a principal, was only an agent, and known to be such, and had, in fact, not contracted on his own account at all $(n)$.

A mere agent, indeed, who gives an order as such, and contracts orally for another, cannot, under ordinary circumstances, be made personally liable upon such contract, by reason of the want of privity in law between himself and the other contracting party $(o)$. And to a like reason may be referred the rule, that a servant of the Crown, contracting

(i) Toodin v. Burford, 2 Cr. \& M. 391 ; Wilson v. Barthrop, 2 M. \& W. 363; Fenn v. Hamison, 3 T. R. 757 ; Polhill v. Walter, 3 B. \& Ad. 114; ser Lord Abinger, C. B., Aeey $v$. Fervice, 7 M. \& IV. 154 ; Collen . Wright, 7 E. \& B. $301 ; S . C ., 8$ Id. 347 , and cases cited post, p. 618 .

(k) Ashton v. Sherman, Holt, 309 ; ited 2 M. \& TV. 218.

(l) Thomas v. Edwards, 2 M. \& W. (m) Judgm., 2 M. \& W. 216, 217 ; Turner v. Mayos of hendal, 13 M. \& W. 171 ; Spurrier v. Allen, 2 C. \& K. 210; Redmond v. Sirith, 8 Scott, N. R. 250 .

(n) See Thomas v. Edwards, 2 M. \& IV. 215; Higgins v. Hopkins, 3 Exch. 16j. Et vide Cooper r. Slade, 6 H. L. Ca. 793.

(o) Ante, p. 312 ; Depperman v. Hubbersty, 17 Q. B. 766,771 . 
in his official capacity, is not thus rendered individually responsible; the rule, or rather legal presumption, which in this case excludes personal liability, being clearly in accordance with public policy, inasmuch as no prudent person would accept a public situation at the hazard of exposing himself to a multiplicity of suits by parties thinking themselves aggrieved $(p)$. Commissioners also, and trustees appointed for carrying out undertakings sanctioned by Parliament, will not, in general, incur liability on contracts made in connection with the subject-matter of the trust confided to them $(q)$.- "When," remarks Lord Eldon (r), "persons act under a Parliamentary trust, and state themselves as so acting, they are not to be held personally liable;" though if, in any particular case, evidence be adduced to show that they pledged their personal credit, a differeht result will follow $(s)$.

Notwithstanding the general rule, however, as to the nonliability ex contractu of a mere agent acting in that character, circumstances do occasionally present themselves under which he may, even thus, incur responsibility. For instance, an action for money had and received lies to recover back money which had been obtained through compulsion, even where it has been received by an agent acting for his principal $(t)$.

In Smout v. Ilbery $(u)$, which has a direct bearing on the

(p) PerDallas, C. J., Gidley r. Lord Palmerston, 3 B. \& B. 286, 28T; 24 R. R. 668; perAshhurst, J., Macbeath v. Haldimand, 1 T.R. 181, 182; 1 R. R. 177; Rice v. Chute, I East, 579; Rice r. Everitt, Id. 583 , n. (a); Myrtle r. Beaver, Id. 135 ; Atlee v. Backhouse, 3 M. \& W. 633 ; R. v. Lords Commissioners of the Tieasury, 4 Ad. \& E. 286, 298; disapproved of, Reg. v. Commissioners of Iulaud Rerenue, 12 Q. B. D. 461.

See further, respecting the protection extended to persons clothed with an official character, Grant v. Secretary of Slate for India, 2 C. P. D. 445; ante, p. 102.

(q) Audrews v. Dally, 4 Bing. 566 : Allen r. Waldegrace, 2 Moore, 621; 20 R. R.j60; Sprottr.Ponell, 3 Bing. 4 is.

(v) Higgins v. Liringstone, $4 \mathrm{Dow}$ $355 ; 16$ R. R. 85.

(s) Eaton r. Bell, 5 B. \& Al\}. 3 t Parrolt r. Eyve, 10 Bing. 283 Horsley r. Bell, Amb. T70.

( $t$ Parker v. Bristol and Exelen R. C., 6 Exch. 702, 707; Steek r. Williams, S Exch. 625; Snoudon r. Daris, 1 Taunt. 359; per Iord Abinger, C. B., Atlee v. Backhouse, 3 M. \& W. 645.

(ii) 10 M. \& W. 1. 
subject before us, the facts were somewhat peculiar : there the defendant was a married woman, to whom the plaintiff, a butcher, had been in the habit of supplying meat for the support of herself and her family. Meat had been thus supplied, not only whilst the defendant's husband was residing with her, but after he had left this country on a distant voyage, during which he died, and the question was, whether the defendant was liable for the price of such meat is was furnished to her after her husband's death, but before he news of his decease had come to hand; no evidence of raud or suppression of facts, peculiarly within the defenlant's knowledge, was given at the trial ; and the Court held hat the question just put was to be answered in the regative, reference being had to the recognised legal loctrines defining the liability of an agent who contracts is such $(x)$. There is no doubt, the Court remarked, that in agent guilty of a fraudulent misrepresentation of his suthority, with an intention to deceive, would be personally esponsible. And, as they further observed, there are two ther classes of cases in which an agent, who, without ctual authority, makes a contract in the name of his prinipal, is personally liable, even where no proof of such raudulent intention can be given; first, where the agent las no authority, and knows it, but, nevertheless, makes he contract as if he had it; here, on the plainest principles

(x) Smout v. Ilbery, supra, shows lat an abstract right may exist withut any legal means of enforcing it, or, under the circumstances there opearing, no liability would attach to ie estate of the husband (Rlades $\mathrm{v}$. ree, 9 B. \& C. 167 ; explained per ollock, C. B., 1 H. \& C. 253, 255 ; anpanari v. Woodburn, $15 \mathrm{C}$. B. 00), the agency of the wife having stermined on his death. It must be membered, however, that the situation a married woman as a contracting urty is sui generis. For an individual ho contracts with an ordinary agent intracts with one capable of contract- ing in his own name; whereas an individual contracting with a married woman knows that she is in general incapable of making any contract by which she is personally bound (and this is so still in spite of subsequent legislation, except as to her separate property, v. post, p. 682), and she therefore stands in the same situation as an agent who has expressly stipulated that he shall not, uuder any circumstances, be held personally liable, - a stipulation which it is of course quite competent to him to make: Judgm., 10 M. \& W. 11, 12. 
of justice, he is liable, because he induces the contractee to enter into the contract on what amounts to a misrepresentation of a fact peculiarly within his own knowledge. A second case, in which a mere agent will incur liability, may present itself where the party contracting as agent bon fide believes that due authority is vested in him, whilst, in fact, he has no such authority - as where he acts under a forged warrant of attorney, which he believes to be genuine, - under such circumstances, it seems clear that an action for damage resulting from the misstatement would be maintainable against the agent for the breach of an implied warranty of authority $(y)$.

It will of course be noticed, that the remarks just made apply to the liability ex delicto of an agent who has in some way misrepresented the existence or extent of his authority: and in cases of this lind one or other of the following ingredients will be found to be essential to the maintenance of an action against him, viz., that the agent has been guilty of some fraud, has made some statement which he knew to be false $(z)$, or has stated as true what he did not know to be true, omitting, at the same time, to give such information to the other contracting party, as would have enabled him equally with himself to judge as to the sufficiency of the authority under which he (the agent) pro. posed to act.

Contract in writing by agent.

2. From Jenlins v. Hutchinson (a), Dowmman v Williams (b), Mahony v. Kélulé (c), and Green v. Koplie (d) we may infer, that where a contract in writing has been entered into between parties the character of either part.

(y) Richardson v. Williamson, I. R. 6 Q. B. 279 ; Story on Agency, p. 225, n. 3 .

(z) See Polhill r. Walter, 3 B. \& Ad. 114, cited post, Book 1II.; Callow v. Jenkinson, 6 Exch. 666.

In Udell v. Atherton, cited ante, p. $33 \bar{i}$, the agent would clearly have been liable.

(a) 13 Q. B. 744.

(b) 7 Q. B. 103. Acc. Leacis Nicholson, 18 Q. B. 503. Compar Parker $r$. Winlotc, 7 E. \& B. 942 Lennard r. Robinson, 5 E. \& B. 125.

(c) 14 C. B. 390 .

(d) 18 C. B. $549,558$. 
to it, whether as principal or agent, and consequently his right to sue $(e)$, or liability, upon the contract, will, if possible, have to be determined by reference to its terms, the question being one of intention to be collected therefrom $(f)$.

The first-mentioned of the cases above cited further shows that a party who executes an instrument in the name of another, whose name he puts to the instrument, adding ais own name only as agent for that other, cannot be ireated as a party to that instrument, and be sued upon it, inless it be shown that he was the real principal (g) ; and, urther, if the instrument be ambiguous it will be conitrued against the party signing $(h)$. If, however, the agent hooses to make himself a contracting party, the other conracting party may either sue the agent who has himself contracted, though on behalf of another, or he may sue the rincipal who has contracted through his agent; and this rhether the principal was known at the time or not, or rhether it was or was not known that there was a rincipal $(i)$.

"No doubt," said Jessel, M. R. (k), with reference to a rroker's contract, "it does not absolutely follow from the lefendant's appearing on the contract to be broker that he 3 not liable as principal. There are two ways in which he aight so be made liable: first, intention on the face of the ontract making the agent liable as well as the principal; econdly, usage."

(e) A principal who permits his zent to describe himself as principal i a written contract may, in some Lses, thus estop himself from suing pon it. See Humble r. Hunter, 12 ․ B. 310 ; Bickerton v. Burvell, 5 I. \& S. 383 ; Rayner v. Grote, 15 1. \& W. 359 ; Schmaltz v. Avery, 3 Q. B. 655 ; Cox v. Hubbard, 4 B. 317 .

(f) See Wilson จ. Zalueta, 14 Q. B. J5, 414; Pennell v. Alexander, 3 E.
\& B. 283; Jinng v. Phosphate of Lime Co., L. R. 3 C. P. 139.

(g) Judgm., 13 Q. B. 752 ; Car. r. Jackson, 7 Exch. 382.

(h) Per Crompton, J., Deslandes r. Gregory, 2 E. \& E. 602, 610, cited in Jung v. Phosphate of Lime Co., supra.

(i) Per Blackburn, J., Christoffersen v. Hansen, L. R. 7 Q. B. 513.

(k) Southwell v. Boulditch, 1 C. P. D. 377 . 
Three well-known cases-Collen v. Wright $(l)$, Kelner v. Baxter (m), and Humfiey v. Dale (n)-are important in reference to the liability of an agent who signs a written contract. From Collen v. Wright, we learn that a personwho induces another to contract with him as the agent of a third party by an unqualified assertion of his being authorised to act as such agent is answerable to the person who so contracts for any damages which he may sustain by reason of the assertion of authority being untrue, and that this liability may be enforced by an action $e x$ contractu, inasmuch as a person professing to contract as agent for another impliedly, if not expressly, undertakes to or promises the person who enters into such contract, upon the faith of the professed agent being duly authorised, that the authority which he professes to have does in point of fact exist (o). In Kelner v. Baxter this proposition is laid down $(p)$ :- " Where a contract is signed by one who professes to be signing 'as agent,' but who has no principal existing at the time, and the contract would be altogether inoperative unless binding upon the person who signed it, he is bound thereby; and a stranger cannot by a subsequent ratification relieve him from that responsibility" $(q)$. In a recent case, however, it was denied that there is any general principle of law that whenever an agent or a representative affects to conclude a contract on behalf of

(I) 7 E. \& B. $301 ; S . C$. (in Error), 8 E. \& B. 647 ; cited in Dickson 5 . Reuter's Telegram Co., 3 C. P. D. 5 , 7, 8; Pow v. Laris, 1 B. \& S. 220 .

(m) L. R. 2 C. P. 174; Richardson จ. Williamson, L. R. 6 Q. B. 279; Firbank v. Humplieys, 18 Q. B. D. 54.

(n) 7 E. \& B. 266 ; S. C. (in Error), E. B. \& E. 1004; Fleet v. Murtow, L. R. $i$ Q. 13. 126; recognising Fairlie r. Fenton, I. R. 5 Ex. 169 ; Paice v. Walker, L. R. 5 Ex. 173; commented on, Gadd v. Houghton, 1 Ex. D. 35\%; Hongh r. Manzanos, 4 Ex. D. 104 ;
Hutchinson v. Tatham, L. R. 8 C. P. 48:. Compare Southuell r. Boseditch, 1 C. P. D. 374; Hutcheson v. Eaton, 13 Q. B. D. 861.

(o) Judgm., 8 E. \& B. 657,658 ; Simons r. Intchett, 7 E. \& B. 568 ; Pow r. Daris, 1 B. \& S. 220 ; In re National Coffie Palace Co., Ex parte J'anmure, 24 Ch. D. $36 \pi$; and cases supra.

(p) Per Erle, C. J., L. R. 2 C. P. 183.

(q) See Scott v. Lord Ebury, Id. $255,264$. 
an alleged principal, and no such principal exists, the agent is in law himself the contracting party. "If an alleged agent," it was there said, "professes to conclude a contract in the name, and on behalf of an alleged principal, and without using language expressing that he contracts personally, no rule of law can convert his position into that of a contracting party by reason only of there not having oeen at the time any principal in existence who could be oound. He may be liable for a false representation, or for $\checkmark$ breach of warranty of authority, if the true facts would ;ustain either cause of complaint" $(r)$. In Dale v. Humfrey, he majority of the Court of Exchequer Chamber, affirming ihe judgment below, held that evidence of the usage of rade might be admitted to render liable brokers who, as igents for an undisclosed principal, and in their character if brokers, signed a contract-note for the purchase of oil, icceptance of which was afterwards refused. The contract ras here within the 17th section of the Statute of Frauds; und Cockburn, C. J., after observing, that "where, either yy any rule of law or by the usage of any trade, the terms if a contract acquire a particular meaning, the contract nust be taken to express that meaning as much as though t had been set forth in extenso," proceeded to remark that "this obtains as much for the purpose of satisfying the tatute as for that of establishing the contract independently f the statute" $(s)$.

In connection with this part of the subject, I will merely dd that where a party signs a contract as principal $(t)$ he annot (as we have already seen) discharge himself from ability by showing that he was, in fact, an agent merely Ir some third party, though proof of such agency may be iven with a view to charging the real principal (u).

(r) Hollman r. Pullin, 1 C.\& E. 254. (s) E. B. \& E. 1021. The judgtent of Martin, B., diss. (in Error), also well worthy of perusal. See also Cropper r. Cook, L. R. 3 C. P. 194.

(t) See Hough r. MLanzunos, 4 Ex. D. 104 .

(u) Higgins r. Senior, 8 M. \& T. 
If a written contract is duly signed by one on behalf of others as well as himself, Lucas v. Beale (x) shows us that the individual signing must be regarded as an agent merely, and will not, therefore, be entitled to sue upon the contract; whilst from Clay v. Southern $(y)$ we learn that a party signing a memorandum of agreement in his own name simpliciter will, in the absence of anything clearly inconsistent with such hypothesis, be regarded as a principal in the trans. action. "Prima facie when a man signs a contract in his own name he is a contracting party; and there must be something very strong upon the face of the instrument to prevent that liability from attaching to him " $(z)$. Whether a contract be to pay for another, or whether it be on belaly of another to pay, may manifestly be a question of vital importance in regard to the liability of the individual who has attached to it his signature $(a)$.

Contract under seal by agent.

3. An agent who is required to execute a deed for his principal should have express authority under seal for that purpose $(b)$. When thus authorised, he may sign either in the name of his principal, or as agent for and on behalf of him (c). The solemn nature of a deed, however, excludes parol evidence to show that one who has executed it as principal was, in fact, but an agent $(d)$. The above rule,

834 ; approved Fleet v. Murton, I. R. 7 Q. B. 131 ; Browning v. Provincial Ins. Co. of Canada, L. R. 5 P. C. C. 263, 272; Calder v. Dobell, L. R. 6

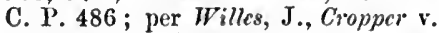
Cook, L. R. 3 C. P. 199 ; per Martin, B., Holding v. Elliott, $5 \mathrm{II}$. \& N. 121, 122; per Williams, J., Dale v. IIumfiey, E. B. \& E. 1020 ; Magee v. Athinson, 2 MI. \& W. 440.

The question whether a signature attached to a written instrument is to be taken as a signature to the whole paper was much considered in Fostev v. Mentor Life Ass. Co., 3 E. \& I3. 48.

(x) 10 C. B. 739.

(y) 7 Exch. 717 ; Higgins v. Senior, 8 M. \& W. 834 ; Sowerby v. Butcher, 2 C. \& M. 368 ; Spittle v. Latender,
2 B. \& B. 452 ; 23 R. R. 508.

(z) Per Cressucell, J., Cooke v. Wil. son, 1 C. B., N. S., 162 ; Parker r. Winlow, 7 E. \& B. 942 , and caset there cited.

(a) See, per Iord Lyndhurst, C. B., IIall v. Ashhurst, 1 C. \& M. 719.

(b) IIarrison v. Jackson, 7 T. R. 207,$210 ; 4$ R. R. 422; Wilks $\mathrm{r}$, Back, 2 East, 142 ; 6 R. R. 409 ; White r. Cuyler, 6 T. R. $176 ; 3$ R. R 147; Judgm., IInnter v. Parker, : M. \& W. 343 .

(c) Combes's case, 9 Rep. 76 b ? White v. Cuyler, supra. See Apple. ton v. Binks, 5 East, 148; 7 R. R. 672

(d) Sehack r. Anthony, 1 M. \& S 573 ; Berkeley v. IIardy, 5 B. \& C. 355 ; Netcalf v. Rycroft, 6 M. \& S 
which exists at common law, is, however, modified by various ;tatutory provisions, having reference to particular kinds of agency existing in connection with public companies.

Let us, in conclusion, consider shortly a point of coniderable importance, to which some reference has already seen made $(e)$, viz., the liability of an innocent principal

he remedies open to the person so defrauded against the rincipal and agent.

These remedies are twofold, either to rescind the contract, $r$ to bring an action of deceit to recover damages. In the irst case the rule is, that if the purchaser can return the ubject-matter of the contract in the same condition as he eceived it, ex. gr. a log of mahogany before it has been awn up, he may rescind the contract; but if he has so ealt with the thing bought that it cannot be returned in be same condition, then he will not be entitled to rescind de contract, but must fall back upon his second remedy, amely, an action for deceit $(f)$.

This action he can maintain against the agent peronally $(g)$, and also in cases where the fraud of the agent as committed within the scope of his authority, and the rincipal has benefited thereby, against the principal (h), hether such principal be an individual or a corpora-

; Hancock v. Hodgson, 4 Bing. 269 ; acon v. Dubarry, 1 Ld. Raym. 246. Je Gibson v. Winter, 5 B. \& Ad. 96. a agent, howerer, need not be autho:ed to sign his principal's name to a emorandum of association by deed ider seal: Re Whitley \& Co., Ex parte ulan, 32 Ch. D. 337 .

(c) Ante, p. 333.

(f) Udell v. Atherton, 7 H. \& N. '2; Addie v. Western Bank of Scotnd, L. R. 1 Sc. App. 146.

(g) Weir v. Bell, 3 Ex. D. at 248; Addie v. Western Bank of otland, L. R. 1 Sc. App. 146, 160, 7.

(h) Barwick v. English Joint Stock
Bank, L. R. 2 Ex. 259: Mackay v. Commercial Bank of Now Brunsucich, L. R. 5 P. C. 394 ; Caygill v. Bower, 10 Ch. D. 514; Shaw v. Port Philip Gold Mining Co., 13 Q. B. D. 103; British Wutual Bank Co. r. Charnuood Forest Railuay, 5́5 L. J. Q. B. 339. Semble, that this would be so in any case where the principal had benefited by the fraud: Weir r. Bcll, 3 Ex. D. p. 247 . Secus, where the fraud is committed without the scope of the agent's authority : Nexclands $\mathrm{r}$. Nat. Employers' Accid. Assoc., 51 L. J. Q. B. 428 ; followed in Barnett v. South London Tramways Co., 18 Q. B. D. 815 . 
tion (i). A director, however, will not be liable for the fraud of his co-directors or agents, unless he has either expressly authorised or tacitly permitted the commission of the fraud $(k)$; neither can a shareholder in a joint-stock bank, who has been induced to purchase his shares by the fraud of the agent of the company, bring an action of deceit against the company so long as he himself is a member of it $(l)$.

The principle upon which the liability of the principal is based is thus laid down by Willes, J., delivering the opinion of the Exchequer Chamber in Baruick v. English Joint Stock Bank (m), a judgment which has since been frequently approved and followed $(n)$ :- "With respect to the question, whether a principal is answerable or not for the act of his agent in the course of his master's business, and for his master's benefit, no sensible distinction can be drawn between the case of fraud and the case of any other wrong. The general rule is that the master is answerable for every such wrong of the servant or agent as is com. mitted in the course of the service, and for the master's benefit, though no express command or privity of the master be proved. . . . In all these cases it may be said that the master has not authorised the act. It is true he has not authorised the particular act, but he has pu the agent in his place to do that class of acts, and he mus be answerable for the manner in which the agent ha conducted himself in doing the business which it was the act of the master to put him in."

In the subsequent case of Wreir v. Bell (o), Bramucell L. J., while doubting the reasoning upon which it wa

(i) Mackay v. Commercial Bank of New Brunseick, ubi sup. ; Houldsworth $v$. City of Glasgow liank, 5 App. Cas. 31\%, per Lord Sellonne, at p. 326 ; see per Lord Blackburn, at pp. 339,340 .

(k) Peek v. Gurney, L. R. 6 H. I. 377; Caygill v. Bouces, 10 Ch. D. 514; Weir v. Bell, 3 Ex. D. 238. (l) Addie v. Western Bank of Srot land, ubi supra: Houldsworth r. Cit. of Glasgow Bark, ubi supra.

(m) L. R. 2 Ex. 259, 265.

(n) Ex. gr. Stcive v. Francis, App. Cas. 106 ; Chapleo v. Brunsucie Building Society, 5 C. P. D. 331.

(o) 3 Ex. D. 238. 
unded, approved the principle of the above-quoted judgsent, and suggested that it might be supported on the ound that every person who authorises another to act $r$ him in the making of any contract undertakes for the sence of fraud in that person in the execution of his thority, as much as he undertakes for its absence in mself when he makes the contract.

Further, on the ground that the knowledge of the agent by imputation the knowledge of the principal, an innont principal may suffer for the dishonesty or neglect of s agent. The facts of a recent case $(p)$ were as follows:te plaintiff had effected an insurance against accidental ury with the defendants through their agent. The untiff, who was a one-eyed man, and who, although nost unable to read and write, could write his name, ned, at the request of the agent, a proposal form in which ras stated, contrary to the fact and to the agent's knowge, that he was free from any physical infirmity. Some years later the plaintiff lost his second eye, and claimed inst the defendants, on the basis of total disablement. 'otal disablement" was stated in the policy to mean, ?r alia, "the complete and irrevocable loss of sight to h eyes." The Court of Appeal held that the defendants e liable for the sum claimed, being the sum agreed to paid in the event of total disablement.

now proceed briefly to inquire as to the manner in ch partners may contract at law so as to acquire rights o incur liabilities as such, and whether under any, and ), under what circumstances, the existence of the relaof partner and co-partner may cause an incapacity to ract. The law of partnership has been declared and nded by the Partnership Act, 1890 (53 \& 54 Vict. c. 39).

Bawden v. London, Edinburgh, 2 Q. B. 534, C. A.

Glasgow Insurance Co., (1892)

C.L. 
Partnership - what it is.

The term "partnership" is at common law used to signify a contract founded in consent between two or more persons, by which they agree to employ their capital, labour, and skill, in trade or business, with a view to a communion in profit and loss between them $(q)$. In connection with any definition, however, which may be offered of the rord "partnership," must be kept in mind the distinction between a partnership inter sese and a partnership quoad third persons, for persons not being in fact co-partners may by their conduct and mode of dealing incur liability as such to third parties.

Partnership may be constituted in one or other of various ways, but " whenever a contract of partnership among com. mercial men exists, each partner is in point of law the agent for the others and for the firm collectively, and they are bound by any contract he may enter into within the scope of the partnership with reference to the nature of the undertaking, this agency being an incident to the contract of co-partnership " $(r)$, and deduced from it $(s)$.

If two persons agree that they will carry on a trade and share the profits of it, each is a principal and each is an agent for the other in carrying on the trade; the adage, moreover, well known to our customary law-that he who takes the profits ought to bear the loss $(t)$-being rather the consequence than the cause of partnership liability (u).

(q) By s. 1, subs. 1, of the Act, partuership is defined as " the relation which subsists between persons carrying on a business in common with a view of profit," but a company registered under the Companies Acts, or formed or incorporated by, or in pursuance of, any other Act or letters patent or royal charter, or a company working mines within and subject to the jurisdiction of the Stannaries, is not a partnership within the Act (Id. subs. 2). As to the difierence between a partuership and a company, sec per James, L. J., Smith v. Auderson, 15 Cb. D. at p. 273. (r) Per Kelly, C. B., Holme v. Hammond, L. R. 7 Ex. 227. See also s. 5 , post, p. 631 .

(s) Per Cleasby, B., Id. 233.

(t) As to this proposition at common law, see Bulles v. Sharp, L. R. 1 C. P. S6, and cases there discussed; Cox v. Hickman, 3 H. L. Ca. 268 ; per Mellor, J., L. R. 8 Q. B. 191 ; as to the proportion in whieh losses are to be borne, see per Jessel, M. R., Re Albion Assuranec Co., 16 Ch. D. 83, 87.

(ii) Per I.ord Wenslcydale, Cox r. Hickman, 8 II. L. Ca. 312, 313; Bullew v.' Sharp, L. R. 1 C. P. 86, 103. See Walker v. Hirsch, 27 Ch. D. 460. 
Partners may indeed stipulate among themselves that me of them only shall enter into particular contracts, or to any contracts, or that, as to certain of their conxcts, none shall be liable except those by whom they e actually made, but with such private arrangements ird persons dealing with the firm without notice have concern. The public have a right to assume that *3ry partner has authority from his co-partner to bind to whole firm by contracts made according to the ordinary iges of trade $(x)$.

The above principle applies not only to persons acting only and avowedly as partners, but to others who, though ; so acting, are by secret and private agreement partner's h those who appear ostensibly to the world as the persons rying on the business $(y)$.

(n determining whether or not a partnership exists regard nI st be had to the following rules $(z)$ :-

oint tenancy, tenancy in common, joint property, cimon property, or part ownership, does not of itself (1) bte a partnership as to anything so held or orrned, ther the tenants or owners do, or do not, share any pits made by the use thereof.

he sharing of gross returns does not of itself create a nership, whether the persons sharing such returns have, rave not a joint or common right or interest in any terty from which, or from the use of which, the returns a) lerived.

le receipt by a person of a share of the profits of siness is prima facie evidence that he is a partner in the oess, but the receipt of such a share, or of a payment a) ngent on or varying with the profits of a business, does

Per Lord Cranworth, 8 H. L. Cat 14, 305. Third persons having not are, however, bound by such ements; see s. 8 . (y) Per Lord Cranworth, 8 II. I. Ca. 30 n.

(z) S. 2 ,
Rules in determining whether partwership exists. 
not of itself make him a partner in the business $(a)$, and in particular-

(a) The receipt by a person of a debt or other liquidated amount by instalments or otherwise out of the accruing profits of a business does not of itself make him a partner in the business or liable as such :

(b) A contract for the remuneration of a servant or agent of a person engaged in a business by a share of the profits of the business does not of itself make the servant or agent a partner in the business or liable as such :

(c) A person being the widow or child of a deceased partner, and receiving by way of annuity a portion of the profits made in the business in which the deceased person was a partner, is not by reason only of such receipt a partner in the business or liable as such :

(d) The advance of money by way of loan to a person engaged, or about to engage, in any business on a contract with that person that the lender shall receive a rate of interest varying with the profits, or shall receive a share of the profits arising from carrying on the business, does not of itself make the lender a partner with the person or persons carrying on the business or liable as such, provided that the contract is in writing, and signed by or on behals of all the parties thereto :

(e) A person receiving, by way of annuity or otherwise a portion of the profits of a business in consideration of th sale by him of the goodwill of the business, is not by reasor only of such receipt a partner in the business or liable a such $(b)$.

(a) Cf. Cox v. Hickman, 8 H. L. Ca. 268. See also Badeley r. Consolidated Bank, 38 Ch. D. 238 ; Datis v. Datis, (1894) 1 Ch. 393.

(b) In the erent of any person to whom money has been adranced by way of loan upon a contract as is mentioned above, or of any buyer of a goodwill in consideration of a share of the profits of the business, being ad judged a bankrupt, or entering into a arrangement to pay his creditors les than twenty shillings in the pound, dring in insolrent circumstances, th lender of the loan will not be entitle to recover anything in respect of $b$ loan, and the seller of the goodwill $w_{\text {: }}$ not be entitled to recorer anything i 
When a partnership has been effectually constituted between A. and B., either partner becomes at common law, ipso facto, incapacitated from contracting with his co-partner in respect of any matter directly connected with the partnership (c), for a man cannot contract with himself $(d)$; he cannot be at once plaintiff and defendant in an action $(e)$; and it is a rule, that between partners, whether they are so generally, or for a particular transaction only, no account can be taken at law $(f)$. It has been held that one partner cannot recover on a bill of exchange drawn by him on and accepted by the firm of which he is a member $(g)$, and that one mercantile firm cannot maintain an action ex contract" against another firm, where the same person is a partner in both houses, and the right of action accrued during the period of his being such partner (h).

Where, however, a ground of defence, founded on the existence of a partnership between plaintiff and defendant, seems prima facie to be available, care may be needed in determining whether the apparent partnership does in fact exist (i), in assigning the limits of a particular partnership (k), in

respect of the share of profits contracted for, until the claims of the other creditors of the borrower or buyer for raluable consideration in money or money's worth have been satisfied:5. 3.

(c) The provisions of the Act regulating the relation of partners to one inother are contained iu ss. 19-31.

(d) In illustration of this remark, see Faulkner $\nabla$. Lowe, 2 Exch. 595 ; but iee as to this ease, per Williams, J., Aulton r. Attins, 18 C. B. 253.

(e) Per Best, C. J., 4 Bing. 151.

(f) Per Abbott, C. J., Borill, จ. Hammond, 6 B. \& C. 151; Wood v. II ood, L. R. 9 Exch. 190. See French $\therefore$ Styring, 2 C. B., N. S. 357 ; Uarrey F. Kay, 9 B. \& C. 356; Holmes $\vee$ Higgins, 1 B. \& C. 74 ; IITlson v. Viscount Curzon, 15 M. \& N. 532 ; Mrilburn v. Codd, 7 B. \& C. เ19; Goddard v. Hodges, 1 Cr. \& M.
43 ; per Bramwell, B., Sedguick r. Daniell, 2 H. \& N. 323.

(g) Tealc v. Turton, 4 Bing. 149; Tcague v. Hubbard, 8 B. \& C. 345. See Fox v. Frith, 10 M. \& W. 131.

(h) Bosanquet r. Wray, 6 Taunt. $597 ; 16$ R. R. 677; Mainwaring v. Newman, 2 B. \& P. 120 ; 5 R. R. 55t. See H'aters v. Towers, 8 Exch. 401.

(i) See Caldicott v. Griffiths, 8 Exch. 898 ; Reg. v. Wortley, 21 I. J. M. C. 44 ; Brown v. Tapscott, 6 M. \& W. 119 .

(k) That is, a partnership in respect of one particular venture or transaction. See Lucas v. Beach, 1 M. \& Gr. 417.

For the purposes of actions for breach of contract, part-owners of a ship who are working it together for profit are in the same position as partners: Judgm., Jebsen $\mathrm{v}$. East and I'"est India Dock Co., L. R. 10 C. P. 305 . 
distinguishing between a joint contract, or liability $e x$ con tractu, and a partnership $(l)$.

There is, moreover, a large class of cases, separated some times by a rather fine line from those above specified, i? which the existence of the relation of partnership betwee the litigating parties mill be found, on examination, to $\mathrm{b}$ immaterial with reference to the matter sub judice. Where for instance, such matter is in no way connected or mixed $n$ with the partnership affairs $(m)$, or where a final balance ha been ascertained and struck between partners, provided th settlement be one which is binding and conclusive upo them, an action lies for such balance at the suit of the part ascertained to be entitled to it (n). It may be well als to add, that sometimes power is given by statute to on member of a partnership to sue a co-partner on behalf of th concern $(o)$.

Observing, then, that the capacity to contract efficient may, in certain cases, be affected by the existence of a par nership between the contractor and contractee, we mu repeat $(p)$ that any one member of an ordinary trading fir is, in contemplation of our common law, an accredite agent of the firm, so as to bind it by his act done, assurance made, with reference to and in the ordina course of business transacted by it $(q)$, in the absence

(I) Batard v. Hawes, 2 E. \& B. 287; Earl of Mountcashcll r. Barbes, 14 C. B. 53 ; Kcmp r. Finden, 12 M. \& W. 421 ; Edger v. Kuapp, 5 M. \& Gr. 753 ; Tonssaint v. Martinnant, 2 T. R. 100 ; Blackett r. Wcir, j B. \& C. 387 (with which compare Sadler v. Nixon, 5 B. \& Ad. 936 ; Osborne v. IIarper, 5 East, 225; 7 R. R. 696).

(m) Story on Partnership, p. 320 ; Cross v. Cheshire, 7 Exch. 43 ; Scdg. uick v. Daniell, 2 H. \& N. 319.

(n) Wray v. Milestone, 5 M. \& W. 21 ; Faster v. Allanson, 2 T. R. 479 (with which compare Middleditch v. Ellis, 2 Exch. 623) ; Rackstraw r. Imbes, 2 Holt, N. P. C. 368.

See Fromont v. Corpland, 2 Bing.
170; Carr v. Smith, 5 Q. B. 128, 13 Jackison v. Stopherd, 2 Cr. It M. 36 Coffec r. Brian, 3 Bing. 54 ; Wils v. Cutting, 10 Bing. 436. See Lon v. Bradshaw, 9 C. B. 620 ; Broten Tapscott, 6 M. \& W. 119.

(o) See, as an instance, Reddish. Pimock, 10 Exch. 213.

(p) Ante, p. 626.

(q) Per Abbott, C. J., Sandilands. Marsh, 2 B. \& Ald. 678; Marsh. Feating, 2 Cl. \& F. 250 ; Blair Bromley, 5 Hare, 542 (applied Moore r. Knight, (1891) $1 \mathrm{Ch}$. 3t: S. C., 2 Phill. 354 ; with which cas compare Bishop r. Countess of Jers, 2 Drew. 143. See Bcale r. Cadd?, 2 H. S N. 326 ; cf. s. 5. 
collusion between himself and the other contracting party $(r)$. One partner, by virtue of that relation when completely formed, is constituted a general agent for the firm as to all matters within the scope of the partnership dealings, and has communicated to him all authority necessary for carrying on the partnership, and such as is usually exercised by a partner in that business in which he is engaged (s). The Partnership Act now enacts that "every partner is an agent of the firm and his other partners for the purpose of the business of the partnership; and the acts of every partner who does any act for carrying on in the usual way business of the kind carried on by the firm of which he is a member bind the firm and his partners, unless the partner so acting has in fact no authority to act for the firm in the particular matter, and the person with whom he is dealing either knows that he has no authority, or does not know or believe him to be a partner" $(t)$.

Hence, as a general rule, "where a partnership name is pledged, the partnership, of whomsoever it may consist, and whether the partners are named or not, and whether they are known or secret partners, will be bound" (u), each individual member of the firm being answerable in solido for the whole amount of the partnership debts, withont reference to the proportion of his interest as between himself and his co-partners $(x)$. Even a nominal partner, i.e.,

(r) Per Bayley, J., Vere v. Ashby, 10 B. \& C. 296; Leuis r. Reilly, 1 Q. B. 349 , as to which case see Lindley on J'artnership, 6th ed., p. 225 .

(s) See per Lord Wensleydale, Ernest จ. Nicholls, 6 H. L. Ca. 417, 418.

In Brown v. Kidger, 3 H. \& $\mathbf{N}$. 858, Watson, B., observes, "Generally speaking, one partuer has power to borrow mouey for the purpose of carrying on the partnership business. But it may be that the business is to be carried on with ready money only, and that there is no authority in one partner to pledge the credit of the firm.
Everything depends on the nature of the partnership."

(t) S. 5 .

(u) Judgm., Wintle v. Crouther, 1 Cr. I J. 318; De Mautort v. Saundors, I B. \& Ad. 398, 401 ; Bonfield v. Smith, 12 II. \& Wr. 405; Ex perte Hamper, 17 Tes. 403 ; 11 R. R. 115; Drake v. Beckham, 11 M. \& IT. 315; S. C., 9 X. \& W. 79;2 H. L. Ca. 579; per Cocliburn, C. J., Bottomley $v$. Nuttall, j C. B., X. S., 139, 140.

(x) Cf. ss. 6,9 . See also ss. 10 , 11, 12 . 
one who lends his name to a firm or holds himself out as a partner without participating in its profits, is generally responsible to third persons as a partner; for he may induce them to give that credit to the firm which otherwise it would not receive, nor perhaps deserve $(y)$. Assuming as true the above elementary propositions, without citins additional authorities in support of them, let us inquire how they may assist towards determining the mode ir which a trading partnership may contract.

Agency of partner of trading firm -its nature.

The difference which exists between the lind of agency implied by law from the relation of partnership betweer individuals, and that which has (in many cases) to be proved in order to fix joint contractors (not being tradin partners) with liability, may be illustrated by reference ts the responsibility of a member of a club.

In the case of a club, a committee is usually chosen ou of the entire body of the members, and is invested witl certain powers, more or less clearly defined, for carryin out the objects of the institution. The general liabilit: accordingly of any individual member of the club for good ordered, or on contracts entered into, by a fellow-member will depend upon the question-whether such latter part. was or was not an agent duly and sufficiently authorised $t$ pledge the credit of his fellow-members in such manne as he has assumed to do. Further, the members of th club, or some portion of them, may be rendered jointl liable by showing that they have authorised the contrac declared upon, either through the medium of the con mittee, or of some accredited officer of the club, or by the own direct act, without the intervention of any other party $e x . g r .$, by having attended and voted on the committee $c$ at a general meeting of the club. Usually, indeed, associs tions of the kind alluded to agree among themselves upo 
certain written rules and regulations for their guidance, and from such rules the committee or managing body derive their right to pledge the individual credit of the members in certain cases, the right to bind the subscribers being restrained within the limits thus defined, and any contract entered into by the committee not falling within such limits being invalid as regards those who are not directly parties to it $(z)$.

In the class of cases, then, just adverted to, the liability of the party charged upon a contract will usually depend, as pointed out, upon express proof of agency; and the same remark applies to an action for goods sold and delivered brought against a member of the provisional committee of a railway company, where it will be necessary for the plaintiff by reference to the law of principal and agent, in such manner as was explained at p. 599, to connect the defendant with the order given for the goods.

The liability, on the other hand, of a trading co-partnership in respect of a contract entered into by one of its members, must be determined by different considerations.

Where a contract is entered into by one member of a firm expressly in its name or on its behalf, the liability or non-liability of the firm will mainly depend upon this inquiry - Was the particular contract declared upon within the ordinary scope of the partnership dealings? If so, the firm will in general be liable upon the contract.

A partner in trade or business may, for example, bind his co-partners by buying, selling, or pledging goods, by paying (a), receiving, or borrowing (b) money, or by doing

(s) Earl of Mountcasholl จ. Barber, 14 C. B. 53 ; Todd v. Emly, 8 M. \& W. 505; Flemyng r. Hector, 2 M. \& IT. 172; Cockevell v. Aucompte, 2 C. B., N.S. 440,453; Tyrrell r. Woolley, 2 Scott, N. R. 271; Heraud v. Leaf, 5 C. B. 157 ; Remie r. Clar\%e, ò Exch. 292; Cross v. Williams, $7 \mathrm{H}$. \& N. 675 . (a) See Fendal r. Wood, L. R. 6 Exch. 243.

(b) "It is established that in trade partnerships one partner may borrow money for the partuership, and will bind his partner by so doing: " per M. Snith, J., Alliance Bank 1. Eearsley, L. R. 6 C. P. 437. 
other acts incident or appropriate to the particular trade o business, and in accordance with its common course an usage $(c)$. But to allow one partner to bind another b. contracts out of the ordinary scope of the partnershi dealings, even though they be reasonable acts toward effecting the partnership purposes, would be attended wit great danger $(d)$. "Where one partner pledges the cred" of the firm for a purpose apparently not connected with th firm's ordinary course of business, the firm is not bound unless he is in fact specially anthorised by the othe partners;" the personal liability of the individual partne is not affected by this provision $(e)$.

In Nicholson v. Ricketts $(f)$, Cockburn, C. J., observe that, in order to bind a member of a partnership by an ac done by another member of the partnership in the way drawing or accepting a bill, there must be express authorit so to do, or authority implied by operation of law. "I the ordinary case of commercial partnership there is $n$ need of express authority, because the law at once implie an authority, inasmuch as the drawing a bill for the par nership (being a trading commercial partnership) is one the ordinary incidents of such a partnership. Again, if be not what is called a 'commercial partnership' in it ordinary sense, but a trading partnership, yet if it obvious from the very nature of the partnership, or $i$ particular constitution, or the particular purpose 1 which the bill is to be applied, that the drawing of th bill is incidental, there again by operation of law a implied authority to the one partner to bind the other wi arise."

(c) Story on Partnership, s. 102, and cases there cited; Story on Ageney, s. 124, cited and adopted in Bunk of Australasia r. Breillut, 6 Moo. 1. C. c. 193.

(d) Judgm., Brettel v. Milliams, 4 Exch. 630, citing Hawtayne v. Bunrne, ante, p. 605 n. (n).

(e) S. 7 .

(f) 29 L. J. Q. B. 55,$64 ; S .4$

2 E. \& E. 497 . See Stephens r. $R t$ nolds, 5 H. d. X. 513, 516-7.

See Ex parte Buckley, 14 M. \& V 469 ; Maclae v. Sutherland, 3 E. 
There is, however, no custom or usage that solicitors should be parties to negotiable instruments; nor is it necessary, for the purposes of their business, that they should be so $(g)$; a solicitor, therefore, has no implied authority to accept bills in the name of the firm (h). Neither will a guarantee given by a solicitor be binding on his co-partner in the absence of proof of knowledge or privity on the part of the latter, and there being no evidence to show that the security was given in pursuance of the ordinary practice of the parties (i). Nor has a member of a firm of solicitors implied authority to bind his co-partners by a post-dated cheque drawn in the name of the firm $(k)$. So, although it is part of a solicitor's business to prepare conveyances, to examine titles, and so forth, he is not, qua solicitor, a scrivener $(l)$; nor is he impliedly authorised by his co-partners to receive money indefinitely from a client, with a view to laying it out upon proper security when found $(m)$. It is, however, incidental to the business of a solicitor to receive money for the purpose of laying it out upon a particular mortgage; and in this latter case a firm might be liable for the receipt of money by one of its members (n). A partner cannot bind the firm to which he belongs by deed, unless he has express authority by deed for that purpose $(o)$. Nor does it seem

B. 1 ; Healey v. Story, 3 Exch. 3 ; Jenkins จ. MLorris, 16 M. \& W. 877 ; Mason . Rumsey, 1 Camp. 384; Lindus v. Melrose, 3 H. \& N. 177, affirming S. C., 2 Id. 293 ; Bottomley r. Fisher, 1 H. \& C. 211.

(g) Hedley v. Bainbridge, 3 Q. B. 316,321 ; Levy v. Pyne, Car. \& M. 453 .

(h) Per Bramuell, B., L. R. 7 Ex. 232.

(i) Hasteham v. Foung, 5 Q. B. 833. See Brettel v. Williams, 4 Exch. 623 ; Bishop v. Countess of Jersey, 2 Drew. 143. 163.

(k) Forster v. Macreth, L. R. 2 Ex. (l) A scrivener is a person who receives money to lay out upon security, and to hold in his hands until an opportunity offers for laring it out: per Lord Campbell, C. J., 2 E. \& B. 66.

(n) Harman v. Johnson, 2 E. \& B. 61. See Sims r. Brutton, 5 Exch. 802 ; Cleather v. Twisden, $28 \mathrm{Ch}$. D. 340 ; distinguished, Rhodes r. Moukes, (1895) 1 Ch. 236.

(n) Harman . Johnson, supra.

(o) Cf. s. 6. Elliot พ. Daris, 2 B. \& P. 338; 5 R. R. 616; Judgm., Bank of England v. Anderson, 3 Bing. D. C. 658 ; Hawison v. Jaclison, $i$ T. R. $207 ; 4$ R. R. 422; Horsley v. Rush, cited Id. 209; Hall v. Bain- 
that a subsequent ratification of the execution of the deed would suffice to render it effective $(p)$. Power is, howerer, usually given by statute, charter, or otherwise, to certain specified officers of a public company to execute deeds on its behalf.

Again, where a contract has been made by one member of a partnership with a stranger, difficulty sometimes occurs in determining as to the true character of the contract (q); thus, if an account be opened at a banker's by one of two partners in his own name, that fact, however strong, would not be conclusive to show that the account was opened on his own individual behalf; but the banker might give evidence, per contra, to prove that the account was really with the firm, and that the individual opening the accoun acted in so doing as their agent $(r)$. There is, however, no implication of law from the mere existence of a trading partnership that one partner has authority to bind the firm by opening a banking account on its behalf in his orr name $(s)$. So the giving of partnership money for a privat debt is beyond the ordinary authority implied by the nam of partner $(t)$.

So, if an application for a loan be made generally to partner in a bank, the borrower thereby entitles the part.

bridge, 1 M. \& Gr. 42 ; Steiglitz r. Egginton, Holt, X. P. C. $141 ; 17$ R. R. 622 .

(p) See Hunter v. Parker, 7 M. \& W. 322; Ball v. Dunsterille, 4 T. R. 313 ; 2 R. R. 394; Haukshaw v. P'arkins, 2 Swanst. 544; 19 R. R. 125; Bouker $\nabla$. Burdekin, 11 M. S W. 128 . (q) Beckham v. Drake, 10 M. \& W. $79 ; 11$ M. \& W. 315 , is a leading authority to show that an action may be maintainable against a firm on a written agreement signed by some only of its members.

(v) Cooke v. Seeley, 2 Exch. 746; Sims r. Bond, 5 B. \& Ad. 359, 393; Sims r. Brittain, 4 B. \& Ad. 37 ó, and Ireland $\vee$. Thompson, 4 C. B. 149 (which are cited and distinguished in
Walsh r. Proran, \& Exch. 8\$3) Driver v. Burton, 17 Q. B. 989.

See Broucurigg r. Rac, 5 Exch. 489 Lucas v. De La Cour, 1 M. \& S. 249 14 R. R. 426 ; Cox v. Hubbard, 4 C. I 317 ; Garvett r. Handley, 3 B. \& 462 ; S. C., 4 B. \& C. 664 ; wi which compare Agacio r. Forbes, 1 Moo. P. C. C. 160; Arden v. Tueke 4 B. \& Ad. S1ä; Skimner v. Stack: 4 B. S Ald. $437 ; 23$ R. R. 337 Bauden v. Ilowell, 4 Scott, N. R. 331 Brandon r. Hubbard, 2 B. \& B. 11 Bosicell r. Sinith, 6 Car. \& P. 60 Story v. Richardson, 6 Bing. N. O. 12

(s) Alliance Bauk v. Kcarsley, I R. 6 C. P. 433.

( $t$ ) Per Cockburn, C. J., Fendal Irood, L. R. 6 Ex. 251. 
;o applied to, on making the advance, to hold him answerble in either of his (the lender's) capacities of a partnel $r$ of a private individual, according as it may be shown in which character he made the advance $(u)$.

"So in the ordinary case of one partner oraering goods or a firm, there being a third person, a member of the firm, vho was not known to the seller as such at the time of the ransaction, the unknown partner is liable equally with the serson who appears in the transaction, when discovered, inless the seller, having notice of the partnership, chooses, nstead of relying upon the firm, to accept the liability of he particular individual with whom he is dealing" $(x)$. 'If the seller refuses to deal with the firm, but elects to leal exclusively with the individual, he cannot afterwards reat the firm as his debtors, and sue one whom he did not nean to trust" $(y)$.

Where, moreover, it is sought to charge several persons s partners upon a contract ostensibly entered into by one o-partner only, it may be necessary, in order to fix the artnership with liability, to look to the terms of any greement, written or oral (z), subsisting between the arties charged, with a view to showing that there was joint authority given for entering into the contract. If by the terms of the partnership all the capital is supplied y A. and the business is to be carried on by B. and C. in heir own names, it being a stipulation in the contract that L. shall not appear in the business or interfere in its aanagement, that he shall neither buy nor sell nor draw nor ccept bills, no one would say that as amongst themselves lere was any agency of each one for the others. If, ideed, a mere dormant partner were known to be a artner and the limitation of his authority were not known,

(u) See per Bayley, B., Alexande. Barker, 2 Cr. \& J. 138.

(x) Per Cockburn, C. J., Bottomley

Nuttall, 5 C. B., N. S. 139, 140. (y) Id., Ibid.

(z) See Heraud v. Leaf, 5 C. 13. 157. 
he might be able to draw bills and give orders for goods which would bind his co-partners, but in the ordinary case this would not be so, and he would not in the slightest degree be in the position of an agent for them " $(a)$.

From the brief remarks which have preceded, we may collect that the mode of contracting, as well as the capacity to contract, may be materially affected by the relation of partnership existing as between some or all of the contracting parties ; for, by reason of this relationship, important rights may be conferred, or liabilities may be imposed, on parties who are not ostensibly either contractors or contractees. In order fully to carry out this inquiry, a minute examination (incompatible with the plan of this work) of the remedies by and against partners would be requisite. The subjoined remarks may, however, throw some additional light upon the subject before us, or, at all events, assist the student in pursuing it.

Contimuance

The rights and liabilities in regard to third persons of an as partner. individual, quì partner, on a contract, must obviously, in many cases, depend upon the answer to be given to this question-Was the particular contract entered into during the continuance of the partnership? The liability of a partner as such commences at the date of his admission into the firm; so that he will not, in general, be liable on a Cessation of contract effected prior thereto $(b)$. His liability ceases on
liability as jartuer. the dissolution of the firm, or on his retirement from it, accompanied by due notice thereof $(c)$, or (it may be) by

(a) Per Cleasby, B., Holme r. Hammond, L. R. i Ex. 233, 234.

(b) See Wilsford v. Wood, 1 Esp. 183 ; Beale v. Mouls, 10 Q. B. 976 ; Battley v. Lewis, 1 M. \& Gr. 155; Shirreff r. Wilks, 1 East, 48; 5 R. R. 509 ; Wilson v. Lewis, 2 M. \& Gr. 197: per Bayley, J., Fere v. Ashby, 10 B. \& C. 297 . See s. 17 , subs. 1 .

(c) "A retiring partner omitting to inform his customers of the fact, in the usual mode, that the coutinuing partners were no longer authorised to act as his agents, is bound by all contracts made by them with third persons on the faith of their being so anthorised:" Judgm., Freman r. Cooke, 2 Exch. 663-4. See s. 36. A partner retired without notifying his retirement, and the remaining partners continued to pay interest on a loan. Such payment was held to be on behalf of the retired partner, and to prevent the Statute of Limitations running in his farour: Tucker, In re, (1894) 1 Ch. 724, affirmed (1S9t), 3 Ch. 429 (C. A.). 
roof of the creditor's knowledge of the fact $(d)$. "Where person deals with a firm after a change in its constitution e is entitled to treat all apparent members of the old firm s still being members of the firm until he has notice of se change" $(e)$. An advertisement in the "London razette" as to a firm whose principal place of business in England or Wales suffices as notice to persons who ad not dealings with the firm before the date of the issolution or change advertised $(f)$. "The estate of a artner who dies, or who becomes bankrupt, or of a artner who, not having been known to the person dealing ith the firm to be a partner, retires from the firm, is not able for partnership debts contracted after the date of 1e death, bankruptcy, or retirement respectively" ( $g$ ). he retiring partner will still, however, remain liable in sppect of previous engagements, unless the creditor who eks to charge him has ever, expressly or impliedly, rreed to the substitution of the credit of the new firm I that of the old $(h)$, and the onus of proving such an rreement, or of showing that it must necessarily be ferred from the knowledge and conduct of the creditor, is on the parties originally liable (i).

The liability of the retiring partner will also be deterined by any unequivocal act of election on the part of the editor. Thus, where a firm consisting of two partners ssolved, and one retired, while the other continued to rry on the business with a new partner under the same le, a customer of the old firm who supplied goods to the

d) Hart r. Alexander, 2 M. \& W. ; Neusome v. Coles, 2 Camp. 617 ; R. R. 756 ; Parkins v. Carruthers, sp. 248 ; 6 R. R. 828 ; Grahan v. pe, Peake, N. P. C. 154.

e) S. 36 , subs. 1 .

f) Id., subs. 2 .

g) Id., subs. 3 .

h) S. 17, subss. 2 and 3 .

Hart $\mathbf{}$, Alexander, supra ; cited

R. 6 Ex. 157; Dobbin v. Foster,
1 C. \& K. 323; Kirwan v. Kïrwan, 2 C. \& M. 617; Thompson r. Perciral, 5 B. \& Ad. 925; Lyth v. Ault, 7 Exch. 669 (which shows that the acceptance by a creditor of the sole and separate liability of one of several joint debtors is a good consideration for an agreement to discharge all the other debtors from liability: ante, p. 314); Thomas v. Shilliber, 1 M. \& W. 121; Bedford v. Deakin, 2 B. \& Ald. 210. 
new firm without notice of the change, and subsequently, after notice, sued the new firm, and, on their bankruptcy, proved against their estate for the debt, was held to have precluded himself from recovering against the late partner $(k)$.

The Court held that the liability of the late partner was one by estoppel only, and so could not amount to a joint liability with the new firm, who were liable on the facts. "The two principles are not capable of being brought into play together: you cannot at once rely upon estoppel and set up the facts; and if the estoppel makes A. and B. liable, and the facts make $\mathrm{B}$. and $\mathrm{C}$. liable, neither the estoppel, nor the facts, nor any combination of the tro, can possibly make A., B., and C. all liable jointly" (l). As to what will amount to such election on the part of the creditor, we may refer to the judgment of Lord Blackburn in the same case: "The principle, I take it, running through all the cases as to what is an election is this, that where a party in his own mind has thought that he would choose one of two remedies, even though he has written it down as a memorandum, or has indicated it in some other way, that alone will not bind him; but so soon as be has not only determined to follow one of his remedies, but has communicated it to the other side in such a way as to lead the opposite party to believe that he has made that choice, he has completed his election, and can go no further" $(m)$.

So if a banking firm makes payments professedly on account of a customer without his authority, and those payments are entered to the debit of the customer in the books of the firm, parties who afterwards become partners in that firm are not to be considered as agreeing to impose upon themselves a liability for anything more than that

(k) Scarff. Jardine, 7 App. Cas. 345.350 .

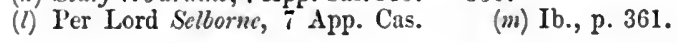


sum which by the books themselves, which are hander ver to the new firm, appears to be due to the customer. And, in order to render the new firm liable for the imounts which do not so appear in the books, it will be aecessary to show that the old firm have ceased to be iable, and are discharged, by proof of an agreement setween the old firm, the new firm, and the customer, hat the new firm is to be considered as substituted, as the lebtors, in lieu of the old, for the amount sought to be ecovered $(n)$.

The liability of a dormant, as of an active partner, will ease on his retirement from the firm, except quoad such ersons as, at the time of contracting, knew him to be a artner. To these parties notice of withdrawal should be iven, though none others are entitled to it $(o)$.

The above remarks point to the manner in which the apacity to contract-ex. gr., to bind or benefit others, hose names do not expressly appear therein, by a conract-may, in ordinary mercantile transactions, be affected $y$ the relation of partnership; for we have seen that a artner in many cases may bind his co-partners, or so ontract as to bind himself only, and not his co-parters $(p)$. With reference to this part of the subject, it 1ay be well to add that at law as well the remedy availble to, as the liability $(q)$ enforceable against, a partner in trading firm passes or attaches on his death to his suriving co-partners; the rule here applicable being, that !e remedy survives, but not the right; for jus accrescendi iter mercatores, pro beneficio commercii locum non habet;pon the dissolution of a mercantile or manufacturing $\left(r^{*}\right)$

(n) Craufurd v. Cocks, 6 Exch. 287, (o) Per Patteson, J., Heath v. Sann, 4 B. \& Ad. 117 ; Evans v. Drumnd, 4 Esp. 89 ; Carter v. Whalley, B. \& Ad. 11 ; Farrav v. Deflinne, J. \& K. 580.

B.C.L. (p) Per Maule, J., Holcroft r. Hoggins, 2 C. B. 492.

(q) See per Lord Holt, Hyat $\mathrm{r}$. Hare, Comb. 383, cited 2 T. R. 479.

(r) Buchley v. Barber, 6 Exch. 164, with which compare Crossfield v. Sueh, 8 Exch. 825. This latter case show's 
partnership by death, the property and effects thereof do not belong exclusively to the survivors, but are to be dis. tributed between them and the representatives of the deceased, in the same manner as they would have been upon a voluntary dissolution inter viros (s).

In the preceding pages those rules only relating to partner ship have been mentioned which are most frequently applie in Courts of law. Equity concerns itself especially witl adjusting the rights and liabilities of partner's inter se $(t)$ arranging, where necessary, the terms on which a partner ship is to be dissolved and its affairs liquidated, in dis tinguishing between the joint and the separate estates partners, and in adjudicating with regard to matters whic never were within the cognisance of tribunals administerin our common law. The Partnership Act, 1890, has embodie in its provisions dealing with the relation of partners one another $(u)$, and dissolution and its consequences $(x)$, th rulings of equity concerning these points. In genere accordingly, little difficulty is likely to be felt in assignin to the proper Division of the High Court of Justice cas involving partnership, either as governed by the strict legal doctrines which have been heretofore stated or falling within one or other of well-known branches equitable jurisprudence.

Contracts b) corporations.
It was anciently a rule of our common law that a corpor tion aggregate must contract by deed, and could not bi

that the right of survirorship holds at common law, save where a ense falls within the principle of the exception introduced by the Lex Mereatoria.

(s) Story on Partnership, s. 342 ; adopted Judgm., 6 Exch. 180.

$(t)$ In the absence of nn express agreement to assign the goodwill, the remaining partners have no right to use the name of a retired partner, for the purpose of carrying on the business under the old partnership name: Gray r. smith, 43 Ch. D. 208.
A person who has been taken into $p$ nership on the terms that on the exp tion of the partnership the good will of 9 business shall belong solely to the of $\mathrm{r}$ partners is not entitled to make co s of entries in the partnership books the avowed object of using such ens: at its termination to assist him to o: pete in business with his former If ners: Trego r. Hunt, (1896) (A.). T, reversing $S . C .,(1895) 1 \mathrm{Ch.} 4$
(u) Ss. 19-31.
(x) Ss. 32-44. 
tself by parol; the principle on which this rule rested being, hat a corporate body has no mode of indicating its consent 0 an act done save by the affixing of its common seal to ome document (y), which is thus evidence as well of the ct done as of the assent to it of the body corporate (z). In o other way could the concurrence of the entire body cororate in the particular act be authenticated. It could not, or instance, be evidenced by the resolution of a meeting omposed of members of the corporation, however numejusly attended $(a)$.

As exemplifying the operation of the above rule, the folwring cases may be mentioned:-Arnold v. The Mayor of 'oole (b), where it was held that a solicitor who had been mployed by the mayor and town council of Poole to conuct suits on their behalf, but had not been appointed nder seal, could not recover his bill of costs against the orporation; Diggle v. The London and Blackuall R.C. (c), here the facts were these:-The plaintiff, who was a railay contractor, entered into an agreement, not under seal, ith the defendants, to do certain work upon their railway; aring done some of the work in pursuance of the agreeent, he was then ordered to discontinue it by the comany; and it was held that he could not recover for any ortion of the work so done $(d)$.

(y) Delivery is not necessary in the se of acorporation: ante, p. $264, \mathrm{n}$. (n). (z) Upon this point, Blackstone tells ( 1 Com., p. 475 ) that, after a corration has been formed and named, acquires certain "capacities and apacities, some of which are necesily and inseparably incident to it;" longst these is the having a common ?. "For a corporation being an isible body, cannot manifest its intion by any personal act or oral disurse; it therefore acts and speaks 'y by its common seal. For though particular members may express ir private consents to any act by rds or signing their names, yet this does not bind the corporation-it is the fixing of the seal, and that only, which unites the several assents of the indiriduals who compose the community, and makes one joint assent of the whole."

(a) Judgm., Hayor of Ludlow r. Chaviton, 6 M. \& W. 823 ; followed in Austin v. Guardians of Bethnal Green, L. R. 9 C. P. 91 . See Warchant r. Lea Conservancy Board, L. R. 9 Ex. 60.

(b) 4 M. \& Gr. 860 .

(c) 5 Exch. 412; London Dock Co. r. Simnott, 8 E. \& B. 347 .

(d) See also Mayor of Oxford v. Crow, (1893) 3 Ch. 535 (following Mayor of Kidderminster v. Hardwick, L. R. 9 Ex. 13). 
As regarded municipal and ecclesiastical corporations exceptions to the above rule were from very early times allowed, in order that they might be enabled, without the formality of sealing, to transact matters of minor import ance and of daily occurrence $(e)$. The rule, indeed, tha a corporation can only act or speak by its common seal though true in theory, was found intolerable in practice $(f)$ The act of affixing the seal, of lifting the hand, or openim the mouth, could only be done by some individual member theoretically quite distinct from the body politic, or b some agent. The management of the corporate property the daily sustentation of the members, the performance the very duties for which the corporation was creater required incessantly that acts should be done, sometime daily recurring; sometimes entirely unforeseen yet admi ting of no delay; sometimes of small importance, or relatir to property of little value. The same cause also require that contracts to a small amount should often be enter into. In any such case, the affixing of the common se was impossible; and therefore, from time to time, exce tions were admitted to the rule $(g)$, the decisions respectir which, as remarked by Lord Denman, C. J. (h), furnish t principle on which they were established, and show that was "concenience amounting almost to necessity" (i).

Accordingly, it was held that a corporation such as la mentioned might give a personal command, and, by par do sundry small acts, that it might retain a servant $(k)$ authorise another to make a distress, or the like, th

(e) Per M. Smith, J., South of Ireland Colliery Co. v. Wadelle, I. R. 3 C. I. $474 ;$ S. C. aftirmed, I. R. 4 C. 1 . 617 ; Mayor of Iridderminster v. Hardiciek, L. R. 9 Ex. 13.

(f) The rule has been desiguated as "a relic of barbarous antiquity :" per Cockbum, C. J., L. R. 4 C. P'. 618.

(g) Judgm., Beverley r. Lincoln Gas Light and Coke Co., 6 Ad. \& E. 84t; per Parke, B., Cope v. Thames Huten
Dock and IR. C., 3 Exch. 844.

(h) Church v. Imperial Gas $L$ and Cole Co., 6 Ad. \& E. 861.

(i) See Clarke $v$. Cuckfield $\mathrm{CH}_{\mathrm{n}}$ 21 L. J. Q. B3. $349 ; S_{0} . C_{\circ}, 1$ C. C. 81: Nicholson $\checkmark$. Brad Union, L. R. I R. B. 620 ; Wel, Kingston-"pon-Hull, L. R. $10 \mathrm{C}$ ? $402,409$.

(i) Judgm., Arnold v. Mayp of Poole, 4 M. \& G. R. 89 \%. 
seing acts which require to be done for the ordinary conenience of the body corporate, and which the head of the orporation is delegated by its other members to perform. Chese several exceptions to the general rule clearly origirated in necessity, or in convenience almost amounting to recessity $(l)$.

As regards trading corporations, the exceptions to the ule at common law have gradually and largely been stended; for the doctrine now is that a corporate body stablished for the purpose of trading may make all such ontracts as are of ordinary occurrence in that trade-irrepective of the magnitude of the particular transactionithout the formality of a seal, and that the seal is required nly in matters of unusual and extraordinary character, - hich are not likely to arise in the routine of business $(\mathrm{m})$. As an example of this important restriction of the general ule, The Copper Miners' Company v. Fox (n) may be cited; hat was an action at suit of a corporation on a contract by

(I) See also per Lord Denman, .J., Hall v. Layor, \&e., of Swansea, Q. B. 546 ; Judgm., 4 ML. \& Gr. 3.); De Grace r. Mayor, ge., of Conmouth, 4 Car. \& P. 111.

(mi) South of Ireland Colliery Co. v. Taddle, L. R. 3 C. P. 463, 469, 474; C. affirmed, L. R. 4 C. P. 617.

(n) 16 Q. B. 229.

In Batcman v. Mid-Wales R. C., . R. 1 C. P. 510, Byles, J., observes, Only three instances can be cited of ce acceptance of negotiable instruents by corporations. The first is at of the Bank of England ; but that tablishment was incorporated for the Iry purpose, its promissory notes id bank post bills forming a very rge portion of the circulating medium this country. The second is that of e East India Company ; there the ithority to draw, accept, and endorse Ils and notes, if not created, is at all ents ratified and confirmed by two cts of Parliament, the $9 \& 10$ Will. c. 44 and 55 Geo. 3 c. 155 . The ird instance is that of Slark $\mathrm{v}$. ighgate Archicay Co., 5 Taunt. 792, where the company had express authority to give bills. Excepting these, there is no authority to show that a common law corporation can draw, accept, or endorse bills of exchange."

In Crouch v. Crédit Foncier of Englanl, L. R. 8 Q. B. 382, the Court observes as follows: "When a corporation is established for trading purposes, it is from its nature capable of drawing a bill of exchange." "This is not by virtue of any statute but from the conimon law. But all such bills of cxehange in practice alurays have been made under hand by an agent authorised to draw or accept, as the case may be."

"Capacity to incur liability" as a party to a bill is co-extensive with capacity to contract. Provided that nothing in this section shall enable a corporation to make itself liable as drawer, acceptor, or indorser of a bill, unless it is competent to it so to do under the law for the time being in force relating to corporations: " 45 \& 46 Vict. c. 61 , s. 22 , subs. 1. 
parol for the supply of iron rails to the defendant, and th action was held not sustainable, upon proof that the con pany's charter incorporated them for the purpose of uorkin copper mines and selling copper ore, but contained nothin which authorised the company to deal in iron. "Had th subject-matter of this contract been copper," observed th Court of Queen's Bench, "or if it had been shown in an way to be incidental or ancillary to carrying on the busine of copper miners, the contract would have been bindin although not under seal; for where a trading company created by charter, while acting within the scope of th charter, it may enter into the commercial contracts usual such a business in the usual manner. But the iron rail the subject-matter of this contract, were not shown to ha any connection with the business of copper miners." T) distinction here taken by the Court precisely illustrates th scope and meaning of the restriction of the general ro respecting contracts by bodies corporate above adverted

Another exception which may be noticed to the comm law rule that a corporation must contract under seal, thou. not so well defined as the preceding, seems to require its support this special ingredient, riz., the adoption of $t$ particular contract in question, and the enjoyment of $t$ benefits resulting from it, by the corporation or by th other contracting party, or in other words some degree mutuality $(o)$.

Thus it has been held, that an action for use and occus tion will lie at suit of a corporation where the tenant 1 held premises under them, and paid rent $(p)$. It has be

(c) The rule that "when a corpora. tion may sue upon a simple contract, it may also be sued," is true only where "the want of mutuality would leare one party without a ralid or arailahle consideration for his promise:" per Cleasby, B., Ecclesiastical Commis. sianer's v. Merral, L. R. 4 Fx. 168, distinguished in Mayor of $K$ id minster" v. Havducick, L. R. 9 $13,18$.

(p) Mayor of Stafford v. Ti Bing. 75; Mayos of Carmarthe Lexeis, 6 Car. \& P. 608; Itan, of Rochester. T. Pierce. 1 Camp. Hayor of London $v$. Hunt, 3 Jer. 
held, also, that if a contract with a corporation is executed by them, if the persons who are parties to the contract with the corporation have received the benefit of the consideration moving from the corporation, these last-mentioned parties are bound by the contract, and liable to be sued thereon by the corporation $(q)$.

Further, where the guardians of a union verbally directed their officer to have gates made for the union workhouse, and the plaintiff, in pursuance of orders from the officer, lurnished the gates, which were erected, the jury having found for the plaintiff, the Court of Queen's Bench refused to disturb the verdict, inasmuch as the work, after it had been done and completed, was adopted by the defendants ior purposes connected with the corporation $(r)$.

The judgment in Clarke v. The Cuckfield Union (s) is important with reference to the class of cases now under notice. There the action was in debt for goods sold and lelivered, and for work and labour, the claim being in espect of water-closets put up by the plaintiff at the union workhouse, by the direction and with the approbation of the lefendants at a regularly constituted meeting of the Board of Guardians. The broad question for judicial decision was his, whether, assuming the articles supplied to have been such as were proper and needful for the workhouse ; assumng also, that the defendants ordered them, at a meeting of he board, to be furnished by the plaintiff, and afterwards ipproved of and kept them, they were exonerated from

(a) Judgm., Fishmongers' Co. v. Robertson, j M. \& Gr. 192 ; Pegge v. Lampeter Union, L. R. 7 C. P. 366 ; Reg. จ. Mayor of Thetford, 2 Ld. Raym. 848 ; Barber Surgeons of London v. Pelson, 2 Lev. 252; East Condon Wateruorks Co. v. Bailey, 4 3ing. 287.

The principle stated in the text is lot to be extended to an executory ontract by a corporation: Mayor of ridderminster v. Havdiciel, L. R.
9 Ex. 13, 21 ; Judgm., Copper Mincrs' Co. v. Fox, 16 Q. B. $237,238$.

(r) Sanders r. St. Teots Union, 8 Q. B. 810 ; with which compare Paine r. Strand Union, Id. 326 ; Lampiell r. Billevieny Union, 3 Exch. 283, 307; and cases cited post.

(s) 21 L. J. Q. B. 349 ; S. C., 1 Bail C. C. 81 ; followed in Nicholson r. Bradfield Únion, L. R. 1 (2. B. 620 . 
liability, on the ground that no contract under seal for the supply in question had been entered into? Wightman, J. after adverting to the general rule applicable to the contrac of a body corporate, and the exceptions to it, held that the defendants could not thus repel the claim against them "I am disposed to think," said the learned Judge, "tha wherever the purposes for which a corporation is created render it necessary that work should be done, or goods sup plied, to carry such purposes into effect, as in the case o the guardians of a poor-law union, and orders are given a a board regularly constituted, and having general authorit to make contracts for work or goods necessary for the pur poses for which the corporation was created, and the wor is done, or goods supplied, and accepted by the corporation and the whole consideration for payment executed, th corporation cannot keep the goods or the benefit an refuse to pay, on the ground that though the members the corporation who ordered the goods or work were com petent to make a contract and bind the rest, the formalit of a deed or of affixing the seal were wanting, and then say 'No action lies; we are not competent to make a par contract, and we avail ourselves of our own disability."

We thus see that where a corporation has acted as upo an executed contract a presumption has in various case been raised as against the corporate body from its acts this effect, that it has contracted in such manner as to bin itself $(t)$.

This principle does not appear to have been extende hitherto to contracts of a large amount, and in any event will be limited to cases where the benefit has actually bee enjoyed, and where the order given was necessary for th purpose of enabling the corporation to do their duty,

(t) Doe d. Pennington v. Tanieve, 12 Q. B. 998 ; Totterdell v. Faveham Brick Co., L. R. 1 C. P. 674 ; Lone v. Lonulon and N. W. R. Co., 21

L. J. Q. B. $361 ; S . C ., 15 \mathrm{Q}$. 632 ; Pauling v. London and $N . W$. Co., 8 Exch. 867; Scott $r$. Clif School Boavd, 1+ Q. B. D. 500. 
carry out the purposes for which they were called into existence ( $u$. The cases, however, on this subject are very numerous and conflicting, and they require review and anthoritative exposition by a Court of Appeal $(x)$; and it has recently been decided by the House of Lords that, whatever may be the authority of this rule, it has certainly no application in cases under the Public Health Act, 1875, s. 174 , subs. 1 , of which, enacting that every contract made by an urban authority whereof the value or amount exceeds fifty pounds shall be in writing and sealed with the common seal of such authority, is obligatory, and not merely directory $(y)$. If, however, in a contract entered into by an urban sanitary authority under the Act, it is not ascertained at the time of so entering into it that the sum will exceed fifty pounds, the fact that it subsequently does saceed it will not invalidate the contract if not under seal $(z)$.

In equity it is well established that part performance by entering into possession of land under a verbal contract for ts purchase is sufficient to take the case out of the operaion of the Statute of Frauds, the reason of the rule being hat possession by a stranger is evidence that there was ome contract, and will compel the Court to admit proof as o its terms in order that justice may be done between the parties. "The Statute of Frauds says that in certain cases 10 action shall be maintained unless there is evidence in rriting to show what the contract was. But if a Court of ¿quity finds an overt act, such as the possession of land, hen the presumption of a contract is raised, and the Court rill, in consequence of that overt act, allow parol evidence o be given for the purpose of ascertaining what the actual

(u) Per Bramiell, L. J., Hunt v. Vimbledon Local Baard, 4 C. P. 1. 53 .

(x) Per Lindley, L. J., Foung v. arp. of Leamington, 8 Q. B. D. 579 ; r Lord Blackburn, $S . C ., 8 \mathrm{App}$. Cas. 23, from which case we also learn that a parol order given by an agent with authority under seal will not be sufficient to bind the corporation.

(y) Foung $v$. Corporation of Lermington, 8 App. Cas. ら̈17. 529 . (z) Eatan Y. Basker, 7 Q. B. D. 
contract was" $(a)$. This equitable doctrine cannot however be called in aid of the proposition that a corporation is liable to be sued in an action at law whenever goods hare been supplied or work has, been done in pursuance of a contract entered into not under seal, and the corporation has had the full benefit of such contract.

Trading companies.

A new class of exceptions has, in modern times, sprung up to the general rule, that a corporate body must contract under seal. Corporations are now frequently established by charter, letters patent, or Act of Parliament (b), for the purpose of carrying on trading speculations to which the making of particular kind of contracts is essential, and in such cases power is usually conferred on certain of the corporate officers, designated by the Crown or legislature to enter into contracts, such as alluded to, on behalf of all the members of the corporation, otherwise than under seal Difficulty can scarcely arise respecting the efficacy of con tracts which profess to be thus made, unless it be from th ambiguous wording of the statute, charter, deed of settle ment, or other instrument, under which the company if question has been constituted; and when governed b. express statutory provisions, the rule applicable is, that body corporate must contract either under seal or in suc manner as is prescribed or sanctioned thereby $(c)$.

(a) Per Cotton, I. J., Hunt v. Wimbledon Local Board, 4 C. P. D. 61, citing Ungley v. Ungley, 5 Ch. D. 887 ; ante, p. 386.

(b) See particularly the Companies Act, $1862(25$ \& 26 Vict. c. 89), amended by 30 \& 31 Vict. e. 131 , of which sce $5.37 ; 42$ \& 43 Vict. c. 76 , s. 4 .

As to the winding up of companies, see 53 \& 54 Vict. c. 63 .

As to the existence of privity as between a third person and the company, sce Ely r. The Positire Gorernment See, and Ass. Co., 1 Ex. D. 88 ; Broune v. La Trinidad, $37 \mathrm{Cb}$. D. 1.
As to the effect of a transfer shares by a sharelolder iu regard to $b$ release from liability, see per Io Cairns, C., Tement v. City of Glasgd Bank, 4 App. Cas. 621.

(c) Homersham v. Holterhampt Wateruorks Co., 6 Exch. 137, disti guished in Smith v. IIull Glass C 11 C. B. 928 ; Frend v. Dennett, C. B., N. S., 576; approved in Iou v. Corp. of Leamington, 8 Q. B. $579 ; 8$ App. Cas. 517; Prince Wales Ass. Co. r. Harding, E. B. E. 183: Kirk r. Bell, 16 Q. B. 29 followed in Bottomley's case, $16 \mathrm{Ch}$. 685 ; Nowell r. Mayor, ge., of $W^{\circ}$ 
Further, it is obvious, that companies, regulated hy statute and deed of settlement, are not to be treated as ordinary trading partnerships; such companies are only bound by contracts made by their director's or other ofticer's within the scope of their authority (d); any contract $01^{\circ}$ agreement entered into ultra vires, will (as a general rule) be roid, not enforceable against the company, nor capable of being ratified by them $(e)$.

This doctrine, however, is to be applied reasonably; so that whatever is fairly incidental to those things which the legislature has authorized by an Act of Parliament onglit not (unless expressly prohibited) to be held as ultra rives ( $\left.f^{\prime}\right)$.

"There can be no doubt," as observed by Lord Wousleydale (9), "that a corporation is fully capable of binding itself by any contract under its common seal in England, and without it in Scotland $(h)$, except where the statutes by which it is created or regulated expressly or by necessary implication prohibit such contract between the parties;

cester, 9 Exch. 457; Cope r. Thames Haten Dock and R. Co., 3 Exch. 811. See Payne r. New South Wales Coal, ge., Co., 10 Exch. 283.

(d) Smith r. Hull Glass Co.; $11 \mathrm{C}$. B. 926,927. See Ridley v. Plymouth, ge., Baking Co., and Kingsbridge Flour Will Co. r. Same, 2 Exch. 711, 718; Hallett v. Doudall, 18 Q. B. 2; Hambro' $r$. Hull and London Fire Ins. Co., 3 H. \& N. 789 ; Agar v. Athenoum Life Ass. Soe., 3 C. B., X. S., 725. By $53 \& 5 t$ Tict. c. 6?, the Compamies (Memorandum of Association) Act, 1890 , provision is made for altering the memorandum of association of a company without recourse to the method previously necessary of winding up and reconstruction. Further, the Act allows the substitution of a memorandum and articles of association for a deed of settlement where companies have been formed in such way.

(e) Ashbury Railway Carriage Co. v. Riche, J. R. 7 H. L. 6.53 , as to which case see Wenlock (Baroness) r. loctrine of uitra vires. 
primâ facie, all its contracts are valid, and it lies on those who impeach any contract to make out that it is avoided. This is the doctrine of ultra vires, and is no doubt sound law, though the application of it to the points of each particular case has not always been satisfactory."

To the above subject, which is one of great and increasing importance to the community, a bare allusion must here suffice.

Projected companies.

In the cases below cited (i) will be found resolved various questions raised as to the respective liabilities of shareholders, directors, managing committee-men, and others concerned with projected companies or associations $(k)$. The general deduction to be made from these cases is that, when one is engaged to act with others for the purpose of establishing a particular scheme, neither is a co-partnership to be assumed necessarily to arise thereon, nor a quasico-partnership, such as shall of itself render any one of the individuals so associated together agent for any other, or for all the others, for the purposes of attaining the common object. It is not merely by agreeing to act with others that a man is rendered liable on contracts made by those associated with him; but if by his consent, conduct, or ratification he authorize any one to act for him, and work is done and credit given on the faith of his responsibility, he will be liable in respect of contracts which have been thus entered into $(l)$. The liability of the promoter or director of a company for fraud will be touched upor hereafter.

(i) Taylor r. Croveland Gas and ruke Co., 10 Exch. 293; Preston r. The Lirerpool, Manchester, and Tew. instle-upon-Tyme $R . C ., \quad 1 i$ liear. 114 ; Bull r. Chapman, 8 Exch. 444; Reymell v. Levis, Wyld v. Hopkirs, 15) M. \& W. 517; Wilson r. Fisconnt Cre:-on, Id. 532 ; Barwett v. Lambert, Id. 493 .

(k) Nelhado v. Porto Alegre R. C.,
L. R. 9 C. P. 503 ; Cross v. Hilliams 7 H. \& N. 675 .

(l) Sce Walstab v. Spottisucoode, i M. \& W. 501; Garrood v. Ede, Exch. 264; Ward r. Lord Londes borough, 12 C. B. 252 ; Clements Todd, 1 Exch. $26 \mathrm{~S}$; Jones v. Harrison 2 Exch. 52; Woutner r. Shairp, C. B. 404; Joore v. Gareood, Exch. 6S1. 
We proceed next to notice some of the leading provisions Bankruptw. of the Bankruptey Act, 1883 (m), which have a material bearing upon the capacity to contract as affected by bankruptcy. The limits of these commentaries, however, will not permit us to do more than refer to some of the main prorisions of the Act, leaving the student to seek for further information in works dealing specially with the subject.

We will treat, 1st, of those provisions which deal with the commencement of bankruptey and the appointment and duties of the Official Receiver, and which indicate the effect of bankruptcy as touching rights of suit against the bankrupt; 2ndly, of those which specify the debts provable in bankruptey, and protected transactions; 3rdly, of those which concern the vesting and assignment of the banlirupt's property, and the functions of the trustee; 4thly, of those which define the status of a bankrupt who has or has not obtained his order of discharge; and finally, of those which concern certain contracts of the bankrupt.

1. All proceedings in bankruptey are to be commenced by a bankruptey petition which may be presented either by the creditor or the debtor (n), and will, if suceessful, be tollowed by a receiving order made by the Court for the protection of the debtor's estate. This order, which will be made upon proof of one or more of the conditions enumerated in s. 6, subs. 1, constitutes an Official Receiver as receiver of the debtor's property, and is followed by this important consequence, that thereafter, except as directed by the Act, no creditor to whom the debtor is indebted in respect of any debt provable in bankruptcy shall have any remedy against the property or person of the debtor in respect of the debt, or shall commence any action or other legal proceeding, unless with the leave of the Court, and on such terms as the Court may impose (o).

(m) $46 \& 47$ Vict. c. 52 .

(n) S. 5.

(o) S. 9 , subs. 1 . 
The Court may further, if it be shown to be necessary for the protection of the estate, at any time after the presentation of a bankiuptcy petition, and before the receiving order is made, appoint the Official Receiver to be interim receiver of the property of the debtor or of any part thereof, and direct him to take immediate possession thereof, or of any part thereof, and also stay any action, execution, or other legal process against the property or person of the debtor ; and any Court in which proceedings are pending against a debtor may, on proof that a bankruptcy petition has been presented by or against the debtor, either stay such proceedings or allow them to continue on such terms as it may think just $(p)$.

A landlord, or other person to whom any rent is due from the bankrupt, may, however, at any time, either before or after the commencement of the bankruptcy, distrain upon the goods or effects of the bankrupt for the rent due to him from the bankrupt, with this limitation, that if such distress for rent be levied after the commencement of the bankruptcy, it shall be available only for six months' rent accrued due prior to the date of the order of adjudication; but he may prove under the barkiruptey for the surplus due for which the distress may not have been available $(q)$.

Debts

provable in bankruptey.

2. Demands in the nature of unliquidated damages arising otherwise than by reason of a contract, promise, or breach of trust, are not provable in bankruptcy, and a person having notice of any act of banliruptcy $(r)$ available against a debtor cannot prove under the order for any debt or liability contracted by the debtor subsequently to the date

(p) S. 10.

(q) S. 42, subs. 1. "Six months" " is substituted for "one year's" by the Bankruptcy Act, 1890 (53 \& 54 Vict. c. 71$)$, s. 28. Preferential debts within s. 1 , subs. 1 , of 51 \& 52 Vict. c. 62 , are a first charge on goods distrained within three months next before the date of th receiving order or the proceeds of th sale thereof. Cf. id. subs. 4.

$(r)$ As to what constitutes an act 0 bankruptcy, see s. 6 , subs. $1:$ s. 8 subs. 1 . 
If his so having notice. But, with these exceptions, all debts nd liabilities, present or future, certain or contingent, to vhich the debtor is subject at the date of the receiving order Ir to which he may become subject before his discharge y reason of any obligation incurred before the date of such rrder, are deemed to be debts provable in bankruptey.

"Liability" for the purposes of the Act includes any ompensation for work and labour done, any obligation or rossibility of an obligation to pay money or money's worth in the breach of any express or implied covenant, contract, greement, or undertaking, whether the breach does or loes not occur $(s)$, or is or is not likely to occur or capable of cecurring, before the discharge of the debtor, and generally t includes any express or implied engagement, agreement, r undertaking to pay, or capable of resulting in the payaent of money or money's worth, whether the payment is, s respects amount, fixed or unlimited; as respects time, rresent or future, certain or dependent on any one continency, or on two or more contingencies; as to mode of aluation, capable of being ascertained by fixed rules, or as aatter of opinion.

An estimate is to be made by the trustee of the value of ny debt or liability provable as aforesaid which, by reason $f$ its being subject to any contingency or contingencies or or any other reason, does not bear a certain value. If, owever, any person is aggrieved by the estimate, he can ppeal to the Court, when it will be held to be provable or ot according as the Court is of opinion that the value hereof is or is not capable of being fairly estimated; and he Court may direct the same to be valued before it, ithout the intervention of a jury, and the amount when

(8) The House of Lords in Hardy v. othergill, $13 \mathrm{App}$. Cas. $35 \mathrm{l}$, held that le future and contingent liability of te assignee of a lease on a covenant to idemnify the lessee was provable under the corresponding section of the Act of 1869, unless a declaration by the Court that it was a liability which could not be estimated had been obtained by the lessee. 
The public exanination.

Trustee.

assessed shall be deemed to be a debt provable in bankruptcy $(t)$.

Bonk fide transactions are protected in certain cases, provided that, 1stly, the payment, delivery, conveyance, assignment, contract, dealing, or transaction takes place before the date of the receiving order, and also, 2ndly, that the person so dealing with the debtor has not, at the time of so doing, notice of any available act of bankruptcy com. mitted by the bankrupt before that time $(u)$.

Under the new statute one of the first acts after the receiving order is the public examination of the debtor upon oath as to his conduct, dealings, and property. This is a rigorous examination, in which any creditor who has tendered a proof may question the debtor as to his affairs and the causes of his failure $(x)$.

3. The effect of making a receiving order against a debtor is (unless a composition or scheme $(y)$ is accepted and approved within fourteen days after the conclusion of the examination of the debtor, or such further time as the Court may allow), that the Court will adjudge the debtor bankrupt, and thereupon his property $(z)$ will becom divisible among his creditors and vest in a trustee $(a)$.

Until a trustee is appointed the Official Receiver will b. the trustee for the purposes of the Act, and immediately or a debtor being adjudged bankrupt his property will vest is such trustee. On the appointment of a trustee the propert. will forthwith pass to and vest in the trustee appointed

(t) S. 37 .

(u) S. 49 .

(x) S. 17 . Cf. Act of 1590, s. 2 , subs. 1 .

(y) As to composition, cf. s. 3 of the Act of 1890 (53 \& 54 Vict. c. 71) and s. 19 of the Act of 1883 . No conposition of less than seven shillings and sixpence in the pound will be allowed if any facts are prored which would justify the Court in refusing, qualifying, or suspending the debtor's discharge.
Cf. s. 3 , subs. 9 , of the Act of 1590 .

(z) "Property" includes mone goods, things in action, land, at every description of property, wheth real or personal, and whether situa in England or elsewhere, also oblig. tions, easements, and every descriptic of estate, interest, and profit, prese or future, rested or contingent, arisin out of, or incident to, property as abo defined : s. 168.

(a) S. 20, subs. 1 . 
The property of the bankrupt will pass from trustee to rustee, including under that title the Official Receiver vhen he fills the office of trustee, and will vest in the rustee for the time being during his continuance in office, ithout any conveyance, assignment, or transfer whatver $(b)$.

The property of a bankrupt divisible among his creditors oes not comprise : 1 . Property held by the bankrupt on ust for any other person ; 2. The tools (if any) of his :ade, and the necessary wearing apparel and bedding of imself, his wife, and children, to a value, inclusive of tools nd apparel and bedding, not exceeding $£ 20$ in the whole. ;oes, however, comprise: 1. All such property as may along to or be rested in the bankrupt at the commencelent of the bankruptcy, or may be acquired by or devolve a him before his discharge; 2 . The capacity to exercise, ad to take proceedings for exercising, all such powers in : over or in respect of property, as might have been exersed by the bankrupt for his own benefit at the commenceent of his bankruptcy, or before his discharge, except the ght of nomination to a vacant ecclesiastical benefice; All goods being, at the commencement of the bankiptcy, in the possession, order, or disposition of the mkrupt, in his trade or business, by the consent and rmission of the true owner, under such circumstances at he is the reputed owner thereof; provided that ings in action, other than debts due or growing due to e bankrupt in the course of his trade or business, will not deemed goods within the meaning of this section (c). Where any part of the property of a bankrupt consists of ad (d) of any tenure burdened with onerous covenants, or

Property of bankrupt.

b) S. 54 , subss. $1,2,3$.

c) S. 44. The last clause of the tion confines the doctrine of reputed nership to trade goods. See Chalmers 1 Hough, Bankruptcy Acts, 1883 to B.C.L.
1890, 3rd ed., p. 100 .

(d) S. 55 (which binds the Crown: In re Thomas, 21 Q. B. D. 380), as amended by s. 13 of the Act of 1890 . It would seem that where the trustee
Disclaimer by trustee. 
shares or stock in companies, of unprofitable contracts or of any other property that is unsaleable, or not readily saleable, by reason of its binding the possessor thereof to the performance of any onerous act, or to the paymen? of any sum of money, the trustee, notwithstanding tha he has endearoured to sell or has taken possession of th property, or exercised any act of ownership in relation thereto, but subject to the provisions of the section, ma by writing signed by him (e), at any time within twels months after the first appointment of a trustee, disclain the property; provided that, where any such propert shall not have come to the knowledge of the trustee withi one month after such appointment, he may disclaim suc property at any time within trelve months after he fir became aware thereof.

A lease cannot be disclaimed without the leave of th Court, excepting in certain cases specified in No. 69 of th Bankiuptcy Rules $1890(f)$.

The section further deals with the effect of such di claimers, their use in relation to leasehold property (? and the determination of the trustee's right to disclail where an application in writing has been made to him any person interested in the property requiring him decide whether he will disclaim or not, and he has for period of twenty-eight days after the receipt of the appcation, or such extended period as may be allowed by to

disclaims freeholds as being " burdened with onerous covenants," under this section, they will (subject to the prorisions of $s .55$, subs. 6 ) revert to the Crown : Re .llereer and Moore, 14 Ch. D. $28 \%$.

(e) A disclaimer in writing signed br the trustee's solicitor is uot a ralid disclaimer "by writiug under the hand", of the trustee: Wilson r. Mallumi, 5 Ex. D. 155.

(f) S. 55 , subs. 3 , ante, p. 561 . Rule 320 of 1856 has been replaced, with additions, by Rule 69 of 1890 . (g) Should the trustee not mak? ralid disclaimer of leaseholds, he ti be personally liable for the rent acd ing due after his appointment, and the corenants of the lease: $E x p$ Daris, ye Sneezum, 3 Ch. D. 463 ie Solomon, ex parte Dressler, $9 \mathrm{Ch}$ ? 252; Wilson v. Wallani, 5 Ex.? 15.). But he may relieve himself to liability to the landlord by assign: the lease, eren though be knowst assignee to be a pauper: Hopkinsar. Lorering, 11 Q. B. D. 92. 
Jourt, declined or neglected to give notice whether he dislaims the property or not. The section also provides for he vesting of disclaimed property in, or delivery thereof o, persons interested therein, or liable thereunder, in such nanner and on such terms as the Court thinks just. Any serson injured by the operation of a disclaimer under this ection shall be deemed to be a creditor of the bankrupt o the extent of the injury, and may accordingly prove the ame as a debt under the bankruptcy $(h)$. Or if interested a the disclaimed property he may apply to the Court or an order vesting the property in him upon proper erms $(i)$.

The 56th section deals with the powers of the trustee $\mathrm{s}$ to selling the property of the bankrupt, giving receipts, roving for debts due to the bankrupt, and generally under re Act; while the 57th section specifies those modes of ealing with the property of the bankrupt which require ie permission of the committee of inspection ( $k$ ), such as, ter alia, carrying on the business of the bankrupt, taking gal proceedings in reference thereto, mortgaging or pledgig any portion thereof, and making any compromise or yreement for reference to arbitration in relation thereto.

As regards the assignment of the bankrupt's property, it Assizmment enacted :-

(1.) That where any part thereof consists of stock, shares ships, shares or any other property transferable in the roks or any company, office, or person, the trustee may ercise the right to transfer the property to the same tent as the bankrupt might have exereised it, if he had t become bankrupt $(l)$.

(2.) That where any part of the property of the bankrupt nsists of things in action, such things shall be deemed to

h) S. 55 , subs. 7 .

i) Ib. subs. 6 (under which even lessor may apply: Finley, In re, Q. B. D. 475$)$. (k) As to which, see s. 22 , as amended by s. 5 of the Act of 1890 .

(l) S. 50 , subs. 3. 
Right of bankrupt to sue in actions ex delicto.

have been duly assigned to the trustee $(m)$. Where a bankrupt is a contractor in respect of any contract jointly with any person or persons, such person or persons may sue or be sued in respect of the contract without the joinder of the bankrupt $(n)$.

Where a member of a partnership is adjudged bankrupt, the Court may authorize the trustee to commence and prosecute any action in the names of the trustee and of the bankrupt's partner (o), and any release by such partner of the debt or demand shall be void; but notice of the application for authority to commence the action shall be given to him, and he may show cause against it, and on his application the Court may, if it thinks fit, direct that he shall receive his proper share of the proceeds of the action, and if he doe not claim any benefit therefrom he shall be indemnified against costs in respect thereof as the Court directs $(p)$.

The effect of bankruptcy upon the right to sue in action ex delicto is, that, whilst the trustee must be plaintiff it respect of an injury committed to the bankrupt's estate b which the amount of the fund belonging to his creditors $i$ lessened $(q)$, yet when the injury complained of is to hi person $(r)$, feelings, or reputation $(s)$, the right to su remains vested in him. Actions for injuries to person chattels, whereby they are directly affected, and are pr vented from coming to the hands of the trustee, or becon diminished in value, undoubtedly pass $(t)$.

Again, a bankirupt, whilst uncertificated (u), has bee accounted able to enter into a contract of such a kind th its breach would occasion a personal injury to himself $e x . g r$., to contract to be cured of a wound or to marrysuch a case the trustee could not interfere to prevent $t 3$

(m) Ib. subs. 5 .

(n) S. 114.

(o) S. 113 .

(p) S. 113.

(q) IIancock v. Caffyn, 8 Bing. 3 s8.

(r) Hourd r. Crouther. 8 M. \& W.
603.

(s) Bensonv. Flower, Sir W. Jones, 3.

(t) Bechham r. Drake, 2 H. L. $626 ; S . C ., 11$ M. \& W. 315.

(u) Under 32 \& 33 Vict. c. 71 , earlier Acts. 
Jankrupt from suing for damages, although the latter might se compelled to hand them over for the benefit of the creditors vhen recovered. Some difficulty was formerly experienced $\mathrm{n}$ defining with precision the class of cases in which a rerson's capacity to contract remained unimpaired by his pankruptcy, as well as in determining when a right of sction ex contractu vested in the bankrupt before bankuptcy would not be divested thereby. Light, however, ras thrown upon this subject by Beckham v. Drake $(x)$ and iogers v. Spence $(y)$, decided by the House of Lords, from he former of which we deduce that the right of action does lot pass to a bankrupt's trustee where the damages are to ie estimated by immediate reference to pain felt by the ankrupt in respect of his body, mind, or character, and rithout immediate reference to his rights of property. The rustee cannot sue for breach of promise of marriage, eduction, defamation, battery, injury to the person by segligence, as by not carrying him safely, not curing him, lot saving him from imprisonment by process of law $(z)$; nd if in such case a consequential damage to the personal state follows from the injury to the person, that may be so ependent upon and inseparable from the personal injury, hich is the primary cause of action, that no right to aintain a separate action in respect of such consequential amage will pass to the bankrupt's trustee. Under the ircumstances supposed, moreover, the primary cause of ction is of a nature properly speaking personal, and the ight to maintain it would die with the bankrupt $(a)$.

The bankrupt being thus on the one hand divested of all

(x) 2 H. L. Ca. 579.

(y) 12 Cl. \& F. 700.

(z) 2 H. L. Ca. 604; Howard r. routher, 8 M. \& W. 601 ; Hancock Caffyn, 8 Bing. 358, 366; Benson Flower, Sir W. Jones, 215.

(a) Judgm., Drake r. Beckham, II. \& W. 319. And see also, with reference to the "mixed case of injury to the person and injury to the property," per Lord Campbell, Rogers v. Spence, 12 Cl. \& F. 720, 721: Hodgson v. Sidney, L. R. 1 Ex. 313; followed in Morgan v. Steble, L. R. 7 Q. B. 611; Einden r. Carte, 17 Ch. D. 169, 768 . 
Status of discharged bankrupt-

property in which he was beneficially interested, receires on the other hand protection from liability in respect of contracts entered into by him prior to his bankiruptey and discharge, which will, however, be no bar to an action against him for a tort committed by him before obtaining his discharge $(b)$.

4. The effect of the order of discharge, when obtained by a bankrupt under section 8 of the Act of $1890(c)$, is this: it will not release him from any debt or liability incurred by means of any fraud, or fraudulent breach of trust, to which he was a party $(d)$, nor from any debt or liability whereof he has obtained forbearance by any fraud to which he was a party, but it will release him from all other debts provable in bankruptcy, except,-

(1.) Any debt due on a recognizance; (2.) Any debt with which he is chargeable at the suit of the Crown or of any person for any offence against a statute relating to any branch of the public revenue, or at the suit of the sheriff or other public officer, on a bail-bond entered into for the appearance of any person prosecuted for any such offence. unless the Treasury certify in writing their consent to his being discharged therefrom $(e)$.

An order of discharge is conclusive evidence of the bank ruptcy, and of the validity of the proceedings therein, and ir any proceedings that may be instituted against a bankrupt who has obtained an order of discharge, in respect of any deb from which he is released by the order, the bankrupt ma? plead that the cause of action occurred before his discharge and may give the Act and the special matter in evidence $(j)$

An order of discharge, however, will not release an?

(b) Lloyd v. Peell, 3 B. \& Ald. 408 ; Wilmer $r$. White, 6 Bing. 291. See Doe d. Daries v. Thomas, 6 Exch. 854.

(c) Replacing s. 28 of the Act of 1883 , which was repealed by s. 29 of the Act of 1890 . (d) Overriding Cooper v. Pritchar 52 L. J. Q. 13. 526; Chalm. ay Hough, Bankruptey Acts, 1863 1890 , 3rd ed., p. 76 .

(e) S. 30 , subs. $1,2$.

$(f)$ Ib. subss. 3 . 
Jerson who at the date of the receiving order was a partner or co-trustee with the bankrupt, or was jointly bound or had made any joint contract with him, or any person who was jurety or in the nature of surety for him (q).

Where a debtor having obtained an order of discharge inder 32 \& 33 Vict. c. 71 , promised for a new and valuable onsideration to pay a debt which, by virtue of section 49 the corresponding section of that Act), had been released, it ras held that an action was maintainable against him for he amount of the debt $(h)$.

The Court may on hearing the application of the bankupt, after having taken into consideration a report of the )ficial Receiver as to the bankrupt's conduct and affairs, ither grant or refuse an absolute order of discharge, or susrend the operation of the order for a specified time, or grant n order of discharge subject to any conditions with respect o any earnings or income which may afterwards become ue to the bankiupt, or with respect to his after-acquired roperty. The order will be refused in all cases where the ankrupt has committed any misdemeanour under the lebtors Act, 1869 (i), or the principal Act, or any other iisdemeanour connected with his bankruptey, or any felony onnected with his bankruptcy, unless for special reasons be Court otherwise determines; and it may be refused, uspended for a period of not less than two years, or until a ividend of not less than ten shillings in the pound has een paid, or suspended conditionally as above, on proof of ny of the facts mentioned in the section $(k)$. If at the end f two years from the date of an order made under this zetion the bankrupt satisfies the Court that there is no zasonable probability of his being in a position to comply

(g) Ib. subs. 4.

(h) Jakeman r. Cook, 4 Ex. D. 26, stinguishing Heather v. Webb, 2 C. P. - 1; and distinguished in Ex parte arrow, 18 Ch. D. 470. (i) $32 \& 33$ Yict. c. 62 .

(k) S. 8 of the Act of 1890 . Such as omission to keep proper accounts, prerious bankruptcy, fraud, \&c. 
- of un. discharged bankrupt.

with the terms of such order, the Court may modify the terms of such order as it may think fit.

Inasmuch as the provisions of $32 \& 33$ Vict. c. 71, s. 54 , are not reproduced in the Act, a bankrupt who has failed in obtaining his order of discharge will not be protected from any legal proceedings on the part of his unpaid creditors; and it is further provided that if an undischarged bankrupt who has been adjudged bankrupt under the Act obtains credit to the extent of $£ 20$ or upwards from any person without informing such person that he is an undischarged bankrupt, he shall be guilty of a misdemeanour under the Debtors Act, $1869(l)$.

Save as above, and subject to the right of his trustee to interfere, an undischarged bankrupt may contract, claim the benefit of the contract, and sue in his own name for it breach $(m)$. It has also been held that he can contract fo: his own work and labour, and recover money due in respec thereof, as well as for materials found incident and neces sary thereto, or money lent if earned thereby $(n)$. Th extent and limit of the rule, however, upon this subjectallowing an undischarged bankrupt in certain cases to kee the produce of his personal labour-has not been exactl defined. The burden will, in any event, be upon the bank rupt to prove that the money sought to be recovered doe not pass to the trustee $(o)$.

(l) S. 31 : Reg. v. Peters, 16 Q. B. D. 636 .

(n) Herbest r. Sayer, 5 Q. B. 965 , followed in Jameson v. Brick and Stone Co., 4 Q. B. D. 208, in Jackson v. Burnham, 8 Exch. 173, and approved in Cohen v. Mitchell, 25 Q. B. D. 262; Kitchen v. Bartsch, 7 East, 53 ; Drayton v. Dale. 2 B. \& C. 293 ; Fyson v. Chambers, 9 M. \& W. 460 ; judgm., Morgan v. Knight, 15 C. B., N. S., 677 , followed in Ex parte Watson, re Roberts, 12 Ch. D. 382. $A$ second adjudication against an un. discharged bankrupt, who has been allowed by the trustee to carry business, is not roid: Ib.

(n) Chippendale $\mathrm{v}$. Tomlinson, cite

7 East, 57 , n. $(h)$; Ib. 52 ; Willian v. Chambers, 10 Q. B. 337 ; Silk Osborn, 1 Esp. 140; Erans r. Brove 1 Esp. 170; Elliot v. Clayton, Q. B. 581 ; Crofion v. Poole, 1 B. Ad. 568 ; Kitson $v$. Harducick, L. I 7 C. P. 473,479 , cited by Fry, J Emden r. Carte, 17 Ch. D. 169,172 S. $C$., Ib. p. 768 .

(o) See Wadling r. Oliphant, Q. B. D. 145,151 ; Emden v. Car ubi supra. 
5. The following provisions of the Act affect certain contracts by a bankrupt, and under the circumstances specified Contracts affected by avoid them :-

(1.) Any settlement ( $p$ ) of property not being a settlement made before and in consideration of marriage, or made in favour of a purchaser or incumbrancer, in good faith and for valuable consideration $(q)$, or a settlement made on or for the wife or children of the settlor of property which has accrued to the settlor after marriage in right of his wife, shall, if the settlor becomes bankrupt within two years after the date of the settlement, be void against the trustee in the bankruptcy, and shall, if the settlor becomes bankrupt at any subsequent time within ten years after the date of the settlement, be void as against the trustee in the bankruptcy, unless the parties claiming under the settlement can prove that the settlor was at he time of making the settlement able to pay all his debts without the aid of the property comprised in the settlenent, and that the interest of the settlor in such property ad passed to the trustee of such settlement on the execuion thereof $(r)$.

(2.) Any covenant or contract made in consideration of narriage for the future settlement on or for the settlor's rife or children of any money or property wherein he had lot at the date of his marriage any estate or interest, rhether vested or contingent, in possession or remainder, ind not being money or property of or in right of his wife, hall, on his becoming bankrupt before the property or noney has been actually transferred or paid pursuant to he contract or covenant, be void as against the trustee in iankruptcy $(s)$.

(3.) Every conveyance or transfer of property, or charge

(p) "Settlement" shall for the puroses of this section include any con3yance or transfer of property: s. 47 , ibs. 3. 
thereon made, every payment made, every obligation incurred, and every judicial proceeding taken or suffered by any person unable to pay his debts as they become due, in favour of any creditor or any person in trust for any creditor, with a riew of giving such ereditor a preference orer the other creditors, shall, if the person making, taking. paying, or suffering the same is adjudged bankrupt on a bankruptcy petition presented within three months after the date of making, taking, paying, or suffering the same be deemed fraudulent and void as against the trustee ir bankruptcy $(t)$. This section will not, howerer, affect thi rights of any person making title in good faith and fo' valuable consideration through or under a creditor of the bankrupt $(u)$.

In conclusion we may add that bankruptey proceeding by debtor's summons are now abolished, and are super seded by the provision for service of a bankruptcy notic on failure to pay a judgment debt $(x)$; and further tha the Court may annul a bankruptcy on approval of a com position or scheme, or where it is of opinion that th debtor ought not to have been adjudged bankiupt, or of proof that the debts of the bankrupt have been paid $i$ full $(y)$.

\section{Sect. II.-Contracts with Non-mercantile Persons.}

In this section I propose to inquire how far the capacit to contract may be affected by Infancy, Corerture, Ments Imbecility, or otherwise, and under what circumstances a executor or administrator may enter into a contract binc ing as regards himself, or as regards the estate which 1

(t) S. 48 , subs. 1 .

(ii) S. 48 , subs. 2 . This section alters the law as laid down in Butcher v. Stead, I. R. 7 H. L. 839 ; Chalm. and Hough, Bankruptey Acts, 1883 to
1890, 3rd ed., p. 113.

$(x)$ S. 4 , subs. $1(g)$. Sce as judgment debtors, s. 103.

(y) Ss. 23, 35 . 
has to administer and on behalf of which he may be supposed to act.

Inasmuch as "the law as to the contracts of infants, and as to the ratification made by persons of full age of contracts made by them during infancy, and as to necessaries," has been simplified and amended by stat. $37 \& 38$ Vict. c. 62 , much of the learning upon this subject has become obsolete, and must be collected from older treatises.

An infant, by reason of his tender years and presumed immaturity of judgment, has long been specially protected by our customary law; and, by sect. 1 of the above Act, when voil. "all contracts, whether by specialty or by simple contract, aenceforth entered into by infants for the repayment of noney lent or to be lent, or for goods supplied or to be supplied (other than contracts for necessaries) (z), and all rccounts stated $(a)$ with infants shall be absolutely roid: provided always, that this enactment shall not invalidate iny contract into which an infant may by any existing or uture statute, or by the rules of common law or equity, nter, except such as now by law are voidable" (b).

What then, in the first place, are necessaries for which in infant may still bind himself by contract? Things recessary are those without which an individual cannot easonably be supposed to exist. In the first place, food, aiment, lodging, and the like, are clearly necessaries. Igain, as the proper cultivation of the mind is as expedient is the support of the body, instruction in art or trade (c)

(z) An infant cannot bind himself by he acceptance of a bill of exchange, ven though the bill is given for necesaries: Soltykoff, In re, Margrett, Ex arte, (1891), 1 Q. B. 413.

(a) See Williams v. Moor, 11 M. \& V. 256 .

(b) In Valentini v. Canali, 24 Q. B. ). 166, an infant who had for the use f a furnished house paid the defendant certain sum was held not to be entled by the section to recover back
Contraces by infant- 
or intellectual, moral, and religious information may be a necessary also (d). Again, as man lives in society, the assistance and attendance of other's may be a necessary to his well-being. Hence, attendance may be the subject of an infant's contracts $(e)$; 'and the expenses of the marriage settlement of an infant may properly be deemed necessaries $(f)$.

The several classes of things which may be necessaries being thus established, the subject-matter and extent of the particular contract on which it is sought to charge the infant may vary according to his state and condition in life. His clothes may be fine or coarse, according to his rank: his education may vary according to the station he is to fill and the medicines chargeable to him as necessaries wil depend on the illness with which he is afflicted, and the extent of his probable means when of age $(g)$. The Sale 0 Goods Act, $1893(h)$, enacts that where goods of the natur of necessaries are sold to an infant he must pay a reason able price therefor, and defines necessaries as goods suitabl to the condition of life of the infant, and to his actua requirements at the time of the sale and delivery. So again, the nature and extent of the attendance will depen on his position in society; ex. $g r$., a servant in livery ma be allowed to a rich infant, because such attendance i commonly appropriated to persons in his rank of life Subject, however, to the above remarks, it must always b made out that the things furnished, which form the subjec matter of the given contract, are essential to the existend and reasonable advantage and comfort of the infant cor

(d) Co. Litt. 172 a; Bac. Abr. Infancy I.; Whittingham v. Hill, Cro. Jac. 494; Manby v. Scott, 1 Sid. 112 ; 2 Sm. L. C., 9th ed., 466, citing Clare and Darnell's case, 2 Car. Ko. 521; and see Young v. Foucler, March, at p. 40; Pickering v. Gunuing, Palm. $52 S$; S. C., Jones, 182 ; Roll. Abr. II. p. 767 ; Chapple r. Cooper, 13 MI.
W. 258 .

(e) Judgm., 13 M. \& W. 258.

(f) Helps $v$, Clayton, 17 C. I N. S., 553.

(g) See Hart r. Prater, 1 Jur. 6:

(h) 56 \& 57 Vict. c. 71, s. 2. 
tractor. Thus articles of mere luxury are always excluded, though luxurious articles of utility are in some cases allowed. So contracts for charitable assistance to others, though highly to be praised, cannot be allowed to be binding, because they do not relate to the infant's own personal advantage (i).

"The true rule," said Parke, B., in a case $(k)$ often cited in reference to the subject before us, "I take to be this: All such articles as are purely ornamental are not necessary, und are to be rejected, because they cannot be requisite for uny one: and for such matters, therefore, an infant cannot se made responsible. But if they are not strictly of this lescription, then the question arises, whether they were ought for the necessary use of the party, in order to support himself properly in the degree, state, and station of ife in which he moved; if they were, for such articles the nfant may be responsible." The question for the jury will se this: Were the articles bought for mere onnament? If so, hey cannot be necessaries for any one. Were they bought or real use? If so, they may be necessaries, provided they ure suitable to the infant's age, state, and degree. The ury, therefore, must say whether they are such as reasonbble persons of the age and station of the infant would equire for real use. If so, they will be necessaries for rhich an infant will be liable $(l)$.

(i) Judgm., Chapple v. Cooper, 13 11. \& W. 258 (where an infant widow ras held to be liable on her contract o pay for the funeral of her husband, vho died leaving no property).

(k) Peters v. Fleming, 6 M. \& W. 7 ; followed in Ryder v. Wombuell, ¿. R. 4 Ex. 32, 38; Wharton v. Uackenzie and Cripps v. Hills, 5 Q. B. i06, 611. See Burghart v. Hall, 4 4. \& W. 727.

(l) Per Alderson, B., Peters v. Fleming, 6 M. \& W. 48 . As to what re or are not necessaries for an infant, ee further Harrison v. Fane, 1 M. \&
Gr. 550; Brooker v. Scott, 11 M. \& W. 67 ; Bumard, app., Haggis, resp., 14 C. B., N. S., 45 . When an infant is sued for goods supplied to him on credit, evidence may be given that he was already at the time supplied with goods of a similar description, for the purpose of showing that they were not necessaries, and it is immaterial whether the plaintiff did or did not know of such supply. Barnes v. Toye, 13 Q. B. D. 410, overruling the opinion of the majority of the Court in Ryder v. Wombuell, uhi supra, followed in Johnstone v. Marks, 19 Q B. D. 509. 
In any such case there may be a preliminary question fo: the judge, $x i z$., whether there is any evidence on which thi jury could properly find for the party on whom the onus o proof lies ; if not, a nonsuit, or a verdict for the defendant should, according to circumstances, be directed $(m)$.

Various contracts by an infant not within the operation of the statute are roid or roidable at common law (n) They are so, according to the weight of authority, whes manifestly and necessarily prejudicial to him $(o)$. Thus i is laid down $(p)$ that "an infant may bind himself to pa: for his necessary meat, drink, apparel, necessary physic and such other necessaries, and likerise for his good teach ing or instruction, whereby he may profit himself after wards $(q)$; but if he bind himself in an obligation or othe writing with a penalty for the parment of any of these, the olligation shall not bind him." So a contract by an infam binding him to serve during a certain time for wages, br enabling the master to stop the work whenever he chose and to retain the wages during stoppage, was in Reg. T Lord ( $r$ ) adjudged to be inequitable and wholly roid.

(in) Judgm., Riyder r. Hombuell, L. R. 4 Ex. 38,39 .

(n) It would seem to be the better opinion that at common law an infant's contracts are not roid, but roidable: Pol. lork on Contracts. 6th el.. p. 52 et seq.

(o) Oliver. r. Woodroffe, 4 M. \& W. 650: Latt r. Booth, 3 C. \& K. 292.

"An infant, or one in privity to him, may object to a contract on the ground that it was not for his bencfit:" per Jerris, C. J., Dounlas v. I"atson, 17 C. B. 691 .

See Flouer v. London and WorthHestern R. C., (1894) 2 Q. B. 65 (C. A.), where an infant's coutract to forego any right of action he might have against the defendants, it they were guilty of negligence in carrying $\lim$ as a passenger, was held roid. See also Rhodes v. Sicithenbunk, 22 Q. B. D. 577 (C. A.). Inut contrast Clements r. Loudon and North-Western R. (?, (1894) 2 Q. 13. 482 (C. A.), where an infant's contract to become member of, and to be bound by $t$ rules of the insurance society form. among tbe defendants' employés, a? under whose rules the amounts recore able for temporary or permanent reli were less than the limits recorerat under the Emplorers' Liability A was held to be a proper one for infant to have entered into.

(p) Co. I.tt. 172 a; adopted I Tinderl, C. J., 10 Bing. 25\%. 1 M. \& Gr. $5 j \mathrm{l}(b)$.

(q) See Cuoper r. Simmons, i H. N. 707,719 : Fisher v. Moubray, East, 330 ; Baylis $\mathbf{v}$. Dinely, 3 M. S. 477: Walter v. Eievard, (1891) Q. B. 369 .

(v) 12 Q. B. 757 , followed Meakin, app., Morris, resp., $12 \mathrm{Q}$. D. 352. Cf. also De Francesco Banum. 45 Ch. D. 430 ; Corn Mathere, (1893) I Q. B. 310. Itood r. Fenciek, 10 M. \& W. 1s: 
Again, in Perkin's Profitable Book (s), it is said to be a zommon learning, "that all such gifts, grants, or deeds made by an infant, as do not take effect by delivery of his aand, are void. But all gifts, grants, or deeds made by an infant by matter in deed or in writing, which take cffect (t) by delivery of his own hand, are voidable by himself and ais heirs, and by those who have his estate." The doctrine aere laid down was assented to by Lord Mansficld, C. J., in Zouch v. Parson (n), where a conveyance by an infant nortgagee was held to be voidable only; and a distinction was taken between the deed of a feme covert and that of in infant-the former being void, the latter voidable. The same doctrine was also recognised as sound in Allen v. Allen $(x)$ by Sir E. Sugden, who observes, "It cannot be 3aid that all instruments executed by infants are void" ex.gr., "a lease executed by an infant with a reservation of rent is only voidable" $(y)$ ), though, "if an infant has executed a deed which proves to be injurious to his interests, $t$ is voidable, and he may set it aside when he attains his sull age."

The capacity of an infant to contract, and the questionUnder what circumstances will he, on becoming of full age,

R. v. Inhabs. of Chillesford, 4 B. \& J. 94, 101. An infant caunot be nade bankrupt: Re Rainey, 3 L. R. Ir. 159 ; Ex parte Jones, re Jones, $18 \mathrm{Ch}$. D. 109; neither can he be convicted under the Debtors Act, 1869 (32 \& 33 Vict. c. 62), for defrauding his creditors: Reg. v. Wilson, 5 Q. B. D. 28. I'he House of Lords in Lovell and Christmas v. Beauchamp, (1894) A. C. 607 , decided that in an action against i firm for goods supplied to the irm, one nember of which is an infant, judgment cannot be recovered 1gainst the firm simply; and if an act of bankruptcy is committed, a receiving order cannot be made against the firm imply. Each must be made against he firm "other than the infant partaer." If a receiving order has been made without such limitation, it may be amended under s. 105 of the Bankruptcy Act, 1883 . The C. A. had simply set aside the order. Cf. (1894) 1 Q. B. 1.

(s) S. 12 .

(t) "The words "which do take effect' are an essential part of the definition, and exclude letters of attorney, or deeds which delegate a mere power and convey no interest:" 3 Burr. 1804.

(u) 3 Burr. 1794, 1804; recognised by Lord Eldon, Anon. v. Handiock, 17 Ves. 383.

(x) 2 Dr. \& W. $307,338$.

(y) See Judgm., 5 Exch. 126; per Parke, B., 4 Exch. 30 ; per Buller, J., Maddon v. White, 2 'I. K. 161, 1 R. R. 453 ; Platt on Leases, vol. 1, p. 28 . And see the authorities cited in Judgm., 3 Exch. 575. 
be liable on his contract made durante minore atate?-have been much considered where actions of debt have been brought against infant shareholders in railway companies to compel the payment of calls due upon their shares. Now in general, "an infant or minor hath, without consent 0 any other, capacity to purchase; for it is intended for hi benefit, and at his full age he may either agree thereunt and perfect it, or, without any cause to be alleged, waive of disagree to the purchase " $(z)$. So an infant shareholder ir a railway company acquires, on being registered, a vested interest of a permanent character in all the profits arising from the land and other effects of the company; he mas be deemed a purchaser in possession of such interest, an is placed in a position analogous to that of a purchaser is possession of real estate. Under the Companies Clause Consolidation Act, an infant, registered as a shareholder i a railway company, is not absolutely bound, nor deprive of the right which the law gives every infant of waivin and disagreeing to the purchase which he has made; if $\mathrm{h}$ does so, the estate acquired by the purchase is at an end and with it the infant's liability to pay calls, though th avoidance may not have taken place till the call was due ( $a$.

Where, however, an estate has become and remains veste in an infant, the burthen in respect of it will remain oblige tory until a waicer or disagreement by the infant takes piac which, if made on or within a reasonable time after ( attaining his full age, will avoid the estate altogether, an revest it in the party from whom the infant purchased $(c)$.

Lastly, under this head I may observe that althoug where it is sought to recover damages against an infant $k$

(z) Co. Iitt. 2 b.

(a) North-Western R. C. v. M'Mi. chael, 5 Exch. 114; Birkenhead, \&c., R. C. v. Pilcher, Id. 24, 114 ; Leeds and Thirsk R. C. Y. Fearnley, 4 Exch. 26 ; Cork and Bandon R. C. v. Cazenore, 10 Q. B. 935 . (b) Dublin and Wicklow R. C. Black, 8 Exch. 181.

(c) Dorth-Western R. C. v. $\boldsymbol{M}^{4} \mathrm{~J}$ chael, 5 Exch. 114; Birkenhead, of R. C. v. Pilcher, Id. 24, 114 ; Nen and Euniskillen R. C. v. Coombe, Exch. 565. 
ction ex contractu the fact of his infancy at the date of be contract will, in most cases, be available in answer to uch action $(d)$, an infant is not incapacitated from suing or breach of a contract entered into with him (e), as for breach of promise of marriage $(f)$.

In some cases, however, within the jurisdiction of a Court Equity, relief would be refused, on the ground of want mutuality, to an infant suing upon contract $(g)$.

The foregoing remarks, it must be observed, apply excluvely to the capacity of persons within the age of discreon to contract. "The capacity of infants," it has been id (h), "to commit crimes, their punishableness for" iminal offences, their liability civilly for various wrongs t connected in any sense with contract, as for instance, ittery and slander (i), to say nothing of the clear right, in me circumstances, to maintain trover" or trespass $(k)$ against them, are of universal recognition. But quesms, which have not been considered free from difficulty, ve arisen whether, or how far, persons are civilly liable law for wrongs, or such acts as if they were the acts of ults would be wrongs, done during infancy, when concted, or supposed to be connected, with contracts." In $\mathrm{y}$ such case, the gist of the action must be narrowly amined, with a view to determining whether it be really inded in contract or in tort. An infant who has induced adult to contract with him, by representing himself to of full age, could not at law be made answerable as for a

1) This privilege "is given as a 5.ld and not as a sword," and "it I er shall be turned into an offensive Ipon of fraud or injustice: " per Id Mansfield, C. J., 3 Burr. 1802. Warwick v. Bruce, 2 M. \& S. 205;

1. .. R. 634 ; $S$. C. (iu Error), 6 Taunt.

1; Bac. Abr. "Infancy" (I. 4).

f) Holt v. Ward, $2 \mathrm{Str}, 937$; Goode r Carrison, 5 B. \& Ald. 147, 159; 24 H.. 307; Corpe v. Orerton, 10 Bing. 2 applied Hamilton $\vee$. Taughan-

3.C.L.
Sherrin Electrical Co., (1894) 3 Ch. 589 ; per Gibbs, C. J., 6 Taunt.120.

(g) Watson, Comp. Eq. 1. 86, 87, citing Flight $\mathrm{v}$. Bolland, 4 Russ. 298.

(h) Per Knight-Bruce, V.-C., Stilieman v. Dawson, 1 De G. \& S. 110.

(i) Per Lord Kenyon, C. J., 8 'T. R. 337 ; Hodsman v. Grissel, Noy, 129 ; Co. Litt. 180 b, n. (4); Johnson v. Pie, 1 Lev. 169 ; S. C., 1 Kéb. 905,913.

(k) Bumard, app., IIaggis, resp., 14 C. B., N. S., 45, 53. 
tort $(l)$; and generally if the cause of action against an infant be founded upon contract, it cannot, at the mere option of the plaintiff, be converted into a tort, for the purpose of charging the infant defendant $(m)$.

An infant, however, although for his own sake protected in regard to contracts, may be doli capax, in a civil sense and for civil purposes, in the view of a Court of Equity ( $n$ ) where " in the case of fraud of which an infant is cognisan infancy affords no defence" $(o)$.

The stat. $37 \& 38$ Vict. c. 62 , s. 2 , enacts that thence forth "No action shall be brought whereby to charge any person upon any promise made after full age to pay an! debt contracted during infancy, or upon any ratificatios made after full age of any promise or contract made durin, infancy, whether there shall or shall not be any ne consideration for such promise or ratification after ful age" $(p)$. It has been held that the above section applie to the case of a promise of marriage $(q)$.

That this section will be construed strongly again. ratification is plain from the decision in Ex parte Kilbl.

(l) See Price v. Hevett, 8 Exch. 146; Liverpool Adelphi Loan Association v. Fairhurst, 9 Exch. 422; Wright r. Leonard, 11 C. B., N. S., 258 ; Ovcrton r. Banistcr, 3 Hare, 503 ; Goode r. Harrison, 5 B. \& Ald. 147 ; 24 R. R. 307.

(m) Jennings v. Rundall, 8 T. R. 338 ; De Roo v. Foster, 12 C. B., N. S., 272; Bartlett v. Wells, 1 B. \& S. 836 ; Johnson r. Pie, 1 Lev. 169 ; S. C., 1 Keb. 905,913 ; Green v. Greenbank, 2 Marsh. 485; Judgm., Manby v. Scott, 1 Ler. 4 ; 2 Sm. I. C., 9 th ed., 466.

(n) Judgm., 1 De G. \& S. 109.

(o) Macpherson on Infants, p. 494.

(p) Reference should also be made to the Betting and Loans (Infants) Act, 1892 (55 \& 56 Vict. c. 4), which by s. 5 enacts that should an infant, who has contracted a loan which is roid in law, agree after he comes of age to pay any money which in whole or in part represents or agreed to be pail in respect of as such loan, and is not a new adranc such agreement, and any instrume: given in pursuance of and for carryi into effect such agreement or otherwi in relation to the payment of mon representing or in respect of such lo shall, so far as it relates to mon which represents or is parable respect of such loan, and is not a n advance, be absolntely roid. It difficult to see wherein this diff. from the above section of the Infan Relief Act, 1874. The general eff of the Act is "to make penal inciting infants to betting or mageri or to borrowing moner."

(a) Coxhead v. Mnillis, 3 C. P. 439 , distinguished in Northeote Doughty, 4 C. P. D. 355, and ct sidered in Ditcham $v$. Worrall, 5 P. D. 410. 
e Onslow $(r)$. In that case, an infant, before the passing f the Act, gave a bill of exchange, payable after his 1ajority, to a jeweller in payment for goods supplied. fter his majority, and before the passing of the Act, the reditor obtained judgment by default in an action on the ill, and then took out a debtor's summons. This not eing complied with, he filed a petition for adjudicating ie debtor a bankrupt. The Court, however, held that the ztition must fail, as the Act prevented the ratification of ich a debt. It will be observed that the ratification here old ineffectual took the highest possible form, namely that a contract of record.

The position and status of married women has been so uch altered by recent legislation that the greater part of Contracts by married e learning on the subject has now become obsolete. It is oposed, therefore, to give a brief sketch of the position and sabilities of married women according to the common law, id then consider the changes wronght by various statutes. The effect of marriage at common law was to merge Iring coverture the existence of the wife in that of the isband and to constitute them one person $(s)$. Hence, at w, no contract could be made between husband and wife thout the intervention of trustees; the feme, moreover, ing considered as sub potestate viri, and deemed incapable contracting with the baron. "A man," therefore,

r) L. R. 10 Ch. App. 373. See $E x$ te Lennox, 16 Q. B. D. 329 ; Smith v. ig, (1892) 2 Q. B. 543; 5 R. R. 448. s) 1 Bla. Com. 442 ; Co. Litt. 112 ; rshall v. Rutton, 8 T. R. 546 ; $\therefore$ R. 448 .

here are, however, exceptions to rule: 1 Bla. Com. 444; 1 Powell, itr., p. 60 ; per Maule, J., Wenman $18 h, 13$ C. B. 844,845 , where that ned Jndge remarks, that, "in the of the law, no doubt, man and wife for many purposes, one; but that strong figurative expression, and lot be so dealt with as that all the consequences must follow which would result from its being literally true. For many purposes they are essentially distinct and different persons-and, amongst others, for the purpose of having the honour and the feelings of the husband assailed and injured by acts done or communications made to the wife." So the husband may be found guilty of crimes of violence towards the ivife, and vice versâ.

See Phillips v. Barnet, 1 Q. B. D. 436,438 , et seq., where instances of the rule stated in the text are given.
Effect of marriage at common law on the wife's capacity to contract. 
" cannot grant anything to his wife, or enter into covenant with her; for the grant would be to suppose her separate existence, and to covenant with her would be only to covenant with himself" $(t)$ : and hence, also, it was generally true, "that all compacts made between husband and wife when single are voided by the intermarriage" (u); and that, if a man marries a woman to whom he is indebted, the debt is extinguished. This, however, would not have been the case when the marriage was in the contemplation of the parties, and a third person was associated with the wife as trustee for her $(x)$.

Husband and wife being in law one person, it followed that neither could maintain an action for tort against the other, ex. gr., for an assault; nor did it make any difference that prior to the commencement of the action the marriage had been dissolved by a decree absolute in the Divorce Court $(y)$.

A further effect of marriage at common law was to rest in the husband the wife's personality in possession; to entitle him to the rents and profits of her real estate; and to confer on him the right of reducing into possession, for his own benefit, her chattels real and choses in action (z).

( $t$ ) 1 Bla. Com. 442. See Meus v. Metes, 15 Bear. 529; Price v. Price, 14 Id. 598; $S . C ., 1$ De G., Mac. \& G. 308. The Court of Appeal in McGregor ๙. McGregor, 21 Q. B. D. 424 (attirming $S . C ., 20$ Q. B. D. $529)$, decided that a contract by way of comprouise of legal proceedings, although entered into by the wife without the intervention of a trustee, by which the husband was liable to pay weekly sums for maintenance, was eutorceable against him at the suit of the wife.

(iv) 1 Bla. Com. 442.

(x) I'er Coleridge, J., Dolling r. White, 22 L. J. Q. B. 327. 436.

(y) Phillips v. Barnet, I Q. B. D.

(z) 2 Bla. Com. 433, 435; Robertson v. Worts, 11 Q. B. $916 ;$ Flet v.
Petrins, I. R. 4 Q. B. 500 ; Co. Litt. 300 a, $351 \mathrm{~b}$; Com. Dig. "Bar. and Feme" (F); Bac. Abr. "Bar. and Feme" (C) ; Maddox r. Wynne, 3 Salk. 62. See Fitzgerald r. Fitzgerald, $8 \mathrm{C}$. B. 592 , and the authorities there cited : Dodgson v. Bcll, 5 Exch. 967 ; Simmons v. Edicards, 16 M. \& W. 838 ; Waller v. Drakeford, 1 E. \& B 749. A husband is still entitled on the death of his wife to an estate by the curtesy in her undisposed-of real estate Hope r. Hope, (1892) 2 Ch. 336.

As to the reduction into possessiol of the wife's property by ber husband see Howard v. Oakes, 3 Exch. 136 Sherrington $\mathrm{v}$. Yates, 12 II. \& W 85̄́: Richbell v. Alexander, 10 C. B. X. S., 324; Hart r. Stephens, 6 Q. H 937: distinguished in Rogers r. Bolton 8 L. R. Ir. 73 ; Scarpellini r. Atcheson 
So completely was a feme covert disabled at common law rom holding or recovering property during coverture in er own right, that if a woman possessed personal proerty, married, and settled it upon herself without the atervention of a trustee, the husband became; in law, the bsolute owner of the property $(a)$; the property in wearig apparel bought by the wife for herself, whilst living ith her husband, out of money settled to her separate use efore marriage, and paid to her by the trustees of her attlement, vested by law in the husband $(b)$; and the wvings of the wife, whilst separated by agreement from er husband, out of a weekly sum allowed by him for her upport, could, after her death, have been recovered in an ation, at his suit, from one to whom, before her death, rey had been disposed of by the wife by way of gift $(c)$.

In equity it is clear that the savings of a married oman's separate estate, like the income itself, became her parate estate $(d)$.

Further, at common law the husband could recover, in is own name, wages accruing to his wife $(e)$, or the profits a business carried on by her $(f)$; he could sue for her ork and labour $(g)$, and for goods sold or money lent by or $(h)$.

Upon this rule of our common law, innovation has been ade by various statutory provisions, which may be divided to three groups.

Q. B. 864 ; Gaters v. Madeley, 6 . \& W. 423; Topham v. Morecraft, E. \& B. 972 ; Jones v. Cuthbertson, R. 7 Q. B. 218.

(a) Per Williams, J., 13 C. B. 648. (b) Carne v. Briee, 7 M. \& W. 183 ; cussed and approved in Riehards $\mathrm{v}$. nkins, 17 Q. B. D. 544.

(c) Messenger r. Clarke, 5 Exch. 3; Bird v. Peagrum, 13 C. B. 639 ted Judgm., Sloper v. Cottrell, 6 \& B. 505); Tugman v. Hopkins, II. \& Gr. 389.

(i) Brooke v. Brooke, 25 Beav. 342 ;
Duncan v. Cashin, L. R. 10 C. 1'. 554.

(e) Per Lord Abinger, C. B., Dengate v. Gardiner, 4 M. \& W. T.

(f) Sarille v. Suceney, 4 B. S. Ad. $514,522,524$.

(g) Buckley v. Collier, I Salk. 114, 3 Id. 63; Bac. Abr. "Bar. and Feme" (D).

(h) Com. Dig. "Bar. and Feme" (W); Holmes v. Hood, l Barnard. 75,249 , cited 2 Wils. 424 , and $2 \mathrm{M}$. \& S. 396; Bidgood r. IFay, 2 W. Bla. 1236; Hing r. Basingham, 8 Mod. 199,341 .
Statutory provisions married wollen. 
1. By the Act of 1857 (20 \& 21 Vict. c. 85), to amend the law relating to Divorce and Matrimonial Cases in England, and the Act of 1858 (21 \& 22 Vict. c. 108), amending the above :-

(i) A woman divorced from her husband is restored to the position of a feme sole.

(ii) A woman judicially separated from her husband is from the date of the sentence, and while the separation continues, to be considered as a feme sole with respect to property of every description which she may acquire, or which may come or devolve upon her (i), and also for the purposes of con tract, and wrongs and injuries, and suing and beins sued in any civil proceedings $(k)$.

(iii) A woman deserted by her husband can get a pro tection order, the effect of which is, that 1 property acquired by her since such desertion i protected as against the husband and all person claiming under him $(l)$.

This protection to the property of women judicially sepa rated, or deserted, has been further extended to property $t$ which the wife becomes entitled as executrix, adminis tratrix, or trustee, since the sentence of separation or th desertion $(m)$.

2. The Married Women's Property Act, 1870 (33 \& 3 Vict. c. 93), enabled a feme covert to hold various kinds c property as undermentioned :-

Where any freehold, copyhold, or customaryhold propert has descended upon her if married after the passing of th Act $33 \& 34$ Vict. c. 93 , as heiress or co-heiress of a

(i) $20 \leqslant 21$ Vict. c. 85, s. 25.

(k) Ib., s. 26.

(I) Ib., s. 21. A wife who has ob. tained an order of protection under this section has been held entitled to sue in her own name for libel: Rams- den r. Brearley, L. R. 10 Q. B. 14

See further, as to the maintenauce married women in case of desertic 58 \& 59 Vict. c. 39.

(ii) 21 \& 22 Vict. c. 108, s. 7. 
intestate, the rents and profits of such property, subject and without prejudice to the trusts of any settlement affecting the same, belong to the married woman for her separate use $(n)$.

Where any woman married after the passing of the said Act during her marriage becomes entitled to personal property as next of kin or one of the next of kin of an intestate, or to a sum of money not exceeding $200 l$. under any deed or will, such property, subject and without prejudice to the trusts of any settlement affecting the same, belongs to the woman for her separate use $(o)$.

The wages and earnings of any married woman acquired or gained by her after the passing of the Act in any employment, occupation, or trade in which she is engaged or which ihe carries on separately from her husband, and also any money or property so acquired by her through the exercise ff any literary, artistic, or scientific skill, and all investments of such wages, earnings, money, or property, are to ze deemed and taken to be property held and settled to her separate use, independent of her husband $(p)$.

Further, annuities granted by the Commissioners for the Reduction of the National Debt and deposits in savings Janks made in the name of a married woman, or of a woman narried after such grant or deposit, are now deemed to be her separate property, and are to be accounted for and paid io her as if she were unmarried $(q)$. And analogous prorisions are inserted in the Act for protecting the property of any woman, married or about to be married, in the public funds $(r)$, or consisting of shares or stock, to which

(n) S. 8. Semble that this section pplies to the corpus, as the "rents nd profits" therein mentioned are not imited to those arising during the life of the married roman: King v. Voss, 3 Ch. D. 504.

(o) S. 7. The 200l. limit only aplies to money coming to the married roman "by deed or will," and not to personal estate to which she may have become entitled as next of kin to an intestate: King v. Toss, ubi supra.

( $p$ ) S. 1. See Lorell r. Neuton, 4 C. P. D. 7 ; followed in James $r$. Dearmer, 53 L. 'T. 905.

(q) S. 2.

(r) The amount not being less than 20l.: s. 3. 
no liability is attached, in a joint stock company $(s)$, o] shares in an industrial benefit building or loan society $(t)$.

Under the statute last cited, a married woman may effec a policy of insurance upon her own life or the life of het husband for her separate use, and the same and all benefi thereof, if expressed on the face of it to be so effected, wil enure accordingly $(u)$. So a policy of insurance effected by a married man on his own life, and expressed upon the fac of it to be for the benefit of his wife or of his wife anc children, or any of them, will enure and be deemed a trus for the benefit of his wife for her separate use, and of hi children, or any of them, according to the interest si expressed, and will not, so long as any object of the trus remains, be subject to the control of the husband or to hi creditors, or form part of his estate $(x)$.

The statute further provided efficacious remedies for : married woman by enabling her to maintain an action is her own name for the recovery of wages, earnings, money and property by the Act declared to be her separate property or of property belonging to her before marriage, and whic] her husband, by writing under his hand, has agreed wit] her shall belong to her after marriage as her separat property $(y)$. Under this section, as expanded by s. 1 a married woman has been held entitled to maintain a action against her bankers for dishonouring her eheque $(z)$ Further, a married woman is liable to be sued for debt contracted by her before marriage, and any propert belonging to her for her separate use will be liable $t$ satisfy such debts, as if she had remained unmarried ( $a$ and the husband need not be joined with her in th action (b).
(s) S. 4 .
(t) S. 5 .
(u) S. 10 .
(x) S. 10
(y) S. 11 .

(z) Stummers v. City Bank, L. I 9 C. P. 580.

(a) S. 12 .

(b) Mercier v. Wilians, 9 Q. B. 1 337 ; 10 App. Cas. 1. 
The statute $(c)$ amending the Married Women's Property tct, 1870 , sets forth by way of preamble that "it is not ust that the property which a woman has at the time of 1er marriage should pass to her husband, and that he should not be liable for her debts contracted before narriage," and enacts, that husband and wife married after he passing of the Act may be jointly sued for any debt of he wife contracted before marriage $(d)$. In such action as rell as in an action brought for damages sustained by reason if any tort committed by the wife before marriage or by eason of the breach of any contract made by the wife fefore marriage, the husband is made liable for the debt or lamages respectively to the extent only of the assets below pecified $(e)$.

The provisions of these statutes will still be important a considering the position of women married before he 1st January, 1883, with regard to property acquired $y$, or devolving upon them after marriage. In all ther respects they have been consolidated and amended y the Married Women's Property Act, $1882(45 \& 46$ ict. c. 75), the main provisions of which are as llows :-

(c) $37 \& 38$ Vict. c. 50.

(d) S. 1.

(e) S. 2. The assets in respect of id to the extent of which the husbandill in any such action be liable are as llows: (1.) "The value of the pernal estate in possession of the wife, hich shall have vested in the husund; (2.) The value of the choses action of the wife which the husind shall have reduced into posses$\mathrm{Jn}$, or which with reasonable diligence might have reduced into possessiou ; -) The value of the chattels real of e wife which shall have rested in the 1sband and wife; (4.) The value of e rents and profits of the real estate the wife which the husband shall ive received, or with reasonable ligence might have received; (5.) re value of the husband's estate or interest in any property, real or personal, which the wife in contemplation of her marriage with him shall have transferred to him or to any other person; (6.) The value of any property, real or personal, which the wife in contemplation of her marriage with the husbaud shall with his consent hare transferred to any person with the view of defeating or delaying her existing creditors." When, however, the husband after marriage pays any deht of his wife, or has a judgment bonâ fide recovered against him in any such action as is mentioned in the Act, then to the extent of such parment or jutgment the husband will not in auy subsequent action be liable: s. 5. See De Greuchy r. Wills, 4 C. P. D. 362. See also ss. 3,4 .
Marriel] Women's Property Act, lss?. 
Contractual capacity.

1. As to her contractual capacity, it is enacted that married woman shall be capable of entering into and ren dering herself liable in respect of, and to the extent of, he separate property on any contract $(f)$, and of suing an being sued either in contract or in tort, or otherwise, in al respects as if she rere a feme sole, and her husband neer not be joined with her as plaintiff or defendant, or be mad a party to any action or other legal proceeding brought b. or taken against her. Damages and costs recovered b. the wife will be her separate property, and any recovere against her will be payable out of her separate property and not otherwise $(g)$. Under this section a husband ca sue his wife in respect of her separate estate for mone advanced to her by him $(h)$, and he will still be liable fo her wrongful acts during coverture, it being in the discre tion of the plaintiff to sue the husband and wife jointly, $c$ the latter alone (i). A married woman cannot contrac or make herself liable upon contracts, in respect of be separate estate, if it is subject to a restraint upon anticips tion $(k)$. It was held that a married woman could n contract if at the time of making the contract she had $n$ separate property $(l)$. The Married Women's Property Ac $1893(\mathrm{~m})$, however, enacts that every contract entered in by a married woman after the passing of the Act shall 1 deemed a contract entered into by her in respect of $h$ separate property, whether at the time of contracting s?

(f) "Contracts" shall include the acceptance of any trust, or of the oftice of executrix or administratrix : s. 24.

(g) S. 1, subs. 2.

(h) Butles r. Butler, 14 Q. B. D. $831 ; 16$ Id. 374.

(i) Scroka r. Kattenburg, 17 Q. B. D. $17 \%$.

(k) Drayeott r. Hayrison, 17 Q. B. D. 147. The restraint on anticipation does not apply to income accrued due. A judgment creditor mar enforce the judgment aganst income which has accrued due at or before the date the judgment: Hood Barrs v. Her (1896) A. C. 174, reversing Hood Ba v. Cathcart, (1894) 2 Q. B. 559, Loftus v. Heriot, (1895) 2 Q. B. (C. A.).

(I) Palliser r. Gurney, 19 Q. B. 519, approving Deakin r. Lakin, Ch. D. 169; Leak v. Driffield, Q. B. D. 98 ; Stogdon r. Lee, (189) Q. B. 661 (C. A.).

(m) $56 \& 57$ Viet. c. 63 , s. 1. 
as or has not separate property, and shall bind all separate property which she may at such time or thereafter be possessed of or entitled to, and shall also be enforceable by rocess of law against all property which she may thereafter while discovert be possessed of or entitled to $(n)$; but he section does not affect, so as to render liable, property subject at the time of contracting, or which thereafter secomes subject, to a restraint upon anticipation $(o)$. On he other hand, she can now bring an action in her own lame for a wrong done to her before the passing of the 1ct, and the Statute of Limitations will only begin to run is from that date $(p)$. Judgment may now be signed gainst a married woman, either by default or under )rd. XIV. $(q)$.

Every married woman carrying on a trade separately rom her husband is, in respect of her separate property, ubject to the bankruptcy laws in the same way as if she

(n) This part of the section [1(c)] verrules the case of Beckett v. Tasker, 9 Q. B. D. 7.

(o) The next section, howerer, enbles the Court before which an action $r$ proceeding has been instituted by a oman or her next friend to order the ayment out of property subject to deh restraint of the other party's ssts. Cf. Pelton v. Harrison. (1891) Q. B. 422 (C. A.). The section oes not apply to costs of an appeal 1 which the married woman, the dendant in the Court below, was ppellant. The words " action or proseding instituted" do not include any lotion or step taken by a married oman in an action in which she is afendant: Hood Barrs v. Catheart, 894) 3 Ch. 376. A counter-claim by married woman is, however, within le section: Hood Barrs v. Cathcart, 895) 1 Q. B. 873 . The section does tt apply to an order made before te passing of the Act: Hood Barrs Catheart, (1894) 3 Ch. 135.

(p) Weldon v. Winslou, 13 Q. B. D. 34; Weldon v. De Bathe, 14 Id. 39; Turnbull v. Forman, 15 Id. 34 ; Lowe v. Fox, Ib. 667 . (q) Perks r. Mylrea, W. N. 1884, 64 ; Seott v. Morley, 20 Q. B. D. 120. A married woman who has made default in paying a sum for which judgment has been recovered against her under this section cannot be compritted to prison under the Debtors Act, 1869 (32 33 Vict. c. 62, s. 5), ib. The judgment is a personal one, although enforceable only against her property, and not against her person: Holtby $\mathrm{r}$. Hodgson, 24 Q. B. D. 103 (see the dictum of Lindley, L. J., at p. 108, doubted by Div. Court, In re Hewett, Ex parte Lavene, (1895) 1 Q. B. 328); Pelton v. Harrison, (1892) 1 Q. B. 121 (C. A.).

A bankruptey notice under s. 4 , subs. $1(g)$, of the Act of 1883 , which requires her to pay personally, cannot be issued against a married woman: In re Lynes, Ex parte Lester; (1893) 2 Q. B. 113 (C. A.), nor even after the death of her husband: In re Hereet, Ex parte Lavene, (1895) 1 Q. B. 328. In Robinson, King, \& Co. v. Lymes, (159t) 2 Q. B. 577 , the plaintiffs recorered judgment against a married woman enforceable against her person in respect of an ante-nuptial debt. 
were a feme sole $(r)$. Prior to this Act a married woman could not be made a bankrupt, even though she had a separate estate, and had contracted engagements after her marriage $(s)$; and even now it would seem that her liability is not personal, but depends upon her separate estate $(t)$.

By section 3 it is provided that any money or other estate of the wife lent or entrusted by her to her husband for the purpose of any trade or business carried on by him, or otherwise, shall be treated as assets of her husband's estate in case of his bankruptcy, under reservation of the wife's claim to a dividend as a creditor for the amount or value of such money or other estate after, but not before, all claims of the other creditors of the husband for valuable consideration in money or money's worth have been satisfied. This section has, however, been held not to be retrospective, and consequently not to invalidate existing rights $(u)$, nor does it affect the rights of a married woman who has lent money to a firm of which her husband is a member $(x)$.

By virtue of the Act a married woman can effest a policy upon her own life, or the life of her husband, for her separate use $(y)$; and, whether married lefore or after tha Act, has in her own name, against all persons whatsoever, including her husband, the same civil remedies, and alsc (subject as regards her husband to the proviso subsequently

(r) Ib., subs. 5. "Separate property" ouly includes that which would if she were unmarried be her property, and therefore does not include a general power of appointment by will or deed, of which she is donee, but which has not been exercised: Inve Armstrong, Ex parte Gilchrist, 17 Q. B. J). 521 . liy s. 152 of the Bankruptey Act, 1583 ( 46 if 47 Vict. c. 52), it is provided that nothing in the Act shall aftect the provisions of the Married Woncu's l'roperty Act, 1882. lint a married woman who does not carry on a trade separately from her husband is not subject to the operation of the baukruptey laws, and cannot commil an act of bankruptey nnder $46 \& 47$ Vict. c. 52, s. 4: In re Gardiner, El parte Coulson, 20 Q. B. D. 249.

(s) Ex parte Jones, re Grissell, 1! Ch. D. 484 .

(t) S. 15 .

(ii) Ex parte Irome, 54 I. T. 301.

ix) In re Tutf and Nottingham, 50

L. J. (2. B. 440 .

(y) S. 11 . 
mentioned) the same remedies and redress by way of criminal proceedings, for the protection and security of her own separate property, as if such property belonged to her as a feme sole $(z)$.

Finally, a married woman will continue liable in respect, and to the extent, of her separate property for all debts contracted, and all contracts entered into, or wrongs committed by her before her marriage $(a)$. But nothing in the Act is to increase or diminish the liability of any woman married before its commencement for any such debt, contract, or wrong, except as to any separate property to which she becomes entitled by the Act, and which she would not have been entitled to had it not passed (b).

2. As to the capacity of a married woman to hold separate property $(c)$, it is provided that a married woman shall be capable of acquiring, holding, and disposing by will or otherwise of any real or personal property, as her separate property, in the same manner as if she were a feme sole, without the intervention of any trustee $(d)$. Further, a married woman's will, prima facie, speaks from the date of her death, irrespective of whether at the time of making it she had separate property, and does not require to be re-executed or republished after the husband's death $(e)$.

Such property in the case of a woman married after the 1st January, 1883, will include all real and personal property belonging to her at the time of marriage, or acquired by, or devolving upon her after marriage, including any wages, earnings, money, and property gained or acquired by her in any employment, trade, or occupation in which she is engaged, or which she carries on separately from
(z) S. 12.
(a) S. 13.
(b) Ib.
(c) The word "property" in this Act includes a thing in action: $\mathrm{s}$. 24 .
(e) $56 \& 57$ Vict. c. 63 , s. 3 . The section applies to every will made by a married woman who dies after the passing of the Act: Wylie, In re, Wylie v. Moffat, (1895) 2 Ch. 116.

(d) S. 1, subs. 1 . 
her husband, or by the exercise of any literary, artistic, on scientific shill $(f)$.

In the case of a woman married before that date, it will include all real and personal property her title to which, whether vested or contingent, and whether in possession, in reversion, or remainder, shall accrue after the commencement of the Act, including any wages, earnings, money, and property so gained or acquired by her as above mentioned $(g)$. But when she has acquired prior to the passing of the Act a title, whether vested or contingent, and whether in reversion or remainder, to any property, such property is not made her separate estate by this section, though it falls into possession after that date $(h)$.

The Act also contains provisions as to stocks, shares, \&c., at or after the commencement of the Act standing in, or transferred to, the sole name of a married woman, or in the joint names of a married woman and persons other than her husband. They will be deemed her separate property unless and until the contrary is shown, and the fact of them so standing in her sole name will be sufficient primi facie evidence that she is beneficially entitled thereto for her separate use, so as to entitle her to receive the dividends, interest, and profit thereof without the concurrence of her husband, and indemnify those paying her in respect of such payments (i).

II usband and wiferanedies afainst one another.

3. As to the position of husband and wife, and their remedies against each other other than those already $(k)$ referred to, it is provided that if any investment in any

(f) S. 2 The Act has not altered the law as to paraphernalia: Tasker. Tasker, (1895) p. 1. Accordingly a husband can still give his wife presents of jewels "to be worn as ornaments of her person only," and the same not become her separate property.

(g) S. 5. Damages recovered for personal injuries which were awarded to a marricd woman in an action where she and her husband were co-plaintiffs were held to be her separate property within s. 5: Beasley v. Roney, (1891) 1 Q. B. 509.

(h) Reid v. Reid, 31 Ch. D. 402, overruling Baynton v. Collins, 27 Id. 604; In re Tucker, 54 L. J. Ch. 874; In re Adames' Trusts, Ib. 878 ; $\mathrm{Web}$ ster $\mathrm{r}$. Riekards, 55 Id. 300.

(i) Ss. 6, 7, 8 .

(k) S. 12 ; supra, p. 653. 
shares or stock, \&c., is made by a married woman by means of moneys of her husband without his consent, the Court may, upon application under section 17 (which provides that questions as to property between husband and wife may be settled in a summary. manner), order such investment and the dividends thereof, or any part thereof, to be transferied and paid respectively to the husband $(l)$.

Save as in section 12 provided, no husband or wife will be entitled to sue the other for a tort, nor can a wife take any criminal proceedings against her husband by virtue of the Act while they are living together as to or concerning any property claimed by her, nor while they are living upart as to or concerning any act done by the husband while they were living together concerning property claimed by the wife, unless such property has been wrongfully aken by the husband when leaving or deserting, or about io leave or desert, his wife $(m)$. It may be added that a narried woman could not before, and cannot since, the oassing of the Act, take criminal proceedings against her lusband for defamatory libel. Prior to that date the emedy by criminal proceedings was confined to cases of odily violence, and now it has only been extended to rrongful acts in respect of her property $(n)$.

In any indictment or other proceeding under this section, $t$ will be sufficient to allege the property to be the property $f$ the wife, and in any proceeding under this section, a usband or wife will be competent to give evidence against ach other, any statute or rule of law to the contrary notithstanding $(o)$.

It is further provided that a wife doing any act with espect to any property of her husband which, if done by

(l) S. 10.

(m) S. 12. See Lemon r. Simmons, 7 L. J. Q. B. 260 . A husband is it prerented by this section from forcing against his wife an underking as to damages where an injunc- tion has been wrongly granted: Hunt v. Hunt, 54 L. J. Ch. 289.

(n) Reg. v. London (Lord .Yayor of), 16 Q. B. D. 772.

(o) Reg. v. London (Lord Mayor of), 16 Q. B. D. 772 . 
the husband with respect to property of the wife, would make the husband liable to criminal proceedings by the wife under the Act, shall in like manner be liable to criminal proceedings by her husband $(p)$.

Respective liability for
debts of wife incurred before coverture-

4. As to the liability of the husband and wife respectively for the debts, contracts, wrongs, or liabilities $(q)$ of the wife, the statute provides as follows :-

In regard to ante-muptial liabilities, the wife will be liable in such cases to the full extent of her separate property, and as between her and her husband, unless there is any contract between them to the contrary, her separate property will be deemed to be primarily liable for all such claims, including costs and damages $(r)$. The husband will be liable in such cases to the extent of all property which he shall have acquired or become entitled to from or through his wife, after deducting therefrom any payments made by him, and any sums for which judgment may have been bon $\hat{\imath}$ fide recovered against him in any proceeding at law in respect of such ante-nuptial liabilities, but no further or otherwise. The Court may direct an inquiry to ascertain the value of such property.

These provisions will not affect the liability of any husband married before the commencement of the Act $(s)$.

(p) S. 16. Under this section the evidence of the husband was held not admissible on a criminal charge against the wife: Reg. v. Brittleton, 12 Q. B. D. 266. Bint it has since been expressly declared admissible, 47 \& 48 Fict. c. 14, s. 1: Reg. F. Mallory, 13 Q. 13. D. 33.

(q) The prorisions of this Act as to the liabilities of married women shall extend to all liabilities by reason of any breach of trust or devastarit committed by any married woman being a trustee, or executrix, or administratrix, either before or after her marriage, and her husband shall not be subject to such liabilities, unless he has acted or intermeddled in the trust or administration: s. 24 . (v) S. 13. In Axford v. Reid, 22 Q. B. D. 548, the C. A. held that the corresponding section (s. 12) of the Act of 1870 extended to separate property subject to restraint from anticipation, and accordingly such property was liable in respect of ante-nuptial debts.

A judgment obtained against a married woman during her first mar riage becomes an ante-nuptial debt if she marry a second time. The "ante" is to be regarded with respect to the time her liability is under consideration: Jay v. Robinson, 25 Q. B. D. 467 .

(s) S. 14. A judgment against " married woman which remains unsatis. fied by reason of her having no separate estate is no bar to an action against the 
The husband and wife may be jointly sued in any such case where the plaintiff seeks to establish his claim, either wholly or in part, against both of them. If the husband, whether sued separately or jointly with his wife, is successful, he will be entitled to judgment for the costs of his defence, whatever may be the result of the action against the wife. If in a joint action it appears that the husband is liable wholly or in part, the judgment, to the extent of the amount for which the husband is liable, will be a joint judgment against the husband personally, and against the wife as to her separate property ; as to the residue, if any, of the amount recovered, the judgment will be a separate judgment against the wife, as to her separate property only $(t)$.

Before taking leave of the Act, we may add that it saves existing settlements, and also the power to restrain a married woman from anticipation, with certain exceptions $(u)$. It also provides for the performance of the duties of executrix and administratrix by a marxied woman as though she were a feme sole $(x)$.

Finally, a married woman is by the Act placed under a iability to the parish for the maintenance of her husband, hildren, and grandchildren, similar to that already imposed ipon the husband, who will, however, still remain liable for he support of his children and grandchildren $(y)$.

It will be observed that the Act does not directly deal coverturis. rith the question of the husband's liability for the debts or

usband. He cannot, howerer, be made able for ante-nuptial simple contract ebts which accrued due against the ife more than six years before action rought. Though marriage fixes the ate of the husband's liability, the date 'om which the Statute of Limitations Ins is not so fixed: Beck v. Pierce, 23 1. B. D. 316 .

(t) S. 15 .

(u) S. 19. As to the effect of this etion as exempting settlements from

B.C.L. the effect of s. 5, see In re Stonor's Trusts, 24 Ch. D. 19.5, approved in In re Whittaker, 34 Id. 227; In $r e$ Queade's Trusts, 54 L. J. Ch. 786; Smith v. Whitlock, 5อ L. J. Q. B. 286 ; Hancock v. Hancock, 38 Ch. D. 78 (disapproring In re Queade's Trusts, supra); Stcrens v. TrevorGarrick, (1893) 2 Ch. 307.

(x) S. 18.

(y) Ss. $20,21$. 
contracts of his wife incurred or entered into during coverture, which must therefore be answered by a reference to the rules of common law as laid down in decided cases, subject to some possible statutory qualification.

The wife, being by marriage divested of her property and rendered incapable (except sub modo) of acquiring and re. taining any, could not, in reason, be held liable upon contracts ostensibly entered into with her; and accordingly, at common law, a feme covert was incompetent to enter intc a contract, save as the agent of her husband $(z)$. "A con. tract made by a wife during coverture is indeed a bargair by her on behalf of her husband" $(a)$. Such a contract: if unauthorised by him, was altogether void; it could give no right of action to the wife $(b)$, nor impose a severa: liability upon her $(c)$.

The leading case on this point is the celebrated case of Manby v. Scott (d), where it was held, 1. That husbands art bound to supply their wives with necessaries; 2 . That th contract of a married woman is merely void as far as she i concerned by our law; 3. That if the wife purchases goods and the husband by any act, precedent or subsequent ratifies the contract by his assent, the husband shall br liable upon it; whereas the husband is not liable in respec of a contract made by his wife without his assent to it, anc a party seeking to charge him in respect of such a contrac is bound to prove either an express assent on his part, 0

(z) If A. and B. live together as man and wife, although not really so related to each otber, $A$. may, even after the connection has been serered, be liable on B.'s contracts; whether he is so or not will usually depeud upon the proof of agency: Ryan v. Sams, 12 Q. B. 460.

(a) P'er Bramuell, B., De Wahl v. Braune, 1 H. \& N. 182.

(b) See, however, ante, p. 677.

(c) Judgm., 9 Exch. 429; Com. Jig. "Bar. and Feme" (Q). See Sintith v. Plomer, 15 East, 607 ;
13 R. R. 536 ; Saunderson v. Griffith 5 B. \& C. 909 ; Dick v. Tolhatusen, H. S N. $69 \bar{j}$.

In Irens $\nabla$. Butler, 7 E. \& B. 15 \& a married woman who had been take in execution on a judgment obtaine against husband and wife for the del of the latter dum sola was ordered 1 be discharged from custody, thes heing no evidence to show that sl had separate property. See Ex par Butler, 1 H. \& C. 637 ; Poole Canning, L. R. 2 C. P. 241.

(d) 1 Lev. 4 ; 2 Sm. J. C., 9 thed., 46 
circumstances from which such assent is to be implied (e), and hence it is generally said that the wife can only contract as agent for her husband $(f)$. "The authority of a wife to pledge the credit of her husband is a delegated, not an inherent authority. If she binds him, she binds him only as his agent" $(g)$.

How far the first resolution in Manby v. Scott $(h)$ will be supported in the future in the face of recent legislation must remain uncertain until the point is determined by judicial decision (i). We have seen $(k)$ that a married woman is now capable of entering into and becoming liable upon contracts $(l)$ to the extent of her separate property, which she will continue to hold after marriage as absolutely as she did before as far as her husband is concerned $(\mathrm{m})$; and further, that every contract entered into by a married woman will for the future be deemed a contract entered into by her with respect to and to bind her separate property, unless the contrary be shown $(n)$. Prior to the commencement of the Act the onus lay upon the plaintiff ;o show, in cases where credit was given to the wife, that ler contract was entered into with reference to her separate state $(0)$; but this rule has now been expressly abolished yy the Act. It seems probable, however, that this preumption is confined to cases where credit has been given 0 the wife alone, and where a remedy is sought against ier estate only, and that where it is sought to charge the usband for liabilities contracted by the wife as his agent

(e) Per Littledale, J., 3 B. \& C. 37.

(f) Judgm., Johnston v. Simner, H. \& N. 265-6; Co. Litt. 112 a ; om. Dig. "Bar. and Feme" (D. 1); r Blackstone, J., Sterenson v. Hardie, W. Bla. 873; Sinout v. Ilbery, 10 . St W. 1 , cited ante, p. 616 ; Longeid v. Holliday, 6 Exch. 761.

(g) Judgm., 3 Q. B. D. 435.

(h) Ubi supra.

(i) In Wilson v. Glossop, 20 Q. B.
D. 354 , it seems to have been assumed that the recent legislation has made no change.

(k) Ante, p. 682.

(l) $45 \& 46$ Vict. c. 75 , s. 1 , subs. 1.

(iin) S. 2.

(n) S. 1, subs. 3.

(o) Johnson v. Gallagher, $3 \mathrm{De} G$. F. \& J. 514, 515; London Chavtered Bank of Australia v. Lempriere, L. R. 4 P. C. 591. 
the old common law principles will still remain in force. Assuming, therefore, that a husband is still bound to supply his wife with necessaries, and that in consequence she may still have an implied authority from the law to pledge his credit for such things without his express assent, it becomes important to consider what are "necessaries," and what are the circumstances under which she has such authority.

Now, in the first place, the word "necessaries" has a very wide application. "The word "necessaries" " in its lega sense, as applied to a wife, "merely means something which it is reasonable that she should enjoy" $(p)$. This being so, the circumstances under which a feme covert has an implied authority to bind her husband for necessaries $(q$ ) may be thus classified $(r)$ :-

1. In the first place, whenever the husband and wife ar living together, and the husband provides the wife witl necessaries, the husband is not bound by contracts of th wife, even for necessaries, unless there be reasonabl evidence to show that the wife has made the contrac with his assent $(s), e x . g r$., if he has seen her habituall wearing expensive articles of dress without expressin disapprobation $(t)$, or if he has adopted and ratified he act $(u)$.

(p) Per Thesiger, L. J., Ottaway r. IIamilton, 3 C. P. D. 401 , which shows that a suit for a separation may be a "necessary" because a wife stands in need of protection from the cruelty of her husband, and a suit for dissolution of marriage may be equally a " necessary" when to cruelty is superadded adultery.

(q) As to what are necessaries, see Hunt v. De Blaquiere, 5 Bing. 550; Chapple r. Cooper, 13 M. \& W. 252 ; Grindell v. Godmond, 5 Ad. \& E. 755 ; per Lord Hrougham, C., Howard $\mathbf{v}$. Digby, 2 Cl. \& F. 679, and cases infra.

$(r)$ See the judgment in Johnston $\mathrm{v}$.
Sumner, 3 II. \& N. 261.

An epitome of the law as to $t$ busband's liability for necessaries su plied to the wife is giren by Lo: Holt, C. J., in Etherington r. Parro 1 Salk. 118.

(s) Per Bayley, J., 3 B. \& C. 63 Seaton v. Benedict, 5 Bing. 28; $2 \mathrm{St}$ L. C., 9th ed., 512; Spreadbury Chapman, 8 Car. \& P. 371 ; Holt Brien, 4 B. \& Ald. 25", "the margin note of which is deficient;" per Lo Blackbum, Debenham r. Mellon, App. Cas. 27.

( $t)$ Per Best, C. J., 5 Bing. 31 ; Sm. L. C., 9th ed., 515.

(u) West v. Wheeler, 2 C. \& K. 7 ) 
In Montague v. Benedict (x), which is a leading authority upon this part of the subject, the action was for goods sold and delivered. It appeared that the plaintiff was a jeweller, who, in the course of two months, had delivered articles of jewellery to the defendant's wife amounting in value to $83 l$; the defendant was a certificated special pleader, living in a ready-furnished house, of which the annual rent was $200 l$. ; he kept no manservant; his wife's fortune, upon her marriage, was less than 4,000l.; she had, at the time of her marriage, jewellery suitable to her condition; and it was proved that she had never in her husband's presence worn any of the articles furnished by the plaintiff. It appeared also that the plaintiff, when he went to the defendant's house to ask for payment of his bill, always inquired for the wife, and not for the defendant. It was held, that the goods for which the plaintiff sued were not necessaries, and that, as there was no evidence of any assent of the husband to the contract made by his wife, the action could not be maintained. "If," remarked Bayley, J., " a tradesman is about to trust a married roman for what are not necessaries, and to an extent beyond what her station in life requires, he ought in common prudence to inquire of the husband if she has his consent for the order she is giving; and if he had so inquired in this case, it is not improbable that the husband might have told him not to trust her."

Again, where the husband and wife are living together, in regard to orders given by the wife in those departments If her husband's household which she has under her conirol the jury may infer that the wife is the agent of her iusband, unless or until the contrary appear $(y)$. So for

(x) 3 B. \& C. 631 ; 2 Sm. L. C., ith ed., 504 .

(y) Per Lord Abinger, C. B., Freetone v. Butcher, 9 Car. \& P. 647; nd in Emmett v. Norton, 8 Id. 510 ; luddock v. Marsh, 1 H. \& N. 601; explained by Bramuell, I. J., 5 Q. B. D., at p. 399 ; Jolly v. Rees, 15 C. B., N. S., 628 , approved and followed in Debenham v. Mellon, 5 Q. B. D. 394, 398, 402 ; 6 A pp. Cas. 24, 33. 
articles necessary for the wife, such as clothes, if the order is given by the wife, and she is living with her husband, and nothing appears to the contrary, the jury do right by. inferring the agency; but if the order is excessive in point of extent, or if, when the husband has a small income, the wife gives extravagant orders, these are circumstances from which the jury would infer that there was no agency $(z)$. The tradesman, then, who supplies goods to a married woman will if the bill is one of an extravagant nature, such as the husband would never have authorised, run the risk of losing his money, because from the extravagance of the order, coupled with other circumstances, the jury may reject the inference of agency $(a)$. "It is the bounden duty of tradesmen when they find a wife giving extravagant orders to give notice to the husband immediately, if they mean to hold him liable" (b).

It has been held that a husband is not liable for money lent to his wife, although it be afterwards expended by her in procuring necessaries for which the husband would have been liable $(c)$.

2. Where husband and wife are living together, and the husband will not supply his wife with necessaries or the means of obtaining them, she is, by our common lar, at liberty to pledge her husband's eredit for what is strictly requisite for her own sxpport $(d)$.

"Undoubtedly," said Holroyd, J. (in Montague v. Benc. dict (e), already cited), "the husband is liable for neces, saries provided for his wife where he neglects to provid. them himself. If, however, there be no necessity for th articles provided, the tradesman will not be entitled to

(z) Ib.

(a) See the remarks of Iord Abinger, C. B., in Frecstone v. Buteher, supra, as qualified by Parke, $\mathrm{B}$, in Lane $\mathrm{r}$. Iiomonger, 13 M. \& W. 370 ; Phil. lipson r. Hayter, L. R. 6 C. P. 38.

(b) Frecstone v. Butcher, supra. (c) Innox r. Bushell, 3 C. B., X.S. 334. As to this case, see Iush, Th Law of Husband and Wife, p. 338 .

(d) Per Baylcy, J., 3 B. at C. 631 2 Sm. L. C., 9th ed., 507.

(e) 3 B. \& C. 636,$637 ; 2 \mathrm{Sm}$ L. C., 9 th ed., 509 . 
recover their value unless he can show an express or implied assent of the husband to the contract made by the wife. Where a tradesman takes no pains to ascertain whether the necessity exists or not, he supplies the articles at his own peril ; and if it turn out that the necessity does not exist, the husband is not responsible for what may be furnished to his wife without his knowledge. Where a tradesman provides articles for a person whom he knows to be. a married woman, it is his duty, if he wishes to make the husband responsible, to inquire if she has her husband's authority or not, for where he chooses to trust her, in the expectation that she will pay, he must take the consequence if she does not" $(f)$. "When a wife is living with her husband, if he gives her nothing but the shelter of his house, she would have a right to provide food and apparel for herself at his expense, and he would be bound to pay or them; in cases such as these a wife has undoubtedly ower to bind her husband" $(g)$.

3. Where the husband and wife are living apart by mutual :onsent, and the husband makes the wife a sufficient allowance for her support, he is not liable to a tradesman or goods supplied to her; and whether the tradesman inew of such allowance or not has been held to be immaerial $(h)$. In this case, accordingly, the question for the ury will be-Has the husband given the wife sufficient for recessaries suitable to his degree? If so, he will not be iable on the wife's contracts (i), unless proof be given that re has sanctioned or adopted them $(k)$. It has been held

(f) See Jolly v. Rees, 15 C. B., X. S., 28; Reneaux v. Teakle, 8 Exch. 680 ; ltkins v. Curvood, 7 Car. \& P. 756 ; 'entley r. Griffin, 5 Taunt. 356.

(g) Per Bramuell, L. J., Debenham Mellon, 5 Q. B. D., at p. 398.

(h) Reeve $\mathbf{v}$. Marquis of Conyngham, C. \& K. 444 ; Holder v. Cope, Id. 37. See Reg. v. Plumminer, 1 C. \& . 600; Edwards v. Towels, 5 M. \&
Gr. 624 ; Howard v. Digby, 2 Cl. \& F. 679; Dixon v. Hurvell, 8 Car. \& P. 717.

(i) Per Lord Abinger, C. B., Emmett v. Norton, S Car. \& P. ó11 ; Hodgkinsos $v$. Fleteher, \pm Camp. $70 ; 15$ K. R. 725; Liddlow r. Wilmot, 2 Stark. N. P. C. $86 ; 19$ R. R. 6st; Wilson v. Simyth, 1 B. \& dd. sol.

(k) Waithman v. Wakefield, 1 Camp. $120 ; 10$ R. R. 654 . 
that the authority of a wife to pledge her husband's credit is no greater where he is a lunatic than it is if he be sane $(l)$.

Where the husband and wife are living separate, we mustremember, that (as observed by Albott, C. J., in Mainuaring v. Leslie $(m)$ ) there is no presumption that the wife has authority to bind her husband "even for necessaries suitable to her degree in life; it is for the plaintiff to show that, under the circumstances of the separation or from the conduct of her husband, she had such authority. The mischief of allowing the ordering of goods by a married woman living apart from her husband to be prima facie evidence, so as to charge him for them, would be incalculable."

In Johnston v. Sumner ( $(n)$ also, the Court of Exchequer stated their opinion to be that, in the case now under notice, "the burthen of proof is on the person who has trusted the wife; and that when the husband and wife are living apart the wife's authority is not shown where it is proved she is living apart from her husband by mutual consent, with an agreement as between him and her that she is not to pledge his credit, and with an allowance not shown to be inconsistent with that being the real intention." As well in the case here put as in that presently considered, viz., where the wife leaves her husband without his consent, it would seem that the husband's authority to pledge his credit must be affirmatively shown.

Where husband and wife separate by mutual consent, the wife making terms as to her income, and that income proves insufficient for her support, she has no authority to pledge her husband's credit $(o)$.

(I) Richardson r. Du Bois, I., R. 5 Q. K. 51. See Drew v. Nimn, 4 Q. B. D. 689 .

(m) Moo. \& M. 18; Clifford r. Laton, Id. 101, 102.

(n) 3 H. \& N. 267, 268. See, as to this case, $2 \mathrm{Sm}$. L. C., 9th ed., 520 and per Lord Selborne, Debenham o Mellon, 6 App. Cas. p. 32; Biffin r Bignell, 7 H. \& N. 877, 879. 432. 
It is clear that the agency of the wife, when living apart from her husband, to bind him for necessaries, is determined by her adultery $(p)$.

4. If the husband has deserted his wife $(q)$ or turned her out of doors, or has caused her, from reasonable apprehension of cruelty, to leave him (v), or by his indecent conduct has precluded her from living with him (s), and does not give her adequate means of subsistence, according to his degree in life and his fortune, the law in general $(t)$ regards her as his agent to order such things as are reasonable and necessary for herself; but it gives her no liberty to go into any extravagance, or to pledge his credit for anything beyond what would be reasonable and necessary for her subsistence (u). In like manner, "if a man will not receive his wife into his house, he turns her out of doors; and if he does so, he sends with her credit for her reasonable expenses" $(x)$. If a husband turns his wife out of doors, or conducts himself so that she is obliged to leave him, it is a legal duty upon him to maintain her; and if he will not himself perform that duty, she has power to pro-

(p) Cooper v. Lloyd, 6 C. B., N. S., 519. See Needham v. Bremner, L. R. l. C. P. 583. Nor can a husband be ompelled to support an adulterous rife, under 31 \& 32 Vict. c. 122, . 33 : Calley v. Charman, 7 Q. B. J. 89 .

(q) See Wilson v. Ford, L. R. 3 3.. 63.

(r) Broun r. Ackroyd, 5 E. \& B. 119; Rice v. Shepherd, 12 C. B., i. S., 332 ; Baker v. Sampson, 14 B., N. S., 383.

(s) Bazeley v. Forder, L. R. 3 ใ. B. 559,562 , where the reasonable xpenses of providing for an infant nder seven years of age, of which the ife had the legal custody, were held 3) be within the abore rule as to ecessaries.

(t) In Johnston r. Sumner, 3 H. \& i. 266, the Court observed, "If the usband turns bis wife away, it is not nreasonable to say she has an autho- rity of necessity, for she by law has no property, and may not be able to earn her living; but we should hesitate to say that if a labouring man turned his wife away, she being capable of earning, and earning, as much as he did, or if a man turned his wife away, she having a settlement double his income in amount, the wife in such case would bind the husband."

(it) Per Lord Abinger', C. B., Enmett v. Norton, 8 Car. \& P. 510, and in Hardie v. Grant, Id. 516; Hunt v. De Blaquiere, ๖' Bing. 557, 562 ; per Bayley, J., Montague v. Benedict, 3 B. \& C. $635 ; 2$ Sm. L. C., 9th ed., 504 ; per Lord Kenyon, C. J., Hodges v. Hodges, 1 Esp. $441 ; 4$ R. R. 889 ; per Lord Ellenborongh, C. J., 2 Stark. T. P. C. 87 ; Harris v. Momis, 4 Esp. 41; Houliston v. Swyth, 2 Car. \& P. 22.

(x) Per Lord Eldon, Raulyns $\checkmark$. Fandyke, 3 Esp. 250; Reed r. Hoore, 5 Car. \& P. 200. 
vide for herself at his expense: that is to say, she can pledge his credit for necessaries, such as food, apparel, lodgings, and perhaps medicine and physic $(y)$.

5. But although "the law presumes that the husband will furnish necessaries for his wife so long as she is a member of his family, and that he undertakes to pay for such necessaries," yet " when the wife roluntarily abandons and relinquishes her family, by this conduct she renders herself incapable of enjoying the before-mentioned privilege, and places herself without the pale of her husband's maintenance; and therefore it shall not be presumed that the husband has entered into such an assumpsit in that case " (z). A tradesman, therefore, supplying necessaries to the wife whilst living apart from the husband against his will, could not recover from the latter $(a)$, unless proof were given that he had assented to the wife's contract.

6. If the wife be living in open adultery, her husband is not bound by any contract which she may make (b), eren for necessaries $(c)$, unless there be evidence of authority from him $(d)$, or of condonation on his part, or he forgire her and receive her back again $(e)$, or has connived at the adultery committed by her $(f)$.

7. It is enacted by the stat. 20 \& 21 Vict. c. 85, s. 26 , that where upon a judicial separation " alimony has been decreed or ordered to be paid to the wife, and the same shall not be duly paid by the husband, he shall be liable for necessaries supplied for her use."

Although in general it is upon the ground of agency

(y) Per Bramuell, L. J., Debenhan v. Mellom, 5 Q. H. D., at p. 398.

(z) Manby $\mathrm{r}$. Scott, 1 Ler. 4 (ad finem): 2 sm. L. C., 9th ed., 502.

(a) Himlley v. Marquis of West. meath, 6 B. d. C. 200.

(b) Atkyns v. I'carce, 2 C. B., N.S.763.

(c) Per Lord Abinger, C. B., Emmett

r. Norton, 8 Car. SE P. jlo; Haidic

r. Grant, Id. 512; Gorier r. Hawcock,
6 T. R. $603 ; 3$ R. R. 271; Morris v. Martin, Str. 647; Mantairing $\mathrm{r}$. Sands, Id. 706.

(d) See per Cockturn, C. J., Atkyns v. Pearce, supra.

(e) See Nortoul r. Fazan, 1 B. \& P. 226 ; 4 R. R. 785 ; Cooper r. Lloyd, 6 C. H., N. S. 519.

(f) Hilson v. Glossop, 19 Q. B. D. $379 ; 20$ Id. 354. 
merely that questions as to the liability or non-liability of the husband in respect of the contracts for necessaries of the wife have been discussed $(g)$, yet it would seem that this matter may, not inaccurately, be regarded from a somewhat different point of view ; that the husband, on assuming such character, incurs ipso facto, at common law, certain responsibilities quoad the wife, the nature of which has been partially indicated in the preceding pages. Thus Alderson, B., in Read v. Legard (h), says:-By the marriage contract, the husband takes on himself the duty of supplying his wife with necessaries ; that is to say, the wife is entitled to be supported according to the estate and condition of her ausband. "If she is compelled by his misconduct to procure the necessary articles for herself,-as, for instance, $f$ he drives her from his house, or brings improper persons nto it, so that no respectable woman could live there $(i)$,ccording to the decided cases, he gives her authority to ledge his credit for her necessary maintenance elsewhere, rhich means that the law gives that authority by force of the elation of husband and wife. So, if a husband omit to urnish his wife with necessaries while living with him, she aay procure them elsewhere, otherwise she would perish." ind, by parity of reasoning, "if the husband becomes unatic by the visitation of God and therefore unable to rovide his wife with necessaries, he is in the same situation s a husband omitting to furnish them; and as by the elation which he originally contracted he undertook to rovide her with them himself, he becomes liable to any erson who does it for him " $(k)$.

(g) See Judgm., 3 H. \& X. 265,

i6 ; ante, p. 691.

(h) 6 Exch. 636 .

See also Judgm., Manby v. Scott, Lev. 4 ; 2 Sm. L. C., 9 th ed., 466 . (i) See Aldis v. Chapman, Selw. P., 13th ed., 232.

(k) Per Alderson, B., 6 Exch. 642.
"The true principle seens to be that when a man marries he contracts an obligation to support his wife; and, in point of law, he gives her authority to pledge his credit for her support, if circumstances render it necessary, she herself not being in fault: " per Pollock, C. B., Id. ibid. 
In conformity with the doctrine above laid down, a hus. band has been held liable for the necessary expenses attendant on the decent interment of his wife, who at the time. of her death was living separate from him, although such expenses were incurred, and in the first instance defrayed, by the plaintiff, a mere volunteer, without any prior communication with the husband. There can be no question, remarked Jervis, C. J., in the case here alluded to, that an undertaker who conducts a funeral may recover from the executor of the deceased (having assets) the reasonable and necessary expenses of such funeral without any specific contract, the liability of the executor resulting from the duty imposed upon him by the character which he fills, regard being had to decency and to the comfort of others; and an equal responsibility is for the same reasons cast upon the husband of a deceased wife, such responsibility being directly referable to the character with which he is invested $(l)$.

The marital relation may also be severed and determined by the eivil death of the husband $(m)$. It may in certain cases be suspended by some temporary disability cast upon $\lim (n)$.

Contracts of lunatics.

"A lumatic, or non compos mentis," says Blackstone (o) " is one who hath had understanding, but by disease, grief or other accident has lost the use of his reason." In pur. suing the present inquiry, it becomes important to consides how far, by the defect of reason here pointed at, the con tracts of a lunatic are rendered voidable or void.

A lunatic is liable for the price of necessaries, i.c., o

(l) Ambrose v. Ferrison, 10 C. B. 7i6 (recognising Jenkins v. Tucker, 1 H. Bla. 91); Bradshaw r. Beard, 12 C. B., N. S., 344.

(ii) Bellnap's case, Co. Litt. 132 b; Julgm., Beard v. Welb, 2 B. \& P. 105. See Barden r. De heicrbery, 2
M. E W. 61 .

(i) Sparrois r. Carmithers, cited W. BI. $1197 ;$ Ex parte Franks, Bing. 762; Carrol r. Blenear, 4 Esp 2i. See Boggett v. Fries, 11 Eas 301.

(o) 1 Bla. Com. p. 304. 
goods or things suited to his state and degree, actually ordered and enjoyed by and bon $\hat{a}$ fide supplied to him (p). Further, a person who supplies a lunatic with necessaries, snowing him to be one, can maintain an action against him on the ground of an implied obligation $(q)$.

With regard to the right of a lunatic, or his representatives, to rescind an executed contract entered into by him not being for necessaries, Molton v. Camroux $(r)$ must be egarded as the leading authority. There, a lunatic having purchased of a life assurance company certain annuities, Ind having paid the consideration money and a premium n respect thereof, an action was, after his death, brought or recovery of these moneys by his. administratrix, under he following state of facts, as found by the special verdict: -At the time of the granting of the annuities and payment If the consideration money aforesaid, the intestate was a unatic and of unsound mind, so as to be incompetent to nanage his affairs, but of this the society had not, at that ime, any knowledge; the purchases of the annuities took lace in the ordinary course of business ; they were fair and on $\hat{\imath}$ fide transactions; the grantee then appearing to the ociety to be of sound mind, although he was in fact of unound mind. All suspicion of fraud or unfairness being hus excluded, the question was, by the special verdict bove abstracted, broadly raised-whether the mere fact of unsoundness of mind, not apparent at the time of the conract in question, was sufficient to vacate it, albeit executed $y$ the grantee by payment of the consideration money, and atended bon $\hat{\imath}$ fide to be executed by the grantor by payment

(p) Baxter v. Earl of Portsmouth, 5 \& C. 170 ; S. C., 2 Car. \& P. 178 ; Telson v. Duncombe, 9 Beav. 211. ee Read v. Legard, 6 Exch. 636. Cf. so 8. 2 of the Sale of Goods Act, 393.

(q) Rhodes, In re, 44 Ch. D. 94, disapoving the dicta in Weaver, Re, $21 \mathrm{Ch}$. .615 (r) 4 Exch. 17; affirming Judgm. in S. C., 2 Exch. 487.

In Price v. Berrington, 3 Mac. \& G., Lord Truro, C., expressed a doubt as to whether a conreyance executed by a lunatic was, in the then state of the law, absolutely roid in the absence of notice and fraud (at p. 498). 
of the annuity. In deciding this question, the Court of Exchequer Chamber made the following remarks $(s)$ :- "The old doctrine was, that a man could not set up his own lunacy, though such as that he did not know what he was about in contracting $(t)$; and the same doctrine was applied to drunkenness $(u)$. It is true that there are some exceptions in the old authorities, and the doctrine is not laid down uniformly with perfect distinctness; but, in general, it was as above stated. Modern cases have qualified it, and enabled a man or his representatives to show that he was so lunatic or drunk as not to know what he was about when he made a promise or sealed an instrument. The special verdict hardly shows any such state of mind; but, even if it did, the modern cases show that when that state of mind was unknown to the other contracting party, and no advantage was taken of the lunatic, the defence cannot prevail, especially where the contract is not merely executory, but executed in the whole or in part, and the parties cannot be restored altogether to their original position." The principle deducible from the whole case may be thus stated, that "when a person apparently of sound mind, and not knomn to be otherwise, enters into a contract for the purchase of property which is fair and bona fide, and which is executed and completed, and the property, the subject-matter of the contract, has been paid for and fully enjoyed, and cannot be restored so as to put the parties in statu quo, such contract cannot afterwards be set aside either by the allegec lunatic or those who represent him " $(x)$.

(8) 4 Exch. 19.

(t) See Bercrley's case, 4 Rep. 123 b; Co. Litt. 247 b.

(u) Post, p. T04.

(x) Judgm., 2 Exch. 503, with which acc. Bcaran v. M'Donncll, 9 Exch. 309 ; S. C., 10 Id. 184.

See also Jane v. Kirkwall, 8 Car. \& P. 679; Broun v. Jodrell, 2 Car. S P. 30 ; Nicll v. Morley, 9 Ves. 478 ;
Aleock v. Alcock, 3 M. \& Gr. 268 Tavbuck v. Bispham, 2 M. \& W. 2 Frost v. Bcaven, 22 I. J. Chanc 638: Drewe v. Nunn, 4 (Q. B. D. 661

Where an action is brought to recore money paid under a contract on th ground of the plaintifi's lunacy, an' the issue is, whether at the time of th particular transaction the fact of th plaintiff's insanity was known to th 
The Court of Appeal in The Imperial Loan Company v. Stone $(y)$ decided that where to an action of contract the defendant sets up a plea of insanity he must show that his insanity was known to the plaintiff at the time of the contract, whether such contract be executed or executory: "When a person enters into a contract and afterwards alleges that he was so insane at the time that he did not know what he was doing, and proves the allegation, the contract is as binding on him in every respect, whether it is executory or executed, as if he had been sane when he made it, unless he can prove further that the person with whom he sontracted knew him to be so insane as not to be capable of understanding what he was about $(z)$. . . . It thus appears hat there has been grafted on the old rule the exception hat the contracts of a person who is non compos mentis nay be avoided when this condition can be shown to have seen known to the plaintiff" $(a)$.

The old rule, referred to in the passage quoted from Fry, L. J.'s, judgment in the case last cited, was, that lthough in certain cases the Crown $(b)$, and in other cases ersons who claimed under one who was non compos rentis, could set up the disability, the man himself could lot do so. The exception now recognised is where the mbecility of mind was known to the plaintiff. A deed xecuted by a lunatic during a lucid interval will bind him $(c)$. 'he imbecility of mind which the law will require is an ssential privation of the reasoning faculties or an incapacity

fentant, eridence will be admissible the plaintiff's conduct upon various casions, both before and atter the date the particular transaction, with a ew to showing that the plaintiff's alady was of such a kind as would ake itself apparent to the defendant the time when the parties were aling together : Beavan v. $\boldsymbol{I} \boldsymbol{I}^{\prime}$ Donnell, 1 Exch. 184.

(y) (1892) 1 Q. B. 599.

(z) Per Lord Esher, M. R., at p. 601. (a) Per Fry, L. J., at p. 602.

(b) As to aroidance of act by the Crown on inquisition found, see Pope, Lunacy Law, 2nd ed., p. 248 .

(c) Shelf. Lunatics, 2nd ed., p. 340 : "All acts done during a lucid interral are to be considered done by a person perfectly capable of contracting, managing, and disposing of his aftairs at that period:" per Sir $W$. Grant, M. R., Hall v. Warren, 9 Ves. 610. 
of understanding and acting with discretion in the ordinary affairs of life. The law cannot undertake to measure the validity of contracts by the greater or less strength of the understanding, and if the party be compos mentis the mere weakness of his mental powers does not incapacitate him. Weakness of understanding may, however, be a material circumstance in establishing an inference of unfair practice or imposition, and it will naturally awaken the attention of a Court of Justice to every unfavourable appearance in the case $(d)$.

The mere existence of a delusion in the mind of a person making a disposition or contract is not suft. cient to avoid it, even though the delusion is connected with the subject-matter of such disposition or contract and it will be a question for the jury whether the delusion did in fact affect such disposition or contract $(e)$ So, too, though a man, albeit capable of transactinc business of a complicated and important kind, may ye be subject to delusions so as to be unfit to make will, still, if the delusions in question are such tha they could not reasonably be supposed to have affecter the dispositions made by his will, the will will br valid $(f)$.

As to how far the lunacy of a principal operates as ? revocation of the authority of the agent, reference shoul be made to the case of Drew v. Nunn $(g)$.

Intoxication -its effect on con. tracts.

Although formerly the intoxication of a contractin party was held to afford no ground for repudiating liabilit upon a contract $(h)$ made by him whilst in that state, th established modern doctrine seems to be, that a person wh

d) Kent, Com., 12th ed., rol. 2, p. 609 ; see per Lord Cranu'orth, C., 6 H. L. Ca. 45.

(c) Jenkins r. Morris, 14 Ch. D. 674. (f) Smee r. Smee, 5 P. D. 84;
Bank's r. Goodfellour, L. R. 5 Q. B. 54 ! (g) 4 Q. B. D. 689 ; ante, p. 696. (h) Beierley's ease, 4 Rep. 125 : per Parke, B., 13 JI. \& W. 626; C Litt. 247 a. 
has contracted, even by deed (i), whilst so wilfully intoxicated as to be deprived of his reason-as not to know the consequences of his act-may successfully dispute his liability in respect of such transaction, particularly if the other contracting party was aware of the condition of the party so incapacitated $(k)$.

The contract of a man too drunk to know what heis about is roidable only, not void, and is therefore capable of being ratified by him when he becomes sober $(l)$, and if so ratified will bind him to perform it. And it seems clear, that a tradesman who supplies a drunken man with necessaries may recover the orice of them, if the party keeps them when he becomes sober $(m)$. It will further be remembered, that actual fraud night plainly be evidenced by the conduct of a person aking an obligation from one intoxicated and then known by the contractee to be so (n).

A state of partial intoxication merely-less in degree than hat just indicated-would seem, in the absence of frand and infair'dealing, to afford no defence to an action founded ipon contract $(o)$.

Besides the various grounds of incapacity to contract lready mentioned, some others occasionally present themelves, to which, as being of little practical importance, a rief allusion will suffice. The capacity to contract may in gal contemplation be wholly destroyed by duress $(p)$, Duress.

(2) Per Sir W. Grant, M. R., Cooke Clayworth, 18 Ves. 15, 16; 11 R. R. 17; followed by Sir $E$. Sugden in Nagle Baylor, 3 Dr. \& W. 64, 65 ; Shaw r. hackray, 17 Jur. 1045.

(k) Gore r. Gibson, 13 M. \& W. $: 3$, which "was no doubt rightly cided, but some of the dicta of the Idges cannot be supported in all their Iness since the decision in Molton $\mathrm{v}$. mroux" (ante, p. 701) : per Pollock, , Matthews V. Baxter, L. R. 8 Ex. 4.

(l) Matthews v. Baxter, L. R. 8 Ex.
132.

(m) Per Pollock, C. B., 13 M. \& WT. 625,626 . Cf. s. 2 of the Sale of Goods Act, 1893.

(n) Lery v. Baker, Moo. \& M. 106, n. $(b)$; per Parke, B., 13 M. \& W. 626. Sce Sentance r. Poole, 3 Car. \& P. 1.

(o) See the authorities cited n. (i) supra; per Parke, B., I3 M. \& TV. 624,626 .

(p) For " nil consensui tam contrarium est quam vis atque metus:" D. 50. 17.116. 
which may be of one or other of two linds: duress per minas, i.e., coercion imposed by fear of loss of life or limb, or duress of imprisonment, where a man actually loses his liberty $(q)$. With reference to this latter kind of duress, Blackstone tells us $(r)$, that " the confinement of the person, in any wise, is an imprisonment. So that the keeping. a man against his will in a private house, putting him in the stocks, arresting or forcibly detaining him in the street, is an imprisonment. And the law so much discourages unlawful confinement, that, if a man is under duress of imprisonment or compulsion by an illegal restraint of liberty, and he seals a bond or the like, he may allege this duress and aroid the extorted bond. But if a man be lawfully imprisoned, and, either to procure his discharge or on any other fair account, seals a bond or a deed, this is not by duress of imprisonment, and he is not at liberty to avoid it." There can be no doubt that duress of the person, whether evidenced by threats or by imprisonment will nullify a contract executed under its pressure $(s)$, anc that money paid in pursuance of such contract may br recovered back $(t)$. It may, perhaps, be considered a doubtful whether duress of goods would suffice to avoid : contract $(u)$ - whether if the signature to an agreemen were procured by a threat of detention of a person's goods or of injury to them, the agreement thus signed could $b$ repudiated by the party so coerced. There are America authorities and dicta $(x)$ in support of an affirmative answre

(q) 1 Illa. Com. 131 ; post, Book III.

(20) 1 Bla. Con. 136.

(s) Supra; and see Comming r. Ince, 11 Q. B. 112; Elleick r. Haxkes, 18 Ch. D. 199.

(t) Duke de Cadaral r. Collins, 4 Ad. \& F. 858; cited in Thomas $r$. Brou"n, 1 (2. B. D. 722.

(ii) But in Glymn v. Thomas, 11 Exch. 878,879 , the Court allude to cases as deciding that "where goods are unlawfully detained, or an injurious act is about to be done to them, or if som act which it was the duty of a party do in respect of them be refused t be done unless money be paid, and th moner be paid under protest as th only means of aroiding the immedia injury which would result from th detainer, the injurious act, or th wrongful refusal, the noney so pa: may be recorered back." 613. 
to this question, but in our own Courts the weight of direct authority is somewhat the other way $(y)$.

The following additional grounds of incapacity to contract should also, perhaps, be specified, presenting themselves, 1 , in the case of an alien $(z)$ enemy, who, unless duly authoIncapacity of alien ellemy or outlaw to contract. rised by the Crown $(a)$, is, from considerations of expedience and public policy, deemed incapable of entering into a valid contract $(b) ; 2$, in the case of an outlaw, who, whilst civilly dead, is under certain circumstances $(c)$ incompetent to contract; 3 , in the case of an attainted felon $(d)$. In either of the cases here mentioned, however, the disability flowing from the cause indicated seems to be partial only. It is laid down that an alien enemy or an outlaw may be sued in our courts upon contracts here entered into by him $(e)$.

(y) Skeate r. Beale, 11 Ad. \& E. 383, 990 (with which, howerer, comsare Wakiefield $\mathrm{v}$. Neubon, 6 Q. B. 376, 280. The authorities there cited eem to show, that "moner extorted iy duress of the plaintiff's goods, ind paid by the plaintiff under protest, nay be recorered in an action for noney had and receired "). See also ver Coleridge, J., Ashmole r. Waincright, 2 Q. B. 846. "The distincion appears to be, that although he mere duress of goods will not void a contract, a payment of noney in order to obtain goods imiroperly detained is not a voluntary arment, and is therefore recoverable ack:" 2 Sm. L. C., 9th ed., 452. ;ee also per Parke, B., Parker v. 3ristol and Exeter R. C., 6 Exch. 05 ; Oates x. Hudson, 6 Exch. 346; ireen r. Duekett, 11 Q. B. D. 275.

(z) The general rule is, that an alien i.e., an alien friend) may acquire pernal rights and maintain personal ctions in respect of injuries to them. Le cannot maintain real actions, beuuse he cannot hold land:" Judgm., ocks v. Purday, 5 C. B. 884. An lien friend is now capable of holding al and personal property in all rerects as a British subject, by virtue of re Naturalisation Aet, 1870 (33 Vict. c. 14), sare that he cannot acquire property in a British ship: s. 14.

(a) See Fenton v. Pear'son, 15 East, $419 ; 7 \& 8$ Vict. c. 66 , s. 6 .

(b) Co. Litt. 129 b; Willison v. Pattison, 7 Taunt. 439; Bravidon v. Nesbitt, 6 T. R. 23 ; 3 R. R. 109 ; Bristow v. Towers, Id. 35 ; Brandon v. Curling, 4 East, 410 ; 7 R. R. 592 ; per Lord Ellenborough, C. J., Flindt r. Water's, 15 East, 265, 266; 13 R. R. 457 ; Casseres r. Bell, 8 T. R. 166. See a plea that plaintiff has become an alien enemy since the cause of action accrued: Aleinous v. Aygrin, 4 E. \& B. 217.

As to the validity of a contract with an alien who before its performance becomes an enemy, see Clemontson r. Blessig, 11 Exch. 135, 141, and note to that case : per Martin, B., De Wahl r. Braune, 1 H. \& N. 182; Barricli r. Buba, 2 C. B., N. S., 563, and cases there cited.

(e) Co. Litt. 128 b. See Sowerlyy v. Wadsucorth, 2 II. \& C. 701. Outlawry has been abolished in civil procedure : ante, p. 191.

(d) Bullock r. Dodds, 2 B. \& Ald. 258; 20 R. R. 420.

(e) Loukes r. Holbeach, 4 Bing. 419; 421; Ramsay r. ML'Donald, $1 \mathrm{WW}$. Bl. 30 ; Banyster v. Trussel, Cro. 
Contracts of executors and administrators.

Whilst speaking of the capacity to contract, some remarks must be directed to the peculiar position occupied by an executor or administrator, who under certain circumstances may contract in that character so as to charge or benefit the estate which he administers, entailing thereby no personal liability upon and securing no possibility of advantage to himself-under another state of facts may find that he is individually answerable in respect of a contract made or intended to be made by him in relation solely to the assets of his testator or intestate.

The question-Under what circumstances may a personal representative properly contract in that character? is one of manifest importance, to which, however, justice cannot be done by brief discussion. In regard to it, reference must be made to standard Treatises and to decided cases; of these latter, some only of the more recent or important will here be indicated.

An executor, it will be remembered, derives his interest and title as such from the will itself, of which the probate is merely operative as the authenticated evidence. The property of the deceased vests in the executor from the moment of the testator's death, and to that date the probate is said to have relation $(f)$. An executor, therefore, may in that character validly contract immediately after the death of the testator has occurred.

An administrator, on the other hand, derives title from the letters of administration, such title, however, relating back to the date of the intestate's decease $(g)$. By virtue 0

Eliz. 516 ; Com. Dig. "Abatement" (E. 3) ; Grifith r. Middleton, Cro. Jac. 425 , ad tin.

(f) Judgm., Pemberton v. Chapman, 7 F. \& B. 217, 218 ; Hensloe's case, 9 Rep. 38 a ; Judgm., Cummins v. Cummins, 3 J. \& L. 92, 93 ; Roll. Abr. "Executors" (A.), vol. 1, p. 917, cited Judgm., Easton v. Carter, 5 Exch. 14 ; Wanlford v. Wankford, 1
Salk. 302,$303 ; W_{c} b b$ r. Alkins, 1 . C. B. 401,406 , followed in Tarn v Commercial Banking Co. of Sydury 12 Q. B. D. 294.

"Relation means treating a thing a happening at some preceding time: per Maule, J., Graham v. Furber, 1 C. B. 152 .

(g) See Crossfield v. Such, 8 Exch 825; Mrorgan จ. Thomas, Id. 302 
this doctrine of relation, an administrator, on becoming duly clothed with that character, will sometimes find that he is in legal contemplation constituted party to a contract antecedently made, and is entitled to sue, or liable to be sued, in autre droit thereupon. Thus A., having sent goods. to his agent abroad for sale, died intestate, and after A.'s death the defendant purchased the goods from the agent, who sold them for the benefit of the intestate's estate. Subsequently to the sale, the plaintiff took out letters of administration to the intestate, and then sued the defendants for the price of the goods in question; the action thus brought was held to be maintainable, in conformity with the doctrine of relation above stated, and with the rule of law, that, when one assumes to act as agent for another, a subsequent ratification by that other is tantamount to a orior command $(h)$. So where money belonging to an ntestate at the time of his death, or due to him and paid $n$ after his death, has, before grant of administration, been ipplied by a stranger to the payment of the intestate's debt ind funeral expenses, the administrator may recover it rom such stranger as money had and received to his use is administrator (i).

Without pausing minutely to inquire what rights of ction, vested in the deceased, do or do not pass to his peronal representatives (an inquiry which could not be here rursued in extenso), the general rule is deserving of our rotice, that executors or administrators may be regarded is contracting in that character wherever the damages ecoverable for breach of the particular contract would be vailable to increase or would go to diminish (as the case

er Parke, B., Forston v. Fether, 14 C. \& W. $854 ;$ Bodger v. Arch, 10 ixch. 333 ; Prosser v. Wagner, 1 C. , N. S., 289; Barnett v. Earl of uildford, 11 Exch. 19.

(h) Foster v. Bates, 12 M. \& W.
226; Tharpe r. Stallerood, 5 M. \& Gr. 760 ; Fysan v. Chambers, 9 M. \& W. 460 ; ante, p. 305.

(i) Welchman v. Sturgis, 13 Q. B. 552. See Vaughan r. Mattheus, Id.

187. 
may be) the personal estate of the deceased $(k)$. Where goods are ordered of the deceased in his lifetime, but delivered subsequently to his death $(l)$, the contract to pay. for them may be sued upon as having been made with the personal representatives. Where a passenger on a railway was injured by an accident, and after an interval died in consequence of the injury, his executrix was held entitled to recover from the railway company in an action for breach of contract, the damage to deceased's personal estate arising in his lifetime from medical expenses and loss occasioned by his inability to attend to business ( $m$ ).

The decision just referred to was questioned, although followed as binding, in Leggott v. The Great Northern R. C. (n), where it was held that an action at suit of an administratrix, under Lord Campbell's Act, was brought in a different right from that in which a personal representative generally sues on behalf of the estate of the intestate; so that a judgment with satisfaction having been recovered under the statute, the plaintiff was not estopped from recovering in another action damages for pecuniary loss sustained by the deceased in his lifetime consequential on defendant's negligence.

In a later case the general proposition was laid down that " wherever a breach of contract or a tort has been com. mitted in the lifetime of a testator his executor is entitled

(k) Coucell r. Watts, 6 East, 405; Judgm., Heath r. Chiltom, 12 U. \& Wr. 637 ; Webb v. Coucdell, 14 M. \& IV. 820 ; Grisscll r. Robinson, $3 \mathrm{Bing} . \mathrm{N}$. C. 10; Webster v. Spencer, 3 H. \& Ald. $360 ; 22$ R. R. 427 . An action for breach of promise of marriage will not survive against the personal representative unless there has been special damage, which must be to the property, not to the person, of the promisce, and must hare been in the contemplation of both parties at the tine of making the promise. And even then the action will only lie for the special, not for general, damage: Fimluy v. Chirnay, 20 Q. B. D. 494. Con versely, no action ean be brought by the personal representative of the pronisee : Chamberlain r. Williamon 2 M. \& S. $408 ; 15$ R. R. 295 Preface $v$.

(I) Marshall v. Broadhurst, 1 Cr. \& J. 403, 405, reeoguised per Parke. B., 2 II. \& WT. 191; Werner v. Hum phreys, 2 M. \& Gr. $\$ 53$.

(ii) Bradshaw v. Lancashire and Forkshive R. C., I. R. 10 C. P. 189 followed and approved in Daly $\mathrm{v}$. Dub lin, Wicklore, and Wexford Railuay, 30 I. R. 1r. 514.

(n) 1 Q. B. D. 599. 
to maintain an action, if it is shown upon the face of the proceeding that an injury has accrued to the personal estate" $(o)$.

But in an action brought by the plaintiff, as administratrix of her late husband, for damage caused to the intestate's estate by reason of his having been prevented from following his business by injuries caused by his having been run over at a level crossing by an engine of the defendants, Denman, J., said: "Some of the expressions used by the judges in the case of Tuycross v. Grant ( $p$ ) seem, no doubt, to go to considerable lengths, but those expressions must be construed with reference to the cause of action in that case;" and the Court, while expressly distinguishing the case of Bradshaw v. Lancashive and Yorkshire R. C. $(q)$, on the ground that the action there was based on contract, held that the action before them, being founded on tort, was barred by the maxim "Actio bersonalis moritur cum person $\hat{\imath} "(r)$.

If a party contract for himself and his executors to build 3 house, and die before it is completed, the executors must proceed with the work, at the risk of being held responsible, quà executors $(s)$ for breach of contract $(t)$, and if they thus oroceed, the work and labour will be done by them as executors, they may recover for it as executors, and the lamages so recovered will be assets in their hands $(u)$. If,

(o) Per Brett, L. J., Tityeross v. Grant, 4 C. P. D. 46, distinguishing Peek v. Gurney, L. R. 6 H. L. 377, 392, 393.

(p) Ubi supra.

(q) L. R. 10 C. P. 189.

(r) Pulling v. Great Eastern R. C., Q. B. D. 110. See Phillips r. Homiray, 24 Ch. D. 439.

(8) As to the joinder of claims by or gainst personal representatives, ante, 123.

(t) Quiek v. Ludborrow, 3 Bulst. 30, ecognised 1 M. \& W..423; per Lord 1binger, C. B., Corner ₹. Shew, 3 if. \& W. 353, 354; Wentuorth v. rock, 10 Ad. \& E. 42 ; Aspinall v. Take, 10 Bing. 51.
But it would seem that "all contracts for personal services which can be performed only during the lifetime of the party contracting are subject to the implied condition, that he shall be alive to perform them; and should he die, his executor is not liable to an action for the breach of contract occasioned by his death:" per Pollock, C. B., Hall v. Wright, E. B. \& E. 793, 794. Et ride Judgn., Taylor $v$ Calduell, 3 B. \& S. 835.

(u) Per Cur., Marshall r. Broadhurst, 1 Cr. \& J. 405 ; Eduards v. Grace, 2 II. \& W. 190 : per Lord Abinger, C. B., Siboni v. Kirkman, 1 M. \& W. 422. See Crosthuate v. Garduer, 18 Q. B. 640. 
however, money be lent to or had and received by an executor or administrator $(x)$, or if rork and labour be performed for, or goods be sold and delivered to him (y), the personal representative will be held to have contracted in his individual character, and will be personally liable. So if B. (an executor) request A. to forbear suing him in respect of a debt due from the testator, and promise to pay interest thereupon, such promise will evidence a personal contract with B. To make him liable for interest as cxecutor, a contract must be shown by the testator to pay interest so long as the debt should be forborne $(z)$.

A. contracted with the plaintiff that plaintiff should endeavour to sell a picture belonging to A., and that, if he succeeded in doing so, A. should pay him 100l. The plaintiff, in pursuance of this agreement, endeavoured to sell the picture, and after A.'s death actually disposed of it, which sale was (as alleged in the declaration) confirmed by the defendant, his administratrix. From this latter party, accordingly, the plaintiff claimed the 100l. as due to him, by virtue of the agreement just mentioned. It was held, however, that the defendant would not, by merely confirming the sale, render herself liable on the original contract, the authority conferred by which on the plaintiff was determined by the death of A., although, if on the happening of that event the administratrix had ordered the sale, that would clearly have evidenced a fresh employment by her of the plaintiff, and have rendered her liable to remunerate him for his services in effecting it $(a)$. The true nature, then, of the particular contract in respect

(x) Ashby r. Ashby, 7 B. \& C. 444 ; Waite r. Gale, 2 D. N. I. 925.

See Blakeslcy r. Smallicood, 8 Q. B. 53s: Mardall $r$. Thellusson, is Q. 13. 857; Watts v. Ries, 9 Exch. 696; Chuchill v. Bertrand, 3 Q. IB. 568.

(y) Cormer r. Sherc, 3 M. \& W.
350 ; Kitchenman r. Skeel, 3 Exch. 49. See Prior r. Hembrow, 8 M. S. W. 873.

(z) Bignell v. Harpur, 4 Esch. 773, 775 ; Childs $\mathbf{}$. Monins, 2 B. \& B. 460.

(a) Campanari r. Woodburn, 15 C. B. $400 ; 23$ R. R. 513 . 
whereof it is sought to charge a personal representative in that character, must, before suing upon it, be carefully and critically examined $(b)$. And it must be remembered that a mere authority is determined by death, whereas death does not in general operate to revoke or dissolve a contract $(c)$, unless for personal service $(d)$.

In cases such as specified-where one of the contracting parties is invested with a twofold character, his private and his representative-the effect on his capacity to contract thence resulting is not so marked or so easily traceable, as in some of the other instances previously adverted to. That in effect is produced thereby must, however, be admitted, ind is not the less true because in some cases it may be a jure question of fact-and, therefore, for the jury-In what haracter did executors or administrators really contract $(e)$ ? With reference to that part of the subject immediately pefore us, I will merely add, that the power of an executor reing founded upon the special confidence and actual ppointment of the deceased, the executor is therefore .llowed to transmit such power to another in whom he has qual confidence. Consequently, the executor of A.'s exeutor, if the latter has proved the will $(f)$, is to all intents nd purposes the executor and representative of A. himself, nd may accordingly, in like manner as the executor origially appointed, contract for the benefit of A.'s estate $(g)$.

(b) We have seen (ante, p. 377), that, torder to charge an executor or adinistrator upon any special promise - answer damages out of his own tate, the agreement on which such :tion shall be brought or some memoudum or note thereof shall be in riting, and signed by the party to be larged, or some other person thereito by him lawfully authorised.

0 wing to the community of interest bsisting between executors or admistrators, they are precluded from conucting with each other in such chacter: Moffatt v. Fan Millengen, 2
B. \& P. 124 , n.; 5 R. R. $55 \%(c)$; recognised in Fitzgerald v. Boehm, 6 Moore, 332 ; art. Raclinson v. Shau, 3 T. R. $558 ; 1$ R. R. 768.

(c) Bradbury v. Morgan, I H. \& C. $249,256,25 \pi$. 744 .

(d) Farrow v. Milson, I. R. 4 C. P.

(e) Heath v. Chillon, 12 M. \& W. 632; Brassington v. Ault, 2 Bing. 177; Turner v. Hardey, 9 M. \& W. 770.

(f) Hayton v. Wolfe, Cro. Jac. 614; Wanlford v. Wankford, 1 Salk. 308, 309.

(g) $25 \mathrm{Edw} .3$ st. 5 , c. 5. 
The executor of A.'s administrator, or the administrator of A.'s executor, is not, however, the representative of A.; for an administrator is merely the officer of the ordinary, prescribed to him by Act of Parliament $(h)$, in whom the deceased has reposed no trust at all (i). Hence it is, that on the death of A.'s administrator, or of A.'s executor, if intestate, or whenever the course of representation from executor to executor is interrupted by any one administration, it is necessary that an administrator de bonis non should be appointed, who will thereupon become, in law, the sole personal representative of $A$., and will alone be entitled to contract in respect of his personal estate $(k)$.

The remarks made in the preceding pages have been meant as suggestive only in regard to the effects produced on the capacity to contract by various ordinary mercantile re. lations, or by the incidents attaching to certain persons nonmercantile. A brief résumé of the principal subjects touched

Résunué of matters treated of in this Chapter. upon in the foregoing Chapter may assist perhaps towards rendering distinct the results at which we have arrived. and may show the general bearing of what has beer now said upon the point which we have intended to eluci. date.

In the first place, then, it will have been noticed that the relation of principal and agent rarely so operates in practice as to render wholly nugatory a contract apparently binding on some party. Where this relation exists, the question usually is as to the liability of the principal for the ac of a professing agent, or as to the liability of the agen

(h) $31 \mathrm{Edw} .3$ st. 1, c. 11.

(i) 2 Bla. Com. 506.

(k) Id.; Elliott r. Kemp, 7 M. \& W. 306 ; Venables v. Enst India Co., 2 Exch. 633.

A person who deals with the goods of a testator as agent of the executor cannot be treated as executor de son! tort: Sykes v. Sykes, L. R. i C. I 113.

For is the executor of an executri de son tort liable for a breach of $\operatorname{con}$ tract committed by the person wit whose property the executrix do 50 tort has intermeddled: Wilsen Hodson, L. R. 7 Ex. St. 
himself, that of the principal being admitted, such question, of course, requiring for its solution a reference to those doctrines of the law of agency which may seem applicable to the given case.

Where the relation of partnership exists between indiviIuals, they are, as between themselves, in many cases wholly ncapacitated from contracting at law by reason of the unity ind identity of interest (partners being joint tenants) which ;ubsists between them. In regard to third persons, howsver, the relation of partnership may introduce a question such as this-whether on a given state of facts the firm is oound or the individual partner who contracted, no doubt ir difficulty arising as to the capacity to contract.

On inquiring into the attributes of a corporation at :ommon law, we are at once struck by the fact, that it can n general contract only under its common seal, exceptions o this rule sometimes occurring, where the subject-matter If a contract is necessary and incidental to the purposes for inich the corporation was created, or sometimes where it las been adopted and acted upon by the corporation, or inere it falls within the words of the statute, charter, or etters patent, by virtue of which the body corporate was onstituted.

It might readily be surmised that the transfer of proerty effected by bankruptcy would have some material afluence upon the bankrupt's eapacity to contract. And, ecordingly, the power to contract concerning the property f one who has been adjudicated bankrupt will in general e found to be vested in his trustee. And, further, in some $3 w$ cases his contracts duly authenticated and primâ facie alid are rendered void in toto by the express words of the egislature.

Amongst disabilities attaching to persons non-mercantile, le effect of infancy on the capacity to contract has first zen noticed. I have shown that it is essential to dis- 
tinguish between contracts prejudicial to the infant, which are deemed absolutely void, and contracts not necessarily or presumably prejudicial to him, which are voidable. except for necessaries. We have stated also what is the true legal meaning of this term " necessaries."

The position of a married woman as regards contract has next been discussed, and the alterations effected therein by recent statutory provisions carefully indicated; the general result being that the capacity of the wife to enter into, and to become liable upon contract, is, as far as regards her separate property, no longer interfered with by coverture, though the husband may still become liable upon his wife's contract in accordance with the principles of the law of agency.

The effect of mental imbecility upon the contract of one labouring under it has, further, been examined. As already stated, a contract entered into with a person who is non compos mentis, whether it be executory or executed, cannot be avoided by the imbecile unless it can be shown that such condition of mind was known to the contracting party of sound mind. A contract, however, for things necessary for his subsistence, or suited to the station of life in which he moves, cannot be avoided by the imbecile, for the law raises an implied obligation (which is now a statutory one) to pay fer-the same.

Lastly, we have seen that when an individual clothed with a representative character enters into a contract, although doubt may often be felt respecting the character in which he contracted, his capacity to contract will not in general come in question. 


\section{CHAPTER VIII.}

THE JEASURE OF DAMAGES-IN ACTIONS OF CONTRACT $(a)$.

If a contract be submitted to the notice of a pleader, ith a view to bringing an action for breach of it, he will, i the first instance, inquire whether such contract is valid $\mathrm{y}$ applying to it tests indicated in the preceding pages; aould he satisfy himself on this point, and conceive that a ght of action in truth exists and is enforceable, he may ill, on behalf of his client, deem it expedient to inquire hat will probably, in the event of success, be the amount if compensation to be awarded by the jury. Will it be ibstantial or nominal only? Is it, in short, worth while ir the complainant (regard being had to all the facts subitted) to incur the anxiety of litigation, to risk the chance defeat, with the penalty consequent thereupon in the rape of costs (b), whilst in pursuit of a favourable verdict id the damages which are to crown it? This is a question much importance, a partial solution of which will be tempted in the present Chapter.

The term "damages" will here be used to signify a suniary compensation for breach of contract, recoverable

(a) In connection with this Chapter onld be read the corresponding rtion of the next Book, entitled The Measure of Damages - in tions of Tort."

An attempt has above been made exhibit the rules applicable in linary cases only for the assessment damages. (b) " Costs as between party and party are given by the law as an indemnity to the person entitled to them; they are not imposed as a punishment on the party who pays them, nor given as a bonus to the party who receives them : "per Bram. well, B., Harold v. Simith, 5 H. \& $\mathrm{N}$. 385. See R. S. C. 1883, Order lxr. 
by action, damages being of three kinds:-1st. Nominal damages, which occur in cases where the Judge is bound to tell the jury only to give such, as, for instance, wherethe seller brings an action for the non-acceptance of goods the price of which has risen since the contract was made; 2ndly. General damages, the nature of which is stated by Cressuell, J., in Rolin v. Stevard (c). They are such as the jury may gire where the Judge cannot point out any measure by which they are to be assessed, except the opinion and judgment of a reasonable man. 3rdly. Special damages, which are given in respect of any consequences "reasonably or probably" arising from the breach of contract complained of $(d)$.

The expression "measure of damages" will be used as synonymous with the 'scale' or 'rule' by reference to which damages are in any given case to be assessed; for although, on an ordinary trial at Nisi Prius, the act of finding the damages is for the jury, there are, nevertheless, certain established and recognised rules according to which, under particular circumstances, the jury ought to find $(e)$.

In the first place, it ordinarily holds true, that, in an action for breach of contract, the intention or motive of the party charged cannot be inquired into, and indeed will be irrelevant to the issue raised. In such an action the main questions for determination will be, What was the contract? Was it broken by the defendant? If the terms of the contract be ascertained, and its breach be proved, the only other inquiry will be as to the amount of damages to be arcarded; and, in estimating these damages, the motive or intention of the defendant will be immaterial. The good of society requires that contracts mutually assented to

(c) 14 C. 13. 605.

(ii) Per Bustin, B., Prelun r. Royal Bank of Literpool, 1. R. 5 Ex. 99,
100.

(e) Per Pollock, C. B., Alder r keighley, 15 M. \& W. 120. 
should be inviolably observed and strictly executed $(f)$. if a man expressly covenants or on proper consideration oromises to do an act which he would not otherwise be pound by law to perform, he, by his own deliberate act, mposes on himself a responsibility from which, it would eem, he cannot, in the absence of an implied stipulation o that effect $(g)$, as where the intervention of the act of yod must be taken to have been contemplated by the arties $(h)$, be relieved unless by the consent of the conractee, or by act of the legislature $(i)$, or of the Crown $(k)$; nd, should he commit a breach of his covenant or promise, he is compellable to make compensation in damages to the ontractor $(l)$. Our law makes a broad distinction, in egard to the proper measure of compensation to be warded to a plaintiff, between actions of contract and ctions of tort; and while it permits the jury in the latter ase to take into consideration the intention of the offendag party, to review all the circumstances of the case, and 0 apportion the damages accordingly, thus to some extent ausing the verdict to operate as a medium for punishment $s$ well as compensation $(m)$, yet, in actions of contract, the rotive or animus of the defendant is, in general, entirely isregarded, and the damages should be limited to the ecuniary loss resulting not too remotely $(n)$ from the breach f contract. Such is the rule applicable in most actions f contract, though sometimes-ex. gr., in an action for

(f) Platt on Corenants, pp. 25, ;.

(g) See Hall v. Wright, E. B. \& E. :6; Taylor v. Calduell, 3 B. \& S. :6; Appleby r. Myers, L. R. 2 C. .651 ; Ford r. Cotesworth, L. R. 5 B. 544,548 ; followed in Ckinning$m$ r. Dumn, 3 C. P. D. 443; Boast Firth, L. R. 4 C. P. 1.

(h) Boast r. Firth, supra.

(i) "I apprehend that nothing can ader void a valid contract except an st of Parliament: " per Martin, B., H. \& N. 182. See Walsh v. Secre. tary of State for India, 10 H. L. Ca. 367.

(k) For instance, a declaration of war by this country against a foreign power imports a prohibition of commercial intercourse with the subjects of that power: Barrich v. Buba, 2 C. I., N. S., 563, and cases there cited.

(l) Platt on Covenants, pp. 25, 26. See Howard r. Loregrore, L. R. 6 Ex. 43,45 ; Jones v. St. John's Coll., L. R. 6 Q. B. 115 .
(m) Post, Book III., Chap. 5.
(n) Post, p, 734. 
breach of promise of marriage (o) - a jury will assume to themselves a wide latitude and discretion, will assume, in some sort, to punish the defendant, as well as to compensate the plaintiff.

It follows, from what has been above said, that, for a bare breach of contract or of duty, nominal damages $(p)$, at all events, will be recoverable $(q)$; and further, that where an agreement, good in law, stipulates for the payment on a day named of a specific and ascertained sum by one of the parties to it, the primi facie measure of damages will be the precise sum thus stipulated to be paid ( $r$ ), together with interest when recoverable $(s)$. Where, in other words, an action is brought for the recovery of a fixed pecuniary demand founded upon contract, and the plaintiff's claim is unreduced by any set-off or counterclaim, or by proof of a partial failure of consideration, the measure of damages, as determined by the act of the parties, will be that sum which the defendant has under-

(o) See, for instance, Smith $r$. Troodfine, 1 C. B., X. S., 660 : Derry v. Da Costa, I. R. 1 C. P. 331, 333, approved in Millington r. Loring, 6 Q. B. D. 195.

(p) See West v. Honghton, 4 C. P. D. 197 (as to which case see per James and Lush, L.JJ., Lloyd's r. Harper, 50 L. J. Ch. 140); Hcy r. Wyche, 2 G. \& D. 569 ; Broune r. I'rice, 4 C. B., N. S., 598; Rolin r. Stercard, 14 C. B. 595; Nichol r. Besterick, 28 L. J. Ex. 4; Matthen's v. Discount Corp., I. R. 4 C. P. 228.

(q) King v. Norman, 4 C. 13. 884 ; Marzetti v. Williams, 1 B. \& Ad. 41 , 424 (cited Boorman r. Brou'n, 3 Q. B. 526 ; S. C., 11 Cl. \& F. 1 ; and Bell v. Carey, 8 C. 13. 893); Cahill r. Datcson, 3 C. B., N. S., 106 ; National Assur. Ass. v. Best, 2 H. \& N. 605 ; Stecr $\mathrm{Y}$. Crouley, 14 C. B., N. S., 337.

Where a rendor corenants that he has good right to convey, immediately on the execution of the conreyance, if he has not such right, his corenant is broken, and an action mar instantly be commenced by the coreuantee, without waiting for a disturbauce of his possession ; for an eriction does not constitute the breach of the corenant in question, but is consequential damage arising therefrom : Platt on Covenants, p. 311 ; per Sir J. Mansficld, C. J., Ling $\mathrm{v}$. Jones, 5 Taunt. 426 ; 15 R. R. 533.

(r) To the class of cases here indi. cated, the remark of Lord Mansfield in Robinson $v$. Bland, 2 Burr. 10\%, 1086 , applies, - that where an action is brought for the breach of a contract for the payment of moncy only the suit, although nominally for damages, does, from the very nature of the case, become a suit for specitic performance.

(s) "No matter what the amount of inconvenience sustained br the plaintift in the case of non-payment of moncy, the measure of damages is the inters of the money only:" per Willes, J., 17 C. B. 29. 
jaken or contracted to pay $(t)$. Thus, in Lethbridge v. Iytton (u), the defendant, by settlement made upon lis narriage, conveyed estates upon certain trusts, and covesanted with the trustees to pay off incumbrances upon the istates so conveyed to the amount of $19,000 l$. within a year. it was held, that, upon the defendant's default in paying iff these incumbrances, the trustees were entitled to recover gainst him the whole $19,000 l$. in an action of covenant, lthough no special damage was laid or proved. In this ase, however, execution was ordered not to issue until a uture day named by the Court; and Lord Tenterden intiaated, that the defendant might in the interim, if he hought fit, make application to a Court of Equity, where we matter could be better and more satisfactorily arranged aan at law.

In any case similar to the preceding, and generally in n action for the non-payment of a liquidated sum, the leasure of damages will be the sum agreed to be paid by le defendant to the plaintiff. If the precise sum due and ayable to the plaintiff is not ascertained by the contract, will be for the jury to say how much has been proved to 3 due to the plaintiff at the time of bringing the action $(x)$. nd, in either of these cases, interest will or will not be coverable according to the nature of the demand, and e manner in which it arose $(y)$.

If, it has been judicially observed $(z)$, a man pays a sum money as the consideration for something to be done, id nothing whatever is done, so that in technical language e consideration wholly fails, as a general rule, he may cover back the money he has paid as a debt, or he may

t) See, for instance, Taylor v. Chister, \&c., R. C., 4 H. \& C. 402.

u) 2 B. \& Ad. 772; Loosemore v. tford, 9 M. \& W. 657; Hodgson v. od, 2 H. \& C. 649 ; Re Arthur, Ch. D. 603 .

r) See Walker v. Broadhurst, 8 B.C.L.
Exch. 889.

(y) The cases in which interest is recoverable :are specified at the end of this Chapter. See Weeks r. Propert, L. R. 8 C. P. 427 .

(z) Per Martin, B., Brady v. Oastler, 3 H. \& C. 121, 122 . 
at his option bring a special action upon the contract an recover back the money, and also damages for the breach.

And again, "A party who has been induced by fraudu lent misrepresentation to purchase a given article, unles he rescinds the contract and returns the thing bought, . . can only recover damages to the extent of the loss he ha actually sustained. He cannot recover the entire price $h$ has paid, unless the thing prove wholly worthless. If th thing has any appreciable value, the damages must b reduced pro tanto " (a).

The foregoing are simple illustrations of the mode measuring the damages, and equally simple is the rule tha in an action for a sum certain or capable of being reduced a certainty, the damages recoverable for detention of th debt are, at common law, merely nominal $(b)$, and th amount to be awarded to the plaintiff will, due regard bein of course had to the evidence adduced, be purely matter calculation. Sometimes, moreover, the law itself defin the mode of computing the amount recoverable in an actio: as, for instance, where the plaintiff sues his co-contractors $f$ contribution $(c)$, or where the claim is for general average (d

Hence it has been said (c), that, " in contract, the measu of damages is generally matter of account, and the damag given may be demonstrated to be right or wrong," $t$. rule most frequently applicable being, that "the amou which would have been received if the contract had be kept is the measure of damages if it be broken" $(f)$.

(a) Per Cockburn, C. J., Tuycross v. Grant, 2 C. P. D. 543.

(b) Nosotti r. Page, 10 C. B. 643 ; Loure v. Stecle, 15 M. \& W. 380 ; Gell v. Burgess, 7 C. B. 16.

(c) Batard v. Haues, 2 E. \& B. 287 ; Boulter v. Peplou, 9 C. B. 493, 508 ; ante, p. 307.

(d) See Hallett v. Wigram, 9 C. B. 580 ; Atkinson $\mathrm{r}$. Stephens, 7 Exch. 567.

(e) Per De Grey, C. J., Sharpe v.
Bricc, 2 W. Bla. 942; cited a Williams r. Currie, I C. B. 845 .

(f) As to the mode of comput the damages in an action for freig. see per Maule, J., Cockburn r. Alexd. der, 6 C. B. 814,815 , -in an action breach of charter-party, see Joncs. Adamson, 1 Ex. D. 60; Dimech. Corlett, 12 Moo. P. C. C. 199 (w) also are discussed the rules of const. tion applicable to mercantile contrad; distinguished in Behn r. Burnes 
take a simple instance of this :-A. being indebted to B. in the sum of 500l. for goods sold, gave B. a bill for $600 l$. drawn by himself (A.) to get discounted, upon these erms:- that B. should retain to his own use the sum of 100l. and the discount, and should pay over the balance to 1. Here the measure of damages in an action by A.'s เssignees against $\mathrm{B}$. was held to be the amount of the bill ninus the $100 l$. and discount $(g)$.

The last-mentioned rule flows directly from the fundanental principle on which damages are awarded by our law, $i z$, that compensation may thus be made to the party tho complains of breach of contract; sufficient examples of he practical working of this elementary doctrine will almost nmediately present themselves.

Again, in written contracts, whether special or simple, not unfrequently happens that the parties themselves Penaltyliquidated damages

ssume to define the precise amount of liability which shall 3 incurred for breach of contract. If so, and if it appears lat the amount thus specified is really intended $(h)$ as puidated (or ascertained) damages, the jury will be relieved om any inquiry touching the amount of compensation to awarded to the plaintiff; but will, under the direction of e Judge, find the precise sum agreed upon and stipulated be paid by the parties.

Where, however, parties agree and sufficiently indicate eir intention that a specific sum shall be payable by way

\& S. 751, 760,761; Stanton v. Rich'son, L. R. 7 C.P. 421, 436 ; S. C., emed, L. R. 9 C. P. 890 ; Featherv. Wilkinson, L. R. 8 Ex. 122 ; wart v. Rogerson, L. R. 6 C. P. ,-in an action upon a policy of ine insurance, Cator $\%$ Great stern Ins. Co. of New York, L. R. - $P .552,-$ in an action against the ter of a ship for not taking reason: care of the goods intrusted to him, fara . Henderson, L. R. 7 Q. B.

1) Alder v. Keighley, 15 M. \& W.
117 ; cited per Crouder, J., 17 C. B. 28. See Deverill v. Purnell, L. R. 8 C. P. 475 .

(h) "The cases upon the subject of penalty or liquidated damages are very numerous. The result of them seems to be this, that what the Courts look at is the real intention of the parties as it is to be gathered from the language they have used:" per Keating, J., Lea v. Whitaker, L. R. 8 C. P. 73, and in Magee v. Lavell, L. R. 9 C. P. 115. 
of penalty for breach of contract, our Common Law Court avail themselves of the $8 \& 9$ Will. 3, c. 11, s. 8, and appl: equitable principles in the assessment of damages; not indeed, allowing them to exceed the sum thus stipulated but requiring evidence to be given for the purpose of fixin their precise amount, and enabling the jury to award $j$ accordingly (i).

The distinction, sometimes difficult to appreciate, whic. exists betreen a penalty $(k)$ and liquidated damages, may $\mathrm{b}$ illustrated by the case of Kemble v. Farren (l). That wa an action for the breach of an engagement by the defer dant to perform as an actor at the plaintiff's theatre durin several consecutive seasons. This agreement containe various clauses and stipulations between the parties, inte alia, that the defendant should perform, that the plainti should pay him so much on every night that the theats should be open for theatrical performances during the tir in question, and that if either of the parties should negle or refuse to fulfil the said agreement or any part therec or any stipulation therein contained, such party should $\mathrm{p} \varepsilon$ to the other the sum of $1,000 l$., which sum was declared be liquidated and ascertained damages, and not a penalt or in the nature thereof. Notwithstanding, however, th expression of the intention of the parties, the Court Common Pleas held that the amount specified was be regarded as a penalty merely, and not as liquidat damages $(m)$; for they observed that if an agreeme:

(i) See per Bramicell, B., Betts v. Burch, 4 H. \& N. 510 ; per Erle, J., Reynolds r. Bridge, 6 E. \& B. 5 $\$ 3$, 544 ; per Iord Cranterth, C., Ranger v. Great Westerm R. Co., 5 II. L. Ca. 94.

(k) "I understand a penalty to be something which a debtor is to pay, orer and above his original liability, as a punishment:" per Lush, L. J., kx parte Burden, re Teil, $16 \mathrm{Cb}$. D.
675, 680. See Protector Loan Co. Grice, 5 Q. B. D. 592.

(l) 6 Bing. 141, distinguished ? Lord Westbury, Thompson r. Hud, I. R. 4 H. L. 30 ; Horner v. Flin: 9 II. \& W. 67s; per Bayley, Davies v. Penton, 6 B. \& C. 2 Edcards .. Williams, 5 Taunt. 2 Beckham r. Drake, 2 H. L. Ca. : 598,614 .

(m) Et ride Reindel v. Schel t 
zontains clauses, some sounding in uncertain damages and thers relating to certain pecuniary payments, as happened n the case sub judice, and the action is brought for the reach of a clause of an uncertain nature, it would be lbsurd to construe the sum specified in the agreement as iquidated damages, because, if so, a very large sum might recome immediately payable in consequence of the nonayment of a very small one, such case being precisely that n which Courts of Equity have always relieved, and gainst which Courts of Law have, in modern times, endeaoured to relieve, by directing juries to assess the real amages sustained by the breach of contract.

The principle above laid down must, however, be very autiously applied, and can be safely relied on only where se terms of the agreement in question are similar in kind s those which came before the Court in Kemble v. Farren; us where the defendant had contracted not to practise as perfumer within a certain district, and for the observace of this contract bound himself to the plaintiff in the Im of 5,000l., "as and by way of liquidated damages, and ot of penalty," the case last cited was held inapplicable $(n)$, $a$ the ground that although where a deed contains several ipulations of various degrees of importance, as to some which the damages might be considered liquidated, hilst for others they might be deemed unliquidated, and sum of money is made payable upon a breach of any of em, the Courts have held it to be a penalty only, and not luidated damages, yet, where the damage is altogether Icertain, and a definite sum of money is, nevertheless,

B., N.S., 97 ; per Keating, J., Lea Whitaker, L. R. 8 C. P. 74; gee v. Lacell, L. R. 9 C. P. 107,

n) Price v. Green, 16 M. \& W. 3; S. C., 13 Id. 695; Rawlinson Clarke, 14 M. \& W. 187 ; S. C., Id. 292 ; Hinton v. Sparkes, L. R.
3 C. P. 161; Athyns v. Kinnier, 4 Exch. 776 ; Hurst v. Hurst, Id. 571; cited per Brameell, B., Leigh v. Lillic, 30 L. J. Ex. 25, 28, 29 ; Galsuorthy v. Strutt, 1 Exch. 6.59; cited Betts v. Burch, 4 H. \& N. 511 ; Leighton r. Wales, 3 M. \& W. 54. And see Beckham v. Drake, ante, note $(l)$. 
expressly made payable in respect of it by way of liquidated damages, those words must be read in their ordinary sense, and cannot be construed to import a penalty $(o)$.

The whole question as to the distinction between penalties and liquidated damages has been since dealt with by the Court of Appeal in the case of Wallis v. Smith $(p)$, where the former decisions are reviewed and commented on. Jessel, M. R., in delivering judgment, divides the cases into four classes.

1. Where a sum of money is stated to be payable either by way of liquidated damages, or by way of penalty for breach of stipulations, all or some of which are, or one of which is, for the payment of a sum of money of less amount, that is really a penalty, and only the actual damage can be recovered. The Court will not in such cases sever the stipulations, and if any one of them is for the payment of a sum of money of less amount, the proviso will be bad $(q)$.

2. Where the amount of damages is not ascertainable per se, but where the amount of damages for a breach of one or more of the stipulations either must, or in all human probability will be small, so that the Court can assume it to be small, in this case there is no express decision whether or not the same rule applies as in the first case, though there are licta on both sides. It probably will do so where some of the covenants are of such a character that obviously the damage which can possibly arise from a breach in any way of that covenant would be very insignificant compared witl the sum which has been fixed by the parties $(v)$.

(o) Per Alderson, B., 13 M. \& W. 701, 702 ; and in Atkyns r. Kimnier, 4 Exch. 784 ; per Parke, B., Id. 783; per Coleridge, J., Reynolds r. Bridye, 6 E. \& B. 541 (which follows Atkyns v. Kinnier, supra); Mercer v. Inving, E. 13. \& E. 563 ; Sparrow r. I'aris, 7 II. \& N. 594 ; Cames r. Nesbitt,
Id. 158, 778; Catton v. Benuelt, 5 L. T. 70 .

(p) 21 Ch. D. 243.

(q) Ib. p. 256. See Elphinstone r Monkland, \&e., Co., 11 App. Cas. 332

(v) Ib. p. 257, per Cotton, L. J., a p. $2 \% 0$. 
3. Where the damages for the breach of each stipulation are unascertainable or not readily ascertainable, but the stipulations may be of greater or less importance or of equal importance, there, though there are dicta to the contrary, the rule to be collected from the decisions is, that though the stipulations vary in importance, the sum is not treated as a penalty, but as liquidated damages $(s)$.

4. Where a deposit is to be forfeited for the breach of a number of stipulations some of which may be trifling, some of which may be for the payment of money on a given day, laere too the sum will be treated, not as a penalty, but as iquidated damages $(t)$. "One rule which appears to be ecognised in the cases as a canon of construction with egard to agreements of this kind is that where the parties io a contract have agreed that, in case of one of the parties loing or omitting to do some one thing, he shall pay a pecific sum to the other as damages, as a general rule such um is to be regarded by the Court as liquidated damages, nd not a penalty" $(u)$. An exception to such rule is where larger sum is to be payable upon the non-payment of a maller one. A further exception is suggested (loc. cit.) vhere the sum agreed to be paid is so large with respect to he matter in respect of which it is to become payable, $s$ to render the contention that it should be regarded as iquidated damages absurd.

Where the contracting parties have not by mutual stipuations precisely indicated the amount of damages to be ecoverable by either in the event of a breach of contract, uch damages will have to be assessed according to the eneral rules of law:- " that where a person makes a ontract and breaks it he must pay the whole damage susined" $(x)$; " that where a party sustains a loss by reason

(s) Ib., p. 258.

(t) Ib.

(u) Law v. Local Board of Redditch,
(1892) 1 Q. B. 127 (C. A.), at p. 130.

$(x)$ Per Alderson, B., Robinson v.

Harman, 1 Exch. 85\%, 856. 
of a breach of contract he is, so far as money can do it, tc be placed in the same situation with respect to damages as if the contract had been performed" $(y)$.

The rules just stated admit of simple illustration. Thus A., having recovered a judgment for 281 . $3 s$. 6d. against B., agreed with C. to forbear to sue out execution upon the judgment until a future day, in consideration whereof $\mathrm{C}$ : undertook that he would on or before that day erect a sub. stantial dwelling-house, and cause a lease of the same to be granted to A., such lease when granted to be in satisfaction of the judgment. In an action by $A$. against $C$. for breach of this undertaking, the measure of damages was held to be the value of that (viz., the lease of the house in question) which the defendant had promised to give in consideration of the plaintiff's forbearance $(z)$.

The following classes of cases concerning contracts for the sale or demise of real property, contracts of hiring and service, \&c., may properly be noticed in connection with the rules for determining the measure of damages.

In an action for breach of a contract to replace stocl shares, \&c. lent, the measure of damages is the price of the stock on the day when it ought to have been replaced, or it price on the day of the trial, at the plaintiff's option (a) "The true measure of damages" in all these cases "is that which will completely indemnify the plaintiff for thi breach of the engagement. If the defendant neglect $t$ replace the stock at the day appointed, and the stock after wards rise in value, the plaintiff can only be indemnifie by giving him the price of it at the time of the trial. Ant

(y) Per Farke, B., Id. 855. See Williams r. Earle, L. R. 3 Q. B. 739 .

(z) Strutt v. Farlar, 16 M. \& W. 249 ; and see Alder v. Keighley, 15 II. \& W. 117 ; Hill r. Smith, 12 II. \& W. 618: Cort v. Ambergate, fe., R. C., 17 Q. B. 127 ; Petve v. Dun- combe, 20 L. J. Q. B. 242 , followed i Re For, Ex parte Bishop, 15 Ch. D.421

(a) Shepherd v. Johwson, 2 Eas $211 ;$ Mr Arthur v. Lord Seaforth, Taunt. 257; 11 R. R. 559; Iotenes Back, 1 Stark. N. P. C. $318 ; 18$ R. I 7\%2; Harrison v. Harrison, 1 C. \& I 412. 
it is no answer to say that the defendant may be prejudiced by the plaintiff's delaying to bring his action, for it is his own fault that he does not perform his engagement at the time; or he may replace it at any time afterwards, so as to avail himself of a rising market" $(b)$. So in an action for not re-delivering mining shares, lent to the defendant upon a contract to return them on a given day, the true measure of damages will, if they have not been replaced, be the market price of the shares at the time of the trial $(c)$.

In Hochster v. De la Tour (d), it was held that a party ito an executory agreement may, before the time for executing it has arrived, break the agreement either by disabling himself from fulfilling it or by renouncing the contract, and hat an action will lie for such breach before the time for he fulfilment of the agreement. "The man who wrongully renounces a contract into which he has deliberately ntered cannot justly complain if he is immediately sued or a compensation in damages by the man whom he has njured; and it seems reasonable to allow an option to the njured party either to sue immediately or to wait till he time when the act was to be done, still holding it as rospectively binding for the exercise of this option, which nay be advantageous to the innocent party, and cannot be rejudicial to the wrong-doer." And, " in either case, the ury in assessing the damages would be justified in looking 0 all that had happened, or was likely to happen, to acrease or mitigate the loss of the plaintiff down to the ay of trial." In an action ex contractu, however, the amages cannot be reduced by proof of a breach of contract

(b) Per Grose, J., 2 East, 212.

(c) Oven r. Routh, 14 C. B. 327.

(d) 2 E. \& B. 678 ; cited in Roper Johnson, L. R. 8 C. P. 167, and I Blackburn, J., Unwin v. Clarke, .R. 1 Q. B. 421 ; Tycrs v. Rosedale id Ferryhill Iron. Co., L. R. 10 Ex. 15, 199 ; Danube, \&c., R. C. v. enos, 13 C. B., N. S., 825 ; Bar. tholomew v. Markwick, 15 C. B., N. S., 711,716 ; Hall v. Conder, 2 C. B., N. S., 22 ; Synge v. Synge, (1894) 1 Q. B. 466 (C. A.).

See also Hall v. Wright, E. B. \& E. 746 ; Taylor v. Caldicell, 3 B. \& S. 826 ; Stirling v. Maitland, 5 Id. 840 ; ante, p. 112 . 
on the plaintiff's part subsequently to the commencement of the action $(e)$.

The "scandal and absurdity" $(f)$ of a circuity of action, with a view to setting up a cross-demand by way of defence to an action upon contract, may now be avoided by counterclaim.

On refering to cases latterly cited, it may perhaps be found, as suggested at p. 723 , that the very terms of the particular contract under consideration indicate more or less clearly the true measure of damages applicable on its breach ; it cannot be denied, however, that sometimes the rule by which to adjust the damages is ill-defined, and sometimes much latitude, even in actions strictly founded upon contract, is allowed to the jury in assessing them.

What, it may be asked, are the damages recoverable for breach of a covenant to deliver up premises in repair? The Court of Appeal in a recent case decided that the cost of putting the premises into the state of repair required by the covenant was the measure of damages, and that such measure was not affected by the fact that the lessor had granted another lease from the expiration of defendant's term and was no worse off $(g)$. The damages recoverable, however, in an action brought during the currency of the tenancy for a breach of a covenant to repair are measured by the loss to the landlord as measured by the depreciation in the saleable value of the reversion $(h)$. Where, however; the premises were held under an under-lease, and the under lessee had notice at the time of entering into his covenant to repair of a similar covenant in the superior lease, the fact that the lessor was under a liability to yield up in

(e) Per Jerris, C. J., Bartlett v. Holmes, 13 C. B. 638 . And see per Munle, J., Lewis r. Clifden, 14 C. B. 255.

(f) Per Lord Demman, C. J., IIalmesley v. Cooper, 11 Ad. \&. E. 216; Charles v. Altin, 15 C. B. $46,62$. (g) Joyner v. Wceks, (1891) 2 Q. B 31 (C. A.). Whether such measure of damages is an absolute rule cf. pe: Lord Esher, M. R., at p. 43.

(h) Heuderson r. Thorn, (1893) 
repair is a circumstance to be looked at in assessing the damages (i). A lessee, in breach of his covenant, having assigned without his lessor's consent to a person who intended, as the lessee $\mathrm{knew}$, and did in fact use the premises as a turpentine distillery, and the premises having been burnt down by a fire arising from such use, was held liable to pay by way of damages for his breach the amount of the damage done by the fire $(k)$.

Let us next inquire what, in an action for breach of an agreement of hiring and service by wrongful dismissal of the plaintiff from his employment, would be the proper measure of damages? It would be obtained by considering what is the usual rate of wages for the employment contracted for, and what time would be lost before a similar employment could be obtained. The law considers that employment in any ordinary branch of industry can be obtained by a person competent for the place, that the usual rate of wages for such employment can be proved, and, lurther, that when a promise for continuing employment is broken by the master it is the duty of the servant to use diligence to find another employment $(l)$. If, indeed, the particular employment could not be again obtained without delay, and if the wages stipulated for in the contract rroken were higher than usual, the damages should be such is to indemnify for the loss of wages during that delay, ind for the loss of the excess of the wages contracted for ibore the usual rate; but no allowance would be made in he nature of pretium affectionis, nor for any pain caused o the plaintiff by his dismissa! in consequence of his being ittached to the place of his employment $(\mathrm{m})$.

In the case of a wrongful dismissal, then, we may

(i) Ebbetts v. Conquest, (1892) $2 \mathrm{Ch}$. ii (C. A.).

(k) Lepla v. Rogers, (1593) 1 Q. B. 1 .

(l) Per Erle, J., Beckham v. Drakc,
2 H. L. Ca. 606, and in Groodman r. Pocock, 15 Q. 13. 584; per Ciomptom, J., Emmens r. Elderton, 13 C. B. 508.

(im) Per Erle, J., 2 H. L. C'a.607. 
conclude that the servant or party dismissed may recover such damages as the jury think the loss of the situation has occasioned. If the plaintiff has obtained, or is likely. to obtain, another situation, the damages ought, on that ground, to be proportionately less, or even nominal, regard being had to the real loss sustained $(n)$. Considerable latitude seems, however, in cases of the lind before us, to be permitted to the jury (o).

In an action on an indenture of apprenticeship, the apprentice having wrongfully quitted the master's service, damages can only be recovered up to the time of action brought, not prospective damages up to the time when the term of apprenticeship would end $(p)$.

Of the general rule laid down at pp. 727,728, and heretofore partially illustrated-that ' where a party sustains a loss by reason of a breach of contract he is, so far as money can do it, to be placed in the same situation with respect to damages as if the contract had been performed,'-some qualifications of practical importance demand our notice.

In the first place, when a person contracts to sell real sale of land. property, there is an implied understanding, that, if (without fraud on his part) he fails to make out a good title, the only damages recoverable, over and above the deposit-money paid with interest, will be the expenses which the vendee may be put to in investigating the title (q.) Nominal damages only are, in the case here supposed, -i.e., in the absence of fraud or misrepresentation on the part of the vendor-recoverable by the vendee for the loss of his bargain $(r)$.

(ii) Per Crompton, J., 13 C. 13. 508 ; Muchomell $\therefore$. Marsden, 1 C. \& E. 281.

(o) Simith v. Thompson, 8 C. B. 44.

(p) Lewis v. Peachey, 1 II. \& C. i)18. The damages for wrongful dismissal of an apprentice without notice on grounds difierent to those on which he might have been dismissed with a week's notice are not linited to th. value of the week's notice: Mran $\mathrm{v}$ Jones, 25 (2. B. D., p. 107.

(q) Yer l'arke, B., Robinson v. Har man, 1 Exch. 855.

(v) Pounsett v. Fuller, 17 C. B. 663 Sikes v. Irild, 1 ]3. \& S. 587 ; S. C. 4 Ill. 421. See Hodges v. Earl ? Lichficld, I ling. N. C. 492. 
Upon the point just mentioned. Flureau v. Thornhill (s) and Bain v. Fothergill ( $t$ ) are leading authorities, in the latter of which cases Lord Hatherley observed as follows:"It is recognised on all hands that the purchaser knows, on his part, that there must be some degree of uncertainty as to whether, with all the complications of our law, a good title can be effectively made by his vendor; and taking the property with that knowledge, he is not to be held entitled to recover any loss on the bargain he may have made, if in effect it should turn out that the vendor is incapable of completing his contract in consequence of his defective title. All that he is entitled to is the expense he may have been put to in investigating the matter" $(u)$.

"If," as further observed by Lord Chelmsford, "a person enters into a contract for the sale of a real estate knowing that he has no title to it nor any means of acquiring it, the purchaser cannot recover damages beyond the expenses he has incurred by an action for the breach of the contract; he can only obtain other damages by an action for deceit" $(x)$.

Moreover, " under ordinary circumstances, where the purchaser fails to complete without any default on the part of the vendor, the latter is entitled to recover all the expenses he has incurred in preparing for the sale and also the loss incurred upon a re-sale, that is, the difference of price, if any " $(y)$.

(s) Flureau v. Thornhill, 2 W. Bla. 1078 , "establishes that where there is no fraud and no express contract to sell property with a knowledge on the rendor's part that he has not the title to sell . . no damages for loss of bargain can be recorered:" per Cleasby, B., L. R. 6 Ex. 69, cited per Bramwell, B., Gray v. Fouler, L. R. 8 Ex. 263. Flureal r. Thormhill is distinguished in Wall v. City of London Real Property Co., L. R. 9 Q. B. 249,252 . See Godwin . Francis, L. R. 5 C. P. 295. (t) L. R. 7 H. L. 158 (where the cases are collected), overruling Mopkins v. Grazebrook, 6 B. \& C. 31.

(u) Bain r. Fothergill, L. R. 7 H. L. 210, 211. See also per Lord Campbell, C. J., Simons v. Patchett, 7 E. \& B. 572; Judgm., Worthington v. Warrington, 8 C. B. 134; followed in Schreiber v. Dinkel, 54 L. T. 911.

$(x)$ Bain v. Fothergill, I. R. 7 H. L. 207.

(y) Per Brett, J., Essex v. Daniell, L. R. 10 C. P. 553 . 
Where a party has been let into possession of land under a contract of purchase which he then refuses to complete, and no conveyance is executed, the vendor cannot recover from him the whole amount of the purchase-money, but only the damages actually sustained by his breach of contract $(z)$. The measure of damages in an action of this nature is the detriment sustained by the plaintiff by reason of the defendant not having performed his contract. The question is, How much worse off is the plaintiff, owing to the diminution in the value of the land or to the loss of the purchase-money, in consequence of the non-performance of the contract? "It is clear he cannot have the land and its value too." And a party "cannot recover the full value of a chattel, unless under circumstances which import that the property has passed to the defendant, as in the case of goods sold and delivered, where they have been absolutely parted with and cannot be sold again" (a).

Damagewhen too remote.

The next point which may present difficulty in applying the general rule for measuring the damages is in determining whether or not the damage stated in the claim is sufficiently connected with the alleged injury to justify its recovery by action $(b)$. As introductory to this part of the subject, the following remarks of Dr. Story in his Treatise on Agency (c) may advantageously be noticed, indicating a kind of damage which would certainly be too remote. "If," says that learned writer, " an agent who is bound to render an account and to pay over monies to his principal at a particular time should omit so to do, whereby the principal should be unable to pay his debts or to fulfil his other contracts, and should stop payment and fail in

(z) Per Parke, B., Laird v. Iim, 7 II. \& W. 474,478 , cited in East London Union v. Metropolitan R. C. L. R. 4 Ex. 309, 310. See further, as to the liability of a purchaser who fails to complete his purchase, Ockenden v. Henly, E. B. \& E. 485.

(a) Per Parke, B., 7 M. \& W. 478.

(b) Ante, Book I., Chap. 3.

(c) 9th ed., p. 263. 
business, or be injured in his general credit thereby, the agent would not be liable for such injury; for it is but a remote or accidental consequence of the negligence. So if an agent, having funds in his hands, should improperly neglect to ship goods by a particular ship according to the orders of his principal, and the ship should duly arrive, and, if the goods had been on board, the principal might, by future re-shipments and speculations, have made great profits thereon, the agent will not be bound to pay for the oss of such possible profits, for it is a mere contingent lamage or an accidental mischief." And "the same easoning would apply to a case where, by the neglect of an agent to remit money, the principal has been prerented from engaging in a profitable speculation in some ther business by his want of the funds" $(d)$. So the ailure of an engagement to pay acceptances at maturity nay cause the destruction of the creditor's trade, and the lebtor may know that his inevitable ruin will be the result If such breach of contract; yet the true measure of lamages here applicable is "a reasonable compensation or the non-performance," which, in practice, is settled yy the allowance of interest. The actual amount of damage ustained would not be recoverable (e), unless in the case If a special contract where the damages can be considered s having been reasonably within the contemplation of the rarties $(f)$.

The subject of remoteness of damage $(g)$ in an action of ontract was much considered by the Court of Exchequer a Hadley v. Baxendale (h), where the following rule in $\checkmark$

(d) Story on Agency, 9th ed., p. 263.

(c) Per Bovill, C. J., British olumbia Saw Mill Co. v. Nettleship, .. R. 3 C. P. 506.

(f) Prehn v. Royal Bank of Liverool, L. R. 5 Ex. 92 ; Manchester, c., Bank r. Cook, 49 L. T. 674. (g) The principles with regard to moteness of damage are the same whether the action is brought for breach of contract or for tort. The Notting Hill,9 P. D. 105, approved in Victorian Rly. Comm. v. Coultas, 13 App. Cas. 222.

(h) 9 Exch. 341 ; Gee, app., Lancashire and Yorkshive R. C., resp., 6 H. \& X. 211 ; Sanders $v$. Stuart, 1 C. P. D. $326,328$. 
regard to it is laid down:- -that "where two parties have made a contract which one of them has broken the damages which the other party ought to receive in respect. of such breach of contract should be such as may fairly and reasonably be considered either arising naturally, i.e., according to the usual course of things, from such breach of contract itself (i), or such as may reasonably be supposed to have been in the contemplation of both parties ( $k$ ) at the time they made the contract as the probable result of the breach of it" $(l)$. Where (as the Court in the case just cited proceed to remark) a contract is made with reference to special circumstances, and such special circumstances are communicated by the plaintiff to the defendant, and are thus known to both the contracting parties $(m)$, the damages which might reasonably be contemplated as likely to result from a breach of such contract would be the amount of injury which would ordinarily follow from a breach of contract under the special circumstances so known and communicated. But, on the other hand, if the special circumstances were wholly unknown (n) to the party breaking the contract, he, at the most, could

(i) See Burrous v. Marsh Gas and Coke Co., L. R. 7 Ex. 96 ; Lilley v. Dombleday, 7 Q. B. D. 510 ; Hobbs v. London and South-Western R. C., I. R. 10 Q. B. 111, doubted in McMahon r. Field, 7 Q. B. D. 591; Featherston r. Wilkinson, I. R. 8 Ex. 122 ; Moubray v. Merryueather, (1895) 2 Q. B. 640 (C. A.), affirming S. C., Id. 1 Q. B. $85 \pi$. As to the recovery from a person of costs incurrel in defending an action resulting from the default of such person, see IIammond ऽ. Bussey, 20 Q. B. D. 79 . If such costs are reasonably incurred they are recoverable under the rule in $H a d l e y \mathrm{v}$. Baxendale (Hammond v. Bussey, lor. eit.). See this case as to Baxendale $\mathrm{r}$. London, Chatham, and Doter $R$. C., I. R. 10 Ex. 35 , and Fisher r. I'al de T'ures' Asphalte Co., 1 C. P. D. 511.

(k) This part of the rule laid down in Halley v. Baxendale, supra, was much discussed in Home $\mathrm{v}$. Midland R. C., I. R. 8 C. P. 131, 141. See also Judg., Elbinger Aetien Gesellschaft $\mathbf{v}$. Armstivng, L. R. 9 Q. B. 478,479 , approved in Grebert-Borgnis v. Nugent, 15 Q. B. D. 85 . The rule above commented on was applied by Kelly, C. B., in Prehn r. Royal Bank of Lirerpool, L. R. 5 Ex. 97, and by the Court of Appeal in Hammond r. Bussey, 20 Q. B. D. 79, 88.

(l) Portman v. Middleton, 4 C. B., N. S., 322, 328, 329. See also Randalh v. Raper, E. B. \& E. 84 ; Josling r. Irvine, 6 H. \& N. $512 ;$ Broom r. Hall, T C. B., N. S., 503; Duehworth v. Ewart, 2 H. \& C. 129.

(m) Adopted per Lord Chelmsford in Bain r. Fothergill, L. R. 7 II. I. 203. Sce Sinth v. Green, 1 C. P. D. 92.

(n) Skinner v. City of London, ge., 14 Q. B. D. 882,88 i. 
only be supposed to have had in his contemplation the imount of injury which would arise generally, and in the reat multitude of cases not affected by any special circumitances, from such a breach of contract. For, had the pecial circumstances been known, the parties might have pecially provided for the event of a breach of contract recurring by special terms as to the damages to be paid in uch case, and of this advantage it would be very unjust to leprive them.

In Hadley v. Baxendale, the rule above laid down and xplained was applied $(o)$. That was an action for the reach of a contract whereby the defendants (who were arriers) had undertaken to convey for the plaintiffs (who pere millers and occupiers of a steam mill) a broken shaft, sed for working the mill, which was forwarded to the onsignee, to serve as a pattern by which a new shaft ight be constructed. The breach alleged was, that, by se negligence of the defendants, the broken shaft was not elivered in a reasonable time to the consignee, in conzquence whereof the completing of the new shaft was elayed, and the plaintiffs were prevented from working reir steam mill and supplying their customers with flour, ad were deprived of the gains and profits which they ight have made by so doing. It was proved, at the trial : this case, that the plaintiff's servant, on delivering the aaft to the defendant's clerk, had stated that 'the mill as stopped, and that the shaft must be sent immediately;' it it did not appear that any further details, showing te exigency of the case, had been communicated on the ie side, or that any promise to use special diligence id been given on the other. The Court of Exchequer 3ld, that the damage here claimed by the plaintiffs is too remote to be recoverable, the loss of profits com(o) See also Hobbs v. London and 111 ; but see also Mellahon v. Field, "th-Western R. C., L. R. 10 Q. B. 7 Q. B. D. $594,596$.

B.C.L. 
plained of not being such a consequence of the alleged breach of contract as could have been fairly and reasonably contemplated by both the parties when they made it $(p)$.

To a similar effect it has been observed that "the extent of a carrier's liability is to be governed by the contract he has entered into, and the obligations which the law imposes upon him. $\mathrm{He}$ is not to be made liable for damages beyond what may fairly be presumed to have been contemplated by the parties at the time of entering into the contract. It must be something which could have been foreseen and reasonably expected, and to which he has assented expressly or impliedly by entering into the contract" $(q)$.

As regards the liability of a land carrier for delay in the conveyance of goods or live stock, "the law, as it is to be found in the reported cases, has fluctuated; but the principle is now settled that whenever either the objec1 of the sender is specially brought to the notice of the carrier, or circumstances are known to the carriel from which the object ought in reason to be inferred so that the object may _be taken to have been withir the contemplation of both parties, damages may be recovered for the natural consequences of the failure 0 that object" $(r)$.

(p) Acc. Wilson r. Lancashire and Forkshire R. C., 9 C. B., N. S., 632; followed in Schultze v. Great Eastern Ry., 19 Q. B. D. 30 ; Hales v. London and North-Western R. C., 4 B. \& S. 66.

With Hadley r. Baxendale, supra, compare Black v. Baxcndale, I Exch. 410: Waters v. Toucers, 8 Id. 401; Randall v. Raper, E. B. \& E. 84.

(q) Per Bovill, C. J., British Columbia Saw.mill Co. v. Nettleship, I. R. 3 C. P. 505, 506, and cases there cited ; Cory v. Thames Ironworks, fic., Co., I. R. 3 Q. B. 181 ; cited Judgm., L. R. 9 Q. B. 477 ; Wilson v. Nev- port Dock Co., L. R. 1 Ex. $17 i$ Woodger v. Great Western R. C. I. R. 2 C. P. 319 ; Williams Reynolds, 6 B. \& S. 495 . As regard the liability of carriers in connectio with remoteness of damage, seo Mille v. Brash, 8 Q. B. D. 35 ; Balduin ? London, Chatham, and Doter R. C. 9 Q. B. D. 582.

(r) Per Cockburn, C. J., Simpson V London and North-Western $k$. c., Q. B. D. 274, 277 (with which con trast Sander's r. Stuart, 1 C. P. I 326); Smith v. Green, 1 C. P. D. 92 94 ; Randall v. Newson, 2 Q. B. I 102, 111 ; Jameson v. Midland R. $C$ 
The substance of the above remarks may be thus exemlified :- "If goods are sent by a carrier to be sold at a articular market; if, for instance, beasts are sent by ailway to be sold at Smithfield, or fish is sent to be sold $t$ Billingsgate, and, by reason of delay on the part of the arrier, they have not arrived in time for the market, no oubt damages for the loss of market may be recovered. 0 if goods are sent for the purpose of being sold in a articular season when they are sold at a higher price than ley are at other times, and if by reason of breach of intract they do not arrive in time, damages for loss of arket may be recovered. . Or if it is known to both parties lat the goods will sell at a better price if they arrive at ie time than if they arrive at a later time, that may be a ound for giving damages for their arriving too late and lling for a lower sum" $(s)$. There is, however, a difference this respect between the liability of a carrier by land id a carrier by sea. Damages for loss of market caused ; accident or delay at sea cannot be recovered, as being o remote $(t)$.

Perhaps the best practical test which can be suggested $r$ determining the right of a party who claims damages leged to have flowed from breach of contract is this, that, the profits are such as would have accrued and grown out the contract itself as the direct and immediate results of $v$ fulfilment, then they would form a just and proper item damages to be recovered against the delinquent party on a breach of the agreement. The realisation of such Jits as are here indicated may, indeed, be considered as ming part and parcel of the contract itself, and must ve been in the contemplation of the parties when the

L. T. 426. But see Thol r. Henon, 8 Q. B. D. 457.

i) Per Mcllish, L. J., The Parana, D. 121 ; Hydraulic Engineering v. IIcHaffie, 4 Q. B. D. 670,67t. (t) The Parana, 2 P. D. 118 ; The Notting Hill, 9 Id. 105 ; Haules v. South-Eastern R. C., 54 L. J. Q. B. 174. 
agreement was entered into; but if they are such as would have been realised by the party from other independent and collateral undertakings, although entered into in con sequence and on the faith of the principal contract, then they are too uncertain and remote to be taken into con. sideration as a part of the damages occasioned by the breach of contract in suit (u).

The general rule laid down in Hadley v. Baxendale wa: applied in Theobald v. The Railway Passengers' Assuranc. Company $(x)$, where the action, in form ex contractu, wa brought to recover compensation from the defendants in respect of an injury sustained by the plaintiff, one of thei insured, whilst travelling by railway. The true measure of damages in this case was held to be compensation for th personal injury resulting from the accident, not exceeding however, the sum which the company would have bee liable to pay in the case of death, and irrespective of an loss of time or profits consequential on such injury; fo "what the insurance company calculate on indemnifying th party against is the expense and pain and loss immediatel connected with the accident, and not remote consequence that may follow, according to the business or profession 0

(u) Fox r. Harding, 7 Cushing (U. S.) R. 522, 523; Richardson :. Dimm, 8 C. B., N. S., 655; HIanslip v. I'aduick, 5 Exch. 615.

It has been held that in an action for breach of warranty of a horse the loss of a bargain for resale of the horse is not recoverable as special damage: Clare v. Maynard, 6 Ad. \& E. 519. Nor in such an action can the costs of tmprocidently defending an action, brought against the plaintiff by lis sub-rendee for breach of warranty, be recovered: Wrightup v. Chamberlain, 7 Scott, 598 (with which compare Maimearing y. Brandon, 8 Taunt. 202). "No person," says Lord Denmun, C. J., in Short v. Kelloway, 11 Al. \& E. 31 , "has a right to inflame his own account against another by incurring additional expense in the unrighteous resistance to an acti which he cannot defend." Acc. Brod r. IIall, 7 C. B., N. S., 503. B under a covenant to indennify agair all actions and claims in respect of $t$ covenants of a lease costs proper incurred in reasonably defending action brought for a breach of 0 of the covenants are recoverable damages: Ifurell v. Fysh, $1 \mathrm{C}$. E. 80 .

See also Walker v. IIatton, 10 M. W. 249 ; cited Williams v. William L. R. 9 C. P. 659, 666; Malden Fyson, 11 Q. B. 292; Richardson Chasen, 10 Id. 756 ; Piever . II liams, 23 L. J. Exch. 322 ; Smith Howell, 6 Exch. 730; Bramley Chesterton, 2 C. B., N. S. 592.

(x) 10 Exch. 45. 
the passenger," also in Collen v. Wright (y), which decided that a person who makes a contract as agent thereby impliedly warrants that he has authority in that capacity io contract $(z)$, and where it was held that the costs of a Jhancery suit instituted by plaintiff in reliance upon the Igent's representation of authority might be recovered. The ule as to the measure of damages thus laid down has ince been adopted $(a)$. And upon the whole, we may conlude, that, under ordinary circumstances, loss recoverable or breach of contract must be such as would naturally (b), .e., in a great majority of similar cases, flow from the breach lleged $(c)$.

Interest is in certain cases recoverable as damages by Interestwhen retatute, in other cases at common law. The stat. $3 \& 4$ coverable. Vill. 4 c. 42 , s. 28 , enacts, "that upon all debts or sums ertain, payable at a certain time or otherwise, the jury, on he trial of any issue or on any inquisition of damages, may, ' they shall think fit, allow interest to the creditor, at a ate not exceeding the current rate of interest, from the me when such debts or sums certain were payable, if such ebts or sums be payable ly virtue of some uritten instruent at a certain time $(d)$, or, if payable otherwise, then

(y) 7 E. \& B. $301 ; S . C$. (in rror), 8 Id. 647 , recognising Ravdell Trimen, 11 C. B. 786 ; Henderson Squire, L. R. 4 Q. B. 170, 174. e Simons r. Patehett, 7 E. \& B. 568 ; no v. Davis, 1 B. \& S. 220 ; Riehard". D. Dunn, 1 C. B., N. S., 655 ; ilph v. Crouch, L. R. 3 Ex. 44.

(z) See Diekson v. Reuter's Teleam Co., 3 C. P. D. 5, 7, 8.

(a) Spedding r. Nevell, L. R. 4 C. P. 2 ; and cases supra. See also 1 reek Wendt, 21 Q. B. D. 126.

(b) "Great difficulty, no doubt, ses from the use of the word atural' in these cases," i.e., cases acerning the remoteness of damage : (c Grove, J., Smith v. Grien, 1 C. P. 96. (e) Collard v. South-Easter'n R. C., 7 H. \& N. 79 ; Great Western R. C. v. Redmayne, I. R. 1 C. P. 329 ; Simeed v. Foosd, 1 E. \& E. 602; Simpson v. London and N.-W. R. C., 1 Q. B. D. 274.

Where goods are delivered to a carrier to be carried from $A$. to $\mathrm{B}$., and are lost, their owner has been held entitled to recover the value of the goods at B.: Riee r. Baxeudale, 7 H. \& N. 96.

(d) See London, Chathan, and Dorev R. C. v. South-Eastern R. C., (1892) $1 \mathrm{Ch} .120$, following Merchant Shipping Co.v. Armitage, L. R. 9 Q. B.99, but not following Duneombe v. Brighton Club Co., L. R. 10 Q. B. 371. 
from the time when demand of payment shall have been made in writing, so as such demand shall give notice to the debtor that interest will be claimed from the date of such demand until the term of payment $(e)$, provided that interest shall be payable in all cases in which it is now payable by law" $(f)$. Sect. 29 further empowers the jury on the trial of any issue, or on any inquisition of damages, if they shall think fit, to give damages in the nature of interest, over and above the money recoverable, in all actions on policies of insurance made after the passing of the Act.

The former of these sections, it will be remarked, is per. missive merely - not imperative - as regards the allowance of interest $(g)$.

Again, by sect. 57 of the Bills of Exchange Act, 1882 (45 \& 46 Vict. c. 61 ), it is provided that where a bill is dis. honoured the measure of damages, which shall be deemed to be liquidated damages, shall be (amongst other things) interest thereon from the time of presentment for payment if the bill be payable on demand, and from the maturity o: the bill in any other case $(h)$. Such interest, however, may if justice require it, be withheld wholly or in part. It ha: been decided in a recent case (i) that this section i intended to describe the damages which may be treated a liquidated damages for the purpose of specially indorsing

(c) See Mouratt r. Lord Londesborough, 3 E. \& B. 307,336 ; S. C. (in Error), 4 Id. 1.

(f) See Harper v. Williams, 4 Q. B. 219, 234; Alucood r. Taylor, 1 M. S. Gr. 279, 332; Edwards v. Great Western R. C., 11 C. B. 588, 650.

(g) By stat. 1 \& 2 Vict. c. 110, s. 17, a judgment debt curries interest at $4 \hat{l}$. per cent. per annum from the time of entering up the judgment.

Sec Lery r. Langridge, 4 M. \& W. 337; Hooper v. Lane, 6 H. L. Ca. 444. As to allowing compound interest, see Ferguson r. Fyffe, 8 Cl. \& F. 121.
As to claiming interest in speciall indorsed writ, Sheba Gold Mining Co v. Trubshaxe, (1892) 1 Q. B. 6it Wilks v. Wood, (1892) 1 Q. B. 684.

(h) See, as to claiming interest i specially indorsed writ on bills exchange, London and Unicersal Bam. ऽ. Clancarty, (1892) 1 Q. B. 689 Laurence \& Sons r. Wilcocks, 189 ? 1 Q. B. 696 ; Dando v. Boden, (1594 1 ( . B. 318.

(i) Ex parte Robarts, In re Gillespi 16 (Q. B. D. 702 ; 18 Id. 286 ; In ? Commercial Bank of South Australio 36 Ch. D. $522,52 \%$. 
writ under Ord. XIV., and that it does not deprive the drawer of his right to recover from the acceptor any special damage of an unliquidated character which he can show that he has sustained. It is still therefore law, as laid down in earlier cases $(k)$, that the drawer of a bill of exchange in a foreign country which is accepted in England is entitled, on the bill being dishonoured and protested, to recover from the acceptor, not only the amount of the bill with interest, but also all such reasonable expenses as may have been caused by the dishonour, including the expenses of re-exchange.

At common law interest is recoverable in the following cases $(l):-$

1. By the usage of trade, ex. gr., on bills of exchange $(m)$ or promissory notes, or on an agreement to pay for goods, \&c., by a bill or note $(n)$, or on a guarantee for the due payment of a bill $(o)$. On a bond $(p)$ also, and on a mortgage, interest is recoverable $(q)$.

2. Where there has been an express contract to pay interest $(v)$. "If," says Tindal, C. J. (s), "it be the intention of the party to obtain interest, it is always in his

(k) Walker v. Hamilton, 1 De G. F. \& J. 602 ; In re Gen. South American Co., 7 Ch. D. 637.

(l) See per Lord Ellenborough, C. J., De Havilland v. Bouerbank, 1 Camp. 50 ; Page v. Nevman, 9 B. f C. 378,381 ; per Lord Mansfield, C. J., Eddowes v. Hopkins, 1 Dougl. 376 ; Calton v. Bragy, 15 East, 223, $226 ; 13$ R. R. 451 .

(m) Byles on Bills, 14th ed., p. 444 st seq.; Gibbs v. Fremont, 9 Exch. !5; Hutton v. Ward, 15 Q. B. 26 ; Florence v. Jenings, 2 C. B., N. S. 54 ; Florence v. Drayson, 1 C. B., I. S., 584. See Suse v. Poimpe, 8 J. B., N. S., 538. But now the ecorery of interest is provided for by itatute, ante, p. $7+1$.

(n) Daris v. Simyth, 8 M. \& W. 399 ; Farr v. Ward, 3 Id. 25 ; Mar. shall v. Poole, 13 East, 98, 101 ; 12 R. R. 310 ; Middleton v. Gill, 4 Taunt. $298 ; 13$ R. R. 595; Porter v. Palsgrave, 2 Camp. $4{ }^{2}$; Becher. v. Jones, Id. 428, n.; 11 R. R. 786 ; Boyce v. Warburton, Id. 480.

(o) Ackerman v. Ehrenspergcr, 16 M. \& W. 99.

(p) Farquhar v. Horris, 7 T. R. 124. See Hogan v. Page, 1 B.\& P. 337.

(q) Price v. Great Western R. C., 16 II. \& W. 244; Morgan v. Jones, 8 Exch. 620; Wms. Saund., 6th ed., vol. 1, p. 201, u. $(r)$.

(v) Attwood r. Taylor, 1 M. \& Gr. 279 ; Orme v. Galloway, 9 Exch. 544; Francis v. Wilson, Ry. \& Moo. 105 ; Doman v. Dibdcn, Id. 381. See Re Gosman, 17 Ch. D. 771.

(s) Fostcr v. Weston, 6 Bing. 714. 
power to insert in the contract an express stipulation to that effect."

3. Where, from the course of dealing between parties, a contract to pay interest may be implied $(t)$.

The Sale of Goods Act, 1893, expressly provides $(u)$ that nothing in the Act shall affect the right of the seller to recover interest or special damages in any case where by law interest or special damages may be recoverable.

What has been set forth in the preceding paragraphs seems to be included within the words of Lord Westbury $(x)$, who says that " interest can be demanded only in virtue of a contract, expressed or implied, or by virtue of the principal sum of money having been wrongfully withheld, and not paid on the day when it ought to have been paid."

In taking leave of the subject of contracts, some brief concluding observations may not be deemed superfluous. The importance of a knowledge of the higher classes of contracts, and of the qualities which attach to judgments of our Courts of Record or to instruments under seal, will, I apprehend, readily be conceded. And the necessity of having an acquaintance with the characteristics of simple contracts (to a consideration of which the foregoing pages have principally been devoted) will be at least equally obvious, when we reflect that mercantile engagements, almost without exception, belong to this, the lowest class of contracts-that transactions such as these, ranging from the simplest to the most elaborate and important depend often upon nothing more than the hastily writter and peculiarly worded correspondence of trading firms separated by either of the great oceans from each other

(t) Nichol v. Thompson, 1 Camp. 52 , 1., and cases there cited; 2 R. R. 759: Petre v. Duncombe, 20 L. J. Q. B. 242 ; Denton v. Rodie, 3 Camp. 496 ; 14 R. R. 823 ; Gwyn v.
Godby, 4 Taunt. 346.

(u) S. 54. As to interest in Scotland, cf. s. 49 , subs. 3 .

(x) Caledonian R. C. v. Carmichael I. R. 2 Sc. App. Cas. 66. 
bearing this in mind, we shall perforce admit that not merely to the professed lawyer, but to the layman, some considerable familiarity with the elements, with the principles, of our law merchant is essential. In the ordinary affairs of life, also, in the constantly recurring cycle of daily or familiar events, as well the most momentous as the most trivial compacts known to law are authenticated neither by seal nor by record. The purchase of necessaries in a shop and the solemn contract of marriage, which is founded on the consent of the contracting partiessvidenced per verba de presenti,- - seem to be, in strictness, like referable to the class of simple contracts.

In proportion, however, to its importance, is the diffisulty of acquiring the knowledge here alluded to. Not only ure causes of action ex contractu almost infinitely varied, out the matters of defence pleadable in such actions are qually diversified; whilst statutory provisions, relative to he one and to the other, are extremely numerous. Hence he learning applicable to contracts can but be acquired pradually-by experience and practice. In connection vith the lowest, as with the best authenticated contractrith that which is oral as with that which is founded on ecord or on Act of Parliament (y),-points of perplexity nd doubt will suggest themselves to the inquirer. The ;reat principles, however, which support this entire subject, $r e$ at all events, surely traced and ascertained, and the ietter they are understood, illustrated by a comparison of ecided cases, tested and examined, the more will they be ound consistent with common sense, with sound policy, ith the dictates of wisdom and of justice.

(y) Ante, pp. 256, 263. 


\section{BOOK III.}

\section{TOR T S.}

\section{CHAPTER I.}

TORTS GENERALLY : THEIR NATURE AND CLASSIFICATION.

A TorT (a) is a wrongful act involving the idea, if not of some infraction of law, at all events of some infringement or withholding of a legal right or some violation of a legal right $(b)$.

An action of tort will lie for a direct injury to the person or property, for the wrongful taking or conversion of goods, for consequential damage, the right of action for a tort being founded-1, on the invasion of some legal right; or 2 , on the violation of some duty towards the public productive of damage to the plaintiff; or 3 , on the infraction of some private duty or obligation productive likewise of damage to the complainant.

The importance of having a correct perception of the nature of a right of action founded upon tort will justify \&

(a) "Tortus"--lammum, injustitia, vis, violentia alicui illata: Iucange Gloss. ad verb. "As right siguitieth law, so tort, crooked or wrong, signifieth injury:" 2 Inst. 56. 118.

(b) Co. Litt. $15 \mathrm{~s} \mathrm{~b} ; 3$ Bla. Com.

The word "duty" above used signifies " that which a person owes to another or to the public generally- that which a person is bound by an legal obligation to do or to perform; see Webster Dict. ad verb. Althoug the above definition would inclad within the tern "duty" the obligatio to pay a debt or to perform an agree ment, it is not usual to employ thi term in reference to obligations purel ex contractu. 
brief examination of each of the three classes of cases above specified.

First, then, as to the class of cases in which complaint is made of the invasion of some legal right (that is, of some legal right actually in the possession of the complainant, and to the enjoyment whereof he is entitled)—ex. gr., where wrong is done to the person or reputation, where goods are tortiously dealt with or withheld from their rightful owner, or a direct injury is done to property $(c)$. Here a plaintiff, in order to entitle himself to damages, may be called upon to show two things - the existence of the right alleged $(d)$ and its violation $(e)$.

Now, the existence of the right alleged will have to be established by reference to legal principles. It sometimes admits of easy proof, as in the case of an action of trespass for taking away goods, where the plaintiff would have a prima facie case, sufficient to entitle him to recover, upon merely proving his own possession of the goods, and that they were tortiously taken out of it by the defendant; the ceason of this being, that the bare possession gives a right is against a wrong-doer, for the invasion whereof an action will lie $(f)$.

So we have already seen $(g)$ that trespass will lie for a nere entry upon land in possession of another, although, $f$ an action be brought by a reversioner for damage done ;o his reversionary interest in land demised, a foundation or the claim to damages would have to be laid by howing that the injury complained of was of so durable

(c) Post, Chap. 3.

(d) In Rogers v. Dutt, 13 Moo. P. .C. 209,216 , the judgment of the ;upreme Court at Calcutta proceeded xpressly on the ground that a right ad become rested in the plaintiff and lad been invaded by the defendant; his judgment, howerer, was reversed iy the Privy Council. The case may sefully be consulted in regard to the
Rights of action $\mathrm{ex}$

Cuass I. Action for invasion of a right. 
a kind as necessarily to be productive of damage to his estate $(h)$.

But, further, the existence of a right may have to be proved by an appeal to elementary principles and by deductions ingeniously drawn from them, by a discussion of general doctrines of public policy, or by embarrassing inquiries touching the intention of the legislature. In support of this remark, I would refer to the great case of Ashby v. White, formerly abstracted (i); to the equally important judgment in Semayne's case (k), illustrating the fundamental maxim of our law, that 'every man's house is his castle' $(l)$; to the opinions of the Judges, and the decision of the House of Lords in Jefiereys v. Boosey $(\mathrm{m})$, where the long-vexed question as to the existence of copyright at common law was reagitated, and an opinion in the negative regarding it was expressed $(n)$; to all those numerous cases (some of which will have to be hereafter noticed) wherein the existence of a right has been found to depend upon the interpretation of the statute law, and the unravelling of its perplexities $(o)$.

In the class of cases now under consideration it will be (noticed, that proof of actual damage has not been specified las requisite to entitle a complainant to recover. Many in-

(h) Post, Chap. 3, s. 1.

(i) Ante, p. 8\%.

(k) 5 Rep. $91 ; 1$ Sm. L. C., 9th ed., 115.

(l) The maxim extends only to the dwelling-louse. A sheriff may, for the purpose of executing a fi. ta., break open the outer door of a building not being the dwelling-house: Model'r v. Williams, (1895) 2 Q. B. 663 (C. A.), following Penton v. Browne, I Sid. 186; 1 Keb. 698.

(iii) 4 L. Ca. 815. See this case distinguished, Trude Auxiliary Co. r. Middlesborough Tradesmen's Protection Association, 40 Ch. D. 425 , at p. 434 .

(n) See particularly per Lord Brongham, 4 H. L. Ca.962; per Lord St. Lionards, Id. 977.
As to copvriglit, see further Routledge v. Love, L. R. 3 H. L. 100; IF corl v. Bocsey, L. R. 3 Q. B. 223; Tuck and Sons r. Priester, 19 Q. B. D. 629 (reversing $S . C$. loc. cit., at p. 48); Warme v. Seebohm, 39 Ch. D. 73; IIanfstaengl v. $M$. and R. Baines and Co., (1895) A. C. 20 (attirning C. A. 1894, 3 Ch. 109); Exchange Telegruph Co. v. Gregory and Co., (1896) 1 Q. B. 147 (C. A.). As to musical and dramatic copyright, see Wall v. Taylor, 11 Q. B. D. 102; Dick v. Bates, 12 Q. B. D. 79 ; 13 Id. 843 ; Fuller v. Blackpool Winter Gardens Co., (1895) 2 Q. B. 429 (C. A.).

(o) See, for instance, lickering $\mathrm{v}$. James, L. R. 8 C. P. 489 ; Ellucll r. Proprietors of the Birmingham Canal Nai., 3 H. L. Ca. 812. 
stances confirmatory of this remark-that an action may lie for the invasion of a right without proof of special damage-have been already cited $(p)$, where, inter alia, reference was made to decisions which establish that the fraudulent use and appropriation of a trademark is, per se, actionable $(q)$.

A right of action to recover the possession of goods (and the same remark seems applicable to replevin), falls, it is conceived, within the class of rights of action ex delicto under our notice, although in such an action substantial damages are in practice usually sought for.

To the class under notice is also referable the right of action for a libel, or for slander where the words spoken are actionable per se; the right to sue for words actionable only when productive of special damage offering an exception to the class in question (resulting, as it would seem, from an application of the maxim, De minimis non curat lex), in

(p) Ante,p. 82, et seq. See Gambart r. Sumner, 5 H. \& N. 5.

In Chamberlaine $\mathbf{v}$. Chester and Birkenhead R.C., 1 Exch. 870, 876, 877, we read that "where a statute projibits the doing of a particular act affecting the public no person has 1 right of action against another nerely because he has done the pronibited act. It is incumbent on the sarty complaining to allege and prove that the doing of the act prohibited as caused him some special damage, some peculiar injury beyond that which he may be supposed to sustain n common with the rest of the Zueen's subjects by an infringement if the law. But where the act prolibited is obviously prohibited for the protection of a particular party, here it is not necessary to allege special lamage." The reason on which this vle is fourded seems to be, that, inasnnch as the statute recognises the ight of the plaintiff, the breach of ihat recognised right gives him a title :0 sue without showing special damage, n accordance with the principle stated in the text.

(q) In Marsh v. Billings, 7 Cush. (U. S.) R. 322, it was held that a coach proprietor running carriages between a railway station and a town has no right falsely to hold himself out as being in the employment or under the patronage of a particular hotel-keeper in such town, by affixing to his carriage, \&c., the name of the hotel, this being done to the detriment of some other party lawfully entitled to the privilege in question. And it was further held that the representation thus falsely made for the purpose of enticing pas. sengers from the plaintiff's carriages would be a frand on him, and a violation of his rights, for which an action would lie without proof of actual or specifie danuge.

See also Nerchall $v$. Ireson, 8 Cush. (U. S.) R. 595; Laveson v. Bank of London, 18 C. B. 92 ; Wotherspoon v. Curvie, L. R. 5 H. L. 508; Thompson v. Montgomery, 41 Ch. D. 35 ; Reddaway. Banham, (1896) A. C. 199. 
respect of the necessity of proving such special damage in order to sustain the action $(r)$.

Rights of action ex delicto.

Class II. Action for breach of public duty - producing damage.
Public duty -at com. mon law.

Secondly, an action ex delicto may be founded on the violation of some public duty (i.e., of some duty towards the public), and consequent damage to the complainant. Now here three different matters may have to be proved in order to entitle the plaintiff to a verdict, viz., the existence of the alleged duty, its breach, and damage; the existence of a public duty may be established either by bringing the facts of the case within the reach and control of some acknowledged doctrine of the common law, or by showing that they are within the words, spirit, or purview of an Act of Parliament.

Let us, under the term "public duty," include the duty towards the public of refraining from doing, as well as that of doing, acts of a particular kind or tendency, and we may then lay down the proposition above stated, thus in a somewhat expanded form-Wherever a duty has to be observed towards the public by an individual, and another is specially injured in consequence of the non-observance or non-discharge of such duty, or through misfeasance or malfeasance in its discharge, an action will lie at suit of the latter party against the former.

Very many reported cases, of which comparatively few can here be cited, establish the proposition that negligence, i.e., the breach of a duty to take care $(s)$, causing damage is actionable $(t) ; e x . g r$. , where an instrument dangerous in

(r) See Miller $v$. David, L. R. 9 C. I. 118 ; post, Chap. 2.

(s) Vide per Bramuell, B., Hayn v. Culliford, 4 C. P. D. 185 ; I'earson $\mathrm{r}$. Cox, 2 C. P. D. 369 : Tarry v. Ashton, 1 Q. B. D. 314 , and cases there cited; Holmes v. Mather, I. R. 10 Ex. 261; Richardson v. Great Eastern R. C., 1 C. P. D. 342 .

( $t$ " "There is no absolute or intrinsic negligence; it is always relative to some circumstance of time, place, or person:" per Bramuell, B., Degg r. Midland R.C., 1 H. $\mathcal{E}$ N. 781 , and in Rnck v. Williams, 3 Id. 318 . "The ideas of negligence and duty are strictly correlative, and there is no such thing as negligence in the abstract. Negligence is simply the neglect of some care which we are bound by law to exercise towards somebody:" per Bouen, L. J., Thomas v. Quartermaine, 18 Q. B. D. 685,694 ; Eeans v. Manchester, $\$ c ., R$. C., 36 Ch. D. 626 , 
its existing state, and calculated to inflict damage on those who may come in contact with it, is so placed as to be ikely to cause bodily hurt, the person thus placing it is iable, if hurt ensues, to the party injured $(u)$.

Negligence may be evidenced in an infinite variety of rays, and where complicated the points of difficulty usually ire in regard to the burthen of proof, and the question to se decided by the Judge-Is there evidence of it for the ury $(x)$ ? the phrase res ipsa loquitur being sometimes used

34. "Negligence may be either irect or arising from circumstances :" er Watson, B., Hiphins v. Birminglam Gas-light Co., 5 H. \& N. 87; i. C., 6 Id. 250 . "What constitutes 'gross negligence' is always excessively ifficult either to define or, by way of nticipation, to illustrate:' ' per Lord ranworth, Colyer v. Finch, 5 H. I. 'a. 924. "Actionable negligence onsists in the neglect of the use of rdinary care or skill towards a person 0 whom the defendant owes the duty f observing ordinary care and skill, y which neglect the plaintiff, without ontributory negligence on his part, has affered injury to his person or proerty : " per Brett, M. R., Heaven v. 'ender, 11 Q. B. D. 503,507; Elliott . Hall, 15 Q. B. D. 315; Thrussel v. Tandyside, 20 Id. 359,363 .

As to evidence of negligence, see Tearney v. London, Brighton, and South oast R. C., L. R. 6 Q. B. 759 , Id. 411; Great Hestern R. C. of anada v. Braid, 1 Moo. P. C. C., N. .101 ; Toomey r. London, Brighton, nd South Coast R. C., 3 C. B., Y. S. 16 ; Cornman r. Eastern Counties $R$. , 4 H. \& N. 781 : Roberts v. Great Testern R. C., 4 C. B., N. S. 506 ; remantle v. London and NorthTestern R. C., 10 C. B., N. S. 89; lyth v. Birmingham Waterworks Co., Exch. 781 ; Manchester, \&e., R. C., 'p., Fullarton, resp., 14 C. B., N. S.

"Negligence alone without damage es not create a cause of action: " per 'atson, B., Duekworth v. Johnson, 4 . \& N. 659 .

(u) Dixon v. Bell, 5 M. \& S. $198 ; 17$ R. 308; and see Hearen v. Pender, 11
Q.B.D.503, 517; distinguished, $O^{\prime}$ Teil v. Ererest, 61 I. J. Q. B. 453 ; Clark v. Chambers, 3 Q. B. D. 327, and cases there collected; Scott $r$. Shcpherd, cited ante, Book 1., Chap. 3; Gilbertson v. Richardson, 5 C. B. 502; Bird r. Holbrook, 4 Bing. 628, with which compare Ilott v. Hilhs, 3 B. \& Ald. 304 ; 22 R. R. 400; Jordin v. Crump, 8 M. \& W. 782; Deane v. Clayton, 7 Taunt. 489 ; 18 R. R. 5.53 ; Wootton v. Dawkins, 2 C. B., N. S., 412; Judgm.,'6 Exch. 767, 768.

In Taughan v. Taff Tale R. C., 5 H. \& N. 685 (with which compare Jones v. Festiniog R. C., I. R. 3 Q. B. 733 ; and Simith r. London and South-Western R. C., L. R. 6 C. P. 14), Cockbum, C. J., observes, that "when the legislature has sanctioned and authorised the use of a particular thing, and it is used for the purpose for which it was authorised, and every precaution has been observed to prerent injury, the sanction of the legislature carries with it this consequence, that if damage results from the use of such thing, independently of negligence, the party using it is not responsible." See, hawerer, per Bramucll, L. J., Poucll v. Fall, 5 Q. B. D. 597, 601; Dunn r. Birmingham Can. Co., L. R. 8 Q. B. 42,47 : per $D a \%$, J., Reg. v. Essex, 14 Q. B. D. 753, 763 .

(x) Daniel 5. Metropolitan R. C., L. R. 5 H. L. 45 ; Vorth-Eastem R. C. v. Wanless, L. R. i H. L. 12 ; Bridges v. Worth London R. C., Id. 213; discussed in Pearson r. Cor, 2 C. P. D. 369: Cockle r. Sonth-Eastern R. C., L. R. 7 C. P. 321 ; Ellis v. Great Western R. C., L. R. 9 C. P. 551; Siner v. Great Western R. C., 
with reference to a state of facts which seems necessarily indicative of negligence $(y)$. In cases such as adverted to, the doctrine of contributory negligence needs often to be applied. This doctrine will hereafter be considered.

Inasmuch as the ingredient of negligence in an action founded upon tort will in the ensuing pages repeatedly claim attention, it may be well to state in limine the rule which, after many conflicting decisions, has been estab. lished-that in any such case "the Judge has to say

vhether any facts have been established by evidence from which negligence may be reasonably inferred; the jurors have to say whether from those facts, when submitted to them, negligence ought to be inferred "' $(z)$.

Let us pause here for a moment to notice one character. istic of the class of cases now under revier. The breach o. a public duty causing damage to an individual, in truth, com bines two tortious ingredients, which are, according to cir cumstances, more or less clearly distinguishable from eacl other-the wrong done to the public and the wrong doni to the individual. That which is, in strictuess, correlativ to a public duty is a right enforceable at suit of the public But, then, the general rule of law is settled, that an indi vidual cannot enforce a public right or redress a publi injury by suit in his own name. Where he suffers wron or sustains damage in common with other members of th community, no personal right of action thence accrues. Th.

L. R. 4 Ex. 117 ; Robson v. TorthEastern R. C., I. R. 10 Q. B. 271; Williams v. Great Western R. C., L. R. 9 Ex. 157; Cliff v. Mirland R. C., L. R. 5 Q. B. 258; Welfare v. Loudon and Brighton R. C., L. R. 4 (2. B. 693; Rose v. North-Eastern R. C., 2 Ex. D. 248 ; Lewis $\vee$ London, Chatham, and Dover R. C., L. R. ? (2. 13. 66; Blamires v. Laneashireand Yorkshire R. C., L. R. 8 Ex. 283; Simson ヶ. London General Omnibus Co., L. R. 8 C. P. 390 ; Gee r. Metropolitan
R. C., I. R. 8 Q. B. 161 ; Ceech, Gen. Steam Jat. Co., I. R. 3 C. 1 14.

(y) Briggs v. Oliter, 4 H. \& C. 40 : $40^{-}$; Scott v. London, Se., Docks Co 3 II. \& C. 596.

(z) Per Lord Cairns, C., Metrop litan R. C. r. Jackson, 3 App. Ca: 197 (where Bridges v. Worth Londs R. C.. L. R. 7 H. L. 213, is explained" Dublin, Wicklow, and Wexford $R$. i v. Slattery, $3 \mathrm{App}$. Cas. 1155. 
rivate grievance is merged in that of the public, and the emedy (if any exists) will be by public prosecution, in irder that the rights of the public may thus be vindicated. ven where one person sustains damage in common with he public, and, from the circumstances in which he happens o be placed, suffers more frequently or more severely than thers, he will not, on that account, have, as of course, a eparate right of action. It is only where he suffers some pecial damage, differing in kind from that which is comcon to others, that a personal remedy accrues to him (a).

In every case belonging to the class now under consideraion will be found as an ingredient some nonfeasance, miszasance, or malfeasance of a public duty-constituting pro into an offence (not necessarily indictable) against the ublic-also an injury productive of special damage to an idividual.

Thus, in Ellis v. The Sheffield Gas Consumers' Co. (b), le action was brought against a registered joint-stock comany, who had contracted with an individual for the laying own of their gas pipes in the town of Sheffield, without aving obtained any special powers for that purpose. It ppeared that, in the course of making the necessary excaations, a heap of stones had been left in one of the streets, ver which the plaintiff, whilst passing in the dark, felllus sustaining damage. The declaration charged that the fendants had committed a nuisance in obstructing, without 1e powers, the public thoroughfare; and the plaintiff having tained a verdict, it was contended that the action should wve been brought against the contractor whose rorkmen id caused the damage, and not against the company; but

(a) See Brainard v. Connecticut ver R. C., 7 Cush. (U. S.) R. 510, 1.

(b) 2 E. \& B. 767 ; Whiteley . pper, 2 Q. B. D. 276; Blake v. irst, 2 H. \& C. 20 ; Hole v. Sittingune and Sheerness $R . C ., 6$ H. \& N.

B.C.L.
488; Gray r. Pullen, 5 B. \& S. 981, reversing $S . C .$, Id. 970 . See Reg. $v$. Longton Gas Co., 2 E. \& E. 651 : Oeerton v. Freeman, 11 C. B. 967 ; Gayford r. Nicholls, 9 Exch. 702 ; Clothier r. Webster, 12 C. B., I. S., 790 .

$3 \mathrm{C}$ 
Lord Campbell, C. J., observed, this " is simply the case o persons employing another to do an unlawful act, and , damage to the plaintiff from the doing of such unlawfu act $(c)$. We have the injuria et damnum, which constitut a ground of action." Again-in Barnes v. Ward (d), thi question was - whether or not there is a duty cast upon th. owner of a house and premises adjoining a public footra: to fence them off in such a manner as to prerent damagr to any one lawfully passing along the public way wh might otherwise, by diverging accidentally from his track owing to the state in which the premises chanced to be meet with an accident? The Court held that such a dut or obligation is, under the circumstances named, cast upo] the owner of property; and that its non-observance wil render him liable for damage caused thereby, the groun of this decision being, that the excavation (which causer the damage complained of) was a public nuisance (e). I

(c) See also per Lord Campbell, C. J., Sadler r. Henlock, + E. \& B. 577, citing Ellis r. Sheffeld Gas Consumers' Co., supra ; per ITilliams, J., Pickard r. Smith, 10 C. B., X. S., 480. See also Black v. Christchurch Finance Co., (1894) A. C. 48 ; Hardaker v. Idle District Conneil, (1896) 1 Q. B. 335 (C. A.).

(d) 9 C. B. 392 , cited 2 App. Cas. 864: White r. Hindley Local Board, L. R. 10 Q. B. 219 , affirmed in Blackmore v. Iestry of Wile End Old Town, 9 Q. B. D. 451 ; Wwore r. Lambeth Waterccorls Co., 17 Q. B. D. 468; Judgm., 8 M. \& W. 788: Hadley v. Taylor, L. R. 1 C. P. 53. With Barnes v. Ward, supra, compare Corby r. Hill, 4 C. B., X. S., 556 ; Burchell r. Huskisson, 50 L. J. Q. B. 101 ; Stovic r. Jackson, 16 C. B. 199; Chapman r. Rotherell, E. B. \& E. 168: Hounsell v. Simyth, 7 C. B., N. S., 731: Bolch r. Smith, 7 H. \& N. 736, 744; Wil. liams $\mathrm{x}$. Groucott, 4 B. d S. 149 (listinguished in Great Laxey Mining Co. v. Clague, 4 App. Cas. 115, 119); Indermaur v. Isames, L. R. 2 C. I'. 311, followed in White r. France, 2 C. P. D. 308,310 ; Swith r. Landon, \&.c., Dock Co., L. R. 3 C. P. 326 distinguished in $O$ 'Neil r. Ererest, 6 L. J. Q. B. 453 ; Gautret r. Egertin L. R. 2 C. P. 371 . Per Byles, J Witherley v. Regent's Canal Co., 1 C. B., N. S., 6 ; Robbins r. Jones, 1 C. B., N. S., 221. See Cornicell , Metropolitan Commissioners of Secer. 10 Exch. 771, 774. Bnt a mes licence to lodgers to use the roof of house as a drring-place for linen dor not impose any duty upon the landlor to repair the railing round the roof Iray $r$. Hedges, 9 (Q. B. D. $80 ; B a$ chelor r. Fortescue, 11 Q. B. D. 47 Nor is there any duty on the part the occupier of premises to rend them secure for persons nsing the without invitation for their own grat fication: Jerson r. Gatti, l C. \& ] 564. The owner of a building let : chambers or offices to different tenant retaining in his possession the stai case, is under a duty to persons usir the staircase when having bosiness wi the tenants, to keep it in a reasonab safe condition: Iriller r. Hancac 1893, 2 Q. B. 17 (C. A.).

(c) Hardcastle r. South Iorkshi Kuiluay and Kicer Dom Co., 4 H. \&: 
zach of the foregoing cases we find, as elements in the ight of action, a breach of public $(f)$ duty and a private wrong producing damage $(g)$.

As throwing light upon the subject before us, Broun v. Mallett $(h)$, and the elaborate judgment therein delivered y Mr. Justice Manle, demand careful examination. The question raised in that case was as follows:- What is the luty of the person who had the possession and control of vessel, which, without any fault of his, has, whilst in his ossession, sunk, so as to obstruct a public navigable river, hith respect to vessels navigating the river after his poszssion and control have ceased? "There seems no oubt," observed the Court, "that it is the duty of a erson using a public navigable river, with a vessel of hich he is possessed and has the control and management (i), , use reasonable skill and care to prevent mischief to

$70 ;$ Bucks v. South Forkshire and ver Dun Co., 3 B. \& S. 241, 252, 254 ; r Williams, J., and Keating, J., C. B., N. S., 742, 745; Or Exing Colquhoun, 2 App. Cas. 864.

(f) As exemplifying the difference ween a public and a pricate duty, npare Holmes v. Worth-Eastern $\dot{R}$. L. R. 4 Exch. 254 (with which Wright v. London and Forth stern R. C., L. R. 10 Q. B. 298), h Indermaur v. Dames, I. R. 2 C. 311 ; and Corby v. Hill, 4 C. B., S., 5.56; followed in White v. ince, 2 C. P. D. 308 .

g) Pickardv. Sinith, 10 C. B., X.S., , 479; as to which see Whiteley Pepper, 2 Q. B. D. 276, 278.

and may, however, be dedicated to public as a highway, subject to inrenience or risk arising from its ting condition: Fisher v. Prowse, \& S. 770. See Horant v. Chamin, 6 H. \& N. 541; ante, Book I. 1.

5 C. B. 599; Submarine Teleih Co. v. Diekson, 15 C. B., N. S., ; White v. Crisp, 10 Exch. 312 ; an v. Mcrsey Docks Board, L. R. P. 19, 29 ; Ihite v. Phillips, 15 i., N. S., 245 ; Bartlett v. Baker,
3 H. \& C. 153.

As to the liability of commissioners trustees, or local boards acting under the statute law for negligeuce and breach of duty, see Merscy Docks Trustees v. Gibbs, Sane v. I'cnhallow, 11 H. L. Ca. 686, approved Reg. v. Williams, 9 App. Cas. 418, and in Sanitary Commissioners of Gibruller v. Orfila, 15 App. Cas. 403 ; Forbes v. Lee Conservancy Board, 4 Exch. D. 116; Hill v. Managers of Metropolitan Asylum District, 4 Q. B. D. 433 ; 6 App. Cas. 193, 203, 208 ; Winch v. Thames Conservators, L. R. 9 C. P. 378; Jolliffe v. Wallasey Local Board, L. R. 9 C. P. 62 ; Coe จ. Irise, L. R. 1 Q. B. 711 ; Oh, by v. Ryde Comm. 5 B. \& S. 743 ; Collins v. Widale Level Comm., L. R. 4 C. P. $279 ;$ Ruck v. Williams, 3 H. \& . 308 ; cited Judgm., Great West. of Canada R. C. v. Braid, I Moo. P'. C. C., N. S., 119 ; Gibson v. Wayor of Preston, L. R. j Q. B. 218 (approved in Couley r. The leumarket Local Board, (1592) A. C. 345): Gilbert v. Tivity Housc, 17 Q. B. D. 795 .

(i) See Manley r. S't. Helen's Car. and R. C., 2 H. \& N. 840. 
other vessels; and that, in case of a collision, arising from his negligence, he must sustain, without compensation, the damage occasioned to his own vessel, and is liable to pay. compensation for that sustained by another navigated with due skill and eare. And this liability is the same whether his ressel be in motion or stationary, floating or aground, under water or above it; in all these circumstances the vessel may continue to be in his possession, and under his management and control ; and, supposing it to be so, and a collision with another vessel to occur from the improper manner in which one of the two is managed, the owner of the vessel properly managed is entitled to recover damages from the owner of that which was improperly managed. This duty of using reasonable skill and care for the safety of other vessels is incident to the possession and control of the vessel. Subject to this obligation, the owner has a right, while his ressel is afloat, to proceed in any direction and to remain at any place; and when it is aground, whether sunk or not, to remain as long as the occasions of his royage require. Of the existence of these rights and of these duties, so long as the possession and control of the vessel continue in the same person, there seems to be no doubt. Nor does there seem to be any doubt, that, if these welt transferred to another person, the rights and the duties would also be transferred to him, and the original ownes would cease to be entitled to or bound by them." A person however, may cease to have the possession and control of a vessel, although they are not transferred to any othe: person, ex.gr., by some casualty of navigation (as in thr case sub judice)-what then are the rights and obligation of the owner? Assuming that the loss of the vessel aros from unavoidable accident - that the owner is wholly blame less in regard to it, and that there are no special circum stances casting upon him a continuing liability, it seem clear that he is not compellable to remove the obstructio 
to the navigation caused by the sunken vessel, nor eren to take measures for diminishing the danger arising from it. Inasmuch, then, as an indictment would not lie under the circumstances stated, for the danger and impediment to the public, no action would be maintainable for particular damage resulting from the obstruction in question to an individual. The duty of the defendant (if it existed at all) would be of a public nature; and the plaintiff, in order to succeed, would have to show a breach of public duty as well as special damage to himself $(k)$.

In any such case the plaintiff in his claim must allege facts raising the duty for breach of which coupled with damage he sues ; any allegation of duty, however, is " useless where the [claim] is insufficient, and superfluous when sufficient without it" $(l)$. Various cases which have given rise to interesting discussions respecting legal duties are cited infra $(\mathrm{m})$.

Wherever, then, an action is brought for damage caused by breach of a public duty, the damage and not the breach of duty, is that for which the complainant sues: his object being-not to vindicate a right on behalf of the public, but - to recover compensation for a wrong done to himself. Between the public and the private wrong, concurring in a cause of action such as now alluded to, the distinction should carefully be traced. The mode of tracing it may be illustrated by Couling v. Coxe (n), where the action was in

(c) See Jndgm., 5 C. B. 620. See ulso Arrow Shipping Co. v. Tyne Imrotement Commissioners, (1894) A. C. j08.

(I) Per Maule, J., 5 C. B. 615, dopted Judgm., 11 Exch. 270.

(m) Southcote v. Stanley, 1 H. \& N. :47, which "stands entirely upon the elation of host and guest, and was deided upon this principle, that one who hooses to become a guest cannot comlain of the insufficiency of the accomrodation afforded him:" per Williams, ., Corby r. Hill, 4 C. B., N. S.,
565, 566; Collis r. Selden, L. R. 3 C. P. 495; Hill v. Balls, 2 H. \& X. 299 (with which compare Simith v. Green, 1 C. P. D. 92; I'ard r. Hobbs, 4 App. Cas. 13); Mullett v. ICa.son, L. R. 1 C. P. 559 : Ibottson v. Peut, 3 H. \& C. 644 ; Dalton r. Denton, 1 C. B., I. S., 672. Et vide per l'olloct, C. B., Abraham r. Reynolds, 5 H. \& N. 148; Cracknell r. Thetford, L. R. 4 C. P. 629 ; distinguished in Geddis v. Proprietors of Bamn Reservoir, it App. Cas. 430.

(ii) 6 C. B. 703. 
tort against a witness for not obeying a subpona ; and the Court observed, "that, in such an action brought for a breach of duty-not arising out of a contract between the plaintiff and the defendant (o), but-for disobeying the order of a competent authority,-the existence of actual damage or loss is essential to the action, as the law will not imply a loss to the plaintiff from mere disobedience to the subpœna" $(p)$. In other words, the law will here dis. criminate between the breach of the public duty and the personal damage which form the component elements of the complete right of action. In resolving the question, whether or not an action under the circumstances supposed is maintainable, the Court has to direct its attention as well to the private damage as to the contempt or public offence ; whereas, on motion for an attachment, it has to consider the latter only. "T'o found a motion for an attachment against a witness for disobeying a subpœna, it must be shown that he has wilfully abstained from attending in pursuance thereof, or that he has in some way treated the process of the Court with contempt." Should the party subpœnaed succeed in purging himself of the alleged contempt, he will still be liable to an action for any damage which the plaintifi may have sustained in consequence of his non-attendance at Nisi Prius; and in support of such action there will yet remain, as an ingredient, a wrong towards the public in disobeying the process of the Court. Not only in the case above put does the right of action admit of satisfactory analysis, but in other cases falling within the class now under notice a similar process may often, without difficulty, be pursued.

In the examples latterly presented, the right of action has been founded on the breach of a public duty, existing

(a) See Featmon v. Dempsey, 9 C. B., X. S.. 881 .

(p) Judgm., 6 C. B.718,719; Mullett v. Hunt, 1 C. \& M. 752 ; Needham. Fraser, 1 C. B. 815 . See ll'ade r. Simeon, 2 C. B. 548, 566. 
at common law, productive of damage to the plaintiff. A public duty may also be imposed, in part or wholly, by the statute law $(q)$; when this is so, the precise nature and extent of the statutory duty must of course be determined by reference to the words of the Act creating it, as stated at p. 750 , and as illustrated by cases below cited $(r)$; the general rule being that "a person damnified by the failure to perform a statutory duty is entitled to maintain an action" $(s)$.

Lord Holt indeed lays down ( $t$ ), that "wherever a statute enacts anything, or prohibits anything for the advantage of any person, that person shall have remedy to recover the advantage given him, or to have satisfaction for the injury Jone him, contrary to law, by the same statute; for it would be a fine thing to make a law by which one has a ight, but no remedy but in equity" $(u)$ - which seems squivalent to saying, that "when a statute gives a right, hen, although in express terms it has not given a remedy, he remedy which by law is properly applicable to that ight follows as an incident" $(x)$.

Such as above set forth being the rule generally appliable, some qualification of it must be noticed, for the reach of a public statutory duty causing damage does not lways and necessarily vest a right of action in the person uffering such damage against the person guilty of the

(q) In Mills v. Mayor, \&e., of Colsester, 17 C. B., N. S., 635, no atutory duty was held to have been uposed. See also Cornell v. Hay, - R. 8 C. P. 328 ; Twycross v. rant, 2 C. P. D. 469,487 ; Hamond v. St. Paneras, L. R. 9 C. P. 6, followed in Bateman v. Poplar. sard of Works, $37 \mathrm{Ch}$. D. 272; yams v. Webster, L. R. 4 Q. B. i8, L. R. 2 Q. B. 264 ; Holborn nion v. St. Leonard, Shoreditch, 2 B. D. 145 .

(r) Hilcoat v. Arehbishop of Canbury, 10 C. B. 327 ; Robinson v.
Statutory public duty. 
breach; whether the right of action exists, and, if so, against whom it should be exercised, must depend upon the object, language, and policy of the particular statute $(y)$.

Moreover, a man may be morally, and, under the terms of a statute, legally culpable, and yet his conduct may not give any right of action to a private individual who sustains damage thereby. The breach of a statutory duty causing damage may fail to lay the foundation of an action $(z)$.

The subject before us has been thus judicially elucidated :"The ordinary rule," we read, "is that when the law creates a duty and the party is disabled from performing it without any default of his own, by the act of God or the king's enemies, the law will excuse him ; but when a party by his own contract creates a duty, he is bound to make it good, notwithstanding any accident by inevitable necessity" (a).

In an interesting case $(b)$ which was finally disposed of by the House of Lords, the facts were as under :-Damage was done to a pier through the violence of the wind and waves by a vessel at a time when the master and crew had been compelled to escape from her, and had consequently no control over her-regard being had to the words of a statute applicable, the owners of the vessel were adjudged not to be liable. In this case the common law liability was held not to have been extended by the legislature, and the case had consequently to be decided by reference to that liability. "If," said Lord Cairns, C., " a duty is cast upon an indi. vidual by common law, the act of God will excuse him from the performance of that duty. No man is compelled to dc that which is impossible. It is the duty of a carrier tc

(y) Atkinson v. Netcenstle and Gateshead Wateruorls Co., 2 Ex. D. 441 , questioning Couch v. Stecl, 3 E. \& B. 402. See Ross r. Rugge-I'rice, 1 Ex. D. 269, approved and followed in Brain v. Thomas, 50 I. J. Q. B. 664 ; Wiseman จ. Booker, 3 C. P. D. 184 . (z) Ward v. Hobhs, 4 App. Cas. 13

(a) Judgm., Niehols r. Marsland 2 Ex, D. 4. See Paradine r. Jane Alevn, 26.

(b) Rircr Itar Commissioners : Adamson, 2 App. Cas. 743 , referrin to Dennis r. Totell, L. R. 8 Q. B. 10 
deliver safely the goods entrusted to his care; but if in carrying them with proper care they are destroyed by lightning or swept away by a flood, he is excused, because the safe delivery has, by the act of God, become impossible $(c)$. If, however, a man contracts that he will be liable for the damage occasioned by a particular state of circumstances, or if an Act of Parliament declares that a man shall be liable for the damage occasioned by a particular state of circumstances, I know of no reason why a man should not be liable for it, whether brought about by the act of man or by the act of God. There is nothing impossible in that which, on such an hypothesis, he has contracted to do, or which he is by the statute ordered to do, namely, to be liab!e for the damages" $(d)$.

Torts, being in kind exceedingly diversified, and some considerable familiarity with their leading characteristics being essential, it may be proper to offer some further explanatory remarks and cite some additional cases concerning them $(e)$.

To commence, then, with Favcett v. The York and North Vidland $R . C .(f)$-that was an action founded in tort against the company just named, the declaration in which charged that, under certain Acts of Parliament, the defendants were required to keep closed the gates leading from in adjoining highway on to their railway, so as to prevent zattle or horses passing along the road from entering thereupon, save and except at such times as the gates were recessarily open for the purpose of allowing carriages and rattle, \&c., to cross the line. The breach alleged was that ihe defendants, "disregarding their duty and the statutes $\mathrm{n}$ that behalf, did not maintain good and sufficient gates

(c) As to the liability of a common arrier as an insurer, post, Chap. 3, .2.

(i) Per Lord Caims, C., 2 App. as. 70 . (e) See also Couley r. Mayor, \&.e, of Sunderland, 6 H. \& X. 565 .

(f) 16 Q. B. 610 . Compare with the above case Ifatson r. Baird, 3 App. Cas. 1082. 
across each end of the said highway at the point where the same was crossed by the railway," and did not keep the gates across the said highway at that point shut and closed, but omitted to do so during long spaces of time, and when the gates were not required to be open for other purposes; such being the gravamen of the charge, the damage alleged was, that certain horses belonging to the plaintiff, and at the time of the happening of the alleged wrongful act laufully being on the highway in question, strayed from thence on to the railway, and were there run down and killed by a train of carriages.

Now, it appeared in evidence that the plaintiff's horses had escaped from an adjacent field belonging to him on to the highway, and an issue was accordingly raised on the record as to whether or not the horses could be said to have been "lawfully" upon the highway in question, before passing through the gate belonging to and under the control of the company. The Court of Queen's Bench, however, in the first place, thought, that, as against the defendants, the horses were lawfully upon the highway, and, this point being disposed of, further held that the railway company were bound and required, to keep the gate in question shut at all times, except those specified in their Act; and that, havine been guilty of a breach of their duty in this behalf, and having thus occasioned damage to the plaintiff, they wert legally compellable to make it good. In this case, accord. ingly, the gist of the action was the wrongful breach of $\varepsilon$ statutory public duty cast on the defendants, coupled witl consequential damage to the complainant.

With the preceding case should be compared Ricketts $\mathrm{v}$ The East and West India Docks, dc., R. C. (g). That wa:

(g) 12 C. B. 160 ; Acc. Mranchester, Sheffield, and Lincolnshire R. C. v. Wallis, 14 C. B. 213 (citing Bird v. Holbrook, 4 Bing. 628; and Barmes r. Wurd, ante, p. 754); Midland R. C. v. Daykin, 17 C. B. 126 ; Roberts v.
Great Westem R. C., 4 C. B., N. S. 506 ; Sharrod $v$. London and N. II R. C., 4 Exch. 580.

As to obligation to maintain gates a level crossing, see Charman $v$. South Eastern R. C., 21 Q. B. D. 524 (C. A. 
an action for damage done to sheep of the plaintiff, which, straying from his land on to the defendants' lailway, were there killed. The declaration alleged that it was the duty of the defendants to make and erect a sufficient fence in and upon land taken for the use of the railway, \&c., so as to prevent cattle from escaping out of the adjoining lands on to the railway; and the breach averred was the non-observance of this duty. Such being the nature of the charge made, the defendants pleaded, inter alia, as follows:-That, at the time of the occurrence complained of, another railway company (to wit, the Great Northern) were possessed of the lands adjoining to and abutting on the defendants' lineand that the sheep of the plaintiff, being urongfully and unlaufully upon such lands, had thence escaped and strayed upon the railway, the plaintiff not being the ouner or occupier. of those lands. To this plea the plaintiff demurred; and it was therefore open to him to avail himself as well of any statutory liability imposed on the defendants, as of any negligence or misfeasance on their part at common law. Accordingly, in the first instance, reliance was placed, in his behalf, upon the stat. $8 \& 9$ Vict. c. 20 , s. $68(h)$, by which railway companies are bound to make and maintain sufficient fences "for separating the land taken for the use of the railway from the adjoining lands not taken," and "for" preventing the cattle of the owners and occupiers thereof trom straying thereout," \&c. This section of the Act, however, was held not to apply under the circumstances, inasmuch as the plaintiff was not the owner or occupier of he adjoining land. The plaintiff was consequently obliged io fall back upon his rights at common law, and to contend, imongst other things, that the defendants, carrying on a langerous trade, were bound to exercise it with more than redinary caution, so as not to do damage to the public.[o this argument, it was answered, however, that negligence

(h) See Wiscman r. Booker, 3 C. P. D. 184. 
was not alleged, and that at common law the company were only bound to keep their fences in repair, as against the proprietors of the adjoining lands, and not as against the plaintiff whose sheep were wrongfully thereupon (i).

It has more recently been held, that the duty to fence under the statutory provision above cited, is an obligation not as to passengers but with regard to the owners and occupiers of adjoining lands, and that the duty imposed on a railway company at common law is, to take every reasonable care to prevent danger to their passengers from cattle coming on to the line" where it is probable that such an event may occur $(k)$.

Again-under the stat. 1 \& 2 Vict. c. 98, the public duty was imposed upon a railway company of conveying (and therefore of conveying safely) officers of the post-office, in charge of the mails and letter bags transmitted along their line; through negligence in the performance of this duty damage was caused to the plaintiff, an officer so being conveyed; the company causing it were held to be liable tc him for their misfeasance (l).

Lastly, upon this part of the subject may be cited $C$ o v. Platt $(\mathrm{m})$, as exemplifying the importance of lookinc narrowly at the language of a statute imposing a publis duty before suing for its breach.-There the decision of the Court principally turned on the meaning of the 21st sectior of the Factory Act ( $7 \& 8$ Vict. c. 15), which required amongst other things, that "all parts of the mill-gearin in a factory should be securely fenced," and that, "th said protection to each part shall not be removed whil

(i) See Irauson r. Midland R. C., L. R. 8 Ex. 8; Marfell $v$. South Wales R. C., 8 C. B., X. S., 525; Bessant $\vee$. Great Western R. C., Id. 368.

(k) Buxton v. North-Eastem R. C., I. R. 3 Q. B. 549,553 .

(I) Collett v. London and $\mathrm{N}$. $\mathrm{H}^{*}$
R. C., 16 Q. B. 984 . In connectio with which case, see Great Forther R. C. r. Harrison, 10 Exch. 376 Lygo r. Nexbold, 9 Exch. 302.

(m) 6 Exch. 752 ; $S$. $C$. (in Error ; Id. 460 ; Britton r. Great IFester Cotton Co., L. R. 7 Ex. 130 ; follor ing Holmes r. Clarke, 7 H. \& X. $93^{4}$ 
the parts required to be fenced are in motion by the action of the steam-engine, water-wheel, or other mechanical power, for any manufacturing process." The declaration in the case before us stated that the defendants were the occupiers of a building in which steam power was used to work machinery employed in manufacturing cotton, and in part of which building there was certain mill-gearing, being a shaft which was worked and put in motion by the said steam power, yet the defendants disregarded their duty in this, that the shaft was not securely fenced, contrary to the form of the statute, whereby the plaintiff received great bodily injury, \&c. On demurrer, the above declaration was held bad, because it did not show that at the time of the accident the shaft which occasioned it was in motion for a "manufacturing process." The defect thus exposed in the declaration having been amended by inserting in it an allegation, that a certain part of the millgearing by which the accident was occasioned was in motion at the time for a mannfacturing process, the plaintiff was again defeated upon the following facts : the injury complained of was received from a vertical shaft in motion, but at a time when by its motion it turned no machinery immediately connected with it, either in the room where the plaintiff was, or in any other room, the shaft in question being itself turned by a horizontal shaft communicating with the motive power. Looking at the evidence adduced, the Court held, that the shaft, which caused the damage, could not when it happened, be said to have been in motion for " any manufacturing process," and did not therefore at that time need to be fenced under the provisions of the Factory Act $(n)$.

We may now conclude that a statutory duty towards the public may. consist either in doing, or in abstaining from

(n) Coe v. Platt, 7 Exch. 923. See Doel v. Sheppard, 5 E. \& B. 856; Casuell v. Worth, Id. 849, as to which see per Pigott, B., L. R. 7 Ex. 139 ; $19 \& 20$ Vict. c. 38. 
doing, some particular act. And in regard to cases such as spoken of, the following propositions may be stated as often found applicable to facts falling within the class which has been under our notice:- that "if the law casts any duty upon a person, which he refuses or fails to perform, he is anstrerable in damages to those whom his refusal or failure injures" (o)-that the non-performance of a legal obligation of this kind will not be actionable without special damage $(p)$; that "when a ministerial duty is imposed, an action lies for breach of it without malice or negligence" $(q)$,- -and further, that "where any law requires one to do any act for the benefit of another, or to forbear the doing of that which may be to the injury of another, though no action be given in express terms by the law for the omission or commission, the general rule of law in all such cases is that the party so injured shall have an action" $(r)$ : this last proposition being, however, subject to an important qualification, viz., "that an action will not lie for the infringement of a right created by statute, where another specific remedy for infringement is provided by the same statute" (s) or as remarked in Doe d. Bishop of Rochester v. Bridges ( $t$ ), "where an Act creates

(o) Per Lord Brougham, Ferguson v. Earl of Kinnoull, 9 Cl. \& F. 289; Hurst v. Taylor, 14 R. B. D. 918.

(p) As to this proposition, see the reasoning, ante, p. 749, n. $(p)$. See also Onen v. Legh, 3 B. \& Ald. 470 (distinguished in Cort $v$. Ambergate, \&r:., R. C., 1 E. \& B. 120, where Coleridge, J., observes,_- "If a man sells a book in my library without meddling with it, he does me no harm; but if he takes it away and sells it in market overt, I lose my book," and shall consequently be entitled to redress as against the wrong-doer): Rodgers v. Invker, 18 C. I3. 112 ; Luens v. Tarleton, 3 H. \& N. 116.

(q) l'er Bovill, C. J., Thekering v. James L. R. S C. 1. 503.

(v) I'er Lord Holt, C. J., Ashby v. White (ed. 1837), p. 11 .

(s) Judgm. Stevens r. Jeacacke, II Q. B. 741 (citing Uuderkill v. Ellicombe, M'Cl. \& Y. 450); Watkins r. Great Jorthern R. C., 16 Q. B. 961. See Chapman v. Pickersgill, 2 Wils. 146, 147. Manchester, \&c., $R y$. . Denaby Main Coll. Co., 14 Q. B. D. 209, affirming $S . C ., 13$ Id. 674 ; followed in Rhymney $R$. C. . Rhymney Iron Co., 25 Q. B. D. 146 (C. A).

(t) 1 B. \& Ad. 847,859 .

Further, it seems to be true, tbat, "Where authority is given by the Legislature to do an act, parties injured by the doing of it have no legal remedr, but should appeal to the Legislature:" Filgrim $v$. Southampton and Dorchester R. C., 7 C. B. 226 . 
in obligation and enforces the performance in a specified nanner," it holds generally true " that performance cannot se enforced in any other manner" $(u)$. Where, moreover, $\checkmark$ statutory duty is created with the object of preventing a nischief of a particular kind, and a person by reason of he neglect of such duty by another, suffers a loss of a lifferent kind, the party suffering such loss is not entitled o maintain an action in respect of it $(x)$.

Thirdly, a right of action ex delicto may be founded on he infraction of some private compact, or of some private luty or obligation, and consequential damage to the omplainant.

Any duty must, in strictness, be deemed "private" which Rights of action ex delicto.

Class III. Action for breach of jrivate duty - producing dainagre.

$s$ to be observed, not towards the community at large, but n relation to one or more individuals. The class of private uties is extremely large: it comprehends duties flowing rom contract express or implied, from bailment, from the elation of master and servant, of host and guest $(y)$, of hopkeeper and customer $(z)$, or of landlord and tenant,rom the occupancy of land or houses $(a)$, \&c.; as throwing ome light upon the nature of such duties, the authorities ifra may be consulted (b).

Upon a railway company stringent obligations are imosed, having reference to passengers and others-thus:

(u) See Coe v. Wise, L. R. 1 Q. B. 11.

(x) Gorris r. Scott, L. R. 9 Ex. 125, 30.

(y) Southcote r. Stanley, 1 H. \& X. 17: cited per Williams, J., Corby v. lill, 4 C. B., N. S., 565 ; Walker . lidland R. C., 55 L. T. 489.

(z) Chapman r. Rothuell, E. B. \& . 168, which "falls within the class i cases where the liability results from 1 inritation being held ont to third ersons to go upon the premises" here the injury complained of hapans: per Keating, J., Hounsell v. myth, 7 C. B., N. S., 740.

See Boleh r. Simith, 7 H. \& N. 736,
744; Williams v. Groucott, 4 B. \& S. 149 ; John v. Bacon; L. R. 5 C. P. $43 \%$.

(a) See Nelson r. Liverpool Brevery Co., 2 C. P. D. 311 ; Giles r. Walker, 24 Q. B. D. 656.

(b) Wood v. Curling, 15 M. \& W. 626 ; S. C., 16 Id. 628; White r. Phillips, 15 C. B., X. S., 245, 254; Cooke v. Wilson, 1 C. B., X. S., 153 ; Keates v. Farl of Cadogan, 10 C. B. 591: Gott v. Gandy, 2 E. \& B. 845 ; Colebeck r. Girdlers' Co., 1 Q. B. D. 234; Alston r. Grant, 3 E. \& B. 128 ; Seymour r. Maddox, 16 Q. B. 326; Wilkinson v. Fairrie, 1 H. \& C. 633; Broun r. Booman, 11 Cl. \& F. 1. 
Where a man is on the premises of such a company for the purpose of carrying into effect a contract of carriage and delivery, and gets the assent of the company (as indicateo by the usual course of business) to assist in the delivery the plaintiffi is entitled to redress if the part of the premises where he is engaged is in a condition which is dangerous to the persons engaged upon it and injury ensues to him (c)

In any case referable to the class before us the plaintif must, in order to sustain his action, be able to prove some kind of contract or obligation out of which the specific duty with a breach whereof the defendant is charged, will flow in legal contemplation, or he must adduce evidence of fact: establishing such a relation between the defendant and him. 1. self, that such specific duty will thence result $(d)$. Further 2. than this, he must, of course, show a breach of the duty 3 thus raised, and consequential damage $(e)$ to himself.

Statutory private duts.
A private as well as a public duty may exist by virtue of the statute or of the common law. Thus, it has been held that an action will lie against a railway company for wrong. ful omission of their statutory duty in regard to the transfer of shares, and for wrongfully declaring the same forfeited and selling them $(j)$. " "The declaration," said Lord Camp. bell, C. J., in the case referred to, "shors both, injuria and damnum. The defendants have been guilty of a wrongfu. act of omission in not registering the plaintiff's name in their books, and also of a wrongful act of commission ir declaring the shares to be forfeited, and in confirming tha forfeiture. It is said that the plaintiff could sustain no injury; but he has been deprived of the ordinary privileges of shareholders, and contingently of any profits that migh

(c) Per Cleasby, B., Wright s. London and Forth-Western R. C., $\mathbf{Q}$. B. D. $25 \%$, approving Holmes r. WorthEastern R. C., L. R. 4 Ex. 254, 6 Id. 123.

(d) See W"ilson r. Nexberry, L. R. † Q. B. 31 . 190.

(e) See Hood r. Hood, L. R. 9 Er

(f) Catehpole r. The Ambergate, ge. R. C., 1 E. \& B. 111 ; Skimner o City of London Insce. Co., 14 Q. B. D 882 . 
have arisen upon the shares. These are clearly injuries, for which he has a right to bring an action."

Again-a private duty may exist at common law (g), for breach whereof, coupled with consequential damage, an action will be sustainable (h). Upon this part of the subject I shall here offer a few general remarks, which will be applied seriatim to several large and important classes of cases.

In the first place it may be conrenient to observe, that although tort in general differs essentially from contract as Tort flowing of coutract. the foundation of an action, it not unfrequently happens hat a particular transaction admits of being regarded from iwo different points of view, so that when contemplated rom one of these it presents all the characteristics of a rood cause of action ex contractu; and, when regarded from he other, it offers to the pleader's eje sufficient materials shereupon to found an action ex delicto (i). Thus carriers rarrant the transportation and delivery of goods entrusted ;0 them; solicitors $(k)$, surgeons and engineers undertake 0 discharge their duty with a reasonable amount of skill, ind with integrity; and for any neglect or unskilfulness by ndividuals belonging to one of these professions, a party rho has been injured thereby may maintain an action ither in tort for the wrong done or in contract at his elecion (l). In short, to use the words of Lord Campbell, C. J., n Broun v. Boorman ( $m$ ), wherever there is a contract, and

(g) Duties, such as are now alluded 3, oftentimes arise by virtue of estalished maxims of our common law ; for stance, the maxim, Sic ntere tuo ut jenum non lædas, in connection with le rights of ricinage. See Leg. Max., th ed., p. $347 ;$ Borcer ₹. Peate, 1 .B. D. 321 ; and see many of the cases ready cited as illustrating the nature a tort. Ante, p. 79 ; post, p. 881 .

(h) See Dutton v. Porles, 2 B. \& S. i4, 191.

(i) See Legge v. Tucker, 1 H. \& $\mathbf{N}$.

B.C.L.
Privateduty at common law.
500; Tattan r. Great Western R. C., 2 E. E E. 844; Morgan r. Rarey, 6 H. \& X. $265 ;$ Corbett r. Packington, 6 B. \& C. 268 .

(i.) See, for instance, Whiteman r. Hackins, + C. P. D. 13.

(I) See Bartholomew r. Bushnell, 20 Day (U. S.) R. 279, 280 ; Poz=i r. Shipton, 8 Ad. S E. 963.

In Lee r. Walker, L. R. T C. P. 121, a patent-agent was held liable for negligence.

(m) 11 Cl. \& F. 44. 
something to be done in the course of the employment which is the subject of that contract,-if there is a breach of a duty in the course of that employment, the plaintifl may recover either in tort or in contract: that is to say, " where there is an employment, which employment itself creates a duty, an action . . . will lie for a breach of that duty, although it may consist in doing something contrary to an agreement made in the course of such employment by the party upon whom the duty is cast" $(n)$. "Gene. rally speaking," indeed, said Maule, J. (o), "the law has endeavoured to assimilate actions of tort arising out of contract with actions on contracts : " so that the breach of a contract may be a wrong, in respect of which the party injured may sue in tort, instead of suing upon the contract $(p)$.

Privitywhether necessary in an action ex delicto.

Now, where the tort complained of thus flows from a contract express or implied, there is manifestly direct privity between the parties $(q)$. It must not, however: thence be inferred that privity is in general necessary tc support an action ex delicto; many of the cases already cited show that it is not so. As illustrating the distinctior here adverted to between actions of contract and of tort cases may readily be instanced:-A. (a stage-coach pro. prietor) contracts with B. to carry his servant (C.), and ir so doing is guilty of negligence, which causes bodily harm to C., and consequent damage, by reason of loss of servic to his master. Under these circumstances, A. may br sued in an action ex contractu by B., and in an action ex delicto by C.-privity not being needed to support sucl latter action-which is founded upon the principle, that where a coach proprietor undertakes to convey a passenger

(n) Per Jervis, C. J., Courtenay v. Earle, 10 C. B. 83. 319 .

(o) Howard 8 . Shepherd, 9 C. B.

(p) Per Cresucell, J., 9 C. B. 321.

An action of tort, however, would not lie for a mere breach of contract:
Judgm., Woods r. Finnis, 7 Excl 372 .

(q) Playford v. Cnited Kingda Telegraph Co., L. R. 4 Q. B. $70 t$ followed in Dickson v. Rewter's Tel graph Co., 2 C. P. D. 62, S. C affirmed 3 Id. 1. 
and does so negligently, he is answerable for the consequences $(r)$.

The following state of facts, put hypothetically by a learned Judge (s), may further exemplify our subject. "Railway $A$. issues tickets for railway $A$. and railway $B$. The traficic is sometimes worked by carriages and servants belonging to railway $A$., and sometimes by carriages and servants belonging to railway $B$. A passenger takes a ticket from railway $A$. and gets into a carriage belonging to railway $B$., drawn by railway B.'s engines and manned by railway B.'s servants. The passenger traverses some portion of railway B.'s line, an accident is caused by the negligence of railway B.'s servants and through some defect in railway B.'s aarriages not being properly adapted to the exigencies of the traffic." Under such circumstances it seems, according to the authorities, that the passenger could sue either railray A. or railway B. "He could sue railway $A$. on the sontract arising from the ticket issued by the company to zarry him the whole distance with reasonable care and saution, or he could sue railway $B$. as the immediate uuthors of the negligence, on the implied contract or Indertaking which would arise from his having been eceived into the carriage, or from his having been invited o go into the carriage, of railway B., and become a pasenger on the railway."

As to whether the facts of a case give rise to a cause of ction founded on tort or upon contract, the following emarks of Smith, L. J., in Kelly v. Metropolitan K. C. (t), re in point:- "The distinction is this: if the cause of

(r) Marshall จ. York, Neucastle, hed Berwich R. C., 11 C. B. 655; ited in Foulkes v. Metropolitan Disiet $R$. C., 4 C. P. D. $277,278,281$.

(8) Per Lopes, J., in Foullies v. Cetropolitan District R. C., 4 C. P. D. $82 ;$, followed in Hooper $\mathrm{v}$. London 4d North-Western R. O., 50 L. J. B. 104, where semble that Ifytton
F. Midland R. C., 4 H. \& N. 615 , is overruled. See also Berringer v. Great Eastem R. C., 4 C. P. D. 163.

( $t$ ) (1895) 1 Q. B. 944 (C. A.) at p. 947 . Cf. also this case as to Taylor v. Manchester, Sheffield, and Lincolnshive R. C., (1895) 1 Q. B. 134 (C. A.). See also Meux v. Great Eastern R. C., (1895) 2 Q. B. 387 (C. A.). 
complaint be for an act of omission or nonfeasance whicl without proof of a contract to do what has been left undon would not give rise to any cause of action (because no dut? apart from contract to do what is complained of exists) then the action is founded upon contract and not upor tort. If, on the other hand, the relation of the plaintiff: and defendants be such that a duty arises from the rela tionship, irrespective of contract, to take due care, and thr defendants are negligent, then the action is one of tort."

Additional states of facts here in point will sugges themselves to the reader. If a mason contracts to erec a bridge or other work on a public road, and erect it not in accordance with his contract, and so as to be nuisance to the highway, a third person who sustain injury by reason of its defective construction may recove damages from the contractor, who will not be allowed $t$ protect himself from liability by showing an absence $c$ privity between himself and the injured party, or $b$ showing that he (the defendant) is also responsible $t$ another for breach of contract (u). So, if an apothecar administer improper medicines to his patient, or a surgeo unskilfully treat him and thereby injure his health, th apothecary or surgeon will be liable to the patient, eve where the father or friend of the patient may have bee the contractee; for, though no such contract had bee made, the apothecary, if he gave improper medicines 1 a customer, or the surgeon, if he unskilfully treated patient, would be liable to an action for misfeasance $(x)$.

The general rule, that 'privity is not requisite to suppo an action ex delicto,' was recognised and applied by th Court of Queen's Bench in Gerhard v. Bates $(y)$. The:

(u) Judgm., 6 Exch. 767. See Recdie $\mathrm{r}$. London and North-Western R. C., 4 Exch. 244, 257 ; Kearney r. London and South Coast R. C., L. R. 6 Q. B. 759. (x) Pippin r. Sheppard, 11 Pri 400; Gladecell v. Steggall, 5 Bir N. C. 733 ; Judgm., 6 Exch. 767.

(y) 2 E. \& B. 476 ; Pcck v. Gurm L. R. 6 H. L. 377 , post, p. 776 . 
the declaration contained two counts-the one founded in contract, noticed at p. 318; the other founded in tort, which, after stating the formation of a company for the purpose of smelting and refining the ores of certain Spanish mines, and that twelve thousand shares therein were to be appropriated and offered to the public at $12 s .6 d$. per share, alleged that the defendant, intending to defraud, deceive, and injure the public, and to cause it to be publicly represented and advertised that the said company was likely to be a safe and profitable undertaking, and also to deceive the public, who might become purchasers of the said twelve thousand shares, and to induce them to become such purchasers, falsely, fraudulently, and deceitfully caused and procured to be publicly advertised and made known, by a ertain prospectus, certain false statements, by means of which the defendant wrongfully and fraudulently induced the plaintiff to become the purchaser and bearer of a large number of shares in the said undertaking, in consequence whereof he incurred loss. Against the sufficiency of this rount it was strongly urged that no privity was shown to xist between the plaintiff and defendant, and that such rivity was necessary, as the action did not arise from any public wrong, or the neglect of any public duty. The jourt, however, held that the action was maintainable, 'being founded, irrespectively of contract, upon a false epresentation, fraudulently made by the defendant to the laintiff, for the purpose of inducing the plaintiff to act pon it, the plaintiff showing that by so acting upon it he ad suffered damage. Under such circumstances, although he parties be entire strangers to each other, the action es; and it would be strange if a man who has so suffered amage from the wrongful act of another were without emedy" (z).

( $)$ Judgm., 2 E. \& B. 491 ; Richard$n$ r. Silvester, L. R. 9 Q. B. 34 ;
$B e h n$ พ. Kemble, 7 C. B., N. S., 260.

See Childers v. Wooler, 2 E. \& E. 287. 
In the declaration above abstracted it will be noticed that fraud was distinctly alleged. In Langridge v. Levy (a) (which is a leading case in regard to privity as an ingredient in an action of tort, and demands accordingly investigation), fraud was both alleged and proved. This remark will presently be found material. The facts in Langridge v. Lery were as follows:-The plaintiff's father purchased of the defendant a gun, warranted to have been made by a particular maker, stating at the same time that the gun was required for the use of himself and his sons. The plaintiff, having been injured by the bursting of the gun, sued the defendant for damages in an action of tort. At the trial it was proved that the gun had not, in fact, been made by the particular individual named in the warranty; and a general verdict, with heavy damages, was found for the plaintiff. The defendant having moved in arrest of judgment, the Court were called upon to decide as if the following facts had been actually found by the jury $(b)$, viz., that the defendant had knowingly sold the gun in question to the father for the purpose of being used by the plaintiff: and had knowingly made a false warranty that this might be safely done, in order to effect the sale; and, further; that the plaintiff, on the faith of such warranty, and believing it to be true, used the gun, and thereby sustained damage Now here it was contended, on behalf of the defendant that there was no privity whatever between himself and the plaintiff, that there was no breach shown of any public duty, nor even a violation of any private right existing between the parties to the action. The Court, however

(a) 2 M. \& W. 519 ; S. C. (in Error), 4 Id. 337 ; George v. Skitington, L. R. 5 Ex. 1. See Barry r. Croskey, 2 J. A II. 1 .

"The rule deducible from Langridge ․ Levy, and the cases there referred to, is that when the action is not upon a contract, in order to constitute a cause of action for false representation the plaintiff must prove that the de fendant was guilty of fraud, and tha he has sustained damage the result 0 that fraud :" per I"atson, B., East rcood r. Bain, 3 H. \& . . $7 \notin 2$.

(b) See Judgm., 2 M. \& W. 531. 
held that the defendant, having been guilty of deceit, was responsible for its consequences whilst the instrument sold by him was in the possession of an individual to whom his fraudulent statement had been communicated, and for whose use he knew that it was purchased $(c)$. It has been held under analogous circumstances that negligence producing damage is actionable $(d)$. Further, a person who gives another dangerous goods to carry is bound to give notice of their dangerous character to the party employed to carry them, and will be liable for damages resulting from his omission to do so $(e)$.

It must not, however, be inferred from the preceding cases hat "wherever a duty is imposed on a person by contract or otherwise, and that duty is violated, any one who is njured by the violation of it may have a remedy against ihe wrong-doer" $(f)$. Such a principle, if recognised, would mpose an indefinite extent of liability and lead to the "most absurd and outrageous consequences" $(g)$. This imjortant limitation of the rule respecting privity is exemplified $\mathrm{n}$ and was fully established in Longmeid v. Holliday (h). There a husband and his wife sued in tort for an injury to he wife, caused, as alleged, by the fraudulent and deceitful rarranty of a lamp sold by the defendant. Now, in this ase, the warranty was made to the husband, the jury regatived the existence of fraud, and it was held that the rife could not properly be joined as a co-plaintiff in the iction, because the injury to her flowed from the breach of

(c) "The ground of the decision" in he case abstracted, supra, "was, that he gun was expressly bought for the on to use": per Crowder, J., Behn v. Temble, 7 C. B., N. S., 267. Et vide ver Pollock, C. B., 4 H. \& N. 548, 549. (d) George v. Skivington, L. R. 5 ix. 1.

(e) Farrant v. Barnes, 11 C. B., i. S. 553; Brass v. Maitland, 6 3. \& B. 470 .

(f) Judgm., 2 M. \& W. 530. (g) Per Lord Abinger, C. B., Winterbottom v. Wright, 10 M. \& W. 114.

Compare Priestly v. Fowler, 3 M. \& W. 1 (as to which, howerer, v. post, p. 811).

The principles there laid down do not apply to a contract of towage: Bland v. Ross, 14 Moo. P. C. C. 210 ; approved in Spaight v. Tedcastle, 6 App. Cas. 217.

(h) 6 Exch. 761 ; with which compare George v. Skivington, L. R. 5 Ex. 1. 
contract, which was with the husband alone. The absence of fraud distinguishes this case from Langridge v. Levy. "There is no doubt," as observed by the Court, " that if the defendant had been guilty of a fraudulent representation that the lamp was fit and proper to be used, knowing that it was not, and intending it to be used by the plaintiff's wife or any particular individual, the wife (joining her husband for conformity), or that individual, would have had an action for deceit upon the principle upon which all actions for deceitful representations are founded, and which was strongly illustrated in the case of Langridge v. Lery (i), viz., that if any one knowingly tells a falsehood with intent to induce another to do an act which results in his loss, he is liable to that person in an action for deceit. But the fraud being negatived in this case, the action cannot be maintained on that ground by the party who sustained damage."

In an important case $(k)$ originating in Chancery the bill alleged misrepresentation and concealment of facts by the directors of a company in a prospectus issued by them with a view to its formation, whereby plaintiff had been induced to purchase shares in the company, and had been damnified. The bill sought to enforce indemnity from the estates of the directors. Lord Chelmsford here observed that the suit was precisely analogous to the common law action for deceit. "There can be no doubt that equity exercises a concurrent jurisdiction in cases of this description, and the same principles applicable to them must prevail both at law and in equity." His lordship further showed that the directors had been guilty not merely of passive reticence or conceal-

(i) Whieh case is also eommented on and explained in Howard v. Shepherd, 9 C.13. 297 ; Winterbottom v. Wright, 10 M. \& W. 109, 113; Collis v. Selden, L. R. 3 C. P. 495, 497; Gerhas'd v. Bates, 2 E. \& B. 48t, 491; Blukemore v. Bristol and Exeter R. C., 8 E. \& B. 1052, 1053 (where Coleridge, J., delivering judgment, observed, "It

has always been considered that Lang. ridge v. Levy was a case not to be extended in its applieation"). See Collins v. Cave, 4 H. \& N. 225 ; Heacen v. Pender, 11 Q. B. D. 503, 513. 377 . 
ment, but of active misrepresentation of the truth-for which civil responsibility would attach to them-but held that on technical grounds an insuperable difficulty existed to making the defendants responsible upon the facts, there being nothing to connect the directors making the represenfation complained of with the party complaining that he had been deceived and damaged by it. The parties had never been brought into direct communication with each ther. "The purchaser of shares in the market, upon the aith of a prospectus which he has not received from those who are answerable for it, cannot, by action upon it, so sonnect himself with them as to render them liable to him or the misrepresentations contained in it, as if it had been uddressed personally to himself" $(l)$.

In the case referred to, Lord Chelmsford held that the axecutors of a deceased director could not be charged for he fraud of their testator in violation of the well-known naxim-Actio personalis moritur cum personâ. There can se no doubt, said he, that " if an action at law had been rought by plaintiff instead of this proceeding in equity, he executors could not have been made liable, and in the xercise of a concurrent jurisdiction by Courts of Law and Iquity both Courts ought to proceed upon the same priniples." No case is producible "in which, upon a claim gainst a testator ex delicto, executors have been held liable n equity to answer for it in damages, and it would be conrary to principle to hold that an action which in a Court if Law would be held to die with a testator should be aaintainable in a Court of Equity of concurrent jurisdicion against executors."

The proposition, then, already stated, that "privity is ot requisite to support an action ex delicto," must be

(l) See Weir v. Bell, 3 Exch. D. 38,242 ; secus if one of the obcts of the prospectus is to induce persons to whom it is sent to purchase shares in the market, Andreus v. Mlockford, (1896) 1 Q. B. 372, C. A. 
limited; "an action will not lie at the suit of $\mathrm{C}$. for the breach by B. of a duty which he owes to A." $(m)$; A. employs B., a solicitor, to do some act for the benefit of C., A. having to pay B., and there being no intercourse of any sort between $B$. and $C$.,-if through the gross negligence or ignorance of $\mathrm{B}$. in transacting such business $\mathrm{C}$. loses the benefit intended for him by A., C. cannot maintain an action against $B$. to recover damages for the loss. sustained. If the law were so, a disappointed legatee might sue the solicitor employed by a testator to make. a will in favour of a stranger whom the solicitor never saw or before heard of, if the will were void for not being properly signed and attested $(n)$.

If, on the other hand, in a transaction of borrowing and lending money on security, A., the borrower, employs B., a solicitor, to transact the business, in which both $\mathrm{A}$., the borrower, and C., the lender, have their separate interests, and for which A. alone is to pay B., although C. has no personal intercourse with B.,-if from the instructions expressly given by $A$. to B., or from the usual course in which such business is conducted, B. knows that he, and no other professional lawyer, is employed in the transaction, and that B. is to act for both A. and for C. in preparing the security, a jury, from this employment of B., might properly infer an undertaking from $B$. to $C$. to conduct the transaction on his part with reasonable skill and diligence. And so if in the transaction of a loan on security C. Tas a surety for the borrower, and, according to the transaction as explained by A. to B., C. was to have a counter-security from A., to be prepared and completed by B. for C., as the only lawyer to be employed between them, a similar undertaking from B. to C. might be inferred $(o)$. Under such

(m) Yer Willes, J., Barker v. Midland R. C., 18 C. 13. 59.

(ii) Per Lord Campbell, C., Robertson v. Fleming, 4 Macq. H. L. Ca.
177 ; per Lord Cramuorth, Id. 184, 185.

(o) Per Lord Campbell, C., 4 Macq. II. L. Ca. 177,178 . 
circumstances there would be some evidence of privity between the last-named parties.

Secondly, not only may a right of action ex delicto spring at once out of a contract: it may exist by virtue of the rule laid down by Mr. Smith, in his note to Coggs v. Bernard $(p)$, in these terms: "The confidence induced by undertaking any service for another is a sufficient legal consideration to create a duty in the performance of it."

The rule here stated is one of much importance, and applies so as to fix with liability even an unremunerated gratuibailee or agent, who, having actually entered on the pertormance of his duties, is guilty of negligence in discharging them $(q)$. The rule in question cannot, however, be exsended so as to render a mere licensee liable for damage, provided that he takes reasonable care of that which he is permitted to use $(r)$, or to make a gratuitous agent guilty or nonfeasance, as, for instance, in refusing to assume he office which he had voluntarily offered to assume $(s)$.

Thus,-A. is the owner of a vessel, which B. voluntarily indertakes to get insured; B. neglects to do so, and, the ressel being lost, $\mathrm{A}$. thus sustains damage through the nonperformance of his undertaking by $B$. A. will be without :edress $(t)$, inasmuch as there was no consideration for B.'s romise.

To cases falling within the operation of the rule just ;tated, further reference will be made in connection with he law of bailments $(u)$.

The third class of cases to which attention must specially se drawn, pending this inquiry as to the nature of a right

Action for breach of duty undertaken; (p) Ld. Raym. 909 ; 1 Sm. L. C., 9th d., 201 ; Judgm., Blakemore v. Brisol and Exeter R. C., 8 E. \& B. 1050 , 051. See White v. Humphery, 11 Q. 3. 43 ; Judgm., MacCarthy v. Young, H. \& N. 336 . 4 .

(a) Wilkinson v. Coverdale, 1 Esp. (r) See Williains v. Jones, 3 H. \&
C. 602 .

(s) Balfe v. West, 13 C. B. 466 , and cases there cited. See Simpson v. Lamb, 17 C. B. 603.

$(t)$ So held in Thorne v. Deas, 4 Johus. (U. S.) R. 84 ; cited arg., 13 C. B. 470 .

(u) Post, Chap. 3, s. 2.
Right of action founder on frawl, deceit, or 
misrepresentation, and consequential damage.

Right of action founded on the malicious doing of an act and conse. quential damage.

of action ex delicto founded on the breach of a private duty and consequential damage, has been already from time to time indicated. It is characterised by the existence of fraud on the part of the defendant, prejudicing the plaintiff $(x)$.

Fraud and deceit in the defendant and damage to the plaintiff, it has been said, are a sufficient foundation for an action founded in tort, "though no benefit accrue to the defendant. The action will lie whenever there has been the assertion of a falsehood with a fraudulent design as to a fact when a direct and positive injury arises from such assertion" $(y)$. "There being fraud and a consequential loss arising from that fraud, there is a complete cause of action against the party guilty of that fraud" $(z)$. In any case of this kind the plaintiff's cause of action is that he has been damaged by the defendant's fraud $(a)$. Simple fraud $(b)$ or misrepresentation $(c)$ gives no cause of action, and unless the plaintiff can show that he has been injured by it he will not succeed. In Chap. IV. of this Book we shall inquire somewhat further as to the nature of an action for fraud producing damage.

In the fourth and last class of cases here demanding notice, the right of action $e x$ delicto is founded upon the malicious doing of a wrongful act and consequential damage to the plaintiff. As in the chapter next ensuing an inquiry respecting the legal signification of the word 'malice' will become necessary, it will suffice for the present to refer to

(x) See Wilkin v. Reed, 15 C. B. 192; Milne v. Marwood, Id. 778, which is a rather curious case.

(y) Judgm., White v. Merritt, 3 Seld. (U. S.) R. 356, 357; Childers v. Wooler, 2 E. \& E. 287 , and cases there cited; Denton v. Great Worthern R. C., 5 E. \& B. 860 . See post, Chap. 4.

(z) Per Lord Wensleydale, Cullen v. Thomson's Trustees, 4 Macq. Sc. App. Cas. 439. (a) If, howerer, "A. makes a false statement upon which the plaintiff would not have acted but for a subsesequent false statement by $\mathrm{B}$., $\mathrm{A}$. would not be liable to an action. B. would be the causa causans: "per Bramiell, B., Tatton r. Wade, 18 C. B. 382.

(i) Per Parke, B., Price r. Hewett, 8 Exch. 148. 738 . 
an action for a malicious prosecution, or for a malicious arrest, the nature whereof is hereafter considered $(d)$, and also to the cases below cited (e), as showing the nature of the right of action alluded to.

Having thus to some extent investigated the nature of and ingredients in a right of action ex delicto $(f), \mathrm{I}$ shall proceed to speak-1st, of Torts to the Person and ReputaClassification of torts adopted in the ensuing tion; 2ndly, of Torts to Property, whether Real or Personal; 3rdly, of Torts not directly affecting the Person, Reputation, or Property. Subsequently the measure of damages in an action founded upon tort will briefly be indicated.

Besides the convenience of the arrangement just suggested for an elementary treatise, there is to some extent wuthority for its adoption ; for instance, Sir Henry Finch (g) tells us that our law regards the person above his possessions, life and liberty most, freehold and inheritance above chattels, and chattels real above personal.

(d) Post, Chap. 2.

(e) Rogers v. Macnamara, 14 C. B. 27, where the defendant, who had emloyed the plaintiff as conductor of a netropolitan stage carriage, was charged with wrongfully and maliciously damag$\mathrm{ng}$ and defacing the plaintiff's licence. With the above case should be comjared Hurrell v. Ellis, 2 C. B. 295. See also Haddan v. Lott, 15 C. B. 111 ; Collins v. Cave, 4 H. \& N. 225; S. C., 6 Id. 131.

(f) A right of action for an injury to the wife, child, or servant of the complainant, will fall under the second or third of the above classes of rights of action ex delicto, according as the circumstances of the particular case disclose a breach by the defendant of a public or of a private duty. A right of action ex delicto, available under Lord Campbell's Act or otherwise, with a view to benefiting the estate of the deceased, may be referred to one or other of the above three classes, regard being had to its specific nature.

(g) Discourse of Law, p. 29. 


\section{CHAPTER II.}

TORTS TO THE PERSON AND REPUTATION.

"The right of personal security," says Sir W. Blackstone (a), "consists in a person's legal and uninterrupted enjoyment of his life, his limbs, his body, his health, and his reputation," to each of which he may be said to have a natural inherent right, which cannot be wantonly destroyed, infringed, or restricted " without a manifest breach of civil liberty" $(b)$, laying in very many cases the foundation of an action for damages.

Torts to the personwhat.

Torts to the Person, with a consideration of which this chapter may properly commence, include-1. Bodily injuries, whether direct, as assault and battery, or consequential, resulting from negligence or otherwise; 2 . Injuries to the health or comfort of an individual; 3. Torts which affect personal liberty.

Action for bodily injury.

Intentionwhether inaterial.

1. To the constitution of a right of action for a bodily injury, whether direct or consequential, it is material in limine to observe, that the existence of an evil intention in the mind of the wrong-doer is not essential. "Though a man doth a lawful thing, yet if any damage do thereby befall another, he shall answer it, if he could have aroided it" (c).

(a) 1 Bla. Com., p. 129.

(b) Id., p. 130.

(c) Lambert v. Bessey, T. Raym. 422 ; cited per Lord Cranuorth, Rylands v. Fleteher, L. R. 3 H. L. 341 , who says - "When one person in managing his own affairs causes, however innocently, damage to another, it is obviously only just that he should be the party to suffer:" Fleteher v. Smith, 2 App. Cas. 781 , cited post; Gilbon r. Tepper, Salk. 637. See Wilson $\mathrm{v}$. Newbery, L. R. 7 Q. B. 31 ; and per Isord Fitzgerald, Nitehell v. Dorley Main Colliery, 11 App. Cas. 127, 143. Holmes v. Irather, I. R. 10 Ex. 261, well illustrates the words italicised in the text. 
And again, "trespass may sometimes lie for the consequences of a lawful act" $(d)$. Thus, "if a man assault me, and I lift up my staff to defend myself, and in lifting it up [undesignedly] hit another, an action lies by that person; and yet I did a lawful thing " $(e)$ in endeavouring to defend myself. The case of Weaver v. Ward $(f)$, moreover, clearly shows that trespass may lie for a mere mischance-for an act done by the defendant casualiter et per infortunium et contra voluntatem suam-the accident not having been inevitable nor occasioned by the plaintiff's negligence.

Perhaps, however, the most convincing proof which can be given that our law will not excuse a person charged ex delicto by reason of the absence from his mind of any wrongful or malicious motive, is this, that even a lunatic will be civilly answerable for his torts, although wholly incapable of design-a doctrine flowing from the general principle already intimated, that, whenever one person receives an injury or bodily hurt directly from the voluntary act of another, that is a trespass, although there was no design to injure $(g)$.

So to an action brought for bodily injury, caused by negligence or want of skill, the mere absence of a design to injure will not furnish ground of defence, although in determining the amount of damages to be awarded to the complainant in such a case a jury will doubtless look at all the surrounding circumstances which accompanied the doing of the act complained of, and, inter alia, at the apparent animus of the defendant.

Whether an act causing bodily hurt to another were or were not purposely done to effect that end may, indeed, as regards the criminal liability of the actor, be most material.

(d) Per Blackstone, J', Scott $\mathrm{v}$ Shepherd, 2 W. Bla. 894.

(e) Lambert v. Bessey, T. Raym. 123; Underwood v. Hewson, Str. 596 ; Leame v. Bray, 3 East, 595, 596; see
Preface to 7 R. R. vii.

(f) Hobart, 134.

(g) Wearer v. Ward, Hob. 134; Bac. Abr. "Trespass" (G); Cross v. Andrews, Cro. Eliz. 622. 
The object which purely civil procedure has in view is, however, rather the compensation of a private wrong sustained, than the punishment of a public offence.

Having premised these general remarks, I will briefly notice the remedies afforded by our law for bodily injuries, direct or consequential.

Assanlt- An assault may be committed without actual battery ; an attempt or offer to beat another without touching him, as if one lifts up his cane or his fist in a threatening manner at another, or strikes at but misses him $(h), \ldots$ " a threat of violence exhibiting an intention to assault, and a present ability to carry the threat into execution " (i)-will amount and battery. in law to an assault. So also, a fortiori, does a battery, which includes an assault $(k)$, and is described as the unlarful beating of another-the least touching of another's person wilfully or in anger $(l)$; for " the law cannot draw the line betreen different degrees of violence, and therefore totally prohibits the first and lowest stage of it, every man's person being sacred, and no other having a right to meddle with it in any the slightest manner" $(m)$. An assault, however, must be an act done against the will of the party

(h) 3 Bla. Com. 120.

(i) Per Jervis, C. J., Read r. Coker, $13 \mathrm{C}$. B. $\mathrm{S} 50, \mathrm{~S} 60$, where various authorities upon this subject are cited (of which see particularly Stephens $v$. Myers, 4 Car. \& P. 349); Innes $\mathrm{r}$. Wylie, 1 Car. \& K. 257; Blake v. Barnard, 9 Car. \& P. 626 ; Reg. r. St. George, Id. 4S3, doubted in Reg. r. Broicn, 10 Q. B. D. 381, overruled Reg. F. Duekecorth, (1892) 2 Q. B. 83; Reg. ^. James, 1 Car. \& K. 530; Coucard r. Baddeley, 4 H. \& N. 478.

In Cobbett r. Grey, 4 Exch. 744, Pollock, C. B., observes as follows :"I own I have considerable doubt whether any mere threat not in the slightest degree executed, that is, a person saring to another, "If you do not move, I shall use such and such force,' is an assault. My impression is, that it is not. I do not know at what distance it is necessary for the party to be. No doubt, if you direct a weapon, or if you raise your fist within those limits which give you the means of striking, that may be an assault; bat if you simply say at such a distance as that at which you cannot commit an assault, 'I will commit an assault,' I think that is not an assault." In Allsop v. Allsop, 29 L. J. Ex. 310 (S. C., 5 II. \& N. 534), the same learned Judge observes, "If a sword is flourished at such a distance that it would be impossible to hurt any person, it would not be an assault."

(k) Bull. N. P., 7th ed., 15 a.

(l) 3 Bla. Com. 120. As to what may constitute a battery, see also Iursell r. Horn, \& Ad. \& E. 602; Raulings v. Till, 3 M. \& W. 28.

(m) 3 Bla. Com. 120. 
assaulted; it would be " a manifest contradiction in terms to say, that the defendant assaulted the plaintiff by his permission" $(n)$. An act prima facie amounting even to a battery is, moreover, in some cases, "justifiable or lawful, as where one who hath authority, a parent or master, gives moderate correction to his child, his scholar, or his apprentice $(o)$. So also on the principle of self-defence; for if one strikes me first, or even only assaults me, I may strike in my own defence, and if sued for it may plead son assault demesne $(p)$, or that it was the plaintiff's own original assault that occasioned it. So, likewise, in defence of $\mathrm{my}$ goods or possession $(q)$; if a man endeavours to deprive me of them, I may justify laying hands upon him to prevent him, and, in case he persists with violence, proceed to beat him away" $(r)$. There is, however, a manifest distinction between endeavouring to turn a man out of a house or 3lose, into which he has previously entered quietly, and :esisting a forcible attempt to enter; in the first mentioned of these cases a request being necessary, whereas in the latter it is not $(s)$. Again, the captain of a vessel conveyng passengers may justify an assault committed for the reservation and maintenance of due order and discipline in board $(t)$. And in the exercise of an office, as that of

(n) Christopherson v. Bare, $11 \mathrm{Q}$. 3. 473,477 ; Latter v. Braddell, 50 . J. Q. B. 166 ; Ib. 448 ; Wellock - Constantine, 2 H. \& C. 146. See Tacanagh r. Gudge, 7 M. \& Gr. 316 ; ․ ธ. Read, 2 Car. \& K. 957 ; but see 3 \& 44 Vict. c. 45 , s. 2.

(o) See Penn r. Ward, 2 Cr. M. \& 338; Winterburn v. Brooks, 2 Car. K. 16.

(p) See Moriarty v. Brooks, 6 Car. P. 684 .

(q) See Holmes v. Bagge, 1 E. \& B. 28 ; Roberts v. Tayler, 1 C. B. 117 ; Teaver v. Bush, 8 T. R. 78, 81; Layling ₹. Okey, 8 Exch. 531; Gayrd r. Morris, 3 Id. 695.

As to the right of the owner of land

B.C.L. to enter forcibly thereupon, and to eject the wrongful occupant, see the cases collected, ante, p. 206.

As to the right of the owner of land to eject from it one who has entered under a parol license, see $\operatorname{Food} \mathbf{v}$. Leadbitter, 13 M. \& VI. 838 ; Judgm., Adams v. Andrens, 15 Q. B. 296.

(r) 3 Bla. Com. pp. 120, 121; Alder. son $\mathbf{v}$. Waistell, 1 Car. \& K. 358.

(s) Polkinhorn r. Wright, 8 Q. B. 197, 206; Tullay v. Reed. 1 Car. \& P. 6 ; Jelly v. Bradley, Car. \& M. 270. See arg., 3 Exch. 696 ; Griffiths v. Dunnett, 7 M. \& Gr. 1002 .

( $t$ ) Noden $\mathbf{v}$. Johnson, 16 Q. B. 218. 
churchwarden or beadle, a man may lay hands upor another to turn him out of church and prevent his dis turbing the congregation by indecent behaviour during th performance of divine service $(u)$. If sued for such or th like battery or assault $(x)$, a defendant will be enabled t. set forth the whole case, and plead that he laid hands upor the plaintiff gently-molliter manus imposuit $(y)$-for th particular purpose above indicated.

Inasmuch, then, as an act prima facie amounting to battery may be justifiable, a battery is defined to be th unlawful beating of another, for which, as for an assault an action lies.

otherbodily Besides an assault or battery, other torts to the persor might be specified-direct or consequential-the natur whereof will in part appear from the references infra $(z$ some few of which may usefully be consulted. Negligence however, causing bodily hurt, may be proved in an infinit?

(u) Burton v. Henson, 10 M. \& W. 105: Worth v. Terrington, 13 MI. \& W. TS1; Williams v. Glenister, 2 B. s C. 699 . See Hatce v. Planner, 1 Wms. Saund. 13.

(x) An innkeeper cannot justify an assault under pretence of detaining the plaintiff for a debt due to him : Simbolf v. Alford, 3 M. \& W. 248 .

(y) See Oakes r. Wood, 3 M. \& W. 150; Gregory r. Hill, 8 T. R. 299 ; Noden r. Johnson, 16 Q. B. 218.

See also Harrison v. Rutland (Dule of), (1893) 1 Q. B. 142 (C. A.).

Compare Butler. v. Manehester, Sheffield, and Lincolnshire R. C., 21 Q. B. D. 207 (C. A.).

(z) As exemplifying or illustrating the nature of actions for direct bodily injuries, see Scott r. Shepherd, p. 93; Weater ₹. Ward, Hobart, 134 ; Leame v. Bray, 3 East, 593; sce Preface to 7 R. R. vii.; Chandler v. Bronghton, 1 Cr. \& M. 29; Gilbertson v. Richardson, 5 C. B. 502 ; Stanley v. Poutell, (1891) I Q. B. 86; for bodily injuries caused by negligence, sec Ellis v. Sheffield Gas Consumers' Co., cited p. 753; Overton ₹. Freeman, 11
C. B. $86{ }^{\circ}$; Watling r. Oastler, L. $\mathrm{h}$ 6 Ex. 73; Goldthorpe v. Hardman 13 M. \& W. 377; Dixon r. Bell, M. \& S. 198; 17 R. R. 30S; IForeto v. Hardern, 4 B. \& C. 233.

As to an injury caused by an anims belonging to defendant, and as to th necessity of proring the scienter, se Applebee r. Percy, L. R. 9 C. P. 647 Baldwin v. Casella, L. R. 7 Ex. 325 Hudson v. Roberts, 6 Exch. 697; Co: v. Burbidge, 13 C. B., N. S., 430 Card r. Case, 5 C. B. 622; Jackson v Smithson, 15 M. \& W. 563 ; Ma r. Burdett, 9 Q. B. 101 ; Cooke r Waring, 2 H. \& C. 332; Wort r. Gilling, I. R. 2 C. P. 1 ; swith Great Eastern R. C., Id. 4; Ell v. Loftus Iron Co., L. R. 10 C. P. 10 Sanders v. Teape, 51 L. T. 263.

The owner of a dog is now liable $\mathrm{i}$ damages for injury done by it to catt? or sheep, without proof of the sciente or of neglect on the part of the owner $28 \& 29$ Vict. c. 60, s. 1. See Wrigh r. Pearson, L. R. 4 Q. B. 582.

As to the liability of the owner of dog which destroys game, see Read Eduurds, 17 C. B., S. S., 245. 
rariety of ways, so that the student might look in vain hrough the reports for a case which would unerringly guide iim to a right conclusion where the facts submitted for onsideration are novel and peculiar. This remark forcibly pplies where personal injury has resulted from a railway cident. The statutory provisions, innovating on our ustomary law, which allow pecuniary compensation to be nforced when death has thus been caused, will presently e noticed, and some authorities whence principles may be stracted are subjoined $(a)$.

In cases such as are now adverted to, three several states f facts may present themselves raising difficulty: 1st, here the plaintiff has, by his own negligence or misconduct, ntributed to cause the injury sustained; 2ndly, where to defendant acted by his agent or servant in the matter rarged against him ; 3rdly, where the relation of master Id servant, or employer and employed, existed, co instante, between the plaintiff and defendant.

Reported cases falling under one or other of these classes e extremely numerous.

As to the first of them, viz., where the plaintiff has in me way himself contributed to the injury sustained, the le was long since stated (b) in these words: "Although ere may have been negligence on the part of the plaintiff, it unless he might, by the exercise of ordinary care, have oided the consequences of the defendant's negligence, he

a) Richardson v. Great Eastern $R$. 1 C. P. D. 342 ; Readhead v. Midl R. C., L. R. 4 Q. B. 379 ; cited Pollock, B., Wright v. Midland C., L. R. 8 Ex. 146; and in hadall v. Newson, 2 Q. B. D. 102, 1, 110 ; Buxton v. North-Eastern C., L. R. 3 Q. B. 549 ; Great thern R. C. v. Hawcroft, 21 L. J. B. 178; Hutchinson $\nabla$. York, castle, and Beruick R. C., 6 Rail. 580; Perren v. Monmouthshire and C. C., 11 C. B. 85̄ ; Great thern R. C. v. Harrison, 10 Exch.
376; Gallin v. London and WorthWestern R. C., L. R. 10 Q. B. 212 ; McCawley v. Furness R. C., L. R. 8 Q. B. 57; Grote v. Chester and Holyhead $R$. C., 2 Exch. 251.

(b) Per Parke, B., Bridge v. Grand Junction R. C., 3 M. \& IV. 248, and in Davies v. Mann, 10 M. \& W. 548. The abore rule as to contributory negligence is also stated in Judgm., Tuff v. Warman, 5 C. B., N. S., 573 ; S. C., 2 Id. 740; and applied in Senior $v$. Ward, 1 E. \& E. 385 . And see Harris v. Mobbs, 3 Ex. D. 268. 
is entitled to recorer; if by ordinary care he might hav avoided them, he is the author of his own wrong," and wil be held to have disentitled himself to complain $(c)$.

The law in regard to contributory negligence has been se forth more recently at greater length in two propositions.

"The first proposition is a general one to this effect, tha the plaintiff in an action for negligence cannot succeed if $i$ is found by the jury that he has himself been guilty of an: negligence or want of ordinary care which contributed t. cause the accident.

"But there is another proposition equally well estab lished, and it is a qualification upon the first, namely, tha though the plaintiff may have been guilty of negligence and although that negligence may, in fact, have contribute to the accident, yet if the defendant could in the result, $b$ the exercise of ordinary care and diligence, have avoide the mischief which happened, the plaintiff's negligence $m i$ not excuse him " (d).

"Every person," however, "who does a wrong is at leas responsible for all the mischievous consequences that ma reasonably be expected to result under ordinary circumstance from such misconduct" $(c)$; and the question whether $c$ not the complainant contributed to the mischief the happened, by want of ordinary caution, is necessarily or of degree, to be answered by reference to the facts adduce

(c) Martin r. Great Northern R.C., 16 C. B. 179 , as to which see Cormman r. Eastern Counties R. C., 4 H. \& N. 781, 784; Toomey v. London, Brighton, and South Coast R. C., 3 C. B., N.S., 146; Fordham r. London, Brighton, and South Coast R. C., L. R. 4 C. P. 619 ; Weller r. London, brighton, and South Coast R. C., L. R. 9 C. P. 126 ; Holden v. Lirerpool Gas Co., 3 C. B. 1 ; Datey r. London and Sonth-Western R. C., 11 Q. B. D. $213 ; 12$ Id. $70 ;$ Wright $\mathrm{r}$. Midland R. C., 51 L. T. 589 ; Brotch v. Great Westerm R. C., 52 Id. 622 ; as to the onus of proof in such cases, : Wakelin r. London and Sonth. Westo R. C., 12 App. Cas. 41 ; as to t Adniralty rule on this point, 8 Cayzer v. Carron Co., 9 App. Cas. Si 880.

(d) Per Lord Penzance, Radley London and North-Hestern R. C., App. Cas. 759.

(e) Per Pollock, C. B., Rigby Heuitt, 5 Exch. 243 (cited per Byi J., Hoey v. Felton, 11 C. B., N. ! 143); and in Greenland $\mathbf{v}$. Chaplin Exch. 248. 
in evidence $(f)$. If the plaintiff voluntarily incurred danger so great that no sensible man would have incurred it, he will sue in vain for compensation $(f)$. If the plaintiff voluntarily places himself in a position relatively to the defendant which he has no lawful title to occupy, or if, being cognizant of danger, he voluntarily exposes himself to it, he may, ipso facto, preclude himself from insisting that there has been negligence in the defendant productive of danger to himself $(g)$.

The rule as to contributory negligence is applicable in the zase of an infant $(h)$, or where one of tender years is under he care of an adult through whose negligence a bodily hurt s done to the infant, the negligence of the person having harge of the child being looked upon as the negligence of he child itself $(i)$. But it is no defence to an action to ecover damages for injuries caused by the negligence of he defendant, or his servants, that the injuries have been artly caused by the contributory negligence of a third erson, unless such third person was the agent or servant f the plaintiff $(k)$.

It may be well to add that for an accident which hapened entirely without default on the part of the defendant, r blame imputable to him, he will not, unless by force of ome express statutory provision, be responsible $(l)$; the

(f) Clayards v. Dethick, 12 Q. B. 39, 446; followed in Thompson $\mathbf{v}$. orth-Easter* R. C., 2 B. \& S. 106, $4,118,119$; sed vide per Bramwell, . J., in Lax v. Corporation of Dar:ggton, 5 Exch. D. 35 ; ML IIahon $\mathrm{v}$. ield, 7 Q. B. D. 574 ; Smith, The IW of Negligence, App. $B$.

(g) Lygo v. Newbold, 9 Exch. 302 , th which compare Lynch v. Nurdin, Q. B. 29 ; Singleton v. Eastern unties $R$. C., 7 C. B., N. S., 287 ; eat Northern R. C. v. Hawison, 10 ich. 376 ; Bird v. Holbrook, 4 Bing. 8 ; Caswell v. Worth, 5 E. \& i. 9 ; Doel v. Sheppard, Id. 856; isop v. Yates, 2 H. \& N. 768, 771; iffiths r. Gidlow, 3 H. \& N. 648. (h) Hughes v. Maefie, Abbott v. $\left[\begin{array}{l}\text { vede Sungeter } \\ v \\ \text { Eatin } 250.1\end{array}\right.$ Macfie, 2 H. \& C. 744; Mangan $\mathrm{r}$. Atterton, L. R. 1 Ex. 239, as to which see Clark v. Chambers, 3 Q. B. D. $338,339$.

(i) Waite v. North-Eastcrn R. C.,

E. B. \& E. 719.
(i) The Borina, 12 P. D. 58 ; 56. Sucthutfryeo L. J., P. D. \& A. $31 ; 13$ App. Cas. 1, overruling Thorogood r. Bryan, 8 C. B. 115 , and Armstrong r. Lancashire and Yorkshire R. C., L. R. $10 \mathrm{Ex} .47$.

(l) Per Dallas, C. J., Wakeman v. Robinson, 1 Bing. 215 ; Holmes v. Mather, L. R. 10 Ex. 261 ; Hall v. Fearnley, 3 Q. B. 919 ; Gibbon r. Pepper, Salk. 637, 638. 
onus, however, of establishing this defence will be on the defendant, where the facts proved are such as raise a primá facie case against him $(m)$, and it will be for him to show that the mischance occurred in consequence of ris majoi where that ground of exoneration from liability is relied upon $(n)$.

Liability of master for tortious act of his servant.

Secondly, it has been judicially observed $(o)$ that "the liability of any one, other than the party actually guilty of any wrongful act, proceeds on the maxim, Qui facit per alium facit per se. The party employing has the selection of the party employed, and it is reasonable that he who has made choice of an unskilful or careless person to execute his orders should be responsible for any injury resulting from the want of skill, or want of care, of the persor employed $(p)$; but neither the principle of the rule, nor the rule itself, can apply to a case where the party sought tc be charged does not stand in the character of employer of the party by whose negligent act the injury has been occr. sioned" $(q)$. Upon this subject (one very comprehensirt and important) of the liability of the master for the act of his servant, two leading decisions are Laugher v. Pointer ( $r$. and Quarman v. Burnett (s).

In Langher v. Pointer the facts were as undermentioned - The owner of a carriage had hired of a stable-keeper : pair of horses for his carriage for the day, the driver bein

(iii) Bys'ne r. Boadle, 2 H. \& C. 722 ; Skinner v. London, Brighton, and Sowth Coast R. C., 5 Exch. is7, 789; I'iggott v. Eastern Counties R. C., 3 C. 13. 229 ; Vanghen r. Tuff lale R. C., 5 H. A N. 679 ; Fremantle v. London and North-Wëstern R. C., 10 C. B., N. S., 89 ; per Lord Denman, C. J., Curpue v. London and Brighton R. C., 5 Q. B. 747. See Templeman v. IIaydon, 12 C. 13. 507; Perien v. Monmonthshire K. \& Can. Co., 11 C. 13.855 .

(n) See Great Western R. C. of Canada v. Braid, 1 Moo. P. C. C., N. S. 101, and cases there cited. (o) Judgm., 4 Exch. 255.

(p) See, for instance, Burns v. Poul som, L. R. 8 C. P. 563 ; Lord Boling broke $\mathrm{r}$. Sicindon Lacal Board, L. K 9 C. P. 575.

(q) Et vide the remarks of Lon Crancorth in Bartonshill Coal Co. $\mathrm{r}$ Reid, 3 Macq. H. L. Ca. 282, 2St cited post, p. 778 .

(r) 5 B. C. C. 547 .

(s) 6 M. \& W. 499 ; Jones i Licerpool Corposation, 14 Q. B. D 890 ; as to this case, see Donovan I Laing Construction Syndicate, (1593) Q. B. 629 (C. A.). 
provided by the owner of the horses; and it was held by Lord Tenterden and Mr. Justice Littledale (whose opinions in this case have since been recognised as law), that the owner of the carriage was not liable for an injury caused by the negligence of the driver. In this case, it must be observed, there was no evidence of any kind of contract or agreement between the owner of the carriage and the coachman who caused the injury, which circumstance is very material with reference to what is there said by the learned Judges just named. "According to the rules of law," says Littledale, J., "every man is answerable for injuries occasioned by his own personal negligence; and he is also answerable for acts done by the negligence of those whom the law denominates his servants, because such servants cepresent the master himself, and their acts stand upon the same footing as his own. And in the present case the juestion is, whether the coachman by whose negligence he injury was occasioned is to be considered a servant of he defendant. For the acts of a man's own domestic iervants there is no doubt but the law makes him responible; and if this accident had been occasioned by a oachman who constituted a part of the defendant's own amily, there would be no doubt of the defendant's liability $(t)$; nd the reason is, that he is hired by the master, either ersonally, or by those who are entrusted by the mastel Fith the hiring of servants, and he is therefore selected by he master to do the business required of him." The rinciple of these remarks is in truth expressed by the axim Respondeat superior $(u)$, which applies not only to omestic servants who may have the care of carriages, orses, and other things in the employ of the family, but extends to other servants whom the master or owner elects and appoints to do any work, or superintend any

( $t$ ) See per Blackburn, J., Williams Jones, 3 H. \& C. 609,610 . (u) See Tebbutt v. Bristol and Exeter R. C., L. R. 6 Q. B. 73. 
business, although such serrants be not in the immediate employ or under the superintendence of the master" $(x)$.

Thus, "if a man is the orner of a ship, he himself appoints the master, and he desires the master to appoint and select the crew; the crew thus become appointed by the owner, and are his servants $(y)$, for the management and government of the ship; and if any damage happens through their default, it is the same as if it happened through the immediate default of the orner himself $(z)$. So the same principle prevails if the owner of a farm has it in his own hands, and he does not personally interfere in the management, but appoints a bailiff, or hind, who hires other persons under him, all of them being paid out of the funds of the owner, and selected by himself, or by a person specially deputed by him; if any damage happen through their default the owner is answerable, because their neglect or default is his, as they are appointed by and through. him (a). . So, in the case of a mine, the orner employs a sterrard or manager to superintend the working of the mine, and to hire under-workmen, and he pays them on behalf of the

(x) In Steel r. Lester, 3 C. P. D. 121, many cases illustrating the text are collected.

(y) See Omoa Coal and Iron Co. v. Huntley, 2 C. P. D. 464.

$\Leftrightarrow$ See Martm r. Tempcrley, $4 \mathbf{Q}$. B. 298; Dunford v. Trattles, 12 M. \& W. 529 ; Fenton v. City of Dullin Steam Packet Co., S Ad. \& E. 835; Cuthbertson v. Parsons, 12 C. B. 304; Rodrigues v. Mclhuish, 10 Exch. 110.

In Schuster v. Mc Kellar, 7 E. \& B. i24, Lord Campbell, C. J., delivering judgment, says, that the orner, although the ship be chartered, "is clearly liable for a collision arising from the improper management of the ship, and for what the master does within the scope of his general authority as master which cannot be ascribed to his agency as charterer." Where the lessee of a ferry hired of the defendant for the day a steamer and a crew to convey his passengers across, the defendant was held liable for damage caused to a passenger by the negligence of the crem : Dalycli v. Tyjer, E. B. If E. 889.

As to the liability of owner or master. of a ship for damage caused by negligence in stowing goods, fic., see Sack r. Ford, 13 C. 13.. N.S., 90 ; Blailie v. Stembridye. 6 Id. S94; Sandeman v. Scurr, L. R. 2 Q. B. 86; Murray r. Curve, I. R. 6 C. P. 24,-for damage caused by collision through negligence of pilot, Clyde Nac. Co. r. Barclay, 1 App. Cas. 790 ; Gen. Stean Nal. Co. vo British, Ge., Nav. Co., L. R. 4 Ex. 238; Tyme, fe., Comm. T. Gen. Steam Nar. Co., L. R. 2 Q. B. 65.

(a) See Holmes r. Onion, 2 C. B., X. S., 790, where the defendant was held responsible for the act of a thatcher hired by him to do thatching work at weekly wages for his profit. 
owner. These under-workmen then become the immediate servants of the owner, and the owner is answerable for their default in doing any acts on account of their employer " $(b)$. And the same kind of reasoning would manifestly apply in many other cases, as where, in the absence of any special contract or agreement between the parties $(c)$, it is sought to charge a railway, or other incorporated company, for damage caused by the negligence or misconduct of its officers or servants $(d)$. In order, however, to make the mployer liable, the act complained of must have been sommitted within the fair scope of the duty of the servant (e). Thus a waterworks company was held not inswerable for an assault committed by their broker while xecuting a warrant of distress, on the ground that it was 10 part of his duty to commit an assault, his duty being imply to levy the rate due to the company $(f)$.

The judgment of the Court of Exchequer in Sharrod v. The London and North-Western R. C. $(g)$ (where the plainiff sued the defendants $(h)$ for driving a railway engine

(b) Judgm., 5 B. \& C. 554. Acc. udgm., Earwick v. English Jt. Sth. $3 k$, L. R. 2 Ex. 265, 266 ; Swive v. rancis, L. R. 3 App. Cas. 106, 113 ; Lackay v. Commercial Bh. of New innswich, L. R. 5 P. C. 394.

(c) See Machuv. London and SouthVestern R. C., 2 Exch. 415; approved 1 Doolan v. Midland R. C., 2 App. as. 792.

(d) Bayley v. Manehester, Sheffield, nd Lincolnshire R. C., L. R. 8 C. P. 18; Moore v. Metropolitan R. C., - R. 8 Q. B. 36 .

(e) Cf. Abrahams v. Deakin, (1891) Q. B. 516 (C. A.) ; Guilliam F. wist, (1895) 2 Q. B. 84 (C. A.) rersing $S$. C., (1895) 1 Q. B. 557 .

(f) Richards v. West Middlesex aterworks Co., 15 Q. B. D. 660.

(g) 4 Exch. 580.

(h) It had been settled that trespass ould lie against a corporation. See taund v. Monmouthshive. Can. Co., 4 . \& Gr. 452; Goff v. Great Northern
R. C., 3 E. \& E. 672; Paulton v. London and South- Western R. C., I. R. 2 Q. B. 534; Eastern Connties R. C. v. Broom, 6 Exch. 314 ; Chilton v. London and Croydon R. C., 16 M. \& IV. 212.

A body corporate may also be liable for libel published by order of the corporation : "Ihitfield $v$. South-Eastern R. C., E. B. \& E. 115 ; see also Lawson v. Bank of England, 18 C. B. 84 -or for the intentional misfeasance, or the fraudulent misrepresentation, of their servant: Ba *wiel v. English Jt. Stk. Bh., L. R. 2 Ex. 259; Weir v. Bell, 3 Exch. D. 238 ; Weir v. Barnett, Id. 32 ; Swift v. Jeusbury, I. R. 9 Q. B. 301 ; Green v. London General Ommibus Co., 7 C. B., N. S., 290. See MeGowan v. Dyer, L. R. 8 Q. B. $141,145$.

A corporation may sue for libel: Metropolitan Omibus Co. v. ILawkins, 4 H. \& N. 87. Compare Mayor of Manchester v. Williams, (1891) 1 
against his sheep, and so destroying them) may be cited as illustrating the remark last made, and as throwing additional light upon the extent and nature of the liability imposed upon a master for the tortious act of his servant. It indicates various and dissimilar states of facts under which respectively a master may be answerable $e x$ delicto for the acts of his servant (i). The general grounds of this liability are indeed sufficiently stated in Laugher v. Pointer, and in Quaman v. Burnett, where it is said, "Upon the principle that qui facit per alium facit per se, the master is responsible for the acts of his servant; and that person is undoubtedly liable who stood in the relation of master to the wrong-doer,- -he who had selected him as his servant from the knowledge or belief in his skill and care,-and who could remove him for misconduct $(k)$, and whose orders he was bound to receire and obey; and whether such servant has been appointed by the master directly or intermediately through the intervention of an agent authorised by him to appoint servants for him can make no difference. But the liability, by virtue of the principle of relation of master and servant, must cease where the relation itself ceases to exist" $(l)$.

Hence, when he who does the mrongful act, either in person or by his servant, exercises an independent employment, his immediate superior will not be liable, as in Milligan v. Wedge $(m)$, where damage was done by a bullock through the careless driving of a boy employed by the drover, who was himself in the employment of the

Q. B. 94 ; Sonth Hetton Coal Co. v. North - Eastcrn Ners Association, (1594) 1 Q. B. 133 (C. A.). 591 .

(i) See Gregory r. Fiper, 9 B. \& C.

(i) The mere fact that a railway company has, by agreement with one who has contracted to make a portion of the line, power to remove his workmen for incompetence, will not suffice to create the relation of master and servant between the company and the workmen. In this case the contractor would be the master: Reedie r. London and North-Western R. C., 4 Exch. 244.

(l) In Lueas v. Mason, L. R. 10 Ex. 251, the relation of master and servant relied upon was held not to have existed.

(ii) 12 Ad. \& E. $73 \pi$. 
butcher, to whom liability was accordingly held not to attach; or in Rapson v. Cubitt $(n)$, where the injury complained of was done by the negligence of the servant of a gas-fitter employed by the defendant, a builder, who had himself contracted to make certain alterations in a club-house, and who, it was held, could not be made responsible for the damage thus occasioned.

With the foregoing case may be compared Parry v. Smith (o), where the facts were these:-the defendant, a gas-fitter, was employed by the plaintiff's master to repair a gas-meter upon his premises, and for the purpose of doing so took away the meter, and in lieu of it made a temporary connection by means of a flexible tube between the inlet pipe and the pipe communicating with the house. The plaintiff having gone, in the ordinary performance of his duty, into the cellar where the meter had been, gas, which had escaped by reason of the insufficiency of the connecting tube, exploded and injured him. The jury having found that the work had been negligently done, and that the injury to the plaintiff had proceeded entirely from ;uch negligence, the defendant was held to be liable: saving been guilty of a misfeasance independent of conract. No privity was here needed between the party njured and him by whose breach of duty the injury was saused.

In Overton v. Freeman ( $p)$, the facts were as follows:he defendants had been employed by certain paving comnissioners to pave a particular district, and contracted with

(n) 9 M. \& W. 710.

(o) 4 C. P. D. 325.

(p) 11 C. B. 867 , where many uthorities upon the subject above lluded to are collected, of which see articularly Knight v. Fox, 5 Exch. 21 ; Burgess Y. Gray, 1 C. B. 578 ; Reedie $v$. London and North-Western i. C., 4 Exch. 244. See also Forezan v. Mayor of Canterbury, L. R.
6 Q. B. 214 ; Murray v. Currie, L. R. 6 C. P. 24; Peachey . Rowland, 13 C. B. 182 ; Butler v. Hunter, 7 II. \& N. 826 , which, however, "must now be taken to be superseded by Boucer v. Peate, 1 Q. B. D. 321, so far as the cases are in conflict: " per Bowen, J., in Pereiral r. Hughes, 9 Q. B. D. 441 , and vide per Lord Blackbum, S.C., 8 App. Cas. 447. 
B. to pave one of the streets included in such district. B.'s workmen, whilst paving the street, left a heap of stones at night in so unsafe a position, that the plaintiff fell over it and sustained an injury. There was no evidence to shori that the defendants had interfered in or sanctioned the placing of the stones; and it appeared that B. was in reality acting under the direction of the engineer and surveyor of the commissioners. Upon these facts the defendants were held not liable, for " the relation of master and servant," observed Maule, J., "has no existence in \& case like this. . . . I think the present case falls within the principle of those authorities which have decided that the sub-contractor, and not the person with whom he contracts, is liable civilly as well as criminally for any wrong done by himself or his servants in the execution o: the work contracted for" $(q)$.

But although it is established by Laugher v. Pointer, and Quarman v. Burnett, that if the owner of a carriage hires hor'ses of a stable-keeper, who provides a driver, through whose negligence an injury is done, the driver must in general be considered as the servant of the stable-keepes or jobmaster-the conclusion of law will, nevertheless be different if there be special circumstances in the case showing an assent, either express or implied, to the tortious act complained of by the party hiring the horses ( $r$ ) or showing that the individual whom it is sought to charge had control over the servant whose act caused damage, and was in fact dominus pro tempore $(r)$; and the same genera

(q) See further, in general illustration of the above remarks, Pearson v. Cox, 2 C. P. D. 369 ; Cuthbertson v. I'arsuns, 12 C. B. 304; Allen r. Hayuard, 7 Q. B. 960; Dunean v. Findlater, $;$ Cl. \& F. 894, 904, followed in Thomson v. Mitchell, 7 Id. 564, and commented on in Mersey Docks Trustecs v. Gibbs; Same v. P'enhallon', 11 1I. L. Ca. 686, approved Rey. v. Üilliams, 9 App. Cas. 418; Hill v.
Managers of Metropolitan Asylwn District, 4 Q. B. D. 433,$442 ; 6 \mathrm{App}$ Cas. 193; Goslin v. Agricultural Hal Co., 1 C. P. D. 482 ; Steel r. South Eastern R. C., 16 C. B. 550; Seri vener r. Pusk, 18 C. B., N. S., 785 Jonovan v. Laing Wharton Construc tion Symdicate, (1893) 1 Q. B. 62 (c. A.)

(v) II'Laughlin r. Pryor, 4 M. \& Gr. 48 ; s. C., 1 Car. \& M. 354 . 
principle applies where the carriage and horses are borrowed for the day $(s)$, though a person hiring or borrowing a carriage, and providing horses and servants, would be liable $(t)$.

Further, where the injury in question was committed by the defendant's servant uilfully, whilst not employed in the master's service and whilst not acting within the scope of his authority (u), a remedy cannot be had against the master - the servant only will be liable $(x)$, as if, for instance, a servant authorised merely to distrain cattle damage feasant, drives cattle from the highway into his master's close, and there distrains them $(y)$; or if he wantonly, and in order to effect some purpose of his own, strikes the plaintiff's horses, and thereby causes an accident ( $z)$. Should, indeed, the servant be guilty of negligence, productive of an injury to the plaintiff, whilst on his master's business (a), as when driving his master's carriage, although he may at the time be going out of the direct road for some purpose of his own, the master may be answerable $(b)$. "No doubt," as

(8) See Hart v. Crowley, $12 \mathrm{Ad}$. \& E. 378; Tarerner v. Little, 5́ Bing. N. C. 678; Stables v. Eley, 1 Car. \& P. 614; Wheatley v. Patriek, 2 MI. \& W. 650 .

As to liability of proprietor of hackney carriage plying for hire within netropolis, cf. Ienables r. Smith, 2 Q. B. D. 279, and cases cited after it at p. $930 \mathrm{n}$. (c).

The fact that a man allows a carriage to go out with his name upon it is only prima facie evidence of his liability for the negligence of any person driving it: Smith v. Bailey, (1891) 2 Q. B. 403 (overruling Stables v. Eley, as reported) ; 1 Car. \& P. 614.

(t) Croft v. Alison, 4 B.\& Ald. 590 ;

23 R. R. 407 ; Scott v. Scott, 2 Stark.

I. P. C. 438 ; 20 R. R. 711 .

(w) See Edwards v. London and Forth-Western R. C., L. R. 5 C. P. 445; Walker r. South-Eastern R.C., Id. 640 ; Allen F. London and SonthFestern R. C., L. R. 6 Q. B. 65 ; Whatman v. Pearson, L. R. 3 C. P. 422 ,
Story v. Ashton, L. R. 4 Q. B. 476 ; Sterens v. Wooduavd, 6 Q. B. D. 318.

(x) Lyons r. Martin, 8 Ad. \& E. 512; Coleman v. Riches, 16 C. B. 104; M'Manus v. Crickett, 1 East, 106 ; 5 R. R. 518; Leame r. Bray, 3 East, 593; see Preface to 7 R. R. vii.; Middleton v. Fouler, 1 Salk. 282; Lamb r. Palk, 9 Car. \& P. 629.

(y) Lyons v. Martin, 8 Ad. \& E. 512.

(z) Croft r. Alison, 4 B.\& Ald. 590 , 592; 23 R. R. 407 ; Lamb r. Palk, 9 Car. \& P. 629; Gregory r. Piper, 9 B. \& C. 591; Huzzey พ. Field, 2 Cr. MI. \& R. 432; per Erle, J., Free man v. Rosher, 13 Q. B. 785; cited per Bramuell, B., Collett v. Foster, 2 H. \& N. 361; and cases cited supra.

(a) As to the proper signification of these words, see Limpus v. General Omnibus Co., 1 H. \& C. 526 ; Seymour v. Greenwood, 7 H. \& X. $355 ; S . C$., 6 Id. 359 ; cited in Judgm., Lucas $\mathrm{r}$. Mason, L. R. 10 Ex. 253.

(b) Joel v. Morison, 6 Car. \& P. 501; Sleath r. Wilson, 9 Car. \& P. 607. 
observed by Jerris, C. J. (c), " a master may be liable for injury done by his servant's negligence, where the servant, being about his master's business, makes a small deviation, or even where he so exceeds his duty as to justify his master in at once discharging him," but, "at all events, if the master is liable where the servant has deviated, it must be where the deviation occurs in a journey on which the servant has originally started on his master's business ; in other words, he must be in the employ of his master at the time of committing the grievance." No liability attaches to the master if the servant, without his leave or knowledge, takes his carriage, and with it commits an injury, because in this case the master has not entrusted the servant with the carriage, or commissioned him to perform any service $(d)$.

It seems, moreover, true, as a general proposition, that where one employs another to do an act which may be done in a lawful manner, and the latter, in doing it, unnecessarily commits a public nuisance, where injury results to a third person, the employer will not be responsible for such injury (e). If, however, A. employs B., a contractor, to do an unlawful act-ex. gr., to erect a nuisance in the public highway - which B. does by his work-people and servants, A. will be answerable in an action of tort for damage thence resulting to a third party $(f)$. The two preceding propositions are clearly in accordance with the dictates of common sense, as well as sustainable by che authorities cited in support of them.

(c) Mitchell r. Crassiccller, 13 C. B. 237,245 ; Venables v. Smith, 2 Q. B. D. 279 ; approred $K_{i n g}$ v. London Cab Co., 23 Q. B. D. 281 ; Patten v. Rea, 2 C. B., N. S., 606 .

(d) Mitchell v. Crassweller, supra; Rayner v. Mitchell, 2 C. P. D. 357; Sleath v. Wilson, 9 Car. \& P. 607; Lamb r. Palk, Id. 629; Goodman v. Kenncll, 3 Car. \& P. 167; Joel $r$. .Morison, 6 Car. \& P. 501. (c) Peachey v. Roucland, 13 C. B. 182, with which compare Sadler r. Henlock, 4 E. \& B. $5 \% 0$; Gray r. Pullen, 5 B. \& S. 970; Mills r. Holton, 2 H. \& N. 14; Wrilliams r. Jones, 3 H. \& C. 602 .

(f) Ellis v. Shefficld Gas Consumers' Company, 2 E. \& B. 767 ; Blake v. Thirst, 2 H. \& C. 20 ; Hole v. Sittingbonrne and Shcerness $R$. C., 6 H. \& X. 488. 
It should here, perhaps, be noticed, that cases are to be found in the books which seem to show that wider liability attaches to the owner of real than to the owner of personal property in respect of an injury resulting from its negligent management $(g)$. It may, however, be considered as settled, that no such distinction thus generally worded does in truth exist, though where the act complained of amounts in law to a nuisance, and where the owner of the premises whereon the nuisance is erected is himself $i n$ occupation of them $(h)$, or has in some manner participated in or expressly sanctioned the erection of the nuisance $(i)$, liability may attach to him.

If a landlord lets premises not in themselves a nuisance, but which may or may not be used by the tenant so as to become a nuisance, and it is entirely at the option of the tenant so to use them or not, and the landlord receives the same benefit whether they are so used or not, the landlord cannot be made responsible for the acts of the tenant, and i fortior $i$ he would not be liable if he had taken an obligation from the tenant not to use them so as to create a auisance, even without reserving a right to enter and abate $i$ nuisance, if created $(k)$.

In Reedie v. The London and North-Western R. C. (l), the Jourt observes, with reference to the point above mooted, is follows :- " It is not necessary to decide whether, in any sase, the owner of real property, such as land or houses, nay be responsible for nuisances occasioned by the mode in

(g) See Bush r. Steinman, 1 B.\& P. 04 ; Judgm., 4 C. B. 800,801 ; per Littledale, J., 5 B. \& C. 559,560 ; udgm., 6 Y.. \& W. 510 ; Leslie v. Dounds, 4 Talint. 649 ; 13 R. R. 718. Randleson v. Murray, 8 Ad. \& E. 09 (which "seems at variance with he current of authority": per Pollock, $\because$ B., Ifurphy v. Caralli, 3 H. \& 465); Burgess v. Gray, 1 C. B. 78.

(h) See Bishop v. Trustees of Becford Charity, 1 E. \& E. 697, 714; Robbins v. Jones, 15 C. B., N. S., 221 ;
Preston v. Norfolk R. C., 2 H. \& N. 735.

(i) Todd v. Flight, 9 C. B., N. S., 377; distinguished in Pretty v. Bickmore, L. R. 8 C. P. 401, 404, 405, which is followed in Gwimell $\mathrm{v}$. Eamer, L. R. 10 C. P. 658. See Nelson r. Liverpool Brevery Co., 2 C. P. D. 311 ; Hawis r. Janes, 45 L. J. Q. B. 545 .

(k) Judgm., Rich v. Basterfield, 4 C. B. 804,805 .

(l) 4 Exch. 244; Butley v. Hunter, 7 H. \& N. 826, as to which v. p. 795 . 
which his property is used by others not standing in the relation of servants to him, or part of his family. It may be that in some cases he is so responsible. But then his liability must be founded on the principle that he has not taken due care to prevent the doing of acts which it was his duty to prevent, whether done by his servants or others. If, for instance, a person occupying a house or a field should permit another to carry on there a noxious trade, so as to be a nuisance to his neighbours, it may be that he would be responsible, though the acts complained of were neither his acts nor the acts of his servants. He would have violated the rule of law, sic utere tuo, ut alienum non ladas" (m). If howerer A., the owner of land, contracts with B. to do work or to erect buildings upon it, and B.'s workmen do an injury to the owner of the adjoining land by carrying away materials belonging to him, A. will not, unless he interfered in the tortious transaction, be responsible for it $(n)$.

Thus far has been discussed the liability of a master for the tortious act of his servant-of the employer for the tortious act of the employed-where there is evidence adducible of an authority to do the act in question, either express or implied from the relation which exists between the actual wrong-doer and the party charged. I propose, in the next place, to inquire as to the effect of ratifying or adopting a wrongful act as regards the liability of him who thus ratifies or adopts it.

Effect of ratification of a tort.

Now as, on the one hand, it is true, that, "if a servant commit a trespass by the command or encouragement of his master, the master shall be guilty of it, though the servant is not thercby excused (o), for he is only to obey his

(m) Judgm., 4 Exch. 256, 257; Judgm., Rich v. Basterfield, 4 C. B. 802. See Gott v. Gandy, 2 E. \& B. 845; Alston r. Grant, 3 E. \& B. 128; Saxby v. Manchester, Sheffield, \&c., R. C., L. R. 4 C. P. 198.

(i) Gayfordv. Nicholls, 9 Exch. 702. (o) "No party can be permitted th excuse himself," when charged witl having knowingly joined with and as sisted his master in the commission of a fraud, "on the ground that he actec as the agent or as the servant o. another; and the reason is plain-for 
naster in matters that are honest and lawful " $(p)$, so also ' he that receiveth a trespasser, and agreeth to a trespass fter it be done, is no trespasser, unless the trespass was done , his use or for his benefit, and then his agreement ubsequent amounteth to a commandment" $(q)$. The main uestion in regard to liability by ratification will, accordigly, be this-Was the tortious act, alleged to have been itified, originally intended to be done to the use or for the enefit of the party who is said to have subsequently itified it? If so, the party ratifying the antecedent act ill be liable in respect of it; $e x . g r .$, a corporation may lus become liable for an assault committed by their rvant $(r)$.

The doctrine of "ratihabitio" is, however, of more diffilt application in reference to torts than in reference to intracts $(s)$. If A., professing to act by my authority, does at which prima facie amounts to a trespass, and I afterards assent to and adopt his act, there he is treated as เving from the beginning acted by my authority, and I come a trespasser, unless I can justify the particular act aich is to be deemed as having been done with my prejus sanction $(t)$. In this case the party ratifying becomes, it were, a trespasser by estoppel ; at all events, he is preaded from denying that he gave antecedent authority for at act which he afterwards admits himself to have thorised $(u)$.

contract of agency or of service not impose any obligation on the nt or servant to commit or assist in committing of fraud:" per Lord stbu'y, C., Cullen v. Thomson's estees, 4 Macq. Sc. App. Ca. 433.

p) 1 Bla. Com. 430 ; Sands v. ld, 3 Lev. 352; Jones v. Hart, 1 Raym. 738; Britton v. Cole, 1 k. 408 ; Stephens v. Elucall, 4 M. . 259; Hollins v. Fowler, L. R. 7 L. 757 ; Mill v. Hawker, L. R. 10 92.

2) 4 Inst. 317 ; Wilson v. Barker, 3.C.L.
4 B. \& Ad. 614; Eggington v. MLayor of Lichfield, 5 E. \& B. 100.

(r) Eastern Counties R. C. v. Broom, 6 Exch. 314. See Roe v. Birkenlect, Lancashire, and Cheshire Junction R. C., 7 Exch. 36, 40 ; cited 6 H. \& N. 364,365 ; Chectham v. Mayor, \&c., of Manchester, L. R. 10 C. P. 249.

(s) Ante, p. 305.

(t) See Judgm., Bird v. Brown, 4 Exch. 799 ; Phillips v. Eyre, L. R. 6 Q. B. 1,23 .

(u) Id. 
In Wilson v. Tumman (x), the rule under notice is fully and elaborately stated in these words:- "That an act done for another by a person not assuming to act for himself, but for such other person, though without any precedent authority whatever, becomes the act of the principal, it subsequently ratified by him, is the known and well-estab. lished rule of law. In that case the principal is bound by the act, whether it be for his detriment or his advantage, and whether it be founded on a tort or a contract, to the same extent as by-and with all the consequences whicb follow from-the same act done by his previous authority." But this is not so where the actual wrong-doer, at the time of committing the tort in question, assumed to act for him. self only, and not as agent for, or as servant of, another: so that if a bailiff take a heriot, claiming property in it himself, the subsequent agreement of the lord would no: amount to a ratification of his authority as bailiff at the time; but if he took it at the time as bailiff of the lord, the subsequent ratification by the lord would make him bailif at the time $(y)$.

The distinction here insisted upon is practically impor. tant. If, for instance, a judgment creditor issues executior against his debtor, and directs the sheriff acting under thi writ to seize goods belonging to some third party, sucl previous direction would undoubtedly make the executior creditor a trespasser, because all who procure a trespass th be done are trespassers themselves, and the sheriff woul be supposed not to have taken the goods merely under thi authority of the writ, but as the servant of the executios creditor. Whether a seizure of particular goods under fi. $f a$. was directed by the execution creditor, so as to mak

(x) 6 M. \& Gr. 236, 242, 243: per Irramecll, B., Withers r. Parker, 4 II. \& N. $534 ; S_{.} C ., 5$ Id. 725 ; per Coltman, J., Walker v. Hunter, 2 C.
B. 334 ; Wright v. Crookes, 1 Scot N. R. 6S5. See Moon r. Tuters, C. B., N. S., 611 .

(y) Judgm., 6 M. \& Gr. 243. 
im liable for the act of the sheriff, is a question of fact $(z)$. Ind it is not within the scope of the implied authority of he solicitor to direct the sheriff to seize particular goods, $o$ as to render the execution creditor liable in trespass (a). $f$, on the other hand, we suppose that the sheriff, acting nder a valid writ by the command of the Court and as he servant of the Court, seizes the wrong person's goods, subsequent declaration by the plaintiff in the original ction, ratifying and approving the taking, would not suffice , alter its original character, and make it a wrongful liking by the execution creditor $(b)$.

Lerris v. Reade $(c)$ is worthy of notice in connection with iis subject, viz., as to the effect of ratifying a tort. There landlord authorised bailiffs to distrain for rent due to him om his tenant of a farm, expressly directing them not to ke anything except on the demised premises. The bailiffs, pwever, distrained cattle belonging to another person (supsing them to be the tenant's) beyond the boundary of e farm. The cattle were sold, and the landlord received e proceeds. Upon these facts the Court of Exchequer Id, that the landlord was not liable in trover for the value the cattle unless it were found by the jury that he had tified the acts of the bailiffs with knowledge of the irreguity, or unless it were found that he chose, without quiry, to take the risk upon himself, and to adopt the role of their acts. Hence we may infer that a principal ll not be liable in trespass for the act of his agent unless either authorised it beforehand, or subsequently assented it with knowledge of what had been improperly done $(d)$.

b) Smith v. Keal, 9 Q. B. D. 340 , re Jarmain r. Hooper, 6 M. \& Gr. , is distinguished. See also Morris ialberg, 22 Q. B. D. 614 (C. A.). this case it was held that the inement on a writ may amount to a ction, and it is a question of fact ther it does. The cases childers Wooler, 2 E. \& E. 287; Jarmain v. Hooper, 6 M. \& Gr. 827, and Smith v. Keal, 9 Q. B. D. 340 , are there considered.

(a) Smith v. Keal, loc. cit.

(b) 6 M. \& Gr. 244; Woollen v. Wright, 1 H. \& C. 554.

(c) 13 M. \& W. 834 .

(d) Freeman v. Rosher, 13 Q. B. 780 ; Haseler v. Lemoyne, 5 C. B., 
Further, the case of Buron v. Demman (e), tried at ba before the Court of Exchequer, is important as showing the effect of the ratification of an act prima facie tortious dom by an agent; and although it was there held, that thi party who had ultimately ratified the trespass could not be made responsible for it, yet the general effect, operation and applicability of the doctrine of ratihabitio were judi cially admitted and recognised. In the case just cited, th facts were these:-the action, which was in trespass, $\mathrm{ma}$ brought by a slave-dealer, resident on the coast of Afric and there carrying on his trade, against a commander 0 the British navy on that station, whose duty it was t. enforce the provisions of a certain treaty between our om and the Spanish Government for the suppression of th slave-trade. The gist of the action was, that the defen dant had committed a trespass in destroying the propert: and carrying off the slares of the plaintiff; and in answe to this charge the defendant put on the record a series 0 pleas, by some of which he justified the alleged torts a having been done by command of the Crown, - a defene which, if established, would be good on grounds of genern policy, which protects the servants of the public from lia bility in respect of any acts done by them in the regula course of discharging their official duties $(f)$. The prin cipal question to be decided in Buron v. Denman accord ingly was, whether the conduct of the defendant in carryin away the slaves, and committing the other alleged tres passes, could be justified as an act of state, done b authority of the Crown? It was not, indeed, contende that there was any previous authority for the acts cor

N. S., 530 ; Collett r. Foster, 2 H. \& N. 356,361 .

(e) 2 Exch. 167. Acc. Judgm., Secretary of State for India r. Sahaba, 13 Moo. 1'. C. C. 86. See Ihillips r. Eiyre, L. R. 6 Q. B. 1. (f) Grant v. Secretary of Stole $f$ India, 2 C. P. D. 445 , and cases the cited; Johnstone v. Sitton, 1 T. I 510 ; 1 R. R. 25\%, 269; per Bulle J., Macbeath v. IIaldimand, Id. 152 
olained of. The justification of the defendant depended apon an alleged subsequent ratification of his acts. Now, $n$ this case there was ample evidence to show that the Jovernment had expressed their approval and intimated heir adoption of the acts of the defendant, and it conseguently only remained to consider whether the rule of law upplicable amongst private individuals in regard to the ffiect of ratification applied also to the Crown. The Court reld that it did so apply, and that the defendant was ccordingly justified in what he had done whilst acting in he public service.

As, on the one hand, liability may be incurred by the doption of a tortious act antecedently done, so, on the ther hand, may benefit in some cases be derived from the atification of an act prima facie and ostensibly wrongful; hus where an act, which if unauthorised would amount 0 a trespass, has been done in the name and on the behalf f another, though without previous authority from him, is subsequent ratification may enable the party on whose ehalf the act was done to take advantage of it, and to treat ; as having been done by his direction. But this doctrine uust be taken with the qualification, that the act of ratificaon take place at a time and under circumstances when the atifying party might himself have laufully done the act which e ratifies $(g)$.

The conclusions arrived at in the preceding pages, with ference to the doctrine of ratification, may thus briefly be resented :-

1. If A. commit a trespass, whether to the person or to roperty, professing at the time to act on behalf of $B$., rough without authority from him, and B. afterwards

(g) Judgm., Bivd v. Broun, 4 Exch. 18, 799 (where some cases are cited ustrating the above doctrine) ; eited Idgrn., Simpson v. Eggington, 10 sch. 849, where the Court remark that in Bird v. Broun grave doubts are suggested as to the effect of the retrospective ratification of a tort by one meaning to act as agent for him who ratifies it. 
knowingly ratify the trespass, B. may thus be renderer liable for it.

2. If A. does a tortious act, either on behalf of himsel or as agent for B., and C., with whom A. has had ni previous communication in regard to it, afterwards ratifie: or adopts the act, C. will not, by so ratifying or adopting it incur liability ex delicto in respect of it.

3. One who adopts and ratifies an act done in his nam or on his behalf, though without previous authority fron him, may sometimes (h) thereby enable himself to tak advantage of the act done, provided he could himself lam fully have done it at the time when in fact it was performed

Liability of master to servant for injury sustained by latter in his service.

Thirdly, the principle upon which a master is in genera liable to answer for accidents resulting from the negligene or unskilfulness of his servant does not apply to protec the servant guilty of such negligence or want of skil against the claim of a third party who has been injures thereby (i). Nor, if the servant by his own unskilfulnes: sustain injury, can he claim damages from his master upor an allegation that his own negligence was in point of lar the negligence of his master $(k)$. Moreover, formerly wher several servants possessed of competent or reasonable car and skill were employed by the same master, and injur! resulted to one of them from the negligence of anothe; fellow-servant, the master was not in general responsible "Put the case," observes the Court of Exchequer (l), afte!

(I) See cases cited Judgm., 4 Exch. 799,800 .

(i) Ante, p. 800 n. (o).

(k) Judgm., 5 Exch. 350.

(l) Judgm., Hutchinson r. Fork, Nercastle, and Bericiek R. C., is Exch. 351. Ace. Wigmore r. Jay, Id. 354; Skipp v. Eastern Counties IR. C., 9 Exeh. 223 ; I'riestley r. Foncler, 3 M. o IV. 1; Romlie v. White Moss Colliery $\mathrm{Co}_{0,2} 2$ C. P. D. 205 ; distinguished in Jones v. Licerpool Corporation, 14 (2. li. D. 890 . Is to this case see
Donoran r. Laing Construetion Symli cate, (1893) 1 (2. B. 629 (C. A.) following Rourke v. White Joss Cul liery Ca.; lose $\mathbf{r}$. Lancashive an Forkshive R. C., 2 H. \& X. i2s 734 (where, however, the rule did no apply); Dynen v. Leach, $26 \mathrm{I}_{\text {s. }} \mathrm{J}$ Ex. 221 ; Griftiths r. Gidlone, 3 II. X. 645 ; Wiggett ง. For, 11 Exch. S3"? questioned by Coekburn, C. J., 2 C. I 1. 208; commented on Johusom r Lindsay, (1591) A. C. 371 . 
laying down the foregoing propositions, "of a master employing A. and B., two of his servants, to drive his cattle to market. It is admitted that if, by the unskilfulness of A., a stranger is injured, the master is responsible. Not so if A. by his unskilfulness hurts himself; he cannot treat that as the want of skill of his master. Suppose, then, that, by the unskilfulness of A., B., the other servant, is injured, while they are jointly engaged in the same service, there ro think $B$. has no claim against the master. They have both engaged in a common service $(m)$, the duties of which impose a certain risk on each of them; and, in case of negligence on the part of the other, the party injured knows that the negligence is that of his fellow-servant, and not of ais master. He knew, when he engaged in the service, hat he was exposed to the risk of injury, not only from his own want of skill or care, but also from the want of it on he part of his fellow-servant; and he must be supposed to lave contracted on the terms that, as between himself and) is master, he would run this risk" (n).

The rule above stated holds in regard to a mere volunteer rho assists the servants of another whilst engaged in their ridinary employment (o). "If," for instance, "a man's ervant invites a friend for his own amusement, as it were, o take part in a dangerous duty, and he meets with injury n the course of it, the master is not liable" $(p)$.

(m) Compare Charles v. Taylor, 3 $\therefore$ P. D. 492, with Swainson r. NorthZustern R. C., 3 Ex. D. 341 ; they ust also have been in the service of a ommon master: Johnson v. Lindsay, 1891) A. C. 371 (reversing $S$. $C$., 3 Q. B. D. 508 (C. A.) ; approved yystrom v. Cameron, (1893) A. C. 08.

(n) See Lovell v. Howell, 1 C. P. D. 61 ; Woodley v. Metropolitan R. C., Exch. D. 384 ; Skipp v. Eastern 'ounties R. C., 9 Exch. 223; Priestley - Fovler, 3 M. \& W. 1; Winter. sttom r. Iright, 10 M. \& W. 109 , cited per Colevidge, J., 2 E. \& 13.253; Morgan v. I'ale of Neath R. C., L. R. 1 Q. B. 149; Hall v. Johnsom, 3 H. \& C. 589 ; Felthan v. Englund, L. R. 2 Q. B. 33 ; Tunney v. Hidland R. C., L. R. 1 C. P. 291.

(v) Degg v. Midland R. C., 1 H. \& N. 773 (with which ace. I'otter v. Faulkner, 1 B. \& S. 800), with which compare Abraham r. Reymolds,

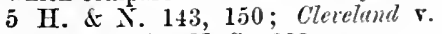
Spiev, 16 C. B., N. S., 399.

(p) Per Mellish, L. J., Wiright v. London and North-Ifestern R. C., 1 Q. B. D. 256 . 
But although a master was not in general responsible to one servant for an injury occasioned to him by the negli gence of a fellow-servant while they were acting in on common service, yet this rule was subject to the qualifi cation that the master had not personally interfered ir causing the hurt complained of $(q)$, and had taken dut care not to expose his servant to unreasonable risks, $c x . g r$. by employing defective machinery $(r)$ or incompetent work. men. For the servant when he engaged to run the risks of his service, including those arising from the negligence of fellow-servants, had a right to understand that the master had taken reasonable care to protect him from such risks by associating him only with persons of ordinary skill and care $(s)$. And in a case such as supposed " the master is not, and cannot be, liable to his servant unless there be negligence on the part of the master in that in which he (the master) has contracted or undertaken with his servant to do" $(t)$.

Neither would a master be exempt from responsibility to his servant for an injury occasioned to him by the act of another servant where the servant injured was not, at the time of the injury, acting in the service of his master. In such a case the servant injured is substantially a stranger, and entitled to all the privileges which he would have had if he had not been a servant $(u)$. The rule is similar where the complainant sustains a hurt through the negligence of

(q) Brotch v. Acerington Cotton Co., 3 H. \& C. 511; Roberts r. Simith, 2 H. \& N. 213; Ormond r. Holland, E. B. \& E. 102; Williams v. Clough, 3 H. \& N. 258; Griffiths v. Gidlou, 3 II. S. N. $648 ;$ Dynen v. Leneh, 26 L. J. Ex. 221.

(v) Wcems r. Mathieson, \& Macq. H. L. Ca. 215 ; Searle v. Lindsay, 11 C. B., N. S., 429 ; Clarke v. Holmes, i H. S N. 937 ; S. C., 6 Id. 349. See Riley v. Baxendale, 6 H. d N. 445 : Coucley v. Mayor, \&e., of Sumberland, 6 H. \& X. 565; Mellours V. Sheur, 1
B. S S. 437 ; citing Asheorth r. Stanecix, 30 L. J. Q. B. 183.

(s) Judgm., 5 Exch. 353 ; Tarrant ง. Webb, 18 C. B. 797 ; Ormond $\mathrm{r}$. Holland, supra.

(t) Per Lord Caims, C., Wilson T. Merry, L. I. 1 Sc. App. Ca. 332; followed iu Howells r. Lamiore Stal Co., L. R. 10 Q. B. 62, 64, and distinguished in Swith r. Stcele, Id, 125 ; dilen $\therefore$. Tew Gas Co., 1 Ex. D. 251 ; hiddle r. Lorett, 16 R. B. D. 605,611 .

(ii) Judgm., 5 Exch. 352 . 
defendant's servants when not under the same control as himself, or engaged with him in effecting some common object $(x)$ :

In The Bartonshill Coal Company v. Reid (y), which came before the House of Lords on appeal from the Court of Session in Scotland, the question for decision was whether if in the working of a mine one of the servants employed is killed or injured by the negligence of another servant employed in some common work, that other servant having been a competent workman and properly employed to discharge the duties intrusted to him, the common employers of both are responsible to the servant who is injured, or to his representatives, for the loss occasioned by the negligence of the other?

In answering the above question in the negative, Lord Crantorth offered some remarks which are here apposite $z$ ) as explaining the doctrine of our law respecting the liability of a master to a stranger for bodily hurt sustained through the negligence of his servant. " Where," he says, "an injury is occasioned to any one by the negligence of another, if the person injured seeks to charge with its consequences any person other than him who actually caused the damage, it lies on the person injured to show that the ircumstances were such as to make some other person :esponsible. In general, it is sufficient for this purpose to show that the person whose neglect caused the injury was it the time when it was occasioned acting not on his own iccount, but in the course of his employment as a servant $n$ the business of a master, and that the damage resulted rom the servant so employed not having conducted his naster's business with due care. In such a case the

(x) Abraham v. Reynolds, 5 H. \& N. 143 ; per Lord Chelmsford, C., 3 Iacq. H. L. Ca. 307.

(y) 3 Macq. H. L. Ca. 266; Weems - Mathieson, 4 Id. 215, 226.

\section{4.}


maxim 'Respondeat superior' prevails, and the master is responsible.

"Thus if a servant driving his master's carriage alonę the highway carelessly runs over a bystander, or if gamekeeper employed to kill game carelessly fires at a hare so as to shoot a person passing on the ground. or if a workman employed by a builder in building a house negligently throws a stone or brick from a scaffold and so hurts a passer-by, in all these cases (and instances might be multiplied indefinitely) the person injured has a right to treat the wrongful or careless act as the act of the master: Qui facit per alium facit per se. If the master himself had driven his carriage improperly, or fired carelessly, or negligently thrown the stone or brick, he would have been directly responsible, and the law does not permit him to escape liability because the act complained of was not done with his own hand. $\mathrm{He}$ is considered as bound to guarantee third persons against all hurt arising from the carelessness of himself or of those acting under his orders in the course of his business. Third persons cannot, or at all events may not, lnow whether the particular injury complained of was the act of the master or the act of his servant. A person sustaining injury in any of the modes I have suggested has a right to say, 'I was no party to your carriage being driven along the road, to your shooting near the public highway, or to your being engaged in building a house. If you choose to do, or cause to be done, any of these acts, it is to you, and not to your servants, I must look for redress, if mischief happens to me as their consequence.' A large portion of the ordinary acts of life are attended with some risk to third persons, and no one has a right to involve others in risks without their consent. This consideration is alone sufticient to justify the wisdom of the rule which makes the person by whom or by whose orders these risks are in- 
curred responsible to third persons for any ill consequences resulting from want of due skill or caution."

Where, however, servants are engaged, not in one common work, but in different departments of duty, the master may be liable in respect of damage done to one servant by another through carelessness or negligence in the same manner as if the servant injured stood under no such relation to him $(a)$. No contract can be implied that the servant shall take upon himself the risk of injury resulting under such circumstances from the negligence of other servants $(b)$. "Workmen," however, " do not cease to be fellow-workmen because they are not all equal in point
of station or authority" $(c)$.

More recently, however, the law relating to the liability Employers of employers to make compensation for injuries suffered by Act, 180 . workmen $(d)$ in their service has been extended and regulated by the Employers' Liability Act, 1880 (43 \& 44 Vict. c. $42(e))$, by which it is provided that where after the commencement of the Act personal injury is caused to a workman such workman, or, in case the injury results in death, his legal personal representatives, and any persons entitled in case of death, shall, in certain cases, have the

(a) Per Lord Chelinsford, C., Bartonshill Coal Co. v. MeGuire, 3 Macq. Sc. App. Ca. 306 ; Holmes r. Clarke, 7 H. $\&$ N. 937 ; s. C., 6 Id. 349 ; per Martin, B., Waller v. South-Eastern R. C., 2 H. \& C. 111; IYurphy v. Smith, 19 C. B., N. S., 361 ; Warburton r. Great IVestern R. C., L. R. 2 Ex. 30. 125.

(b) Smith v. Stccle, L. R. 10 Q. B.

(c) Per Lord Cranworth, Wilson v. Iferry, L. R. 1 Sc. App. Ca. 334; and see per Lord Cairns, C., Id. 332, also Hedley v. Pinkiney S. S. Co., (1894) A. C. 222, affirming (1892) 1 Q. B. 58 (C. A.).

(d) The statute does not apply to all serrants, but only to such as are defined as "workmen" by $3 S \& 39$ Tict. c. 90 , s. 10 ('The Employers and Workmen Act, 1875). See Jaekson v. Hill, 13 Q. B. D. 618 ; Broun r. Butterley Coal Co., 53 L. T. 969 . It would seem, however, that all railway servants, whether engaged in manual work $\mathrm{or}^{\circ}$ not, are included; vide s. 8 . An omnibus conductor paid daily wages is not within the statute: Morgure $r$. London General Omnibus Co., 12 Q. B. D. 201; 13 Id. 832 ; nor the driver of a tramcar: Cook w. North Metrop. Tramucays Co., 18 Q. B. I. 683. The driver of a trolley in the service of a wharfinger is within the statute: Farmouth r. France, 19 Q. B. D. 647 .

(e) Continued until the 31st Dec., 1896 , by 59 Vict. c. 1, s. 1, subs. I. 
same rights of compensation and remedies against the employer as if the workman had not been a workman or in the service of the employer, nor engaged in his work. Such right of compensation and remedies are given where the personal injury has been caused-

1. By any defect $(f)$ in the condition of the ways $(g)$, works (h), machinery, or plant (i) connected with or used in the business of the employer $(k)$, provided that the defect arose from, or had not been discovered or remedied $(l)$ owing to, the negligence of the employer, or of some person in his service entrusted with the duty of seeing that they were in proper condition $(m)$.

2. By the negligence of any superintendent while acting as such $(n)$, or of any person to whose orders or directions the workman was bound to conform, and did conform, where the injury resulted from his so doing $(o)$.

3. By the act or omission of any person in the service of the employer done or made in obedience to the rules or byelaws of the employer, or to the particular instructions given by any person delegated with the authority of the employer in that behalf $(p)$, where the injury resulted from some impropriety or defect in them $(q)$.

(f) Thomas r. Quartermaine, 17 Q. B. D. 414 ; 18 Id. 685 , distinguishing Neblin $\mathrm{v}$. Ballard, 17 Id. 122; Iegram v. Dixon, 55 L. J. Q. B. 447; Yaimouth r. France, 19 Q. B. D. 647 . See this case considered in Simith $r$. Baleer, (1891) A. C. 325 , at pp. 345, 364 ; Walsh v. Whiteley, 21 ( 2. B. D. 371 (C. A.) ; Willetts v. Watts, infra.

(g) MeGiffen v. Palmer's, \&c., Co., 10 (2. B. I. 1 ; Heske r. Samuelson, 12 (2. B. D. 30, approved in Cripps $\mathbf{v}$. Judye, 13 (2. B. D. 583 ; Willetts r. Witts, (1892) 2 Q. B. 92 (C.A.).

(h) This refers to works alrendy completed, not to works in course of coustruction, which are on completion to be connected with, or used in, the business of the employer: Hove $v$. Jak Fineh, 17 (Q. B. D. 187: Simith v. Baker, (1591) A. C., at p. 354:
Brannigan r. Robinson, (1892) I Q. B. 344.

(i) "Plant" inclndes horses: Yormonth v. France, 19 Q. B. D. 647.

(k) S. 1, subs. 1.

(l) Paley r. Garnett, 16 Q. B. D. 52.

(ii) S. 2, subs. 1 ; Kiddle v. Lorett, 16 Q. B. D. 605,610 . 619.

(n) Osborne v. Jackson, 11 Q. B. D.

(o) S. 1, subss. 2, 3; Robins $\mathrm{v}$. Cubitt, 46 L. 'T. 535 ; Shaffers v. Gen. Steam Nav. Co., 10 Q. IJ. D. 356; Osborne v. Jackson, 11 Q. B. D. 619; Banker v. Miallaud R. C., 47 L. T. 476 ; Milkard v, Midland R. C., 14 Q. B. D. 68; Kellaid r. liooke, 19 Id. 5si, attirmed 21 Id. 367 ; "Iild r. Waygood, (1892) 1 (2. B. 783 (C. A.).

(p) S. 1, subs. 4.

(I) S. 2, subs. 2 . 
4. By the negligence of any person in the employer's service who has the charge $(r)$ or control of any signal, points, locomotive engine, or train upon a railucay (s). The workman will not, however, be able to recover in any case where he knew of the defect or negligence, and failed within reasonable time to give or cause to be given information thereof to the employer or some superior employee, unless he was aware that they knew of it already ( $t)$. Neither can he recover where, with knowledge of the defect, he has used the defective thing and injured himself, though he knew how to use, and could have used it, so as to cause no injury $(u)$.

The sum recoverable by a person claiming under this Act is limited to a sum equivalent to the estimated earnings, during the three years preceding the injury, of a person in the same grade employed during those years in the like employment, and in the district in which the workman was employed at the time of the injury $(x)$. Any penalty or part-penalty paid to the workman or his representative under the provisions of any other Act of Parliament in respect of the same cause of action must be deducted from any compensation awarded under this Act, and any compensation so awarded will prevent the party receiving it from recovering any penalty or part-penalty under any other Act in respect of the same cause of action $(y)$. Actions under this Act must be commenced within six

(r) Cox v. Great Western R. C., 9 Q. B. D. $106 ;$ Gibbs v. Great Western R. C., 11 Q. B. D. $22 ; 12$ Ib. 208.

(s) As to the meaning of "railway," see Doughty v. Firbank, 10 Q. B. D. 358 ; as to "locomotive engine," see Murphy v. Wilson, 52 L. J. Q. B. 524 ; as to "train," see MeCord v. Cammell, (1896) A. C. 57, at p. 63. A person who has the charge or control of a train does not necessarily cease to have charge of it, within the meaning of the Act, because some of the carriages are uncoupled from one another and from the engine, in order that they may be separately dealt with (s. c.)

$(t)$ S. 2, subs. $3:$ Weblin r. Ballard, 17 Q. B. D. 122.

(ic) Martin v. Connah's Quay, 33 W. R. 216.

$(x)$ S. 3 . This section does not give the measure of damages, but only the limit within which the jury may award them: Borlick v. Head, 34 W. R. 102 .

(y) S. 5 . 
months of the injury, or in case of death within twelve months from the time of death. No action will be maintainable unless notice (as to which see sect. 7) (z) that injury has been sustained is given within six reeks unless, in the case of death, the Judge is of opinion that there was reasonable excuse for the omission $(a)$. Every such action must be brought in a County Court; it may, however, be removed into a superior Court upon the application of either party in the same way as any other County Court action (b).

It is competent to a workman to contract with his employer not to claim compensation for personal injuries under the Act. And so where a workman had contracted with his employer for himself, his representatives, and any person entitled in case of death, not to make any such claim for personal injuries, whether resulting in death or not, it was held that sect. 1 only affected the contract of service so far as to negative the implication of an agreement by the workman to bear the risks of the employment, and did not render his express contract not to claim compensation invalid. The Court further held that the contract was not invalid, as being against public policy, and that the workman's widow, suing for damages under Lord Campbell's Act, was bound by it $(c)$. The effect of the Act is to place the workman in the same position as a stranger lawfully on the property by the invitation of the occupier, but in no higher (or better position $(d)$; the employer, therefore, will be able

(z) The notice must be in writing: Mayle v. Jenkins, 8 Q. B. D. 116 ; and must contain all the particulars required by s. 7 . A letter referring to a rerbal notice is not a sufficient notice under this Act: Keen v. Millwall Dock Co., 8 Q. B. D. 482. See this case, howerer, distiuguished, $P, C$ ridli r. Gatti, 36 W. R. 670 . As to stating the cause of injurr, see Clark. son $v$. Musgraic, 9 Q. B. D. 386; Sitme v. IIyde, Id. 76. The onission of the date of the injury is a "defect or inaccuracy," not necessarily inralidating the notice: Carter v. Divysdale, 12 Q. B. D. 91.

(a) S. 4.

(b) S. 6. Munday v. Thames, Se., Co., 10 Q. B. D. 59 ; Reg. r. City of Loudon Court (Judge of), 14 Q. B. D. 905.

(c) Griffiths v. Dudley (Earl of), ? Q. B. D. 357 .

(d) Per Fry, I. J.. Thomas r. Quartermaine, is Q. B. D., at p. 703. 
, avail himself of all defences which would be open to him gainst a stranger, ex. gr., contributory negligence $(e)$, ceeptance of risks, in cases where the maxim, volenti non t injuria, will apply $(f)$, or that the negligent servant was ot acting within the scope of his employment $(g)$.

Prior to the stat. 9 \& 10 Vict. c. 93 (h), intituled "An et for compensating the families of persons killed by scidents" («mended by $27 \& 28$ Vict. e. 95 ), an action was tt maintainable against one who by his negligence occaAction for compensation, where deatli has been eausel by neglioned the death of another, for in such a case the rule of w applied-actio personalis moritur cum persona (i). By ct. 1, however, of that statute, it is enacted, "that whenhever the death of a person shall be caused by wrongful it, neglect, or default, and the act, neglect, or default is tch as would (if death had not ensued) have entitled the urty injured to maintain an action and recover damages respect thereof $(k)$, then and in every such case the

(c) Radley v. London and Sorthestern R. C., 1 App. Cas. 754; ullin, Wicklou, \&c., R. C. v. Slattery, tpp. Cas. 1155 ; Struart v. Erans, 31 R. 706; MacCarthy v. British ipouners' Co., 10 I. R. Ir. 384; cblin v. Ballard, 17 Q. B. D. 122. (f) Thomas v. Quartermaine, 18 B. D. 685, disapproving of Weblin Ballard, 17 Id. 122. See further, to this maxim, Famouth v. France, Id. 647 (as to which case see Smith Baker, (1891) A. C. 325 , at pp. 345 , 1); Osborne v. London and Northestern R. C., 21 Q. B. D. 220 ; sodley v. Metrop. Distriet R. C., E. D. 384; Thrussel v. Handyside, Q. B. D. $359 ;$ Nembery v. $G$. $W$. C., 14 App. Cas. p. 179, per Lord amwell, at p. 187 ; Simith v. Baker, 91) A. C. 325 , where Lord Bram"l took a similar view of the maxim in Membery v. G. W. R. C., but the use of Lords beld that continuance the employment with full knowledge 1 understanding of the danger is not clusire eridence that the workman "volens." See this case (loc. cit.), Lord Watson, at p. 355.

g) Ante, pp. 797, 798. (h) This statute does not apply to actions bronght in the Admiralty Conrt for collision between ships. See The Veva Cruz, 9 P. D. 96 ; S. C., Seward v. "Vera Cruz," 10 App. Cas. 59, overruling The Franeonia, 2 P.D. 163; The Bernina, 12 P. D. 58 ; 56 L. J. P. D. \& A. 31; 13 App. Cas. 1.

(i) Leg. Max., 6th ed., 855. Vide per Lush, J., Read v. Great Eastern R.C., L. R. 3 Q. B. 558, which clearly decides " that Lord Campbell's Act did not give any new cause of action, but only substituted the right of the representative to sue in the place of the right which the deceased himself would have had had he survived:" per Field, J., Griffiths r. Dudley (Earl of), 9 Q. B. D., at p. 363 . And so where the deceased could have bronght no action had he survived his persoual representatives will be unable to do so: Haigh v. Royal Mail Steam P'aeliet Co., 52 L. J. Q. B. 640.

See also per Parke, B., Armsurorth v. South-Eastem R. C., 11 Jur. 758.

(k) The words supra have reference, not to the nature of the loss or injury sustained, but to the circumstances under which the bodily injury arose 
person who would have been liable if death had not ensued shall be liable to an action for damages notwithstanding the death of the person injured, and although the death shall have been caused under such circumstances as amount in law to felony." By sect. 2 of the statute above mentioned, it is further enacted, that "every such action shall be for the benefit of the wife, husband, parent $(l)$, and child $(m)$ of the person whose death shall have been so caused, and shall be bronght by and in the name of the executor or administrator of the person deceased;" or if there be no executor or administrator of the deceased, or such action as aforesaid be not brought within six calendar months after his death, then it may be brought in the name or names of all or any of the persons for whose benefit the personal representatives of the deceased would have sued $(n)$. In every such action the jury may give damages proportioned to the injury resulting from the death of the deceased person to those parties respectively for whom and for whose benefit such action shall be brought; and the amount so recovered, after deducting the costs not recovered from the defendant, shall be dividec amongst the before-mentioned parties in such shares as the jury by their verdict shall direct. Sect. 3 of Lord Camp. bell's Act further enacts, " that not more than one actior shall lie for and in respect of the same subject-matter 0 complaint;" and that every action brought by persona representatives under the statute shall be commenced withir

and the nature of the wrongful act, neglect, or default complaiued of: Judgm., Pym r. Great Northern R. C., $213 . \&$ S. $767 ; S . C$. (in Error), 4 B. \& S. 396.

(I) Iy s. 5, the word "parent" shall include father and mother, and grandfather and grandmother, and stepfather and stepmother. See Hetherington v. North-Eastern R. C., 9 Q. 13. I. 160 .

(iii) lyy s. 5, the rord "child" shall include son and daughter, an grandson and granddaughter, and ster son and stepdaughter.

An illegitimate child is not rithi the abore section: Dickinson r. Dorth Eastern R. C., 2 H. \& C. 735.

(n) 27 \& 23 Vict. c. 25 , s. 1.

By s. 2 of this statute, the defet dant may pay money into Court in or sum, without regard to its dirision in shares. 
twelve calendar months after the death of the deceased person; and in every such action it is required (section 4) that the plaintifi on the record shall, together with the declaration, deliver to the defendant or" his solicitor " a full particular of the person or persons for whom and on whose behalf such action shall be brought, and of the nature of the claim in respect of which damages shall be sought to be recovered" (o).

The rules of law applicable in actions brought by per;onal representatives under the abore statute are identical with those applicable in actions of tort brought for bodily njuries at suit of the injured parties themselves $(p)$. The mus of showing negligence lies upon the plaintiffs $(q)$. If the lefendant by his own negligence or carelessness materially $?$ plounty ontributed to the accident $(v)$, his representatives will not ie entitled to recover $(s)$. Should it be contended that the ctual wrong-doer stood in the relation of servant to the efendant, with a view to casting liability upon the latter, nd should it appear that in fact such relation did not exist etween them, but that some link in the chain which had een relied upon as connecting them together was in truth anting, the action brought for compensation will not be

(0) See also in connection with the atutes cited in the text the $31 \leqslant 32$ ict. c. 119 , ss. 25,26 , which concern .e arbitration of damages where a rson has been killed or injured by an cident on a railway, and the examinaon by a medical man of a person so jured.

$(p)$ See the judicial reasoning in arris v. Mobbs, 3 Ex. D. 268. te also Swainson v. North-Eastern C., 3 Ex. D. 341 ; Tucker v. iaplin, 2 C \& K. 730 ; Watling v. ustler, L. R. 6 Ex. 73 ; Bornes Word, 9 C. B. 392 ; Binks v. South mkshire R. C., 3 B. \& S. 244; Rob18 ₹. Jones, 15 C. B., X. S., 221; vkin v. Brown, 8 C. B. 92 ; Birkett Whitehaven Jnnction R. C., 4 \& N. 730 ; Manley v. St. Helen's n. and R. C., 2 H. \& N. 840 ;

B.C.I.
Cotton v. Wood, 8 C. B., N. S., 568. See Griffths v. London and St. Katharine Docks Co., 12 Q. B. D. 493 ; 13 Id. 259; decided under $43 \& 44$ Tict. c. 42.

(q) Hammack v. White, 11 C. B., X. S., 588, approved and followed in Manzoni v. Donglas, 6 Q. B. D. 153. 'The phrase "res ipsa loquitur" (ante, p. 751) might, in a case such as above noticed, be applicable: ex. gr., if two trains proceeding in opposite directions on the same line of rails came into collision.

(r) Withcrley v. Regent's Can. Co., 12 C. B., N. S., 2. See Holden v. Lirerpool Gas Co., 3 C. B. 1 ; Flower v. Adem, 2 Tannt. 314 ; 11 R. R. 591; and cases, p. $78 \pi$.

(s) Judgm., Pym r. Great Northern R. C., 2 B. \& S. 767 . 
sustainable $(t)$. Further, if it be shorn that the injur. which caused death was occasioned by the negligence of th deceased's fellow-servant in the course of their commos employ, such latter person being possessed of competen care and shill (u), a like result (subject to the remark already made $(x)$ ), will follow $(y)$.

In an action founded upon the statute before us (th operation whereof, it will be noticed, is confined to cases i which reath has been caused by negligence), the measure 0 damages is not the loss or suffering of the deceased, but th pecuniary loss, actual or prospective $(z)$, resulting to hi family from his death; nor can the jury, in assessing th amount of compensation to be arrarded to the person on whose behalf the claim to it is put forward, take int consideration the mental anguish sustained by them (a).

Torts to the health and comfort of indiviluals.

2. Following the arrangement specified at p. 782, propose, in the next place, to speak of torts to the healt and comfort of individuals which are clearly to be include under the general head of Torts to the person. Injurie affecting the health of an individual, civilly cognisable $b$ Courts of law, may be committed in various ways, ex. gr.Where, "by any unwholesome practices of another, a ma sustains any apparent damage in his vigour or constitutios

(t) Pecdic v. London and TorthWestern R. C., and Hobbit r. The Same, 4 Exch. 244.

(iv) Hutchinson r. Yoik, Vercastle and Bertcick R. C., j Exch. 5\$3; Wigmore r. Jay, Id. 354.

(x) Ante, p. 806.

(v) See Sinith r. Stcele, I. R. 10 Q. B. 125 .

$\Leftrightarrow$ Franklin r. Suuth-Eastern $R$. C., 3 H. \& N. 211, 214 (where the Court say that "the damages should be calculated in reference to a reasonable expectation of pecuniary benefit, as of right or otherwise, from the continuance of the life"): followed in Inalton $\mathrm{r}$. South-Eostery R. C., \& C. B., N. S., 296, 305: Rateley r. Londion and Wurth-Mestern R. C., 1. R. 8 Ex. 221: liym r. Great Worthein R. C.,
2 B. \& S. 759 ; Duckicorth r. Johnso 4 H. \& N. 653 (as to which case ह Hull v. Great Dorthern R. C., L. R. Ir. 2S9); per Bramicell, E Bradburn r. Great Mestern R. C L. R. 10 Ex. 1.

(a) Blake r. Midland R. C., Q. B. 93 . Section 1 of the $A$ (9 \& 10 Vict. c. 93 ) recites that " jt oftentimes right and expedient that $t$ wrong-doer in such case should answerable in damages"-not alva! That means if damages have be sustained: if not, the action is I maintainable; per Pollock, C. Duckicorth r. Johnson, 4 H. \& X. 6 ? As to the damagres recoverable in action under Lord Campbell's Act, also Leggott r. Great Northern $R$. 1 Q. B. D. 599 , cited p. 710. 
is by selling him bad provisions or wine; by the exercise f a noisome trade which infects the air in his neighbourood; or by the neglect or unskilful management of his hysician, surgeon, or apothecary. For it hath been olemnly resolved, that mala praxis is a great misdemeanor nd offence at common law, whether it be for curiosity and speriment or by neglect; because it breaks the trust which ze party had placed in his physician and tends to the atient's destruction" (b).

Treating of torts to the health and comfort of individuals the order above indicated, Burnby v. Bollett (c) may first Sale of unwholesome 3 cited. There a question raised as to the civil liabilities of butcher who sells meat unfit for human food was learnedly scussed; and the conclusion there come to was, that ctuallers, butchers, and other common dealers in prosions, are not merely in the same situation as dealers in her commodities and liable under the same circumstances they are, so that if an order be sent to them to be executed, ey are presumed to undertake to supply a good and merantable article; but they are also liable to punishment $r$ selling corrupt victuals by virtue of an ancient statute rrtainly if they do so knouingly, and probably if they do it), and are therefore responsible civilly to those customers whom they sell such victuals, for any special or parular injury by the breach of the law which they thereby mmit $(d)$. They would not, however, be liable on an plied warranty $(c)$.

b) 3 Bla. Com. 122, citing $D r$. vencelt's Case, 1 Ld. Ravm. 214.

dr. Chitty also says (Gen. Pract., vol. 1. 42), "The health of an individual i 7 be injured by a public or private sance, as by breaking quarantine, by of unwholesome food, by want of due in medical practitioners, or by sudden ms affecting the nerrous system."

) $16 \mathrm{M}$. A VI. 644. Shillito $\mathrm{r}$. mpson. 1 Q. B. D. 12.

i) Judgm., 16 M. \& W. 654 ; 4th
Inst., 261 ; Chitt. Gen. Pract., vol. 1, pp. 42, 43. See the Public Health Act, 1875 (38 \& 39 Vict. c. 55, ss. 116, 119), and the Food and Drugs Act, 1875 (38 \& 39 Vict. c. 63 , ss. $3-9$ ).

(e) Emmerton v. Watheus, 7 H. \& X. 586. See Wardv. Hobbs, 4 App. Cas. 13. Cf., however, s. 14, subs. 1, ot the Sale of Goods Act, 1893, ante, p. 425, and see Chalmers, "The Sale of Goods Act," 2nd ed., p. 32. 
Nuisances affecting health.

Public nuisance.

In the next place, as regards misances calculated injuriously to affect the health or comfort of individuals,the distinction betreen a public and a private nuisance must be kept in view, - the mode of procedure for the abatement of the former being different from that available to an individual in respect of the latter.

To constitute a public nuisance, the thing complained of must be "such as in its nature or its consequences is a muisance-an injury or a damage to all persons who come within the sphere of its operation, though it may be so in a greater degree to some than it is to others" $(f)$. For example: if, during the operation of a manufactory, volumes of noxious smoke or of poisonous efflnvia are emitted; to persons who are at all within the reach of these operations, a nuisance, in the popular sense of the term, is committed; although to those who are nearer to the manufactory in question the nuisance and inconvenience caused by it may be greater than it is to those who are more remote from it. So, the stopping of the king's highway is a nuisance to all who may have occasion to travel upon that highway; it may be a much greater nuisance to a person who has to travel along it every day than it is to an individual who has to travel along it only once a year; but it is more or less a nuisance to every one who has occasion to use it-it is a 'public' nuisance $(g)$. And an asylum for sick paupers including those suffering from small-pox, though erected under statutory powers, may be maintained in such manner as to create a nuisance $(h)$.

(f) Per Kindersley, Y.-C., Soltau v. De Held, 2 Sim. Ni. S. 142.

(g) Judgm., 2 Sim. N. S. 143.

In regard to the question-What is a public nuisance? see also $A t t .-G e n$. §. Sheffield Gas Consumers' Co., 3 De G. M. St G. 304; Imperial Gas Light and Coke Co. v. Broadbent, 7 H. L. Ca. 600 ; Crouder צ. Timkler, 19 Ves. 617 ; 13 R. R. 267; Thom v'. Taw lale R. C., 13 Beav. 10, 21;
Bostoek r. North Staffordshire R. C. 5 De G. \& S. 584; Reg. r. Train, B. \& S. $640 ;$ Att.-Gen. v. Corporation of Manelester, (1893) 2 Ch. 87. A to what will amount to an obstructiot of a highway, see Harris $\mathrm{v}$. Mlobbs, Ex. D. 268 ; $W_{\text {ilkins r. Day, } 12 \text { Q. B. D }}$ 110 ; Nicol r. Beaumont, 53 L. J. Ch 853.

(i) Hill r. Managers of Metropol tan Asylum District, 4 Q. B. D. 433 
If, however, the thing complained of is such that it is

nuisance to those who are more immediately within the nuisance. phere of its operation, but is no nuisance or inconvenience shatever, or is even advantageous or pleasurable to those ho are more removed from it, there the matter in question oes not properly come within the meaning of the term public' nuisance (i). Thus, a peal of bells may be an atolerable nuisance to one who lives very close to them, hilst to a person who resides at a distance from them the ound thereby produced may be pleasurable $(k)$.

It does not, then, follow, because a thing complained of a nuisance to several individuals, that it is therefore a ublic nuisance, $e x . g r$. - if a man by building up a wall arkens the ancient windows of several different dwellingouses, he is not in thus acting necessarily guilty of a public aisance $(l)$.

Now, in the case of a public nuisance the remedy at law by indictment, the remedy in equity is by information at Remedy in either of the ie suit of the Attorney-General. In the case of a private uisance the remedy is by action in one of the divisions of e High Court of Justice for damages and an injunction $(m)$. here, indeed, that which is a public nuisance is also a ivate nuisance to an individual by inflicting on him some ecial or particular damage, the individual thus specially grieved may have his private remedy at law or in equity $(n)$. From the foregoing remarks will be inferred the extreme pportance of determining the true nature of an alleged isance prior to advising respecting the mode of procedure lich should be adopted in regard to it.

It would of course be useless to attempt to enumerate e various kinds of nuisances prejudicial to health, which

App. Cas. 193. See London and ighton R. C. r. Tiuman, 11 App. i. 45,53 .

i) Soltau v. De Held, 2 Sim. I. S. i, 143.

k) Id. (l) Id. 144.

(m) Hill v. Managers of Metropolitan Asylum District, 4 Q. B. D. 433.

(n) Judgm., 2 Sim. X. S. 145, citing Iieson v. Woore, Comb. 4S0, and other cases ; 3 Bla. Com. 220. 
are actionable by virtue of the principles above laid down. Upon this subject Aldred's case (o) may advantageously be consulted: it illustrates the rule of the Roman law there cited, prohibetur ne quis faciat in suo quod nocere possit alieno $(p)$. Without, then, dwelling at any length upon this part of the subject, it will possibly obviate difficulty to (observe that a private nuisance may be to the person or to the property $(q)$ of another ; it may be of a mixed kind $(r)$, being in part productive of personal discomfort or annoyance to the plaintiff, in part causing a depreciation in the value of property occupied by him. As regards the amount of personal inconvenience, the infliction whereof by another may be deemed to justify the interference of a court of equity, or may sustain an action at law, the test would seem to be that suggested by Knight-Bruce, V.-C., in Walter v. Selfe $(s)$, in these words-Ought the inconvenience in question to be considered in fact as more than fanciful, or as one of mere delicacy or fastidiousness $(t)$; "as an inconvenience materially interfering with the ordinary comfort physically of human existence, not merely according to elegant or dainty modes and habits of living, but according to plain, sober, and simple notions among the English people?"--and by Lord Westbury, C., in St. Helen's Smelting Company v. Tipping (u), who says-Whether that which causes personal inconvenience, and interferes with one's enjoyment, is to be denominated a nuisance, must depend greatly on the circumstances of the place where the thing complained of occurs. If a man lives in a town it is necessary that he should subject himself to the consequences of those operations of trade which are needed for trade and

(o) 9 Rep. 57 b.

(p) See Jones r. Porcell, Palm. 536.

(q) Post, Chap. 3, sect. 1.

(r) See White v. Cohen, 1 Drew. 312; Flight v. Thomas, 10 Ad. \& E. 590; Bliss v. Hall., 4 Bing. N. C. 183. (s) 4 De G. \& S. 315 , adopted in Soltau r. De Held, 2 Sim. X. S. 159.

$(t)$ Lex non faret delicatorum rotis 9 Rep. 58 a : Fleming r. Hislop, 11 App. Cas. 686, 690. See Christi r. Darey, (1893) 1 Ch. 316.

(u) 11 H. L. Ca. 650. 
commerce, and also for the enjoyment of property, and for the benefit of the inhabitants of the town, and of the public at large. "If a man lives in a street where there are numerous shops, and a shop is opened next door to him, which is carried on in a fair and reasonable way, he has no ground for complaint because to himself individually there may arise much discomfort from the trade carried on in that shop. But when an occupation is carried on by one person in the neighbourhood of another, and the result of hat trade or occupation or business is a material injury to property, then there unquestionably arises a very different "onsideration."

The action for negligent treatment of a patient alluded to py Blackstone in the passage formerly cited $(x)$, is sustainable upon this principle, that every person who enters into a earned profession undertakes to bring to the exercise of it r reasonable degree of care and skill. He does not, indeed, $f$ he be a surgeon, undertake that he will perform a cure, hor does he undertake to use the highest possible degree of kill; but he undertakes to bring a fair, reasonable, and ompetent degree of skill to the treatment of his patient; nd it will be for the jury, in any given case involving a harge of negligence, to say whether the injury complained f really was occasioned by the want of such skill in the efendant $(y)$.

3. Torts affecting personal liberty are False Imprisonaent and Malicious Arrest.

To constitute the injury of false imprisonment there are wo requisites, the detention of the person, and the unlawlness of such detention. The confinement of the person 1 anywise is an imprisonment, which may even be ridenced by the forcibly detaining of another in the public

(x) Ante, pp. 818, 819.

(y) Per Tindal, C. J., Lanphier. hipos, 8 Car. \& P. 475, 479. See ater v. Baker, 2 Wils. 359 ; Pippin v. Sheppard, 11 Price, 400 ; Seare v. Prentice, 8 East, 348; Hancke v. Hooper, 7 Car. \& P. 81.
Action for negligent treatment of patient.
Torts to personal liberty.

False imprisonment. 
street $(z)$. False imprisonment consists in such confine ment or detention without sufficient authority $(a)$. As i A. is arrested on a criminal charge under a warrant agains B. (b). In this case, the arrest effected under the warran is illegal, as unauthorised by it; and the party taking ou the warrant and delivering it to the constable will be liabl for a trespass at suit of the individual arrested. So, thi wrongful removal of a prisoner from one part of a prisor to another, and his detention in the part to which he is si removed, will lay the foundation of an action for trespast and false imprisonment, in which even the Home Secretar? may be liable, if it appear that the complainant $\mathrm{ma}$ removed under a general order issued by such Secretary fo: the classification of the prisoners, which he had no lega authority to make $(c)$.

An arrest and imprisonment may, however, be justifier in certain cases by statute $(d)$, or by reference to acknow ledged principles of law, or as having been effected unde the sanction of judicial process $(c)$, or its tortious characte may be neutralised by ex post facto legislation $(f)$.

Thus it is laid down that a private person is justified is arresting any of the Queen's subjects if there be a breacl of the peace actually continuing, or if he has reasonabl ground to believe that a breach of the peace which ha been committed will be renewed $(g)$. It is also clear tha

(z) As to the question-What may suffice to constitute an "imprisonment" ? see further, Warner, app., Riddiford, resp., 4 C. B., N. S., iso, 204, 205: Bird v. Jones, 7 Q. B. 742 ; Wright v. Wilson, 1 Ld. Raym. 739 ; Arourmith v. Le Mesurier, 2 B. \& P. N.1R.211;9 IR.R. 642; Cant v. Parsons, 6 Car. \& P. 504; Wood v. Lane, Id. 7T4. (a) 3 Hla. Com. 12i. See Mostyn r. Fabriyas, Cowp. 161: 1 Sm. L. C., 9th ed., 628; Worth v. Terrington, 17 M. \& W. 781; Moore v. Rose, I. R. 4 Q. B. 486 ; Austin, app., Jouling, resp., I. R. 5 C. P. 534 . (b) Hoye v. Bush, 1 M. \& Cr. 775.

(c) Cobbett v. Grey, 4 Exch. 729.

(d) See, for instance, Hadley Perks, L. R. 1 Q. B. 444, 456.

(e) It is said that "there are tw classes of rightful arrest; the or where the arrest is enjoined as a dut the other where it is permitted as just fiable:" Arg., $R$. v. Howarth, Mo C. C. 213 . See also Hawk, Pl. C., 81 ed., vol. 2, p. 114 ; Neuton v. Boodl 3 C. B. 795 .

(f) Phillips v. Eyre, L. R.4 Q. B. 22

(g) Irice v. Seeley, 10 Cl. \& F. $\approx$ Grant v. Moser, 5 M. \& Gr. 12 : 
any bystander may and ought to interfere to part those who make an affray, and to stay those who are going to join in it; further, he may arrest the affrayers and detain them until their heat be over, and then deliver them to a constable $(l)$ : the principle of these decisions being that, "for the sake of the preservation of the peace, any individual who sees it broken may restrain the liberty of him whom he sees breaking it, so long as his conduct shows that the public peace is likely to be endangered by his acts" (i).

So, if a person comes into a house, or is in it, and makes a noise and disturbs the peace of the family, although no assault has been committed, the master of the house may turn him out, or call a policeman to do so $(k)$. And if a man stations himself opposite to another's house, making $\checkmark$ disturbance, exciting others to disturbance and riot, and postructing the public way, these are facts which may well mount to such a breach of the peace as justifies an irrest $(l)$.

It seems clearly established, however, that a private indiidual who has seen an affray committed is not justified in riving in charge to a constable who has not, after the affray las entirely ceased, after the offenders have quitted the lace where it was committed, and when there is no danger if its renewal $(m)$. Though a private person may set in notion a constable who has seen a breach of the peace ommitted, without incurring liability $(n)$. Inasmuch, noreover, as the power of a constable, at common law,

iaynes v. Brewster, 2 Q. B. 375. See Vooding v. Oxley, 9 Car. \& P. 1.

(h) Timothy v. Simpson, 1 Cr. M. \& 157.

(i) Judgm., 1 Cr. M. \& R. 762.

(k) Per Lord Campbell, C. J., Shaw: Chairitie, 3 Car. \& K. 21, 25 ; Rose Wilson, 8 Moore, 362; Green v. artram, 4 Car. \& P. 308 ; Reece v. inylor, 4 N. \& M. 469. Per Patteson, , Wheeler v. Whiting, 9 Car. \& P.
262 ; Clifford v. Brandon, 2 Camp. 358 ; 11 K. R. 73; Preface vii. ; Preface to $14 \mathrm{R}$. R. vii.

(l) Webster v. Watts, 11 Q. B. 311, 324 ; Cohen v. Huslisson, 2 M. \& W. 477.

(mi) Baynes v. Breuster, 2 Q. B. 375 ; Judgm., Timothy v. Simpson, 1 Cr. M. \& R. 761 . 488 . 
to take into his custody, upon the information of a privat person, under such circumstances, must be correlative witl that of the latter to give in charge, it follows that the con stable will not be justified in taking a party designated a the offender into custody upon such information $(o)$.

A private individual also, being present at the time whes a felony is committed, may legally and ought to arrest 0 aid in arresting the offender $(p)$. He may even break int a private house in order to prevent the commission of felony $(q)$. Or, a felony having been committed, he ma, give in charge the guilty party to a policeman $(r)$.

Again, an arrest and imprisonment may be justified 0 . this ground, that a felony having been committed there wa reasonable and probable cause to suspect and accuse th plaintiff of it, and therefore to arrest and imprison hir with a view to charging him with the offence $(s)$. In an such case it is laid down that to justify depriving a perso of his liberty, the party so doing must allege such a groun of suspicion as the Court can see to be reasonable $(t)$. will then be for the jury to say whether the facts allege are proved, and for the Judge to determine whether or $n$ they amount to reasonable and probable cause-not $\mathrm{fc}$ suspecting, but-for imprisoning the plaintiff $(u)$.

Although, however, it is clear that a private individu cannot arrest upon bare suspicion, a constable may $\dot{d}$

(o) Judgm.. 1 Cr. M. \& R. 761.

(p) Chitt. Gen. Pract., vol. 1, p. 618.

(q) Handcock v. Baker, 2 B. \& P. 260 ; 5 R. R. 587.

(r) Atkinson $\mathrm{r}$. Warne, $1 \mathrm{Cr}$. M. \& R. 827. See Perkins r. Iaughan, 4 II. \& Gr. 988; and compare Fox r. Gaunt, 3 I. \& Ad. 798, 800.

(8) Ledwith v. Catchpole, Cald. 291. Sce Guppy v. Brittlebank, 5 Price, 525 ; Allen v. Wright, 8 Car. \& P. 522: Williams r. Crosswell, 2 Car. $\&$ K. 422 ; and cases, infra.

(t) Broughton r. Jackson, 18 Q. B. 378.

(u) Lister r. Perryman, I. R. 4
H. L. 521, 539; $\Gamma_{\text {cst }}$ r. Baxenda

9 C. B. 141, 152; Halles r. Marl

7 H. \& N. 56 ; Sinith r. Shirle 3 C. B. 142.

"If treason or felony be done, a one hath just cause of suspicion, this a good cause and warrant in law 1 him to arrest any man, but he m? show in certainty the cause of his sl picion; and whether the suspicion just or lawful shall be determined the justices in an action of false is prisonment brought by the pa grieved, or upon a habeas corp' \&c. :" 2 Inst. 52. 
so $(x)$. There is this distinction between the two parties just named: In order to justify the former in causing the imprisonment of a person, he must not only make out a reasonable ground of suspicion, but he must prove that a felony has actually been committed; whereas a constable, having reasonable ground to suspect that a felony has been sommitted, is authorised to detain the party suspected until nquiry can be made by the proper authorities $(y)$; but neither a constable nor a private individual can at common aw arrest a person merely on suspicion of his having llegally obtained goods $(z)$.

Not only under circumstances such as above indicated nay a private person justify in an action for false imprisonnent, but he may sometimes do so by virtue of particular tatutes.

One practical remark in connection with this part of the ubject may be made. Inasmuch as a private individual rho directs a police officer to take a person into custody nay by so doing render himself liable to an action for false mprisonment $(a)$, and as, in such an action, if the verdict e adverse to the defendant, heavy damages are usually iven $(b)$, it is safer in any doubtful case for a private erson, especially when time will allow, rather than thus cting for himself, to apply to a magistrate for a warrant; ecause, whenever an arrest takes place under such instrulent, the party arrested cannot maintain an action against 1e party who makes the charge, although it should turn

(x) Beekwith v. Philby, 6 B. \& C. 38, 639; Hobbs v. Branscomb, 3 Camp. :0; Handcock v. Baker, 2 B.\& P. 260 ; R. R. 587 ; Hall v. Booth, 3 N. \& M. 6 ; Matthews v. Biddulph, 4 Scott, . R. 54 ; Davis v. Russell, 5 Bing. i4, 363; Samuel v. Payne, Dougl, 9.

(y) See preceding note.

(z) Per Blackbuin, J., Hadley $\mathrm{v}$ rrks, L. R. 1 Q. B. 456 .

(a) Hopkins v. Crowe, 7 Car. \& P.
373; Austin, app., Dowling, resp., L. R. 5 C. P. 534 . See Gosden v. Elphich, 4 Exch. 445, 447; Grinham v. Willey, 4 H. \& N. 496 ; Stammers v. Fearsley, 10 Bing. 35.

(b) Per Parke, B., Waruich v. Foulkes, 12 M. \& W. 509, where that learned Judge observes, that " if people choose to settle private disputes by giving others into custody, they must take the consequences." See per Pollock, C. B., 4 H. \& N. 499. 
out that no offence whatever had been committed, unless he can prove that the party who applied for and got the warrant acted maliciously and without probable cause (c).

An inquiry will presently be instituted in regard to the true meaning and significance of the words "malice" anc "malicious" in connection more particularly with torts.

Constableliability ofin action for false imprisonment.

The irresponsibility of a constable or police officer ir respect of an act, done by him officially, affecting the liberty of the subject is, as might be supposed, greater than that accorded to a private individual. " A constable,' says Blackstone $(d)$, "hath great original and inheren" power with regard to arrests. He may, without warrant arrest any one for a breach of the peace committed in hi: vieu (e), and carry him before a justice of the peace. Anc in case of felony actually committed, or a dangerou wounding whereby felony is likely to ensue, he may upor probable suspicion, or upon a reasonable charge made b! a third person $(f)$, arrest the felon, and for that purpost is authorised (as upon a justice's warrant) to break ope! doors, and even to kill the felon if he cannot otherwise br taken."

Should a particular statute authorise a constable to taki into custody without a warrant any one offending agains its provisions within view of such constable, it will ba requisite for the officer's justification to show that hi has acted in strict conformity with the language of th Act $(g)$.

The warrant of a Court of competent authority will is many cases protect the ministerial officer employed is executing its process, when sued in an action for fals

(c) Chitt. Gen. Pract., rol. 1, p. 620; Siloneliouse v. Elliott, 6 T. R. 315 ; 3 R. R. 183. See Hope v. Erered, 17 Q. H. D. 338 .

(d) 4 Com. p. 292 ; Levy v. Edcards, 1 Car. \& P. 40.

(c) Ste Griffin r. Coleman, 4 H. \& X.
265 ; Derecourt r. Corbishley, 5 E. \& I 188; Reg..v. Light, Dearsl. \& B. 33: 417

(g) Simmons r. Millingen, 2 C. I 524; Justice v. Gosling, 12 C. B. 3! See Borditch r. Balchin, ó Exch. 3 ? 
imprisonment $(h)$. Upon this subject the well-established rule for our guidance is, that where a Court has jurisdiction of the cause before it, and in disposing of it proceeds inverso ordine, or erroneously, then the party who sues (i), or the officer or minister of the Court who executes its precept or process, will not be liable to an action $(k)$. Where, however, the Court has not jurisdiction of the cause before it, then the whole proceeding is coram non iudice, and the parties above specified may be liable to an action for false imprisonment under the process of the Court (l), for these parties are to be presumed to know the law, and therefore to be cognisant of the want of jurisdiction aforesaid. Protection is, however, by stat. 24 Geo. 2, c. 44, ss. 6, 8, extended to constables, acting under magisterial warrants issued without jurisdiction, and in jome other cases $(m)$.

But "whenever a warrant has been issued to arrest a person charged with an offence in respect of which he zannot be apprehended without a warrant, the police officer nust have the warrant in his possession at the time when ae executes it; if he has not, the arrest will be illegal " $(n)$, and so a conviction for assault cannot be maintained where she constable attempts to arrest the prisoner with a warrant ot properly backed $(o)$.

In Howard v. Gosset ( $p$ ) (in which the prior authorities,

(h) See Galliard, app., Laxton, esp., 2 B. \& S. 363,373 ; Codd $\mathrm{v}$. $\checkmark a b c, 1$ Ex. D. $352,355,356$.

(i) A fortiori, a plaintiff acting inder a regular warrant of a comretent Court, will be protected thereby. iee Daries v. Fletches, 2 E. \& B. 271.

(k) The Marshalsea Case, 10 Pep.

is b, 76 a. See Levy r. IToylan, 10

J. B. 189; Thomas v. Hudson, 14 I. \& W. 353,$377 ; S . C ., 16$ Id. 885 ; Andrexs v. Marris, 1 Q. B. 3, with ihich compare Dews v. Riley, 11 C. B. 34; Baylis r. Strickland, 1 M. \& Gr. 91; Cobbett v. Hudson, 13 Q. B. 497 ;
Prentice v. Harrison, 4 Q. B. 852, cited and explained per Alderson, B., Brown v. Jones, 15 M. \& W. 192 ; Herring v. Hudson, 3 Exch. 107.

(l) The Marshalsea Case, supra: Judgm., Morrell v. Martin, 3 M. \& Gr. 593 ; Carratt v. Morley, 1 Q. B. 18; Tinniswood v. Pattison, :3 C. B. 243.

(m) See Pedley v. Davis, 10 C. B., N. S., $492,513$.

(n) Per Mellor, J., Codd v. Cabe, 1 Ex. D. 356 . 341.

(o) Reg. v. Cumpton, 5 Q. B. D.

(p) 10 Q. B. $359,411$. 
having reference to justification under warrants, ar collected) it was held, that the warrant of the Speaker $c$ the House of Commons, having issued in a matter ove which the House had jurisdiction, was to be construed ol the same principle as a mandate or writ issuing out of superior Court acting according to the course of commos law, and that it afforded a valid defence to an action fo assault and false imprisonment brought against the Serjeant at-arms who acted in obedience to such warrant. An Entick v. Carrington $(q)$ is the leading case in regard to th power to arrest, and to seize papers under a warrant issue by the Secretary of State.

From The Marshalsea case $(r)$, we learn that a party wh merely originates a suit by stating his case to a Court c justice is not guilty of trespass and false imprisonment though the proceedings leading to the arrest of the com plainant should be erroneous or without jurisdiction $(s)$ And a like remark applies where an individual prefers complaint to a magistrate and procures a warrant to $b$ granted upon which the accused is taken into custody, th magistrate having in fact no jurisdiction $(t)$.

A solicitor, however, who deliberately directs the execu tion of a bad warrant, may by so doing render himsel responsible in trespass $(u)$. It is true, as remarked by th Court of Common Pleas $(x)$, that if he does no more tha set a Court of competent jurisdiction in motion, on behal of his client, he is no trespasser, notwithstanding that suc]

(q) 19 How. St. Tr. 1030 ; S. C., 2 Wils. 275. See alsn Leach r. Money, 12 How. St. Tr. 1002 ; S. C., 3 Burr. 1692,$1743 ; R$. v. Wilkcs, 2 Wils. I51; Wilkes v. Wood, 19 How. St. Tr. 1154, 1167 : Sayre r. Earl of Rochford, 20 Id. 1286.

(r) Supra, n. $(k)$.

(s) Carratt v. Morley, 1 Q. B. 18, 28 ; Walley $\%$ M.Conmell, 13 Q. B. 903, followed in Kelly r. Lawrence, 3 H. \& C. 1. See also Abley v. Dale,
11 C. B. 378.

(t) Broucn v. Chapman, 6 C. B. 36i 376. See Lock v. Ashton, 12 Q. I 871.

(u) Green v. Elgie, 5 Q. B. 99 Eggington v. Mayor of Lichfield, E. \& B. 100.

(x) Kinning v. Buchanan, 8 C. I 271,291 ; Bryant v. Clutton, 1 M. \& IT 408; Williams r. Smith, 14 C. B N. S., 596. 
Court should on his motion do an act of trespass by its officers. But where he admits and undertakes to justify his concurrence in the act complained of, he can only make out his justification by showing a legal authority under which he acted.

Where malice is charged as an ingredient in the alleged tort, the action will be for a malicious arrest or for a malicious prosecution; to each of which I propose hereafter to advert.

Touching the liability of a justice of the peace in an zetion for false imprisonment some brief remarks merely can be offered. Justices of the peace, says Sir M. Hale (y), aave a double power in relation to the arrest of felons; original or upon complaint of another person. "If," bsserves the same eminent lawyer (z), "a justice of the seace see a felony or other breach of the peace committed $n$ his presence, he may in his own person apprehend the elon. And so he may by word command any person to spprehend him, and such command is a good warrant withrut writing; but if the felony or other breach of the peace re done in his absence, then he must issue his warrant in vriting under his seal to apprehend the malefactor.

Conformably to the principle stated in a former part of his work (a), in connection with the civil liability of judicial fficers, it may be laid down, that where a justice of the peace cts judicially upon the complaint of another person, he will ot be liable for a mere error of judgment $(b)$; and by tatute $(c)$ he is protected from liability in respect of "any

(y) Pl. Cr., vol. 2, p. 86.

( ) Id. ibid.

(a) Ante, p. 103.

(b) Linford v. Fitzroy, 13 Q. B. 10 ; Judgm., Garrett v. Ferrand, 6 \& C. 625,626 ; Penney v. Slade, 7 cott, 285; Kondillon v. Maltby, Car. II. 402 , as to which case see Munster. Lamb, 11 Q. B. D. 588, 608.

(c) 11 \& 12 Vict. c. 44 , s. 1 ; as which see Barton v. Brieknell, 13
Q. B. 393 ; Bott v. Ackroyd, 28 I. J., M. C. 207: Sommerville v. Mirchouse, 1 B. \& S. 652. Section 4 of this Act further enacts, "That in all cases where a discretionary pouer shall be given to a justice of the peace by any Act or Acts of Parliament, no action shall be brought against such justice for or by reason of the manner in which he shall have exercised his discretion in the execution of any such power."
Justice of the peaceliability of, in action for false imprisonment. 
act done by him in the execution of his duty as such justice," unless where proof is given that the act in question "was done maliciously and uithout reasonable and probable cause" (d).

Again-where the justice has acted in a matter within his jurisdiction, a subsisting conviction good upon the face of it will be a sufficient protection to him when sued under section 1 of the Act above adverted to; for such conviction, so long as it remains in force, is conclusive evidence of the facts stated in it; and this evidence cannot be impugned or rebutted by proof of corrupt motives or of malice $(e)$. "It is," said Lord Tenterden, C. J. $(f)$, " a general rule and principle of law, that, where justices of the peace have an authority given to them by an Act of Parliament, and they appear to have acted within the jurisdiction so given, and to have done all that they are required by the Act to do in ordes to originate their jurisdiction, a conviction drawn up in dut form, and remaining in force, is a protection in any actior brought against them for the act so done."

As regards the liability of a justice of the peace in anothes important class of cases, riz., where he acts without juris. diction or exceeds it, we must resort for information to section 2 of the $11 \& 12$ Vict. c. 44 , which enacts, that "for any act done by a justice of the peace in a matter of which by law he has not jurisdictiom, or in which he shall hav exceeded his jurisdiction, any person injured thereby, or by any act done under any conviction or order made or warran issued by such justice in any such matter, may maintain al

See R. r. Young, 1 Burr. 556 ; Bassett v. Godschall, 3 Wils. 121.

(d) As to evidence of want of "reasonable and probable cause, in the case supra, see Burlcy v. Bethune, 5 Taunt. 580 .

(e) See, per Dallas, C. J., Brittain v. Kinnairl, 1 B. \& B. $437 ; 21$ R. R. 680 (designated as a "very celebrated case:" per Lord Colevidge, C. J., Usill v. Hales, 3 C. P. D. 324); hilby v.
Simpson, 10 Exch. 358, 365 ; Fuccel r. Fowlis, 7 B. \& C. 394 ; Basten । Carcu, 3 B. \& C. 649; Baylis : Strickland, 1 Scott, N. R. 540; Ash croft v. Bourne, 3 B. \& Ad. 684 Strickland v. Ward, 7 T. R. 631, 633 Aldidge r. Haines, 2 B. \& Ad. 395 Fendall $v$. Wilkinson, $4 \mathrm{E}$. \& $\mathrm{E}$ 680.

(f) 3 B. \& C. 652, 653. See Lim say v. Leigh, 11 Q. B. 45 . 
ction against such justice in the same form and in the same ase as he might have done before the passing of this Act $(g)$, ithout making any allegation in his declaration, that the ct complained of was done maliciously or without reasonable ir probable cause $(h)$ : provided, nevertheless, that no such ction shall be brought for anything done under such convicon or order, until after such conviction shall have been uashed, either upon appeal or upon application to her [ajesty's Court of Queen's Bench." The section before us irther goes on to provide that no such action shall " be rought for anything done under any such warrant, which ball have been issued by such justice to procure the appearace of such party, and which shall have been followed by a nnviction or order in the same matter, until after such coniction or order shall have been so quashed as aforesaid; : if such last-mentioned warrant shall not have been llowed by any such conviction or order, or if it be a arrant upon an information for an alleged indictable fence, nevertheless, if a summons were issued previously such warrant, and such summons were served upon such irson, either personally or by leaving the same for him th some person at his last or most usual place of abode, id he did not appear according to the exigency of such mmons, in such case no such action shall be maințained ainst such justice for anything done under such urrant" (i).

The effect of the foregoing section may be shortly stated be, that no action shall be brought for anything done ider a conviction or order, where the magistrate has no risdiction or has exceeded it, until such conviction or der shall have been quashed; nor for anything done

g) See Leary v. Patrick, 15 Q. B. , 272; Crepps v. Durden, Cowp. h) Pease v. Chaytor, 1 B.\& S. 658. B.C.L. (i) As to the latter part of the above section, see Bessell v. Wilson, 1 E. \& B. 489. 
under a warrant to compel an appearance, followed by conviction or order, until the same shall have bee: quashed; nor for anything done under such warrant, nc followed by a conviction or order, or under a warrant fo an alleged indictable offence, if a summons had bee: previously served and not obeyed.

The main distinction to be noted in regard to the remed available against a magistrate who acts without jurisdic tion, and that available against a magistrate who act erroneously within his jurisdiction, is thus pointed or by Mr. Justice Erle $(k)$ : "If the act of the magistrate $\mathrm{j}$ done without jurisdiction it is a trespass; if within th jurisdiction, the action rests upon the corruptness , motive, and to establish this the act must be shown $t$ be malicious."

Besides the above provisions for the protection of justice contained in the statute, others scarcely less importan but of too technical a character to allow of their being her examined, are included in it. Of these may be specifie section 8 , which prescribes the period of limitation in a action against a justice of the peace for anything done $\mathrm{l}$ him in the execution of his office; and section 9, whic requires a month's notice of the intended action to be gire to the justice $(l)$.

It will readily be inferred from what has been said in th preceding pages, that, in actions for false imprisonmen nice and difficult questions in regard to the jurisdiction Courts-the validity of their judgments and conviction the legality of process, the powers properly exercisable 1 those who enforce it-may arise; touching such matte

(k) Taylor v. Nesfeld, 3 E. \& B. 724. See also Verbould v. Coltman, 6 Exch. 189; Pedley r. Davis, 10 C. B., X. S., 492, $51 \mathrm{I}$; Haylock v. Sparke, I E. S 13.471; Gelen v. Hall, 2 H. \& N. 379.

(l) See Kirby v. Simpson, 10 Exch.
358.

As to the damages recoverable in action for false imprisonment agail a magistrate, see Mason r. Bark: 1 Car. \& K. 100: against a coron see Foxhall v. Barnett, 2 E. \& 928. 
nformation must be sought for from works specifically eroted to their investigation. With reference to the ction before us, I shall merely add that where two or ore persons have so conducted themselves as to be liable be jointly sued for trespass and false imprisonment the amages must be assessed against all jointly $(\mathrm{m})$, each of he defendants being responsible for the damage sustained y their common act $(n)$. " Where two persons," it has een said $(o)$, "have a joint purpose, and thereby make 1emselves joint trespassers, and the one beats violently, ad the other a little, the real injury is the aggregate of te injury received from both. So, if motive be taken into nsideration, the motive of $\mathrm{A}$. may be most aggravated Id the motive of $\mathrm{B}$. most mitigated, then the damages ust be regulated accordingly."

Before proceeding to consider the nature of malicious juries to the person, it may be well briefly to inquire as the meaning of the terms "malice" and "malicious" hen used with reference to civil proceedings.

We have already seen $(p)$ that in some classes of cases, ving rise to actions ex delicto, the intention. which actued the wrong-doer is wholly beside the question, whether not an action will, under the given circumstances, lie. others, again, the animus, motive, or intention of the rty charged constitutes an essential element in-if not e very gist and substance of-the charge $(q)$. Falling thin this latter class are the torts now to be discussed.

"Malice," says Lord Campbell, C. J. $(r)$, "in the legal ceptation of the word, is not confined to personal spite

m) Eliot v. Allen, 1 C. B. 18.

n) Per Rolfe, B., Clark r. Newsam, 3xch. 140. See per Willes, J., 17 B. 71 .

o) Per Alderson, B., 1 Exch. 140. Gregory r. Cotterell, 5 E. \& B. 571. p) Ante, p. 782.

g) See Jrogul S. S. Co. r. McGregor ' $x$, (1892) A. C. 25, affirming $S . C$,
23 Q. B. D. 598 (C. A.) ; Temperton v. Russell, (1893) I Q. B. 715 (C. A.) ; Flood r. Jackson, (1895) 2 Q. B. 21 (C. A.).

(r) 9 Cl. \& F. 321; per Sir W. Follett, arg., Nitehell v. Jenkins, 5 B. \& Ad. $590 ; 1$ Wms. Saund. 242 b. n. $(e)$.
Malicious injuries.

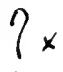


against individuals, but consists in a conscious violation 0 the law to the prejudice of another." Malice is of $t w$ kinds-malice in law, and malice in fact. Malice in law $\mathrm{i}$ where a wrongful act is done intentionally, without jus cause or excuse $(s)$. If, for instance, I traduce a mar whether I know him or not, and whether I intend to d him an injury or not, the law considers it as done of malic because it is wrongful and intentional $(t)$; it equally work an injury whether I meant to produce an injury or not; an if I had no legal excuse for the slander, why should ther not be a remedy against me for the injury which it pre duces $(u)$ ? Such being legal "malice," it follows that som acts are in law always malicious $(x)$, without any proc being given of personal ill-will or ill-feeling.

" Malice in fact" is said to be of two kinds, viz., person malice against the individual, and that sort of general dis regard of the right consideration due to all mankind whicl indeed, may not be previously directed against any one, br is nevertheless productive of injury to the complainant ( $y$ This seems very nearly equivalent to saying that "malice $i$ fact " may be proved to have existed in one or other of tis ways-either by direct evidence, as of expressions user of declarations made, or of conduct generally-evincir enmity towards a particular individual ; or, again, it may 1 shown by proof of some act from which a jury would I held justified in inferring a malicious motive; and the a relied upon as evidence of malice may possibly be one n aimed at the particular individual who has suffered by it.

To support an action for a malicious injury there mus in many cases, be both injury, in the strict sense of tl word (that is, a wrong done), and loss resulting from th

(8) Judgm., Bromage v. Prosser, 4 B. \& C. 255 ; arg., Shertein v. Suindall, 12 M. \& W. 787 .

(i) Judgm., 4 B. \& C. 255.

(v) Ibid. 791.

(x) See per Parke, B., 12 M. \& W.

(y) See per Pollock, C. B., M. \& W. 787,788 ; per Lord Elh borough, C. J., Tounsend r. Wath 9 East, 280, 281 ; 9 R. R. 553. 
njury; the injury or wrong done must be the act of the lefendant; and the loss must be a direct and natural, not remote and indirect consequence of the defendant's act. Inless, indeed, there be a loss thus directly and proxiaately connected with the act, the mere intention, or even he endearour, to produce it will not found an action $(z)$. . man's motives will not make wrongful an act which in iself is not wrongful $(a)$. An act which does not amount o a legal injury cannot be actionable because it is done ith a bad intent $(b)$. An action does not lie against a an for maliciously doing his duty $(c)$. And although the sistence of a malicious intention is often an essential inredient in order to constitute the wrongfulness or injurious ature of an act, yet it will supply neither the want of the et itself nor of its hurtful consequences; however complete 1e injuria, and whether with malice or without, if the act e, after all, sine damno, no action founded upon the idea of reach of duty causing damage will lie. For instance, if a nntract has been made between $\mathrm{A}$. and $\mathrm{B}$. that the latter rould go supercargo for the former on a voyage to China, Id C., however maliciously, persuades B. to break his intract, but in vain, it could not successfully be contended rat an action would lie against $\mathrm{C}$., his malice having been effectual, and no loss having resulted from it to A. $(d)$. eeping these elementary principles in mind, let us proed to inquire as to the action for a Malicious Arrest-for Malicious Prosecution-for Defamation.

The first-mentioned of these actions is of less importance Jw than before the almost total abolition in civil procedure Action for malicious -except in the County Courts-of arrest and imprisonment $r$ debt. The action proceeds upon this idea, that to put in
(z) Per Coleridge, J., 2 E. \& B. 246,
(a) Per Jervis, C. J., Heall v. Carey, C. B. 993.
(b) Judgm., Sterenson r. Neunham, hadfoud. Prikles
allun, flood.

13 C. B. 297.

(c) Per Mellor, J., Darthins r. Loid Paulet, L. R. 5 Q. B. 114. cited post. (d) Per Coleridge, J., 2 E. \& B. 247 . 
force the process of the law maliciously, and without reaso: able or probable cause $(e)$, is wrongful, and that if therel another is prejudiced in property or person, there is th conjunction of injury and loss which will lay the foundatic of an action $(f)$.

The ground on which such an action would lie und the 32 \& 33 Vict. c. 62 , s. 6 , would be, that the par obtaining the capias had imposed on the Judge, who allowe it to issue, by some false statement-some suggestio fa or suppressio veri-and had thereby satisfied him not on of the existence of a debt to the requisite amount, but al that there was reasonable ground for supposing that ti debtor was about to quit the country. In an action $f$ a malicious arrest under that statute, it would be essenti that the plaintiff should allege falsehood or fraud obtaining the original order $(g)$, and should show th the defendant had in some way misrepresented the fact or imposed upon the Judge in his representation them $(h)$.

If, indeed, a person truly states certain facts to a Judg and the Judge thereupon does an act which is erroneou and which the law will not justify, the party who made ti statement is not liable, because in that case the grieran complained of arises not from the false statement of th party, but from a mistalie of the Judge; but this is not

(e) Lister r. Perryman, I. R. 4 II. I. $5: 21$; Huntley r. Simpson, 2 II. S. N. 600 ; Phillips r. Saylor, 4 II. \& X. 565 .

(f) Per Lord Campbell, C. J., Chivehill v. Siggers, 3 E. \& B. 937 . See De .Medina r. Groce, 10 Q. B. 152, 17:; Leylend v. Tuncred, 16 Q. B. 609 ; S. C., Id. 664.

In Migotti r. Colvill, 4 C. P. D. 233, the action was brought against the governor of a bouse of correction for improperly and unlawfully refusing to discharge the plaintiff fron custody and set him at liberty, and keeping him in prison for one day longer than term for which he was sentenced to imprisoned.

See Moore v. Guardner, 16 M. \& 595: Magnay r. Burt (in Error), Q. B. 381; Whalley v. Pepper, Car. \& P. 506 ; Hounsfield $\mathrm{r}$. Dru 11 Ad. \& E. 98.

(g) Judgm., Daniels v. Fielding, M. \& W. 206, 207, followed in Bryd v. Bobbett (Exch.), 11 Jur. 102 Rass ₹. Jorman, 5 Exch. 359; Ro r. Lextis, 5 D. \& L. 371.

(h) Gibbons r. Alison, 3 C. B. 1 
where the statement which put the Court in motion is maliciously false (i).

Process of execution on a judgment seeking to obtain satisfaction for the sum recovered is of course prim $\hat{\imath}$ facie lamful. Should, however, the debtor's goods have been taken in execution for a larger sum than remained due on the judgment, this having been done by the creditor malisionsly and without reasonable or probable cause-i.e., the reditor well knowing that the sum for which execution is zued was excessive-his motive being to oppress and injure he debtor, an action would lie for this malicious injury $(k)$ : or here would be present damnum et injuria, giving a claim o redress and compensation.

In treating of Torts to the Reputation, the action for a Torts to the Ialicious Prosecution may first conveniently be noticed. Chis action, though analogous to the action for a malicious arest, differs altogether from that for false imprisonnent $(l)$.

The essential ground of the action for a malicious proseution is, that a legal prosecution was instituted or carried n maliciously and without reasonable or probable cause,

(i) Per Lord Campbell, C. J., Farlie - Danks, 4 E. \& B. 499 ; cited in ohneon r. Emerson, L. R. 6 Ex. 343, 79 ; considered in Quartz Hill, \&c., b. r. Eyre, 11 Q. B. D. 674.

(k) Churchin r. Siggers, 3 E. \& B. 29, 937 ; Jenings r. Florence, 2 C. B., $\therefore$ S., 467, 470; Gilding r. Eyre, o C.B., X. S., 592, 603. See Huffer - Allen, L. R. 2 Ex. 15; Dimmackr. :oreley, 2 C. B., N. S., 542.

(l) There is no similitude or analogy etween an action for a trespass or false aprisonment and an action for a malious prosecution: the former lies for te defendant's haring done that which pon the stating of it is manifestly legal; the latter kind of action is for prosecution which npon the stating it is manifestly legal: Johistone $r$.
Sutton, 1 T. R. 54t: 1 R. R. 25\%, 269 with which compare Mostym $\mathrm{r}$. Fabrigas, Cowp 161; $1 \mathrm{Sn}$. L. C., 9th ed., 628). See also Guest r. Warren, 9 Exch. 379; Austim, app., Durling, resp.. L. R. 5 C. P. 534. As to the burden of proof in each case, r. post, p. 841 .

As to who mar be liable in this action, see Clemnent.s r. Ohrly, 2 Car. $\mathrm{E}$ K. 686; Osterman r. Bateman, Id. i2s. It has been held that an action for malicious prosecution will lie against a compans: Edecards r. The Midland $R$. C.. 6 Q. E. D. 2ST, orerruling the opinion of Alderson, B., in Sterens r. Midland Counties P.C., 10 Exch. 35?. But see per Lord Bramicell in Abrath $\mathrm{s}$. Worth-Eastern R. C., 11 App. Cas. 247 , at p. 250. 
whence damage has ensued to the plaintiff $(m)$. This alle gation of the want of probable cause, as remarked in.Joln stone v. Sutton (n), "must be substantively and expressl: proved, and cannot be implied. From the want of probabl cause malice may be, and most commonly is, implied; th knowledge of the defendant is also implied. From th most express malice the want of probable cause cannot $b$ implied. A man from a malicious motive may take up : prosecution for real guilt, or he may, from circumstance which he really believes, proceed upon apparent guilt; an in neither case is he liable to this kind of action (o). "I is true," said Tindal, C. J. (p), " that in order to suppor such an action there must be a concurrence of malice is the defendant and want of probable cause. Malice aloni is not sufficient, because a person actuated by the plaines malice may nevertheless have a justifiable reason fo: prosecution. On the other hand, the substantiating the accusation is not essential to exonerate the accuser from liability to an action, for he may have had good reason th make the charge, and yet be compelled to abandon thi prosecution by the death or absence of witnesses, or thi difficulty of producing adequate legal proof. The law therefore, only renders him responsible where malice is combined with want of probable cause. What shall amoun: to such a combination of malice and want of probabli

"No action for a malicious prosecution will lie aganst a corporition. To maintaip au action for a malicions prosecution it must be slown that there was an absence of reasonahle and prohable cause, and that there was malice or some indirect and illegitimate motive in the prosecutor. A corporation is incapable of malice or of motive."

The action was held maintainable where the prosecution had been instituted by order of a County Court Judge: Fitzjolin v. Mackinder, 9 C. B., X. S., 505 ; s. $C ., 8$ Id. 75.

(m) "The meaning of a malicious prosecution is that a party from mali cious motives, and without reasonabl or probable cause, sets the law in motion against another:" per Irillieme J., Barber v. Lesiter, I C. M., X.S., 186

(i) 1 T. R. 544, 545; 1 R. R. $25 \%$ 269; Michell r. Willians, 11 M. \& W 205, 211; Afrsgroere r. Aetedl, ! M. \& W. 582; 1 Wms. Saund 230 b; Hicks v. Faulkner, 8 Q. B. D $16 \pi, 174$.

(o) Et ride per Parke, J., in Mritchel v. Jenkins, 5 B. \& Ad. 594.

(p) Willans v. Taylor, 6 Bing. 186 S. C., 2 B. \& Ad. $\$ 45$. 
ause is so much a matter of fact in each individual case is to render it impossible to lay down any general rule in the subject $(q)$; but there ought to be enough to satisfy i reasonable man that the accuser had no ground for pro"eeding but his desire to injure the accused." Moreover, n connection with the action for a malicious prosecution r arrest, the term "malice" is to be understood in a sense lready assigned to it at p. 835, as signifying not necessarily pite or hatred towards an individual, but malus animus, nd denoting that the defendant was actuated by improper nd indirect motives $(r)$.

"Reasonable and probable cause," it has been judicially bserved, "is an honest belief in the guilt of the accused, ased upon a full conviction, founded upon reasonable rounds, of the existence of a state of circumstances which, ssuming them to be true, would reasonably lead any dinarily prudent and cautious man, placed in the osition of the accuser, to the conclusion that the party aarged was probably guilty of the crime imputed. There ust be, first, an honest belief of the accuser in the guilt : the accused ; secondly, such belief must be based on an onest conviction of the existence of the circumstances hich led the accuser to that conclusion; thirdly, such condly-mentioned belief must be based upon reasonable ounds; by this I mean such grounds as would lead any irly cautious man in the defendant's situation so to lieve; fourthly, the circumstances so believed and relied I by the accuser must be such as amount to reasonable ound for belief in the guilt of the accused" $(s)$.

It is important to observe that whereas in an action for lse imprisonment the onus will lie upon the defendant to ead and prove affirmatively the existence of reasonable

(q) See also per Kelly, C. B., L. R. ix. 203.

(r) Per Parke, J., Mitchell r. Jenis, 5 B. \& Ad. 595 ; 1 Wms. Saund.
$230 \mathrm{~b}$.

(s) Per cur. Hicks v. Faulkner, 8 Q. B. D. 167,172 ; affirmed 46 L. T. 127. 
cause as his justification, in an action for malicious prose cution the plaintiff must allege and prove affirmatively it non-existence $(t)$. In such actions the burden of proof a to all the issues arising therein lies upon the plaintiff; an although he proves his innocence, and the Judge, in orde to enable himself to determine the issue of reasonable an probable cause, leaves subsidiary questions of fact to th jury, nevertheless the onus of proving the existence of sucl facts as tend to establish the want of reasonable and pro bable cause on the part of the defendant rests upon th plaintiff $(u)$.

In an action for a malicious prosecution, it is a questios for the jury whether the facts brought forward in evidenc be true or not; but the question. What is reasonable 0 probable cause? is to be determined by the Judge $(x)$. Th belief of the accuser in the guilt of the accused; his belie in the existence of the facts on which he acted, and th reasonableness of such last-mentioned belief, are question of fact for the jury, whose findings upon them become $s$ many facts from which the Judge is to draw the inference and determine whether they do or do not amount to reasor able and probable cause $(y)$. Hence the reasonablenes and probability of the ground for prosecution may depenc not merely upon the proof of certain facts, but upon th inquiry whether other facts which furnished an answer $t$ the prosecution were known to the defendant at the time: was instituted $(z)$. They may depend upon the inquir? whether the facts stated to the defendant at the time, an which formed the ground of the prosecution, were believe

(t) Ib. 170 .

(ii) Abrath v. North-Eastem R. C., 11 (2. B. D. $440 ; 11 \mathrm{App}$. Cas. 247.

(x) See Jhichell $\mathrm{v}$ II Tlliams, 11 I. \& W. 205; per Bramucell, B., Hailes v. Marks, 7 H. A X. 63 ; citing l'unton v. Williams, 2 Q. B. 169; IVatson v. Whitmoie, 14 L. J. Ex.
41 ; Hinton v. Heather, 14 II. . T 131 ; Wyatt v. White, 5 H. \& N.37] Frazer v. Hill, 1 Macq. H. L. Ca. 39 398 ; and cases infra.

(y) Hicks v. Faulkner, S Q. B. at p. 172 .

()) Judgm., Panton ₹ Williams, Q. B. 194 . 
by him or not (a), or upon this question, whether, from the conduct of the defendant himself, the jury will infer that he was conscious he had no reasonable or probable cause. In any such case, however, the knowledge, the belief, and the conduct of the defendant are for the consideration of the jury, to whom nothing is left but the truth of the facts proved and the justness of the inferences to be drawn from them; the law being laid down by the Judge, that, according as the facts are found by the jury to be proved or not proved, and the inferences warranted or not, there was reasonable and probable ground for the prosecution, or the reverse $(b)$.

It is not within the ordinary scope of a bank manager's authority to order the arrest and prosecution of an offender. Therefore, in order that the bank may be rendered liable for such an act of its manager, evidence must be forthcoming to show an authority for it, either general or special, as derived from the exigency of the particular occasion on which it was exercised $(c)$.

In the action for a malicious prosecution it is incumbent on the plaintiff to show that the proceeding was determined in his favour $(d)$, if from its nature it be capable of such a termination $(e)$.

(a) See Haddriek r. Heslop, 12 Q. B. 267 ; Turner v. Ambler, 10 Id. 252 ; Hinton v. Heather, 14 M. \& W. 131 .

(b) Judgm., Panton v. Williams, 2 Q B. 124 (as to which see per Coleridge, J., Douglas v. Corbett, 6 E. \& B. 514); Heslop v. Chapman, 23 L. J. Q. B. 49 ; Blachford v. Dod, 2 B. \& Ad. 179 ; Broad v. Ham, ó Bing. N. C. 722 ; Delegal . Highley, 3 Bing. N. C. 950 ; James v. Phelps, 11 Ad. \& E. 483. See also Broun v. Hawkes, (1891) 2 Q. B. 718 (C. A.). The jury bad found that the defendant honestly believed the full charge, but was instigated by malice in the proceedings taken against the plaintiff.

As to the action for maliciously conspiring to sue the plaintiff, see Cotterell v. Jones, 11 C. B. 713 , approved in Coondoo v. ILookerjee, 2 App. Cas. 186 ; Castrique v. Behrens, 3 E. \& E. 709to cause him to be suspected of a breach of the excise laws, see Barber v. Lesiter, 7 C. B., N. S., 186.

(e) Bank of New South Wales v. Ouston, 4 App. Cas. 270, where many analogous cases are collected. See also Abrahams v. Deakin, (1891) 1 Q. B. 516 (C. A.).

(d) Basebe v. Mattheus, L. R. 2 C. P. 684 ; Barber v. Lesiter, 7 C. B., N. S., 186.

Secus in an action for maliciously procuring the plaintiff to be held to bail by a magistrate: Stewaid r. Gromett, 7 C. B., N. S., 191.

(e) Per Crompton, J., Castrique v.

Behrens, 3 E. \& E. 721. 
Without dwelling longer upon this action, it may be proper to observe, that suits for injuries akin thereto have occasionally been brought, wherein also malice was held tc

Action for unaliciously suing out commission of bank. ruptey. be a necessary ingredient: thus in Chapman $\mathrm{v}$. Pickersgill $(f)$ the action was for falsely and maliciously suing out a commission of bankruptcy under the old system against the plaintiff, which was afterwards superseded : this action was held to be maintainable, Lord C. J. Pratt observing, "Here is falsehood and malice in the defendant, and great wrong and damage done to the plaintiff thereby. Now, wherever there is an injury done to a man's property by a false and malicious prosecution, it is most reasonable he should hare an action to repair himself. But it is said, this action was never brought before; I wish never to hear this objection again. This action is for a tort; torts are infinitely various, not limited or confined, for there is nothing in nature but may be an instrument of mischief." In connection with the preceding case, Farlie v. Danks (g), and Johnson v. Emerson (h), may be consulted.

Libel. Of torts to the reputation of an individual, libel and slander in the next place demand attention. A libel (i) may be defined to be a malicious defamation expressed in print, writing, or by signs, tending to injure the reputation of another, and exposing him to public hatred, contempt, or ridicule $(k)$. It is not, however, the mere writing of libellous

(f) 2 Wils. 145. See Whiturorth v. Hall, 2 B. \& Ad. 695 ; Cotton v. Jnmes, 1 B. \& Ad. 128 ; Metrop. Bank r. I'ualey, 10 App. Cas. 210.

(g) 4 E. \& H. 493 . See liolett v. Sympson, s E. \& B. 344 .

With Farlie v. Hanks, supra, compare Fitzjohn r. Mackinder, 9 C. B., X. S., 505; S. C., 8 Id. 78. Et vide per Erle, C. J., Steuard r. Gromett, 7 C. H., N. S., 204.

See turther, in illustration of actions for injuries somewhat similar to those above commented on, Ite Medina v. Grore, 10 (2. B. 152, 172; Craig r.
IIassel, 4 Q. B. 481; Westaway r. Frost, 17 L. J. Q. B. 286: Siuther. land $\mathbf{v}$. ILuray, cited 1 T. R. 538; ] R. R. $28 \%$.

(h) I. R. 6 Ex. 329, considerec in Quartz Hill, $q c .$, Co. $r$. Eyre, 11 Q. B. D. 674.

(i) As to the form of a claim for libel, see Harris v. Warre, 4 C. P. D. 125.

(k) Selw. N. P., 13th ed., rol. 2 p. 981; Digby r. Thompson, 4 B. \& Ad. 821 ; per Bayley, J., Macgregor v. Thuates, 3 B. S- C. 33; Du Bas v. Beresford, 2 Camp. 511 ; 11 R. R 
natter which is actionable; there must be a publication of ihe libel in order to entitle the party aggrieved by it to 6 civil remedy. The libellous matter must moreover be alsely and maliciously published.

On examining the various ingredients in the right of iction for libel, the following prefatory remarks suggest ihemselves :-

The alleged libellous matter must be false; its truth may je set up by way of defence to the action $(l)$. Further, the natter complained of must be shown to have been maliiously published. This remark, however, must be underitood in a somewhat qualified sense; for, "where the ratural tendency and import of the language used in any ublication is to defame and injure another, the law will hen presume that the publisher acted maliciously" $(m)$. $f$ the tendency of the publication were injurious to the laintiff, the law will presume that the defendant by pubishing it intended to produce that injury which it was alculated to effect $(n)$. "Defamation pure and simple ffords presumptive evidence of malice" $(o)$.

In an action for libel either party may indeed, with a

82; Anon., 11 Mod. 99 ; per Parke, i., Parmiter v. Coupland, 6 M. \& W. 08; Cook v. Ward, 6 Bing. 409 ; The C'ase of Libels, 5 Rep. 125 a.

In regard to the question, What a libel? see Leyman v. Latimer, 3 x. D. 15; Id. 352; Mulligan v. Cole, 1. R. 10 Q. B. 549 ; Shepheard v. Thitaker, L. R. 10 C. P. 502; Hoare Silverlock, 12 Q. B. 624; Hearne Stowell, 12 Ad. \& E. 719 ; Capel v. ones, 4 C. B. 259; Wakley v. Coolie, Exch. 511; Ingram v. Lawson, 6 ing. N. C. 212 ; Wakley v. Healey, C. B. 591 ; Walker v. Brogden, 19 . B., N. S., 65 ; Cox v. Lee, L. R. 4 ix. 284; Jenner v. A'Beekett, L. R. Q. B. 11 .

(l) Per Holt, C. J., Anon., 11 Mod. ?; per Parke, J., Cockayne v. Hodg. isson, 5 Car. \& P. 548. See Rumsey - Webb, Car. \& M. 104; Weaver v. loyd, 2 B. \& C. 678; Chalmers v.
Shackell, 6 Car. \& P. 475; Helsham v. Blaekwood, 11 C. B. 111; O'Brien v. Bryant, 16 M. \& WV. 168; O'Brien v. Clement, Id. 159; Tighe v. Cooper, 7 E. \& B. 639 ; Prior v. Wilson, 1 C. B., N. S., 95; Honess v. Stubbs, 7 C. B., N. S., 555 ; Leyman v. Latimer, supra n. $(k)$.

"The truth is an answer to the action, not because it negatives the charge of malice, \&c., but because it shows that the plaintiff is not entitled to recover damages. For the law will not permit a man to recover damages in respect of an injury to a character which he either does not or ought not to possess:" per Littledale, J., M'Pherson v. Daniets, 10 B. \& C. 272.

(m) Arg., 9 B. \& C. 644.

(n) Per Littledale, J., Haire v. Milson, 9 B. \& C. 645.

(o) Per Evle, C. J., Whiteley $\mathbf{v}$ Adams, 15 C. B., N. S., 414. 
view to the damages, give evidence to prove or disprove the existence of a malicious motive in the mind of the publisher of the defamatory matter; for the spirit and intention of the party publishing a libel are fit to be considered by a jury in estimating the injury done to the plaintiff $(p)$. But in such an action, though evidence of malice may be given to increase the damages, it never is considered as essential, " nor," remarks Bayley, J. $(q)$, "is there any instance of a verdict for a defendant on the ground of want of malice. Numberless occasions must have occurred (particularly in cases where a defendant only repeated what he had before heard, but without naming the author) upon which, if that were a tenable ground, verdicts would have been sought for and obtained; and the absence of any such instance is a proof of what has been the general and universal opinion R.S.O.C. 68 upon the point." By the statute $6 \& 7$ Vict. c. 96 (s. 2), it is, however, enacted $(r)$, that in an action for a libel contained in any public newspaper, or other periodical publication, it shall be competent to the defendant to plead that such libel was inserted therein "without actual malice, and without gross negligence; and that before the commencement of the action, or at the earliest opportunity afterwards, he inserted in such newspaper, or other periodical publication, a full apology for the said libel, or, if the newspaper or periodical publication in which the said libel appeared should be ordinarily published at intervals exceeding one week, had offered to publish the said apology in any newspaper or periodical publication to be selected by the plaintiff in such action ; "and by the same statute it is

(p) Pearson v. Lemaitre, 5 M. \& Gr. 719,720 . Evidence as to the cireum. stances under which the libel was published, or as to the charaeter of the plaintiff, caunot be given with a view to mitigation of damages by a defendant who does not assert the truth of the libel, unless reven days at least before the trial he furnishes the plaintiff with particulars of such eridence: Order xxxri. Rule 37 .

(q) Judgm., Bromage v. Trosser, 4 B. \& C. 257 .

(v) See Chadwick v. Merapath, 3 C. $3.885 ; 8$ \& 9 Vict. c. $75 ; 0^{\prime} \mathrm{Br}$ iew r. Clement, 15 M. \& W. 435 . 
urther provided, that, upon filing such plea as aforesaid, $\mathfrak{S}$. he defendant shall be at liberty to pay into Court a sum f money by way of amends for the injury sustained by the ublication of the libel complained of $(s)$. And under ection 1 of this statute, the defendant may in any action or defamation, after notice in writing of his intention so to o duly given to the plaintiff at the time of filing or elivering the plea, give in evidence in mitigation of amages that he made, or offered an apology to the plaintiff Ir such defamation before the commencement of the stion, or as soon afterwards as he had an opportunity of bing so, in case the action shall have been commenced efore there was an opportunity of making or offering such pology. Evidence in mitigation of damages to the effect lat the plaintiff has already recovered (or has brought ztions for) damages, or has derived or agreed to receive ompensation in respect of a libel or libels to the same arport or effect as the libel in respect of which action is cought, may be given when such action is against a ewspaper (51 \& 52 Vict. c. 64 , s. 6 ).

In general, then, our law considers the publication of a atement, which is false in fact and injurious to the charac$r$ of another, as malicious, unless it be privileged. If made ader eircumstances entitling it to be so considered, the ceasion itself prevents the inference of malice which the w would draw in the case of an unauthorised comunication, and affords a qualificd defence in the absence of tual malice $(t)$. To present this doctrine under a somehat different form, our law will permit the inference of alice raised by the publication of libellous matter to 3 rebutted by proof of circumstances showing that the

(8) See Jones v. Mackie, L. R. 3 $\therefore 1$; Lafone v. Smith, 3 H. \& N. $5 ; 15 \& 16$ Vict. e. 76 , s. 70 .

(t) Toogood v. Spyring, 1 Cr. M. \& R. 3 ; Darby v. Ouseley, 1 H. \& N. 1;
Cook r. Wildes, 5 E. \& B. 328 , following Tuson v. Evans, 12 Ad. \& E. 733 ; Hemmings v. Grasson, E. B. \& E. 346 , and cases post; Davies $\mathrm{r}$. Snead, L. R. 5 Q. B. 608 .

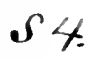


statement complained of was privileged; but this defenc may itself be rebutted or altogether neutralised by proof c (actual express malice (u). " "The rule," said Lord Campbel C. J. $(x)$, " is that if the occasion be such as repels the pre sumption of malice, the communication is privileged, and th plaintiff must then, if he can, give evidence of malice. If $h$ gives no such evidence, it is the office of the Judge $(y)$ to sa that there is no question for the jury, and to direct a nonsui or a verdict for the defendant." If, however, at the close s the plaintiff's case there is any evidence which would warrar the jury in inferring actual or express malice, the Judg cannot withdraw the case from them $(z)$.

Tests of actual malice have been thus indicated-" If man is proved to have stated that which he knew to be falst no one need inquire further. . . . So if it be prove that out of anger or for some other wrong motive th defendant has stated as true that which he does not kno' to be true, and he has stated it whether it is true or no recklessly, by reason of his anger or other motive, the jur may infer that he used the occasion, not for the reaso which justifies it, but for the gratification of his anger $c$ other indirect motive" $(a)$.

In illustration of the preceding remarks, I may observ that a character bona fide given to a servant of any descri tion is deemed a privileged communication, because it $\mathrm{i}$ for the advantage of the public, and of honest servant generally, that characters should be freely given; in givin a character accordingly, bona fides is to be presumei Even though the statement complained of as defamator

(ii) See Clarke v. Molyneux, 3 Q. B. D. 237 .

(x) Taylor v. Hawkins, 16 Q. B. 321 ; Somertille v. Hauckins, 10 C. B. 583; Harris v. Thompson, 13 C. B. 333. See Kelly r. Partington, 4 B. $\mathcal{E}$ 1d. $700 ;$ Weatherston v. Havkins, T. 12. 110; Wright v. Woodgate, 2 Cr. II. \& R. 573. (y) See Spill v. Manle, L. R. \& E 232; Laucless r. Anglo-Egyptian Co ton, \&c., Co., L. R. 4 Q. B. 162.

(z) Jackson v. Hopperton, 16 C. B x. S., 829; Proctor v. Webster, ! Q. B. D. 112.

(a) Per Brett, L. J., Clarke v. Mol neux, 3 Q. B. D. 247. 
hould be untrue in fact, the master will be held justified I. the occasion in making that statement, unless it can be hown to have proceeded from a malicious mind; as, for sample, if the statement were proved to have been false o the knowledge of the party making it, or if the master antonly and capriciously volunteered to make a statement jurious to the servant (b).

Again, a master has clearly a right to charge his servant ma fide for any supposed misconduct in his service, and to ive him admonition and blame; and the simple circumstance ft the master exercising this right in the presence of another ill not of necessity take away from him the protection of the .r. Should it, however, appear in evidence that an oppormity had been sought for making such charge before third rsons when it might have been made in private, this fact one would be strong in proof of a malicious intention, and ight deprive the master, if sued for defamation by his serint, of that immunity which the law allows to a statement ich as supposed when made with honesty of purpose $(c)$. The existence of malice may be satisfactorily established a vast variety of ways. Thus proof of a long practice of selling the plaintiff would be evidence to show that the fendant was actuated by malice in the particular publicaon complained of, and that it did not take place through caressness or inadvertence; and the more nearly the evidence proaches to proof of a systematic practice of libelling, the

b) Fountain v. Boodle, 3 Q. B. 11, ; per Williams, J., 13 C. B. 352 ; Wightman, J., Gaidner r. Slade, Q. B. 801 ; Rogers v. Clifton, 3 B. P. 587 ; Child r. Afleek, 9 B. \& C. 3, 406 (citing per Lord Mansfield, J., Edmonson r. Sterenson, Bull P. 8) ; per Lord Ellenborough, J., 1 B. \& Ald. $239,240$.

When the master volunteers to gire character, stronger evideuce will be ded to show that he acted bonâ fide $n$ in the case where he has given the racter after being required so to do: per Littledale, J., Pattison v. Jones, 8 B. \& C. 586; Coxhcad r. Richards, 2 C. B. 597, 601, 610 ; Bernett v. Deacon, 2 C. B. 628.

(e) Somerrille $\mathrm{F}$. Haukins, 10 C. B. 583: Taylor v. Hawkins, 16 Q. B. 308; Jaekson v. Hopperton, 16 C. B., N. S., 829; Toogood r. Spyring, 1 Cr. M. \& R. 181.

The transmission unnecessarily by post-office telegram of libellous matter which would hare been privileged if sent in a sealed letter aroids the privilege: Williamson r. Freer, L. R. 9 C. P. 393. 
more convincing will it be. The circumstance, that the othe: libels are more or less frequent-more or less remote fron the date of the publication of that in question-will affec merely the weight, not the admissibility, of the evidence $(d)$

In cases such as have latterly been specified, malia might properly be inferred by a jury to have actuated th party publishing the alleged libel. Where, however, th circumstances under which a particular communication $i$ made are consistent with either the presence or the absenc of malice it will be incumbent on the plaintiff to prov malice in order that he may successfully sue for libel; an where the circumstances do not present any justifiabl occasion for writing and publishing the defamatory mattes the communication is said not to be privileged $(e)$.

Commnnicationwhere privileged.

The question, however, still demands our attentior Under what circumstances will a communication prim facie libellous be deemed in law to have been privileged 1 It will be so when made bon $\hat{a}$ fide by the party charged $\mathrm{i}$ the performance of some social or moral duty $(f)^{2}$; or $\mathbf{i}$ the conduct of his own affairs, and with a fair and reasor able hope of protecting his own interest in a matter whel it is concerned $(g) ;{ }^{3}$ or where there is a correspondin

(d) Per Parke, B., delivering the opinion of the Judges in Barrett $\mathrm{r}$. Long, 3 H. L. Ca. 414.

See also, as to proof of malice, Brine r. Basalgette, 3 Exch. 615; Gilpin r. Fouler, 9 Exch. 692; Simpson v. Robinson, 12 Q. B. 511; Cook r. Wildes, 5 E. \& B. 328.

"Matters occurring after action may be given in eridence to enhance the damages as shoring the malice of the original publication, just as a repetition of the same or a similar libel may be:" per Pollock, C. B., Darby v. Ouseley, l II. S . N. 9, 13.

(e) Yer Maule, J., Wenman r. Ash, 13 C. B. 846, and cases cited, p. 848 .

(f) Clark v. Molynewx, 3 Q. B. D. 237. See Stuart r. Bell, (1891) 2 Q. B. 341 (C. A.), where Lindley, L. J., said, at p. 346 , “'The reason for holding any occasıon privileged common convenience and relfare society, and it is obvious that definite line can be so drawn as mark off with precision those occasio which are privileged, and sepan them from those which are not."

(g) Judgm.: Toogood v. Spyring, Cr. M. \& R. 193 ; Judgm., Somerri v. Haukins, 10 C. B. 589 ; per Maw J., 13 C. B. 846 ; Hamon $\checkmark$. Falle App. Cas. 247; per Parke, J., Car ayne v. Hodgkisson, 5 Car. \& P. 5t Harrison v. Bush, 5 E. S. B. 34 Cook r. Mildes, Id. 329 (distingui: able from Lacless r. Anglo-Egypti Cotton, \&c., Co., I. R. 4 Q. B. 2 267); hershaw v. Bailey, 1 Ex. 743; Hopveod v. Thorn, 8 C. B. 2! Harris v. Thompson, 13 C. B. 3. Acc. per Willes, J., Huntley v. $\Pi_{a}$ 
interest in the party receiving the communication $(h) ;{ }^{4}$ and also in some special cases which will hereafter separately be noticed.

The judgments of Tindal, C. J., and Erle, J., in Coxhead v. Richards (i), deserve careful perusal as throwing light on this subject.

Reference may also be made to Blackham v. Pugh (k), as showing under what circumstances the claim to privilege may be substantiated on the ground that the communication complained of was made by a person in the conduct of his own affairs, and in some matter wherein his interest was concerned. The facts in Blackham v. Pugh were very simple. The defendant had supplied goods to the plaintiff on certain credit, before the expiration whereof the plaintiff, meaning to retire from business, employed an auctioneer to sell his stock in trade, and absented himself under circumstances calculated to induce the belief that an act of bankruptcy had been committed. The defendant thereupon gave notice to the auctioneer not to pay over to the plaintiff he proceeds of the sale, he "having committed an act of bankruptcy." This communication was by the majority of he Court of Common Pleas held to have been privileged, is having been made by the defendant in the conduct of lis own affairs, and in a matter which concerned his गwn interest $(l)$.

C. B., N. S., 517, who says that "where the matter is written in the ssertion of some legal or moral duty $r$ in self-defence, and the thing is done onestly and without sinister motive, nd in the bonâ fide belief in the truth $f$ the statement at the time of making " " the law declares it privileged.

(h) Per Erle, C. J., Whiteley v. Idans, 15 C. B., N. S., 414 (which ccords with Harrison v. Bush, 5 E. B. 344, and Toogood v. Spyring, 1 'r. M. \& R. 181). See Fryer v. Kinersley, 15 C. B., N. S., 422 ; Croft $\mathrm{v}$ terens, 7 H. N. 570. It is not suff. cient that the maker of the statement honestly and reasonably believes that the person to whom the same is made has such an interest: Hebditch v. MracIlwaine, (I894) 2 Q. B. 54 (C. A.).

(i) 2 C. B. 569 ; Hanon v. Falle, 4 App. Cas. 247. See Beatson v. Skene, 5 H. \& N. 838.

(k) 2 C. B. 611 ; Davics v. Snend, L. R. 5 Q. B. 608,611 .

(l) As to the question, Under what circumstances will a communication be privileged, on the ground of duty or of interest? see further Gilpin v Fowler, 9 Exch. 615 ; TVenman v. Ash, 13 C. B. 
The two cases of Pullman v. Hill $(m)$ and Boxsius y Gollet (n) may be usefully contrasted. In the former : letter containing the alleged libel was dictated to a short hand clerk, who subsequently wrote the letter out. Afte: being copied by an office-boy in a copy-press, it was sen addressed to the plaintifis, and was opened by one of th plaintiffs' clerks. The Court of Appeal decided that ther was publication to the clerks both of the plaintiffs an defendants, and that neither occasion was privileged. I the latter case, a solicitor dictated to his clerk a letter written on behalf of his client. The letter, which containe the alleged libel, was addressed and sent to the plaintis after having been copied into the letter-book by anothe clerk. The publication to the solicitor's clerks was hel. by the Court of Appeal to have been necessary and usua. and in the interest of the client, and so privileged.

a Besides cases falling within the rules above considerec 'disparaging communications made under other and dis similar circumstances are, on grounds of policy or expr diency, held by our law to be privileged. Thus, by stat. 3 , 4 Vict. c. 9, proceedings civil or criminal against persons $\mathrm{fc}$ the publication of papers printed by order of either Hous of Parliament are to be stayed upon delivery of a certificat such as is in the Act mentioned, properly verified by aff davit, setting forth that they were published by the orde and under the authority of Parliament.

; Again, every individual has a right to comment on tho acts of public men or matters of public interest $(o)$ whic concern himself as a subject of the realm, if he do not mal $\checkmark$ his commentary a cloak for malice and slander. "There no doubt that the public acts of a public man may lawful

S36: Harris r. Thompson, Id. 333; Blayg r. Sturt, 10 Q. B. SS9, and cases cited infra.

(m) (1591) 1 Q. B. 524 (C. A.).

(n) $(1894) 1$ (2. 1. $842($ C. A.). (o) Wran v. Walter, L. R. \& R. 73; Kelly s. Tiuling, L. R. 1 ( . 699 : Dreis r. Duncan, L. R. 9 C. 396, 399. 
be made the subject of fair comment or criticism, not only by the press, but by all members of the public. But the distinction cannot be too clearly borne in mind between comment or criticism and allegation of facts such as that disgraceful acts have been committed, or discreditable language used. It is one thing to comment upon or criticise, even with severity, the acknowledged or proved acts of a public man, and quite another to assert that he has been guilty of particular acts of misconduct" $(p)$. There is, indeed, a material distinction between publications relating to public and to private persons as regards the question whether they be libellous. Criticism may reasonably be applied to a public man in a public capacity which may not be applied to a private individual. But any imputation of wicked and corrupt motives is unquestionably libellous, whether applied to a public man or to a private individual $(q)$. Fair and candid criticism, however severe, of a literary work is likewise privileged, provided there be not mixed up with it personal abuse of the author, or matter unconnected with his work defamatory of him $(v)$.

Further, within the class of privileged communications may, as a general rule, be included the publication of a full, fair, substantially correct $(s)$, and unvarnished account $(t)$

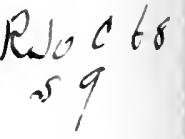
of what passed in a public Court of justice (u), not being mixed up with ex parte statements or injurious comments $(x)$. To this rule there are, indeed, exceptions ; ex. gr.,

(p) Per curiam, Daris r. Shepstone, 11 App. Cas. 187, 190.

(q) Per Parke, B., Parmiter F. Coupland, 6 M. \& W. 108 . See Gathercole r. Miall, 15 II. \& W. 319, 328.

(r) Carr r. Hood, 1 Camp. 354, n.; 10 R. R. 701 ; Tabart v. Tipper, Id. 350 ; Green v. Chapman, 4 Bing. N. C. 92 ; Paris v. Levy, 9 C. B., N. S., 342 ; Campbell $\mathrm{r}$. Spottiswoode, 3 B. \& S. 769 ; approved in Merivale v. Carson, 20 Q. B. D. 275 .

(s) Alexander v. North-Eastern R.
C., 6 B. \& S. 340 .

$(t)$ Stiles v. Toakes, 7 East, 493; Dunean v. Thucates, 3 B. \& C. 556 ; see $\boldsymbol{I}^{\prime}$ Gregor v. Thuaites, Id. 24.

(u) See Ryalls r. Leader, L. R. 1 Ex. 296. See 51 \& 52 Vict. c. 64, s. 3.

(x) Saunders r. Mills, 6 Bing. 213 ; Delegal v. Highley, 3 Bing. N. C. 950, 960 . The publication, without malice, of a fair and accurate report of proceedings ex parte before magistrates in open Court, is privileged : cf. Leu is v. Levey, E. B. \& E. 537 ; Usill v. 
matters may appear in a Court of justice having so immoral a tendency, or being so injurious to the character of an individual, that their publication could not be tolerated $(y)$. "The only case," says Littledale, J. (z), " in which an editor of a newspaper can justify a libel on the ground that it contains an account of a trial, is where he really gives a true and accurate report of it; and even in that case it will be for the Court to consider whether it was lawful to publish it."

The publication in a newspaper of a report of proceedings at a meeting of poor-law guardians when ex parte charges of misconduct against the medical officer of the union were made is not privileged by the occasion $(a)$.

S.A fair and accurate report published in any newspaper of the proceedings of a public meeting $(b)$, or of any meeting (except where neither the public nor any newspraper reporter is admitted) of certain bodies, including restries, town councils, school boards, boards of guardians, may be privileged by virtue of the Law of Libel Amendment Act, 1888 (51 \& 52 Vict. c. 64 , s. 4). Such report is privileged unless made or published maliciously, provided that the matter is neither blasphemous nor indecent and is of

ITales, 3 C. P. D. 319 ; himber v. The Press Association, (1893) 1 Q. B. 65 (C. A.). And a report of the judgment only will be privilegea, if published bonâ fide and without malice: Maciongall v. Knight, 17 Q. B. D. 636. As to whether a verbatim report of a Judge's judgment is necessarily privileged, see Maciougall v. Fuight, 14 App. Cas. 194 (aftirming S. C. at 17 (2. B. D. 636 on other grounds), at p. 200, per Lord Halsbury, I. C.

(y) Iloare . Silierlock, 9 C. B. 20; Fint v. Hike, 4 B. \& C. $473,478-480$. In $R$. Y. Carlile, 3 B. \& Ald. 161, 171, 22 R. R. 333. Best, J., states the rule above laid down, with this qualification, that "what is contained in the publicaion must be neither defamatory of an imlividual, tending to excite disaffection, mur colrulated to offend the morals of the people." See R. v. Creerey, 1 M. \& S. 273, n.; 14 R. R. 427 ; Judgm., E. B. \& E. 553 .

(z) Flint v. Pike, 4 B. \& C. 4 St.

(a) Purcell $\nabla$. Souler, 2 C. P. D. 215. See Daris v. Shepstone, 11 App. Cas. 187. Such a publication mar now be privilered; see 51 \& 52 Tict. c. 64, s. 4 . The privilege attaching to the statements of a nember of the board relative to a person who had been a servant of the board is not destroyed by the presence of reporters: Pittard r. Oliver, (1891) 1 Q. B. 4it (C. A.).

(b) I.e., a meeting bona fide an lawfully held for a lawful purpose and for the furtherance or discussion of any matter of public concern, whether the admission thereto be general or restricted: Id. s. 4. 
ublic interest, and provided the defendant has not refused 0 insert in the newspaper in which the report complained if appeared a reasonable letter or statement of explanation or contradiction.

5 A judicial officer, as formerly stated, is privileged $(c)$. And io, on grounds of public policy, is a superior officer in miliary or naval command who in the course of duty publishes i report reflecting on the character of a subordinate officer under his orders $(d)$. A counsel, moreover, entrusted with he interests of others, and speaking from their information, or the sake of public convenience, is privileged in commentng fairly and bona fide on the circumstances of the case onfided to him and in making observations on the parties oncerned and their instruments or agents in bringing it nto Court (e). But, though such may be the duty of :ounsel, and though it may be incumbent on him to state acts injurious to the characters of individuals, if he speak onscientiously, according to his instructions, it does not ollow that others will be privileged in printing and publishng what he says ; for as to them the reason of the priviege, which is the advancement of public justice, does not pply. They may consequently be required to prove the ruth of the imputations complained of $(f)$, or, at all events, 0 show that the publication contains a full and accurate ccount of the proceedings which it professes to report $(g)$. Ind it has never yet been decided that counsel " would not ie subject to an action for words spoken even during the

(c) Ante, p. 104 ; Scott r. Stansfeld, R. 3 Ex. 220; Thomas v. Churton, B. \& S. 475 .

(d) Dawkins v. Lord Paulet, L. R. Q. B. 94, 102, citing Sutton v. Johntone, 1 T. R. 493 ; 1 R. R. 257.

(e) Hodgson v. Scarlett, 1 B. \& lld. 232,240 ; 19 R. R. 301 ; S. C., Iolt, N. P. C. 621 ; and see the note, d. 626; Needham v. Dowling, 15 J. C. P. 9 ; Brooke v. Montague,
Cro. Jac. 90 ; Fairman r. Ires, 5 B. \& Ald. 645; 24 R. R. 514; Doyle $\mathbf{v}$ O'Doherty, Car. \& M. 418; Mackay v. Ford, 5 H. \& N. 792 ; Munster v. Lamb, 11 Q. B. D. 588 (followed and approved, Pedley v. Morris, 61 L. J. Q. B. 21).

(f) Per Bayley, J., Lewis v. Walter, 4 B. \& Ald. $613 ; 23$ R. R. 415. 950 . 
conduct of a case, if the words were irrelevant, mali fid and spoken with express malice" $(h)$.

$\checkmark$ A member of either House of Parliament is privileged: there making reflections on individuals; but this privile does not extend to him or to any other person in publishir the defamatory speech (i). It was formerly no ground privilege for the publication of matter defamatory of $\varepsilon$ individual that the libel was contained in a fair report $j$ a newspaper of what passed at a public meeting $(k)$. B now, as already stated, it may be by virtue of s. 4 of tl Law of Libel Amendment Act, 1888.

$\theta$ An action will not lie against a person who in t] course of a cause gives evidence $(l)$ or makes an affidar containing matter scandalous, false, and malicious co: cerning the complainant $(m)$. Nor will an action lie $f_{\text {. }}$ defamatory words spoken in the course of litigation whis are relevant to that litigation $(n)$.

From what has been said we may infer, as was observ by Kelly, C. B. (o), that there are various distinct class of cases to which the doctrine of privilege has been he applicable.

$k$ The first of these classes includes cases like Harris v. Bush $(p)$, where the communication complained of lefamatory was addressed to one in authority with a vif to the institution of judicial proceedings.

1 The second class of cases where the defence of privile

(h) Per Lord Coleridge, C. J., Seaman v. Netherelift, 1 C. P. D. 545 (where the cases as to privilege in an action for defamation are reviewed); Gotfin r. Domelly, 6 Q. 13. D. 307.

(i) R. v. Lord Abingdon, 1 Esp. 226; 5 R. R. 733 ; R. v. Crevey, 1 M. S. S. 273, n.; 14 R. R. 427; Holt, N. P. C. 621. See per Lord Campbell, C. J., T E. \& B. 233; Ex parte Wason, L. R. 4 Q. B. 573.

(k) Inacison v. Innean, $i$ E. \& B. 229; Popham v. Pickbun, 7H.S. X. 891. (l) Seaman v. Netherclift, 2 C. D. 53.

(m) Henderson v. Broomliead, 4 \& N. 569, recognising Revis r. Sui 18 C. B. 126.

(ii) Per Erle, J., \& H. \& N. 5; per Jeritis, C. J., and Willes, J., C. B. 141,143; Seaman v. Netherel. 2 C. P. D. 53.

(o) Dickeson v. Hillard, L. R Ex. 82, 83 .

( $p) 5$ E. \& B. 344. 
has prevailed "is that of military offences where a Court of inquiry into alleged misconduct is either being, or about to be, held; and a communication made either to the Court or before the Court is held, with a view of assisting the Court, is held privileged because the proceedings, if not strictly judicial, are in the nature of judicial proceedings, and it is the duty of every one concerned to give information which may assist in the proper prosecution of the inquiry" $(q)$. " The policy of the law covers, and rightly covers, such information with privilege." The principle is that "public policy requires that witnesses should give their testimony free from any fear of being harassed by an action on an allegation, whether true or false, that they acted from malice" $(r)$.

$\mu$ "The third class of privileged communications is of a different nature, and consists of cases where the defendant makes a defamatory statement to some one who applies to him for information, and to whom he has a moral or social, if not a legal, duty. The most familiar instance is that of giving a character to a servant, where a libel if bona fide published, and without express malice, is shielded. Other cases might be put, for example, a statement made by one member of a vestry or club defamatory of another to persons who had an interest in hearing it" $(s)$. The principle upon which such cases are founded is "an universal one: that the public convenience is to be preferred to private interests, and that communications which the interests of society require to be unfettered may fairly be made by persons acting honestly without actual

(g) Daukins г. Lord Rokeby, L. R. 8 Q. B. 255 ; S. C., affirmed L. R. 7 H. L. 744; Daukins v. Lord Paulet, L. R. 5 Q. B. 94 ; Beatson r. Skene, 5 H. \& N. 838 .

(r) Per Kelly, C. B., Daukins v. Lord Rokeby, L. R. 7 H. L. 753 ; et ride per Lord Penzanee, Id. $755,756$. (s) Harrison r. Bush, 5 E. \& B. 344 , distinguished in Dickeson v. Milliard, L. R. 9 Ex. 84.

Cases falling within the class above specified are enumerated by Willes, J. : Henuood v. Harrison, L. R. 7 C. P. 621 et seq., as to which case see Morivale พ. Carson, 20 Q. B. D. 275. 
malice, notwithstanding that they involve relevant com. !ments condemnatory of individuals" $(t)$.

publication. Publication of a libel must be proved in order that an action for it may be sustainable. A libel may be 'published' in various ways, $e x . g r$. , by reading it aloud $(u)$, by selling it $(x)$ or distributing it gratis, by sending it by post or otherwise to any third person, or through the medium of an agent, who is authorised or requested to publish it $(y)$. Publication is " the making known the defamatory matter after it has been written to some person other than the person of whom it is mritten (z). A paper containing libellous matter may, moreover, be published without any actual manifestation of its contents, in like manner as an individual publishes an award without reading it to the parties who have submitted to his arbitration, or a will without declaring its contents to those to whom he makes the publication. In the case of a libel, 'publication,' it has been said $(a)$, is nothing more than doing the last act for the accomplishment of the mischief intended by it." The moment a man delivers a libel from his hands, and ceases to have control over it, there is an end of his locus penitentic; the injuria is complete, and the libeller may be called upon to answer for his act $(b)$.

(t) Per Willes, J., L. R. 7 C. P. 622: see Waller $v$. Loch, T Q. B. D. 619; Hill r. Hart-Daris, 21 Ch. D.798.

(i) Per Abbott, C. J., 4 B. \& Ald. 160.

What is sutticient evidence of publication? Fryer v. Gathercole, 4 Exch. 262 ; Cook r. ITard, 6 Bing. 409.

The Newspaper Libel and Registration Act, 1881, was passed with a view of facilitating the proof of publication a libel contained in a newspaper (see s. 1ij). Formerly provision was made hy 6 d 7 Will. 4 , c. 76 , ss. 6,8 . See Dicke of Bronswich v. Harmer, 19 I. J. Q. B. 20.

(x) As to the liability of a vendor of uewspapers, see Emmions r. I'ottle, 16 R. B. D. 3ist.

(y) See J'arkes r. Prescott, I. R. 4
Ex. 169. In Reg. r. Holbrook, 4 Q. B. D. 42 , cited post, the proceeding was by criminal information.

(z) Per Lord Esher, M. R., Pull. man v. Hill, (1891) \& Q. B. 524 (C. A.), at p. 527 , a letter dictated to a shorthaud clerk and receired by a clerk of the plaintiff's firm.

(a) Per Best, J., R. v. Burdett, 4 B. \& Ald. $126 ; 23$ R. R. 284 ; per Abbott, C. J., Id. 160.

(b) Per Holroyd, J., 4 B. \& Ald. 143, who obserres, that "in 5 Rep. $126 \mathrm{a}$, it is laid down that a scandalous libel may be published traditione, when the libel or any copy of it is delivered orer to scandalise the party. So that the mere delivering over or parting with the libel with that intent is demanct? 
The making of a libel known, then, to any individual other than the party libelled, amounts indisputably in law to a publishing of the libel $(c)$. Even the addressing to the wife a letter containing libellous matter reflecting on her husband is a publication $(d)$. And in an action for libel it is no justification that the libellous matter was previously published by a third person, and that the defendant, at the time of his publication of it, disclosed the name of that person, and believed all the statements contained in the libel to be true $(e)$. In pleading to an action for libel it is not competent to the defendant to deny generally in his statement of defence that he wrote and published the same falsely and maliciously, as alleged. He must further set out the facts upon which he relies either to show justification or privilege $(f)$.

Assuming that on the trial of an action for libel proof has been duly given of the alleged libel, and of its publication, what, it may be asked, are the respective functions $\|$ of the Judge and jurry in regard to the matter before them? The question "whether libel or no libel is for the jury, unless a question of privileged communication arises" $(g)$. It has, however, long been the practice for the Judge in such cases first to give a legal definition of the tort charged against the defendant, and then to leave it to the jury to say whether the facts necessary to constitute that offence are proved to their satisfaction. It is the Judge's duty also to determine whether or not a written statement is capable

'publishing.' It is an uttering of the Iibel, and that I take to be the sense in which the word 'publishing' is used inlaw. Though, in common parlance, that word may be confined in its meaning to making the contents known to the public, yet its meaning is not so 7 limited in law." See Griffiths v. Levois,
(c)

(c) See previous note. But the defendant's showing the libel to his wife has been beld no evidence of publication: Wennhak v. ILorgan, $20-\mathrm{Q}$. B. D. 635 .

(d) Wenman v. Ash, 13 C. B. 836.

(e) Tidman v. Ainslie, 10 Exch. 63; Tatkin v. Hall, L. R. 3 Q. B. 396, which was an actiou for slander.

(f) Belt v. Lawes, 51 L. J. Q. B. 359.

(g) Per Williams, J., Paris v. Lery, 9 C. B., N. S., 352. 
of being libellous (h), and whether or not an alleged libel is capable of the meaning ascribed to it by an innuendo, though where he is satisfied of that it must be left to the jury to say whether the publication in question has the meaning so ascribed to it (i), or was levelled at the plaintiff $(k)$.

We have seen $(l)$ that a publication without justification or lawful excuse which is calculated to injure the reputation of another, by exposing him to hatred, contempt, or ridicule, is a libel. Whether the particular publication which is the subject of inquiry is of that character, and would be likely to produce that effect, is a question upon which a jury is to exercise their judgment, and to pronounce their opinion as a question of fact. The Judge, as a matter of advice to them in deciding that question, may, indeed, give his orm opinion as to the nature of the publication complained of, but is not bound to do so as a matter of law $(m)$.

Where the words relied on as libellous are not so in their primary meaning, the onus will lie upon the plaintiff to establish clearly by evidence their secondary and defama. tory meaning. In an important case the facts were as follows:-The defendants occasionally received in payment from their customers cheques on various branches of a bank, which the bank cashed for the convenience of the defendants at a particular branch. After a quarrel with

(h) See Fray r. Fray, 17 C. B., N. S., 603.

(i) Sturt v. Blagg, 10 Q. B. 906, 908 ; S. C., Id. 899 ; Barrett v. Long, 3 H. L. Ca. 395 ; Babonneau y. Farrell, 15 C. B. 360 .

(k) Merywether ฯ. Turnex, 7 C. B. 251. See Le Fanu v. Malcolmsone, 1 H. L. Ca. 637 ; Griffiths v. Lewis, 7 (2. I3. 61.

(l) Ante, p. 844.

(m) Per l'arke, B., and Alderson, B., I'crmiter v. Coupland, 9 M. \& W. 108, 109. See further, as to the func. tions of Judge and jury in actious of libel, Fisher v. Clement, 10 B. \& C. 472; Reeres r. Templar, 2 Jur. 137; Hughes v. Reeves, 4 M. \& W. 204: Seales v. Cheese, 10 M. \& W. 488 ; Cox v. Lee, L. R. 4 Ex. 284, 290.

Words uttered must be construed in the sense which hearers of common and reasonable understanding would ascribe to them, eren though particular individuals, better informed on the matter alluded to, might form a different judgment on the subject: Mankinson v. Bilby, 16 M. \& W. 442, 445. See Daines r. Hartley, 3 Exch. 200. 
he manager of that branch, the defendants sent a printed sircular to a large number of their customers (who knew nothing of the dispute) in the following words :- "Messrs. H. and Sons hereby give notice that they will not receive in payment cheques drawn on any of the branches of the Bank." This circular became known to other persons, and there was a run on the bank and loss intlicted. On an action being brought by the bank for libel, it was held by the majority of the House of Lords, affirming the judgment of the majority of the Court of Appeal, that in their natural meaning the words were not libellous; that the inference suggested by the innuendo was not the inference which reasonable people would draw; that the onus lay upon the plaintiffs to show that the circular had a libellous tendency; that the evidence, consisting of the circumstances attending the publication, did not show it; that there was no case for the jury; and that the defendants were entitled to judgment $(n)$.

The Court has jurisdiction to restrain by injunction the publication of a libel. An interlocutory injunction will not, except in the clearest cases, be granted, e.g., where, if a jury did not find the matter libellous, the Court would set aside the rerdict as unreasonable $(o)$.

The remarks heretofore made with respect to libel will be slander. found generally applicable in regard to oral defamation. There is, however, this great distinction between the two actions, that from a libel damage is always implied by law, whereas some linds of slander only are actionable without proof of special damage. In order to sustain an action for slander without proof of special damage, evidence must be given of some imputation on the plaintiff of a crime punishable by law, or of the having some contagious disorder

(n) Capital and Counties Bank r. Henty, 7 App. Cas. 741.

(o) Cf. Bomard v. Perryman,
(1891) 2 Ch. 269; Salomons v. Knight, Id. 294; cf. also Monson r. Tussaud, (1894) 1 Q. B. 671. 
which may exclude from society, or the words complained of must be shown to have been spoken of the plaintiff with reference to his trade, office, or profession, and to have been calculated to injure him therein $(p)$. What are such words, and what are not, it may be difficult to determine $(q)$. Words which merely convey suspicion will not sustain an action for slander. Should, however, the words admit fairly, and in their natural sense, of two meanings, the one being an imputation of suspicion only, the other of guilt, the sense in which they were attered must be left to the jury $(r)$.

"If a man states of another, who is a trader earning his livelihood by dealing in articles of trade, anything, be it what it may, the natural consequence of uttering which would be to injure the trade and prevent persons from resorting to the place of business, and it so leads to loss of trade," this is actionable $(s)$.

To say of a tradesman, "If he does not come and make terms with me, I will make a bankrupt of him and ruin him," must necessarily be highly prejudicial to him in his

(p) See per Bayley, J., M'Gregor r. Thecaites, 3 B. \& C. 33.

(q) As to defamatory words falling under the first or second of the three classes above specified, see Huckle r. Reynolds, 7 C. B., N. S., 114; Heming v. Pocer, 10 MI. \& W. 564; Edsall v. Russell. 4 M. S Gr. 1090 ; Curtis r. Curtis, 10 Bing. 477 ; Slouman r. Dutton, Id. 402: Tozer r. Mashford, 6 Exch. 539 ; Wwisuorth v. Bentley, 23 L. J. Q. B. 3 ; Helsham $\checkmark$. Blackwood, 11 C. B. 111 ; Blooduerth v. Gray, 7 M. \& Gr. 334; Webb r. Beavan, 11 Q. B. D. 609 , which shows that words imputing any criminal offence are actionable per se. But see Lemon v. Simmons, $5 i$ I. J. Q. B. 260 . As to defamatory words falling within the third of these classes, see Southee r. Denny, 1 Exch. 196 : Foulger r. Nercomb, L. R. 2 Ex. $32 \pi$; Irein v. Brandecood, $2 \mathrm{H}$. \&. C. 960 ; Botterill v. Whytehead, 41 L. T. 588; and cases infra.
Quxre, whether the word "black. leg" is actionable without special damage : Barnett v. Allen, $3 \mathrm{H} . \& \mathrm{~N}$. 376. See Homer v. Taunton, 5 H. \& N. 661.

To say of a town councillor that he is an habitual drunkard is not actionable in the absence of special damage: Alexander v. Jenkins, (1892) I Q. B. 797 (C. A.). Words which impute dishonesty or malversation to an alderman are actionable without proof of special damage: Booth r. Arnold, (1895) 1 Q. B. 571 (C. A.).

(r) Simmons v. Mritchêll, 6 App. Cas. 156.

(s) Per Kelly, C. B., Riding r. Smith, 1 Ex. D. 93. The issues of fact in an action to restrain the publication of a trade libel may be tried before a Judge alone, and an injunction will be granted to restrain its further publication: Thomas v. Williams, 14 Ch. D. 864. 
business; such words are in their nature defamatory, because, when used by the defendant, they necessarily imply that he has the power to carry his threat into execution $(t)$. On the other hand, no action will lie, without averment and proof of actual damage, for verbally imputing incontinence to a clergyman, unless he is beneficed or holds some clerical office or employment of temporal profit $(u)$, though any disparaging words spoken of another without legal justification are actionable, if productive of special damage $(x)$ flowing naturally from the slander $(y)$. And words, written or oral, which falsely depreciate the value of chattel property may also be made the subject of an action, provided special damage ensue from them $(z)$. The distinction between a libel or slander on a person in the way of his trade, which is actionable, as we have already seen, without proof of special damage, and words injuriously reflecting on the quality of his wares and merchandize, is sometimes rather fine $(a)$. Words spoken and published which impute unchastity or adultery to any

(t) Broun v. Smith, 13 C. B. 596. See Rolin v. Steward, 14 C. B. 603; Bellamy v. Burch, 16 M. \& W. 590 ; Griffiths v. Lewis, 7 Q. B. 61 ; Robinson v. Marchant, 7 Q. B. 918.

(u) Galluey v. Marshall, 9 Exch. 294 (citing Hopwood v. Thorn, 8 C. B. 293, and other cases) ; see Pemberton v. Colls, 10 Q. B. 461 .

$(x)$ See Roberts v. Roberts, 5 B. \& S. 384 ; Wilby v. Elston, 8 C. B. 142; Dixon v. Smith, 5 H. \& N. 450 ; Evans v. Harries, 1 H. \& N. 251; Bateman v. Lyall, 7 C. B., N. S., 638; James v. Brook, 16 L. J. Q. B. 17.

(y) Allsop v. Allsop, 5 H. \& N. 534; approved in Lynch v. Knight, 9 H. L. Ca. 577, 592; Miller v. David, L. R. 9 C. P. 118, and cases there cited; Davies v. Solomon, L. R. 7 Q. B. 112 ; per Martin, B., Dixon v. Smith, supra; per Crompton, J., Roberts v. Roberts, supra; Tunnicliffe v. Moss, 3 Car. \& K. 83; Chamberlain v. Boyd, 11 Q. B. D. 407 ; Weldon v.
De Bathe, 54 L. J. Q. B. 113; Duyer v. Meehan, 18 L. R. Ir. 138.

In Parkins v. Scott, 1 H. \& C. 153, held that slanderous words not actionable per se would not become so by reason of damage resulting from an unauthorised repetition of such words by a third person: Dixon v. Sinith, supra.

The existence of a mere rumour does not justify the repetition of slander without showing that the defendant believed it to be true, and spoke the words complained of on a privileged occasion: Watkin v. Hall, L. R. 3 Q. B. 396.

(z) See Cooke on Defamation, p. 20. $A s$ to restraining by injunction the utterance of oral slander calculated to injure another person's business, see Hermann Loog v. Bean, 26 Ch. D. 306.

(a) Evans v. Harlow, 5 Q. B. 624; Jenner v. A' Bechett, L. R. 7 Q. B. 11; Ingrain v. Lauson, 6 Bing. N. C. 212. 
RJoc.68. 55.

Slander of title.

- woman or girl do not require special damage to render them actionable (cf. the Slander of Women Act, 1891, 54 \& 55 Vict. c. 51), but the plaintiff cannot recover more costs than damages, unless the Judge certifies that there was reasonable ground for bringing the action.

There is one rather peculiar kind of slander-riz., slander affecting property $(b)$-which, in concluding the present Chapter, may be noticed. Slander of title signifies a statement of something tending to cut down the extent of title to some estate vested in the plaintiff; and this is actionable only when it is false and malicious, i.e., done with intent to injure the plaintiff. Suppose, for instance, that one having an infirm title to property is about to sell it, or to make it the subject of a settlement, and that another, moved by spite and malice, discloses what he believes to be a defect in the title, which information afterwards turns out to be untrue; suppose, further, that damage thence results to the proposed rendor; in such case an action will lie at suit of this latter party, the statement being false and malicious and injurious to him; but, under the circumstances just supposed, both the falsehood of the statement made and express malice on the part of the defendant must be shown, or there will be no case for the jury $(c)$.

Where defendants without legal occasion or necessity used language concerning the plaintiffs' goods which was false, and such as to injure the plaintifis in their business, and damage thence ensuing was alleged, a good cause of action was held to be disclosed (d).

\footnotetext{
$12 \cdot 2$

(b) Stetcard r. Ioung, L. R. 5 C. P. (c) Iater r. Bakes, 3 C. B. 831 ; lirook r. Raul, \& Exch. 521. See fiugers r. Macnamara, 14 C. B. 27; Hignell צ. Buzzard, 3 II. \& N. 217, where Chamnell, li., remarks, "In slauder the plaintifi may rely on proof of special damage. In libel special damage has no existence as a ground of actirns. This is an intermerliate case-
}

it is not slander of title; but may there not be a case of libel of title?" See also Carr r. Duckett, 5 H. \& X. $7 \mathrm{S3}$; Young r. Macrae, 3 B. \& S. 264, 269; Wren r. Wield, L. R. 4 Q. B. 730 ; followed in Halsey $\mathrm{v}$. Brotherhood, 19 Ch. D. $38 s$; Hart r. Hall, 2 C. P. D. 146.

(d) Western Connties .Manure Co. r. Laves Chemical Manure Co., L. R. 9 Ex. 21s, distinguishing Young r. 
We may add in conclusion that, though an action $f(0)$ defamation, either of private character or of a person in relation to his trade, comes to an end on the death of the plaintiff, according to the maxim Actio personalis moritur cum person $\hat{a}$, yet an action for the publication of a false and malicious statement, causing damage to the plaintiff's personal estate, will survive to his personal representatives $(e)$.

Macrae, supra. See Mellin v. White, (1895) A. C. 154 (reversing C. A., 1894, 3 Ch. 276). An action will not lie for a false statement disparaging a trader's goods where no special damage is prored (S. C., loc. cit.). Quære. whether an action will lie in any case for disparaging a trader's goods merely by stating that some other trader's goods are better, either generally, or in this or that respect (loc. cit.). 771 


\section{CHAPTER III.}

TORTS TO PROPERTY.

Harrsg in the preceding Chapter treated of Torts to the Person and Reputation, a brief and elementary view musi now be taken of the ordinary civil Wrongs which may be done to Property, Real or Personal. The nature of the remedy allowed by law for the recovery of land, for enforcing compensation in damages for an injury direct of consequential done to it, for recovering chattel property tortiously withheld from its owner or compelling pecuniary satisfaction for any injury to it, must also be specified Before inquiring as to these subjects the reader may br reminded that the several rules and principles of law which will now for a while engage our attention, concernand have been fashioned to protect-that absolute right which, as Blackstone (a) tells us, is inherent in every Englishman-the right of property; consisting " in the free use, enjoyment, and disposal of all his acquisitions, with out any control or diminution, save only by the laws of th land." Whatever may be the origin of private property the modifications to which it is subjected and the metho of conserving it in the present owner or of transferring it from man to man are entirely derived from socia exigencies $(b)$, and are scrupulously regulated by our law which is extremely watchful in ascertaining and protecting the rights in question.

From Magna Charta downwards, not merely the land and

(a) 1 Com., p. 138

(b) Id. ibid. 
freehold of the subject, but his goods and chattels, have in innumerable instances been jealously guarded by enactment; and, although there are cases in which pro salute populi the rights of property are violated or infringed, such invasion of them is never, without due caution and inquiry, tolerated or sanctioned; and, even when this is permitted, compensation is usually $(c)$ granted to or made enforceable at suit of the individual aggrieved; the principle of our law being to give to him, either out of the public purse or from some private source, an indemnification and equivalent for the damage sustained.

Save, however, in extreme or urgent cases, such as have been just adverted to, the words of $\operatorname{Sir} \mathrm{E}$. Coke $(d)$, in his commentary on our celebrated statute, still hold true, - that every subject for injury done to him in goods, in lands, in person, by any other subject, " may take his remedy by the course of the law, and have justice and right for the injury done to him, freely without sale, fully without any denial, and speedily without delay."

\section{SECT. I.-Torts to Real Property.}

Of ordinary injuries or torts to real property, that which must first be noticed is constituted by the wrongful detention Action for recovery of or withholding of land from its lawful owner, by possession and occupancy adverse to his rights. For this injury the remedy is by action at suit of the claimant against the wrongful occupier of the land.

This action for the recovery of land is brought rather with a view to recovering the possession of land than in assertion of a title to it which shall be indefeasible $(c)$. If

(c) "It seems to me that it is a proper rule of construction not to construe an Act of Parliament as interfering with or injuring persons' rights, without compensation, unless one is obliged so to construe it:"' per Brett, M. R., Att.-
Gen. v. Homer, 14 Q. B. D. 257.

(d) 2 Inst. 55.

(e) As to the old action of ejectment, see per Lord Blackburn, Bristow v. Cormican, 3 App. Cas. 601. 
A. claims land of which B. is in possession, B. is in law tc be considered as owner of the land until the contrary be proved $\left(f^{*}\right)$. So that A. will necessarily have to recovel possession, if at all, by the strength of his own, and not by the realness of B.'s title $(g)$. Should A. succeed in doing so, and should it happen that $B$. or any other person afterwards becomes clothed with a better title than A., a second action may be brought, and A. may be ejected from the land. Hence Lord Mansfield took occasion $(h)$ to observe, that "in truth and substance" a judgment in this action is "a recovery of the possession (not of the seisin or freehold) without prejudice to the right, as it may afterwards appear even between the parties." $\mathrm{He}$, then, who thus recovers land can only be possessed according to the right which he has. If he has a freehold interest in the land, he is in as a freeholder. If he has a chattel interest therein, he is in as a termor. If he has no title at all, he is in as a trespasser, and will be liable to account to the true owner for the profits of the land $(h)$. A judgment in the action for recovery of land cannot, even as between the same parties, be deemed conclusive evidence of title, for a person may have a title to the possession of land at one time and not at another; such a judgment, however, would be evidence on behalf of the party who obtained a verdict on the first trial (i).

This action, then, depends mainly upon title, and by it a person having a right of entry into land recovers its possession, a remark which holds true whether the relation of landlord and tenant exists or not between the litigating

(f) See, for instance, Asher $r$. "hillack, L. R. 1 Q. B. 1.

(g) Per Lee, C. J., Martin v. stiucherin, is T. R. 110, n.

(h) Triglor d. Atkyns v. Horde, 1 linrr. $11 \%$.

(i) l'er Lord Alinger, C. B., and l'rilie', B., Doe d. Strode v. Seaton,
2 Cr. M. \& R. 728. See Aslin r. Parkin, 2 Burr. 66.5; Doe v. Wellsman, 2 Exch. 368; Doe v. Huddart, 2 Cr. M. \& R. 316 ; per Jertis, C. J., Wilkinson v. Kirby, 15 C. B. 439 , 443 ; Doe d. Brayme v. Bather, 12 Q. B. 941 ; Litchficld v. Ready, 5 Exch. 939. 
parties. Where this relation does not exist, the plaintiff must show in himself a good and sufficient legal title to the land claimed. So that, if the occupant can answer the case set up on the part of the claimant by showing the title to be in another, that will suffice for his defence $(k i)$. Reasonable presumption, however, will be admitted in farour of a title-for instance, if the plaintiff claims as heir at law of A., it will be sufficient for him to prove that A. was in possession, and that the plaintiff is his heir ; for it shall be intended prima facie that $\mathrm{A}$. was seised in fee until the contrary appear $(l)$.

Where the relation of landlord and tenant exists between the claimant of land and the party in possession it will not be necessary for the landlord claiming the land to prove his title to it, by virtue of the well-known rule, that a tenant shall not be allowed to dispute his landlord's title, i.e., shall not be permitted to dispute the original right of him by whom he has himself been admitted into possession. If $\mathrm{B}$., claiming under A.,"lets land to C. for a year and dies, and A. afterwards brings an action against C. for recovery of the land, C. may in some cases be estopped from disputing A.'s title paramount thereto $(\mathrm{m})$. A tenant, however, may show that his landlord's title has ceased and determined subsequently to his own entry into the land and attornment to the plaintiff. And, in a word, as betreen landlord and tenant the right to maintain the action under our notice will depend upon this question, whether the landlord or the tenant was at the particular date specified in the claim entitled to the possession of the land for which the action was brought-a question which may have to be determined by reference to the terms of the demise, or to the covenants and conditions (if any) contained in the lease between the parties.

(k) Adams, Ejectm., 4th ed., p. 28. (l) Id., p. 240. (m) Bawick r. Thompson, 7 T. R. 488 . 
A landlord, then, suing his tenant for recovery of the land demised will in general merely be required to prove the circumstances under which the defendant or the party under whom he holds was admitted into possession, and, further, to show that his right to the possession has ceased $(n)$.

Trespass to land.

Trespass to realty, which in the next place demands attention, is founded upon possession $(0)$; in it an award of damages only can be obtained as compensation for the wrong done to the plaintiff, an injunction being also sometimes granted by the Court to restrain a continuance of the trespass $(p)$.

Trespass to realty consists in a wrongful and unwarrantable entry upon the soil or land of another. "Every man's land," says Blackstone $(q)$, "is in the eye of the law enclosed and set apart from his neighbour's, and that either by a visible and material fence, as one field is divided from another by a hedge, or by an ideal invisible boundary existing only in the contemplation of law, as when one man's land adjoins to another's in the same field." Any entry upon or breach of a man's close, if unauthorised by him, and unjustified by law $(r)$, carries necessarily along with it some damage or other $(s)$. So that proof of the alleged trespass will, without any

(n) Adams on Ejectment, 4th ed., p. 232. Where indeed the privity is not betwcen the immediate parties to the action the claimant will also have to prove his derivative title from the party by whom the defendant was origiually admitted in to possession : Id. ibid. As to the law of laudlord and tenant generally, see ante, p. 509.

(o) I'er Lord Kenyon, C. J., Graham v. I'eat, 1 East, 244,$246 ; 6$ R. R. 268; 11 R. R., Prefaee v.; per Martin, B., Hodson v. Walker, J. R. 7 Ex. 69; Daris r. Danks, 3 Exch. 435, 437 ; Lee v. Stevenson, E. B. \& k. 512 .

(p) The Supreme Court of Judiea. ture has no jurisdiction to entertain an action to recover damages for a trespass to land situate abroad: Companhia de Moçambique r. British South Africa Co., (1893) A. C. 602, reversing C. A. 1892,2 Q. B. 358.

(q) 3 Com., pp. 209, 210.

(r) Lifosd's ease, 11 Rep. 02 a; Randall $\mathrm{v}$. Stevens, 23 L. J. Q. B. 68 ; Keyse v. Powell, 2 E. \& B. 132. See Holmes v. Neulands, 11 Ad. \& E. 44 ; Knapp v. Iondon, Chatham, and Dover R. C., 2 H. \& C. 212.

(s) Per Lord Camden, Entick v. Carrington, 19 How. St. Tr. 1066.

"In determining the question of trespass or no trespass the Court can. not measure the amount of the alleged trespass; if the defendant place a part 
proof of damage sustained, entitle the plaintiff to a verdict; and the reason of this has been well explained $(t)$ as follows: For the vindication of every right there is a remedy; when, therefore, there has been a violation of a right, the person injured is entitled to an action, and, consequently, to at least nominal damages, such damages being given in order to vindicate the right which has been invaded, and such further or special damages being awarded as may be proper to remunerate and compensate the plaintiff for any specific damage which he has sustained. It is on this principle that a person may support an action of trespass for an unauthorised entry on his land, although he show no actual specific damage to have thereby accrued to him, nay, even though the defendant show that the act in question was positively beneficial to the plaintiff.

In the recent case of Harrison v. Duke of Rutland (u), a highway, the soil of which was vested in the defendant, was used by the plaintiff not for the purpose of passing and repassing, but of interfering with the defendant's right of shooting over certain moors, adjoining the highway. The Court of Appeal held that the plaintiff was a trespasser on the highway. Lord Esher, M. R., says (v)-"Therefore on the ground that the plaintiff was on the highway, the soil of which belonged to the Duke of Rutland, not for the purpose of using it to pass and repass, or for any reasonable or usual mode of using the highway as a highway, I think he was a trespasser." Lopes, L. J.(w), says-"The conclusion which I draw from the authorities is that if a person uses the soil of the highway for any purpose other than that in respect of which the dedication was made and the easement acquired, he is a trespasser."

of his foot on the plaintiff's land unlawfully, it is in law as much a trespass as if he had walked half a mile on it:' per Lord Coleridge, C. J., Ellis v. Loftus Iron Co., L. R. 10 C. P. 12 ;
Wiseman r. Booker, 3 C. P. D. 184.

( $t$ ) Sedgw. Dams., 7th ed., p. 266.

(u) (1893) 1 Q. B. 142 (C. A.).

(v) At p. 146.

(w) At p. 154 
The action for trespass to land is founded upon possession by the plaintiff, i.e., possession by himself, or by his servant $(x)$ or agent, of the locus in quo. Should he be out of possession, as if he has demised it to another, trespass for an entry upon such land will clearly not lie at his suit, the tenant in possession being here the party aggrieved, and being therefore entitled to complain by action $(y)$.

Possession, then, is necessary to the maintenance of an action for trespass to land, and the party in possession will make out a primâ facie case sufficient to entitle him to a verdict by proof of such possession in himself, and of entry by the defendant. This is, of course, equivalent to saying that entry upon the land of another is prima facie tortious, so as to cast upon the defendant the necessity of showing title in himself or some third person and proving authority from that person to enter upon the land in question $(z)$. Without such authority fox-hunting over another man's land cannot be justified (a).

The doctrine just stated, though manifestly founded in common sense and convenience, may sometimes lead to rather singular results. As soon as a person entitled to the possession of land peaceably enters upon it in the assertion of that title, the law immediately vests the actual possession in him who has so entered. "If," says Maule, J. (b), " there are two persons in a field, each asserting that the field is his, and each doing some act in the assertion of the right of possession, and if the question is, Which of those two is in actual possession? I answer, The person who has the title is in actual possession, and the other person is a tres$3+7$

(y) Cooper v. Crabtree, 20 Ch. D. 589.

(દ) Per Wightman, J., Jones v. Cliapman, 2 Exch. 816; per Jerris, C. J., Wilkinson v. Kirby, 15 C. B. 43 ; Slocombe v. Lyall, 6 Exch. 119;
Judgm., Hayling r. Okey, 8 Exch.545. (a) Paul v. Summerhayes, 4 Q. B. D. 9.

(b) Jones v. Chapman, 2 Exch. 821 ; cited per Parke, B., 5 Exch. 947 ; and per Lord Selborme, Lous v. Telford, 1 App. Cas. 426. 
passer $(c)$. They differ in no other respects." It cannot, indeed, be said that in the case here supposed there is a joint possession, or a possession by the two as tenants in common. It cannot be denied that one is in possession and the other a trespasser; which is the trespasser must be determined by the fact of title. And although both are apparently in actual possession, yet the question which of them really is so will depend upon this rule-that the law makes the possession under such circumstances follow the titie $(d)$. The example thus put by $\mathrm{Mr}$. Justice Maule seems specially well adapted to illustrate the elementary rule before adverted to, viz., that the possession of land will suffice to sustain an action of trespass as against one who tortiously enters upon it $(e)$.

In further illustration of the rule just stated, let us suppose that land is held by A. under B., who is tenant for life; that B. dies; and that A. subsequently to his death, being out of actual possession, does no act indicating his intention to continue his possession of the premises-as if $\mathrm{A}$. is tenant of a field, which, becoming flooded during the winter, is not subsequently thereto and after the death of the tenant for life (A.'s landlord) reoccupied by him-in such a case the tenancy would, in fact, have been determined by the death of the tenant. for life, and therefore an action of trespass would not be maintainable at the suit of $\mathrm{A} .(f)$. Nor will trespass lie against the occupier of land at suit of a mortgagee who has never been in actual possession, or

(c) Hence a person wrongfully holding possession of land cannot treat the rightful owner who enters on the land as a trespasser, for the party entitled to the land acquires by entry the lawful possession of it, so that he may maintain trespass against any person who, being in possession at the time of his entry, wrongfully continues upon the land: per Bayley, J., Butcher v. Butcher, 7 B. \& C. 402 ; cited per Iartin, B., L. R. 7 Ex. 69 ; Hey v.
Moorhouse, 6 Bing. N. C. 52 ; v. ante, p. 206.

(d) 2 Exch. 821.

(e) See also per Holroyd, J., Harper v. Charlesworth, 4 B. \& C. 592 : Judgm., Ryan r. Clark, 14 Q. B. 71; Harrison v. Blackburn, 17 C. B., N. S., 678, 691; Dyson r. Collich, 5 B. \& Ald. $600 ; 24$ R. R. 484.

(f) Broutn v. Notley, 3 Exch. 219 ; Smith v. Milles, 1 T. R. 475. 
been seised of the land, and has not obtained a judgment in an action for its recovery $(g)$. And before entry neither can a freeholder $(h)$, nor the customary heir of a copyhold tenement (i), nor a lessee, nor the assignee of a term of years $(k)$, maintain trespass for an unlawful entry upon his land.

In order that an action for trespass to land may be sustainable, the possession must be exclusive (l). If a meadow be divided and parcelled out annually among the parishioners by lot, then after each person's several portion has been allotted he may sue in trespass for the breach of his several close, because he has an exclusive interest therein for the time being $(m)$. So trespass will lie at suit of one who has an exclusive right or interest in land the soil of which belongs to another, as the exclusive right to cut turf in a waste belonging to the lord of the manor $(n)$. Further, it has been held that a person entitled to the exclusive enjoyment of a growing crop during the proper period of its growth, and until it was cut and carried away, might maintain trespass in respect of such exclusive right; and one entitled exclusively to the "vesture" of land, that is, to the corn, grass, underwood, and the like, growing upon it, may have an action of trespass $(o)$.

(g) Turner v. Cameron's Coalbrook Steam Coal Co., 5 Exch. 932 ; Litchfield v. Ready, Id. 939; Wheeler $v$. Montficore, 2 Q. B. 133 (explained in the judgment, Doe d. Parsley r. Day, 2 Q. B. 155).

(h) 3 Bla. Com. 210, citing 2 Roll. Abr. 553.

(i) Barnett r. Earl of Guildford, 11 Exeh. 19, which shows that after entry there may be a relation back to the time when the title acerued.

(k) JIarrison v. Blaclburn, 17 C. B., X. S., supra, n. (e).

(I) Revelt v. Broutn, 5 Bing. 7 ; Sitocky v. Booth, 1 T. R. 428, 430; 1 R. R. 244; Maimuaring v. Giles, 5 H. A Ald. $356 ; 24$ R. R. 417 ; Greatheud r. Morley, 3 M. \& Gr. 139 ; com- mented on and distinguished in Evart $\mathrm{r}$. Graham, 7 H. L. Ca. 331 ; S. C., 1 II. \& N. $550 ; 11$ Exch. 326. See Holford v. Bailey, 13 Q. B. 426 ; S. C., 8 Id. 1000 ; Marshall v. Ulleswates Steam Nat. Co., 3 B. \& S. 732, 749; Holmes v. Bagge, 1 E. \& B. 782: Rigg r. Earl of Lonsdale, $1 \mathrm{H}$. \& N. 923 ; S. C., 11 Exch. 654; Lee r. Sterenson, E. B. \& E. 512.

(iin) 3 Bla. Com. 210.

(n) Per cur., Wilson v. Mackreth, 3 Burr. 1824; Welden r. Bridgeacater, Cro. Eliz. 421.

(o) Crosby v. Wadsworth, 6 East, 602 ; 8 R. R. 566 ; Preface vii.; Co. Litt. 4 b; $\Pi^{e l s h}$ v. Hall, cited 2 Selw. N. P., 13th ed., 1243. 
A reversioner also, though out of possession of land, may sue for any injury of a permanent kind done to his reversion. Upon this point Cox v. Glue $(p)$ is an authority. There the plaintiff was seised in fee of land upon which the burgesses of a certain town had a right during a portion of the year to depasture their cattle, and of which also during such period they were entitled to the exclusive possession. Trespasses having been committed as well to the surface as to the subsoil of the land in question (whilst in the occupation of the burgesses), it was held that in respect of the latter (the injury to the subsoil) an action would well lie at suit of the plaintiff (the tenant. in fee), but that in respect of the former (the injury to the surface of the land) it would not.

It cannot of course be denied that the possession of the surface of land may be in one person whilst the possession of the subsoil is in another. The right, for instance, either to the surface or to the subsoil may be derived by grant, or inferred from a long and uniform course of enjoyment, which will be supposed to correspond with some interest created by a grant, and the action of trespass, being a remedy given for an interference with possession, may be maintainable at suit of a party entitled to either of the rights just specified when it has been invaded.

It is, however, important to note this difference between an action for a trespass to land and an action for damage done to the reversion. In the former action, as stated at p. 871, special damage need not be proved with a view to supporting it. In the latter action it must be so ; that is to say, the plaintiff, suing as reversioner, must show that, by the acts complained of, his reversionary estate and interest were depreciated or lessened in value, or he must show that the alleged tort was of a kind which was neces-

(p) 5 C. B. 533. See Marker r. Woodcock, 5 M. \& W. 5s7, 594.

Kenrick, 13 C. B. 188 ; Weeton v. 
I sarily ealculated to prejudice the reversion $(q)$. The following hypothetical state of facts may serve to illustrate this part of the subject: A. is tenant in possession of an estate under a lease; through this estate runs a public road, which is stopped up by $B$. (the defendant), in consequence whereof $A$. sustains some special and peculiar damage, which will entitle him to an action against $B$. In this case, C., the landlord, who is out of possession, is in nowise damnified by his tenant's being prevented from enjoying his estate in so ample a manner as he might otherwise have done, and he (the landlord) will not be entitled to redress in the absence of proof of damage to his reversion. That such damage might under the circumstances here supposed really ensue, or be reasonably presumable, is extremely probable; for if an obstruction of a public road appeared to be of a permanent nature, or professed, either by notice affixed, or in any other way, to deny the public right, thus leading to an opinion that no road was there, the value of the estate might be lowered in public estimation, and pecuniary loss might follow, for which an action would lie $(r)$.

In Simpson v. Savage (s), the Court laid down this proposition upon the subject before us, that, since, in order to give a reversioner a right of action for consequential damage, " there must be some injury done to the inheritance, the necessity is involved of the injury being of a permanent character," not necessarily in the sense of lasting many years, but of its enuring as an injury to the reversion $(t)$.

(2) Dobson v. Blackmore, 9 Q. B. 991 ; Jackson v. I'esked, I M. \& S. 234 ; 14 R. R. 417.

(v) Judgm., 9 Q. B. 1004.

(s) 1 C. 13., N. S., 347; Mrumford $\checkmark$ Oxford, Worcester, and Wolverhampton R. C., 1 H. \& N. 34: Bell v. Midland R. C., 10 C. B., $\dot{X}$. S.,

(t) Metropolitan Ass. v. Petch, 5
C. B., N. S., 504, following Kidgill r. Moor, 9 C. B. 364. See also Wiltshear v. Cottrell, 1 E. \& B. 674 ; Baxter v. Taylor, 4 B. \& Ad. 72; Twelier v. Nercman, 11 Ad. \& E. 40 ; Yosung $\mathrm{r}$. Speneer, 10 B. \& C. 145 ; per Best, C. J., Strother v. Barr, 5 Bing. 153; Alston v. Scales, 9 Bing. 3 ; Ilosking v. Phillips, 3 Exch. 168. 
In connection with torts to realty, it should be noticed, that "a man is answerable for not only his own trespass, but that of his cattle also : for if, by his negligent keeping, they stray upon the land of another (and much more if he permits or drives them on), and they there tread down his neighbour's herbage, and spoil his corn or his trees, this is a trespass for which the orwer must answer in damages; and the law gives the party injured a double remedy in this case by permitting him to distrain the cattle thus 'damage feasant,' or doing damage, till the owner shall make him satisfaction, or else by leaving him to the common remedy in foro contentioso by action," wherein, "if any unwarrantable act of the defendant or his beasts, in coming upon the land, be proved, it is an act of trespass for which the plaintiff must recover some damages, such, however, as the jury shall think proper to assess " $(u)$. The damage in respect of which trespassing animals may be distrained includes injuries to other animals $(x)$.

A trespass may be of a permanent nature, where the injury is continually renewed $(y)$, as by spoiling or consuming the herbage with the defendant's cattle, or by continuing illegally in the plaintiff's dwelling-house after a forcible entry into it $(z)$.

Sometimes, however, a forcible entry on another's land or house is justifiable, and shall not be accounted trespass (a), as if a man comes thither to demand or pay money there payable, or to execute in a legal manner the process of the law (b). Thus a landlord may justify entering to distrain for rent; a person may in some cases enter upon his neigh-

(u) 3 Bla. Com., pp. 211, 212. See Ellis v. Loftus Iion Co., L. R. 10 C. P. 10 ; Wiseman v. Booker, 3 C. P. D. 184 .

(x) Bowden v. Briscoe, (1894) 1 Q. B. 608 .

(y) 3 Bla. Com., p. 212.

(z) Percival v. Stamp, 9 Exch. 167, 174, where Parke, B., says, "It is common learning, that every continuation of a trespass is a fresh trespass."

(a) See Burridge v. Nicholetts, 6 H. \& N. 383.

(b) See Hewitt v. Macquire, 7 Exch. 80; Ash v. Dawnay, 8 Exch. 237, 243 ; Keane v. Reynolds, 2 E. \& B. 748. 
bour's land to abate a nuisance $(c)$; a commoner may enter to attend his cattle commoning on another's land, a reversioner to see if any waste be committed on the estate; and under circumstances of extreme necessity $(d)$, or where the law presumes a right of way, an intrusion on another's land may be justified. Moreover, a man may justify entering into an inn or public-house without the leave of the owner first specially asked, because, when one professes the keeping of such inn or public-house, he thereby gives a general license to any person to enter his doors $(c)$, such license being of course subject to statutory restrictions, and liliewise to this proviso, that there is suitable accommodation at the innkeeper's disposal, and that the guest applies peaceably for admission, and is ready and able to pay reasonable compensation for what he has $(f)$.

A man may also justify in an action for trespass on

(c) Ante, p. 209.

(d) Leg. Jax., 6th ed., p. 2. See Pimington v. Galland, 9 Exch. 1, and cases there cited; White v. Bass, 7 H. \& N. 722, 732; Pearson v. Spencer, 1 B. \& S. 761 ; S. C., Id. 571 ; Pyer v. Carter, 1 H. \& N. 916 , 922 (questioned in Suffield 5. Broun, 33 L. J. Ch. 249, and in Wheclion r. Burous, 12 Ch. D. 31); Euart v. Cochrane, 4 Macq. Sc. App. Cas. 117,122 ; Hall r. Lund, I H. \& C. 676 ; Dodd r. Burchell, 1 H. \& C. 113 ; Buckby v. Cotcs, 5 Taunt. 311; 15 R. R. 508 ; Proctor r. Hodgson, 10 Exch. 824 ; v. post, p. 892.

(c) 3 Bla. Com., p. 212 . See Reg. ง. Rymer, 2 Q. B. D. 136, cited infra, 11. $(f)$.

"Leave and license" may of course afford a good defence to an action of trespass to land. See Heutit v. Isham, i Fixch. 77 ; Joe d. Mndson v. Leeds and Braiford R. C., 16 (2. B. 796; cited per Channell, B., Knapp r. London, Chatham, and Doter R. C., 2 II. ㅈ C. 222 .

(f) Story on Bailm., Sth ed., pp. $411, \$ 12:$ R. V. Iiens, 7 Car. \& 1 . 213; Thampson $\times$. Lacy, 3 B. \& Ald.
283, 285 ; 22 R. R. 385; Haucthorn v. Hammond, 1 Car. \& K. 404 ; per Coleridge, J., Dansey r. Richardson, 3 E. \& B. 159.

An innkeeper is not, howerer, bound to proride for his guest the precise rooin which the latter may select; all that the law requires of him is to find for his guest reasonable and proper accommodation: Fell v. Knight, 8 M. $\&$ W. 269,276 .

Nor is an innkeeper bound to receire into the bar attached to his inn a customer with his dogs : Reg. v. Rymer, 2 Q. B. D. 136.

As to obligation of an innkeeper to receive goods, see the remarks per cur. in Broadicood r. Granara, 10 Exch. 417, and cases there cited.

As to an innkeeper's right of lien, see Threfall v. Borwich, L. R. 7 Q. B. i11; S. C., affirmed L. R. 10 Q. B. 210 ; Snead v. Watkins, 1 C. B., N. S., 267 ; Allen r. Smith, 12 C. B., N. S., 638 ; Mulliner v. Florence, 3 Q. B. D. 484 ; Angus r. MeLachlan, 23 Ch. D. 330 .

As to the right of an innkeeper to dispose of goods left with him, see stat. 41 \& 42 Vict. c. 38, s. 1. 
account of the freehold and right of entry being in himself, a defence which brings the title to the estate in question.

There are one or two rather peculiar principles of our law Trespass which, in connection with injuries to real property, invite our notice. "Where," says Blackstone (g), " a man misdemeans himself, or makes an ill use of the authority with which the law intrusts in him, he shall be accounted a trespasser $a b$ initio, as if one comes into a tavern and will not go out in a reasonable time, but tarries there all night contrary to the inclinations of the owner, this wrongful act shall affect and have relation back even to his first entry, and make the whole a trespass. But a bare nonfeasance, as not paying for the wine he calls for, will not make him a trespasser, for this is only a breach of contract." Such are the remarks of Blackstone upon the point in question, the law in regard to it being fully stated in The Six Carpenters' Case (h). The doctrine referred to is in practice most frequently, though not exclusively, applied in connection with trespasses to land, as where he who enters an inn or tavern commits a trespass there, as by carrying anything away; or if the lord who distrains for rent, or the owner for damage feasant, works or kills the distress ; or if he who has a right of entry to take one heriot enters and takes two $(i)$; or if a lessor who enters on demised premises to see if waste be done breaks the house, or stays there all night; or where a commoner cuts down a tree growing on the commonable land. In these and the like cases the law holds that the wrong-doer entered with intention to do the wrongful act of which he subsequently was guilty; and

(g) 3 Com., p. 213.

(h) 8 Rep. 146 a; 1 Sm. L. C., 9th ed., 144. See Leg. Max., 5th ed., pp. 301 et seq.; West v. Nibbs, 4 C. B. 172,$187 ;$ Ash v. Dawnay, 8 Exch. 237; Percivalv. Stamp, 9 Exch.
167 ; Burdett v. Colman, 14 East, 163 ; 12 R. R. 478, Preface vii.; Ambergate, \&.., R. C. v. Midland R. C., 3 E. \& B. 793. 559 . (i) Price v. Woodhouse, 1 Exch. 
because the act which demonstrates the intention is a trespass, the individual doing it shall be accounted a trespasser al initio $(k)$. A man cannot, however, be made. a trespasser by relation where the act complained of was lawful at the time when done $(l)$.

Ratification of tres]ass.

Another important principle occasionally applicable in an action for trespass to land, the nature and limitations whereof have already been illustrated and defined, is that of ratification by a principal of a wrongful act done in his name or on his behalf by a third person. The judgment in Buron v. Denman, noticed at pp. 103, 804, and the cases there cited, should be examined in connection with the subject treated of in this section.

As exhibiting the nature of and remedy for a nuisance at common law, the following remarks are offered :-

A private "nuisance" has been defined to be "anything done to the hurt and annoyance of the lands, tenements, or hereditaments of another," as if one erects a smeltinghouse for lead so near the land of another that the vapour and smoke kill his corn and grass, and damage his cattle therein $(m)$. And where no right by prescription or agreement exists to carry on a particular manufacture in a particular place, the principles to be applied for determining the manufacturer's liability for a nuisance to adjacent land, caused by his works, have been thus authoritatively expressed :-Every man is bound to use his own property in such a manner as not to injure that of his neighbours; the law, however, does not regard trifling inconveniences, and therefore the injury to be actionable must be such as visibly to diminish the value of the complainant's property, and the enjoyment of it; and all the circum-

(k) The Six Carpenter's' Case, 8 Rep. 146 b; 1 Sm. L. C., 9th ed., 144; Bramuell v. Attack, 3 B. \& S. 520 .

(I) See Tharpe v. Stallwood, 5 M. \& Gr. 760 ; Foster v. Bates, 12 M. \&
W. 226 ; Welchman r. Sturgis, 13 Q. B. 552 ; per Parke, B., Yorston r. Fether, 14 M. \& W. 854.

(m) 3 Bla. Com., pp. 210, 217. 
stances adduced in evidence, including those of time and locality, ought to be considered by the jury $(n)$.

As to whether the plaintiff is entitled to damages or an injunction, Smith, L. J., in Shelfer v. City of London Electric Lighting Co. (o), stated the following as a good working rule: damages in substitution for an injunction may be given (1) if the injury to the plaintiff's legal rights is small; and (2) is one which is capable of being estimated in money; and (3) is one which can be adequately compensated by a small money payment; and (4) the case is one in which it would be oppressive to the defendant to grant an injunction.

Many other analogous torts to property, falling within the class now before us, and resulting from non-observance of the maxim, Sic utere tuo ut alienum non laedas $(p)$, will without doubt readily suggest themselves to the reader. If my neighbour is bound to scour a ditch, or cleanse and keep in repair a drain, and neglects to do so, whereby my land is overflowed and my goods are damaged, this is an actionable nuisance $(q)$. If a man builds a house so near to mine that his roof overhangs my premises, and throws the water off his roof upon them, this is a nuisance for which an action founded in tort will lie $(r)$, even without proof that water has thus fallen or been discharged upon my land $(s)$; and a person who for his own purposes brings on to his land, and collects and keeps there anything-

(n) St. Helen's Smelting Co. v. Tipping, 11 H. L. Ca. 642; Cavey v. Leadbitter, 13 C. B., N. S., 470; Bamford v. Turnley, 3 B. \& S. 62, 66.

(o) (1895) 1 Ch. 287.

(p) Leg. Max., 6th ed., 347 et seq., where many cases are cited illustrating the nature of a nuisance to real property. See also Chauntler v. Robinson, 4 Exch. 163; Richards v. Rose, 9 Exch. 218; and cases cited ante, Bk. I. Ch. 3 : Laurence v. Great Northern R. C.,
16 Q. B. 643 ; Clothier v. Webster, 12 C. B., N. S., 790, 796.

(q) 3 Bla. Com., p. 218; Alston v. Grant, 3 E. \& B. 128; Harrison v. Great Northern R. C., 3 H. \& C. 231.

(r) Penruddock's Case, 5 Rep. 100.

(s) Fay v. Prentice, 1 C. B. 828; Harvey v. Walters, L. R. 8 C. P. 162 ; Baten's Case, 9 Rep. 53, b. See Pickering v. Rudd, 1 Stark. N. P. C. 56; Kenyon, app., Hart, resp., $6 \mathrm{~B}$. \& S. 249. 
$e x . g r .$, water-likely to do mischief if it escapes, must keep it in at his peril, and if he does not do so is prima facie answerable for all the damage which is the natural consequence of its escape $(t)$.

Easements. Amongst torts to realty, besides such as are evidenced by a mere wrongful entry upon land, or by the committing of such nuisances as those just referred to, are to be included all infringements of the class of rights known to the law as easements (u). These must be distinguished from those natural rights which are incident to the possession of realty, inasmuch as the former are founded upon prescription or upon a grant express or implied.

An "easement" may be defined as "a privilege which the owner of one neighbouring tenement hath of another existing in respect of their several tenements, by which the servient owner is obliged to suffer or not to do something on his own land for the advantage of the dominant owner" $(x)$. Easements must also be distinguished from mere obligations, which only confer a personal right against the owner, as opposed to a right over his land, and for a breach of which the remedy would only be by an action on the contract; and also from rights to participate in any profits arising from such land, such as rights of common,

(t) Rylands r. Fletcher, I. R. 3 H. L. 330 (distinguished in Anderson ₹. Oppenheimer, 5 Q. B. D. 602); Crowhurst r. Amersham Burjal Board, 4 Ex. D. 5, 10, 11 ; Nichols r. Marsland, 2 Ex. D. 1 ; Carstairs r. Taylor, L. R. 6 Ex. 217; Humphries r. Consins, 2 C. P. D. 239, 246; distinguishing Ross v. Fedden, L. R. T Q. J. 661, 666; Wilson v. Neuberry, L. R. 7 Q B. 31 ; Fleteler v. Smith, 2 App. Cas. 781 ; Hurdman v. North Enstern R. C., 3 C. P. D. 168, 174; Swith r. Fletcher, I. R. 9 Ex. 64; Inon r. Birmingham Canal Co., I. R. $;$ Q. B. 244, 260, 261 ; S. C., Id. 421 ; Snow v. Whitehcad, 27 ('h. D. 588. See Rylands r. Flctcher, followed Nitional Telephoncs Co. v.
Baker, (1893) 2 Ch. 186, where the principle was held to cover the case of a man creating on his own land an electric current. See also Ponting r. Toakes, (1894) 2 Q. B. 281, the case of a yew tree, none of whose branches overhung the plaintiff's land. The defendant was held not liable in respect of a horse of the plaintiff which bad died after eating of the tree.

(u) The following sketch of the law of easements has been mainly derired from Mr. Gale's valuable work on the subject, which should be consulted by the student who is anxious for further information.

(x) Terms de la Ley, Tit. Easements. 
hooting or fishing, which are known to the law as profits prendre $(y)$.

An easement is an incorporeal right imposed upon cororeal property for the benefit of real $(z)$ property $(a)$, and reeding therefore two distinct tenements, the dominant to vhich the right belongs, and the servient upon which the bligation is imposed (b). Easements are either affirmative ir negative; the former authorise the commission of acts njurious to the owner of the servient tenement, $e x . g r$., ights of way, or support; the latter restrict the neighbouring owner in his use of his tenement, ex. gr., an bligation not to block an ancient window. They are also ither continuous, ex. gr., the employment of light ; or disontinuous, ex. gr., a right of way; and apparent, where the asement is shown by works, as the construction of a waterourse, or the opening of a window ; or non-apparent, where here is no such outward sign, as in the case of a prohibiion to build so as to interfere with the access of light.

Before considering further the nature of easements proserly so called, it will be advisable to refer to the most mportant natural rights of property, inherent in its very oossession. Of these the principal ones are the right to upport for land in its natural condition, and the right to he use of flowing water.

As to the first of these, it is obvious that "if neighbourng owners might excavate their soil on every side up to

he boundary line to an indefinite depth, land thus deprived if all support on all sides could not stand by its own coheence alone " $(c)$. Such excavation, therefore, is forbidden $\mathrm{n}$ accordance with the maxims, Sic utere tuo ut alienum non

(y) Cf. Addison on Torts, 5th ed., 1. 255 .

(z) Gale on Easements, 6th ed., cf. thap. 2.

(a) There can be no such thing as an asement in gross. "There can be no asement properly so called, unless here be both a servient and a domi- nant tenement." Per Lord Cairns, L. J., Rangeley v. Midland R. C., L. R. 3 Ch. App. 310.

(b) Gale on Easements.

(c) Per cur., Humphries v. Brogden, 12 Q. B. 739,744 , citing Gale on Easements, p. 358 . 
laedas, and Prohibetur ne quis faciat in suo quod nocere potest alieno. "It seems that a man who has. land closely adjoining my land cannot dig his land so near mine that mine would fall into his pit, and an action brought for such an act would lie" (d).

This right extends to support not only of land by adjacent, but also by subjacent land, when the surface and subsoil are vested in different owners $(e)$. "In the natural state of land one part of it receives support from another, upper from lower strata, and soil from adjacent soil. This support is natural, and is necessary, so long as the status quo of the land is maintained; and therefore, if one parcel of the land be conveyed so as to be divided in point of title from another contiguous to it, or (as in the case of mines) below it, the status quo of support passes with the property in the land, not as an easement held by a distinct title, but as an incident to the land itself, sine quo res ipsa haberi non potest. All existing divisions of property in land must have been attended with this incident, when not excluded by contract, and it is for that reason often spoken of as a right by law ; a right of the owner to the enjoyment of his own property, as distinguished from an easement supposed to be gained by grant; a right for injury to which an adjoining proprietor is responsible," upon the principles already stated $(f)$.

This natural right can be surrendered by agreement, and possibly a right to let down adjacent or superior soil might be claimed by prescription or custom $(g)$ : but there must

(d) Rolle's Abr. II. 564. Trespass, Justification, I pl. 1; Wilde v. Mrin. sterley, ib. p. 564 .

(c) Humphries v. Brogden, 12 Q. B. 739: Hunt v. Peake, 1 Johns. 705; 29 I. J. Ch. 787; North-Easteru R. C. v. Elliot, 2 De G. F. \& J. $423 ; 10$ II. I. Ca. 333; IIarris v. Ryding, i) Y. S W. 60 ; Caledonian R. C. v. sprot, 2 Macq. Sc. App. 449 ; Buckhouse v. IBonomi, E. B. \& E. $655 ; 9$ II. I. Ca. 503.

(f) Per Lord Selborne, Dalton v.
Angus, 6 App. Cas. 740, 791, eiting Humphries r. Brogden, ubi supra ; Rowbotham v. Wilson, 8 E. A B. 142, 146, 151 ; Backlouse v. Bonomi, ubi supra; Dixon v. White, $8 \mathrm{App}$. Cas. 833.

(g) On this point, see Hilton $\mathbf{r}$. Earl Granville, 5 Q. 13. 701; Blackett v. Bradley, 1 B. \& S. 940 ; Wakefield v. Duke of Buccleugh, L. R. $4 \mathrm{El}$. Ca. 199 ; L. R. 4 H. L. 377 ; Gill v. Dickinson, 5 Q. B. D. 159.

As to mines under land taken under 
be clear words indicating an intention to confer such $\dot{a}$ right in derogation of the ordinary and prima facie right of support as against the adjacent owner $(h)$.

As introductory to the consideration of the second of these natural rights, a few elementary remarks are needed. "The word 'land," says Sir Ellward Coke (i), in legal contemplation, "comprehendeth any ground, soil, or earth whatsoever, as meadows, pastures, woods, moors, waters, marshes, furzes, and heath;" upon which passage Blaclistone observes $(k)$ as follows: "It is observable that uater is here mentioned as a species of land, which may seem a kind of solecism, but such is the language of the law; and therefore I cannot bring an action to recover possession of a pool or other piece of water by the name of 'water' only, either by calculating its capacity, as for so many cubical yards, or by superficial measure, for twenty acres of water, or by general description, as for a pond, a watercourse, or a rivulet; but I must bring my action for the land that lies at the bottom, and must call it twenty acres of land covered with water. For water is a moveable wandering thing, and must of necessity continue common by the law of nature. So that I can only have a temporary, transient, usufructuary property therein; wherefore, if a body of water runs out of my pond into another man's, I have no right to reclaim it. But the land which that water covers is permanent, fixed, and immoveable, and therefore in this I may have a certain substantial property of which the law will take notice."

Such being the distinction between "land " and "water"

the Railway Clauses Consolidation Act, 1845, see Great Western $R$. $C$. v. Bennett, L. R. 2 H. L. 27 ; Midland R. C. v. Robinson, 15 App. Cas. 19, affirming $C$. A. 37 Ch. D. 386 ; Ruabon.Briek Co. v. Great Westem R. C., (1893) $1 \mathrm{Ch} .427$.

(h) Smart v. Morton, 5 E. \& B. 30 ; Roberts v. Haines, 6 E. \& B. 643;
7 Ib. 625; Dugdale v. Robertson, 3 Kay \& J. 695; Proud v. Bates, 34 L. J. Ch. 406; Davis v. Treharne, 6 App. Cas. 460 ; Lore v. Bell, 9 App. Cas. 286.

(i) Co. Litt. 4 a., cited per Martin, B., Allaway r. Wagstaff, 4 H. \& N. 313.

(k) 2 Comm., p. 18 .
Landhow distinguisherl from water in legal contemplation. 
in strict legal contemplation, let us, somewhat more minutely, inquire respecting the nature of the right to the use and enjoyment of running water possessed by a riparian proprietor.

Right to flowing water.

Flowing water, it has been observed, as well as light and air, is in one sense publici juris $(l)$. It is a boon from Providence to all, differing from the other elements, however, in its mode of enjoyment. Light and air are diffused in all directions, flowing water in some. When property was established, each one had the right to enjoy the light and air diffused over and the water flowing through the portion of soil belonging to him; the property in the water itself was not in the proprietor of the land through which it passed, but only the use of it as it passed along, for the enjoyment of his property, and as incidental to it ( $m$ ); aqua currit et debet currere is the language of the law; and the rule is that prima facie the proprietor of each bank of a stream is the proprietor of half the land covered by the stream (n), but there is no property in the vater. Every proprietor has an equal right to use the water which flows in the stream, and consequently no proprietor can have the right to use the water to the prejudice of any other proprietor $(o)$. Without the consent of the other proprietors who may be affected by his operations, no proprietor can either diminish the quantity of water which would otherwise descend to the proprietors below, nor throw the

(l) As to the meaning of these words, see per Care, J., Ormerod r. Todmorden, 11 Q. B. D. 155, 160.

(m) Judgm., 3 Exch. 775 ; Judgm., 6 Exch. 369.

(ii) Bickett v. Morris, I. R. I II. I. S. C. 47 ; distinguished in Kensit ฯ. Great Eastern R. C., 23 Ch. D. i7 $0 ; 27$ Id. 122. See Micklethecaite r. Detclay Briage Co., 33 Ch. D. 133.

(o) Acc. the general principles of law deducible from Embrey v. Otcen,
6 Exch. 353, viz., that "every proprietor of lands on the banks of a natural stream has a right to use the water, provided he so uses it as not to work any material injury to the rights of other proprietors above or below the stream : "Jugdm., Sampron v. Iloddinott, 1 C. B., N. S., 611, 612: 3 Id. 596 ; Orr-Ewing r. Colquhoun, ? App. Cas. 854, 855. See Lord r. Comm. of Sydney, 12 Jyoo. 1'. C. C. 473. 
water back upon the proprieftors above" $(p)$. Subject to such restrictions, however, each riparian owner is entitled to the usufruct of the stream for all reasonable purposes $(q)$ -ex. gr., to drink, to water his cattle, or to turn his milland each such owner has a remedy for the infringement of his right.

"By the general law applicable to running streams," observed Lord Kingsdown ( $r$ ), " every riparian proprietor" has a right to what may be called the ordinary use of the water flowing past his land, for instance, to the reasonable use $(s)$ of the water for his domestic purposes, and for his cattle, and this without regard to the effect which such use may have in case of a deficiency upon proprietors lower down the stream. But, further, he has a right to the use of it for any purpose, or what may be deemed the extraordinary use of it, provided that he does not thereby interfere with the rights of other proprietors either above or below him. Subject to this condition he may dam up the stream for the purpose of a mill, or divert the water for the purpose of irrigation. But he has no right to interrupt the regular flow of the stream if he thereby interferes with the lawful use of the water by other proprietors, and inflicts upon them a sensible injury" $(t)$.

The following propositions upon the subject now before us have been laid down :-That " a substantial interference with the bed of a stream, so as to increase or diminish the flow of water to the detriment of other riparian owners, is a thing actionable in itself ;" and "damage resulting

(p) Per Sir J. Leach, V.-C., Wright v. Howard, 1 S. \& S. $203 ; 24$ R. R. 167 ; adopted per cur. Mason v. Hill, 3 B. \& Ad. $312 ; 5$ Id. 1 ; and in Acton v. Blundell, 12 M. \& W. $348,349$.

(a) Sampson v. Iloddinott, 1 C. B., N. S., 590 ; 3 Id. 596.

(r) Judgm., Miner v. Gilmour, 12 Moo. P. C. C. 156; adopted Nuttall v. Braceuell, L. R.. 2 Ex. 9, 13 ; Conm. of French Hoek v. Hugo, 10
App. Cas. 336 ; "quoted again and again with approbation in our Courts." I'er Pollock, B., Kensit v. Gieat Eastern R. C., 23 Ch. D. 570 ; 27 Id. 122.

$(s)$ See Suindon Waterworks Co. . Wilts and Berks Canal Nav. Co., L. R. 7 H. L. $697,704$.

$(t)$ Cited Orr-Euing v. Colquhoun, 2 App. Cas. 85j. 
therefrom is actionable damage" $(u)$. That "even though immediate damage cannot be described, even though actual loss cannot be predicated, yet if an obstruction be made to the current of a stream, that obstruction is one which constitutes an injury which the Courts will take notice of, as an encroachment which adjacent proprietors have a right to have removed " $(x)$. That the right of a riparian owner to the use of the stream does not depend upon the ownership of the soil of the stream $(y)$. That as soon as the owner of land on a stream has appropriated the water to a beneficial use he may sue for an injury done to him in respect of such new use $(z)$. That if a stream be diverted by altering its course (a), or cutting down its banks, or if the water be abstracted from it for unauthorised purposes, the owner will have his right of action against the wrongdoer (b) ; and that an action will lie for fouling water to the use of which the plaintiff is entitled $(c)$.

Right to artificial watercourse.

" The right," however, " to the water of a river flowing in a natural channel through a man's land, and the right to water flowing to it through an artificial watercourse constructed on his neighbour's land, do not rest on the same principle. In the former case, each successive riparian proprietor is, prima facie, entitled to the unimpeded flow of the water in its natural course, and to its reasonable

(ui) Per Lord Coleridge, C. J., Rhodes ヶ. Airrdale Drainnge Commissioners, 1 C. P. D. 393.

(x) Per Lord H"estbury, Bickett $\mathrm{r}$. Norris, L. R. 1 H. L. Sc. $4 \pi, 62$. See hensit r. Great Eastern R. C'., 23 Ch. D. 570 ; 27 Id. 122.

(y) Lyon v. Fishmongers' ('o., 1 App. Cas. 662, followed North Shore R. C. v. Pion, 14 App. Cas. 612.

(z) Judgm., Holker v. Pouritt, I. R. 10 Ex. 62, citing Mason v. Hill, ij B. \& Ad. 1 .

(a) See Northam v. Murley, 1 F. \& B. 665; Whitehcad r. I'arks, 2 II. א X. 870, 879, which show that where " upon a question of water rights there is an agreement by deed, such deed will regulate the rights of the parties:" Embrey r. Oucen, 6 Exch. 353, 372.

(b) Judgm., 7 Exch. 301 ; Dudden r. Clutton tuion, I H. \& N. 627 ; Judgm., Wood $v$. Waud, 3 Exch. 780 , 781; Embrey v. Oxcen, 6 Exch. 353 ; Rochdale C'anal Co. r. King, 14 Q. B. 122; Mcducay Nar. Co. v. Earl of Romney, 9 C. B., N. S., 5i5. See Murgatroyd r. Robinson, $i$ E. \& B. 391.

(c) See Laing r. Whaley, 3 H. \& X. 675,901 ; Hodgkinson v. Eunor, 4 I3. \& S. 229 . 
enjoyment as it passes through his land, as a natural incident to his ownership of it. In the latter, any right to the flow of water must rest on some grant or arrangement, either proved or presumed, from or with the owners of the lands from which the water is artificially brought, or on some other legal origin " $(d)$.

Turning next to the consideration of easements proper, as opposed to natural rights of property, it is proposed to state the general rules for their acquirement, and discuss some of the more important. Easements, we have already seen (e), may be acquired by grant, express or implied, or by prescription.

Cases of express agreement are comparatively rare, and present little difficulty, the rights of the parties being Easements
by express grant. regulated by the instrument creating them $(f)$; it must, however, be borne in mind that an easement, being an incorporeal hereditament, can only be created by an instrument under seal; in the language of the law "they lie in grant and not in livery " $(g)$. A parol license, on the other hand, is not a grant, and may be revoked at any moment at the will of the licensor (h), though in such cases a reasonable time must be allowed to the licensee to remove himself and his property from the premises (i). At equity, however, the want of a seal would not be allowed to prevail, where it would in the opinion of the Court be a fraud to insist upon the legal right, as where persons either by acquiescence or express consent have induced their licensees to incur expense in the erection of permanent works, or the like $(k)$; and by virtue of the Judicature Act, 1873, sections

(d) See Singh v. Pattuk, 4 App. Cas. 121, 126 ; approving Wood v. Waud, 3 Exch. 738, v. post, p. 903.

(e) Ante, p. 882.

(f) Ante, p. 888 n. (a).

(g) Co. Litt. 9 a ; Heulins v. Shippam, 5 B. \& C. $221,229$. 830 . (i) Cornish v. Stubbs, L. R. 5 C. P. 334 ; Mellor v. Watkins, L. R. 9 Q. B. 400 .

(k) Dnke of Deronshive v. Eglin, 14 Beav. 530; Darn v. Spurrier, 7 Ves. 235; 7 R. R. 797 ; Ramsden v. Dyson, L. R. 1 H. L. 140 ; approved in Plimmer v. Wellington (Ifayor of), 9 App. Cas. 699 ; Bankart v. Tennant,
Easements proper 
24 and 25 , subs. 11 , this rule will for the future be followed in all the Courts. It must, however, be remembered that, in the absence of a deed, the party claiming the easement. will be obliged to show consideration, as he will be also in an action for damages for breach of an agreement to grant one.

Easements by implied grant

Easements acquired by implied grant, as distinguished from those acquired by prescription, which will be considered further on, arise when the owner of property severs it into two or more portions, either retaining one in his own possession, or disposing of both to different purchasers. It is plain that where two adjoining tenements belong to different owners any right, as of support or light, beyond the natural rights of property, can only be acquired by the one owner against the property of the other, either by grant or by acquiescence. Where, however, the same person owns both tenements, it is equally plain that he may attach any quasi-easements $(l)$ he chooses, whether apparent and continuous or not, to either of the tenements in favour of the other. The question then arises whether upon the sale of one of the tenements, it will pass to the purchaser enjoying or burdened with, such quasi-easements.

It has long been decided that in the case of continuous and apparent easements the benefit thereof will pass to the purchaser without an express grant, on the principle that " no man shall derogate from his own grant." There has, however, been a considerable conflict of judicial decision as to whether the law would imply a corresponding reservation of easements in favour of the tenement retained, as against the purchaser. The rule would now appear to be that, unless in cases of absolute necessity, no such reservation will be implied. The following abstract from the judgment of

I. K. 10 Eq. Ca. 146 ; Daries r. Sear, I.. R. 7 Eq. Ca. 427; Mc.Manus v. Cooke, 35 Ch. D. 681.
(I) So called because, strictly speaking, no man can have an easement in his own property. 
the Court of Appeal in a well-known case states both the above propositions very fully. "I think," said Thesiger, L. J., in delivering the judgment of the Court, "that two propositions may be stated as what I may call the general rules governing cases of this kind. The first of these rules is, that on the grant by the owner of a tenement of part of that tenement as it is then used and enjoyed, there will pass to the grantee all those continuous and apparent easements (by which, of course, I mean quasi-easements), or in other words, all those easements which are necessary to the reasonable enjoyment of the property granted, and which have been and are at the time of the grant used by the owners of the entirety for the benefit of the part granted. The second proposition is that, if the grantor intends to reserve any right over the tenement granted, it is his duty to reserve it expressly in the grant $(m)$. Those are the general rules governing cases of this kind, but the second of those rules is subject to certain exceptions. One of these exceptions is the well-known exception which attaches to cases of what are called ways of necessity $(n)$ : and I do not dispute for a moment that there may be, and probably are, certain other exceptions" $(o)$.

Again, when the two tenements are granted to different purchasers at the same time, it seems that they will pass

(m) Mundy r. Rutland (Duke of), 23 Ch. D. 97.

(n) Midland R. C. v. Miles, 33 Ch. D. 632,$644 ;$ Brown v. Alabaster, 37 Ch. D. 490.

(o) Wheeldon v. Burrous, $12 \mathrm{Ch} . \mathrm{D}$. 31,49 , where the following cases are considered, Palmer v. Flctcher, 1 Lev. 122 ; Nicholas v. Chamberlain, Cro. Jac. 121 ; Swansborough v. Coventry, 9 Bing. 305 ; Cox v. Mattheres, 1 Ventr. 237; Rosewell v. Pryor, 6 Mod. 116; Pyer v. Carter, 1 H. \& N. 922; White v. Bass, 7 H. \& N. 722 ; Suffield v. Brown, 4 De G. \& S. 185 ; 33 L. J. Ch. 249 ; Crossley v. Light- owler, L. R. 2 Ch. App. 478; Watts v. Kelson, L. R. 6 Ch. App. 166; followed in Bay'ey v. Great Westem R. C., 26 Ch. D. 434 ; Thomas v. Owen, 20 Q. B. D. 225 ; and as to the reservation of necessary easements, Pinnington v. Galland, 9 Exch. 1; 1 Wms. Saund. $323(n)$, citing Clarke v. Cogge, Cro. Jac. 170 ; Staple v. Heydon, 6 Mod. 1 ; Chichester v. Lethbridgc, Willes, 72 n.; Dutton r. Taylor, L. R. 7 Eq. Ca. 427 ; Richards v. Rose, 9 Exch. 218 . See Russell v. Watts, 25 Ch. D. 5 ว 9 ; 10 App. Cas. 590 . 
with the reciprocal burden and benefit of their continuous and apparent quasi-easements, so that the purchaser of one will not be entitled to block the lights of the other as against his fellow-purchaser, though he might have done so as against the vendor. "The sales to the plaintiff and defendant being sales by the same vendor, and taking place at one and the same time, we think the rights of the parties are brought within the application of this general rule of law," namely, that a grantor shall not derogate from his own grant $(p)$.

Easements of necessity.

The most common form of the easements of necessity above referred to is that of the right of way across the land of another. "Where a man, having a close surrounded with his own land, grants the close to another in fee, for life or years, the grantee shall have a way to the close over the grantor's land, as incident to the grant, for without it he cannot derive any benefit from the grant. So it is where he grants the land and reserves the close to himself" (q). In fact all such cases come under the principle, Cum aliquid alicui conceditur, conceditur et id sine quo res ipsa haberi non potest $(r)$.

Easements by prescription.

When the easement claimed has not been acquired by grant express or implied, the claim must be founded upon prescription, that is to say, upon an enjoyment of the benefit claimed co-extensive with legal memory, "during time whereof the memory of man runneth not to the contrary." Legal memory, as we have already seen $(s)$, formerly dated from the reign of Richard I., A.D. 1189. From an early

(p) Per Tindal, C. J., Sicansboiough r. Cocentry, 2 Bing. 305, cited per Jessel, M. R., Allen v. Tayloi, 16 Ch. D. 3.55, 358 ; Barnes v. Loach, 4 Q. B. D. 497 ; Rigby 5. Benuet, 21 Ch. D. 559.

(n) 1 Wms. Saund. $323(n) ; 1$ Notes to Saund. 570 ; l'innington r. Galland, 9 Exch. 12; Wheeldon r. Burrotes, 12 Ch. D. 31 ; Shubrook r. Tuffuell,
46 I. T. 186, Russell r. Watts, 25 Ch. D. 559 ; 10 App. Cas. 590 : London Corporation v. Riggs, $13 \mathrm{Ch} . \mathrm{D}$. 798 .

(i) Liford's Case, 11 Rep. 52; IJarey v. Askwith, Hob. 234; Dand r. Kingscote, 6 M. \& W. 196; Shubrook v. Tufficll, 46 L. T. 886; Goodhart v. IIyett, 25 Ch. D. 182.

(s) Ante, p. 11. 
period, however, it was decided that evidence of enjoyment for a shorter time raised a presumption that such enjoyment had been for the necessary period $(t)$; but this presumption could still be defeated by showing affirmatively the commencement of the enjoyment relied upon. To avoid the hardship of this rule of law, a new method of claim was introduced, by which the right was based upon a grant made and lost in modern times, in all cases where the enjoyment had lasted without interruption for twenty years. Thus where the claim was by prescription, the length of enjoyment itself constituted the title, whereas if the right was claimed under a "lost grant" the long enjoyment was only evidence of a title, which though in theory only presumptive was in practice conclusive $(u)$.

Nevertheless, doubts arose from the uncertain language of some Judges in leaving these questions to the jury, some of them treating the evidence as conclusive, while others considered it to be only " cogent evidence," which they advised the jury to adopt. It was therefore with the two-fold object of getting rid of the doubts arising from the conflicting opinions of the Judges, and of "putting an end to the scandal on the administration of justice which arose from forcing the consciences of juries, in cases in which the presumption was known to be a mere fiction $(x)$, that the Prescription Act (2\& 3 Will. IV. c. 71) was passed.

Section 1 of the Act deals with profits à prendre, and enacts that any claim thereto shall not be defeated after thirty years' enjoyment, by showing only the commencement of such enjoyment; and further, that after sixty years' enjoyment the right shall be absolute unless had by consent or under an agreement in writing $(y)$. 894 .

(u) Vide per Parke, B., Bright v. Walker, 1 Cr. M. \& R. 217 ; per Alderson, B., Jenkins v. Hartey, ib., p. 895 .

(x) Per Cockburn, C. J., Angus v. Dalton, 3 Q. B. D., p. 10 อ.

(y) The statute does not apply to profits à prendre in gross, ex. gr., to a
Prescription Act. 
Section $2(z)$ provides that "no claim which may be lawfully made at the common law, by custom, prescription, or grant, to any way or other easement, or to any. watercourse or the use of any water, to be enjoyed or derived upon, over, or from any land or water" of any person, when such way or other matter "shall have been actually enjoyed by any person claiming right thereto without interruption for the full period of twenty years, shall be defeated or destroyed by showing only that such way or other matter was first enjoyed at any time prior to such period of twenty years, but nevertheless such claim may be defeated in any other way by which the same is liable now to be defeated; and where such way or other matter shall have been so enjoyed as aforesaid for the full period of forty years, the right thereto shall be deemed absolute and indefeasible, unless it shall appear that the same was enjoyed by some consent or agreement given or made for that purpose by deed or writing."

Formerly, in order to prove that an easement had been acquired, it was necessary to show that the enjoyment had been peaceable, open, and as of right, Nec ri, nec clam, nec precario $(a)$, and the party against whom the claim was made could give in evidence any facts rebutting this, as, ex. $g r$., that the law prohibited such an acquisition, for no man shall prescribe against a statute $(b)$, or again, that the enjoyment had been under a written or verbal licence, or in the absence and ignorance of the person whose property was affected by it. Now it is important to observe at the outset that the statute does not abolish any of the methods of claiming such rights which existed prior

claim of a free fishery in the waters of another: Shuttleworth v. Le Fleming, 19 C. I3.. N. S., 687.

(z) Which does not apply to light: Wheaton r. Maple, (1893) 3 Ch. 48 , following Perry r. Eames, (1891) 1
Ch. 658 .

(a) Co. Iitt. 1136 ; Bract., lib 2, f. $51 \mathrm{~b}, 52 \mathrm{a}, 222 \mathrm{~b}$; Partrilge $\mathrm{v}$. Scott, 3 M. \& W. 229.

(b) Co. Litt. 115 a. 
to its enactment. "The statute only applies where you want to stand upon thirty years' user; but here, where the title is one of 200 or 300 years, that statute is not needed, and the title can be rested on the original right before the passing of the statute $(c) . "$

The next point for observation is that the statute makes no change as to the nature or extent of the rights that may be claimed, or, with a single exception, in the old rule, that the enjoyment relied upon must have been $N e c$ vi, nec slam, nec precario; further, any evidence which prior to the statute would have defeated the claim by showing that it could not have been of right will do so still $(d)$, or that the owner of the servient tenement was incapable of giving $x$ right, such as claimed, by express grant (e); and so, as cegards the shorter periods, will evidence of licence or ignorance $(f)$. The one exception above referred to is this, that a user extending over either of the longer periods, under t parol licence, not renewed during it, will confer a right, though at common law it would have been precarious $(g)$; if made, however, or renewed during the sixty or forty years, the licence would defeat the claim, by destroying the zontinuous enjoyment as of right $(h)$.

It may be added that there are certain difficulties in proceeding under the Act which did not exist at zommon law.

1. The period of the duration of the enjoyment of that to which a right is asserted under the statute must be

(c) Warwiek v. Qucen's College, Oxford, L. R. 6 Ch. App. 728 ; Ladynan $\mathbf{v}$. Grave, Id. 764 n.; and vide jer Mellish, L. J., in Aynsley v. Glover, L. R. 10 Ch. App. 283.

(d) Onley v. Gardiner, 4 M. \& W. 199 ; Monmouth Canal Co. v. Harford, I Cr. M. \& R. 614 ; Beasley v. Clarke, 2 Bing N. C. 705; Warburton v. Parke, 2 H. \& N. 64; Tickle จ. Brozon, 4 A. \& E. 383; Kinloch v. Verile, 6 M. \& W. 806; Tone v.
Preston, 24 Ch. D. 739.

(e) Rochdale Canal Co. v. Radeliffe, 18 Q B. $287 ; W e b b$ v. Bird, 10 C. B., N. S., 268; 13 C. B., N. S., 841 .

(f) Bright v. Walker, 1 Cr. M. \& R. 219 ; Tickle v. Brown, 4 A. \& E. 383 ; Beasley v. Clarke, 2 Bing. N. C. 705. (g) Tickle v. Brown, supr.; Comm. of Freneh Hoek v. Hugo, 10 App. Cas. 336.

(h) Id. 
computed next before the commencement of the action in which the right is contested (i).

2. Although the acts of user need not necessarily continue down to the very moment of action brought, yet some act of the kind must be proved to have taken place in the first and last, and probably in every year $(k)$.

3. There must be nothing in the facts inconsistent with the user having been as of right against all persons $(l)$.

4. A right claimed by user can only be co-extensive with the user $(m)$.

Light. Section $3(n)$ deals with the easement of light, and enacts that "when the access $(o)$ and use of light for any dwelling-house, workshop, or other building shall have been actually enjoyed therewith ( $p$ ) for the full period of twenty years without interruption $(q)$, the right thereto shall be deemed absolute and indefeasible $(r)$, any local usage or custom to the contrary notwithstanding $(s)$; unless it shall

(i) Parker v. Mitchell, 11 A. \& E. 788; Flight v. Thomas, $8 \mathrm{Cl}$. \& $\mathbf{F}$. 242 ; Eaton v. Secansea Waterucorks, 17 Q. B. 272, which shows that a contentious enjorment during the full statutory period of twenty years will not confer a right: "Wight v. Williams, 1 M. \& W. Ti; Richards r. Fry, 7 A. \& E. 698; Ward v. Robins, 15 M. \& W. 242.

(k) Parker v. Mitchell, ubi supra; Flight r. Thomas, ubi supr.: Bailey v. Appleyard, 8 A. \& E. 161 ; Carr v. Foster, 3 Q. B. 581; Louce v. Carpenter, 6 Exch. 825; Hollins v. Ferney, 11 Q. B. D. 715 ; 13 Id. 304.

(l) Winship v. IIudspeth, 10 Exch.5; Warburton v. Parke, 2 H. \& N. 46 (decided under section 1); Tickle r. Brown, 4 A. \& E. 369 ; cited per Erle, C. J., Gared ₹. Martyn, 19 C. B., N. S., 743. See section 5; Holford v. Hankinson, 5 Q. B. 584.

(m) Daries v. Williams, 16 Q. B. 546 ; see Flight r. Thomas, 10 A. \& F. 590. In immemorial right of way is not necessarily lost by nere nonuser for twenty years: IG $a r d$ v. Ward, T Exch. 838, cited per Willcs, J., 12
C. B., N. S., 470 ; Reg. v. Chorley, 12 Q. B. 515.

(ii) Which does not bind the Crown, Wheaton v. Maple, (1893) 3 Ch. 48, following Perry v. Eames, (1891) $1 \mathrm{Ch}$. 658.

(o) Scott r. Pape, 31 Ch. D. 554; Harris r. De Pinwa, 33 Ch. D. 238; Greentood v. Hornsey, Ib. 471 ; Cooper v. Straker, $40 \mathrm{Ch}$. D. 21. (See this case also as to "enjoyed.")

( $p$ ) As to the omission in this section of the words "by persons claiming right thereto;" vide per Maule, J., Flight r. Thomas, 11 A. \& E. 695 ; and per Tindal, C. J., Mayor of London v. Peuterers' Co., 2 Moo. \& Rob. 409: Frevcen v. Philipps, 11 C. B., N. S., 449; followed in Mitehell $\mathrm{r}$. Cantrill, 37 Ch. D. 56 ; Simper v. Foley, 2 J. \& H. 555; Truscott r. Mevehant Taylor's' Co., 11 Exch. 855.

(q) See Glorer v. Coleman, L. R. 10 C. P. 108 ; Plastercr's' Co. v. Parish Clerks' Co., 6 Exch. 630. 304 .

(r) Tapling v. Jones, 11 H. L. Ca.

(s) Salters' Co. v. Jay, 3 Q. B. 109 ; Truscott $\mathrm{P}$. Merchant Taylors' Co., 11 
ippear that the same was enjoyed by some consent or agreement $(t)$ expressly made or given for that purpose by leed or writing " $(u)$. The effect of this clause is to convert nto a right such enjoyment only of the access of light over sontiguous land as has been had for the whole period of twenty years in the character of an easement, distinct from the enjoyment of the land itself $(x)$, the species of " negative" easement, as it has been called, to which a right may be acquired by this section, being put on the same footing in this respect as those "positive" easements provided for by other sections of the Act, all of which, after long enjoyment as easements, are invested with the qualities of rights $(y)$.

"The section," said Coleridge, J. (z), "seems to me to simplify and almost new-found the mode of acquiring the right to access of light. It founds it on actual enjoyment for the full period of twenty years without interruption, unless that enjoyment is shown to have been by consent or agreement expressly made by deed or writing, thus putting the right on a simple foundation, and with the simplest exception." "The right," as observed by Lord Westbury (a), "to what is called an 'ancient' light now depends upon positive enactment. It is matter juris positivi, and does not require, and therefore ought not to be rested on, any presumption of grant or fiction of a license having been obtained from the adjoining proprietor. Written consent or agreement may be used for the purpose of accounting for the enjoyment of the servitude, and thereby preventing

Exch. 855 ; Cooper v. Hubbuck, 12 C. B., N. S., 456 ; Yates r. Jack, L. R. 1 Ch.App. 299 ; Dent v. Auction Mart Co., L. R. 2 Eq. Ca. 249.

(t) Bewley v. Atkinson, $13 \mathrm{Ch} . \mathrm{D}$. 283, distinguished in Mitchell $\mathrm{r}$. Cantrill, ubi supra.

(u) Thackeray v. Wood, 5 B. \& S. 325; 6 Id. 766 ; Bewley r. Atkinson, 13 Ch. D. 283.

(x) Harbidge r. Warwick, 3 Exch.
556,557 .

(y) Harbidge r. Warwick, 3 Exch. $556,557$.

(z) Truscott r. Merchant Taylors' Co., 11 Exch. 863; adopted, Frewen v. Phillips, 11 C. B., N. S., 454. See per Bouten, I. J., Scott v. Pape, 31 Ch. D. 554, 571.

(a) Tapling r. Jones; 11 H. L. Cas. $304,305$. 
the title which would otherwise arise from uninterrupter user or possession during the requisite period. . . After an enjoyment of an access of light for twent? years without interruption, the right is declared by the statute to be absolute and indefeasible; and it wouk seem, therefore, that it cannot be lost or defeated by : subsequent temporary intermission of enjoyment, no amounting to abandonment. Moreover, this absolute ani indefeasible right, which is the creation of the statute is not subjected to any condition or qualification; nor is it made liable to be affected or prejudiced by any attempt to extend the access or use of light beyoni that which, having been enjoyed uninterruptedly during the required period, is declared to be not liable to be defeated." During a unity of occupation of the twi tenements the running of the twenty years is only sus. pended $(b)$.

If, then, the owner of a dwelling-house containing a window, which under the statute has acquired an absolute and indefeasible right to a certain access of light, opens two other windows, one on each side of the old window, the indefeasible right does not thereby become defeasible. By opening the new windows the owner of the dwelling-house does no wrong in the eye of the law to his neighbour, whe is at liberty to build up against them on his own land, though he cannot build so as to obstruct the ancient window $(c)$. In the case of windows "with moveable shutters, which are opened at the omner's pleasure for admission of light, the right is gained at the end of twenty years, if he opens them at any time he pleases during those twenty years, and there is no such interruption $o$ : access over the neighbouring land as is contemplated by

(b) Ladyman จ. Grace, I. R. 6 Ch.

Jones, 11 H. L. Cas. 306; Neteson r (6).

(c) Per Lord Westbury, Tapling v. Pender, 27 Ch. D. 43. 
section $4 "(d)$. If a building has been pulled down, and it cannot be shown that the windows of the new building are in any way identified with the old windows, the easement will be lost $(e)$. But the mere fact that, owing to a building (whose windows had acquired an easement of light) having been pulled down, there are at the time no windows actually existent, will not prevent an injunction being granted to restrain the erection of buildings which would interfere with windows in the same position as the old ones, always supposing that the right has not been abandoned $(f)$. An enlargement of an ancient window, which substantially includes within its area the ancient light, will not cause the loss of the easement $(g)$, nor will its diminution be evidence of an abandonment as regards the remaining part $(h)$. Neither will the easement be lost by an alteration in the plane of the dominant tenement, either by advancing or setting it back, provided that the light reaching the new windows be substantially the old cone of light which entered the windows in their former position (i); and generally the pulling down of a house will not cause the loss of any easements already attaching to it, if it is intended to rebuild it within a reasonable time $(k)$. Upon a general conveyance of land there is no implied grant by the purchaser of the easement of light necessary for the enjoyment of an adjacent house of the vendor $(l)$.

A person who claims a twenty years' enjoyment of light under this section must prove affirmatively a prima facie case of enjoyment. The defendant may then disprove the prima facie case, and this he may do either by proving the

(d) Per Kay, J., Cooper v. Straker, 40 Ch. D. 21, at p. 28.

(e) Fowlers v. Walker, 49 L. J. Ch. 598; 51 L. J. Ch. 443 ; Scott v. Pape, $31 \mathrm{Ch}$. D. 554, 570.

(f) Eccles. Comm. v. Kino, $14 \mathrm{Ch}$. 1. 213.

(g) Tapling v. Jones, ubi supra ;
Newson v. Pender, ubi supra.

(h) Scott v. Pape, ubi supra.

(i) Ib.

(k) Luttrel's Case, 4 Rep. 86; Bullers v. Dickinson, 29 Ch. D. 155.

(l) Ellis v. Manchester Carriage Co., 2 C. P. D. 13, ante, p. 890. 
existence of an obstruction at the commencement, or a statutory interruption of the enjoyment at some time during the twenty sears, or by showing by other evidence that the plaintiff's evidence of enjoyment cannot be relied upon $(m)$.

Interrup. The 4th section provides that "each of the respective
tion-what? periods of years" hereinbefore mentioned "shall be deemed and taken to be the period next before some suit or action wherein the claim or matter to which such period may relate shall have been or shall be brought in question" $(n)$; and.further that " no act or other matter shall be deemed an interruption within the meaning of this statute unless the same shall have been or shall be sub. mitted to or acquiesced in for one year after the party interrupted shall have had or shall have notice thereof, and of the person making or authorising the same to be made" $(o)$. It would seem that the person who asserts that an alleged trenty years' enjoyment of light has been interrupted during that period is bound to prove under this section that some notice (other than that which arises from the mere existence of a physical obstruction) was given to the person interrupted by the person by whose authority the interruption was made $(p)$.

Pleading. The 5th section, as dealing only with the method of pleading, may be dismissed with the remark that its provisions are subject to the Rules of the Supreme Court, 1883; and we may next consider the 6th section, which provides that "no presumption shall be allowed or made in favour or support of any claim upon proof of the exercise or enjoyment of the right or matter claimed for any less

(ii) Scddon r. Bank of Bolton, 19 Ch. D. 462.

(n) See Bennison v. Cartwright, 5 B. \& S.1; Cooper r. Hubbuck, 12 C. B., N. S., 456.

(o) Gale r. Albott, \& Jur., N. S., 987; Warcick v. Qucen's College',
Oxford, L. R. 10 Eq. Ca. 128 ; L. R. 8 Ch. App. 728 ; Glover v. Coleman, L. R. 10 C. 1. 108; Ladyman r. Grave, L. R. 6 Ch. App. 768 , ante, p. $895:$ Presland v. Bingham, 41 Ch. D. 268.

(p) Seddon r. Bank of Bolton, 19 Ch. D. 462. 
reriod of time or number of years" than is mentioned in he statute as applicable to the particular case $(q)$.

The 7th section contains a proviso for disabilities such as nfancy, idiocy, coverture $(r)$, tenancy for life, or pendency Persons under if any action in which the right is called in question; such seriods are to be excluded in the computation of the periods jefore mentioned in the Act, except only in cases where the ight or claim is declared to be absolute and indefeasible $(s)$. While by section 8 , in all cases where "any land or water ipon, over, or from which any such way or other conenient $(t)$ watercourse or use of water shall have been or ; hall be held under or by virtue of any term of life, or any erm of years, exceeding three years from the granting hereof, the time of the enjoyment of any such way or natter, during the continuance of that term, shall be axcluded in the computation of the said period of forty ;ears, in case the claim shall within three years next after he end or sooner determination of such term be resisted y any person $(u)$ entitled to any reversion expectant on he determination thereof " $(x)$.

An easement may be abandoned $(y)$; but mere non-user loes not amount to abandonment, and it is always a question Abandonment of of fact under all the circumstances whether the act amounts to an abandonment, or was intended as such $(z)$.

Having thus seen how easements may be acquired and

(q) Bright v. Walker, 1 Cr. M. \& R. 217 ; per Patteson, J., Carr v. Foster, 3 Q. B. 581 ; per Parke, B., Lowe v. Carpenter, 6 Exch. 825 ; as to the ralue of such evidence as tending to prove a grant, see Hanmer v. Chance, 34 L. J. Ch. 413.

(r) But quare as to coverture since the Married Women's Property Act, 1882 , ante, p. 682.

(8) Clayton v. Corby, 2 Q. B. 813; Pye v. Mumford, 11 Q. B. 666 ; Onley v. Gardiner, 4 M. \& W. 499.

(t) As to this word, and whether it can be read "convenience" or " ease- ment," see Laird r. Briggs, 19 Ch. D. $25-27,33$.

(iv) As to who are such persons, see Laird v. Briggs, 19 Ch. D. 22.

(x) Palk v. Skinner, 18 Q. B. 568, which shows that s. 9 only applies to the period of forty years. A remainderman is not such a person: Symons v. Leaker, 15 Q. B. D. 629.

(y) Dynevor (Lord) v. Tennant, 32 Ch. D. $375 ; 33$ Id. 420 , affirmed 13 App. Cas. 279.

(z) Cook v. Mayor of Bath, L. R. 6 Eq. Ca. 177; Crossley v. Lightowler, L. R. 2 Ch. App. 478. 
lost, we will, in conclusion, briefly consider some of the more important of these rights.

Extent of right to

light and air.

Running water.

To begin with claims of light and air. Each orner is entitled, as a natural right, to all the light and air that can reach his tenement from above, in accordance with the maxim Cujus est solum ejus est usque ad cœlum et ad inferos; but he has no right to the unobstructed passage of light and air $(a)$ in a lateral direction, unless he has acquired it as an easement. As to the method of acquiring, or prerenting the acquirement of, such rights, the reader is referred to the comments upon section 3 and the cases there cited $(b)$. It may be added that such rights in the case of air are quite independent of the natural right, which each owner has, to prevent his neighbour from transmitting to him air in an impure condition $(c)$.

The natural rights of a riparian owner in respect of running water have already been discussed at p. 886 ; and it only remains to add that any further right claimed by one ormer in derogation of those of his neighbours, whether above or below, can only be acquired in the same way as other easements, either by grant or prescription. Such rights are those of throwing back water upon his neighbours abore, stopping the flow of the current, increasing the quantity or altering the quality of the water sent down below. In the absence of a grant, any riparian owner who goes beyond his natural rights will be liable to an action by any other riparian owner whose right is thus invaded,

(a) Harris v. De Pinna, $33 \mathrm{Ch}$. D. 238. See Bass v. Gregory, 25 Q. B. D. 481 ; a lost grant of a right to the free passage of air in a defined channel was inferred.

(b) Supra, p. 896 ; Hoore v. Rau. son, 3 B. \& C. 332,340 ; Chandlev r. Thompron, 3 Camp. 82; 15 R. R. 756. There can be no easement of prospecl apart from an express corenant by the grantor: Aldred's Case, 9 Rep. 5े b;
Squires r. Campbell, 1 M. \& Gr. 459 ; All.-Gen. r. Doughty, 2 Ves. sen. 452; and vide per Lord Blackburn, Dalton v. Angus, 6 App. Cas. 740, 823.

(c) Moseley r. Bland, cited in Aldred's Case, 9 Rep. 58 b ; Bliss v. Hall, 4 Bing. 5. C. 183; Walter v. Selfe, 4 De G. \& S. 315; Tipping r. st. Helen's Smelting Works, 4 B. \& S. 608 ; 11 H. L. Cas. 642. 
unless and until such invasion has been justified by a user of sufficient duration, and that whether or no the plaintiff has sustained actual damage, "where the act complained of, if continued, may become the foundation, by lapse of time, of an adverse right in the defendant" $(d)$.

The right of an individual to an artificial watercourse as against the party creating it is, as we have already seen (e), Artificial waterof a different kind, and will depend upon the character of the watercourse, and the circumstances under which it was created $(f)$. For the diversion of such a watercourse no action will lie where, from the nature of the case, the enjoyment of it obviously depended upon temporary circumstances, and was not of a permanent character, and where the interruption was by the party who stood in the situation of grantor. The flow of water, accordingly, from the eaves of a house would not give a right to the neighbour to insist that the house should not be pulled down or altered so as to diminish the quantity of water flowing from the roof; nor would the flow of water during twenty years from a drain made for the purposes of agricultural improvements give a right to the neighbour so as to preclude the proprietor from altering the level of his drains for the greater improvement of his land. In such a case the state of circumstances shows that one party never intended to give, nor the other to enjoy, the use of the stream as a matter of right ( $g$ ). If, however, the artificial channel be of a permanent nature,

(d) Per Story, J., Webb v. Portland Manufacturing Co., 3 Sumner (U. S.) R. 189.

(e) Ante, p. 888.

(f) See Sutcliffe v. Booth, 32 L. J. Q. B. 136, cited L. R. 2 Ex. 14 and approved and followed in Roberts v. Richards, 50 L. J. Ch. 301 ; Gavcd F. Mfartyn, 19 C. B., N. S., 732, 753, 754; Stockport Waterworks Co. v. Potter, 3 H. \& C. 300; approved, Ormerod v. Todmorden, 11 Q. B. D. 155; Auttall v. Bracewell, L. R. 2
Ex. 1, cited in Holker v. Porvitt, L. R. 10 Ex. 63.

(g) Wood v. Waud, 3 Exch. 776778; approved in Singh v. Pattuk, 4 App. Cas. 121 ; Greatrex v. Hayuard, 8 Exch. 291; Arkwright r. Gell, 5 M. \& W. 203; recognised but distinguished in Beeston v. Weate, 5 E. \& B. 986, 995 , where there was evidence that an easement had been acquired; Chamber Coll. Co. v. Hopwood, 32 Ch. D. 549. See Mragor v. Chadwick, 11 A. \& E. 571. 
rights in the nature of easements may be acquired therein, so as to prevent the maker from polluting the water, to the injury of a lower riparian proprietor $(h)$.

In Nield v. London and North-Western R. C., the facts were these:-The defendants, owners of a canal, being threatened with an overflow of flood-water from a neighbouring river, and fearing damage might be done to their premises on the banks of the canal, placed across it at a higher point planking which penned back the flood-water, and caused it to overflow the banks of the canal, and so damage the plaintiff's premises above those of the defendants. It was held that an action would not lie to recover com. pensation for this damage, for the water which did the damage was not brought into the canal by the defendants, and no duty was imposed upon them analogous to that imposed upon the owners of a natural watercourse not to impede the flow of waters down it (i). It has similarly been held that a man may, without regard to his neighbour, protect himself against subterranean water, a canal, or the sea, as against "a common enemy," but not against a river $(k)$.

The rules regulating the right to subterranean water are nean water. not identical with those applicable to the enjoyment of streams and waters above ground. When water is on the surface, the right of the owner of the adjoining land to the usufruct of that water is not a doubtful matter of fact: it is public and notorious; and such a right ought, as a matter of course, to be respected by every one. In like manner, if the course of a subterranean stream were well known-as where a stream sinks underground, pursues for a short space a subterranean course, and then emerges again-it seems clear that the owner of the soil under which the

(h) Blackburne v. Somers, 5 L. R. Ir. 1 .

(i) L. R. 10 Ex. 4.

(k) Smith v. Kenrick, 7 E. \& B.
515: Rex v. Trafford, 8 Bing. 210; Rex v. Pagham, 8 B. \& C. 360 . See, howerer, Whalley v. Laneashire and Forkshire R. C., 13 Q. B. D. 131. 
stream flowed could maintain an action for the diversion of it, if it took place under such circumstances as would have enabled him to recover if the stream had been wholly above ground $(l)$. Where, however, the existence and state of underground water are unknown, and perchance unascertainable, as where a well is sunk, and afterwards there is a difficulty in knowing certainly how much, if any, of the water when the ground was in its natural state belonged to the owner in right of his property in the soil, and how much belonged to his neighbour, who in digging a mine or another well, which drains the water from that previously sunk $(m)$, may possibly be only taking back his own, a rule of law different from that above enunciated may properly be applied $(n)$.

In Chasemore v. Richards (o), which is a leading case regarding the right to subterranean water, the facts $(p)$ were as under :-The plaintiff was the owner of an ancient mill on the river W., and for more than sixty years before the commencement of the action he and all the preceding occupiers of the mill had used and enjoyed, as of right, the flow of the river for the purpose of working their mill. The

(l) Vide per Pollock, C. B., Dudden v. Clutton Union, 1 H. \& N. 630; and see Black r. Ballymena Comm., 17 L. R. Ir. 459.

(m) Acton v. Blundell, 12 M. \& W. 324 , cited ante, p. 76.

(n) See this subject amply discussed in the Judgm., 12 M. \& W. 349-352; Judgm., 7 Exch. 300.

"Although there is no doubt that a man has no right to withdraw from his neighbour the support of adjacent soil, there is nothing at common law to prevent his draining that soil, if for any reason it becomes necessary or conrenient for him to do so : " per Cockburn, C. J., Popplewell v. Hodkinson, L. R. 4 Ex. 251.

(o) 7 H. L. Ca. 349 ; S. C., 2 H. \&N. 168; 11 Exch. 602 (where Dickinson v. Grand Junction Canal Co., 7 Exch. 282 , is much commented on) ; Broadbent v. Ramsbotham, 11 Exch. 602 (distinguished, Bunting v. Hicks, 70 L. T., N. S., 455); Raustron v. Taylor, Id. 369. In Chascmore v. Richards, supra, Acton v. Blundell, 12 M. \& W. 324 , is recognised, and the authorities generally are reviewed. In Reg. v. Metropolitan Board of Works, 3 B. \& S. 710 , the right to intercept the water from underground springs was much considered. See Lyon v. Fishmongers'. Co., 1 App. Cas. 662; Ballacorkish Mining Co. v. Harrison, L. R. 5 P. C. C. 49 . See also Hodgkinson v. Ennor, 4 B. \& S. 229 ; Ewart v. Bclfast, 9 L. R. Ir. 172. An action will lie against a landowner for polluting underground water, so as to render it unfit for use: Ballard v. Tomlinson, 29 Ch. D. 117, reversing $S . C ., 26$ Ch. D. 194; Snow v. Whitehead, 27 Ch. D. 588 .

$(p)$ Which have been briefly stated, ante, p. 76 . 
river W. was and always had been supplied abore the plaintiff's mill in part by the water produced by the rainfall on a district of many thousand acres in extent, comprising the town of $\mathrm{C}$. and its vicinity. The water of the rainfall used to sink into the ground to various depths, and then to flow and percolate through the strata to the river W., part rising to the surface and part finding its way underground in courses which constantly varied. The defendant represented the members of the Local Board of Health of C., who, for the purpose of supplying the town of $\mathrm{C}$. with water and for other sanitary purposes, sank a well in their own land in the town of $\mathrm{C}$., and about a quarter of a mile from the river $W$., and pumped up large quantities of water from their well for the supply of the town of C., and, "by means of the rell and the pumping, the Local Board of Health did divert, abstract, and intercept underground water, but underground water only, that otherwise would have flowed and found its way into the river W., and so to the plaintiff's mill; and the quantity so diverted, abstracted, and intercepted was sufficient to be of sensible value towards the working of the plaintiff's mill." The question was, whether the plaintiff could maintain an action against the defendant for such diversion, abstraction, and interception of the underground water,

The Judges, in giving their opinion upon this question, observed as follows:- "In such a case as the present, is any right derived from the use of the water of the river $W$. for upwards of twenty years for working the plaintiff's mill? Any such right against another founded upon length of enjoyment is supposed to have originated in some grant which is presumed from the owner of what is sometimes called the servient tenement. But what grant can be presumed in the case of percolating waters, depending upon the quantity of rain falling or the natural moisture of the soil, and in the absence of any visible means of knowing 
to what extent, if at all, the enjoyment of the plaintiff's mill would be affected by any water percolating in and out of the defendant's or any other land? The presumption of a grant only arises where the person against whom it is to be raised might have prevented the exercise of the subject of the presumed grant; but how could he prevent or stop the percolation of water? The Court of Exchequer, indeed, in the case of Dickinson v. The Grand Junction Canal Company (q), expressly repudiates the notion that such a right as that in question can be founded on a presumed grant, but declares that with respect to running water it is jure nature. If so, à fortiori, the right, if it exists at all, in the case of subterranean percolating water, is jure nature, and not by presumed grant, and the circumstance of the mill being ancient would in that case make no difference.

"The question then is, whether the plaintiff has such a right as he claims jure nature to prevent the defendant sinking a well in his own ground at a distance from the mill, and so absorbing the water percolating in and into his own ground beneath the surface, if such absorption has the effect of diminishing the quantity of water which would otherwise find its way into the river W., and by such diminution affects the working of the plaintiff's mill. It is impossible to reconcile such a right with the natural and ordinary right of landowners, or to fix any reasonable limits to the exercise of such a right. . . . Such a right as that claimed by the plaintiff is so indefinite and unlimited that, unsupported as it is by any weight of authority, we do not think that it can be well founded, or that the presentaction is maintainable." The opinion thus expressed by the learned Judges was acquiesced in by the House of Lords, who affirmed the judgment in the defendant's favour of the Court below.

The right of the owner of land to divert or appropriate (q) 7 Exch. 282. 
the percolating water within his own land is the same whether his motive be to improve his own land, or to maliciously injure his neighbour $(r)$.

Ways. As to rights of way $(s)$, it is sufficient to remark that it will be necessary to prove that the grantwas co-extensive with the user claimed. Thus proof of a right of way to a shed will not imply a right of way to a house built afterwards on the same site $(t)$. A right of way to carry coals would not necessarily include a right to carry other burdens, and vice versî $(u)$; and a right to drive pigs has been held not to include a right to drive horned cattle $(x)$.

Support for buildings.

In conclusion, it remains for us to consider the right that can be gained for the support of buildings by soil or buildings, and whether this easement is one that can be claimed under the Prescription Act. We have already seen that the right of support from land to land is a natural right of property $(y)$; but this must be understood of land only, without reference to buildings. "Support to that which is artificially imposed upon land cannot exist ex jure nature, because the thing supported does not itself so exist; it must in each particular case be acquired by a grant, or by some means equivalent in law to a grant, in order to make it a burden upon the neighbour's land, which (naturally) would be free from it. This distinction (and at the same time its proper limit) was pointed out by Willes, J., in Bonomi v. Backhouse (z), where he said, "The right to

(r) Corporation of Bradford v. I'ichles, (1895) App. Cas. 58\%̄, affirming C. A., 1895, I Ch. 145 .

(s) See Mann r. Brodic, 10 App. Cas. 378,385 . As to evidence sufficient to support clain. in thinly inpulated district, see Macpherson $\mathrm{v}$. Srottish Rights of Way Socicty, 13 App. Cas. 744 .

(t) Allan v. Gomme, 11 A. \& E. 760 : Bayley r. Gieat Western R. C., 26 Ch. D. 434 ; sed ride $H$ emming $\vee$. Burnet, 8 Exch. 194.

(ii) Reynolds v. Eduards, Willes,
2S2; Iveson v. Moore, 1 Salk. 15 ; Stafford v. Coney, 7 B. \& C. 257.

(x) Ballard v. Dyson, 1 Taunt. 279;

9 R. R. 7\%0. See Serff v. Acton Local Board, 31 Ch. D. 679 .

(y) Ante, p. 883 .

(z) E. J. \& E. 655; distinguished in Spoor r. Grecn, L. R. 9 Ex. 99, 111 ; Bibby r. Carter, 4 H. \& N. 153 ; Haines จ. Roberts, 7 E. \& B. 625; Rogers v. Taylor, 2 H. \& N. 828; Incke of Bucclengh v. Wakefield, I. R. 4 H. L. 377 ; ante, p. 884. 
support of land and the right to support of buildings stand upon different footings as to the mode of acquiring them, the former being prima facie a right of property analogous to the flow of a natural river, or of air, though there may be cases in which it would be sustained as matter of grant (see Caledonian $R$. C. v. Sprot) (a), whilst the latter must be founded upon prescription or grant, express or implied; but the character of the rights when acquired is in each case the same.' Land which affords support to land is affected by the superincumbent or lateral weight, as by an easement or servitude ; the owner is restricted in the use of his own property, in precisely the same way as when he has granted a right of support to buildings. The right, therefore, in my opinion, is properly called an easement, as it was by Lord Campbell in Humphries v. Brogden (b), though when the land is in its natural state the easement is natural, and not conventional" $(c)$.

In the case of Dalton v. Angus, above cited, which must now be regarded as the leading case upon the subject, the House of Lords, after taking the opinion of the Judges, decided that a twenty years' enjoyment, " nec vi, nec clam, nee precario," was sufficient at common law to confer a right of support to buildings as against neighbouring land. In dealing with the question whether the enjoyment of such support was not, in effect, clam, Lord Selborne said, "There are some things of which all men ought to be presumed to have knowledge, and among them ( $\mathrm{I}$ think) is the fact that, according to the laws of nature, a building cannot stand without vertical or (ordinarily) without lateral support." In the same case Lord Selborne (with whose judgment Lord Coleridge, C. J., coneurred) came to the conclusion that such a right of support was an easement

(a) 2 Macq. Sc. App. 449; and see Elliot v. North-Eastern R. C., 10 H. L. Cas. 333 ; Stourbridge Can. Co. r. Earl of Dudley, 3 E. \& E. 409. (b) 12 Q. B. 742.

(c) Per Lord Selborne, Dalton v. Angus, 6 App. Cas. 740, 792. 
within the meaning of, and could be claimed under, the 2nd section of the Prescription Act $(d)$; and in the subsequent case of Lemaitre v. Daris (e) Hall, V. C., held that the right of support for buildings could also be acquired against buildings as opposed to land, and that, like the right to support from soil, it was within the 2nd section of the Act.

In a recent case in Ireland the principle of Dalton v. Angus $(f)$ was applied to impose a liability upon the owner of a building separated from that of the plaintiff by an intervening house. It was there held, distinguishing Solomon v. The Vintuers' Co. $(g)$, that, as the evidence showed that the injury was caused by the rebuilding of the defendant's premises, he was liable for the damage suffered by the plaintiff, even if the rebuilding had been performed with due skill $(h)$.

Finally, we must repeat that as these easements are not natural rights of property, so until they have (in the absence of a grant) become secured by prescription, either at common law or under the statute, their acquisition may be prevented by any one whose interest it is to do so. Thus where a house has not stood for twenty years " the owner of the adjacent soil may with perfect legality dig that soil away, and allow his neighbour's house, if supported by it, to fall in ruins to the ground" (i); and if a house, not being "ancient" in law, is supported by the buildings of a neighbour, it would seem on the same principles that the neighbour will not be liable for any damage caused by his pulling down his buildings and so

(d) Ib. 798 .

(e) 19 Ch. D. 852.

( $f$ ) Ubi supra.

(g) 4 H. \& N. 599.

(h) Latimer $r$ Official Co-operative Soc., 16 L. R. Ir. 305.

(1) P'er Iord Penzance, Dalton v. Angus, 6 App. Cas. 740, 804. But if the land would have fallen in by reason of the digging, even without the additional weight of the buildings, the value of the buildings can be recovered as damage resulting from the principal injury : Wyatt v. IIarrison, 3 B. \& Ad. 871; Stroyan r. Knoulcs. 6 H. \& N. 454 ; Hamer v. Knorcles, Ib.; Hunt v. Peake, 29 L. J. Ch. 785. 
withdrawing the support needed by the house, unless the pulling down is performed so negligently and violently as to amount to a trespass upon the adjoining property $(k)$. Similarly a new window may be blocked so as to prevent its becoming an "ancient" one under the 3rd section of the Act.

When, however, the easement has once been acquired, it will, as we have already seen, stand upon the same footing as a natural right of property, and any infringement thereof will be punished at law either by damages for the unlawful acts, or an injunction to prevent their repetition.

From what has been said in the foregoing pages touching the more important-when practically regarded-of ordinary torts to realty will be inferred the solicitude of our law so to regulate the rights of property, that, whilst its free use and enjoyment by each individual are not unduly interfered with, the privileges legally vested in other members of the community may be respected.

\section{Secr. II.-Torts to Personal Property.}

Chattels personal are, strictly speaking, "things moveable, which may be annexed to or attendant on the person Chattels personal of the owner, and carried about with him" from one place to another (l). Under the term "chattels" are included animals of various kinds, household furniture, money, jewels, corn, articles of clothing, and everything which can properly be transferred from place to place $(l)$.

Now in discussing, so far as space will permit, the ordi- Tortsto nary torts to personalty, it may be convenient to treat, 1 st, $\frac{\text { phow clas- }}{\text { sified. }}$ Of torts to property in the possession of the owner ; 2ndly, Of torts to property out of the owner's possession.

(k) See on this point, which can hardly be considered as settled, Gale on Easements, 6th ed., pp. 376 et seq.; Chadwick v. Magor, 6 Bing. N. C. 1, reversing $S . C ., 3$ Bing. N. C. 334 .

(l) 2 Bla. Com., p. 387 ; 3 Id., p. 144. 
Torts to personalty in possession.

First, then, a tort to personalty in the possession of the owner may be constituted by the wrongful deprivation of that possession, or by an abuse of, or damage done to, the chattel whilst in his possession.

It may readily be conceded, that where a rightful possession of goods and chattels has once been gained, either by a just occupancy or by a legal transfer, whoever, whether by force or fraud, dispossesses the holder of them is guilty of a tort, remediable by action, "for," as remarked by Blackstone $(m)$, "there must be an end of all social commerce between man and man unless private possession be secured from unjust invasions; and if an acquisition of goods by either force or fraud were allowed to be a sufficient title, all property riould soon be confined to the most strong or the most cunning; and the weak and simple-minded part of mankind (which is by far the most numerous division) conld never be secure of their possessions."

But, further, it is also a true proposition, that one who is in possession of a chattel vrongfully as regards some particular individual, provided he be rightfully possessed of it quoad the defendant, may sue this latter party for a tort done to the specific chattel. The decision in Armory v. Delamirie (n) established that bare possession constitutes a sufficient title to enable the party enjoying it to obtain legal remedy against a mere wrong-doer $(o)$. It was there beld, that one who had found a jewel might maintain an action for it or its value against a jeweller whose opinion had been

(m) 3 Com., p. 145.

(II) 1 Str. $505 ; 1$ Sm. I. C., 9th et., 385.

See per Pollock, C. B., commenting upon the above case, White v. Mullett, 6 Exch. 714; Bridges v. Hankesworth, 21 L. J. Q. B. 75 (with which cf. South Staffordshire Watemeorks v. Sharman, 12 Times L. R. 402); Buekley v. Gross, 3 B. \& S. 566.

(o) Acc. Northam r. Bouden, 11 Exch. 70 ; Stapleton r. Haymen, 2
H. \& C. 918.

In Jeffries v. Great Western R. C., 5 E. \& B. 805, Lord Campbell, C. J., observes-"The law is that a person possessed of goods as his property has a good title as against every stranger, and that one who takes them from him, having no title in himself, is a wrongdoer, and cannot defend himself by showing that there was title in some third person; for against a wrong-doer possession is a title." 
asked respecting it, and who, having got possession of it, tortiously retained it, and applied it to his own use. The Court in this case further resolved that the finder of the jewel, though he did not by such finding acquire an absolute property or ownership in it, yet had such a property therein as would entitle him to keep it against all but the rightful owner.

There are, it may be remembered, two kinds of propertyabsolute and special. Absolute property is where one having the possession of chattels has also the exclusive right to enjoy them-which right can only be defeated by some act of his own; special property is where he who has the possession holds them subject to the claims of other persons $(p)$. But besides the right of property in the goods sued for, there must be a right to their possession in order to support an action for them or their value. It has been held accordingly that the purchaser of goods which remain in the vendor's possessicn, subject to his lien for unpaid purchase-money, cannot maintain an action against a third person for a tortious removal of the goods $(q)$.

An apt and curious example is cited infra $(r)$ in support of the proposition that an action for recovery of a chattel or its value is maintainable where the right of property and the right of possession are concurrently vested in the plaintiff.

An interference with these concurrent rights-the right of property and the right of possession-actionable at law may be constituted by a wrongful assertion of dominion (s) over the chattel, or by dealing with it in a manner incon-

(p) Per Lawrence, J., Webb r. Fox, 7 T. R. 398 ; 4 R. R. 472; Fell v. Whittaker, L. R. 7 Q. B. 120.

(q) Lord v. Price, L. R. 9 Ex. 54.

(r) Scattergood r. Sylvester, 15 Q. B. 506, with which compare Lee v. Bayes, 18 C. B. 599 , and Walker v. Matthews, 8 Q. B. D. 109 , which shows that the bonâ fide purchaser of stolen beasts, sold in market orert, cannot, in answer to a claim for them by the original

B.C.L. owner, after the conviction of the thief, counter-claim for the cost of their keep while they were in his possession, for they were his own property until on the conviction the property revested in the original owner.

(s) See Fowler v. Hollins, L. I. 7 Q. B. 616; per Maule, J.. Heald . Carey, 11 C. B. 993; Chinery r. Viall, 5 H. \& N. 28s: Hilbery v. Hatton, 33 L. J. Ex. 190. 
sistent with the owner's title to it. The measure of damages indeed in an action brought for recovery of a chattel tortiously taken or withheld from plaintiff, or destroyed, or misappropriated by defendant, may differ from the measure, applicable where plaintiff's enjoyment of the chattel merely has been interfered with, or where an injury has been done to it,-yet for any one of these dissimilar wrongs an action might be maintainable $(t)$.

Decided cases show that an action may lie for a wrong done to chattel property under any of the following states of facts:-where one finding or having the goods of another in his possession applies them to his own use without the consent of the owner, such application to the finder's use being often evidenced by a demand of the goods and a refusal to give them up $(u)$; where a person intermeddles with my property and disposes of it $(x)$; when a man takes possession of the chattel of another without justifiable cause, and sells it without justifiable cause $(y)$; where a man forcibly takes away without any felonious intention the chattel of another $(z)$,-though here to entitle the plaintiff to sue in trespass, he must, at the time when the act was done which constitutes the trespass, either have the actual possession in him of the thing which is the object of the trespass, or else he must have a constructive possession in respect of the right being actually vested in him $(a)$; the nature of what is called a "con-

(t) See Hiort v. Bott, L. R. 9 Ex. 86 ; Eugland v. Couley, L. R. 8 Fx. 126, 132 .

(ii) 10 Rep. 56 b, 57 a.

(x) l'er Lord Ellenborongh, C. J., Stephens v. Elwall, 4 MI. \& S. 261; Hollins r. Fouler, L. R. 7 H. L. 757.

(y) Judgm., Hilbery r. Hatton, 2 H. \& C. 822 .

(z) Where goods are taken by an act of trespass, and are subsequeutly sold by the trespasser and turned into money, the owner may sue for the forcible injury; or, waiving the tort, he may sue for the money received by defeudant: Judgm., Rodgers r. Mare, 15 M. \& W. 448; Judgm., Clark r. Gilbert, 2 Bing. N. C. 357; Swith r. Baker, L. R. 8 C. P. 850. See Lythgoe v. Vermon, 5 II. \& N. 180.

(a) Per Ashhurst, J., Smith r. Milles, 1 T. R. 480; Brierly r. Kendall, 17 Q. B. 937; Bradley v. Copley, 1 C. B. 685 . See also, in support of what is above said, Watson v. Maequire, 5 C. B. 836,844 ; White v. Morris, 11 C. B. 1015 . 
tructive" possession may be illustrated by reference to the ase of an executor whose right to the goods of the testator ccrues immediately on his death, and such right draws ifter it a constructive possession-so that an executor may naintain trespass for goods of testator taken between he death and grant of probate $(b)$. The same rule also upplies in the case of an administrator, who may sue in respass for goods taken between the death and the grant of etters of administration-by virtue of which relation the idministrator is enabled to recover against such persons is have interfered with the estate, and thereby to prevent $t$ from being prejudiced and despoiled $(c)$.

In regard to the latter of the two kinds of injuries (specified it p. 912), which may be offered to things personal whilst $\mathrm{n}$ the possession of the owner, consisting in an abuse of or lamage done to them, ex. gr., by hunting a man's deer, hooting his dogs, poisoning his horses $(d)$ or cattle, or in inywise taking from the value of any of his chattels, or naking them in a worse condition than before, it suffices to ay that an action will lie for such wrong in which damages rill be recoverable in proportion to the injury which the omplainant proves, by apt evidence, that his property has ustained $(e)$.

Torts to personalty, whilst de facto out of the owner's ossession, may occur under many dissimilar circumstances, is where the chattel wrongfully seized or injured is in the Torts to out of the owner's possession. ustody of the law $(f)$, or under bailment to another. In eference to the latter state of facts, a few remarks may se offered.

A bailment $(g)$ is a delivery of a thing in trust for some

(b) Tharpe v. Stallwood, 5 M. \& Gr. 60 ; Foster v. Bates, 12 M. \& W. :33; Kirk v. Gregory, 1 Ex. D. 55.

(c) Morgan v. Thomas, 8 Exch. 302. (d) See Crouthurst v, Amersham Burial Board, 4 Ex. D. 5.

(e) 3 Bla. Com., pp. 153, 154. See
Tancred v. Allgood, 4 H. \& N. 438.

(f) Turner v. Ford, 15 M. \& W. 212; Wilbraham v. Snow, 2 Wms. Saund. 47 a; cited Jeffrics v. Great Western R.C., 5 E. \& B. 805.

(g) As to the nature of a bailment, see Reg. v. MeDonald, 15 Q. B. D. 
special object or purpose, and upon an undertaking-express or implied-to conform to the object or purpose of the trust. Two ingredients are indeed essential to and must be presented (under some form or other) in every satisfactory definition of a bailment-a delivery and a trust-this latter term being used to signify the confidence which one man reposes in another $(h)$.

The nature of a bailment may admit of illustration in an infinite variety of ways-thus, if cloth be delivered to a tailor to make a suit of clothes, he takes it upon an implied contract, $v i z$., to make the clothes in a workmanlike manner, and to deliver them to his customer when made. $\mathrm{He}$ is therefore a bailee. And so is a pawnbroker who receires plate or jewels as a pledge or security for the repayment of money lent thereon-the contract or trust being in this case to keep the thing pledged with ordinary care and diligence, and to restore it upon redemption, i.e., upon repayment of the money advanced upon it by the pawnor. So, if a man talies in cattle to graze and depasture on his land, he is a bailee (this particular kind of bailment being technically termed an agistment), and the bailee takes the cattle in this case on an implied contract or undertaking that he will look after them with ordinary diligence,-which means, with that degree of diligence which men in general exert in respect to their own concerns (i). For example, the agister of a horse is, although he does not insure the safety of the horse, bound to take reasonable care of it, and if it be killed through his negligence, is liable $(k)$.

In any of the foregoing instances of bailments it will be found that there is a delivery of the subject-matter of the

323; Reg. v. Ashuell, 16 Id. 223. As to the character of bailee, see Forler ․ Lork, I. R. 7 C. P. 272 ; s. C., L. R. 10 C. P. 90 ; Batut v. ILwtley, I. R. 7 (2. 13. 594. As to the difference between a mere licence to use and a bailment, see Williams r. Jones, 3 H. \& C. $602,611$.

(h) See Toml. I. Dict. ad verh. "'Trust."

(i) 2 Bla. Com., pu. 451, 452.

(i) Sinith r. C'ook, 1 Q. B. D. 79. 
bailment and a trust, i.e., a confidence reposed by the bailor and a corresponding undertaking by the bailee.

The classification of bailments usually adopted is into three great heads $(l)$, whereof the first comprises bailments in which the trust is exclusirely for the benefit of the bailor: it includes, therefore, mandates and deposits, terms, doubtBailment. Class I. Trust for exclusive benefit of bajlor.

less, used more frequently by the civil than by the common law writers, but still not alien to our system of jurisprudence. A 'deposit' is commonly defined to be a naked bailment of goods to be kept for the bailor gratuitously; and returned when he shall require them, and a 'mandate' is likewise a gratuitous bailment of goods to be carried and conveyed from one place to another, or made with a view to some act being performed about them. Now, in the case of a mandate or a deposit (between which there is no distinction to be noted material for the present inquiry), the bailment is made for the benefit of the bailor, and the law applicable to these cases is that the bailee is bound merely to use a slight degree of diligence respecting the thing bailed, and is liable for gross negligence only-the reason being that the bailee is to receive nothing for his services.

The celebrated case of Coggs v. Bernard $(m)$ falls within the general class of bailments now under consideration. There the plaintiff declared that, whereas the defendant undertook and promised safely and securely to talie up certain hogsheads of brandy out of a cellar where they were deposited and to lay them down in another place, he so negligently and carelessly put them down again, that, by his negligence, one of the casks was staved and a quantity of brandy spilt. After verdict an objection was taken to this declaration on the ground that it contained no averment

(l) For the following brief sketch of the leading classes of bailments I am mainly indebted to Dr. Story's admirable treatise upon that subject. This general acknowledgment will obviate the necessity of repeated reference to the work in question.

(m) Id. Raym. 909: 1 Sm. L. C., 9th ed., 201. See Holder v. Sou'by, 8 C. B., X. S., 254. 
that the defendant was a common carrier (in which case, a we shall presently see, peculiar responsibilities would hav been cast on him), or that he was to have received anythin for his services; and the simple question consequently was whether a man not being a common carrier, whe undertakes gratuitously to carry goods or to perform some act in connection with them, is liable for any and what degree of negligence in the performance of his undertaking: the decision come to in this case established the law relat. ing to contracts of mandate as it has been above stated; and, in the course of his judgment, Lord Holt took occasion minutely to consider the various classes and subdivisions of bailments, together with the legal principles applicable to them.

Instances of the kind of bailment now referred to do not often present themselves in our modern law reports; they do, however, sometimes occur, as in Doorman v. Jenkins (n), and Rooth v. Wilson (o), in the former of which Taunton, J., after remarking upon the difficulty of determining what is gross negligence, for which alone a mandatary or depositary is liable, observes that there may be cases where this question will be matter of law more than of fact, and others again where it will be matter of fact more than of law $(p)$. So, in regard to the question-What is to be deemed reasonable care, the absence of which will indicate gross negligence?-Dr. Story $(q)$ observes that, being a bailee without reward, a depositary is bound to slight diligence only, "but in every case good faith requires that he should take reasonable care of the deposit, and what is reasonable care must materially depend upon the nature, value, and quality of the thing [bailed], the circumstances under

(n) 2 dd. \& E. 256.

(o) 1 H. \& Ald. 59, 61, ubi vide per Iord Ellenborough, C. J., 18 R. R. 431 : see also Mytton r. Cock, 2 Str. 1099 ; Dartnall v. Howard, 4 B. \& C.
345 ; White v. IIumphrey, 11 Q. B. 43.

(p) See Melville v. Doidge, 6 C. l'. 450.

(q) Bailm., sth ed., p. 56 ; Giblin v. ILc.llullen, I. R. 2 P. C. $317,336$. 
which it is deposited, and sometimes upon the character and confidence and particular dealings of the parties" $(r)$.

Further, it is necessary to observe, in connection with the particular class of bailments under consideration, that even a gratuitous bailee who accepts his trust for the benefit of the bailor will, if possessed of skill with reference to the specific subject-matter of the bailment, be bound to use it ; for instance, a person conversant with horses might be answerable for damage happening to a horse whilst under his gratuitous care or management, for which an individual not so skilled might be irresponsible $(s)$.

With respect to bailments purely gratuitous, one question may with good reason be asked-Can a contract to accept such a bailment and to discharge its resulting duties be enforced ; would not an action for the purpose of enforcing it or obtaining damages for its non-performance fail by reason of the maxim-Ex nudo pacto non oritur actio? The answer is, that such an action would fail, and that the party who has entered into a gratuitous contract of the kind supposed may relieve himself from liability before performance by a simple refusal to discharge the trust. If, however, he accept the bailment, he will thereby render himself liable for negligence (of the degree before specified) during its continuance. This liability results directly from the rule cited at a former page $(t)$, that " the confidence induced by undertaking any service for another is a sufficient legal consideration to create a duty in its performance;" and it is, accordingly, generally true with respect to gratuitous contracts, that for nonfeasance, even when a party suffers a damage thereby, no action lies, but for misfeasance an action will lie $(u)$.

(r) See Mills v. Holton, 2 H. \& N.

(s) Wilson v. Brett, 11 M. \& W. 113.

(t) P. 779 ; see Shillibeer r. Glyn, 2 M. \& W. 143.

(u) Balfe v. West, 13 C. B. 466 ;
Elsee v. Gatward, 5 T. R. 143, 149, 150 ; Wilkinson v. Coverdale, 1 Esp. 74. Thus no duty is cast upon the recipient of goods voluntarily sent to him without any request on his part : Howard v. Harris, 1 C. \& E. 253. 
Bailments. Class II. Trust for exclusive henefit of luailee.
Next in order of the three leading classes of bailments, already adverted to, is that in which the trust is exclusively for the benefit of the bailee, and in which the thing bailed is usually to be restored in specie. A bailment of this kind was denominated in the civil law commodatum, in ours it is called a loan, and the degree of diligence here required from the bailee is very much, if not precisely, that required from a gratuitous bailee possessing skill, who, as above stated, is bound to exercise the skill which he possesses; the reason being, that a gratuitous bailee for use must be taken, in point of law, to have represented himself to the bailor as a person of competent skill-a much greater degree of diligence will therefore be expected from him than from one who is a mere gratuitous bailee for the benefit of the bailor. The law applicable to the class of bailees now in question is explained in Wilson v. Brett (x), already cited, illustrated to some extent by Lord Camoys v. Scurr (y), and commented on by Lord Campbell, C. J., in Dansey v. Richardson (z), and by Lord Holt in Coggs v. Bernard, where the latter eminent Judge takes occasion to observe, that the party to whom a loan of chattels is made gratuitously "is bound to the strictest care and diligence to keep the goods [lent] so as to restore them back again to the lender ; "for the bailee, having a benefit by the use of them, will be answerable if guilty of the least neglect, as if a man should lend another a horse to go westward, or for a month, and the bailee go northward, or keep the horse above a month, if any accident happen to the horse in the northern journey, or after the expiration of the month, the bailee will be chargeable, because he has made use of the horse contrary to the trust under which he was lent; and it may be, if he had been used no otherwise than as had been intended, the accident would not have happened $(a)$.

(x) 11 M. \& W. 113, 115.

(y) 9 Car. \& Y'. 383.

(z) 3 E. \& B. 167.

(a) Blakemore v. Bristol and Exeter 
One ordinary instance of the above kind of bailment nccurs in the case of a gratuitous or simple loan of money. And in connection either with the present or the preceding class of bailments (for the facts as reported do not enable us positively to say to which it may belong), should be mentioned-Nicolls v. Bastard (b), which shows, that, if chattel property be taken wrongfully out of the possession of a gratuitous bailee, he may sue for it in his own name, or the bailor may sue, the former having a special, and the latter an absolute property in the chattel.

To the third class of bailments, in which the trust is for the benefit of both parties, is referable the law relative to radium, the pledging or pawning of a chattel, and that Bailments. Class III. Trust for benefit of relating to locatio-conductio, a bailment for reward or compensation, of which the more important subdivisions are: 1 . The hiring of a thing for use (locatio rei). 2 . The hiring of work and labour (locatio operis faciendi). 3 . The hiring of care and services to be performed or bestowed on the thing delivered (locatio custodie). 4. The hiring of the carriage of goods (c) from one place to another (locatio operis mercium vehendarum). The class of bailments before us is, then, obviously far more comprehensive and practically important than either of the two kinds previously mentioned (d), embracing, inter alia, bailments to pawnbrokers, innkeepers, and carriers; as to each of which successively some observations are subjoined.

It may, however, in this place be well to premise that the general rule applicable where the bailment is reciprocally

R. C., 8 E. \& B. 1035, 1050, shows that the duties of the borrower and lender of a chattel are in some degree correlatire: Judgm., MacCarthy r. Young, 6 H. \& N. 336. See Judgm., Taylor v. Calducell, 3 B. \& S. 838, 839.

(b) 2 Cr. M. \& R. 659 .

(c) The fifth sort of bailment mentioned by Lord Holt in Coggs v. Bernard, viz.," " a delivery to carry, or otherwise manage, for a reward to be paid to the bailee," includes cases where there is either a delivery to one exercising a public employment-such as a common carrier-or a delivery to a prirate person-such as a livery stablekeeper, who undertakes for reward to receive a carriage and lodge it in a coach-house. See Searle v. Laverick, L. R. 9 Q. B. 122 .

(d) Ante, pp. 917, 920. 
beneficial to both parties to it is, that ordinary diligenee on the part of the bailee is required, so that (to put the converse of the rule) he will be responsible for ordinary neglect $(e)$.

On the deposit of goods for reward with a bailee-not being a public carrier or inn-keeper-he undertakes to use proper care that the goods shall be safely kept from loss or injury; thus much is implied by law from the bailment. If, however, the bailor and bailee agree that the goods shall be deposited on other terms, those terms will regulate the bailee's responsibility $(f)$. That is to say, where the agreement between the parties is in writing the liability of the recipient of the goods must be determined by reference to it. And though one of the parties to the bailment may not have read the writing, he may nevertheless be bound by its terms in accordance with the doctrine of estoppel $(g)$ - the party receiving the paper may, by receiving and keeping it, be held to have assented to the conditions contained in it, although he did not read them, and did not know what they were $(g)$. In such cases one general rule of law cannot be applied $(h)$.

The degree of care or diligence required in this third class of bailments is, in most cases, intermediate between that required from a bailee in the first and in the second class.

Pawneeliability of.

A pledge (i) or pawn may be defined to be " $a$ bailment of goods to a creditor, as security for some debt or

(e) The hirer of a carriage and horse is liable in respect of injury to the same the result of his servant's negligent driving, even where the serrant was driving the horse and carriage for his own purpose and in disobedience to his master's onlers: Conpé Co. r. Maddick, (1891) 2 Q. B. 413.

(f) See, for instance, Scaife r. Farrant, I. R. 10 Ex. 35s.

(g) See per Mellish, I. J., I'arlier r. South-Eastem R. C., 2 C. I'. D. 421. (h) Parker v. South-Eastern R. C., 2 C. P. D. 416 ; S. C., 1 Id. 618 ; Harris v. Great Western R. C., 1 Q. B. D. 515, 529, 530; Henderson v. Stevenson, L. R. 2 H. L. Sc. 470 ; distinguished in Burke r. South-Enstern R. C., 5 C. P. D. 1 ; and see Watkins r. Rymill, 10 Q. B. D. 17 S.

(i) As to the distinction betreen a lien and a pledge, see Lonald $\mathrm{r}$. Sivck. ling, L. R. 1 Q. B. 585, 604 ; approved in Halliday $v$. Holgate, L. R. 3 Ex. 299,302 , where we read that "there are three kinds of security-(1) a 
engagement" $(k)$; and with respect to it, the rule deducible from the judgment of Lord Holt in Coggs v. Bernard is, that the pawnee is bound to use ordinary diligence in the care and safeguard of the pawn, so that if the thing parned be lost, notwithstanding the exercise of such diligence, the pawnee may still resort to the pawnor for the amount of the debt secured by the pawn (l). "If," said Lord Holt, "the pawn be such as it will be the worse for using, the pawnee cannot use it, as clothes, \&c. ; but if it be such as will be never the worse, as if jewels for the purpose were pawned to a lady, she might use them, but then she must do it at her peril ; for whereas if she keeps them locked up in her cabinet, if her cabinet should be broken open and the jewels taken from thence, she would be excused; if she wears them abroad, and is there robbed of them, she will be answerable; and the reason is, because the pawn is in the nature of a deposit, and as such is not liable to be used $(m)$. But if the pawn be of such a nature as the pawnee is at any charge about the thing pawned, to maintain it, as a horse, cow, \&c., then the pawnee may use the horse in a reasonable manner, or milk the cow, \&c., in recompense for the meat."

The pawnee, however, is bound to give up to its lawful owner the thing pawned, upon a tender of the amount due to himself; and consequently if the chattel in question be lost after such tender has been made, the pawnee will be

simple lien; (2) a mortgage passing the property out and out; (3) a security intermediate between a lien and a mortgage-viz., a pledge, where by contract a deposit of goods is made a security for a debt, and the right to the property vests in the pledgee, so far as is necessary to secure the debt."

(k) Story, Bailm., 7th ed., p. 25 ; per Lord Holt, C. J., 2 Ld. Raym. R. 918.

"To constitute a valid pledge, there must be a delivery of the article either actual or constructive to the pawnee:" per Erle, C. J., Martin ${ }^{\prime}$. Reid, 11 C. B., N. S., 734 .

(l) As to the liability of a pawnbroker for damage, done to goods pawned, by an accidental fire, see Syred v. Carruthers, E. B. \& E. 469 . Should, however, the bailee, having contracted to warehouse goods at a particnlar place, warehouse them elsewhere, where thev are destroyed, though without any negligence on his part, he will be liable for the loss so caused: Lilley v. Doubleday, 7 Q. B. D. jँ10.

(m) Citing Owen, 123. 
responsible as having made himself a wrong-doer by his detention of the pawn, and if a man keeps goods by wrong, he will be answerable for them at all events ( $n$ ). Subject to. the qualified property in the goods pawned thus transferred to the pawnee, the pawnor retains his property in them : and, as incident to such property, he (the pawnor) has a right to sell the chattel pledged $(o)$; and when this right has been exercised, the purchaser has the same interest in the chattel which the pawnor had $(p)$, so that in an action of tort brought for it by the pawnor against the pawnee, on repayment of the amount for which the thing was pledged, the jus tertii might, in general, be successfully set up (q).

The business of pawnbrokers is regulated by the statute law $(r)$, which, inter alia, provides, that if the pledge be not redeemed at the expiration of a year and a day, the pawnbroker may then, subject to certain provisions, expose it to sale; but if at any time before the sale has actually taken place the owner of the chattel pawned tender the principal and interest due, together with the expenses (if any) incurred, he is entitled to a return of the chattel; for the power of sale is allowed the pawnbroker merely to secure to him the money which he has advanced, together with interest $(s)$. Should the forfeited pledge, however, be sold, in accordance with the power of sale given by the Act, the question presents itself - Is the pawnbroker to be regarded as warranting the title of the chattel sold? In Morley v. Attenborough ( $t$,

(ii) Per Lord Holt, C. J., Coggs v. Bermerd, 2 Ld. Raym. 917; I Sm.

J. C., Sth ed., 211.

(o) As to the right of the pawnee to sell the pledge, see Donald r. Suckling, I. IR. 1 Q. 13. 585 ; Halliday v. Holyate, L. R. 3 Ex. 299.

(p) Franklin r. Neate, 13 M. \& Wr. 481, 486. See Reeres v. Capper, j ling. N. C. 136 ; Flory v. Inemy, 7 F.xeh. 581.

(q) Cheesman r. Exall, 6 Exch. 341 ; Thurne r. Tillury, 3 If. \& $\mathrm{x}$. 534. Is "1) when a bailee may set up jus tertii, see Rogers r. Lambert, (1891) 1 Q. B. 318 (C. A.), approring Biddle v. Bond, o B. \& S. $225^{\circ}$.

(v) The statutes relating to pawnbrokers were consolidnted and amended by stat. 35 \& 36 Vict. c. 93 .

(s) Per Abbott, C. J., Walter $\mathbf{r}$. Swith, 5 B. \& Ald. 439, 441 .

(t) 3 Exch. 500. Ace. Judgm., Hall r. Conder, 2 C. B., X. S., 40 ; Smith r. Veale, Id. 67, 80, 89 ; Judgm., Enmerton v. Matherc8, 7 H. \&. .. 593 . 
the Court of Exchequer, after an examination of the earlier cases, came to the conclusion that there is no implied warranty of title on the sale of an ascertained chattel (u); and that, if there be no fraud, a vendor is not liable for a bad title, unless there is an express warranty, or an equivalent to it, by declarations or conduct $(x)$. Usage of trade, they remarked, if proved as a matter of fact, would, of course, be sufficient to raise an inference of such an engagement; and, without proof of such usage, the very nature of the trade may be enough to lead to the conclusion that the person carrying it on must be understood to engage that the purchaser shall enjoy that which he buys as against all persons $(y)$. Applying these remarlis to the case of a pawnbroker selling a forfeited pledge eo nomine, we infer that he must be considered as selling merely the right to the pledge which he himself had (z), as undertaking merely that the subject of sale is a pledge, and is irredeem-

(u) In a contract of sale, unless the circumstances show a different intention, a warranty of title is now implied. See the Sale of Goods Act, (1893) s. 12 , subs. 1 .

$(x)$ "It seems now to be well established that on the sale of a lease there is an implied contract on the part of the vendor, that he will show a good title in the landlord. But that may be dispensed with:" per Byles, J., Tweed r. Nills, L. R. 1 C. P. 45.

(y) In Sims v. Marryat, 17 Q. B. 291, Lord Campbell, C. J., after citing and approving of the judgment delirered by Parke, B., in Morley v. Attenborongh, supra, proceeds thus :"It may be that the learned Baron is correct in saying, that, on a sale of personal property, the maxim cavent emptor does by the law of England applr; but, if so, there are many exceptions stated in the judgment which will well nigh eat up the rule. Executory contracts are said to be excepted, 60 are sales in retail shops [or in a warehouse, Eichholz v. Bannister, 17 C. B., N.S., 708], or where there is an usage of trade: so that there may be difficulty in finding cases to which the rule would practically apply." See further, as to the point above adverted to, Westropp v. Solomon, 8 C. B. 345 , and cases there cited.

(z) See Chapman v. Speller, 14 Q. I. 621 ; Bagueley v. Hauley, I. R. 2 C. P. 625, 628, where Borill, C. J., says, "I cousider the general rule to he that upon the sale of goods there is no warranty of title implied by law."

In Morley r. Attenbororigh, 3 Exch. 514, the Court observes as follows:"It may be, that though there is no implied warranty of title, so that the vendor would not be liable for a breach of it to unliquidated damages, yet the purchaser may recover back the purchase-money, as on a consideration that failed, if it could be shown that it was the understanding of both parties that the bargain should be put an end to, if the purchaser should not have a good title. But if there is no impiied warranty of title, some circumstances must be shou'n to enable the plaintiff to recover for money had and received." See Gompertz r. Bartlett, 2 E. \& B. 849 . 
able, and that he (the vendor) is not cognisant of any defect of title to it. Under the circumstances here supposed, accordingly, a pawnbroker selling a forfeited pledge would not be liable to refund the purchasemoney if the vendee should afterwards be compelled to restore the chattel to some third party, as being the rightful owner of it $(a)$. Innkeeper-
liability of. loss of a guest's property whilst sojourning at his inn rests, not on mere reason, but on custom, growing out of a state of society no longer existing $(c)$. By legal implication, the property of the guest is deemed to be in the actual care and custody of the innkeeper, who is, with some rare exceptions, held responsible for its safety $(d)$, and has a right to make such charges as may compensate for the responsibility thus imposed on him (c). Upon this subject Calye's case $(f)$ is the leading authority, whence we deduce that, in order to charge a person with the responsibilities of an innkeeper, it must be shown that he is the keeper of a common "inn" $(g)$, i.e., of a house where the traveller is furnished with everything which he has occasion for whilst upon his way $(h)$.

Assuming the above condition to be satisfied, an innkeeper's liability seems closely to resemble-though it is not altogether so great as-that which attaches to a common carrier by our customary law. "An innkeeper," says Bayley, J. (i), "is primî facie liable for any loss not

(a) The Sale of Goods Act, 1893, has presumably made no change in the law in this respect.

(b) If goods be lost at an hotel, of which a company are proprietors, the action for compensation should be brought against the company, not against the paid manager: Dixon $r$. Birch, I. R. 8 Ex. 135.

(c) Per Coleridgc, J., 3 E. \& B. 159.

(c) I'er Wightman, J., 3 E. \& B. 15i. See Day r. Bather, 2 H. \& C. 11. (e) Per Erle, C. J., Holder P. Soulby, 8 C. B., N. S., 264 ; Calye's case, 8 Rep. 32 a., Ist Resol.

(f) 8 Rep. 32 ; Benwett r. Mellor, 5 T. R. 273; 2 R. R. 593.

(g) " Inn," hospitium, diversorium.

(h) Per Bayley, J., Thompson r. Lacy, 3 B. \& Ald. 286 ; 22 R. R. 385.

(i) Richmond v. Smith, 8 B. \& C. 9 ; Tent v. Shuckard, 2 B. \& Id. 803, shows that there is no distinction between money and goods as regards the innkeeper's liability. 
sccasioned by the act of God or the king's enemies, lithough he may be exonerated where the guest chooses so have his goods under his own care;" the latter part of his remark being well illustrated by the case of Burgess v. Clements $(k)$. The rule as to an innkeeper's liability seems, ndeed, substantially to be that indicated by the words of ihe writ in Calye's case, which alleges that " by the custom of the realm innkeepers are obliged to keep the goods and shattels of their guests who are within their inns $(l)$ without subtraction or loss day and night, so that no lamage in any manner shall thereby come to their guests rom the negligence of the innkeeper or his servants." The presumption of negligence from the mere fact of loss will, accordingly, be against the innkeeper; but it will be ppen to him to repel this presumption, by showing that the loss is attributable to the personal negligence of the zuest $(m)$, or to the act of God, or to vis major $(n)$, or hat the goods when the loss occurred were in the custody and under the control, not of himself but of his guest $(o)$. [n Cashill v. Wright ( $p$ ), the Court of Queen's Bench jhus stated the law "resulting from all the authorities" especting the common law liability of an innkeeper:"The goods [of the guest] remain under the charge of ihe innkeeper and the protection of the inn, so as to make the innkeeper liable as for breach of duty unless the aegligence of the guest occasions the loss in such a way is that the loss would not have happened if the guest had used the ordinary care $(q)$ that a prudent man may

(k) 4 M. \& S. $306 ; 16$ R. R. 473 ; cited 6 E. \& B. 895 . See also Reg.v. Rymer, 2 Q. B. D. 136, 140.

(l) See Jones v. Tyler, 1 Ad. \& E. 522 ; Strauss v. County Hotel Co., 12 Q. B. D. 27.

(m) Armistead v. Wilde, 17 Q. B. 261.

(n) See Walker v. The British
Guarantee Ass., 18 Q. B. 277.

(o) Judgm., MLorgan v. Ravey, 6 H. \& N. 277.

(p) 6 E. \& B. $891,900$.

(q) The legal meaning of "gross negligence" is "greater negligence than the absence of such ordinary care:" Judgm., 6 E. \& B. 899. 
be reasonably expected to have taken under the circumstances" $(r)$.

An innkeeper is responsible for the loss of goods, only. when they were received by him in that character; if not so received his liability will have to be determined by reference to the law of bailments generally $(s)$.

The liability of an innkeeper at common law, being such as above stated, has been materially diminished by the stat. $26 \& 27$ Vict. c. 41 , which enacts, section $1(t)$, that " no innkeeper shall be liable to make good to any guest of such innkeeper any loss of or injury to goods or property brought to his inn, not being a horse or other live animal, or any gear appertaining thereto, or any carriage, to a greater amount than the sum of $30 l$., except in the following cases-that is to say-1. Where such goods or property shall have been stolen, lost, or injured through the wilful act, default or neglect of such innkeeper, or any servant in his employ. 2. Where such goods or property shall have been deposited expressly for safe custody with such innkeeper, provided that in the case of such deposit the innkeeper may, if he think fit, require as a condition of his liability, that such goods or property shall be deposited in a

(r) Acc., Oppenheim r. White Lion Ilotel Co., L. R. 6 C. P. 515. As to what will amount to evidence of negligence, see Herbert v. Markwell, 45 I. T. 649 ; affirmed W. N. 1882, 112 . See also Medacar v. Grand Hotel Co., (1891) 2 Q. B. 11 (C. A.), where the guest was negligent, but it was impossible to show that his loss was the result of his negligence.

(s) As to the lien of an innkeeper, see Threfall v. Borwick, L. R. 10 (2. B. $210 ;$ Allen r. Smith, 12 C. B., N. S., 638 ; Broadicood v. Granara, 10 Exch. 417 ; Simith v. Dearlore, 6 C. B. 132 ; Angus v. McLachlan, 23 Ch. D. 330,336 ; Stat. 41 \& 42 Vict. c. $38, \mathrm{~s}, 1$-Gordon $\mathrm{v}$. Silier, 25 Q. H. D). 491 ; Robins r. Gray, (1895) 2 Q. 13. 301 (C. A.), aftirming Id. $78,-$ of a livery-stable keeper, see I'arsons v. Gingell, 4 C. B. $545,-$ of a trainer of race-horses, see Forth v. Simpson, 13 Q. B. 680 , - of a solicitor, see Cross r. Cross, 43 L. T. 533 ; Ex parte Fuller, re Long, 10 Ch. D. 617; Fouler r. Foucler, 50 I. J. Ch. 686; Re Tolemen, 13 Ch. D. 885 , - of a railwar upon articles deposited in their cloak rooms, Singer Mamufactyring Co. v. London and South.Western R. C., (1894) 1 Q. B. 338 .

(t) Of this section a copy must be exhibited in a conspicuous part of the hall or entrance to the inn, and the innkeeper will be entitled to the benefit of the Act in respect of such goods or property only as are brought to his inn while such cops is so exhibited: 8. 3. See Spice r. Bacm, 2 Ex. I. 463. 
box or other receptacle fastened and sealed by the person lepositing the same. Section 2 of the same statute further enacts, however, that "if any innkeeper shall refuse to eceive for safe custody, as before mentioned, any goods or oroperty of his guest, or if such guest shall, through any lefault of such innkeeper, be unable to deposit such goods or property as aforesaid," such innkeeper shall not be entitled to the benefit of the Act in respect thereof $(u)$.

In Medauar v. Grand Hotel Co. $(x)$ the facts were as ollows. Trinkets belonging to the plaintiff were stolen. [t ras impossible to prove whether the same were stolen when the plaintiff's luggage was in a bedroom or in a sorridor into which a servant of the hotel removed the uggage. If the former were the case, the defendant's regligence could have been shown to have been the cause of his loss; if the latter, the neglect of the innkeeper sould have entitled the plaintiff to recover the value of the rinkets, although exceeding $30 l$. The onus of proving segligence, whether in the guest or innkeeper, being upon he party relying upon it, the plaintiff recovered onfy $30 l$.

The liability of a boarding-house keeper in respect of the roperty of a guest who is lodging with him has not in any eported case been very clearly defined; it seems clearly, lowever, to be less than that of an innkeeper. But a soarding-house keeper is, at all events, bound to exhibit rdinary care towards the guest and his goods-to take as nuch care of the goods of the guest as an ordinary prudent rousekeeper would take of his own $(y)$. How far the keeper if a boarding-house may be answerable for the negligence If his servant, and what may be the extent and limits of

(u) The word "inn" used in the bove-mentioned statute "shall mean ny hotel, inn, tarern, public-house, or ther place of refreshment the keeper of rhich is now by law responsible for he goods and property of his guests," and the word " innkeeper" shall mean the "keeper of any such place."

(x) (1891) 2 Q. B. 11 (C. A.).

(y) Dansey r. Richardson, 3 E. \& B. 114 ; explained per Erle, C. J., Holder v. Soutby, 8 C. B., N. S., 266.
Boarding-

house

keeper-

liability of. 
the maxim Respondeat superior, in case of a loss of proper resulting to the guest from such negligence, the authoriti do not enable us precisely to determine $(z)$.

Lodging.

house

keeper-

liability of.

Land car. rier-liability of.

A lodging-house keeper is not responsible for a loss of $b$ lodger's goods which has arisen, not from his misfeasane but only from an absence of proper care $(a)$.

A bailee of goods, with a view to their being conveyed 1 him from place to place, may, it is conceived, fill one । other of the four following characters: 1. He may be gratuitous bailee, in which case, as already shown $(b), 1$ will be liable merely for gross negligence, and bound on to exercise slight diligence in reference to the goor entrusted to him. 2. He may be a bailee for hire-thouq not charged upon any custom of the realm-and boun. accordingly, to a greater degree of diligence $(c)$. 3. F may be a common carrier; or 4 . He may belong to sou particular class of carriers, whose liabilities are regulate by the statute law. To land carriers falling within eith of the two last-mentioned of the foregoing classes will tl following observations be restricted. In perusing them, tl reader will remember that several decisions, which by for of section $7(d)$ of the $17 \& 18$ Vict. c. 31 (the Railway ar Canal Traffic Act) are no longer applicable to compani brought within the scope of its provisions, are still bindir as authorities in other cases, and must not, therefore, 1 wholly lost sight of. It cannot, however, be denied th the decisions alluded to $(e)$, inasmuch as railway and can

(z) Dansey Y. Richardson, supra, where the Court of Queen's Bench was equally divided in opinion as to the above question. 254.

(a) Holder r. Soulby, 8 C. B., X. S.,

(b) Ante, p. 917

(c) See Ross v. Hill, 2 C. B. 877, where the action was brought for loss of luggage against a cab-driver, not charged as a common carrier: $W_{i l}$ loughby v. Horridge, 12 C. B. 742. A cab-proprietor will be liable on the ce tract of his licensed driver: Poocles Hider, 6 E. \& B. 207 ; approred Venables v. Sinith, 2 Q. B. D. 2' 283 ; approved in King $\mathrm{Y}$. London 1. proved Cab Co., 23 Q. B. D. 2. (C. A.); this last-mentioned c: overruled, King v. Spurr, 8 Q. B. 105 ; cf. Keen v. Henry, (1894) 1 Q. 292 (C. A.).

(d) Post, p. 937.

(e) Those decisions more particula I 
companies have to a great extent monopolised the inland aarrying trade of the country, are now invested with comparatively little value or importance.

A land carrier exercising his calling according to the custom of the realm-that is, publicly undertaking to carry ior hire the goods of such as choose to employ him $(f)$-is by the common law looked upon as an insurer; so that in the event of the goods entrusted to him being lost or damaged, to use the words of Sir $W$. Jones $(g)$, "nothing will excuse him except the act of God or of the ling's enemies;" the expression "act of God" being understood to signify inevitable overwhelming ( $h$ ) accident, and by the "king's enemies" being meant public enemies with whom the nation is at open war $(i)$.

which have reference to the validity of notices issued in regard to the conrejance of cattle by railway companies.

$(f)$ The question- Who is a common carrier? is considered in Story Bailm., 8th ed., p. 440; Scaife v. Farrant, L. R. 10 Ex. 358 ; distinguishing Liver Alkali Co. v. Johnson, L. R. 9 Ex. 338.

(g) Bailm., p. 104. See Phillips v. Clarke, 2 C. B., N. S., 156.

"To give due security to property," says Best, C. J., in Riley v. Home, 5 Bing. 220, "the law has added to that responsibility of a carrier which immediately rises out of his contract to carry for a reward, namely, that of taking all reasonable care of it, the responsibility of an insurer. From his liability as an insurer, the carrier is ouly to be relieved by two things, both so well known to all the country when they happen, that no person would be so rash as to attempt to prove that they had happened when they had not, namely, the act of God and the king's enemies."

Again, in Coggs v. Bernard, $2 \mathrm{Ld}$. Raym. 918, Lord Holt, C. J., observes that the law charges a common carrier "to carry goods against all events but acts of God and of the enemies of the king. For, though the force be nerer so great, as if an irresistible multitude of people should rob him, nevertheless he is chargeable: and this is a politic establishment, contrived by the policy of the law for the safety of all persons, the necessity of whose affairs obliges them to trust these sort of persons, that they may be safe in their ways of dealing: for else these carriers might have an opportunity of undoing all persons that had any dealings with them, by combining with thieves, \&c., and yet doing it in such a clandestine manner as would not be possible to be discovered: and this is the reason the law is founded upon in that point." See also, as to the liability of a common carrier, Bourne v. Gatliff, $11 \mathrm{Cl}$. \& F. 45 ; per Cotton, L. J., Berghein v. Great Eastern R. C., 3 C. P. D. 222, 223. But see 13 App. Cas. 31, and post, p. 945 .

(h) Oakley v. Portsmouth and Ryde Steam Paeket Co., 11 Exch. 618, 623. See Bridden v. Great Northern R. C., 28 L. J. Ex. 51 ; Great Western R. $C$. of Canada v. Braid, 1 Moo. P. C. C., N. S., 131. See Nichols v. Marsland, 2 Ex. D. 5 ; Nitro-Phosphate Co. v. St. Katharine's Docks Co., 9 Ch. D. 515, 516; Dixon v. Metrop. Board of Works, 7 Q. B. D. 418.

(i) Story, Bailm., 8th ed., pp. 26-29. See Mlorewood v. Pollok, 1 E. \& B. 743. 
"The carrier," it has been said, "is bound to do hi utmost to protect goods committed to his charge from loss or damage, and if he fails therein he become liable from the nature of his contract. . . . If, by hi default in omitting to take the necessary care, loss or damage ensues, he remains responsible, though the so. called act of God may have been the immediate cause 0 : the mischief" $(k)$.

A common carrier is not, however, liable "for accidents happening through the inherent vice of the thing in. sured" $(l)$.

The operation of the above general rule (which was sub ject to some few and unimportant exceptions merely), bein found prejudicial to carriers, was in practice greatly re stricted by issuing notices limiting the carrier's liability and acceded to as between himself and his customers. Tht precise modus operandi thus adopted for the protection 0 . the carrier was as follows:-a notice was issued by the carrier stating that " he would not be accountable for any property above a certain value, unless insured and paic for at certain extra rates at the time of delivery." Tc this notice, if proved to have come to the knowledge of the customer $(\mathrm{m})$, his assent was implied; so that the carrie; was protected accordingly, except, indeed, in the case 0 wilful misfeasance or gross negligence, which was heli not to be within the scope or purview of the notice os within the intention of the parties $(n)$.

(k) Per Cockburn, C. J., Niggent v. Smith, 1 C. P. D. 436, reversing $S . C$., Id. 19, where the question what constitutes an " act of God" was much considered.

(l) Per Willes, J., Blower v. Great Western R. C., L. R. 7 C. P. 663 ; Fendull v. London and South-Western R. C., L. R. 7 Ex. 373.

(in) See Rowley v. Horne, 3 Bing. 2; Judgm., Riley v. Horne, 5 Bing. 223; Clark v. Gray, 4 Esp. 177, 178. (n) A loss of goods by the felony o the carrier's servant would not neces sarily have resulted from gross negli gence so as to exclude the carrier fron the protection afforded by his notice See Butt v. Great Western R. C., l C. B. 140, explained in Metcalfe $v$ London, Brighton, \&c., R. C., 4 C. B. N. S., 309, 310, and in Great Wester R. C., app., Rimell, resp., 18 C. B 585 ; Finucane v. Small, 1 Esp. 315. 
In Riley v. Horne (o), the effect of a notice such as above alluded to was much considered, and the liability attaching to a carrier, as the law stood prior to the stat. $11 \mathrm{Geo} .4$ \& 1 Will. 4, c. 68 , was briefly defined per cur.; it is there said, "that a carrier is an insurer of the goods which he sarries; that he is obliged for a reasonable reward to carry any goods [unless specially dangerous $(p)$ ] to the place to which he professes to carry goods that are offered him $(q)$ if his carriage will hold them " [and he is informed of their quality $(r)$ and value] ; and further, that if he does not ask for this information, or if, when he asks and is not 3nswered, he takes the goods, he is answerable for their amount, whatever that may be; that he may limit his cesponsibility as an insurer by notice, but that a notice will aot protect him against the consequences of a loss by gross aegligence $(s)$.

The contract between the carrier and his customer may,

(o) 5 Bing. 217, 224; Izett v. Mountain, 4 East, 371 ; cited per Willes, J., MeAndrew v. Electrie Telegraph Co., 17 C. B. 17.

(p) $29 \& 30$ Vict. c. 69 , s. 6 . Repealed $38 \& 39$ Vict. c. 17 , s. 122 ; see sections 34,35 .

(q) "At common law a carrier is not bound to carry for every person tendering goods of any description, but his obligation is to carry aceording to his oublic profession. . . . A person may profess to carry a particular description of goods only; for instance, sattle or dry goods, in which case he could not be compelled to carry any other kind of goods, or he may limit his obligation to carrying from one place to another, as from Manchester to London; and then he would not be bound to carry to or from the intermediate places. Still, until he retracts, every individual (provided he tenders the money at the time, and there is room in the conveyance) has a right to call upon him to receive and carry goods according to his public profesion:" per Parke, B., Johnson v. Midland R. C., 4 Exch. $3 \pi 2,373$, cited 7 Exch. 712 ; and followed in Re Oxlade and North-Eastern R. C., 15 C. B., N. S., 693, 694; Crouch v. London and North-Western R. C., 14 C. B. 255 ; per Crompton, J., 5 E. \& B. 868; Judgm., Garton v. Bristol and Exeter R. C., 1 B. \& S. 162.

See further, as to the obligation of a carrier, Hales v. London and NorthWestern R. C., 4 B. \& S. 66; Taylor v. Great Northern R. C., L. R. 1 C. P. 385 ; Riehardson v. Great Eastern R. C., 1 C. P. D. 342.

(r) See Lebeau v, Gen. Stcam Nav. Co., L. R. 8 C. P. 88.

A carrier is not in all cases entitled to know the nature of goods tendered to him for carriage. See per Jervis, C. J., and Maule, J., 14 C. B. 291, $294,295$.

(s) See Phillips v. Clark, 2 C. B., N. S., 156 ; cited in Steel, app., State Line Steamship Co., resp., 3 App. Cas. 88; followed in Tattersall v. National Steamship Co., 12 Q. B. D. 297 ; Phillips v. Edwards, 3 H. S N. 813 ; The United Service, 8 P. D. 56 ; 9 Id. 3. 
however, be rescinded by the former on the ground o fraud $(t)$.

Such being, in brief, the liability of a carrier for loss o or damage done to goods entrusted to him at common law the operation of the Carriers' Act $(u)(11$ Geo. $4 \& 1$ Will. 4 c. 68) upon his liability has been this: as regard: certain articles $(x)$ enumerated in section 1 of the Act including (amongst other things) gold or silver coin jerrellery, trinkets $(y)$, bills, bank-notes, securities for thr payment of money $(z)$, pictures $(a)$, plate, china, silks $(b)$ furs, or lace $(c)$, being articles possibly of much valut although of little bulk, it is provided that the carrier shal not be liable for the loss of or any injury to any " parcel or package" $(d)$ containing such articles-when exceeding it value 10l.- - unless the value and nature of the article shal have been declared, at the time of its delivery, by the person sending or delivering the parcel, and an increasec charge for carriage or an engagement to pay the same be accepted by the party receiving it $(e)$. By section 2 the carrier will be entitled to demand $(f)$ for the carriage 0 :

(t) Clough r. London and NorthWestern R. C., L. R. 7 Ex. 26, cited in Morrison r. Universal Marine Insurance Co., L. R. 8 Ex. 203.

(u) Which applies where there is one entire contract to carry partly by land and partly by sea, such contract being divisible so that as to the land journey the carrier is within the protection of the Act : Le Conteur v. London and South-Mestern R. C., L. R. 1 Q. B. 54 .

(x) Things accessory thereto would also be within the protection of the above scction. See Henderson v. London and North-Western R. C., L. R. 5 Ex. 90 ; Treaduin r. Great Eastern R. C., L. R. 3 C. P. 308.

(1) Sec Bernstein r. Baxendale, 6 C. B.. X. S., 251 .

(z) See Stoessiger r. South-Eastern R. C., 3 E. \& B. 549.

(a) See Wooduard v. London and North. Western R. C., 3 Ex. D. 121.

(b) See lirunt . Midland $R$. C., 2 II. \& C. 889. (c) Being other than machine-made See $28 \& 29$ Vict. c. 94 , s. 1.

(d) As to the question, what is : "parcel or package" within section ? of the Carriers' Acts, see Whaite $r$ Lancashire and Yorkshire R. C., L. R 9 Ex. 67.

(e) By section 7 , where any parce has been delivered to the carrier, it ralue and contents declared, and as increased rate paid for carriage, thi customer may, in the event of thi parcel being lost or damaged, recores the increased charge so paid, in addi tion to the valne of the parcel. See further, as to the measure of damage in an action for loss of or damage don to goods confided to a common carrier section 9 .

( $f$ ) It is incumbent on the carrie to demand-not on the customer to tender-the increased charge: Grea Northern R. C., app., Behrens, resp. 7 H. \& N. $950 ; S . C .6$ Id. 366. 
iny parcel containing any of the articles specified in soction 1 of the Act an increased rate of charge, to be rotified by some notice $(g)$ affixed in legible characters in a Jublic and conspicuous part of the office or receiving house (h) of the carrier, in which case the party forwarding goods will be bound by the notice without any further proof being yiven of its having come to his knowledge. By section 3 the carrier must also (if required so to do) give a receipt to the sender for the amount paid for carriage of any article the value of which has been declared as above mentioned; and "if such receipt shall not be given when required, or such notice as aforesaid shall not have been affixed," the carrier will be disentitled to any benefit or advantage under the Act, but will be responsible as at common law and liable to refund to his customer the increased rate of charge paid by him.

Again, section 4 of the Act invalidates all notices issued for the purpose of limiting the carrier's liability in respect of articles not enumerated in section 1. By section 6, nothing in the Act shall "extend or be construed to annul or in anywise affect any special contract" (i) which may be entered into between a common carrier and another party for the conveyance of merchandise and goods, and which may in express terms limit the carrier's liability; it being "open to carriers to limit their common law liability by special agreement with the consignors of goods" $(k)$. Section 8 further provides, that nothing in the Act contained shall be deemed to protect any mail contractor, stage-coach proprietor, or other common carrier for hire from liability to answer for loss of or injury to "any goods or articles

(g) See Owen v. Burnett, 4 Tyr. 134 a.

(h) See section 5 of the above Act; Syms v. Chaplin, 5 Ad. \& E. 634.

(i) As to which see $D^{\prime} A$ re v. London and North-Western R. C., L. R.
9 C. P. 325; Baxendale v. Great Eastern R. C., T. R. 4 Q. B. 244.

(k) P. and O. Steam Nav. Co. v. Shand, 3 Moo. P. C. C., N. S., 272, 293. 
whatsoever arising from the felonious acts of any coachman, guard, book-keeper, porter, or other servant in his or their employ, nor to protect any such coachman, guard, book-keeper, or other servant from liability for any loss or injury occasioned by his or their own personal neglect or misconduct" $(l)$.

Now, the first general remark to be made with reference to the Carriers' Act is, that neither by it nor by the special contract between parties (if there be one) are common carriers brought into the position of ordinary bailees for hire. They still continue common carriers, and liable to all the duties attaching to them in that character, except so far as they are qualified by the statute where the statute applies, or by the special contract where the special contract applies $(m)$. And it has been repeatedly held that railway companies invested by statute with permissive powers to act as carriers become, if they avail themselves thereof, subject to the liabilities imposed on common carriers by our customary law $(n)$. Bearing this in mind, we shall find, that, under the statute, persons sending goods of a particular description and value by a carrier, when they deliver them at his office are bound to give him information of their nature and value $(o)$. If the sender of the goods omits to give this information, he will be disentitled to sue the carrier for loss $(p)$ of the goods, eren

(l) Stephons v. London and South. Western R. C., 18 Q. B. D. 121.

(m) Per Maule, J., Butt v. Great Meste'n R. C., 11 C. B. 152.

(n) See, for example, Palmer . Grand Junction R. C., 4 M. \& W. 749, 766; Pickford v. Grand Junction R. C., 10 M. \& W. 399,422 ; followed in Baxendale r. Great Western R. C., 14 C. B., X. S., 1, aftirmed 16 Id. 137.

(o) Havt v. Baxendale, 6 Exch. 769 ; Judgm., Great Northern R. C., app., Lehrens, resp., 7 H. \& N. 953; Simith v. London, Brighton, and South Cuast R. C., 7 C. B. 782 ; but see p. 933 n. (r). ip) Section 1 of the Act applies to protect the carrier where the chattel is either abstracted, lost, or injured whilst in his personal care, but not in cases where the owner of the article sufiers or sustains damage from the refusal of the carrier to take goods: Pianciani v. London and South- IV estern R. C., 18 C. B. 226 ; - or from the neglect of the carrier to deliver in due time: Hearn v. London and SouthWestern R. C., 10 Exch. 793. A carrier, however, is not deprived of the protection afforded by the Act merely by the fact that the loss of the goods is temporary, and not permanent ; nor can 
where occasioned by gross negligence $(q)$, provided there be no wilful neglect, no misfeasance, nor abandonment of the character of carrier $(r)$; though to such a defence under the statute plaintiff may reply that the loss arose through the felonious act of the carrier's servant $(s)$, for, in this latter case, the statute would not afford protection $(t)$.

Another condition, however, must be fulfilled in order that the carrier may be entitled to demand an extra charge for carrying the goods specified in section 1 of the Carriers' Act: he must comply with the requirements of section 2 of the Act in putting up the notice in his office; he must also give a receipt, if required, for the amount paid for carriage.

Such being the effect of a notice restricting the carrier's liability, whether at common law or under the provisions of the Carriers' Act, it becomes necessary to examine the effect and operation of the stat. $17 \& 18$ Vict. c. 31 , which applies, however, exclusively to railway and canal companies, and moreover expressly provides, that nothing therein contained shall alter or affect the rights, privileges, or liabilities of any such company under the 11 Geo. 4 \& 1 Will. 4 , c. 68 , with respect to articles of the descriptions

the owner of goods, which ought to hare been but were not declared pur. suant to the statute, recover damages for the consequences of their loss as distinguished from the loss itself: Millen $\mathrm{v}$. Brasch, 10 Q. B. D. 142, and cases there cited.

(q) Great Western R. C., app., Rimell, resp., 18 C. B. 575 ; Metcalfe r. London, Brighton, \&c., R. C., 4 C. B., N. S., 307 .

(r) See Hinton v. Dibbin, 2 Q. B. 646 ; cited in Morritt v. North-Eastern R. C., 1 Q. B. D. 302,$309 ; W y l d$ v. Pickford, 8 M. \& W. 443, as explained by Jervis, C. J., in Butt v. Great Western R. C., 11 C. B. 150; Smith r. London and Brighton R. C., 7 C. B. 782. The meaning of the term "gross negligence" is examined minutely in
Judgm., Austin v. Manchestcr, Sheffield, and Lincolnshire R. C., 10 C. B. 474,475 .

(s) As to the proofs in support of this replication, see Vaughton $\checkmark$. London and North-Western R. C., L. R. 9 Ex. 93.

(t) Section 8, as explained per Platt, B., Machu v. London and South: Western R. C., 2 Excl. 432 (who observes, that "its effect is to take out of the operation of the statute all losses occasioned by felony on the part of persous who, in the case of loss, might be treated as servants of the carrier"): Metcalfe r. London, Brighton, $\& \cdot c$., R. C., 4 C. B., N. S., 307, 311. See Way v. Great Eastern R. C., 1 Q. B. D. 692; $I^{\prime}$ Queen v. Great Western R. C., L. R. 10 Q. B. 569 . 
mentioned in that Act. The Railway and Canal Traffic Act has reference then to articles not brought within the provisions of the prior statute-especially to cattle and other animals, which form an important item in the carrying trade of our great companies. Section 7 of the Act alluded to enacts, that every company to which it applies (u) "shall be liable for the loss of, or for any injury done to any horses, cattle, or other animals $(x)$, or to any articles, goods, or things in the receiving, forwarding, or delivering thereof, occasioned by the neglect or default of such company or its servants, notwithstanding any notice, condition, or declaration being made and given by such company contrary thereto, or in anywise limiting such liability $(y)$; every such notice, condition, or declaration being hereby declared to be null and roid: provided always, that nothing herein contained shall be construed to prevent the said companies from making such conditions with respect to the receiving, forwarding, and delivering of any of the said animals, articles, goods, or things as shall be adjudged by the Court or Judge before whom any question relating thereto shall be tried to be just and reasonable (z). Provided always, that no greater damages shall be recovered for the loss of or for any injury done to any of such animals beyond the sums"

(u) See section 1 (the interpretation clause). Where section 7 does not apply, the liability of the company may hare to be determined by reference to the ordinary law of bailment. See Richardson v. Worth-Eastern R. C., L. R. 7 C. P. $75,81$.

(x) $\mathrm{A} \operatorname{dog}$ is within these words: Harison v. London, Brighton, \&c., R. C., 2 B. \& S. 122, 152. See Ashendon $v$. London and Drighton $R$. C., 5 Exch. D. 190; Dickson r. Great Western R. C., 18 Q. B. D. 176.

(y) A passenger's luggage is within the above words: Cohen v. SouthEastern R. C., 2 Ex. D. 253.

(z) See Leucis v. Great Western R. C., 3 Q. B. D. 195 (in which case Peek r. North Staffordshire R. C., 10 H. L.
Ca. 473, was much considered, and the meaning of the words "wilful misconduct" was discussed); Harrison v. Lowdon, Brighton, \&c., R. C., 2 B. \& S. 122 (orerruled as to reasonableness of notice by Pcek r. North Stafford. shire R. C., 10 H. L. Ca. 473 , per Hawkins, J., Ashendon r. London, Brighton, \&c., R. C., 5 Ex. D. 190 ; but see Manchester, Sheffield, \&c., $R$. C., v. Broun, 8 App. Cas. 703, 710, 716); Doolan v. Midland R. C., 2 Apv. Cas. 792 ; Beal r. South Devon R. C., 3 H. \& C. 337 ; Lord v. Midland $R$. C., L. R. 2 C. P. 339 ; Rooth $\mathrm{v}$. NorthEastern R. C., L. R. 2 Ex. 173 ; Cutler r. London and North-Western R. C., 19 Q. B. D. 64. 
specified in the Act (a), "unless the person sending or delivering the same to such company shall, at the time of such delivery, have declared them $(b)$ to be respectively of higher value" than that mentioned in the Act, " in which case it shall be lawful for such company to demand and receive, by way of compensation for the increased risk and care thereby occasioned, a reasonable percentage upon the excess of the value so declared above the respective sums so limited as aforesaid, and which shall be paid in addition to the ordinary rate of charge: and such percentage or increased rate of charge shall be notified in the manner prescribed in the statute 11 Geo. $4 \& 1$ Will. 4 , c. 68 , and shall be binding upon such company in the manner therein mentioned (c) : provided also, that the proof of the value of such animals, articles, goods, and things, and the amount of the injury done thereto, shall in all cases lie upon the person claiming compensation for such loss or injury" $(d)$.

The true construction of the earlier portion of the clause above set out may, according to Lord Westbury, C. (e), be expressed in few words. "I take it," said his Lordship, "to be equivalent to a simple enactment, that no general notice given by a railway company shall be valid in law for the purpose of limiting the common law liability of the company

(a) That is to say-for any horse, $50 l$.; for any neat cattle, per head, $15 l$; for any sheep or pigs, per head, $2 l$.

(b) See Robinson v. London and South-Western R. C., 19 C. B., N. S., 51 ; M'Cance v. London and NorthWestern R. C., 3 H. \& C. 343 ; Hodgman v. West Midland $R$. C., 5 B. \& S. 173, 187, affirmed, 6 Id. 560.

(c) Ante, p. 935 .

(d) Section 7 does not apply to a contract exempting a railway company from loss on a railway not belonging to or worked by the company: Zunz v. South-Eastern R. C., L. R. 4 Q. B. 539. See, as to this case, Watkins v. Rymill, 10 Q. B. D. 178.

(e) Peek v. North Staffordshire $R$.
C., 13 H. L. Ca. 566; per Williams, J., 4 H. \& N. $349 ;$ Ir'Manus $\vee$. Lancashire and Yorkshive R. C., 4 H. \& N. 327 (commented on in Beal v. South Devon R. C., 5 H. \& N. 875); $M^{\prime}$ Cance v. London and NorthWestern R. C., 7 H. \& N. 477 ; Harrison v. London and Brighton R. C., 2 B. \& S. 152; Gregory v. West Midland R. C., 2 H. \& C. 944 ; Simons v. Great Western R. C., 18 C. B. 805 ; followed in Garton v. Bristol and Excter R. C., 1 B. \& S. 162 ; London and North-Westcrn R.C. v. Dunham, 18 C. B. 826 ; Lewis v. Great Western R. C., 5 H. \& N. 867; Allday v. Great Westcrn R. C., 5 B. \& S. 903. 
as carriers. Such common law liability may be limited by such conditions as the Court or Judge shall determine to be just and reasonable, but with this proviso, that any such condition so limiting the liability of the company shall be embodied in a special contract in writing between the company and the owner or person delivering the goods to the company, and which contract in writing shall be signed by such owner or person."

A condition which, if embodied in a contract between a railway company and the owner of goods delivered to be carried by that company, would exempt the company from responsibility for damage done to the goods however caused -including, therefore, gross negligence, and even fraud or dishonesty on the part of the servants of the companywould be neither just nor reasonable $(f)$.

Prior to the Railway and Canal Traffic Act above in part set out, a special contract for the conveyance of goods or cattle between a railway company and their customer (which, as already shown, was unaffected by the Carriers' Act $(g)$ was usually evidenced by some memorandum appended to the receipt given at the company's receiving house for goods, \&c., brought thither for conveyance by train, the carriage of which was paid there; and to the validity of such a contract the signature of the consignor (or his agent) was held not to be indispensable or essential, provided that his assent to the restrictive conditions put forth by the company could from the facts adduced in evidence fairly and reasonably be inferred $(h)$. Consequent on the decisions of our Courts touching the special contracts referred to, a wide immunity

(f) Peek v. North Staffordshire R. C., 10 II. I. Ca. 473 (where the cases are collected); Aldridge $\mathbf{\text { v. Great }}$ Uestern R. C., 15 C. B., N. S., 582 ; Lewis v. Great Western $R$. C., 3 Q. B. D. 195 ; Manchester, Sheffield, dc., R. C. v. Brown, 8 App. Cas. 703, $710,716$. (g) Section 6.

(h) See per Coleridge, J., Great Northern $R$. C. v. Morville, 21 L.J. Q. B. 319 ; Fork, Nercastle, and Beruick R. C. v. Crisp, 14 C. B. 527 ; Walker v. York and North Midland R. C., 2 E. \& B. 750,762 . 
from liability was enjoyed by railway companies acting as carriers of cattle or goods, to curtail which within more reasonable limits the $17 \& 18$ Vict. c. 31 , s. 7 (which, it must be remembered, applies to such goods and articles merely as are not within the provisions of the Carriers' Act), provides that " no special contract" between a railway or canal company and any other parties "respecting the receiving, forwarding, or delivering of any animals, articles, goods, or things," as in the statute mentioned, "shall be binding upon or affect any such party unless the same be signed by him or by the person delivering such animals, articles, goods, or things respectively for carriage" (i).

Assuming that the requirements of the Carriers' Act have been duly observed, and that there was no fraud, inducing the consignor to sign the contract $(k)$, the cases below cited will suffice to show how effectually the liability attaching to a railway company as common carriers may, by means of a special contract, be restricted $(l)$. A condition contained in the contract, exempting the company from liability for loss of or injury to cattle caused by restiveness, would not relieve them from liability for damage resulting from the negligence of their servant $(m)$.

(i) As to what will constitute a special contract under the abore section, see Peek v. North Staffordshive R. C., 10 H. L. Ca. 473 ; S. C., E. B. \& E. 958,986 ; Aldridge v. Great Western R. C., 15 C. B., N. S., 582; Manchester, Sheffeld, \&c., R. C. v. Brown, 8 App. Cas. 703, 710, 716.

(k) Simons v. Great Western R. C., 2 C. B., N. S., 620.

(l) White v. Great Western R. C., 2 C. B., N. S., 7 ; Pardington v. South Wales R. C., 1 H. \& N. 392; Shaw v. York and North Midland R. C., 13 Q. B. 347; Austin v. Manchester, Sheffield, and Lincolnshire R. C., 16 Q. B. 600 , and 10 C. B. 454 ; Carr v. Lancashire and Forkshire R. C., 7 Exch. 707 ; Crouch v. London and North-Western R. C., 7 Exch. 705; Chippendale v. Lancashive and York- shire R. C., 21 L. J. Q. B. 22 ; Slim v. Great Northern R. C., 14 C. B. 647 ; Hughes v. Great Western R. C., 14 C. B. 637 ; Walker v. Fork and North Midland R. C., 2 E. \& B. 750 ; Fork, Newcastle, and Berwick R. C. v. Crisp, 14 C. B. 527.

The doctrine as to " contributory negligence" (ante, p. 787) may sometimes apply to relieve a carrier from liability. See Wise v. Great Western R. C., I H. \& N. 63 ; Hutchinson v. Guion, 5 C. B., N. S., 149 ; Brass v. Sraitland, 6 E. \& B. 470 ; followed in Farrant v. Barncs, 11 C. B., N. S., 553, 562; Richardson r. NorthEastern R. C., L. R. 7 C. P. 75.

(m) Gill v. Manchester, Sheffield, and Lincolnshive R. C., L. R. 8 Q. B. 186. 
Prior to the stat. $17 \& 18$ Vict. c. 31 , it was held, that a special contract would relieve from liability a railway com. pany undertaking to deliver goods to a consignee beyond the limits of its own line, but declaring that it would not be responsible for any loss of or damage done to such goods beyond certain limits specifically indicated; and that where a railway company receives a parcel for carriage to a point beyond that to which its own means of conveyance extend the question whether it is liable or not for its loss in transitu to that point from its own terminus will depend upon the nature of the contract for conveyance actually entered into-was it a contract to carry the parcel, or to cause it to be carried to its final destination, or was it a contract to carry as far as its own line may extend, and then to transfer the goods to another carriage $(n)$ ? It is clear that where such a company undertakes to convey the customer's goods for an entire journey or transit, the company will be liable for a loss of the goods occasioned during the transit by the neglect of any person other than themselves who may at the time of the loss, in point of fact, be carrying them $(o)$. It seems also clear that the company actually in charge of the goods will be liable for a breach of duty in case of their loss, apart from contract $(p)$. The points thus decided hold in regard to cases falling within the provisions of sections 2 and 7 of the Railway and Canal Traffic Act. And it has further been enacted, that where a company by through-booking contracts to carry any animals, luggage, or goods from place to place, partly by railway or canal and partly by sea, a condition

(n) Fowles v. Great Western R. C., 7 Exch. 699.

(o) Bristol and Exeter R. C. r. Collins, 7 H. L. Ca. 194 : Mytton r. Midland R. C., 4 II. \& $\dot{X} .615$; following Muselomp v. Manchester and Preston R. C., 8 M. \& W. 421; Coxon r. Great Viestern R.C., 5 H. \& N.
274; Scothorn r. South Staffordshire R. C., 8 Exch. 341 .

(p) Foulkes v. Metropolitan R. C., 5 C. P. D. 157, orerruling on this point Mrytton $\mathrm{v}$. Midland $R$. C., $4 \mathrm{H}$. \& N. 615, per cur. Hooper v. London and North-Western $R$. C., 5 L. J. Q. B. 103. 
exempting the company from. liability for any loss or damage which may arise during the carriage of such animals, luggage, or goods by sea, from " the act of God, the king's enemies, fire, accidents from machinery, boilers, and steam, and all and every other dangers and accidents of the seas, rivers, and navigation of what nature and kind soever," shall, if published conspicuously in the office where such through-booking is effected, and if legibly printed on the receipt or freight note given by the company for the animals, luggage, or goods, be valid as part of the contract between the consignor and the company, in like manner as if the company had signed and delivered to the consignor a bill of lading containing such condition $(q)$. And where a railway company works steam vessels in connection with its land traffic, the provisions of the stat. 17 \& 18 vict. c. 31, so far as applicable, have been extended to such steamers and the traffic carried on thereby $(r)$; and some special regulations for securing equality of treatment of passengers using such steamers have been provided ( $s$ ).

Questions of more or less difficulty, to which an allusion merely must suffice, may sometimes arise as to whether the goods alleged to have been lost or injured were at the time of the loss or injury sustained in the custody of a railway company as carriers $(t)$ : whether the goods were delivered by the consignor in accordance with or in violation of the known course of business of the company $(u)$; whether the goods were accepted or dealt with on behalf of the company by its servant or agent duly constituted and acting within the scope of his powers $(w)$; it may, however, safely be laid down

(q) $31 \& 32$ Vict. c. 119 , s. 14 .

(r) 26 \& 27 Vict. c. 92 , s. 31. Where the vessel is not owned by or worked by the company, see $34 \& 35$ Vict. c. 119 , s. 12 . Cf́. also 57 \& 58 Vict. c. 60 , ss. 502,503 .

(s) $51 \& 52$ Vict. c. 25, s. 28.

(t) See Giles v. Taiff Vale R. C., 2 E. \& B. 822 . As to when common carriers cease to be such and become warehousemen, see Chapman r. Great Western R. C., 5 Q. B. D. 278.

(u) Slim v. Great Northern R. C., 14 C. B. 647 .

(w) See Giles v. Taff Vale R. C., supra; Roe v. Bivkienhead, \&c., R. C., 7 Exch. 36 ; cited 6 H. \& N. 364, 365. 
as a proposition holding generally true, that when once a railway company "have held themselves out to be comnion carriers there is engrafted upon their acceptance of the goods to be carried a common law liability to carry to all places to which they profess to carry $(x)$, exen if one of those places should be beyond the confines of the realm " $(y)$. So, likewise, " they must equally take upon themselves the other part of the common law liability of carriers, viz., an obligation to accept all goods which are reasonably offered to them for conveyance to and from the places to which they profess to carry, whether one of those places be without the rcalm or not " $(z)$. There is, however, no obligation on a railway company, whether at common law or under the Railway and Canal Traffic Act, to carry goods otherwise than according to their profession $(a)$.

Again, where a passenger travelling by railway takes with him an amount of luggage (b) not exceeding that which he is allowed to take under the bye-laws $(c)$ of the company without being subjected to the payment of any extra charge, the company will not, in respect of the luggage, stand on the footing of mandataries or gratuitous bailees for the benefit of the bailor, and be bound therefore to use only a slight degree of diligence, but they will be liable for loss of the luggage in their capacity of carriers, and such liability will have to be determined at common law $(d)$; or by refer-

(x) Per Crompton, J., Denton r. Great Worthern R. C., 5 E. \& B. 868.

(y) Crouch v. London and WorthWestern R. C., 14 C. B. $255,290$.

(z) Id.

(a) Re Oxlade and North-Eastern R. C., 15 C. B., X. S., 680.

(b) This term "comprises clothing, and such articles as a traveller usually carries with him for his personal convenience:" vide per Pas'ke, B., Great Northern R. C. v. Shepherd, \& Exch. 38; Macrow v. Great Western R. C., L. R. 6 Q. B. 612 ; which cases also show that the company will not, in the absence of notice, be responsible for the loss of merchandise packed in the luggage. Acc. Cahill r. London and North-Western R. C., 13 C. B., N. S., 818; S. C., 10 Id. 154: Belfast and Ballymenr, \&c., R. C. v. Keys, 9 H. L. Ca. 556. See also Hudston r. Midland R. C., L. R. 4 Q. B. 366 ; Phelps v. London and Torth-Westerm R. C., 19 C. B., N. S., 321.

(e) See Great Worthern R. C. F. Shepherd, 8 Exch. 30.

(d) Story, Bailm., 8th ed., p. 448 . 
ence to the provisions of the Carriers Act; or by looking at the terms of any special contract bearing upon the point in question which may have been entered into $(e)^{\prime}$; or, lastly, if need be, at the bye-laws of the company, and the rules and regulations made under the powers conferred upon them $(f)$. If the luggage of a passenger is at his request placed in the carriage with him, the company's contract to carry it safely is subject to an implied condition that the passenger takes ordinary care of it, and should his negligence cause the loss of the luggage, the company will not be answerable for it $(g)$. And it has been expressly held that a railway company are not insurers in respect of luggage placed at a passenger's request in the compartment in which he intends to travel should the luggage be lost or stolen without negligence on their part $(h)$. The general principle applicable in such cases has been recently stated as follows :-So long as a passenger's luggage, intended to be taken in the train with the passenger, is in the custody of a porter for the purpose of the transit, either at the commencement or conclusion of the journey, the railway company are common carriers of it, but while it is in the carriage, and partially under the control of the passenger, the railway company are not common carriers, but are liable as carriers for negligence only (i).

(e) Van Toll v. South-Eastern R. C., 12 C. B., N. S., 75 ; Stallard v. Great Western R. C., 2 B. \& S. 419,425 ; Cohen v. South-Eastern R. C., 2 Ex. D. 253.

(f) See Mrunster v. South-Eastern R. C., 4 C. B., N. S., 676 ; Williams v. Great Western R. C., 10 Exch. 15 (where a bye-law unduly restricting the liability of the defendants was held bad); Great Western R. C. v. Goodman, 12 C. B. 313 ; Stewart v. London and North-Wester'n R. C., 3 H. \& C. 135.

(g) Talley v. Great Western R. C., L. R. 6 C. P. 44

(h) Bergheim v. Great Eastern R. C., 3 C. P. D. 221 . The reasoning in B.C.L.
Bergheim v. Great Eastern R. C. was disapproved in Bunch $\mathrm{v}$. Gieat Western R. C., $13 \mathrm{App}$. Cas. 31 . The railway company under such circumstances enter into a contract as common carriers, subject to this modification: that in respect of his interference with their exclusive control of his luggage the company are not liable for any loss or injury occurring during its transit to which the act or de. fault of the passenger has been contributory (semble by Lord Halsbury, L. C., and Lords Watson, Herschell, and Hacnaghten (Lord Bramwell dissenting).

(i) Per Lord Esher, M. R., Bunch r. Great Western R. C., ubi supr. Compare Welch v. London and NorthWestern R. C., 34 W. R. 166. 
As to the commencement and termination of a railway company's liability in respect of luggage, we may say tha where the passenger has delivered his luggage to one of the servants of the company with a view to its being labeller and placed in the luggage van for the purpose of conveyance the company will, in the event of a subsequent loss of th luggage, clearly at common law be responsible for it (k) And the action, being here founded on the breach of dutynot on contract $(l)$-will lie at suit of a servant whose fart was paid by his master, with whom he was travelling wher the loss occurred $(m)$. An action will also lie at the suit 0 the master where property belonging to the master, which is carried as the servant's personal luggage, is damaged by the misfeasance of the railway company $(n)$. In general however, if the company be sued for breach of contract whether in not carrying a passenger (o), for loss 0 : baggage $(p)$, or otherwise $(q)$, the rule noticed in a formes Chapter $(r)$ respecting privity must be observed.

Lastly, it may be noticed, that land-carriers usually undertake, expressly or impliedly, to deliver goods $(s)$, anc cannot be said to have fulfilled their contract to carry without delivery $(t)$. "The duty of common carriers," remarks Wilde, C. J. $(u)$, "by the common law is perfectly wel. understood; it is a warranty safely and securely to carry

(k) Great Western R. C. v. Goodman, 12 C. B. 313.

(l) Tattan r. Great Western R. C., 2 E. \& E. 844.

(m) Marshall v. Fork, Nexcastle, and Beruick R. C., 11 C. B. 655: Austin $\mathrm{v}$. Great Western R. C., I. R. 2 Q. B. 442.

(n) Menx r. Great Eastern R. C., (189.) 2 Q. B. 387 (C. A.).

(o) Jennings r. Great Northern R. C., L. R. 1 Q. B. 7. Seo Dearden จ. Tounsend, Id. 10.

(p) Martin v. Great Indian Pen. R. C., L. R. 3 Ex. 9.

(q) Alton v. Midland R. C., 19 C. B., N. S., 213 ; Becher v. Great Eastern R. C., L. R. 5 Q. B. 241. (r) Book II., Chap. 1.

(s) Shepherd v. Bristol and Exotel $R$. C., L. R. 3 Ex. 189. As to thi carrier's duty in regard to the goods i: payment of the carriage be refused, ser Great Western R. C. . . Crouch, $3 \mathrm{H}$ \& N. 183; Hudson v. Baxendale, H. \& N. 575 . As to the carrier' duty in regard to the goods if the con signees fail to take delirery of them see Great Northern R. C. v. Sicaffield L. R. 9 Ex. 132 ; Heugh v. Londos and North-Western R. C., L. R. 5 Ex 51 ; Mitchell $\mathrm{r}$. Lancashire and Iork shire R. C., L. R. 10 Q. B. 256.

(t) Per Cressuell, J., 7 C. B. 859.

(u) 7 C. B. 858. 
whether they be guilty of negligence or not is immaterial ; the warranty is broken by the non-conveyance or nondelivery of the goods intrusted to them."

Where the luggage travels by the same train as the passenger, but not under his control, it is the duty of the railway company when the luggage reaches its destination to have it ready for delivery upon the platform at the usual place of delivery until the owner can, exercising due diligence, receive it; and the liability of the company does not cease before the expiration of a reasonable time allowed for such purpose $(x)$. Where, moreover, the company are in the habit of delivering the passengers' luggage at the end of the journey in a particular manner, with a view to their (the passengers') convenience-as by employing porters to carry it across the platform to the vehicles by which it is to be taken away-the company's liability as carriers. will continue until the porters have so discharged their duty $(y)$, in the absence of proof of any agreement by the plaintiff to accept a delivery of his luggage short of the ordinary delivery and in the absence also of proof that the porter was deputed or specially employed by the plaintiff to conver the luggage to the carriage $(z)$. In any such case, however, some evidence of the non-performance of the defendant's contract must be given by the plaintiff $(a)$, so as to shift the burthen of proof on to the other party (b).

Such being a brief view of the liabilities of carriers of goods by our law, and more especially of railway companies when acting in that capacity, allusion must be made to that Tort by third persons to chat. tels under bailment. particular subdivision of torts to personalty which comprises

(x) Patscheider v. Great Western $R$. C., 3 Ex. D. 153, 156, citing Richards ₹. London, Brighton, and South Coast R. C., 7 C. B. 839 ; distinguished in Hodkinson v. London and North-Western R. C., 14.Q. B. D. 228 . (y) Richards v. London, Brighton, and South Coast R. C., 7 C. B. 839 ;
Kent จ. Midland R. C., L. R. 10 Q. B. I.

(z) Butcher v. London and SouthWestern R. C., 16 C. B. 13.

(a) Midland R. C. v. Bromley, 17 C. B. 372, following Gilbart v. Dale, ;) Ad. \& E. 543.

(b) Kent v. Midland R. C., L. R. 10 Q. B. 1. 
cases wherein a tortious act is done by a third party to goods whilst under bailment and out of the possession of their owner. Now, in very many cases, an action may be maintainable in respect of such wrongful act either by the general ormer of the goods in question or by the special owner intrusted therewith $(c)$. Thus a carrier may maintain an action against a stranger who takes the goods out of his possession $(d)$; and so may a factor $(e)$, a warehouse-keeper $(f)$, or an auctioneer $(g)$; and a trustee $(h)$, pawnee $(i)$, licensee $(k)$, or gratuitous bailee $(l)$, may respec. tively sue for a tort to the chattel held in trust or on bailment; and, in any such case as above specified, the owner of the goods may under certain circumstances alsc sue. The distinction is this: where the bailor has only partially parted with his possession to the bailee, an action to recover possession of the chattel will lie at the suit of either the bailor or the bailee $(m)$; where, however, the possession has been entirely parted with, the bailee only will be entitled to bring an action the object of which is to vindicate the right of possession, and the bailor wil only be able to sue in cases where his reversionary right: are endangered $(n)$.

It is, moreover, as remarked by Parke, B. (o), "an ancien rule of law, that, if goods are taken from the bailee, eithe. the bailor or bailee may maintain trespass, and recore

(c) Per Lord Loughborough, C. J., 1 II. Bl. 85 ; per Laurence, J., 8 T. R. 334 ; per Grose, J., 7 T. R. 12 ; 2 W'ms. Saund. 47 e.

(d) Per Lord Ellenborough, C. J., Martini จ. Coles, 1 M. \& S. 147; Arnold r. Jefferson, 1 Ld. Raym. 275, 270; 1 Roll. Abr. 4 (1), pl. 1.

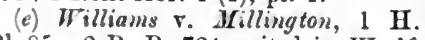
Bl. 85 ; $2 \mathrm{R}$. R. 724 ; cited in $W^{\text {coolfe }}$ จ. Horne, 2 Q. B. D. 358,360 .

(f) Per Lord Ellenborough, C. J., 1 II. \& S. $14 \%$.

(g) Williams v. Millington, 1 II. Bl. 81, 84; 2 R. R. 724; Robinson r. Rutter, 24 L. J. Q. B. 250. (h) 2 Wms. Saund. 47 b, n.

(i) Com. Dig. "Trespass", (B. 4).

(k) Northam r. Bowden, 11 Exct 70.

(l) Rooth r. Wilson, 1 B. \& Ali 59; 18 R. R. 431 ; Nicolls r. Bastart 2 Cr. M. \& R. 659; cited arg., $H_{1}$ worth r. Tollemache, 5 Scott, N. R. 33: (m) Nicolls r. Bastard, ub. sup: Manders r. Williams, 4 Exch. 339.

(n) Halliday r. Holgate, L. R. 3 E: 299.

(o) Reg. v. Tincent, 2] L. J. M. 109, 111 (S. C., 2 Den. C. C. 464 citing 2 Roll. Abr. "Trespass," 551 Davis r. Damks, 3 Excb. 435. 
damages for the taking." So a mere gratuitous permission to a third person to use a chattel does not, in legal contemplation, take it out of the possession of the owner; and accordingly either the owner may maintain an action of tort for an injury done to it whilst so used $(p)$, or the gratuitous bailee may sue $(q)$. And where there is an injury to the reversion, as in the case of a horse let on hire to A., and killed by defendant's violent driving, although an action for the trespass lies at suit of $A$., the party in possession, the owner may have an action for the injury to his reversion $(v)$. To entitle the reversioner to sue for an $v$ injury to a chattel, such injury must, however, have been permanent in its nature $(s)$.

An action, moreover, for the recovery of goods being founded on the right as well to the possession of, as to the property in, them, will not in general lie, at suit of the owner, for chattels which have been let to hire or demised for an unexpired term $(t)$, although there are cases showing that where goods are bailed, and the tailment is determined by the tortious act of the bailee-as by selling the goodsthe property therein reverts at once to the bailor, so that he will be entitled to recover the goods or their value, even from a bon $\hat{a}$ fide purchaser $(u)$, otherwise than in market overt.

It does not seem necessary here any further to advert to torts committed to chattel property out of the actual possession of its owner; and on the assumption that enough has been said in the present section to indicate

(p) Lotan v. Cr.oss, 2 Camp. 464.

(q) Rooth v. Wilson, 1 B. \& Ald. 59; 18 R. R. 431.

(r) Hall v. Pickard, 3 Camp. 187 ; Ferguson v. Cristall, 5 Bing. 305. See Harrison v. Parker, 6 East, 154; 8 R. R. 434 ; Lade v. Shepherd, 2 Str. 1004. (s) Mears $\mathrm{r}$. London and SouthWestern R. C., 11 C. B., N. S., 850 .

(t) Gordon v. Harper, 7 T. R. 9 ; 4 R. R. 369, Preface r.; Bloxam v.
Sanders, 4 B. \& C. 941 ; Milgate v. Kebble, 3 Scott, N. R. 358 ; cited and distinguished in Chinery r. Fiall, 5 H. \& N. 294; Pain v. Whittaker, 1 R. S M. 99. See Farrant r. Thompson, 5 B. \& Ald. 826,$828 ; 24$ R. R. 571.

(u) Bryant v. Wardell, 2 Exch. 479 , 482, following Cooper v. Willomatt, 1 C. B. $672 ;$ Fenn v. Bittleston, 7 Exch. 152; Judgm., Chinery . Viall, 5 II. S. N. 293 . 
a classification, characterised by simplicity and practical utility, of Wrongs to Personalty, I proceed, in the ensuing Chapter, to inquire as to another leading class of Torts, differing somewhat materially from either of those classes which have been noticed. 


\section{CHAPTER IV.}

TORTS NOT DIRECTLY AFFECTING THE PERSON OR PROPERTY.

Thus far in the present Book I have spoken of Torts to the Person, to the Reputation, and to Property ; of bodily injuries, whether direct or consequential, injuries to the health or comfort of an individual, wrongs which affect personal liberty, libel, and slander; of torts to realty, whether in possession or reversion, and to chattels. There is yet another class of torts demanding notice, within which arrange themselves such wrongs as do not directly affect either the person or the property of the party injured. True it is that, in some sense, almost any wrongful act which could be named may be said to operate injuriously either on the person or on the property of him aggrieved; but, nevertheless, an intelligible line may be drawn between cases wherein it so operates directly and those in which it so operates indirectly. For instance, if $\mathrm{A}$. is induced to take $\mathrm{B}$. into his service in consequence of a false character respecting him fraudulently communicated by C., and B. afterwards is guilty of the crime of embezzling his master's property, it cannot be said that A. is directly, though he certainly is indirectly, damaged by the fraud of C.; such a case would obviously bring itself within the class of torts concerning which I now propose very briefly to inquire. It consists of two kinds or species of wrongs, which are clearly distinguishable from each other,-wrongs done to the 
Torts to absolute or relative rights.

Fraud in connection with companies.

absolute and wrongs done to the relative rights of individuals. The instance just given would serve to exemplify the former of these two subdivisions of the subject. The principle of the particular case specified falls, indeed, within the general proposition formerly mentioned $(a)$, that if $A$. fraudulently makes a representation which is false, and which he knows to be false, to B., meaning that B. shall act upon it, and B., believing it to be true, does act upon it, and thereby sustains damage, A. will be liable to an action for damages at suit of $\mathrm{B} .(b)$; for, although fraud without damage or damage without fraud may give no cause of action, yet "where these two do concur," "there an action lieth" $(c)$. "A mere lie," indeed, "thrown out at random without any intention of hurting anybody, but which some person was foolish enough to act upon," will not support an action of deceit, "for the quo animo is a great part of the gist of the action" $(d)$.

Having in former pages had occasion to advert to frand as constituting the main ingredient in a right of action or as affording matter of defence, some few references are here inserted showing the nature of one particular kind of fraud, which of late years has been specially mischievous to society. It consists in offering to the public for bonit fide investment shares in a projected company worthless or issued at a price greatly in excess of their real value, this

(a) Ante, p. 780.

(b) See Sicift v. Jevsbury, L. R. 9 Q. B. 301 ; Milne v. Marwood, 15 C. B. 778 ; Judgm., 16 Q. B. 679 ; Belin r. Kemble, 7 C. B., N. S., 260 ; Clarke r. Dickson, 6 C. B., N. S., 453 ; C'quhart v. Maepherson, 2 App. Cas. $831,837,838$; Scott v. Dickson, 29 L. J. Ex. 62 n. ; Smith v. Chadeick, $20 \mathrm{Ch} . \mathrm{D} .27$ (as to dicta of Jessel, M. R., cf. Derry r. Peek, 14 App. Cas. 337 , at p. 372 ); S. C., 9 App. Cas. 187; Edgington r. Fitzmaurice, 29 Ch. D. 459,482 .

Is showing that the scienter must be alleged and proved to support an action for misrepresentation, see particularly Childers 5 . Wooler, 2 E. \& E. 287, and cases there cited; Cronshaw v. Chapman, 7 H. \& X. 911; Derry v. Peek, loc. cit.

(c) Per Croke, J., 3 Bul. 95 ; cited per Buller, J., Pnsley v. Freeman, 3 T. R. $56 ; 1$ R. R. $634 ; 2$ Sm. I. C., 9th ed., it; Cullen v. Thompson's Trustees, 4 Macq. H. L. Ca. 424, 439 ; Imperial Gas Light, \&.c., Co. r. London Gas Light Co., 10 Exch. 39.

(d) Per Ashurst, J., 3 T. R. 63; 2 Sm. L. C., 9th ed., pp. 90, 91. 
being done scienter and with a view to cheat (c). The forms under which fraud may present itself are infinitely various, so that Courts of Law and of Equity have at all times carefully abstained from attempting a nice definition of fraud with reference to the rights which the practice of imposition may confer upon the parties injured by it. "It is notorious that every mode which can well be conceived of dealing with contracts which ought not to be maintained, in consequence of some deception which vitiates them, has from time to time come before the consideration of the Courts of Equity, and there is scarcely any one which can be set on foot that is not struck at by the general doctrines" of the Courts $(f)$; the drift of this remark holding true also as regards Courts of Law.

Companies such as referred to are in their initial stages variously constituted; a promoter, a syndicate, or partnership producing the capital first needed, directors and shareholders taking part in their formation, assisted by broliers and agents for dispersing the shares when issued amongst the public and getting subscribers to the undertaking.

The modus operandi adopted for misleading the public by the projectors of and those who assist in launching a bubble company may be by the issuing of false prospectuses $(g)$, by non-compliance with the statutory requirements of 30 \& 31 Vict. c. 131 , s. 38 , in keeping from the knowledge of intended shareholders contracts which are material and ought to be specified $(h)$, in payments improperly made by way of promotion money, bribery, or otherwise.

The liability of directors, promoters, and persons who

(e) Reference should be made to p. 336, ante, and to the case of Derry v. Peek, 14 App. Cas. 337, which decided that there is no duty enforceable at law to be careful in the representation that is made in the case of statements in a prospectus.

See also Arnison v. Smith, $41 \mathrm{Ch}$. D. 348 ; Lynde v. Anglo-Italian Hemp
Spinning Co., (1896) I Ch. 178.

(f) Vide per Lord Hatherley, Evlanger v. New Sombrero Phosphate Co., 3 App. Cas. 1243.

(g) Weir v. Barnett. 3 Ex. D. 32 ; Ainison v. Smith, 41 Ch. D. 348 . See also Andrews r. Mockford, cited ante, p. $777 \mathrm{n} .(l)$.

(h) Tuycross v. Grant, 2 C. P. D.469. 
authorise the issue of a prospectus or notice, soliciting applications for shares or debentures in a company, in respect of any untrue statement contained in such prospectus or notice, is now the subject of statutory enactment; cf. the Directors' Liability Act, 1890 (53 \& 54 Vict. c. 64). Such persons are liable to pay compensation to any one who, on the faith of such prospectus or notice, has subscribed for shares, debentures, or debenture stock, and has suffered damages by reason of any untrue statement contained in the prospectus or notice, or in any report or memorandum appearing on the face thereof, or by reference incorporated therein or issued therewith, unless it is proved-

1. Where the statement does not purport to be made on the authority of an expert, or of a public official document or statement, that up to the time of allotment the statement was believed by them to be true; and-

2. Where the statement purports to be made by an expert, or to be contained in what purports to be a copy of or extract from a report or valuation of an engineer, valuer, accountant, or other expert, that it fairly represented the statement made or was a correct and fair copy or extract, provided that if such be proved to be the case liability will still attach, if it be proved that they had no reasonable ground for believing that the person making the statement, report, or valuation was competent to make it; and-

3. Where the statement purports to be made by an official person, or to be contained in what purports to be a copy of or extract from a public official document, that it was a fair and correct representation of such statement, copy, or extract; or unless it is proved that,

4. Having consented to become directors, they withdrew their consent before the issue of the prospectus or notice, and that the same was issued without their knowledge or corisent ; or- 
5. That the prospectus or notice was issued without their knowledge or consent, and that on becoming aware of its issue they forthwith gave reasonable public notice of such fact ; or-

6. That after the issue of such prospectus or notice and before allotment thereunder they, on becoming aware of any untrue statement therein, withdrew their consent thereto, and caused reasonable public notice of such withdratral, and of the reason therefor, to be given (i).

The term "promoter," it has been said (k), as used in connection with a company, has no very definite meaning; it involves "the idea of exertion for the purpose of getting up and starting the company (of what is called 'floating' it), and also the idea of some duty towards the company jmposed by or arising from the position which the so-called promoter assumes towards it." By promoters of public companies, however, forgetful of their duty, and persons acting in concert with them, frauds have unhappily been often perpetrated, to the detriment of the ignorant and unwary.

The vendor of property meant to be taken and subscribed for by the public may or may not assume the character of promoter. Should he not be such, fraud coming under the notice of Courts of Law will probably, in cases now referred to, fall within one or other of two classes: 1st, it may have been practised directly as between the vendor and purchaser in dealing about the subject-matter of the sale; or, 2ndly, it may be thus evidenced-that an agent for the purchaser has received a gratuity from the vendor $(l)$.

(i) S. 3, subs. 1. A "promoter" within the section does not include any person by reason of his acting in a professional capacity for persons engaged in procuring the formation of the company (subs. 2). "Expert" includes any person whose profession gives authority to a statement made by him (subs. 4). The Act also provides for indemnifying any person whose name has been improperly inserted as a director (s. 4), and for contribution from co-directors (s. 5).

(k) Judgm., Emma Silver Mining Co. v. Lewis, 4 C. P. D. 407.

(l) See Harington V. Victoria Graving Dock .Co., 3 Q. B. D. 549; Smith v. Sorby, Id. 552. 
With regard to the conduct of the vendor of property about to be taken up by a company, it is clear that he must not be guilty of any unfair concealment of facts which ought to be disclosed to a person seeking to purchase, or entering into a treaty with him for that purpose ; such unfair concealment would amount to fraud $(m)$, though there are cases in which, in the absence of active fraud, passive mis. representation - that is to say, silence as to some fact which it would be material to the one party to know, but which the other is not legally bound to communicate-may involve the one in loss, whilst the party suffering what amounts to a moral, but not to a legal, wrong, has no remedy at law $(n)$. We have already seen that this may be so in an ordinary transaction of sale between individuals $(o)$.

When the vendor of land, perhaps, or minerals, with a view to the formation of a company, adopts the character of promoter, a fiduciary, or, at all events, a quasi-fiduciary, relation arises between him and the company, whether in posse or in esse. $\mathrm{He}$ is bound to protect its interests and those of the shareholders. All his dealings with them and for them should be uberrime fidei. He should conceal nothing from them which it is essential to them to know $(p)$. And accordingly a negotiation carried on between the agent for the purchaser and the vendor as principal, in which the agent for the purchaser receives benefits or advantages of any lind from the intending vendor, is primu facie impeachable as a fraud upon the purchaser $(q)$.

Not unfrequently proofs have been forthcoming in an action at suit of a shareholder against directors of a com. pany, founded upon some such misfeasance as suggested, at

(m) See the substance of Lord Hatherley's remarks in Erlanger v. Nev Sombrero Phosphate Co., 3 App. Cas. 1243, 1244.

(n) P'er Cockburn, C. J., Tuycross v. Grant, 2 C. P. D. 532. (o) Ante, p. 330

(p) Per Cockibu'n, C. J., 2 C. P. D 538.

(q) Per Lord Hatherley, 3 App. Cas 1244. See Whaley Bridge, dr. Co ४. Green, 5 Q. B. D. 109. 
its inception, though the right of a shareholder, who has been induced to take shares in a company by the fraudulent representation of its directors, to repudiate his shares and recover the money paid by him for them in the event of the company going into liquidation or being voluntarily wound up, as shown by the cases below cited $(r)$ and by the remarks subjoined, admits of other and different considerations.

Where in the course of the winding up of a company under the Companies Acts it appears that any person who has taken part in the formation or promotion of the company, or any past or present director, manager, liquidator, or other officer of the company, has misapplied or retained or become liable or accountable for any moneys or property of the company, or been guilty of any misfeasance or breach of trust in relation to the company, the Court may on the application of the official receiver, or of the liquidator of the company, or of any creditor or contributory of the company, examine into the conduct of such promoter, director, manager, liquidator, or other officer of the company, and compel him to make repayment or restoration, together with interest at such rate as the Court thinks just, or to contribute by way of compensation to the assets of the company such sum as the Court thinks just $(s)$.

In an ordinary partnership $(t)$, not formed on the jointstock principle, it is impossible, as a general rule, for a partner at any time to retire from or repudiate the partnership without satisfying, or remaining bound to

(r) Stone v. City and County Bank, 3 C. P. D. 282 ; Oakes v. Tirquand, L. R. 2 H. L. 325 ; cited in Tement v. City of Glasgow Bank, 4 App. Cas. 621 ; Addie v. Western Bank of Scotland, L. R. 1 Sc. App. 146 ; Houldsvorth v. City of Glasgow Bank, 5 App. Cas. 317 ; ante, p. 624 .

(s) S. 10 , subs. 1,53 \& 54 Vict. c. 63 (Companies (Winding-up) Act, 1890).
See In re London and General Bank, (1895) 2 Ch. 673, affirming Id. 166 ; In re Kingston Cotton Mill Co., (1896) 1 Ch. 6; In re Kingston Cotton Mill Co. (No. 2), 12 Times L. R. 430 (C. A.), reversing (1896) I Ch. 331 .

$(t)$ The remarks which follow in the text were made per Earl Cairns, L. C., in Tement v. The C'ity of Glasgow Bank, 4 App. Cas. 621, 622 . 
satisfy, the liabilities of the partnership (u). He may have been induced by his co-partner's by fraud to enter into the partnership, and that may (in equity) be a ground of relief against them, but it is no ground for getting rid of a liability to creditors. This is the case whether the partnership is a going concern or whether it has stopped payment or become insolvent.

In the case of a joint-stock company, howerer, the shares are in their nature and creation transferable, and transferable without the consent of creditors, and a shareholder, so long as the company is a going concern, can, by transferring his shares, get rid of his liability to creditors either immediately or after a certain interval. The assumption is that, while the company is a going concern, no creditor has any specific right to retain the individual liability of any particular shareholder.

A shareholder may, therefore, whilst the company is a going concern, throw back upon the company shares which he has been induced to take by fraud without reference to any claims of creditors. If, however, the company has become insolvent and has stopped payment, serious injury might be inflicted on its creditors could shares, on the ground above supposed, be repudiated. A shareholder, though grievously wronged, cannot thus rescind his original contract to take shares and retire from the concern $(x)$.

Keeping these leading principles in mind, I may add that the main difficulty which a plaintiff suing the promoter or any director of a company for fraud producing damage has at law to contend with lies in connecting the particular defendant with the fraud complained of, and so making him responsible for its consequences. Sometimes, doubtless, this may be done directly ; ex. gr., the defendant has signed

(u) Ante, p. 638 et seq.

(x) Tennent v. The City of Glasgow
Bank, 4 App. Cas. 615; Houldsuorth r. City of Glasgor Bank, 5 App. Cas 317. 
prospectuses, has attended and taken part at meetings of the shareholders, has surreptitiously accepted monies appertaining to the funds and capital of the concern, and so forth. More often, perhaps, the defendant has to be made liable, if at all, in virtue of the relation of principal and agent, and the well-understood doctrines applicable thereto $(y)$.

Where an action is brought at suit of a third person against a company to recover back money obtained by them through fraud, the nature of the evidence sufficing to sustain it has been thus tersely indicated:- "Where a company has obtained a benefit through the fraud of an agent, the person defrauded may recover back his money from the company," proof being adduced on behalf of the plaintiff that "he paid his money in consideration of certain statements and acts of the secretary, directors, and managers of the company; that the circumstances under which they got the money were fraudulent; that the transaction was not bonâ fide, but a fraudulent transaction to get his money without any consideration; and that the money found its way into the coffers of the company" $(z)$.

Where an agent employs a sub-agent, and the latter, in the course of his employment, is guilty of fraud or misrepresentation, and the agent, with knowledge of the fraud, derives a material benefit from it, the case is analogous to that of a person who profits by the fraud of his agent, the principle being that he who profits by the fraud of one who is acting generally by his authority, though the specific fraud complained of were committed without his authority, adopts the act of the agent, and becomes responsible to the party who has

(y) See Weir r. Barnett, 3 Ex. D. 32 ; Weir v. Bell, Id. 249 ; ante, p. 623. (z) Per Grove, J., Blake v. Albion Life Ass. Co., 4 C. P. D. 99, 100. See Swire r. Francis, 3 App. Cas. 106. 
been imposed upon and has sustained damage by reason of it $(a)$.

Estoppel in In connection with torts involving misrepresentation and I. ais.

fraud, the doctrine of estoppel in pais is frequently brought into operation. The rule applicable in such cases has been thus laid down (b):- " that where one by his words or conduct wilfully causes another to believe the existence of a certain state of things, and induces him to act on that belief so as to alter his own previous position, the former is concluded from averring against the latter a different state of things as existing at the same time" $(c)$. By the term "wilfully," above used, "we must understand, if not that the party represents that to be true which he knows to be untrue, at least that he means his representation to be acted upon, and that it is acted upon accordingly $(d)$; and if, whatever a man's real intention may be, he so conducts himself that a reasonable man would take the representation to be true, and believe that it was meant that he should act upon it, and did act upon it as true, the party making the representation would be equally precluded from contesting its truth; and conduct, by negligence or omission, where there is a duty cast upon a person by usage of trade or

(a) See per Cockburn, C. J., Weir v. Bell, 3 Ex. D. 249.

(b) Judgm., Pickard r. Sears, 6 Ad. \& E. 474, cited Judgnı., Nickells r. Atherstone, 10 Q. B. 949 ; per Erle, C. J., White, app., Greenish, resp., 11 C. B.. X. S., 229. In Gregg r. I'ells, 10 Ad. \& E. 97, 98, Lord Denman, C. J., lays down the rule in these words: - that "a party who negligently or crelpably stands by and allows another to contract on the faith and understanding of a fact which he can contradict cannot afterwards dispute that fact in an artion against the person whom he has himself assisted in deceiring." The rule as there laid down is too broadly stated: per Lord Crancorth, C., Jorden Y. Joney, 5 H. I. Ca. 214.
See Davies r. Marshall, 10 C. B., N. S., 697 ; Ashpitel v. Bryan, 3 B. \& S. $474 ;$ Cave v. Mills, 7 H. \& $\mathrm{S}$. 913.

(c) See Morrison $\nabla$. Universnl Marine Assur. Co., L. R. 8 Ex. 197, 200, 206 ; Stimson v. Farnham, L. R. 7 Q. B. 175,180 .

(d) Acc. In re Bahia, \&c., R. C., L. R. 3 Q. B. 584,595 . See this case explained, In re Ottos Kopje Co., (1893) $1 \mathrm{Ch}$. 618. See also the following cases: Bishop v. Balkis Co., 25 Q. B. D. 512 (C. A.), where the effect of a certification of a transfer is considered; Tomkinson r. Balkis Co., (1893) A. C. 396, affirming $S$. C., (1891) 2 Q. B. 614. 
otherwise to disclose the truth, may often have the same effect $(e)$.

"In order," however, "that a party shall be estopped from denying his assent to an act prejudicial to his rights, and which he might have resisted, but has suffered to be done, it is essential that knowledge of the thing done shall be brought home to him " $(f)$.

The doctrine thus enunciated $(g)$ should cautiously be restricted within its legitimate limits as above defined; for what is termed an estoppel by act or representation has the effect of concluding the party who did the act or made the representation $(h)$, and of shutting out the truth $(i)$ : it is therefore "odious," and must be strictly made out $(k)$. In Suan v. The North British Australasian Company $(l)$ the applicability of the doctrine of estoppel was much discussed. And in a subsequent case $(m)$, the facts of which will be

(e) Judgm., Frecman r. Cooke, 2 Exch. 663 (which is a leading case with reference to the doctrine of estoppel in pais); cited and approved in Miles $\mathrm{v}$. McIlwraith, 8 App. Cas. 120, 133 ; Jorden r. Money, 5 H. L. Ca. 213, 255 ; per Lord Chelmsford, C., Clarke v. Hart, 6 H. L. Ca. 655,656 ; per Crompton, J., Howard v. Hudson, 2 E. \& B. 13. "The word vilfully in the rule as laid down in Pickard $\mathrm{v}$. Scars (6 Ad. \& E. 469) means nothing more than volumtarily:" per Pollock, C. B., Cornish v. Abington, 4 H. \& $\mathrm{N}$. 5.5.5, which recognises the doctrine in Freeman r. Cooke, supra; per Blackburn, J., Polak r. Everett, I Q. B. D. 673 , referring to the relation of principal and surety, and distinguished in Rainbow v. Juggins, 5 Q. B. D. 138; and in Taylor r. New South Wales Bank, 11 App. Cas. 602. See further as to the above doctrine: Camam v. Farmer, 3 Exch. 698; Liverpool Adelphi Loan Ass. v. Fairhurst, 9 Exch. 422 ; cited Wright v. Leonard, 11 C. B., N. S., 258; Waller v. Drakeford, 1 E. \& B. 749 ; Foster $\mathrm{r}$. Jentor Life Ass. Co., 3 E. \& B. 48, 64, $36,75,79$; Bowes v. Foster, 2 H. \& N. 779; Tyerman v. Smith, 6 E. \& B. 119; Hawop, app., Bayley, resp.,
İd. 218 ; Andreus r. Elliott, 5 E. \& B. 502 ; per Williams, J., Simpson v. Ace. Death Ins. Co., 2 C. B., X. S., 289 ; Alderson v. Maddison, 5 Ex. D. 296; Simm v. Anglo-American Telegraph Co., 5 Q. B. D. 188; distinguished Tomkinson r. Balkis Co., (1893) A. C. 396 , at pp. 405,412 ; Scaiff v. Jardine, 7 App. Cas. 350.

See Prince of Wales Ass. Co. v. Harding, E. B. \& E. 183; Levy r. IIale, 29 L. J. C. P. 127.

(f) Per Cockburn, C. J., Johnson v. Crédit Lyonnais Co., 3 C. P. D. 40.

(g) See per Jcrvis, C. J., Lewis $\mathbf{}$. Clifton, 14 C. B. 25t; and in Lee v. Baycs, 18 C. B. 603.

(h) Secus as to a stranger, see Richards v. Johnston, 4 H. \& N. 660,664 , citing per Bayley, J., Heane v. Rogers, 9 B. \& C. 586.

(i) Cf. pp. 964, 965, extract from judgment of Bouen, L. J.

(i) Per Lord Campbell, C. J., Houard v. Hudson, 2 E. \& B. 10.

(l) 2 H. \&C. $175 ; S . C ., 7$ H. \& N. 603 ; Ex parte Su'an, 7 C. B., N. S., 400 .

(iin) Cary v. London and ForthWestern R. C., L. R. 10 C. P. 307 , 316-318, followed in Corentry v. Great Eastern R. C., 11 Q. B. D. 776; and 
presently stated, the existing law as to estoppel in pais is thus set forth :-

1. If a man by his words or conduct wilfully endeavours to cause another to believe in a certain state of things which he knows to be false, and if the other person belieres in such state of things, and acts upon his belief, he who lnowingly made the false statement is estopped from averring afterwards that such a state of things did not in fact exist. To bring a case within the scope of this proposition there must be proved some statement false to the linowledge of defendant, but where this is proved the party is held to have precluded himself from denying or questioning the accuracy of the statement or representation made by him, on the faith of which another has acted $(n)$.

2. Another recognised proposition seems to be that if a man, either in express terms or by conduct, makes a representation to another of the existence of a certain state of facts which he intends to be acted upon in a certain way, and it be acted upon in that way, in the belief of the existence of such a state of facts, to the damage of him whe so believes and acts, the first-mentioned party is estopped from denying the existence of such a state of facts.

3. Another proposition is that if a man, whatever his real meaning may be, so conducts himself that a reasonable person would take his conduct to mean a certain represen. tation of facts, and that it was a true representation, anc that the latter was intended to act upon it in a peculias way, and he, with such belief, does act in that way, to his lamage, the first-mentioned party is estopped from denying that the facts were as represented.

Where, for instance, a person is charged as a member o a partnership - not because he is a member, but because hr has represented himself as such-the law proceeds on the

in Seton r. Lafone, 18 Q. B. D. 139 ; 19 Id. 68. (n) Citing Freeman r. Cooke, Exch. 654. 
principle that if a person so conducts himself as to lead another to imagine that he fills a particular situation, it would be unjust to allow him to turn round and say that he did not fill that situation. If, therefore, he appears to the party who is seeking to charge him to be a partner, and has represented himself as such, he camnot afterwards be allowed to say that that representation was incorrect, and that he was not a partner $(o)$. Here the conduct of that party as against whom the estoppel operates is less objectionable than in the state of facts first supposed, for the element of fraud is absent.

4. Another proposition applicable to the present subject is this-If in the transaction which is in dispute one has led another into the belief of a certain state of facts by culpable negligence calculated to have that result, and such culpable negligence has been the proximate cause of leading, and has led, the other to act by mistake upon such belief to his prejudice - the party first indicated cannot be heard afterwards, as against the party secondly mentioned to show that the state of facts referred to did not exist.

The defendants, a railway company, received goods for consignment to plaintiff by their line, and informed him that they had three parcels of goods subject to his orders and to payment of rent and charges. In point of fact, defendants had received two such parcels of goods only-the third parcel remaining in the hands of the party from whom the plaintiff had purchased the goods. Two days after the notice to plaintiff the defendants' servants became aware that they had not received the third parcel of goods, but they abstained from informing plaintiff of the fact. Plaintiff sold the goods as consisting of three parcels, and as he could only deliver tico of these, was obliged to pay to his

(o) Per Rolfe, B., Ness v. Angas, 3 Exch. 813. 
vendee a sum equal to the difference between the price at which the undelivered portion of the goods had been sold to him by plaintiff and the market price which his vendee had been obliged to pay for similar goods to make up the entire quantity. Plaintiff thereupon sued the railway company for non-delivery, and also for a tortious appropriation of the goods, and the main question raised in this case was :-were the defendants - after admitting that they held to plaintiff's order three parcels of goods-estopped from afterwards denying the receipt of the third parcel? The Court in Banco, applying various tests to the facts before them, and remarking that negligence on the part of defendants had not been found by the jury, that there was no proof of culpable negligence, and that if there were, it did not induce the plaintiff to resell the goods, which resale had caused him damage, decided that the doctrine of estoppel by words and conduct did not apply $(p)$.

The doctrine of estoppel has long been recognised and applied by Courts of Equity as well as by Courts of Law, for example :- "If an individual who has to his linowledge title to land sees another (who is ignorant of such title and believes that he has a good title) expending money on the land, and yet gives no notice of his own title, a Court of Equity will not afterwards allow him to assert his title to the prejudice of the person whom he has allowed to act in ignorance of that title" $(q)$.

$\sqrt{ }$ "Estoppel is only a rule of evidence ; you cannot found an action on estoppel. Estoppel is only important as being one step in the progress towards relief on the hypothesis that the defendant is estopped from denying the truth

(p) Carr r. London and SorthHestern R. C., L. R. 10 C. P. 307 , 316-318; Farmeloe r. Bain, 1 C. I. D. 445, 450; Corentry r. Great Eastern K. C., II Q. B. D. 776 ; Seton r.
Lafone, 18 Q. B. D. 139 ; 19 Id. 68.

(q) Per Cotton, L. J., Huat r. Irimbledon Local Board, 4 C. P. I. 62. 
of something which he has said" $(r)$. In the case from the judgment of Bowen, L. J., in which the above is an extract, it was decided that there is no obligation on a trustee to answer the inquiries of a stranger about to deal with the cestui que trust. If the trustee honestly answers the inquiries he is under no liability unless his statement amounts to a warranty, or he is estopped from afterwards denying the truth of what he has said.

To the class of torts affecting the absolute rights of individuals-though not directly affecting the person or property -are referable a vast variety of cases, whereof many, especially such as involve fraud or malice, have been already sufficiently discussed. It is indeed generally true, that as injuries are multiplied, so must new remedies be devised to meet them,-as torts of a kind previously unknown spring into existence, so must the flexible power of the law exert itself to compensate the injured party - to mulct and punish the wrong-doer. The leading rule here applicable being that where a case is new in its principle, there it is necessary to have recourse to legislative interposition in order to remedy the grievance: but where the case is only new in the instance, and the sole question is upon the application of a principle recognised in the law to such new case, it will be just as competent to Courts of Justice to apply the principle to any case which may arise two centuries hence as it was two centuries ago. If it were not, we ought to blot out of our law books one-fourth part of the cases that are to be found in them $(s)$.

Torts belonging to the class here more particularly under our notice being thus multifarious, to the instances already given of them I will merely add, that negligence, when productive of damage, is clearly actionable; and where a

(r) Per Bowen, L. J., Low v. Bouverie, (1891) 3 Ch. 82, at p. 105. (s) Per Ashurst, J., 3 T. R. 63 ; 2 Sm. L. C., 9th ed., 91. 
solicitor $(t)$ or a patent agent (u) has been proved guilty of crassa negligentia in the management of business confided to him, he will at all events be liable to an action for damages at suit of his client, the action being here founded upon a breach of contract with or neglect of a duty towards the client $(x)$ which the law imposes $(y)$.

In connection with the subject before us we must bear in mind that a master may be civilly responsible as well for the fraud as for the negligence of his servant whilst acting in the course of his employment, albeit he is not thus liable for the tortious act of his agent in any matter beyond the scope of his agency, unless he has expressly or impliedly authorised the act in question to be done or has subsequently adopted it for his own use and benefit $(z)$.

Thus dismissing the important and comprehensive class of wrongs done to absolute rights, let us, in the next place, consider what is meant by torts affecting the relative rights

Torts to relative rights. of individuals. Relative rights are such as are incident to persons considered as members of society, and comnected with each other by various ties and relations $(a)$. Torts to such rights include, therefore, injuries done to persons under the four following relations:- of husband and wife; of parent and child; of guardian and ward $(b)$; of master and servant.

(t) Thitcman r. Hackins, 4 C. P. D. 13 ; Purves v. Landell, $12 \mathrm{Cl}$ \& $\mathrm{F}$. 91 ; Cox r. Leech, 1 C. B., X. S., $61 \%$; Long v. Orsi, 18 C. B. 610 ; Chapman r. Tun Toll, Tan Tull v. Chapman, 8 E. \& B. 396 ; Purker v. Kolls, 14 C. B. 691 ; Letcis v. Collard, Id. 208; Hunter r. Caldicell, 10 Q. B. 69 ; per Taunton, J., Dowman r. Jenkins, 2 Ad. \& E. 256; Watts r. Iurter, 3 E. \& B. T43; Couper v. Stephenson, 21 L. J. Q. B. 292; Hnukins $\vee$ Harecood, 4 Exch. 203; per Tiudal, C. J., Godfioy r. Dalton, 6 ling. 467,468 . See North-Western I. C. Y. Sharp, 10 Exch. 451.

As to the liability of a valuer of ccclesiastical property for ignorance and want of skill, see Jeukins r. Betham, 15 C. B. 168.

(u) Lee r. Walker, L. R. 7 C. P. 121.

$(x)$ There must be privity of cun. tract to support the action. See Robert. son r. Fleming, 4 Macq. Sc. App. Cas. 167 ; ante, p. 778 .

(y) I'er Tindal, C. J., Godefroy r. Jay, 7 Bing. 419 ; see Fray r. Joules, 1 E. S. E. 839 ; Chown v. Parrott, 14 C. B., N. S., 79 .

(a) Caleman v. Riches, 16 C. B. 104.

(a) 3 Bla. Con., p. 138.

(b) For information respecting the relation of guardian and ward, the reader is referred to Broom and Hadler Com., vol. ii., pp. 147, 17t, vol. iii., p. 152. 
For the abduction of the wife, or for an assault committed upon her per quod consortium amisit, the husband is allowed a civil remedy by our law $(c)$. Of a declaration for the former of these two causes of action, which is not of very common occurrence, a precedent offers itself in Norris v. Seed $(d)$, where the plaintiff sued in trespass for assaulting, ill-treating, and carrying away his wife, whereby he was deprived of her company and assistance. "The gist of the action," observed Parke, B., in this case, "being the loss of the comfort and society, an assault which did not end in the loss to the plaintiff of the comfort and society of his wife, would not support an action. It is only such an assault and conduct on the part of the defendant as deprives the plaintiff of the power of associating with his wife as would support the action-i.e., as would support an action brought at suit of the husband to recover for the special damage sustained by him. If, indeed, the wife be assaulted, maliciously prosecuted, illegally imprisoned, or otherwise personally injured $(e)$ by a thiird party, our law in general $(f)$ gives an appropriate remedy to recover damages in the names of the husband and wife jointly; whereas, if the beating be so great, or the injury sustained by the wife be such that the luusband can allege and prove that thereby consortium amisit, he will be entitled to a separate remedy against the wrong-doer in his own name $(g)$.

The foundation of the action at suit of a parent for seduction of his child has been uniformly placed, from the earliest times, not upon the seduction itself, which is the wrongful act of the defendant, but upon the loss of serrice

(c) An action for criminal conversation is not now maintainable: $20 \& 21$ Vict. c. 85, s. 59 .

(d) 3 Exch. 782; Foung v. Pridd, Cro. Car. 89.

(e) See Smith r. Hixon, 2 Str. 977 ; Dalby r. Dorthall, Cro. Car. 553. (f) See Longmeid r. Holliday, 6 Exch. 761, eited ante, p. 775. Now the wife can sue in her own name as if she were a feme sole. $45 \& 46$ Tict. c. 75 , s. 1 , ante, p. 682 .

(g) 3 Bla. Com. 140 ; Hyde $\checkmark$. Scysser, Cro. Jac. 538.
Parent and child. 
of the daughter, in which service the parent is supposed to have a legal right or interest. Therefore some loss of service must be alleged in the claim $(h)$ and must be proved at the trial, in order that the plaintiff may be legally entitled to redress $(i)$. It cannot be denied that this state of the law occasionally operates most harshly; for where it appears in evidence that the plaintiff's daughter was, at the time of the occurrence complained of, in the service of another, without any animus revertendi $(k)$, although that other were the seducer himself, the action will not be maintainable $(l)$. Aware of the hardship and lack of justice thus entailed, and with a view to averting it, when that may be done consistently with acknowledged legal principles, our Courts grasp willingly at any, the slightest, proofs of loss of service which may be adduced to support an action for the injury alluded to, and to establish the existence of the relation of master and servant as betreen the parent and child, upon which the maintenance of the action for seduction, in truth, depends ( $m$ ). Assuming, however, that this foundation for the action is laid, the plaintiff is permitted in it to recover damages ultra the mere loss of service for the injury inflicted on him (n).

On the same footing with the right of action for seduction

(7) See Form, Rogers's Jud. Acts, p. 420 ; R. S. C. 1883 , A. C., rection ri., No. 9.

(i) Grimell r. Wells, 7 M. \& Gr. 1033, 1041, and cases there cited; Enger v. Grimecoud, 1 Exch. 61 ; Hedgex r. Tagg, L. R. 7 Ex. 283.

(k) See Tery v. Hutchinson, L. R. 3 (L. 13. 599 ; Hedges r. Tagg, supra.

(t) Thompson v. Ross, 5 H. \& $\mathrm{X}$. 16 ; Mnnley r. Field, 29 I. J., C. P. 79 ; Hlaymire v. Haley, 6 M. \& W. 5) I Invies r. Whlliams, 10 Q. B. 725 ; Rist r. Faux, 32 I. J., Q. B. 386 ; Hawris v. Butler, 2 M. \& W. 539; per I'arke, B., Id., 542; Deanv. Peel, i) East, 45 ; i R. R. 6.53.

(im) Griffiths v. Teetgen, 15 C. B. 344, following Speight v. Oliriera, 2 Stark. N. P. C. 693 ; 20 R. R. 728; Bennett r. Alleott, 2 T. R. 166; Torrevere v. Gibbins, 5 Q. B. 297 ; Hollowry r. Abel, ; Car. S P. 528; Rist r. Fanx, supra.

The action for seduction lies without proof of special damage. See $\mathrm{Nood}$ ecard r. Walton, 2 S. R. \pm 76 ; Ditcham v. Bond, 2 II. \& S. $436: 14$ R. R. 835: Chamberlain v. Mazleicood, s M. \& W. 515-517.

(ii) Per Lord Ellenborough, C. J., Irein v. Dearman, 11 East, 2t; 10 R. R. 423; per Lord Abinger, C. B., Howard v. Crouther, 8 M. \& W. 603. As to the action for seduction, sce further, ante, p. 75 . 
stands that brought by a parent for a personal injury to his child (o) -or by a master for the battery of his servant -per quod servitium amisit. "It is the invasion of the Master and servant. legal right of the master to the services of his servant that gives him the right of action for beating his servant." And "if," as we further read in Robert Mary's case (p), "my servant is beat, the master shall not have an action for this battery unless the battery is so great that, by reason thereof, he loses the service of his servant; but the servant himself, for every small battery, shall have an action; and the reason of the difference is, that the master has not any damage by the personal beating of his servant," but by reason only of its consequences, viz., the loss of service; "for be the battery greater or less, if the master doth not lose the service of his servant, he shall not have an action" $(q)$. Nor can an action be sustained by the master for consequential damage caused by an injury to his servant, where such injury arose from the breach of a contract between the servant and the wrongdoer $(r)$. Neither can the master sue in respect of a bodily hurt done to the servant causing his immediate death $(s)$.

Another species of injury incident to the relation between master and servant may here be noticed. It consists in the wrongfully and maliciously or with notice interrupting this relation, by procuring the servant to depart from the

(o) Per Tindall, C. J., 7 M. \& Gr. 1041 (citing Russell v. Corme, 2 Ld. Raym. 1031, and Gray v. Jefferies, Cro. Eliz. 55); Hall v. Hollander, 4 B. \& C. $660 ;$ Dixon v. Bell, 5 M. \& S. 198: 17 R. R. 308. See Veuton v. Holford, 6 Q. B. 921 .

As to an action for the abduction of a child, see Bla. Com., p. 141 ; Barham г. Dennis, Cro. Eliz. 770 (cited 4 B. \& C. 662); Arg., 5 M. \&W. 516; Gilbert v. Schuenck, 14 M. \& W. 488 ; Lumley v. Gyc, 2 E. \& B. 250, 257; Exans v. Walton, L. R. 2 C. P. 615.

(p) 9 Rep. 113 a, cited Judgm., 3
C. B. 91, 92; Martinez v. Gerber, 3 M. \& Gr. 88; Bervinger r. Great Eastcrn R. C., 4 C. P. D. 163.

(q) As to the measure of damages in the action by a master founded on loss of service, see, per Lord Tenterden, C. J., Hall v. Hollander, 4 B. \& C. 663 ; Hodsoll r. Stalebrass, 11 Ad. \& E. 301 .

(r) Alton v. Midland R. C., 19 C. B., N. S., 213. See as to this case Taylor v. Manchestci, Sheffield, and Lincolnshive R. C., (1895) 1 Q. B. 13 t (C. A.). (s) Osborn v. Gillett, L. R. 8 Ex. 88. 
master's service, or by harbouring and keeping him as servant after he has quitted it, and during the time stipulated for as the period of service, whereby the master is injured. Whoever thus entices away the servant of another commits a wrongful act, for which he is responsible at law $(t)$. Nor does the principle here stated seem to be limited in its applicability to the case of menial or extra. menial servants. It has been held to extend to the case of persons who have contracted for personal service for a time, and who, during such period, have been wrongfully procured and incited to abandon such service, to the loss of the persons whom they have contracted to serve $(u)$. For this injury an action is maintainable against the wrong-doer, though the master may also have an action against the servant for non-performance of his agreement $(x)$.

(t) Per Croupton, J., Lumley r. Gye, 2 E. \& B. 224; per Lord Kenyon, C. J., Nichal v. Martyn, 2 Esp. 734: 5 R. R. 770 ; per Cockburn, C. J., 6 C. B., N. S., 385 ; Etans r. Walton, I. R. 2 C. P. 615 .

(i) Per Wightman, J., 2 E. \& B. 240 ; Bouen r. Hall, 6 Q. B. D. 31 ; Temperton r. Russell, (1893) I Q. B. 715 (C. A.). But no action lies for enticing away an apprentice, unless serving under a valid contract of apprenticeship): Cox v. Muncey, 6 C. B.. X. S. 375 .

(x) 3 Bla. Com., p. 142.

As to the measure of damages in an action for enticing away the serrant of another, see Gunter v. Astor, 4 Mloore, 12 ; 21 R. R. 733. 


\section{CHAPTER V.}

THE MEASURE OF DAYAGES-IN ACTIONS OF TORT.

THE damages recoverable in an action ex delicto are in general regarded by our law as purely compensatory, although a wider latitude is necessarily allowed to the jury assessing them than in actions of contract $(a)$. The general rule, moreover, as in actions of contract, is, that "a plaintiff must recover once for all, by one and the same action, all damage, past, present, and future, resulting from one and the same cause of action" $(b)$. For example:-

In an action for the obstruction of ancient lights, the jury were directed to consider whether there had been a sensible diminution of light so as to make the plaintiff's premises less available for the purposes of occupation or business to which they were then or might thereafter be made applicable, and that the damages were to be estimated according to the diminution in value of the premises for such purposes. This was held to have been a right direction $(c)$.

The principle first above stated may thus be illustrated:In an action for a trespass, by cutting into the plaintiff's

(a) "In the case of wrongs not founded on contract the damages are entirely a question for the jury, who may consider the injury to the feelings, and many other matters which have no place in questions of contract. In actions for breaches of contract, the damages must be such as are capable of being appreciated or estimated:" Judgm., Hamlin v. Great Northern R. C., I H. \& N, 411 . (b) Lamb v. Walker, 3 Q. B. D. 389 , 395 , which case, however, has since been overruled, though without questioning the principle here stated, on the ground that the cause of action was not the original excavation but the subsequent subsidence: Mitekell $\mathrm{r}$. Darley Wain Colliery, 14 Q B. D. $125 ; 11$ App. Cas. $12 \%$.

(c) Mroore $r . H a l l, 3$ Q. B. D. 178. 
close and carrying away his soil, the question as to the amount of compensation to which the plaintiff is entitled must be determined by ascertaining what the land was worth to him $(d)$. So, in an action for recovery of goods wrongfully taken (e) or dealt with $(f)$, the measure of damages is the value of the goods when the tortious act was done $(g)$; and where the plaintiffs sued for a bill of exchange for $1,600 l$., deposited by them with the defendant, and it appeared that the defendant had wrongfully dealt with the bill, and had afterwards raised $800 l$, by discounting it, the plaintiffs were held entitled to a verdict for $1,600 l$. (h). Though when a defendant, after having misapplied goods to his own use, delivers them back to the plaintiff, the actual damage sustained is the measure of damages (i). So, where a man has temporary possession of a chattel, the ownership being in another, the bailee can recover only the real damage sustained by him in being deprived of the possession $(k)$. Again, - the value of a chattel sued for may, in some cases, be properly estimated and determined by applying the legal maxim, Omnia presumuntur contra spoliatorem $(l)$. In case against the sheriff for taking an

(d) Jones v. Gooday, 8 M. \& W. 146. S.ee Thompson v. Pettitt, 10 Q. B. 101.

(e) Per Brameell, B., Keen v. Priest, 4 H. \& N. 242.

(f) Edmonson v. Tuttall, 17 C. B., I.S., 280; Johnson v. Lahcashire and Forkshire R. C., 3 C. P. D. 499 ; per Patteson, J., Finch จ. Blount, 7 Car. c. 1'. 478; and in Cook v. Hartle, 8 1d. 568 ; Watson v. JeLeun, E. B. \&. E. 5 ; Reid v. Fairbanks, 13 C. B. 692.

(g) France v. Gaudet, L. R. 6 Q. B. $199,204$.

(h) Alsager v. Close, 10 M. \& T. $576,584$.

(i) l'rima facie in an action for the recovery of goods, the plaintiff gets their ralue; but if the goods have been given up, that may be taken into account in the reduction of damages: per Willes, J., Tumvaco v. Simpson, 19 C. B., ${ }$. S., 478. Et vide, per Pollock, C. B., Grviffiths v. Orcen, 13 M. \& W. 63 .

See also Dreyfus v. Peruvian Guano Co., 42 Ch. I. 66 . The plaintifis recovered by way of damages for their loss, by being kept out of the possession of cargoes, 5 per cent. interest upon the value of the cargoes down to the date of the judgment. Affirmed $43 \mathrm{Ch}$. D. 316.

(k) Judgm., Chinery v. Tiall, 5 H. \& N. 295 ; cited and distinguished in Attack v. Bramuell, 3 B. \& S. 527-529; Johnson v. Stear, 15 C. B., X. S., 330: distinguished in Surive v. Leach, 18 C. B., X. S., 479,492 ; ride per Williams, J., Edmonlson r. Nuttall, 17 C. B., N. S., 292, 293.

(l) Armory v. Delamivie, 1 Str. 505 ; $1 \mathrm{Sm}$. L. C., 9 th ed., 385. 
insufficient replevin bond, the reasonable measure of damages is the amount of rent distrained for, together with the expenses of the distress $(m)$. So, in an action against a solicitor for negligence, damages should be awarded commensurate with the loss sustained $(n)$. And in a class of cases already noticed, for a mere breach of duty, nominalsometimes even substantial-damages will be recoverable (o).

Where a company refused to register a transferee of shares who had bought on the faith of a certificate issued by the company to the transferor, the measure of damages was held to be the market price of the shares at the date of the refusal to register $(p)$.

It is, indeed, easy to suggest a state of facts giving rise to an action ex delicto, which would at once present the true measure of damages to be arrarded to the complainant, and in which no ground for aggravated damages beyond such measure would exist. Thus, in case by a reversioner for injury to his reversionary freehold interest in land, by pulling down a house erected upon it, the measure of damages would be ascertained by considering to what extent the land was lessened in value by the wrongful act of the defendant $(q)$. In an action by a tenant against his landlord for selling goods under a lauful distress, but without having them properly appraised, the measure of damages was held to be the real value of the goods sold, minus the rent due $(r)$. And the general rule is, that where an injury has been done to land or goods, the compensation to be awarded

(m) Edinonds v. Challis, 7 C. B. 413.

(n) Morgan r. Stehle, L. R. 7 Q. B. 611 ; Watts v. Porter, 3 E. \& B. 743, 751: Workman v. Great Norther'n R. C., 32 L. J., Q. B., 279.

(o) See Sanders v. Stuart, 1 C. P. D. 326 ; Fray .. Toules, 1 E. \& E. 839 ; Marzetti r. Williams, 1 B. \& Ad. 415; Rolin v. Steward, 14 C. B. 595; Cahill r. Dauson, 3 C. B., N. S., 106, 120. (p) In re Ottos Topje Co., (1893) 1 Ch. 618 (C. A.).

(q) Hosking r. Phillips, 3 Exch. 168: per Jervis, C. J., Batteshill r. Reed, 18 C. B. 713 .

(v) Knight r. Egerton, 7 Exch. 407. As to the damages recoverable for an illegal or irregular distress, see Keen v. Priest, 4 H. \& N. 236, and cases there cited: Attaek r. Bramuell, 3 B. \& S. 520 ; Bemett v. Bayes, 5 H. \& N. 391. 
should be proportioned to the amount of the plaintiffs interest therein $(s)$.

To take a different case- " Suppose that a horse has been sold with a fraudulent warranty, and suppose the horse is resold with knowledge of the defeet which had been fraudulently concealed, the damages to be recovered would be the difference in the prices obtained at the two sales" $(t)$.

But although, as remarked by Lord Denman, C. J. (u), "it is important to uphold the principle, that a plaintiff is entitled to recover, by way of damages, all that at the commencement of the suit he has lost through the mrongful act for which the defendant is sued," the rule here stated will often fail to guide us, with satisfactory certainty, to a determination of the measure of damages in tort. If, for example, in an action for a trespass to land and injury done by treading down the grass and herbage, the jury, in estimating damages, were to be restricted to exactly the amount of the injury sustained by the plaintiff, it would, in effect, be placing a wrong-doer, in many cases, upon precisely the same footing as one who enters with the owner's permission; for the lowest terms upon which the party so entering could have expected to have obtained such permission would have been, that he should make compensation for the full amount of damage that might be done to the grass; in other words, it would be putting an unlicensed trespasser upon the same footing as one who entered with leave and licence $(x)$. So, in an action against the sheriff for wrongfully seizing the plaintiff's goods, it was remarked by Alderson, B. $(y)$, that

(s) See Tucyman v. Finoules, 13 C. B. 22.2; Brierly v. Kendall, if Q. B. 937; followed in Toms r. Wilson, 4 13. \& S. 458 ; Turner r. Havdeastle, 11 C. B., N. S., 683 ; Harey r. Pocuek, 11 M. \& W. 740 ; Pritchard v. Long, 9 M. \& W. 666 ; Baleley r. rigurs, 4 E. \& B. 71 ; Pell r. Shicarman, 10 Exch. 766.

(i) I'er Bramuell, L. J., Waddell v. Ilockey, 4 Q. B. D. 681 . (u) Rundle r. Little, 6 Q. B. 178.

(x) I'er Maule, J., Williams r. Currie, 1 C. B. 847.

(y) Lockley r. Pye, \& II. \& W. 13.5. See Gillard r. Brettan, 8 M. \& W. 575; Waruick r. Foulkes, 12 M. \& W. $50 \%$.

As to the damages recorerable in replevin, see Gibbs v. Corikshank, L. R. 8 C. I. 454 . 
juries have not much compassion for trespassers, and are not bound to "weigh in golden scales" how much injury a party has sustained by a trespass. And on one occasion $(z)$, where the action was for entering the plaintiff's house, breaking his locks, and seizing his papers, \&c., Pratt, C. J., thus forcibly delivered himself: "Damages," he remarked (a), "are designed not only as a satisfaction to the injured person, but likewise as a punishment to the guilty, to deter from any such proceeding for the future, and as a proof of the detestation of the jury to the action itself." At all events, without adopting literally the above expressions, there can be no doubt that, in actions for seduction $(b)$, or malicious injuries, juries have been allowed to give exemplary, or what are sometimes called vindictive damages, and to take all the circumstances into their consideration $(c)$, -a remark which seems applicable also to any case in which the process of a Court of justice has been abused, and a gross outrage has been committed under the forms of law $(d)$. So, if the defendant persists in continuing a nuisance erected upon land in which plaintiff has a reversionary interest, the jury may give such damages as may compel him to abate the nuisance (e). Inasmuch, moreover, as it is the peculiar province of the jury to assess the damages, the Court will not grant a new trial on the ground that the amount awarded is insufficient $(f)$, or excessive $(g)$, unless

(z) Wilkes v. Wood, 19 How. St. Tr. 1153.

(a) Id. 1167.

(b) Tullidge v. Wade, 3 Wils. 18 ; Berry v. Da Costa, L. R. 1 C. P 331 ; Terry v. Hutchinson, L. R. 3 Q. B. $599,603$.

(c) Per Pollock, C. B., Doe r. Filliter, 13 M. \& W. 51 ; Emblen v. Myers, 6 H. \& N. 54 ; per Lord Tentevden, C. J., Sears ₹. Lyons, 2 Stark. N. P. C. 318 ; 20 R. K. 688 ; per Lord Ellenborough, C. J., Bracegirdle v. Orford, 2 M. \& S. 77 ; Beardmore v. Carrington, 2 Wils. 244 ; per Bowen, L. J., Whitham v. Kershaw, 16 Q. B. D. p. 618.
As to vindictive damages against a carrier for refusing to take plaintiff's goods, or to carry them at the ordinary rate, see Crouch v. Great Norther R. C., 11 Exch. 742, 759 .

(d) Gregory v. Slowman, 1 E. \& B. 360,370 ; Duke of Brunswick v. Slowman, 8 C. B. 317.

(e) Batteshill v. Reed, is C. B. 696.

(f) Howard r. Barnard, 11 C. B. 653; Apps v. Day, 14 C. B. 112 : Armytagc r. Haley, + Q. B. 917 ; cited and distinguished in Vichal r. Bestwick, 28 L. J., Ex. 4; Kelly v. Sherlock, L. R. 1 Q. B. 686 .

(g) Chambers r. Caulficld, 6 Eas', 
they are satisfied that the jury either have made a compromise in awarding nominal damages $(h)$, or were actuated by some improper motive or proceeded upon a wrong prin. ciple in making their assessment, or unless the damages are so small as to show that they must have omitted to take into consideration some of the elements of damage (i); for the rell-known maxim is, Ad questionem facti non respondent judices.

Whether damages be regarded as "a compensation and satisfaction for some injury sustained $(k)$, or as in their nature penal, so that they may, in certain cases, be given to punish or to deter, and not merely to compensate $(l)$, the inquiry, how far a jury in assessing damages for a tort may properly take into account the motive and intention which actuated the wrong-doer, is one of much interest and im-

Intention or motive of wrongaloer -whether material in estimating damages.

portance. Now, it will at once strike us, that there are very many tortious acts which suffice to entitle an aggrieved party to damages, without any reference at all being had to the motive or intent which may have prompted them; whilst other cases will as readily suggest themselves, in which the animus, motive, or intention of the party charged constitutes an essential element in, if it be not the very gist and substance of, the charge alleged against him. It is clear, that, if a trespass be done to my land, or if my goods are illegally withheld from me, or if I sustain bodily hurt by reason of the negligence and want of due caution of

244. See Rolin v. Stcucard, 14 C. B. 595 ; Beardmove v. C'arrington, supra, n. (r). See also Poatd v. Graham, 24 (2. B. D. 53 (C. A.). "If ... the damages are so excessive that no twelve men could reasonably have given them, then they ought to interfere with the verdict" (per Lord Esker, M. R., at p. 55). In actions for libel, "the jury, in assessing damages, are entitled to look at the whole conduct of the defendant from the time the libel was published down to the time ther gire their verdict" (Id.).

(h) Falley v. Stanford, L. R. 10 Q. B. 54.

(i) See Phillips $\mathbf{v}$. South-Western R. C., 4 Q. B. D. $406 ; 5$ Q. B. D. 78; Williams r. Cuvrie, 1 C. B. 841: Chilton r. London and Croydon R. C. (Exch.), East. 'T. 1848, reported for another point, 16 M. \& W. 212.

(k) 2 Bla. Com., p. 438.

(n) Supra, n. (c). Per Lord Canden, C. J., 2 Wils. 206, 207, 248; per Heath, J., 5 Taunt. 444. 
another, I may maintain against him an action of tort to support which no evidence will be needed of any malicious motive or wrongful intention on the part of the defendant. In an action for trespass to land, the defendant pleaded that he had land adjoining plaintiff's close, and upon it a hedge of thorns : that he cut the thorns, and that they ipso invito fell upon the plaintiff's land, whereupon the defendant removed them thence as soon as possible. Upon demurrer to this plea, judgment was given for the plaintiff $(m)$; for, in a civil action of this nature, "the intent is immaterial if the act done be injurious to another" $(n)$.

We have already seen that an infant $(o)$ or a lunatic $(p)$ is civilly liable for his tortious act.

But although an action ex delicto may sometimes, in strictness, be maintainable for an injury done unintentionally during the prosecution of a lawful act, yet, in determining the amount of damages to be awarded to a complainant, a jury will, in general, doubtless look at all the circumstances accompanying the particular act complained of, and amongst them at the apparent animus of the defendant. It seems, indeed, just and right that they should do so, inasmuch as the amount of injury for which compensation is to be given will, in some cases, be most materially affected by the motive which prompted to its commission, or by the intention with which it was done. Thus, in an action ex delicto for a trespass to the person, an insulting gesture accompanying an act which, though not attended with violence, imounts in law to an assault, may greatly augment the mental anxiety and injury caused thereby ; and the offensive lemeanor of a defendant, or the rank and social position of plaintiff, may properly be taken into account in fixing the

(m) Lambert v. Bessey, Sir T. Raym.

(n) Per Lord Kenyon, C. J., Hayraft r. Creasy, 2 East ; 104, 6 R. R. 180. See Simmons v. Lillystone, 8
Exch. 431 ; Stead r. Anderson, 4 C. B. 806; Judgm., Rogers v. Dutt, 13 Moo. P. C. C. 236.

(o) Ante, p. 673 .
(p) Ante, p. 783. 
damages which, in such a case, should attend the verdict $(q)$.

Again, wherever the gist of an action ex delicto is mala ficles, fraud, or deceit $(r)$, it is manifest that the motive or intention of the party charged with want of good faith or with deceit is a matter peculiarly and specially for investigation before a jury. Whether particular facts do or do not in any given case furnish evidence of fraud in law may indeed depend upon the wording of an Act of Parliament $(s)$, or may have to be determined by applying one or other of those rules laid down in former pages of this Work whereby our law sometimes judges of and ascertains the intention. Cases of the lind alluded to, however, alike serve to illus. trate and sustain the proposition, that, in an action ex delicto, our law does not seldom regard, as most material, the intent and animus of the defendant.

Lastly, in connexion with this inquiry, it will not be controverted, that, in very many rights of action founded upon tort not involving malice or deceit, the intention wherewith an act was done, and which gives to such act a colour and a meaning, is, lilie any other fact, to be determined by the jury. Let us suppose, for instance, that an action is brought for the misappropriation or unlawful detention of a bill of exchange, and the defence is, that the bill was handed over to the defendant as a gift; the intention with which it was transferred to him would necessarily become at the trial the main, if not the sole, subject of inquiry; for a bill of exchange being a chattel, the gift

(q) See Merest r. IIarrey, 5 Taunt. 442 ; $15 \mathrm{R}$. R. 548 ; Price v. Serern, 7 IBing. 316, 319 ; per Bosanquet, J., James v. C'amplell, 5 Car. \& P. 372; per Jyyles, J., Bell צ. Midland $R$. $C$., 10 C. B., N. S., 308.

$(r)$ As to the measure of damages in an action for fraud or misrepresentation, see Twyeross v. Grent, 2 C. I'. D. 469 ; Waidell v. Bloekey, 4 Q. B. D.
678

(s) See per Lord Deniman, C. J., Rouch v. Great Western R. C., 1 Q. B 60, 61 ; per Park, J., Raıcson r. Haigh, 2 Bing. 104; Thoyts r. IHobbs, Exch. 810. See Hutton v. Cruttwell, 1 E. \& B. 15; Fonong r. Traud, 8 Exch. 221; Lee v. Hart, 11 Exch. 880 ; Bell v. Simpson, 2 II. \& N. 410. 
would become complete "by delivery coupled with the intention to give" $(t)$. " "To pass the property in a chattel," says Alderson, B. (u), "there must be both a gift and a delivery;" so that where A. had possession of certain silver plate belonging to B., and B. said to A., "I will give you all the plate that is mine," but no actual delivery of the plate ever took place, the words used were held to admit of literal signification merely, and to be indicative of a bare intention to give at some future time $(x)$. So, again, wherever the animus revertendi or the animus cancellandi has to be inquired into, we have additional instances illustrative of what has just been said. Whenever, indeed, the intention with which an act was done becomes material, the jury will have to decide upon it, subject, of course, to the effect of such legal presumptions as may, under the circumstances, apply. In a case turning upon this point (y), Williams, J., is reported to have said, that "no question of the intention of parties can be a question of law."

Damages, as stated at p. 718, are either nominal $(z)$, jeneral, or special. 'General' damages are such as the law Damages-
general or special.

mplies or presumes to have accrued from the wrong zomplained of $(a)$. 'Special' damages are such as really :ook place, and are not implied by law; they are either ;uperadded to general damages arising from an act njurious in itself, or are such as arise from an act ndifferent and not actionable in itself, but injurious only in its consequences $(b)$. Substantial damages may in some cases, - as in an action against a banker for not duly ronouring a cheque or an acceptance of his customer $(c)$,

(t) Per Parke, B., Milnes v. Dawon, 5 Exch. 948.

(u) 4 Exch. 479.

(x) Shower v. Pilck, 4 Exch. 478.

(y) Blyth r. Demett, 22 L. J. C. P. 9,80 ; S. C., 13 C. B. 178.

(z) See Hiort r. London and NorthWestern R. C., 4 Ex. D. 188, 194;
Sanders r. Stuart, 1 C. P. D. 326.

(a) Ante, pp. 73 et seq.; Cotterill r. Hobby, 4 B. a C. 465 .

(b) 1 Chitt. Pl., Tth ed., p. 410.

(c) Rolin r. Stemaid, 14 C. B. 595. See per Lord Derman, C. J., Roger's พ. Spence, 13 M. \& W. 581 ; r. p. 84 . 
or for slander of a person in the way of his trade $(d)$, or for writing a libel on a servant's character $(e)$,-be recovered, although special damage be neither alleged nor proved.

When, however, the law does not, as of course, imply that the plaintiff sustained damage by the act complained of, the resulting damage should be set forth with particularity $(f)$. And when the damages sustained have not necessarily accrued from the act complained of, and consequently are not implied by law, then, in order to prevent the surprise on the defendant which might otherwise ensue at the trial, the plaintiff must in general state the particular damage which he has suffered, or he will not be permitted to give evidence of it $(g)$.

Consequential damage recoverable providerl it be not too remote.

In an action of tort, then, damages consequential on the tortious act complained of may (provided they be not too remotely connected with it) be recovered $(h)$. If, for instance, a sheriff wrongfully seizes goods which are afterwards taken from him by another wrong-doer, the owner of the goods may recover against the sheriff as special damage the amount necessarily paid to the second wrong-doer, in order to get back the goods (i). The decision in this case, indeed, may clearly be supported without in any way referring to the legal doctrine as to remoteness of damage, inasmuch as the price paid by the plaintiff to recover possession of his goods from

(d) Per W:lliams, J., 14 C. B. 607 ; ante, p. 862 . 635 .

(e) Wennhak v. Morgan, 20 Q. B. D.

(f) See, for instance, Mavtin v. Great Northern R. C., 16 C. B. 179.

(g) See Richardson r. Chasen, 10 Q. 13. 756 ; Thompson v. Wool, 4Q. B. 493.

(h) As exemplifying the above proposition, see Hopkins v. Great Worthern R. C., 2 Q. 13. D. 224; Foxhall r. Burnett, 2 E. \& B. 928; Mullett v. Mason, L. R. 1 C. I'. 559 ; Collins r. Widdle Level Comm., L. R. 4 C. P. 279 ; per Tindal, C. J., Corbett v.
Brown, j Car. \& P. 363; Eubanh v. Nutting, T C. B. 797 ; Bodlcy r. Reynolds, 8 Q. 13. 779: Moon r. Raphael, 2 Bing. N. C. 310 : Roucland v. Samuel, 11 Q. B. 39 ; Tindall $\mathrm{r}$ Bell, 11 M. \& W. 2:28.

(i) Kecne v. Dilke, 4 Exch. 388. See Barrow v. Amaud, 8 Q. B. 595.

An action will not lie against the slseriff for a false return to a writ o renditioni exponas, Levy v. Hale, L. J. C. P. 127-or for negligence it not levying under a fi. fa., Hobson $\mathrm{r}$ Thellusson, L. R. 2 Q. B. 642, withou showing actual danıage. 
the third party might very fairly be taken by the jury as affording a true criterion of their value $(k)$.

As regards the question, What damage is too remote to be recoverable in an action of tort? I must, to avoid repetition, refer to the remarks made and cases formerly cited (l) touching remoteness of damage in actions founded upon contract $(m)$. Although the general rule as to this subject is clear,-that the damage specifically claimed for must be such as naturally flowed from the tortious act or conduct complained of $(n)$,- yet, inasmuch as each case, raising a question as to remoteness of damage ex delicto, must necessarily be decided upon its own facts or by analogy with some special precedent, the rule in question may more zasily be exemplified than in specific terms be qualified or restricted $(o)$.

(k) See further, as to the criterion rhereby to measure damages, Sanquer r. London and South-IVestern R. C., 6 C. B. 163.

As to damages in an action for aking goods, see Reid r. Fairbanks, 3 C. B. 692 ; Martin r. Porter, 5 M. E W. 351 : Wood v. Morewood, 3 Q. B. 40 , n. See also Morgan v, Powell, d. 278; Hitchman v. Walton, 4 М. it W. 409, 416; Wild v. Holt, 9 I. \& W. 672; Thompson v. Pettitt, 10 I B. 101; ante, Chap. 3., s. 2.

(l) See also many instances in which lannage would be too remote, put by cord Penzance, in Simpson v. Thomson, ipp. Cas. 289, 290.

(m) Ante, pp. 734 et seq.

(n) See, as exemplifying this prorosition, Barber v. Lesiter, 7 C. B., ז. S., 175 ; Collins v. Cave, $4 \mathrm{H} . \$ \mathrm{~N}$. :25; Hoey v. Felton, 11 C. B., 广. S., 42 ; Dixon v. Faweus, 30 L. J. ฉ. B. 137; Haddan v. Lott, 15 C. B. : II; Walker v. Goe, 4 H. \& N. 350; 5. C., 3 Id. 385 , and cases there cited; Alston v. Herring, 11 Exch. 822; Hutchinson v. Guion, 5 C. B., N. S., 55; Thompson r. Hopper, E. B. \& 2. 1038 ; Lumley v. Gye, cited ante, 3ook I., Chap. 3; Flouer r. Adam, Taunt. 314: 11 R. R. 591; Powell v. Salisbury, 2 I. \& J. 391 ; cited Lawrence v. Jenkins, L. R. 8 Q. B. 27t; Sneesby v. Laneashire and Yorkshive R. C., 1 Q. B. D. 42.

In Lock v. Ashton, 12 Q. B. 871, one portion of the damages claimed was held not recorerable, inasmuch as it could not in law have flowed directly from the plaintiff's act. See Fitzjohin r. Mackinder, 9 C. B., N. S., 505 ; S. C., 8 Id. 78 ; Blagrave v. Bristol Wateruorks Co., 1 H. \& X. 369.

(o) The doctrine as to remoteness of damage may present itself under various and dissimilar circumstances where a passenger by railway complains of having been unduly delayed on his journey. See particularly Le Blariehe r. London and Worth-Wester'n R. C., 1 C. P. D. 286, 313: Haml in r. London and Worth-Western R. C., 1 H. \& N. 408; Hobbs v. London and SouthWestern R. C., L. R. 10 (2. B. 111, 117 ; Denton v. Gieat Worthern R. C., 5 E. \& B. 860, 868, where Crompton, J., observed, "A public carrier of goods must carry according to his public protession; I think, howerer, that there has beeu no decision that carriers of passenger's are under the same obligation." As to the duty of the company to start a train at a particular 
The following remarks made by a learned Judge in an action ex contractu may perhaps in reference to torts also be of service to the reader, the principle enunciated applring in either case. "The fact," he says, "that a binding agreement has been arrived at does not of itself create a responsibility for all the injury flowing from a breach of it: the wrong-doer is prim $\hat{a}$ facie only liable for the natural and ordinary consequences of the breach ; but where at the tine of entering into the contract both parties know and contemplate that if a breach of the contract is committed some injury will accrue, in addition to the natural and ordinary consequences of the breach, the person committing the breach will be liable to give compensation in damages, upon the occurrence of that injury ; and where the contractee states that he wants the article agreed to be made in order to carry out another contract, the contractor, if he commits a breach in the delivery of the article, is liable for the loss sustained by the contractee, if he becomes unable to carry out that other contract" $(p)$.

Having now classified rights of action ex delicto, and specified the ingredients therein, it may be well to inquire in what respects a tort differs from a contract and from a crime. A moment's reflection will suggest some important points of difference between a right of action upon contract and one upon tort. A contract is founded upon consentit requires privity, more or less immediate, between the

time, see Hurst r. Great Western R. C., 19 C. B., X. S., 310.

As to robbery of passenger in overcrowded carriage and refusal of station-master to detain train to have occupants of carriage searched see Cobb v. Great W"este" R. C. (1894) A. C. 419 , atfirming $\$$. C.. (1S93) I Q. B. 459 (C. A.). The damages were held to be too remote. See this case (at P. 4?3, per Lord Selborne) as to Founiter $r$. North-Eastern R. C., (1892) I Q. B. 385.

(j) Per Bramecell, L. J., Hydraulic Engineering Co. v. MCHaftie, \& Q. B. D. 674; and per Cotton, I. J., Id. $67 \%$.

See also, as to remoteness of damage, Randall $\mathrm{r}$. Vercson, 2 Q. B. D. 102. 
contracting parties; in reference to it no inquiry is, in general, needed as to the motive or intention of the contractor when proved to have committed a breach of contract; the measure of damages ex contractu is, under ordinary circumstances, more or less nearly determined by the stipulations of the parties. To constitute a right of action ex delicto, on the other hand, no privity is needed, nor of course do the parties consent ad idem, for a tort is inflicted without or against the consent of the party who sustains it. In tort, moreover, the measure of damages is, in general, by no means strictly limited, nor is it capable of being indicated with precision; a wide discretion is there allowed to the jury in determining the proper amount of compensation to be awarded, whilst, in so doing, many elements are rightly deemed material which could not properly affect the verdict in an action purely of contract. Besides the important differences thus pointed out, a comparison of the introductory Chapters of Books II. and III. herein contained, having reference to contracts and to torts, will show, that rights of action, founded respectively thereupon, present to our view, when analysed, wholly dissimilar ingredients, and must therefore, apart from mere technical distinctions, be separately treated and considered.

But how, it may be asked, does a tort differ from a crime? To answer this question fully would, of course, necessitate the anticipation of what yet remains to be said in this Volume. I would, however, observe, that a tort mainly differs from a crime in this respect-that the former is a violation of a private right, whereas the latter is a wrong done to the public.

What doubtless tends to introduce confusion and perplexity into the mind of one called upon to draw the distinctions now adverted to is, that sometimes out of the same facts may originate a right to sue in contract or in tort, or even a right to prefer a criminal indictment. Thus 
a forcible entry upon land, or an assault, is clearly indictable; it will as clearly give to the injured party a remedy by action ex delicto. A libeller may, in many cases, be proceeded against either by indictment or by action; the object of the first-mentioned remedy being to punish the offence committed against the public, for every libel has a tendency to cause a breach of the peace on the part of the person libelled,- - the remedy by action being with a view to vindicating the character of the plaintiff and compensating him in damages for the injury sustained. Cases might, moreover, easily be put showing that a transaction may involve a criminal, also a tortious element, and, lastly, a breach of contract; so that if the criminal element be disregarded, a valid right of action ex delicto is disclosed; and if the tortious ingredient be also rejected, a remedy ex contractu will remain to the complainant. Let us, for instance, suppose that a person fraudulently obtains goods under circumstances which would render him liable to be indicted by our law, that he afterwards sells the goods and receives the proceeds of their sale; here the individual who wrongfully possessed himself of the goods would be liable to an indictment for fraud, to an action at suit of the rightful owner for recovery of the goods or their value, or, lastly, to an action for the money had and received by defendant, notice of the criminal or tortious ingredients in the particular transaction being waived.

Without attempting just now to enter further into the inquiry before us respecting the distinction between a tort, a contract, and a crime, the following brief view of the subject may be suggested. The wisdom of ages, says Mr. J. Burrough, has in England established and perfected a system of law called the common law; this law is adapted to the general regulation of the conduct of the subjects of the Crown as members of society; its principles, if accurately 
attended to, will be found all to point to that end $(q)$. Our law, accordingly, sometimes allows the same state of facts to be regarded from totally different points of view; and yet, on each occasion of viewing and considering it, presents a remedy adapted to the requirements of society or of an individual, allowing the person aggrieved, within certain limits and subject to certain restrictions, to select that particular mode of procedure which he prefers.

In every action $e x$ delicto it will be found that some specific wrong or injury has been done, for which it is the object of the plaintiff to enforce compensation or to seek redress; and "since" (to use the words of Sir W. Blackstone $(r)$ ) " all wrong may be considered as merely a privation of right, the plain natural remedy for every species of wrong is the being put in possession of that right whereof the party injured is deprived;" this, under some circumstances, being effected by the re-delivery or restoration of the thing sued for to its legal owner, in others by making the sufferer a pecuniary satisfaction in damages for the injury sustained. As well, however, in the wrongful abstraction of property, as in a tortious act done to it or to its owner, ingredients may enter cognisable solely by our criminal law; and hence it is that these Commentaries, which commenced with an examination of Legal Rights, and of the component elements of our common law, and have since been successively directed to the Law of Contracts and of Torts, will properly terminate with an inquiry as to offences against society punishable as Crimes.

(q) Deane v. Clayton, 7 Taunt. $496 ; 18$ R. R. 553.

(r) 3 Com., p. 116. 


\section{BOOK IV.}

\section{CRIMINAL LA W.}

\section{CHAPTER I.}

CRININAL LAW GENERALLY-ITS ELEMENTARY PRINCIPLES.

Importance of a knowledge of our criminal law.

Ignorance of law no excuse for infringing it.
The law nwaks im. jeratively.

THE extreme importance of a knowledge of our criminal law will be admitted by him who reflects, however cursorily, on the well-known maxim-Ignorantia juris quod quisque scire tenetur neminem excusat. A mistake in point of law, which every person of discretion not only may, but is bound and presumed to, know, affords, in criminal cases, no sort of defence $(a)$; so that when an offender is arraigned at the bar of justice a plea that he has mistaken the law,however much, if proved, it might operate in mitigation of punishment,-is one which the Court will not be at liberty to entertain (b). "The law," as remarked by ligh authority, "is administered upon the principle, that every one must be taken conclusively to know it, without proof that he does lnow it" $(c)$.

But, further, our criminal law, whether common or dependent upon statute, is imperative with reference to the

(a) 4 Bla. Com., p. 27 ; Hale, P. C., Chap. 6; per Beareroft, arg., R. $r$. Ilean of St. Asaph, 21 IIow. St. Tr. 942 : per Pollock, C. B., Cooper r. Simmons, i H. \& N. 717.

(4) Ex parte Barronet, Dearsl. 51; R. r. Esop, 7 Car. \& P. 456 ; R. r.
Bailey, Russ. \& Rr. 4. See Reg. r. Cractshax, Bell, C. C. 303, 316.

(c) Per Timdal, C. J., delirering the opiniou of the majority of the Judges iu M'Naghten's Case, $10 \mathrm{Cl}$. \& F. 210. 
conduct of individuals; so that, as will presently be seen, if a statute forbids or commands a thing to be done, all acts or omissions contrary to the prohibition or command of the statute are offences at common law, and ordinarily indictable as such. In support of what has just been said, and as illustrating the rule, that, whenever the law positively forbids a thing to be done, it becomes thereupon ipso facto illegal to do it (d), may be mentioned Reg. v. Woodrou (e), where a dealer in tobacco, having in his possession adulterated tobacco, although ignorant of its adulteration, was held, under a penal statute, liable to the penalties imposed by the Act $(f)$. Moreover, constructive knowledge may under a statutory provision-ex. gr., $35 \& 36$ Vict. c. 94 , s. 17 - supply the place of actual knowledge $(g)$.

The law, being thus imperative, cannot be called in question, nor can it be made to bend in accordance with the opinion or the will of those subjected to it. "There can be nothing more dangerous," it has been said $(h)$, "than to allow the obligation to obey a law to depend upon the opinion entertained by individuals of its propriety, that opinion being so liable to be influenced by interest, prejudice, and passion."

And again, it has been said (i) that " where any act is by law defined to be illegal and criminal every one is punishable who voluntarily does the prohibited act without some legal justification or excuse, furnished by the occasion and circumstances, and without regard to his real motive and intention. To hold that a man should be absolved from penal responsibility merely because his motives were benevolent would be to set private opinion above the law."

(d) Per Ashurst, J., 4 T. R. 457.

(e) 15 M. \& W. 404.

(f) See also Lee r. Simpson, 3 C. B. 871; recognised Rende v. Conquest, 11 C. B., N. S., $492 ;$ Re Humphreys, 14 Q. B. $388 ; R$. r. Jones, 2 B. \& Ad.
611.

(g) Bosley r. Daries, 1 Q. B. D. S4, 88; Rerlgate r. IIaynes, Id. 89.

(h) Per Lord Camphell, $9 \mathrm{Cl}$. \& F. 324.

(i) Cr. L. Com., 6th Rep., p. 32. 
Our criminal law is, then, to be made to bear alike and equally on all, and must be applied, in the great majority of cases, without paying heed to any excuse founded upon ignorance of its precepts or disapproval of its provisions. All subjects and foreigners $(k)$ within the realm are alike bound to obey the law, for the law speaks to all uno ore ( $(l)$.

Our law, whether written or unwritten, being thus stringent in its requirements, let us consider the consequences which follow on an infringement of its ordinances.

Meaning of word "crime."

The word "crime" is popularly understood as conveying the idea of something done in violation of law ( $m$ ), and therefore, it may be presumed, exposing the "criminal," in some sort, to punishment. The technical meaning of the words just used-" crime" and "criminal "-is sometimes, however, by no means manifest.

One test for determining whether a particular act be " criminal" was suggested by Erle, J. (n). It is afforded by the nature of the penalty which may be imposed for doing it. Speaking of an offence against the game laws cognisable at petty sessions, that learned Judge observed"There is one thing strongly indicative that this is a crime, for, upon conviction, the offender may be ordered to pay a fine, and in default of payment may be imprisoned with hard labour; that punishment is one appropriate to a proceeding for a 'crime,' not to any civil proceeding ;" and Crompton, J., suggested that for deciding the question raised it was necessary to see whether the fine was a debt or a punishment, observing that under the Act it seemed to be meant as a punishment.

The proceeding, however, against the putative father of an illegitimate child to obtain an order of affiliation and maintenance, is a proceeding not in panam, to punish

(k) Ex parte Baryonet, Dearsl. 51 ; ad roc.

1. צ. Exop, 7 Car. \& I'. 456.

(l) 2 Inst. 184.

(m) Sue Webst. Dict, or Johns. Dict.

(ii) Cattell r. Ireson, E. B. S. E. 91, $99 ; 27$ L. J. M. C. 170. 
for a crime, but merely to impose a pecuniary obligation $(o)$. And " contracts illegal, in one sense, as being roid because in restraint of trade, are not therefore necessarily criminal " $(p)$.

Further, in regard to the legal meaning of the word "crime," the following case has been put:-_" Public policy has," from time to time by various enactments, "for the protection of the Bank of England against forgery, rendered it criminal to make paper bearing the same water-mark as Bank of England notes. The making of such paper is in itself an indifferent act, but, inasmuch as it may afford facilities for forgery, the Legislature has on that account prohibited the act" $(q)$; that is to say, an act in itself indifferent may have impressed upon it a criminal character by force and virtue of the Statute Law. If this be so, it is evident that any correct technical definition of the word "crime" ought to include and be appropriate in a case like that just mentioned, where nothing malum in se is involved in the act done. It is indisputable, on the one hand, that the quality of an act may be flagitious $(r)$, and yet the act itself may be dispunishable $(s)$; and, on the other hand, that an individual, impelled to an act by the purest motives, may nevertheless in doing it violate the law and render himself amenable to its censures $(t)$.

Crimes are offences of a public nature, i.e., such acts or

(o) Per Lord Campbell, C. J., Reg. ऽ. Berry, Bell, C. C. 46 , recognised in Reg. r. Fletcher, L. R. 1 C. C. 320 , $324,325$.

(p) Per Cockbun, C. J., Reg. v. Stainer, L. R. 1 C. C. 234 ; cf. per Lord Halsbury, L. C., Jogul S. S. Co. จ. McGregor Gow, (1892) A. C. at p. 39 , also at p. 46 .

(a) Per Pollock, C. B., Atkins r. Kinnier, 4 Exch. 782.

$(r)$ For instance, gambling on the Stock Exchange through the medium of time bargains, though " demoralizing and reprehensible," is not necessarily illegal nor punishable : Thacker $\vee$

\section{Hardy, 4 Q. B. D. 685, 688.}

(s) "Human laws are made not to punish sin, but to prevent crime and mischief:" per Pollock, C. B., 2 H. \& C. 526 .

$(t)$ See, for instance, Reg. $\mathrm{v}$. Sharpe, Dearsl. \& 13. 160; Willians v. Williams, $20 \mathrm{Ch}$. D. 663 . Et vide lieg. v. Feist, Dearsl. \& B. 590. To burn a dead body instead of burying it is not a misdemeanor, unless it is so done as to amount to a public nuisance: Reg. v. Price, 12 Q. B. D. 247 ; or to prevent the holding thereon of au intended coroner's inquest: Reg. $\mathrm{V}$. Stephenson, 13 Q. B. D. 33 I. 
A crime is an otfence of a public natıre. attempts as tend to the prejudice of the community $(u)$. "There can be no doubt," says Serjt. Hawkins $(x)$, "but that all capital crimes whatsoever, and also all kinds of inferior crimes of a public nature, as misprisions (y), and all other contempts, all disturbances of the peace, all oppressions, and all other misdemeanors whatsoever of a public evil example against the common law, may be indicted, but no injuries of a private nature, unless they some way concern the king." "Also," he adds, " it seems to be a good general ground, that wherever a statute prohibits a matter of public grievance to the liberties and security of a subject, or commands a matter of public convenience, as the repairing of the common streets of a town, an offender against such statute is punishable not only at the suit of the party aggrieved, but also by way of indictment for his contempt of the statute (z), unless such method of proceeding do manifestly appear to be excluded by it."

The case of Rex v. Wheatley (a) may be useful for reference where difficulty occurs in distinguishing between indictable offences and wrongs remediable by action, and as exhibiting clearly the test in such cases applicable. There the defendant was indicted for knowingly, fraudulently, and with intention to deceive the prosecutor, selling him beer short of the just measure. After a verdict of guilty, the defendant's counsel moved in arrest of judgment, on the ground that the fact charged against the defendant was, in truth, nothing more than a mere breach of a civil contract, not an indictable offence ; and of this opinion was the Court, Lord Mansfield, C. J., observing, that the alleged offence was, in truth, only " an inconvenience and injury to a private

(u) See per Laucrence, J., 2 East. 21. (x) Hawk. Pl. Cr., Book II., Chap. 25. s. 4 .

(y) 'Misprision' "properly signifieth nefrlect or contempt," but in law is ajplicd more particularly " when one knoweth of any treason or felony and concealeth it:" 3 Inst. 36.

(z) lieg. พ. Buchanain, 8 Q. B. 883.

(a) 2 Barr. 1125 ; R. จ. Dunnage, Id. 1130 . 
person," against which he might have guarded by due caution. "The selling an unsound horse as and for a sound one is not indictable; the buyer should be more upon his guard: " the offence that is indictable must be such an one as concerns the public.

An indictment will only lie for some wrong common to all the subjects of the Crown, common thus far, that it affects them all, not of necessity equally, but in some sense and in some degree. The distinction of public wrongs from private -of crimes from civil injuries-seems principally to consist in this, that private wrongs " are an infringement or privation of the civil rights which belong to individuals, considered merely as individuals," whilst public wrongs or crimes "are a breach and violation of the public rights and duties due to the whole community, considered as a community in its social aggregate capacity" $(b)$. Treason, murder, and robbery, are properly ranked amongst crimes, since, besides the injury involved in them to individuals, they strike at the rery being of society, which cannot possibly subsist where acts of this sort are suffered to escape with impunity $(c)$. Many inferior offences, also, of a public nature are indictable. And it is material to observe, that a crime will be deemed of a public nature, not merely where it causes some hurt, damage, or inconvenience to the public, but also where it is " of a public evil example." It is an indictable offence for a parent who has the means of supporting her child $(d)$ to neglect to provide sufficient food or necessaries for it $(e)$ whilst of very tender years and unable to take care of itself $(f)$. It is an offence at common law knowingly to send to market for human food meat which is unfit for human food (g). It is at common law indictable knowingly to take a glandered

(b) 4 Bla. Com., p. 5.

(c) Id. ibid.

(d) Reg. r. Chandler, Dearsl. 453 ; Reg. v. Ryland, L. R. 1 C. C. 99.

147 . (f) R. v. Friend, Russ. \& Ry. 90.

(g) Shillito r. Thompson, I Q. B. D. 12,14 ; Wavd v. Hobbs, 3 Q. B. D. 150; $S$. C., affirmed $\&$ App. C'as. 13. 
horse into a market, fair, or other place of public resort, to the danger of the liege subjects of the Crown $(h)$. It is by the common law of England a nuisance and an indictable offence to manufacture, or to keep in large quantities, gun. powder or any other explosive and inflammable material in a town or closely inhabited place (i). And any outrage upon public decency $(k)$, as well as against the public peace, is indictable.

Bearing in mind what has been just said, we may conclude that, in general, a 'crime' consists in some act or' combination of acts involving a violation of some right, or an attempt to violate some right, aggravated by the use of force and violence tending to a breach of the peace, or by the existence in the mind of the criminal of a fraudulent or malicious intention $(l)$. The meaning of this word

'intention,' in connection with criminal law, is most material. 'Intention' is, by non-professional writers, defined to be the design, purpose, or fixed direction of the mind to some particular object $(m)$. It is clearly distin. guishable from motive, or that which incites and stimulates to action. The motive which actuated a wrong-doer may doubtless serve as a clue to the intention; the latter, however, not the former, it is which gives in law the character and quality to an act. "The intention to do the act:" moreover, "exists for all criminal purposes where it is wilfully done, although the act itself was merely intended as a means of obtaining some ulterior object" $(n)$.

(h) Reg. r. IIenson, Dearsl. 24. See Hill v. Balls, 2 H. \& N. 299; Wullett v. Mason, L. R. 1 C. P. 559.

(i) Reg. v. Lister, Dearsl. \& B. 209.

(k) R. v. Sedley, 17 How. St. Tr. 155, n.; Reg. r. Harris, L. R. 1 C. C. 282 ; Reg. r. Holmes, Dearsl. 207: Keg. v. Webb, 1 Den.C. C. 338 ; s. C., 2 Car. \& K. 933 : Reg. r. Sunndes', 1 (2. B. D. 15; heg. Y. Watson, 2 Car. \& K. 936 , n. $(g)$. See lieg. r.
Elliatt, L. \& C. 103 ; Reg. r. Thallman, Id. 326 ; Bradlangh v. Reg., 3 Q. B. D. 607 ; Reg. v. Clark, 15 Cox, C. C. 171 .

(l) What is above said is not offered as a definition of the word "crime," but rather as explanatory of its meaning.

(iin) Webst. Dict. ad rerb. "Intention."

(n) Cr. L. Com., 4th Rep., p. 15. 
To illustrate what has been above said, a man who takes a horse from the owner's stable without his consent may intend to defraud him of it, and fraudulently to appropriate it for his own benefit; in this case he is guilty of theft: he may intend to use it for some temporary occasion of his own, and then to return it to the owner; in this case he commits a trespass only. $\mathrm{He}$ may take the horse as a distress for rent due from its owner, in which case he is justified by the law. In each of these cases the act done is substantially the same; the intention of the person doing it mainly determines whether it shall be the subject of civil or of criminal cognisance, or whether it be altogether innocent.

Sometimes, no doubt, as before observed, the statute law expressly declares, that such and such acts shall be criminal, and shall expose to punishment the individual convicted of doing them. In these cases any inquiry as to the intent which actuated the party charged would, unless with a view to a mitigation of punishment, be immaterial (o). So, too, where a person was indicted under 8 \& 9 Vict. c. 100 , ss. $44(p), 90$, for receiving two or more lunatics into a house not duly licensed or registered, it was held to be immaterial that she honestly believed the patients to be in fact not insane $(q)$.

Sometimes a particular act is declared by the legislature to be prima facie criminal, so as to cast upon the party convicted of having done it the omus of proving that his intent was innocent. In much the larger class of cases the intent of the actor is material, and, to ensure conviction,

(o) See Hudson, app., II 'Rae, resp.; 4 B. \& S. 585. As to a "wilful" trespass, see Foulger r. Steadman, L. R. 8 Q. B. 65 .

The effect of intent on the quality of an act was much discussed in Att. - Gen. r. Sillem, 2 H. \& C. 431 ; S. C., 10 H. L. Ca. 704 .

$(p)$ Now repealed, but re-enacted.

B.C.L.
See 53 Vict. c. 5, s. 315 .

(q) Reg. v. Bishop, it Cox, C. C. 404. So, too, knowledge of the condition of the person served is not necessary to constitute an offence against $35 \& 36$ Vict. c. 94 , s. 13 , which forbids the sale of intoxicating liquor to a drunken persou : Cundy, app., Le Cocq, resp., 13 Q. B. D. 207 . 
must satisfactorily be proved on the part of the prosecution $(r)$. It was, indeed, laid down by Lord Mansfield, as generally true $(s)$, that where an act in itself indifferent, if done with a particular intent, becomes criminal, there the intent must be proved and found by the jury; but where the act is in itself unlawful, the proof of justification or excuse lies on the defendant, and, in failure thereof, the law implies a criminal intent.

A guilty mind $(t)$ or knowledge $(u)$, however, is, in general, essential to the legal conception of crime. In what, then, it may be asked, does the mens rea consist $(x)$ ? It would seem to include, 1st, every case of intentional or voluntary wrong, where the mind is actively in fault; 2ndly, cases where the mind is as it were passively to blame, as where hurt or damage results from want of exercising sufficient caution $(y)$. With reference to each of these classes of cases, a few remarks may here be offered.

As regards the former class of cases, where the mind is actively in fault, we may infer, from what was said at a former page (z), that there are two linds of "malice," hy either of which an offender may be actuated: malice in fact, where he acted from "a motive of actual ill-will and a design to injure;" and malice in law, which consists in

(r) "Generally speaking, where an offence cannot be committed unless the mind goes along with the aet, the act alone is not sufficient to render the party liable:" per Pollock, C. B., 5 II. N. N. 84. See Reg. v. Slecp, L. \& C. $44 ;$ Reg. v. Ingham, Bell, C. C. 181 ; Bouman v. Blyth, 7 E. S B. 26, 43. Et vide per King, C. J., $R$. v. Woodburne, 16 How. St. Tr. 79 .

See Reg. v. Bailey, Dearsl. 244, with which compare Reg. $v$. Oklham, 2 Den. C. C. 472 .

(s) R. v. Fuodfall, o Burr. 2667.

(t) See, ex. gr., Reg. v. Thomas, L. \& C. 313; Aberdare Local Board r. IIammett, I. R. 10 Q. B. 162.

(a) See Core, app., James, resp., I. R. 7 Q. 13. 135; Davies, app.,
Harvey, resp., L. R. 9 Q. B. 433 : Mrullins, app., Collins, resp., L. R. 9 Q. B. 292: diseussed in Somerset $r$. Hav' 12 Q. B. D. 360 ; distinguished, Bond r. Evans, 21 Q. B. D. 249: approved, Somerset r. Wade, (1594) 1 Q. B. 574 (where Bond v. Erans is explained); Nickols r. Hall, L. R. s C. P. 322; eited in Dickenson v. Fletcher, L. R. 9 C. P. 1, 6; Fit:patrick, app., Kelly, resp., L. R. S Q. B. 337 ; Reg. v. IIariey, L. R. 1 C. C. 284 ; Gibson, app., Barton, resp., L. R. 10 Q. B. 329 .

(x) See particularly Reg. r. Prince, L. R. 2 C. C. 154.

(y) Cr. L. Com., 7th Rep., p. 22.

(z) Ante, p. 836 . 
"the wilful doing of a prohibited or injurious act without lawful excuse" $(a)$. The legal import of the word "malice" differs, indeed, somewhat from its acceptation in common conversation. It is not, as in ordinary speech, an expression merely denoting the existence of hatred or ill-will to an individual, but may mean any wicked or mischievous intention of the mind $(b)$.

It can scarcely be necessary to add, that where the mind is actively in fault it will make no difference in the criminal Where mind is actively quality of the act done whether the offender do it directly with his own hand, or indirectly by some other means $(c)$. If poison be administered through the medium of an innocent agent, the prime mover is criminally responsible (d). And if a man employ a conscious or unconscious agent to commit an offence in this country, he may be amenable to the laws of England, although he was at the time living out of the jurisdiction of our Courts $(e)$.

In the latter of the two classes of cases above alluded to, riz., where the mind is passively to blame, criminality Where mind is passively would seem to consist in the vilfully $(f)$ incurring the risk of causing loss or suffering to others. If the doer of an act know or believe that an evil consequence will result therefrom, he is just as culpable as if he had acted with the most direct intention to injure. If a person take upon himself to administer drugs being ignorant of their probable effects, and thus cause the death of another, he will be guilty of culpable, i.e., criminal negligence.

(a) Cr. L. Com., 6th Rep., p. 52 ; per Littledale, J., .II'Pher-son v. Daniels, 10 B. \& C. 272.

"A man acts maliciously when he wilfully does that which he knows will injure another in person or property:" per Blackburn, J., Reg. v. $W a \cdot d, \mathrm{~L}$. R. 1 C. C. 360 . See Reg. v. Pembliton, L. R. 2 C. C. 119 ; distinguished in Reg. v. Latimer, 17 Q. B. D. 359 ; Reg. v. Child, L. R. 1 C. C. 307.

(b) See per Best, J., R. v. Havey, 2 B. \& C. 268 ; R. ₹. Hunt, Moo.
C. C. $93 ;$ R. v. Cooke, 8 Car. \& P. 582;R. r. Farrington, R. \& Ry. 207 ; Reg. v. Latimer, 17 Q. B. J. 359.

(c) Per Jerris, C. J., Reg. v. Wilson, Dearsl. \& B. 128; Reg. v. Butcher, Bell, C. C. 6.

(d) Cr. L. Com., Tth Rep., p. 30; Reg. v. Ifichael, 2 Moo. C. C. 120.

(e) Per Lord Campbell, C. J., Rcg. v. Gayett, Dearsl. 241.

(f) This word may mean "wantonly" or "causelessly:" Smith v. 
Intentionhow provable.

A wrong intent, then, or something tantamount thereto, being ordinarily an essential element in crime, how is this intention to be proved? A jury is justified in inferring the intent from orert acts, because every man, as well in criminal as in civil $(g)$ procedure, must be taken to have intended that which is the necessary or natural consequence of his act. It is an universal principle, that, "when a man is charged with doing an act of which the probable consequence may be highly injurious, the intention is an inference of law resulting from the doing the act" $(h)$. Thus where the defendant was indicted for a nuisance, and it was on his behalf contended, that, to render him liable, it must be his object to create a nuisance, or else that that must be the necessary and inevitable result of his act, Littledale, J., answered, "If it be the probable consequence of his act, he is answerable, as if it were his actual object. If the experience of mankind must lead any one to expect the result, he will be answerable for it" (i). And similarly, if there be an infraction of the law by publishing obscene matter, the intention to break the law must be inferred, and the criminal character of the publication is not affected or qualified by there having been some ulterior object in view (which was the immediate and primary object of the defendant) of an innocent and honest character $(k)$.

The rule just stated as to proof of intention, which is of much importance in criminal cases, is well illustrated by

Barnham, 1 Ex. D. 419, 423, 424. See Walker v. Horner, 1 Q. B. D. 4 ; Jor. v. Martin, 8 Q. B. D. 54.

(g) Per Cressuell, J., 12 C. B. 98 ; per Jerris, C. J., Id. 103, cited arg., 8 Fixch. 229.

(i) Per Lord Ellenborough, C. J., R. v. Jhixon, 3 M. \& S. 15; 15 R. R. 381; I. v. Jhilip, 1. Moo. C. C. 263, 274; lieg. v. Irill, 8 Car. \& P. 2it; $R$. . Slicppard, Russ, \& Ry. $169 ;$ R. v. ILazagor"l, Id. 291 ; per Lord Campbell, 9

\section{Cl. \& F. 321.}

(i) R. r. Woore, 3 B. \& Ad. Ist, 188: cited per Blackburn, J., Haigh v. Toun Council of Sheffield, I. R. 10 Q. B. 10 T: per Lit:ledale, J., Reg. r. Locett, 9 Car. \& P. 466. Cf. also Reg. v. Serné, 16 C. C. C. 311 , at p. 312.

(k) Jieg. r. Micklin, I. R. 3 Q. B. 360,370 : followed in Siecle r. Brannan, L. R. T C. P. 261 ; and cited in Reg. r. Irince, L. R. 2 C. C. 164. 
Mr. Starkie $(l)$, who remarks, that, in estimating the real intention of an accused person, all the surrounding facts and circumstances of the case must be carefully examined: ex. gr., on a trial for murder, the nature of the instrument used, and the part of the body of the deceased on which the wound was inflicted, must especially be taken into consideration in determining the precise nature and quality of the offence; and this must be done in accordance with what that learned writer describes as "the plain and fundamental rule that a man's motives and intentions are to be inferred from the means which he uses, and the acts which he does." In Rex v. Farrington ( $m$ ), the prisoner was indicted, under a repealed statute, for setting fire to a mill with intent to injure the occupier thereof; and, after a verdict of guilty, sentence was respited, a doubt being entertained whether it was not requisite to give in evidence some fact, other than the mere act of setting fire to the mill, from which an intent to injure some one might be inferred; the conviction, however, in this case, was held to have been right, because " a party who does an act wilfully necessarily," in legal contemplation, "intends that which must be the consequence of the act" $(n)$.

Mere intention, nevertheless, however criminal, cannot render the person entertaining it amenable to law $(o)$; some outward overt act coupled with a wilful disposition or culpable negligence is essential to fill out the legal conception of a crime. Hence it is necessary to distinguish between a bare intention and an attempt $(p)$, in which an Mere intention not cognisable by law.

(l) Evid., 3rd ed., vol. 2, p. 692.

(ii) Russ. \& Ry. 207.

(n) Et vide per Bayley, J., R. v. IIartey, 2 B. \& C. 261 : per Holvoyd, J., Id. 267 ; per Lord Ellenborough, C. J., Newton v. Chantler, 7 East, 143; Reg. v. Martin, 8 Q. B. D. 54 : Reg. v. Halliday, 38 W. R. 256; Reg. v. Serné, 16 C. C. C. 311.

$(0)$ "The imagination of the mind to do wrong, without an act done, is not punishable in our law:" arg., Hales v. Petit, Plowd. 259 a.

(p) See Holloucuy v. lieg., 17 Q. B. 317. An "attempt" is an "abortive or frustrated effort.' See Rey. v. Broun, 10 Q. B. D. 381; Reg. v. Duckucorth, (1892) 2 Q. B. 83, orerruling Reg. v. St. Genrge, 9 Car. \& P. 483, and doubting Re'g. $r$ Lew is, Ib. 523.
An attempt nisy be so. 
act is superadded to the intention. An attempt merely to commit a crime may be indictable $(q)$. " So long," says Lord Mansfield in Rex r. Scofield $(r)$," as an act rests in bare intention, it is not punishable by our laws; but immediately when an act is done the law judges, not only of the act done, but of the intent with which it is done; and if it is coupled with an unlawful and malicious intent, though the act itself would otherwise have been innocent, the intent being criminal, the act becomes criminal and punishable" $(s)$.

In Rex v. Higgins $(t)$, the act of soliciting and inciting a servant to steal his master's goods was held to be indictable, for "the solicitation is an act." In unison also with the principle before us, it has been held, that "the mere possession of obscene and indecent prints is not indictable, because the law will not take notice of an intent without an act," and possession is not an act; but the procuring of such prints with intent to publish them is indictable, being an act done, sc. the first step towards the committing the serious offence of publishing obscene prints (u). To define what is and what is not such an act done in furtherance of a criminal intent as will constitute an offence would be difficult or impossible, but it may safely be affirmed that an attempt at committing an indictable offence is not an indictable attempt unless it is an act directly approximating to the commission of the offence $(x)$.

But though "it is a principle of natural justice and of

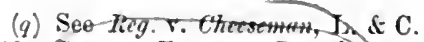
140 ; Reg. v. Ferguson, Dearsl. 127 ; Kég. r. Marsh, 1 Den. C. C. 50.5.

An attempt to commit suicide is indictable at conmon law: Reg. r. Burgess, L. \& C. 258.

(r) Cald. 397,403 .

(s) In Reg. v. Cullins, I. \& C. 471, it was held that an attempt can ouly be when there is such a beginuing is if uninterrupted would end in the completion of the act. This was, however, overruled in Reg. r. Broten, 24 Q. B. D. 3.5. See also Reg. r. King, 61 L. J. II. C. 116.

(t) 2 East, 5: 6 R. R. 3.58; $\mathrm{keg}$. v. Gregory, L. R. 1 C. C. $7 ;$; $R$ v. Tanghan, 4 Burr. 2494.

(iv) Digdale r. Reg.. 1 E. \& B. 435. 439. See $R$. v. Heath, Rus. \& Rr. 184; R. v. Fuller, Id. 308.

(x) Per Parke, B., Reg. r. Roberts, Dearsl. 539, 551, following Reg. $\mathrm{r}$. Eagletori, Id. $376,515,525,535$. 
our law, that actus non facit reum nisi mens sit rea (y),the intent and the act must both concur to constitute the crime" ( $z)$,-we may conclude that, where no evil effect whatever is produced, criminal endeavours, evidenced by manifest overt acts, are and ought justly to be punishable. And, this being so, little difficulty need be felt in regard to another important class of cases, viz., where some mistake is made in carrying out the criminal design, so that it causes results not intended nor anticipated by the actor. Suppose, for instance, that a mistake is made in respect of the person at whom the crime is levelled, as where the offender shoots at A. supposing he is shooting at B. It is clear that the difference of persons can make none in the quality or magnitude of the offence or in the amount of punishment due to it. The crime here consists in the wilful doing of a prohibited act--the act of shooting at A. was wilful, although the offender mistook him for another $(a)$. A like remark also is applicable where, through accident or the mistake of a party not privy to the criminal design, the mischief falls either on a person not intended, or on the party intended, but in a manner different from that intended (b). In cases such as the foregoing, the act done is prima facie criminal, and the mind of the party doing it or planning it is criminal, and, consequently, justice requires that the amount of punishment assignable for such act should be unaffected by the accident which affected the result.

From the general principle already illustrated-that our criminal law looks mainly to the intention which actuated Capacity crime. the accused,-important consequences flow. The very

(y) Upon this maxim Mr. Erskine delighted to expatiate: see 21 How. St. 'Tr. 594,$921 ; 27$ Id. $660,661$. See, howerer, per Stephen, J., Cundy, app., Lecocq, resp., 13 Q. B. D. 207.

(z) Per Lord Kenyon, C. J., Foulev v. Padget, 7 T. R. $514 ; 4$ R. R. 511. (a) See Reg. v. Smith, Dearsl. 559, cited per Blackburne, J., 1 Q. B. D. 35.5 ; Reg. r. Fretuell, L. \& C. 443.

(b) Cr. L. Com., Tth Rep., p. 27 ; per Park, J., R. v. Connor, 7 Car. \& P. 438 . 
statement of this proposition implies a presumption that the individual, whom it is sought to bring within the operation of the law, has mental capacity, is a free agent, and possesses the power of electing to abstain from what is forbidden rather than suffer the consequences of offending; our criminal law declines therefore to punish where a party, from want of understanding or mental disease, is either unconscious of what he does or ignorant of the nature and moral quality of his act. Hence the exemption from criminal responsibility of lunatics and children of very tender years.

Neither does our law ordinarily inflict its penalties where a party is, against his will, compelled to do a wrongful act, inasmuch as the dread of future penalties cannot be expected to prevail against the certainty of present suffering. Hence the doctrine that duress will in some cases excuse an act criminal per se, as when committed by a feme covert sub potestate viri. Further the principle upon which our criminal law acts is inapplicable where hurt or damage results from innocent mistalie or inevitable accident, which could not have been foreseen or avoided, for here no blame of any kind is justly attributable to the author of the injury done or calamity occasioned. Of the particular class of cases now adverted to, homicide by misadventure presents a familiar instance. Again, where an individual in the performance of his official duties, as the sheriff or the gaoler, is required to inflict punishment, he may be deemed to stand excused as not being a free agent, but rather a passive instrument to carry out the law, and blameless by virtue of the maxim Quod necessitas cogit, excusat.

In any of the cases just specified, a criminal intention, in the full sense of that term, is wanting, and therefore the act done is deficient in that particular quality or ingredient which is necessary to constitute a crime. The aim and 
object, moreover, of punishment is to deter $(c)$, and it obviously will not be effectual to deter those who, being similarly circumstanced with the accused individual, either cannot, through lack of understanding, appreciate its meaning and nature, or, being coerced by some overruling influence, are insensible to its terrors.

Neither, by parity of reasoning, will punishment in any of the cases supposed deter the criminal himself from again offending. Lunatics, infants, and femes coverts are, then, in many cases held irresponsible and dispunishable for acts prima facic criminal done by them. Restricting my remarks in regard to the capacity to commit crime almost wholly to the three classes of persons here indicated, I will first inquire to what extent and under what circumstances mental derangement or insanity may excuse from the ordinary consequences of crime. Now, Mr. Erskine, in his argument in Hadfield's case (d), thus forcibly states the elementary principles which are here to guide us. "It is Non compos when held irresponagreed," he says, " by all jurists, and is established by the law of this and every other country, that it is the reason of man which makes him accountable for his actions, and that the deprivation of reason acquits him of crime. Neither in civil nor in criminal cases, however, will our law, provided a man be compos mentis, measure the degree of his capacity. A weak man, albeit much below the ordinary standard of human intellect, is bound by his contracts, may exercise dominion over his property, and is responsible for his crimes. From such responsibility he alone is emancipated who is, in the language of our law, non compos mentis (e).

(c) The end of punishment is to prerent the criminal from doing further injury to society, and to prevent others from committing the like offence: Beccar. Cr., Chap. 12.

(d) 27 How. St. Tr. 1309, 1310.

(e) See per Erskine, arg., in Hadfield's ease, above cited; per Lord Cramuarth, C., 6 H. L. Ca. 45 ; Reg. r. Burton, 3 Fost. \& F. 772; Reg. v. Vyse, Id. 247; per Waule, J., Rey. r. Higginson, 1 Car. \& K. 130; per I'olloek, C. B., Clift r. Schwabe, 3 C. B. 478 ; Borraduile v. Hunter, 5 M. \& $\mathrm{Gr}$ 639. And see Dormay v. Borradaile, 5 C. B. 380 ; S. C., 16 L. J. Chanc. 337. 
The main inquiry before us, accordingly, is this:-What may, in connection with criminal law, be the meaning and significance of the phrase just used? what is that kind or species of insanity which exempts from punishment on the ground that its existence is inconsistent with the criminal intent? Clearly it is not every degree of insanity which suftices for this purpose. Many men of general ability are upon some one topic insane, provided their opinions be tested by those entertained by the world at large. One labouring under the grossest delusions may for many purposes be treated and held accountable, as if sane : $e x . g r$. , he may possibly be admitted to give evidence on a criminal trial in a Court of Law; and where such an objection is taken to the competency of a witness, it is for the Judge to say whether the insane person has the sense of religion in his mind, and whether he understands the nature and sanction of an oath; and then the jury will have to decide on the credibility of, and weight due to, his evidence $(f)$. It is clear, then, that a man may be non compos mentis quoad hoc, and yet not non compos mentis altogether $(g)$.

In $M$ 'Naghten's case (h), the accused was charged with murder, and, the fact of wilful homicide being established, the defence of insanity was set up, supported by evidence that the accused was affected by morbid delusions which carried him beyond the power of his own control as regarded acts connected therewith, and left him no moral perception of right and wrong. It was further shown to be the nature of the disease under which the prisoner suffered gradually to acquire intensity, and then suddenly to develop itself with great violence; the prisoner was acquitted on the

(f) Reg. r. Hill, 2 Den. C. C. 254. (I) See per Alder'son, B., 2 Den. C. C. 260 .

(b) $10 \mathrm{Cl}$. \& F. 200, cited per Sir J. Hannen, Bonghton v. Knight, I. R. 3 I'. d I). il. See Reg. v. Tuurvey,
3 Fost. \& F. $\$ 39$.

Of the doctrines laid down in M'. Sughten's case some have been questioned br eminent criminal law. yers. In the text it has, however, been ihought well to state thein at length. 
ground of insanity. In consequence of this verdict, which led to some discussion in the House of Lords, certain questions were by that House proposed to the Judges, from the answers to which, given by the majority of the Bench (i), must be deduced the degree of criminal responsibility attaching to one affected with mental disease; it becomes necessary, therefore, in this place to set out the substance of the questions, on the occasion alluded to, thus formally proposed, and of the answers advisedly returned thereto.

The first question submitted to the Judges in $M I^{\prime}$ Naghten's case was as follows:- " What is the law respecting alleged crimes committed by persons afflicted with insane delusion in respect of one or more particular subjects or persons, as, for instance, where at the time of the commission of the alleged crime the accused knew he was acting contrary to law, but did the act complained of with a view, under the influence of insane delusion, of redressing or revenging some supposed grievance or injury, or of producing some supposed public benefit?" To this question, the answer given was, that a person labouring under such partial delusion only, and not being in other respects insane, although he did the act complained of with a view, under the influence of insane delusion, of redressing or avenging some supposed grievance or injury, or of producing some public benefit, is nevertheless punishable according to the nature of the crime committed, "if he knew at the time of committing such crime that he was acting contrary to law," i.e., to the law of the land $(k)$.

We further collect from $M I^{\prime}$ Naghten's case, that when a person alleged to be afflicted with insane delusions respecting one or more particular subjects or persons is charged with the commission of a crime, and insanity is set up as a defence, the jury should be instructed that every man is 
presumed to be sane, and to possess a sufficient degree of reason to be responsible for his crimes, until the contrary be proved to their satisfaction $(l)$; and that, to establish a defence on the ground of insanity, it must be clearly shown that at the time of the committing of the act charged in the indictment the party accused was "labouring under such a defect of reason, from disease of the mind, as not to know the nature and quality of the act he was doing, or if he did know it, that he did not know he was doing what was wrong." If the accused was conscious that the act in question was one which he ought not to do, and if that act was at the same time contrary to the law of the land, he is punishable. The usual course, accordingly, is to leare the question to the jury whether the party accused had a sufficient degree of reason to know that he was doing an act which was wrong; the question thus submitted being accompanied with such observations and explanations as the circumstances of each particular case may require $(m)$.

"It is essential to constitute responsibility for crime that a man shall understand the nature and quality of the thing he is doing, or that he shall be able to distinguish in the act he is doing right from wrong. Now a very small degree of intelligence is sufficient to enable a man to judge of the quality and nature of the act, and whether he is doing right or wrong, when he kills another man; accordingly he is responsible for the crime committed if he possesses that amount of intelligence" $(n)$.

Another question of much interest also sometimes presents itself on a criminal trial:-If a person under an insane delusion as to existing facts commits an offence in consequence thereof, is he thereby excused? The answer to this question is, that if the accused labours under a

(I) See also per Rolfe, B., Reg. r. Stokes, 3 Car. \& K. 188.

(m) $10 \mathrm{Cl}$. \& F. 210, 211. See Reg. v. Oxfordl, 9 Car. \& P. 525; s. C.,
'Townsend's St. Tr., vol. 1, p. 110. (ii) Per Sir J. Hannen, Boughton r. Knight, L. R. 3 I. \& D. 72. 
partial delusion only, and is not in other respects insane, he must be considered in the same situation as to responsibility as if the facts with respect to which the delusion exists were real. For example, if, under the influence of his delusion, he supposes another man to be in the act of attempting to take away his life, and he kills that man, as he supposes, in self-defence, he will be exempt from punishment. If his delusion were that the deceased had inflicted a serious injury on his character and fortune, and he killed him in revenge for such supposed injury, he would be liable to punishment $(o)$.

To the evidence of scientific men, conversant with the disease of insanity, who have examined and conversed with the accused person,- - who can, besides testifying to his words and actions, explain the nature of the delusions under which he may be labouring, and the ordinary effect of such delusions upon the mental functions,-much weight will naturally be attached by a jury when engaged in the arduous task of investigating the question, whether one accused of crime was sane or insane at the time of its commission. Where, moreover, on the trial of such an issue, the facts of the case are admitted or not disputed, and the question becomes substantially one of science only, it may be convenient to ask a medical witness, who has been present during the trial, his opinion as to the state of the prisoner's mind at the time of the commission of the alleged crime, and as to his perception of the difference between right and wrong; but, as we learn from M'Naghten's case $(p)$, it is not a matter of right to put such a question.

Amongst medical practitioners, however, and those experts who have appeared as witnesses to give evidence touching insane and morbid delusions at criminal trials, a wide difference of opinion exists on various important points

(o) 10 Cl. \& F. 211.

(p) 10 Cl. \& F. 212. 
relating to the responsibility of persons mentally affected, and mainly as to these fundamental questions: Are there states and conditions of mind in which responsibility is modified only, not annulled? May the insane be, in certain cases, fit objects for punishment? Nay, further, may not punishment be so applied to some criminals of unsound mind that the reason of its application may be appreciated by them and beneficial results thence ensue? It is the opinion of some scientific men, that much may be said in favour of a scale of punishments for the insane, graduated, so far as the results of experience and observation may permit, to their different degrees of responsibility and criminality. The inquiry hinted at, however, could scarcely with propriety be conducted in these Commentaries, which profess to deal with the law as it is, not as, in the opinion of jurists, it ought to be. I will merely add, therefore, that when a person, upon his trial for an alleged crime, seeks to excuse himself upon a plea of insanity, it will be for him to make out clearly that he was insane at the time of committing the offence charged against him. The ouus of so doing rests on him, and the jury must be satisfied that, at the time in question, he actually ras insane. If the matter be left in doubt, it will be their duty to convict him, for, as stated at p. 1004, " erery man must be presumed to be responsible for his acts till the contrary is clearly shou'n" $(q)$.

At present the law is $(r)$, that where in any indictment or information any act or omission is charged against any person as an offence, and it is given in evidence on the trial of such person for that offence that he was insane, so as not to be responsible, according to law, for his actions at the time when the act was done or omission made, then if it appears to the jury before whom such person is tried that he

(q) I'er Rolfe, B., 3 Car. \& K. $18 s$. And see 47 \& 48 Vict. c. 64

(r) $46 \& 47$ Vict. c. 38, s. 2, subss. 1, 2. 
did the act, or made the omission charged, but was insane as aforesaid at the time when he did or made the same, the jury shall return a special verdict to the effect that the accused was guilty of the act or omission charged against him, but was insane as aforesaid at the time when he did the act or made the omission. Where such special verdict is found, the Court shall order the accused to be kept in custody as a criminal lunatic in such place and in such manner as the Court shall direct till Her Majesty's pleasure shall be known; and it shall be lawful for Her Majesty therempon, and from time to time, to give such order for the safe custody of the said person during pleasure in such place and in such manner as to Her Majesty may seem fit. It sometimes happens that, upon arraignment on a criminal charge, the accused appears manifestly to be insane; when this is so, the question as to his sanity will have to be tried by a jury returned instanter for that purpose, and, if found to be insane, the detention of the prisoner will be ordered $(s)$.

An inquiry somewhat analogous to the preceding here invites attention: What degree of liability attaches to one who, whilst intoxicated, commits a crime? "If," says

Responsibility of one who commits crime whilst inParke, B., " a man voluntarily makes himself drunk, that is no excuse for any crime which he may commit whilst in that state; he must take the consequence of his own act, tor many crimes would otherwise go unpunished " $(t)$. But drunkenness may, it seems, be taken into consideration in cases of homicide where what the law deems sufficient provocation has been given, because the question in any such case is whether the criminal act is to be attributed to malice or to the passion of anger excited by the previous

(8) $39 \& 40$ Geo. 3 c. 94 , s. 2 . See R. v. Pritchard, 7 Car. \& P. 303; Reg. v. Goode, 7 Ad. \& E. 536.

By 47 \& 48 Vict. c. 64 , s. 5 , any "criminal lunatic" (as defined by s. 16) may be discharged absolutely or conditionally by order of the Home Secretary.

( $t) R$. v. Thomas, 7 Car. \& P. 820 ; 4 Bla. Com., p. 26, citing Co. Litt. 247. 
provocation $(u)$, and that passion is more easily excitable in a person when in a state of intoxication than when he is sober $(x)$, though, if there were really a previous determination to resent a slight affront in a barbarous manner, the state of drunkenness in which the prisoner was would furnish no excuse $(y)$.

Again, in Reg. v. Cruse (z), Patteson, J., observes: "Although drunkenness is no excuse for any crime whatever, yet it is often of very great importance in cases where it is a question of intention $(a)$. A person may be so drunk as to be utterly unable to form any intention at all, and yet he may be guilty of very great violence." So where the question is whether the accused attempted to commit suicide (b), or whether words accompanying an act were uttered with a deliberate purpose or were merely idle expressions, the drunkenness of the accused person may properly, and ought to be considered $(c)$. And it is evident that, where the question is whether an act was wilful or accidental, all the circumstances of the case must be taken fully into account. If, for instance, the question is whether a house was set on fire designedly or by accident, evidence of the inebriated state of the person charged with the arson will be admissible to induce the jury to come to the more favourable conclusion.

Habitual drunkenness, although not in itself affording excuse for crime, may induce insanity, which will render the individual affected by it wholly irresponsible for his acts $(d)$; and delirium tremens, caused by drinking, and differing from drunkenness, if it produces such a degree of

(ui) Bishop, Crim. Law, 6th ed., s. 4 l4.

(x) R. v. Thomas, supra: R. v. Menkin, 7 Car. \& 1. 297 ; Cr. L. rom., Tth Rep., p. 20. But sce $R$. r. 'arroll, 7 Car. \& P. 145, where J'ark, J., dissents from R. r. Grimlley, cited 1 Russ. Cr., sth ed., p. 115: lieg. v. Inolierty, 16 C. C. C. 306 , at p. 308 .

(y) l'er I'mike, B., 7 Car. \& I' 820. (z) S Car. \& 1. 541, 546 .

(a) So " intoxication is no defence against a crime, but it is a clear defence agaiust that sort of conduct which is to raise an inference of a crime: " arg., R. v. Crossficld, 26 How. St. Tr. 122.

(b) Reg. v. Jloo'e, 3 Car. \& K. 319.

(c) Per Parke, B., 7 Car. \& P. 820.

(d) See $U$. S. ₹. M'Glue, 1 Curtis (U. S.) R. 1. 
madness, even for a time, as to render a person incapable of distinguishing right from wrong, relieves him from criminal responsibility $(e)$.

Incapacity to commit crime may result from immaturity of years, the rule of our law being that under seven years of Crininnal bility of infant: age an infant cannot be guilty of felony, for then a felonious intention is almost an impossibility in nature $(f)$, also that although an infant under fourteen years of age shall be primâ facie adjudged to be doli incapax, yet if it appears to the Court and jury that he was doli capax and could discern between good and evil, he may be convicted even capitally, because in such case the rule would apply-malitia supplet retatem. Accordingly in York's case $(g)$, a boy ten years old was held to have been rightly convicted of murder, many minate facts having been adduced in evidence on the part of the prosecution which were "tokens of a mischievous discretion " in him. In that case, indeed, the prisoner, after several reprieves, received finally a conditional pardon. But in another case $(h)$, a boy between eight and nine years of age, having been found guilty of setting fire to certain buildings, and it appearing that he had been actuated by malice, cunning, and revenge, is said to have been hanged. In Rex v. Wilde (i), also, the prisoner, a boy under the age of fourteen years, was convicted of murder and sentenced to death, although his life was subsequently spared. And in Rex v. Owen $(k)$, where the accused, a child ten years of age, was indicted for stealing coal, Littledale, J., thus stated the law touching the criminal liability of infants: "Whenever a person committing a felony is under fourteen years of age, the presumption of law is that he or she has not sufficient capacity to know that it is wrong, and such person ought

(e) Reg. v. Davis, 14 Cox, C. C. 563. (f) 4 Bla. Com., p. 23 ; Marsh v. Loader, 14 C. B., N. S., 535.

(g) Foster, 70.

(h) R. v. Dean, I Hale, P. C. (ed.

B.C.I.
$1800)$, p. 25, n. (u); and see the cases cited Id., pp. 26, 27 ; 4 Bla. Com., pp. 23, 24.

(i) 1 Moo. C. C. 452.

(k) 4 Car. \& P. 236. 
not to be convicted, unless there be evidence to satisfy the jury that the party, at the time of the offence, had a guilty knowledge that he or she was doing wrong."

A male infant under the age of fourteen years is by a presumption of law which cannot be rebutted $(l)$ deemed incapable of committing a rape; for although in some cases, as just observed, malitia supplet cetatem, yet in this particular species of felony the law supposes an imbecility of body as well as of mind $(m)$.

"As to . . . offences that are not capital," says Sir M. Hale (n), " in some cases an infant is privileged by his non-age, and herein the privilege is all one, whether he be above the age of fourteen years or under, if he be under one-and-twenty years : but yet with these differences, if an infant under the age of twenty-one years be indicted of . . a riot or battery $(o)$, he shall not be privileged barely by reason that he is under twenty-one years, but if he be convicted thereof by due trial, he shall be fined and imprisoned : and the reason is, because upon his trial the Court ex officio ought to consider and examine the circumstances of the fact, whether he was doli capax and had discretion to do the act wherewith he is charged; and the same law is of a feme covert. But if the offence charged by the indictment be a mere non-feasance (unless it be of such a thing as he is bound to by reason of tenure or the like, as to repair a bridge $(p)$, \&c.), there, in some cases, he shall be privileged by his non-age, if under twenty-one,

(l) Reg. v. Jordan, 9 Car. \& P. 118 ; Reg. v. Brimilow, Id. $366 ;$ Reg. v. Phillips, 8 Car. \& P. 736; R. v. Ellesshaw, 3 Car. \& P. 326.

(m) 4 Bla. Com., p. 212; R. v. Groombridqe, 7 Car. \& P. 582.

See further, in connection with the above subject, Reg. v. Allen, 1 Den. C. C. $364 ; 1$ Hale P. C., p. $670 ; 3$ Inst. 59.

(n) P. C., rol 1, p. 19; 4 Bla.
Com., p. 22.

(o) Or assault, Reg. v. Read, 1 Den. C. C. 377 ; Reg. v. Broadley, 49 L. J.. M. C. 88. An infant above the age of fourteen may be convicted of larceny a a bailee of goods under $24 \& 25$ Vict c. 96, 8. 3 . Reg. v. MeDonald, 16 Q. B. D. 323 .

( $p$ ) See R. r. Sutton, 3 Ad. \& E 597; Macpherson Inf., p. 451. 
though above fourteen years, because laches in such a case shall not be imputed to him."

Although duress will sometimes afford ground of defence on a criminal trial $(q)$, yet as regards persons in private relations, the constraint of a superior is not, save in the case of a feme covert acting sub potestate rivi, allowed as an excuse for criminal misconduct; neither a son nor a servant being excused for the commission of any crime by the command or coercion of the parent or master. In some cases, however, the command, or authority of the husband, either expressed or implied, will privilege the wife from punishment $(r)$. If, for instance, a woman commit theft, burglary, or some other offences against the laws of society, by the coercion of her husband, or even in his company, which the law construes a coercion, she is in general held excused by our law as having acted under compulsion, and not of her own will (s). But immunity is not granted to the wife when guilty of treason, murder, or manslaughter in the presence of or under the actual coercion of her husband $(t)$, and husband and wife may be jointly convicted of an assault $(u)$ in which the wife was actively concerned $(x)$. And even where offence charged is less heinous in degree, special circumstances-as if the husband was a cripple and bedridden-may be given in evidence to repel the presumption of coercion $(y)$. Lastly, where the wife commits a felony or other crime in the absence of her husband, although by his command, she may be convicted as a primcipal $(z)$.

(a) Ante, p. 1000 ; per Lord Denman, C. J., Reg. v. Tyler, 8 Car. \& P. 620.

(v) 4 Bla. Com., p. 28.

(8) 4 Bla. Com., p. 29 ; 1 Hale P. C., pp. 45,$516 ; 1$ Hawk. P. C., c. 1 , 3. 9. See Reg. v. Brooks, Dearsl. 184 ; R. v. Price, 8 Car. \& P. 19 ; Reg. v. Matthews, 1 Den. C. C. 596; Reg. v. Dykes, 15 Cox C. C. 771 ; Archb. Cr. Pl., Index, tit. Husband.

(t) 1 Hale P. C., p. 44; Reg. จ.
Manning, 2 Car. \& K. 903, n.; Arg., 4 How. St. Tr. 1169.

(u) Reg. r. Cruse, 1 Car. \& P. 511; Reg. v. Ingram, 1 Salk. 384 ; Reg. r. Bird, 2 Den. C. C. 94.

(x) Reg. r. Sinith, Dearsl. \& B. J53.

(y) Per Traughan, J., Reg. r. Cruse, 8 Car. \& P., 5๊ 3 , 5. 4; R. r. Hughes, Russ. Cr., 3rd ed., p. 18.

(z) 1 Hale P. C., p. 45; R. Morvis, Russ. \& Ry. 270.
Criminal responsí. bility of fene covert. 


\section{CHAPTER II.}

OFFENCES AGAINST THE SOVEREIGN, THE STATE, AND THE COMIUNITY.

The design of this Chapter is to exhibit briefly the characteristics of the more prominent and practically important offences levelled and specially directed against the Sovereign, the State, or the Community.

High

High treason being an offence committed in breach of the duty of allegiance, I may, before speaking of it, properly consider from whom and to whom allegiance is due.

The duty of allegiance-natural or local-is founded in the relation which subsists betwixt him who owes it and the Crown, and in the privileges derived by the former from that relation. Of ' natural' allegiance, says Sir M. Foster (a), the whole doctrine is comprehended in the maxim Nemo potest exuere patriam, whence it follows that a natural borm subject owes allegiance at all times and in all places to the Crown, as head of that society whereof he has through life been a member. 'Local' allegiance is founded in the protection which a foreigner enjoys for his person, his family, and effects during his residence here. The tie in question is severed therefore, ipso facto, on the determination of such residence.

An alien, whose sovereign is in amity with the Crown of England, residing here and receiving the protection of our law, owes during the time of his residence a local allegiance

(a) Disc. High Tr., p. 184. 
to the Crown. And if, during such time, he commit an offence which in the case of a natural born subject would amount to treason, he may be dealt with as a traitor. For his person and personal estate are as much under the pro. tection of the law as those of a natural born subject, and if he be injured in either he has a remedy at law for such injury (b). An alien also, whose sovereign is at enmity with us, living here under the Queen's protection, if guilty of an act amounting to treason, may likewise be proceeded against as a traitor, inasmuch as from him is due a temporary local allegiance founded on that share of protection which he receives $(c)$.

Protection and allegiance are, then, reciprocal obligations, and the allegiance due to the Crown must clearly be paid to him who is in the full and actual exercise of the regal power, and to none other-a king de facto, being in the full and sole possession of the crown, is a king within the Statute of Treasons presently adverted to; and, the throne being full, any other person out of possession but claiming title is no king within the Act, be his pretensions what they may $(d)$.

Such being, in brief, the nature of that tie which binds the subject to his sovereign, let us consider the ingredients constituting the crime of treason; for a specification whereof recourse must be had to the Statute-book. Now the Statute of Treasons (25 Edw. 3, st. 5, c. 2), which was declaratory of the common law, enumerates the following species of treason, that is to say, "when a man doth compass or imagine (e), the death of our lord the king, or of our lady his queen, or of their eldest son and heir; or if a man do violate the king's companion, or the king's eldest daughter unmarried, or the wife of the king's eldest son and heir ; or if a man do levy war against our lord the king in his realm,

(b) Fost. Disc. High Tr., p. 185 ; Calvin's Case, 7 Rep. ó b. See Isaacson ₹. Durant, 17 Q. B. D. 54, 59.

(c) Fost. Disc. High Tr., p. 185. (d) Fost. Disc. High Tr., p. 188 ; 4 Bla. Com., p. 77 ; Hall. Const. Hist., 8th ed., vol. 1, pp. 9, 10.

(e) See 7 How. St. Tr., $961 \mathrm{n}$. 
or be adherent to the king's enemies in his realm, giving to them aid and comfort in the realm or elsewhere; and thereof be proveably attainted of open deed " $(f)$. Further, it is material to notice that the stat. $7 \& 8$ Will. 3, c. 3 (intituled an "Act for regulating of Trials in cases of Treason and misprision of Treason "), enacts (section 2) that no person shall be convicted of high treason or misprision of treason $(g)$, "but by and upon the oaths and testimony of two lawful witnesses, either both of them to the same overt act, or one of them to one and the other of them to another overt act of the same treason," unless the party indicted and arraigned shall confess the same. This statute, however, does not extend to " cases of high treason in compassing or imagining the death of the king, or of misprision of such treason, where the overt act or overt acts of such treason which shall be alleged in the indictment for such offence shall be assassination or killing of the king, or any direct attempt against his life, or any direct attempt against his person whereby his life may be endangered or his person may suffer bodily harm ;" but the individual indicted for any such offence as just specified shall be tried "in every respect and upon the like evidence" as if he stood charged with murder $(h)$.

Again, by the 36 Geo. 3, c. 7, s. 1 (i), (so far as it remains unrepealed by the stats. $11 \& 12$ Vict. c. 12 , s. 1 , and $34 \& 35$ Vict. c. 116, s. 1), any person is declared to be guilty of treason who shall " within the realm or without, compass, imagine, invent, devise, or intend death or destruction, or any bodily harm tending to death or destruction, maim, or wounding, imprisonment or restraint" of the heirs and

(f) By the above statute some other acts are also declared to be treasonable, which have ceased to be so.

(g) ' Misprision of treason' consists "in the bare knowledge and concealment of treason, without auy degree of assent thereto:" 4 Bla. Cons., p. 120.

(h) $39 \& 40$ Geo. 3, c. 93 , extended by $5 \& 6$ Vict. c. 51, s. 1 .

(i) Made perpetual by 57 Geo. 3, c. 6. See $11 \& 12$ Vict. c. 12. 
successors of King George III., and "such compassings, imaginations, devices or intentions, or any of them," shall "express, utter, or declare, by publishing any printing or writing, or by any overt act or deed, being legally convicted thereof upon the oaths of two lawful and credible witnesses."

Such are the statutory provisions now in force relating to treason, besides some others of much practical importance to the details whereof allusion cannot, however, here be made, which concern the mode of procedure to be adopted in reference to this offence, or when an accused party is about to be put on his trial for it $(k)$. Confining my remarks, then, almost wholly to the first and most heinous of the several kinds of treason mentioned in the Statute of Edward 3, viz., where a man "doth compass (l) or imagine" the death of the sovereign, it is worthy of notice that an apparent exception here presents itself to the doctrine laid down by Lord Mansfield in Rex v. Scofield, cited at p. 998 - that the bare intent of an individual is not punishable by our law. But although in treason the substantive offence or corpus delicti is constituted by the mere secret intention of compassing the king's death, an overt act, though not essential to the abstract crime, is still essential to the offender's conviction, as he must, in the language of the Statute of Treasons, "be thereof proveably attainted of open deed." The statute in question, as observed by the Criminal Law Commissioners $(m)$, has thus wisely provided that in this particular kind of treason, which manifestly tends to the most extensive public evil, the intention shall constitute the crime, but has at the same time, with equal wisdom and with a proper care for the safety of the accused, provided that the intention shall be manifested by some act tending

(k) See particularly the stats. $7 \& 8$ Will. 3 , c. $3 ; 20$ Geo. 2 , c. $30 ; 36$ Geo. 3 , c. 7 , s. 5 .

(l) The word 'compassing' or 'imagining' signifies the "purpose or de- sign of the mind or will, and not, as in common speech, the carrying such design to effect:" 4 Bla. Com., p. 78 .

(m) Cr. L. Com., 6th Rep., p. 4. 
towards the accomplishment of the criminal object; and this act must (save in cases falling within the operation of the stats. $39 \& 40 \mathrm{Geo} .3$, c. 93 , and $5 \& 6$ Vict. c 51 , s. 1 ) be proved by two credible witnesses.

Such is the meaning of the maxim Voluntas reputatur pro facto in connection with the crime of treason; an indictment for which offence, when belonging to that particular species now under notice, must charge that the defendant did "traitorously compass and imagine" the death of the sovereign, and then go on to allege overt acts as the means employed by the defendant for executing his traitorous purposes; for the compassing the death is considered as the treason, the overt acts as the means made use of to effectuate the intentions and imaginations of the heart $(n)$, which, it has been further said $(n)$, our law esteems " in the same degree of guilt as if carried into actual execution from the moment measures appear to have Orert act- been taken to render them effectual." Hence, if con-
what. spirators meet together, and consult how to kill the king, though they do not then fall upon any scheme for that purpose, this is an overt act of compassing his death, and so are all means made use of, be it advice, persuasion, or command, to incite or encourage others to commit the fact or to join in the attempt." And any person who but assents to any overtures for that purpose will be involved in the same guilt $(o)$. On like grounds, to provide weapons or ammunition for the purpose of killing or deposing the sovereign, is held to be a palpable overt act of treason in imagining his death $(p)$. And " to conspire to imprison the king by force, and move towards it by assembling company, is an overt act of compassing the king's death, for all force used to the person of the king in its

(i) Fost. Disc. High. Tr., p. 194.

1 East, P. C., p. 60 ; 3 R. R. 254,

(o) Id., p. 195. $257 ; 24$ How. St. Tr. 199.

(j) 4 Bla. Com., p. 79 ; R. v. Hardy, 
consequence may tend to his death, and is a strong presumption of something worse intended than the present force, by such as have so far thrown off their bounden duty to their sovereign" $(q)$. It seems also established, though doubts formerly existed upon the subject, that an offence within one branch of the stat. of Edward 3 may constitute an overt act of a different species of treason $(r)$; and it is clear that an act in itself innocent may constitute an overt act of treason if it be done towards or in the course of executing a preconcerted treasonable scheme; thus, in Lord Preston's case (s), it was held, that the embarking on board a vessel in London, for the purpose of prosecuting a treasonable project abroad, was a sufficient overt act of treason.

Bare words, indeed, not relative to any act or design, would not suffice to constitute an overt act of treason; they are at the worst no more than indications of the malignity of the heart. Words, however, may safely be relied upon to explain the meaning of an act. Hence, where C., being beyond sea, said, "I will kill the king of England if I can come at him," and the indictment, after setting forth the above words, charged that $C$. came into England for the purpose indicated by them, it was held that C. might on proof of the above facts rightly be convicted of treason; for the traitorous intention evinced by the words uttered converted an action innocent in itself into an overt act of treason $(t)$. The deliberate act of writing treasonable words is moreover to be regarded in a different light from a mere uttering of them, and may constitute an overt act, for scribere est agere; but even in this case the bare words are not the treason $(u)$. And the preponderance of

(q) 4 Bla. Com., p. 79. See, however, in connection with the passage above cited, the remarks of Mr. Hallam, Const. Hist., 8th ed., vol. 3, p. 153. (r) Cr. I. Com., 6th Rep., p. 5.

(s) 12 How. St. Tr. 727.

(t) Fost. Disc. High Tr., pp. 200, 202.

(u) 4 Bla. Com., p. 80 . 
authority is in favour of the rule, that writings not published cannot constitute an overt act of treason $(x)$.

Construclive treason.

In regard to the doctrine of constructive treason, it has been well observed by the Criminal Law Commissioners $(y)$ that those clauses of the Statute of Treasons which declare it to be treason to compass and imagine the death of the sovereign, to levy war against him, or to adhere to his enemies, have been, at various periods of our history, fruitful sources of accusations, founded upon a technical and figurative construction of the words used in the Act totally different from their plain and obvious signification, and inconsistent with the original design and application of the law. Thus a riotous assembly meeting and attempting by force to redress a public grievance, to compel the repeal of a law, to pull down all enclosures, or to burn all meetinghouses, has been held to be treason, as a levying of war against the king, though there were no direct intention or design whatever against the state or the person of the sovereign $(y)$. This construction is said to be founded upon the doctrine, that by reason of the universality of the design, such acts and conduct amount to what in ancient times was called an "accroachment of royal power" $(z)$, and constitute what Serjt. Hawkins describes $(a)$ as an insolent invasion of the king's prerogative, " by attempting

(x) Cr. L. Com., 6th Rep., p. 6.

Upon Algernon Sidney's case, 9 How. St. 'Tr. 818, Sir M. Foster (Disc. High Tr., p. 198) thus remarks: "In Mr. Sidney's case, it was said scribere est agere. This is undoubtedly true under proper limitations, but it was not applicable to his case. Writing, being a deliberate act and capable of satisfactory proof, certainly may, under some circumstances, with publication, be au overt act of treason; and I freely admit that, had the papers found in Mr. Sidney's closet been plainly relative to the other treasonable practices charged in the indictment, they might have been read in eridence against him, though not published." See also
4 Bla. Com., pp. 80,81 .

(y) Cr. L. Com., 5th Rep., p. 91 ; 1 East P. C. 66 ; Dammaree's case, 15 How. St. Tr. 522 ; Reg. v. Purchase, Id. $651 ; R$. v. Lord George Gordon, 21 How. St. Tr. 485 ; Reg. v. Frost, 9 Car. \& P. 129: S. C., 1 Towus. Mod. St. Tr., p. 1 ; Reg. v. O'Brien, Id. p. 469 ; O'Brien r. Reg., 2 H. L. Cas. 465 .

(z) See Hall. Const. Hist., 8th ed., rol. 3, p. 150 .

(a) Hawk. P. C., Book I., Chap. 17 , 8. 25 . In treason, except where directed against the person of the sovereign, the period of limitation is three years: $7 \& 8$ Will. 3 c. 3 , ss. 5,6 . 
to do that by private authority which he by public justice ought to do."

In connection with what is here said, and whilst treating of offences against the sovereign, it may be proper to add, that by section $3(b)$ of the stat. $11 \& 12$ Vict. c. 12, any person is declared guilty of felony who shall "within the United Kingdom, or without, compass, imagine, invent, devise, or intend, to deprive or depose our most gracious lady the Queen, her heirs or successors, from the style, honour, or royal name of the imperial crown of the United Kingdom, or of any other of Her Majesty's dominions;" or to levy war against Her Majesty within any part of the United Kingdom, in order by force or constraint to compel her to change her counsels, or in order to put any force or constraint upon, or in order to intimidate or overawe either House of Parliament, or to move or stir any foreigner or stranger with force to invade the United Kingdom; "and such compassings, imaginations, inventions, devices, or intentions, or any of them, shall express, utter, or declare, by publishing any printing or writing, or by open and advised speaking, or by any overt act or deed." And by section 7 of the same Act an indictment for felony, framed under its provisions, will be valid, although the facts proved on the trial of the accused party shall amount in law to treason.

The $5 \& 6$ Vict. c. 51 , s. 2, renders it a high misdemeanor to strike at the sovereign or to discharge firearms near to her person with intent to alarm Her Majesty.

Respecting offences against the State inferior in degree to treason, but having a tendency to occasion political hurt or detriment, a few general remarks must here suffice. Such

Offences against the Stateendangering the public safety. (b) See Mrulcahy v. Reg., L. R. 3 H. L. 306, 328, where Lord Chelmsford observes that a conspiracy may be an overt act of treason: Reg. . Gallagher, 15 Cox, C. C. 291 ; Reg. จ. Deasy, ib. 334. 
offences may consist of specific acts inconsistent with the public safety, - as the seducing or endeavouring to seduce the subjects of the realm from their allegiance, or raising bodies of armed troops without lawful authority. Within this class may also be included all endeavours or attempts to perpetrate treason not actually amounting thereto; all endeavours to promote public disorder or disturbance, as by seditious meetings, libels, or conspiracies for the purpose of creating or inflaming discontent or exciting men to resort to violent and unconstitutional means for the redress of supposed grievances; various misprisionswhich may be negative, as in the case of a bare concealment of treason, or positive, as contempts against the king's courts or his prerogative $(c)$; also offences against religion-by blasphemous publications or otherwise.

conspiracy. The crime of Conspiracy $(d)$ included in the above list of offences against the State is complete, where two or more than two agree to do an illegal thing, that is either to effect something in itself unlawful-ex. gr., as being in violation of an Act of Parliament (e)-or to effect by unlawful means something which in itself may be indifferent or even lawful $(f)$. " It has," remarked Tindal, C. J. (g), "always been held to be the law that the gist of the offence of

(e) See Reg. r. O'Connor, 5 Q. B. 16: O'Connell v. Reg., $11 \mathrm{Cl}$. \& $\mathbf{F}$. 155.

Under the elass of offences agrinst the State may properly be included the publishing of a libel on a foreign potentate, particularly when it has a tendency to interrupt the pacific rela. tions existing between the two countries: R. r. Peltier, 28 How. St. Tr., 529.

(d) When two persons are indicted for conspiring together and they are tried together, both must be acquitted or both convicted: Reg. r. Manning, 12 (2. B. D. 241. Although conspiracy may not give a right of action, if con. spiracy is alleged its effect may be twofold: (1) making the defendants jointly liable; (2) showing malicious or wrongful intention governing the acts of the defendants. See Kearney $r$. Lloyd, 26 L. R. Ir. 268, at p. 280; Mogul S. S. Co. v. ALEGregor Goir, 23 Q. B. D. 598 , at p. 616 (C. A.).

(e) See Reg. r. Rosclands, 2 Den. C. C. 364 .

(f) Per Tindal, C. J., O'Connell v. Reg., 11 Cl. \& F. 233, quoted hy Frigh, J., Mogul S. S. Co. r. MeGregor Gow. 23 Q. B. D., at p. 624 (C. A.) ; R. v. Seicard, 1 Ad. \& E. 706 ; per Erle, J., Reg. v. Carlisle, Dearsl. 341 ; Reg. v. Mears, 2 Den. C. C. 79 ; Reg. v. Parnell, 14 Cox, C. C. 508.

(g) 11 Cl. \& F. 233; Judgm., Reg. r. Kenrick, 5 Q. B. 61 . See Reg. จ. Button, 11 Q. B. 929. 
conspiracy is the bare engagement and association to break the law, whether any act be done in pursuance thereof by the conspirators or not." "A conspiracy," observed Lord Chelmsford (h), "cannot exist without the consent of two or more persons, and their agreement in an act in advancement of the intention which each of them has conceived in his mind." Hence, the agreeing of divers persons together to.raise discontent and disaffection among the liege subjects of the Queen,-to stir up jealousies, hatred, and ill-will between different classes of her Majesty's subjects,-would clearly be indictable (i). So the agreeing and conspiring together to cheat or defraud the government $(k)$, or the public $(l)$, or a private individual $(m)$, or to obtain money by false pretences $(m)$, or to extort money or goods, or falsely to accuse of any crime $(n)$, or to obstruct, prevent, pervert, or defeat the course of public justice $(o)$, is indictable. And a conspiracy to raise by false rumours the price of the public securities to the detriment of the king's subjects $(p)$, or by falsehood to raise fictitiously the market value of shares in a railway or joint-stock company, that the Queen's subjects may be deceived and injured, and that at their

(h) Mfulcahy v. Reg., L. R. 3 H. L. 328.

(i) Per Tindal, C. J., 11 Cl. \& F. 234 ; and see the indictment in $O^{\prime}$ Connell's case, as reported by Armstrong and Trevor, p. 9.

(k) Reg. v. Thompson, 16 Q. B. 832 ;

Reg. v. Blake, 6 Q. B. 126.

(l) Reg. v. Aspinall, 1 Q. B. D. 730 ; S. C., affirmed 2 Id. 48.

(m) Reg.v. Warburton, L. R. 1 C. C. 274, 276; Reg. v. Kenrick, 5 Q. B. 49 ; Reg. v. Gompertz, 9 Q. B. 824 ; Reg. v. Carlisle, Dearsl. 337 ; Sydserff v. Reg., 11 Q. B. 245 . See Reg. v. Peck, 9 Ad. \& E. 686; Reg. v. King, 7 Q. B. 782 ; Reg. v. Hudson, Bell C. C. 263 .

"If a number of persons combine and confederate to cheat a particular indiridual there can be no doubt that that is a criminal conspiracy at law." Per Cockburn, C. J., Reg. v. Gurney, reported by Mr. Finlaison, p. 213.

(n) 4 Bla. Com., p. 136.

(o) $14 \& 15$ Vict. c. 100 , s. 29 (which is in part repealed by the $24 \&$ 25 Vict. c. 95 , and the $38 \& 39$ Vict. c. 66, s. 1) ; post, p. 1024 .

As to the action for conspiracy, see Gregory v. Duke of Brunsucick, 1 Car. \& K. 24 ; Dickson . Visc. Combermere, 3 Fost. \& F. 527.

(p) R. v. De Berenger, 3 M. \& S. 67; 15 R. R. 415 (cited per Cockburn, C. J., Reg. v. Gurney, supra, n. $(k))$; R. r. Lord Cochrane, Id. 10, n., as to which see the remarks of Lord Brougham, 2 H. L. Ca. 531, 532; see also, Towns. Mod. St. Tr., rol. 2, p. 10, where the above case is reported at length; Reg. v. Aspinall, 1 Q. B. D. 730, 743: $S$. C., affirmed, 2 Id. 48 . See also Scott v. Broun, (1892) 2 Q. B. 724, at p. 730 (C. A.). 
expense a profit may be made by the conspirators $(q)$, would amount in law to a misdemeanor. An agreement between two persons to buy shares in a company with a view to induce the public to believe that the shares are at a premium and that there is a market for them, the parties to the agreement knowing such not to be the fact, may be made the subject of an indictment $(r)$. A conspiracy to murder any person "whether he be a subject of Her Majesty or not, and whether he be within the Queen's dominions or not," is constituted a misdemeanor by stat. 24 \& 25 Vict. c. 100 , s. $4(s)$, and an article in a newspaper exulting in the recent murder of the Emperor of Russia, and commending it as an example, has been held to constitute an encouragement or endeavour to persuade to murder within this section, although not addressed to any person in particular $(t)$. And the conspiring to raise wages by riot and tumult is a misdemeanor at common law $(u)$.

An agreement, however, by members of either House of Parliament amongst themselves to make defamatory speeches in the House respecting a person not being a member of the House would not, on the ground of privilege, be indictable $(x)$.

To conspire to do that which if done by one would not be a crime may be criminal. Upon this point Lord Bramwell in Mogul S. S. Co. v. McGregor Gow, observes: "It has been objected by capable persons that it is strange that that should be unlawful if done by several which is not if done by one, . . . I think there is an obvious answer, indeed two: one is, that a man may

(q) Per Lord Campbell, Burnes r. Pennell, 2 H. L. Ca. 525.

(r) Scott r. Broun, (1892) 2 Q. B. 24 (C. A.).

(8) See Reg. v. Bernard, 1 Fost. \& F. 240.

(t) Reg. v. Most, 7 Q. B. D. 244.

(u) R. v. IIanson, 31 St. Tr. 1.
The stat. 38 \& 39 Vict. c. 86 , amends the law as to conspiracy in trade disputes: Connor $\nabla$. Kent, 17 C. C. C. 354 . See $47 \& 48$ Vict. c. $43,8.4$. 573. 
encounter the acts of a single person, yet not be fairly matched against several. The other is, that the act when done by an individual is wrong though not punishable, because the law avoids the multiplicity of crimes: de minimis non curat lex; while if done by several it is suffciently important to be treated as a crime $(y)$.

Under the general head of crimes against the State may ofences

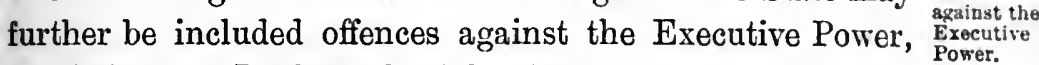
consisting-1. In the unlawful refusal to take and execute a public office; 2. In unlawful omissions by officers or others to execute or discharge any official or other public duty, or in the negligent and imperfect execution or discharge of any such office or duty $(z) ; 3$. In disobedience of an Act of Parliament or of any lawful order or command emanating from a competent official authority, -an indictment will therefore lie for a refusal to comply with an order of justices for the payment of money (a), or of a Court of Quarter Sessions for the payment of costs $(b) ; 4$. In unlawfully resisting and obstructing the administration of the executive power; or in unlawful practices tending to obstruct, weaken, or corrupt its due administration-ex.gr., by the selling of offices or bribery,-which is defined to be the receiving or offering of any undue reward by or to any person whatsoever, whose ordinary profession or business relates to the administration of public justice, in order to influence his behaviour in office, and incline him to do anything against the known rules of honesty and integrity $(c)$. The definition here given, however, in limiting the offence of bribery to the offer or acceptance of rewards to or by

(y) (1892) A. C. at p. 45. See also Kearney v. Lloyd, 26 L. R. Ir. at p. 285.

(z) See 56 \& 57 Vict. c. 61 (The Public Authorities Protection Act, 1893).

(a) Reg.v. Ferrall, 2 Den. C. C. 51 ; Reg. v. Brisby, 1 Den. C. C. 416; Reg. v. Biduell, Id. 222 ; Reg. v. Dale, Dearsl. 37.

(b) Reg. v. Martlock, 7 Q. B. 459 ; Reg. v. Stamper, 1 Q. B. 119.

(c) Hawk. P. C., Book I., Chap. 67 , s. 2 ; Russ. Cr., 5th ed., rol. 1, p. $318 ; 3$ Inst. 147 . 
officers connected with the administration of justice, is clearly too narrow $(d)$.

Lastly, under the head of offences against the executive power must be included abuses of official authority by exercising it partially, corruptly, or oppressively-for instance, by extortion $(e)$, committed colore officii, or by embezzlement or other fraudulent application of public funds $(f)$, or by betraying matter of confidence, or by the taking of bribes, or by the illegal sale of an office or appointment $(g)$.

Offences arainst the administra. tion of justice ;

-by judicial officers ;

-by private persons.

Offences against the Administration of Public Justice are divisible into offences committed by officers of justice, judicial or ministerial, who neglect their duty or abuse the authority with which they are invested, and those committed by private persons.

A Judge who maliciously obstructs the course of justice is guilty of a misdemeanor $(h)$, and it is a familiar principle that every Court of Justice is bound to take care that its process shall not be abused for purposes of injustice (i), nor its authority be deliberately perverted to bad and wicked ends $(k)$, - as by the compounding of a criminal charge $(l)$.

Offences by private persons against the administration of justice may consist in resistance to the execution of such official duties as are strictly essential or ancillary thereto, and particularly in resistance to ministers of justice acting in the discharge of their proper functions; in escapes from lawful custody; and in aiding others to escape $(m)$, or in

(d) See $R$. v. Vaughan, 4 Burr. $2494 ; R$. v. Beale, cited 1 East, 183.

(e) Louglas พ. Reg., 13 Q. B. 74 ; S. C. Id. $42 ;$ Re Douglas, 3 Q. B. 825.

(f) R. v. Bembridge, 22 How. St. T., $1,155-157$.

(q) Reg. v. Charretie, 13 Q. B. 447.

(h) Per Lord Campbell, C. J., Reg. v. Marshall, 4 E. \& B. 480 . See Ex perte Ramshay, 18 Q. B. 173.

(i) In Reg. r. Richmond, Bell, C. C. 112 , the indictment was framed under the stat. $9 \& 10$ Vict. c. 95, s. 57.

(k) Per Colevidge, J., Reg. r. Alleyne, Dearsl. 510 ; S. C., 4 E. \& B. 186 ; 5 E. \& B. 399.

(I) See Reg. v. Alleyne, Dearsl. 505: Keir v. Leeman, 9 Q. B. 371, 395 ; S. C., 6 Q. B. 308; Goodall r. Lowndes, 6 Q. B. 464; Reg. v. Pascoe, 1 Den. C. C. 456. Ante, p. 27s, where various cases bearing on the subject supra are cited. $31 \%$. 
rescuing them therefrom; or in hindering a witness from appearing to give evidence in a Court of justice $(n)$; $\mathrm{Or}^{\circ}$ in perjury, which, by the common law $(o)$, may be defined to be the assertion of a falsehood upon oath in a judicial proceeding respecting some fact material thereto $(p)$, or to the point to be decided in such proceeding $(q)$; the characteristic of this offence being not the violation of the religious obligation of an oath, but the injury done to the administration of public justice by false testimony. "The offence of perjury," it has been observed $(r)$, "consists in taking a false oath in a judicial proceeding, and whether the oath is taken in a judicial proceeding before a Court at common law, or acting under an earlier or a later statute, it is equally an oath taken in a judicial proceeding and equally perjury," punishable by penal servitude.

An offence against the Public Peace may be constituted by an actual or by a constructive breach of the peace, sc., Offences against the Public by some act-as the sending of a challenge or a threatening letter-having a tendency to make others break the peace, or by making use of threatening, abusive, or insulting language or behaviour which might provoke a breach of the peace $(s)$.

Of actual breaches of the peace, the more important are Riots, \&c. riots, routs, unlawful assemblies, and forcible entries upon land, and in regard to these our Legislature has at various times deemed it expedient to enact specific ordinances.

(n) Reg. v. Stowell, 5 Q. B. 44.

(o) Reg. v. Hodgkiss, L. R. 1 C. C. 212. False swearing is also in various zases punishable by the statute law. dn attempt to pervert the course of justice by preparing false evidence to je used in an arbitration, although wch eridence be not used, is a punishible misdemeanor: Reg. v. Vreones, 1891) 1 Q. B. 360.

(p) See per Maule, J., Reg. v. Phillpotts, 2 Den. C. C. 306.

(q) See Lavey v. Reg., 2 Den. C. C.
504; S. C., 17 Q. B. 496 ; Reg. r. Phillpotts, Id. 302 ; Reg. v. Cooke, Id. 462; Reg. v. Millard, Dearsl. 166; Reg. v. Stone, Id. 251; King v. Reg., 14 Q. B. 31 ; Reg. v. Chapman, 1 Den. C. C. 432 ; Reg. v. Simmons, Bell, C. C. 168 ; Reg. v. Westley, Id. 193.

(v) Judgm., Reg. v. Castro, L. R. 9 Q. B. 357. See Reg. v. Johnson, I. R. 2 C. C. 15 ; per Brett, J., Reg. v. Widdop, Id. 9.

(s) Reg. v. King, 14 Cox, C. C. 434.

B.C.L. 
" Riots, routs, and unlawful assemblies," remarks Blackstone $(t)$, " must have three persons at least to constitute them. An unlauful assembly is when three or more do assemble themselves together to do an unlawful act, as to pull down enclosures, to destroy a warren or the game therein, and part without doing it or making any motion towards it ; " or to obstruct the officers of the law, in which case all persons so assembling are guilty of an unlawful assembly $(u)$. But persons assembling for a lawful purpose, with no intention of carrying it out unlawfully, will not be guilty of an unlawful assembly merely because they know that their assembly will be opposed, and have good reason to suppose that a breach of the peace will be committed by their opponents $(x)$. "A rout is where three or more meet to do an unlawful act upon a common quarrel, as forcibly breaking down fences upon a right claimed of common or of way; and make some advances towards it. A riot is where three or more actually do an unlawful act of violence, either with or without a common cause or quarrel : as if they beat a man ; or hunt and kill game in another's park, chase, warren, or liberty ; or do any other unlawful act with force and violence; or even do a lawful act, as removing a nuisance, in a violent and tumultuous manner." Now it is material to observe that by our common law the injury or grievance complained of and intended to be remedied by those who are parties to a riot, rout, or unlawful assembly, must be private, or at all events must concern a limited class only. In reference to this point, indeed, it is noticeable that the Statute of Treasons $(y)$ declares that if " any man ride openly or secretly with men of arms against any other to slay or to rob him, and to take and keep him till he make fine for his deliverance, it is not the mind of the

(t) 4 Com., p. 146; Hawk. P. C., Book I., Chap. 65.

(ui) Per Fitzgerald, J., Reg. v. McNaughton, 14 Cox, C. C. 576 . (x) Beatty v. Gillbanks, 9 Q. B. D. 308. Doubted in O'Felly v. Hareey, 15 Cox, C. C. 435.

(y) Ante, p. 1013. 
ling nor his counsel that in such case it shall be judged treason; but it shall be judged felony or trespass according to the laws of the land of olden time used, and according as the case requireth." Upon which Sir M. Foster remarks $(z)$ that the cases of assembling to kill, rob, or imprison are put by uay of example only, and will not exclude others which may be brought within the same rule-that is, all cases which are of the like private nature.

With a view to preventing tumults and riotous assemblies, Riot Act. and for the more speedy and effectual punishment of rioters, the stat. 1 Geo. 1 , st. 2, c. 5 (usually called the Riet Act), by reason of the proved inefficacy of various prior enactments, was passed ; its general effect $(a)$ is to provide "that if any twelve persons are unlawfully assembled to the disturbance of the peace, and any one justice of the peace, sheriff, under-sheriff, or mayor of a town, shall think proper to command them by proclamation $(b)$ to disperse, if they contemn his orders and continue together for one hour afterwards, such contempt shall be felony." And further, if the reading of the proclamation be by force opposed, or the reader be in any manner wilfully hindered from the reading of it, such opposers and hinderers, and all persons to whom such proclamation ought to have been made, and knowing of such hindrance and not dispersing, wre likewise declared to be guilty of felony $(c)$.

Likewise by the $24 \& 25$ Vict. c. 97 , s. 11 (d), it is znacted, that if any persons riotously, $(e)$ and tumultuously assembled together to the disturbance of the public peace, shall unlawfully and with force demolish, or pull down or

(z) Disc. High Tr., p. 209.

(a) See Bla. Com., p. $143 ; R$. v. Tames, 5 Car. \& P. 153.

(b) Of which a form is given in the tet (section 2). See R. v. Child, 4 Car. i. P. 442.

(c) 7 Will. 4 \& 1 Vict: c. 91, s. 1. The dnty of a magistrate in regard 0 the quelling of a riot is explained at length by Littledale, J., in R. v. Pin.ney, 5 Car. \& P. 254 ; and see $R$. v. Kennet, Id. 282, n.

(d) See Reg. v. Howell, 9 Car. \& P. 437; Reg. v. Harris, Car. \& M. 661 ; Reg. v. Simpson, Id. 669.

(e) See Reg. v. Langford, Car. \& II. 602 . 
destroy, or begin $(f)$ to demolish, pull down, or destroy any church, or chapel, or any house or building used in farming land or in earrying on any trade or manufacture, or any machinery, \&c., they shall be guilty of felony.

Another offence against the public peace consists in a forcible entry or detainer-i.e., where possession is taken or kept of either house or land, with such number of persons and show of force as is calculated to prevent resistance and to deter the rightful owner from repelling the wrong-doers, and resuming his own possession (g). In ancient times, remarked Lord Denman, C. J. (h), violent acts were frequently committed in taking possession of property, sometimes by those who were really the owners of the property, sometimes by those who were not. To meet this mischief various statutes (i) were passed, giving " a great and indeed violent power to the magistrates;" for it is thereby provided that, upon any forcible entry or forcible detainer after peaceable entry into any lands, one or more justices of the peace, taking sufficient power of the county, may go to the place at which the offence was committed, and there "record the force upon his own view as in case of riots, and upon such conviction may commit the offender to gaol till he makes fine and ransom to the king " $(k)$. The justice moreover is empowered by the statutes in question to summon a jury to try the forcible entry of detainer complained of ; and, if the same be found by that jury, restitution of possession may be made, without inquiry into the merits of the title being instituted. The

(f) See Reg. v. Houcell, 9 Car. \& P. 437 ; Reg. r. Adams, Car. \& M. 299 ; $R$. v. Thomas, 4 Car. \& P. $237 ; R$. v. Price, 5 Car. \& P. 510.

(g) l'er Lord Tenterden, C. J., Mril. ner v. Maclean, 2 Car. \& I. IS ; and in 1 . v. Simyth, 5 Car. \& I'. 204. 828.

(i) 15 Ric. 2 c. 2 . See Lou's v.
Telford, 1 App. Cas. 414; Beddall v Maitland, 17 Ch. D. 174; Edvick 5 Hackes, 18 Ch. D. 199 ; ante, p. 207 8 Hen. 6 c. 9 ; 31 Eliz. c. 11 ; 2: Jac. 1 c. 15 .

(k) 4 Bla. Com., p. 145; Arch. Just I., 4 th ed., vol. 1 , pp. $464474 ; R$. I'ilson, 3 Ad. S E. $817 ; R$. v. Oakley 4 B. \& Ad. 307. 
same object may likewise be effected by indictment preferred at the assizes-where, on the finding of the bill by the grand jury, it is discretionary with the Judge of assize, on ground shown by affidavit, to grant a warrant of restitution $(l)$. The proceeding under the statutes of forcible entry is thus peculiar, and has been said to furnish "the only instance known to the law of England in which a party may be turned out of possession by ex parte steps taken" $(m)$.

Where a person having the legal title to land is in actual possession of it, an attempt to eject him by force would bring the person making such attempt within the provisions of the stat. 15 Ric. 2 c. 2 against forcible entry $(n)$.

It may be well to add, that a forcible entry is also indictable at common law; although a mere trespass to land, remediable by civil action, is not so $(o)$.

Amongst offences against the Public Peace may further properly be included assault and battery, which will, however, be more conveniently noticed in the ensuing chapter $(p)$; and next in order must be mentioned offences against the Public Revenue and Trade-as smuggling and fraudulent bankruptcy $(q)$-and offences against the Public Morals $(r)$, Health, and Police, comprising, inter alia, bigamy (s), infringements of the game laws, and nuisance, respecting which latter only will some few remarks be here offered.

(l) R. v. Harland, 8 Ad. \& E. 826 .

(m) Per Lord Denman, C. J., 8 Ad.

\& E. 829. See ante, p. 207.

(n) See Lou's v. Telford, 1 App. Cas. 414.

(o) Per Lord Kemyon, C. J., R. v. Wilson, 8 T. R. 360 ; 4 R. R. 694 ; R. r. Blake, 3 Burr. 1731.

(p) Section 1

(q) $32 \& 33$ Vict. c. 62 , ss. 11 et ser. ; 46 \& 47 Vict. c. 52, s. 163. $32 \& 33$ Vict. c. 62 , s. 11 , is amended by $53 \& 54$ Vict. c. 71 , s. 26.

(r) See R. v. Curll; 17 How. St.
Tr. $153 ;$ R. v. Sedley, Id. 155, u.;

Reg. v. Haris, L. R. I C. C. '282; $R$. v. Williams, 26 How. St. Tr. 653; Reg. v. Hieklin, L. R. 3 (Q. B. 360 ; followed in Steele r. Bramnam, L. R. 7 C. P. 261 ; R. v. Hilkes, 4 Burr. 2527, 2574. See Reg. ․ Elliot, L. \& C. 103.

(s) See the stat. $24 \& 25$ Vict. c. 100 , s. 57 . A bonâ fide belief on reasonable orounds that the first hus. band is dead at the time of the second marriage is a good defence: $R e g . \mathrm{v}$. Tolson, 23 Q. B. D. 168.
Offences against pub. lic trade;

or against public morals and police. 
A common nuisance, observes Blackstone $(t)$, is an offence " against the public order and œconomical regimen of the state, being either the doing of a thing to the annoyance of all the king's subjects, or the neglecting to do a thing which the common good requires;" the true nature of a common or public nuisance, and the test whereby to distinguish it from a private nuisance, having been already pointed out $(u)$, I need here only remind the student that common nuisances are such inconvenient or troublesome offences as annoy or endanger $(x)$ the community in general, and not merely some particular person or persons, and therefore, with a view to avoid multiplicity of suits, are indictable only and not actionable. Of this nature are annoyances in highways or footways $(y)$ and public rivers $(z)$, by rendering the same inconvenient or dangerous to pass, either positively by actual obstruction or negatively by want of reparation (a), for which public nuisance the person so obstructing, or the individual bound to repair, or the parish at large in which the obstruction has occurred, or want of reparation has been tolerated, may, according to circumstances, be indicted $(b)$. The proper and ordinary $(c)$ remedy, then, for obstruction of a public highway, whether by land or water, being by indictment $(d)$, difficult questions not unfrequently arise in determining whether the road or river obstructed is public, and whether the obstruction proved is such as may amount

(t) 4 Com., p. 166.

(u) Inte, pp. 820, 821, 880 .

(x) See Reg. v. Lister, Dearsl. \& B. 209.

(y) See T"alker r. Horner, 1 Q. B. D. 4 ; Reg. v. Mutters, I. \& C. 491; Gully r. Smith, 12 Q. B. D. 121.

(z) See lieg. r. Stephens, I. R. 1 Q. 13. 702, which shows that the owner of works may be criminally liable for a nuisance caused by acts of his morkmen done without his knowledge and contrary to his general orders.

(ii) i Bla. Com., p. 167; Reg. v.
Train, 2 B. \& S. 640.

(b) See Gibbons' Law of Nuisances, \&c., 2nd ed., pp. 326 et seq. ; Reg. r. Inhabitants of Hornsea, Dearsl. 291; Reg. . Bradjord Nav. Co., 6 B. \& S. 631,648 .

(c) There are many nuisances, for which, under particular statutes, as Highway or Building Acts, proceedings may be taken before justices of the peace.

(d) Judgm., Mayor of Colchester $\mathrm{v}$. Brooke, 7 Q. B. $37 \%$. 
to a nuisance at common law. In reference to the former of these points the cases below cited may be consulted $(e)$. With reference to the latter it must be remembered, that although even a small offence cannot legally be committed $(f)$, yet the consequences of an obstruction of a public thoroughfare or navigable river may be "so slight, uncertain, and rare" as not to entail on the offending party criminal responsibility $(g)$; the question, however, whether a particular erection is or is not commune nocumentum (h), being for the jury (i).

(e) R. v. Riehards, 8 T. R. 634; 5 R. R. 489 ; Reg. i. Betts, 16 Q. B. 1022 ; Reg. v. Petrie, 4 E. \& B. 737.

(f) Per Lord Campbell, C. J., Reg. v. Russell, 3 E. \& B. 952.

(g) R. v. Tindall, 6 Ad. \& E. 143 ; per Crompton, J., 3 E. \& B. 953 . See
Reg. v. Charlesworth, 16 Q. B. 1012 ; R. v. Ward, 4 Ad. \& E. 384.

(h) See Reg. v. Vann, 2 Den. C. C. 325 .

(i) Reg. v. Betts, 16 Q. B. 1022, 1038 . 


\section{CHAPTER III.}

\section{OFFEXCES AGAINST INDIVIDUALS.}

THE present chapter will be devoted to a brief notice of certain criminal acts directed against the Person, Reputation, or Property of an individual.

We have inserted in this portion of our work references, almost exclusively, to cases on Crown law which show the principles on which it rests, eschewing those which exemplify merely its eccentricities.

Section I.-Offences against the Person, Reputation, and Property.

Homicidedegrees of.

\section{Murder.}

$Y_{n n-}$ slaukhter.

The law of England recognizes (independently of the crime of suicide) two degrees of culpable homicide, murler and manslaughter: it recognizes also two degrees of homicide-excusable and justifiable-which do not expose to punishment.

'Murder' is constituted by the killing of any person under the king's peace with malice aforethought express or implied (a). 'Manslaughter' is " the felonious killing of another without malice express or implied" (b), so that

(i) 1 Russ. Cr., 5th ed., p. 641 ; 4 Bla. Com., p. 195 ; 3 Inst. 47.

See lieg. v. Maugridge, Kelynge, 128 ; S. C., 17 How. St. Tr. $57 ; R$. v.
Lard Byron, 19 How. St. Tr. 1177;

$R$. r. Earl Ferrers. Id. 885.

(b) See 1 Hale, P. C., p. 449. 
this offence differs from murder not in " substance of the fact" $(c)$, but in degree $(d)$.

The peculiar characteristic of murder, then, as distinguished from manslaughter, is the ingredient in it of Malice malice, either express or implied. The nature of express malice may be illustrated by the case where one person kills another with a deliberate mind and formed designsuch design being evidenced by external circumstances discovering the inward intention $(e)$-as, for instance, in the case of duelling, which, if it end fatally, is punishable as murder $(f)$. Implied malice is malice inferred or presumed by law from any deliberately cruel act committed by one person against another $(g)$. Thus, if a man kills another suddenly without any, or indeed without some considerable, provocation; the law implies malice, because "no person, unless of an abandoned heart, would be guilty of such an act upon a slight or no apparent cause" $(h)$; and if A. lays poison for B., which is taken by C., against whom A. had no malicious intent whatever, the individual last named will clearly be guilty of murder $(h)$. So if a man throw himself into a river under such circumstances as render the act not voluntary on his part, as if violence be used to the body or threats which operate on the mind, he is guilty of murder who drove deceased to the act which caused his death, i.e., provided the apprehensions were of immediate violence and apparently well founded (i). So, if two persons mutually agree to commit suicide together, and the means employed to produce death take effect upon

(c) I Hale, P. C., p. 466.

(d) In the crime of murder, "the killing is the substance and the malice prepense the manner of it": Mackalley's case, 9 Rep. 67 b.

(e) I Hale, P. C., p. 451.

(f) Reg. v. Barronet, Dearsl. 51 ; Reg. v. Cuddy, 1 Car. \& K. $210 ; 4$ Bla. Com., p. 199. See Helsham v. Blackwood, il C. B. 111.

(g) See, also, as to the legal mean- ing of the word "malice," per Raymond, C. J., R. v. Oneb!, 17 How. St. Tr. 43 et seq., and in $R$. v. Huggins, Id. 374, 375; per Lord Ellenborongh, C. J., R. v. Pieton, 30 Id. 488 ; per Jacionald, C. B., R. v. Wull, 28 How. St. Tr. 145.

(h) 4 Bla. Com., p. 200 .

(i) Per Erskine, J., Reg. r. Pitts, Car. \& M. 284; R. v. Etans, cited 1 Russ. Cr., 5th ed., p. 489. 
one only, the survivor will, in point of law, be guilty of murder $(k)$. Again, if an individual do any act with regard to a human being, helpless and unable to provide for itself, which must necessarily lead to its death, the crime amounts to murder. But if the circumstances were not such that the parties must have been aware that the result would be death, the offence would be reduced to manslaughter, provided the death was occasioned by an unlawful act, but not such as to imply a malicious mind. For instance, if a person leaves a child at a man's door where it is likely to be found almost immediately and taken care of, it would be too much to say that if the child's death were thence to ensue, the act done would amount to murder $(l)$. If, on the other hand, it were left in an unfrequentea place, on a barren heath, for instance, what inference could be drawn but that the party left it there in order that it might die $(m)$ ? So, if a person has the custody and charge of another, and being able to supply proper food and lodging for the latter, neglects to do so, such person is responsible, if from such neglect death results to the person in his custody $(n)$; on the other hand, if a female having the free control of her actions, and able to take care of herself, remains in a service where she is starved and badly lodged, the mistress will not be criminally responsible for the consequences $(o)$. "Moreover, to render a person who has the charge of another criminally responsible for neglect, there must be on the part of such person a duty arising from the helpless character of the person who is under control.

(k) Reg. v. Alison, 8 Car. \& P. 418 ; li. v. Dyson, Russ. \& Ry. 523. See li. v. Russell, 1 Moo. C. C. 356. See also Reg. v. Jessop, 16 C. C. C. 204.

(l) See Reg. v. White, L. R. 1 C. C. 211 Jeg. $\vee$ Fallingham, L. R. i C. C. 222 .

(im) Per Coltman, J., Rrg. r. Walters, Car. \& M. 164 ; Reg. v. Waters, 2 Car. \&. 864. See Keg. Y. Gray,
Dearsl. \& B. 303, where the indictment was on the repealed stat. 7 Will. 4 \& 1 Vict. c. 85 , s. 2 . 602

(ii) Cf. Reg. v. Instan, 17 C. C. C.

(o) Per Evle, C. J., Reg. v. Smith, L. \& C. 624,$625 ;$ Reg. v. Rylend, L. R. 1 C. C. 99 ; Reg. v. Chandler, Dearsl. 453. 
Such a duty, for instance, arises in the case of those who have charge of infants $(p)$, invalids, or lunatics $(q)$. So, also, such a duty arises where the person exercising the restraint exercises it to such an extent as to entirely deprive the person who is subject to it of all liberty whatever" $(r)$.

Malice, then, in general, may be said to denote "a wicked, perverse, and incorrigible disposition" (s), and to emanate from " $\mathrm{a}$ heart regardless of social duty and fatally bent upon mischief" $(t)$; the term "malice aforethought" being, however, sometimes applied to a state of circumstances involving only malice in a legal sense, and where malice according to the ordinary signification of the word does not exist $(u)$.

Now, it is an important rule of our law that all homicide is presumed to be malicious until the contrary is shown $(r)$, so that any homicide will, in legal contemplation, amount to murder unless where justified by the command or permission of the law-excused on the ground of accident or because done in self-preservation $(x)$-or alleviated into manslaughter by concomitant circumstances $(y)$. And where the question arises whether a homicide was committed wilfully and maliciously or under circumstances justifying, excusing, or alleviating it, the solution of the question,are the facts alleged by way of justification, excuse, or alleviation, true? is the proper and only province of the jury. But whether, the truth of the facts being assumed, such homicide be justified, excused, or alleviated, must be submitted to the judgment of the Court; in cases of doubt

(p) $57 \& 58$ Vict. c. 41.

(i) See 53 \& 54 Tict. c. 5, s. 341 ; Buchanan v. Hardy, 18 Q. B. D. 486. (v) Per Blackburn, J., Rcg. v. Simith, L. \& C. 629.

(s) Fost. Disc. Hom., p. 257, cited per Mellor, J., Reg. v. IIard, L. C. 1 C. C. 361 ; Mason's case, Fost. Disc. Hom. 132 ; Reg. r: Tivey, 1 Den. C. C. 63 ; Reg. r. Cluderay, 1 Den. C. C. 514 . (t) Fost. Disc. Hom., p. 257.

(u) Cr. L. Com., 4th Rep., p. 22; per Lord Derman, C. J., Reg. r. Tyler; 8 Car. \& P. 620.

(r) 4 Bla. Com., p. 201 ; Fost. Dist. Hom., p. 255; 1 Russ. Cr., jth ed., p. 642 .

(x) Reg. v. Dudley, 14 Q. 13. D. 273.

(y) 4 Bla. Com., p. 201.
Homicide presumed to be inaliclons. 
and difficulty, the jury having a right to state facts and circumstances in a special verdict, and where the law is clear, being directed by the Judge in regard to it-matters of fact being still left to their determination $(z)$.

Precisely in accordance with the terms in which the above important legal presumption respecting homicide has been stated is the summing up of T'indal, C. J., in Reg. v. Greenacre $(a)$, in the course whereof he remarks, that, "where it appears that one person's death has been occasioned by the hand of another, it behoves that other to show from evidence, or by inference from the circumstances of the case, that the offence is of a mitigated character and does not amount to the crime of murder." And in Reg. v. Kelly (b), Rolfe, B., observes that "primâ facie, when any man takes away the life of another, the law presumes that he did it of malice aforethought, unless there be evidence to show the contrary," i.e., to reduce the killing to manslaughter, or to one or other of the inferior species of homicide $(c)$.

Various states of facts might readily be suggested which would suffice thus to mitigate the character of homicide. It will, in the first instance, be advisable however to observe, that the essential distinction between culpable homicide and such as is justifiable or excusable, as also between the two degrees of culpable homicide, will be found necessarily to depend upon the following considerations-riz., the mind and intention of the party in doing the act which caused death, the particular occasion of the act and circumstances attending it, collateral grounds of legal policy $(d)$.

A case frequently occurring in practice, which raises difficulty in distinguishing between the legal degrees of guilt attaching to homicide, is where, some degree of

$\Rightarrow$ Fost. Disc. Hom., pp. 255, 266: Iiey. v. Inolley, 1t Q. B. D. 273.

(ii) 8 Car. A P. 35, 42.

(b) 2 Car. \& K. sit. (c) Per Prike, J., Reg. v. Fisher, 8 Car. \& P. 1S5.

(I) Cr. I. Com., 4th Rep., p. 19. 
provocation having been offered, the question is whether the homicide shall be accounted murder, or shall be regarded as extenuated by provocation given and as amounting to manslaughter only. The law, indeed, whilst making allowance for the infirmity of man's temper, ordains that a ferocious excess of violence, far beyond what the particular provocation called for, and which therefore cannot be attributed to mere heat and passion so momentarily excited, shall not be held justifiable, but shall be accounted murder; it does not, however, attempt to define generally in what circumstances such excess shall be deemed to consist, or to lay down any precise test by which the existence of 'malice aforethought,' which we have seen to be an essential ingredient in the crime of murder, may, in any conceivable case, be affirmed or negatived. If, upon a slight blow given, the party struck returned a moderate blow not likely to prove fatal, and death ensued, these facts would clearly not justify a conviction for murder. If, in a similar case, the offended party were for a great length of time to continue his blows and not to desist until he had ascertained that life was extinguished, it might thence be easily inferred that the death resulted not from any sudden heat and passion caused by the original provocation, but that the excess was attributable only to a deliberate intention to kill. Nevertheless, between the two extreme cases here put intermediate cases may arise in which the determination of perplexing questions of fact may, subject to judicial comments and advice, be cast upon the jury.

In every case of homicide upon provocation, observes Sir M. Foster (e), how great soever it be, if there is sufficient time for passion to subside and for reason to interpose, such homicide will be murder; whereas, if the fatal blow be struck in heat of blood, and without circumstances importing

(e) Disc. Hom., pp. 295, 296; R. v. Thomas, 7 Car. \& P. 817. 
malice, the homicide will be manslaughter. No mere provocation, however, can reduce homicide in degree below manslaughter. So that, although if a man were to kill another suddenly without provocation, the act would amount to murder; yet, if the provocation were great and the retaliation immediate, the killing would be manslaughter only. If a person receives a blow and immediately avenges it with any instrument which he may happen to have in his hand, then the offence will be only manslaughter, provided the stroke is to be attributed to anger arising from the previous provocation. But in dealing thus leniently with an offender, our law requires two things: 1st, that there should be sufficient provocation; and 2ndly, that the fatal stroke should be clearly traceable to the influence of passion arising from it. If a person denote by the manner in which he avenges a previous blow, that he is not excited by a sudden transport of passion, but is acting under the influence of that wicked disposition which the law terms 'malice' in the definition of wilful murder, then the offence would not be manslaughter, but murder $(f)$. A. uses provoling language or behaviour towards $B$., and B. strikes him, whereupon a combat ensues, in which $A$. is killed; $B$. is guilty of manslaughter, for the affray was sudden, the parties fought upon equal terms, and in such combats, upon sudden quarrels, it matters not who gave the first blow $(g)$. But if B. had drawn his sword and made a pass at A., whose sword was undrawn, and thereupon $\mathrm{A}$. had drawn, and a combat had ensued in which $\mathrm{A}$. had been killed, this would have been murder: for B., by maling his pass whilst his adversary's sword was undrawn, evinced malice; and A.'s endeavour to defend himself, which he had a right to do, will not excuse B. $(g)$. No provocation by words or gestures

(f) l'er Parke, B., R. v. Thomas, 7 Conr. \& I'. $817 ;$ R. v. Hayuard, 6 Id. 157 : I. v. Lynch, 5 Id. 324 ; Reg. v. hivkham, 8 Id. 115. (g) Fost. Disc. Hom., p. 295 ; Rcy. v. Maurgridge, Kel. 128. See $R$. v. Losd Byron, 19 How. St. Tr. 1177. 
only will indeed suffice to reduce the crime of murder to that of manslaughter $(h)$; nor, as already stated, will every provocation by blows avail to do so, particularly when the prisoner appears to have resented them by using a weapon calculated to cause death (i). If, however, there be a provocation by blows which would not of itself render the killing manslaughter, but which is accompanied by insulting words and gestures calculated to produce a degree of exasperation equal to that which would be caused by a violent blow, the law would probably regard such special circumstances as reducing the crime of premeditated homicide to that of manslaughter $(k)$.

Again, all struggles in anger, whether by fighting, wrestling, or otherwise, are unlawful $(l)$; so that if death Struggles in anger. result to one of the parties engaged in such contest, the individual causing it will be guilty certainly of manslaughter, and perhaps even of murder $(m)$. "When," observed Bayley, J. $(n)$, "persons fight on fair terms, and merely with fists, where life is not likely to be at hazard, and the blows passing between them are not likely to occasion death, if death ensues, it is manslaughter; and if persons meet originally on fair terms, and, after an interval, blows having

(h) Fost. Disc. Hom., p. 290.

(i) Reg. v. Eagle, 2 Fost. \& F. 827, where, Erle, C. J., observes, " the law implies malice where one has killed another by the use of a deadly weapon, unless the circumstances rebut the inference and reduce the offence to manslaughter. The circumstances of the case do rebut the inference of malice if they show that the blow was given in the heat of passion arising on a sudden provocation, and before the passion had time to cool."

(k) Per Polloek, C. B., Reg. v. Sherwood, 1 Car. \& K. 556. 359.

(l) Reg. v. Canniff, 2 Car. \& P.

(m) Where an injury was inflicted on a person by a blow which in the judg. ment of competent medical men rendered an operation advisable, and the patient died under the administration of chloroform, though it was admitted that he would not have died but for its administration, the prisoners were nevertheless held indictable for manslaughter: Reg. v. Davis, 15 Cox, C. C. 174 .

(n) R. v. Whiteley, 1 Lew. C. C. $175,176$.

Persons present at and sanctioning a prize-fight which ends fatally are indictable for manslaughter: $\dot{R}$. v. Mfurphy, 6 Car. \& I. 103 ; R. v. Hargrave, 5 Id. $170 ; R$. v. Perkins, 4 Id. 537. But mere roluntary presence at a fight does not as a matter of law necessarily render persons so present guilty of an assault as aiding and abetting in such fight: Reg. v. Coney, 8 Q. B. D. 534. 
been given, a party draws, in the heat of blood, a deadly instrument, and inflicts a deadly injury, it is manslaughter only. But if a party enters a contest dangerously armed, and fights under an unfair advantage, though mutual blows pass, it is not manslaughter, but murder" $(0)$.

Honsicide caused by undue correction.
Homicide throush negligence

Even where the act upon which death ensues is lawful or innocent, it must be done in a proper manner and with due caution to prevent mischief in order that the individual thus causing the death of another may be held excused. Thus parents, masters, and others having authority in foro domestico, may give reasonable correction to those under their care, and if death thence result without their fault, it will be regarded as accidental. But if the chastisement inflicted exceed the bounds of due moderation, either in degree or in respect of the instrument used, the homicide thus committed will be murder $(p)$ or manslaughter, according to the circumstances of the case. If a schoolmaster correct his scholar with a cudgel or other thing not likely to kill, though improper for the purpose of correction, he will, if death ensue, be amenable to a charge of manslaughter - if with a dangerous weapon likely to kill or maim, due regard being had to the age and strength of either party, he may be answerable for murder $(q)$; for the using of a weapon from which death is likely to ensue imports a mischievous disposition, and the law accordingly implies that a degree of malice attended the act, which, if death result from it, will be murder $(r)$.

Further, it is obvious that a person may be culpable either in the doing of an act rashly without knowing its nature or probable consequences, or in the careless and

(o) See per Ward, C. B., R. r. hield, 14 How. St. Tr. 145.

(p) R. v. Wall, 28 St. 'Tr. 51.

(a) Fost. Lisc. Hom., p. 262 ; per Ilolt, C. J., R. r. Keite, 1 Ld. Raym.
144. See Reg. r. Hopley, 2 Fost. \& F. 202.

(r) Per Nares, J., R. . Wiggs, Ieach, C. C. 378, n. 
incautious manner of doing it. In the former predicament are cases where a person unacquainted with the effect of a powerful medicine or drug administers it to another; or where a person rashly and improvidently presents a gun at another and draws the trigger, not supposing it to be loaded, when it is in truth loaded, and death results. And, as a general rule deducible from decided cases, it may be laid down that where death is caused by negligence without malice, the person guilty of such negligence will be indictable for manslaughter $(s)$; and where more persons than one are engaged in a dangerous act, whereby through the absence of proper precautions life is lost, all the persons so engaged are guilty of manslaughter $(t)$. If, indeed, a workman (to take an instance often put) employed in the repair of a building throws stones or rubbish from the house-top, and thereby kills an individual passing underneath, this act will, in the eye of the law, amount to murder, manslaughter, or excusable homicide, according to the degree of precaution taken, and the necessity for taking it. If the act were done, without any lind of warning, in a public street, at a time when persons were usually passing, this might in strictness be esteemed murder-if at a time when persons were not likely to be passing, it would be manslaughter ; if done in a retired spot where no persons were in the habit of passing, it would be homicide by misadventure. So, if a person, riding tlrough a street slowly, and using reasonable caution to prevent mischief, rides over and kills a child which is heedlessly crossing the road, the result is purely accidental; but if he had used such speed as under the circumstances was not unlikely to occasion accident, the want of caution might render him amenable to a charge of manslaughter; and were he to ride into the midst of a crowd at so furious a rate as that loss of life was likely thence to ensue and did ensue, he

(s) Reg. v. Suindall 2 Car. \& K. 230 ; Reg. v. Lowe, 3 Car. \& K. 123.

B.C.L. (t) Reg. r. Salmon, 14 Cox, C. C. .494 .

$3 \mathrm{x}$ 
Homicide caused by negligence of medical practitioner;

might, by his wilful endangering of life, be guilty technically of the crime of murder $(u)$.

With reference also to negligent treatment by medical practitioners, it has been observed $(x)$, that if a medical or any other man cause the death of another intentionally, that, of course, will be murder ; but where a person, not intending to kill a man, by his gross negligence, unskilfulness, and ignorance, causes death, he is guilty of culpable homicide. If, therefore, an operation, which results in the death of the patient, be performed by one whether duly qualified or not to act as a surgeon, the questions for the jury will be, first, whether the deceased died from the effects of the operation performed on him by the accused; secondly, whether the treatment pursued by the prisoner towards the deceased was marked by negligence, unskilfulness, and ignorance.

The general doctrine applicable in cases such as are now under our notice seems well established, "that what constitutes murder, being by design and of malice prepense, constitutes manslaughter when arising from culpable negligence" $(y)$ of the accused; such negligence being personal, not merely that of his servants $(z)$.

$\rightarrow$ of trustees

But although the neglect of a personal duty, when death ensues as the consequence of such neglect, renders the guilty party liable to an indictment for manslaughter, this proposition holds true only where the neglect is personal, and the death was the immediate result of that personal neglect (a). Trustees appointed to repair roads, under a local Act, are not chargeable with manslaughter, if a person using one of

(u) See Rey. v. Dant, L. \& C. 367 ; Reg. v. Fenton, 1 Lew. C. C. 179; Jieg. r. Franklin, $15 \mathrm{Cox}$, C. C. 163.

(x) Per Munle, J., Keg. v. Whitehead, 3 Car. \& K. 202, 204. See J. v. Lom 4 Car. \& $\mathrm{P} .423 ; R$. v. Webb, I II. \& Rob. 405 ; R. v. Spilling, 2 Y. \& Rob. 107; R. v. Ian Butchell, 3 Car. \& P. 629; leg. . C'rick, l Fost. \& F. 519 ; Reg. r.
Crook, Id. 521.

(y) Per Lord Campbell, C. J., Reg. v. Hughcs, Dearsl. \& B. 250 .

(z) Reg. v. Bennett, Bell, C. C. 1; R. v. Huggins, 17 How. St. Tr. 298, 310 .

(a) Reg. v. Bennett, Bell, C. C. 1; see Rey. v. Hounes, 1 Q. B. D. 25, which was decided under stat. 31 \& 32 Vict. c. 122 , s. 37 . 
such roads is accidentally killed, in consequence of the road being out of repair, through neglect of the trustees to contract for its due reparation $(b)$. " In all the cases," remarlied Erle, J. (c), "in which a party has been indicted for. manslaughter, in causing death by his omission to perform a particular duty, I think the neglect of duty was immediately connected with the death, as in the case of careless driving on a railway or of not supplying an infant with food. The present case does not fall within this class.

Let us now turn, for a moment, to the consideration of another class of cases-riz., where homicide occurs in the course of resistance offered to the enforcement of public Honuicide
caused by resisting officer of justice. Policy, or rather necessity, obviously requires that every minister of justice should be protected, not only in executing any express sentence of the law, but also in doing every act which the law obliges him to do in the administration and advancement of justice. This principle, which is essential to the existence of the law as an imperative rule of conduct, extends also to the protection of all who either lawfully assist ministers of justice in executing their duties, or who, being mere private persons, legally execute such powers as the law casts upon them, for the advancement of justice and the prevention of wrong. Hence, where persons having authority to arrest or imprison, and using the proper means for that purpose, are resisted in so doing, and the party making resistance is lilled in the struggle, this homicide is justifiable. On the other hand, if the party having authority to arrest and imprison, using the proper means, happens to be killed, all who take a part in such resistance will be guilty of murder $(d)$; and where a homicide talies place in consequence of an unlawful assembly, every one

(b) Reg. v. Pricock, 17 Q. B. 34.

(c) Reg. v. Pocock, 17 Q. B. 39.

(d) Fost Dise. Hom., p. 270; Mac. kalley's case, 9 Rep. 61 b. See Reg. v. Davis, L. it C. 64 . 
taking part in the obstruction may be himself personally responsible for the homicide $(e)$.

Where a person criminally charged, being apprehensive of an arrest, flies from the officer of justice, who, in pursuing, kills him, this homicide may amount to murder or manslaughter, according to circumstances; for if the officer in the heat of pursuit, and merely in order to overtake the defendant, should strike him with a stick, or other weapon not likely to kill, and death should thence result, this will, at most, be manslaughter, and may amount only to accidental homicide; whereas, if a deadly weapon had been used, it might have been murder $(f)$. The remark just made seems to hold equally true whether the flight took place through fear of arrest on a warrant for a breach of the peace, or any indictable offence.

Where, however, a felony having been committed, the felon flies from justice, it is the duty of every individual present to use his best endeavour to prevent his escape; and if in the pursuit the party flying is killed, when he cannot be otherwise overtaken, this will be deemed justifiable homicide; for the pursuit was not barely warrantable but required by the law; it being, moreover, the duty of an offender quietly to yield himself up to public justice $(g)$.

It may readily be inferred, from what has been above said, that, on a charge of homicide in resisting an arrest, the guilt of the accused may, under the law as it now stands, depend entirely upon nice and difficult questions belonging to the civil branch of the law, such as the technical regularity of civil process, or the precise duty of a minister of justice in its execution (h). In any case of the lind alluded to, three points will be found to deserve especial

(c) P'er Fitzgerald, J., Reg. v. ICA Aunghton, 14 Cox, C. C. 576.

(f) Fost. Disc. Hom., p. 271.

(g) Id. ibid.; 1 Hale P C., p. 481.
See Reg. ₹. Dadson, 2 Den. C. C. 35.

(h) See Galliard, app., Laxton, resp., 2 B. $\mathcal{S} \mathrm{S} 363,370 ;$ Codd $\mathrm{v}$. Cabe, 1 Ex. D. 352, 355, 356. 
notice-viz., the legality of the deceased's authority (i), the legality of the manner in which he executed it $(k)$, and the defendant's knowledge of that authority. If an. officer of justice be killed in attempting to execute a writ or warrant invalid on the face of it $(l)$, or against a wrong person, or out of the district in which alone it could legally be executed, or if a private person interfere and act in a case where he has no authority by law to do so $(m)$, or if the defendant had no knowledge of the officer's character or business $(n)$, or of the intention with which a private person interferes, and the officer or private person be resisted and killed, the killing will be manslaughter only. Though if malice prepense be evidenced-as if a man is taken into custody by a police officer without authority, and out of revenge for the act shoots the officer-that is murder $(o)$.

In Reg. v. Serva ( $p$ ), a question somewhat analogous to the above was learnedly discussed-riz., as to the legality of the capture by a British man-of-war of a vessel alleged to be a slaver, and the lawfulness or otherwise of homicide committed by her crew in attempting to regain possession of her after capture from the officer and men placed in charge of her by the Queen's ship. The accused, however, in this case were eventually acquitted, on the ground of a want of jurisdiction in our Courts to try the offence charged $(q)$.

Homicide, then, may be of various kinds and degrees. It may be .justifiable, as where a sheriff executes a criminal in Homicidewhere jus. tiflable. strict conformity with his sentence; or where, as above-

(i) R. v. Thompson, l Mood. C. C. 80 ; R. v. Fold, Russ. \& Rr. $329 ; R$. v. Curran, 3 Car. \& P. 397 .

(k) R. v Cook, Cro. Car. 537. 281 .

(m) Reg. r. Phelps, Car. \& M. 180; $R$. v. Curvan, 1 Mood. C. C. $132 ; R$. v. Curran, 3 Car. \& P. 397. See Reg. r. Price, 8 Car. \& P. 282; Derecourt v. Corbishley, ; E. \& B. 18s; ante, p. 824 et seq.

(n) See R. v. Woolmer, 1 Mood. C. C. $33 t ;$ R. r. Houraith, Id. 207 ;

Fost. Dise. Hom., p. 298.

(o) Per Cockburn, C. J., Rcy. v. Sattler, Dearsl. N B. 5tl.

(p) 1 Den. C. C. 104.

(q) See Reg. v. Anderson, L. R. 1

C. C. 161, and cases there cited. 
mentioned, an inferior officer of justice kills a person who forcibly and illegally resists capture, or who attempts the rescue of a prisoner; or where the death of an individual attempting to commit some atrocious crime is caused by the individual whose person or property is threatened by his violence; where, indeed, a felony is attempted on the person, as robbery or murder, the party assaulted may repel force by force $(r)$. A woman, in defence of her chastity, may lawfully kill an assailant; and if an attempt be made to commit arson, or burglary, the orner of the dwellinghouse, or any member of his family, or even a lodger, may, in preventing the mischief contemplated, lawfully kill the assailant $(s)$. A mere trespasser, however, on the land of another, although actuated by a felonious intention, could not legally be shot at $(t)$. And if A., finding a trespasser upon his land, beats and thus chances to kill him, he is guilty of manslaughter; or, if there be added to the above state of facts circumstances eridencing malice, of murder $(u)$.

The authorities below cited will suffice to show, that, in some special cases involving circumstances of peculiar aggravation, homicide may, in the absence of malice, be reduced in degree from murder to manslaughter $(x)$.

Homicidewhere ex. cusable.

Homicide may also be excusable; as where it occurs by misadventure-i.e., where " a man doing a lawful act, without any intention of hurt, unfortmately kills another" $(y)$; as if he were shooting at a mark in a place adapted for that pastime, and under circumstances which rendered it permissible.

So, homicide may by ignorantia facti be rendered excusable; as where a man, intending to kill a thief or

(r) See Reg. r. Huntley, 3 Car. S K. 142 .

( ) Fost. Disc. Hom., p. 274; $\boldsymbol{R}$. r. Hunt, 1 Mood. C. C. $93 ;$ K. r. Lerett, cited Cro. Car. 538.

(t) R. v. Scully, 1 Car. \& P. 319 ; Rey. r. Dudson, 2 Den. C. C. 35 . See
R. v. Meade, 1 Ler. C. C. 18.5.

(ii) Fust. Dise. Hom., p. 291.

$(x)$ Fost. Disc. Hom., p. $296 ; R$. r. Maming, T. Rarm. 212; Reg. $\mathrm{r}$. Fisher, \& Car. \& P. 182; Reg. v. Kielly, 2 Car. \& K. 814.

(y) \& Bla. Com., 182. 
housebreaker being in his house, by mistake lills one of his own family $(z)$. And if a man receiving a drug from an apothecary or chemist, without any reason to suppose it to be other than a salutary medicine, were to administer it, being in truth deadly poison, his utter ignorance of the fact would excuse him, there being no evidence of negligence on his part.

Again: there are cases in which a man may be excused, who, to protect himself in the course of a sudden broil or quarrel, kills his assailant; homicide when excusable under such circumstances being, however, with difficulty distinguishable from manslaughter. $\mathrm{He}$ who in the case of a homicide by his hand, happening in the course of a mutual conflict wherein he was engaged, would excuse himself upon the ground of self-defence, "must show that, before a mortal stroke given, he had declined any furtber combat, and retreated as far as he could with safety, and also that he killed his adversary through mere necessity, and to avoid immediate death." Should the accused party fail in these particulars, he will incur the penalties of felonious homicide $(a)$. A., of malice prepense, discharges a pistol at B., and then runs away. B. pursues him; whereupon A.turns back, and in his own defence kills B. This is murder (b). C. being assaulted by $\mathrm{D}$. returns the blow, and a fight ensues; C., before a mortal wound given, declines any further conflict, and retreats as far as he can with safety, and then in his own defence kills D. This homicide is excusable, as being done in self-defence. Where a son, believing that his father was cutting the throat of his mother, shot and killed him, it was held that if he had reasonable grounds for believing, and honestly believed that his act was necessary for the defence of his mother, the homicide was excusable $(c)$.

(z) Id., p. 27.

(a) Fost. Disc. Hom., p. 277. (b) Fiel. 129.

(c) Reg. r. liose, 15 Cox, C.C. 540. 
It is provided by statute $(d)$ that " no punishment or forfeiture shall be incurred by any person who shall kill another by misfortune, or in his own defence, or in any other manner without felony."

From what has been heretofore said we may infer that a charge of murder involves the less serious charge of felonious homicide, so that a person indicted for the former may be convicted of the latter crime $(e)$.

Assault. Next in order to the offence of homicide, felonious or otherwise, may be noticed assaults against the person,

Agrgravated assault. which are usually classified under two heads, aggravated and common assaults. Belonging to the former class of assaults are some-ex. gr., an assault with intent to robto which brief reference will presently be made. Let us here consider the liability attaching to one who makes an Assault and assault or battery on another, unattended by any specially aggravating circumstances. At a former page $(f)$ has been stated the signification of either of the words just used in connection with purely civil proceedings: and it will now suffice to add that, according to our writers upon criminal law, an "assault" is an attempt to offer, with force and violence, to do a corporal hurt to another,-as by striking at him either with or without a weapon, or presenting a gun at him if within range, or by pointing any other dangerous weapon at him whilst standing within reach of it, or by holding up one's fist at a man, or by any such like act done in an angry, threatening manner, under circumstances denoting an intention, coupled with a present ability, of carrying the threat into execution $(g)$; or by encouraging a

(d) $24 \& 25$ Vict. c. 100, s. 7 .

(e) See, for instance, Rcg. v. Richards, 2 Q. B. D. 311, where it was held that a person charged as an acces. sory after the fact to murder might rightly be convicted as an accessory to manslaughter.

An accessory after the fact is one who, knowing a felony to bate been committed by another, receives, relieves, comforts, or assists the felon: 1 Bla. Com. 37 .

(f) Ante, p. 784 .

(g) Hawk, P. C., Book I., Chap. 52, s. 1; 1 East, P. C., p. 406; Osboin v. Feitch, 1 Fost. \& F. 317. 
dog to bite a man (h); or by unlawful imprisonment (i); though words only cannot constitute an assault $(k)$. A "battery," however, includes any injury, however slight, actually done to the person of another in an angry, revengeful, rude, or insolent manner ; even touching the person of another against his consent might constitute a battery $(l)$.

It may be well further to observe, that although an assault cannot in law be committed on one who actually consents thereto $(\mathrm{m})$, yet where non-resistance to an act is obtained by fraud, such act may constitute an assault ( $u$ ). There is an appreciable difference between consent and submission or non-resistance induced by malpractice $(o)$, or resulting from weakness of intellect $(p)$; or from ignorance of the nature of the act done $(q)$; for although every consent involves a submission, it by no means follows that a mere submission involves consent $(r)$. It seems clear, too, that the fact of consent will in general be immaterial where an actual battery and brcach of the peace has been committed $(s)$. 958.

(h) Russ. Cr., 5th ed., vol. 1, p.

(i) Id., p. 960.

(k) Hawk, P. C., Book I., Chap. 32, s. 1 .

(l) Id. s. 2 ; Coward v. Baddeley, 4 H. \& N. $478,481$.

See also $R$. v. Nichol, Russ. \& Ry. 130 ; R. v. Rosinski, 1 Moo. C. C. 19 .

(m) Reg.v. Read, 1 Den. C. C. 377 ; followed in Reg. v. Roadley, 14 Cox, 463: Reg. v. Martin, 2 Moo. C. C. 123.

(n) Reg. v. C'ase, 1 Den. C. C. 580 ; Reg. v. Flattery, 2 Q. B. D. 410, 413 ;

Reg. v. Saunders, 8 Car. \& P. 265 ; Reg. v. Williams, Id. 286. See Reg. v. Clarke, Dearsl. 397 ; Reg. v. Hunsom, 2 Car. \& K. 912 ; Reg. v. Stanton, 1 Car. \& K. 415.

(a) See Reg. v. Case, supra.

(p) Reg. v. Fletcher, Bell, C. C. 63, approved in Reg. v. Barratt, L. R. 2 C. C. 81. See Reg. v. Fletcher, L. I. 1 C. C. 39.

(q) Reg. v. Flattery, 2 Q. B. D.

$410 ; \operatorname{Reg}$. r. Lock, L. R. 2 C. C. 10 , where Quain, J., says: "Mere submission by one who does not know the nature of the act done cannot be consent. In many cases, as where an act is done to a person who is asleep or who has been drugged, there is no consent, though there is no active dissent."

(v) Per Colcridge, J., Reg. v. Day, 9 Car. \& P. 724. See Reg. v. Cumplin, 1 Den. C. C. 89 ; Reg. v. Barrouc, L. R. 1 C. C. 156 ; not followed in Reg. v. Dee, 15 Cox, C. C. 579.

(s) In 1 Den. C. C. 380 , u., occur the following remarks, apposite to the above point, by the learned Reporter: "An assault seems to be any sort of personal ill-usage, short of a battery, done to another against his consent. Therefore such act done with consent is no breach of the peace or crime. A battery is simply a beating, or some act which the law deems equivalent. It is not only a trespass, but a breach of the peace, and, though done with consent, is primâ facie illegral. 'There- 
An actionable injury amounting to an assault, or even to a battery, is not necessarily indictable ex. gr., if it be purely accidental $(t)$.

Libel. The offence of libel $(u)$ against an individual (to which species of libel the following remarks will be restricted), observes a learned writer upon that department of our criminal law $(x)$, consists in the act of publishing the defamatory matter set forth on the record in the sense attributed to it by the innuendos, with the intention alleged in the indictment-riz., to injure, vilify, and prejudice the prosecutor, and to deprive him of his good name, \&c., and to bring him into public contempt-maliciously, without any legal justification or excuse.

Nor, on examining the constituent ingredients in this offence as above set forth, we shall observe that the fact of publishing the illegal matter, and of its being published in the particular sense assigned to it $(y)$, the existence or nonexistence of the circumstances relied upon as affording a legal justification or excuse for the alleged libel, and

fore, the consent of each party in a prize fight does not legilise the battery, though it negatives the mere assault. In such a case the rule would seem to apply. that "licence to beat me is roid, because it is against the peace.", See Iatther r. Ollerton, Comb. 218.

(t) R. r. Gill, Str. 190. See Lindercond r. Heuson. Str. 596 ; Dickenson v. Iratson, T. Jones, 20 .

In Cleary r. Booth, (17 C. C. C. 611) the question raised was whether the head master of a board school is justified in inflicting corporal punishment on a pupil who has misconducted himself outside the school, on his way to sehool, and out of school hours. The Court (Lacrence, J. and Collins, J.) held the schoolmaster had the authority, and renitted the case for the magistrates to find whether the punishment administered was excessive.

(ic) Is to blasphemous libel, see Rex. v. Curlile, 3 I. \& Ald. 161 ; 22 R. R. 333 ; Reg. v. Bradlaugh (Wo. 2), 1.5 Cox, C. C. 217 : Odgers, Libel aud
Slander, p. 394. The mere denial of the truth of the Cliristian religion or of the Scriptures is not enough, per se, to constitute a writing a blasphemous libel, so as to render the writer or publisher indictable. But indecent and offensire attacks on Christianity or the Scriptures. or sacred persons or objects, calculated to outrage the feelings of the general body of the community, do constitute the offence of blasphemy, and reuder writers or publishers liable at common law to criminal prosecution: Reg. r. Ramsay, 15 Cox, C. C. 231.

$(x)$ Starkie on Slauder and Libel, 4th ed., p. 586. As to libels on a dead persou, see Hawk, Pl. Cr., Sth ed., p. 542 ; Reg. v. Lahouchere, 12 Q. B. D. $320 ; 322$.

(y) The jury should " read the paper stated to be a libel is men of common understanding, and say whether, in their minds, it convers the idea im. puted : " per Buller, J., R. r. Watsm, 2 T. R. 206 ; 1 R. R. 461. 
generally, the question whether the act of publication charged was done maliciously or wrongfully $(z)$, are properly for the decision of the jury. Whereas, it is for the Court to determine whether the facts proposed to be proved rould, if proved, suffice in law to constitute a publication and to support the innuendos; it will be for the Court to say whether the matter charged as libellous is so in law-and whether the facts accompanying the publication amount to a legal justification or excuse for it $(a)$.

Before the passing of Mr. Fox's celebrated Libel Act in the year $1792(b)$, it was judicially laid down, that, although it was the province of the jury thus to determine the fact of publication, and whether or not the libel meant that which it was alleged in the indictment to mean, it was exclusively the province of the Court to say whether such meaning were criminal or not; and that, if the jury should disiegard the opinion of the Judge in respect to this point, they would violate their oaths and duty $(c)$; the practice, accordingly, on a criminal trial for libel, at the time alluded to, was this: where no facts or circumstances appeared raising any justification or excuse for the alleged libel in point of law, and where consequently there was no real question of intention to be left to the jury, the Court directed them to find a verdict of guilty if they were satisfied as to the fact of publication, and the truth of the innuendos set forth in

(z) In R. v. Shipley, 4 Dougl. 177, Ashurst, J., observes, that " every man (who is of sufficient understanding to be responsible for his actions) is supposed to be cognisant of the law, as it is the rule by which every subject of the kingdom is to be governed; and therefore it is his business to know it. If, therefore, a man publishes that which the law says is treasonable, seditious, or rebellious, the alleging in the indictment or information that the party did it with a libellous or seditions intent, is a mere matter of legal interence from the fact of publication, and not the object of proof either on the one side or the other." "But, where the fact of publication is ambiguous (as where it may be a doubt whether the party pulled the paper out of his pocket by accideut or ou purpose, or whether he gave one paper instead of another, or any such supposable case), there the maxim holds that Actus non facit reum nisi mens sit rea." See R. r. "I"utson, 2 B. \& C. $25 \%$.

(a) Stark. on Slander aud Isibel, 4th ed., p. 589 . See Gregory r. Keg., 15 Q. B. 957 .

(b) 32 Geo. 3, c. 60.

(c) See IIall. Const. Hist. Eug., 8th ed., vol. 3, p. 169.
Libel Act of IIr. Fox: 
the indictment; although if the alleged libel were in point of law no libel, the defendant might have arrested the judgment by reason of the defect, which would in that case be apparent on the record $(d)$. Strong opinions being entertained, however, adverse to this mode of procedure by many, apprehensive that the liberties of the subject might be thus threatened, the statute above referred to $(32 \mathrm{Geo} .3$, c. 60) was passed (e), enacting by its first section,- which was declaratory of the law and designed to put prosecutions for libel on the same footing as other criminal cases $(f)$ that on every trial of an indictment $(g)$ for a libel, the defendant having pleaded not guilty, the jury sworn to try the issue thus raised may give a general verdict of guilty or not guilty upon the whole matter put in issue upon such indictment, and shall not be required or directed by the presiding Judge to find the defendant guilty merely on proof of the publication by him of the paper charged to be a libel, and of the sense ascribed to the same in such indictment. Section 2 of the Act, however, provides that on every such trial the Judge shall, according to his discretion, give his opinion and directions to the jury on the matter in issue, between the Crown and the defendant, in like manner. as in other criminal cases, the jury (under section 3) being also entitled in their discretion to return a special verdict, and the defendant, after an adverse verdict, being entitled (section 4 ) to move in arrest of judgment as he might have done before the Act.

-of Lord

The effect of the statute above abstracted seems to have been simply to restore in criminal trials for libel the ordinary course and practice of the common law $(h)$. Long, indeed,

(d) Stark. on Slander and I.iluel, th -d., p. 738. See per Lord IIansfield, C. J., K. v. Woodfall, 5 Burr. 2666 ; k. $\vee$. Withers, 3 T. R. $428: R$. Incan of St. Asaph, Id., n. (a); $k$. v. Shipley, 4 Dougl. 73;21 How. St. Tr. 847. (e) See 22 How. St. Tr. 294.

(f) Per Parke, B., I'armiter r. Cunpland, 6 M. \& W. 108.

(g) The statute applies also to the trial of an information for libel.

(h) Stark. on Slander and Libel, th ed., p. 589 . 
before Mr. Fox's Libel Act, and from its date down to the passing of the enactment $6 \& 7$ Vict. c. 96 , the truth of the charges contained in a libel afforded no ground of defence to an indictment or criminal information for publishing it (i). "The truth of such charges could not" then " be given in evidence under a plea of not guilty, and no special justification on the ground of truth could be pleaded. It was even said, that ' the greater the truth the greater the libel.' 'The Legislature," however, "thinking that such a maxim misapplied brought discredit on the administration of justice, and that under certain guards and modifications the truth of the charges might advantageously be inquired into, and might be permitted to constitute a complete defence," passed the statute last referred to $(k)$; by section 6 whereof the defendant may now, in answer to an indictment for libel, allege the truth of the matters charged therein in the manner required in pleading a justification to an action for defamation, and may further allege that it was for the public benefit that the said matters charged should be published, and the particular fact or facts by reason whereof it was so. If a plea of the kind just specified be pleaded, the defendant will be entitled to give evidence of the truth of the matters charged as libellous, by way of defence to the indictment; and "the truth of the matters charged may" then "be inquired into, but shall not amount to a defence, unless it was for the public benefit that the said matters charged should be published." Where prima facie evidence is given in proof of the justification, the onus will then be on the prosecutor to disprove it, and his not calling witnesses, whom he must be in a position to call, and who will be friendly to him, will be strong evidence against him $(l)$. Issue being taken on this plea, and the defendant

(i) See Hall. Const. Hist. Eng., 8th ed., vol. 3 , p. 169 , n.

(k) Judgm., Reg. v. Newman, I E.
\& B. $573 ; S . C$. , Dearsl. 85.

(l) Reg. v. Labouchere, $14 \mathrm{Cox}$, C. C. 419 . 
being convicted, it is competent to the Court in pronouncing sentence to consider whether the guilt of the defendant is aggravated or mitigated by the plea pleaded, and by the evidence given to prove or disprove the same.

It is clear, that, if to a plea of justification the prosecritor replies that the defendant wrongfully published the libel charged in the indictment without the cause alleged, and issue is joined upon this replication, the prosecutor will be entitled to a verdict, unless the defendant establishes the truth of all the material allegations in the plea, the only function allotted to the jury in the case supposed being to say whether the whole plea is proved or not. If they find that it is proved, the defendant is acquitted. If they think that it is not, they are to declare that the defendant wrongfully published the libel without the cause alleged, and he is convicted. The jury are then functi officio $(m)$, and nothing will remain save for the Court to pass sentence on the defendant. In doing so, however, the just measure of punishment to be awarded may materially depend upon the bona fides or otherwise of the unsuccessful plea of justification, and on the nature and weight of the evidence giren under it $(m)$.

A comparison of sections 4 and 5 of Lord Campbell's Libel Act will further show that the punishment assigned by the Legislature to the publisher of a defamatory libel varies according as he did or did not know it to be false. And under section 7 of the same statute, when evidence has been given establishing a presumptive case of publication against the defendant by the act of any other person by his authority, it is competent to him to prove that the publication in question was made without his anthority, consent, or knowledge, and that the said publication did not arise from want of due care or caution on his

(mi) Judgm., Reg. r. Vetcman, 1 E. \& B. 573, 5it; s. C., Dearsl. 85. 
part $(n)$. Also, by section 8 , the defendant, if acquitted on a prosecution, at suit of a private prosecutor, for a defamatory libel, will be entitled to recover from him his costs, whereas if the defendant fails upon a special plea of justification, he will have to pay the costs sustained by the prosecutor by reason of such plea.

Besides the procedure by indictment for a libel on an individual, a criminal information $(o)$ will in some cases be granted by the Court of Queen's Bench, ex. $y r$., where the libel conveys imputations of a serious nature, and is declared by affidavit to be false $(p)$.

Further, it remains to add that not merely will the actual publisher of a libel be amenable to our criminal law ; so will he be who shall threaten to publish any libel upon any other person, or shall directly or indirectly threaten to print or publish, or propose to abstain from printing or publishing, or offer to prevent the printing or publishing of any matter or thing touching any other person "with intent to extort any, money, or security for money, or any valuable thing from such or any other person, or with intent to induce any person to confer or procure for any person any appointment or office of profit or trust" $(q)$.

The Newspaper Libel and Registration Act, $1881(4 \pm \& 45$ Vict. c. 60), is concerned with libels published in newspapers. As stated at p. 854, a fair and accurate report of

Newspapers Libel and Registration Act. (u) See Reg, $\mathbf{v}$ Holbrook, 4 Q. B. D. $42 ; 3$ Id. 60 . There the defendants, proprietors of a newspaper, had appointed an editor with general authority to conduct the paper-they themselres taking no part in the management of it, and the main question was whether the general authority thus given to the editor was per se evidence that the defendants had authorised or consented to the publication of a libel contaned in it within the meaning of the abore section. (a) See, for instance, Reg. ․ Holbrook, suprit.

(p) See lieg. v. Tetman, I E. \& B. 268 ; S. C., Dears]. 85; Ex parte Duke of Ifarlborongh, 5 (Q. B. 95, ; Reg. v. Gregory, 8 Ad. \& E. $90 \overline{7}$; Ex parte Chapman, 4 Ad. \& E. 773 ; inte, p. 230. As showing nnder what circumstances words spoken are indictable, see per Holt, C. J., Reg. r. Langley, 6 Mod. 124; and in R. v. Bear, ? Salk. 417 .

(q) 6 \& 7 Vict. c. 96, s. 3 . 
the proceedings at a meeting may be privileged. A Court of summary jurisdiction may hear eridence as to whether the libel is true and for the public benefit, and may if it appears improbable that a jury would acquit the person charged, dismiss the case $(r)$, or, if the libel is of a trivial nature, deal summarily with it $(s)$.

No criminal prosecution shall be commenced against any proprietor, publisher, editor, or any person responsible for the publication of a newspaper, for any libel published therein, without the order of a Judge at Chambers being first had and obtained. Such application shall be made on notice to the person accused, who shall have an opportunity of being heard against such application $(t)$.

Further, by section 1 of the Corrupt and Illegal Practices Prevention Act, 1895 (58 \& 59 Vict. c. 40), any person who, or the directors of any body or association corporate which, before or during any parliamentary election, shall, for the purpose of affecting the return of any candidate at such election, make or publish any false statement of fact in relation to the personal character or conduct of such candidate, shall be guilty of an illegal practice within the meaning of the provisions of the Corrupt and Illegal Practices Prevention Act, $1883(u)$, and shall be subject to all the penalties for, and consequences of, committing an illegal practice mentioned in the Act, unless it is proved that the person charged had reasonable grounds for believing, and did believe, the statement made by him to be true.

Such is the state of our criminal law at the present day, in regard to offences against the reputation of individuals, amended as it has been with a threefold view-for the better protection of private character, for more effectually

(v) 44 \& 45 Vict. c. 60, s. 4 .

(s) Ib., s. 5.

(t) 51 \& 52 Vict. c. $64, \mathrm{~s} .8$, amending 44 \& 45 Vict. c. $60, \mathrm{~s}, 3$. Bo

appeal lies from an order made under the section: Ex parte Pulbrook, 17 C. C. C. 464 .

(Ii) 46 \& 47 Vict. c. 51 . See s. 10. 
securing the liberty of the press, and for the prevention of abuses in exercising such liberty $(x)$.

Simple Larceny-i.e., larceny at common law, or, as Simple Blackstone $(y)$ describes it, "plain theft, unaccompanied with any other atrocious circumstance" - has heretofore been defined to be "the mrongful taking and carrying away of the personal property of another, with a felonious intent to convert it to the taker's own use, without the consent of the orner' $(z)$, this taking and carrying away or "asportation" of the property of another being effected without consent or by consent obtained by intimidation $(a)$ or fraud $(b)$, so as the owner consent not in the latter case to part with his entire right of property, but with the temporary possession of it only.

The offence of larceny viewed independently of the statute law is very technical. Of certain things larceny cannot by our common law be committed. For,-1. Our common law holds exempt from being the subject of larceny whatever is attached to or savours of the realty $(c)$. For this rule various subtle reasons have been assigned; but whether it originated in the notion that the severed portion of the realty, though removable and actually removed, was, in legal construction, still adhering to the freehold, and therefore incapable of removal; or that the wrong-doer acquired some sort of property in the severed chattel; or that it never was a chattel in the possession of the orner of the realty; the reason is alike unsatisfactory to modern intelligence. However, the taking of chattels real, or anything savouring of the land, as a box of title-deeds, or sharters that concern it, is at common law no larceny $(d)$.

$(x)$ See the preamble to $6 \& 7$ Vict. 3. 96 .

(y) 4 Com., p. 229.

(z) See the opinion of the Judges in Hammon's case, 2 Leach, C. C. 1089 ; rudgm., Reg. v. Thurborn, 1 Den. C. C. 388; Reg. v. Middleton, L. R. 2 C. C. I8, 49, 60,66; Reg. r. McGrath, A. R. 1 C. C. $205,209,210$.

B.C.L. (a) See Reg. r. IIcGrath, L. R. 1 C. C. 205 ; followed in Reg. r. Lovell, 8 Q. B. D. 186.

(b) Reg. v. Hollis, 12 Q. B. D. 25 : Reg. v. Buckmaster, 20 Q. B. D. 182 : Reg. 、. Russett, (1892) 2 Q. B. 312.

(c) See Reg. r. Joncs, Dearsl. \& B. 555 ; Reg. v. Rice, Bell, C. C. 87.

(d) 1 Hale, P. C., pp. 509, 510 ;
Of what things lar. ceny cannot be committed at com. mon law.

\section{Things at} taclied to or savouring of the realty. 
Nor can larceny be committed at common law of standing corn $(e)$, nor of fruit from a tree which is growing, "because, from its adherence to the freehold, it is not larceny to steal the tree itself" $(f)$.

Choses in action.

Animals fere na. ture, \&c.

2. Larceny cannot at common law be committed of a chose in action, as a bond, bill of exchange, \&c. $(g)$, which is but evidence of a right, and stealing the evidence of a man's right does not necessarily interfere with the right itself $(h)$.

3. A corpse is not the subject of property (i). And of animals fere nature, unreclaimed $(k)$ and unconfined, nay, even of some domesticated animals, ex. gr. dogs, which are in their nature unfit for human food ( $l$ ), larceny cannot, at common lar, be committed. "In animals ferce nature," as judicially remarked $(m)$, "there is no absolute property. There is only a special or qualified right of property-a right ratione soli to take and kill them. When killed upon the soil they become the absolute property of the owner of the soil."

In modification of the above-mentioned doctrines of our common law, various enactments have from time to time been passed containing important provisions with regard to the felonious removal of various things annexed to the freehold; with regard to instruments coming within the

per Alderson, B., Reg. v. Watts, Dearsl. 334. Cf., howerer, the case where after a trespasser has cut growing grass and defers taking it away for some days. If after sererance the trespasser abandons possession and subsequently takes away the cut grass, he can be convicted of larceny. See Reg. ฬ. Foley, 16 C. C. C. 142 .

(c) 1 Hale, H. C., p. 510. 171.

(f) R. v. Martin, 1 Leach, C. C,

(g) 8 Rep. 33 b; R. v. Mead, 4 Car. \& P. 535 ; Reg. v. Powell, 2 Den. C. C. 403 .

(h) Per Lord Campbell, C. J., Reg. v. Watts, Dearsl. 332 ; per Alderson, B., Id. 331. See Reg. v. Morrison,
Bell, C. C. $158,165-167$.

(i) 4 Bla. Com., p. 236 ; Williams v. Williams, $20 \mathrm{Ch}$. D. 659 .

(k) See Reg. r. Shickle, L. R. 1 C. C. 158 , following Reg. v. Cory, 10 Cox, C. C. 23.

(I) Reg. v. Robinson, Bell, C. C. 34 ; $R$. v. Searing, Russ. \& Ry. $350 ; R$. v. Brooks, 4 Car. \& P. 131 ; Reg. r. Cheafor, 2 Den. C. C. 361; Reg. T. Howell, Id. 363, n.; Hannam r. Mrockett, 2 B. \& C. $934,944$.

(m) Per Bovill, C. J., Reg. v. Townley, L. R. 1 C. C. 317 ; citing Blades v. Higgs, 11 H. L. Ca. 621 ; Lord Lonsdale v. Rigg, 1 H. \& N. 923.

See Reg. v. Townley, L. R. 1 C. C. 315 ; Reg. v. Read, 3 Q. B. D. 131. 
class of choses in action; with regard also to various animals of which larceny could not, without the interposition of the Legislature, have been committed.

To constitute the offence of larceny, the chattel feloniously taken must have been the property, absolute or special (n), Property in chattel stolen-how of its alleged owner. And cases sometimes occur in which a doubt may exist as to the party in whom the ownership of or property in a chattel was, at the time of its assumed wrongful conversion, really vested. In Reg. v. Smith (o), the following facts appear in evidence: the prisoner, professing to be about to pay the prosecutor some money due to him, produced a receipt stamp, which the latter filled up for the amount mentioned by the prisoner, who then, without paying the money due, went away with the receipt, intending to defraud the prosecutor; upon these facts it was held, that the prisoner could not be found guilty of stealing the receipt stamp from the prosecutor, because it had never been in his possession independently of the prisoner, nor was it ever intended that the receipt should be the property of the prosecutor.

Again, at common law, in order to constitute a taking within the meaning assignable to that word in the definition of simple larceny, the chattel alleged to have been taken must have been in the possession, actual or constructive, of him in whom the property is laid.

Reed's case ( $p$ ) shows clearly what is meant by a 'constructive' possession sufficient to support an indictment for arceny. There the prisoner (Reed) had been sent by his naster, with a cart belonging to the latter, to fetch coals rom the wharf of a company with whom he dealt for that

(n) See, for instance, Reg. v. Rowe, 3ell, C. C. 93 . If property be stolen rut of the possession of a bailee, it may ie described in the indictment as the roperty either of the bailor or of the ailee : 2 Hale, P. C., p. 181.

(o) 2 Den. C. C. 449 (with which compare Reg. v. McKale, L. R. I C. C. 125). See also Reg. ז. Johnson, 2 Den. C. C. 310 ; Reg. v. Frampton, 2 Car. \& K. 47 .

(p) Dearsl. 168, 257 ; Reg. v. Kay, Dearsl. \& B. 231; Reg. v. Rogers, L. R. 1 C. C. 136 .
Possession actual or coustruetive. 
article. On his way home with the coals the prisoner, without authority for so doing, disposed of a quantity of them to a third person, and the question was whether he could be convicted of larceny for so doing. It was held that he might be thus convicted. There can be no doubt, remarked Lord Camplell, C. J., that, to support an indictment for larceny in such a case, the goods alleged to have been stolen must have been in the actual or constructive possession of the master; and "if the master had not otherwise the possession of them than by the bare receipt of his servant upon the delivery of another for the master's use, although as against third persons this is in law a receipt of the goods by the master, yet in respect of the servant himself this will not support a charge $(q)$ of larceny, because, as to him, there was no tortious taking in the first instance, and consequently no trespass." . . . "But if the servant has done anything which determines his original exclusive possession of the goods, so that the master thereby comes constructively into possession, and the servant afterwards converts them animo furandi, he is guilty of larceny," the reason being that in this latter case there is a tortious and felonious 'taking' within the meaning of that word as used in the definition of larceny. The constructive possession of the coals by the prosecutor, in the case above cited, had commenced at the moment when they were placed in his cart, so that there was a subsequent taking of the coals by the prisoner, whose intention was beyond all question felonious.

Where pro. lerty al. legeri to have beels stolent cane righifully into posssesnion of accused.

Further, at common law, there would not be a 'taking' sufficient to constitute larceny where the property alleged to have been stolen came into the hands of the prisoner rightfully in the first instance, and without an animus furandi,

(g) So it is laid down by Sir Mr. Hale (I l'. C., p. 513), that a wife cannot commit felony of the groods of the husband, because husband and wife are one person in law. See Reg. r. Kenny, 2 Q. B. D. $30 \bar{t}$. As to larceny by 2 D adulterer, see Reg. r. Flatman, it Cox, C. C. 396. 
although it were afterwards wrongfully appropriated by him $(r)$; the rule being furtum non est uli initium habet detentionis per dominum rei (s). And this ancient doctrine that an innocent receipt of a chattel and its subsequent iraudulent appropriation do not constitute larceny has not been questioned by later decisions $(t)$.

An observance of the above technical rule has led to peculiar results :-If $A$. lend $B$. a horse for a particular journey, and B., having received the horse bona fide, afterwards ride away with it, he will not at common law be guilty of lareeny $(u)$. If goods were sold upon credit and delivered, no subsequent dealing with them by the vendee could amount to larceny $(x)$; and if A. delivered to B. a watch to be regulated or repaired $(y)$, or a horse to be agisted $(z)$, and $\mathrm{B}$. sold it, this was not larceny, because the watch in the one case, and the horse in the other, was delivered voluntarily, and not taken animo furandi $(a)$.

It was further laid down that "all felony includes trespass," and that, if the party accused of stealing "be guilty of no trespass in taking the goods, he cannot be guilty of felony in carrying them away" $(b)$; and that "to support an indictment for larceny the prosecutor must have such possession as would entitle him to bring trespass" $(c)$. Hence, if goods were bailed, and the bailee converted or

(r) Reg. v. Thristle, 1 Den. C. C. 502, 504. See also Reg. v. Gardner, L. \& C. 243 (where the facts adduced in evidence on a charge of larceny failed to show a felonious taking), with which compare Reg. v. Poynton, Id. 247 .

(s) 3rd Inst. 107. As illustrating the rule above cited, see Reg. v. Thomas, 9 Car. \& P. 741; Reg. v. Goodbody, 8 Car. \& P. 665; Reg. v. Evans, Car. \& M. 632 ; R. v. Jackson, I Mood. C. C. 119 ; Reg. v. Adams, I Den. C. C. 38 .

( $t$ Reg. v. Flowers, 16 Q. B. D. 643 , sommenting on Reg. v. Ashuell, Ib. 190. (u) 1 Hale, P. C., p. 504 ; Hawk. 9. B., Book I., Chap. 33, s. 2 ; R. v. Banks, Russ. \& Ry. 441 ; R. v.
$P e a r, 1$ Leach, C. C. 212.

(x) See Reg. v. Cohen, 2 Den. C. C. 249 (where the goods were parted with on the express understanding that they were to be paid for at the tinie, and were taken by the prisoner animo furandi); R. v. Campbell, 1 Mood. C. C. 179.

(y) Reg. v. Thristle, I Den. C. C. 502 ; R. v. Levy, 4 Car. \& P. 241.

(z) R.v. Smith, 1 Mood. C. C. 473.

(a) See also Reg. v. Pratt, Dearsl. 360 .

(b) Hawk. P. C., Book I., Chap. 33, s. 1. See Reg. v. Iymm, 1 Den. C. C. $365,367$.

(e) Per Parke, B., Reg. v. Stear, 1 Den. C. C. 355 ; Reg. v. Smith, 2

Den. C. C. 449 . 
disposed of them animo furandi, this act would not have been, at common law, punishable as larceny, because, being lawfully in possession of the chattel, the taking it would not have constituted either a trespass or a felony, though the case rould have been different if the bailee had "broken bulk," i.e., broken open a bale of goods entrusted to him, because by so doing the nature of the chattel would have become changed-the bailment would have been determined, and the property and possessory title would have reverted to the bailor $(d)$.

It is now provided by statute that whosoever, being a bailee of any chattel, money, or valuable security, shall fraudulently take or convert the same to his own use, or the use of any person other than the owner thereof, although he shall not break bulk or otherwise determine the bailment, shall be guilty of larceny, and may be convicted thereof upon an indictment for larceny. This section does not, however, extend to any offence punishable on summary conviction (e). And it has been decided that a person is not a bailee within the statute unless he is under obligation to return the identical chattel deposited with $\operatorname{him}(f)$.

It may readily be supposed that much difficulty has sometimes been felt in regard to the proof of a 'taking' sufficient to satisfy the definition of simple larceny. Thus in one case it appeared that the prisoner was a depositor in a post-office savings bank in which 11s. stood to his credit. He gare notice in the ordinary form to withdraw 10 s., stating in his notice the number of his depositor's book and the amount to be withdrawn. A warrant for 10s. was thereupon issued to

(d) Year Book, 13 Edw. 4 fol. 9 b ; Judgm., Fenn v. Bittleston, 7 Exch. 159, 160; Reg. r. Cornish, Dearsl. 425 ; Keg. $\vee$. Poyser, 2 Den. C. C. 233 ; R. v. Howell, 7 Car. \& P. 325; lieg. r. Jenkins, 9 Id. 38; Reg. r.
Stear, 1 Den. C. C. 349.

(e) 24 \& 25 Vict. c. 96, s. 3.

(f) Reg. v. Hassall, L. \& C. os; Reg. v. De Banks, 12 Q. B. D. 29, 31; Reg. v. Ashwell, 16 Id. 190, 199. 
the prisoner, and a letter of advice was sent to the post-office at N. to pay 10s. to the prisoner. He went to that office and handed his depositor's book and the warrant to the clerk. The clerk, instead of referring to the proper letter of advice for $10 s$., referied by mistake to another letter of advice for $8 l .16 s .10 d$. , and placed the latter sum upon the counter. The clerk also entered such amount in the prisoner's depositor's book and stamped it. The prisoner took up the money and went away, having at the moment of taking it up, as found by the jury, an animus furandi. It was upon the above-stated facts held that the prisoner had committed larceny $(g)$.

In Reg. v. Ashuell (h), which was argued before all the Judges, the facts were as follows:-The prisoner asked the prosecutor for the loan of a shilling; the prosecutor gave him a sovereign believing it to be a shilling, and the prisoner took it under the same belief. Subsequently, however, he discovered the mistake, and fraudulently appropriated the sovereign to his own use. On the above facts it was unanimously determined that the prisoner had not been guilty of larceny as a bailee under the abore statute; but the Court were equally divided upon the question whether or no he was guilty of larceny at common law.

In practice, a difficulty has also sometimes been experienced in determining whether goods alleged to have Goods ob
tained in Iunnasice been stolen were not in fact obtained in pursuance of a contract between the prisoner and the prosecutor. Here care has been found necessary in scrutinising the facts adduced in evidence and in ascertaining whether the alleged or colourable contract were not a mere pretence, trick, and fraud upon the prosecutor, part of a scheme for feloniously getting possession of his property, so as to render the

(g) Reg. v. Middleton, L. R. 2 C. C. Prinee, L. R. 1 C. C. 150.

38, 44, 50; distinguishing Reg. v. (h) 16 Q. B. D. 190. 
intention which actuated the prisoner in doing so felonious (i), and to satisfy the idea of a 'taking.'

The taking must have been animo furandi.

In order to constitute larceny at common law, the 'taking' must have been animo furandi, and with intent to deprive the owner wholly of his property in the thing taken; the jury having in any particular case to determine whether the facts adduced in evidence really prove such an intent. Thus, in Reg. v. Holloway (k), the prisoner, a workman, employed in a tan-yard to dress leather, was indicted for stealing certain skins of that material, which it appeared from the finding of the jury that he took, "not with intent to sell or dispose of," but with a view to charging for them as if they had been dressed by himself, and so obtaining payment for them from his master. Upon this finding of the jury the Court held that the prisoner could not be convicted of larceny, because there had been no intent on his part to deprive the owner wholly of his property in the leather. "If," said Alderson, B., in the above case, "a servant takes a horse out of his master's stable, and turns it out into the road, with intent to get a reward the next day by bringing it back to his master, would that be larceny?" a question which might safely be answered in the negative, upon the simple ground that the facts here supposed would not evidence a felonious intent, i.e., an intent to deprive the owner wholly of his property in the thing taken $(l)$.

A felonious intent could not, of course, be inferred from a taking of property in mere thoughtlessness or by way of joke, nor even if the taking were with a mischievous

(i) Reg. v. Bramley, L. \& C. 21 ; Reg. v. Thompson, Id. 225 ; Reg. r. Morgan, Dearsl. 395; R. v. I'atch, 1 Leach, C. C. 238 ; R. v. Moore, Id. 314; Reg. v. Wilson, s Car. \& P. 111 ; Reg. $\vee$ Robins, Dearsl. 418 ; Reg. $\because$. Broun, Id. 616; Scmple's case, 1 Leach, C. C. 420.

(k) 1 Den. C. C. 370 , followed in lieg. v. I'wole, Dearsl. \& B. 345, and distinguished in Reg. v. Trebilcock, Id.
453 ; 3rd Inst. 107 ; R. v. Holloway, 5 Car. \& P. 524; Reg. T. Prient, I Den. C. C. 193 (citing R. M Morfitt, Russ. \& Ry. $307 ; R$. v. Cabbage, Id. 292): Reg. v. Gruncell, 9 Car. \& P. 365: Reg. v. Handley, Car. \& M. 547 ; Reg. v. Richards, 1 Cur. \& K. 532 .

(l) See Reg. r. Fork, 1 Den. C. C. 335.; 1 Hale, P. C., p. 509. 
design other than that of depriving the owner of it. And where an assertion of property is meant by the taking, all semblance of a criminal intent manifestly disappears.

Where goods of a third person, having been lost, are appropriated by the finder to his own use, such appropriation under certain circumstances will, whereas in others it will not, amount, in contemplation of our common law, to larceny. It will be larceny if the finder takes the goods with the intention of wholly applying them to his own use, at the same time " reasonably believing that the owner can be found;" this is the rule laid down in Reg. v. Thurborn (m) (which, though not altogether acquiesced in, is recognised as a binding decision ( $n$ ), where the Court observe, that, although in applying it questions of some nicety may arise, yet it will generally be ascertained whether the accused had reasonable belief that the owner could not be found by evidence of his previous acquaintance with the ownership of the particular chattel - the place where it is found, or the nature of the marks upon it, - in some cases the existence of such a belief in the mind of the finder would be at once obviousin others it would appear only after an examination into the particular circumstances. Thus if a horse is found feeding on an open common or on the side of a public road, or a watch is found apparently hidden (o) in a hay-stack, the taking of either description of property would be larceny, because the taker could have no right to presume that the owner did not know where to find it.

If, on the other hand, a man finds goods which have been actually lost, or which may reasonably be supposed by him to have been lost, and appropriates them with intent to

(m) 1 Den. C. C. $387,394,396$. Acc. Reg. v. Moore, L. \& C. 1 ; Reg. v. Christopher, Bell, C. C. 27 ; Reg. จ. Glyde, L. R. 1 C. C. 139 ; Reg. v. Dixon, Dearsl. 580 ; and cases cited, post, pp. 1066, 1067.

(n) See per Martin, B., and Black-
Apropropra. tion of lost goods by inder. 
take the entire dominion over them, really beliering, when he takes them, that the owner cannot be found, this is not larceny $(p)$; nor could it be, if the taking occurred in such a place and under such circumstances as that the orner might be reasonably presumed by the taker to have abandoned his property in the particular chattel, or at least not to know where to find it. In order to appreciate correctly the grounds upon which the distinction just pointed out depends, we must look, not so much to abstract legal principles, as to motives of expediency, in which much of our criminal law doubtless originated; and we shall then see that, cases of abstraction of lost property being of rare occurrence when compared with violations of property in the possession of an owner, there was in the former case no need of so severe a penalty as in the latter; and the civil remedy, viz., by action of tort, for recovering possession of the chattel misappropriated, was deemed sufficient $(q)$. It is moreover an elementary rule of our criminal law, that actus non facit reum nisi mens sit rea (r), whence it follows that the guilt or innocence of an accused person must depend on the circumstances of the particular case as they appear to lim, so that the crime of larceny cannot be committed unless the goods alleged to have been feloniously taken appear to have an owner, and further unless the taker must have known or beliered that the taking was inrito domino, which could not be if the property were believed to have been abandoned.

The law thus laid down in Thurborn's case, as applicable where goods apparently lost, or at all events without any risible owner, are appropriated by the finder to his own use, was recognised by the Court of Criminal Appeal in Reg. $v$. Preston (s), which shows that if a man were to pick up in

(p) Judgm., 1 Den. C. C. 396.

(q) Judgm., 1 Den. C. C. 393.

(r) Judgm., 1 Den. C. C. 359 ; 3rd Inst. 107. But see p. $999(y)$.

(s) 2 Den. C. C. 353. 
the street a bank-note marked with the owner's name, so that he could easily be discovered, with the innocent intention of finding out the owner and restoring him the note, but were afterwards to change his mind and to convert the note to his own use, this would not amount to larceny.

In Reg. v. West ( $t$ ) the accused was charged with stealing a purse and its contents under these circumstances: The prosecutor, after making a purchase at the prisoner's stall at market in a country town, accidentally left his purse upon it; the prisoner thereupon appropriated it to her own use, and, on the prosecutor demanding it from her, denied all knowledge of it. The jury found that the prisoner took up the purse knowing that it was not her own, and intending at that moment to appropriate it. They also found that the prisoner did not then know who was its rightful owner. The prisoner having been convicted, the Court held the conviction right, observing, that if there had been evidence that the purse and its contents were lost property according to the strict meaning of that term, and the jury had so found, they ought further to have been asked whether the prisoner had reasonable means of finding the orner, or reasonably believed that the owner could not be found. . . . There is a clear distinction, they further remarked, between property lost and property merely mislaid, or put down and left by mistake under circumstances which would enable the owner to know the place where he had left it, and to which he would naturally return for it.

As showing what would amount to larceny under circumstances somewhat analogous to those latterly considered may be specified the following cases:-where a hackney coachman abstracts the contents of a parcel which has been accidentally left in his coach by a passenger whose address he could easily ascertain; or where a tailor finds and applies to his own use a pocket-book left in a coat sent to him to

( $t)$ Dearsl. 402. 
repair by a customer; or where the purchaser of an article of furniture, as a desk, at a sale by auction, discovers valuables in it, and appropriates them to his own use, provided in this case that the purchaser either had express notice that he was not to have any title to the contents of the desk if there happened to be anything in it, or provided, without such express notice, that he had no ground to believe that he had bought the contents, and had reason to think, as he most likely would have, that the owner could be discovered $(u)$.

But although it be true, that, where the taking of a chattel is in its inception lawful, a subsequent conversion of the thing taken, however tortious or wrongful it be in a moral point of view, does not constitute the offence of larceny $(x)$, yet, if the taking be in itself wrongful and unlawful, albeit without any felonious intent, a subsequent conversion of it with such intent may suffice to constitute the offence in question. Thus, in Reg. v. Riley (y), the prisoner was indicted for stealing a lamb under the following circumstances : it appeared that, having in the first instance put twenty-nine black-faced lambs, belonging to himself, into a field which contained ten white-faced lambs of the prosecutor, he afterwards took away his own lambs and offered them for sale as amounting in number to twentynine; the proposed purchaser, however, on counting the lambs, pointed out to the prisoner that there were in fact thirty in the flock, which included one white-faced lamb belonging to the prosecutor. The prisoner nevertheless sold them all to the other party on his own individual

(ii) Judgm., Irevry v. Green, 7 M. \& W'. 623, and cases there cited; Judgm., Reg. v. Thurbern, 1 Den. C. C. $394,395$. The civil rights of the finder of lost property, as against any one save the true owuer, will appear from Bridges ․ Havlicsucarth, 21 L. J. (2. B. 75 (with which cf. South Staffordshive Hatertorks v. Sharman, 12 Times
L. R. 402 ); Mcrvy v. Grecn, supra ; Armory v. Delamiric, cited p. 912 ; Buckley v. Gross, 3 B. \& S. 566.

(x) Judgm., Reg. v. Thurborn, 1 Den. C. C. 397 ; Reg. v. Preston, 2 Id. 353. See Reg. v. IJaries, Dearsl. 640, following $R$. v. Mucklow, 1 Mood. C. C. 160.

(y) Dearsl. 149. See Reg. v. Ashvell, 16 Q. B. D. 190. 
account. Now, on the trial of this case, the jury found that at the time of leaving the field the prisoner did not know that the prosecutor's lamb was in the flock, but that he had a felonious intention when he sold it. The question accord. ingly was, Could the prisoner, upon the above facts and finding, be convicted of larceny? and the Court of Criminal Appeal held that he might be so, because the original taling was wrongful, for, assuming that the prisoner was ignorant of the fact of the lamb being in his flock when he drove it from the field, the so driving it away and keeping it was a tortious act for which trespass would have lain, and this act of continuing trespass became felonious when the prisoner, knowing that the lamb in question was not lis own, sold it. Cases thus distinctly illustrating the practical operation of the doctrine of relation in felony do not very frequently present themselves in our Reports.

It has now been shown, that, to sustain an indictment for larceny, proof must be given that the specific chattel alleged to have been stolen was taken out of the possession, actual or constructive, of its owner-inrito domino and animo furandi-and that the intention in taling it was wholly to deprive the owner of his property therein. Another ingredient, not as yet specifically noticed in the crime of larceny, is the 'carrying away' or 'asportation' The aspor. tationof the said chattel; for, to constitute this offence, there must not only be a taking, but a carrying away. A bare removal, however, from the place in which he found the goods, though the thief does not quite make off with them, is a sufficient asportation, as if a man be leading another's horse out of a close and be apprehended in the fact $(z)$; or if a servant, animo furandi, take his master's hay from his stable and put it into his master's waggon $(a)$; or if a thief, intending to steal plate, takes it out of a chest in

(z) 4 Bla. Com., p. 231; 3 Inst. 108,109 . (a) Reg. r. Gruncell, 9 Car. \& I'. 365. 
which it was, and lays it down upon the floor, but is surprised before he can make his escape with it $(b)$; or if gas be fraudulently severed and abstracted from the main against the will and without the knowledge of the company who supply it $(c)$, or water from their pipes $(d)$. In any of these cases there is a sufficient 'asportation' ( $e$ ) within the meaning of that term as used in the definition of simple larceny.

Larceny effected by ueans of innocent sgent.

Receiving stolen goods.

In connection with the taking and asportation as constituent ingredients in larceny, it may be well to add, that, if a man, by means of an innocent agent, does an act which amounts in law to this crime, the employer, and not the innocent agent, is the person accountable for that act $(f)$.

Closely allied to larceny, and sometimes scarcely distinguishable from it, is the offence of receiving goods, monies, sc., knowing them to have been stolen. It has been held, on the one hand, that a person who, whilst waiting outside a house, receives goods which a confederate is stealing in the house, is a principal $(q)$; and, on the other hand, that if the goods be removed some little distance from the house before they are delivered into the prisoner's hands, he will be indictable as a receiver only $(h)$.

To constitute the offence of receiving stolen goods, it must be shown in evidence that the goods were stolen (i), and that they were received by the prisoner with knowledge that they had been stolen. Recent possession of stolen

(b) R. จ. Simson, Kel. $31 ; R . \mathbf{v}$. Halsh, 1 Mood. C. C. $14 ; \operatorname{Reg}$. v. Samucays, Dearsl. 371.

(c) Tieg. r. White, Dearsl. 203; Reg. r. Firth, I. R. 1 C. C. 172.

(d) Ferens v. O'Bricn, 11 Q. B. D. 21 .

(e) As to which see further 2 East, P. C. 556 : R. v. Pearson, 4 Car. \& P. $572 ; R$..$M a l s h$, cited Id. 576 , n. $(d)$.

(f) Per Erle, J., Reg. v. Bleastale, 2 Car. \& K. 768.

(g) R. v. Ouen, 1 Mood. C. C. 96.
"If one burglar stands outside a window while another plunders the house and hauds out the goods to him, he surely could not be indicted as a receiver:" per Alderson, B., Reg. v. Perkins, 2 Den. C. C. 461 . See Reg. v. IIilton, Bell, C. C. 20.

(h) R. v. King, Russ. \& Ry. 332.

(i) Cf. Reg. v. Yillensky, (1892) 2 Q. B. 597. The rightful owner had resumed possession of the stolen goods before the prisoners received them. It was held they could not be convicted. 
property is evidence either that the person in possession of it stole the property, or that he received it knowing it to have been stolen ( $k$ ), though, in order to sustain an indictment for receiving stolen goods, it is not necessary to show manual possession of them by the prisoner, provided they be within his control, or constructively in his possession $(l)$.

Another indictable offence, which, although of frequent occurrence, will here be but barely noticed, is that of obtaining goods, money, \&c., by false pretences.

Between the crime just specified and that of larceny, the most intelligible distinction, perhaps, is this:--In larceny, the owner of the thing stolen has no intention to part with his property therein to the person taking it; in the former case the owner has such an intention, but the money or chattel is obtained from him by fraud $(m)$. "If," said Parke, B. (n), "a person, through the fraudulent representations of another, delivers to him a chattel, intending to pass the property in it, the latter cannot be indicted for larceny, but only for obtaining the chattel under false pretences."

The distinction referred to may be thus exemplified :-If a servant, having a general authority co-equal with his master's, intentionally parts with his master's property under a misconception fraudulently induced as to the real facts, such property cannot be said to have been stolen, inasmuch as the servant intended to part with it. But if the servant, having only a limited authority and being precluded from parting with the goods, is nevertheless tricked out of them, he will be deemed to have parted with

(k) Reg. v. Langmead, L. \& C. 427 . As to the admissibility of evidence that the prisoner has been found in possession of other stolen property, see $34 \&$ 35 Vict. c. 112 , s. 19 ; Reg. v. Drage, 14 Cox, C. C. 85; Reg. v. Carter, 12 Q. B. D. 522 . (l) Reg. v. Smith, Dearsl. 494.

(im) Per Talfourd, J., White v. Garden, 10 C. B. 927 ; lieg. r. Barnes, 2 Den. C. C. 59.

(ii) Poicell v. Hoyland, 6 Exch. 70: R. r. Adtms, Russ. \& Ry. 225. otaining goods, inoney, kc., by false pretences. 
the possession of the goods merely, and the offence thus committed will be larceny $(o)$.

Where, then, a man represents as an existing fact that which is not an existing fact, and so gets the money or chattels of another, that is a false pretence $(p)$, it being for the jury to say whether or not the defendant, at the time he did the act, had guilty knowledge of the quality of such act, and whether or not the pretence used rere the means of obtaining the property. And, again, "the pretence," it has been said $(q)$, " in order to justify a conviction, must be of existing facts. It may be made either by words or by acts $(r)$. It is sufficient if it can be reasonably and naturally inferred from the words or from the acts, in order to raise a question for the decision of the jury. It is not necessary that the rords or that the acts should be capable only of the meaning charged by the indictment."

By way of putting this subject clearly before the reader the following passage is inserted:-To support a charge of this kind, i.e., of obtaining money, \&c., by false pretences $(s)$, it is necessary to show that the accused person, with a wicked or criminal mind $(t)$, stated something which, if true, would be an existing fact; that he did so with intent to procure the possession of money, \&c. ; that he knew his statement was-that is to say, that so far as his mind was concerned he intended that his statement should be-false; that by the statement he did so act on the mind of the

(u) Reg. v. Prince, L. R. 1 C. C. 150, 155 ; distinguished in Reg. . Middletoni, L. R. 2 C. C. 38.

(p) Reg. v. Woolley, 1 Den. C. C. 559 ; Reg. v. Welman, Dearsl. 188; lieg. r. Archer, Id. 449; Reg. v. Thompson, L. \& C. 233 ; Reg. v. Lee, Id. 309 ; keg. v. Kerrigan, Id. 383.

(q) l'er Linsh, J., Reg. v. Cooper, 2 Q. B. D. 514; Reg. v. Foster, 2 Q. B. D. 301 .

(r) R. v. Barward, 7 Car. \& P. ist; Rex r. Story, Russ. \& Ry. S1;
Reg. r. Speed, 15 Cox, C. C. 24. The false pretence must not be too remote: Reg. v. Larmer, 14 Cox, C. C. 497. See Reg. r. Gardner, 7 Cox, C. C. 136; Reg. r. Irartin, L. R. 1 C. C. R. 56.

(s) The indictment must state to whom the false pretence was made, and from whom the money was obtained: Reg. v. Soucerby, (1894) 2 Q. B. 173, distinguished Reg. $r$. Silterlock, Ib. 766 .

( $t$ ) See Reg. r. Franeis, L. R. 2 C. C. 128 . 
prosecutor as that he did thereby obtain money, \&c.; that the statement was in fact untrue, in the sense of being incorrect. And both the last allegations are necessary facts of the charge set forth in the indictment; for although the accused had a criminal intent, and believed that his statement was false, yet if in fact the prosecutor was not therely persuaded, or if by chance the statement was not incorrect, the charge is not supported, the crime is not committed (u). Thus, where the false pretence charged was the giving of a certain name and address, but there was no evidence that the goods had not been delivered before the name and address were asked for, it was held that the indictment could not be sustained, as it was essential to prove that the goods were delivered on the faith of the false pretence charged $(x)$.

The offence of embezzlement by a clerk or servant is also closely allied to that of larceny by a servant $(y)$. The usual Einbezzle. ment. mode of exemplifying the distinction between the two offences being this :-if the servant received the property in question and converted it to his own use before it came to the possession of the master, the offence is embezzlement; whereas if the property had come to the possession of the master, and the servant afteruards converted it to his own use, it is larceny. Thus, if a butler, having the care and custody of his master's plate, should receive plate from the silversmith for his master at his master's house, and afterwards fraudulently convert it to his own use before it had in any way, other than by his act of receiving it, come into the possession of the master, the butler would be guilty of larceny $(z)$. But if a servant, whose duty it is to

(u) PerBrett, J. A., Reg.v. Aspinall, 2 Q. B. D. 57 ; Reg. T. Hazelton, L. R. 2 C. C. 134 ; Reg. v. Pourell, 54 L. J. Q. B. 26 ; Reg. v. Burton, 16 Cox, C. C. 62.

(x) Reg. v. Jones, $15 \mathrm{Cox}, \mathrm{C}$. C. 475. (y) See, for instance, Reg. v. Read, 3 Q. B. D. 131.

In Reg. v. Wright, Dearsl. \& B.
442, Watson, B., obserred, "In point of moral turpitude, embezzlement and larcenr br a servant are the same, and I think it would be well if the legal distinction were abolished.

(z) See Reg. r. IIatts, 2 Den. C. C. 14 ; Reg. r. Cooke, L. R. 1 C. C. 29.5 , 300 .

B.C.L. 
receive property and pass it on to another servant, converts that property to his own use, he is guilty of embezzlement, because the property when so converted is in transitu merely towards the master, and not in his actual or constructive possession (a).

Larceny from the person.

Robbery.

"Lareeny from the person," says Blackstone (b), " is either by privately stealing, or by open and violent assault, which is usually called robbery" $(c)$, the difference between the two offences here specified being thus set forth:'robbery,' even in its least aggravated form, is "an open and violent larceny from the person," or the felonious and forcible taking from the person or in the presence of another, of goods or money against his will by violence or by putting him in fear $(d)$, whereas a conviction for stealing from the person will be sustained by evidence of a clandestine taking and removal of property from the person by ever so small a space $(e)$.

In order to sustain an indictment for robbery, the prosecutor must prove either that he was actually in bodily fear $(f)$ from the defendant's actions at the time of the robbery, or he must prove circumstances accompanying the act, such as in common experience are likely to induce a man to part with his property for the safety of his person; for although the putting in bodily fear is said to be a necessary ingredient in the constitution of this offence, yet the law in odium spoliatoris will presume fear where there appears to be a just ground for it $(g)$.

(il) Judgm., Reg. r. Watts, 2 Den. C. C. 30 ; Reg. r. Masters, 1 Den. C. C. 332 ; Reg. v. Gill, DearsI. 289 ; kig. v. Wright, Dearsl. \& I. 431, 441.

(b) 4 Com., p. 242.

(e) Robbery includes simple larceny: Reg. Y. MLGrath, L. R. 1 C. C. 205.

(il) 4 Bla. Com., 242; Judgm., Jie Rothschilel $\mathrm{v}$. Royal Mail Steam I'acliet ('o., 7 Exch. 742; Fost. Cr. I., pp. 128, 129; R. v. Jason, Russ. \& Ry. 419; Reg. r. Walls, 2
Car. \& K. 214; R. v. Gnosil, 1 Car. \& P. $304 ; R$. v. Moore, 1 Leach, C. C. 335 ; Reg. v. Lovell, 8 Q. B. D. 185.

Iu some statutes the word 'robbery' is used in a sense more comprehensive than that above assigned to it, so as to include a taking without force: Judgnı., 7 Exch. 742.

(c) Reg. v. Simpson, Dearsl. 421; R. v. Lapier, 1 Leach, C. C. $320 ; \boldsymbol{l}$. v. Farvell, Id่, 322.

(f) See Reg. v. IInlton, L. \& C. 285. (J) Fost. Cr. L. 128, 129. 
A glance at the "Criminal Law Consolidation and Amendment Acts," especially at those enactments which concern offences against the person-larceny, and malicious injuries to property-will show how fine and almost numberless are the distinctions betwixt offences pervading this department of our law $(h)$. Any further attempt, therefore, at dealing with it in these pages must, at this particular juncture, be declined (i).

(h) See particularly the sections of stat. 21 \& 25 Yict. c. 96 , which have reference to breaking and entering a building, dwelling-house, \&c. (subs. 50 et seq.).

(i) Knowledge arailable for practical purposes respecting the ingredients in specific offences can for the present readily be got from Mr. Archbold's work ou Criminal Pleading.

Throughout the preceding chapter the common law ingredients in some ordinary indictable otfences have been, almost exclusirely, set forth. 


\section{CHAPTER IV.}

CRIMINAL PROCEDURE.

Br statute (42\& 43 Vict. c. 22$)$, which came into operation on the 1st of January, 1880, a Director of Public Prosecutions was appointed $(a)$, whose duty it was under the superintendence of the Attorney-General "to institute, undertake, or carry on such criminal proceedings (whether in the Court for Crown Cases Reserved, before sessions of oyer and terminer or of the peace, before magistrates or otherwise), and to give such advice and assistance to chief officers of police, clerks to justices and other persons, whether officers or not, concerned in any criminal proceeding, respecting the conduct of that proceeding, as may be for the time being prescribed" by regulations under the Act, "or may be directed in any special case by the Attorney-General"' (b).

Such regulations, as may be made from time to time, are " to provide for the Director of Public Prosecutions taking action in cases which appear to be of importance or difficulty, or in which special circumstances, or the refusal or failure of a person to proceed with a prosecution, appear to render the action of such Director necessary to secure the due prosecution of an offender " (c).

When the Director of Public Prosecutions gives notice to any justice or coroner that he has instituted or undertaken or is carrying on any criminal proceeding, such justice or coroner is required to transmit to the said Director every
(n) S. . .
(b) S. 2 .
(r) Id. 
recognizance, information, certificate, inquisition, deposition, document and thing which is connected with the proceeding in question, and which the justice or coroner is required by law to deliver to the proper officer of the Court in which the trial is to be had, and thereupon such documents and so forth are to be delivered to such officer by the Director $(d)$.

Provisions are moreover contained in this Act enjoining the delivery of recognizances, inquisitions, and so forth, to the said Director, and requiring clerks to justices or police magistrates to transmit a copy of the information, depositions, and other documents relating to any case in which a prosecution is withdrawn or is not proceeded with within a reasonable time $(e)$.

Where any criminal proceeding has been instituted or undertaken by the Director of Public Prosecutions any person having the right to institute and carry on such proceeding may, if he have good cause for so doing, show by affidavit to a Judge that such Director has abandoned such proceeding or has neglected duly to carry on the same, and proper directions will thereupon be given by the Judge $(f)$.

Nothing in this Act contained will interfere with the right of any person to institute, undertake, or carry on any criminal proceeding,

Also where any such proceeding is instituted, undertaken, or carried on by the Director, he will not be bound over to prosecute or conduct such proceeding, nor required to give security for costs. Neither shall it be necessary to bind over any person to prosecute or conduct such proceeding, though if bound over and security has been given for costs it is enacted that he shall, upon the Director undertaking the case, be released from such obligation-that the security given shall be deemed to have been cancelled, and that the Director shall be liable for costs in lieu of such person $(g)$.

(d) S. 5 .

(e) Id. (f) S. 6 .

(g) S. 7. 
Lastly, the prosecution of an offender by the Director of Public Prosecutions will, "for the purpose of enabling a person to obtain restitution of property $(h)$, or obtaining, exercising, or enforcing any right, claim, or adrantage, whatsoever, have the same effect as if such person had been bound over to prosecute and had prosecuted the offender, subject to this proviso, that such person shall give all reasonable information and assistance to the said Director in relation to the prosecution" (i).

More recently by virtue of $47 \& 48$ Vict. c. 58 , amending $42 \& 43$ Vict. c. 22 , all appointments made in pursuance of the earlier Act have been revoked, and the Solicitor to the Treasury for the time being has been appointed Director of Public Prosecutions. It is further declared that any assistant Solicitor for the affairs of Her Majesty may act on behalf of the Solicitor to the Treasury in his capacity of Director of Public Prosecutions $(k)$, and the chief officer of every police district is bound to give information from time to time to the Director with respect to indictable offences alleged to have been committed in his district, and to the dealing with the same $(l)$.

Keeping in view that eases involving peculiar diffeulty and responsibility will henceforth be placed in charge and under control of a public prosecutor, we may remind the reader that besides trials taking place at the assizes, at the Central Criminal Court $(m)$, or before Judges acting in virtue of a special commission from the Crown, there are casesnot a few-in which express power is given to inferior tribunals or to particular functionaries, as recorders and others, to deal with certain kinds of offences according to

(h) See I'ilmont . Bentley, 12 App. Cas. 47 , overruling Moyce v. Newing. ton, 4 Q. B. D. 32 . Vilmont $\mathrm{s}$. Bentley is now overridden. See ante, p. 430 .

(i) 5.7 (k) S. 2.

(l) S. 3.

(ii) As to the jurisdiction of this Court, see Reg. v. Keyn, 2 Ex. I). 63; Harris v. Ouners of Franconia, ? C. P. D. 173 . 
their discretion, guided and limited more or less stringently by the statute law. From amongst functionaries clothed with such discretionary powers, justices of the peace, in connection with the subject of this chapter, claim especial notice.

The power of a justice of the peace as a criminal Judge is derived in part from his commission proceeding from the astices of the peacegeneral view of their Crown, and in part from particular Acts of Parliament. jurisliction. Under the commission of the peace $(n)$ the justice derives a twofold power-first, when out of sessions, and secondly, when sitting in sessions, either general or petty. When out of sessions the commission emporwers him singly to conserve the peace, to suppress riots and affrays, to take security for keeping the peace, and to apprehend and commit felons and other criminals. The commission of the peace also empowers any two or more justices to hear and determine all felonies and other offences, which, as Blackstone remarks $(o)$, is the ground of their jurisdiction at sessions-a jurisdiction which was, however, materially restricted by 5 \& 6 Vict. c. 38, section 1-intituled “An Act to define the Jurisdiction of Justices in General and Quarter Sessions of the Peace," and has been further restricted or put aside by other statutes. The statute of 5 \& 6 Vict. inter alia enacts that justices shall not at any session of the peace, or at any adjournment thereof, try any person for any treason, murder, or capital felony, or for any felony which, when committed by a person not previously convicted of felony, was then punishable by transportation beyond the seas [now penal servitude $(p)$ ] for life, or for any of the following (amongst other) offences:-Misprision of treason; Offences against the Queen's title, prerogative, person, or government, or against either House of Parlia-

(n) Of which the form may be seen in Burn's J. P., 30th ed., rol. iii., p. 111, and in Dickinson's Qunarter Sescions, 5th ed., p. 65.
As to the powers of stipendiery magistrates, see 21 it 22 Vict. c. 73.

(o) 1 Com., p. 354 .

(p) $20 \leqslant 21$ Vict. c. 3, s=. 2, 6 
ment; Offences subject to the penalties of pramunive $(q)$; Blasphemy and offences against religion ; Administering or taking unlawful oaths; Perjury and subornation of perjury : Suborning any person to make a false oath, affirmation, or declaration punishable as perjury or as a misdemeanor; Forgery; Unlawfully and maliciously setting fire. to crops of corn, or to any part of a wood, coppice, \&c., \&c.; Bigamy and offences against the laws relating to marriage ; Abduction of women and girls ; Endeavouring to conceal the birth of a child; Composing, printing, or publishing blasphemous, seditious, or defamatory libels; Bribery $(r)$; Unlawful combinations and conspiracies $(s)$, except conspiracies or combinations to commit any offence which such justices or recorder respectively have or has jurisdiction to try when committed by one person $(t)$; Stealing or fraudulently taking or injuring or destroying records or documents belonging to any Court of law or equity, or relating to any proceeding therein; Stealing or fraudulently destroying or concealing wills or testamentary papers, or any document or written instrument being or containing evidence of the title to any real estate, or any interest in lands, tenements, or hereditaments.

The foregoing catalogue of offences, which by reference to various statutes might readily be extended, suffices to show that the jurisdiction of quarter sessions has, since Blackstone wrote his Commentaries, been materially curtailed.

It seems clear that county justices have by their commission power as regards any indictable offence to receive the information of any individual respecting it, to grant a summons or warrant thereon to bring the accused party before them, to examine the witnesses on oath, to hear what the accused has to say in his defence, to take down

(7) In regard to the offence of pronumire, see 4 Bla. Corn., Chap. 8.

(r) Offences against $52 \& 53$ Vict. (. 69 (1'ub)lic Bodies Corrupt Practices
Act, 1889), are triable at quarter sessions. See 8. 6.

(s) See 38 \& 39 Vict. c. 86.

(b) See Reg. r. Stripp, Dearsl. 648. 
the examination in writing, and then either to discharge the accused, to admit him to bail, or to commit him for trial :-The mode of enforcing the attendance of the party accused or suspected of crime before the justice, or of apprehending one against whom an indictment has actually Leen found, of compelling the attendance of witnesses, of conducting their examination, of taking down the depositions, of receiving the statement, if any, of the accused (u), of transmitting the depositions and statement to the Court in which the trial is to be had, being minutely regulated by the 11 \& 12 Vict. c. 42 , intituled "An Act to facilitate the Performance of the Duties of Justices of the Peace out of Sessions within England and Wales with respect to Persons charged with Indictable Offences," the provisions of which statute $(x)$, as amended in some important particulars by the $30 \& 31$ Vict. c. 35 , should of course be carefully studied in reference to the due discharge of magisterial duties by those who are invested with them.

As regards cases falling within their summary jurisdiction, justices of the peace should consult the statute entitled "An Act to amend the law relating to the summary jurisdiction of magistrates " $(y)$, which is likely to prove most beneficial, and may even be said to initiate a new era as regards the mode of dealing with minor criminals. This Act, containing no less than fifty-five sections and very many subsections, empowers any Court of summary jurisdiction to mitigate the punishment imposed $(z)$ under the provisions of the statute law in respect of an offence summarily punishable, and to adjust the penalty of im.

(u) See Reg. v. Stripp, Dearsl. 648.

$(x)$ The provisions of this statute are extended to proceedings under the 38 $\& 39$ Vict. c. 86 , which gives a useful jurisdiction to justices concerning contracts between master and serrant. See s. 21. (y) $42 \& 43$ Vict. c. 49 . Amended $44 \& 55$ Vict. c. 24 . See 47 \& 48 Vict. c. 43 . See also 58 \& 59 Vict. c. 39.

(z) As by omitting to sentence to hard labour, or reducing the term of imprisonment, or the fine imposed, Sce., s. 4.
Sumuary jurisdiction. 
prisonment in default of payment of fine inflicted, according to a graduated scale $(a)$. It further enacts that the sum recoverable by summary order in respect of an offence shall be deemed a civil debt (b), and may be made payable by instalments-also that satisfactory security may be taken for it $(c)$.

The Act further provides that where a sum is directed to be paid by instalments, and default is made in the payment of any one of such instalments, the same proceedings may be taken as if default had been made in payment of all the instalments then remaining unpaid $(d)$.

In other sections, more important than those which have been noticed, this Act provides generally for the summary trial when deemed expedient of children $(e)$ for indictable offences other than homicide, unless objected to by the child's parent or guardian $(f)$, and prescribes the punishment which may on conviction be awarded $(g)$.

For the purpose of a proceeding under this provision, it has been enacted that the Court at any time during the hearing of a case such as referred to, at which they become satisfied by the evidence that it is expedient to deal with it summarily, shall cause the charge to be reduced into writing and read to the parent or guardian of the child, and then shall address a question to such parent or guardian to the following effect:- "Do you desire the child to be tried by a jury and object to the case being dealt with summarily?" the meaning of the case being "dealt with summarily," and information as to the Court-whether"

(a) S. 5 .

(b) S. 6 .

(c) S. 7 .

By s. 35 , the mode of recovering civil debts in a Court of summary juris. diction is provided for.

(il) S. 7 .

(e) By s. 49 the expression "child" means a person who, in the opinion of the court betore whom lie is brought, is under the age of twelve years.

( $f$ ) The expression "guardian" here used includes any person who, in the opinion of the Court, has for the time being the charge of, or control over, the child: s. 49 .

In the absence of the parent or guardian the child may be remanded: s. 10 (3).

(I) S. 10 (1). 
assizes or sessions-at which the child will be tried if tried by a jury being, when thought desirable, explained $(h)$.

The section of the Act under notice (i) does not render punishable for an offence any child who is not, in the opinion of the Court before whom he is charged, above the age of seven years, and of sufficient capacity to commit crime.

Where a young person $(k)$ is charged with any indictable offence specified in the first column of the first schedule $(l)$ to the Act, a portion of which is here abstracted, the Court, if it think expedient and with the consent of the accused, may deal summarily with him, and may, should he be found guilty, inflict such punishment as prescribed $(m)$.

The Court, moreover, if satisfied by the evidence that it is expedient to deal with the case summarily, may at any time during the hearing-having caused the charge to be reduced into writing, and having addressed the young person charged as to his wish to be tried by a jury, or summarily, in the event of his expressing a wish to be tried summarily-proceed so to try him $(n)$.

An adult (o), also charged before a Court of summary jurisdiction with any indictable offence specified in the second column of the first schedule to the Act may, mutatis mutandis, be similarly dealt with $(p)$, or if he plead guilty when charged with an indictable offence specified in the first column of the first schedule to the Act, the Court shall proceed to judgment accordingly $(q)$.

(h) S. $10(2)$.

(i) S. $10(5)$.

(k) The expression "young person," used in the Act, means a person who, in the opinion of the Court, is of the age of twelve years and under the age of sixteen years.

(l) In Schedule I to the abore Act is giren a list of indictable offences which can be dealt with in a summary way under it; the first column in this schedule applies when young persuns consent to be tried and adults plead guilty. The second column applies where adults consent to be summarily tried.

(m) S. 11 (1).

(ri) S. 11 (2).

(o) That is, a person who, in the opinion of the Court, is of the age of sixteen years or upwards.

(p) S. 12.

(q) S. $13(1)$. 
The Court, however, before asking the adult whether he is guilty or not, shall explain to him that he is not obliged to plead or answer ; that if he pleads guilty he will be dealt with summarily, and that if he does not plead or answer or pleads not guilty, he will be dealt with in the usual course, with a statement, if thought desirable, of the meaning of the term 'summarily dealt with' and 'in the usual course,' and as to the Court at which the trial, if by a jury, will be $(r)$. The accused is further to be told that anything he may say will be taken down in writing, and may be given in evidence against him at his trial; and, lastly, that he has nothing to hope or fear from any promise of favour or any threat which may have been held out to him to make any admission or confession of his guilt $(s)$.

Another important section $(t)$ of this statute provides as follows:-That a person when charged before a Court of summary jurisdiction with an offence, in respect of the commission of which an offender is liable on summary conviction to be imprisoned for a term exceeding three months, and which is not an assault, may, on appearing before the Court, and before the charge is gone into but not afterwards, claim to be tried by a jury, and thereupon the Court of summary jurisdiction shall deal with the case in all respects as if the accused were charged with an indictable ofience and not with an offence punishable on summary conviction, and the offence shall as respects the person so charged be deemed to be an indictable offence, and, if the person so charged is committed for trial, or bailed to appear for trial, shall be prosecuted accordingly, and the expenses of the prosecution shall be payable as in cases of felony.

A Court of summary jurisdiction, before the charge is gone into in respect of an offence to which this same
(r) S. $13(2)$.
(s) Id.
(t) S. 17 (1). 
section $(u)$ applies, for the purpose of informing the defendant of his right to be tried by a jury in pursuance thereof, shall address him to the following effect:-_"You are charged with an offence in respect of the commission of which you are entitled, if you desire it, instead of being dealt with summarily, to be tried by a jury; do you desire to be tried by a jury?" with a statement, if the Court think such statement desirable for the information of the person to whom the question is addressed, of the meaning of being 'dealt with summarily,' and of the assizes or' sessions (as the case may be) at which such person will be tried if tried by a jury.

The section above recited does not apply to the case of a child unless the parent or guardian of the child is present; but the Court shall ascertain whether the parent or guardian of the child is present, and, if he is, shall address the above question to such parent or guardian by whom the claim under it may be made $(x)$.

Such as above set forth are the leading provisions of this enactment, though some others below indicated are well deserving of attention $(y)$.

From what has been above said we may infer that the jurisdiction exercised by justices of the peace is in some cases substituted for, whilst in others it is ancillary to, that of a superior tribunal. In point of fact, almost every criminal offender who appears for trial at the assizes has in the first instance been examined and committed by a magistrate in the ordinary way, having been brought before him either with or without a summons or warrant

(u) S. 17 (2).

(x) S. 17 (3).

(y) For instance, s. 9 et seq., which relate to the enforcing of recognizances, and s. 16, under which the Court is empowered to discharge an accused person without punishment where the offence was trifling.
Also ss. 19,31 et seq., relating to the right of appeal from a summary conviction to quarter sessions, and the procedure thereon.

Also s. 41 , which relates to the return of property, taken from the prisoner, by order of the Court. 
by a police constable acting on his own judgment or on the complaint of some private individual. Cases do, nevertheless, present themselves in which the preliminary process here spoken of is wanting-as where a prisoner has been committed by the coroner in pursuance of the verdict of his jury $(z)$-a committal, however, which does not in any way oust the jurisdiction of ordinary justices-or where a supposed criminal is arrested by virtue of a warrant issued by the Privy Council or a Secretary of State $(a)$; or where an information is filed by the AttorneyGeneral ex officio, or by the Master of the Crown-office, with leave from the Court of Queen's Bench, at the instance of an individual; or where a presentment is made by the grand jury of an offence within their own knowledge or observation $(b)$; or, lastly, where a private person prefers a bill to the grand jury, without preliminary notice, against an absent party - a mode of proceeding, however, on which restriction has, as regards various offences, been imposed $(c)$, and which may entail on the prosecutor the liability to costs should the accused person be acquitted $(d)$.

lrocedure by indictn:ent.

We read, however, in a work of authority (e), that prosecution by indictment $(f)$ is the most usual and constitutional course for bringing offenders to justice on criminal charges. The "indictment" is an accusation preferred in the name of the sovereign to a grand jury, competent by law to find it, and found by them on their oaths $(q)$; this accusation, when first preferred to the grand jury, being called a bill, and being properly termed

$\Leftrightarrow$ A coroner is now empowered to accept bail for a person against whom a verdict of manslaughter has been found by his jury : 22 Vict. c. 33, s. 1.

(a) Sce the cases in regard to such warrants collected: Toml. L. Dict., tit. "Commitment," I.

(b) 4 Bla. Com., p. 301.

(c) 22 \& 23 Vict. c. 17 , as limited by 30 \& 31 Vict. c. 35, s. 1 .

(i) 30 \& 31 Vict. c. 35, s. 2. (e) Dickinson's Quarter Sessions, 5th ed., p. 168.

$(f)$ A criminal information only differs in mere form from an indictment ; instead of the jurors presenting a bill the Queen's coroner prefers the information : per Lord Coleridge, C. J., Reg. v. Steel, 2 Q. B. D. 40.

(g) Dickinson's Quarter Sessions, 5th ed., p. 168.

By the stat. 19 \& 20 Vict. c. 5t, s. 1 , 
an indictment only when found by them. The office of the indictment is to inform the prisoner of the charge which he is called upon to answer. The indictment must therefore contain an allegation of every fact necessary to constitute the criminal charge preferred by it $(h)$. As in order to make an act criminal it must [almost] always be done with a criminal mind, the existence of that criminality of mind must be alleged (i). If, in order to support the charge, it is necessary to show that certain acts have been committed, it is necessary to allege that those acts were in fact committed. If it is necessary to show that those acts, when they were committed, were done with a particular intent, it is necessary to aver that intention. If it is necessary, in order to support the charge, that the existence of a certain fact should be negatived, that negative must be alleged $(k)$.

The form of the indictment has now been much simplified by legislation, and many grounds of objection to it which could once have been taken are no longer tenable $(l)$; an indictment, indeed, is now generally characterised by extreme brevity and simplicity. It consists of :-

1st. The venue, which indicates the Court before which the offender is to appear, and the jurisdiction within which the offence charged was committed or is triable $(m)$.

the foreman, or acting foreman, of the grand jury, is now "authorised and required " to administer the usual oath, \&c., to witnesses for examination in support of the bill of indictment.

(h) Per Brett, J. A., Reg. v. Aspinall, 2 Q. B. D. 56, and in Bradlangh v. Reg., 3 Q. B. D. 626.

(i) For instance, in the preliminary assertion that the accused did the thing or things complained of "fraudulently," " falsely," " unlawfully," or "feloniously," \&c.

(k) See, further, as to the indictment, Bradlaugh v. Reg., 3 Q. B. D. 607,615 , and cases there collected.

(l) Mere surplusage does not vitiate an indictment: Reg. v. Parker, L. R. 1 C. C. 225; Reg. v. Netcboult, Id. 344. As regards the time at which a bill may be preferred and an indictment found, it may be well to observe that, by virtue of the rule nullum tempus occurrit regi, this may be done, where a particular period of limitation is not prescribed by statute, at any length of time after the offence was comnitted.

(m) Under the stat. 19 of 20 Vict. c. 16, s. 3, the Court of Queen's Bench (now the Q. B. Division of the High Court of Justice) nay order that auy person charged with an offence committed out of the jurisdiction of the 
2ndly. The statement of the offence, which must, as we have above said, contain such ingredients as are essential either at common law or by statute to constitute it.

And 3rdly. The conclusion, with reference to which I may say that, although section 24 of the $14 \& 15$ Vict. c. 100 rendered the want of a proper or formal conclusion to an indictment immaterial, yet this must not be understood as having affected the practice as to concluding the indictment contra formam statuti, where the offence charged in it is founded upon the statute law (n).

Arraignment.

Let us now suppose that the bill has been duly presented to and found by the grand jury, and that the accused party is in custody, the next step in the proceedings is to arraign the prisoner-i.e., to call upon him when placed at the bar of the Court to answer the matter charged against him in the indictment $(o)$. On this Plea. arraignment the prisoner is required to plead "guilty" or " not guilty," unless indeed, as rarely happens in practice, he has some special matter of defence to urge in answer to the indictment. Of special pleas the most usual and important is, that he (the prisoner) has already been lawfully acquitted or convicted of the identical offence charged and specified in the indictment; and this plea would, of course, if substantiated, offer good ground of defence; for it is a principle designated by Lord Campbell, C. J. $(p)$, as a "sacred maxim" of our law, that-Nemo bis rexari debet pro eadem causî-no man ought to be twice tried, or brought into jeopardy of his life or liberty more

Central Criminal Court shall, nevertheless, be tried at that Court. See Reg. v. Palmer, 5 E. \& B. 1024; Reg. v. Wilks, Id. 690 . See $44 \& 45$ Vict. c. 64, 8. 2 .

(n) The reason why an indictment for a statutory offence should conclude contra formam statuti, is stated in
Hawk. P. C., Book II., Chap. 25, ss. $115,116$.

(o) 4 Bla. Com. p. 322. See Reg. r. Key, 2 Den. C. C. 347 ; Reg. :. Shuttleucosth, Id. 351 ; Reg. r. Clark; Dearsl. 198. 222. 
than once for the same offence. In Reg. v. Bird (q), the effect of the plea of autrefois acquit in connection with a particular statutory provision $(r)$ since repealed, and in Reg. v. Morris (s), the effect of a conviction for assault and imprisonment consequent thereon by way of answer to a subsequent indictment for manslaughter, were discussed $(t)$.

With the exception of the particular grounds of defence just adverted to, a special plea to an indictment is little known in practice $(u)$; and should the prisoner on his arraignment plead "not guilty" $(x)$, the next step in the proceedings will be to swear the jury, or to administer to any juror who objects from conscientious motives to be sworn, the affirmation or declaration prescribed by statute (y), which is done subject to a right of challenge to the array or to individual jurymen on the part of the prisoner or defendant and of the Crown $(z)$. When the jury have been sworn the prisoner is 'given in charge' to them, the meaning of which phrase is shown by the address of the Giving in charge. Clerk of Arraigns to the jury ; for, after stating the specific offence on which the prisoner stands indicted and his plea thereto, he tells them that their "charge is to inquire

(q) 2 Den. C. C. 94.

(r) 7 Will. 4 \& 1 Vict. c. 85 , s. 11 ; repealed by $24 \& 25$ Vict. c. 95 , s. 1 .

(s) L. R. 1 C. C. 90 . This case was followed: Reg. r. Friel, 17 C. C.C. 325.

(t) See also Reg. r. Knight, L. \& C. 378 ; Reg. v. Green, Dearsl. \& B. 113; Reg. v. Moah, Dearsl. 626, 630; Reg. v. Charlesworth, 1 B. \& S. 460 ; Wemyss, app., Hopkins, resp., L. R. 10 Q. B. 378; Reg. v. Gilmore, 15 Cox, C. C. 85 .

(ii) A special plea may be to the jurisdiction of the Court, or in abatement. See O'Brien r. Reg., 2 H. L. Ca. $469 ;$ O' Connell v. Reg., 11 Cl. \& F. $155,165,465,469$; R. v. Johnson, $29 \mathrm{How}$. St. Tr. 385 ; and autrefois attaint, or a pardon from the Crown, is also pleadable.

The prisoner may, moreover, demur to the indictment, on the ground that it is " not sufficient in law." See keg. v. Faderinan, 1 Den. C. C. 565,570 .

$(x)$ If the prisoner on being arraigned should "stand mute of malice or will not answer directly to the indictment," the Court may order a plea of "not guilty" to be entered on behalf of the prisoner by the proper officer, and the plea so entered will have the same force and effect as if the prisoner had actually pleaded the same: i \& 8 Geo. 4 , c. 28 , s. 2 .

(y) See 51 \& 52 Vict.c. 46 (repealing 30 \& 31 Vict. c. 35 , s. S).

(z) Mansell v. Reg., Dearsl. \& B. 375; S. C., 8 E. \& B. it ; Muleahy v. Reg., L. R. 3 H. L. 306 ; lieg. v Iellor, Dearsl. \& B. 468 ; $0^{\circ}$ Connell v. Reg., 11 Cl. \& F. 155: Grays. Reg., Id. $42 \tau ;$;'Brien v. Teg., 2 II L. Ca. 465, 470, are important with reference to the right and grounds of challenge.

B.C.L. 
whether he be guilty or not guilty, and to hearken to the evidence."

Case for the The above form having been duly observed, the counsel
crown. for the prosecution opens his case to the jury, produces evidence, and calls witnesses in support of it, whose examination is conducted in accordance with certain principles, which must needs be observed and scrupulously adhered to, experience teaching us that the truth will far more often and more surely be arrived at if sought by the aid of inflexible rules than if pursued by ingenious surmises, or traced by the light of proofs, which though in the particular case apparently sufficient, are nevertheless shown by abstract reasoning to be deceptive and fallacious. It has been affirmed, indeed, that no material difference exists, in regard to the rules of evidence, betreen criminal and civil procedure (a) - that what may be received in the one case may be receired in the other, and what is rejected in the one case ought to be rejected in the other $(b)$-that, in short, "a fact must be established by the same evidence, whether it is to be followed by a criminal or civil consequence" $(c)$.

Rules of pvidence to be observerl

In either mode of procedure, for instance, civil or criminal, the following rules obtain: that the proofs adduced must be relevant to the issue, that the best evidence which the nature of the case will admit of must be given, that secondary evidence will only be receivable where the best and most direct evidence cannot be had, that hearsay is not in general admissible as evidence, because the individual whose words are spoken to was not sworn nor can be submitted to cross-examination, that entries made by a person since deceased when against his own interest, or made in the usual course of business, may

(a) Judgm., Reg. Y. Francis, I, R. 2 ('. C. 133 .

(b) Per Abbott, J., li. v. Mintsun. 2 stirk. X. I'. C. 15.; per Best, J.,
R. v. Burdett, 4 B. \& Ald. 122; 22 R. R. 53?.

(c) l'er Lord Erstime, C., at Lord Melville's trial, 29 How. St. Tr. 764. 
be received-that the Court must construe written documents, and the jury must decide upon the facts.

It is, moreover, a well-known rule, the expediency of which however has often been questioned, that the person actually on trial for an alleged crime is inadmissible to give evidence respecting it $(d)$. As innovating to some extent upon this rule, the stat. $40 \& 41$ Vict. c. 14 must be noticed. It enacts (s. 1) that "on the trial of an indictment or other proceeding for the non-repair of any public highway or bridge, or for a nuisance to any public highway, river, or bridge, and of any other indictment or proceeding instituted for the purpose of trying or enforcing a civil right only, every defendant to such indictment or proceeding, and the wife or husband of any such defendant, shall be admissible witnesses and compellable to give evidence." And by virtue of 47 \& 48 Vict. c. 14, in any criminal proceedings anthorised by the Married Women's Property Act, 1882 (45 \& 46 Vict. c. 75), the husband and wife are respectively rendered competent and admissible, and, if not defendant, compellable witnesses. Further, under the Criminal Law Amendment Act, 1885 (48 \& 49 Vict. c. 69), the person charged and the husband or wife of the person charged are competent but not compellable witnesses (s. 20).

Other ordinary rules of evidence observed at a criminal trial are these-that our law presumes in favour of the innocence of an accused, that it regards the evidence of accomplices with suspicion $(e)$, that a confession, whether judicial or extra-judicial-i.e., whether made in Court and in the due course of legal proceeding, or made elserrhere and under other circumstances-is admissible provided it

(d) Where two prisoners are indicted and tried together, one is not a competent ritness for the other: Reg. $\mathrm{r}$. Payne, L. R. I C. C. 349 ; nor is the wife of one a competent witness for the other: Reg. v. Thompson, Id. 377 . (e) See per Lord Ellenharough, C. J.. summing up in Itesparl's case, 28 How. St. Tr., pp. 4si et seq., and in Watson's case, 3.2 Id. 583: per Abbatt, C. J., charging the grand jury in Thistlewrood's cuse, 33 Id. 659. 
was voluntary, and must, if admissible, be received in its entirety $(f)$, that a dying declaration may be received in evidence on a trial for homicide, where the death of the deceased is the subject of the charge and the circumstances of the death is the subject of the dying declaration $(g)$. Further, by $30 \& 31$ Vict. c. 35 , s. 6 , persons not expected to live, who are able and willing to give material information relating to any indictable offence, or person accused of such offence, are enabled to make a statement in mriting on oath to a justice of the peace, which in case of the deponent's death or inability to travel may be read at the trial in evidence, provided that reasonable notice of the intention to take such statement has been served upon $(h)$ the person against whom it is proposed to be read in evidence.

It should also be borne in mind that if any evidence not legally admissible against the prisoner is left to the jury, and they find him guilty, the conviction will be bad, even

$(f)$ "By the law of Eugland," says Prike, B., in Reg. v. Baldry, 2 Den. C. C. 444,445 , "in order to render a confession admissiblein evidence. it must be perfectly voluntary; and there is no doubt that any inducement in the nature of a promise or of a threat held out by a person in authority vitiates a confession;" the ground for rejecting the evidence when so obtained being, that "it would not be safe to receive a statement made under any influence or fear." Per Pollock, C. B., Id. 442; Re\%. r. Javis, L. R. 1 C. C. 96 ; followed in Reg. v. Reere, L. R. I C. C. 362 ; Reg. v. Fermell, 14 Cox, C. C. 607 : Reg. r. Hatts, 49 L. T. 780 ; Reg. v. Thompson, (1893) 2 Q. B. 12.

$A$ s to the question who is "a person in authority " within the meaning of the rule above laid down, see Reg. $r$. Hoore, 2 Den. C. C. 522; Req. v. steman, Dearsl. 249; Reg. v. Lueh. lurst, Id. 245; Reg. v. Langher, 2 Car. \& K. 225 ; Reg. v. Jones, 49 J. P. 728 .

(g) Per Abbott, C. J., R. ․ Mead, 2 B. ct C. 608 ; R. v. Hind, Bell, C. C. 253. See Reg. v. Jenkins, I. R.
1 C. C. 187 .

Dying declarations, says Eyie, C. B., in R. v. "Woodcock, 1 Leach, C. C. 502, are made in extremity when the party making them is at the point of death, and when every hope of this world is gone, when every motive to falsehoor is silenced, and the mind is induced by the most powerful considerations to speak the truth : a situation so solemn and so awful is considered by the law as creating an obligation equal to that which is imposed by a positive oath administered in a court of justice. See Reg. r. Jenkins, L. R. I C. C. 187, 192; per Iord In'mman, C. J., Sussex Pecrage case, 11 Cl. \& F. 112; per Cur. $R$. v. Drummoml, 1 Ieach, C. C. 337: Tinliler's crese, 1 East, P. C., 354; Reg. r. Reaney, Dearsl. \& 13. 151 : Req. r. Hubbard, $14 \mathrm{Cox}$, C. C. 565 ; Reg. צ. Osman, 15 Cox, C. C. 1; Rey. r. Goddard, Ih., $\mathrm{i}$; Reg. r. Gloster, 16 C. C. C. 4il: also Req. v. Nitchell, 17 C. C. C. 303.

(h) The notice thus required must be in writing: Reg. v. Shlurmer, 17 Q. B. I. 323. 
though there was other evidence before them properly admitted, and sufficient to warrant a conviction (i).

Specifying the above-mentioned rules of evidence, as peculiarly applicable in criminal inquiries, I may observe in the words of Eyre, C. B. (k), that, although " the most common and ordinary species of legal evidence consists in the depositions of witnesses taken on oath ( $l$ ), before the jury, in the face of the Court, in the presence of the prisoner, and received under all the advantages which examination and cross-examination can give"-besides this kind of proof and certain species of hearsay evidence which are for various reasons admitted by law; - the examination of a prisoner and the depositions of the witnesses who may be produced against or for him, taken officially, may, under certain circumstances, be substituted for virâ roce testimony ( $m$ ).

The right is now given by statute to counsel for the Crown on a criminal trial, if no evidence is to be adduced for the defence, to address the jury a second time in support of his case for the purpose of summing up the proofs against the prisoner $(n)$.

Upon the case for the prosecution being closed, and by Cian for thas inefrues. way of answer to the evidence given in support of it, counsel for each prisoner may open his case and examine witnesses and sum up the evidence $(o)$; and the counsel for the prosecution may, where evidence is adduced, reply. Where indeed the only evidence called on the part of the prisoner is evidence to character $(p)$, although the counsel for the

(i) Reg. v. Gibson, 18 Q. B. D. 537.

(k) R. v. Iroodeock, supra.

(I) See 51 \& 52 Vict, c. 46 , which gires relief to persons unwilling from conseientious motives to be sworn.

(m) As to the prisoner's statement before the committing magistrate, see stat. 42 \& 43 Vict. c. 49 , s. 13 (2), already cited. Ante, p. 1081.

As to the depositions of witnesses, see stats. $11 \& 12$ Vict. c. $42, s, 1 \%$;
30 \& 31 Vict. c. 35, s. 6; Rey. v. Wellings, 3 (2. B. D. 426; Keg. 、. Furrell, L. R. 2 C. C. 116; Rey. v. Coclibum, Dearsl. it B. 203; licy. v. Riley, 3 Car. \& k. 116 ; Reg. v. II'uth, L. E C. 339 .

(n) 25 a 29 Vict. c. 1s, s. ‥ Sue Reg. r. Kain, 15 Cox, C. C. 3st.

(o) 28 s 29 Vict. c. 1s. s. 2.

(p) As to which. see lery. V. limenton, I. $\mathbb{d}(\therefore .520$. 
prosecution is entitled to reply, it is a matter for his discretion, whether he will use this right or not, though cases may occur in which it will be fit and proper so to do $(q)$. The Attorney-General, or Solicitor-General, appearing for the Crown in his official capacity, has the right of reply, whether the prisoner gives evidence or not, but it has been doubted whether this right extends to counsel instructed to appear as the representative of the Attorney-General by any department of government $(r)$.

The practice as to the reception of prisoners' statements made personally or through the month of their counsel was for a long time very uncertain. The rule, however, has now been laid down by Cave, J., with the concurrence of the other Judges of the High Court, as follows :-A prisoner, even though defended by counsel, may if he chooses make his statement to the jury, the right time for so doing being at the conclusion of his counsel's speech; he ought to be heard in his defence, and have the opportunity of making his explanation of the circumstances proved against him. True it is that his statement is not made on oath, nor is he liable to cross-examination, and therefore what he says is not entitled to the same weight as sworn testimony; still it is entitled to such weight as the jury may think it deserves, and if the prisoner chooses to make such a statement he can do so, bearing in mind that his so doing will entitle the prosecuting counsel to reply, such statement being in the nature of new matter laid before the jury (s). This rule, however, only applies where no witnesses are called for the defence; when it is proposed to call witnesses on behalf of the prisoner, it will not be competent for him to make any statement to the jury in addition to his counsel's address $(t)$.

(g) 7 Car. \& l'. 677.

(4) Sitephen, Jaw of Criminal l'roreslure, 1. Is?.

(A) Rirg. v. Shimmin, li) Cox, C'. C.
$1: 2$.

(t) Re'j. r. .rillhouse, Ij Cox, C C. 
Assuming that the case on both sides has been closed, the evidence summed up, the law applicable to it laid down by the Judge, and the verdict given (11), the next point of practical importance to be noticed is with respect to the mode in which the judgment should be entered $(x)$, as to Julkment. which it must suffice to say that the safe and proper course for adoption, where the indictment on which a conviction has been had contains counts of donbtful validity, is for the Court to pronounce judgment on each separate count of the indictment $(y)$, and to have such judgment entered accordingly.

Although any formal defect in an indictment being ground of demurrer, if taken at the proper time, $r i z$, before the jury are sworn, may be amended by the Court $(z)$, defects of sulstance may still be taken advantage of, where not cured or amended, by motion in arrest of judgment, which is made after verdict and before judgment pronounced, or, if apparent on the record, by writ of error. Of a writ of error, indeed, the full effect was made attainable by a much more

(u) A mistake in delivering the verdict may be corrected within a reasouable time: Reg. r. Fodden, Dearsl. 229.

The Judge at a trial for felony may in his discretion discharge the jury, and the exercise of his discretion in this respect will not be reviewed in error: Winsor v. lieg., L. R. 1 Q. B. 390.

A discharge of the jury is not equivalent to an acquittal: "Irinsor v. Rey., supra ; Re Nevton, 13 Q. B. 716.

$(x)$ G'Comell v. Reg., $11 \mathrm{Cl}$. \& F. 155; Camplell v. Reg., 11 Q. B. 799, $813,814,837$; Ryalls v. Reg., Id. 781, 795 .

"In the case of an indictment with some good and some bad counts, after a verdict for the Crown upon all the counts, the Court below ought to arrest the judgment on the bad counts, and pass sentence on the good ones. Should the Court below, however, have pronounced judgment generally, "the Court of Error may now order judg- meut to be arrested on all the bial counts and pronounce the proper judyment on all the grood counts." l'er Lord Camplell, C. J., Holloweny v. Reg., 2 Den. C. C. 295.

Where an indictment contains several counts, it is no ground of error that on some of them a verdict has not been given, provided a verdict has been tound on one good count, and judgment has been given generally, " each count being in fact and theory a separate indictment:" Lathum r. Key., ; B. \& S. $635,6+3$.

(y) See King v. Reg. It (2. 1. 31. In $O$ 'brien v. Reg., 2 H. 1. Cn. t6.j, 470 , it is said that sentence was distinctly repeated as to each of the five counts of the indictment on which the defendant had been convicted See also Giegory v. Reg., 15 (2. B. 974; Rey.r. Viton, $1+$ Cox, C. C. 436 , j) 46 . Ei). 
court for Crown Ciases Bestervell.

speedy and less expensive process under the provisions of the stat. 11 \& 12 Vict. c. 78, intituled "An Act for the further Amendment of the Administration of the Criminal Law," by virtue of which a Court of Criminal Appeal was established for determining any question of law, which, in the discretion of the Judge presiding at the trial of a criminal offender, might be reserved by him for their consideration. The question or questions thus reserved are, under section 2 of the Act just cited, to be stated in a case signed by the Judge, together " with the special circumstances upon which the same shall have arisen;" and this case is then to be transmitted to and argued before the Court of Criminal Appeal, who will deliver judgment thereupon. The nature and precise extent of the jurisdiction of the Court for the consideration of Crom Cases Reserved, henceforth exerciseable by certain Judges of the High Court of Justice (a), will more distinctly appear on examination of the authorities below cited $(b)$.

It has been decided that, under The Judicature Acts, 1873 and 1875, there is no appeal to the Court of Appeal in a criminal case, except for error on the record $(c)$.

Further, when judgment-unimpeachable on any substantial ground-has been passed upon an offender, nothing can absolve him from the penalties indicated thereby, sare only endurance of the same, or a pardon, the right to rouchsafe which is, according to our constitution, the peculiar prerogative of the Cromn-the fountain not only of honour, but of mercy. The effect of a pardon, if absolute and unconditional, is to make the offender a new man,

(11) Stat. 36 \& 37 Vict. c. 66, s, 47 . The practice with respect to Crown ('ases leserved remains as ret unaltered: 35 \& 39 lict. c. $\%$, s. 19 , and order lxviii.

(b) ling. r. Clark, 1.. R. I C. C. 5t; distinguished, Reg. r. Broten, 24 Q. B.

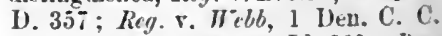
33S : Reg. v. Faderman, Id. 565 ; Reg. v. Harris, Dearsl. 344.

(c) Reg. v. Stecl, 2 Q. B. D. 37 ; Reg. v. Fletcher, Id. 43, 44. 
to acquit him of all corporal penalties and forfeitures annexed to the particular offence, and to give him a new credit and capacity $(d)$.

A pardon, however, may be conditional only, in which case it operates to purge the particular offence upon perI'ardois conditioust. formance of the condition-i.e., upon suffering the punishment imposed in lieu of the original penalty by the Crown (e).

Finally, although the plan of this Work precludes a consideration of the punishments inflicted upon criminal offenders, it may be right to add that forfeiture on conFirferitum (on) (")ilivin tíon for felony. viction for felony was abolished by stat. 33 \& 34 Vict. c. 23 , under section 9 whereof the Crown is empowered to appoint an administrator of the property of a convicted felon, which by section 10 will vest in him. Such administrator is authorised, out of the convict's property, or the proceeds of it, to pay the costs of prosecution, the debts and liabilities of the convict, besides other charges and expenses mentioned in the Act $(f)$, and subject thereto, the administrator will hold such property in trust to revert to the convict or his representatives on the completion of his sentence, or on his pardon, or his death $(g)$. If there be no such administrator, an intrim. curator may be appointed in manner specified by the Legislature $(h)$.

And here these Commentaries, which have been devoted Conclubling rworks.

to an examination, more or less detailed, of each of the three leading branches of our Common Law-Civil, Quasi-

(d) 4 Bla. Com. 402. "Where the rigour of law bordereth upon injustice, mercy should, if possible, interpose in the administration."-Fost. Disc. Hom., 264, and Disc. High Treas., 184.

See Lerien r. Reg., L. R. 1 P. C. 536.

(c) See the proceedings in Simith
O'Brien's cuse, as narrated in 'Towns. end's Mod. St. Tr., vol. 1, p. 469 ; and the Declaratory Act $(12$ id 13 Vict. c. 27 ), passed in consequence of his rejection of a conditional pardon.

$\left(f^{\prime}\right)$ See particularly ss. $3,4,11$, $13-16$.

(g) S. 18

(h) 5.21 et sey 
Criminal, and Criminal-must conclude: not, indeed, for lack of matter, inasmuch as many topics which might with propriety have been discussed have been altogether passed over or but slightly handled; rather for lack of space, those limits having been reached which, at the outset of this Work, it was deemed advisable should not be exceeded. 


\section{INDEX.}

\section{ABANDONING EXCESS}

to give jurisdiction to County Court, 58

\section{ABATEIENT}

of action, none, 124

of private nuisance, 209

of public nuisance, 211

without notice, 209

when allowed, 211

may sometimes justify entry on the land of another, $s ; 8$

\section{ABDLCTION}

of wife, action for, $96 \mathrm{t}$

of child, $969(o)$

of women and girls not triable by justice of the peace, 1080

ABILITY,

meaning of, in 9 Geo. IV., c. 14, s. 6, 384

ABSCONDING DEBTOR,

proceedings against, 132

ABSOLUTE RIGHTS, torts to, 952

AC ETIAM,

clause of, 31

how abolished, 32

aCCEPTANCE. See Bill of Exchaxge, Costract of Sale uf Goops. of bill of exchange, 451 ( $a$ )

nature of, 467

how made, 467

by whom, 467

accommodation, 454

per procuration, 467,472

general, 467,469

qualified, 469

conditional, 469

partial, 469

local, 469

qualified as to time, 469

hy one or more, but not by all the drawees, 469

iuportance of nature of, 470

when general, presentment unnecessary to charse accejtor, $4: 0$

how effect of, can be restrained as against the drawer, 467

presumption as to date of, $46 \vec{i}(b)$

varying from the tenour of the bill will bind accertor, 471 
ACCEITANCE-continued.

drawer or indorser not authorising or assenting to qualified acceptance discharged, $4{ }^{\prime} \cdot 2$

by agent, 472,473

by partner, 473 without authority, 473

in trading firm, 473

in non-trading firm, 473,474

by direetors without anthority, $473(k)$

effect of, payable at a banker's, 475

request to lend implies promise of repayment, 303

and offer must be oud idem, 298

of goods, what was, within the Statute of Frauds, 409, 110 within s. 4 of the Sale of Goods Act, 1893, 409, 411 of contract by letter, 299,300

ACCEPTANCE FOR HONOUR, $465,467,474$

for part only; 474

reyluisites of, 474

for whose honour made, 474

Sie AcCeplaxe, Bill of Exehasid.

ACCEPTOR,

Inimarily liable on bill of exchange, 453

on accommolation bill, 454

contract of, revocable until delivery, 455

Iosition of, after indorsement, $45 \mathrm{~s}$

engagement of, 459,464

is not discharged by non-presentment of bill, 460

does not need notice of dishonour, 460

no duty on, not to facilitate fraud, $469(l)$

what presentment necessary to charge, 471

is bound by acceptance varying from the tenour of the bill, 471,472

doctrine of estoppel in regard to, 472

for honour, position of, 474

payment by, at maturity discharges the bill, 476

if becomes holder of bill in his own right at maturity it will be discharged, 476

may be diseharged while other parties are held liable, 497

eannot set up previous or contemporaneous agreement varyilg his acceptance, 370

ACCESSORI

after the fact to felony, who is, $1048(c)$

ACCIDENT,

when lefendant is liable for, withont defant, 789

as excusing criminal act, 1000

ACC(NIJOLATION ACCEPTANCE.

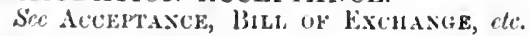

ICCOMIOUATION BLL.

what it is, 454

liability in respeet of, 454

druwer has no right to notice of dishonour, 461

an indorser has, 461

when discharged, 498

aceptor has an inplied anthority to pay, 500

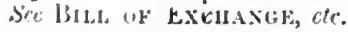

ACCORD AXI) SATISFAC'TION,

whell pleadable, 290 ct sc\%.

meaning of, $292(n)$ 
ACCORD AND SATISFACTION-continuel.

doctrine of, 396 et seq.

jart payment camnot be, 396

unless time or place of payment be altered, 397

- or new consideration, ex. gr., withdrawal of a plea of infancy, 393

ACCOUNT,

cannot be stated with an infant, $66 \%$

ACCROACHMENT

of royal power, what is, 1018

ACT OF GOD,

what it is, 931

whether it will excuse breach of contract, $719, ; 60$

of statutory duty, 760

failure of carrier, 761,931

of innkeeper, 927

ACT OF PARLIAMENT,

how to be construed, 2 et scq., 867 (c)

general words in, 6

when retrospective, 6

penal, how to be construed, 6

repealed, 6

relating to former courts, 109

ACTION AT LAW,

when it lies generally, 70

for depriving of a right, 82

for not honouring cheque, 84

for act of trespass evidencing title, 86

for non-repair of sea-wall, 97

sometimes not allowed on grounds of public policy, $9 b^{\circ} \mathrm{ct} \mathrm{se}$

for recovery of a penalty under a statute, 99

rejected for novelty and inconvenience, $104(q)$

meaning of word, 109

does not include criminal prosecution, 109 (c)

essential elements of, 110

matter preliminary to, 111

cause of, must be complete, 111

for breach of promise of marriage, 112

of future contract, 112, 113

right of, may have been postponed, 114

depend upon condition precelent, 112

have been extinguished, 114

be barred by Statute of Limitations, $11:$

by express cuactment: 115

be res julicata, 115

statutory requirements, 115

consent of judge or attorney-general may be necessary, 115

notice may be necessary, 115

nature of clain, 116

transfer of, 117, 125

parties to, 117, 118

not defeated by mis-joinder, 120

or non-joinder, 120

by or against infant, 120

married woman, 120

lunatic, 121

partners, 120 
ACTIOS AT LAW-continued.

by or against trustee in bankruptey, 120

executor or adninistrator, 121

joinder of claims, 123

not abated by marriage, death, or bankruptcy, 124

how commenced, 125

atdition of party to, 124,125

to recover land in case of vacant possession, 129

discontinnance of, 145

may be stayed, 145

as frivolous or vexations, $46(r)$

causes of, united, $146^{\circ}$

or dismissed, 145

when separated, 146

forms of, 146 et seq.

formerly three classes of, 146

real, what they are, 146

mixerl, 147

personal, 147

ex contractu, 147

ex delicto, 147

of dower, 146

of quare impedit, 146

when removed from district registry to London, 169

how removed, 169,170

trial of, 170 et seq.

in County Court, how commenced, 196

for reward offered by advertisement, 319 (i)

Sce Thial, Covsty Covrt.

ACTION OF MaNDaMUS, $214(x)$. Sec Mandaucs.

ADDRESS

of plaintiff and solicitor 1nust be indorsed on writ, 127

\section{ADEQUACY}

of consideration, court will not inquire into, 315

ADIINISTRATION OF ASSETS,

rules as to, 289,290

service of writ ont of jurisdiction allowed in some cases, 129

ADIIXISTRATION OF JUSTICE,

offences against, 1024

hy judicial officers, 1024

ty private persons, 1024, 1025

ADMINISTRATOR. Sce ExEctTol.

derives title from letters of administration, 708

de baitis non, 714

constructive possession of, 215

of felon, 1097

ADMINISTRATRIX,

protection of married woman as, 678

ADHISSIONS, 164

of docunients, 167

of facts, $16 \mathrm{~s}$

consequences of refusal to admit, 168

consequences of refusal to admit, 168

of statements in pleadings, 141

of plaintiff's claim in County Court, 200 
$\triangle \mathrm{DULT}$,

meaning of, in $42 \& 43$ Vict. c. $4 \uparrow, 10 \$ 3$ (1)

ADULTERY, agency of wife letermined by, 695

liability of linsband for wife living in, 698

AIDVERTISEMENT, actions on promises contained in, 3i9, $319(i), 320(k),(l)$

AFFIDAVIT,

nature of, 47

in support of motion or summons, $4 i$

costs of, unnecessary, 47

evidence by, 174

cross-examination of deponent, 175

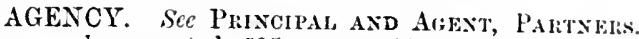

how created, 595 et seq., 600

by immediate act of principal, 600

special, 598

by representation of principal, 600

general, 598

universal, 598

difference between special and general, 601

fact of, how proved, 599

to what matters authority of agent extends, 603

did agent contract as such ? 600,605

damages for false representation of, 741

of married woman for her husband, $690 \mathrm{et} \mathrm{ser}$.

determined by adultery, 697

AgENT. See Agency, Priscipal anil Agest.

duty of, to account, 38

of solicitor has no privity with client of latter, 310

innocent principal, how far liable for fraud or tort of, $333 \mathrm{at} s, \mathrm{z}$., 959

fraud of, good defence to suit for specific performance, 333 (l)

principal liable for purposely employing ignorant agent, $337(b)$

for acts of agent in the course of his business, 337

del eredere, nature of his undertaking, 383

implied warranty of authority by, 342

might sign memorandum within s. 17 of the Statute of Frauls, 406,415

may sign memorandum within s. 4 of the Sile of Gools Act, 1893 . 406,414

is estopped from disputing title of principal in subject-matter of agency, $395(\mathrm{~m})$

anthority to execnte deed must be under seal, 399

acceptance of bill of excliange by, 472,473

withont authority, 473

extrinsic evidence not admissible to clischarge, when he has signel contract as principal, 577

nced of full disclosure by, before dealing as principal with his employer, $592(d)$

did he contract as such ? 600,605

partner is agent of firm, 599

wife is sometimes, of husband, 599

authority of solicitor as, 604,605

may be personally liable if he has pledged his own credit, 606 


\section{AGENT-continued.}

impliel authority of, 605

appointed under seal cannot bind corporation by parol orler, $649(x)$ not liable for remote lamage, $734,73.5$

gratuitous, liable for misfeasance, 779 not for non-feasance, 779

AGGRAVATED ASSAULT, what is, 1048

AGISTER,

duty of, 916

\section{AGISTMENT,}

what it is, 916

live stock at, conditionally exempt from distraint, $\mathbf{5 5 3}$

AGREEMENT. See Coxtract, Statute of Frauds.

to oust jurisdiction of the court, 41

to gire jurisdiction to County Court, $56^{\circ}$

to let furnished house, implied condition in, 248,569

to suppress prosecntion for felony is illegal, 351

to publish libel and defend action is illegal, 351

to indemnify bail is illegal, $355(i)$

against public policy, 352

meaning of, within the Statute of Frauds, 374

must include consideration, 374

secus, in case of guarantie, 375

upon consideration of marriage, 385

not to be jerformed within a year, 391

for sale of realty and personalty, if roid as to realty under the

Statute of Frands, s. 4, void also as to personalty, 391

proplosal signed by defendant, and orally assented to by plaintiff,

way be a sufficient memorandum under $I b$., s. 4, 393

previous written, cannot vary subsequent deed, 574

AGRICUITURAL HOLDINGS ACTS, 539 et seq.

improvements under, $5 \notin 0$

three classes of, $540 \mathrm{ct}$ seq.

claims for compensation under, 54?

landlord's right of set-off, 542

to make improvements, 543

regulations as to fixtures, $5 \pm 3$

IIR, 902. See Easfarests.

ALIEN,

friend, position of, $707 \Leftrightarrow$

enemy, 707

cannot acquire property in a British ship, $707(\%)$

allegiance due from friendly, 1012

from hostile, 1013

ALIMONY,

liability of lussluanl not paying, decreel, 698

\section{ILLFGIANCE,}

natural, 1012

local, 1012

and prctection reciprocal, 1013

to whom due, 1013 
ALTERATION

of written agreement within s. 17 of the Statute of Frauds neither

rescinded the old contract nor made a new one, 413

material, in bills of exchange and promissory notes, what is, $500 \mathrm{ct} \mathrm{seq}$. in deeds, 501

in bank-notes, 502

immaterial, effect of, 502

AMBIGUITY,

may be patent or latent, 574

if patent cannot be helped by evidence, 575

when primá facie patent may be shown not really to exist, $\mathbf{5 7 6}$

evidence admissible to identify subject-matter of, $5 ; 6$

parties to, 577

to explain mercantile terms, $578 \mathrm{et} \mathrm{scq.}$

AMENDMENT

of pleadings, 140

of indictments, 1095

ANCIENT INSTRUMENTS,

evidence to explain, 581

ANCIENT LIGHTS, 896, 902. See EASEMExTs.

ANIMALS,

injury caused by, $786(z)$

whether the scienter must be proved, $7 \delta 6(z)$

ferce naturce, no larceuy of, at common law, 1058

ANIMIUS

cancellandi, question for the jury, 979

furandi, essential to constitute larceny, 1060, 1064 et seq.

how evidenced in appropriation of lost goods, $1064 \mathrm{ct} \mathrm{scq}$.

revcrtendi, question for the jury, 979

ANTENUPTIAL DEBTS, 685. See Married Womas.

APOTHECARY,

implied warranty by, 342

liable ex deliclo without privity, 772, 819

negligence of, causing homicide, 1041, 1042

APPEAL

to Honse of Lords, 36

permission to, to House of Lords, may be refused, 36 (c)

when leave is required, $50,50(i)$

to Divisional Court, 50

from judge at Chambers, 52

from Master, 54

proceedings on, 186

to Court of Appeal, 187

from a Judge, in matters of practice and procednre, 189

when to be brought, 186,187

effect of, 187

nature of, 187

notice of, 187,188

right of, restricted in certain cases by Jndicature (Procedure) Act,

1894,189

lies against order striking solicitor off the rolls, $213(r)$

in Habeas Corpus, 237

from County Court, 203

in action of contract or tort, 203

where title to hereditament in question, 203

of replevin, 203

B.C.L. 
APPEAL, COURT OF, 34, 35, 186. See Covrt of Appeal.

\section{APPEARANCE}

of defendant to writ, 133

how entered, 133

when to be entered, 133

where to be entered, 133

memorandum of, what it must contain, 133

by formal defendant, 134

by partners, $133(n)$

by person not named as defendant, 134

by landlord in possession by his tenant, 134

solicitor not entering, liable to attachment, $133(l)$

to specially indorsed writ, 134

default of, 136,137

by infant, or person of unsound mind not so found, $136(i)$

by some of defendants, $136,13 \pi$

in action for detention of goods, 136, 137

of third party, 160,161

for recovery of land, 137

default of, by third party, 161

by defendant in County Court, 197

APPRAISEIENT OF DISTRESS, necessity for, abolished except where required by tenant, 555

APPRENTICE,

measure of damages in action on indentures, 732

action for enticing away, when it lics, $970(x)$

contract of apprenticeship not void by reason of master being a corporation, $66 \bar{i}(\mathrm{c})$

\section{APPROPRIATION}

in reference to contract of sale, 427,428

unconditional, in contract of sale of unascertained or future goods by description, 427

assent of seller or buyer to such, necessary, 428

of lost goods may amount to larceny, $1064 \mathrm{ct} \mathrm{seq.}$

APPROVAL,

goods sent on, 427

ARBITRATION,

contract to refer to, 41,42

enactments relating to, amended and consolidated by the Arbitration Act, 1889. $42(f)$

master may exercise the jurisdiction and powers, under the Act, of the Court or a Judge, $53(k)$

power of Court or a Judge to refer under the Act, 172.

ARBITRATOR,

not liable for negligence, $104(0)$

ARRAIGNIIENT

of prisoner, 1088

ARREST. See Maliciors Arrest

of absconding debtor, 132

on non-compliance with order of County Court judge, 201, 202

under writ of attachment, 191

right ful, 824

of affrayer, when justifiable, 824

of felon justifiable, 826

when justifiable, 824

reasonable anil probable cause, 826 
difference in case of private person and constable, 826

advisable to proceed upon magistrate's warrant, 827

ARREST OF JUDGMENT,

ART,

motion in, 1095

evidence to explain terms of, 581

asportation. See Larceny, Crimisal Law, what amounts to, 1069

ASSAULT,

what it is, 784

what is not, $784(i)$

when justifiable, 785

correction by parent, 785

son assault demesne, 785

in defence of goods or possession, 785

in removing wrongful holder, 206 et seq., 785

in ejecting intruder, 785

by captain to preserve discipline, 785

by church warden or beadle, 786

molliter manus imposuit, plea of, 786

by innkeeper, when not justifiable, $786(x)$

by broker, employer not liable for, 793

infants liable for, $1010(o)$

ferme covert may be convicted of, jointly with lusband, 1011

offence against public peace, 1029

person voluntarily present at prize-fight not necessarily guilty of, $1039(n)$

aggravated, 1048

common, 1048

may occur where submission obtained by fraud, \&c., 1049

limitation in action of, 158

ASSEMBLY, 1026. See UNLawful Assembly.

ASSENT,

meaning of, $248(x)$

of donee, when presumed, $263(d)$

reciprocity of, 300

ASSESSORS,

trial with, 171

\section{ASSETS}

by descent, 289

administration of, 290

ASSigneE, See Chose ix Action, Laxdond axd Texast.

when bound by covenants of assignor, 270,271

as to things not in esse, $271(r)$

who is within stat. Hen. VIII. c. $34,271(s)$

of life policy may sue in his own name, 505

of marine policy, 505

of bill of lading, 505 et seq.

ASSIGNMENT. See Chose in ACrion.

under the Judicature Acts, 446

of chattel interest, when requires deed, 399

of contract, limitations of, $445(u)$

by trustee in bankruptcy, $658(g)$

of bankrupt's property, 659

conveyance of landlord's whole interest is, 509

by act of law, 559 
ASSIZES,

origin of, 26

ASSUMPSIT, action of, what it is, $225(y)$

ATTACHMIEN'T,

what it is, 48

writ of, 191

form of writ, 191

of debts, 227

solicitor not entering an appearance liable to, $133(l)$

ATTEMPT

to commit a crime may be indictable, $99 \mathrm{~S}$

what is, $998(s)$

to commit suicide is indictable at common law, $998(q)$

how distinguishable from intention, 997

ATTORNEY. See Solicitor.

general, 27

employment of, as of right, 27

now styled solicitor, $46(s)$

ATTORNEY-GENERAL,

order made on suggestion of, $48(a)$

when consent of, necessary before action, 115

right of reply of, 1094

has a right to file criminal information, 231

of Duchy of Lancaster has not, 231 (i)

ATTORNMENT. SCe LANDLORD AND TeNaNT.

relation of landlord and tenant created by, 521

no longer necessary, 556

AUCTIONEER,

might sign memorandum within s. 17 of the Statute of Frauds, 414 et seq.

may render himself personally liable, 414

position and duties of, 414, 415

determination of authority of, 415,416

cannot vary contract by oral statement, 415

has special property in goods, 416

can maintain action against stranger taking them, 948

can sue for their price, 416

cannot arail himself of his own signature where party to an action, 416

unless the signature is his clerk's, 416

licence to, to enter premises under parol agrcement to sell goods there, is revocable, 399

has no implied authority to warrant goods sold by him at public auction, $605(n)$

\section{AUCTIONS,}

law as to, $414(f), 441$

liability of agent purchasing goods at, $608(d)$

person appropriating money found in desk bought at auction may be guilty of larceny, 1068

AUDITA QUERELA,

remedy by, abolished, $190(u)$

AULA REGIS,

its origin, 23

appeal lay to, 26 
AUTRE DROIT,

right of administrator to sue in, 709

AUTREFOIS ACQUIT,

plea of, 1089

AUTREFOIS.ATTAINT,

plea of, $1089(u)$

AVERAGE ADJUSTERS, practice among, $10(q)$

AVOIDANCE. See Bankruttcy. of voluntary settlements by bankrupt, $286(e), 665$

AWARD,

finality of, $262(x)$

BAIL,

contract to indemnify, is illegal as against public policy, 355 (i) power of justice of the peace to almit to, 1081

may be taken by coroner for person found guilty of manslanghter by jury, $1086(z)$

\section{BAIL BONDS,}

are assignable, 445

bankrupt debtor on, is not released by order of discharge, 662

BaIleE. See Bailmext, Tort.

character of, $916(g)$

duty of, in 1st class, 917

liable for gross negligence, 917

bound to use any special skill he may possess, 919

duty of, in 2nd class, 920

in 3 rd class, 922

if there is a written agreement that regulates position of the parties, 922

is liable for accident without negligence, if, having contracted to warehouse goods at one place, he do so at another, $923(l)$

when may set up jus tertii, $924(q)$

measure of damages in action by, for chattel, 972

if chattel stolen from, property may be laid in bailor or bailee, $1059(n)$

converting chattel not guilty of larceny at common law, unless he broke bulk, 1062

is so by statute, 1062

even if an infant, $1010(0)$

who is, by statute, 1062

gratuitous, duty of, 917 et seq.

liability of, 779

cannot be compelled to undertake the trust, 919

is liable for nisfeasance, 919

right of, to sue, 921,948

\section{BAILMENT,}

what it is, 915

ingredients of, 916

how it differs from mere license to use, $916(y)$

illustrations of, 916 
BAILMENT-continued.

three classes of, 917

1. For exclusive benefit of bailor, 917 et seq.

duty of bailee in 1st class, 917

liable for gross negligence, 917

bound to use any special skill he may possess, 919

2. For exclusive benefit of bailee, 920

includes commodatum or loan, 920

duty of bailee in 2nd class, 920

3. For benefit of both parties, 921 et scq.

what it includes, 921

estoppel on parties to, 922

gratuitous, performance of cannot bc enforced, 919

if accepted, bailee liable for gross negligenee, 919

liability of parnee, 923

duty of pawnee, 923

liability of innkeeper at common law, 926

no distinction between money and goods, 926 (i)

larceny of chattel under, 1061, 1062

BaIlor. Sce Bailee, Bailuext.

may sue for chattel wrongfully taken out of the possession of a gratuitous bailee, 921

\section{BALANCE OF ACCOUNT,} what is, 57

BANK,

liabilities of old and new partners respectively, 638 et seq.

BANK MANAGER,

authority of, to direct prosecution of offender, $603(f)$

not within ordinary scope of his anthority to order arrest and prosecution of offender, $8 \pm 3$

\section{BANK NOTE,}

definition of, 492

peculiar qualities of, 49.2

circulates as money, 492

rules as to presentment of, $493 \mathrm{et} s e q$.

of Bank of England are legal tender save at the Bank and its branches, $492(z)$

right of holder against transferor without indorsement, 495

effect of receiving forged, 495

material alteration in, 502

\section{BANK OF ENGLAND,}

alteration of number of note of, is material, 502

criminal offence to make paper with the water-mark of, 989

notes of, when legal tender, $492(z)$

BANhFR. See Cheque, Bill of Exchasge. general lien of, 9

judicially noticed, 9

right to satisfy himself of genuineness of cheque, $84(a), 476(b)$

aetion against, for dishonouring chẹue, 84

substantial damages for, though no special damage, 979

of married woman, 680

relation of, to customer, 475

duty of, 475

to jay bill aceepted payable at bank, 475

paying bill witl forged indorsement, 475,476 
BANKER-continued.

duty of, if unwilling to decide on genuineness of indorsement, 476 where indorsement is suspicious, 476

remedy against person presenting bill, $476(z)$

liability of, if cancels acceptance of bill which he afterwards receives orders not to pay, $476(z)$

crediting customer with amount of a cheque, becoming holder for value, 478

duty and authority of, to pay cheque when determined, 479

duty of, when crossed cheque is drawn on him, 480

protected in paying cheque not apparently crossed, 481

in receiving payment of crossed cheque, 481

paying forged cheque liable, 481

unless there has been gross laches on the part of the customer, $482(c)$

not liable for paying cheque with forged indorsement, 483

not liable, without laches, to person paying in worthless notes, $495(k)$ position of parties where one partner has opened an account at bauk in his own name, 636

where borrower applies to a partner at the bank for a loan, 636,637

BANKRUPT. See BANKRUPTCX.

avoidance of voluntary settlements by, $286(c), 665$

\section{BANKRUPTCY,}

proceedings in, how commenced, 653

petition, 653

receiving order, 653

effects of, 653

official receiver, 653,654

right of landlord to distrain, 654

debts provable in, 654,655

meaning of "liability" in the Act, 655

how to be estimated, 655,656

bona fide transactions protected, 656

public examination of debtor, 656

effect of receiving order, 656

composition or scheme, 656

appointment of trustee, 656

meaning of "property" in the Act, 656 ( $z$ )

property of bankrupt divisible among his creditors, 657

disclaimer of property by trustee, 657,658

of leaseholds, $561,562,658$

liability of trustee not disclaining validly, $658(g)$

may relieve himself by assigning to pauper, $658(\mathrm{~g})$

doctrine of reputed ownership of goods, $657(c)$

disclaimer of freeholds, $657(d)$

what is a sufficient disclaimer, $658(e)$

powers of trustee, 659

of committee of inspection, 659

assignment of bankrupt's property; 659,660

of member of a partuership, 660

right to sue in actions $c x$ delicto of baukrupt, 660,661

of trustee, 660,661

status of discharged bankrupt, 662

protection to bankrupt, 662

order of discliarge conclusive evidence, 662

can only be pleaded in County Court after notice, 199

who are not released by it, 662,663 
BAX゙KRUPTCY-continued.

debtor after order of discharge held bound by promise for new and valnable consideration to pay debt, 663

misdemeanour in, 663

conrt may refuse order of discharge, 663

or suspend it, 663

or grant it conditionally, 663

status of undischarged bankrupt, 664

contracts affected by, 665,666

a second adjudication against an undischarged bankrupt allowed by

his trustee to carry on business is not void, $664(\mathrm{~m})$

meaning of "settlement" in the Act, $665(p)$

fraudulent preference in, 666

contract for, illegal, 356

proceedings by debtor's summons in, abolished, 666

when annulled by the court, 666

infant cannot be made bankrupt, $671(r)$

married woman, how far liable to, 683,684

Married Women's Property Act, 1882, not affected by Bankruptcy Act, $1883,684(r)$

will not abate action, 124

canses transfer of choses in action, 445

assignment of lease and corenants, 559

of customer determines banker's authority to pay cheque, 479

action for malicionsly suing out commission of, 844

joinder of claims of trustee in, 120

fraudulent, an offence against the public revenue and tridae, 1029

BANKRUPTCY PETITION. See BANKRUPTCY.

BARGAIx. Sec CoNtiact, Contract of SAle of Goods.

BarON AND FEME, 675 t seq. Sec Married Womax.

BARRISTER,

cannot sue in respect of professional services, 322 nor be sued, $322(z)$

implied authority of, to compromise snit, 604 (i)

his privilege of speech, 853

BASTARD, 326, 988. Se Illegitimate Child.

BATTERY,

what it is, 784,1049

definition of, 786

when justifiable, 785

limitation in action of, 158

infant liable for, 1010

consent immaterial, if amounts to a breacb of the peace, 1049

BEADLE,

assault ly, when justifiable, 786

BIGAMY,

an offence against public morals, 1029

not triable by justice of the peace, I0s0

bona fide belief on reasonable grounds that first husband dead, $1029(s)$

BILL of ExCHANGe. See Acceptaxce, Foreign Bill, etc.

law as to, codified by lills of Exchange Act, 1882, 449

construction of the Act, $448(g)$

cletinition of, 449

inland, 477

foreign, 477

operation of lex loci upon, 252,478

exception to general rule forbidding assignment of chosesin action, 447 
BILL OF EXCHANGE-continued.

origin of, 447

reluctantly allowed by the courts, $\mathbf{4 4 7}$

quality of negotiability, 447

is inherent, unless bill contains words prohibiting transfer, 454

judicially noticed, 9

caunot be under seal at common law, $494(k)$

does not operate as assignment of funds in hands of drawee $449(h)$

must be unconditional, $4 \$ 9$

if payable on a contingency, is bad, 449

will not be cured by the contingency happening, 449

reason of this, 450

must be in writing, 449

payable on demand or at some fixed or determinable future time, 450

for payment of a sum certain in money, 450

drawee must be named or indicated, 451

bill cannot be directed to alternate or snccessive drawees, 451

if accepted or indorsed when overdue, becomes payable on demanl, $450(q)$

if not payable to bearer, must name or indicate payee, 451

form of, 451

when it is optional to treat instrument as bill of excliange or promissory note, 452

payee fictitious or non-existing person, 452

how accepted, $451(a)$

when words and figures differ, the words prevail, $452(b)$

use of, in mercantile transactions, 453

parties to, 453,454

drawee is not liable on, if he does not accept, $449(h)$

may be addressed to two or more drawees, $453(l)$

referee in case of need, $453(l)$

acceptor primarily liable on, 453

accommodation bill, 454

acceptor primarily liable on, 454

drawer is in the position of surety for the acceptor, 453,454

bill payable to $C$. D. or bearer passes by delivery, 454

indorsement of, 455 or order passes by indorsement, 454

blank or special, 455

delivery necessary after indorsement, 455

contract incomplete till delivery, 455

restrictive indorsement, 455,456

conditional delivery, 456

" retiring," meaning of word, $456(b)$

rights of holder, 456,457

holder has no cause of action until expiration of last day of grace, $453(\mathrm{o})$

consideration piesumed until holder's title is impeached, $4 \$ 8,493$

need not be alleged in action, 144

unless it is a substantive ground of claim, 14t

effect of fraud on title to, 457

of delivery of, 457

of indorsement by wrongful holder, 457

of transference without indorsement, 4.7

of transfer of overdue bill, 457,458 .

of taking dishonoured bill with notice, 458

bill payable on demand, when deemed overlue, $45 \mathrm{~s}$

parties to bill after indorsement, $45 \mathrm{~S}$

steps to be taken by holder to obtain payment, 458,459

presentment for payment, 459 


\section{BILL OF EXCHANGE-continued.}

notice of dishonour, 459,465

failure to give, will not prejudice the rights of a holder in due course, 466

their importance, 459

two kinds of dishonour, $459(p)$

by non-acceptance, $459(p)$

by non-payment, $459(p)$

engagement by acceptor, 460,464

aceeptor is not discliarged by non-presentment, 460

cannot require notice of dishonour, 460

has no duty not to facilitate fraud, $469(l)$

relation between parties to bill, 460

notice of dishonour, when dispensed with, 460, 462

presentment, rules for, 470,471

to cliarge acceptor, 470,471

drawer, 471

indorser, 471

necessity of speedy presentment of, 491

excuses for delay, $460(t), 464$

for non-presentment, $460(t)$

notice of dishonour to indorser, when dispensed with, 462

probability of dishonour is not equiralent to notice, 462

neither is knowledge, 462

effect of dishonour, 462

if bill dishonoured by non-acceptance, need not be presented for payment, unless afterwards accepted, 462

notice must be given to all parties who are to be held liable on the bill, 462

how it must be given, 463

when, 463

when deemed to be given, 464

engagement by indorser, 464,466

person signing bill otherwise than as drawer or acceptor incurs the

liability of an indorser, $464(0)$

liability of persons indorsing as co-sureties, $464(0)$

engagement by drawer, 465

right of action on dishonour, 465

acceptance, nature of, 467

low made, 467

by whom, 467

general or qualified, $46 \bar{\tau}, 468,469$

may be restrained as against the drawer by a contemporaneous

written, but not by an oral agreement, 370, 467

$8 c c u s$, if subsequent, 370

presumption as to date of, $467(b)$

three forms of, $46 \pi$

importance of nature of 470

if general, presentment unnecessary, 470

varying from tenour of bill will bind acceptor, 471

lolder of, entitled to absolute, 471,472

failing which he may treat the bill as dishonoured, 472

if takes qualified, should give notice of qualification, 472

holder or indorser not authorising or assenting to, is discharged, $4 i_{2}$

per procuration, 472,473

if without authority fraudulent, 332

by agent, 472,473

by partuer, 473

without authority, 473 
BILL OF EXCHANGE-continued.

acceptance by partner in trading firm, 473

by partner in non-trading firm, 473

by director without authority, $473(k)$

for honour, 467,474

may be for part only, 474

for whose honour made, 474

requisites of, 474

must be attested by notarial act, 474

position of acceptor for honour, 474

payment of, supra protsst, 474

effect of accepting bill payable at a banker's, 475

no title can be made throngh forgery, 476

effect of discounting forged, 495

doctrine of estoppel, as against acceptor of, 472

effect of signing blank, 468

must be filled up in reasonable time as against prior parties, $46 \mathrm{~S}$

not as against holder in due course, 468

how discharged, 476, 497, 498

if paid by acceptor, 476

by drawer, 476

by indorser, 476

cancelling acceptance of, $476(z)$

presentment of, 491

when not discharged by payment, 497

defence of payment, 497

cancellation, 498

intentional, 498

unintentional, 498

no consideration, 498,499

rule as to onus probandi in issue of, 499

good pro tanto against an immediate party, if for specific ascertained amount, 500

material alteration, 500 et seq.

loss, 503 et seq.

- at common law, 503

by statute, 503,504

in action on non-negotiable instrument, 504

illegality, 504

fraud, 504

duress, 504

drunkenness, 504, 505

forgery, 505

who is capable of incurring liability upon, $645(n)$

how far corporations can, $645(n)$

liability of principal on bill accepted by agent, 602

solicitor cannot bind partner by accepting, 635

signature by partner in whose name business of trading firm is carried on, 577

months in, are calendar months, $450(r)$

interest on, $466(u), 743$

on dishonour, $466(u)$

measure of damages for conversion of, 972

no larceny of, at common law, 1058

BILL OF LADING,

what it is, 505

shipowner is not estopped by signature of master to, $505(\nu)$

effect of, at common law; 506

rights of consignor, 506 
PILL OF LADING-continued.

stoppage in transitu, $50 \bar{T}$

rights of consignee, 507

of assignee, 507

statutory provisions as to, 507

extrinsic evidence admissible to prove allowance of discount on, 583

BLASPHEMY, $1050(u)$

not triable before justice of the peace, 1080

BOARDING-HOUSE KEEPER,

liability of, for loss of guest's property, 929

BOND,

definition of, 272

single, 272

with condition, 272

condition of, to be strictly performed, $273(a)$

relief against forfeiture, 273

will not merge debt for rent, $273(d)$

nor another bond, $273(d)$

will work an estoppcl, 276

a merger, 273,274

discharged by payment before aciion brought, 293, 294

marriage brocage, void, 355

to carry on trade according to will of majority void, 364

with penalty does not bind infant, 670

not assignable at common law, 443

no larceny of, at common law, 1058

BOROUGH ENGLISH,

nature of this custom, 10

BOCGHT AND SOLD NOTES,

what they are, 418

if they agreed they formed a contract within s. 17 of the Statute of Frauds, $\$ 18$

if not, a nullity, $\$ 18$

material alteration in sold note without knowledge of seller prerented buyer from suing on the contract, $418(c)$

\section{BREACH OF PROMISE OF MARRIAGE,}

when action may be brought for, 112

infant may bring action for, 673

when can be brought by or against personal representative, $710(k)$

BRIBEPY,

vitiates agreement, 353

criminal information lies for, 232

definition of, 1023

not triable by justice of the peace, 1080

liROKER,

definition of, 417

etfect of signature of, 417

may bind principals, 417

might sign memorandum within s. 17 of the Statute of Frauds, 417

duty of, 412,417

caninot delegrate his authority without consent, $417(s)$

nor sne in his own name on a contract made by him as broker, $417(u)$

may by local usage incur liability as principal, $417(y)$

evidence of usage almissible to fix with liability as principal, 585

employer not liable for assanlt by, 793 


\section{BURNING}

of dead body, when a misdemeanour, $989(t)$

BUYER. See Contract of Sale of Goods.

BYE-LAWS

of corporate bodies, 317,318

CAB-DRIVER,

liability of, for loss of luggage, 930 (c)

relation of, to proprietor, $930(c)$

CALENDAR MONTH, how computed, $580(f)$

CANAL,

action lies for drawing water from, without proof of actual damage, 87

liability of owner penning back water of, 904

may protect against water of, as comnon encmy, 904

CANON LAW,

force of, $20(l)$

CAPACITY

to contract, how affected by character of contracting larty, 595 et seq.

to commit crime, 999

\section{CAPTAIN}

of ship, assault by, when justifiable, 785

CARRIAGE,

liability of owner of, 796

of hirer of, 797

\section{CARRIER}

liubility of, $739,930 \mathrm{et} \mathrm{seq}$.

of land-carrier for delay in conveyance, 739

in connection with remoteness of damage, $738(g)$

duty of, 761

warranty by, 769

liability of land-carrier, $930 \mathrm{et} \mathrm{seq.}$

four kinds of, 930

who is a common carrier, $931(f)$

liability and position of, at common law, $931 \mathrm{ct} s \mathrm{sc}$.

excused by act of God, 761, 931

of king's enemies, 931

accident occasioned by inherent vice in thing carriea, 932

effect of notice to protect, 932 et seq.

felony by servant is not necessarily attributable to gross negligence of, $932(n)$

is bound to carry according to his profession, $933(q)$

may rescind contract on ground of fraud, 934

liability of, by statute, 934 et seq.

where contract is to carry partly by land, partly by sea, $934(u)$

obligation of, $933(q)$

is not always entitled to know the nature of goods carried by him, $933(r)$

must demand increased charge under s. 2 of the Carricrs $A$ ct, $934(f)$ notice to limit liability, when invalidated by statutes, 935 


\section{CARRIER-continued.}

protected by s. 1 of the Act where chattel is lost or injured, $936(p)$ secus, where owner is injured by refusal to take goods, $936(p)$ or neglect to deliver them, $936(p)$

does not lose protection because loss is temporary, not permanent, $936(p)$

is not made ordinary bailee for bire by the Carriers Act, 936

liability of, how restricted by special contract, 940

may be relieved by doctrine of contributory negligence, 941 (l)

liability of railway company undertaking to carry beyond their own line, 942

of railway company actually carrying goods, 942

on through booking contract, 942

whether goods were in custody of railway company as carriers, 943 when becomes a warehouseman, $943(s)$

by land undertakes to deliver goods, 946

duty of, if paynient of carriage is refused, $946(s)$

if consignee fails to take delivery, $946(\mathrm{~s})$

may maintain an action against a stranger who takes goods, 948

CARRIERS ACT. See CARrier.

what things are within s. 1 of, 934

"CARRYING ON BUSINESS,"

meaning of phrase, $362(0)$

CASE,

origin of action on the, 29,30

CASE OF NEED,

referee in, $453(l)$

CATTLE,

liability of owner for trespass by, $87 t$

\section{CAUSE OF ACTION,}

must be complete, 111

may be barred by doctrine of res judicata, 115

or by express enactment, 115

joinder of several in same action, 146

separate trials of, may be ordered, 146

what may be joined with action for recovery of land, 146

CENTRAL OFFICE,

issue of writ from, 127

\section{CẼRTIORARI,}

proceedings by, 202

writ of, 224

\section{CESTUI QUE TRUST,}

how far trustees enjoy the privilege of the Statutes of Iimitation against, 153 ( $)$

\section{C'HALLENGE}

to the joll or array, 178

to jury in criminal cases, 1089

is a breach of the peace, 1025

\section{CHAMBERS,}

lowers of judge in, 51, 52

alplication at, how made, 53,54 
CHAMPERTY,

what it is, $356(n)$

promise by solicitor not to charge anything for costs is not, $350(n)$

\section{CHANCELLOR,}

secession of, from Aula Regis, 28

CHANCERY, HIGH COURT OF, origin of, 36

jurisdiction of, transferred to High Court of Justice, 37

CHANGE OF PARTIES

by marriage, death, or bankruptcy, effect of, 124

CHARTER,

evidence to explain ancient, $581(n)$

CHARTER-PARTY,

imports a writing, $368(a)$

evidence to explain, 582

when evidence not admitted, 582

meaning of words "as near thereto as she may safely get" in, $583(p)$

measure of damages in action for breach of, $722(f)$

\section{CHATTEL,}

writ for delivery of, 192,193

execution for delivery of, 229,230

vendor need not point out patent defect in, 331

whether delivery is necessary to pass property in specific, 399,403 , 425

when property passes on sale of, 425 et seq.

right of buyer to return specific, 427 (z)

gift of, inter vivos, must be by deed, 399

or perfected by delivery, 399

may be mortgaged by parol, $399(h)$

without delivery as distinguished from a pledge, $399(h)$

personal chattels, what are, 911

action for recovery of, when maintainable, 913

for wrong done to, 914

duties of borrower and lender of, are correlative, $921(a)$

who can sue for, if wrongfully taken, 921

pawnbroker does not warrant title of, $924 \mathrm{et} s e q$.

interests in land, 509

\section{CHEQUE,}

definition of, 478

person taking stale, does so at his peril, $458(n)$

duty and authority of banker to pay, when determined, 479

action against for dishourouring, 84

right to satisfy himself of genuineness of, $84(a), 476(b)$

if not presented in time, common law rule, 479

crossed, 479

statutory rule, 479

generally, 480

specially, 480

with words "not negotiable," 480

crossing is a material part of, 480

if crossed to more than one banker, $480(x)$

protection to banker receiving payment of crossed, $4 \$ 1$

paying cheque not apparently crossed, 481 


\section{CHEQUE-continued.}

liability of banker paying forged, 481, 482

unless there has been gross laches on the part of his customer, $482(c)$

duty of banker upon whom crossed cheque is drawn, 480

admissibility in evidence of post-dated, $479(0)$

solicitor has no implied authority to bind his partner by post-dated, 635

liability of banker for dishonouring married woman's, 680

\section{CHIEF JUSTICIAR,}

office of, 23

when it fell into desuetude, 28

\section{CHILD,}

meaning of, in Lord Campbell's Act, $816(\mathrm{~m})$

an illegitimate, is not within the Act, $816(\mathrm{~m})$

in $42 \& 43$ Vict. c. $49,1082(e)$

indictable offence for parent not to feed helpless, 991

exposure of, when murder, 1034

manslaughter, 1034

person endeavouring to conceal birth of, not triable by justice of the peace, 1050

\section{CHOSE IN ACTION,}

what it is, 443 .

if not assignable by law merchant or statute cannot be made so by express contract, 444

not transferable, 44

reason of this, 444

exceptions to rule, 445

transferred by death, bankruptcy, and formerly marriage, 445

of Crown are assignable, 445

doctrine in equity as to assignment of, 445,446

bills of exchange and promissory notes, 447

at common law husband could reduce wife's, into possession, 676

no larceny of, at common law, 1058

\section{CHURCHWARDEN,}

assault by, when justifiable, $7 £ 6$

CIRCUITS,

origin of, 26

CIVIL DEATH, marital relation severed by, 700

\section{CIVIL LAW,}

how far binding, 20

CIVIL PROCEEDINGS, what are, 45

CIVIL REMEDY, when suspended, 99

Clais. See Pleidixg.s.

indorsement of, on writ, $116,117,125$

CLIENT,

no pririty between, and town agent of solicitor, 316

\section{CI.LI,}

liability of member of, 622,633 
COAL MIINES,

rights of owners of adjacent, 82

COGNOVIT,

what it is, $255(u)$

COHABITATION,

past, no consideration for promise, 365

bond for past, mar be good, 366

COMMENDATORY EXPRESSIONS

in contract for sale of land, $332(f)$

COMMERCIAL CAUSES, 52

COMMISSION

of judge, 43

of justice of the peace, 1079

evidence on, 175

CONIMISSIONERS,

not personally liable on their contracts, 616

liability of, for negligence, $755(h)$

COMMITMENT

in County Court, 201, 202

'for contempt, 202

under Debtors Act, 202

COMMITTEE OF INSPECTION, 659. See BANKRUPTCY.

COMMODA TUM,

how defined, 920

COMMON,

tresplass to, 86

house interfering with right of, may be pulled down, 209, 210

COMMON CARRIER. See CARIER.

delivery of goods to, may be prima facie deemed to be delivery to buyer, 433

contract with, which seller must make, 434

where goods delivered to, to be carried by sea, buyer to have notice enabling him to insure, 434

COMMON LAW. See Lex nox Scripta.

what it is, 2

assimilated to equity, 38 et seq.

extrinsic evidence almissible at, to annex incident to written contract, 583 et seq.

COMMION PLEAS, COURT OF,

its origin, 26

its former jurisdiction, 32

when it ceased to exist, 33

COMMON PLEAS DIVISION,

its origin, 33

its jurisdiction, 33,34

merged in the Queen's Bench Division, 34

COMMON SEAL, 643 (h). See Conporation.

COMMON SENSE,

what is, in law, 21

COMIION SERVICE,

doctrine of, 807

B.C.L. 


\section{COMMONER,}

action by, for trespass, $\$ 6$

rights of, 99

may abate nuisance, $\approx 09,210$

entry by, when justifiable, 878

COMPANIES (IEMORANDUM OF ASSOCIATION) ACT, 651 (d)

COMPANIES (WINDING-UP) ACT, 1890, $957(s)$

COMPANY. See Corporatios.

contracts for shares in, are uberrime fidei, 332

liability of directors accepting bill of excliange without authority, $473(k)$

sharelolder in, cannot bring action of deceit against, 624

how it differs from a partuership, $626(q)$

privity between third person and, $650(b)$

implied powers of trading, to borrow, $651(f)$

liability of persons concerned in projected, 652

of promoter or director for fraud, 652

winding up of, $650(b), 957(s)$

alteration of memorandum of association, $651(d)$

fraud in connection with, 952

formation of, 953

promoter of, 955

liability of promoter, \&c., under Directors' Liability Act, 954, 955

duty of vendor of property to, 956

action by shareholder against directors of, 956

by third person against, 959

contribution to assets of, in winding up, 957

evidence to be adduced, 959

" COMPASSING AND IMAGINING," meaning of these words, $1015(l)$

COMPENSATION,

statutory rules as to, 95,96

none for noise or smoke of trains, 96

CoMposition, 656. See Bankinytcy.

COMPROMISE

of claim is good consideration for a promise, 313

prosecution for felony, contract for, is illegal, 355

COMPULSION

to lay, what anounts to, $306(n)$

CONCURRENT ADIINISTRATION OF LAW AND EQUITY, rules as to, $39 \mathrm{ct}$ scq.

when rules of equity shall prevail, 38

CONCURRENT IVRIT

of summons, what it is, 131

CONDITION

of bond to be strictly performed, $273(a)$

CONIITION PRECEDENT,

arbitration when, 42,43

when dispensed with by act of party, 112

relief in equity as to, 294

CONFESSIONS,

when admissible in evidence, 1091, 1092

must lie voluntary, 1092 
CONSENT,

jurisdiction by, 43

in Comity Courts, 56

of judge or attorney-general, when necessary hef re action, 115

is of the essence of contract, 248

how discovered, 249 (c)

what it implies, 249

effect of, criminally, 1049

CONSIDERATION,

umnecessary in a deed, 266,284

absence of, may be proof of fraud, 285

good, 286

valuable, 286

importance of distinction, 286

usually acknowledged in a deed, 288

feoffment to stranger without, its effect in equity, 287

by the Statute of Uses, 287

a necessary ingredient in simple contract, $311,395,390^{\circ}$

when it cannot have been gratuitous, request will be impliel, 39

executed, when request will be implied, 305 et ser.

will not sustain subsequent promise, 304

when gromiser has benefited by, request will be implied, 30;

moral, will not support subsequent promise, 309 , $325 \mathrm{ct} s \mathrm{~s}$. exception to this rule, 309

continuing does not need request, 310

definition of, 311

failure of, 311

promise withont, will not support an action, 311

acceptance of separate liability of one of two joint debters is gool

for discharge of the other, $314,639(i)$

compromise of claim is good, 313

court will not inquire into the alequacy of: $31: 5$

but must not be illusory, $: 315$

where plaintiff is a stranger to, 315

past and executed, 320

concurrent, 320

continuing, $310,311,321$

executory, 321

executed, will only support such jromise as woull he implied by law, 323

exception to this rule, 324,325

not atfiliativa a child is gooul, $326(u)$

if bad in part is bad altogether, 348

necessary for contract in restraint of trade, 359

must be stated under Statute of Framds, 375

except in a guarantie, 375,379

where it may be supplied by parol evilence, 380

presumed in bill of excliange and promissory not?, 498

presumption, how rebutted, 499

CONSIGNEE,

rights of, 507

by statute, 507

CONSIGNOR,

rights of, $506^{\circ}$

stoppacre in transitu by, 507

when right to stop ceases, $507(d)$

CONSPIRACY,

how constituted, $1020 \mathrm{ct}: c^{\prime}$. 
CONSPIRACI-continued.

malieions, to sue plaintiff, $843(b)$

may be overt act in treason, $1019(b)$

two persons tried for, must be both eonvicted or botll acquitted, $1020(d)$

effect of avement of, in civil action, $1020(d)$

agreement of members of parliament to defame plaintiff in the House is not, 1022

to do that which if done by one would not be a crime may be criminal. 1022

when cognizable by justice of the peace, 1050

CONSTABLE,

demand for warrant of, before action, 116

may arrest on bare suspicion, 826

powers of, 828

liability of, in action for false imprisonment, 829

jroteeted by warrant of eourt of competent authority, 829

by statute, 829

CONSTRUCTIVE DELIVERY, 40s. See Driskr.

CONSTRUCTIVE KNOWLEDGE,

may supl!! place of actual, by statute, 987

CONSTRUCTIVE POSSESSION, 914, 1055. See Posisesion.

CONSTRUCTIVE TREASON, 1018. See TreAsos.

CONSULAR COUR'T

of Constantinople, judgment in, $261(x)$

CONTEMPT,

judge of County Conrt can eommit for, 202

CONTENTIOUS ENJOYMENT,

will not confer a right under the Prescription Act, 896 (i)

CONTIXUING CONSIDERATION, 310, 311, 321. See Cossmeratios.

CONTRACT. Sce Conpolatios, Isfaxt, Malined Womas, Luxatic, Ixtoxication, Duless, Aliex, Exectror, Priscipal axi, Aliwer, Statute of Frates, Costract of Sale of Goods, LANILOHI AND TENAST, ete.

whether plaintiff should sue on, or in tort, $67(1), 771,772$

nere breach of, is iujuria, 72

actionable to induce third party to break, $91 \mathrm{ct}$ seq.

when liability for breach accrues, 112

reseission of, 114,349

action by or against personal representatives for breach of, $121 \mathrm{ol}$ seq.

rflect of bare denial of, in pleading, 141,142

simple, when barred by Statute of Limitations, 156

lefinition of, 244

Executory, 245

executed, 245

express, 245

right of action may be foundel on executed or executory, 245

implied, " $46^{\circ}$ et seq.

in letting firnished honse, 248

in prepring specitications, 248

on what founded, 248

consent is of the essence of, 248

legislative prohibitions against, 249

incalacity to contraet, 219,250

operation of lex leci un, 251

obligatory force of, whince derived, 25i2 et seq. 
CONTRACT-continucl.

obligatory force of, how discharged, 25.5

classes of: 255,256

of record, 256 et scq.

its characteristics, 256

works a merger, 256,273 et seq.

practical importance of, 258

an estoppel, 260,276 et seq.

judgment, is a consensual contract, 262

constitnted by statute, 263

by specialty, 255,263

unilateral or inter partes, 263

characteristics of, $264,273,395$

signing, whether necessary, 264

delivery, 264

covenants, 267 et ser.

construction of, 268

bond, 272

illegality may be pleaded, $276 \mathrm{ct} s \mathrm{sc}$.

reeds no consideration, 284

binds heir, 289

devisee, 289

how discharged, 290

simple, 256, 296, 395, 396

analysis of, 302

founded on moral obligation void, 309

in frand of creditors is voil, 280

terms of, must be definitely settled, 297

acceptance by letter, 299,300

communication of, $298(a)$

revocation, 299

reciprocity of assent in, 300

mutuality, 300

of infant voidable at his election, 301

binding on other party, 301

ratification of, 305

need of privity, 312 et ser.

who caunot contract, $32 \%$

effect of frand on, 327 et seq.

procured by frand can be ratified, $328(e), 329$

voidable only, not void, $328(e), 329$

for shares in companies is uberrime fulc $i, 332$

for sale of lands avoided by misdescription, 332

of marine insurance, 331

of fire insurance, 331

of life insmrance, 332

contracts uberrime fidei, 331

illegal, 346 et seq.

hy specialty are voik, 346

simple, are void, 346

in violation of the law, no action can be brought upon, 347

illegal quoad promise, 348

quoad consideration, 348

simoniacal, $348(q)$

test as to legality of, 352

illegal, to import goods contraband of war, 351

to indemnify for publication of libel, 351

void as opposed to public policy, 352 ct seq.

ragering, $354,354(u)$

so if they cause waste of time, or are indecent, or annoy

others, 354 
CONTRACT-iontinued.

illegal, to compromise prosecution for felony, 355

in restraint of trade, $356 \mathrm{ct} s \mathrm{sc}$.

against alienation of land, 355

for fraudnlent preference in bankruptey, 356

not to marry, 355

marriage brocage bonds, 355

in contemplation of future sepraration of man and wife, 35.5 secus of inmediate separation, $355(h)$

arising olit of gambling transactions, $356(n)$

to indemnify bail, 355 (i)

for sale of offices, $356(n)$

champerty, maintenance, $356(n)$

immoral, what they are, 365

frarol, what it is, 369

no third class in writing, $36 \mathrm{~s}$

if not specialty, is parol, 369

written, more weighty than oral, 369

evilence inadmissible to rary witten, 369

unless in case of fraud, 369

may be waived or varied orally before breach, 370

when required to be in writing by statute, 372,373

concerning land under s. 4 of the Statute of Frands, $38 \% \mathrm{ct} \mathrm{scq}$.

of sale, what, 402

of drunken man roidable, not void, $505(\mathrm{~m})$

rules of interpretation and evidence in case of witten, 572 ct seq.

two classes of rules, 572 et seq.

ambiguity patent or latent in, 574 ct seq. Sce $\Lambda$ ubigritr.

oral matter cannot vary written, 573

nor previous written agreement vary deed, 574

evidence admissible to identify subject-matter, 576

parties, 577

to charge principal on contract signed by agent, 557

but not to discharge agent, 577

to explain mercantile terms, $578 \mathrm{ct} \mathrm{sc}$.

to prove allowance of discount, 583

to annex incident, by nsage of trade, 583 et seq.

by custom of country, 584 .

by common law 583

hy reasonable laws and usages of the Stock

Exchange, 585

to explain words apparently unambiguous, 587

when terus have both popular and technical meanings, 579

Inovince of court, 579,588

of jury, $579,580,588 \mathrm{ct} s \mathrm{se}$.

where contract evidenced partly by witing, partly by conduct, upuestion for jury, $580(g)$

where terms of science or art occur, 581

where in foreign language, ;SI

where mereantile terms used, 581

"vidence to contradict written, inalmissible, $5 \$ 6$

plaintifl must produce intelligible, 592, 593

rules for exposition of written, 593, 594

with mereantile persons, $595 \mathrm{ct} s \mathrm{c} \%$.

of infant. $667 \mathrm{et} \mathrm{ser}$.

"onld not be at common law between man and wife, 675

of unarried woman, $675 \mathrm{ct} \mathrm{ser}$.

uneaning of, in Married Wonen's Property Act, 1882, 6S2 $(f)$

of lunatic, 700 
CONTRAC'T-continued.

of drunkell man, 704

of person under duress, 705

of alien, 707

of ontlaw or felou, 707

measure of lamages for breach of, $717 \mathrm{ct} \mathrm{scq}$.

importance of a knowledge of, 744

limiting effect of the Railway and Canal Trattic Act, $938 \mathrm{~d} \mathrm{~s} \%$ when unreasonable, 940

special, prior to Act, 941,942

statutory restrictions, 941,942

to restrict carrier's liability, 941

special, what will amount to, 941 (i)

how differs from tort, 982

illegal, not necessarily criminal, 989

\section{CON'TRAC'T OF SALE OF GOODS.}

the Sale of Goods Act, 1893, has codified the law relating to, 40.2 defined, 402

formation of the contract, 402

"goods," meaning of, within Act, 402, 403

"specific," " unascertained," and "future" gools, 403

"sale," "agreement to sell," distinguished, 403

the property in the goods may pass by the contract, 403

capacity to buy and sell, 403

" necessaries" sold and delivered to an infant, 40:;

formalities of the contract, 404

the Statute of Frands, s. 17, 404

object of the Statute of Frands, $404(r)$

Lord 'Tenterden's Act, 405

effect of s. 4 and s. 17 of the Statute of Frands, 405, 406

s. 4 of the Sale of Goods Act, 1893, 406

requisites that must be complied with where goods are of the

value of 101 . or upwards, 407

actual receipt within the section, 408

constructive receipt, 408

acceptance of goods, meaning of, within section, $408 \mathrm{et}$ ser.

part performance of the contract, 412

part payment, 411

earnest, what, 411

note or memorandum within the section, 41\%

alteration by verbal agreement of contract in writing satisfying

Statute of Frands, 413, 418, 419

agent may sign note or memorandum within section, 414

anctioneer, how far agent, 414, 415

broker, how far agent, 416

duty and practice of stock and share brokers, 417

bonght and sold notes, 418

subject matter of the contract, 419

impossibility of performance by reason of goods perishing, 4:0

price may be fixed by contract or otherwise, 420

omission to fix price does not necessarily invalidate the contract, 420

price may be left to be fixed by valuation of a third party, 421

conditions aud warranties, $42 i \mathrm{ct} \mathrm{seq.}$

rights of aggrieved party according as breach is of condition or

warranty, 421

provisions of the Act as to conditions and warranties, 4:2

warranties and conditions implied, $423 \mathrm{et}$ seq.

implicd condition on sale hy description. 423

as to quality or fituess for prarticular ['ul ] ose, $4: 4$ 


\section{CONTRACT OF SALE OF GOODS-continued.}

implied condition that the goods are of merchantable quality, 424 in sale by sample, 424,425

trausfer of property, 425 where the goods are unascertained, 425

where the goods are specific, dependent upon intention of the parties, 425

rules for ascertaining the intention of the parties, 425 et seq.

goods delivered on approval or on sale or return, 427

the seiler may reserve right of disposal, and so property not pass, 428 transfer of risk, 428

transfer of title, 429

general rule of law, no one ean transfer a better title than he has, $4: 29$ exceptions to the rule, $4: 29$

where gools are sold in market orert, 429

where seller has avoidable title not atvoided at time of sale, 429

where the goods have been stolen, and the offender is prosecnted to conviction, 430

the seller contimuing in possession, person receiving in good faith and without notice, 430

the buyer in possession witl seller's consent, person receiving in good faith and without notice of lien, 431

ss. 8 and 9 of the Factors Act, 1889, $430(u), 431(o)$

effects of writs of execution in England and Ireland, 431

performance of the contract, 432

lities of buyer and seller, 432

delivery, rules as to, 432 et scq.

acceptance, when is the buyer deemed to have accepted ? 434

buyer's liability for neglect or refusal to take delivery, 435

unpaid seller's rights against the goods, 435

who is an nnjaid seller within the Aet, 43\%

unpaid seller's lien, 436

un paid seller loses lien in certain cases, 436

stoplpage i: transitu, 436

duration of the transit, 437

exereise of right, method of, 438

re-sale by buyer or seller, 438

rescission of contract by exercise of lien or right to stoppage in transitu in certain eases, 439

breach of contract, actions for, 439

seller's remedies, 439

damages, measure of, 440

buyer's remedies, 440

breach of warranty, remely for, 440

damages, measure of, for breach of warranty, 441

anction sales, 441

(ONTRACTOL,

liability of, for tort of workmen, $794(k)$

(ONTRIBUTION,

right of, between joint contractors, 307

coxTHIBUTORY NEGLIGENCE, 787. SC NEGLIG

fleadable by employer uniler the limployer's' Liability Act,18s0, 815

CONVEYANCF:

of lessor's whole interest is an assigmment, 509

executed by lumatic, whether void in absence of notice or fraul, $701(r)$

CONVFYANCING ACT, 295, 517, $524,559,564$ 
CONVICT,

leases by and to, 513,515

COPYRIGH',

infringement of, is actionable, 85

whether it exists at common law, 748

musical and dramatic, $748(n)$

CORONER,

committal of prisoner by, 1086

power to accept bail, $1086(\approx)$

CORPORATION,

how interrogated, 164, 165

leasing porrers of, 516

how regulatel, 493,516

may be lessees, 516

must in general contract by deed, 399,612

exceptions to this rule, $644 \mathrm{et} s c q$.

not to be extended to executory contracts, $647(q)$

equitable doctrine as to part performanec of contract not applicable, 6.50

delivery of deed by, unnecessary, $264(n), 643(y)$

municipal, 644

ecclesiastical, 644

capacities and incapracities of, $643(h)$

common seal of, $264(i), 643(h)$

want of mutuality in contracts with, $301(y)$

trading, how established, 650

officers appointed to contract for, 650

doctrine of ultra vires as appliet to, 651,652

what able to accept negotiable instruments, 645 (il)

not bound by parol order of agent appointed umler seal, $649(r)$

must employ solicitor under seal, 643

or railway contractor, 643

may sue or be sued for libel, $793(h)$

liable for firaud or misfeasance of servant, $793(h)$

whether action for malicions prosecution will lie against, $\$ 39(l)$

CORPOREAL HEREDITAMENT,

CORPSE

lies in grant as well as in livery, $399(c)$

not the subject of property, 1058

burning, when a misdemeanour, $989(t)$

CORPUS DELICTI, what in treason, 1015

CORRUPT AND ILLEGAL PRACTICES PREVENTION ACT, 1895, 1056

cosTs,

when they follow the event, 181

when are in discretion of court, 181

right of unsuccessful defendant to, $118(d)$

given as punishment, $46(r)$

in County Courts, 201

execution for recovery of, 201

incurred by married woman, payment of out of separate estite subject to restraint, 683 (1)

why given, $717(b)$

incurred in defending action resulting from anotler's lefault, 736 (i) of improvidently defending action not recoverable as ilimages, ifo (in)

COUNSEl. See Barister. 
COUNTERCLAIM AND SET-OFF,

minliquidated, in Connty Conrt, 61 (z), 69

nature of, 150

seprarate against separate plaintiffs, 151

against plaintiff suing in personal character, 151

neel not enual plaintiff's claim, 151

what may be set up as, 159

may be excluded, 159

may be proceecied with though plaintiff's action is stayed, 159

against third party, together with plaintiff, 162

in County Court, 199

of landlord, 570

none by purchaser of stolen beasts in market overt for cost of their

keeI', $913(r)$

\section{COUNTEKMAND}

of jayment of cheque determines banker's authority, 479

\section{COUNTY COURT. Sce SHIRE Cotrt.}

ordinary jurisliction of, 56 et $s c q$.

distinet from old County Court, $56(y)$

compulsory removal of ease to, 56

where has no jurisdietion, 56

juriscliction of, in contraet, 57

-plitting demands not allowed, 58

abantioning excess allowed, 58

must be made on partienlars of demand, $55(0)$

effect of so loing, $\hat{6} 0$

when advisable, bo

actions when sent to, from superior courts, 61,65

unliquiclated counterclaim in, $61(z), 69$

consequences of wrongly suing in superior court, 66

jurisdietion by consent, 61

cases excluded from jurisdiction of, 61,62

jurisdiction of, in ejectment, 62

when title to realty comes into questicn, 63

in replevin, $64(n), 66^{\circ}$

incidentally raised, 64

in tolt, 61

sprecial statutory jurisdiction, $68(f)$

orer partnership aceounts, 67

distributive share of personalty under intestaey, 67

legaeies, 67

explitable relief. $6 s, 6 s(k)$

interpleader, 68

wrongliul possession by tenant, $6 \mathrm{~s}$

A. liniralty, 68

connterelaim, 68, b9

lankruptey, 68

sencely by probihition when juristietion wrongly assumed by, 63(i)

remersial of case to High Conrt, 69

costs of platintitl, 66

fuartice, how constituted, 196

action, how commencerl, $196^{\circ}$

simmons to aplear, 197

service of summons, 197

personal, when dispensel with, 197, 198

Jhint, where enterel, 196

partirulars of elemand must be anuexed to summons, 197

"11. fault surnmous, 197

summons not in orlinary form, 198 
COUNTY COURT-emtinued.

notice of intention to defend, $19 \overline{\mathbf{T}}, 198$

counterclaim, 199

special defences, 198

course of pleading, 198

notice of certain defences, 198

interrogatories, 199

inspection and discovery, 199

trial in, 199

assessors, 199

dities of registrar, 200

judge, 199 et seq.

jury, when summoned, 199

default of appearance, 200

costs, 201

simmons to witness, $200(y)$

execution for recovery of costs, 201

julgment, how enforced, 201

comminiment of debtor, 201

for contempt, 202

ivjunction against nuisance, 201

new trial, 202

certiorari, 202

appeal to superior court, 203

in action of contract or tort, 203

where title to hereditament in question, 203

note by judge, 204 of replevin, 203

COUP'T. Sec Costract, Evidesce, Judge.

summary jurisdiction of, 46

must decide if any extrinsic evidence is admissible to explain written contract, 579

generally must construe written instrument, 579,585 exceptions to this rnle, 588, 589

COURT OF APPEAL,

is a superior court of record, 34

how constituted, 34

its jurisdiction, 31,35

law and equity concurrently administered by, 37

sittings of, 48

power's of single judge of, 49

application to, by motion, $49(f)$

appeal to, 186 et seq.

its eftect, 187

powers of, 188

eridence before, 188 (c)

appeal lies to, against order striking solicitor ofl the rolls, $213(\mathrm{r})$

appeal to, in habeas corpns, $23 i$

in criminal cases, 1096

COVENaNT. Sec Laxilord axd Texast.

definition of, $267(d)$

executed and execntory, $26 \pi(c)$

recital in deed may amount to, $267(f)$

conld not be between husband and wife, 676

what amounts to breach of, for right to conve!, $720(4)$

damages for breach of, to repair, 730

COVENANTS. Sco Laxplond axd Texast.

in deeds, what they are, 267 
COVENANTS-continued.

no special words necled to ereate, 267

how construed, 268, 5.26, 534

independent, 268

dependent, 268

concurrent, 269

real, 269

personal, 269

collateral, 269

in gross, 270

ruming with the land, 270,557

are assignable, 445

express, 271

implied, 271

for yuiet enjoyment, 524

by Conveyancing Act, 1881, 272

action on, 569

COVerture, 675 et seq. See Married Wouls.

whether a disability under the Prescription Act, 901 (i)

notice of, as defence in County Court, 198.

ClEDIT,

sale of goods upon, 426

CREDITORS,

contract in fraud of, void, 284

CRIME. Sece Crimixal Law.

meaning of work, 988

what it is, 990 et seq.

need not be malum in se, 989

test of whether act is, $98 s$

low distinguished from tort, 983 et seq., 990, 991

CRIMIXAL APPEALS, 1096. See Crowy Cases Reserved.

CRIMIINAL CONVERSATION,

action for, not now maintainable, 967 (c)

CRIMINAL INFORMATION, 230. See INFOHMATIOS.

CRIIIYAL LAW. Sce HouICIDE, LARCExy, Munidr, etc.

imprortance of a knowledge of, 956

igrnorance no excuse for infringing, 986

speaks imperatively, 986

cinnot be disobeyed at discretion, 987

what are crimes, 989,990

when inlictment will lic, 991

indietable offences, 991,992

meaning of "intention" in, 992 et seq.

onus of jroving, 993,994

how provable, 996

incres rere, when essential, 994

when mind at fanlt actively, 99:, 995

mbilice, what, 994

passively, 994, 995

immaterial whether act done directly or indirectly; 995

losscession of obscene prints not an indistable offence, $99 \mathrm{~s}$

recus, if procuresl with intent to publish, 998

mere intention not an offence without overt act, 997

luw distiugruished from attempt, 997

woljitition is an act, 998

\#ttemint uay be inllictable, 995

to conmit suicide is, $998(q)$ 
CRIMINAL LAW--continued.

crime by mistake indictable, $\$ 99$

party must be free agent, 1000

exemption of infant, lunatic, feme covert, mder duress, $1000 \mathrm{el}$ or for accident, 1000

homicide by misadventure, 1000

in course of duty, 1000

position of lunatic, 1001 et seq., 1006

meaning of non compos nucntis in, 1002

rules in JleNaghten's case, 1002 et seq.

as to insane delusions, $1003 \mathrm{el}$ seq.

onus of proof of insanity on prisoner, 1006

position of drunken man, 1007 et seq.

of infant under seven, 1009

under fourteen, 1C09

in trial for rape, 1010

in non-capital offences, 1010

not liable for nonfeasance, 1010

exceptions to rule, 1010

duress, when an excuse, 1011

high treason, what, 1012

allegiance, natural and loeal, 1012

duty of friendly alien, 1012

of nnfriendly, 1013

allegiance, to whom due, 1013

and protection reciprocal, 1013

Statute of Treasons, 1013 ct scq.

in treason intention is the crime, 1015

but must be proved by overt act, 1015

wert act, what, 1016 et scq.

constructive treason, 1018

offences against the state and public safety, 1019 ct siy.

seducing subjects from allegiance, 1020

raising trool's without authority, 1020

seditious meetings, 1020

libel, 1020

conspiraey, 1020

misprisions, 1020

contempts, 1020

blasphemous publications, 1020

offences against executive power, 1023 et ser.

against aduinistration of public justice, ?024

by juclicial officers, 1024

by private persons, 1024,1025

escapes, 1024

perjury, 1025

against public peace, 1025 ct s'\%.

riots, 1025,1026

routs, 1025,1026

routawf ful assemblies, 1025,1026

forcible entries, 1025,1026

Riot Act, 1027

riots to remedy private nuisances uot within statut.

of Treasons, 1026

forcible entry indictable, 1029

mere trespass to land is not, 1029

assault and battery, 1029

against public revenue and trade, 1029

smuggling, 1029

fritudulent bankruptey, 1029 
CRIMIXAL LAW-contimed.

oflences against public morals, health, police, 1029

bigany, 1029

breach of game laws, 1029

nuisance, $102 ! 1,1030$

offences against individuals, 1032 et seq.

homicide, degrees of, 1032

murder, 1032

manslanghter, 1032

excusable, 1032

justifiable, 1032

murier distinguished from manslaughter, 1033

exposure of child, 1034

neglect of person in care of prisoner, 1034

homicide presumed to be malicious, 1035

juvince of jurlge and jury in determining whether homicile be murder, 1035

listinction between culpable, excusable, and justifiable homicide, 1036

homicide on provocation cannot be reduced below manslaughter, 1038 struggles, 1039

juize-fights, $1039(n)$

liability of persons present at, $1039(n)$

homicile by nndne correction, 1040

by negligence, $1040 \mathrm{ct}$ seq.

to amount to manslaughter must be personal, 1042

- secus, of trustees not repairing roads, 1042

of medical practitioner, 1042

general doctrine as to, 1042

in resisting officer, 1043

in consequence of unlawful assembly, 1043

by officer may be murder or manslaughter, 1044

secus, if person killed be a felon, 1044

in recapturing slaver, 1045

when justifiable, 1045,1046

not of mere trespasser, 1046

when excusable, 1046

in self-defence, 1047

no forfeiture for, withont felony, 1045

murder involves felonions homicide, 1048

assaults, 1048

aggravated and common, 1048

battery, 1049

incessory aftel fact, who is, $1048(c)$

lilisel, 1050 et ser.

blnsphemous, $1050(u)$

lnty of judge and jury in libel cases, 1050, 1051

Fox's Libel Act, 1051

Lord Camplell's Act, 1052

criminal information for, 1055

threatening to publish libel, 1055

Newspapers Libel und Regristration Act, 1055

Comupt uml lllegal l'ractices l'revention Act, 1895, 1056

simple larceny, $1057 \mathrm{et}$ seq.

of what it cannot be committed at common law, 1057, 1058

iroperty of chattel must be in owner, 105 ?

chattel must have been in actual or constructive possession, 1059

none when property originally obtained lawfully, 1060

trespass included in felony, 1061 
(RIMINAL LAW-continued.

simple larceny-con.

conversion by bailes not larceny at common law, 1081, 10** unless broke bulk, 1062

secus, by statute, 1062

what amounts to a "taking" in, $1062 \mathrm{et}$ seq.

when goods obtained in pursuance of a contract, 1063

taking must have been aninio furandi, 1064

appropriation of lost goods, $1065 \mathrm{ct} 8 \mathrm{cq}$.

doctrine of relation in, 1068

ingredients to support indictment for, 1069

asportation, what, 1069

may be by innocent agent, 1070

receiving stolen goods, 1070

obtaining money by false pretences, $1071 \mathrm{ct} \mathrm{scq}$.

pretence must be of facts, 1072

embezzlement, 1073

larceny from the person, 1074

robbery, 1074

Director of Public Prosecutions, 1076

his duties and powers, 1076,1077

transferred to solicitor to 'Treasury, 1078

justice of peace, powers of, $1079 \mathrm{et} \mathrm{seq}$.

as criminal judge, 1079,1080

restrictions on, 1079,1080

summary jurisdiction of, 1081 et seq.

committal of offenders by magistrate, 1085

by coroner, 1086

by order of Privy Couneil or Secretary of State, 1086

on information by attorney-general or Jlaster of Crown Office, 1086

grand jury, presentment by, 1086

indictment. 1086

bill preferred to, by private person, 1086

form of, 1087, 1088

arraignment, 1088

plea, 1088

lemurrer, $1089(u)$

when prisoner will not plead, $1089(x)$

swearing the jury, 1089

challenge to, 1089

giving prisoner in cliarge to, 1089

case for the Crown, 1090

rules of evidence to be observed, $1090 \mathrm{et} s c q$.

dying declarations, when admissible, 1092

confessions, 1091

must be voluntary, 1092

evidence generally given virấ roce on oath, 1093

may be by depositions, 1093

judge may discharge jury in felony ease, and his discreti un will not

be reviewed, 1095 (u)

case for the defence, 1093

reception of prisoner's statement, 1094

verdict, 1095

iudgment, 1095

indictment, demurrer to formal defect in, 1095

amendment of, 1095

motion in arrest of judgment, 1095

wit of error, 1095 
CRIMINAL LAW-continued.

Court of Crown Cases Reserved, 1096

no appeal to Court of $A_{\text {l'peal, }}$ sare for error on the record, 1096

pardon, absolnte, 1096 conditional, 1097

forfeiture abolished, 1097

administrator of conviets' property, 1097

curator, 1097

CRIMINAL LUNATIC, 1001. Sec Crimisal Law.

CRIMINAL OFFENDERS,

extralition of, $45(p)$

CRIMINAL PROCEEDINGS,

what are, 45

between lusband and wife, $\dot{60} \overline{\boldsymbol{i}}, 688$

CRITICISIS,

fair, not actionable, 74

CROPS,

annexed to land, 388

growing, go to executor, 388

were regarded as within s. 17 of the Statute of Frauds, 359

not within s. 4,389

whether are personal chattels within the Bills of Sale Act, 388 (1/)

whether "goods" within the Sale of Goods Act, 1893, 403

light of tenant to, 527

when distrainable, 553

CROSSED CHEQUE, 479. Sec CheqUe.

CROSSING, 480. See CHeque.

CROWX,

prerogative of, not affected by the Judicature Acts, 33

caunot grant dignity unknown to law, $8(\mathrm{~m})$

jurisdiction of, on ligh seas, $45(p)$

ratitication of trespass by, 103, 804

mandamus will not issue to, $215(z)$

choses in action of, transferable, 445

leasing powers of, 516

scrvant of, contracting officially, not personally liable, 615

mandamus will not issue to, $215(\approx)$

binkrupit debtor to, not released by order of discharge, 662

is the fountain of mercy, 1096

jarlon by, is pleadable to indictment, 1089 (u)

CROWN CASES RESERVED, court of, 1096

iUliATOK

of property of convict, 1097

CUIIIA IIEGIS, 23. Sce AULA Ri:aIs.

( 'USTOII,

loss of, is purely personal right of action, $96 \Leftrightarrow$

CUSTOMARY LAW, 7. Ser LEX NON SCIPTA.

CUSTOMARY RIGHT

to water from spont, 88

CUSTOMFR, 474. See BaxkeI. 
CUSTOMS. See CoNTract, Evidexcl.

general or partisnlar, 7

manorial, 10

particular or local, 10, 11

evidence of enjoyment of, 11

must be contiuued, 12

peaceable, 12

reasonable, 13, 14

certain, 14-16

compulsory, 17

consistent, 17

interpretation of, 18

of the country, 18, 525

mercantile, is $(g)$

of London, how certified, $19(g)$

of trade may annex incident to written contract, 583

of country, 584

DAMAGE,

when natural and probable consequence of act, 94

remoteness of, $91,94(t), 980$

principles as to, same in contract and tort, $735(g)$

when too remote, 734 et seq.

rules as to, 736

liability of carrier in connection with remoteness of, $738(q)$

proof of special, in action for slander, when not necessary, $\$ 61, \$ 62$ prospective, recoverable in action of tort, 971

consequential, when recoverable, 980

remoteness of, in consequence of delay on part of railway company, $981(o)$

DAMAGE FEASANT,

distress, when allowed, 877

\section{DAMAGES}

in contract for sale of goods, measure of, 440

for breach of warranty in, measure of, 441

in contract, meaning of term, 717

nominal, recoverable for violation of right, 89

nominal, 718

general, 718

special, 718

measure of, 718

intention generally irrelevant in contract, 718 secus, in tort, 719

in breach of promise of marriage, 720

nominal, when recoverable, 720

for failure to pay stipulated sum, 720,721

are generally a matter of account, 722

liquidated, defined by parties, 723

how distinguished from penalty, $724 \mathrm{ct} \mathrm{sc}$.

in action for freight, $722(f)$

for breach of charter-party, $722(f)$

on policy of marine insurance, $723(f)$

against master of ship for negligence, $723(f)$

penalties, rules as to, 726,727

for not replacing shares, \&c., 728

for breach of executory contract, 729

not reducible by proof of subsequent breach by [laintiff, 729, 730

for breach of covenant to repair, 730

for wrongful dismissal, $731,732(p)$ 
DAMAGES-continued.

no allowance for pretium affectionis, 731

latitude allowed to jury, 732

in actions on indentures of apprenticeship, 732

for sale of land nominal only in absence of fraud, 732

for loss of market, 739

for personal injury against railway company, 740

for breach of warranty of horse, $740(u)$

costs of improvidently defending action not recoverable as, $740(u)$

for false representation of agency, 741

for non-payment of bill of exchange, 742, 743

practical test as to right to recover, in action on a contract, 739,740

interest, when recoverable as, $741 \mathrm{ct} s c q$.

in tort in action for negligence causing death, 818 under Employers' Liability Act, 1880, $813(x)$

carrying away soil, 972 by master for battery of his servant, $969(q)$ for trespass, 971,974

measure of, generally, 971 ct scq. compensatory, 971

great latitude to jury, 971

who need not "weigh in golden scales," 975

vindictive, 975

new trial on ground of insufficient or excessive, when granted, 975,976

for obstruction to ancient lights, 971

for conversion of bill of exchange, 972

for chattel by bailee, 972

against sheriff for taking insufficient replevin bond, 972

for recovery of goods, $972(i)$

for negligence against solicitor, 973

for mere breach of duty, 973

for refusal to register transferee of shares, 973

for injury to freehold by reversioner, 973

for not properly appraising goods sold as distress, 973

for illegal or irregular distress, $973(r)$

for sale of horse by fraudulent warranty, 974

for libel, what jury entitled to consider in assessing, $976(\mathrm{~g})$

for fraud or misrepresentation, $978(r)$

for slander in way of trade, 980

substantial, though no special damage, 980

for taking goods, $981(k)$

general, 979

special, 979

substantial, when recoverable, 979,980

if not implied, must be proved, 980

criterion to measure, $981(k)$

a question for the jury, $971(a)$

DAMNUM,

how defined, 71

DAMNUM ET INJURIA,

difference between, 71

when fail to give action, $90 \mathrm{ct} s c \mathrm{\text { }}$.

where remedy is by indictment, 96

usually combine to give action, 108

DAMNUM SINE INJURIA,

meaning of, 71

not actionable at law, $72,82,88$ 
DAMNUM SINE INJURIA-continued. examples of, 72 et seq.

DAYS OF GRACE,

when allowed, $251(h), 459,486(r)$

holder of bill has no cause of action until expiration of the last of the, $459(o)$ judicially noticed, 9

DE BONIS NON, administrator, 714

DEAD BODY, $989(t), 1058$. Sce Corpse.

\section{DEATH,}

will not abate action, 124

causes transfer of choses in action, 445

assignment of lease and covenants, 559

of customer determines banker's authority to pay cheque, 479 revokes mere authority, 713

does not revoke contract, unless for personal service, 713

DEBT,

action of, 225

of record, $256(y)$

provable in bankruptcy, 654. Sce Baxkruptcy.

DEBTOR,

absconding, 132

arrest of, 132

imprisonment of, 132, $191(x)$

land of judgment, bound, 262

duty of, to seek ont creditor, $443(k)$

DEBTORS ACT,

abolished arrest for debt, $191(x)$

summons under, 202

commitment under, 201, 202

infaut cannot be convicted under, for defrauding his creditors, $671(r)$

DEBTS,

what can be attached, 228

DECEIT. Scc FraUd.

action of, not maintainable without proof of actual fraud, $333 \mathrm{et} \mathrm{seq}$. will lie for statement made recklessly, 336

\section{DECENCY,}

outrage on public, indictable, 992

\section{DEED,}

origin of name, 263

definition of, $263(e), 264(j)$

unilateral or intcr partes, 263

date of taking effect, 264

needs delivery, 264

has effect of indenture though not actually indented, 264

effect of retention by grantor, 265

cannot be partial execution of, $266(a)$

how delivered, 265

as an escrow, 265

to grantee, 265,266

properties of, 266

works a merger, 266

an estoppel, 266

needs no consideration, 266, 284 
DEED-continued.

sometimes will bind heir, 266

how discharged, 266

essentials to valid, 267

covenants in, 267

recital in, may amount to corenant, $267(f)$

estoppel by, 276

merges simple contract, 273

only where remedy co-extensive, 275

not if intention clear that there shall be no merger, 275

impeachable for frand or illegality, 276 et seq., 329

obligation by record may be released by, $279(x)$

not always avoided for all purposes by fraud or illegality, 282, 283

relief in equity against fruudulent, 284

distinction between, for past or insufficient consideration and for

illegal purpose, 288

consideration usually acknowledged in, 288

when necessary at common law, 398,399

by statute, 400

contract by, cannot be varied by previous written agreement, 574

necessary to authorise partner to bind firm by deed, 635

statitory exceptions, 636

corporation imust contract by, 399, 642. See Corporatiox.

DEFaMatioN, 844, 861. Sce Libel, Slaxder.

DEFAULT

of appearance, 136

by some defendants, 136

by infant or person of unsound mind not so found, 136 (i)

in action for recorery of land, $13 i$

for detention of goods, 137

in appearance by third party, 161

in County Court, 200

in pleading, consequences of, $14 \mathrm{~s}$

in action for recovery of land, 150

of mandamus, 149

of injunction, 119

in issues not between plaintiff and defendant, 162

judgment by, may be set aside, $163,178,179$

summous, 197

DEFECT OF TITLE,

meaning of, $458(\mathrm{~m})$

DEFENCE. See Actiox at Law.

nature of, 148, 150

payment into court, 152

limited to part of property, $13 \bar{t}$

costs of denial of facts which should have been admitted, 150

notice of, in County Court, 198, 199

effect of default in, 198

DEL CREDERE,

agent, undertaking of, 382

DELIRIUM TREMENS, 1008. SCE INTOXICATIOX.

DELIVERY. See DEED.

of deed necessary, 264

except in case of corporation, $264(n), 643(y)$

evidence of, $264(n)$

how effected, 265 
DELIVERY - continued.

not affected by retention by grantor, 265

of deeds as escrow, 265

to grantee, 265,266

of goods under contract of sale of goods, 432 ct scq.

how enforced, 230, 440

of specific chattel, how enforced, 229,230

whether necessary to pass the property in specific chattcl, 403, 425 et seq.

of goods by stated instalments, $\{33$

place of, 432

in third party's possession, 432

of wrong quantity, 433

to common carrier, 433,444

by seller at distant place, risk of deterioration incident to, $\mathbf{4 3 4}$ constructive, 408

may be actual or constructive, 408

implied by receipt, 408

if none, actual or constructive, no receipt, $\mathbf{4 0 8}$

when will pass bill of exchange, 454

necessary after indorsement of, 455

meaning of, $455(x)$

conditional, 456

essential to bailment, 916

and gift necessary to pass property in chattel, 979

DELIVERY OF SPECIFIC CHATTELS,

how enforced, 229, 230

writ for, 192, 193

DELUSIONS,

insane, rules as to, 1003 et seq.

"DEMISE,"

formerly imported covenant for quiet enjoyment, 271, 524

DEMURRER,

abolished, 145

process substitnted therefor, 145

to indictment, $1089(u), 1095$

DEPARTURE,

what it is, 142

not allowed in pleading, 142

DEPOSIT,

how defined, 917

included in first-class bailments, 917

DEPOSITIONS,

when adunissible in a criminal trial, 1093

DETINUE,

action of, 225

DEVASTAVIT,

liability of a married woman for, $688(q)$

DEVISEE,

when liable on deed of devisor, 289

DIRECTOR OF PUBLIC PROSECUTIOXS, appointment of, 1076

duties and powers of, 1076,1077

solicitor to Treasury now is, 1078 
DIRECTORS. See CoMpaxy.

accepting bill of exchange without authority, $473(k)$

when liable for frand of co-directors or agents, 624 personally, 652

liable $c x$ delicto without privity, 772

when not so liable, 777

executors of, not liable for frand of testator, 777

DIRECTORS' LIABILITY' ACT, 1890, 954, 955

DISABILITY, 901. See Easements, Prescription Act. of lessors and lessees, 513

\section{DISCHARGE}

of specialty, 266,290

of executory contract, 396

of executed contract, 396

of jury, 180

not equivalent to an acquittal, $1095(u)$

DISCLAIJIER, 657. Sec BAxKRUPTCY.

of lease, 561,658

avoids tenant right, 528

\section{DISCONTINUANCE}

of action, 145

\section{DISCOUNT,}

extrinsic evidence admissible to prove allowance of, on bill of lading, 583

\section{DISCOVERY AND INSPECTION}

of documents, 38,164

payment of deposit into court condition precedent to order for, 166 if resisted, 167

disobedience to order for, punishable by attachment, 167

in County Court, 199

\section{DISCRETION,}

legal, what, 21

DISHONOUR,

effect of taking bill with notice of, 458

notice of, 459,463

by non-acceptance, $459(p)$

by non-payment, $459(p)$

need not be giren to acceptor, 459,460

when dispensed with, 460 et seq.

to indorser, 462

probability of, not equivalent to notice, 462

nor knowledge, 462

effect of, 462

notice of, how and when it must be giren, 463

delay in giving, when excused, 464

when deemed to be given, 464

furtler dishonour by non-payment need not be given, protest for, 474 unless bill afterwards accepted, $466^{\circ}(t)$

notice of, to indorser of promissory note, $491(s)$

DISTRESS. Sce Laxdlord and Texant.

right of, 547 ct scr.

what protected from, $550 \mathrm{et} \mathrm{seq}$. 
DISTRESS-continued.

bailiff authorised by certificate, 555

horse being ridden, or tools in use, may not be distrained, 210

damage feasant, and for rent, 211,877

if not sold, bars action for rent, $212(n)$

for other purposes, 212

DISTRESS, LAW OF, AMENDMENT ACT', 1888, articles exempted from distress by, 552

bailiff must be authorised by certificate under, 555

appraisement abolished by, 555

except where tenant requires it by writing, $\mathbf{5 5 5}$

DISTRICT REGISTRAR,

appointment of, 54

duties and powers of, 55

DISTRICT REGISTRY,

proceedings in, 168

issue of writ from, 127

entering an appearance in, 133

when judgment to be entered in, 168,169

pleadings and documents to be tiled in, 169

writs of execution to issue thence, 169

action when removed from, to London, 169

how removed, 169,170

DIVISIONAL COURT,

business transacted in, 49

appeals to, 49,50

how constituted, 49

DivorCE, 678. See Married Woman.

DOCUMENT OF TITLE,

what amounts to, $614(g)$

DOCÜMENTARY EVIDENCE. See EvIDExce, etc.

DOCUMenTS, 167, 168. See Admissios, Discovery.

DOG,

liability of owner for damage done to sheep by, $786\langle z\rangle$

need not prove the scienter, $786(z)$

to game, $786(\approx)$

DOLUS DANS LOCUM CONTRACTUI, explanation of this phrase, 337

DOMINANT TENEMENT, 883. See EASEMENTs.

DOWER,

customary, 10

action for, 146

DRAWEE. See Brll of Exchasge.

not liable on bill if does not accept, $449(h)$

DRAWER. See Bili of Exchaxge.

of bill is surety for accommodation acceptor, 454

contract of, revocable until delivery, 455

notice of dishonour to, when excused, 460,461

of accommodation bill has no right to notice of dishononr, 461

contract of, 465

what presentment necessary to charge, 471

not anthorising or assenting to qualified acceptance is discharged, 472 payment by, does not discharge bill, $476^{\circ}$ 
DRUNKENNESS, 704, 1007. SeC IxTOXICATION.

\section{DUELLING,}

if it end fatally, punishable as murder, 1033

\section{DURATION}

of writ of summons, 131

\section{DURESS,}

defence of, in action on bill of exchange or promissory note, 504

its effect on contracts, 705

tiro kinds of, 706

of person, 706

of groods, 706

will not aroid contract, but money paid under may be recovered

back, $707(y)$

when an excuse in criminal law, 1000

DUTY. See Tort, Publc Detr.

definition of, $7 \pm 6(b)$

private, what, 769

by common law or statute, 768

DWELLING-HOUSE,

right of commoner to pull down in certain cases, 209

DYING DECLARATION,

when admissible in evidence, 1092

\section{EARNEST MONEY,}

what it is, 411

effect of payment of, $\mathbf{4 0 6}$

\section{EASEMENTS,}

what they are, $8 \$ 2$ ct scq.

distinguished from natural rights, $8 \$ 2$

obligations, 882

definition of, 882

profits a prendre, $8 \$ 2$

easenent is an incorporeal right, 883

imposed upon corporeal property, 883

needs doninant and servient tenement, 883

affirmative and negative, 883

continuous and discontinuous, $\$ 83$

appareut or non-apparent, 883

none in gross, $883(a)$

proper, how acquired, 889

by express agreement, $8 s 9$

lie in grant, not in livery; 889

equitable relief to licensee, 889

statutory relief, 859,890

by inplied grant, 890 et seq.

riles as to, 891,892

of necessity, 892

hy vrescription, 892

by lost grant. 893

under l'rescription Act, 893 et scq.

how claimed under s. 2 of, 894

clain, how defeated, 894

common law claim not superseded by statute, 894,895

how claimed at common law, 894 


\section{EASEIENTS-continued.}

nee vi, nee clam, nee precario, $\$ 94$

Prescription Act makes no change in nature or extent of rights claimed, 895

does in the rule of ncc $x i, \& c ., 895$

light, 896 et seq.

old window cannot be blocked because new one oprened by it, 898 right to light not necessarily lost by pulling down building, 899 secus, if new windows cannot be in any way identified with old ones, 8.99

jot lost by alteration of plane of dominant tenement, 899

no implied reservation of light to grantor on general conveyance of land, 899

what amounts to interruption of, 900

no presumption under Prescription Act from less enjoyment than would give right, 900,901

value of such evidence as tending to prove a grant, $901(g)$

disabilities under Prescription Act, 901

abandonment of, 901

light and air, 902

natural rights to. 902

none of prospect apart from express covenaut, $902(b)$

running water, 902

artificial watercourse, 903

subterranean water, 904 et seq.

right of way, 908

evidence sufficient to support claim to, in thinly populated district, $903(s)$

support to buildings by soil, 908,909

is within Prescription Act, 910

by buildings, 910

by non-adjacent buildings, 910

acquisition of, how prevented, 910

ECCLESIASTICAL CORPORATION, leasing powers of, 516

ECCLESIASTICAL COURTS, prohibition to, 221, 222

need not be governed by rules of common law, 2\%2 (c)

ECCLESIASTICAL PROPERTY,

liability of valuer of, for ignorance and waut of skill, $966(t)$

EJECTMENT. Sec Recovery of Laxd.

jurisdiction of County Court in, 62

\section{ELECTION,}

evidence of, $607(b)$

may determine liability of retiring partner, 639?

what amounts to, 639

\section{ELEGIT,}

writ of, 19.5

how used, 195

history of, $195(p)$

\section{EMBEZZLEMENT,}

how constituted, 1073

how distinguished from larceny by servant, 1073, 1074 


\section{EIBLEMENTS,}

included in "goods" within Sale of Goods Act, 1893, $390(f), 403$

were within s. 17 , not s. 4 , of Stat. Frauds, 388,389

right of tenauts to, 527

statutory substitutes for, 517

EMPLOYERS' LIABILITY ACT, applies only to workmen, $811(d)$

including railway servants and drivers of trolleys, $811(d)$

not omnibus conductors nor divers of trams, $811(d)$

when employer liable, 811,812

meaning of "railway," $813(s)$

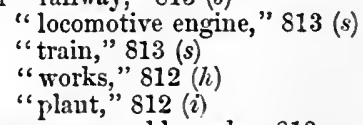

what damages recoverable under, 813

action, when to be conmenced, 813,814

notice to be giveu, 81 t

where to be brought, 814

workman can contract himself ont of, 814

effect of Act, 814

defences open to employer, 814, 815

\section{ENGINEER,}

warranty by, 769

liability of, for negligence or unskilfulness, 769

ENTRY,

necessary to support action for trespass, 874

relation after, $874(i)$

to recover possession, 206 et seq.

forcible. See Forcible Extri.

whether justifiable, 207 et seq.

indictable under statute, 208

\section{ENTRY OF JUDGJENT, 181, 184}

\section{EQUITABLE CLAIM,}

oue purely such will not support action at law, 3 万

\section{EQUITABLE RELIEF,}

given by Common Law Court, 39

\section{EQUITY,}

origin of, 36

administered concurrently with law, 37

rules of, when to prevail, 38

relief in, against fraudulent deed, 284

will not relieve against voluntary gift without proof of undue influence, $285(z)$

will relieve against performance of condition precedent, 294

prefers compeusation to forfeiture, 295

will reform instrument, 294

will discharge specialty by parol agreement, 295

will relieve against penalty of bond, 295

want of mutuality, how dealt with in, 302

loctrine of, as to assigning choses in action, 445

in relation to partnership, 642

married women, 677

licensee, 889

rule in, as to estoppel, 964 
ERROR,

proceedings in, abolished, 186

writ of, in criminal cases, 1095

\section{ESCAPES,}

offences in criminal law, 1024

ESCROW,

delivery of deed as, 265

to grantee, 265,266

\section{ESTOPPEL}

by record, 260 et seq.

secus, if obtained by fraud, 261 .

by deed, $266,276,395$

principle of, $276(p)$

illegality may be pleaded, $276 \mathrm{et}$ scr.

doctrine of, guarded with great strictness, 283

must be certain, 284

if occurs in recital of deed, will be narrowly watched, $28 t$

extends to persons claiming under party estopled, $28 \pm(s)$

none in action not founded ou deed, but collateral to it, $284(s)$

binds parties and privies, not strangers, $396(n)$

lease for term of years by, 519

in cases of tort, $395(\mathrm{~m})$

in regard to bills of exchange, $395(m)$

promissory notes, $395(\mathrm{~m})$

of agent from denying title of principal in subject matter of agency, $395(\mathrm{~m})$

by conduct and representations, $396(x)$

of tenant from denying title of landlord, $395(\mathrm{~m})$

by acts in pais, 395 (n), 960 et seq.

as against drawer of bill of exchange, 465

indorser, 466

acceptor, 472

maker of promissory note, 489

principal, 600

by conduct, rule as to, $600(x), 601(z)$

principal permitting agent to describe himself as principal in a

written contract, $619(\mathrm{c})$

retiring partner, 640

apparent partner, 962

parties to bailment, 922

tenant disputing landlord's title, 869

becoming trespasser by, 801

by negligence, $960(b), 960$

in equity, 964

doctrine of, to be applied carefully, 961

$$
\text { is "odious," } 961
$$

only a rule of evidence, 964

\section{EVICTION,}

remedy by, 206

what constitutes, $206(h)$

is not breach of covenant for good right to convey, but conserguentiu. damage from the breach, $720(q)$

EVIDENCE. Sce Contract, Statute of Fiauls.

preparation of, 174

documentary, 174

how obtained and proved, 174

by affidavit, 174, 175 


\section{EVIDENCE-continued.}

cross-examination of deponent, 175

taken before officer of court or commissioner, 175

usually taken viva voce in court, 175

before Court of Appeal, 188 (c)

attendance of witnesses, how procured, 176

of delivery of deed, $261(n)$

not admissible at law to contradict written instrument, 294, 369 otherwise in equity, 294

admissible in case of frand, 369

parol, two kinds of, $369(f)$

admissible to show there was no agreement at all, $369(d)$

qualification of rule excluding, 371

can supply the consideration, but cannot explain the promise, 380

of acceptance within Sale of Goods Act, 1893, 408

extrinsic, admissible to explain latent, not usually to explain patent ambiguity, 575

to explain ancient instruments, 581

when not admitted, 592

grants, charters; $581(n)$

charter-party, 582

province of judge and jury in dealing with, 579,580

admissible to prore agent personally liable, 621

as to necessaries for infant, $669(l)$

of husband, when admissible against wife, 687

in cases of treason, 1014 et seq.

rules as to, in eriminal trials, $1090 \mathrm{et} \mathrm{seq.}$

that prisoner has been found in possession of other stolen property, $10 \frac{1}{1}(k)$

EXCHANGE. Sec Bill of Exchasge.

when requires deed, 400

EICHEQUER, COURT OF, origin of, 24

jurisdiction of, 24, 33

in revenue cases, $24,25(p)$

in equity, 25

actions removed into, 33

when it ceased to exist, 33

informations, when b:ought in, $230(f)$

EXCHEQUER CHAMBER, COURT OF, constitution and jurisdiction of, $34(0)$

jurisdiction transterred to Court of Appeal, 34

EXCHEQUER DIVISION,

origin of, 33

jurisdiction of, 33,34

merged in Queen's Bench Division, 34

EXCISE LAWS,

action for causing plaintiff to be suspected of breach of, $843(b)$

E.XECLTED CONSIDERATION, 304. Sce Coxsideration.

EXECLTED CONTRACT, 245. Sce CoNTRACT.

can ouly be discharged by release under seal, or performance of obligation, 396

\section{E.XECUTION}

to enforce judgment, 189

issue of writ cif, I89 
EXECUTION-continued.

stay of, 190

writ, how indorsed, 190, 193

how long remains in force, if unexecuted, 195

renewal of, 195

time for issuing, 196

for recovery of costs in County Court, 201

for enforcing judgment of Couuty Court, 201

to enforce judgment, 262

liability of creditor maliciously taking, for too large a sum, $\$ 39$

EXECUTIVE POWER,

offences against, 1023 et seq.

EXECUTOR AND ADMINISTRATOR,

action by, for breach of contract with testator, $121 \mathrm{et}$ seq.

executors have joint and eutire interest in testator's goods, $121(x)$

liability of, for breach of contracts by testator, 122 ex delicto, 123

joinder of claims by or against, with others against them person. ally, 123

common law right of, to sue, $123(l)$

special promise by, to answer damages out of his own estate under s. 4 of the Statute of Frands, 377

of landlord, 559. See LaxDlopd axd Texast.

contracts of, 708 et seq.

executor derives title and interest from will, 708

what actions pass to, 709,710

action for libel causing damage to personal estate, 865

on what contracts of deceased they are liable as such, 711

when personally liable, 712

not liable on contracts for personal service, $711(t)$

cannot contract with each other in that capacity, $713(b)$

question for jury in what character they contracted, 713

may be succeeded by executor, 713

not by administrator, 714

administrator de bonis non, 714

executor de son tort, $714(k)$

of director not liable for testator's fraud, 777

action by, under Lord Campbell's Act, 816

cannot bring action where deceased could not have done so, 815 (i)

constructive possession of, 915

EXECUTORY CONTRACT, 245. See Costract.

request necessary in, 303 et seq.

promise express or implied in every, 321

when property passes under, of sale of goods, $42 \pi, 428$

whether within s. 17 of the Statute of Frauds, 404

included by Lord Tenterden's Act, 405

now within s. 4 , subs. 1, of the Sale of Goods Act, 1893, 407

may be discharged by parol before breach, 396

measure of damages for breach of, 729

EXECUTRIX,

protection of married woman as, 678

EXPERTS,

evidence of, in regard to lunacy, 1005

EXPRESS CONTRACT, 245. See Costiact.

EXPREss PROMISE, 321. See Promise. 
EXPRESS WARRANTY, 340. See Warranty.

EXTENT,

writ of, $195(q)$

EXTRADITION

of criminal offenders, $45(p)$

EXTRAORDINARY JURISDICTION

of legal tribunals, 214

\section{EXTRAORDINARY REMEDIES,}

how classified, 205

by act of party injured, 205

self-defence, 205

recaption, 205,206

eviction, 206, 207, 208

abatement of private nuisance, 209

distress, 211

public nuisance, 211

by operation of law, 212

retainer, 212

remitter, 212

granted by courts of law, 213

motion, 213

mandamus, 214

injunction, 217

order for interim preservation of property, 220

prohibition, 221

quo varranto, 223

certiorari, 224

procedendo, 224

interpleader, 224

garnishment, 227

recovery of small tenements, 228

delivery of specific chattels, 229

criminal information, 230

habeas corpus, 233

petition of right, \&c., 238

EYRE, JUSTICES IN, 25, 26

\section{FACTOR}

might sign memorandum within s. 17 of the Statute of Frauds, 414

may maintain action against stranger taking goods, 948

FACTORS ACT, 1889, $430(n), 431(0), 432(u), 507(a), 613,614$

\section{FALSE IMPRISONAIENT,}

limitation of action for, 158

trial by jury as of right in action for, 171

two requisites of, 823

what will amount to, 823, 824

justification of, 824

in case of private person, 824

$$
\text { bystander, } 825
$$

when not justified, 825

felon may be arrested, 826

liability of constable for, 828 
FALSE IMPRISONMENT-continucd.

liability of justice of the peace, 831

damages recoverable against a magistrate for, $834(l)$

onus of proof, on whom it lies, 841

FALSE PRETENCES,

obtaining money by, 1071

must be of facts, 1072

must have induced prosecutor to part with money or goorls, 1073

how distinguishable from larceny, 1071

FALSEHOOD. Sec Fraud.

without damage will not sustain action, 338

FATHER,

no legal obligation on, to pay debts of son, 326

FELON,

private person justified in arresting, 826

homicide of escaping, justifiable, 1044

Felony. See Crimiral law.

civil remedy suspended when act done is felonious, $99 \mathrm{ct}$ scq. statutory exception, 816

by carrier's servant not necessarily the result of gross negligence, $932(n)$

attempt to commit, may be indictable, 998

may be repelled by force, 1046

accessory to, atter the fact, who is, $1048(e)$

includes trespass, 1061

bailee converting chattel not guilty of, at common law, unless he breaks bnik, 1062

secus by statute, 1023, 1024, 1062

capital, not triable by justice of the peace, 1079

jury may be discharged in trial of, $1095(u)$

FEMIE COVERT, 675 et seq. Sce MLARried Woyas.

exemption of, from criminal liability, 1000

when excused by duress, 1011

when not excused, 1011

may be convicted of assault jointly with husband, 1011

\section{FEOFFMENT}

to stranger without consideration, effect of, in equity, 287

by Statute of Uses, 287, 288

when requires a deed, 400

FERAE NATURA ANIMALS, 1058. Sec ANIMALs.

FERRY,

diverting traffic from ancient, is actionable, 86

liability of lessee of, $792(\xi)$

FIAT,

not needed before proceeding by criminal information, 232

FIERI FACIAS, writ of, 193 et seq.

property seizable under, 194

form of, 195

in County Court, 201 


\section{FIGHTS}

are unlawful, 1039

if deatl ensues may be murder or manslanghter, 1039

persons assisting at prize-fight indictable for manslaughter in case of death, $1039(\mathrm{~m})$

mere voluntary presence at, not necessarily an assault, $1039(\mathrm{~m})$

\section{FINDER}

of lost Iroperty has a right against all the world except the owner, 913 when appropriation of lost chattel by, may amount to larceny, 1065 et seq.

FIRE,

tenant not liable for accidental, 533

secus, if caused by negligence, 533

persons maliciously firing corn, \&c., not triable by justice of the neace, 1080

\section{FIRE INSURANCE,} contract of, 331

\section{FIXTURES,}

what they are, 390

three classes of, 536

right to remove, how lost, 536, 537

trade, 538

agricultural, 539

cannot be distrained, $\mathbf{5 5 0}$

tenant's, 390

how distinguished from landlord's, $390(g)$

mining, $388(v)$

when within Statute of Frauds, 390

FLOWING WaTER, 886. See Water, Easemexts, Natural Rights.

FOOD,

liability for selling unwholesome, 819

indictable offence to send to market meat unfit for, 991

FOOTWAY,

duty cast on owner of premises adjoining, 754

\section{FORBEARANCE}

to sue may be good consideration for a promise, 378

FORCIBLE DETAINER, 1028

FORCIBLE ENTRY. See ExTRY.

an indictable offence, 208,1028

when justifiable, 877,878

FOREIGN BILL,

form of, 471

drawn at usances, 477

in parts, 477

protest of, 477

conflict of laws as to, 478

\section{FOREIGN COURTS,}

judgments of, $261(x)$

\section{FOLEIGN LANGUAGE,}

eridence to explain contracts in, $5 \$ 1$ 
FOREIGN SCRIP,

is assignable, 445

FOREIGNER, 707, 1012. SeC ALIEX.

service of writ on, 44

FORFEITURE

of bond, relief against, $2 \pi 3$

in equity, 288, 295

by statute, 295

of lease, 564

statutory relief against, 564

avoids tenant right, 528

none for homicide withont felony, 1048

for felony abolished, 1097

FORGERY,

no title can be obtained through, 576

defence of, in action on bill or note, 505

not triable by justice of the peace, 1080

FORMS OF ACTION. Sec Action at Law. abolition of, 146 et seq.

FOXHUNTING,

unjustifiable without anthority to enter land, 872

FRAUD,

must be pleaded, 141, 142

when a defence to Statute of Limitations, 159

will vacate judgment obtained by it, 261,329

or order, 262

deed, 281,329

not always for all purposes, 283

good defence to action on deed, 282

absence of consideration may be proof of, 285

effect of, on contracts, 327 et seq.

definitions of, 328

contract procured by, is voidable, not void, $328(c), 329$

can be ratified, $328(c)$

no distinction between moral and legal, 330

cause of error herein, 330

mere non-disclosure is not, 330

reckless assertion may amount to, 336

statement honestly believed to be true not actionable as, $336^{\circ}$

how far it can exist apart from fraudulent intent or moral tur ${ }^{\text {in- }}$ tude, 332

innocent principal, how far liable for agrent, $333 \mathrm{et} \mathrm{seq.,} 623 \mathrm{ct} \mathrm{sc}$. of agent good defence to actiou for specific perfornance, $3: 33$ ( $l$ ) not actionable without damage, $90,328,780$

nor available asdefence, unless induced defendant to contract, 3.98 tests of, 338

how differs from breach of warranty, $339 \mathrm{et} \mathrm{scq}$.

effect of, on title to bill, 457

defence of, in action on bill or note, 504

liability of agent for, 623

of director for co-directors, 624

infancy no defence in equity, 674

evidenced by dealing with intoxicatel man, 705

necessary for liability on contract, cx elelicto, where no privity, ito

action for, ex delicto, producing damage, 779,780

may authorise carrier to rescind contract, 933,934

action for, in connection with companies, 952 et seq.

B.C.L. 
FRAUD-continued.

estoppel $i$ pais in relation to, 960 et seq.

where is gist of action, intention important and for the jury, 978 measure of damages in action for, $978(r)$

when not indictable, 990,991

FRaUdS, STATUTE OF, 368 et seq. See Statute of Frauds.

FRAUDULENT PREFERENCE, 666. See BANKRtPTCY. contract for, illegal, 356

FRAUDULENT REPRESENTATION. Sce FraUd.

position of party induced to contract by, 722

may be replied to defence of release under seal, 281

corporation liable for servant's, $793(h)$

FREE FISHFRY,

claim to, not within Prescription Act, 894 (y)

FREEHOLD

interests in land, 509

FREIGHT,

measure of damages in action for, $722(f)$

FRUIT,

falling on neighbour's land may be retaken, 206

growing, goes to heir, not executor, 389

cannot be taken under a $f$. $f a ., 389$

FURNISHED HOUSE,

implied contract in letting, 248, $243(t), 569$

\section{GAMBLING}

contracts, $354(u), 356(n)$

GAME,

liability of owner of dog damaging, 786 ( $\approx)$

GAME LAWS,

infringement of, criminal, 983, 1029

GAJING ACT, 1892, $354(u)$

GARTISHEE,

who is, 227

duty of, 227, 228

payment by, under order, valid discharge against judgment debtor, 228

\section{GARNISHMENT,}

what it is, 227

what debts liable to, 228

half-pay of officer not liable to, 22.8

GAS,

larceny can be committed of, 1070

GAVELKIND,

custom of, 10

GENERAL MANAGER,

can bind railway company for medical attendanco to injured jassenger, $603(f)$

GIFT

and delivery needed to pass property in chattel, 399, 979

GLOUCESTER, STATUTE OF, 529 


\section{GOLDEN RULE,}

what it is, 2 ct scq.

\section{GOOD FAITH,}

definition of, under Bills of Exchange Act, 1882, 497

GOODWILL,

what, $358(t)$

on sale of, vendor not entitled to canvass customers of oll firm, $359(\ell)$ purcliaser of, entitled to use vendor's name, but not so as to expose him to liability, $358(t)$

GRAND JURY,

presentment by, 1086

bill preferred to, by private person, $10 \mathrm{~S} 6$

indictment found by, 1086

foreman of, can administer oath to witness, $1087(g)$

GRANT,

evidence to explain ancient, $581(n)$

of infant, when void, $6 i 1$

$$
\text { when voidable, } 671
$$

GRASS,

growing, goes to heir, not executor, 389

cannot be taken under a. $f$. $f a ., 389$

\section{GUARANTIE,}

what it is, 378

form of, 3 is

how to be construed, 379

must be in writing. 379

consideration need not be stated under s. 4 of the Statute of Frauds, 379

withdrawal of, $378(q)$

continuing, $379(s)$

consideration may be supplied by parol evidence, 380

cases coming under s. 4 of the Statute of Frauls, $380 \mathrm{ct} \mathrm{scq}$.

provisions of statute, how evaded, 383

no reciprocity of obligation in, 301

effect of concealing material fact from sureties of, $331(x)$

interest on, 743

from recipient of, $331(x)$

GUARDIAN,

who is, within $42 \& 43$ Vict. c. $49,1082(f)$

and ward, relation of, $966(b)$

GUNPOWDER,

indictable offence to store quantities of, in town, 992

\section{HABEAS CORPITS,}

an extraordinary remedy, $233 \mathrm{et} s c q$.

statutes of, $234-236$

disobedience to, how punishable, $237(l)$

writ of, how obtained, 236

ad subjiciendum, 236

ad faciondum et recipiendum, $236 \Leftrightarrow$

appeal in, 237

return to, 237

what is sufficient, $237(p)$

HACKNEY CARRIAGE,

liability of proprietor of, plying for hire within Metropolis, $7: 7(s)$, 930 (c) 
HALF-PAY,

caunot be attached, 228

HEALTH,

torts against, 818

nuisances against, $\$ 20$

when punishable criminally, 1030

HEIR,

when bound by deed of ancestor, $266,289,395$

must be specially named, and have assets by descent, 289

HEREDITAMENTS. Sec LAND.

HIGH COURT OF JUSTICE,

divisions of, 33,34

a superior court of record, 33

jurisdiction of, 33,37

HIGH TREASON, 1012. See TrEasos.

HIGHWAY,

laud may be dedicated as, subject to risks from existing condition, $755(g)$

indictment for obstruction to, 1030

what amounts to obstruction of, $820(\mathrm{~g})$

HipiNg aND SERvice. See Damages, Master axd Servant. damages for breach of contract of, 731

HOLDER. Sce BrLl of Exchasge.

position of, when title to bill defective for fraud, 457

may refuse qualified acceptance, $\mathbf{4 7 2}$

if takes such, should give notice of qualification, $4 \tau_{2}$

rights of, against transferor without indorsement of worthless bank-notes, 495

"HOLDER IN DUE COURSE,"

meaning of term, $448(e)$

rights of, 456

subsequent, not prejudiced by omission to give notice of dishonour, 466

HOLDING OVER, effect of, 570

HOMICIDE,

degrees of, 1032 et seq.

by misadrenture, 1000

in course of duty, 1000

presumed to be malicious, 1035

when culpable, justifiable, or excusable, 1035, 1036

on provocation, 1036 ct scq.

cannot be reduced below manslanghter, 1038

what prorocation will so reduce it, 1038, 1039

by struggles in anger, 1039

by undue correction, 1040

by negligence, 1041 ct seg.

of medical man, 1042

by neglect to repair roads, 1042

position of trustee so neglecting, 1042, 1043

in resisting officer, 1043

in consequence of unlawful assembly; 1043

of fugitive by officer, 1044

of felon, 1044

in recajturing slaver, 1045 
HOMICIDE-continued.

when justifiable, 1045

when excusable, 1046

of ravisher, burglar, attempter of arson, 1046

in self-defence, 1047

no forfeiture for, without felony, 1049

felonious, involved in murder, 1048

HONOUR, 474. See ACceptance, Bill of Exchange.

HORSE,

sale of glandered, gives no right of action ex contractu, 330

excepted from law as to sale in market overt, $429^{\prime} i$

of unsound, not indictable, 991

taking glanderel, to market, indictable oflence, 991, 992

damages for breach of warranty on sale of, $740(u)$

is "plant" within the Employers' Liability Act, 1880, 812 (i)

HOST AND GUEST, relation of, $757(\mathrm{~m})$

HOUSE,

right of support for, 908. See Easemexts, Prescriptios Act.

HOUSE OF LORDS, appellate jurisdiction of, 36

HUMANITY, considerations of, 21

HUNDRED COURTS, 23

HUSBAND, 675 et seq. S'ee Married Woyax. action by, for abduction of wife, 967

IDENTITY,

evidence of, of subject-matter of contract, 576

of parties to, 577

IDIOCY, 700, 1001. Sce Lunatic.

disability nnder Prescription Act, 901

IGNORANTIA FACTI, homicide may be rendered excusable by, 1046

IGNORANTIA JURIS,

is no excuse for crime, 986

ILLEGALITY,

must be pleaded, 142

deed impeachable for, 276

not always for all purposes, 282, 233

its effect on contract, $346 \mathrm{et} s \mathrm{eq}$.

may be in consideration or promise, 348

when may invalidate contract, 350 et seq.

defence of, in action on bill or note, 504

ILLEGITIMATE CHILD,

proceedings to affiliate, not in poenam, 988, 989

personal representative of mother need not expend assets of decensed

in maintenance of, 326

is not within Lord Campbell's Act, $816(\mathrm{~m})$

IMMORALITY,

its effect on contracts, 365 
IMPLIED CONTRACTS, 246. See CoNTRACT.

IMIDLIED PROMISE. See Promise.

none in contracts with barrister, 322

physician, 322

secus, by statnte, $322(b)$

infants, 322

married women, $32 \%$

IMPLIED WARRANTY,

warranties in contract of sale of goods, 421 et seq.

low different from a condition, 421

by sample, 424

remedy for breach of, in contract of sale of goods, 440

measure of damages for breach of, 441

none that building is fit for special purpose, $342(s)$

in agreement to let furnished house, $248,248(t), 569$

on hire of skill, 342

of agency, 342

excluded from written contract, 343

by transferor by delivery, 495

IMPRISONMENT. Sec FALSE IMPRISONMENT.

what it is, $824($ ( )

IMLPOVEMENTS

under the Agricultural Holdings Act, 539 et seq.

INCAPACITY

to contract, 249

to commit crime, 1000 et seq.

INCLOSURE,

unlawful, when it may be abated, $210(f)$

IXCORPOREAL PROPERTY, how defined, $398(c)$

INCORPOREAL RIGHTS,

lie in grant, not in livery, 398

INDENTURE,

deed to have effect of, though not indented, 264

IXDICTABLE OFFENCES, what are, 991, 992

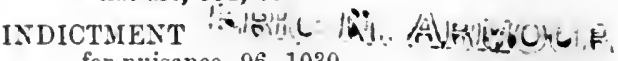

for nuisance, 96,1030

obstructing thoroughfare, 97,1030

procedure by, when applicable, 98

under Married Women's Property Act, 1882, 687

what it will lie for, 991

for a mere attempt, 998

what it is, how found, 1086,1087

what it must contain, 1087

low differs from criminal information, $1086(f)$

form of, 1087, 1088

conclusion of, 1088

not vitiated by surplusage, $1087(l)$

limitation of time, $1087(l)$

pleas to, $108 \mathrm{~s}$

lemurrer to, $1089(u), 1095$

where prisoner leclines to plead, $1089(x)$

amendment of, 1095 
INDORSEE. See Bill of Exchasge, Bill or ladisi.

rights of, 458,506

INDORSEMENT. See Bill of Exchasgf, Writ.

of claim on writ, 125

effect of special, 126

delivery necessary after, 455

blank or specidl, 455

restrictive, $4 \overline{5} 5,456$

conditional, may be disregarded by payer, 4:56

if made wrongfully, only conveys title to bill as against indorser, 457 may be demanded when bill transferred without of, 457

effect of, 466

duty as to deciding upon genuineness of, 475

of note, its effect, 487

of bill of lading, 506 et seq.

INDORSER. See Bill of Exchaxge.

position of, 466

contract of, 458,466

contract revocable until delivery, 455

of accommodation bill has right to notice of dishonour, 461

notice to, when dispensed with, 462

when discharged by failure to gire notice, 462

what presentment necessary to charge, 471

not anthorising or assenting to qualified acceptance is discharged, 472

payment by, does not discharge bill, 476

of note, his contract, 490

presentment to charge, 490

notice of dishonour to, 490

INFANCY. See INFANT.

notice of defence of, in County Court, 198

disability under Prescription Act, 901

INFANT,

action by or against, 120

default of appearance by, $136(i)$

contract of, voidable at his election though binding on other frarty, 301

no implied promise in contracts by, 322

leases by and to, 514

lease by, roidable, 514

statutory powers of leasing, 514

may disagree on majority, 514

cannot contract by agent, 597

can as agent, 597

contract of, when roid by statute, 667

bound for necessaries, 667

what are necessaries, 667 et seq.

rules as to, 668,669

must pay a reasonable price for, 668

cannot bind himself by bill of exchange, $667(\xi)$

evidence admissible that infant was already supplied, $669(t)$

widow liable to pay for funeral of husbanil who left no lroperty;

609 (i)

whether contract of, void or roidable at common law, $670(n)$

not bound by penalty, 670

what grants of, void, 671

what voidable, 671

position of infant shareholder, $67^{2}$ 


\section{INFANT-continusd.}

cannot be made bankrupt, $671(r)$

nor convicted of defrauding ereditors, $6 i 1(r)$

what form of receiving order can be made against firm of which an infant a member, $671(r)$

can sue $\epsilon x$ contractu, 673

want of mutuality might be an answer in equity, 673

waiver of shares by, 672

liable for tort or crine, 673,977

cannot be charged by changing action of contract to one of tort, 674

may be doli eapax in equity, 674

liable for frand, 674

statutory provisions against ratification by, $674,674(p)$

contributory negligenee of, 789

exemption of, from criminal liability, 1000, 1009 et seq.

when incapable of crime, 1009,1010

may be convicted of larceny as bailee of goods, $1010(0)$

when maxim Malitia supplet cetatem applies, 1010

liability for rape, 1010

$$
\text { for non-capital offences, } 1010
$$

not liable for nonfeasance, 1010

exceptions to rule, 1010

laches not imputed to, 1011

criminal responsibility for neglect of helpless, 1035

\section{INFERIOR COURTS,}

appeals from, 49

\section{INFORIIATION}

in Court of Exchequer, $230(f)$

criminal, what it is, 230

by whom filed, 231

legality of, $230(h)$

when it lies, 231, 232

proceedings on, 233, 233 (d)

by Attorney-General, 231

by Queen's Coroner, 231

Att.-Gen. of Duchy of Lancaster canuot exhibit, 231 (i)

fiat of Public Prosecntor not needed before proceeding by, 232

for libel, 1055

how differs from indictnent, $1086(f)$

\section{INHERENT VICE,}

carrier not liable for accillent caused by, 932

\section{INJUNCTION,}

no proceeding in High Court of Justice or Court of Appeal to be restrained by, 41, 219

service of writ ont of jurisdiction, 130

by judge of County Court against nuisance, 201

remedy by, 217 et scq.

writ of, abolished, 218

against tenant, when granted, 570

against mine owner derogating from his grant, 218

against publisher of libel, 219

equitable doctrines as to, for breacl of covenants, $218(x)$

mandatory, when granted, 219

how enforcerl, 219

aranted by interlocutory order, 221

to restrain trade libel, $862(s)$

oral slander, $863(z)$ 
INJURIA,

what it is, 71

none where act authorised by legislature, $71(c)$

INJURIA ET DAMNUM,

when must combine, 90

INJURIA SINE DAMNO,

meaning of, 83

actionable, $82,89,90$

in contract, 85

in tort, 85,86

illustrated by $A$ shby v. White, 83

INLAND BILL, 477. See Bill of Exchaxge.

INN,

meaning of, in $26 \& 27$ Vict. c. 41,929 (u)

entry to, when justifiable, 878

goods of guest not distrainable in, 551

INNKEEPER,

goods of guest of, not distrainable, 551

cannot justify assault in detaining plaintiff for debt, $786(x)$

gives general license to enter his doors, 878

not bound to provide special room, $878(f)$

nor receive customer and dogs into bar, $878(f)$

obligation of, to receive goods, $878(f)$

right of lien of, $878(f), 928(s)$

to dispose of goods left with him, $878(f)$

liability of, at common law, 926

no distinction between money and goods, 926 (i)

duty of, 927

when excused, 927

liable only when received goods as inukeeper, 928

liability of, by statute, 928,929

INSANITY, 700, 1001. See Lunatic.

INSPECTION. See Discovery.

notice to give, of documents, 166

effect of non-compliance with, 166

duty of party receiving, 167

in County Court, 199

of property, order for, 220

\section{INSTRUMENT,}

cannot be negotiable and not negotiable at once, 444

usually to be construed by the court, 579

exceptions to this rule, $57 y$

if ambiguous will be construed against party signing, 619

INSURANCE,

marine, fire, life, 331

contract of, when complete, $332(e)$

policy of, for or by married woman, 680,684

measure of damages in action on policy of marine, $723(f)$

\section{INTENTION,}

wrongful, when immaterial, 95

generally irrelevant in breach of contract, 718

secus, in tort, 719

in action for bodily injury, 782

may be considered by jury, 783 
INTEXTION-continued.

material as regards criminal liability, 783

in estimating damages in actions of tort, $976 \mathrm{ct} s c q$.

unnecessary to support action, 377

important, and for jury, where fraud is gist of action, $97 \mathrm{~s}$

cannot be question of law, 979

meaning of, in criminal law, 992 et seq.

when immaterial, 993

onus of proving innocent, 993

how provable, 996,997

not an offence without orert act, 997

distinguished from attempt, 997

is the crime in treason, 1015

but must be proved by orert act, 1015

fact of drunkenness may be material as regards, 1008

INTERESSE TERMINI, what, 510

\section{INTEREST}

in or concerning lands, \&c., what is, within s. 4 of the Statute of Frauds, 386, 387

on bill of exchange, $466(u)$

when recoverable, 721,741 et seq.

by statute, 741,742

at common law, 743,744

claim for in srecially indorsed writ, $742(g)$

on bill of exchange, $7 \pm 2(h)$

\section{INTERIML ORDER}

for preserration of property, 220

\section{INTERPLEADER}

by sheriff, 226

practice and procedure in, 224 et $s € q$.

appeal from County Court in, 203

\section{INTERROGATORIES,}

Irocedure by, 164, 165

to be exhibited on application for leare to administer, 164

allowing does not preclude an objection to answer being taken, $164(j)$

disallowance of criminating, 38

costs of unreasonable, \&c., 165

to corporations, 164,165

fundarnental rule as to, 165

form of, $165(l)$

application to set aside, 165

oljection to, in affidarit in answer, 165

answers to, 165

if insufticient, 165

use of, at trial, $166(q)$

payment of deposit into court a condition precedent to right to administer, 166

disobedience to order to answer, pumishable by attachment, 167

in County Court, 199

\section{INTOXICATION,}

defence of, in action on bill or note, 505

contract of drunken man voidable, not void, $505(\mathrm{~m}), 705$

effect of, on contracts, 704

if confirmed will be binding, 705

drunken man liable for necessaries, 705 
INTOXICATIOX-continued.

may be proof of fraud, 705

partial, no defence apart from fraud, 705

ignorance of, no excuse for a breach of 35 \& 36 vict. c. 84 , s. 13, $993(q)$

effect upon responsibility for crime of, $1007 \mathrm{ctse}$.

voluntary, no excuse, 1007

may be material to show want of intention, $100 \varepsilon$

habitual, delirium tremens, 1008, 1009

INVALID,

criminal responsibility for neglect of, 1034

INVOICE,

evidence of contract, not contract per se, $369(d)$

\section{ISSUE}

of writ, 127

joinder of, its effect, $1 \$ 2,163$

may be pleaded without leare, 163

ISSUES,

ordered by judge, 163

\section{JOINDER}

of plaintiffs, 117

of defendants, 118

of issue, 163. See Isste.

of causes of action, 146

of claims by parties in different capacities, $146(j)$

JOINT CONTRACTORS, doctrine of contribution between, 307

how distinguished from partners, 632

JOINT TENANT, payment of rent to one, when good, 545

JUDGE,

duties of, 2 et seq.

authority, whence derived, 43

powers of single, 49

vacation, 51

in chamber's, 51,52

appeal from, 52

non-liability of, for judicial acts, 103

reason thereof, 104

liable for corruption, \&c., 105

or ii acts without jurisdiction, 106

mistake in law may be reversed, 107

consent of, when necessary before action, 115

may order issues of fact to be prepared, 163

trial by, 170

province of, at trial, 179

of County Court, powers of, 199

at trial, 199 et seq.

injunction by, against nuisance, 201

can conmit for contempt, $20 \%$

noto by, 203, 204

province of, in deciding on admission of eridence, $57.9,50$

in action for malicious prosecution, $8+2$

for libel, $\$ 59,860,1051$

for homicile, 1035 
JUDGE-continued.

may discharge jury in felony case, and discretion will not be reviewed, 1095 (ut)

obstructing justice guilty of misdemeanor, 1024

JUDGE'S CHAMBERS,

jurisdiction at, 51,52

appeal from, 52

application at, how made, 53, 54

JUDGMENT,

signed under Order XIV., 134

remedy on, in action of corenant, barred after twelve years, $155(d)$

for payment into court, how enforced, $192(a)$

by default may be set aside, 163, 178

entry of, 181,186

notion for, unnecessury, 181, $: 28$

where some only of the issues or questions of fact have been determined, 185

porrers of court on, 185

how enforced, 189,262

conditional, enforcing, 189

for recovery of land, how enforced, 192

against partners, 193, 194

of County Court, 201

merger of inferior contract in, 257

estoppel by, 260

when inter partes, 260

in rem, its effect, $260(p)$

vacated by fraud, 261,329

of foreigu court, $261(x)$

in Consular Court of Constautinople, $261(x)$

binds land of debtor, 262

is a conscnsual contract, 262

how entered in criminal case, 1095

motion in arrest of, 1095

debt carries interest, $742(g)$

creditor becomes trespasser by ratification of acts of bailiff, 802,803

report of, when privileged, $854(x)$

JUDICATURE ACTS, 1873 AND 1875,

purpose of, 38

provisions of, as to courts of law, 33

proceedings in an action regulated by, 109

JUDICIAL OFFICERS,

non-liability of, 103

JUDICIAL SEPARATION, 678. Sec Married WoMAx.

IURISDICTION,

agreement to oust, 41,42

of courts over prerson abroad, $44,129,130$

extent of, 44,45

of Crown over open seas, $45(1)$

of County Court, 56

service of writ out of, 129,130

by consent cannot usually be given, 43

J'RORs,

withdrawal of, 151

how raised by sheriff, 177

formerly how chosen, 178 
JURY. Sec Grand Jury.

trial by, when of right, 171

trial by, 177

when only by leave, 171

how sworn, challenged, 178

discharge of, 180

in trial for felony, $1095(u)$

province of, at trial, 180

verdict set aside, 180

special, 180

when summoned in County Court, 199, 200

province of, in trial of action of contract, 579, 580

in dealing with evidence to vary contract, $5 \$ 8 \mathrm{ct} \mathrm{sel}$.

in action for malicious prosecutiou, 842

for libel, $859,860,1050,1051$

have wider latitude in tort than contract, 971

not bound to "weigh in golden scales," 975

may give vindictive damages, 975

may consider intention, 976

province of, in trial for homicide, 1035

swearing of, in criminal cases, 1089

challenge to, 1089

giving prisoner in charge to, 1089

JUS PRIVATUN,

what, 249

\section{JUSTICE OF THE PEACE,}

proceedings before, for recovery of small tenements, 228,229

liability of , for falso imprisonment, 831

powers of, 831, 1079 et seq.

not liable for error of judgment, 831

protection afforded to, 831 et seq.

not liable for exercise of discretionary power, 831 (c)

if acting within jurisdiction, protected by conviction gool on the face of it, 832

powers of, in case of forcible entry or detainer, 1028

as criminal judge, 1079,1080

restrictions on, 1079,1080

summary jurisdiction of, 1081 et seq.

\section{JUSTICES IN EYRE,}

when first appointed, 25, 26

anthority and functions of, 26

KING,

the, can do no wrong, 103, 243

who is, within the Statute of Treasons, 1013

prerogative of, does not extend to acting as judge in auy court, $29(x)$ offences against title, \&c., of, not triable by justice of the peace, 1079

KING'S BENCH, COURT OF. Sec QteEx's Bexcn Drisios.

its establishment, 28

original jurisdiction, 28,29

how extended, 29 et seq.

how retained, 32

\section{KING'S ENEMIES,}

act of, will excuse breach of statutory duty, 760

innkeeper not liable for act of, at common law, 927

carrier not liable for act of, 931 
LACE, machine-male not within the Carriers Act, $934(c)$

LACHES,

definition of, $471(t)$

not imputed to infant, 1011

LADING, BILL OF, 505. Sce Bill of Ladisg.

LAND,

freehold and chattel interests in, 509

recorery of, in case of vacant possession, 129

bound by judgment, 262

coutracts for sale of, 332

rule where quantity erroneously stated, $332(f)$

contracts concerning, under s. 4 of the Statute of Fratsds, 385 ct seq.

things annexed to, crops, fixtures, 388 ct scq.

contract for investigating title to, not within s. 4 of the Statute of

Frauds, $38 \mathrm{~T}(t)$

may be dedicated as highway subject to existing risks, $755(g)$

right to support for, $81,883,884$

adjacent and subjacent, 884

can be lost by agreement, 884

perhaps by prescription or custom, 884

legal significance of, 885

includes water, 885

\section{LANDLORD. Sce LANDLORd AND TExast.}

liable to outgoing tenant for seed, \&c., 17

appearance by, 134

when liable for nuisance, 118,799

tenant estopped from denying title of, $395(\mathrm{~m}), 869$

right of, to distrain in bankruptey, 654

liability of, for acts of bailiff, $\mathrm{s} 03$

entry of, when justified, $87 \%$

fixtures of, 390 (g). Sce Fixteres.

\section{LANDLORD AND TENANT,}

relation of, when arises, 509, 869

conveyance of whole interest is an assignment, 509

nature of lease, $5 \hat{v} 9$

four classes of tenancies, 509,510

term of years, 510

low created, 518

when by deel, 518

when not, 518

may arise by estopyel, 519

what included in, 519

year to year, $\mathbf{5 1 0}$

when it exists, 510

its nature, $510 \mathrm{ct}$ seq.

how created, 519

by implication of law, 519

notice to determine, 565,566

at will, 510

when it exists, 512

how created, :521

by express agreement, 521

by Statute of Frauds, 521

how determined, 512

by sufferance, 510 


\section{LANDLORD AND TENANT-continued.}

tenaney by sufferance, when it exists, 513 not created by aet of parties, 513

who may be lessors, 513

persons under disabilities, 513

infallts, 514

married women, 514, 515

lunatics, convicts, 515

corporations, \&c., 516

tenants for life, 516,517

mortgagors, mortgagees, 517

provision for emblements when lease at rack-rent, 517

relation, how created, 517 et scq.

by "attornment" clause in mortgage deed, 521

rights and duties of parties, $522 \mathrm{ct} \mathrm{seq}$.

quiet enjoyment, 522

cultivation, 525

custom of country, 525

interpretation of covenants, 526, 534

duty of tenant to repair, 526

what it extends to, 535

conditional, 535

rights of tenant on determination of tenancy, 527

to emblements, 527

tenant right, 527

only when tenaney terminates in natural course, 528

or no express agreement to the contrary, 528

affected by Agricultural Holdings Acts, $52 \dot{8}$

tenant must not conmit waste, $\mathbf{5 2 8}$

voluutary, 529

equitable, 552

not liable for accidental fire, 533

permissive, 533

secus, if caused by negligence, 533

liability to repair of tenant, $\mathbf{5 8 3}$

of landlord, 534

if for term of years, by covenant, 533

if from year to year, without coveuant, 535

fixtures, meaning of, 536. See Fixrunes.

Agricultural Holdings Acts, 539. See AGP.1C. Hold. Acts.

rent defined, 543,544

duty of tenant to pay, 543

out of what reserved, 544

to whom, 544

must be eertain, 544

when and where payable, 545

to whorn, 545

to one joint tenant, 545

right to deduct from, 524,546

right of landlord to distrain, 546

of mortgagor, mortgagee, 548,549

when it exists, 547

what may be distrained, 549 exceptions, fixtures, \&e., 550 et seq.

distress, when to be made, 554

by whom to be made, 554

assignments, 556 et seq.

by death or bankruptcy, 559

attornment no longer necessary, 556

statute Hen. VIII. c. 34,557 
LANDLORD AND TENANT-continued.

assignments, covenants running with the land, 557 ct scq. privity of estate, 5.58

apportionment of covenants and conditions, 559

of rent, 560

rights and liabilities of heir of lessor, 559

of executor, 559

of representative of lessee, 560

of trustee in bankruptcy, 561

determination of tenancies, 562 ct scq.

by effluxion of time, notice, merger, surrender, 562

surrender by operation of law, 563

disclaimer, 564

forfeiture, relief agrainst, 564

replevin, 567

use and occupation, 569

action on covenant, 569

injunction, when obtainable, 570

holding over, 570,571

LANDOWNER,

not bound to repair sea-wall apart from prescription, 79

has a right to enjoy land free from filth, 79

\section{LALCENY,}

simple: 1057

at common law, 1057

cannot be of things sarouring of the realty, 1057

of choses in action, 1058

of animals ferce naturce, 1058

statutory modifications, 1058

chattel must have been property of alleged owner, 1059

infant bailee may be convicted of, $1010(0)$

if goods stolen from bailee, $1059(n)$

must have been in actual or constructive possession, 1059

none where property originally obtained rightfully, 1060

" taking" in, what, 1062 et scq.

where goods obtained in pursuance of contract, 1063

goods must have been taken animo furandi, 1064

appropriation of lost goods, 1065 ct seq.

doctrine of relation in connection with, 1068

ingredients of, 1069

asportation, what, 1069

may be by innocent agent, 1070

can be of gas, water, 1070

how distinguishable from false pretences, 1071

by servant, 1073

from receiving stolen goods, 1070

how distinguishable from embezzlement, 1073

from the person, 1074

how distinguishable from robbery, 1074

LAW MERCHANT. SCE LEX MERCATORIA.

what it is, 9

LAW OF NATURE,

forec of, 20

LEASE,

what, 509

when must be in writing by Statute of Frauds, s. 1, 51s 
LEASE-continued.

when not, 518

when by deed, 518

when required by law to be in writing, must be by deet, 400

not fulfilling statutory requirements is an agreement, 518

implied warranty of title on sale of, $9 \pm 25(x)$

LEAVE AND LICENSE,

good defence in action for tres]rass to lanl, $878(\mathrm{c})$

LEGAL MEMIORY, what it is, 11,892

LEGAL REASON, 21

LESSEE,

who may be, 513. See IAsponon axil Texaxt.

LESSOR,

who may be, 513. See Lasnlond axd Texaxt.

LETTER,

contract by, 299, 300

LEX FORI,

when regarded by our courts, 44

LEX LOCI,

operation of, on contract, 251

on bills of exchange, 478

LEX MEPCATORIA,

what it is, 9

evidence of, 9

judicially noticed, 9

its operation on day of payment of bill or note, 251

terms recognised in, how explicable, $578 \mathrm{ct} \mathrm{seq}$.

LEX NON SCRIPTA,

what it is, 7

whether it ean control the statute law, 8

can nullify acts and contracts of individual, 8

how declared, 19

LEX SCRIPTA,

what it is, 2

how interpreted, 2,5

LIABILITY,

direct and collateral, distinction between, 350

LIBEL,

defined, $86,844,1050$

fair comment on literary work is not, 74

if not privileged, is injuria, 86

trial by jury is of right in action for, 171

notice of truth as defence in Connty Court, 199

contract to indemnify for publishing, voil, 351

right of action for, 749

corporation can sue and he sued for, 793 (le)

ingredients in action of, 845

express malice not essential, 845

statutory protection to newspajers, $810^{\circ}, 847,854,856$

trinth an answer to action for, 845,1053

cvidence in nitigation of damage, notice of, $s 46^{\circ}(p)$

evidence that other actions already brought, $8: 7$

loctrine of privilege, 847 et seq.

rebuttable by evidence of express malice, 845

B.C.L. 
LIBEL- continued.

proceedings ordered to be printed by Houses of Purliament privileged, 852

so is fair conment on jublic men, $£ 52,853$

on literary works, 853

reports of eases, when privileged, 853,854

jud gments only, $854(x)$

judicial officer privileged, 855

naval or military, 855

counsel, 85\%

member of Parliament, 856

witness, 856

classes of privilege, 856,857

jublication of, 858,859

evidence of, $858(u), 858(b)$

restraining, by injunction, 861

liability of vendor of newspaper for, $858(x)$

province of judge and jury in trial for, 859, $860,1051,1052$

if words not primarily libellous, onus on plaintiff to sliow that they are so, 860

how words are to be construed, $860(\mathrm{~m})$

injunction to restrain trade, $862(s)$

trade, 864

whether action lies for, without proof of special damage, $865(d)$ action for, causing damage to personal estate will survive to jersonal representatives, 865

what jury cntitled to consider in assessing damages for, $976(g)$

on foreign potentate indictable, $1020(c)$

on a dead per'son, $1050(x)$

blasphemous $1050(u)$

blasphemous, seditious, sc., not cognizable by justice of the peace, 1080

Fox's Act, 1051

Lord Camplsell's Act, 1052

criminal information for, 1055

liability for threatering to publish, 1055

Newspaper Libel and Registration Act, 1055, 1056

Corrupt and Illegal Practices Prevention Act, 1895, 1056

wife cannot take criminal proceedings against husband for, 687

LIIEL, LAW OF, A.ENDMENT ACT, 1888, 854

fair and accurate report of public meeting privileged under, 854, 856,1055

\section{LICENSE,}

hy jarol revocable, 399,889

equitable relief, 889

statutory, 889,890

right to eject person entering land by parol, $785(q)$

LIFS

licensee nay maintain action against stranger taking goods, 913

of banker, ?

of unpaill seller, 436

of innkeeper, $978(f), 928$ is

of livery-stable keeper, $928(s)$

of trainer, $928(s)$

of solicitor, $928(s)$

of railway company upon articles deposited in cloak-roon, $928(s)$

low distinguished from far w, 922 (i)

LIFE

order to recover property detained for, 221

insurance, contract of, 332

prolicy, assignee of, may sue in his own name, 505 
LIGHT, 896, 902. See EAsEMr.s.

measure of clamages for obstruction to, $9 i 1$

LIMITATION, 153. See Statute of Linitatioss.

in treason. $1018(\omega)$

of time to indictment, $1087(l)$

LIQUIDATED DAMAGES. See DAMAGEs.

how distinguished from penalty, $723 \mathrm{et} \mathrm{seq}$.

LOAN,

implies a request, 305

LOCAL BOARDS, liability of, for negligence, $755(h)$

LOCATIO, conductio, rei, operis faciendi, operis merciun vehendarm, 921

LOCONOTIVE ENGINE, meaning of, in Employers' Liability Act, $813(s)$

LODGER, goods of, protected from distress, 551, 552 remedy of, for illegal distress, 568

LODGING-HOUSE KEEPER, liability of, 929

LONDON STOCK EXCHANGE, rules of, 19

reasonableness of, $19(h)$

gambling on, not necessarily illegal, $589(r)$

\section{LOPPINGS}

falling on neighbour's land may be retaken, $206(e)$

\section{LORD CAMPBELL'S ACT,} remely under, not barred because act was felonious, 102. 816 object ot, 12:

gives no remedy against representatives of deceased tortfeasor, 12: for whose benefit action to be brought, 816

does not apply in cases of collision at sea, $815(h)$

LORD TENTERDEN'S ACT, object of, 157

to explain Statute of Frands, 405

LOSS,

defence of, in action on bill or note, 503,504

at common law, 503

by statute, 504

on non-negotiable instrument, 504

LOST CHATTEL,

title of finder, 912, 913

when appropriation of, amounts to larceny, $106:$

LUGGAGE, meaning of term, $944(b)$

liability of railway company for loss of, $414 \mathrm{ct}$ scy. in respect of, $945(l)$

LUNATIC,

action by and agrainst, 121 
1.VXATIC-continued.

default of appearance by, 136 (i)

leases to and by, 515

caunot contract by agent, 597

position of wife of, 699

definition of, 700

liability of, on executed contracts, $701 \mathrm{et} \mathrm{seq.}$

for necessaries supplied, 700,701

contracts of, voidable when condition shown to have been known to other party, 703

evidence admissible to prove that malady must have been evident to other party, $703(x)$

liable on deed executed in lucid interval, 703

imbecility of inind necessary to aroid contract of, 703

effect of lunacy of principal on authority of agent, 704

civilly liable for tort, 783,977

prescnt position of, at criminal law, 1001 et seq.

exemption of, from criminal liability, 1002 et seq.

must be non compos mentis, 1001

meaning of this in criminal law, 1002

rules in McNaghten's case, 1002 et seq.

criminal responsibility for neglect of, 1035

honest belicf in sanity of patient will not exense a breach of $8 \& 9$ Vict. c. 100 , ss. $4 \dot{t}, 90,993$

Magistrate, 831, 1079. See Justice of the Peace.

duty of, in quelling riot, $1027(c)$

\section{MAGNA CHARTA,}

noticed, $26,234,235,866$

\section{IAIYTENANCE,}

illegal, $356(n)$

IAKER, 489. Sce Prounssoliy Note.

\section{IIALA FIDES,}

not actionable without damage, 90

\section{IALA PRAXIS,}

an offence at common law, 819

IALICE,

meaning of, $835,1033(\mathrm{~g}), 1035$

iu law, 836

iil fact, $\$ 36$

express or implied, 1033

sometimes essential ingrelient in actionable wrong, $78,83(y)$

express, not necessary to support action for libel, 845

unless privileged, 847

tests of, 848

in crimiual law, what, 1035

\section{MALICIOUS ARREST,}

what it is, $837 \mathrm{ct} s \mathrm{se}$.

action against governor of prison for kecping prisoner over time, $838(f)$

\section{M.ILICIOUS INJURY,}

what necessary to support action for, 836

\section{M.ILICIOLS PROSECUTION,}

what it is, 839

trial by jury as of right in action forr, 171 
MALICIOUS PROSECUTION-continued.

essential ground of action, 839

contrasted with false imprisonment, $\& 39$ (l)

whether it will lie against a company, $839(l)$

where prosecution ordered by a County Court judge, 840 (l)

must prove want of probable cause, $8: 0$

malice alone insufficient, 840

onus of proof, on whom? 842

provinee of judge and jury, 842,843

plaintiff must show proceedings terminated in his farour, if sible, 843

MANDAMUS,

action of, $214(x)$

writ of, 214

nature of, 215

how granted, 215

when available, 215

original operation of, 215

will not issue against Crown or its serrants, $215(\approx)$

nor to Central Criminal Court, $216(j)$

extension of, to inferior courts, 216

to County Court, 63

remedy for enforcing the taking up of awards under the Lands

Clauses Act, 216 (i)

in aid of legal proceedings, 217

when refused, 217

return to writ, 217

peremptory, 217

disobedience tn, how punishable, 217

may be granted by interlocutory order, 221

MANDATES,

what, 917

in 1st elass of bailments, 917

MANSLAUGHTER,

what it is, 1032 et seq.

how distinguished from murder, 1033

homicide on provocation cannot be less than, 1038

what provocation will reduce to, 1038, 1039

in fights or struggles, 1039

in abetting a prize-fight, $1039(n)$

by undue correction, 1040

by negligence, 1040 et seq.

of medical practitioner, 1042

negligence must be personal, 1042

not of trustee neglecting to repair roads, 1042

of fugitive by ofticer, 1044

not of felon, 1044

MARINE INSURANCE,

contract of, 331

MARINE POLICY, assignee of, may sue in his own rame, 505

MARKET, damages, when recoverable for loss of, 739

MARKET OVER'T,

effect of sale in, 429,429 (i)

purchaser of stolen beasts in, eannot counterclaim for cost of keep $913\left(r^{\circ}\right)$ 
MARLBRIDGE, statute of, 529,554

\section{Marriage. See Married Womax.}

will not abate action, 124

when action for breach of promise of, may be brought, 112 trial by jury as of right in, 171

not within s. 4 of the Statute of Frauds, 385

agreements made upon consideration of, 385

brocage bonds illegal, 355

contracts in restraint of, 355

formerly caused transfer of choses in action, 445

offence against laws of, not triable by justice of the peace, 1080

\section{MARRIED WOMAN,}

actions by and against, 120,121

no implied promise in contract of, 322

leases to and by, 514,515

cannot contract by agent, 571

is sometimes agent of her husband, 597

position of, in contract, $617(x)$

at common law, 675

coverture merged existence of, in husband, 675

exception to this rule, $675(s)$

could not contract with him withont trustee, 675

contraet between woman and man voided by internaniage, 676

no action of tort letween husband and, 676

personalty of, vested in husband, 676

profits and rents of realty, 676

could reduce her choses in action into possession, 676

cliattels real, 676

savings of, went to husband, 677

secus, in equity, 677

husband could recover wages and profits of, 677

statutory provisions as to, $677 \mathrm{et} \mathrm{seq}$.

$20 \& 21$ Vizt. c. $85,21 \& 22$ Vict. c. 108,678

woman divorced same as feme sole, 678

judicially separated same as feme sole as to separate property, 678

if deserted could obtain proteetion order, 678

maintenance of, in case of desertion, $678(l)$

33 \& 34 Vict. c. 93 , provisions of, as to holding property, 678,679

as to maintaining action in own name, 680

against banker for dishonouring her cheque, 680

$37 \& 38$ Vict. c. 50, liability of husband for debts of wife, 681

present imprortance of above statutes, 681

$44 \& 45$ Vict. c. 75 , provisions of, 681 et seq.

contractual capacity of, 682

can contract as feme sole in reference to separate proprerty, 682

action against, by husband for money advanced, 682

liability of lusband for wrongful acts of, 682

when unable to contract, $68^{\circ} 2$

Married Women's l'roperty Act, 1893, 682, 683 (o)

when Statute of Limitations begins to d'm against, 683

Ineatuing of "property," $685(c)$

of "xeparate property," $684(v)$

judgment by defunlt nay be signed against, 683

payment of eosts incured by, out of separate property subject to restrinint, $683(0)$

(:ontract of, presmued to refer to separate property whether at the time of eontracting she has ol has not any, 682 binds after-acynired property, 633 
MARRIED WOMLAN-continued.

contract of, secus, if subject to restraint on anticipation, 183

if a trader may be male bankrupt, 683

secus, before the Act, 684

or if not trading apart from lussband, $63 \$(r)$

position of, when creditor of bankrupt hnshand, $68 t$

liability of, not personal, 684

cannot be committed under Debtors Act, s, 5, $683(q)$

can effect policies, 684

remedies of, 684,685

liabilities of, 685

if married before Act, 685

eapacity of holding separate property if married before the $\mathbf{\Lambda}, \mathrm{t}, \mathbf{5 . 9 6}$

power of disposing of property by will, 655

if married after the $\mathrm{Aet}$, is 3

will does not require to be re-executed or repnblisherl after husband's death, 685

provision as to shares, \&c., in name of, 686

remedies between husband ant wife, 686 ct seq.

can give evidence against one another, 687

criminal proceedings, 687

cannot take any against husband for defamatory libel, 687

property may be laid in wife in indictment, 687

criminal liability of wife, 687,688

respective liability of husband and wife for debts of wifo contractel

before marriage, 688

liabilities of wife, to what extenderl, $688(\gamma)$

husband can give evidence against wife on criminal charge under s. $16,688(p)$

can enforce undertaking as to damages where injunction wromgly

granted, $687(m)$

settlements on, 689

power of asticipation of, 689

as executrix or administratrix, 689

liable tor support of husband and children, 659

liability of husband for debts of, luring covertmre, $659 \mathrm{elsc}$.

prior to Act contracted as agent for linsband, 690

husband bound to supply her with necessaries, $690 \mathrm{ct} \mathrm{sc}$.

whether husband still liable on contracts of, 691

assumed that legis!ation has made no change, 691 (i)

rules as to necessaries, 692 et seq.

when living together, and the husband snpplies her, $692--691$

and lie does not, 694,695

when living apart by consent, $695-697$

when he descrts or drives her away, 697

agency of wife determinet by adultery, 697, 698

husband sot compellable to support alulterous wife under $31 * 32$

Vict. c. $122,697(p)$

when voluntarily leaves husband, 698

when husband does not pay decreerl alimony, 698

other view of husband's liability, 699

position of wife of lumatic, 699

husband liable to volunteer for funeral expenses of wife, $z 00$

marital relation severed by civil deatl, 700

or temporary disability, 700

MASTER AND SERVANT, servant. When authorised to pledge creclit of, $603(y)$

liability of, for tort of servant $790 \mathrm{et}$ se $\%$.

for negligence of, $797,798,806,807$

for wilful act of, 797 
MASTER AND SERVANT-continued.

civil liability of, for act of, $960^{\circ}$

lialility of, to servant for negligence of fellow-servant, 806

when not in common service, 808,811

for personal interference, 808

for exposure to undne risk by statute, 811. Sce EMPLOYERs'

LIABILITY ACT.

not liable to rolunteer, 807

action by, for battery of servant, 969

measure of damages in, $969(q)$

cannot sue for injury to servant causing death, 969

action by, for enticing away servant, 969

none fol" enticing away apprentice, umless serving under valid articles of indenture, $970(u)$

measure of damages in, $970(x)$

giving character of servant privileged, 848,857

or in reproving before strangers, 849

if volunteers character, stronger evidence will be needed of absence of malice, $849(b)$

NASTER OF SHIP,

jowers of, 605

duties of, $605(0)$

\section{MASTERS OF SUPERIOR COURTS,}

their duties, 52,53

appeal from decision of, 54

reference to, 48

MIXIIS, LIST OF,

actio personalis moritur enin personî, 121, 711, 777, 865

actus non facit rewn nisi mens sit rea, 999, 1051 (z), 1066

ad qucestionem faeti non respondent judices, 976

al proximum antecedens fiat relatio, 573

uqua curvit et debet currere, 886

causa proxima non remota spectatu, 91

carcat emptor, $331,496,925(y)$

consuctudo ex certâ causêt vationabili usitate mivat communem

lcgem, 13

contre non ralentem ageve nulla currit prescriptio, 158

eujus cst solum ejus est usque aul colum et ad inferos, 902

cum aliquid alicui conceditur, conceditur et id sine quo res ipsa

haberi non potest, 892

delrgata potcstas non potest delegari, 417 (s)

de ninimis con curat lex, 749

erery man's house is his castle, 748

ex antcedentibus et consequentibus est optima interpretatio, 594

ex dolo malo now oritur actio, 327,347

er muds pacto non oritur ertio, 919

min lurpi causi non ovitur actio, 347

expressio unius coclusio altritus, 573

e.roressum furit cessere tacitum, 272, 308

sotra territorium jus dicenti impnene non percter, 45

falsa orthorruphia, falsa gremmetica non vitiat cartam vel ronecssionem, 594

frans vilint ommiat, 261, 282

furtum non cst ubi initium hubet eletentionis per dominum rei, 1061

he who takes the protits ought to bear the loss, 626

il crrtum cst quod certum reddi protest, 15, 544

ignurantiu juris quoel quisque scire tenetur, nominem excusat, 986 
MAXIMS, LIS'T OF-continued.

in treeditionibus chartarum non quod dictum cst sed quod facturn col inspicitur, 266

judi is est jus dicere non jus dare, 4

jus accrescendi inter mercatores, pro beneficin commorcii, lсеи "им habet, 641

king (the) can do no wrong, 103, 243

lex est norma recti jubens honeste et prohilens contrurin, 367

lex non favet delicatorum votis, $822(t)$

locus reyit actum, 478

maledicta expositio qua cormempit textum, 594

malitia supplet atatem, 1010

misera est servitus ubi jus cst vagum aut incognitum, 1

nemo allegans suam turpitudinem est audiemulus, 100

nemo bis vexuri debet pro eâdem causit, 1088

nemo dat qui non habet, $400(l)$

nemo debet esse judex in propria causa, 260, 354

nemo cnim aliquam partem recte intelligere possit antequam totum

itcrum atque itcrum perlegerit, 594

nemo potest exuere patriam, 1012

nihil quod est inconveniens, est licitum, 9, 353

nihil tam conreniens est unturali aquitati ut unumqualque dixsolri

co ligamine quo ligatum est, 292

nil conscnsui tam contrariun est quam ris atque metus, 705 (1)

no one shall be permitted to aver against a record, 255

non omne quod licet honestum est, 331

noscitur a sociis, 573

mullum temenus occurrit regi, 1087 (l)

obligatio est juris vinculum quo necessitate ustringimur ulicujus ri

solvenda secundum nostree civitatis jura, 253

obligatio mandati conscusu contrahentium consistit, 596 (c)

omnia presumuntur contra spoliatorem, 972

onnis ratihabitio retrotrahitur et mandato prioni "quiparatur, 30 ?

pacta conventa, que neque dolo malo neque alversus leges facte erwut, servabo, 367

prohibetur ue quis faciat in swo quod nocere possit alieno, 822, SS4

quando aliquid mandatur, mandatur et omne per qual perrenitur ad illud, $604(g)$

qui facit per alium est perinde ac si faciat per seipsum, 5.96

qui facit per alium facit per se, 790, 794, s10

qui havet in litera haret in cortict, 594

qui mandat ipse fecisse, videtur, 596

qui tacet consentive videtur, 366

qui vult decipi decipiatur, 367

quicquid plantatur solo, solo colit, 388, 536

quad fieri non debct factum valet, 283

quod necessitas cogit excusat, 1000

quod turyi ex causâ promissum est reluti si quis homicidium of

sarvilegium se facturem promittat, non valct, 278

res inter alios acte alteri wocere non debet, 260

res ipsa loquitur, 751, $817(q)$

respondeat superior, $791,810,930$

salus rcipublice suprema lex, 9

scribere est agere, 1017

sic utere tuo ut alicuum non levlas, $9,769(\mathrm{~g}), 500,851,853$

silence gives consent, $331(x)$

spondes peritiam artis, 342

tacite inesse videntu, quet sunt monis et conswetudinis, 581

traditio linqui facit chartem, 265

transit in rew judicatem, $257,259,275$ 
MAIIMIS, LIST OF-continued.

turpis cst pars que cum suo toto non convenit, 594

rerba relata inesse videntur, 573

rigilantibus non dormicntibus jure subveniunt, 367

colenti non fit injuria, $\$ 15,815(f)$

rolumes reputatur pro facto, 1016

MEASLRE OF DAMAGES. See DAMAGes.

in contract, 717 et spq.

in tort, $971 \mathrm{et} \mathrm{scq}$.

MEIBER OF PARLIAMENT, privilege of, 856

\section{IIENIORANDUMI}

of appearance, 133

in writing under the Statute of Frauds, 114, $404 \mathrm{et} \mathrm{scq}$.

canuot be altered verbally, 418,419

when it must be signed, 114, 412

may consist of several documents, 412 et seq.

should state price if settled, 413

$$
\text { both names, } 414
$$

signature of party to be charged sufficient, 414

what is sufficient, $414 \Leftrightarrow$

may be signed by agent, auctioneer, \&c., 414 et ser.

MEMORY, LEGAL, 11, 892

IIERCANTILE TERMS, evidence to explain, in written eontracts, 578

MERCANTILE USAGE, 9. See Lex Mercatoria. judicially recognised, $579(a)$

\section{IERCHANT SHIPPING ACT,}

how it affects the trausfer of a ship, 100

\section{IERGER}

of right of action in indictment, 98

of tort in felony, 99

when rule does not apply, 100

exeluded by Lord Campbell's Act, 102

doctrine of: unaffected by Julicature Acts, 258

importance of, 258

what it is, 256 et seq.

of cause of action cx contract $u$ by judgment, 256

$$
\text { ex delicto, } 259
$$

by deed, $266,273,395$

operation of, 274,275

only when remedy co-extensise, 275

none where intention clear that there should be rone, 275

of term in reversion letermines lease, $\mathbf{5 6 2}$

YISE,

rights of owner of, 82

Jiability for negligence of workmen, 792

MISDEMEANOR

under Bankrujtey Act, 663

\section{.II:DESCIIIPTION,}

will arojl contract for sale of lands, 3332 
MISFEASANCE,

gratuitous agent liable for, 779

gratuitous bailee, 919

corporation liable for intentional, of servant, $793(h)$

MISJOINDER

of parties will not defeat action, 119, 120

MISPRISION,

definition of, $990(y)$

of treason, $1014(g)$

not triable by justice of the peace, $10 \% 9$

MISREPRESENTATION. Sce Frald.

with damage actionable ex delicto, 7 79,780

not without damage, 780

estoppel in pais in relation to, 960 et seq.

MINED ACTIONS, 146

MONEY HAD AND RECEIVED, privity necessary to support action for, 316,317

action for, founded on failure of consideration, $311 \mathrm{ct} s \mathrm{~s}$.

MONEY LENT,

antecedent request implied, 303

MONSTRANS DE DROIT, when available as a remedy, 238, 239

MONTH

in contract of sale of goods, primâ facie, a caleular, $422(y)$

at law, a lunar, 554

evidence admissible to show parties to written contract meant calendar, 580

in bills of exchange, a calendar, $450(r)$

MORAL CONSIDERATION, 309, 325. See Cosidekatios.

MORTGAGE,

controlled by $l e x$ loci, 251

of chattels, $399(h)$

IOR'TGAGEE,

leasing powers of, 517

right of distress of, 548,549

MURTGAGOR,

leasing powers of, 517

right of distress of, 549

MORTMAIN AND CHARITABLE USES ACT, 1888, 516

MOTION

in court, 46

notice of, when to be served, $47(y)$

when without notice, 47

how made, 48

when $e x$ partc, 47, 48

for judgment, none necessary, 181, 184

where some only of the issues or ynuestions of fact have been determined, 185

MUNICIPAL LAW,

what it is, 1

its sphere, 254

not antagonistic to universal liww, 254 


\section{MURDER,}

what it is, 1032 et scq.

how distinguished from manslaughter, 1033

in figlits and struggles, 1039

by undue correction, 1040

by negligence, 1040 ct seq.

of fugitive, 1044

homicide of felon is not, 1044

felonious homicide involvel in, 1048

not triable by justice of the peace, 1079

\section{MUTUALITY,}

meaning of term, 300

in contracts of hiring and service, 300 ( $p$ )

want of, in contracts under seal, $301(y)$

by one party, $301(y)$

with corporations, $301(y)$

may be defence in equity against suit for specitic performance, 302

against infant suing cx contract $u, 673$

\section{NATURAL RIGHTS,}

distinguished from easements, 882

support for land, 883

adjacent and subjacent, 884

may be lost by agreement, 884

perhaps by prescription or eustom, 884 to flowing water, 886 et seq.

to light and air, 902

\section{NATUlRE,}

law of, 20

NAVIGABLE RIVER,

liability for obstructing, $755,756,1030$

NEC VI NEC CLAM NEC PLECARIO, 895, 909

\section{NECESSARIES,}

liability of infant for, $66 \boldsymbol{t}$

infant must pay reasonable priee therefor, 668

articles of mere luxury cannot be, 669

husband bound to supply wife with, $690 \mathrm{ct} \mathrm{seq}$.

what are, 692 et seq.

liability of lunatic for, 700

$$
\text { of drunken man for, } 70 \text {; }
$$

\section{NEGLIGENCE,}

not actionable without danıage, $90,751(t)$

must be cansa ceusans, 91

arbitrator not liable for, $104(0)$

causing damage actionable, 750,965

no absolute or intrinsic, $750(\ell)$

meaning of "gross," $927(q), 937(r)$ evidence of, $751(t), 9: 8(v)$

questions for judge and jury in action for, 751, 752 intention immaterial, 782

action for bodily injuries causel by, $786(z)$

in actions on statutes sime rules as at common law, 817

may he a gromud of estoppel, 960,960 (b)

where pluntifl has contributed to injury by his owu, $787 \mathrm{ct} s c q$. 


\section{EGLIGENCE-continucd.}

law as to contributory, 787,788

of infant, guardian, 789

of third person, 789

onus of proof in cases of, $783(c)$

effect of contributory, on carrier, $941(l)$

liability of master for servant's, to stranger, $790 \mathrm{et} \mathrm{se}$.

only when engaged in his business, 797

to fellow-servant, 806 et seq.

of trustees, etc., $755(h)$

of solicitor, 769,966

of patent agrent, $769(l), 966$

of carrier, 769

of engineer, 769

of gratuitous bailee, 919

of medical practitioner, $\$ 23$

of pawnee, 923

of innkeeper, 927

of boarding-house keeper, $9: 29$

of lodging-honse keeper, 930

of railway company for acts of servant, 793

of shipowner for negligence of pilot, $792(\approx)$

of tenant for fire cansed by, 510

no action against sheriff for not levying under a $f$. $f a$. unless has caused actual loss, $89(x)$

measure of damages in action against solicitor, 973

homicide by, 1040 et seq.

for cansing death, 816

to amount to manslanghter must be personal, 1042

not of trustees not repairing roads, 1042

of doctor, when criminal, 1042

\section{NEGOTIABILITY,}

how differs from assignability, 448

inherent in bills of exchange, nnless containing worls prolibiting transfer, 454

NEgotidBLE INSTRUMENT. See biLl of ExchaNie, ete.

what it is, 442

exception to common law rule that choses in action are not assign.

able, 142

equitable rules as to, $\$ 45,446$

when operates as discharge of debt, 493

general duty of holder of, 493,494

how far corporations can accept, $645(n)$

NEGOTIATION

of overdne bill, effect of, 457,458

\section{NEW TRIAL,}

how applied for, 183

when granted, 182 et seq.

when not granted, $183(x)$

in County Court, 202

\section{NEWSPAPER,}

statutory protection to, in actious for libel, 846, 84i, 3:4t, 1055, 1056

liability of vendor of, for libel, $\$ 58(. c)$ 
NISI PRIUS,

origin of, 27

trial at, by a jury, 174 et seq.

NOMINAL DAMAGES, 716, 720. See DAMAges.

recoverable ior violation of a right, 89

NON COMPOS MENTIS. SEC LuXATIC. metning of, in criminal law, 1001

NON-ACCEPTANCE, $459(p)$. See Dishoxour, Bill of Exchaxge.

NON-DISCLOSURE

of facts not necessarily fraudulent, 330,331

NON.FEASANCE.

gratuitous agent not liable for, 779

gratuitons bailee, 919

infant not criminally liable for, 1010

NON-JOINDER

of parties will not defeat action, 119, 120

NON-PAYMENT, $459(p)$. See Dishorour, Bill of Exchaxge.

NON-SUIT, 180,181

NOT GUILTY BY STATUTE,

plea of, $142(m)$

NOTARIAL ACT,

what, 474

NOTICE

of action, when necessary, 115,116

in lieu of service, how given, 131

of trial, when given, 176

how given when evidence taken by affidarit, $177(\mathrm{~m})$

when necessary before abating nuisance, 209, 211

of dishonour, 459. See Dishosour, Bill of Exchaxge.

under Employers' Liability Act, 814

must be in writing, $814(\approx)$

to protect carrier, effect of, $932 \mathrm{et} \mathrm{seq}$.

when invalidated by statute, 935

to determine lease, $\mathbf{5 1 0}, \mathbf{5 6 5}, \mathbf{5 6 6}$

NUDUM I'ACTUM, 314

\section{NUISANCE,}

public, when actionable, 96,97

parties liable for, 118,119

judge of County Cour't can grant injunction against, 201

abatement of public or private, 209 et seq.

by commoner, 209 whether notice necessary, 209, 211

liability of owner of realty for, 798,799

entry on land to abate, 878

jublic, 820

private, 821,880 et seq.

to realty, 880 et seq.

instances of, 880,881

remedy for, 821

test as to whether thing is, 822

plaintiff entitled to injunction or damages, 881 
NUISANCE-continued.

riots to remedy private, not within Statute of Treasons, 1020

owner of works may be liable for nuisance caused by workmen. though without his knowledge and against general orlers, 1030 (:) what is, in criminal law, 1030

remedy for, 1030

OATHS,

persons administering or taking unlawful, not trialile before justice of the peace, 1080

OBLIGATION, definition of, 253

and right are correlative, 254

by record may be released by deed, $259(v)$

moral, 309

distinguished from easements, 882

OBLIGEE

of bond, 272

OBLIGOR

of bond, 272

heir of, when bound, 289

personal representatives oi, when bound, 259

OBSCENE PRINTS,

possession of, not indictable, 998

procuring with intent to publish is, 998

though object innocent, 996

\section{OBSTRUCTION}

of highway, remedy for, 1030

what amounts to, $820(g)$

of due course of justice, 1024

OFFER

and acceptance must be ad idem, 298

by letter, 299,300

\section{OFFICER,}

police, right of, to arrest, $828 \mathrm{et}$ seq.

liability of, for false intprisomment, $\$ 29$

freedoun fiom liability of julicial, $103 \mathrm{et} s c$.

homicide by, 1044

OFFICES,

contracts for sale of, illegal, $356(n)$

OFFICIAL RECEIVER, 653. See BAxkntricr.

OFFICIAL REFEREE, 170. See REFrHE..

OPERATION OF LAW, remedies by, 212

ORAL EVIDENCE. See Evidexck, STATtTE of Fratus.

ORDER,

made on suggestion of Attorney-General, $47(t)$

how enforced, 190

interim, for preservation of property, 220 
ORDER-continuel.

to recover property detained for lien, 2:21

for inspection of property, 220

for'sale of nerishable, 220

will be set aside for frand, 256

application under Order XIV., how made, 135

effect of, 134, 135

appearance to, 134

ORDER OF DISCHARGE, 662. See BANKRUPTCY.

()UTLAW,

cannot contract, 707

OUTLAWRY, abolished in civil proceedings, 191, $707(c)$

(1VERT ACT, necessary to prove treason, 1015

what is an, 1016, 1017

whether bare words are, 1017

writing may be, 1017

conspiracy may be, 1019 (b)

PAIS

estoppel by acts in, 395 (n)

PAPCEL,

what is, within the Carriers Act, $934(d)$

PAPDON,

absolute or conditional, 1096, 1097

PARENT AND CHILD,

relation of, 967

action by, for seduction of child, 967

sround of action, 967

lies withont proof of special damage, 968 (ii)

PARLIAJENTARY TRUSTEES,

liability of, 616

P'AKOL,

agreement before breach cannot discharge specialty, $290 \mathrm{ct} s \mathrm{eq}$.

sccus if after breach, and damages are unliquilated, $290 \mathrm{et}$ seq.

might discharge specialty in equity, 295

contract, what, 368,369 . Sice Costract.

evidence. Sce Evidexce, Statite of Fratds.

license, 889. See Licexise.

P.ART-OWNER OF SHIP,

in same position as partner in action for breach of contract, $629(k)$

jworer of, to bind another for repairs, $605(0)$

I'ART-PAYMENT

in contract of sale of gools, 411

cannot be pleaded in satisfaction of delit, 396

I'AIT-PERFORIANCE

muler s. 4 of the Statute of Framls, 385

(") ility of, under statute, does not extend to contracts not concernin

land, $392(t)$

nor to contracts with corporations, 649,650 
PARTICULARS

of demand, must be annexel to summons in Connty Conrt, 197

PAR'LIES TO ACTIONS,

lefined, $40(x)$

plaintiffs cx contractu, general rule as to ehoice of, 117,118

partners, 120, 626 et seq.

trustee in bankruptcy, 120

married women, 120,121

infants, 120

non compotes mentis, 121

executors and administrators, $121 \mathrm{et} \mathrm{seq.,} 708 \mathrm{et} \mathrm{seq.}$ change of, by death, 124

who should sue on specialty, 263,264

on simple contract, 118,312

joinder of plaintiffs, 117

principal and agent, $596 \mathrm{et}$ seq .

husband and wife, 121, 675 et seq.

bankrupt, 653 et seq.

defendants ex contractu, general rule as to choice of, 118

heir and devisee, 289

principal and agent, $596 \mathrm{ct}$ seq.

partners, 120, 626 ct seq.

husband and wife, 121, 675 ct scy.

executors and administrators, 121 et ser., $703 \mathrm{ct}$ ser.

plaintiff's $\mathrm{ex}$ delicto in trespass to land, $870 \mathrm{et} \mathrm{seq}$.

joinder of plaintiffs, 117

to goods, 912 et scr.

husband and wife, 121,675

executors and administrators, $121 \mathrm{et}$ seq., $708 \mathrm{et}$ siq.

defendants $c x$ delicto, joinder of, 119

executors and administrators, 121 et seq.

partners, 629 et seq.

members of elub, 632

where death is caused by negligence, $811 \mathrm{ct} s e$.

projected companies, 6.2

effect of bankruptcy on, $653 \mathrm{et}$ seq.

PARTIES TO CONTRACT,

evidence admissible to identify, 577

\section{PARTITION}

requires a deed, 400

\section{PARTNER}

is agent of firm, 509,630,631

acceptance of bill by, withont authority, 473

if member of tralling firm. 473

of non-trading firm, 473,474

statutory power of one, to sue co-partner on behalf of concern, dis] whether, can borrow money on behalf of, $6: 31$ ( $v$ )

liability of secret, 627

nominal, 631,632

lormant, +11

old and new, in bank, 640.611

unknown, for goods ordered by jartuer, b3:3

agency of partner in trading firm, $633: 3,6334$

low distingnished from joint eontractor, 632

powers of, in trarling firm, 6333,634

in non-trading firm, 53.5

when not agent for tirm, 637

must be authorised by deed to biml firm by specinlty, $3: 3:$ :

B.C.L. 
PARTNER-continued.

statutory provisions, $630^{\circ}$

liability of, when it begins, 638

when it ceases, 638,639

may be determined br election, 639

is by estoppel only, 640

estopjel as against apparent, 962, 963

rights of, go on death to personal representative, 642

do not go by survivorship to partners, 642

position of, in equity, 642

\section{PARTNERS}

actions against, 120

appearance by, $133(n)$

judgment against, how enforced, 193, 194

are agents for one another, 509, 630

rule as to proportion in which losses are to be borne by, $626(t)$

who are not, 627,628

cannot contract with each other in matter relating to partnership, 629

secus, where does not relate, 630

position of those who are solicitors, 635

\section{PARTNERSHIP,}

what it is, 626

lrow, differs from a company, $626(q)$

how constituted, 626

members of, are agents for one another, $626,630,631$

rules in determining whether, exists, 627, 628

liability of member of trading, how determined, $633 \mathrm{et} \mathrm{seq.}$

prowers of members of, 633 et seq.

josition of parties when member of, has opened acconnt at bank in own name, 636

when borrower applies to partner at bank for a loan, 636,637

hankruptey of nember of, 660

judgment not recoverable simply against firm where infant a partner, $671(r)$

receiving order cannot be made against firm simply, $671(r)$

method of retiring from, 639,957

PARTNERSHIP ACT, 1890

declares and amends the law, 625

definition of "partnership" "within, $626(q)$

PARTY.

defined, $40(x)$

PATENT,

infringement of, is actionable, 85

PATENT AGENT

P'AIIN

liability of, for negligence, $769(l), 966$

What it is, 888

e'ssentials of valid, $889(z)$

distinguisherl from lien, $888(i)$

degree of diligence required in regard of, 889

duty of puwnee in giving np, 889

I'AWNLROKER,

contraet of, 916

lecgal position of, 923, 924

right of, to sell pledge, 924

does not warrant title of ehattel, 924 it seq.

liahility of, for lammage by accidental tire, 923 (I) 
PAWNEE,

liability of, 923,924

duty of, 923

may maintain action against stranger taking goods, 945

PAWNOR.

rights of, 923,924

PaYeE. See Bill of Exchaxge, Promissoric Nutr.

PAYMENT,

must be pleaded, 142

in action on covenant or bond, 293

in contract of sale of goods, 432

supra protest for honour, 474

of bill or note, 497,498

how to be made, 497

when bill not discharged by, 497

supra protest, $498(s)$

into Court, 152

must be pleaded, 152

admits liability unless denied, 152

notice must be given, 152

acceptance of, 152

in case of libel in newspaper, 847

\section{PENALTY,}

by whom recoverable, 99

controlled by lex loci, 252

recorery of, under statute, 318 wlien only by Crown, 318

implies a prohibition, 349

infant cannot bind himself by, 670

how distinguished from liquidated damages, 723

definition of, $724(k)$

rules as to, 726,727

PENSIONS,

for past services attachable by order of garnishment, 2.5

PER QUOD CONSORTIUM AMISIT, 967

PER QUOD SERVITIUM AMISIT, 969

PERFECT AND IMPERFECT RIGHTS, 110

PERFORMANCE,

must be pleaded, 142

PERJURY,

definition of, 1027

compromise of indictment for, illegal, $277 \mathrm{ct} \mathrm{scy}$.

not triable before justice of the peace, 1080

PERPETUITIES,

contracts violating law of, illegal, 355

PERSONAL ACTIONS.

what are, 147

PERSONAL REPRESENTATIVE. See Exi:crul:

PERSONAL SECURITY,

right to, 782 
PETITION OF RIGHT, remedy by, 238 et seq.

statite of, 235,239

lies for breach of contract, 242

Crown is entitled to discovery as against petitioner, $241(e)$

will not lay against the Crown for invading a patent, 242

will not lie for alleged tort, 243

\section{PHYSICIAN,}

no implied promise to, in contract at common law, 322

secus by statute, $322(b)$

negligence of, criminal, 1042

civil liability for, 823

\section{PLAINT,}

in Connty Court, where entered, 196

PIAINTIFF. See Parties to Actioss.

\section{PLANT,}

meaning of, in Employers' Liability Act, 1880, 812 (i)

PLEA. See Pleadisgs.

special, 1088

autrefois acquit, attaint, 1089, 1089 (u)

\section{PLEADINGS,}

trial without, 138

what, 139 et $s \mathrm{sq}$.

eosts of unnecessary prolixity in, 139, 148

statement of claim, when to be delivered, 139

special indorsement equivalent to, 145,146

none after reply without leave, except joinder of issie, 139, 163

statement of defence, when to be delivered, 140, 148

reply, 140, 163

rules for, 140 et seq.

subsequent to reply, 163

amendment of, 140

allegation of fact, if not denied, admitted, 141

admission of statements in, 141

matters to be raised by, 141, 142

must be self-consistent, 142

denials in, must be specific, 142

not guilty by statute, $142(\mathrm{~m})$

joinder of issue, effect of, 142, 163

denials in, must not be evasive, 142

bare denial of contract, effect of, 143

denial in, of representative capacity must be specific, 143

malice, knowledge, etc., how pleaded, 143

contents of documents, 143

notice, 143

facts, where law presumes in plaintiff's favour, 144

matters arising pendente lite. 144

payment into Court, 152, 153

withdrawal of, 145

may be ordered to be struck ont, 145

form of statement of claim, 148

consequences of default in, 148,149,163

in action of mandamus, 149,150

of injunction, 149, 150

for recovery of land, 150

subseinuent to reply, when to be delivered, 163

default in issues not between plaintiff and defendant, 162 
PLEADINGS-continued.

reply; when delivered, 163 statements of fact in last delivered, deemed to be put in ixsue, 163
in County Courts, 198. See Corstr Covrit.

PLEDGF, 916, 922. See BaIlmext, Pawx.

POLICY OF INSURANCE, assignment of, 505

POSSESSION,

writs of, 192

action to reeover goods, ex delicto, 749

assault in defence of, justifiable, 785

necessary to support action for trespass, 872 test of actual, 872

must be exclusive to support trespass, 874

protection of rightful, 912

of wrongful, where rightful quoad defendant, 912

mere, title against wrong-doer, $912(0)$

constructive, what, 914,915

of exeentor, 915

administrator, 915

actual or eonstructive, necessary for lareeny of clattel, 1054

POUNDAGE, \&e., 193

PRACTICE,

in superior courts, how regulated, 109

of County Courts, 196

PRÆCIPE,

to be filed, 190

PREMUNIRE,

offences subject to penalties of, not triable by justice of peace, 1050

PREROGATIVE, 33. See Kis(; Crows.

writ of mandamus, 214 . See MaNDasurs.

\section{PRESCRIPTION}

in a que estate, $11(b)$

easenients by, 892 et seq.

PRESCRIPTION ACT,

why passed, 11,893

provisions of, $893 \mathrm{et} \mathrm{scq}$.

profits $\dot{a}$ prendre, 893

does not apply to profits i premlre in gross, $893(y)$

easement in watercourse, 894

makes no change in nature or extent of rights claimed, 890

does in old rule nee vi nec elam nec precario, 845

difficulties in proeeeding under Act, $895,896^{\circ}$

light, 896 et seq.

easement of light not within s. 2 of, 11 (c), 894 (*)

s. 3 of, does not bind the Crown, $896(u)$

old window eannot be blocked beeause new one opened near it, 589 light not necessarily lost by pulling down building, 899

unless new windows cannot be in any way identitied with oll, 599

interruption under, what amounts to, 900

pleading under, 900

no presumption raised by shorter enjoyment than would giver right, 800 value of sueh evilence as tending to prove a grant, gol $(g)$ 
I'RESCRIPTION ACT-continued.

disabilities under, 901

support for buildings can be claimed under, 909,910

\section{PRESENTMENT}

of bill of exchange for payment, 459

not necessary to charge acceptor, 460

for payment unnecessary where bill dishonoured by non-aceeptance,

unless afterwards accepted, 462

unnecessary when bill accepted generally, 470

when and where to be made to charge acceptor, 470,471

l'nles for, 469

drawer, 471

indorser, 471

of promissory note, when necessary, $491(s)$

may be required by terms of note, $489,491(s)$

delay, when excused, 490

to charge indorser, $491(s)$

generally, wecessity of speedy, 491

for acceptance, when necessary, 491

by grand jury, 1086

what amounts to, $491(q)$

when excused, $491(q)$

\section{PRESUMPTION}

of sanity, i004, 1006

\section{PRINCIPAL AND AGENT,}

relation of, $595 \mathrm{et}$ seq.

limitation to relation of, in case of married women, infants, lunatirs, 597

rule as to porrer of man suijuris, 597

exceptions to rule, $597(g)$

agency, how createll, 600

special, general, universal, 598

special distinguished from general, 601

fact of agency, how provel, 599

to what authority of agent extends, 603

of solieitor, 604,605

implied authority of agent, 605

of master of ship, 605

as a rule, principal not agent is bound, 597

who may be agent, 597

jrineipal when bound, 600

under s. 4, sub-s. 1 of the Sale of Goods Act, 1893, 414 et ser.

under s. 17 of the Statute of Frands, 414

"vidence, when admissible to charge, on contract signed by agent, 577

liability of, on bill accepted by agent, 602

for act of agent in course of his business, 337

for tort of agent, 803

liability, if imocent, for fraul of agent, $333 \mathrm{et} \mathrm{seq.,} 623 \mathrm{ct}$ seq.

if purposely employs ignosant agent will be liable, 337 (b)

is not discharged by payment to agent, unless ventor has estopled hinself from proceeding against the principal, 608 at scy.

alternative lialility of, may be defeated by terms of contract, 612 or by election of creditor, 612

party signing as principal cannot give evidence that he is agent, 621 


\section{PRINCIPAL AND AGENT-continuerl.}

if permits agent to describe himself as principal in written contract, may be estopped from suing on it, 619 (c)

agent estopped from denyiug title of principal in subject natter of agency, $395(\mathrm{~m})$

bound to account to, 38

need of full disclosure by, before treatiug with employer an principal, $592(d)$

contracting as principal incurs personal liability, 507 purchase of goods by, $607 \mathrm{et} \mathrm{seq.}$

rights of seller against principal, 607,608

where principal unknown, 608

liability of agent, purchasing at auction, 607 (n)

rule in dealing with foreign principal, 613

evidence to show different intention, 613

sale of goods by agent, 613,614

provisions of the Factors Act, 1889, 614, 614 $(\mathrm{g})$

liability of, for fraud, $623 \mathrm{et} \mathrm{scq}$.

contracting withont anthority, 614

though supposing that he has, bis

ex contractue, 616

ex delicto, 618

when contracts oraliy, 615

agent signing as agent not personally liable, unless shown to be real principal, 619

if instrument ambiguous, will be construe.l against party signing, 619

liability of, ou written contract, $619 \mathrm{et} \mathrm{ser}$.

falsely claiming to be agent, 620

if no principal at all, 620

evidence adnissible to prove personal liability of, 621

person signing as, cannot sue on contract, 622

in own name withont more, will he deemerl prima facic a principal, 622

agent contracting under seal nust have express authority under seal, 622

but not to sign memorendum of association, $623(d)$

statutory modifications of this rule, 623

did agent contract as such ? 605,606

what was meaning and intention of parties ? 608

agent may be liable if he has pledged his credit, 606

if contract in writing, rights and liabilities must be determined by

its terms, 618,619

partners are agents for one another, 626,631

effect of lunacy of principal on authority of agent, 701

PRINCIPAL AND SURETY,

relation of, 306 et seq.

nature of contract between, $306(0)$

what amounts to compulsion on surety to pay, 303 (ii)

rules as to proportion recoverable among sureties, $30 \bar{i}, 308$

PRIORITY OF PAYMENT

of specialty over simple contract debts abolished, 259, 290

PRISONER

cannot give evidence, 1091

exceptions to rule, 1091

reception of statements by, 1094

PRIVATE DUTY, 768, 769. See Public Duty, Torr.

PRIVATE NUISANCE, 821, 880. Sic Nuisasce. 
PRIVATE WAY, remedy for disturbance of, 97

PRIVILEGE,

in cases of libel, 74

rebuttable by express malice, 848

applies to servant's character, 848

may be lost by transmission throngh telegram, $849(c)$

when it exists, 850 et seq.

reason for holrling an occasion privileged, $850(f)$

letter published to clerk, whether publication privileged, 852

proceedings ordered to be printed by Houses of Parliament, 852

fair comment on public men, 852

on literary productions, 853

reports of cases, when privileged, 853,854

of judgment only, $854(x)$

fair and accurate report of public meeting, 854

of judicial officers, 855

naval and military officers, 855

counsel, 855

member of parliament, 856

witness, 856

newspapers, by statute, 854,856

classes of, 856,857

PRIVITY,

what it is, 312

necessary to sustain action contractu, 312, 315 wint of, $317(z)$

of estate, 558

hetween company and third y,erson, $650(b)$

not generally necessary to sustain action ex delicto, $770 \mathrm{et}$ seq.

in actions of tort flowing from contract, 770

PROCEDENDO,

writ of, 224

PRODUCTION

of documents, 166

PROFITS,

whether loss of can be recovered as damage, 739

PROFITS À PRENDRE,

what they are, 883,884

distingnished from easements, 883,884

under $s .1$ of the Preseription Act, 893

PROHIBITION,

no proceeding in High Court or Court of Appeal to be restrained

by $41,221(q)$

to County Court, $63,63(i), 64$

writ of, its nature, 221

to Ecclesiastical Court, 221,222

whether granting is liscretionary or not, $221(1)$

to Court of criminal jurisdiction, $221(s)$

to temporal courts, 222,223

if judge interested in canse, $222(x)$

pleadings in, 2:3

how enforced, 22:

IROHIHTION OF CONTRACT,

legislative, 249,250

when implied by peualty, 350 
PROJECTED COMPANIES. SeC COMPANES.

liability of member of, 652

liabilities and duties of directors of, $952 \mathrm{ct} . \%$.

PROMISE,

what it is, 321 et seq.

express or implied in every executory contract, 321

subsequent, not supported by executed consideration, 30 :

unless defendant was legally bound, 308

secus, if only morally bound, 309

without consideration will not support action, 311

secus, where though right remains remedy is barred, 323, 324

when implied by law, 308,322

when not implied, 322

may be partly good, partly bad, 348

by execntor under s. 4 of the Statnte of Frauls, $3 \pi i, 3 \pi \mathrm{s}$

to auswer for debt, etc., of another, 378

how to be construed when ambiguous, $593(c)$

when not legally binding, 346,347

\section{PROMISSORY NOTE,}

nature and origin of, $483 \mathrm{ct} \mathrm{scq}$.

cannot be under seal at common law, $484(k)$

whether negotiable prior to $3 \& 4$ Ann. $9,485,456$

put on same footing as bills by $3 \& 4$ Ann. 9, $4 \notin 6$

included in Bills of Exchange Act, 1882, 486

form of, 487

parties to, 487

no particular words needed, 487

structure of, distinguished from bill, $4 \mathrm{~s}$

in case of doubt, holder may treat instrument as, 487, 458

contract of maker of, 489

estoppel against, $395(\mathrm{~m}), 489$

liability upon, 489

demand and presentment usually unnecessary, 459

when like bill, $488,488(f)$

is a present debt, 489

Statute of Limitations runs from date of note, not of demand, $4: 9$ presentnient may be required by terms of note, 489

delay, when excused, 490

contract of indorser of, 490

notice of dishononr to, 490

presentment to charge, 490

what presentment necessary, to charge maker und iuclorset.

respectively, $491(s)$

grounds of defence in actions on, 497

payment, 497

how to be made, 497,495

cancellation, 498

intentional and unintentional, 498

note imports consideration, 498

defence of no consideration, 499, 500

onus probandi therein, 499

good defence pro tanto agaiust intermeliate 1 arty, if for specitic ascertained amount, 500

material alteration, $500 \mathrm{et} \approx \mathrm{sq}$.

loss, 503, 504

at common law, 503

illegality, fraud, duress. intoxication, forgery, $\$ 04,50:$ 
PROMOTER,

of company, 955

action against, 953,954

I'ROPERTY,

Iprotected from execntion, 201

interim order for preservation of, 220

order for sale of perishable, etc., 220

for inspection of, 220

to recover, letained for lien, 221

transfer of, in contract of sale, 425

jules for determining when, is transferred, $425 \mathrm{et} s c q$.

meaniner of, in Bankruptcy Act, $656(z)$

in Married Women's Property Act, 685 ( $z)$

right of, 866,867

absolute and special, 913

PROSECUTION,

contract to compromise, illegal, 355

PROSPECT,

no easement of, apart from express covenant, $902(b)$

PROTECTION ORDER, 678. See MARRIED WOMAx.

FROTEST,

rules for, 477,478

of foreign bill, 478

why required, 478

PRoVOCATION, 1036. Sce Crmisal Law, Honicide.

PUBLIC DUTY,

meaning of term, 750

how distinguished from private, $755(f)$

breach of, when actionable at common law, 96, 97, 750

by statute, 759 et seq.

P'UBLIC EXAMINATION, 656. See BANkRUPTCY.

PUBLIC HEALTH ACT, 1875,

s. 174 , ss. 1 , is imperative, 649

PUBLIC MORALS, etc.,

ollences agrainst, 1029

PUBLIC NUISANCE, 820. See NEISANC:

PÜBLIC P'EACE,

offences against, $1021 \mathrm{ct} \mathrm{sc}$.

l'C'ILIC POLICY,

retress when denied on grounds of, 102

non-liability of judicial officers, 103

contracts void as opposed to, 352 ct ser.

meaning of term, $352(\mathrm{o})$

itreements against, $353(p)$

loctrine not to be extended, 354

P'LBLIC I'ROSFCUTOR, 1076. See Disector of PerLic Prosecutions.

P'LIBLIC REYEXUE. etc.,

offinces ingainst, 1029 
PUBLIC WAY,

remedy for disturbance of, 97,1030

PUBLICATION, of libel, 858 et scq.

evidence of, $858(u),(b)$

PUNISHIENT,

when unaffected by mistake in doing criminal act, 899 aim of, 1001

PURCHASER. Sec Contract of Sale of Goods.

liability of, failing to complete, 733

remedies of, against inuocent principal for fraul of agent, 623 against agent, 623

cannot maintain action for tortious removal of goods in venilor's possession subject to his lien for purchase-inoney, 913 rights of, purchasing pawned chattel from pawnor, 924

QUARE IMPEDIT, action of, 146

QUARTER SESSIONS, jurisdiction of, 1079,1080

QUASI-CRIMINAL PROCEEDINGS, what are, 45

QUASI-EASENENTS, 857

QUE ESTATE, what, $11(b)$

QUEEN'S BENCH, Court of, 32 Division, 34 jurisdiction of, 37 law and equity concurrently administered by, $3 i$

QUO MINUS, clause of, 25

QUO WARRANTO, writ of, its nature, 223 information in nature of, when it will lie, 223 proceerlings in, are civil proceedings, 224

RACKREN'T, what, 517

RAILWAY, meaning of, in Enployers' Jiability Act, $\$ 13(v)$

RAILWAY BONDS, sometimes assignable, 445

RAILWAY CANAL AND TRAFFIC ACT, provisions of, 937 et scq. dog is within, $935(x)$ passengers' luggage, $9: 38$ (y) 


\section{RAILWAY COIPANY,}

not an assignce within Stat. Hen. VIII., c. 34, $271(s)$

station-master cannot bind, for medical attendance to injured passenger, 603

general manager can, $603(f)$

liability of member of provisional committee of, 633

of infant shareholder in, 672

uature of duty of, to fence, 763,764

common law duty of, 764

to convey officers of post-office safely, 764 private duties of, $76 \overline{\mathbf{T}}, 768$

liability of, for negligence of servants, 793

when common carriers, 936

liability of, undertaking to delirer beyond line, 942

actually conreying, 942

on through-booking contract, 942

holling themselves out as common carriers, 944

whether groods in custody of, as carriers, 943

action against, for delay, by passenger, $981(0)$

disty of, to start train at particular time, $981(0)$

\section{RAILWAY CONTRACTOR,}

employed by corporation, mist be appointed under seal, 943

\section{RAILWAY SCRIP,}

not an assignment of a chose in action, 508

\section{RAILWAY SERYANTS,}

are within Employers' Liability Act, $811(d)$

\section{RAPE,}

infant under fourtecn incajable of, 1010

\section{RATIFICATION,}

jrinciples of doctrine of, 800 et seq.

of contract, 805

jrocured by fraud, $328(e), 329$

statutory provisions against, hy infants, $674,674(p), 675$

of tort, 800 et seq.

may make ratifier trespasser by estoppel, 801

secus if agent assumed to act for himself, 802

may produce benefit to ratifier, 805

hut act must lave been done when he could lawfully have done it himself, 805

of acts of bailiff by judgment creditor, 502

of thesplass, sSO

$$
\text { by landlord, } 803
$$

$$
\text { by Crown, 103, } 804
$$

\section{DATIHALITIO. Se RatificatIos.}

\section{REAL ACTION,} what, 146

\section{KEAITY,}

liability of owuer of, for nuisance $798 \mathrm{\ell}$ seq.

torts to, 867 al seq.

tieeprass to, $870 \mathrm{et}$ sey.

unisaluce to, $8 s 0 \mathrm{ct}$ seq.

no larceny at common law of things savouring of, 1057 
REASONABLE AND PROBABLE CAUSE. Sie MAIR⿴囗十 J'HON\%cution.

definition of, 841

evidence as to want of, in action against justice of yrace, $832(\mathrm{in})$

RECAPTION,

remedy by, 205,206

RECEIPT

"actual," meaning of, 408

implies delivery actual or coustructive, 405

evidence of constructive, 408

none without delivery, $40 \mathrm{~S}$

not under seal, is only an admission, 395 (u)

RECEIVER,

may be appointed by interlocutory order, 221

RECEIVING ORDER, 653. Sce BANKRUPT:

RECEIVING STOLEN GOODS,

how distinguished from larceny, 1070

how this offence is constituted, 1070

\section{RECIPROCITY,}

of assent, 300

of obligation, not necessary, 300

\section{RECITAL}

in deed may amount to covenant, $267(f)$

estoppels in, will be strictly watched, 284

\section{RECOGNISANCE}

by statute, $255(x)$

bankrupt not released by order of discharge from debt due on, 662

RECORD,

contract of, 256. See CoNтuAct.

debt of, $256(y)$

imports truth, 260

works on estoppel, 260

secus if obtained by fraul, 261

how tried, $260(\mathrm{~m})$

obligation by, nay be released by deed, $279\left(x^{*}\right)$

person stealing, not triable by justice of the peace, 1050

RECOVERY OF CHATTELS,

proceedings to enforce, 229,230

who may sue for, 948

RECOVERY OF LAND,

statutory provisions as to, 135,146

limitation of action for, 153

judgment for, how enforcel, 192

action for, 867 ct ser.

depends upon title, 868

where relation of landlord and tenant exists betwernl jarties sing

RECOVERY OF MONEY,

writs of execution for, 193

RECOVERY OF SMALL TENEMENTS,

summary proceedings for, 228,229

appeal from County Court, in action for, 203 
HEFEREE,

trial before, 170

special or official, 170

powers and duties of, 173,174

in case of need, $453(l)$

HEFERENCE,

rarious kinds of, 172

under Arbitration Act, 1889, 172, 173

REFORMATION,

of instrument, 294

REGISTERED OWNER OF SHIP,

evidence of ownership and liability of, $605(0)$

REGISTRAR

transmits original documents, \&c., when action removed to London

170

of County Court, duties of, 198, 200

can grant replevins, 147, 567

REGISTRY,

issue of writ from, 127, 128

RELATION,

meaning of term, $708(f)$

of title of executor and administrator, 708

doetrine of, in connection with larceny, 1068

RELATIVE RIGHTS,

torts to, 952, 966 et seq.

RELEASE,

must be pleaderl, 142

RELIEF,

in respect of equitable claims, 40

in equity against forfeiture, 295

by statute, 295,296

in equity against fraudulent deed̀, 284

RESIEDIAL PROCESS,

by summons or motion, 213

REMEDY,

ciril, suspended where act complained of is felonious, 99

REMITTER,

remedy by, 212

Realoteress of Damage, 734 . See Damage.

principles with regard to, the same in contract as tort, $735(g)$

RENEWAL OF WRIT,

how effected, 131

when impossible, 131

evidence of, $131(e)$

RENT. Sice Landenh axd Trasat.

what it is, 543

is specialty lebt, $273(d)$

not morged ly a bond, $273(d)$ 
INIEE.

REPAIR,

duty of tenaut to, 526

"good tentable," defined, $534(\approx)$

damages for breach of covenant to, 730

REPLEVIN,

what it is, 147,567

when it lies, 147, 567

where commenced, $14 i, 56 i$

by whom granted, 147,567

how removed, $147(q)$

new trial, $183(x)$

jurisdiction of County Court in, $64(q), 66$

appeal in, from County Conrt, 203

is an action ex: delicto, 749

REPIAVIN BOND,

is assignable, 445

measure of damages against sheriff for taking insufficient, $80 \% 3$

REPLY. Sce Pleadisg.

when delivered, 140, 163

effect of non-delivery, 163

right of in criminal prosecntion, 1093, 1094

REPRESENTATIONS,

what are, $339(l)$

rules for consideration of, $34 \overline{5}$

distinguished from warranty, 342 et sf .

question for the Court, $342\left(x^{\circ}\right)$

as to the credit of another, under Lord Tenterilen's $\Lambda$ ct, $3 \$ 4$ sey.

estoppel by, $396(n)$

constituting agency, 600

REPRESENTATIVE CAPACITY,

should be shown by indorsement, 126

RePUTation. See libel, Slaxder.

torts to the, 839 et seq.

REQUEST,

necessary in simple contract, 303

in executory contract, 304

when implies promise, 303

to lend acceptance implies promise of repayment, 303

implied, when consideration cannot have been gratuitous, 30 :

when party has been conivelled to do that to which the other was legally compellable, 306

when promisor has benefited by the consideration, 30 J

from principal to surety to pay, if obliged to do so by law, 306,307

from co-contractor to one jaying on compulsion, $30 \pi$

where one has voluntarily done what another was legally. compelled to do, who has expressly promiad, sns

but secus, if only morally bound, 309

when consideration is continning, 310

RES JUDICATA,

doctrine of, 115

RESCISSION,

of contract, 114,341 
RESCUE,

by tenant of goods illegally distrained, 567

RESERVATION, of easements, $\$ 90, \$ 91$

RESTITUTION, of land, warrant of, 1029

RESTRAINT OF TRADE,

contracts in, illegal, 357

in total, bad, 357

in partial, presumed bad, 357

presumption may be excluded, 357

contract void, thongh under seal, 357

unless rood consideration shown, 358

why allowed, 358

must have consideration, 359

courts will not inquire into adequacy of, 359

duratiou of, may be for life of covenantor, 360

limitation as to space, rules, $361 \mathrm{et} \mathrm{seq}$.

reasonableness, test of validity, 361 ( $m$ )

contracts in, illegal only in sense not enforceable, $365(a)$

RETAINER,

remedy by, 212

REVENUE,

jurisdiction of Excheguer, in cases of, 24

offences against, 1029

REVERSIONER,

action by, for trespass to land, 747,875

must show special damage, 875

entry of, when justitied, 878

right of, to sue tor injury to chattel, 949

measure of damages for injury to reversionary freehold interest of, 973

\section{REVOCATION,}

uncommunicated, is no revocation, 299

of auctioneer's authority, $415(f)$

\section{RIGHT}

and remedy are reciprocal, 83

and obligation are correlative, 254

action tor invasion of, 747

how proved, 747,748

in action for trespass to goods, 747

to land, 747

action will lie for invasion of, without proof of special damage, 748

\section{RIGHT OF ACTION,}

what it is, 70

by particular statute, only when damage has been sustained, 90 (c) when postponed, 114

or extinguished, 114

vested, can only be got rill of hy release or accord and satisfaction,

$\$ 90^{\circ}(u)$

er delicfo, iti et seq.

RIGHT OF COMMON OR WAY,

conveyerl by leed, 399 
INDEX.

RIOT,

what it is, 1026

duty of magistrate in quelling, 1027 (c)

of justice of the peace, 1079

infant liable for, 1010

RIOT ACT,

provisions of, 1027

RIPARIAN OWNER,

right of, in flowing water, $886 \mathrm{ct} \mathrm{seq} ., 902$

to reasonable use of, 887

to extraordinary use of, 887

RIVER,

obstructing a navigable, 755,1030

may not protect oneself against as common eneuy, 904

ROBBERY,

how constituted, 1074

includes simple larceny, $1074(c)$

ROMAN LAW,

when courts will listen to arguments drawn from, 20

ROUT,

how constituted, 1026

RULE,

to show cause, 48

absolute, 48

when enlarged, $48(d)$

RULES

for interpretation of witten contracts, 572, 593. Sec Costract.

RULES OF COURT, 109

RUTLAND,

Statute of, 25

SALE, 402 et seq.

contract of, what, 402

the contract of, formation of, 402

subject matter of, 419

in market overt, 429,429 (i)

order for, of perishable property, 220

SALE OF GOODS. See Costract of SALE of Guods, 402 et seq.

SALE OF LAND,

misdescription will avoid, 332

damages for breach of contract for, $732 \mathrm{et} \mathrm{seq}$.

SAMPLE,

implied conditions on sale of goods by, 424,425

taking, may amount to delivery and acceptance, $409 \mathrm{ct} s \mathrm{sq}$.

SATISFACTION, 396. See ACcord axd SATIsfactiox.

SCIENCE.

cvidence to explain terms of, 581

B.C.L. 
SCIENTER,

must be alleged in action of deceit, 334

in action for misrepresentation, $952(b)$

proved in action for injury caused by animal of defendant, $786(z)$

by $\operatorname{dog}, 786(z)$

SCRIP,

who must bear the loss on, when spurious, 496

of projected railway company, whether assignable, 508

SCRIP CERTIFICATE,

what it is, $508(g)$

SCRIVENER,

definition of, $635(l)$

solicitor is not, qu氏 solicitor, 635

SEA,

may protect oneself against as common enemy, 904

SEA WALL,

no obligation on landowner to repair, 79

SEAL

of corporation, $264(i)$

SEAMEN,

restrictions on contracts by, 250

SECURITY,

three kinds of, $922(i)$

\section{SEDUCTION,}

basis of action for, 75,78

action for, 967

trial by jury as of right in, 171

past, no consideration for promise, 365

bond for, may be good, 366

\section{SEIZURE}

must be made in levying distress, $\mathbf{5 5 5}$

SELF-DEFENCE,

remedy by, 205,785

homicide in, when excusable, 1047

SELLER. Sice Contract of SALE of Goods.

rights of unpaid, $435 \mathrm{et} s \mathrm{~s}$.

unpaid seller's lien, 436

stoppage in transitu by, $\mathbf{4 3 7}$

SEPARATE PROPERTY, 678, 685. See MARRIED WoMAN.

SEPARATION,

deeds in contemplation of future, illegal, 355

secus, of immediate, $355(h)$

SEQUESTRATION,

writ of, 191

SERVANT. See Master and Servant.

character of, privileged communication, 848

right of action by, against stage-coach proprietor for not carrying safely, 770

lareeny by, how distinguished from embezzlement, 1073 
SERVICE OF WRIT,

how effected, 128, 129

on particular defenilants, 129

date of service to be indorsed on writ, 129

effect of default herein, 129

affidavit of, necessary before proceeding for itefanlt of al'pearance, 136

out of jurisdiction, 129

application for leave to serve, how unade, 130

when allowed, 129, 130

when notice not writ to be served, $129(s)$

question for decision of judge at chambers, 130

\section{SERVIENT TENEMENT, 883. Sce EAsEMENTs.}

SET-OFF. Sce Counterclaim And SET-off.

admitted, will bring case within jurisdiction of County Court, 53 in County Court, 57, 58

notice of defence of must be given, 198

how differs from payment, $58(\mathrm{~m})$

SETTLED ESTATES ACTS, 514, 517

SETTLED LAW, importance of adhering to, 36 ( $\iota$ )

SETTLEMENT, 665. Sce BANKRU PTCY. avoidance of fraudulent, by bankrupt, $286(c)$

SHAREBROKERS, practice of, 417

SHAREHOLDER, effect of transfer of shares by, $650(b)$

cannot bring action of deceit against company while himself a member, 624

position of infant, 672

in company, position of, 958

in joint-stock company, 958

action by, against directors, 954, 958

SHARES,

what they are, $508(g)$

standing in name of married woman, 686

measure of damages in action for failing to replace, 723

refusing to register transferee of, 878

SHEEP,

liability of owner of dog damaging, $786(\approx)$

SHERIFF,

duty of, to summon jurors, 177

interpleader of, 226

may break open outer door of a buiiding not a dwelling house, its (l) measure of damages against, for taking insufficient replevin bond, 973

consequential damages against, 980

no action against, for false return to writ of venditioni erpmas, $980(i)$

nor for not levying under a $f$. $f a$. without actual damage, $s 9(x)$

nor for false return without actual damage, $\$ 9(x)$

homicide by, in course of duty, 1000

when justifiable, 1045 
SHIP,

transfer or mortgage of British, must be by deed, 400

alien canuot acquire property in British, 707 ( $\approx$ )

SHIP OWNER,

delivering goods bona fide to assignee of one part of bill of lading is not guilty of conversion, $505(r)$

liability of, for negligence of crew, $792(z)$

SHIRE COURT,

its jurisdiction, 23

Signature. See Priscipal and Agent, Statute of Frauds.

when necessary to deed, 264

what it is, $373(t)$

whether to whole docnment, $622(u)$

what required under Statute of Frauds, $376(f)$

SIMONIACAL CONTRACT,

what, $348(q)$

SIMPLE CONTRACT. See CoNtract.

what it is, 296

executed or executory, 296

how evidenced, $296(r)$

analysis of, 302

request necessary in, 303

promise necessary in, 321

avoided by frand, 329

merged by deed, 273

does not work a merger, 395

is an admission, not estoppel, 395

usually needs consideration, 396

binds personal, not real, representative, 289, 396

may sometimes be discharged by parol before breach, 396

\section{SITTINGS}

of High Court of Justice, 50, 51

of Court of Appeal, 50, 51

of vacation judges, 51

SLANDER,

when actionable, 749

without proof of special damage, 861,862

words couveying suspicion not actionable, 862

imputing criminal offence are actionable per se, $862(q)$

not actionable per se will not become so by reason of damage

from unauthorised repetition by third party, $863(y)$

inlusting unchastity or adultery to a woman or girl, 863,864 when words not actionable per se, special damage must be natural consequence, 91

substantial damages for slander in way of trade, without special damage, 980

where restrained by injunction, 863 (z)

trial by jury as of right in action of, 171

limitation of action for, 158

SLANDER OF TITLE,

what, 864

SMUGGLING,

an offence against the public revenue, 1029 
SOLICITOR,

who is, $46(s)$

action will not lie against for suing wrong person, 75

address of, to be indorsed on writ, 127

if writ not issued by or with his anthority, proceedings to be stayed, 127

not entering appearance liable to attachment, 133 (l)

is an officer of court, 213

summary remedies against, 213

punishable by attachment, 213

appeal lies from order striking off rolls, 213 ir)

relation between client, town agent, and, 315,316

implied warranty by, 342

action against, for compromising case, 84,85

duty of, when retained to conduct suit, 604 (i)

power to refer it, 604 (i)

to bind client, $604(i)$

to consent to compromise, 604 (i)

promise by, not to charge anything for costs is not champerty, $356(n)$

authority of, as agent, 604,605

cannot pledge client's authority to bailitf for fees, 604

not liable to bailiff for costs of executing ca. sa. apart from contract, 605

cannot bind partner by accepting bill, 635

or by guarantie, 635

or by post-dated cheque, 635

is not impliedly a scrivener, 635

nor authorised to receive money indefinitely, 635

secus, of money for particular mortgige, 635

emplojed by corporation must be appointed under seal, 643

warranty by, 769

need of privity in action against, i7s

not within inplied authority of, to direct sheritf to seize particular goods, 803

deliberately directing exceution of bad warrunt may be liable, $\$ 30$

lien of, $928(s)$

liable for negligence, 966

measure of damages against, for, 973

SOLICITOR TO THE TREASURY,

is now director of public prosecutions, 1078

SON

cannot bind his father by his contracts, 326

SON ASSAULT DEMESNE, plea of, 785

SovereigN. See Crown, King, Treasos.

SPECIAL CASE,

proceeding' by, 137, 163

SPECIAL DAMAGE,

when necessary to support action, 90

of tort, 748 et seq.

SPECIAL INDORSEMENT,

effect of, 127 
SPECIAL PROMISE,

how used to evade s. 4 of the Statute of Frauds, 383

SPECIAL VERDICT, 180, 1036

SPECIALTY. Sce DEED.

limitation of action on, 155

whether signing necessary to, 264

distinguished from simple contract, 264, 395, 396

works a merger, 273,395

merges not debt, but remedy, 273 (e)

heir when bound by, 289,395

works an estoppel, 276,395

needs no consideration, unless in restraint of trade, 395

how discharged, 290

by specialty, judgment or statute, 395

cannot be discharged by parol before breach, $290 \mathrm{et} s c q$.

discharged in equity by parol, 295

priority of payment of, over simple contracts abolished, 289

not assignable at law, 443

agent contracting by, must have special authority under seal, 622

SPECIFIC CHATTELS,

delivery of, how enforced, 230, 440

SPECIFIC PERFORMANCE,

fraud of agent good defence to action for, $333(l)$

SPECIFICATION,

no implied warranty of possibility in, 248

SPLITTING DEMAND, 58. See Countr Court.

SPOUT,

right to water from, 88

STAMP ACTS, $401(\mathrm{~m})$

STAR CHAMBER, criminal informations in, $230(h)$

abolished by statute, 235

STATEMENT OF ClAIM. Sec Pleadings.

when necessary, 146

form of, 148

unnecessary, 139, 145, 146

when to be deliverel, 139

effect of non-delivery of, 139,140

when time for delivery cannot be extended, 137

costs of unnecessary, 146

of prolixity in, 148

not demurrable for showing cause of action to be unprosecuted felony, 100

STATEMENT OF DEFENCE. SeE Pleadings.

when to be delivered, 140,148

form of, 151

STATION MASTER,

cannot bind railway company for medical attendance to injured passenger, 603

STATUTE, 2 et $s c q$. See Act of Parlanest.

if gives right, there must be remedy, 759 
STATUTE OF FRAUDS,

object of, $264,372,404(r)$

is a weapon of defence, not offence, 373

must be pleaded, 142

what is a sufficient signature under, $376(f)$

s. 1 , when leases must be in writing under, 518 exceptions, 518

effect of ss. 4 and 17 compared, 405

s. 4,374 et seq.

meaning of "agreement" in, 374, 375

need only be signed by party to be charged therewith, 376

no necessary reciprocity of obligation, 301

written proposal orally assented to may be sufficient agreement under, $376,377,393$

consideration must be stated in agreement, 374,375 except in a guarantie, 375

memorandum under, must be of agreement complete at the time, $375(a)$

may consist of several documents if connected, 375,376

special promise by executor, etc., to answer damages out of his own estate, 377

promise to answer for debt, default, ete., of nnother, 378

has no application where guarantor directly liable, 380

nor where original debtor ceases to be liable, 380

question to whom credit was given is for the jury, 3\$1

cases of guarantie coming under, 382

provisions of, apply to tort as well as contract, 353

how evaded, 383

how remedied, 384

agreement made upon consideration of marriage, 355

contracts concerving land, etc., $385 \mathrm{et} \mathrm{seq.}$

what is an "interest in or concerning land" under, $3 \$ 6$. 387

what is not, $387(t)$

equitable doctrine of part-performance, $385 \mathrm{et} \mathrm{se}$.

does not extend to contracts not concerning land, $392(r)$

agreement not to be performed within a year, $391 \mathrm{et} \mathrm{se}$.

contract within, cannot be varied orally, $393 \mathrm{ct} s \mathrm{~s}$.

semble, may be wholly waived, 394

s. 17, 114, 404 et seq.

concerned only direct sales, $404(r)$

executory contracts included by Lord Tenterden's Act, 403

repealed by Sale of Goods Act, 1893, 406

s. 4 of Sale of Goods Act, 1893 , relroduces s. 17, and Lond

Tenterden's Act, 406

" actual acceptance and receipt," what, 408 et sus.

acceptance by taking sample, 410,411

part payment under, 411

earnest, 411

memorandum in writing under, 412

must give all material terms, $\$ 13$

price, if settled, 413

both names, 414

signature of party to be charged was sufficient, 114

might consist of several documents if conuected, $\$ 11$

what was held a sufficient, $414(\xi)$

might be signed by auctioneer, 414

by broker, 414

by factor or traveller, $\mathbf{4 1 4}$ 
STATUTE OF FRAUDS-continued.

part-payment or memorandum must have been before action brought, 412

could not be varied by subsequent oral agreement, 419

STATUTE OF LIMITATIONS. Sce Limitation.

action may be barred by, 115

must be pleaded, 142,153

notice of defence of, in County Court, 199

object of, 153

as regards realty, $153 \mathrm{ct} s c q$.

in actions against trustees, $153(z)$

action on specialty, when barred by, 155

disabilities under, 154,155

mortgages, when barred by, 155

money charged on land when deemed satisfied, 155

action on simple contract, when barred by, 156

executor; when barred by, 156

action for merchant's account, $156(g)$

what is a sufficient acknowledgment under, $156(n), 157$

action for personal tort, when barred by, 157, 158

fraud no answer at law to plea of, $159(\alpha)$

sccus in equity, 159

when begins to run, 158

once begun, continues to $\mathrm{rmn}, 158$

equitable relief against, 159

debt barred by, may be revived by express promise, 309, 324

must be in writing, signed by lebtor or agent, $324(l)$

runs from date of promissory note, 489

in treason, $1018(a)$

STATUTE OF TREasONS, 1013. Sce Treasor.

what not within, 1026,1027

\section{STATUTE OF USES,}

its operation in certain cases, 287

STATUTE STAPLE, AND MERCHANT, $255(x)$

\section{STATUTOPY COMPENSATION,}

none for noise and smoke of trains, 96

\section{STEALING}

from the person, 1074

records, wills, etc. not triable by justice of the peace, 1080

STOCK,

measure of damages in action for failing to replace, 728

standing in name of married womau, 686

STOCK BROKERS,

jractice of, 417

STOCK EXCHANGE. See Loxdox STock Exchaxge.

reasonable rules and customs of, may be annexed to written contract, 585

gambling on, by time bargains, not necessarily illegal, $989(r)$

STOP'AGE IN TRANSITU,

right of, $436 \mathrm{et}$ ser.

\section{STRUGGLES}

in anger unlawful, 1039 
SUBORNATION

of perjury not triable before justice of the peace, 1080

SUBPENA

duces tecum, 174

ad testificandum, 176

action against witness for not obeying, 758

SUBSTITUTED SERVICE,

when allowed, 128,129

\section{SUFFERANCE,}

tenant by, 513. See LaNdiond and Trasist.

SUICIDE,

an offence, 1032

attempt to commit, is indictable, $998(q)$

SUMAIARY JURISDICTION

of Superior Court, 46

over solicitors, 213

to recover small tenements, 228,229

in questions between husband and wife, 687

of justice of the peace, 1081 et seq.

SUMMONS. Sec WrIT.

to appear in County Court, 197

service of, 197

personal service, when dispensed with, 198

to witmess, how obtained, $200(x)$

under Debtors Act, 202

\section{SUPERIOR COURTS,}

history and juriseliction of, 22 et seq., 32 et scq.

extent of jurisdiction, 43

of what they take cognisance, 45

law and equity concurrently administered by, 37

general principles as to jurisdiction of, $41 \mathrm{et} \mathrm{sc}$.

agreement to oust jurisdiction, 41,42

to give jurisdiction, 43

summary jurisdiction of, 46

discretion of, to stay proceedings, $46(r)$

power to punish abuse of process by payment of costs, $46(r)$

SUPPORT. See EASEMENTs.

right to, for land, $81,883,908$

for house, 80

whether within Prescription Act, 909, 910

SUPREME COUNCIL, 23. Sce AUla REgis.

SUPRENE COURT OF JUDICATURE, how constituted, 35

duties of, 36

SURETY. See Prixcipal axd Strety.

rights of, $297(e), 306(0), 307(s)$

SURGEON,

warranty of skill by, 769,823

liable c $x$ delicto without privity, $7 \% 2$

negligence of, criminal, 1042 


\section{SURRENDER}

of interest, when requires deed, 400

of lease, 562

by operation of law, 563

\section{SURVIVORSHIP,}

right of, at common law, 641

none between partners, 642

\section{SUSPENSION}

of civil remedy, 99

TEjPORAL COURTS, 222. See Prohibitiox.

TENANCY. See LANDLord and Texast.

four classes of, 509,510

TENANT. See Laxplokd axd Texast.

estopped from denying landlord's title, $395(\mathrm{~m}), 869$

measure of damages in action by, for not properly appraising distress, 973

for illegal or irregular distresses, $973(r)$

fixtures of, 390 . See Fixtures.

for life, leasing powers of, 516,517

years, liable for permissive waste, $533(0)$

TEXDER,

if pleaded, money must be paid into court, 153

liability of person whose tender is accepted, 302

TExemext. Sec Laxd, Recover of Syald Texemexts.

\section{TERMI,}

what it is, $\mathbf{5 1 0}$

TERIIS,

abolition of, 50

THIRD PARTY, proceedings against, 160

notice to, how served, 160

appearance by, 161

default of appearance, 161

summons for directions, 161

counterclaim against, together with plaintiff, 162

cannot counterclaim against defendant, 162

contributory negligence of, 789

\section{THOROUGHFARE,}

action for obstructing, 97

indictment for, 1030

TIMEE,

stipulations of, how construed in contracts, 252

strict legal doctrine as to, $252(l)$

in contract of sale of goods, 422

\section{TITLE}

to land, whether triable in County Court, 63 et seq.

contract for investigating, is not within s. 4 of the Statute of Frauds, $387(t)$

slander of, 864 


\section{TITLE-continued.}

no warranty of, by pawnbroker selling chattel, 925,928 (a) secus, on sale of a lease, $925(x)$

whether generally on sale of goods, $925(u),(y),(z)$

TORT. Sec Bailmest, Libel, Easemexts, etc.

whether plaintiff should sue iu, or on contract, $67(b), 7 i l, 7 \tau_{2}$ detinition of, 746

limitations of actions for, 157,158

what action will lie for, 746

infant liable for, 673

lunatic civilly liable for, 783

no action between husband and wife at common law, 676

for accident without default, 783, 789

to the person, what, 782

bodily injury, 782

intention immaterial, 782

assault and battery, 784

what is not an assault, 784 (i)

rights of action ex delicto

for invasion of a right, 747

for trespass to land or goods, 747

action by reversioner, 747

may lie without special damage, 748

for invasion of trademark, 749

for libel and slander, 749

to recover possession of goods, 749

where choice between action $c x$ delicto or ex contractu, 769

will not lie for mere breach of contract, $770(p)$

privity in action flowing from breach of contract, $i 70$

not generally needed, 770

no liability $e x$ delicto on warranty where no fraud, $7 i 0$ ratification of, $800 \mathrm{et} \mathrm{seq}$.

servant not excused by, 800

trespass by estoppel, 801

none, if agent assumed to act for himself, 802

ratification of acts of bailitt by judgment creditor, 802

by Crown, 804

$$
\text { by landlord, } 803
$$

rules of law, same in actions on statutes as at common law, $\$ 17$ when case new in principle, 965

in instance, 965

intention immaterial to support action of, $976 \mathrm{ct} \mathrm{sey}$. may be material in assessing damages, $977 \mathrm{ef} s(?$.

damages for, 979

and considerel by jury, 783,977

consequential, 980

remoteness of damage in action of, 981,952

measure of damage in action for negligence causing tleatl, sts

how differs from contract, 982

crine, 983

action for breach of public duty by statute, $750 \mathrm{C} \times \mathrm{s}$.

at common law prodncing clamage, 750

none if common to the community, 752,753

special damage must be proved, $749(p), 753$

negligence producing danage is actionable, $7: 00$

not otherwise, $751(t)$

action lies for private damage, not for breach of pullic duty, ist

distinction between private and public wrong, $75 \%, 75$

breach of statutory duty not always acticuable, $7 \mathrm{in}$ ct $3 \times q$. 


\section{TORT-continued.}

words of statute must be carefully looked at before bringing action, 764 no action where specific remedy giren by statute, 766

nature of statutory duty to public, 765,766

rules as to, 766

if legislature authorises act, no remedy at law for party injured, $766(t)$

breach of statutory duty excused by act of God or king's enemies, 760

action for breach of private duty producing damage, 767

private duties, what, 767

of railway companies, 767,768

action, when flowing from breach of contract, against carriers, solicitors, surgeons, engineers, 769

action for breach of duty undertaken, 779

none against mere licensee, 779

gratuitously, 779

for frand, deceit, etc., prodncing damage, 779,780

for malicious doing of act producing damage, 780

for maliciously defacing conductor's license, $781(c)$

for injury to wife, child, or servant, $781(f)$

under Lord Campbell's Act, $781(f)$

for direct bodily injuries, $786(z)$

caused by negligence, $786(z)$

by animals, $786(z)$

by dog to sheep; to game, $786(z)$

for compensation when death caused by negligence, 815 et seq.

for whose benefit brought, 816

for carelessly repairing gas-meter, 795

for leaving stones in the road, 795,796

for not fencing mill-gear in factory, 764,765

for not fencing premises adjoining a public footway, 754

no duty to fence as against mere licensee, $754(d)$

for obstructing navigable rirer by sunken vessel, $755 \mathrm{ct}$ seq.

against apothecary or surgeon, 772 public thoroughfare, 753,754

directors, 772,773

person erecting a nuisance on highway, 772

railway company for not elosing gates, 761,762

for not fencing, 762,763

for not transferring shares, 768

railway companies working over the same line, 771

seller of gun for damage resulting from fraudulent warranty, 774

stage proprietor for not conveying servant safely, 770

witness for not obeying subpona, 758

liability of contractor for workmen, $794(k)$

corporation for libel, $793(h)$

for fraud or misfeasance of servant, $793(h)$

may sue for libel, $793(h)$

directors for misrepresentation and frand, $772,776,954$

their executors are not liable, 777

cwner of farm, 792

of ferry, $792(\approx)$

of carriage, 796

lirer of carriage, 797

owner of shin, 792

of realty no wider than that of owner of personalty, 798,799 
TORT-continued.

liability of landlord for nuisance on demised premines, 799 person inviting third party to go upon premises, i6s solicitor for negligence producing damage, 966 patent agent, 966 landlord for distress by bailiff, 803 railway company for negligence of servants, 793 trustees for negligence, $755(h)$

master for act of servant, $790 \mathrm{ct} \mathrm{sc}$., 966 principle of, 809,810

none if serrant exercising independent employment, 794 nor if act wilfnl, 797 nor for negligence, if serrant not engaged in employ, 797,798

nor where act could have been lone in lawful manner, 798 sccus, if act unlawful, 798

master to servant, $806 \mathrm{ct}$ seq.

for negligence of fellow-servant, $809 \mathrm{ds}$.

for personal interference and uudue risk, 803

when not in common service, 808

under Emplojers' Liability Act, 811 et $\approx$.

law as to contributory negligence, 788 not liable to volunteer, 807

where defendant acted by servant or agent, 787

where relation of master and serrant existed between jarties, 787

of infant, adult guardian, 789

of third person, 789

torts to health and comfort of individuals, $818 \mathrm{clseq}$.

sale of unwholesome food, 819

liability of vendors of, 819

nuisances, public, 820

private, 821

negligent treatment of patient, 823

to personal liberty, $823 \mathrm{ct} s \mathrm{sc}$.

false imprisonment, 823

malicious arrest, 837

malicious prosecution, 839

maliciously suing out commission of bankruptey, $8+1$

to the reputation, $844 \mathrm{ct} s c q$.

libel, 844 el $s c q$.

when privileged, 847 et siq.

slander, 861 publication of, 858

\section{of title, 864}

to real property, 867 et scq.

wrongful detention of land, $867 \mathrm{ct} s \mathrm{~s}$.

trespass to land, $870 \mathrm{ct} \mathrm{seq.}$

ratification of, 880

nuisance to realty; 880

to personal property, 911 et seq.

in possession, $912 \mathrm{ct} \mathrm{seq}$.

in rightful possession, 912 et siq.

how effected, 913, 914

when action will lie for, 914

under bailment, 915 ct seq.

out of possession, 915 et seq., 947 et seq.

not directly affecting person or property, $951 \mathrm{et} \mathrm{sm}$. 
TORT-continued.

to absolnte and relative rights, 952 et seq.

estoppel in pais in cases of fraud and misrepresentation, 960 et seq.

to relative rights, 966

husband and wife, parent and child, guardian and ward, master and servant, $96 \mathrm{~T}$ ct scq.

abduction of wife, 967

TOWAGE,

contract of, $775(g)$

TRADE, 356. Sce Restraint of Trade, Libel, ctc.

TRADEMIAK,

right to, what, $85(h)$

tortious invasion of, is actionable, 85

fraudulent use of, actionable, without special damage, 749

TRADESMAN,

duty of, supplying goods to married woman, 693 et seq.

TRAM,

driver of, not within Employers' Liability Act, 1880, 811 (d)

TRANSFER

of action, 117, 125

TRANSFERENCE. See Bill of Exchayge.

of bill without indorsement gives right to indorsement of transferor, 457

until then operates as equitable assignment, 457

\section{TRANSFEROR}

by delivery, implied warranty by, 495

\section{TRA VELLER,}

might sign memorandum under Statute of Frauds, s. 17, 414

TREASON,

high, what, 1012

Statute of, 1013 et seq.

ingredients of, $1013 \mathrm{ct} \mathrm{scq}$.

evidence necessary to convict of, 1014

misprision of, $10 \mathrm{i} 4(\mathrm{~g})$

intent punishable, but must be proved by overt act, 1015

overt act in, what, 1016, 1017

whether bare words are, 1017

writing, 1017

constructive, 1018

limitation in, $1018(a)$

conspiracy may be overt act in, $1019(b)$

not triable by justice of the peace, 1079

TREES,

growing, go to heir, not executor, 389

cannot be taken undier a $f$. $f a ., 389$

falling on neigltbour's land may be retaken, 206

branches of, overhanging neighbour's land, 209

TRESPASS

to land, bare, is actionable, 85,747

not indictable, 1029

evidencing title is actionable, 86,87 
TRESPASS-continucd.

to common, 86

ratification of, 880

by Crown, 103

against judge under void commission, 106, 107

for mere mischance, 783

against corporation, $793(h)$

to realty, 870 et seq.

action founded on possession, 870

for, to land abroad not entertainable ly Supreme (onar of Judicature, $870(p)$

what it is, 870

implies damage, 870

use of highway otherwise than for purpose in respect of which dedicated, 871

if owner out of possession, tewant has right of action, $8 \% 2$

will not lie before entry, 874

possession, to support, must be exclusive, 874

by reversioner, 747,875

special damage must be shown, 875

when permanent, 876,877

liability of owner of cattle for, 877

double remedy against, 877

when justifiable, 877,878

leave and license a good defence, $878(c)$

justification by freehold and right of entry, 878,879

$a b$ initio, 879, 880

by misfeasance, 879,880

secus, if mere nonfeasance, 879

measure of damages in action for, 971

jury "need not weigh in golden scales," 975

to goods, 747

when action maintainable by bailor or bailee, $917 \mathrm{clseq}$.

when goods taken and sold owner may sue for them, or wave claim, and sue for money had and received, 914 $(\Leftrightarrow)$

wilful, $993(o)$

included in felony, 1061

\section{TRESPASSER,}

forcible expulsion of, 210

by estoppel, 801

liability of joint, 835

homicide of mere, not justifiable, 1046

TRIAL,

forms of, 170

before a judge, 170

before judge and assessors, 171

before judge and jury, 171, 177

before official or special referee, 172

by jury, when of right, when only by leave, 111

notice of, 176

how given when evidence taken on affidavit, $177(\mathrm{~m})$

default of appearance at, 178

order of proceedings at, 179

right to begin, 179

province of judge, 179, 180

$$
\text { of jury, } 180
$$

new, when granted, 182, 183

powers of County Court judge at, $199 \cdot t \mathrm{sc}$.

criminal, proceedings at, 1086 et seq. 
TROLLY, driver of, within Employers' Liability Act, 1880, $811(d)$

TROVER, action of, what it is, 225 (y)

TRUCK ACT, nature of protection afforded by, 250 omnibus conductor not within, $250(f)$ driver of tram-car not within, $250(f)$ railway guard not within, $250(f)$

TRUST, essential to bailment, 916 liability of married woman for breach of, $688(q)$

TRUSTEE, when protected by Statute of Limitations, $153(z)$

for carrying out parliamentary undertakings, not personally liable, 616

liability of, for negligence, $755(h)$

may maintain action against stranger taking goods, 948

protection of married roman as, 678

neglect of, to repair roads, not manslaughter, 1042

TRUSTEE IN BANKRUPTCY, 656. See BANKRUPTCY.

joinder of claims by, 120

UBERRIMLE FIDEI, contracts, 331

ULTRA VIRES, doctrine of, 651,652

UNDERWRITER, liability of, 91

UNDUE INFLUENCE, equity will not relieve against voluntary deed without proof of, $285(\approx)$

UNIFORMITY OF PROCESS ACTS, 25, 32

UNILATERAL CONTRACTS, instances of, 272, 301, 302

UNIVERSITIES, leasing powers of, 516

UNLAWFUL ASSEMPLY, what, 1026

homicide resulting from, 1043

UNWRITTEN LAW, 7,19 . Sce LEX xox Scripta.

\section{USAGE}

of trade, 18

inercantile, once established, is recognised by court without formal proof, $9,579(a)$

evidence of, must be left to jury, $5 \pi 9 \mathrm{ct} s c q$.

of tralle, extrinsic evidence admissible to annex to writteu contract, $5 \$ 3$ et scq.

to fix brokers with liability as principals, 585 
USAGE-continued.

inadmissible to contradict written contract, $\mathbf{5 8 0}$

general, how to be proved, 585 (n)

must be reasonable, ccrtain, generil, 592

USANCE,

what it is, 477

USE $\triangle$ ND OCCUPATION, action for, 569

USER. See EAsEMExTs.

what is necessary to acquire easement, $895 \mathrm{et} \mathrm{seq}$.

USES, STATUTE OF, 287. See Statute OF Uses.

VACANT POSSESSION,

what, $129(p)$

service of writ in cases of, 129

VACATION JUDGES, their powers, 51

VACATIONS, 50, 51

VADIUM, 921

VENDITIONI EXPONAS,

writ of, 195

action will not lie against sheriff for false return to writ of. 050 (i)

VENDOR. See Seller, Coxtract of Sale of Goons.

need not point out patent defect in elattel, 331

rights of, against principal, 607 et seq.

against unknown principal, 608

of property to company, duty of, 956

of newspaper, liability of, for libel, $858(x)$

VENUE

in indictment, 1087

VERDICT

by default may be set aside, 178,179

special, 180,1036

mistake in delivering, may be corrected within reasonable time, $1095(u)$

VIS MAJOR,

damage caused by, $73(l)$

innkeeper excused by, 927

VOLUNTARY CONVEYANCES ACT, 1893, 286

VOLUNTARY GIFT, equity will not relieve against, without jroof of undue infueser, $285(z)$

VOLUNTARY SETTLEMENT,

by baukrupt, aroidauce of, $2 \$ 6(e)$

VOTE,

action for refusing to receive, 83

maliee esseutial ingredient in, $83(! \prime)$

B.C.L. 


\section{WAGERS,}

contracts of, illegal, $354 \quad 3 \% 4(u)$

\section{WAIVER}

of shares by infant, 672

WAR,

declaration of, imports prohibition of commercial intercourse with enemy, $719(k)$

\section{WAREHOUSE-KEEPER}

may maintain action against stranger taking goods, 948

\section{WAREHOUSEMAN,}

when common carrier becomes, $943(t)$

\section{WARRANT,}

denraind of, 116

of magistrate, arrest by, 827,828

liability of person obtaining, 827, 828

of court of competent jurisdiction will protect officer, 828,829

must be in his possession at the time of arrest, 829

of Speaker, its effect, 830

of Secretary of State, 830, 1086

of Privy Council, arrest by, 1086

WARRANTY,

distinguished from representation, 342 et seq.

question for court, $342(x)$

mere expression of opinion not tantamount to, 344

must be made pending the contract, 344

implied in contract of sale of goods, $423 \mathrm{et} \mathrm{seq.}$

liability, ex delicto, on fraudulent, 744 et seq.

express, 340 ct scq.

patent lefects excluded from, $340(0)$

to what it extends, 340

breach of, 340

distinguished from fraud, 340

definition of, $339(k)$

implied, 342 , ct scq.

founded on presumal intention of parties and reason, 247

of agency, 342

of skill, 342

none that building is fit for specific purpose, $342(s)$

excluded from written contract, 343

by carriers, solicitors, surgeons, engineers, 342,769

none of title by pawnbroker selling chattel, 925,926 (u) secus, on sale of lease, $925(x)$

whether any generally on sale of goods, 423, $925(y)(z)$

measure of danages in action for breach of, 441

\section{WASTE,} on sale of horse, $740(u)$

tenant must not commit, 528

voluntary, 529 ct seq.

by opening unines, \&ic., 529

cutting down trees, 529 ct scq.

lease without impeachment of, 532

equitable, 5.32

lermissive, 533

WATER,

right to, from spout, 88

underground, 76,904 


\section{WATER-continued.}

right to percolating, inlependent of motive, 77, 907

action lies for pollnting, $905(o)$

- may protect oneself as against natural enemy, 901

diversion of, from stream actionable without actual damage, ss

person collecting and keeping on lund hound to keel safe at his peril, 881,882

included in land in legal contemplation, 885

natural right to flowing, 886 et seq.

is mublici juris, 886

rule as to possession of, $886 \mathrm{ct} \mathrm{scq}$.

no property in, 886 et seq.

rights of riparian proprietor in, $886 \mathrm{et} \mathrm{scq}$.

in artificial chaunel, 888,889

easements in running, 902

larceny can be coumitted of, 1070

WATERCOURSE,

rights in artificial, 889

casement over, 903

WAY,

easement of public right of, not within s. 60 of the Connty Courts Aet, 1888, $62(i)$

remedy for disturbance of right of, 97

right of, 908

evidence to support claim to right of, in thinly-populated districts. $908(s)$

immemorial right of, not necessarily lost by 20 years' non-user, $896(\mathrm{~m})$

WAY-GOING CROP, eustom to take, 14,527

WESTMINSTER,

statute of, 27,29

WHARFINGER, delivering goods bont file to assiguee of one part of bill of lading. not guilty of conversion, $505(r)$

WIFE, 675 et seq. Sce Married WoMax. action by husband for abluetion of, $96 \%$

for assault, 967

\section{WILFULLY,}

meaning of, $995(f)$

WILL,

tenant at, 512. Sce LANuLolid ANd Texast.

power of married woman to dispose of property ly, 685

person stealing, not triable by justice of the peace, 10 so

\section{WITNESS,}

attendance of, how enforced, 176

usually examined rivî voce in court, 175

may be by atlidavit, 174

summons to, in County Court, how obtaineel, 200

aetion against, for not obeying subjeena, $75 \%, 758$

oath may be administered to, by foreman of grand jury, $1086,(6)$

WORDS,

not aetionable without special damage, 911

bare, whether overt act in treason, 1017

spoken, when indictable, $1055(p)$ 


\section{WORKMEN,}

who are, within Employers' Liability Act, 811 (d)

WORKS,

meaning of, in Employers Liability Act, 1880, $812(h)$

WRIT,

original, what it was, 29

application to Chancery for, 29

of summens, when established, 31 form of, 125

indorsement of, 126

amendment of, 126

where and how issucd, 127, 128

service of, 128

how effected, 128,129

on particular defendants, 129

out of the jurisdiction, $129 \mathrm{et}$ seq.

duration of, 131

rencwal of, 131

when impossible, 131

low effected, 131

evidence of, $131(c)$

concurrent, 131,132

appearance of defendant to, 133

specially indorsed, now a statement of claim and pleading, 127 appearance to, 134

power of judge to strike out or neglect claim wrongly included in speeially indorsed, 135

for service out of the jurisdiction, 127

of execution, etc., $189 \mathrm{et} \mathrm{seq.}$

- WRIT IN CONSIMILI CASU, 29, 30

WRITING

whether overt act in treason, 1017,1018

WritTeN CONTRaCt. Sec Contract, Evidexce.

WRITTEN LAW, 2, 5. Scc Lex Scripta.

WRONGFUL DISMISSAI,

damages for, 731,732

\section{IEAR,}

agreement not to be performed within one, must be in writing, 391

YOUNG l'ERSON,

who is, within 42 \& 43 Vict. c. $49,1083(k)$

\section{ERIC NIE AMMOUR}






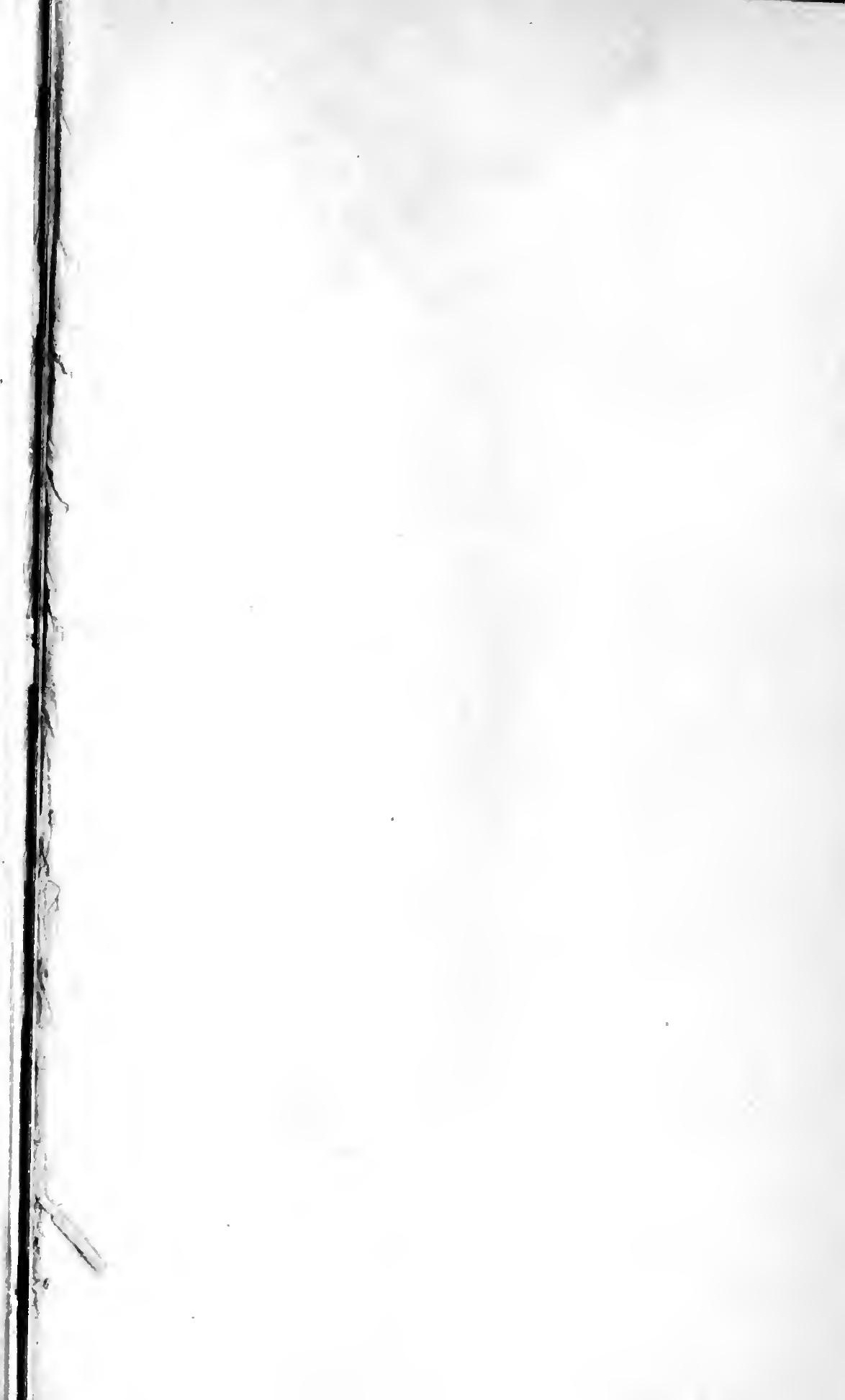






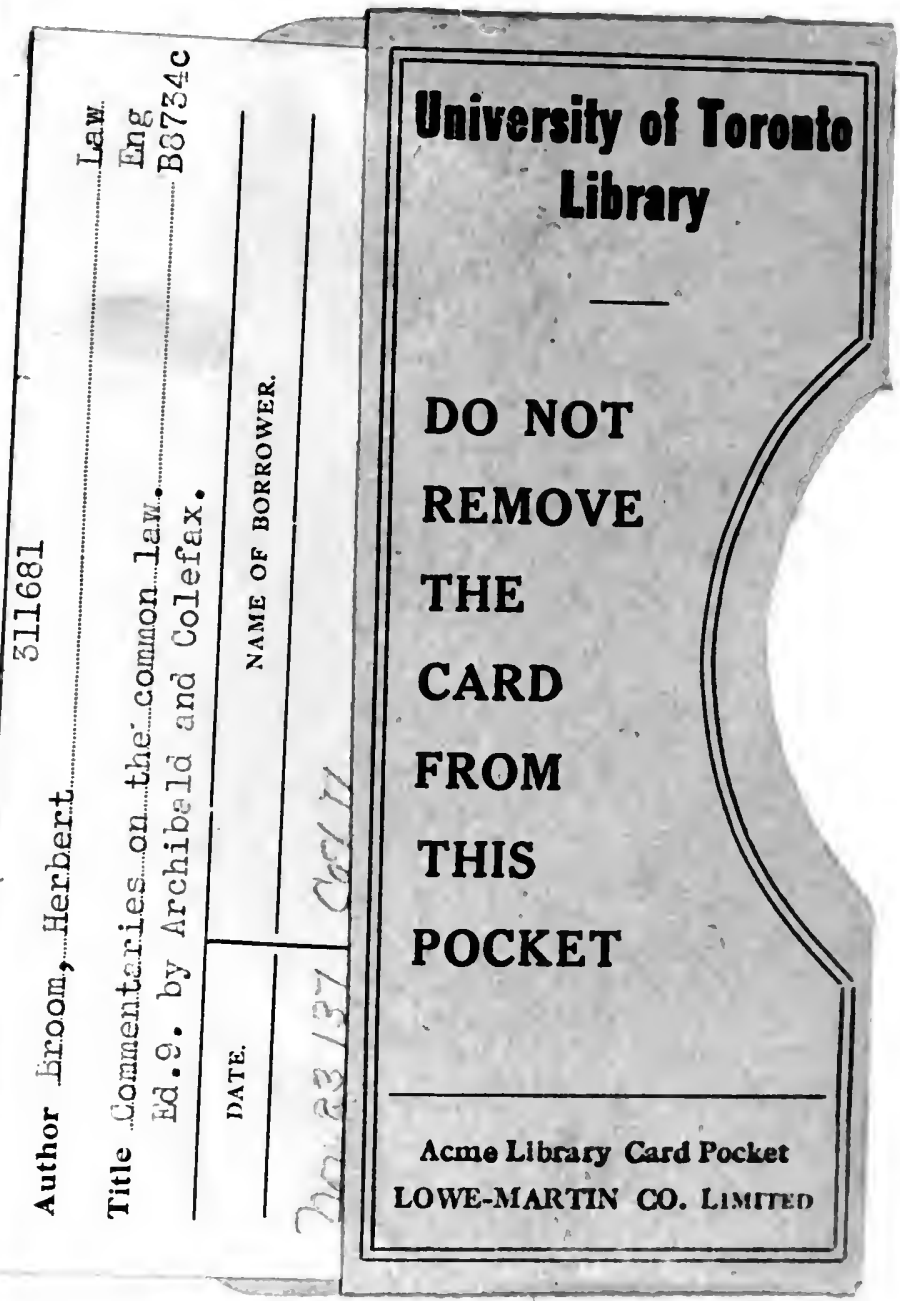


